\title{
Hanford Immobilized Low-Activity Tank Waste Performance Assessment
}

F. M. Mann

R. J. Puigh, II

P. D. Rittmann

Fluor Daniel Northwest

N. W. Kline

Lockheed Martin Services, inc.

J. A. Voogd

Lockheed Martin Hanford Corporation

Y. Chen

C. R. Eiholzer

C. T. Kincaid

B. P. McGrail

Pacific Northwest National Laboratory

Date Published

March 1998

\author{
A. H. Lu \\ G. F. Williamson \\ Westinghouse Hanford Company
}

N. R. Brown

P. E. LaMont

U.S. Department of Energy

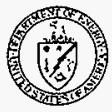

\section{United States}

Department of Energy

P.O. Box 550

Richland, Washington 99352 


\section{RELEASE AUTHORIZATION}

Document Number: DOE/RL-97-69

Document Title: Hanford Immobilized Low-Activity Tank Waste

Performance Assessment

This document, reviewed in accordance with DOE Order 1430.1D, "Scientific and Technical Information Management," and DOE G 1430.1D-1, "Guide to the Management of Scientific and Technical Information," does not contain classified or sensitive unclassified information and is:

APPROVED FOR PUBLIC RELEASE
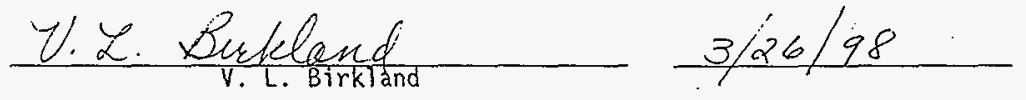

Lockheed Martin Services, Inc.

Document Control/Information Clearance

Roviewed for Applied Technology, Bussiness Sensitive, Classifted, Copyrighted, Export Controlled, Patent, Personal/Private, Proprietary. Protected CRADA, Trademark, Unclassified Controlled Nuclear Information.

Trademark Disclaimer. Reference herein to any specific commercial product, procoss, or sorvice by trade name. trademark. manufacturer, or otherwise, does not necessarily constitute or imply its ondorsement, recommendation. or favoring by the United States Govemment or any agency thereof or its centractors or subcontractors. The views and opinions of authors expressed herein do not necessarily state or reflect those of the United States Government or ony agency thereof. This report has been reproduced from the best availablo copy.

Printed in the United States of America.

Available to the U.S. Department of Energy and its contractors from the U.S. Depertment of Eneroy Office of Sciontific and Technical Information, P.O. Box 62, Oak Pidge. TN 37831: Tolephone: 423/576-8401.

Avaibble to the public from the U.S. Department of Commerce National Technical Information Service, 5285 Port Poyal Road, Springfield, VA 22161: Telephone: 703/487-4650. 
DOE/RL-97-69

Rev. 0

\section{EXECUTIVE SUMMARY}

The Hanford Immobilized Low-Activity Tank Waste Performance Assessment examines the long-term environmental and human health effects associated with the planned disposal of the vitrified low-level fraction of waste presently contained in Hanford Site tanks. The tank waste is the by-product of separating special nuclear materials from irradiated nuclear fuels over the past 50 years. This waste has been stored in underground single- and double-shell tanks. The tank waste is to be retrieved, separated into low- and high-activity fractions, and then immobilized by private vendors. The U.S. Department of Energy (DOE) will receive the vitrified waste from private vendors and plans to dispose of the low-activity fraction in the Hanford Site 200 East Area. The high-level fraction will be stored at Hanford until a national repository is approved.

This report provides the site-specific long-term environmental information needed by the DOE to issue a Disposal Authorization Statement that would allow the

- Modification of the four existing concrete disposal vaults to provide better access for emplacement of the immobilized low-activity waste (ILAW) containers,

- Filling of the modified vaults with the approximately 5,000 ILAW containers and filler material with the intent to dispose of the containers,

- Construction of the first set of next-generation disposal facilities

- Filling of the first set of next-generation facilities.

The performance assessment activity will continue beyond this assessment. The activity will collect additional data on the geotechnical features of the disposal sites, the disposal facility design and construction, and the long-term performance of the waste form. This activity also will.perform analyses to determine the impact of these new data or information collected from other programs. Better estimates of long-term performance will be produced and reviewed on a regular basis. Performance assessments supporting closure of filled facilities will be issued seeking approval of those actions necessary to conclude active disposal facility operations.

This report also analyzes the long-term performance of the currently planned disposal system as a basis to

- Set requirements on the waste form and the facility design that will protect the long-term public health and safety and protect the environment

- Demonstrate that such requirements can be met.

The calculations in this performance assessment show that a "reasonable expectation" exists that the disposal of the immobilized low-activity fraction of tank waste from the Hanford Site can meet environmental and health performance objectives. 


\section{DOE/RL-97-69 \\ Rev. 0}

\section{ES1 BACKGROUND}

The Hanford Site in south-central Washington State has been used extensively as a location for defense materials production by DOE and its predecessor agencies. Over the last 50 years, radioactive and mixed waste from materials production and related activities have been stored on the Hanford Site, primarily in underground single- and double-shell tanks in 18 tank farms.

As part of the Hanford Site's environmental restoration and waste management mission, DOE is proceeding with plans to retrieve the waste from the tanks, some of which have already leaked part of their contents, to accomplish the following:

- Separate the waste into a small quantity of high-level waste and a much larger quantity of low-activity waste

- Immobilize both waste streams

- Store the immobilized high-level waste until it can be sent to a federal geologic repository

- Dispose of the immobilized low-activity waste on-site in near-surface lowactivity waste disposal facilities.

This plan is based on Revision 6 of the Hanford Federal Facility Agreement and Consent Order (Tri-Party Agreement) ${ }^{1}$ and on the Record of Decision for the Tank Waste Remediation Systems, Hanford Site, Richland, Washington ${ }^{2}$. More than $200,000 \mathrm{~m}^{3}\left(7,000,000 \mathrm{ft}^{3}\right)$ of immobilized low-activity waste will be disposed of under this plan. This large volume will contain one of the largest inventories of long-lived radionuclides in the DOE complex to be disposed of in a nearsurface, low-activity waste facility.

By source definition, most of the waste in the Hanford Site tanks is considered high-level radioactive waste. The staff of the U.S. Nuclear Regulatory Commission (NRC) has indicated ${ }^{3}$ that the low-activity waste would be considered "incidental waste" if DOE follows its program plan for separating and immobilizing the waste to the maximum extent possible that is

1 Ecology, DOE, and EPA, 1996, Hanford Facility Agreement and Consent Order, Sixth Amendment, Washington State Department of Ecology, United States Environmental Protection Agency, United States Department of Energy. The document is available from any of the parties.

262 FR 8693. "Record of Decision for the Tank Waste Remediation System, Hanford Site, Richland Washington", Federal Register, Volume 62, page 8693, February 26, 1997.

3 C.J. Paperiello, Classification of Hanford Low-Activity Tank Waste Fraction, letter to Jackson Kinzer, Assistant Manager, Office of Tank Waste Remediation System, dated June 9, 1997. Director, Office of Nuclear Material Safety and Safeguards, U.S. Nuclear Regulatory Commission, Washington, D.C. 


\section{DOE/RL-97-69}

Rev. 0

technically and economically practical, if the wastes meet the Class $\mathrm{C}$ standards of $10 \mathrm{CFR} 61^{4}$, and if the performance assessments continue to indicate that public health and safety would be protected to standards comparable to those established by the NRC for the disposal of low-level waste. Disposal of DOE's incidental waste does not fall under the licensing authority of the NRC.

The current program plan is to use existing disposal vaults and construct additional facilities for ILAW disposal. An earlier program to dispose of the tank waste built four large concrete subsurface vaults with a total usable volume of about $15,000 \mathrm{~m}^{3}$. These vaults will be modified to accept the first waste to be immobilized in the second half of the year 2002. Based on planned ILAW production schedules, additional disposal facilities will be needed in 2005 . The new disposal facilities will be of a different design from the existing facilities. ILAW production is scheduled to continue until 2024, with closure later in the decade. Closing the tanks is a separate program that will occur between 2010 and 2030 .

DOE and its contractors are currently obligated to meet DOE Order on radioactive waste management, currently DOE Order $5820.2 \mathrm{~A}^{5}$. It is anticipated that DOE Order $435.1^{6}$ will become the primary regulation governing management and disposal of radioactive waste at DOE facilities. Before low-level radioactive waste can be disposed of, DOE-Headquarters must issue a Disposal Authorization Statement to the Richland Operations Office. Draft DOE Order 435.1 also requires that the Disposal Authorization Statement be issued before the construction of a new disposal facility. The issuance of this Disposal Authorization Statement is predicated on many analyses, including the performance assessment, which investigates the ability of the disposal system to provide long-term environmental, public health, and safety protection. DOE and its contractors will also meet the requirements of the State of Washington in its regulation of dangerous waste.

\section{ES2 APPROACH}

Because of the duration of the production program, the variability of the ILAW produced over those many years, and the likelihood of different disposal facility designs, this performance assessment takes a three-step approach:

- Understand the important principles, data, and requirements

- Set requirements based on long-term environmental and human health impacts

- Demonstrate that such requirements can be reasonably expected to be met.

10 CFR 61, Section 55, "Licensing Requirements for the Land Disposal of Radioactive Waste," Code of Federal Regulations, as amended.

5 DOE Order 5820.2A, Radioactive Waste Management, U.S. Department of Energy, Washington, D.C., September 26, 1988.

DOE Order 435.1, Radioactive Waste Management, U.S. Department of Energy, Washington, D.C. This order is expected to become effective in 1999. 


\section{DOE/RL-97-69 \\ Rev. 0}

The first step is to understand the important principles, data, and requirements that affect the impact of this disposal action on the public and the environment. Based on applicable regulations and earlier performance assessments, performance objectives were established ${ }^{7}$ to protect the following:

- The general public

- Groundwater resources

- Air resources.
- The inadvertent intruder

- Surface water resources

Protection of Hanford Site workers is assumed to be the same as that for the general public. The performance objectives included not only the peak impact that would be acceptable but also the time period ("time of compliance") over which the impacts would be determined. Data and models were selected based on previous Hanford studies. The data are summarized and the assumptions are listed in Table ES-1. Analyses of likely conditions as well as sensitivity scenarios provide the range of impacts to be expected.

The second step involved using this understanding to set requirements on the disposal facility design and the ILAW product quality. Finally, to show that public health and the environment will be protected with reasonable expectation, this document shows that the requirements are likely to be met.

As more data are collected through performance assessment activity data collection, tank retrieval sampling, ILAW production experience, disposal facility operation history, and other research, this performance assessment will be modified. Because of the requirements of the DOE Order and to follow good business practices, this performance assessment will be revised to reflect our growing knowledge and understanding.

This commitment to iterative analysis is demonstrated by noting that this performance assessment is actually the third set of environmental analyses performed for the program. The first set ${ }^{8}$ provided the background for disposal facility conceptual design and waste form quality. The second set of documents, the Hanford Low-Level Tank Waste Interim Performance Assessment ${ }^{9}$, which provided a set of analyses based on DOE Order 5820.2A showed that the disposal of ILAW would likely meet its performance objectives based on DOE's current plans

F.M. Mann, Performance Objectives of the Tank Waste Remediation Systems Low-Level Waste Disposal Program, WHC-EP-0826, Revision 0, Westinghouse Hanford Company, Richland, Washington, December 1994.

F.M. Mann, C.R. Eiholzer, N.W. Kline, B.P. McGrail, and M.G. Piepho, Impacts of Disposal System Design Options on Low-Level Glass Waste Disposal System. Performance, WHC-EP-0810, Rev. 1, Westinghouse Hanford Company, Richland, Washington, September 1995.

F.M. Mann, C.R. Eiholzer, A.H. Lu, P.D. Rittmann, N.W. Kline, Y. Chen, B.P. McGrail, G.F. Williamson, J.A. Voogd, N.R. Brown, and P.E. LaMont, Hanford Low-Level Tank Waste Interim Performance Assessment, HNF-EP-0884, Rev. 1, Lockheed Martin Hanford Company, Richland, Washington, September 1997. 
DOE/RL-97-69

Rev. 0

and on current knowledge. The present document builds on the analyses presented in the interim performance assessment.

Table ES-1. Major Source of Information for the Base Analysis Case.

\begin{tabular}{|c|c|}
\hline Data Type & Major Source \\
\hline Location & $\begin{array}{l}\text { The existing four disposal vaults at the eastern edge of the Hanford Site } 200 \\
\text { East Area will be used first, followed by the new facilities just southwest of } \\
\text { the PUREX Facility (also in the } 200 \text { East Area). }\end{array}$ \\
\hline Waste & $\begin{array}{l}\text { Immobilized low-activity contents of Hanford Site single- and double-shell } \\
\text { tanks in the } 200 \text { East and } 200 \text { West Areas. }\end{array}$ \\
\hline Inventory & $\begin{array}{l}\text { ASSUMED to be average values calculated from modeling Hanford Site } \\
\text { production reactors corrected for off-site transfers, discharges to the ground, } \\
\text { separations into high- and low-activity fractions, and off-gas generation. }\end{array}$ \\
\hline $\begin{array}{l}\text { Long-term } \\
\text { waste form } \\
\text { performance }\end{array}$ & $\begin{array}{l}\text { ASSUMED to be equal in value to the short-term performance required in } \\
\text { the request for proposals for all non-Tc radionuclides. Tc release in the RFP } \\
\text { is smaller. }\end{array}$ \\
\hline $\begin{array}{l}\text { Disposal } \\
\text { facility design: }\end{array}$ & ASSUMED from preconceptual ideas. \\
\hline Recharge & $\begin{array}{l}\text { For the first } 1,000 \text { years, taken from specifications of the Hanford Site } \\
\text { Surface Barrier. Thereafter, taken from the analysis of current natural } \\
\text { conditions. }\end{array}$ \\
\hline Geotechnical & $\begin{array}{l}\text { Taken from geotechnical measurements studies of other locations in the } \\
\text { Hanford Site } 200 \text { East Area. }\end{array}$ \\
\hline Exposure & Taken from past Hanford Site documents and experience. \\
\hline
\end{tabular}




\section{ES3 RESULTS OF COMPUTER SIMULATIONS}

\section{ES3.1 Introduction}

The data used in this performance assessment are documented in Data Packages for the Hanford Low-Level Tank Waste Interim Performance Assessment ${ }^{10}$. The base analysis and sensitivity cases are provided in Definition of the Base Analysis Case of the Interim Performance Assessment ${ }^{l}$.

Disposal will occur at two facility locations approximately 2 kilometers (1.5 miles) apart. The first facility to be used consists of four existing concrete vaults located just east of the Hanford Site 200 East Area. These vaults, which have an outer layer of asphalt approximately 1 meter thick, were constructed around 1990 as the first of 34 vaults for the disposal of doubleshell tank waste in a grouted waste form. The other disposal facility is to the southwest in a previously unused area. This disposal facility is expected alsó to consist of concrete vaults, but without the asphalt layer. Current planning for the disposal facilities include a surface cover to minimize the flow of water or other potential intrusions into the facility and a sand-gravel capillary barrier to divert water around the waste form.

Geologic, hydraulic, geochemical, and water infiltration data obtained for the 200 Area plateau were used in this analysis and are considered to be representative of the disposal areas. Additional site-specific data are being collected.

The inventory of contaminants in the waste form is based on estimates for the tank waste inventory and uses a conservative estimate to project the low-activity fraction of radionuclides immobilized in the waste form after the separation and immobilization processes. The tank waste inventory estimate is based on computer simulations of the production reactor history and the known reprocessing histories.

The release rate of contaminants from the waste form used in the base analysis case, 4.4 parts per million per year, is based on the request for proposal ${ }^{12}$ issued by the Richland Operations. Office for the separation and immobilization of tank waste. Sensitivity cases also

F. M. Mann, Data Packages for the Hanford Low-Level Tank Waste Interim Performance Assessment, HNF-SD-WM-RPT-166, Revision 0, Westinghouse Hanford Company, Richland, Washington, July 1995.

11 F. M. Mann, C. R. Eiholzer, R. Khaleel, N. W. Kline, A. H. Lu, B. P. McGrail, P. D. Rittmann, and F. Schmittroth, Definition of the Base Analysis Case of the Interim Performance Assessment, WHC-SD-WM-RPT-200, Revision 0, Westinghouse Hanford Company, Richland, Washington, December 1995. Washington, February 20, 1996. These conditions have now been incorporated into contracts with British Nuclear Fuels Limited and with Lockheed Martin Advanced Environmental Services, Incorporated. 


\section{DOE/RL-97-69}

\section{Rev. 0}

were performed for an extensively studied low-level waste glass using a computer simulation code to estimate the rate at which this glass would release the contaminants over time.

A three-dimensional computer code was used to simulate moisture flow and the transport of contaminants from the waste form through the vadose zone to the groundwater. Another three-dimensional computer code simulated the flow and transport in the groundwater. The results from these two codes were combined with inventory and dosimetry data to provide radionuclide concentrations in groundwater and dose rates. Explicit calculations were conducted to 100,000 years after disposal with extrapolations used to extend the results to longer times. For inadvertent intruder analyses, a spreadsheet was used with calculations extending from 100 to 1,000 years.

Because of the very siow predicted release of contaminants from the waste form (hundreds of thousands of years), the estimated concentration of radionuclides in the groundwater does not show a peak, but rather a broad plateau (see, for example, the beta/photon drinking water dose rate shown in Figure ES-1). This contrasts with most other environmental assessments, where the contaminant release time is short compared to the contaminant travel time, resulting in a peaked response.

Figure ES-1. Beta/photon drinking water dose rates for the base analysis case at a well 100 meters downgradient from the disposal facility. The performance objective is less than 4.0 mrem in a year for the first 10,000 years.

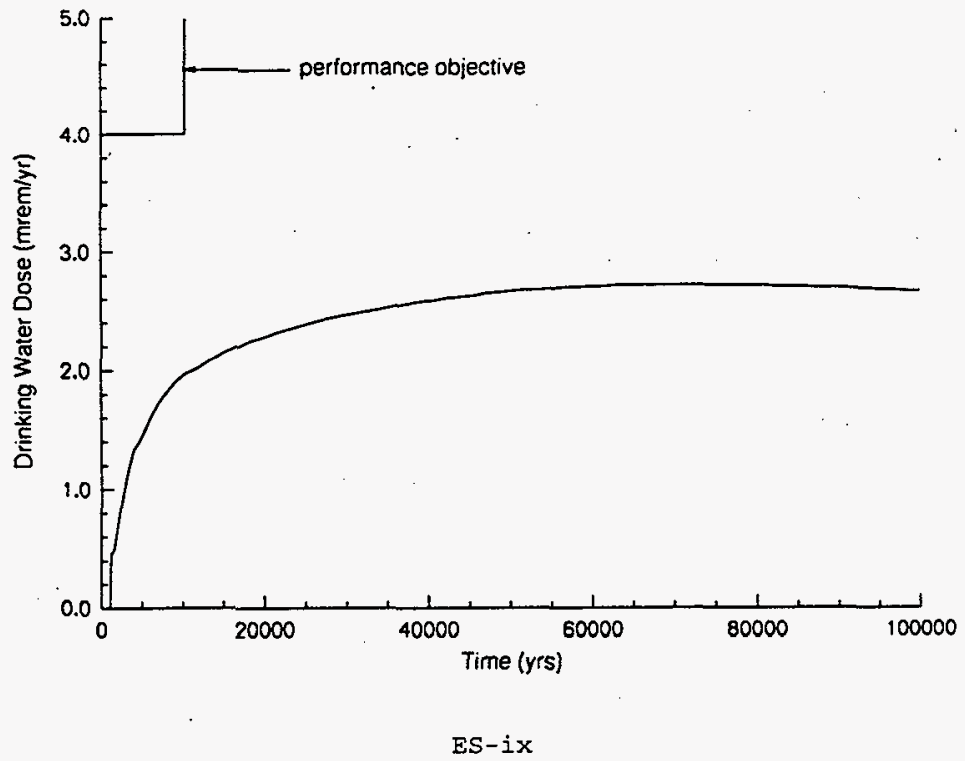




\section{DOE/RL-97-69}

Rev. 0

\section{ES3.2 Protection of the General Public}

Table ES-2 compares the performance objectives for protecting the general public with the results from the base analysis case calculations over the time of compliance $(10,000$ years). The estimated all-pathways doses are significantly lower than the performance objectives. The sensitivity cases show that the all-pathways performance objective would be exceeded if one or more of the following conditions exist for the actual waste disposal action:

- A waste form having a long-term release rate significantly larger than the shortterm release rate specified in the Request for Proposal ${ }^{12}$

- A high infiltration rate and a disposal facility design without a sand-gravel diverter

- A significantly larger inventory of selenium, technetium, or uranium.

During the first 10,000 years (the period of compliance), the estimated doses are at most one-third of the performance objective ( 25 mrem in a year as stated in the DOE order). A time of compliance of 10,000 years was chosen instead of the DOE recommended value of 1,000 years because the $\mathrm{NRC}^{3}$ has indicated for the ILAW product to be ruled "incidental waste" that the performance assessment must also meet their requirements. Technetium-99 is estimated to contribute 58 percent of this dose. The peak all-pathways dose ( $23 \mathrm{mrem}$ in a year) is estimated to occur at about 50,000 years. At the peak, uranium and its daughters are the main contributors.

The other two performance measures (all-pathways including other actions at the Hanford Site and a design that produces doses as low as reasonably achievable [ALARA]) are not expected to exceed $100 \mathrm{mrem}$ in a year or 500 persons-rem per year at any time.

Table ES-2. Comparison of estimated impacts with performance objectives for protecting the public. The time of compliance is 10,000 years. The place of compliance is a well 100 meters downgradient of the facility.

\begin{tabular}{|l|c|c|}
\hline Performance Measure & $\begin{array}{c}\text { Performance } \\
\text { Objective }\end{array}$ & $\begin{array}{c}\text { Estimated } \\
\text { Impact }\end{array}$ \\
\hline All-pathways [mrem in a year] & 25.0 & 6.4 \\
\hline $\begin{array}{l}\text { All-pathways, including other Hanford Site sources } \\
\text { [mrem in a year] }\end{array}$ & 100.0 & $<19.0$ \\
\hline $\begin{array}{l}\text { As low as reasonably achievable (ALARA) (all-pathways) } \\
\text { [persons-rem/y] }\end{array}$ & 500.0 & 5.0 \\
\hline
\end{tabular}




\section{DOE/RL-97-69}

Rev. 0

\section{ES3.3 Protection of Inadvertent Intruders}

Table ES-3 compares the estimated impacts to the performance objectives for protecting the inadvertent intruder. A one-time dose (an acute exposure) scenario as well as a continuous exposure scenario (a chronic exposure) are defined. Both performance objectives are met.

The acute dose, estimated by assuming that a person drills a well through the disposal facility, is much less than the performance objective. The continuous dose, which includes the ingestion of contaminated food and water, the inhalation of air, and direct radiation exposure, is over a factor of 3 lower than the performance objective. At the time of compliance, 500 years, ${ }^{126} \mathrm{Sn}$ contributes more than 95 percent of the dose.

Table ES-3. Comparison of estimated impacts with performance objectives for protecting the inadvertent intruder. The time of compliance is 500 years.

\begin{tabular}{||l|c|c|}
\hline Performance Measure & $\begin{array}{c}\text { Performance } \\
\text { Objective }\end{array}$ & $\begin{array}{c}\text { Estimated } \\
\text { Impact }\end{array}$ \\
\hline Acute exposure [mrem] & 500.0 & 5.5 \\
\hline Continuous exposure [mrem in a year] & 100.0 & 27.5 \\
\hline
\end{tabular}

\section{ES3.4. Protection of Groundwater Resources}

Table ES-4 compares the estimated impacts to the performance objectives for protecting the groundwater resources. These performance objectives are based on the federal drinking water standards. The time of compliance is 10,000 years and the point of compliance is at a well 100 meters down gradient of the disposal facility. The estimated impact from beta emitters is a factor of 2 less than the performance objective and the estimated impact from alpha emitters is a factor of 5 less than the performance objective. The concentration of radium is insignificant.

The most important drivers for determining peak groundwater concentrations are the inventory of technetium for beta/photon emitters and uranium for alpha emitters, the release rate from the waste form, the amount of mixing in the aquifer, and the geometry of the disposal facility relative to the direction of groundwater flow.

For the most part, other geotechnical data (water infiltration rate, hydraulic parameters, and geochemical factors) are less important because they mainly affect the time at which the plateau is reached. The two exceptions are as follows. First, if the water infiltration rate is $0.1 \mathrm{~mm} /$ year (a factor of 5 lower than assumed), the most mobile radionuclides do not reach the groundwater in significant quantities during the compliance period. Second, if both the infiltration rate is $100 \mathrm{~mm} / \mathrm{year}$ and no capillary barrier is in place to divert the infiltration, the uranium group arrives in significant amounts at the water table during the compliance period, causing the drinking water and all-pathways performance objectives to be exceeded. Similarly, if the uranium group is unretarded, significant amounts will reach the point of compliance. 


\section{DOE/RL-97.69}

Rev. 0

The beta/gamma drinking water dose rate is not estimated to exceed 4 mrem in a year for 750,000 years, reaching a maximum value of $14 \mathrm{mrem}$ in a year at the end of the simulation period ( 65 million years). The concentration of alpha emitters is estimated never to exceed $15.0 \mathrm{pCi} / \ell$, reaching a maximum of $8.2 \mathrm{pCi} / \ell$ at 50,000 years.

Table ES-4. Comparison of estimated impacts with performance objectives for protecting groundwater resources. The time of compliance is 10,000 years. The place of compliance is a well 100 meters downgradient of the facility.

\begin{tabular}{||l|c|c|}
\hline Performance Measure & $\begin{array}{c}\text { Performance } \\
\text { Objective }\end{array}$ & $\begin{array}{c}\text { Estimated } \\
\text { Impact }\end{array}$ \\
\hline Beta/photon emitters [mrem in a year] & 4.0 & 2.0 \\
\hline Alpha emitters [pCi/l] & 15.0 & 1.7 \\
\hline Radon [pCi/l] & 3.0 & $<0.001$ \\
\hline
\end{tabular}

\section{ES3.5 Protection of Surface Water Resources}

Table ES- 5 compares the estimated impacts to the performance objectives for protecting the surface water resources. The time of compliance is 10,000 years and the point of compliance is at a well intersecting the groundwater just before the groundwater mixes with the Columbia River. The estimated impacts are over an order of magnitude lower than the performance objectives. The calculations indicate that the impacts never reach the values given as performance objectives. Because of the large flow of the Columbia River, mixing occurs in the river and the predicted impacts actually would be far lower.

Table ES-5. Comparison of estimated impacts with performance objectives for protecting surface water resources. The time of compliance is 10,000 years. The point of compliance is a well located just before the groundwater mixes with the Columbia River.

\begin{tabular}{|l|c|c|}
\hline Performance Measure & $\begin{array}{c}\text { Performance } \\
\text { Objective }\end{array}$ & $\begin{array}{c}\text { Estimated } \\
\text { Impact }\end{array}$ \\
\hline Beta/photon emitters [mrem in a year] & 1.0 & 0.070 \\
\hline Alpha emitters [pCi/l] & 15.0 & 0.058 \\
\hline Radon [pCi/l] & 3.0 & $<0.001$ \\
\hline
\end{tabular}


DOE/RL-97-69

Rev. 0

\section{ES3.6 Protection of Air Resources}

Table ES-6 compares the estimated impacts to the performance objectives for protecting air resources (the values for which are given in federal clean air regulations). The time of compliance is 10,000 years and the point of compliance is just above the disposal facility. The estimated impacts are significantly lower than the values prescribed in the performance objectives.

Table ES-6. Comparison of estimated impacts with performance objectives for protecting air resources. The time of compliance is 10,000 years. The place of compliance is just above the disposal facility.

\begin{tabular}{|l|c|c|}
\hline Performance Measure & $\begin{array}{c}\text { Performance } \\
\text { Objective }\end{array}$ & $\begin{array}{c}\text { Estimated } \\
\text { Impact }\end{array}$ \\
\hline Radon $\left[\mathrm{pCi} \mathrm{m}^{-2} \mathrm{~s}^{-1}\right.$ ] & 20.0 & $<0.001$ \\
\hline Other radionuclides [mrem in a year] & 10.0 & $<10^{-8}$ \\
\hline
\end{tabular}

\section{ES4 SETTING REQUIREMENTS}

Based on the computer simulations, relatively simple requirements on disposal facility design and operation and on waste form characteristics can be set. The requirements are more complex than those normally set, but they are similar.

\section{ES4.1 Intruder Protection}

For the protection of the homesteader, the following equations were used to establish waste concentration and stacking height limits for the disposal facilities:

or

$$
\Sigma \Sigma\left[I_{i j} / V_{j}\right] d_{i}^{h} k_{i}^{h} H_{j}<D^{h}
$$

$$
\Sigma \Sigma\left[I_{i j} / V_{j}\right] H_{j} / Y_{i}<1.0
$$

where the first sum is over contaminants $i$, the second sum is over containers $j$ in a vertical column emplaced within the disposal facility, and where

$I_{i j}=$ the inventory of contaminant $i$ in container $j(C i)$

$V_{j}=$ the volume of container $j\left(m^{3}\right)$

$d_{i}^{h}=$ the dosimetry factor relating response to concentration of contaminant $i$ in the homesteader scenario $\left[(\mathrm{mrem} / \mathrm{yr}) /\left(\mathrm{Ci} / \mathrm{m}^{3}\right)\right]$

$k_{i}^{h}=$ the factor that accounts for the fraction of waste exhumed during drilling, the mixing of the waste in the soil, then transport to point of exposure $(1 / \mathrm{m})$ 


\section{DOE/RL-97-69}

Rev. 0

$\mathrm{H}_{\mathrm{j}}=$ the height of container $\mathrm{j}(\mathrm{m})$

$D^{h}=$ the maximum dose allowable in the homesteader scenario (100 mrem in a year)

$Y_{i}=\left[D^{h} /\left(d_{i}^{h} k_{i}^{h}\right)\right]\left(C i / m^{2}\right)$.

The parameters $d_{i}^{h}$ and $D^{h}$ can be specified and the parameters $k_{i}^{h}$ can be calculated from data presented in this performance assessment. The TWRS Immobilized Waste Program will place restrictions on the concentration of contaminants $\left(\mathrm{I}_{\mathrm{ij}} / \mathrm{V}_{\mathrm{j}}\right)$. Although the height of an individual container is known, the number of containers in a stack has not been determined. Therefore, the program also will restrict the total amount of key radionuclides in a vertical column.

The TWRS Immobilized Waste Program also has decided to place additional restrictions on waste concentrations. To satisfy the $\mathrm{NRC}^{3}$ in their determination that the immobilized lowactivity waste is not high-level waste, the concentration of all radionuclides will be below the Class C limits set in Title 10 Code of Federal Regulations (CFR) Part $61^{4}$.

The DOE has mandated ${ }^{12}$ concentration limits for ${ }^{90} \mathrm{Sr},{ }^{99} \mathrm{Tc}$, and ${ }^{137} \mathrm{Cs}$ for the first phase of waste form production. All waste slated to be placed in the existing disposal vaults will be produced under this contract. Therefore, these contract requirements also will be imposed on the waste to be placed in the existing disposal vaults. Although most of the waste in the first set of units in the new disposal facilities also is expected to be produced under this contract, overall, most of the waste that will be contained in the new disposal facilities will be produced under a different contract. Therefore, to provide maximum flexibility in future decisions, these contract limitations are not placed on this analysis of waste disposed in the new disposal facilities.

The waste to be disposed of must meet both the NRC Class $\mathrm{C}$ limits and the requirements set by this analysis. For the nominal stacking heights of six containers (about 7.2 meters), the NRC Class $\mathrm{C}$ limits will be more restrictive for most of the isotopes. This is because the glass waste form makes the radioisotopes very difficult to ingest or inhale even after they are brought to the surface. A few isotopes (mainly actinides) may be more restricted by this analysis than by the NRC restriction.

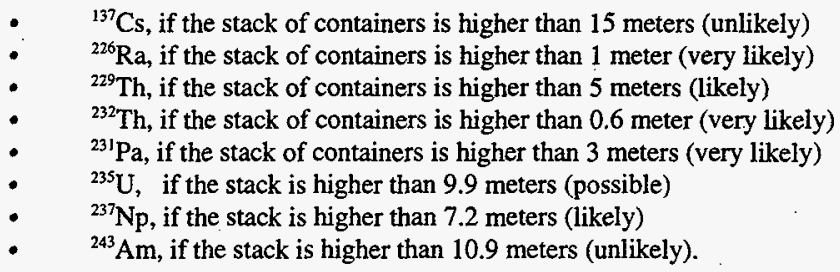

Note that the radioisotope of greatest concern for intruder protection $\left({ }^{12} \mathrm{~S} n\right)$ is not addressed by the NRC regulation. 


\section{DOE/RL-97-69}

Rev. 0

\section{ES4.2 Groundwater Protection}

The computer analysis shows that for groundwater protection the main factors in meeting the requirement are the contaminant flux leaving the disposal facility and the amount of groundwater into which the flux eventually flows. Unlike most environmental analyses where the rate of release is a relatively minor concern, in this analysis it is a driving concern. The groundwater scenario places the restriction that

or

$$
\Sigma I_{i} R_{j} d_{i}{ }^{g w} k_{i}{ }^{g w} / L<D^{g w}
$$

$$
\Sigma\left(I_{i} R_{i} / L\right) / X_{i}<1.0
$$

where the sum is over all contaminations $i$ and where

$$
\begin{aligned}
& I_{i}=\quad \text { the inventory of contaminant } \mathrm{i}(\mathrm{Ci}) \\
& R_{i}=\text { the fractional release rate of contaminant } i \text { from the waste form }(1 / y r) \\
& \mathrm{d}_{\mathrm{i}}^{\mathrm{gw}}=\text { the dosimetry factor relating response to concentration of contaminant } i \text { in the } \\
& \text { groundwater scenario }\left[(\mathrm{mrem} / \mathrm{yr}) /\left(\mathrm{Ci} / \mathrm{m}^{3}\right)\right] \\
& \mathrm{k}_{\mathrm{i}}^{\mathrm{gw}}=\text { the factor that accounts for vadose zone and aquifer transport for contaminant } \mathrm{i} \\
& \left(\mathrm{m}^{2} / \mathrm{yr}\right) \\
& \mathrm{L}=\text { the effective length of the disposal facility perpendicular to groundwater flow } \\
& \text { (m). L is obtained by dividing the volume of the waste by the product of the } \\
& \text { waste column height and of the disposal facility extent parallel to the path of } \\
& \text { groundwater flow. When the groundwater flow is parallel to an edge of the } \\
& \text { facility (which it is in this instance), then } \mathrm{L} \text { is the length of the disposal facility } \\
& \text { perpendicular to groundwater flow } \\
& \mathrm{D}^{\mathrm{gw}^{\mathrm{w}}}=\text { the maximum dose allowable in the groundwater scenario (mrem/yr) } \\
& \mathrm{X}_{\mathrm{i}}=\left[\mathrm{D}^{\mathrm{gw}} /\left(\mathrm{d}_{\mathrm{i}}^{\mathrm{gw}} \cdot \mathrm{k}_{\mathrm{i}}^{\mathrm{gw}}\right)\right][\mathrm{Ci} /(\mathrm{yr} \mathrm{m})]
\end{aligned}
$$

The parameter $I_{i}$ accounts for radioactive decay. The parameters $d_{i}{ }^{g w}$ and $D^{g w}$ can be specified and the parameters $\mathrm{k}_{\mathrm{i}}{ }^{\mathrm{gw}}$ can be calculated from data presented in this performance assessment. The drinking water scenario and the all-pathways scenario are considered in establishing the requirements. Also, the plume overlap caused by the upgradient facility is taken into account. The TWRS Immobilized Waste Program will place restrictions on the inventory $\left(I_{i}\right)$ and the release rate $\left(\mathrm{R}_{\mathrm{i}}\right)$. The effective disposal facility length $(\mathrm{L})$ is a special case. For the existing disposal vaults, $L$ can be calculated. Because the new disposal facilities have not been designed, the program will use the results of this analysis for the design of new facilities.

The isotopes facing the greatest restrictions relative to the expected performance are ${ }^{99} \mathrm{Tc}$ and ${ }^{79} \mathrm{Se}$. This is not surprising because these are the most mobile, because most of the uranium and transuranic elements have been separated from the low-activity waste form, and because other fission products (e.g. ${ }^{14} \mathrm{C}$ and ${ }^{129} \mathrm{I}$ ) found to be important in other wastes are volatile and are not captured in this waste form. The values for required long-term release limits found here are larger than the values for short-term release limits found in the privatization request for proposal. ${ }^{12}$ 


\section{DOE/RL-97-69}

Rev. 0

\section{ES4.3 Requirements on the Disposal Facility}

The major requirements on the disposal facility deal with subsidence, recharge rate, layout, interactions with the waste form, and intruder protection.

The performance assessment assumes that subsidence is small based on the slow degradation of the waste form and the lack of voids in the disposal facility. Thus, the facility must be constructed without significant void space. In addition, after waste is placed inside the facility, the spaces between the waste containers must be filled with a dry material that limits subsidence.

Because the waste form releases contaminants so slowly (on the order of 1 part per million per year), the time dependence of the exposures show more of a plateau structure than a peaked shaped. Therefore, the major effect of the recharge rate is to delay the arrival of contaminants to the groundwater. If the slightly retarded contaminants (for example, uranium) were to arrive before 10,000 years, the all-pathways dose performance objective would be violated and restrictions would have to be placed on the recharge rate. Based on the sensitivity analyses, the recharge rate must be limited to about $3.0 \mathrm{~mm} /$ year (i.e., the natural rate) if no hydraulic diverter is included in the design. If a hydraulic diverter is included, a recharge rate of $100 \mathrm{~mm} /$ year would not violate performance objectives. Gravel-rich and vegetation-free surfaces such as those used in the Hanford Site tank farms would not be suitable. The surface barrier also must deter the inadvertent intruder.

The requirement for groundwater protection $\left[\Sigma\left(I_{i} R_{i} / L\right) / X_{i}<1\right]$ is actually on the disposal system. The designers of the disposal structures must ensure that materials are not used that would accelerate waste form degradation and that the vault layout in relationship to groundwater flow has a sufficient effective length $(L)$. Alternatively, the designers can add components such as hydraulic diverters and getters to minimize the requirements on the waste form.

Designers of the engineered system also may decide to add components to provide greater defense-in-depth. The major components would be a surface barrier to reduce recharge, a hydraulic barrier to divert moisture away from the waste, concrete pads to trap uranium, and other getter materials to trap important radionuclides such as technetium. The recharge rate is the main driving function for the system. With a surface barrier that could reduce this rate, the contaminants would take even longer to reach the groundwater. Diverting water away from the waste by including a sand-gravel capillary barrier would likely reduce the contaminant release rate from the waste form and also would create a greater moisture shadow under the disposal system, which would delay contaminant travel. Concrete is known to highly retard uranium isotopes and so would reduce its impact during the time of compliance. If an inexpensive getter could be found for technetium, the material also could have important impacts. 


\section{DOE/RL-97-69}

Rev. 0

\section{ES5 COMPLIANCE}

Not only must the performance assessment establish the basis for controls to provide a reasonable expectation that the environment and the public health and safety will be protected, but the document also must show that these restrictions can be expected to be met. The major restrictions deal with inventory concentrations, long-term waste form release rates, and disposal facility design.

If the waste packages have the maximum concentrations estimated from the best basis tank by tank inventories ${ }^{13}$ and anticipated separation efficiencies ${ }^{14}$, then almost all the radionuclides will meet the requirements imposed by equations ES.1 through ES.4. However, the producers of the immobilized waste packages are required to meet NRC Class C limits ${ }^{4}$ which for the remaining radionuclides are more restrictive than the limits found here. Thus, the immobilized waste accepted by DOE will meet the requirements set here.

The only other radionuclide of concern in meeting the acceptance requirements based on inadvertent intruder protection is ${ }^{126} \mathrm{Sn}$. This radionuclide does not have a Class $\mathrm{C}$ limit, so its waste acceptance limit is based on this performance assessment. If the ILAW containers having only wastes from the three tanks believed to have large ${ }^{126} \mathrm{Sn}$ concentrations (tanks A-105, A-106, or AX-104) were stacked on top of each other, then the intruder dose would exceed the 100 mrem in a year limit. However, a number of alternatives exist. This performance assessment conservatively assumes that all of the tin would go to the ILAW product. However, a significant fraction may be diverted to the high-level waste stream during separations and treatment. The three tanks of concern have small volumes of waste (19,000 gallons, 125,000 gallons, and 7,000 gallons, respectively). During retrieval the tank contents are likely to be blended with the contents of other tanks that have significantly lower ${ }^{12} \mathrm{Sn}$ concentrations. In addition, the operators of the disposal facility have the option of placing containers with low concentrations of ${ }^{126} \mathrm{Sn}$ on top of a container with a high concentration which would make the stack compliant with the disposal requirements. Finally, because these tanks are likely to be processed during the second phase of immobilization, the DOE could, by contract, have the ILAW producers separate the ${ }^{126} \mathrm{Sn}$ from the low-activity waste and ensure that the ${ }^{126} \mathrm{Sn}$ is below the acceptance limits.

When the restrictions arising from the protection of groundwater are considered, the analyses suggest that compliance will be achievable. Even if the entire ILAW inventory were placed in each set of disposal facilities, for each radionuclide, the $\left(I_{i} R_{i} / L\right)$ product is less than the requirement. The sum for the new disposal facility is 0.34 of the limit. Using the fact that the amount of $\mathrm{Tc}$ to be placed in the existing disposal vaults is limited (by concentrations

"Contract Number DE-AC06-96RL13200; Completion of Milestone T24-97-158, Contractor Letter to Department of Energy, Richland Operations Office, Reporting Completion of Standard Inventory Estimates for all Tanks" letter FDH-9757750 from D.J. Washenfelder to J.K. McClusky, dated August 29, 1997. Richland, Washington, May 22, 1995. 


\section{DOE/RL-97-69}

Rev. 0

specified in the RFP and by the volume of the vaults), the sum for the existing disposal vaults is 0.54 of the limit.

Given these conservative assumptions, expecting groundwater to be protected is reasonable. In particular, the analysis is based on the conservative assumption of a constant release rate from the disposal facility whose value is the maximum observed in detailed waste form calculations. However, these calculated maximum rates do not occur until 8,000 to 16,000 years after closure. Therefore, since it takes many thousands of years for the contaminants to go from the disposal facility to the groundwater, the contamination level in the groundwater will be lower than presented here.

The information in this performance assessment also can be used to back out the maximum allowable contaminant release rate from each facility. For the new disposal facility, the maximum allowable release rate is $2.4 \mathrm{ppm} /$ year assuming that all the inventory of ${ }^{99} \mathrm{TC}$ is placed in that facility. For the existing disposal vaults, the maximum allowable contaminant release rate is higher, being $3.8 \mathrm{ppm} /$ year assuming that the maximum amount of ${ }^{99} \mathrm{Tc}$ is placed in this facility.

The restrictions on the disposal facility design are relatively few and can be easily met. The major facility requirements deal with subsidence, recharge rate, layouts, interactions with the waste form, and intruder protection. Whether a sand-gravel hydraulic moisture diverter actually is used will depend on engineering and cost tradeoffs.

\section{ES6 CONCLUSIONS}

Because this project is in its early stages, conservative assumptions have been used. Given such assumptions, it is gratifying that all the estimated impacts meet the performance objectives. Restrictions placed on the waste product and the disposal facility design will not require heroic efforts to produce a compliant waste form or design a compliant facility.

The numerous sensitivity cases that were run show that the results presented in this assessment are quite robust. The computer simulations of long-term dissolution rates for lowlevel glass (LD6-5412) show that the rate of 4.4 parts per million per year can be met. The calculations are most sensitive to the total inventory of technetium and to the peak concentration of ${ }^{126} \mathrm{Sn}$. For the base analysis case no credit is taken for enhanced chemical separation or separation occurring during immobilization. Computer simulations of flow and transport under a wide variety of conditions show that slightly increased impacts may occur, but that most expected changes would result in larger decreases in estimated impacts.

Future performance assessments, which are required by DOE policy and draft DOE Order 435.1, will benefit from increased knowledge of the waste inventory, the waste form, and the disposal facility design as well as from an extensive data collection activity for the generation of site-specific estimates for geochemical data, hydraulic parameters, and water infiltration and waste form release rates. These performance assessments are expected to confirm this analysis that the on-site disposal of the low-activity waste from Hanford Site tanks can meet the performance objectives with a high degree of assurance. 
DOE/RL-97-69

Rev. 0

\section{TABLE OF CONTENTS}

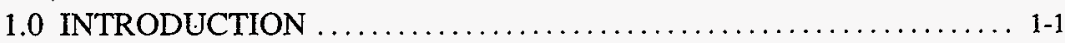

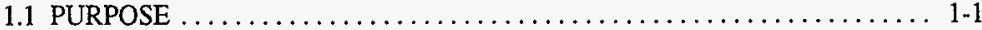

1.2 BACKGROUND $\ldots \ldots \ldots \ldots \ldots \ldots \ldots \ldots \ldots \ldots \ldots \ldots \ldots \ldots \ldots \ldots \ldots \ldots \ldots \ldots, 1-1$

1.3 GENERAL DESCRIPTION OF THE FACILITY $\ldots \ldots \ldots \ldots \ldots \ldots \ldots \ldots 1-3$

1.4 IMMOBILIZED WASTE PROGRAM $\ldots \ldots \ldots \ldots \ldots \ldots \ldots \ldots \ldots \ldots \ldots \ldots \ldots$

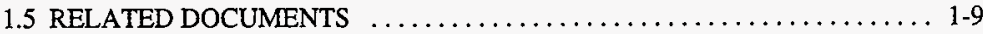

1.5.1 Other Relevant Hanford Site Environmental Assessments ......... 1-9

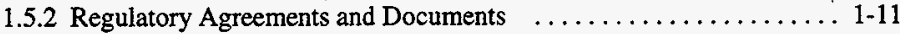

1.5 .3 Guidance Documents ............................ 1-12

1.6 PERFORMANCE OBJECTIVES $\ldots \ldots \ldots \ldots \ldots \ldots \ldots \ldots \ldots \ldots \ldots \ldots \ldots \ldots \ldots, 1-13$

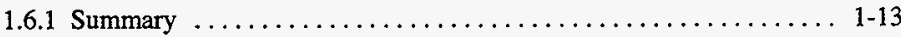

1.6.2 Regulations and Other Performance Assessments $\ldots \ldots \ldots \ldots \ldots \ldots$ 1-15

1.6.3 Programmatic Requirements ......................... 1-20

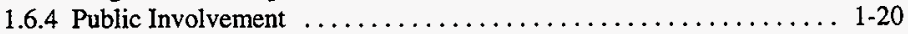

1.7 APPROACH AND MAJOR DATA SOURCES $\ldots \ldots \ldots \ldots \ldots \ldots \ldots \ldots, 1-20$

1.8 STRUCTURE OF THIS PERFORMANCE ASSESSMENT $\ldots \ldots \ldots \ldots \ldots 1-22$

2.0 DISPOSAL FACILITY DESCRIPTION $\ldots \ldots \ldots \ldots \ldots \ldots \ldots \ldots \ldots \ldots .2-1$

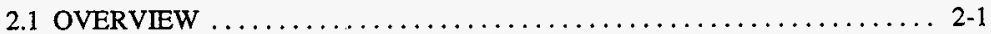

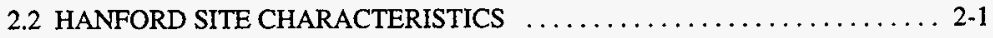

2.2.1 Geography of the Hanford Site $\ldots \ldots \ldots \ldots \ldots \ldots \ldots \ldots \ldots, 2-1$

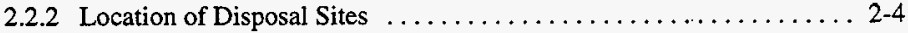

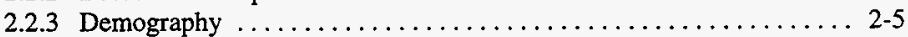

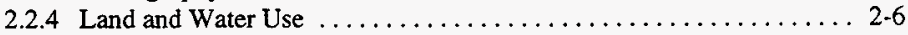

2.2.5 Climate and Meteorology ....................... 2-10

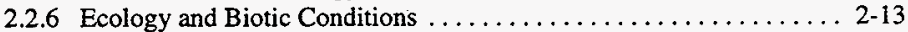

2.2 .7 Regional Geology .......................... $2-14$

2.2.8 Geology of the Proposed Immobilized Low-Activity Tank Waste Disposal

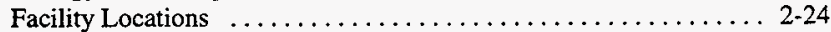

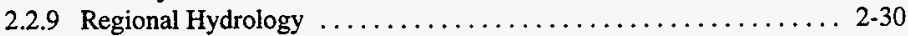

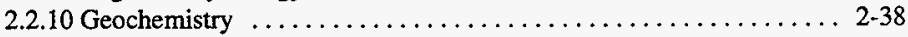

2.2 .11 Natural Resources ......................... 2-39

2.2.12 Regional Background Contamination and Hanford Site Monitoring . . 2-40

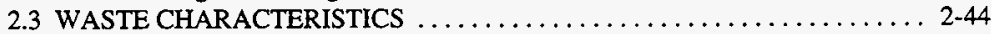

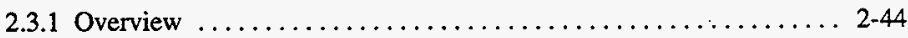

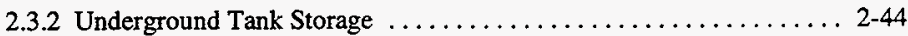

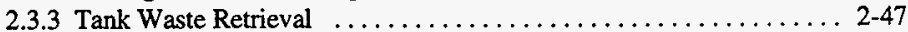

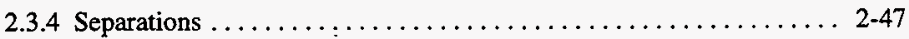

2.3.5 Immobilization of the Low-Activity Waste $\ldots \ldots \ldots \ldots \ldots \ldots .2-49$

2.3.6 Privatization ................................ 2-49

2.3.7 Packaging and Certification ........................ 2-49

2.3.8 Transportation and Waste Emplacement $\ldots \ldots \ldots \ldots \ldots \ldots \ldots . \ldots \ldots$ 


\section{DOE/RL-97-69}

Rev. 0

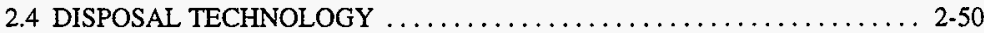

2.4.1 Current and Planned Disposal Units $\ldots \ldots \ldots \ldots \ldots \ldots \ldots \ldots .2-51$

2.4.2 Possible Future Disposal Concepts ................... 2-59

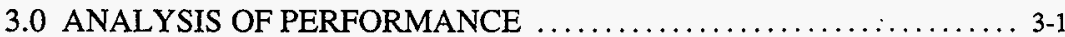

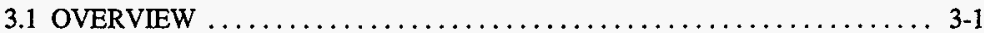

3.2 SOURCE TERMS $\ldots \ldots \ldots \ldots \ldots \ldots \ldots \ldots \ldots \ldots \ldots \ldots \ldots \ldots \ldots \ldots, 3-1$

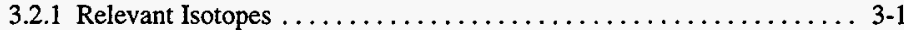

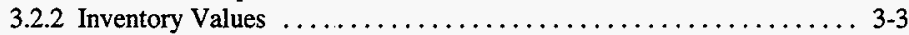

3.2.3 General Description of the Development of Estimated Immobilized LowActivity Waste Radionuclide Inventory $\ldots \ldots \ldots \ldots \ldots \ldots \ldots, 3-5$

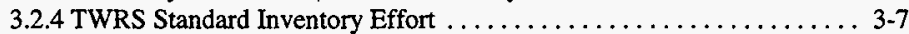

3.2.5 Release Rate from Waste Form $\ldots \ldots \ldots \ldots \ldots \ldots \ldots \ldots \ldots \ldots \ldots \ldots \ldots \ldots$

3.3 PATHWAYS AND SCENARIOS $\ldots \ldots \ldots \ldots \ldots \ldots \ldots \ldots \ldots \ldots \ldots \ldots, 3-15$

3.3.1 Selection Criteria $\ldots \ldots \ldots \ldots \ldots \ldots \ldots \ldots \ldots \ldots \ldots \ldots \ldots \ldots \ldots \ldots \ldots, 15$

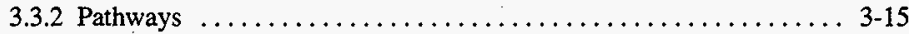

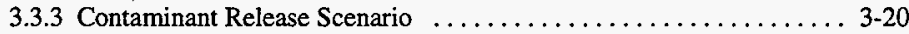

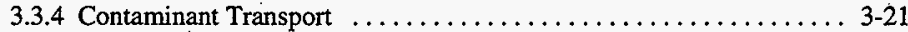

3.3.5 Exposure Scenarios ............................ 3-23

3.4 VALUES AND ASSUMPTIONS $\ldots \ldots \ldots \ldots \ldots \ldots \ldots \ldots \ldots \ldots \ldots, 3-24$

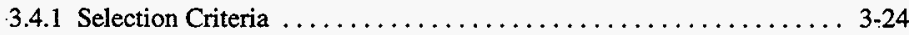

3.4 .2 Key Assumptions $\ldots \ldots \ldots \ldots \ldots \ldots \ldots \ldots \ldots \ldots \ldots \ldots \ldots \ldots \ldots \ldots \ldots, 25$

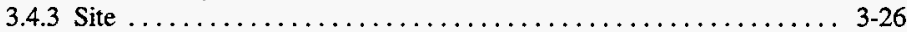

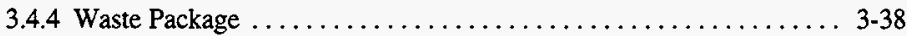

3.4 .5 Waste Disposal Facility $\ldots \ldots \ldots \ldots \ldots \ldots \ldots \ldots \ldots \ldots \ldots, 3-42$

3.4 .6 Infiltration Rate $\ldots \ldots \ldots \ldots \ldots \ldots \ldots \ldots \ldots \ldots \ldots \ldots \ldots \ldots \ldots \ldots \ldots, 4.48$

3.4.7 Exposure Parameters ........................... 3-49

3.5 PERFORMANCE ANALYSIS METHODOLOGY $\ldots \ldots \ldots \ldots \ldots \ldots \ldots, 3-52$

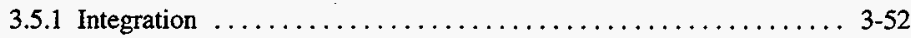

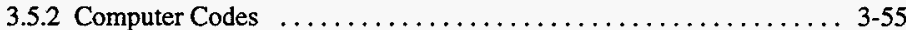

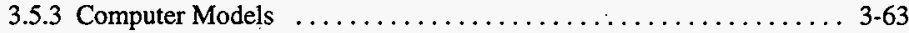

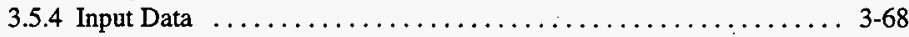

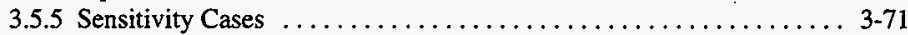

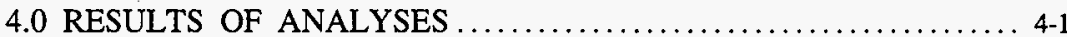

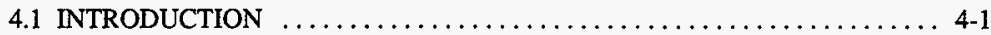

4.2 RESULTS OF GROUNDWATER SCENARIOS - BASE ANALYSIS CASE . . 4-1

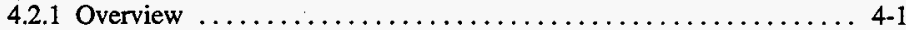

4.2.2 Vadose Zone Transport ....................... 4-2

4.2.3 Base Analysis Case Simulation of Aquifer Transport .......... 4-11

4.2.4 Integrated Simulation Results ...................... 4-14

4.3 RESULTS OF GROUNDWATER SCENARIOS - BASE SENSITIVITY

CASES .................................... 4-24

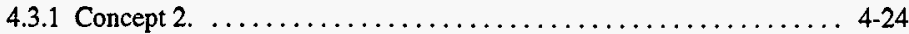

4.3.2 Unit Cell Model. ........................... 4-27 
DOE/RL-97-69

Rev. 0

4.4 RESULTS OF GROUNDWATER SCENARIOS - WASTE FORM SENSITIVITY

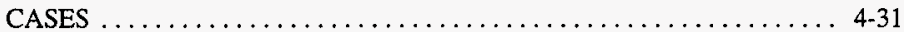

4.4.1 Contaminant Release Rates from Waste Form $\ldots \ldots \ldots \ldots \ldots \ldots$ 4-31

4.4.2 Impact on Exposure Calculations $\ldots \ldots \ldots \ldots \ldots \ldots \ldots \ldots .4 .34$

4.5 RESULTS OF GROUNDWATER SCENARIOS - DISPOSAL FACILITY

SENSITIVITY CASES $\ldots \ldots \ldots \ldots \ldots \ldots \ldots \ldots \ldots \ldots \ldots \ldots, 4.39$

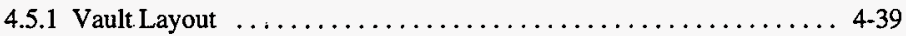

4.5.2 Facility Design Options $\ldots \ldots \ldots \ldots \ldots \ldots \ldots \ldots \ldots \ldots \ldots \ldots, 4-42$

4.5.3 Degradation .............................. 4.45

4.6 RESULTS FOR GROUNDWATER SCENARIOS - VADOSE ZONE

SENSITIVITY CASES $\ldots \ldots \ldots \ldots \ldots \ldots \ldots \ldots \ldots \ldots \ldots \ldots, 4-45$

4:6.1. Hydraulic Parameters . . . . . . . . . . . . . . . . . . . . . .

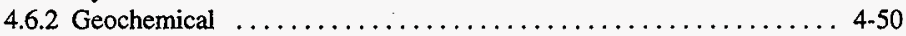

4.6 .3 Infiltration Rate ......................... 4-52

4.7 RESULTS OF GROUNDWATER SCENARIOS - OTHER SENSITIVITY

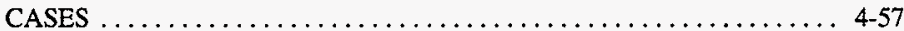

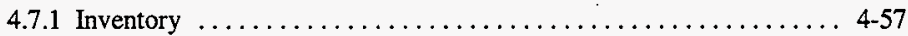

4.7.2 Land Use .................................. 4.59

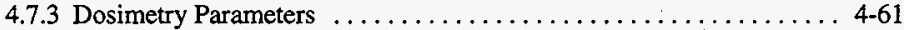

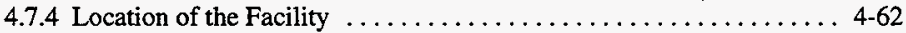

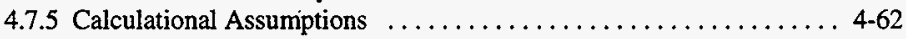

4.7.6 Neglected Processes and Conditions. ................ 4-63

4.8 IMPACT OF OTHER ACTIONS AT THE HANFORD SITE ON

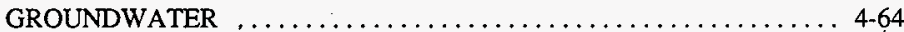

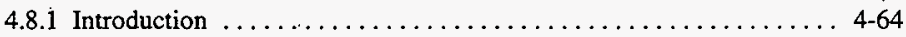

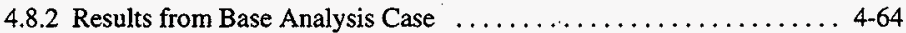

4.8.3 Hanford Site Composite Analysis .................. 4-65

4.9 SUMMARY OF GROUNDWATER SCENARIO $\ldots \ldots \ldots \ldots \ldots \ldots \ldots 4-66$

4.9.1 Maximum Impact of the Groundwater Scenario ............ 4-67

4.9.2 Impact of the Groundwater Scenario at 10,000 Years .......... 4-70

4.10 EFFECTS OF CATASTROPHIC EVENTS $\ldots \ldots \ldots \ldots \ldots \ldots \ldots \ldots, 4-72$

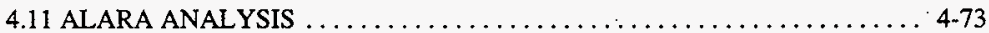

4.12 RESULTS OF SCENARIOS WITH RELEASES TO THE AIR . . . . . . 4-74

5.0 RESULTS FOR INADVERTENT INTRUDER SCENARIO . . . . . . . 5-1

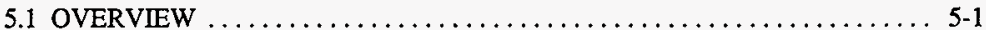

5.2 INADVERTENT INTRUDER SCENARIOS $\ldots \ldots \ldots \ldots \ldots \ldots \ldots \ldots \ldots$ 5-1

5.3 DATA FOR INADVERTENT INTRUDER ANALYSIS $\ldots \ldots \ldots \ldots \ldots \ldots .5-2$

5.4 INADVERTENT INTRUDER ANALYSIS RESULTS $\ldots \ldots \ldots \ldots \ldots \ldots \ldots .5 .4$

5.4 .1 Driller Scenario $\ldots \ldots \ldots \ldots \ldots \ldots \ldots \ldots \ldots \ldots \ldots \ldots, 5.4$

5.4 .2 Homesteader Scenario $\ldots \ldots \ldots \ldots \ldots \ldots \ldots \ldots \ldots \ldots \ldots .6 .7$

5.5 SUMMARY OF THE INADVERTENT INTRUDER SCENARIO $\ldots \ldots \ldots .55-15$ 


\section{DOE/RL-97-69}

Rev, 0

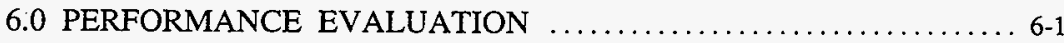

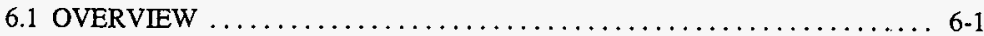

6.2 COMPARISON OF ESTIMATED IMPACTS TO PERFORMANCE

OBJECTIVES $\ldots \ldots \ldots \ldots \ldots \ldots \ldots \ldots \ldots \ldots \ldots \ldots \ldots \ldots, 6,1$

6.2.1 Protection of General Public $\ldots \ldots \ldots \ldots \ldots \ldots \ldots \ldots \ldots \ldots, 6,1$

6.2.2 Protection of Inadvertent Intruders $\ldots \ldots \ldots \ldots \ldots \ldots \ldots \ldots, 6,2$

6.2.3 Protection of Groundwater Resources ..................6 6-3

6.2.4 Protection of Surface Water Resources . . . . . . . . . . . . . . . 6-3

6.2 .5 Protection of Air Resources ......................... 6-4

6.2.6 Application to Existing TWRS Disposal Facility $\ldots \ldots \ldots \ldots \ldots \ldots 6-4$

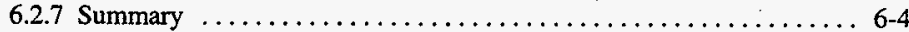

6.3 REQUIREMENTS SET BY PERFORMANCE ASSESSMENT $\ldots \ldots \ldots \ldots 6-5$

6.3 .1 Introduction $\ldots \ldots \ldots \ldots \ldots \ldots \ldots \ldots \ldots \ldots \ldots \ldots \ldots, 6,5$

6.3.2 Requirements Case $\ldots \ldots \ldots \ldots \ldots \ldots \ldots \ldots \ldots \ldots \ldots \ldots$ 6-5

6.3.3 Waste Acceptance Criteria $\ldots \ldots \ldots \ldots \ldots \ldots \ldots \ldots \ldots \ldots .6 .6 .6$

6.3.4 Disposal Facility Requirements ..................... 6-12

6.3.5 Likelihood of Meeting Requirements ................. 6-13

6.4 FURTHER WORK $\ldots \ldots \ldots \ldots \ldots \ldots \ldots \ldots \ldots \ldots \ldots \ldots \ldots \ldots, 6,17$

6.4.1 Future Performance Assessments ................... 6-17

6.4.2 Waste Form Data Collection and Model Development ........... 6-19

6.4.3 Interactions with Disposal Facility Designers .............. 6-21

6.4.4 Geotechnical Data Collection and Model Development ........ 6-21

6.4.5 ILAW Inventory $\ldots \ldots \ldots \ldots \ldots \ldots \ldots \ldots \ldots \ldots, 6,22$

6.4.6 Other Data Collection $\ldots \ldots \ldots \ldots \ldots \ldots \ldots \ldots \ldots \ldots \ldots, 6,22$

6.5 CONCLUSION $\ldots \ldots \ldots \ldots \ldots \ldots \ldots \ldots \ldots \ldots \ldots \ldots \ldots \ldots \ldots, 6,23$

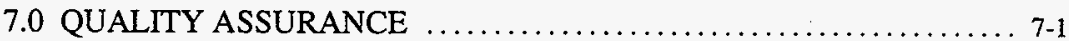

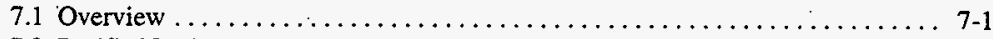

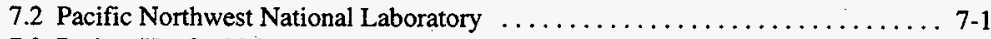

7.3 Project Hanford Management Contractors $\ldots \ldots \ldots \ldots \ldots \ldots \ldots \ldots \ldots \ldots, 7-1$

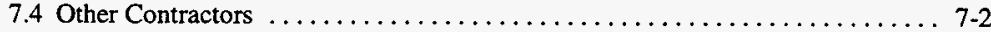

7.5 Hanford Environmental Dose Overview Panel $\ldots \ldots \ldots \ldots \ldots \ldots \ldots \ldots . \ldots \ldots . .2$

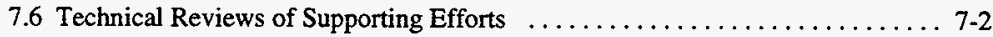

7.7 Review of the Performance Assessment $\ldots \ldots \ldots \ldots \ldots \ldots \ldots \ldots \ldots \ldots, 7-3$

8.0 RESUMES OF PREPARERS AND CONTRIBUTORS $\ldots \ldots \ldots \ldots \ldots$ 8-1

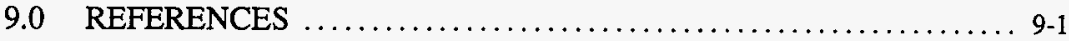

APPENDIX A SPECIFICATIONS FOR IMMOBILIZATION ......... A-1

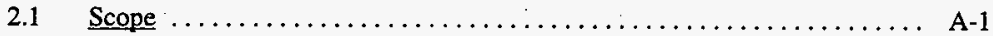

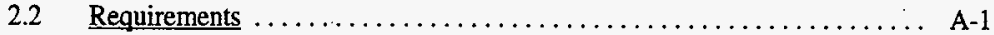

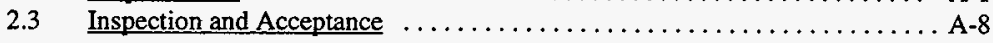




\section{DOE/RL-97-69}

Rev. 0

APPENDIX B DOSIMETRY DOSE FACTORS $\ldots \ldots \ldots \ldots \ldots \ldots \ldots$ B-1

APPENDIX C WASTE FORM RELEASE COMPUTER CODES ...... C-1

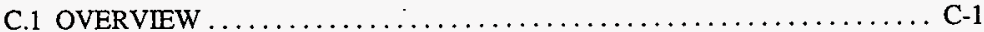

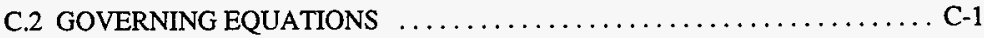

C.2.1 Mass Conservation of Aqueous Solutes $\ldots \ldots \ldots \ldots \ldots \ldots \ldots \ldots$ C-1

C.2.2 Texture Dynamics . . . . . . . . . . . . . .

C. 2.3 Contaminant Release Rate From Glass $\ldots \ldots \ldots \ldots \ldots \ldots \ldots \ldots$ C-3

C.2.4 Reactions Considered .......................... C-4

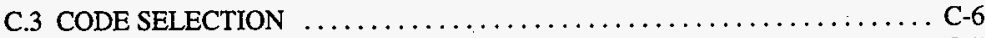

C. 4 VERIFICATION AND BENCHMARKING $\ldots \ldots \ldots \ldots \ldots \ldots \ldots \ldots$ C-7

APPENDIX D MOISTURE FLOW AND CONTAMINANT TRANSPORT

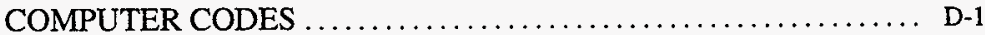

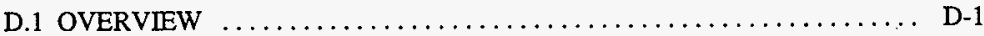

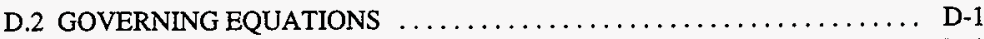

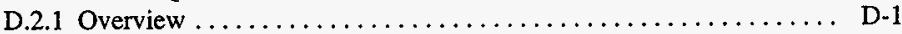

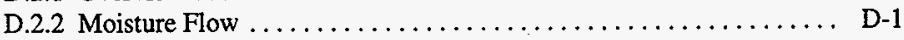

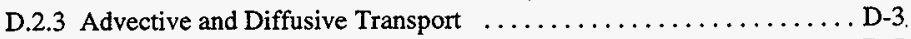

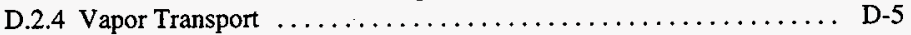

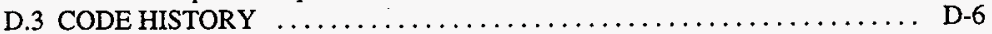

D.3.1 PORFLOW $\ldots \ldots \ldots \ldots \ldots \ldots \ldots \ldots \ldots \ldots \ldots \ldots \ldots \ldots \ldots \ldots \ldots, D-6$

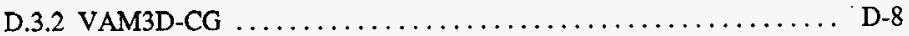

D.4 VERIFICATION AND BENCHMARKING $\ldots \ldots \ldots \ldots \ldots \ldots \ldots \ldots \ldots$ D-8

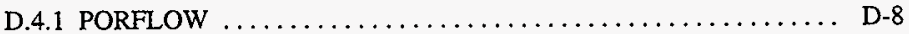

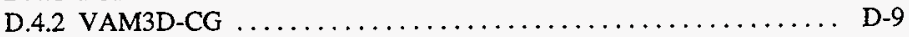

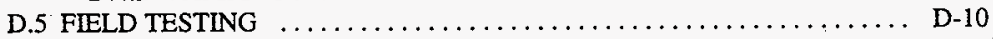

D.5.1 PORFLOW $\ldots \ldots \ldots \ldots \ldots \ldots \ldots \ldots \ldots \ldots \ldots \ldots, \mathrm{D}-10$

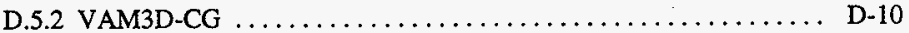

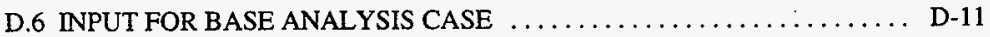

D.6.1 Disposal Facility Model (Concept 1) - PORFLOW ........... D-11

D.6.2 Unit Cell Model - PORFLOW $\ldots \ldots \ldots \ldots \ldots \ldots \ldots \ldots \ldots$ D-29

D.6.3 Pump Model - VAM3D-CG ...................... D.33

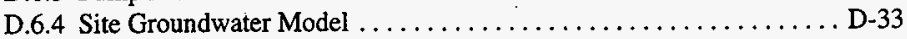

D.6.5 INTEG $\ldots \ldots \ldots \ldots \ldots \ldots \ldots \ldots \ldots \ldots \ldots \ldots \ldots \ldots \ldots \ldots \ldots \ldots$, D. 33

APPENDIX E DETAILED RESULTS $\ldots \ldots \ldots \ldots \ldots \ldots \ldots \ldots \ldots$ E-1

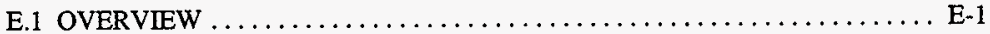

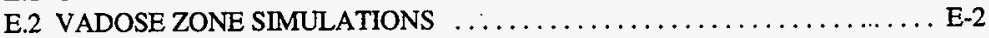

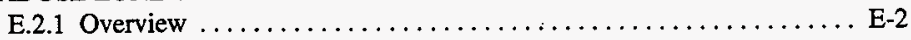

E.2.2 Extension of Calculation to Long Times $\ldots \ldots \ldots \ldots \ldots \ldots \ldots \ldots \ldots$ E-2

E.2.3 Values .................................. E-2

E.3 UNCONFINED AQUIFER SIMULATIONS $\ldots \ldots \ldots \ldots \ldots \ldots \ldots \ldots \ldots$ E-21

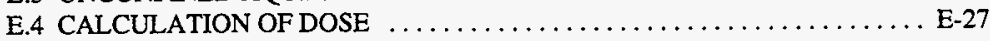




\section{DOE/RL-97-69}

Rev. 0

E.5 WASTE FORM RELEASE CALCULATIONS $\ldots \ldots \ldots \ldots \ldots \ldots \ldots \ldots$ E-40

E.5.1 Simulation Domain and Physical Conditions $\ldots \ldots \ldots \ldots \ldots \ldots \ldots$ E-40

E.5.2 Glass Composition and Dissolution Kinetics ............. E-40

E.5.3 Key Results $\ldots \ldots \ldots \ldots \ldots \ldots \ldots \ldots \ldots \ldots \ldots \ldots \ldots \ldots \ldots$, E-40

APPENDIX F COMMENTS BY REVIEWERS $\ldots \ldots \ldots \ldots \ldots \ldots \ldots$ F-1

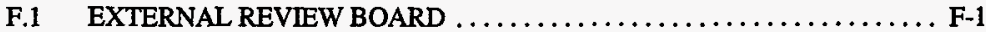

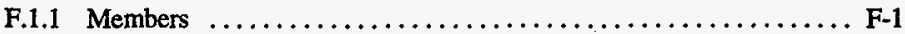

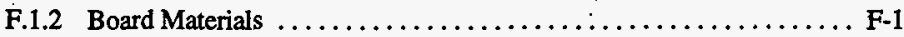

F.1.3 Report of the External Review Board $\ldots \ldots \ldots \ldots \ldots \ldots \ldots \ldots$, F-2

F.1.4 Responses to Board Comments ..................... F-41

F.2 NUCLEAR REGULATORY COMMISSION $\ldots \ldots \ldots \ldots \ldots \ldots \ldots \ldots$ F-61

F.2.1 Letter from NRC Requesting Additional Information $\ldots \ldots \ldots \ldots \ldots$ F-61

F.2.2 Response to NRC Letter . . . . . . . . . . . . . . . . . 66

F.2.3 Letter from NRC on Classification of Hanford Low-Activity Tank Waste

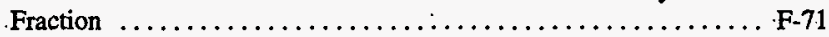

F.3 U.S. DEPARTMENT OF NAVY $\ldots \ldots \ldots \ldots \ldots \ldots \ldots \ldots \ldots \ldots \ldots \ldots \ldots \ldots \ldots \ldots, 74$

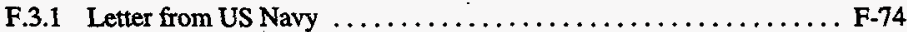

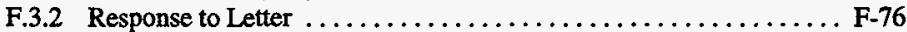

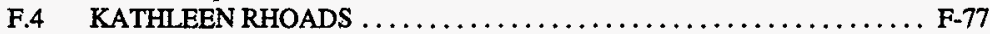

F.5 COMMENTS ON THIS DOCUMENT $\ldots \ldots \ldots \ldots \ldots \ldots \ldots \ldots \ldots$ F-78

F.5.1 Richland Operations Office of the Departmenr of Energy ........ F-79

F5.2 Washington State Department of Ecology ............... F-129

\section{APPENDIX G A STRATEGY TO CONDUCT AN ANALYSIS OF THE LONG-TERM PERFORMANCE OF LOW-ACTIVITY WASTE GLASS IN A SHALLOW SUBSURFACE DISPOSAL SYSTEM AT}

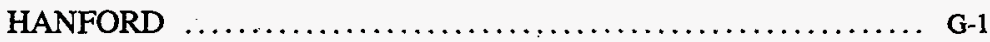

G-1.0 INTRODUCTION $\ldots \ldots \ldots \ldots \ldots \ldots \ldots \ldots \ldots \ldots \ldots \ldots \ldots$, G-1

G-2.0 DISPOSAL SYSTEM DESCRIPTION $\ldots \ldots \ldots \ldots \ldots, \ldots \ldots \ldots$, G-3

G-2.1 Water Infiltration $\ldots \ldots \ldots \ldots \ldots \ldots \ldots \ldots \ldots \ldots \ldots \ldots \ldots \ldots$, G-3

G-2.2 Facility Description $\ldots \ldots \ldots \ldots \ldots \ldots \ldots \ldots \ldots \ldots \ldots, \mathrm{G}-4$

G-3.0 MODELING APPROACH $\ldots \ldots \ldots \ldots \ldots \ldots \ldots \ldots \ldots \ldots \ldots \ldots \ldots \ldots \ldots$

G-3.1 Glass Corrosion Process $\ldots \ldots \ldots \ldots \ldots \ldots \ldots \ldots \ldots \ldots \ldots \ldots \ldots \ldots$, G-6

G-3.1.1 Importance of Secondary Phases $\ldots \ldots \ldots \ldots \ldots \ldots \ldots$ G-6

G-3.1.2 Effect of Ion Exchange ..................... G-7

G-3.2 GLASS CORROSION MODEL $\ldots \ldots \ldots \ldots \ldots \ldots \ldots \ldots \ldots$ G-8

G-3.2.1 Rate Law for Hydrolysis and Dissolution ........... G-8

G-3.2.2 Rate Law for Ion Exchange $\ldots \ldots \ldots \ldots \ldots \ldots \ldots$ G-11 


\section{DOE/RL-97-69}

Rev. 0

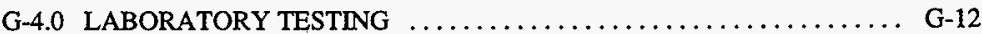

G-4.1 SINGLE-PASS FLOW-THROUGH TEST $\ldots \ldots \ldots \ldots \ldots \ldots$ G-13

G-4.1.1 Well-mixed Batch Reactor ................. G-13

G-4.1.2 Packed Bed Reactor ...................... G-13

G-4.1.3 Fluidized Bed Reactor $\ldots \ldots \ldots \ldots \ldots \ldots \ldots \ldots$, G-14

G-4.1.4 SPFT Testing Strategy $\ldots \ldots \ldots \ldots \ldots \ldots \ldots \ldots \ldots, \mathrm{G}-14$

G-4.2 VAPOR HYDRATION TEST $\ldots \ldots \ldots \ldots \ldots \ldots \ldots \ldots \ldots$ G-15

G-4.3 PRODUCT CONSISTENCY TEST $\ldots \ldots \ldots \ldots \ldots \ldots \ldots \ldots$ G-16

G-4.4 PRESSURIZED UNSATURATED FLOW TEST $\ldots \ldots \ldots \ldots \ldots$ G-18

G-4.5 OTHER TEST METHODS $\ldots \ldots \ldots \ldots \ldots \ldots \ldots \ldots \ldots \ldots \ldots \ldots \ldots \ldots \ldots$, G-19

G-4.5.1 Soxhlet Tests $\ldots \ldots \ldots \ldots \ldots \ldots \ldots \ldots \ldots \ldots$, G-20

G-4.5.2 MCC-1 Test $\ldots \ldots \ldots \ldots \ldots \ldots \ldots \ldots \ldots \ldots \ldots \ldots \ldots$, G-20

G-4.5.3 MCC-3 Solubility Test $\ldots \ldots \ldots \ldots \ldots \ldots \ldots \ldots \ldots$ G-21

G-4.5.4 Periodic Replenishment Tests $\ldots \ldots \ldots \ldots \ldots \ldots \ldots$. G-21

G-4.5.5 Unsaturated or "Drip" Test ................... G-22

G-4.5.6 Accelerated Dissolution Test ................. G-22

G-4.6 REQUIRED TESTS WITH RADIOACTIVE GLASSES $\ldots \ldots \ldots$ G-23

G-4.7 MATERIALS INTERACTION TESTS $\ldots \ldots \ldots \ldots \ldots \ldots \ldots$ G-24

G-4.8 ROLE OF NATURAL ANALOGS $\ldots \ldots \ldots \ldots \ldots \ldots \ldots \ldots$ G-25

G-4.9 LABORATORY TESTING STRATEGY SUMMARY ........ G-26

G-5.0 FIELD TESTING $\ldots \ldots \ldots \ldots \ldots \ldots \ldots \ldots \ldots \ldots \ldots \ldots \ldots \ldots \ldots \ldots \ldots \ldots \ldots$

G-6.0 MODELING THE DISPOSAL SYSTEM $\ldots \ldots \ldots \ldots \ldots \ldots \ldots \ldots$ G-30

G-6.1 SUBPROCESS MODEL DEVELOPMENT $\ldots \ldots \ldots \ldots \ldots \ldots$ G-31

G-6.1.1 Adaptive Reaction Network ................. G-31

G-6.1.2 Composition-Dependent Hydraulic Property Model ...... G-31

G-6.2 NUMERICAL METHODS .................... G-32

G-6.3 DISPOSAL SYSTEM SIMULATIONS FOR THE PERFORMANCE

ASSESSMENT $\ldots \ldots \ldots \ldots \ldots \ldots \ldots \ldots \ldots \ldots \ldots \ldots \ldots \ldots \ldots$, G-33

G-7.0 CONCLUSION $\ldots \ldots \ldots \ldots \ldots \ldots \ldots \ldots \ldots \ldots \ldots \ldots \ldots \ldots \ldots \ldots \ldots \ldots \ldots$

G-8.0 REFERENCES $\ldots \ldots \ldots \ldots \ldots \ldots \ldots \ldots \ldots \ldots \ldots \ldots \ldots \ldots \ldots \ldots \ldots \ldots \ldots \ldots$

APPENDIX H CORRESPONDENCE BETWEEN DOE GUIDANCE AND THIS DOCUMENT $\ldots \ldots \ldots \ldots \ldots \ldots \ldots \ldots \ldots \ldots \ldots \ldots, \mathrm{H}-1$ 


\section{DOE/RL-97-69}

Rev. 0

\section{FIGURES}

1-1. Map of the Hanford Site Showing the Locations of the Hanford Low-Level Tank Waste Disposal Facility $\ldots \ldots \ldots \ldots \ldots \ldots \ldots \ldots \ldots \ldots \ldots \ldots \ldots \ldots \ldots \ldots \ldots \ldots \ldots, 1-2$

1-2. Activities Diagram for the Immobilized Low-Activity Waste Project $\ldots \ldots \ldots \ldots \ldots$ 1-7

2-1. Hanford Site in Washington State. .......................... 2-2

2-2. Hanford Site Map Showing Public Highways and Future Site Boundary. ........ 2-3

2-3. Activities in the 200 Areas. . . . . . . . . . . . . . . . . . . . . . .

2-4. Population Centers Within an $80-\mathrm{km}$ Radius of the Hanford Site. ............ 2-5

2-5. Geologic Structures of the Pasco Basin and the Hanford Site .............. 2-16

2-6. Divisions of the Intermontane Physiographic and Adjacent Snake River Plains

Provinces. ..................................... 2-17

2-7. Landforms of the Pasco Basin and the Hanford Site. ............... 2-18

2-8. Generalized Stratigraphy of the Suprabasalt Sediments Beneath the Hanford Site . . . 2-19

2-9. Comparison of Seismic Hazard for Various Regions of the Hanford Site . . . . . . 2-23

2-10. Location Map for Boreholes Near Existing Disposal Vaults. . . . . . . . . . . . 2-26

2-11. Geologic Cross Section A-A', Existing Vaults. . . . . . . . . . . . . . . . . . 2-27

2-12. Geologic Cross Section B-B', Existing Vaults. ...................... 28

2-13. Stratigraphic Units and Lithology at the Location of the New Tank Waste Remediation

System.Immobilized Low-activity Tank Waste Disposal Facilities $\ldots \ldots \ldots \ldots \ldots .2-29$

2-14. Hydrologic.Basins Designated for the Washington State Portion of the Columbia

Plateau $\ldots \ldots \ldots \ldots \ldots \ldots \ldots \ldots \ldots \ldots \ldots \ldots \ldots \ldots \ldots \ldots \ldots \ldots \ldots \ldots \ldots \ldots \ldots, 2-31$

2-15. Location of Water Disposal Ponds on the Hanford Site $\ldots \ldots \ldots \ldots \ldots \ldots \ldots .2-32$

2-16. Hindcast Water Table Map of the Hanford Site, January $1944 \ldots \ldots \ldots \ldots \ldots \ldots .2-35$

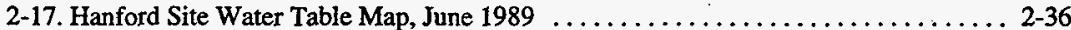

2-18. Averages for Natural and Human-

2-19. Strategy for the Hanford Tank Waste Remediation System $\ldots \ldots \ldots \ldots \ldots \ldots \ldots .2-45$

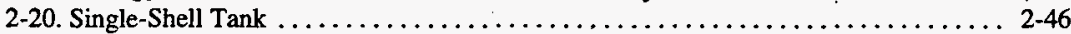

2-21. Double-Shell Tank. .................................... 2-47

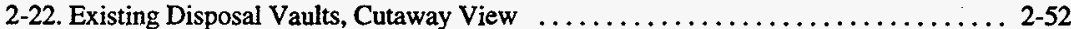

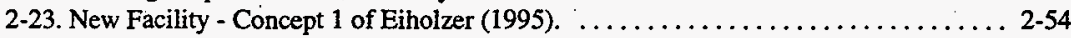

2-24. New Facility - Concept 2 of Eiholzer (1995). . . . . . . . . . . . . . . . . .

2-25. Cross Section of Eiholzer Concept 2. ........................... 2-56

2-26. New Facility Layout - Burbank (1997). . . . . . . . . . . . . . . . . . . . . 2-57

2-27. Cross Section of Burbank (1997) Concept ........................ 2-61

3-1. Predicted Groundwater Flowlines for Post Hanford Conditions. $\ldots \ldots \ldots \ldots \ldots, 3-18$

3-2. Hydrologic-Conductivity Sample Locations. .................... 3-29

3-3. Zone Map for the Upper Layers of the ERC Hanford Sitewide Groundwater Model . . 3-36

3-4. Zone Map for the Lower Layers of the ERC Hanford Sitewide Groundwater Model . 3-37

3-5. Waste Package Spacing for Disposal Facility Concepts 1 and 2 (from

Eiholzer 1996)....................................... 3-45

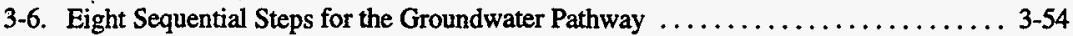

3-7. Zone Map for Disposal Facility Model $\ldots \ldots \ldots \ldots \ldots \ldots \ldots \ldots \ldots \ldots \ldots \ldots \ldots \ldots \ldots \ldots, 64$

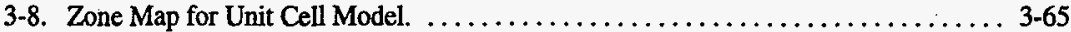

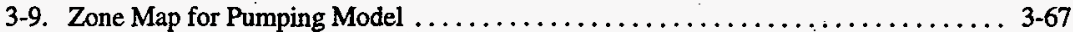




\section{DOE/RL-97-69}

Rev. 0

4-1. General Characteristics of Vadose Zone Transport. ................... 4-3

4-2. Moisture Content and Flow Lines for the Base Analysis Case at 1,000 Years ...... 4-6

4-3. Moisture Content and Flow Lines at 1,000 Years, Emphasizing the Edge of the Disposal

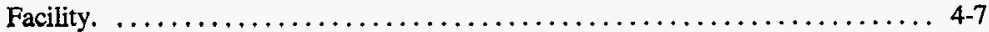

4-4. Moisture Content and Flow Lines at 4,000 Years (Steady State), Emphasizing the Edge of

the Disposal Facility . ................................. 4

4-5. Moisture Content and Flow Lines for the Base Analysis Case at 4,000 Years (Steady

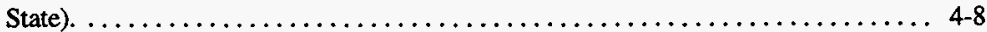

4-6. Normalized Contaminant Flux to the Aquifer for $\mathrm{K}_{\mathrm{d}}=0,0.1$, and $0.6 \mathrm{~m} / \mathrm{g}$

- Base Analysis Case. .................................. 4-9

4-7. Contamination Concentration in Well Water 120 Years After a Vadose Zone Flux of 1

$\mathrm{Ci} / \mathrm{m}^{2}$ and a Recharge Rate of $1 \mathrm{~mm} / \mathrm{year}$ Enter the Aquifer. ............ 4-12

4-8. Concentration Ratios as a Function of Time at Points of Maximum Concentration 100

Meters Downgradient and at the 200 East Boundary $\ldots \ldots \ldots \ldots \ldots \ldots \ldots .4 .13$

4-9. Flow Paths for Locations Beyond 100 Meters ...................... 4-15

4-10. Concentration Ratios as a Function of Time at Points of Maximum Concentration 400

Meters Downgradient and at the 200 East Boundary ................. 4-16

4-11. Concentration Ratio Histories at Downstream Hypothetical Wells. . . . . . . . . 4-17

4-12. Drinking Water Doses for the Base Analysis Case at a Well 100 Meters

Downgradient. .................................... 4-19

4-13. Alpha-Emitting Radionuclide Concentrations for the Base Analysis Case at a Well 100

Meters Downgradient from the Disposal Facility. ................. 4-20

4-14. All-Pathways Doses for the Base Analysis Case at a Well 100 Meters Downgradient. 4-22

4-15. Normalized Contaminant Flux to the Unconfined Aquifer for $K_{d}=0 ., 0.1$, and

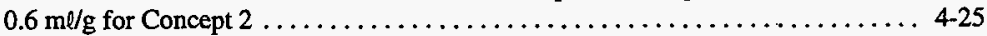

4-16. Normalized Contaminant Flux from the Disposal Facility to the Vadose Zone using the Unit Cell Model .................................... 4-30

4-17. Normalized Contaminant Flux to the Unconfined Aquifer for $K_{d}=0 ., 0.1,0.6$, and 3. $\mathrm{m} / \mathrm{g}$ using the Unit Cell Model. .............................. 4-30

4-18. Glass Dissolution Rate as a Function of Time and Space in the Disposal Vault. . . . 4-32

4-19. Estimated Release Rates through the Vault Floor. .................... 4-33

4-20. Normalized Technetium Fluxes Through the Vault Floor for Various Assumptions. . . 4-34

4-21. Normalized Flux to the Aquifer for $K_{d}=0$ for Concept 2 Simulations Using Constant Contaminant Release and Using Contaminant Release Proportional to Surface Area 4-35

4-22. Beta/Photon Drinking Water Dose When Using Glass Release as a Source Term for a Well 100 Meters Downgradient of a Concept 1 Facility (Unit Cell Model). ......... 4-39

4-23. Normalized Flux to the Aquifer for $\mathrm{K}_{\mathrm{f}}=0$ Elements from Concepts 1 and Concept 2. 4-41

4-24. Moisture Values of Unit Cell Model for steady state. ................ 4-44

4-25. Estimated Unretarded Contaminant Flux to Aquifer for Concept 1 for Different Diffusion Coefficients (Full-Facility Model). . . . . . . . . . . . . . . . . . . .

4-26. Normalized Unretarded Contaminant Flux Entering the Unconfined Aquifer for Three Different Sets of Hydraulic Properties in the Vadose Zone .............. 4-49

4-27, Normalized Contaminant Fluxes at the Unconfined Aquifer for Unretarded Contaminants for Various Infiltration Rates. (Unit Cell Model) $\ldots \ldots \ldots \ldots \ldots \ldots \ldots \ldots \ldots$ 4-54

4-28. Normalized Contaminant Fluxes at the Unconfined Aquifer for $K_{d}=0.6 \mathrm{~m} / \mathrm{g}$ Contaminants for Various Infiltration Rates (Unit Cell Model) 


\section{DOE/RL-97-69}

Rev. 0

5-1. Inadvertent Intruder Results for the Driller Scenario - Base Intruder Case. . . . . . . 5-4

5-2. Inadvertent Intruder Results for the Homesteader Scenario - Base Intruder Case. . . . 5 5-7

5-3. Ratio of Predicted Homesteader Doses for Different Availability of Radionuclides for Ingestion and Inhalation. . . . . . . . . . . . . . . .

5-4. Contribution of Major Radionuclides for the Base Intruder Case and When Ingestion is Allowed. ...................................... 4-13

E-1. Comparison of $K_{d}=3 \mathrm{mg} / \mathrm{l}$ Using Computer Simulations and An Approximation. .... E-3

E-2. Simulated Post-Hanford Operations Water Table and Well Location $\ldots \ldots \ldots \ldots$ E-21

E-3. Simulated Aquifer Thickness - Post Hanford Operations ................ E-22

E-4. Simulated Streamlines for Various Pumping Rates $\left(10 \mathrm{~m}^{3} / \mathrm{day}, 50 \mathrm{~m}^{3} / \mathrm{day}, 100 \mathrm{~m} / \mathrm{day}\right.$, and $150 \mathrm{~m}^{3} /$ day. ........................................ E-23

E-5. Simulated Concentration Contour from New Disposal Facility for Concept 2. . . . . E-24

E-6. Simulated Concentration Contour from the New Disposal Facility for Irrigation North of

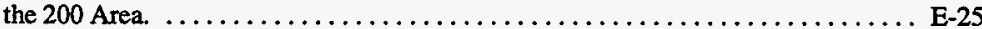

E-7. Simulated Concentration Contour for Existing TWRS Disposal Facilities. . . . . . E-26

E-8. Glass Simulation Domain. ............................... E-40

E-9. Computed pH when Ion Exchange Reaction is NOT Considered. ........... E-41

E-10. Glass Dissolution Rate as a Function of Time and Space when NOT Considering Ion Exchange Reaction. ................................. E-41

E-11. Calculated Total Aqueous ${ }^{99} \mathrm{Tc}$ Concentration as a Function of Time and Space. . ... E-43

E-12. Computed pH in Disposal Vault When Ion Exchange Is Included. ............. E-43

E-13. Effect of Varying Pore Water Velocity on Normalized Flux of ${ }^{99} \mathrm{Tc}$ to the Vadose

Zone. ......................................... E-44

G-2.1. Schematic of ILAW Disposal System. $\ldots \ldots \ldots \ldots \ldots \ldots \ldots \ldots \ldots \ldots \ldots$ G-4

G-3.1. "Top-Down" Strategy for LAW Glass Testing $\ldots \ldots \ldots \ldots \ldots \ldots \ldots \ldots \ldots$ G-7

G-3.2. Release of Na in Excess of that Released by Matrix Dissolution in Static Tests with LD6-5412, a Reference LAW Glass

G-4.1. Schematic of Batch Flow-Through Reactor. .................... G-13

G-4.2. Normalized Si Release Rate as a Function of $\mathrm{pH}$ and Temperature for LD6-5412

Glass. ........................................... G-14

G-4.3. Schematic of VHT $\ldots \ldots \ldots \ldots \ldots \ldots \ldots \ldots \ldots \ldots \ldots \ldots \ldots \ldots \ldots$, G-15

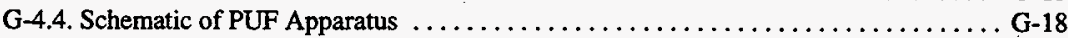

G-6.1. Modeling Strategy for Assessing ILAW Disposal System Impacts $\ldots \ldots \ldots \ldots \ldots$ G-34 


\section{DOE/RL-97-69}

Rev. 0

\section{TABLES}

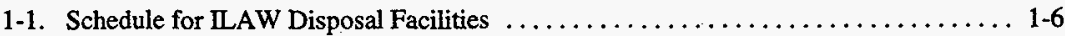

1-2. Schedule for Performance Assessment Activities $\ldots \ldots \ldots \ldots \ldots \ldots \ldots \ldots \ldots \ldots, 1-8$

1-3. Performance Objectives. ................................ 1-13

1-4. Major Source of Information for the Base Analysis Case $\ldots \ldots \ldots \ldots \ldots \ldots \ldots \ldots .22$

2-1. Approximate Probability of Exceeding Given Ground Motions During Selected Time

Periods. ........................................ 2-23

2-2. Activity of Radionuclides in Hanford Sitewide Background Data Set. $\ldots \ldots \ldots \ldots .2-40$

2-3. Provisional Background Values for Hanford Site Groundwater $\ldots \ldots \ldots \ldots \ldots \ldots .41$

3-1. Inventories for Performance Assessment. $\ldots \ldots \ldots \ldots \ldots \ldots \ldots \ldots \ldots \ldots \ldots \ldots \ldots \ldots, 3$

3-2. Best-Basis Global Radionuclide Inventory for Key Isotopes $\ldots \ldots \ldots \ldots \ldots \ldots \ldots$ 3-9

3-3. Best Basis Tank by Tank Inventory for ${ }^{99} \mathrm{Tc},{ }^{126 \mathrm{Sn}},{ }^{137} \mathrm{Cs},{ }^{90} \mathrm{Sr}$, and ${ }^{79} \mathrm{Se} . \ldots \ldots \ldots .3-10$

3-4. Best Basis Tank by Tank Inventory for ${ }^{231} \mathrm{~Pa}$, $\mathrm{U}$ isotopes, ${ }^{239} \mathrm{Pu}$, and ${ }^{241} \mathrm{Am} . \ldots \ldots \ldots$ 3-12

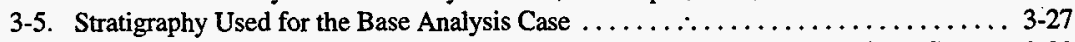

3-6. Values for Hydrologic Parameters for the Vadose Zone for the Base Analysis Case. . 3-30

3-7. Values for Hydrologic Parameters for Construction Materials

for the Base Analysis Case. $\ldots \ldots \ldots \ldots \ldots \ldots \ldots \ldots \ldots \ldots \ldots \ldots \ldots, 3-30$

3-8. Chemical Distribution Coefficients $\left(K_{d}\right)$ for the Base Analysis Case. .......... 3-33

3-9. Hydraulic Parameters for Unconfined Aquifer Immediately Around the Disposal Site 3-34

3-10. Element Material-Zone Flow Properties. . . . . . . . . . . .

3-11. Relative Radionuclide Release Rate from the Waste Form for the Base Analysis Case. 3-41

3-12. Dimension of a Vault Bay for Base Analysis Case. ................... 3-44

3-13. Vault Layout for Base Analysis Case. .......................... 3-44

3-14. Infiltration Rates for Base Analysis Case $\ldots \ldots \ldots \ldots \ldots \ldots \ldots \ldots \ldots \ldots \ldots \ldots .4 .48$

3-15. Base Analysis Case Input Data for the Disposal Facility and Unit Cell Models. . . . . . 3-69

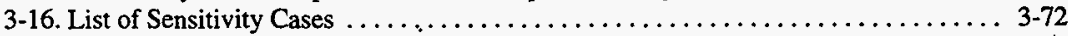

4-1. Fractional Mass Balance Error as a Function of Time for Modeling Concept 1

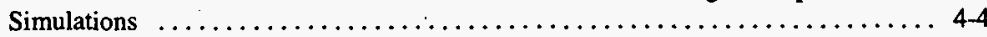

4-2. Major Parameters Describing the Normalized Contaminant Flux to the Aquifer . . . 4-10

4-3. Groundwater Concentration Ratios at Hypothetical Wells $\ldots \ldots \ldots \ldots \ldots \ldots \ldots$ 4-13

4-4. Estimated Impact From Base Analysis Case at a Well 100 Meters Downgradient from the

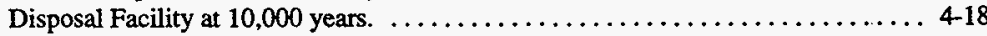

4-5. Major Contributors at 10,000 Years to the Estimated Beta/Photon Drinking Water Dose at a Well 100 Meters Downgradient from the Disposal Facility for the Base Analysis

Case. ........................................ 4-19

4-6. Major Contributors at 10,000 Years to the Alpha-Emitting Radionuclide Concentration at a Well 100 Meters Downgradient of the Disposal Facility for the Base Analysis Case. 4-21

4-7. Major Contributors at 10,000 Years to the All-Pathways Dose at a Well 100 Meters

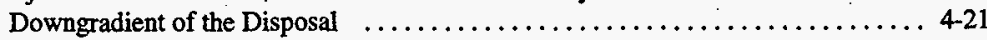

4-8. Estimated Impact From Base Analysis Case from Groundwater Just Before Mixing with the Columbia River at 10,000 Years. . . . . . . . . . . . . .

4-9. Estimated Maximum Impact From Base Analysị Case Using the Groundwater Scenario. 


\section{DOESRL-97-69 \\ Rev. 0}

4-10. Major Parameters Describing the Normalized Contaminant Flux to the Aquifer for

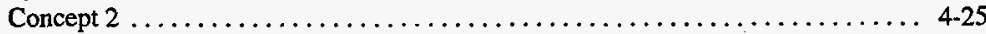

4-11. Estimated Impact Using Concept 2 Geometry at a Well 100 Meters Downgradient from the Disposal Facility at 10,000 Years. . . . . . . . . . .

4-12. Estimated Maximum Impact Using Concept 2 Geometry at 100 Meters Downgradient from the Disposal Facility. ................................ 4-26

4-13. Major Parameters Describing the Normalized Contaminant Flux to the Aquifer Using the Unit Cell Model. . ................................... 4-28

4-14. Estimated Impact at 10,000 Years from Groundwater at a Well 100 Meters Downgradient Using the Unit Cell Model . . . . . . . . . . . . . . . . . . . . . . . . $4-28$

4-15. Estimated Maximum Impact from Groundwater at a Well 100 Meters Downgradient Using the Unit Cell Model for Concept 1 Design . ........................ 4-29 4-16. Maximum Release Rate through Vault Floor as Calculated by AREST-CT.

4-17. Major Parameters Describing the Normalized Contaminant Flux to the Aquifer for

Concept 2 Using Constant Contaminant Release ................... 4-36

4-18. Sensitivity of Impacts Caused by Different Interpretations

of Waste Immobilization Request for Proposal.

4-19. Estimated Impacts at 10,000 Years When Using Calculated Glass Release Rates at a Well 100 Meters Downgradient from a Concept 1 Facility (Unit Cell Model). . . . . . 4 4-38

4-20. Effect of Facility Design Options on Estimated Impacts at 10,000 Years ......... 4-43

4-21. Estimated Beta/Photon Drinking Water Dose at 10,000 Years at a Well 100 Meters Downgradient for Different Diffusion Coefficients.

4-22. Estimated Impact at 10,000 Years Assuming Different Strata (and Hydraulic Properties).

4-23. Normalized Contaminant Flux Reaching the Unconfined Aquifer at 10,000 years as a

Function of Water Table Position. ........................ 4-50

4-24. Effect of Dispersion on $K_{d}=0.6 \mathrm{~m} / \mathrm{g}$ Normalized Contaminant Fluxes

to the Aquifer, Unit Cell Model. ........................... 4-50

425. Effect of Geochemical Parameters on Impacts at a Well 100 Meters Downgradient at

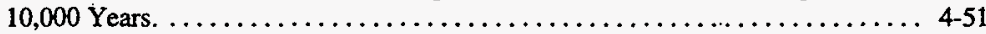

4-26. Effect of Infiltration Rates on Estimated Impacts at 10,000 Years for a Well 100 Meters

Downgradient from the Facility. ............................ 4-53

4-27. Effect of Inventory Changes on Estimated Results at 10,000 Years at a Well 100 Meters

Downgradient from the Facility $\ldots \ldots \ldots \ldots \ldots \ldots \ldots \ldots \ldots \ldots \ldots, 4-58$

4-28. Relative Impact of Pumping Rates on Aquifer Mixing Ratio at a Well

100 Meters Downgradient of the Facility .......................61

4-29. Effect of Different Dose Factor Libraries on the Beta/Photon Drinking Water Dose and

All-Pathways Dose at a Well 100 Meters Down Gradient at 10,000 Years. . . . . . 4-62

4-30. Test of Unit Cell Calculational Assumptions: Normalized Flux

Entering Unconfined Aquifer $\left(K_{d}=0.1 \mathrm{~m} / \mathrm{g}\right) . \ldots \ldots \ldots \ldots \ldots \ldots \ldots \ldots, 63$

4-31. Mixing Factors* from Other Sources for a Well 100 Meters Downgradient of the Low-

Level Tank Waste Disposal Site. .......................... 4-65

432. Maximum Contribution from Contaminants at 10,000 Years at a Well 100 Meters

Downgradient from the Facility, Assuming Instantaneous Vadose Zone Transport, a

Constant Waste Form Release Rate of $4.4 \mathrm{ppm} / \mathrm{y}$, and Concept 1. 


\section{DOE/RL-97-69}

Rev. 0

4-33. Inventory of ${ }^{222} \mathrm{Rn}$ as a Function of Time.

5-1. Driller Intruder Dose (mrem) at Various Intrusion Times (years) . . . . . . . . . . 5-5

5-2. Homesteader Intruder Dose (mrem in a year) at Various Intrusion Times (years) . . . 5-9

6-1. Comparison of Estimated Impacts with Performance Objectives for Protecting

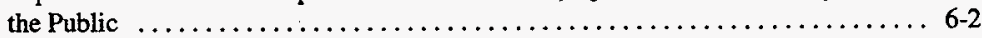

6-2. Comparison of Estimated Impacts with Performance Objectives for Protecting the

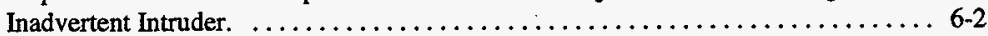

6-3. Comparison of Estimated Impacts with Performance Objectives for Protecting Groundwater Resources. . . . . . . . . . . . .

6-4. Comparison of Estimated Impacts with Performance Objectives for Protecting Surface

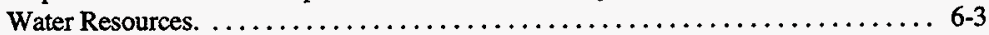

6-5. Comparison of Estimated Impacts with Performance Objectives for Protecting Air Resources. .................................. 64

6-6. Types of Requirements to Be Set $\ldots \ldots \ldots \ldots \ldots \ldots \ldots \ldots \ldots \ldots \ldots \ldots \ldots \ldots$ 6-7

6-7. Waste Acceptance Criteria Based on Protecting Inadvertent Intruder. . . . . . . . . 6-9

6-8. Waste Acceptance Criteria Based on Groundwater Protection . . . . . . . . . 6-11

6-9. Comparison of ILAW Inventory Concentrations to Maximum Concentration Limits. . 6-15

6-10. Comparison of Expected Release Rates to Allowed Release Rates. . . . . . . . . 6-18

B-1. Drinking Water Scenario Dose Factors $\ldots \ldots \ldots \ldots \ldots \ldots \ldots \ldots \ldots \ldots \ldots \ldots \ldots \ldots \ldots$

B-2. All-Pathways Dose Factors $\ldots \ldots \ldots \ldots \ldots \ldots \ldots \ldots \ldots \ldots \ldots \ldots \ldots \ldots \ldots \ldots$

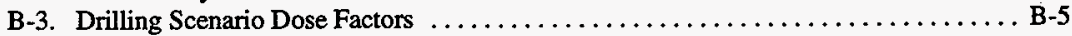

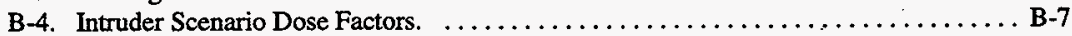

B-5. Ratio of Intruder Dose Factors for $2500 \mathrm{~m}^{2}$ Garden Relative to $500 \mathrm{~m}^{2}$ Garden. . . . . B-12

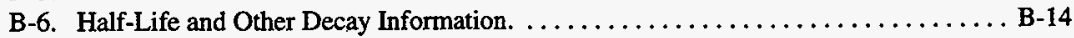

B-7. Ratios of EPA Internal Dose Factors to DOE Values $\ldots \ldots \ldots \ldots \ldots \ldots \ldots \ldots \ldots$ B-17

C-1. List of Reactions Considered in Glass Performance $\ldots \ldots \ldots \ldots \ldots \ldots \ldots \ldots \ldots .4$

E-1. Summary of Vadose Zone Simulations for the Normalized Contaminant Flux Reaching the

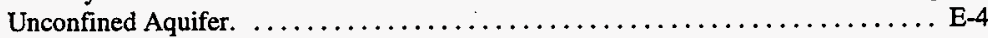

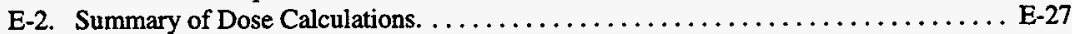

G-4.1. Master Test Matrix for Long Term Performance Evaluation of a Glass . . . . . . . G-27 


\section{DOE/RL-97-69 \\ Rev. 0 \\ Quick Facts}

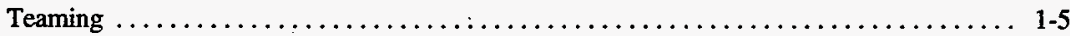

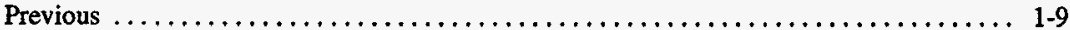

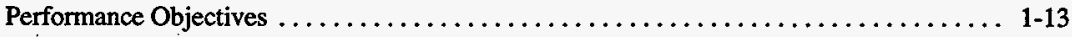

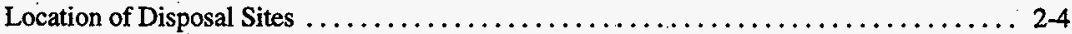

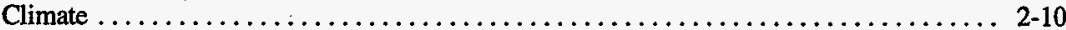

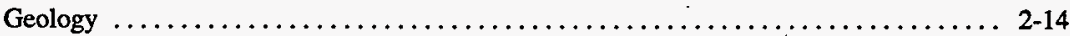

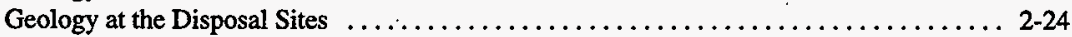

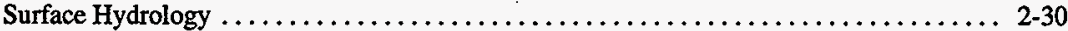

Flooding $\ldots \ldots \ldots \ldots \ldots \ldots \ldots \ldots \ldots \ldots \ldots \ldots \ldots \ldots \ldots \ldots \ldots \ldots \ldots \ldots \ldots \ldots \ldots \ldots \ldots \ldots \ldots, 2-33$

Waste Characteristics ......................................... 2-44

Facility Design $\ldots \ldots \ldots \ldots \ldots \ldots \ldots \ldots \ldots \ldots \ldots \ldots \ldots \ldots \ldots \ldots \ldots \ldots \ldots \ldots \ldots \ldots \ldots \ldots \ldots, 2-50$

Relevant Isotopes $\ldots \ldots \ldots \ldots \ldots \ldots \ldots \ldots \ldots \ldots \ldots \ldots \ldots \ldots \ldots \ldots \ldots \ldots \ldots, 3-1$

Inventory $\ldots \ldots \ldots \ldots \ldots \ldots \ldots \ldots \ldots \ldots \ldots \ldots \ldots \ldots \ldots \ldots \ldots \ldots \ldots \ldots, 3-3$

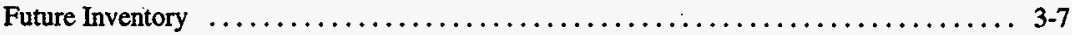

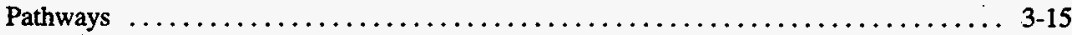

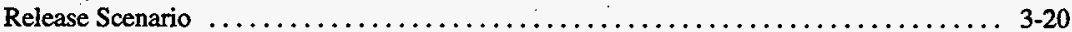

Contaminant Transport $\ldots \ldots \ldots \ldots \ldots \ldots \ldots \ldots \ldots \ldots \ldots \ldots \ldots \ldots \ldots \ldots \ldots \ldots,{ }^{3-21}$

Exposure Scenarios $\ldots \ldots \ldots \ldots \ldots \ldots \ldots \ldots \ldots \ldots \ldots \ldots \ldots \ldots \ldots \ldots \ldots \ldots \ldots \ldots \ldots \ldots \ldots \ldots, 23$

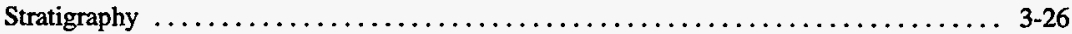

Hydrology $\ldots \ldots \ldots \ldots \ldots \ldots \ldots \ldots \ldots \ldots \ldots \ldots \ldots \ldots \ldots \ldots \ldots \ldots \ldots \ldots \ldots \ldots \ldots \ldots,{ }^{3-28}$

Geochemistry $\ldots \ldots \ldots \ldots \ldots \ldots \ldots \ldots \ldots \ldots \ldots \ldots \ldots \ldots \ldots \ldots \ldots,{ }^{3-31}$

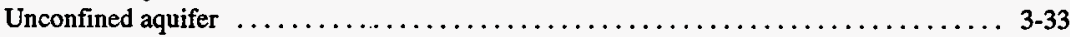

Radionuclide Release Rate $\ldots \ldots \ldots \ldots \ldots \ldots \ldots \ldots \ldots \ldots \ldots \ldots \ldots \ldots, \ldots \ldots \ldots, 3-38$

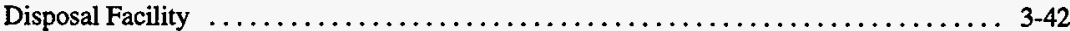

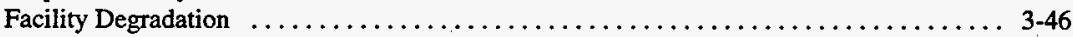

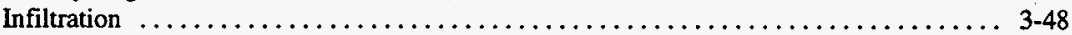

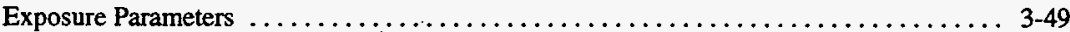

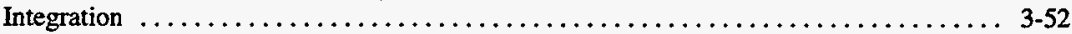

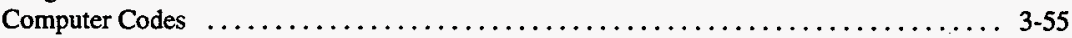

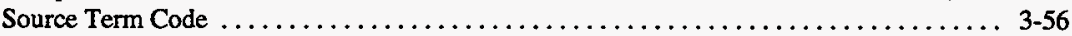

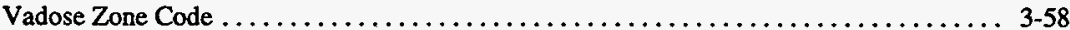

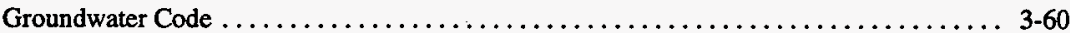

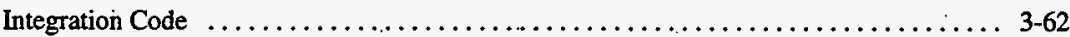

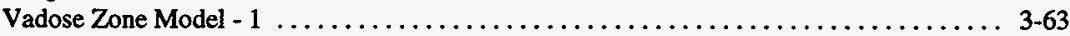

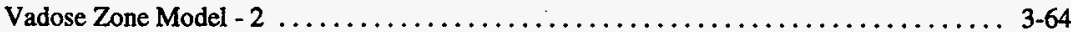

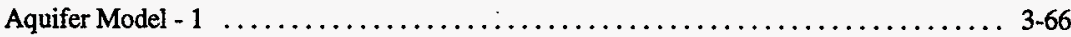

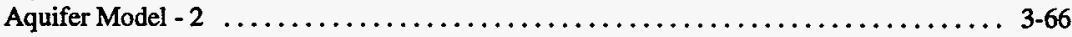

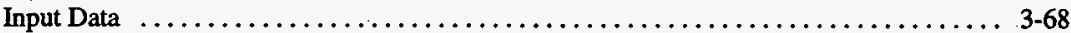

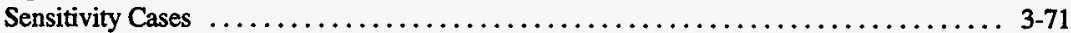

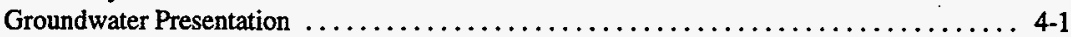

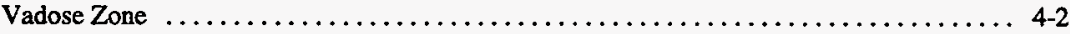

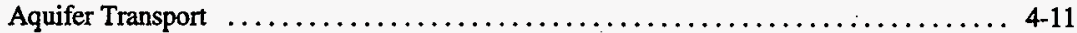

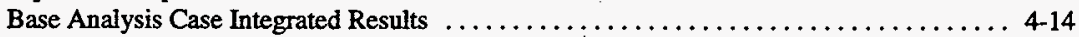


DOE/RL-97-69

Rev. 0

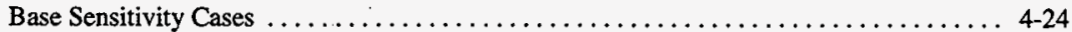

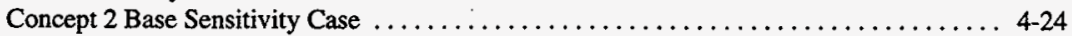

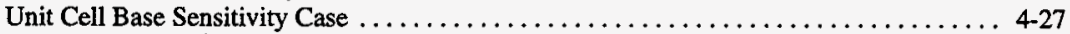

Waste Form Sensitivity Cases $\ldots \ldots \ldots \ldots \ldots \ldots \ldots \ldots \ldots \ldots \ldots \ldots \ldots \ldots \ldots, 4,31$

Facility Sensitivity Cases $\ldots \ldots \ldots \ldots \ldots \ldots \ldots \ldots \ldots \ldots \ldots \ldots \ldots \ldots \ldots \ldots, 4,39$

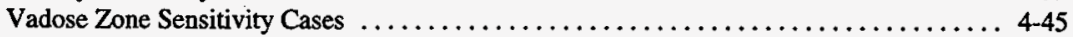

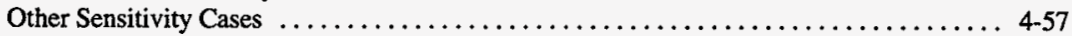

Other Hanford Site Actions $\ldots \ldots \ldots \ldots \ldots \ldots \ldots \ldots \ldots \ldots \ldots \ldots \ldots \ldots \ldots, 4-64$

Effects of Catastrophic Events $\ldots \ldots \ldots \ldots \ldots \ldots \ldots \ldots \ldots \ldots \ldots \ldots \ldots \ldots, 472$

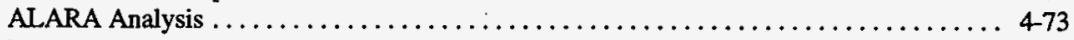

Releases to Air .......................................... 4 44

Inadvertent Intruder Scenarios $\ldots \ldots \ldots \ldots \ldots \ldots \ldots \ldots \ldots \ldots \ldots \ldots \ldots \ldots \ldots \ldots \ldots \ldots \ldots, 1$

Inadvertent Intruder Data $\ldots \ldots \ldots \ldots \ldots \ldots \ldots \ldots \ldots \ldots \ldots \ldots \ldots \ldots \ldots \ldots \ldots \ldots \ldots \ldots, 5,2$

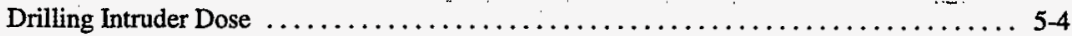

Homesteader Dose $\ldots \ldots \ldots \ldots \ldots \ldots \ldots \ldots \ldots \ldots \ldots \ldots \ldots \ldots \ldots \ldots, 5,7$

Comparison to Performance Objectives $\ldots \ldots \ldots \ldots \ldots \ldots \ldots \ldots \ldots \ldots \ldots \ldots, 6,1$

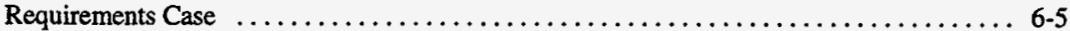

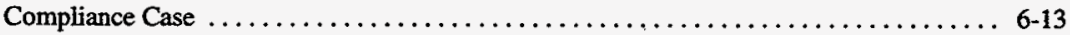




\section{DOE/RL-97-69}

Rev. 0

\section{Acronyms}

$\begin{array}{ll}\text { ALARA } & \text { as low as readily achievable } \\ \text { CERCLA } & \text { Comprehensive Environmental Response, Compensation, and Liability Act } \\ \text { CFR } & \text { Code of Federal Regulations } \\ \text { DNFSB } & \text { Defense Nuclear Waste Safety Board } \\ \text { DOC } & \text { Department of Commerce } \\ \text { DOE } & \text { Department of Energy } \\ \text { EDE } & \text { effective dose equivalent } \\ \text { EIS } & \text { Environmental Impact Statement } \\ \text { EPA } & \text { Environmental Protection Agency } \\ \text { ERC } & \text { Environmental Restoration Contractor } \\ \text { FFTF } & \text { Fast Flux Test Facility } \\ \text { HDW } & \text { Hanford defense waste } \\ \text { HFSUWG } & \text { Hanford Future Site Uses Working Group } \\ \text { HMS } & \text { Hanford Meterology Station } \\ \text { ILAW } & \text { immobilized low-activity waste or immobilized low-activity tank waste } \\ \text { LLW } & \text { low-level waste } \\ \text { NEPA } & \text { National Environmental Policy Act } \\ \text { NRC } & \text { Nuclear Regulatory Commission } \\ \text { OFM } & \text { Office of Financial Management (State of Washington) } \\ \text { PAG } & \text { performance assessment group } \\ \text { PAT } & \text { performance assessment team } \\ \text { PCT } & \text { product consistency test } \\ \text { PNNL } & \text { Pacific Northwest National Laboratory } \\ \text { PUF } & \text { pressurized unsaturated flow (test) } \\ \text { RCRA } & \text { Resource Conservation and Recovery Act } \\ \text { RFP } & \text { request for proposal } \\ \text { SPFT } & \text { single-pass flow through (test) } \\ \text { TPA } & \text { Tri-Party Agreement } \\ \text { TWRS } & \text { Tank Waste Remediation System } \\ \text { VHT } & \text { vapor hydration test } \\ \text { WAC } & \text { Washington (State) Administrative Code } \\ \text { WDAS } & \text { Waste Disposal Authorization Statement } \\ \text { WHC } & \text { Westinghouse Hanford Company } \\ \text { WIT } & \text { waste integration team } \\ \text { WSRC } & \text { Westinghouse Savannah River Company } \\ & \end{array}$




\section{DOE/RL-97-69}

Rev. 0

\subsection{INTRODUCTION}

\subsection{PURPOSE}

This performance assessment examines the long-term environmental and human health effects of the planned Hanford Low-Level Tank Waste Disposal Facility to support the issuance of a Disposal Authorization Statement by the U.S. Department of Energy (DOE) as required by the DOE order on radioactive waste management (DOE Order 5820.2A [DOE 1988a] and its proposed successor, DOE Order 435.1 [DOE 1997a]). This authorization statement would establish DOE's intent to

1) Modify four existing disposal vaults (Project W465),

2) Use these modified vaults for the disposal of immobilized low-activity waste (ILAW) from the treatment of Hanford Site tank waste,

3) Construct the first set of new disposal facilities (Project W520), and

4) Use first set of new disposal facilities for the disposal of ILAW.

Additional performance assessments are planned that will include new information on disposal facility design, expected inventory, additional geotechnical information, and new performance calculations. The additional performance assessments will support construction of follow-on disposal facilities, the use of these facilities, and the closure of all ILAW disposal facilities.

This performance assessment is based heavily on the information and methods used the Hanford Low-Level Tank Waste Interim Performance Assessment (Mann 1997a). This document has benefitted from the comments on the first version of that document and from some newer information. The approach used to prepare this performance assessment document was to

1) Limit its length (the supporting data and definition of analysis cases summarized in this document are fully described in Mann [1995a and 1995b]),

2) Tier from other documents (see, for example, the discussion in Section 1.5.2 on earlier Hanford Site performance assessments and environmental impact statements), and

3) Include detailed results and lengthy technical supporting information in appendices.

\subsection{BACKGROUND}

The Hanford Site, in south-central Washington State (Figure 1-1), has been used extensively for producing defense materials by DOE and its predecessors, the U.S. Atomic Energy Commission and the U.S. Energy Research and Development Administration. Starting 


\section{DOE/RL-97-69}

Rev. 0

in the 1940s, Hanford Site operations were dedicated primarily to producing nuclear weapons materials. In the 1960 s, operations. were expanded to producing electricity from a dual-purpose reactor, conducting diverse research projects, and managing waste. In the late 1980s, the Site's original mission ended. This mission left a large inventory of radioactive and mixed waste stored in buried single- and double-shell tanks in the Hanford Site 200 Areas.

Figure 1-1. Map of the Hanford Site Showing the Locations of the Hanford Low-Level Tank Waste Disposal Facility (HLLTWDF) and of the Existing Disposal Facility (EDF).

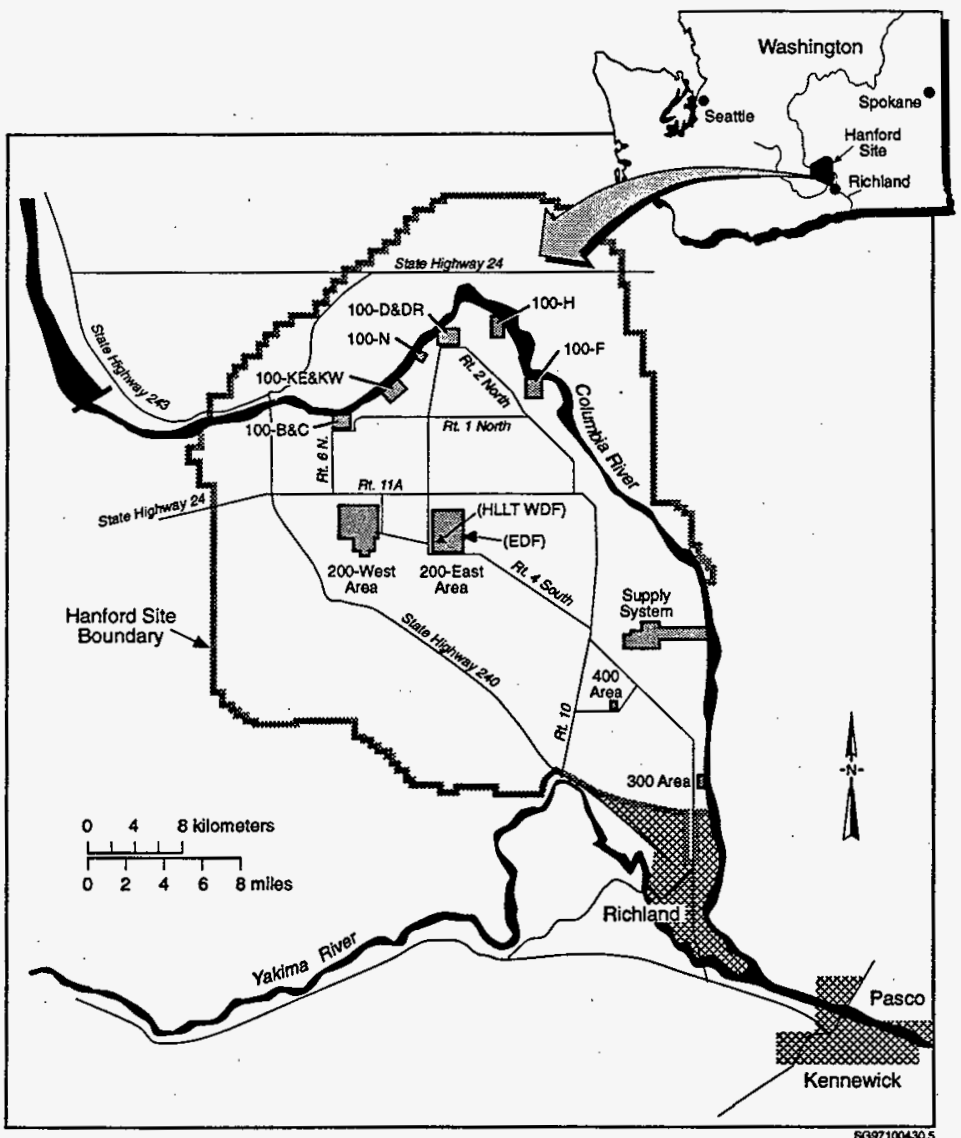




\section{DOE/RL-97-69}

Rev. 0

Today, the Site's missions are environmental restoration, energy-related research, and technology development. As part of its environmental restoration mission, DOE is proceeding with plans to permanently dispose of the waste stored on site. These plans are based on Revision 6 of the Hanford Federal Facility Agreement and Consent Order (Tri-Party Agreement) (Ecology 1996-1) and the Record of Decision for the Tank Waste Remediation Systems Environmental Impact Statement (DOE 1997b). These documents call for the waste to be retrieved from the Hanford Site's single- and double-shell tanks, then treated to separate the low-level fraction (now called the low-activity fraction) from the high-level and transuranic fractions. Both fractions will then be immobilized.

The two products (the small volume of high-level immobilized waste and the much larger volume of low-activity waste) will be disposed of in different locations. The high-level waste will be stored on the Hanford Site until sent to a federal geologic repository. The low-activity immobilized waste will be placed in a near-surface disposal system on the Hanford Site. Over $200,000 \mathrm{~m}^{3}\left(7,000,000 \mathrm{ft}^{3}\right)$ of low-activity immobilized waste will be disposed of under this plan. This is among the largest amounts of waste in the DOE Complex (DOE 1995) and has one of the largest inventories of long-lived radionuclides at a low-level waste disposal facility.

The DOE is proceeding (DOE-RL 1996) to procure privatized services for treating and immobilizing the tank waste. During the spring and summer of 1998, DOE plans to contract with private vendors to produce the ILAW with the first delivery currently scheduled in July 2002. The first phase of the effort would extend for about a decade. The contract for the second phase, in which most of the waste will be processed, will be awarded in the second half of the decade.

\subsection{GENERAL DESCRIPTION OF THE FACILITY}

This section provides a general description of the disposal facilities. Section 2.3 provides much more information including figures showing the conceptual and preconceptual designs.

Based on an investigation of various disposal alternatives (Burbank 1997), the current plan (Shade 1997) for the disposal of immobilized low-activity tank waste (ILAW) is as follows:

1) Modify, and then use, the four existing underground disposal vaults at the eastern edge of the 200 East Area

2) Design, construct, and use concrete vaults in the middle of the southern edge of the 200 East Area

3) Design and construct disposal facilities (possibly of different design) in the middle of the southern edge of the 200 East Area and use them to dispose of the ILAW. 


\section{DOE/RL-97-69}

Rev. 0

The four existing vaults (KEHC 1991) were built as part of the program to dispose of double-shell tank waste using a grout waste form (Project B-714). All four are large, having interior dimensions of $37.64 \mathrm{~m}(123.5 \mathrm{ft})$ long by $15.39 \mathrm{~m}(50.5 \mathrm{ft})$ wide and $10.36 \mathrm{~m}(34.0 \mathrm{ft})$

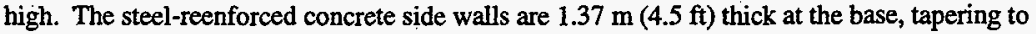
$0.61 \mathrm{~m}(2.0 \mathrm{ft})$ at the top. The end walls have a constant thickness of $7.6 \mathrm{~m}(2.5 \mathrm{ft})$. The concrete pad is $1.37 \mathrm{~m}(4.5 \mathrm{ft}$ ) thick and is flat and level. The concrete roof, made of 29 panels $1.22 \mathrm{~m}(4 \mathrm{ft})$ wide, is $0.66 \mathrm{~m}(2.17 \mathrm{ft})$ thick. The entire structure of each vault is encased in a bituminous sealant and geotextile system, up to $0,91 \mathrm{~m}(3.0 \mathrm{ft})$ thick. Each vault is built above a RCRA-compliant leak detection and collection system.

The planned vault modification (Pickett 1997) consists of removing the roof and associated panels and changing the access of the leachate collection system slightly. This project (W-465) was started based on the assumption that these vaults would be used as interim storage facilities for $\mathrm{LAW}$. However, the project is evaluating the impacts of a change to a disposal mission.

The capacity of the existing vaults is less than 10 percent of the projected need for all ILAW produced during the two phases. The conceptual design activity for the first set of additional facilities (Project W-520) is now in progress. These facilities are expected to be concrete vaults of a simpler design than the existing disposal vaults. Two conceptual ideas (Eiholzer 1995 and Burbank 1997) have been considered. Eiholzer (1995) envisioned immobilized waste being disposed of in vault bays similar in size to the four existing vaults. Six of these bays could be joined lengthwise to form a vault row. Seven vault rows would be needed to house the total inventory. Eiholzer (1995) proposed two options for vault row layout: one in which the vault rows are placed side by side and the other in which the vault rows are separated by a vault-width of backfilled soil. Burbank's (1997) concrete vault concept is similar except that the vault is roughly half as long as the existing disposal vault and the layout of the vault rows is different. Burbank (1997) envisioned 10 sets of vault rows each with two set of vaults separated by an access road. Such a layout would allow a vault row to be customized depending on the radiation level and RCRA status of the waste being received. The Burbank (1997) concept is now the basis for future engineering studies. This concept is derived from disposal technology currently in use in France.

These initial vaults of the next-generation disposal facility are being designed to handle waste of the worst case allowed by the specifications for the ILAW packages (DOE-RL 1996). It is expected that the characteristics of many $\amalg \mathrm{LW}$ packages would allow for simpler and less expensive vaults; therefore, succeeding disposal facilities may not be concrete vaults (see Section 2.4.2). However, it is assumed that all disposal facilities meet the performance characteristics of the project W-520 preconceptual design.

All the disposal systems include a set of barriers. Sand-gravel capillary barriers would be placed over the vaults to divert water around the vault to minimize infiltration. Each disposal facility also would be capped by a surface barrier to minimize water, plant, animal, and human intrusion. 
DOE/RL-97-69

Rev. 0

\subsection{IMMOBILIZED WASTE PROGRAM}

The Tank Waste Remediation System (TWRS) is the group at the Hanford Site responsible for the safe underground storage of the liquid waste from previous Hanford Site operations, the storage and disposal of the immobilized tank waste, and the closure of the underground tanks. The TWRS's Immobilized Waste Program is responsible for

- Designing the disposal facilities for the immobilized low-activity tank waste

- Operating the disposal facilities

- Closing the disposal facilities

- Designing, using, and decommissioning of the facilities for storing the immobilized high-level waste until it is shipped to a federal geologic repository.

As noted in Section 1.3, two sets of disposal facilities are planned. The first, the existing disposal vaults, will be modified to receive the immobilized low-activity waste. The second set will consist of new facilities, possibly of different designs. Table 1-1 presents the schedule for the design of these activities.

Figure 1-2 illustrates the current baseline planning logic for the Immobilized.LowActivity Disposal Project within the Immobilized Waste Program. The performance assessment activity is closely connected with other parts of the Immobilized Waste Program.

The Immobilized Waste Program has established a performance assessment team of leading Hanford Site geotechnical and waste-form experts. The team is supported by Site staff as well as scientists and engineers from around the DOE complex (particularly from the Argonne National Laboratory). The leader of the performance assessment team has been on the decision board for

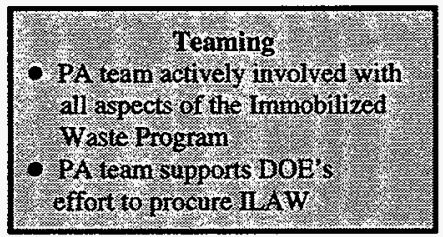
preconceptual design studies and interacts with the engineering and architect-engineering staff on the design. In addition, the team is cooperating closely with the DOE group procuring the immobilized low-activity waste form. Current specifications for waste form performance are based heavily on performance assessment activities. Future modifications to the waste form specifications will also be based on what is learned in the performance assessment activity. Finally, the performance assessment team is closely involved in characterizing (or identifying) the waste inventory. 
DOE/RL-97-69

Rev. 0

Table 1-1. Schedule for ILAW Disposal Facilities.

\begin{tabular}{|c|c|c|}
\hline Description & Date & \\
\hline \multicolumn{3}{|l|}{ Existing Disposal Vaults } \\
\hline Construction of four concrete vaults & & 1991 \\
\hline Issue conceptual design for modification of vauits & December & 1997 \\
\hline Issue detailed design for modification of vaults & March & 2001 \\
\hline Complete modifications of vaults & April & 2002 \\
\hline Start use of existing vaults & June & 2002 \\
\hline Fill the existing vaults & August & 2005 \\
\hline Close the existing vaults & approximately & 2010 \\
\hline \multicolumn{3}{|l|}{ New Facilities } \\
\hline Issue engineering studies & October & 1997 \\
\hline Issue conceptual design for first set of next generation facilities & December & 1998 \\
\hline Issue detailed design for first set of next generation facilities & September & 2002 \\
\hline Complete construction of first set of next generation facilities & October & 2004 \\
\hline Start use of first set of next generation facilities & September & 2005 \\
\hline Fill first set of next generation facilities & September & 2011 \\
\hline Construct and use additional disposal facilities & $\ldots$ & \\
\hline Receive last container of waste & July & 2025 \\
\hline Close last disposal facility & April & 2034 \\
\hline
\end{tabular}

The performance assessment activity supports design, use, and closure of the disposal facilities. Thus the schedule for producing performance assessment documents is iterative. The timing of future performance assessments will depend on the amount of authority granted in the Disposal Authorization Statement. As shown in Table 1-2, present planning (DOE-RL 1997) has the next performance assessment scheduled to be issued in 2001. The next performance assessment would use additional information to support operation of the existing disposal facilities and the construction of additional facilities. Maintenance performance assessments would start with the performance assessment issued in 2003 and would be issued as needed until the final closure performance assessment is issued in about 2027. Performance assessments would deal with closing filled vaults as part of the maintenance performance assessment cycle. 


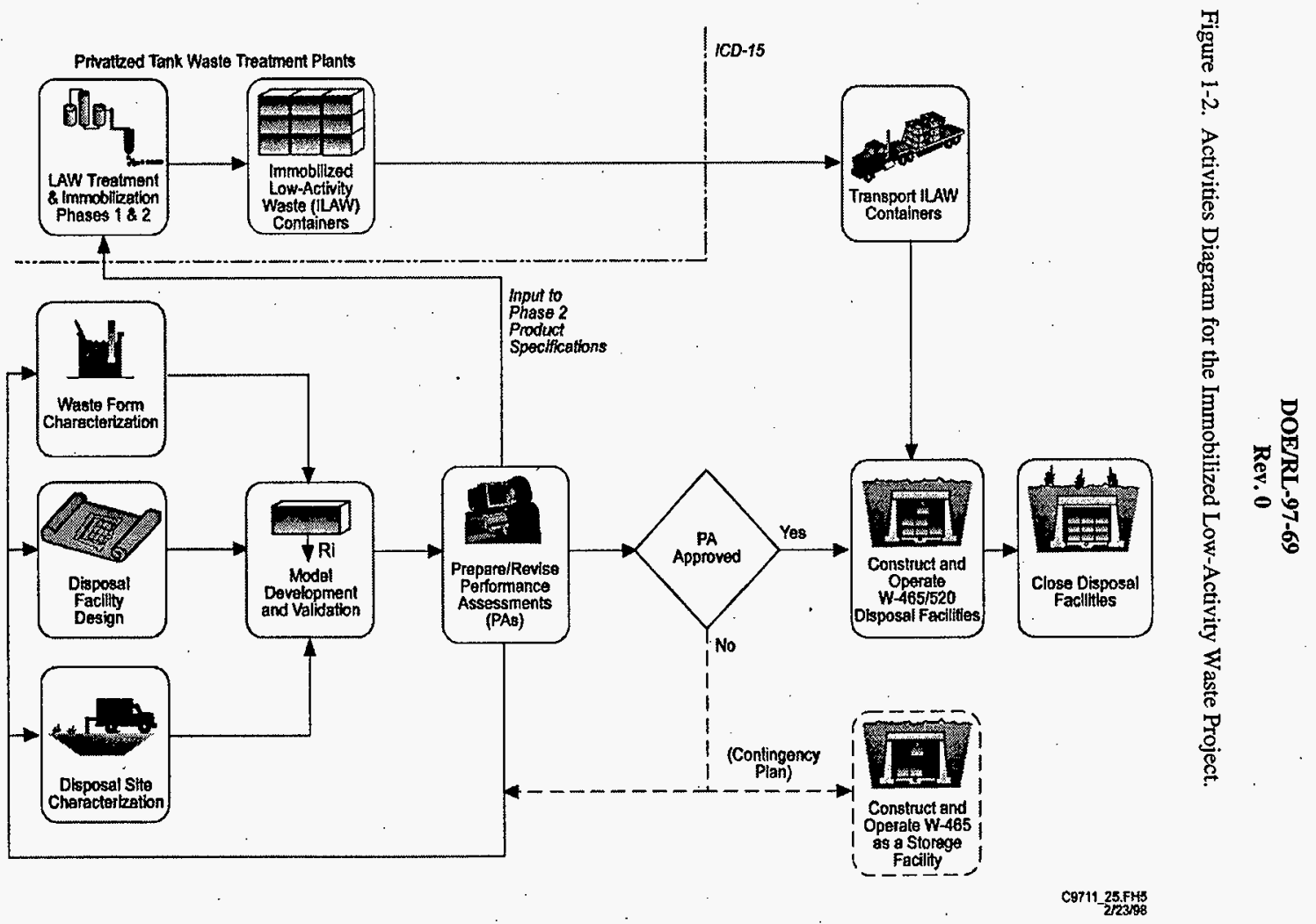


DOE/RL-97-69

Rev. 0

Table 1-2. Schedule for Performance Assessment Activities.

\begin{tabular}{|c|c|c|}
\hline Revision & Purpose & Date of Issue \\
\hline \multicolumn{3}{|c|}{ Interim Performance Assessment } \\
\hline Rev. 0 & $\begin{array}{l}\text { Document potential impacts as early in project's life as } \\
\text { possible. }\end{array}$ & September 1996 \\
\hline Rev. 1 & $\begin{array}{l}\text { Revise Rev. } 0 \text { based on comments, especially those of an } \\
\text { external advisory board. }\end{array}$ & September 1997 \\
\hline \multicolumn{3}{|c|}{ Performance Assessment } \\
\hline $\begin{array}{l}\text { Rev. } 0 \\
\text { (This } \\
\text { document) }\end{array}$ & $\begin{array}{l}\text { Support application for Disposal Authorization Statement to } \\
\text { modify existing disposal facilities, use existing disposal } \\
\text { facilities, construct the first generation of new disposal } \\
\text { facilities, and use the new disposal facilities. }\end{array}$ & March \\
\hline Rev. 1 & $\begin{array}{l}\text { Update Rev. } 0 \text { based on results of waste form performance } \\
\text { testing and simulations, geotechnical data collection and } \\
\text { analysis, design activities, and TWRS Standard Inventory } \\
\text { effort. The impacts of } 1998 \text { contracts between DOE and the } \\
\text { private vendors to immobilize low-activity waste also will be } \\
\text { determined. }\end{array}$ & March \\
\hline Rev. 2 & $\begin{array}{l}\text { Update Rev. } 1 \text { to support construction and use of second } \\
\text { generation of new disposal facilities. Rev. } 2 \text { will be based on } \\
\text { additional performance assessment activity data collection } \\
\text { and analysis (especially testing waste forms under production } \\
\text { conditions) and new design and construction information. }\end{array}$ & September 2003 \\
\hline Rev. 3 & $\begin{array}{l}\text { Update Rev. } 2 \text { to support closure of existing disposal } \\
\text { facilities and possible use of other Hanford Site facilities. } \\
\text { Rev. } 3 \text { will be based on using actual inventories disposed of } \\
\text { in the existing facilities, additional data collection, and } \\
\text { engineering studies investigating the use of other Site } \\
\text { facilities. }\end{array}$ & September 2008 \\
\hline Rev. 4 & Update Rev. 3 using new data & September 2013 \\
\hline Rev. 5 & Update Rev. 4 using new data & September 2018 \\
\hline Rev. 6 & Update Rev. 5 using new data & September 2023 \\
\hline Rev. 7 & $\begin{array}{l}\text { Update Rev. } 6 \text { to support closure of all immobilized low- } \\
\text { activity waste disposal facilities. }\end{array}$ & September 2028 \\
\hline
\end{tabular}


DOE/RL-97-69

Rev. 0

\subsection{RELATED DOCUMENTS}

This section discusses the most important of the environmental assessments completed for the Hanford Site as well as the documents used to provide guidance for the preparation of this document.

$\rightarrow \rightarrow$ See Section 16 for documents supporting the setting of performance ebjectives.

$\rightarrow \rightarrow$ See Sections 3 , and 34 for documents justifying data used in this document

\subsubsection{Other Relevant Hanford Site Environmental Assessments}

Many environmental assessments have been performed at the Hanford Site. They can be classified as documents pertaining to the disposal of immobilized low-activity tank waste, as documents fulfilling the requirements of DOE's order on radioactive waste management, or as more general documents.

1.5.1.1 Previous Work Related to the Proposed Disposal Action. A number of reports have been published on environmental aspects of ILAW disposal.

This performance assessment is based heavily on the Hanford Low-Level Tank Waste Interim Performance Assessment (Mann 1996a and Mann 1997a). This document uses the data and analyses developed for those assessments and incorporates the comments made on those analyses. The interim performance assessment was designed to provide the best available analysis given limited project-specific data. The revision of the interim performance assessment was based on comments received on Mann (1996a).

\section{Data Packages for the Hanford Low-Level Tank Waste Performance Assessment} (Mann 1995a) and Definition of the Base Analysis Case of the Interim Performance Assessment (Mann 1995b) defined the data used in the interim performance assessments. The document covering the data packages document (Mann 1995a) provided justification for the values used in the analysis. The definition document (Mann 1995b) defines all data to be used in the interim performance assessment and the sensitivity cases studied. These documents serve the same purpose for this performance assessment.

Revisions 0 (Rawlins 1994) and 1 (Mann 1995d) of Impacts of Disposal System Design Options on Low-Level Glass Waste Disposal System Performance provided sensitivity analyses of the long-term environmental impact based on various design features for the low-level tank waste disposal facility. The first analysis was updated based on better data and on the comments received on Revision 0. Neither report is as comprehensive as this performance assessment. 
1.5.1.2 Other Hanford Site Project-Specific Performance Assessments. This document also builds on the previous performance assessments prepared for the Hanford Site. These performance assessments were prepared under the requirements of DOE Order 5820.2A (DOE 1988a) for other Hanford Site disposal actions. These documents currently are in various stages of review and approval. All performance assessments prepared under Order 5820.2A were reviewed by the Peer Review Panel (established by the order) for technical adequacy. This panel performs a preliminary review, a completeness review, and a final review for each performance assessment. Then, DOE-Headquarters reviews the documents and may provide approval for the disposal action if the performance assessment satisfies the requirements of Order 5820.2A.

The Long-Term Performance Assessment of Grouted Phosphate/Sulfate Waste from $N$ Reactor Operations (Stewart 1987) forms the basis of the environmental assessment (DOE 1986a) for the disposal of low-level radioactive waste generated by decontamination operations and other activities associated with $\mathrm{N}$ Reactor operations. Because this performance assessment predates the DOE order on radioactive waste management, the DOE review was conducted by reviewing the environmental assessment.

The Performance Assessment of Grouted Double-Shell Tank Waste Disposal at Hanford (Kincaid 1995) dealt with disposing of low-level liquid waste from the double-shell tanks. The waste was to be combined with cement, flyash, and clay to form a grout that would be poured into large subsurface vaults located to the east of the 200 East Area. The grout performance assessment was approved in principle by the Peer Review Panel (Wilhite 1994). DOE (Lytle 1995) found that the analysis performed in Kincaid (1995) was "technically adequate and provides reasonable assurance that the selected performance objectives would be met." Noting, however, that the grout project had been canceled, DOE also stated that a new or revised performance assessment would be needed for routine disposal of waste in the Grout Disposal Facility.

The Performance Assessment for the Disposal of Low-Level Waste in the 200 West Area Burial Grounds (Wood 1994b) dealt with the solid waste from operations at the Hanford Site and other sites. This waste is placed into trenches in the westem part of the 200 West Area and then covered with a Resource Conservation and Recovery Act of 1976 (RCRA)-compliant barrier. The Peer Review Panel found the performance assessment to be technically acceptable. The 200 West Area performance assessment has been "conditionally accepted" by DOEHeadquarters (Cowan 1996). The conditions were related to added documentation.

The Performance Assessment for the Disposal of Low-Level Waste in the 200 East Area Waste Burial Grounds (Wood 1996) addresses waste that is similar to that addressed in the 200 West Area performance assessment. However, the disposal trenches for this waste are in the northern part of the 200 East Area. The final performance assessment for this action has also been conditionally approved by DOE-Headquarters (Frei 1997). 
DOE/RL-97-69

Rev. 0

The Environmental Remediation Disposal Facility Performance Assessment (Wood 1995) was written to support disposal of waste generated by the cleanup of the Hanford Site. Most of this waste is expected to be contaminated soil. Trenches are planned to be the main means of disposal at the facility. Because the Environmental Remediation Disposal Facility is regulated under the Comprehensive Environmental Response, Compensation, and Liability Act of 1980 (CERCLA), this performance assessment was not submitted to the Peer Review Panel. However, a remedial investigation and feasibility study report (DOE-RL 1993d) was written.

1.5.1.3 More General Hanford Site Environmental Assessments. A series of general environmental assessments also have been written for Hanford Site activities. They look at the Hanford Site as a whole or address environmental impacts in a more general manner.

The Composite Assessment for Hanford Site (Kincaid 1998) is being prepared in response to Recommendation 94-2 of the Defense Nuclear Facilities Safety Board to the Secretary of the Department of Energy [DNFSB 1994]. The recommendation noted the need for a risk assessment that investigates the environmental impacts of all radioactive waste disposal actions or leaks at a DOE Site. The authors of the composite assessment are working with the authors of the previous performance assessments to maximize consistency in data and methods. The first version of this analysis was published recently and is undergoing review by DOE. Along with approval of this performance assessment, DOE Order 435.1 requires the approval of the Site's composite analysis before a Disposal Authorization Statement can be issued.

The Environmental Impact Statement for the Tank Waste Remediation System (TWRS EIS) (DOE 1996b) analyzed various options to manage the Hanford Site's tank waste with the record of decision issued early last year (DOE 1997b). Because of the scope of the TWRS EIS, the analyses relied on data less complete and less project-specific than this performance assessment. The record of decision includes the disposal of ILAW in the Hanford Site 200 Areas.

The Hanford Remedial Action Environmental Impact Statement and Comprehensive Land Use Plan (DOE 1996c) analyzes the potential impacts, primarily from remediation activities, associated with establishing future land-use objectives for the Hanford Site. The document also proposes a land-use plan for near-future activities. TWRS activities were not extensively considered because they were part of the EIS and land-use plan.

\subsubsection{Regulatory Agreements and Documents}

The Federal Facility Agreement and Consent Order (Tri-Party Agreement) (Ecology et al. 1996) is an agreement between DOE, the U.S. Environmental Protection Agency (EPA), and the Washington State Department of Ecology (Ecology) concerning the cleanup of the Hanford Site. The Tri-Party Agreement has legally enforceable milestones, some of which (the M90 series) cover the Immobilized Waste Program. Milestone M90-05T (due in March 2002) requires that DOE submit a copy of the performance assessment to Ecology for comment when it submits the document to DOE Headquarters for approval. 
Rev. 0

The DOE has written a groundwater protection management plan (DOE-RL 1995c) with Ecology's approval. However, the management plan's current version does not address longterm protection of the groundwater resource.

\subsubsection{Guidance Documents}

Because DOE Order 435.1 (DOE 1997a) is not yet official, the guidance (DOE 1997c) associated with it is not yet well tested. Therefore the following additional documents also were used as guidance in preparing this performance assessment:

- Critical Assumptions for Department of Energy Low-Level Waste Disposal Facility Assessments (Alm 1997)

- Issuance of Low-Level Waste Performance Assessment Guidance (Frei 1996)

- Recommended Format and Content for DOE Low-Level Waste Disposal Facility Radiological Performance Assessment Reports, DOE/LLW-81 (Case 1989)

- Performance Assessment Review Guide for Low-Level Radioactive Wasie Disposal Facility, DOE/LLW-93 (Dodge 1991)

- Proceedings of the Department of Energy Performance Assessment Briefing, Denver, Colorado, October 29; 1991, DOE/LLW-138 (NLLWP 1992)

- Performance Assessment Task Team Progress Report, Revision I, DOE/LLW-157 (Wood 1994a)

- A Compilation of DOE Performance Assessment Peer Review Panel Review Comments and Recommendations, DOE/LLW-216 (RWSTP 1994).

- DOE Headquarters Review of the "Performance Assessment of Grouted DoubleShell Tank Waste at Hanford" (Lytie 1995).

- Implementation Plan, Defense Nuclear Facilities Safety Board Recommendation 94-2, Compliance with Safety Standards at Department of Energy Low-Level Nuclear Waste Sites (DOE 1996a).

Performance assessments from other DOE sites and the comments on those studies are also reviewed to understand different approaches and methods. 


\subsection{PERFORMANCE OBJECTIVES}

\subsubsection{Summary}

The DOE's requirements for waste disposal (DOE 1988a, DOE 1997a, and DOE-RL 1993a) can be summarized as follows:

- Protect public health and safety

- Protect the environment.

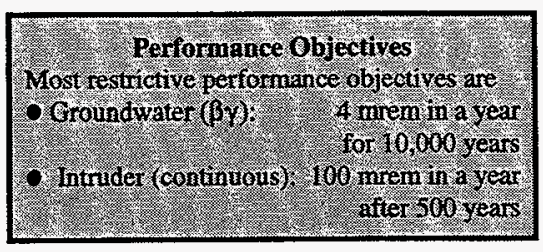

Most of the waste disposal requirements are general (for example: "protect groundwater resources consistent with Federal, State, and local requirements") or indirectly reference other requirements (for example: "releases to the atmosphere shall meet the requirements of 40 CFR $61^{\prime \prime}$ ). A few of the requirements state quantitative limits such as the limit of $25 \mathrm{mrem}$ in a year for all exposures.

For this performance assessment, the following methods were used to establish the quantitative performance objectives as explained in Performance Objectives of the Tank Waste Remediation Systems Low-Level Waste Disposal Program, (PAT 1995a):

- Investigate all potentially applicable regulations as well as interpretations made by the Peer Review Panel (Section 1.6.2)

- Work with Immobilized Waste Project management to establish their needs (Section 1.6.3)

- Work with the Hanford Site stakeholders to understand the values of residents in the Pacific Northwest (Section 1.6.4).

These efforts produced the performance objectives used in this performance assessment. Performance Objectives presented in Table 1-3 are values in additional to any existing amounts or background.

Table 1-3. Performance Objectives. ${ }^{\text {ab }}$

\begin{tabular}{|lr|}
\hline \multicolumn{2}{|c|}{ Protection of General Public and Workers } \\
\hline $\begin{array}{l}\text { All-pathways dose from only this facility } \\
\text { All-pathways dose including other Hanford Site sources }\end{array}$ \\
$\begin{array}{l}\text { ALARA [As low as reasonably achievable] } \\
\text { (treated as an integrated all-pathways dose) }\end{array}$ & 25 mrem in a year ${ }^{c, e, i}$ \\
\hline
\end{tabular}


Table 1-3. Performance Objectives. $a, b$

\begin{tabular}{|c|c|}
\hline \multicolumn{2}{|c|}{ Protection of an Inadvertent Intruder ${ }^{\mathrm{d}, \mathrm{g}}$} \\
\hline $\begin{array}{l}\text { Acute exposure } \\
\text { Continuous exposure }\end{array}$ & $\begin{array}{r}500 \text { mrem } \\
100 \text { mrem in a year } \\
\end{array}$ \\
\hline \multicolumn{2}{|c|}{ Protection of Groundwater Resources ${ }^{c, e, l}$} \\
\hline $\begin{array}{l}\text { Alpha emitters } \\
\qquad{ }^{226} \mathrm{Ra}+{ }^{228} \mathrm{Ra} \\
\text { All others (total) } \\
\text { Beta and photon emitters }\end{array}$ & $\begin{array}{r}5 \mathrm{pCi} / \mathrm{l} \\
15 \mathrm{pCi} / \mathrm{l} \\
4 \mathrm{mrem} \text { in a year } \\
\end{array}$ \\
\hline \multicolumn{2}{|c|}{ Protection of Surface Water Resources ${ }^{c, h}$} \\
\hline $\begin{array}{l}\text { Alpha emitters } \\
\quad{ }^{226} \mathrm{Ra}+{ }^{228} \mathrm{Ra} \\
\text { All others (total) } \\
\text { Beta and photon emitters }\end{array}$ & $\begin{array}{r}0.3 \mathrm{pCi} / \ell^{k} \\
15 \mathrm{pCi} / \ell^{1} \\
1 \text { mrem in a year }\end{array}$ \\
\hline \multicolumn{2}{|c|}{ Protection of Air Resource } \\
\hline $\begin{array}{l}\text { Radon } \\
\text { All other radionuclides }\end{array}$ & $\begin{array}{r}20 \mathrm{pCi} \mathrm{m}^{-2} \mathrm{~s}^{-1} \\
10 \mathrm{mrem} \text { in a year }\end{array}$ \\
\hline
\end{tabular}

- Taken from Performance Objectives of the Tank Waste Remediation Systems Low-Level Waste Disposal Program (PAT 1995a), except for the limit that includes other Hanford Site sources which is taken from DOE 1996.

${ }^{b}$ All doses are calculated as effective dose equivalents; all concentrations are in water taken from a well. Values given are in addition to any existing amounts or background.

${ }^{c}$ Evaluated for 10,000 years, but calculated to the time of peak or 10,000 years, whichever is longer.

${ }^{\circ}$ Evaluated for 500 years, but calculated to 1,000 years.

'Evaluated at the point of maximal exposure, but no closer than 100 meters ( 328 feet) from the disposal facility.

${ }^{f}$ Evaluated at the 200 East Area fence.

${ }^{8}$ Evaluated at the disposal facility.

${ }^{b}$ Evaluated at the Columbia River, no mixing with the river is assumed.

'Main driver is DOE Order 5820.2A, Radioactive Waste Management (DOE 1988a)

' Main driver is DOE Order 5400.5, Radiation Protection of the Public and the Environment (DOE 1993).

${ }^{k}$ Main driver is RL Implementing Directive 5820.2A, Radioactive Waste Management (DOE-RL 1993).

'Main driver is "National Primary Drinking Water Regulations". (40 CFR 141).

"Main driver is "Washington State Surface Water Standards" (WAC 173-201A)

"Main driver is "National Emission Standards for Hazardous Air Pollutants" (40 CFR 61H and 40 CFR 610 ). 


\section{DOE/RL-97-69}

Rev. 0

Most of these performance objectives are consistent with the guidance for draft DOE Order 435.1. The two exceptions are the use of the site's groundwater protection plan for setting the groundwater protection requirements and the time of compliance for groundwater protection. The present version of the Hanford Site Ground Water Protection Management Plan (DOE-RL 1995c) does not address the long-term protection of groundwater resources so federal drinking water standards were used. The guidance for draft DOE Order 435.1 is that the time of compliance is 1,000 years for resource protection. However, because the source of this waste is high-level waste, the U.S. Nuclear Regulatory Commission (NRC) must review

(Paperiello 1997) that the protection the DOE is providing equals the protection that the NRC would provide. Therefore, the more conservative compliance time used by the NRC is used in this performance assessment. established.

The following sections summarize how the quantitative performance objectives were

\subsubsection{Regulations and Other Performance Assessments}

1.6.2.1 Introduction. Several Federal and State regulations potentially apply to how well the public health and safety and the environment must be protected. The following categories of requirements were reviewed for relevance to this proposed disposal action:

- Protection of the general public

- Protection for workers

- Protection of the inadvertent intruder

- Protection of groundwater resources

- Protection of surface water resources

- Protection of air resources.

Appendix B of PAT (1995a) lists the regulations that were reviewed and judged to be potentially relevant to this proposed disposal action. Some regulations and general environmental acts were judged not relevant to the performance assessment activity for one or more of the following reasons,

- $\quad$ Requirements are the responsibility of other participants in the Immobilized Waste Program (for example, ensuring compliance with the National Environmental Policy Act [NEPA]).

- Requirements are for different environmental actions (for example, the Comprehensive Environment Response, Compensation, and Liability Act of 1980 [CERCLA]).

- Requirements deal with general environmental concerns such as the protection of endangered species that are thought to be adequately covered for the long-term by the regulations presented here. 


\title{
DOE/RL-97-69
}

Rev. 0

-

\begin{abstract}
Requirements are only at a preliminary stage and are likely to change, (e.g., the "Radiation Site Cleanup Regulation" [proposed Title 40 Code of Federal Regulations (CFR) Part 196] and "Environmental Radiation Standards for Management and Disposal of Low-Level Waste" [proposed 40 CFR Part 193] from the EPA\}. The development of these requirements will be closely followed and the requirements will be incorporated as appropriate.
\end{abstract}

Performance assessments of low-level waste disposal in the DOE complex were reviewed also to identify any regulations relevant to this proposed disposal action. These assessments provide "case law" interpretations. Appendix C of PAT (1995) lists the other performance assessments in the DOE complex, as well as their performance objectives.

In their review of the Interim Performance Assessment (Mann 1997a), the staff of the NRC (Paperiello 1997) indicated that meeting the performance objectives in that performance assessment (which are the same as the ones in this document) would meet the performance objectives of the NRC regulations (10 CFR 61-3).

1.6.2.2 Protection of the General Public. For this assessment, the performance objective for the protection of the general public is 25 mrem (effective dose equivalent [EDE]) in a year. This value is used consistently in the regulations (DOE 1988a and 10 CFR 61-3) and was used in the past performance assessments. Although other methods are available for determining body dose (PAT 1995a), the effective dose equivalent method was selected because regulations normally use this method. The location for compliance is at the point of maximal exposure, but not less than 100 meters (328 feet) from the disposal facility (Wood 1994a, DOE 1997a).

The Defense Nuclear Facilities Safety Board (DNFSB 1994) noted that a member of the public could receive exposures from several sources at a DOE site. Guidance from DOEHeadquarters (DOE 1996a) is that protection of the general public from multiple sources should be based on Radiation Protection of the Public and the Environment, DOE Order 5400.5 (DOE 1993-1). This order sets a limit of 100 mrem in a year from all sources. The interpretation of DOE Order 5400.5 places the point of compliance at the fence line of the future site. For the Hanford Site, this is considered to be a fence surrounding the present Hanford Site 200 Areas. The Hanford Site Composite Analysis (Kincaid 1998) shows compliance with this requirement.

Little guidance is provided on the interpretation of ALARA (as low as reasonably achievable). The Immobilized Waste Program is integrating design and safety (including environmental considerations) into a single program so that the effects can be minimized. The iterative approach uses environmental and safety analyses of preconceptual designs (see Mann 1996a), followed by preliminary and detailed designs using the results of those analyses, followed by more complete environmental and safety analysis (for example, successors to this document). Disposal facility components will be incorporated whenever their inclusion significantly adds protection to human health or to the environment. For this assessment, the requirements found in U.S. Department of Energy, Richland Operations Office (RL) Implementing Directive 5820.2A, Radioactive Waste Management (DOE-RL 1993), were used. 
This requirement gives as low as reasonably achievable (ALARA) doses as an integrated dose for all pathways of 500 person-rem in a year.

The compliance time for this performance assessment is 10,000 years. (The compliance time is the time starting 100 years from the present over which the predicted dose must remain below the performance objectives.) However, the calculation was carried out to the time of maximum impact if that time is longer than 10,000 years. This compliance time is significantly longer than that included in the guidance for draft DOE Order 435.1 (1,000 years).

The compliance time used is, however, consistent with the compliance time used by the NRC [see, for example, the Branch Technical Position on a Performance Assessment Methodology for Low-Level Radioactive Waste Disposal Facilities (NRC 1997-10)]. Because the waste being disposed of is derived from high-level waste, the NRC has indicated that DOE must protect the public and the environment consistent with NRC standards (Paperiello 1997). Thus, the more conservative time of compliance is used in this performance assessment. The time of compliance used here is consistent with that used in the other Hanford Site performance assessments: the Grout Performance Assessment (Kincaid 1995-1), the 200 West Area Solid Waste Performance Assessment (Wood 1994b-1), and the 200 East Area Solid Waste Performance Assessment (Wood 1996-1).

1.6.2.3 Protection for Workers. For this performance assessment, as for others performed under DOE Order 5820.2A, no distinction is made between performance objectives for workers and for the general public. Because the protection requirements for the general public are more restrictive than those for the workers, the workers will be adequately protected. Protection for workers during construction and operations will be addressed in the safety analysis report that will be written for the Immobilized Waste Program.

1.6.2.4 Protection of the Inadvertent Intruder. The exposure limits for protecting a hypothetical inadvertent intruder are consistent with the regulations (DOE 1988a and 10 CFR 61-3) and with earlier performance assessments. (Appendix Tables B-2 and C-2 in PAT 1995a, respectively, give details). These limits are $500 \mathrm{mrem}$ (EDE) for a one-time (acute) exposure and $100 \mathrm{mrem}(\mathrm{EDE})$ /year for a continuous exposure. These limits are used in this performance assessment.

The compliance time for protecting an inadvertent intruder is defined differently from the time of compliance for protecting the general public or the environment. The inadvertent intrusion time of compliance differs slightly between regulations. Current DOE guidance (Alm 1997) is that active institutional control shall occur for at least 100 years, but notes that longer times can be used if justified. DOE intends to control the Hanford Site 200 Areas as long as necessary to protect the public. RL directive 5820.2A (DOE-RL 1993) allows a compliance - time of 500 years if passive barriers and markers are used. The Hanford Site grout performance assessment (Kincaid 1995-1) used the 500-year compliance time based on the assumption that passive barriers and markers would be present. The performance assessments for the disposal of solid radioactive waste on the Hanford Site (Wood 1994b and Wood 1996) also have used a compliance time of 500 years. This is consistent with the NRC requirement for Class $\mathrm{C}$ waste 
(10 CFR 61-1) that inadvertent intruders be protected for 500 years.

Following the precedent of the other Hanford Site performance assessments, the 500-year compliance time was used in this assessment because passive barriers and markers are planned for this proposed disposal action. Therefore, protection of an inadvertent intruder shall be considered met if the exposure limits are met at 500 years after closure. Calculations were run from 100 years to 1,000 years after the time of disposal to obtain the doses as a function of time.

1.6.2.5 Protection of Groundwater Resources. This is the most complicated requirement to determine. The level of protection for groundwater is usually based on its intended use. However, predicting future groundwater use is highly subjective given the long time frames involved in a performance assessment. The quantities being limited (decay rate and dose) differ in the various regulations. Moreover, different regulatory agencies approach the protection of groundwater resources using different methods. In addition, earlier DOE performance assessments have taken different approaches. The guidance under the new DOE order on radioactive waste management is to use the Site's groundwater protection management plan. However, the Hanford Site's plan (DOE-RL 1995c) is silent on long-term protection of groundwater.

Previous performance assessments have generalized the requirements from the "National Primary Drinking Water Regulations" (40 CFR 141) for determining whether the disposal action met the groundwater protection requirement. The scenario used is based on a public drinking water system serving at least 25 people and located at least 100 meters ( 328 feet) downstream from the disposal facility. The previous performance assessments set a limit for the total exposure from all radionuclides for an individual drinking the water at less than 4 mrem (EDE) in a year. The "National Primary Drinking Water Regulations," however, use the limit of 4 mrem in a year not for all radionuclides, but for just beta and gamma emitters. The distance of 100 meters from the disposal facility is given in the RL Implementing Directive 5820.2A. Four mrem (EDE) in a year was chosen for two reasons. First, the value corresponds to the risk-based limit found in the "National Primary Drinking Water Regulations." Also, for most of the radionuclides, the value is more restrictive (see Table B-3 of PAT 1995a) than decay rate concentration limits specified in the Washington State regulations (WAC 173-200).

The requirements for alpha emitters are the same in both the Washington State (WAC 173-200) and Federal (10 CFR 141) regulations. Both regulations limit alpha emitters by decay rate concentration limits, not annual dose. In addition, both sets of requirements limit the same subsets of alpha emitters ( ${ }^{226} \mathrm{Ra}$, total radium, and other) and set the same quantitative limits. These decay rate concentration limits (Table 1-3) are used for this performance assessment.

Washington State's requirements for beta emitters are based on a screening level previously used by the EPA. These screening levels were selected because the requirements are easily verified in the field. (The current EPA regulations are based on risk limitation.) The current state screening level ensures that even for beta emitters emitting high-energy gamma radiation, the dose limit will be met. However, for low-energy beta emitters, the state screening 
level is overly conservative by a factor of about 100 . This high degree of conservatism exists for radionuclides, such as ${ }^{99} \mathrm{Tc}$, that are important in this performance assessment.

For this performance assessment, the Federal standards are used. This means that the current EPA regulation governing drinking water ( 40 CFR 141) is used to protect groundwater. The "National Secondary Drinking Water Standards" (40 CFR 143) were not used because they are stated only as goals. This follows the precedent set in the Tank Waste Remediation System Environmental Impact Statement (TWRS EIS) (DOE 1996b), a joint publication of the Ecology and DOE. Thus, the performance objective is an EDE of $4 \mathrm{mrem}$ in a year for beta/photon emitters and a concentration of $15 \mathrm{pCi}$ per liter for alpha emitters. Although uranium is not restricted by the regulations, for this analysis it is included under other alpha emitters. The values are displayed in Table 1-3. A dose of 4 mrem (EDE) in a year for 70 years corresponds to an incremental health risk of 0.0001 (EPA 1989b).

To ensure compliance with the intent of Federal and State groundwater regulations, the limits shown in Table 1-3 are applied to a well 100 meters downgradient from the disposal facility for a time of 10,000 years after closure (the same time of compliance as for protection of the general public). The hypothetical well from which the water is drawn is sized to be the minimum public drinking water system to serve 25 people. Further information is given in Section 3.4.7.2. The effects of placing the well at other locations (including the Hanford Site 200 Area fence line) are also determined.

1.6.2.6 Protection of Surface Water Resources. The thrust of the Federal (10 CFR 141) and State requirements (WAC 173-201A) for protecting surface water resources is the same. The point of compliance is where the groundwater is predicted to reach the Columbia River. The concentration of radionuclides in the groundwater at the point where it enters the Columbia River should meet all the standards listed in Table 1-3.

The 1.0 mrem (EDE) dose in a year (one quarter of the EPA drinking water standard) value is used because it meets the Washington State regulation while minimizing reporting requirements. The Washington State regulation (WAC 173-201A) mandates a dose limit that is the lesser of the EPA drinking water standard and explicit limits for each radionuclide contained in the State regulation. For the major radionuclides of interest, the explicit limits when converted to dose are greater than 1.3 mrem in a year. Using $1.0 \mathrm{mrem}$ in a year for the sum of all beta/photon emitters is restrictive.

The compliance time for protecting surface water resources is selected as 10,000 years, the same compliance time as for protecting groundwater resources. However, the calculations are carried out to the time of maximum impact, if the peak occurs after 10,000 years.

1.6.2.7 Protection of Air Resources. Air emissions limits were taken from Parts $\mathrm{H}$ and $\mathrm{Q}$ of the "National Emissions Standards for Hazardous Air Pollutants" (40 CFR 61H and 40 CFR 61Q). These limits are more restrictive than the Washington State requirements (WAC 173-480 and WAC 246-247). Based on these standards, emissions (except radon) are limited to $10 \mathrm{mrem}$ (EDE) in a year with radon emissions limited to $20 \mathrm{pCi} / \mathrm{m}^{2} \mathrm{~s}$. 
DOE/RL-97-69

Rev. 0

\subsubsection{Programmatic Requirements}

The Immobilized Waste Program has also established other requirements. The project mandated that all waste to be disposed of or stored in the facility shall meet NRC Class C concentration limits (10 CFR 61-2). This restriction is established in complying with the need for the NRC to review that the waste being disposed of is "incidental" waste (Paperiello 1997).

\subsubsection{Public Involvement}

It is important that Hanford Site stakeholders have an opportunity to affect the performance objectives of this proposed disposal action. The performance objectives and scenarios (WHC 1994) were summarized for the stakeholders. The summary was sent to each member and alternate of the Hanford Advisory Board, to selected Hanford Site contractor employees, and to selected members of the DOE's Peer Review Panel and Performance Assessment Task Team.

We received feedback from the stakeholders and have responded to their concerns. Copies of the performance objectives document (PAT 1994) were sent to all who requested it. All comments received on either the summary or the performance objectives have been documented as an internal file. These comments and corresponding responses are available for review (Murkowski 1995).

A member of the Hanford Advisory Board (Todd Martin) was a member of the external review board (see Appendix F.1) that commented on the interim performance assessment and the performance assessment activity.

\subsection{APPROACH AND MAJOR DATA SOURCES}

This performance assessment is being performed early in the project's life. Therefore a three-step approach is being taken:

- . Perform "forward" calculations using a series of cases to obtain an understanding on the behavior of the disposal system

- Perform "backward" calculations using the best current data to establish requirements for the waste form and the disposal facility

- Perform forward calculations to show that such requirements can be "reasonably expected" to be met without heroic efforts.

The first set of calculations is built around a base analysis case that reasonably describes our understanding of the system's components and how they will interact. This step starts with the known conditions and estimates the impacts from those conditions (i.e. a forward calculation). 


\section{DOE/RL-97-69}

Rev. 0

These calculations are supplemented by simulations built on a series of sensitivity cases to determine the robustness of the results from the base analysis case and to develop an understanding of the important features and parameters of the disposal system. The second set of calculations reverses the process (i.e. a backwards calculation) to set restrictions on the most important parameters involved in waste form performance and facility design. The final set of calculations shows that engineered solutions exist which can meet these requirements. Because this performance assessment is being done early in the life of the program, the actual engineered solutions may differ, but the engineered solutions actually used should be better (more cost effective, better performance) than the ones used here to show compliance.

Because of the long time frames involved in this analysis, estimates of impacts require computer simulations, rather than on direct observations. The models used in the analyses are very flexible and should be adequate to describe the evolving features of the disposal system. However, because this analysis is performed early in the project's life, much of the data is taken from related Hanford Site projects.

The major sources of information for the base analysis case are present in Table 1-4.

Sensitivity cases (See Section 3.5.5) were performed to determine the impact of uncertain data. Among the most important were the following:

- The waste form was explicitly simulated (assuming it was the extensively studied LD6-5412 low-level glass waste form) to determine release rates.

- Recharge rates and their time history were varied over two orders of magnitude.

- Different amounts of key radionuclides were included.

- Different disposal facility designs were studied.

- Exposure parameters were extensively varied.

\section{$3 \rightarrow-$ See section 3.3 for demition of sensitivity cases}

This performance assessment is the first of a series of performance assessments that will more accurately estimate the impact of the disposal of immobilized low-activity tank waste. Future performance assessments will be issued as new information is found about the waste form, its inventory, the design of the disposal facility, and site characterization and as these factors are better understood. 
Table 1-4. Major Source of Information for the Base Analysis Case.

\begin{tabular}{|c|c|c|}
\hline Data Type & Major Source & $\begin{array}{l}\text { Section Containing } \\
\text { More Information }\end{array}$ \\
\hline Location & $\begin{array}{l}\text { The existing four disposal vaults at the eastern edge } \\
\text { of the Hanford Site } 200 \text { East Area will-be used first, } \\
\text { followed by the new facilities just southwest of the } \\
\text { PUREX Facility (also in the } 200 \text { East Area). }\end{array}$ & Section 3.4.4. \\
\hline Waste & $\begin{array}{l}\text { Immobilized low-activity contents of Hanford Site } \\
\text { single- and double-shell tanks in the } 200 \text { East and } \\
200 \text { West Areas. }\end{array}$ & Section 2.3 \\
\hline Inventory & $\begin{array}{l}\text { ASSUMED to be average values calculated from } \\
\text { modeling Hanford Site production reactors } \\
\text { corrected for off-site transfers, discharges to the } \\
\text { ground, separations into high- and low-activity } \\
\text { fractions, and off-gas generation. }\end{array}$ & Section 3.2 \\
\hline $\begin{array}{l}\text { Long-term } \\
\text { waste form } \\
\text { performance }\end{array}$ & $\begin{array}{l}\text { ASSUMED to be equal in value to the short-term } \\
\text { performance required in the request for proposals } \\
\text { for all non-Tc radionuclides. Tc release in the RFP } \\
\text { is smaller. }\end{array}$ & Section 3.4 .5 \\
\hline $\begin{array}{l}\text { Disposal } \\
\text { facility design: }\end{array}$ & ASSUMED from preconceptual ideas. & Section 3.4.6 \\
\hline Recharge & $\begin{array}{l}\text { For the first } 1,000 \text { years, taken from specifications } \\
\text { of the Hanford Site Surface Barrier. Thereafter, } \\
\text { taken from the analysis of current natural } \\
\text { conditions. }\end{array}$ & Section 3.4 .7 \\
\hline Geotechnical & $\begin{array}{l}\text { Taken from geotechnical measurements studies of } \\
\text { other locations in the Hanford Site } 200 \text { East Area. }\end{array}$ & Section 3.4.4 \\
\hline Exposure & $\begin{array}{l}\text { Taken from past Hanford Site documents and } \\
\text { experience. }\end{array}$ & Section 3.4 .8 \\
\hline
\end{tabular}

\subsection{STRUCTURE OF THIS PERFORMANCE ASSESSMENT}

This performance assessment is divided into nine chapters and eight appendices. The appendices provide additional detailed information about topics presented in the chapters. This section summarizes the contents of each of chapter and appendix.

- Chapter 2 describes the Hanford Site environment, the waste characteristics, and the waste disposal system. 


\section{DOE/RL-97-69}

Rev. 0

- Chapter 3 covers the methods used to assess system performance, including the radionuclide transport pathways and exposure scenarios: It also discusses the assumptions used in modeling system performance.

- Chapter 4 presents and integrates results from the transport and exposure models used to estimate the potential consequences of long-term contaminant release from the disposal vaults.

- Chapter 5 presents the results from the inadvertent intruder analyses.

- Chapter 6 interprets disposal facility performance with respect to the performance objectives defined in Chapter 1, sets waste acceptance criteria and disposal facility requirements, shows that these requirements can be "reasonable expected" to be met, and discusses further work associated with the performance assessment activity.

- Chapter 7 outlines the quality assurance procedures used in the performance assessment activity.

- Chapter 8 contains brief resumes of contributors to the document.

- Chapter 9 lists the cited references.

- Appendix A repeats the specifications for immobilization given in the request for proposal (DOE-RL 1996).

- Appendix B displays the dose factors used in the dosimetry calculations.

- Appendix $\mathrm{C}$ describes the computer simulation of the performance of a glass waste form.

- Appendix D describes the computer codes used in moisture flow and contaminant transport simulations.

- Appendix E provides detailed results of the computer simulations.

- Appendix F contains the comments received on the initial release of the interim performance assessment and the responses to those comments.

- Appendix $\mathrm{G}$ contains the program plan to establish the expected long-term contaminant release rates from vendor-supplied waste forms.

- Appendix $\mathrm{H}$ provides the correspondence between the guidance given for the format and the format used in this document. 
DOE/RL-97-69

Rev. 0

1-24 


\subsection{DISPOSAL FACILITY DESCRIPTION}

\subsection{OVERVIEW}

This chapter explains the expected environment within the region and around the immobilized low-activity tank waste disposal facilities, probable waste retrieval and immobilization methods, and likely design, operating, and closure concepts for the disposal facilities. It covers the following topics.

- Hanford Site Characteristics (Section 2.2): regional and local geography; demography, including future land use; climate, geology, hydrology, soils, ecology and biotic conditions; and natural radiation background.

- Waste Characteristics (Section 2.3): current waste storage in underground tanks and plans for retrieving the waste, separating it into high- and low-activity fractions, and immobilizing the low-activity fraction, including packaging and certification.

- Disposal Technology (Section 2.4): the current concepts on disposal units, waste handling and interim storage operations, waste emplacement, disposal unit closure and stabilization, and site closure.

\subsection{HANFORD SITE CHARACTERISTICS}

This section describes the regional and local environment in which the immobilized lowactivity tank waste disposal facilities will be located. Extensive research has been done on the physical characteristics of the Hanford Site. However, this section will cover only the characteristics that will be used to model the immobilized low-activity tank waste disposal facilities' long-term performance. More complete descriptions will be referenced whenever possible.

\subsubsection{Geography of the Hanford Site}

The Hanford Site is a $1450-\mathrm{km}^{2}\left(560-\mathrm{mi}^{2}\right)$ area of semiarid land located in south-central Washington State. The Hanford Site is owned by the U.S. Government and restricted to uses approved by the DOE. Figure 2-1 shows the Hanford Site in relation to the rest of the state. It also identifies the major cities in the region, Seattle, Portland, and Spokane, which are over $160 \mathrm{~km}(100 \mathrm{mi})$ from the Hanford Site.

The major features of regional geography are the nearby rivers and mountains. The Columbia River, which forms the eastern boundary of the Hanford Site, is an important source of water and hydroelectric power for the region. Other important rivers near the Hanford Site are the Yakima River to the southwest and the Snake River to the east. The Cascade Mountains, 


\section{DOE/RL-97-69}

\section{Rev, 0}

Figure 2-1. Hanford Site in Washington State.

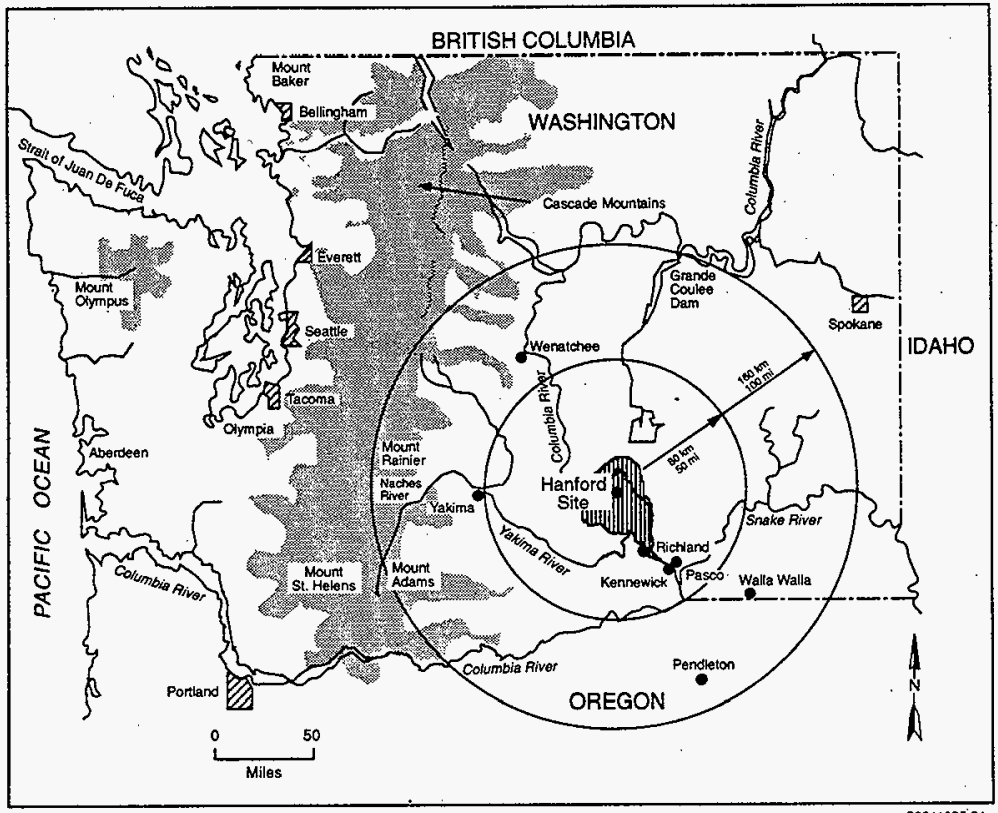

$\$ 921103521$

which are about $160 \mathrm{~km}(100 \mathrm{mi})$ to the west, have an important effect on the climate of the area, which is discussed in Section 2.2.5.

Figure 2-2 shows the Hanford Site. The DOE is planning to release some of the Hanford Site land for public use. The areas planned for release are the area north of the Columbia River and the Fitzner/Eberhardt Arid Lands Ecology Reserve southwest of State Highway 240. The 200 Areas, where the tank waste is located, are in the center of the Hanford Site. Just south of the 200 Areas is land used by U.S. Ecology for commercial low-level radioactive waste disposal.

As discussed more fully in Section 2.2.4.3, the Hanford Remedial Action Environmental Impact Statement and Comprehensive Land Use Plan (DOE 1996c) has defined the future site boundaries as just outside of the 200 Area boundaries, as shown in Figure 2-2. 


\section{DOE/RL-97-69}

\section{Rev. 0}

Figure 2-2. Hanford Site Map Showing Public Highways and Future Site Boundary.

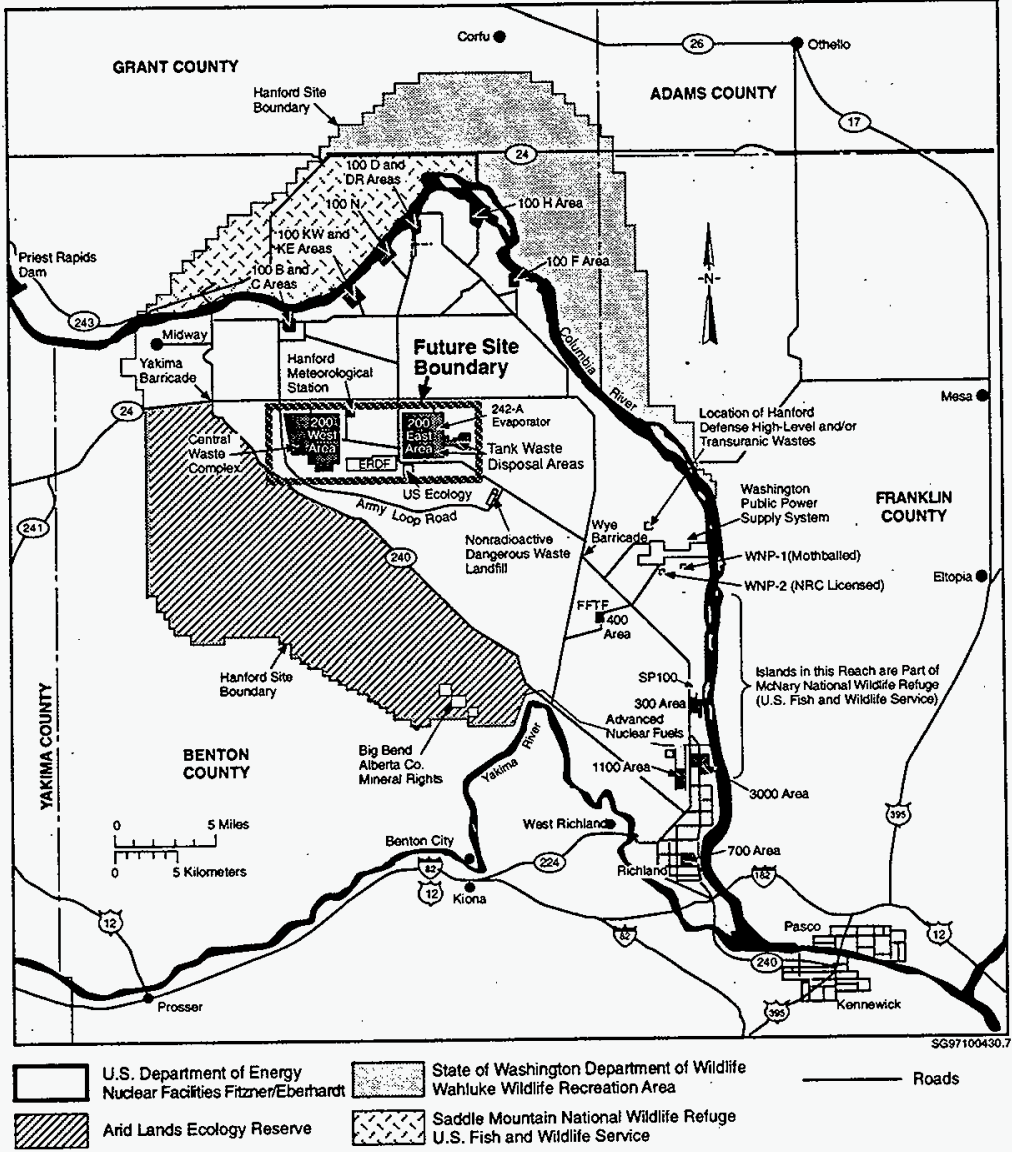


Rev. 0

\subsubsection{Location of Disposal Sites}

Immobilized low-activity tank waste (ILAW) will be disposed of in two locations (Shade 1997). The initial waste packages will be disposed of in four existing TWRS disposal vaults at the eastern edge of

Location of Disposal Sites The disposal sites will be located in the 200 East Area, an area identified for radioactive waste disposal. the Hanford Site 200 East Area (Burbank 1996, Burbank 1997). The vaults are just east of the AP Tank Farm and at the western edge of the Tank Waste Vitrification Area. These vaults were originaily constructed for the disposal of double-shell tank waste in a grouted waste form. Additional waste packages will be disposed of in new facilities located in the south-central part of the 200 East Area between existing office structures and the PUREX fuel reprocessing facility. Figure 2-3 shows the two disposal areas. The location of the new facilities was chosen (Rutherford 1997) for the following three reasons (Shord 1995):

- The location is near existing tank farms:

- Unused land is available.

- The location is inside the fence line of the 200 Areas.

Figure 2-3. Activities in the 200 Areas. The four existing disposal vaults are located at the just east of the AP Tank Farm at the west end of the Phase I Treatment Complex. The new disposal facility is located in the south-central part of the 200 East Area.

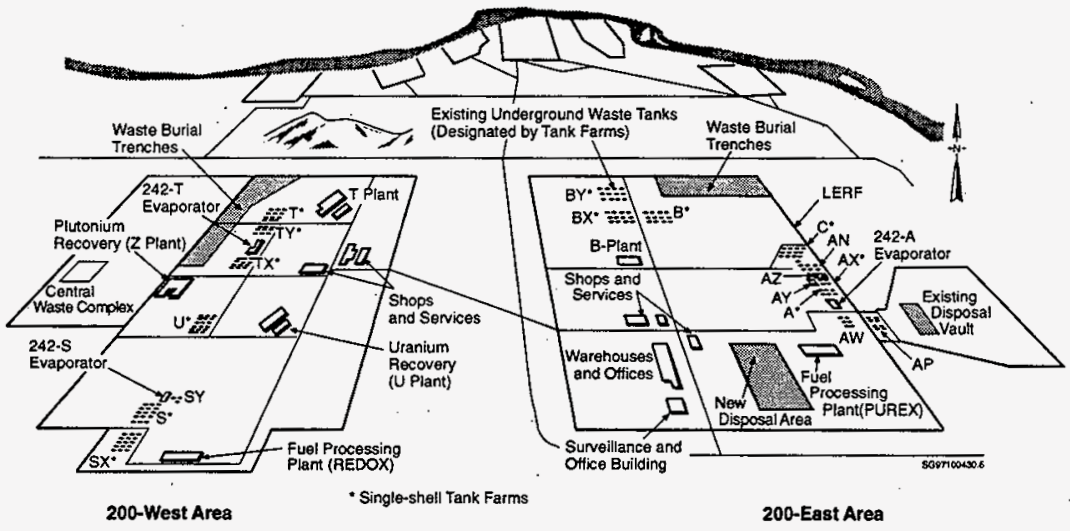


Rev. 0

\subsubsection{Demography}

Demographic data are used in a performance assessment to help set the scenarios and select the dosimetry parameters. This section describes the current population database, area socioeconomics, past and planned DOE activities, and the results of an investigation of future uses conducted by the Hanford Future Site Uses Working Group.

The major population centers within $80-\mathrm{km}$ (50-mi) of the Hanford Site are identified in Figure 2-4, along with populations based on the 1990 U.S. Bureau of Census estimates (DOC 1991). This radius is centered on the Hanford Meteorology Station (HMS), located between the 200 East and 200 West Areas. The Tri-Cities (Richland, Kennewick, and Pasco), southeast of the Site, is the largest population center closest to the Hanford Site. Other major population centers include Yakima and the Yakima Valley towns and Moses Lake in Washington to the west and north, respectively, and Umatilla and Hermiston in Oregon to the south. The cities of Ellensburg and Walla Walla, Washington-lie just beyond the $80-\mathrm{km}(50-\mathrm{mi})$ radius. Portions of Benton, Franklin, Adams, Grant, Kittitas, Yakima, Klickitat, Walla Walla counties in Washington and Morrow and Umatilla counties in Oregon lie within the $80 \mathrm{~km}$ radius.

Figure 2-4. Population Centers Within an 80-km Radius of the Hanford Site. Populations shown are based on 1990 census (DOC 1991).

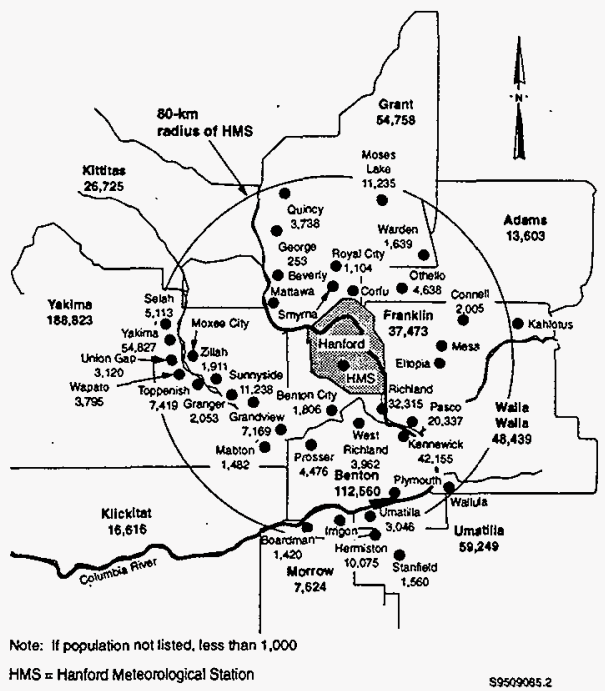


The population estimates for Washington State (OFM 1994) as summarized in Cushing (1995-1) are used. The population in Benton County was approximately 127,000 in 1993. Approximately 35,000 people reside in Richland; 47,000 people reside in Kennewick; and 12,000 people reside in West Richland, Benton City, and Prosser. The approximate population in the unincorporated portions of the county is 32,600 . The estimated population of Franklin County was 43,000 in 1993, with 22,000 people living in Pasco, 3,400 people living in other incorporated areas, and 17,600 people living in unincorporated areas. During 1990, Benton and Franklin Counties accounted for approximately 3 percent of Washington State's population.

Based on estimates made during the 1970 and 1980 census years, the area population grew approximately 55 percent (Watson 1984). This population growth and the subsequent decline in 1982 were attributed to the creation and loss of several thousand construction jobs at the Washington Public Power Supply System power reactors. Watson et al. (Watson 1984) projected that the populations within a $16-\mathrm{km}(10-\mathrm{mi})$ radius, primarily concentrated in the Tri-Cities, would increase by 94 percent between 1980 and 2030 and that the population between 16 and $80 \mathrm{~km}$ (10 and $50 \mathrm{mi})$ would increase by 55 percent.

\subsubsection{Land and Water Use}

Land and water use information are used in a performance assessment to help set the scenarios and select the dosimetry parameters. This section describes area socioeconomics, past and planned DOE activities, and the results of an investigation of future uses conducted by the Hanford Future Site Uses Working Group.

2.2.4.1 Socioeconomics. The major employers in the Tri-Cities area since 1970 have been the DOE and the Hanford Site contractors; the Washington Public Power Supply System, which operates a nuclear power plant; agriculture and a large food-processing industry; plus several smaller industrial operations. Other than DOE activities, agriculture and food processing are the dominant industries. The socioeconomics of the area surrounding the Hanford Site are more fully described in Cushing (1995-2).

The land use classification around the Hanford Site varies from urban to rural. Most of the land south of the Hanford Site is urban, including the Tri-Cities, while much of the land to the north and east is irrigated crop land. Most of the irrigation water comes from the Bureau of Reclamation's Columbia Basin Project, which uses the Grand Coulee Dam as the primary water source. The water is transported via canals to the areas north and east of the Columbia River. The land to the west of the Hanford Site is used for irrigated agriculture near the Yakima River and dry-land farming at the higher elevations.

The area rivers are used primarily as sources of irrigation and drinking water but also for recreation. The National Parks Service has suggested that the free-flowing portion of the Columbia River along the Hanford Site boundary (known as the Hanford Reach) be designated as a recreational river under the Wild and Scenic River system. A record of decision is pending with Congressional action expected. 


\section{DOE/RL-97-69}

Rev. 0

2.2.4.2 Past and Future DOE Activities at the Hanford Site. In 1943, the U.S. Army Corps of Engineers created the Hanford Site from small farming areas along the Columbia River and land ceded by local Native American tribes to locate facilities used to produce nuclear weapon materials for fighting World War II. Since then, the major activities on the Hanford Site have been controlled by the DOE and its predecessors, the U.S. Atomic Energy Commission (1945-1975) and the Energy and Research Development Administration (1975-1976). Current major programs at the Hanford Site are dedicated to waste management, environmental restoration, and research and development.

The DOE nuclear facilities occupy about 6 percent of the Site's total available area. The major operating areas, as shown in Figure 2-2, are identified by numbers: 100 Areas, 200 Areas, 300 Area, and 400 Area. The activities conducted in these areas are described in the following paragraphs.

The 100 Areas, directly bordering the Columbia River-(Figure 2-2), contain nine graphite-moderated plutonium production reactors, eight of which were shut down by the early 1970's. The ninth is the N Reactor, the first dual-purpose reactor built in the United States. N Reactor began operating in 1963 and was shut down in 1986.

Fuel reprocessing, plutonium and uranium separation, plutonium finishing, and waste management, including treatment, storage, and disposal activities, were conducted in the 200 Areas. Some waste from the research and development activities and fuel fabrication activities in the 300 Area, reactor operation programs conducted in the 100 Areas, and the Fast Flux Test Facility (FFTF) in the 400 Area is sent to the 200 Areas for storage and disposal. Waste management activities are scheduled to continue until the mid 21 st century.

Waste management facilities are located in the 200 Areas which are surrounded by security fencing (Figure 2-2). The following major facilities are located in the 200 Areas (see Figure 2-3):

- Burial trenches

- Eighteen underground storage tank farms (the A, AN, AP, AW, AX, AY, AZ, B, BX, BY, C, S, SX, SY, T, TX, TY, and U)

- Very large fuel processing and recovery facilities $(B, T, U$, and $Z$ Plants and the Reduction-Oxidation [REDOX] and Plutonium Uranium Extraction [PUREX] facilities)

- Tank waste water evaporator facilities (242-A, -S, and -T)

- Office and warehouse buildings.

Many of these facilities are inactive. The Canister Storage Building is being built just west of B Plant to store spent nuclear fuel and the immobilized high-level tank waste until a Federal geological repository is ready to receive the waste. 


\section{DOE/RL-97-69}

Rev. 0

Between and just south of the 200 East and West Areas is the Environmental Remediation Disposal Facility (ERDF) (see Figure 2-2). This trench system will hold most of the contaminated soil and materials from facility decontamination and decommissioning and Hanford Site remediation.

A site near the 200 Areas has been leased for disposal of commercial low-level radioactive waste. A $3.9 \mathrm{~km}^{2}\left(1.5 \mathrm{mi}^{2}\right)$ parcel located between the 200 West and East Areas is leased to Washington State. A portion of this land is subleased to U.S. Ecology, Inc., a private company, for the disposal of commercially generated low-level radioactive waste.

The Fast Flux Test Facility (FFTF) is located in the 400 Area. This facility contains a liquid-metal cooled fast reactor previously used for testing breeder reactor fuels, materials, and components. The FFTF operated until 1992 and is now in standby mode.

A $4.4 \mathrm{~km}^{2}\left(1.7 \mathrm{mi}^{2}\right)$ parcel northeast of the 400 Area is leased to the Washington Public Power Supply System for commercial nuclear power reactors. The Washington Nuclear Plant (WNP-2), a boiling-water reactor, is currently the only operating nuclear reactor on the Hanford Site. Construction of two pressurized-water reactors (WNP-1 and WNP-4) will not be completed.

Originally, the 300 Area was dedicated to fabricating fuel for the $\mathrm{N}$ Reactor and other reactors on the Hanford Site. Now, the 300 . Area laboratories constructed over the last 30 years are used for research programs.

2.2.4.3 Future Hanford Use. In 1992, DOE, EPA, and Ecology gathered a group of stakeholders to study future land use of the Hanford Site. This Hanford Future Site Uses Working Group issued a summary (HFSUWG 1992a) and a detailed report (HFSUWG 1992b) of its findings. The Hanford Remediation Action Environmental Impact Statement and Comprehensive Land Use Plan (DOE 1996c). is heavily based on the work of the Hanford Future Site Uses.Working Group. However, DOE's land use planning extends for only 50 years instead of the 100 years forecast by the working group.

HFSUWG (1992a-1) contains the following statement about near-term use of the 200 Areas, called the Central Plateau in the report.

"The presence of many different types of radionuclides and hazardous constituents in various forms and combinations throughout the site poses a key challenge to the Hanford cleanup. To facilitate cleanup of the rest of the site, wastes from throughout the Hanford site should be concentrated in the Central Plateau...Waste storage, treatment, and disposal activities in the Central Plateau should be concentrated within this area as well, whenever feasible, to minimize the amount of land devoted to, or contaminated by, waste management activities. This principle of minimizing land used for waste management should specifically be considered in imminent near-term decisions about utilizing additional uncontaminated Central Plateau lands for permanent disposal of grout." 
DOE/RL-97-69

Rev. 0

The report continues on the subject of future use options (HFSUWG 1992a-2),

"In general, the Working Group desires that the overall cleanup criteria for the Central Plateau should enable general usage of the land and groundwater for other than waste management activities in the horizon of 100 years from the decommissioning of waste management facilities and closure of waste disposal areas."

Based on conversations of the working group, no definition of "general use" could be agreed on. For the "foreseeable future" the working group developed options involving waste treatment, storage, and disposal of DOE low-level radioactive waste. The differences among the options are whether offsite waste (radioactive and/or hazardous) would be allowed to be disposed of on the Hanford Site.

Finally (HFSUWG 1992a-3),

"The working group identified a single cleanup scenario for the Central Plateau.

This scenario assumes that future uses of the surface, subsurface and groundwater in and immediately surrounding the 200 West and 200 East Areas would be exclusive...Surrounding the exclusive area would be a temporary surface and subsurface exclusive buffer zone composed of at least the rest of the Central Plateau...As the risks from the waste management activities decrease, it is expected that the buffer zone would shrink commensurately."

$\rightarrow \rightarrow \rightarrow$ The projected land use for this performance assessment is described in Section 3.3.2.2. It is consistent with the recommendations of the Working Group and with DOE's plans.

For nearer term land use planning, as part of the Washington State Growth Management Act of 1991, Benton County is identifying land uses for the Hanford Site. This plan treats the 200 Areas as industrial areas surrounded by "critical areas." By state law, "critical areas" are defined as land to be protected from use because of wildlife habitat or geologic or environmental conditions. Only the following areas were found suitable for development:

- The McGee Ranch area to the northwest of the 200 West Area (at least $6 \mathrm{~km} \mathrm{[4} \mathrm{mi]} \mathrm{away),} \mathrm{where} \mathrm{farming} \mathrm{would} \mathrm{be} \mathrm{allowed}$

- The area to the east of the 200 East Area (a minimum of $5 \mathrm{~km}$ [3 mi] away), where research and development activities would be allowed.

However, any formal land use planning is not expected to be accurate over the hundreds to hundreds of thousands of years covered in this analysis. 


\subsubsection{Climate and Meteorology}

2.2.5.1 Summary. Local and regional climate patterns and projections must be considered when estimating the effect of water on the disposal system. Both total precipitation and seasonal frequency are important. Potential long-term climatic conditions must be projected to evaluate future climate changes that might cause higher precipitation rates or glaciation. Climate also affects the potential for flooding.

The climate of the Pasco Basin (where the Hanford Site is located) can be classified as midlatitude semiarid or midlatitude desert, depending on the climatological classification system being used. Large diurnal temperature variations are common, resulting from intense solar heating and nighttime cooling. Summers are warm and dry with abundant sunshine. Daytime high temperature in June, July, and August can exceed $40^{\circ} \mathrm{C}\left(104^{\circ} \mathrm{F}\right)$. Winters are cool with occasional precipitation that makes up about 44 percent of the yearly total. During the winter, outbreaks of cold air associated with modified arctic air masses can reach the area and cause temperatures to drop below $-18{ }^{\circ} \mathrm{C}\left(0^{\circ} \mathrm{F}\right)$. Overcast skies and fog do occur during the fall and winter months.

The Cascade Mountain Range greatly affects the temperature, wind, and precipitation in the region. Air masses that reach the Pasco Basin are changed as they pass over the region's relatively complex topography. The mountains limit the Pacific Ocean's maritime influence, making the climate of Eastern Washington drier with greater temperature extremes than the coast. In addition to this rain shadow effect, the Cascades are a source of cold air drainage, which has a considerable effect on the Site's wind regime.

This rest of this section summarizes the modern climate patterns in the Hanford Site area, the regional climate patterns of the recent past, and the possible future changes.

\subsubsection{Current Data. Climatological data are available from the Hanford Meteorological} Station (HMS), located between the 200 East and 200 West Areas at about 215 meters ( 705 feet) elevation (See Figure 2-2). Data have been collected at this location since 1945. Temperature and precipitation data also are available from nearby locations for the period from 1912 through 1943. Data from the HMS are representative of the general climatic conditions for the region and describe the specific climate of the 200 Areas. Summaries have been published by Hoitinik (1994) and Stone (1983).

The average monthly temperature at the HMS is $12^{\circ} \mathrm{C}\left(54^{\circ} \mathrm{F}\right)$. The unusually cool nights that occur result from cool gravity winds originating from the Cascade Mountains. Seasonal temperature extremes at the Hanford Site are greater than they would be without the Cascade Mountains. The Pasco Basin has milder winters than sites at the same latitude on the Great Plains because mountain ranges to the north and east shield the area from many of the arctic surges that descend from Canada. Half of all winters are free of temperatures of $-18^{\circ} \mathrm{C}$ $\left(0^{\circ} \mathrm{F}\right)$ or lower. 
DOE/RL-97-69

Rev. 0

Precipitation has been measured at the HMS since 1945. Average annual precipitation at the HMS is $16 \mathrm{~cm}$ (6.3 in). The precipitation during November, December, and January accounts for 44 percent of this total, while precipitation from July through September accounts for only 13 percent. On the average; only twice a year do 24 -hour amounts of precipitation measure $1.3 \mathrm{~cm}(0.5 \mathrm{in})$ or more. Rainfall intensities of $1.3 \mathrm{~cm} / \mathrm{h}(0.5 \mathrm{in} / \mathrm{h})$ persisting for 1 hour are expected once every 10 years. Occurrences of 24-hour amounts of precipitation of $5.1 \mathrm{~cm}$ ( 2 in) or more have been recorded only twice from 1946 through 1980 . One of these was the record storm of October 1-2, 1957, in which rainfall totaled $2.7 \mathrm{~cm}$ (1.08 in) in 3 hours, $4.3 \mathrm{~cm}$ (1.68 in) in 6 hours, and $4.8 \mathrm{~cm}$ (1.88 in) in 12 hours.

About 38 percent of the precipitation during December through February falls as snow. Winter monthly average snowfall ranges from $0.8 \mathrm{~cm}(0.3 \mathrm{in})$ in March to $13.5 \mathrm{~cm}(5.3 \mathrm{in})$ in January. Only one winter in four is expected to accumulate as much as $15 \mathrm{~cm}(5.9$ in) of snow on the ground. During these winters, four days, on average, have $15.2 \mathrm{~cm}$ ( $6.0 \mathrm{in})$ or more of snow on the ground: However, the 1964-1965 winter had 35 days with snow on the ground, 32 of which were consecutive. That winter also provided one of the deepest accumulations, with $31 \mathrm{~cm}$ (12 in) of snow occurring in December 1964. The record accumulation of snow is $62.2 \mathrm{~cm}(24.5 \mathrm{in})$ in February 1916.

Prevailing wind on the Hanford Central Plateau are from the northwest all year. Secondary maxima occur for southwesterly winds. Monthly average wind speeds are lowest during the winter, averaging about $10 \mathrm{~km} / \mathrm{h}(6 \mathrm{mi} / \mathrm{h})$. The winds are highest during the summer, averaging $15 \mathrm{~km} / \mathrm{h}(9 \mathrm{mi} / \mathrm{h})$. Wind speeds that are well above average are usually associated with southwesterly winds. However, the summertime drainage winds are generally northwesterly and frequently reach $50 \mathrm{~km} / \mathrm{h}(30 \mathrm{mi} / \mathrm{h})$.

This climate profile suggests opportunities for moisture infiltration or recharge. This infiltration is centered around the frequency of precipitation during the winter months when evaporation is less and plant uptake and transpiration are minimal.

\section{See Section 2.2.7.5 for a discussion of natural recharge rates.}

2.2.5.3 Historical Data. Historical climate data can provide insights into how future and current climate patterns may differ. Information exists on climate for the past few centuries and, in less detail, for the last 10,000 years.

Cropper and Fritts (Cropper 1986) derived a 360-year regional reconstruction of seasonal and annual variations in temperature and precipitation from statistical relationships between meteorological records from Columbia Basin stations and tree-ring data from western North America. They calibrated the relationship between Columbia Basin weather records and a network of 65 tree-ring chronologies. The results suggest that the average temperature of the Columbia Basin for the past 3 centuries was slightly higher by $0.09^{\circ} \mathrm{C}\left(0.16^{\circ} \mathrm{F}\right)$ and more variable ( 4 percent higher standard deviation) than in the 20th century. The increase was primarily attributed to warmer winters. This reconstruction also suggests that the past 3 centuries were wetter on the average by $0.8 \mathrm{~cm}(0.3 \mathrm{in})$, primarily in the autumn. Furthermore, 


\section{DOE/RL-97-69}

Rev. 0

droughts were apparently more frequent starting in the second half of the 17th century and lasted longer than 20th century droughts. Gramulich (1987) also used multiple regression models to reconstruct precipitation in the Pacific Northwest. The results indicate that the average precipitation in the 18 th and 19 th centuries was the same as the average precipitation in the 20th century.

Chatters (1991) and Chatters and Hoover (Chatters 1992) summarized proxy evidence for climatic change in the Columbia Basin for the past 10,000 to 13,000 years. They identify an environment of about 13,000 years ago that was kept cool and dry by masses of ice and glacial meltwater, supporting a mosaic of isolated plant and animal communities. This was followed between 10,000 and 8,500 years ago by a period of warmer than modern summers, colder than modern winters and low, but spring-dominant, precipitation. This climate supported extensive grasslands and their associated fauna. By 8,000 years ago, summers and winters were both relatively warm, and precipitation was at least 33 percent below current levels. This climate pattern resulted in reduced stream flows, with late spring flow-maxima, and extensive development of shrub-steppe vegetation throughout most of the region. Between 4,500 and 3,900 years ago, the climate went through a period of transition to wetter and cooler conditions. Rivers flooded frequently and forests expanded into steppe zones. From 3,900 to 2,400 years ago the climate was cool in the summer and cold in the winter, with winter-dominant precipitation at least 30 percent above current levels. Warmer, drier conditions returned between 2,400 and 2,000 years ago, reducing vegetation density and renewing flooding.

2.2.5.4 Long-Range Forecasts. Future long-range forecasts of climate are uncertain. Climatologists universally accept that global climates have undergone significant variation in the past and that such natural variations are expected to continue into the future. Berger et al. (1991) reviewed 7 models of different complexity developed to predict the global climate for the next 10,000 to 100,000 years. All the models are in relatively good agreement. Without human disturbances, the long-term cooling trend that began some 6,000 years ago is expected to continue for the ras 5,000 years. This trend should be followed by a stabilization at about 15,000 years, a cuid interval centered at approximately 25,000 years, and finally a major glaciation at about 55,000 years. Although man-made distributions (such as the green-house effect) may occur, the main effects will be to delay the onset of these trends.

\subsubsection{Severe $W$ eather. Severe weather events are not significant to the Hanford Site.} According to the records of the Hanford Meteorological Station and the National Severe Storms Forecast Center's database, only 24 separate tornado have occurred from 1916 to 1994 within 160 kilometers (100 miles) of the Hanford Site (Cushing 1995-5). Only one of these tomadoes was observed within the boundaries of the Hanford Site (at the extreme western edge), and no damage resulted. The estimated probability of a tornado striking a point at the Hanford Site is $9.6 \times 10^{-6} \% \mathrm{y}$. Hurricanes do not reach the interior of the Pacific Northwest.

Severe winds are associated with thunderstorms or the passage of strong cold fronts. The greatest peak wind gust was $130 \mathrm{~km} / \mathrm{h}(81 \mathrm{mi} / \mathrm{h})$, recorded at $15 \mathrm{~m}(50 \mathrm{ft})$ above ground level at the Hanford Meteorological Station. Extrapolations based on 35 years of observation indicate a return period of about 200 years for a peak gust in excess of $145 \mathrm{~km} / \mathrm{h}(90 \mathrm{mi} / \mathrm{h})$ at 15 meters above ground level. 
DOE/RL-97-69

Rev. 0

2.2.5.6 Climate Summary. The analyses of present and future climatic conditions at the Hanford Site and in the surrounding region suggest that conditions similar to the current climate will prevail for at least 10,000 years and probably considerably beyond. However, considering the uncertainty inherent in any analysis of climate, wetter conditions and associated higher recharge or infiltration rates also will be considered. Scientists generally accept that, at about 50,000 years from now or later, major glaciation will occur, followed by possible flooding similar to what occurred near the end of the last glacial stage. Although considerable uncertainty is associated with future glaciation, some simulations in this performance assessment will examine human health impacts associated with a resident population following flooding and redeposition after 50,000 years.

\subsubsection{Ecology and Biotic Conditions}

This section summarizes the ecology of the Hanford Site, emphasizing plant and animal activities that may affect exposure pathways. The primary impact would be through roots penetrating and animals burrowing through barriers into a disposal facility. Secondarily, the types of plants and animals and their density can affect net groundwater recharge, which is greatly influenced by surface vegetation and burrowing. Cushing (1995-4) details both the terrestrial and aquatic ecology of the Hanford Site and presents extensive listings of plant and animal species. This section will consider only terrestrial ecological effects because the proposed immobilized low-activity tank waste disposal facility sites are not located near significant aquatic ecological systems.

The Hanford Site consists of mostly undeveloped land. Only about 6 percent of the site is occupied by chemical processing facilities, shut down nuclear reactors, and supporting facilities. Most of the Hanford Site has not experienced tillage or agricultural grazing since the early 1940 's.

The Hanford Site is botanically characterized as a shrub-steppe environment. This environment contains numerous plant and animal species adapted to the region's semiarid climate. Because of the aridity and low water-holding capacity of the soils, the productivity of both plants and animals is relatively low.

The dominant plants on the Hanford Site have changed over time. In the early 1800 's, before settlement and agricultural activities, the dominant plants were big sagebrush and perennial bunchgrass. Agriculture opened the area to invasion by alien plants, predominantly cheatgrass. Today, cheatgrass dominates fields and rangeland that were cultivated 50 years ago. The dominant plants on the Hanford Central Plateau are big sagebrush, rabbitbrush, cheatgrass, and Sandberg's bluegrass, with cheatgrass providing half the total plant cover. Root penetration to depths of over several meters has not been demonstrated in the 200 Areas. Rabbitbrush roots have been found at a depth of 2.4 meters ( 8 feet) near the 200 Areas. 


\section{DOE/RL-97-69}

Rev. 0

A variety of birds and mammals inhabit the Hanford Site. The most abundant nesting birds of the shrub-steppe at the Hanford Site are the horned lark and western meadowlark. Significant populations of chukar and gray partridge inhabit the Site. Mourning doves also nest throughout the Hanford Site. The most abundant mammals of the Hanford Site are mice, ground squirrels, gophers, voles, and cottontail rabbits. Larger animals include mule deer and elk. The coyote is the principal mammalian predator on the Hanford Site.

\subsubsection{Regional Geology}

2.2.7.1 Overview. Knowledge of the thickness and lateral distribution of the sediments and other geologic characteristics is required for the following reasons:

- To define a conceptual model for contaminant transport from a disposal facility through the Geolog
Bedrock in the region was formed from
basalt flows millions of years ago. Above
the bedrock are the flood deposits (hundreds
of feet thick) resulting from multiple
catastrophic glacier-age floods. These
deposits are mostly unconsolidated sands. vadose zone (the zone between the surface and the groundwater that is not saturated with water) and from the unconfined aquifer (the upper most groundwater layer) to the human environment

- To define hydraulic parameters

- To interpret modeling results.

The geology of the Hanford Site includes thick sequences of water-derived sediments varying in texture from cobbles and coarse gravels to fine silts and clays. These sediments overlay thick basalt flows. The top sequence or surface soil has been modified by wind. An unconfined aquifer exists in the lower part of the sedimentary sequence overlaying the uppermost basalt flow. This relatively thin aquifer is considered the primary contaminant pathway for evaluating exposure scenarios. The aquifer intercepts infiltration from the vadose (unsaturated) zone above it, providing a pathway for water and contaminant transport to the Columbia River.

The geological and physical settings of the Hanford Site have been extensively characterized. This section summarizes the physical geology and environmental setting of the Hanford Site and of the proposed disposal site. Emphasis is on the sedimentary sequence which is the pathway to the groundwater. More detailed discussions of the geology of the Northwest and the Hanford Site are found in DOE (1987-1), DOE (1988b), Myers (1979), Myers (1981), Reidel (1989), and Delaney (1991).

2.2.7.2 Topography and Physiography. The proposed disposal facilities are on the Hanford Central Plateau, a Pleistocene flood bar most commonly referred to as the 200 Areas Plateau, near the center of the Hanford Site. The Hanford Central Plateau is approximately 198 meters ( 650 feet) to 229 meters ( 750 feet) above mean sea level. The plateau decreases in elevation to 


\section{DOE/RL-97-69}

Rev. 0

the north, northwest, and east toward the Columbia River. The plateau escarpments have elevation changes of 15 to 30 meters ( 50 to 100 feet).

The Hanford Site is situated within the Pasco Basin of south-central Washington State (Figure 2-5). The Pasco Basin is one of many topographic depressions located within the Columbia Intermontane Province (Figure 2-6), a broad basin located between the Cascade Range and the Rocky Mountains. The Columbia Intermontane Province is the product of Miocene continental flood, basalt volcanism, and regional deformation that occurred 6. to 17.5 million years ago. The Pasco Basin is bounded on the north by the Saddle Mountains; on the west by Umtanum Ridge, Yakima Ridge, and the Rattlesnake Hills; on the south by the Horse Heaven Hills; and on the east by the Palouse Slope (Figure 2-5).

The physical geography of the Hanford Site is dominated by the low-relief plains of the Pasco Basin and anticlinal ridges of the Yakima Folds physiographic region (Figure 2-7). The surface topography of the Hanford Site is the result of the following events:

- Uplift of anticlinal ridges

- $\quad$ Pleistocene cataclysmic flooding

- Holocene eolian activity.

Uplift of the ridges began in the Miocene epoch (starting about 17 million years ago) and continues to the present. This uplift is occurring on geologic time scales (i.e., over tens of millions of years). The uplift is not incorporated into our conceptual model of the immobilized low-activity tank waste disposal facilities, which addresses a time scale of tens of thousands of years.

Glacier-related flooding has had a major impact on the physical geography. Cataclysmic flooding occurred when ice dams in western Montana and northern Idaho were breached, allowing large volumes of water to spill across eastern and central Washington. The last major flood occurred about 13,000 years ago, during the late Pleistocene Epoch. Interconnected flood channels, giant current ripples, and giant flood bars are among the landforms created by the floods. These formations resulted in heterogeneous and discontinuous characteristics for sediments ranging in size from silts to coarse gravels. These sediments yield a wide range of vadose zone hydraulic properties.

Landslides have had a limited effect on physical geography. Previous landslide activity in the area is generally limited to the White Bluffs area east of the Hanford Site and the Rattlesnake Hills south of the Site. No landslide activity is observed in the Hanford Central Plateau.

During the Holocene Epoch (the last 11,000 years), winds have locally reworked the flood sediments. The winds deposited dune sands in the lower elevation and loess (very fine wind-blown silts) around the margins of the Pasco Basin. Generally, sand dunes have been stabilized by anchoring vegetation. However, they have been reactivated where vegetation has been disturbed. Most sand dunes on the Hanford Site are located southeast of the 200 East Area and are stabilized by vegetation (Figure 2-7). 
DOE/RL-97-69

Rev. 0

Figure 2-5. Geologic Structures of the Pasco Basin and the Hanford Site:

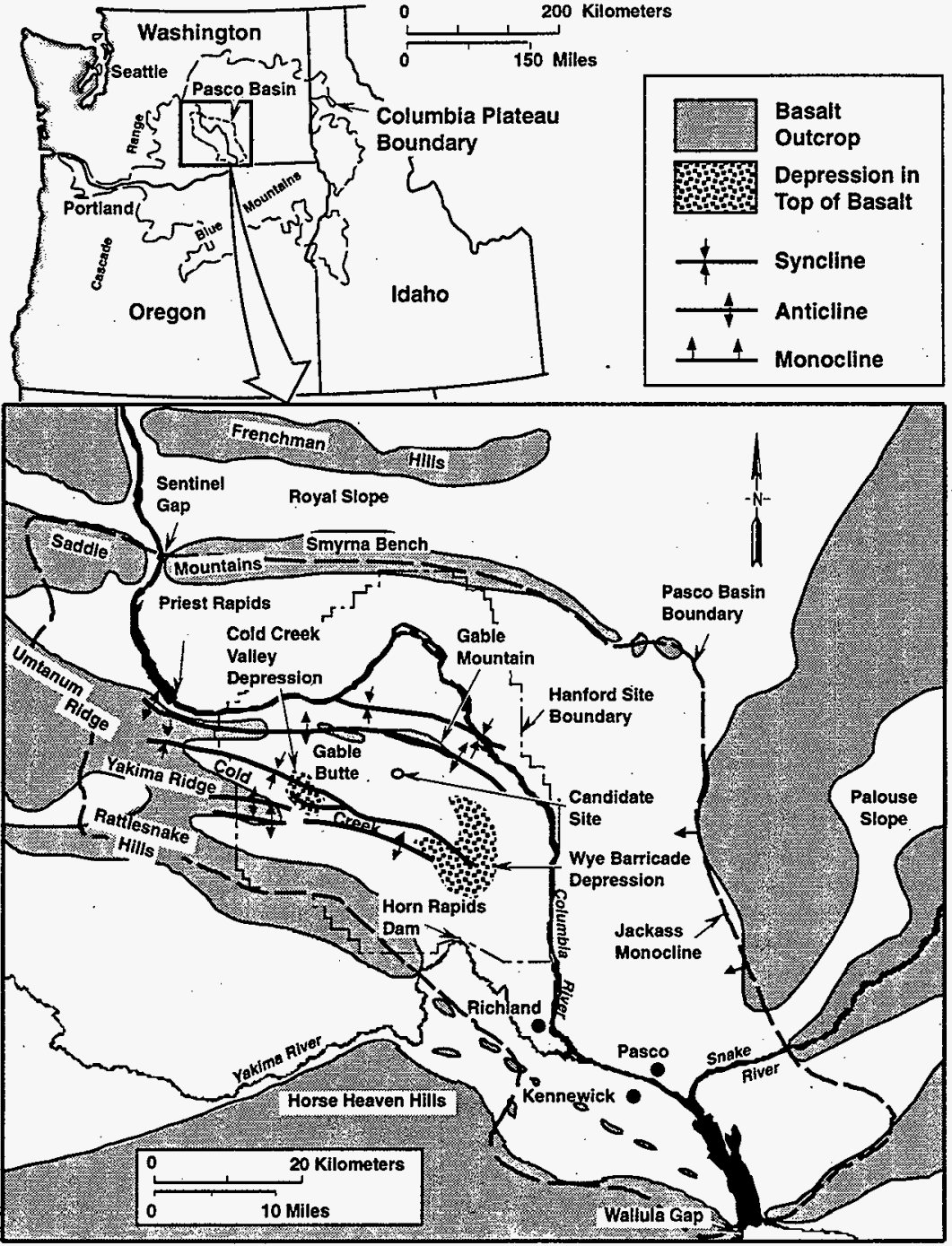

59509085.4 


\section{DOE/RL-97-69}

Rev. 0

Figure 2-6. Divisions of the Intermontane Physiographic and Adjacent Snake River Plains Provinces.
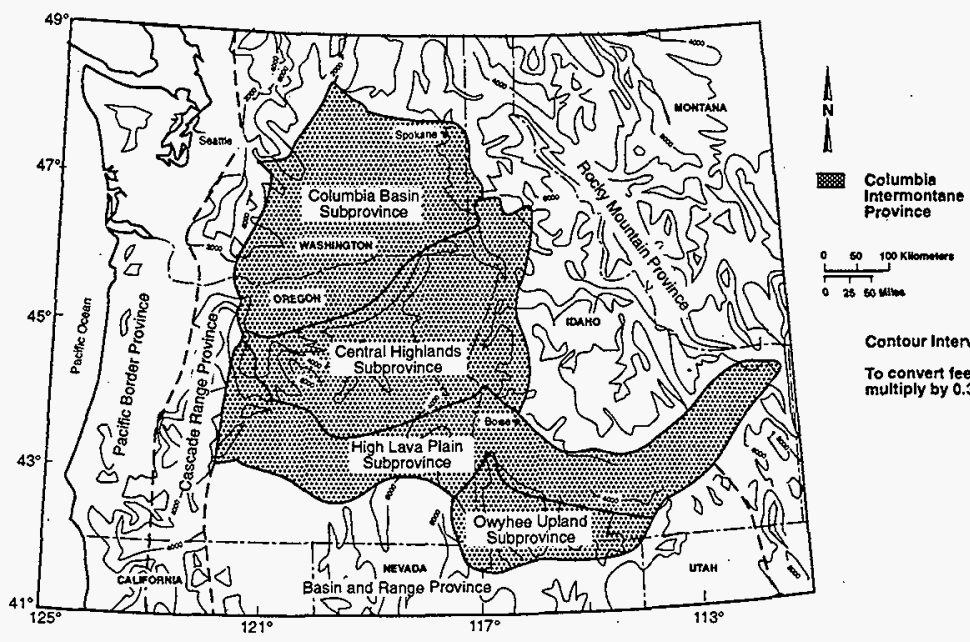

Contour Interval $=2000 \mathrm{H}$

To convert teet to meters mulsiply by 0.3048

The location of the Hanford Site in an intermontane basin helps maintain a semiarid climate with low recharge. Most topographical surface features, such as sand dunes and landslides, that could disturb the near-surface hydraulic characteristics affecting recharge are not found at the location of the immobilized low-activity tank waste disposal facilities. Moreover, sand dunes are indicators of past, cumulative wind directions. Their location approximately downwind of the new disposal facility site suggests that future dune formation over the facility is not likely.

2.2.7.3 Stratigraphy. The stratigraphy or geologic layering is not extremely complex in the Hanford Site region. Late Miocene to Pleistocene suprabasalt sediments (2 to 5 million years old) and Miocene-aged basalt ( 16 to 17 million years old) of the Columbia River Basalt Group mostly lie beneath the Hanford Site. Miocene-aged basalt is exposed at some locations, including Gable Mountain and Gable Butte. The basalts and sediments thicken into the Pasco Basin and generally reach maximum thicknesses in the Cold Creek syncline, which is southwest of the disposal facility sites. Cenozoic ( 25 to 65 million years old) sedimentary and volcaniclastic rocks underlying the basalts are not exposed at the surface near the Hanford Site. 
DOE/RL-97-69

Rev. 0

Figure 2-7. Landforms of the Pasco Basin and the Hanford Site.

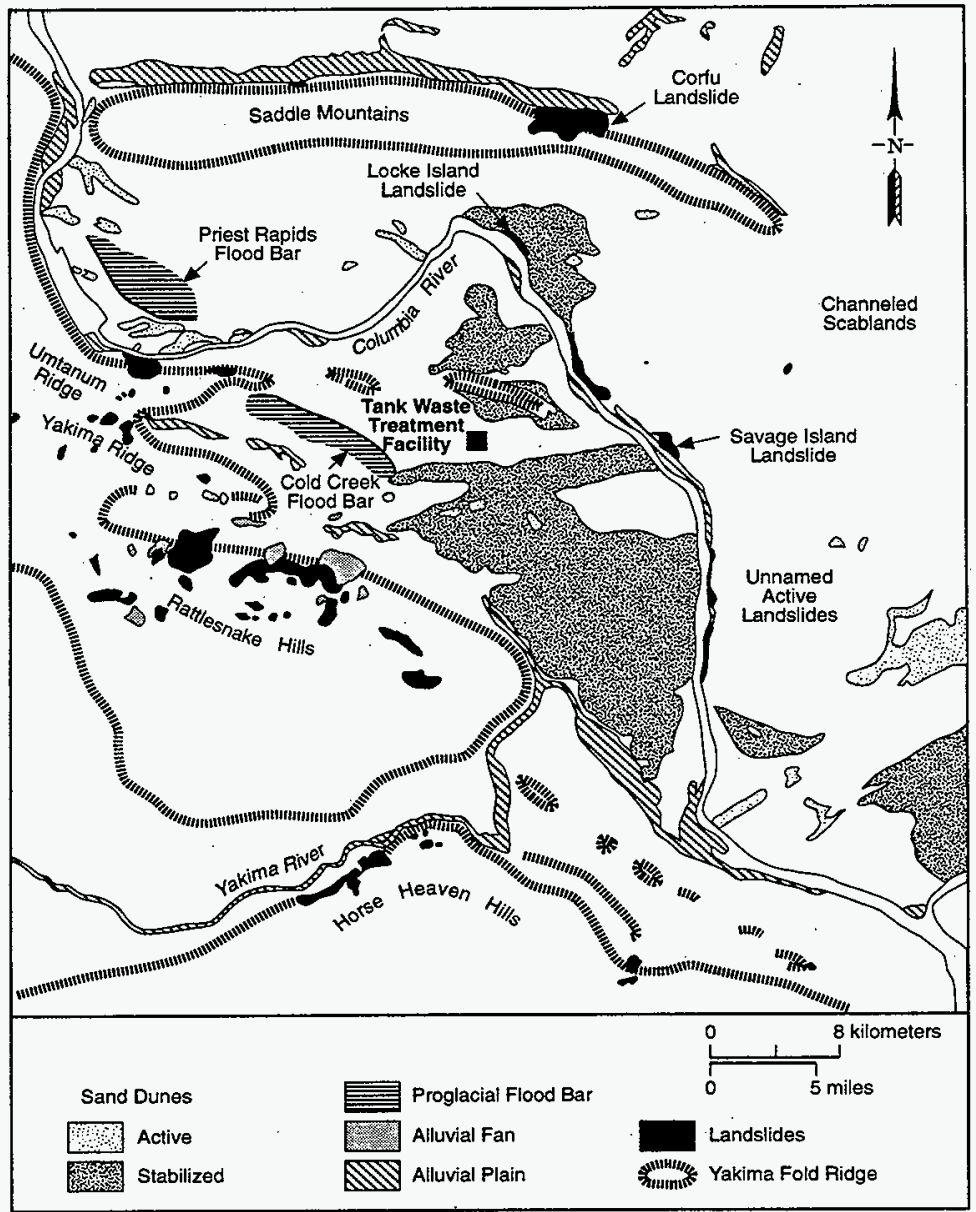

$\$ 9211085.43$ 


\section{DOE/RL-97-69}

Rev, 0

Figure 2-8 delineates the general stratigraphy of the suprabasalt sedimentation that makes up the vadose zone sediments beneath the locations of the disposal facilities. This figure illustrates the degree of heterogeneity and discontinuity in the sediments. The sedimentation is composed largely of Ringold Formation and Hanford formation sediments, with the Hanford formation above the Ringold Formation. At the disposal facility sites, the Hanford formation makes up most of the vadose zone.

Figure 2-8. Generalized Stratigraphy of the Suprabasalt Sediments Beneath the Hanford Site.

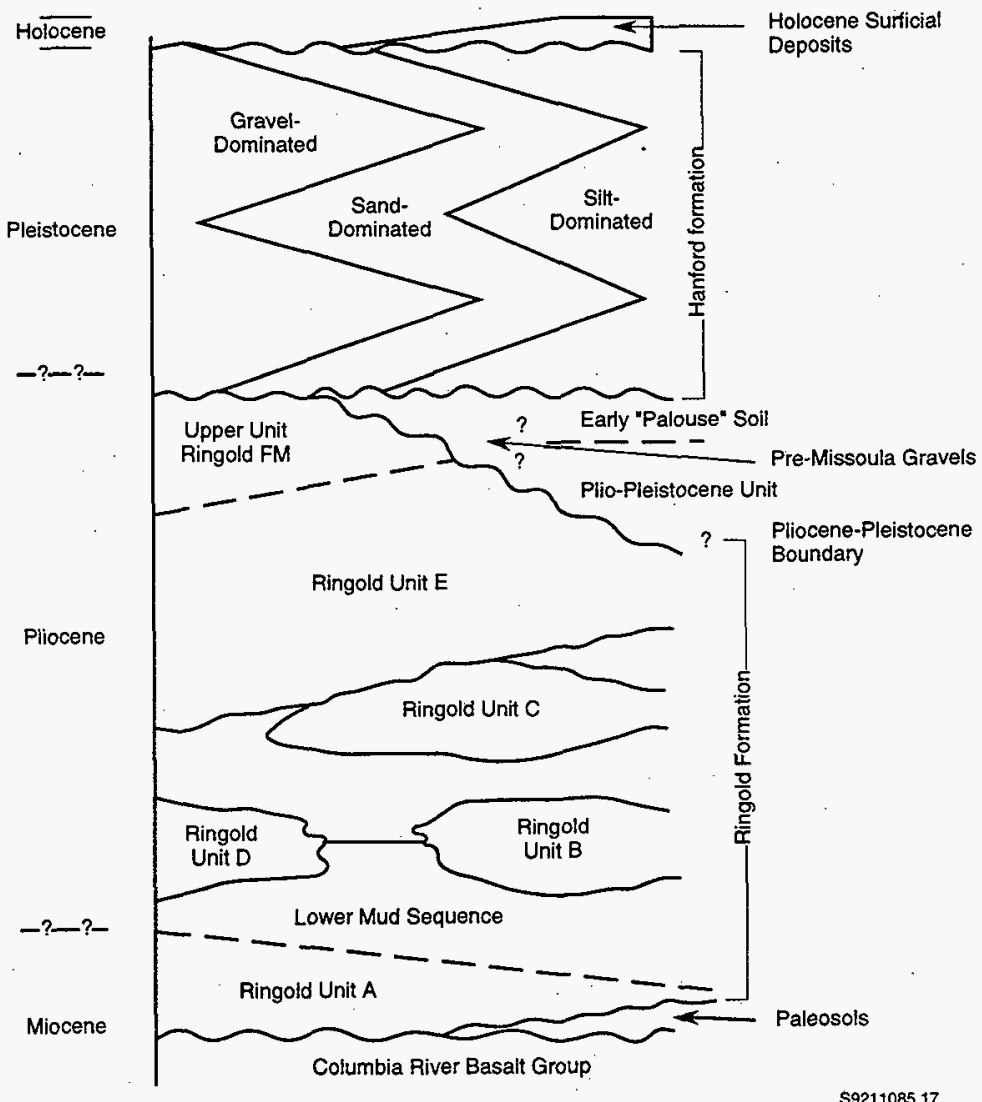




\section{DOE/RL-97-69 \\ Rev. 0}

The suprabasalt sedimentary sequence at the Hanford Site is about $230 \mathrm{~m}$ ( $750 \mathrm{ft})$ thick in the west central Cold Creek syncline. This sedimentary sequence pinches out against the Saddle Mountains anticline, Gable Mountain/Umtanum Ridge anticline, Yakima Ridge anticline, and Rattlesnake Hills anticline. The suprabasalt sediments are dominated by laterally extensive deposits assigned to the late Miocene- to Pliocene-aged Ringold Formation and the Pleistoceneaged Hanford formation (Figure 2-8). Locally occurring strata assigned to the informally defined Plio-Pleistocene unit, early "Palouse" soil, and pre-Missoula gravels compose the remainder of the sequence.

The following sections describe the geology of the Ringold and Hanford formations sediments in some detail. These sediments are the basis for determining vadose zone hydraulic and geochemical properties for contaminant transport modeling.

2.2.7.3.1 Ringold Formation. The Ringold Formation varies in thickness throughout the Hanford Site. It is up to 183 meters (600 feet) thick in the-deepest part of the Cold Creek syncline south of the 200 West Area and 170 meters (560 feet) thick in the western Wahluke syncline near the $100 \mathrm{~B}$ Area. It pinches out against the Gable Mountain, Yakima Ridge, Saddle Mountains, and Rattlesnake Mountain anticlines (Figure 2-5). It is mostly absent in the northern and northeastern parts of the 200 East Area and adjacent areas to the north near West Pond.

The Ringold Formation is assigned to a late Miocene to Pliocene age (Fecht 1987, DOE 1988b) and consists of clay, silt, compacted mud, fine- to coarse-grained sand, and granular to cobble gravel. In general, it tends to be finer-grained, or siltier, in the upper parts just below the Hanford formation.

The strata of the Ringold Formation are generally divided as follows (Newcomb 1958, Newcomb 1972, Myers 1979, Bjornstad 1984, DOE 1988b):

- The gravel, sand, and paleosols of the basal unit

- The clay and silt of the lower unit

- The gravel of the middle unit

- The mud and lesser sand of the upper unit

- The basaltic detritus in localized areas.

Ringold strata also have been divided on the basis of facies types (Tallman 1981) and fining upward sequences (PSPL 1982). Recent studies of the Ringold Formation (Lindsey 1989 and 1991) divided the formation on the basis of sediment facies (individual stratigraphic bodies) associations and their distribution. Facies associations in the Ringold Formation (defined on the basis of lithology, petrology, and stratification) include fluvial gravel, fluvial sand, overbank deposits, lacustrine deposits, and basaltic gravel.

2.2.7.3.2 Hanford Formation. The Hanford formation (an informal designation) is up to 64 meters ( 210 feet) thick in the Cold Creek bar near the 200 areas. It is absent on ridges approximately 360 meters $(1,180$ feet $)$ above sea level. 


\section{DOE/RL-97-69}

\section{Rev. 0}

The Hanford formation was deposited by the catastrophic ice-age flooding that ended about 13,000 years ago. The formation consists of pebble-to-boulder sized gravel, fine- to coarse-grained sand, and silt. It can be divided into two main facies: coarse-grained or gravelly deposits and fine-grained or sandy and silty deposits. The Hanford formation also is commonly divided into two informal members: the Pasco gravels and the Touchet Beds (Myers 1979, Tallman 1981, Fecht 1987, DOE 1988b). The Pasco gravels correspond to the gravelly facies, and the Touchet beds to the sandy and silty facies.

The gravelly facies consists of coarse-grained sand and granule-to-boulder sized gravel. These gravels often lack matrix material and have an open framework appearance. The gravelly facies dominates the Hanford formation in the 100 Areas north of Gable Mountain, the northern part of the 200 East Area, and the eastern part of the Hanford Site, including the 300 Area. In the 200 East and 200 West Areas, the facies association generally becomes finer to the south. The gravelly facies was deposited by high-energy flood waters in flood bars and along channelways such as the Ringold Coulee, east of the Hanford Site, and Gable Mountain channel, north of the Central Plateau.

The sand and silt facies consists of silt and fine- to coarse-grained sand that commonly display normally graded rhythmites a few centimeters to several tens of centimeters thick in outcrop (Myers 1979, DOE 1988b). This facies is found throughout the central, southern, and western Cold Creek syncline within and south of the 200 Areas. These sediments were deposited under slackwater conditions and in backflooded areas (DOE 1988b).

Clastic dikes are vertical features occasionally seen in the Hanford formation. In clastic dikes a vertical hexagonal structure of very-fine grained sand is surrounded by coarser Hanford formation materials. The importance of these features will be investigated in future studies.

2.2.7.3.3 Surficial Deposits. Holocene surficial deposits consist of silt, sand, and gravel that form a thin $(<4.9 \mathrm{~m}[16 \mathrm{ft}])$ veneer atop much of the Hanford Site. These sediments were deposited by wind and flood processes.

2.2.7.4 Soils. Hajek (1966) lists and describes the 15 different soil types on the Hanford Site, varying from sand to silty and sandy loam. The following soils are found in the south-central part of the 200 East Area:

- Burbank Loamy Sand: Dark-colored, coarse-texture soil underlain by gravel. Surface soil is usually about 40 centimeters ( 16 inches) thick but can be $76 \mathrm{~cm}$ (30 in) thick. Gravel content of subsoil ranges from 20 to 80 percent.

- Ephrata Sandy Loam: Surface is dark colored and subsoil is dark grayish-brown medium-texture soil underlain by gravelly material, which may continue for many feet.

- Rupert Sand: Brown-to-grayish brown coarse sand grading to dark grayishbrown at about $90 \mathrm{~cm}$ ( $35 \mathrm{in}$ ). Developed under grass, sagebrush, and hopsage in coarse sandy alluvial deposits that were mantled by wind-blown sand. 


\section{DOE/RL-97-69}

Rev. 0

2.2.7.5 Earthquakes. Seismic events can accelerate the degradation of a disposal facility and of the waste form.

\subsection{Faults and History of Earthquakes.}

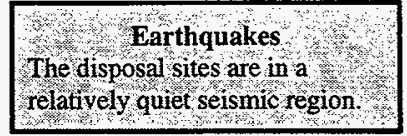

The Hanford Site lies in the Pasco Basin near the eastern

limit of the Yakima Foldbelt. The Site is underlain by basalt of the Columbia River Basalt Group, which is covered by up to $213 \mathrm{~m}$ ( $700 \mathrm{ft})$ of relatively stiff sediments. It is in an area of low-magnitude seismicity and is under north-south compressional stress, which is reflected in the deformation of the Yakima folds. The following sources are major contributors to the seismic hazard in and around the Hanford Site:

- Fault sources related to the Yakima folds

- Shallow basalt sources that account for the observed seismicity within the Columbia River Basalt Group and are not assoeiated with the Yakima Folds

- Crystalline basement source region

- Cascadia Subduction Zone earthquakes.

The largest historical earthquake in the Columbia Plateau occurred in 1936 near Milton-Freewater, Oregon, approximately $90 \mathrm{~km}(54 \mathrm{mi})$ east of the site. The earthquake had a magnitude of 5.75 and was followed by a number of aftershocks. The ground motion from this event is estimated to have been less than $0.03 \mathrm{~g}$ at the Hanford Site.

A seismic monitoring network has been operated in and around the site since 1969. The network, operated by DOE, can locate all earthquakes of magnitude 1.5 and larger on or near the Hanford Site, and magnitude 2.0 and larger throughout south-central and south-eastern Washington State. The largest recorded earthquake on the Hanford Site was a magnitude 3.8 near Coyote Rapids in 1971 and was felt in the $100 \mathrm{~N}$ Area.

2.2.7.5.2 Seismic Hazard Assessment. This section explains the earthquake ground motions that the facility is expected to experience during the performance period. Elements of a disposal facility that serve as barriers in the overall performance must continue to perform at some level throughout the performance period. Deformation and cracking from earthquake ground motion is potentially a major cause of physical. degradation of the engineered system.

A probabilistic seismic hazard analysis was recently completed for the Hanford Site (Geomatrix 1996). Previous seismic hazard analyses were done for Washington Public Power Supply System's WNP-1/4 and WNP/2, which also are located on the Hanford Site (Power 1981). Woodward Clyde Consultants (WCC 1989) later applied the Supply System study to the Hanford Site areas under DOE control. The mean seismic hazard curves for the 200 West, 200 East, and 400 Areas are shown in Figure 2-9. The 200 West Area horizontal ground motion values are shown for the selected time period in Table 2-1. (See Geomatrix [1996] for details including response spectra). 
DOE/RL-97-69

Rev. 0

Table 2-1. Approximate Probability of Exceeding Given Ground Motions During Selected Time Periods.

\begin{tabular}{||c|c|c|c|c|c|}
\hline $\begin{array}{c}\text { Ground } \\
\text { Motion } \\
(\mathrm{g})\end{array}$ & $\begin{array}{c}\text { Retum } \\
\text { Period } \\
\text { (Years) }\end{array}$ & $\begin{array}{c}\text { Annual Probability } \\
\text { of Exceedence } \\
(\mathrm{p})\end{array}$ & $\begin{array}{c}\text { Exceedence } \\
\text { Probability (EP) } \\
\text { over 50 years (\%) }\end{array}$ & $\begin{array}{c}\text { EP over } \\
1,000 \\
\text { years (\%) }\end{array}$ & $\begin{array}{c}\text { EP over } \\
10,000 \\
\text { years(\%) }\end{array}$ \\
\hline 0.19 & $1,000.0$ & $1 \times 10^{-3}$ & 5.0 & 63 & 100 \\
\hline 0.26 & $2,000.0^{\mathrm{b}}$ & $5 \times 10^{-4}$ & 2.0 & 39 & 99 \\
\hline 0.37 & $5,000.0$ & $2 \times 10^{-4}$ & 1.0 & 18 & 86 \\
\hline 0.48 & $10,000.0$ & $1 \times 10^{-4}$ & 0.5 & 10 & 63 \\
\hline
\end{tabular}

EP $=1-(1-p)^{n} \quad$ where

$\mathrm{p} \quad=$ the annual probability of exceedence,

$n=$ the performance life

$\mathrm{EP}=$ the probability of exceedence over the performance life.

.b Performance Category 3, DOE Order 5480.28.

Figure 2-9. Comparison of Seismic Hazard for Various Regions of the Hanford Site.

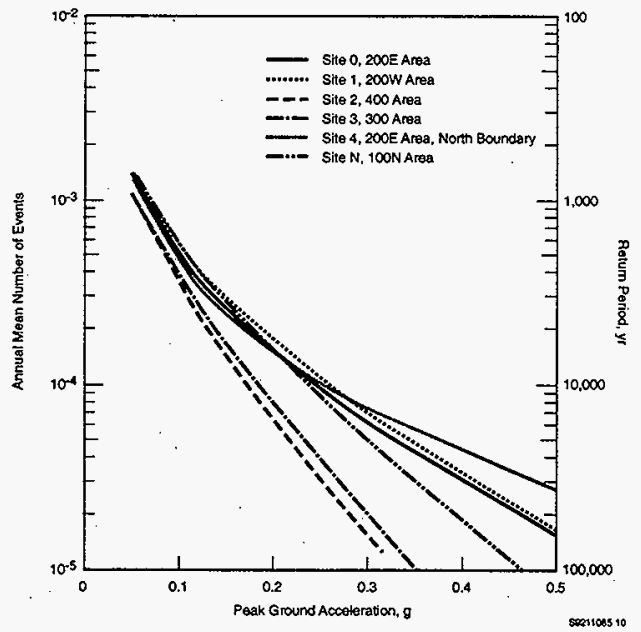

2.2.7.6 Volcanology. Several major volcanoes are located in the Cascade Range, west of the Hanford Site. The nearest volcano, Mount Adams, is about $160 \mathrm{~km}$ (100 mi) from the Hanford Site. The most active volcano, Mount St. Helens, is located approximately $220 \mathrm{~km}$ $(136 \mathrm{mi})$ west-southwest of the Hanford Site. Because of the distance from the range, volcanic flows are not expected; the only effect of an eruption would be ash fall. 


\section{DOE/RL-97-69}

\section{Rev. 0}

\subsubsection{Geology of the Proposed Immobilized Low-Activity Tank Waste Disposal Facility Locations}

\subsubsection{Sources of Information. The} geology and hydrology of the 200 East Area

1979, Myers 1981, Gephart 1979, Tallman 1979, Graham 1981, Routson 1990). The most recent work on the 200 East Area was performed by Lindsey (1992) and by Connely (1992a).

The 200 East Area lies on the Cold Creek bar, a geomorphic remnant of the cataclysmic floods of the Pleistocene era. As the flood waters raced across the lowlands of the Pasco Basin, they lost energy and began leaving behind deposits of gravels. The Hanford Central Plateau is one of the most prominent of these deposits. The plateau lies just south of one of the major channelways across the Hanford Site that forms the topographic lowland south of Gable Mountain.

The principal source of geologic and hydrologic information for the 200 East Area is boreholes. Numerous boreholes have been drilled in the 200 East Area for groundwater monitoring and waste management studies. Most boreholes in the 200 East Area were drilled using the cable-tool methr?. Some boreholes were drilled using rotary and wire-line coring methods. Geologic logs $b_{t}$ sed on these boreholes are constructed by examining chips and cuttings, which limits information on all but the broadest stratigraphic units. Chip samples, which are typically taken at $1.5 \mathrm{~m}(5 \mathrm{ft})$ intervals, are routinely archived at the Hanford Site's Geotechnical Sample Library.

To better determine the site-specific properties of the vadose zone and the unconfined aquifer, three new boreholes are planned (Mann 1997b-2). The new boreholes are expected to provide continuous intact core samples. The need for these boreholes and the integrated characterization plan designed around them are described by Reidel et al (Reidel 1995 and 1997).

2.2.8.2 Geological Structural Framework. The immobilized low-activity tank waste disposal facilities are located south of the Gable Mountain segment of the Umtanum Ridge anticline and north of the Cold Creek syncline (Figure 2-5). The disposal facilities lie about $3 \mathrm{~km}(2 \mathrm{mi})$ north of the axis of the Cold Creek syncline, which controls the structural grain of the basalt bedrock and Ringold Formation. The basalt surface and Ringold Formation trend roughly southeastnorthwest, parallel to the major geologic structures of the Hanford Site. As a result, the Ringold Formation and the underlying Columbia River Basalt Group gently dip to the south off the Umtanum Ridge anticline into the Cold Creek syncline.

Geologic mapping at the Hanford Site has not identified any faults near the proposed disposal facility locations (DOE 1988b). The closest faults are along the Umtanum Ridge-Gable Mountain structure to the north and the May Junction fault to the east. Both faults are about $7.2 \mathrm{~km}(4.5 \mathrm{mi})$ from the disposal sites. 


\section{DOE/RL-97-69}

Rev. 0

2.2.8.3 Stratigraphy Under the Disposal Sites. The geologic features underneath the four existing disposal vaults have been better mapped than for the site of the new disposal facilities. However, because of the extensive geologic mapping of the two areas, a fairly reliable picture can be drawn.

$\rightarrow \rightarrow \rightarrow$ Section $2,2 / 3$ describes the general stratigraphic units and lithology mentioned in Sections 2.2.8.31 through $2,8,3.4$

$\rightarrow \rightarrow \rightarrow$ Section $34.3 . \mathrm{gives}$ the values for stratigraphy used in this assessment

2.2.8.3.1 Boreholes A number of boreholes have been drilled at the site of the existing four vaults (Figure 2-10). Both north-south and east-west cross sections can be determined (Figures 2-11 and 2-12). More information can be found in Lindberg 1993.

Borehole 299-E24-7 lies in the northeast corner of the site of the disposal facilities and 299-E24-18 is located east of the site. The proposed disposal site stratigraphy is estimated from the logs of these boreholes (Figure 2-13). More information can be found in Reidel (1995).

Sections 2.2.8.3.2 through 2.2.8.3.4 give details on the stratigraphic units at the proposed disposal site. The stratigraphy encountered in the boreholes is summarized in Figure 2-8.

2.2.8.3.2 Ringold Formation. At the existing vaults site, the Ringold Formation starts about 90 meters ( 300 feet) below the unperturbed surface. At this location, the Ringold Formation is about 25 to 32 meters ( 82 to 105 feet) thick. At the site of the new disposal facilities, the Formation begins at about 100 meters ( 330 feet) and is about 30 to 38 meters (100 to 125 feet) thick. In both cases the Ringold Formation lies atop the Columbia River Basalt Group.

The primary sediments at the Hanford Site are the Ringold gravel units A and E. Ringold unit $A$ is probably the predominant unit. Both units are a consolidated sandy gravel to muddy sandy gravel. Without an intervening mud unit, distinguishing between the two is difficult.

The Ringold lower mud unit is interpreted to pinch out to the east of or just under the new disposal facilities site. The lower mud unit is absent in borehole 299-E24-7, but might be present farther south under the site. With the lower mud unit absent, gravel unit $E$ directly overlies gravel unit A. The two units cannot be differentiated in borehole 299-E24-7. Studies in the 200 East Area (e.g., Tallman 1979) show that the lower mud must pinch out somewhere between the eastern boundary of 200 East Area and the site of the new disposal facilities. A similar situation exists in the existing vault region. The lower mud unit is seen to the south and east of the existing vaults but the borehole data at the vault site do not conclusively show the mud unit. 


\section{DOE/RL-97-69}

Rev. 0

Figure 2-10. Location Map for Boreholes Near Existing Disposal Vaults. The existing vaults are near the center of the map (between boreholes 2-E25-33 and 2-E25-234).

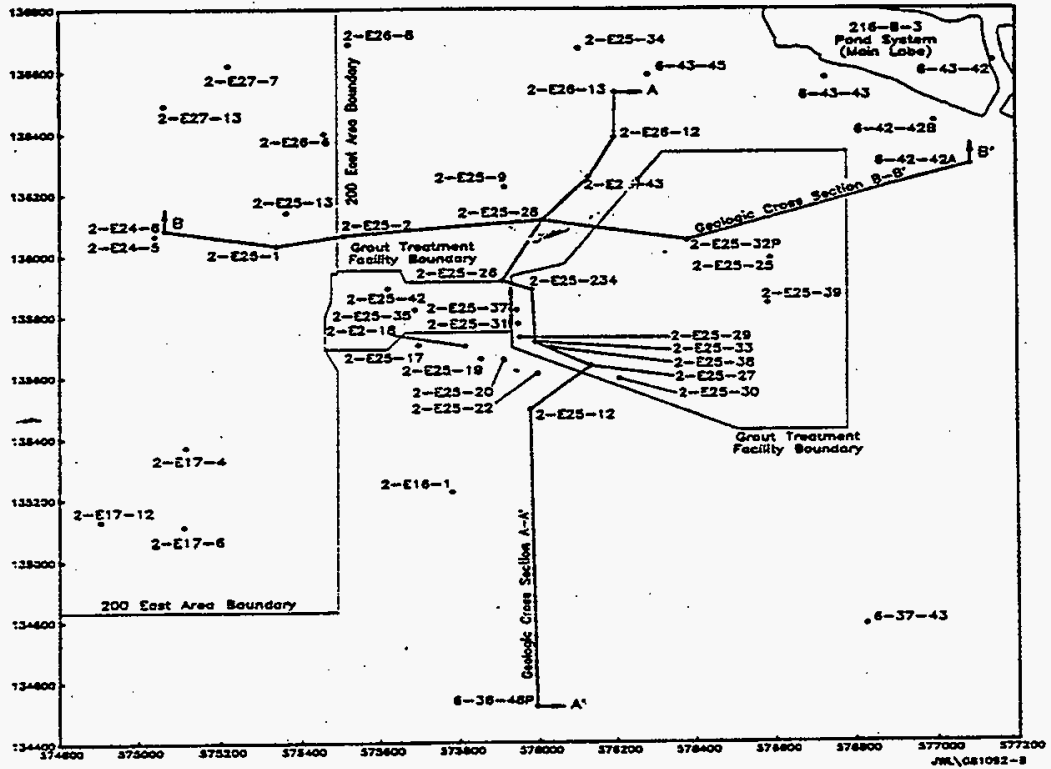

Legend:

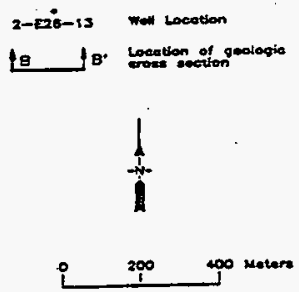




\section{DOE/RL-97-69}

Rev. 0

Figure 2-11. Geologic Cross Section A-A', Existing Vaults.

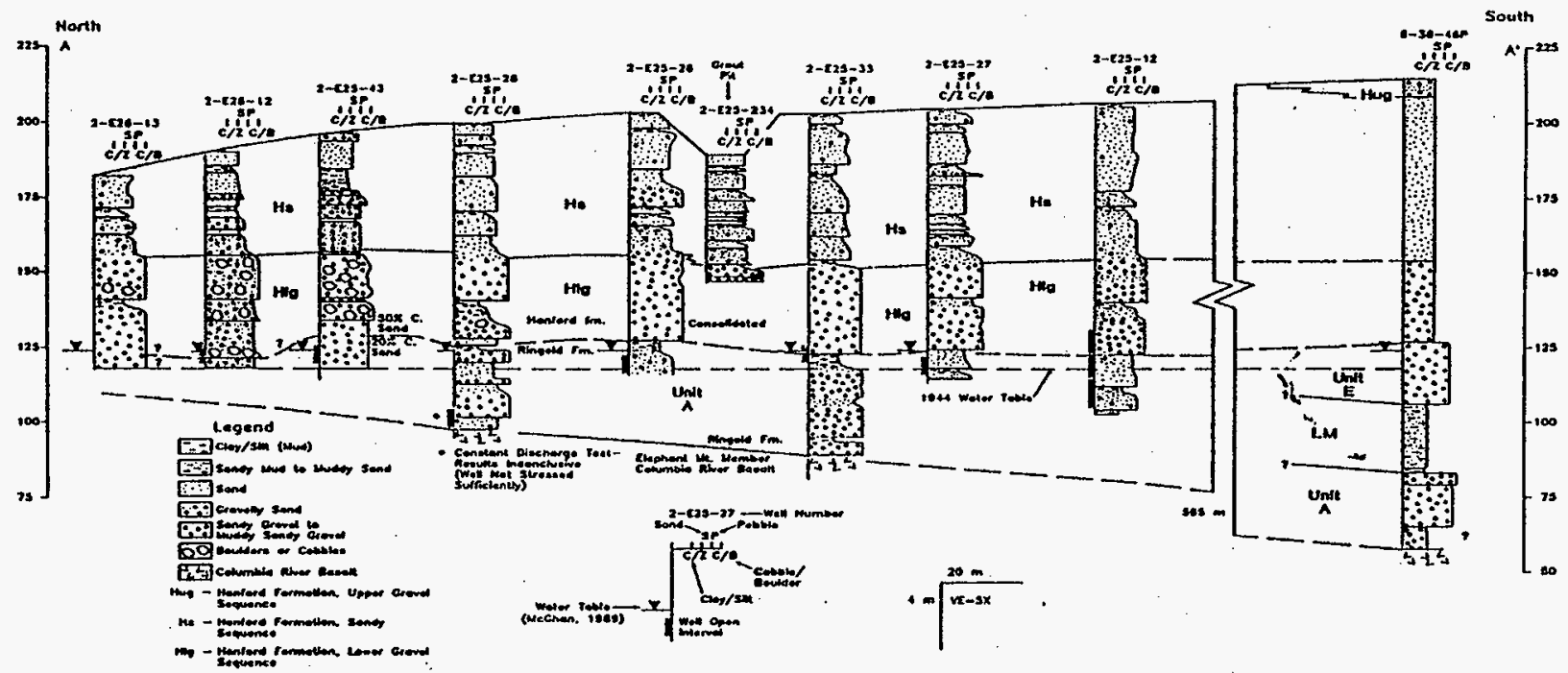

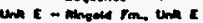

SG97100430.1

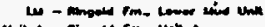




\section{DOE/RL-97-69}

Rev. 0

Figure 2-12. Geologic Cross Section B-B', Existing Vaults.

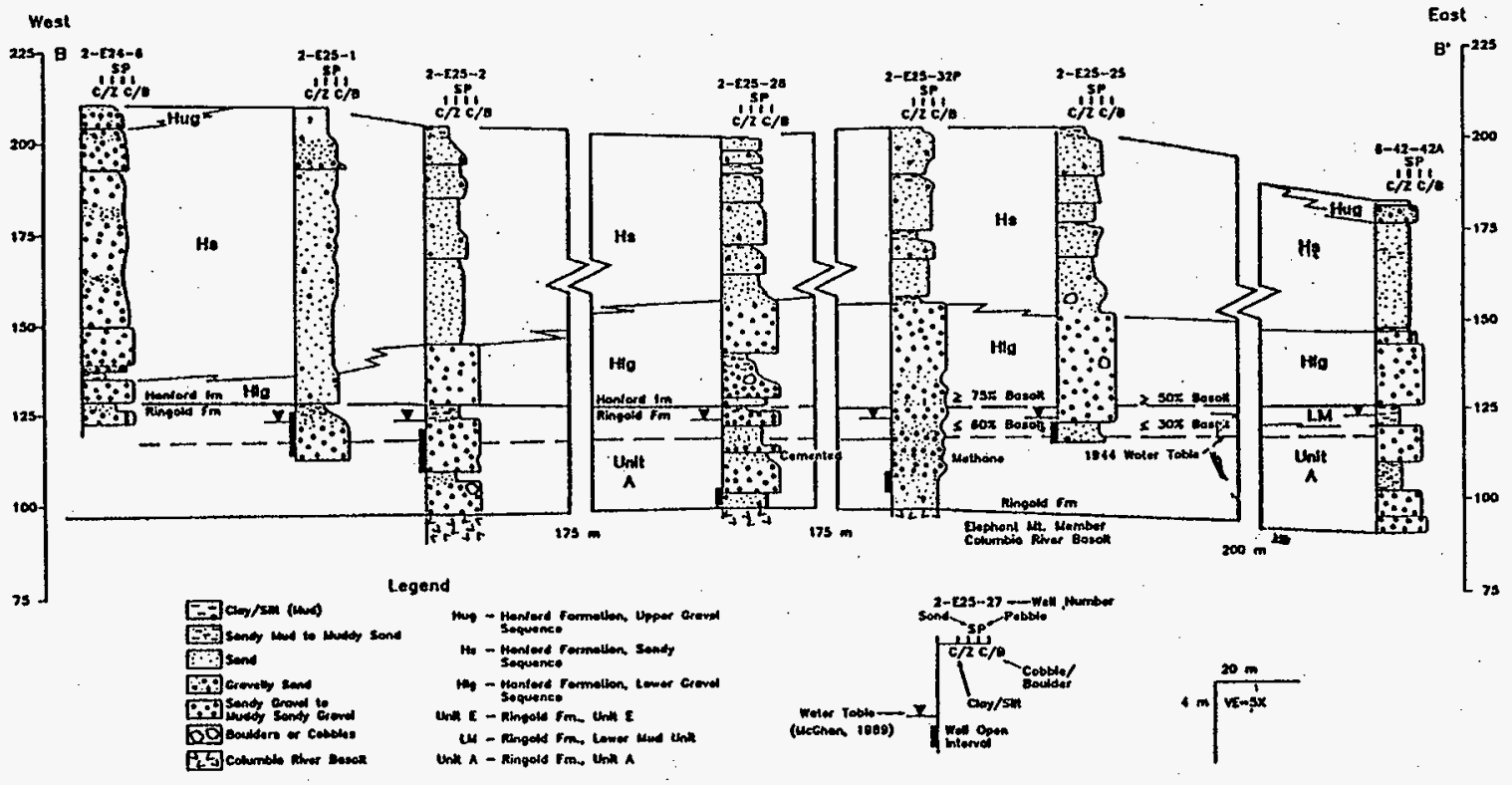




\section{DOE/RL-97-69 \\ Rev. 0}

Figure 2-13. Stratigraphic Units and Lithology at the Location of the New Tank Waste Remediation System Immobilized Low-activity Tank Waste Disposal Facilities.

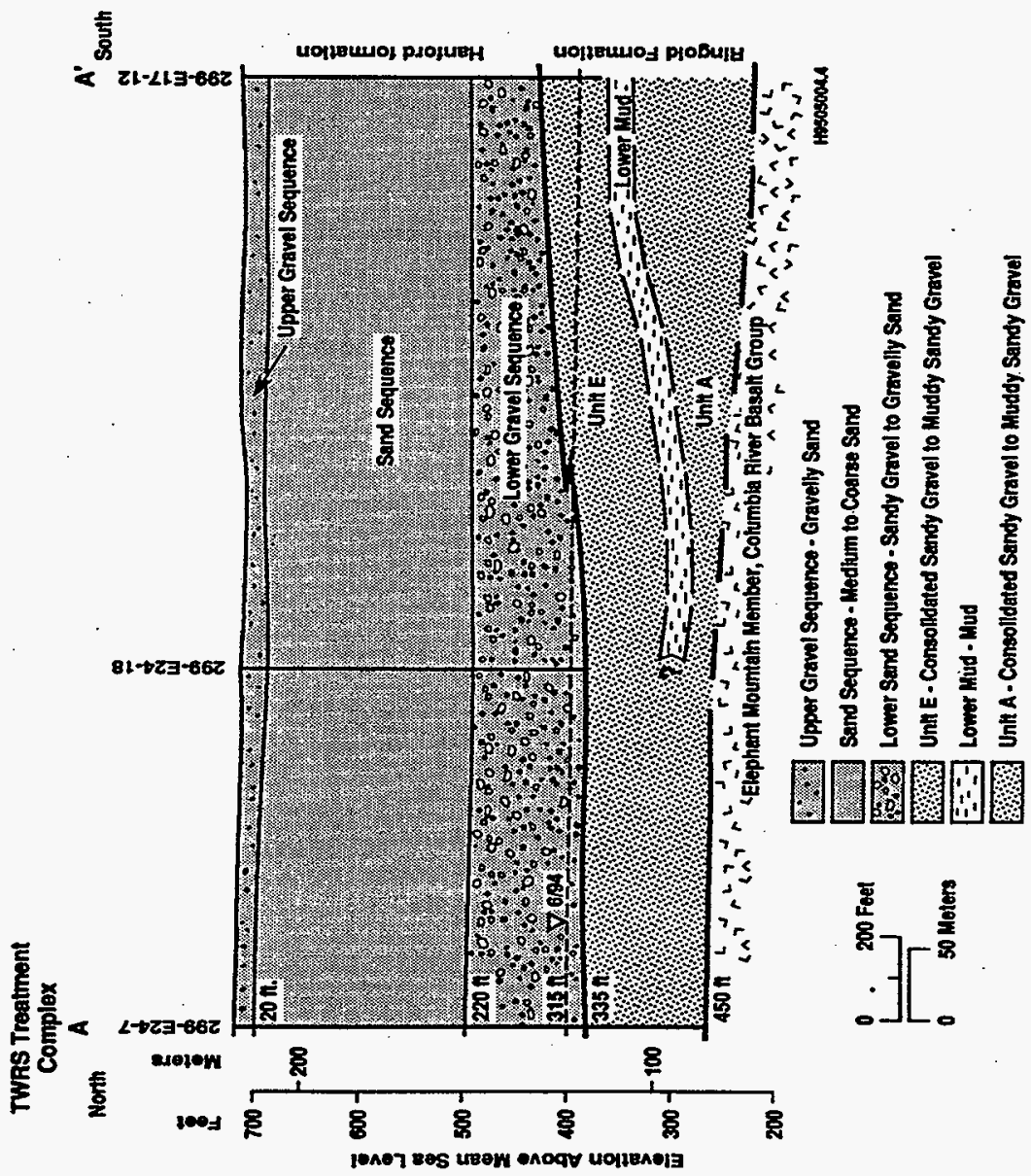




\section{DOE/RL-97-69}

Rev. 0

2.2.8.3.3 Hanford Formation. At the location of the disposal facilities, the Hanford formation is about 90 to $105 \mathrm{~m}$ ( 300 to $345 \mathrm{ft}$ ) thick and consists predominantly of sands and gravelly sands. The sandy sequence is interpreted to lie between a slightly gravelly sand and a lower sandy gravel to gravelly sand. The Hanford formation thickens both to the north and south of the site of the new disposal facilities.

The lower gravel to gravelly sand unit averages about $35 \mathrm{~m}(115 \mathrm{ft})$ thick and probably thins to the east on an irregular Ringold surface. Currently, the water table is probably in this

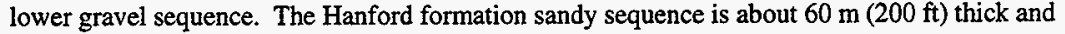
is the dominant facies in the new facility area. The upper $6 \mathrm{~m}(20 \mathrm{ft})$ is composed of an irregularly distributed gravelly sand sequence.

2.2.8.3.4 Holocene Deposits. The southern $200 \mathrm{~m}(656 \mathrm{ft})$ of the site of the new disposal facilities are covered with a stabilized dune sand that is as much as $8 \mathrm{~m}(26 \mathrm{ft})$ high. Mature sagebrush covers much of the site of the new disposal facilities and in particular the sand dunes. The age of the sagebrush indicates that the dune field has been stable since before the Hanford Site was established in the 1940's. Because of the relative flat nature of the surface, landslides are not expected to be significant.

\subsubsection{Regional Hydrology (Both Surface and Groundwater)}

This section describes the concept of recharge rate for the surface and subsurface hydrology of the Hanford Site region and the sites for the disposal facilities. The surface hydrology is important in determining possible surface pathways for dissolved or suspended contaminants, as well as for identifying sources of infiltration. The groundwater hydrology helps determine possible flow paths for contaminants released from a disposal facility and provides a basis for determining vadose zone thickness.

2.2.9.1 Surface Hydrology. The hydrology of the Pasco Basin (Figure 2-14) is characterized by a number of surface sources and aquifers. Surface drainage enters the Pasco Basin from several other basins, including the Yakima River Basin, the Horse
Surface Hydrology Although large rivers are near the Hanford Site, no significant long-term surface water features are near the disposal sites.

Heaven Basin, the Walla Walla River Basin, the Palouse/Snake Basin, and the Big Bend Basin. Within the Pasco Basin, major tributaries, the Yakima, Snake, and Walla Walla Rivers, join the Columbia River. Two intermittent streams, Cold Creek and Dry Creek, cut through the Hanford Site. Water drains through these pathways during wetter winter and spring months. No perennial streams originate within the Pasco Basin.

The total estimated precipitation over the basin averages $16.0 \mathrm{~cm} / \mathrm{y}(6.3 \mathrm{in} / \mathrm{y})$ (Section 2.2.5.2). Mean annual runoff from the basin is estimated to be less than $3.1 \times 10^{7} \mathrm{~m}^{3} / \mathrm{y}$ $\left(2.5 \times 10^{4}\right.$ acre $\left.\mathrm{ft} / \mathrm{y}\right)$, or approximately 3 percent of the total precipitation. The remaining precipitation is assumed to be lost through evapotranspiration, with perhaps a few percent contributing to the recharging of the groundwater (DOE 1988b). 
DOE/RL-97-69

Rev. 0

Figure 2-14. Hydrologic Basins Designated for the Washington State Portion of the Columbia Plateau (DOE 1988b).

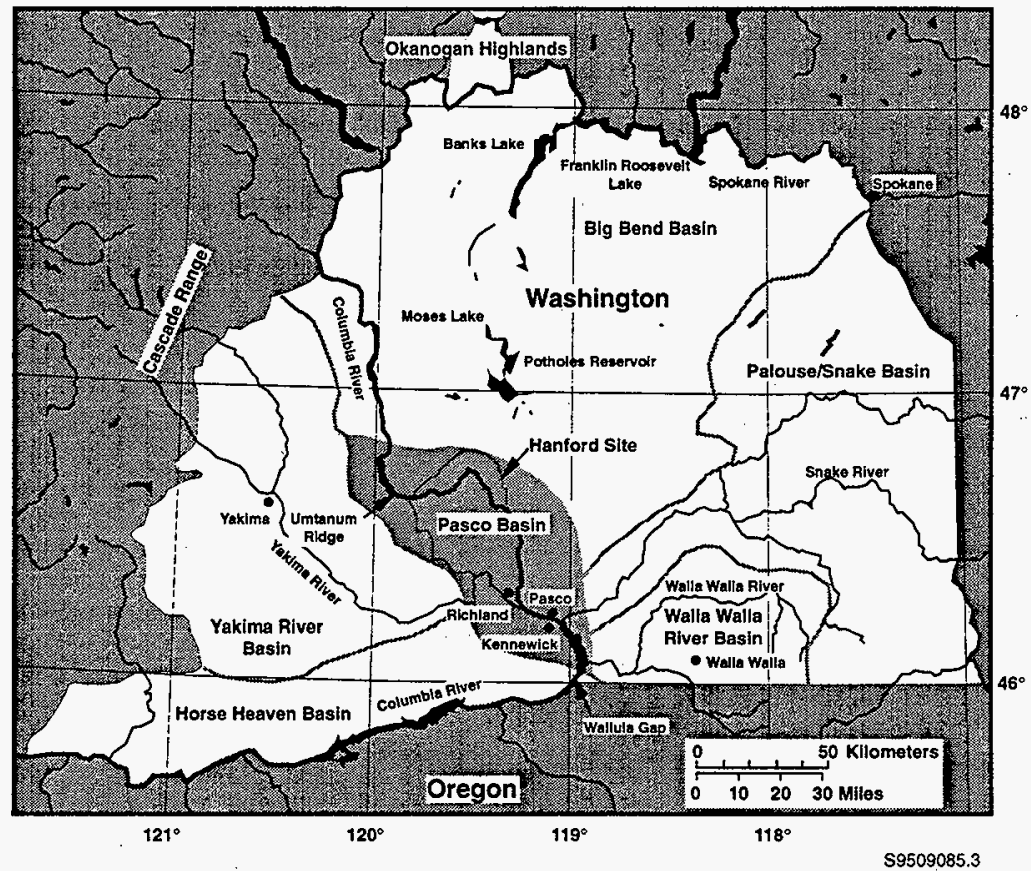

The Hanford Site has one pond, West Lake, and various water disposal ponds. West Lake, located $2.7 \mathrm{~km}$ (1.7 mi) north of the 200 East Area, is a shallow pond with an average

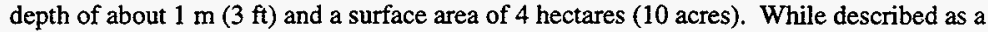
natural lake, the source of recharge to the lake is groundwater that is locally mounded because of infiltration from 200 Area operations. The pond is a topographic depression that intersects the artificially elevated water table (DOE-RL 1993b-1). 200 Area disposal activities are scheduled to halt within a few decades. When this happens, the water table will drop and West Lake will become an intermittent seasonal pond (DOE-RL 1993c). Waste water ponds, cribs, and ditches associated with nuclear fuel processing and waste disposal activities, although currently present on the Hanford Site (Figure 2-15), will not be an important source of water in the future. 


\section{DOE/RL-97-69}

Rev. 0

Figure 2-15. Location of Water Disposal Ponds on the Hanford Site.

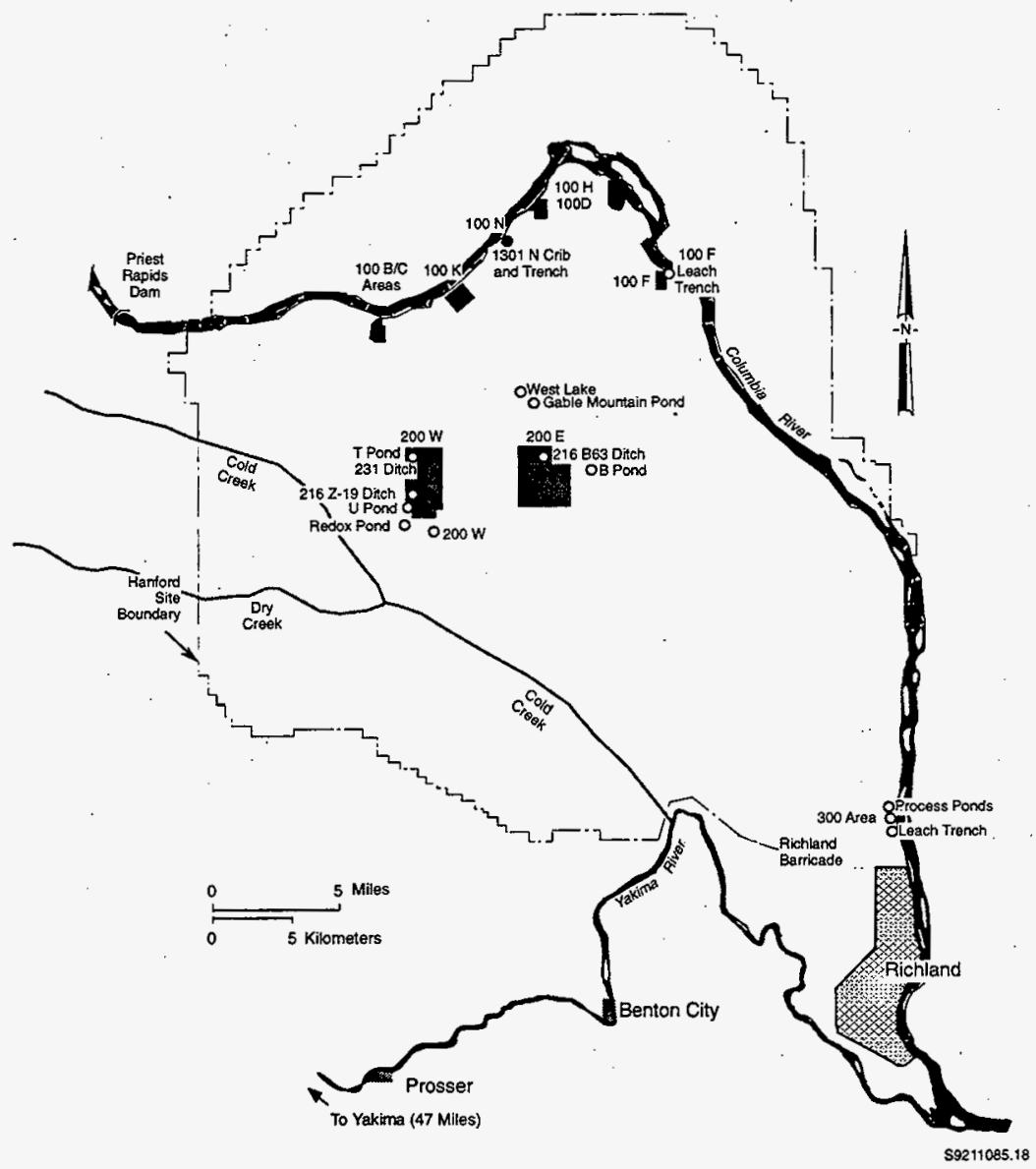

No surface streams are near the proposed disposal facilities, but current disposal ponds have an artificial infiuence on net contributions to the water table. These disposal ponds and related facilities are not expected to exist after current operations end, so their long-term influence is not considered in this performance assessment. 


\section{DOE/RL-97-69}

Rev, 0

The surface drainage characteristics of the Hanford Site and regional area indicate that the Columbia River and its tributaries are the major surface drainage pathways. The Columbia River is the dominant pathway. The large volume of flow in the Columbia River (typically 1,000 to $3,000 \mathrm{~m}^{3} / \mathrm{s}$ [Woodruff 1992]) through the Pasco Basin and downstream greatly dilutes any contaminants that reach the river.

Routine water-quality monitoring of the Columbia River is conducted by DOE for both radiological and nonradiological parameters. The Pacific Northwest National Laboratory (PNNL) has been reporting the water quality data since 1973. Ecology has issued a Class A (excellent) quality designation for Columbia River water from Grand Coulee Dam, through the Pasco Basin, to McNary Dam (Ecology 1992). This designation requires that all industrial uses of this water be compatible with other uses, including drinking, wildlife habitat, and recreation. The Columbia River water is characterized by a low suspended load, a low nutrient content, and an absence of microbial contaminants (Woodruff 1992).

2.2.9.2 Flooding. Cushing (1995-3) describes flooding potentials at the Hanford Site. Except for catastrophic glacier flooding, which is not expected for tens of thousands of years, no floods are expected to affect the Hanford Central Plateau.

The flows for the three largest probable Columbia River flood scenarios range from 17,000 to $600,000 \mathrm{~m}^{3} / \mathrm{s}\left(600,000\right.$ to 21 million $\left.\mathrm{ft}^{3} / \mathrm{s}\right)$. The probable maximum flood on the Columbia River (DOE 1986b), based on natural conditions, has been calculated to be $40,000 \mathrm{~m}^{3} / \mathrm{s}$ (1.4 million $\left.\mathrm{ft}^{3} / \mathrm{s}\right)$. This is greater than the 500 -year flood. A landslide resulting in Columbia River blockage, followed by flooding could yield a maximum flow of $17,000 \mathrm{~m} / \mathrm{s}$ $\left(600,000 \mathrm{ft}^{3} / \mathrm{s}\right)$. The U.S. Army Corps of Engineers estimated that a 50 percent breach in the Grand Coulee Dam, the largest dam in the region, would yield flows of $600,000 \mathrm{~m} / \mathrm{s}$ $\left(21 \mathrm{million} \mathrm{ft}^{3} / \mathrm{s}\right.$ ). None of these flow rates are large enough to cause the waters of the Columbia River to reach the Hanford Central Plateau.

A flood risk analysis of Cold Creek (west of the 200 West Area) was conducted to characterize a basaltic repository for high-level radioactive waste (Skaggs 1981). Based on this evaluation, the probable maximum flood would be $8 \mathrm{~km}(5 \mathrm{mi})$ to the west of the new disposal facility site and its closest approach would be about $6 \mathrm{~km}(3.6 \mathrm{mi})$ to the south. The distance would be even greater for the existing disposal facility site.

2.2.9.3 Groundwater Hydrology. The groundwater pathway is considered the most likely pathway for contaminants released from an immobilized low-activity tank waste disposal facility for the following reasons:

- Low precipitation in the Pasco Basin

- Lack of surface transport pathways near the disposal facilities

- Subsurface location of the disposal facilities 
- Near-surface lysimeter measurements showing downward movement of water

- Samples showing the existence of radioactive contaminant plumes in the groundwater because of past Hanford Site operations.

Evaluating this pathway will require information about the types of aquifers present, depths to the water table, regional flow paths, and the net recharge rate.

The hydrology of the Pasco Basin is characterized by a multiaquifer system. This system consists of four hydrologic units corresponding to the upper three formations of the Columbia River Basalt Group (Grande Ronde Basalt, Wanapum Basalt, and Saddle Mountains Basalt) and the overlying suprabasalt sediments (the Hanford formation and Ringold Formation). The basalt aquifers consist of the tholeitic flood basalts of the Columbia River Basalt Group and relatively minor amounts of intercalated sediments of the Ellensburg formation. Confined zones in the basalt aquifers are present in the sedimentary interbeds and/or interflow zones that occur between dense basalt flows. The main water-bearing portions of the interflow zones are networks of interconnecting vesicles and fractures in the flow tops and bottoms (DOE 1988b).

The uppermost aquifer system consists of fluvial, lacustrine, and glaciofluvial sediments. Within the Pasco Basin, this aquifer is regionally unconfined and is contained primarily within the Ringold Formation and the Hanford formation. The main body of the unconfined aquifer usually occurs within the Ringold Formation. The water table in the southwestern Pasco Basin is generally within Ringold fluvial gravels. In the northern and eastern Pasco Basin, the water table is generally within the Hanford formation. Hydraulic conductivities in the Hanford formation are usually greater than in the gravel facies of the Ringold Formation (Graham 1981). However, fine-grained deposits in the Ringold Formation form locally confining layers for Ringold fluvial gravels.

The base of the uppermost aquifer system is defined as the top of the uppermost basalt flow. This aquifer system is bounded laterally by anticlinal basalt ridges and is about $152 \mathrm{~m}$ $(500 \mathrm{ft}$ ) thick near the center of the Pasco Basin. Within the Hanford Site, this uppermost aquifer system lies at depths ranging from less than $0.3 \mathrm{~m}(1 \mathrm{ft})$ below the ground surface near West Lake and the Columbia and Yakima Rivers, to more than $107 \mathrm{~m}$ (350 ft) in the central portion of the Cold Creek syncline.

$\rightarrow \rightarrow \rightarrow$ The model of the unconfined aquifer is discussed in Section 3.4 .3 .4

$\rightarrow \rightarrow \rightarrow$ Modeling results are given in Section 4.2 .3 .

Because the uppermost unconfined aquifer is considered the primary pathway for possible contaminant transport from an immobilized low-activity tank waste disposal facility, it is especially important in this performance assessment.

Before the liquid waste disposal systems, such as B Pond, began operating, and before the onset of large regional irrigation projects, the groundwater table for the Hanford Site could be represented by a 1944 water table map (Figure 2-16). This water map includes limited 


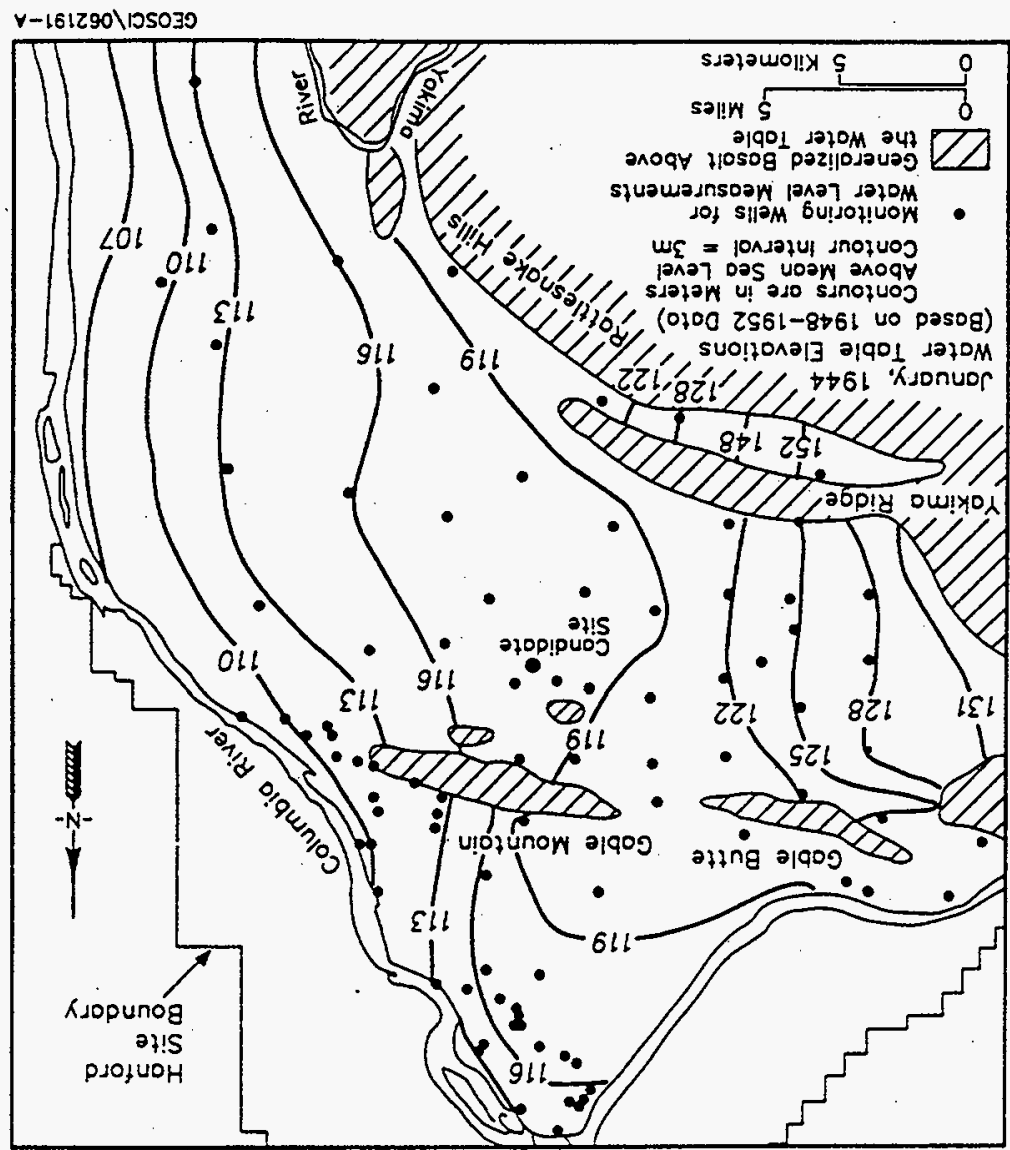

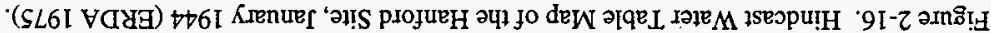

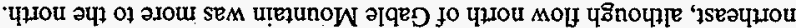

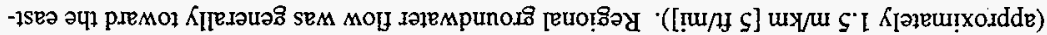

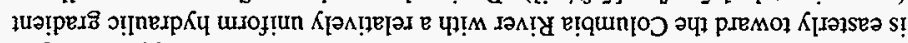

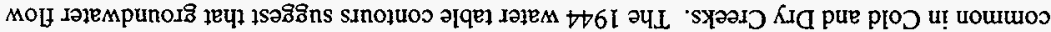

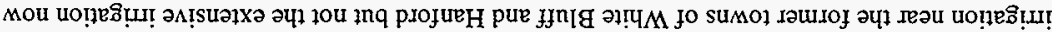

\section{0. Аวิ \\ 69- L6-T\&/3OA}


Effluent disposal at the Hanford Site has altered hydraulic gradients and flow directions of the uppermost aquifer system, particularly near the 200 Areas. Figure 2-17 shows a recent water table map influenced by effluent disposal actions. Regional irrigation projects had a minor influence on the changes shown in Figure 2-17. Groundwater flow is still nominally easterly toward the Columbia River, but mounding occurs in the 200 East Area near B Pond. Groundwater flow north of Gable Mountain now trends in a more northeasterly direction as a result of mounding near reactors and northerly flow through Gable Gap between Gable Mountain and Gable Butte. South of Gable Mountain, flow is interrupted locally by the groundwater mounds in the 200 Areas. Some groundwater from the 200 Areas flows to the north between Gable Mountain and Gable Butte. For the time periods considered in this performance assessment, effluent disposal operations will have stopped.

Figure 2-17. Hanford Site Water Table Map, June 1989 (Smith 1990).

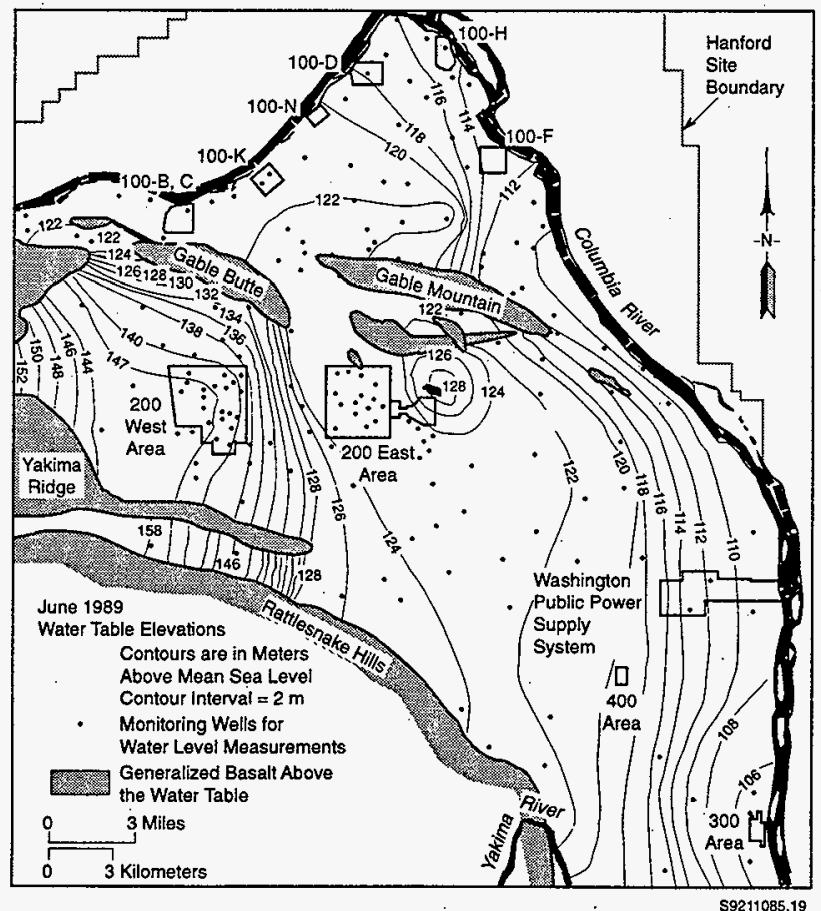


2.2.9.4 Natural Recharge Rates. Recharge is the amount of total precipitation that infiltrates into the unsaturated zone (vadose zone) after runoff, evaporation, and transpiration by plants have occurred. Recharge from rain and snow melt is a major hydrologic variable affecting contaminant transport from an immobilized low-activity tank waste disposal facility.

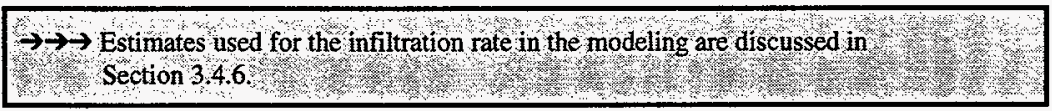

Studies conducted over the last 25 years at the Hanford Site, summarized in the following paragraphs, indicate that long-term recharge can vary greatly depending on factors such as climate, vegetation, land use, and soil texture. As noted in Section 2.2.5, most of the very small amount of precipitation at the Hanford Site falls in the winter and spring. Because of the dry conditions at the Site, most of the precipitation is stored in near-surface soils until used by plants or evaporates during the hot summer months. Natural plants have adapted to use all the water in the near-surface zone. Because of the large storage capacity of the near surface soils, water rarely (just a few days per decade) exits downwards from this near-surface zone. Such rare events typically occur following the rapid melting of a snow pack.

Most recharge rate data at the Hanford Site have been measured directly using a combination of drainage and weighing lysimeters (Rockhold 1995, Gee 1992). These lysimeters are vertical tubes as much as 5 meters long in the ground filled with various type of soils and covered with various types of vegetation. At the bottom of the lysimeters the water that passed through the tube of soil is collected and measured (by volume or weight). The measurements can be used to determine the rate at which moisture escapes the near-surface part of the vadose zone. Because no mechanisms are known to exist that trap the moisture, the measured rate from the lysimeters is considered a good approximation for the recharge rate of the conditions (soil, vegetation, and precipitation) simulated by the lysimeter.

The recharge rate depends on the seasonal distribution of precipitation, type of surface soil and vegetation, and climatic conditions. Maximum recharge events occur following the wettest winter periods. Under normal conditions, the recharge rate is highest in coarse-textured soils without vegetation and is at the measurement threshold in fine-textured soil with or without vegetation. Coarse soil surfaces that are either vegetated with shallow-rooted species or bare exhibit recharge on the order of 50 percent of the precipitation.

Routson and Johnson (Routson 1990) reviewed water infiltration data from a 13-year observation period for a closed-bottom lysimeter located in the 200 East Area and ${ }^{13} \mathrm{Cs}$ profile data from a solid-waste burial ground trench in the 200 West Area. The recharge rate of the closed-bottom lysimeter was estimated to be $0.0 \pm 2.0 \mathrm{~mm} / \mathrm{y}(0.0 \pm 0.08 \mathrm{in} / \mathrm{y})$ based on the 13-year record. Gee (1992) reviewed all published lysimeter studies for the Hanford Site. They noted that the main determiners for recharge were the texture of the soil and the amount and type of vegetation on the soil. 


\section{DOE/RL-97-69}

Rev. 0

The very limited data from environmental tracer techniques are generally consistent with data from the lysimeters. The tracer data indicate that (undisturbed) vegetated sites have experienced as little as 0.01 to $0.1 \mathrm{~mm} / \mathrm{y}(0.0004$ to $0.004 \mathrm{in} / \mathrm{y})$ of recharge and up to 3.0 to $4.0 \mathrm{~mm} / \mathrm{y}(0.1$ to $0.2 \mathrm{in} / \mathrm{y})$ (Prych 1995). However, the tracer techniques, while powerful cannot be applied to disturbed or engineered sites. Also, these techniques have been unable to measure significant rates of recharge at sites with coarse soils and shallow-rooted vegetation, because of deep percolation of natural tracers at these sites.

Besides studying local recharge rates using lysimeter and tracer techniques, scientists have studied recharge on a regional scale. Bauer and Vaccaro (Baver 1990) estimated groundwater recharge for the Hanford Site as part of their study of recharge affecting the Columbia Plateau regional aquifer. Using estimates of soil type and land use and a water balance model, they estimated recharge rates for most of the Site (including the immobilized low-activity tank waste disposal facility sites). These estimates ranged from 0 to $12.7 \mathrm{~mm} / \mathrm{y}$ ( 0 to $0.5 \mathrm{in} / \mathrm{y}$ ). In contrast, near sand dunes in the middle of the Hanford Site, they estimated rates as high as $51.0 \mathrm{~mm} / \mathrm{y}(2.0 \mathrm{in} / \mathrm{y})$.

More recently, Fayer and Walters (Fayer 1995c) estimated recharge rates based on measurements (lysimeters, tracers, and regional studies) and on numerical modeling. Estimates made using these methods were assigned to specific soil-vegetation combinations and distributed across the Hanford Site using a soil map and a vegetation/land use map. The longterm average rates varied from $2.6 \mathrm{~mm} / \mathrm{y}(0.1 \mathrm{in} / \mathrm{y})$ for several soil and vegetation combinations in the 200 Areas (including the immobilized low-activity tank waste disposal facility sites) to $127.0 \mathrm{~mm} / \mathrm{y}(5.0 \mathrm{in} / \mathrm{y})$ for basalt outcrop with no vegetation at the crest of the Rattlesnake Mountain (Fayer 1995c).

Because of the high degree of variability and the importance of recharge rates to the performance assessment, additional work is planned to estimate recharge rates through a combination of computer simulations, lysimeter measurements, and tracer methods (Mann 1997b-1). These efforts will consider the comments made by outside experts (Honeyman 1995).

\subsubsection{Geochemistry}

The Applied Geology and Geochemistry Group of the Pacific Northwest National Laboratory has been studying the geochemistry of the Hanford Site vadose zone and groundwater for a long time. Little work has been done with surface water because geochemistry plays a small role there.

$\rightarrow \rightarrow$ Geochemical values used in this document are presented in Section $3,4,3,3$.

The strategy, as furst outlined in Serne 1990, is to identify waste contaminants, pertinent geochemical conceptual release and sorption models, and available data that quantify the 


\section{DOE/RL-97-69}

Rev. 0

environment (e.g. pH, Eh, and complexing ligands); calculate the range of sorption, solubility, and release rate variables; collect data; simulate the contaminant transport; then determine if the disposal action is acceptable given the data uncertainties. If uncertainties are too high or if requirements change, the process will be repeated.

The Hanford Site has a long history of conducting laboratory experiments to determine geochemical retardation. The results of the first experiment were reported in 1966. These experiments (see Kaplan 1995a for a summary of the experiments) are normally performed by passing a solution thought typical of the contaminant leachate through relevant Hanford Site sediments. The results of these tests have been used to develop a conceptual model representing geochemical retardation away from the waste source region in terms of the $\mathrm{K}_{\mathrm{d}}$ model

$$
\mathrm{R}=1+\mathrm{K}_{\mathrm{d}} \rho / \theta
$$

where $R$ is the retardation factor, $K_{d}$ is the chemical distribution coefficient for the chemical, $\rho$ is the bulk density, and $\theta$ is the volumetric water content. The chemical distribution coefficient for each contaminant can be treated as being from one of the following groups of solutions:

- Alkaline, low salt, low organic, oxidized solutions

- Alkaline, low salt, low organic, anoxic solutions

- Alkaline, high salt, low-organic, oxidized solutions

- Alkaline, high salt, low-organic, anoxic solutions.

These groupings are appropriate because the soils on the Hanford Site are alkaline and contain very little organic material.

In $1996,{ }^{137} \mathrm{Cs}$ was found at significant depths below a leaking underground storage tank. Some (Conway 1997) believe that this discovery invalidated the conceptual model of the Hanford Site vadose zone. However, the leaking tank waste was not representative of other Site conditions, particularly those expected in this disposal action because the waste was at high temperature $\left(>180^{\circ} \mathrm{C}\right)$, high density $\left(>2 \mathrm{~g} / \mathrm{cm}^{3}\right)$, and had a very high chemical salt content.

The data used in this analysis are based primarily on Kaplan 1995a and Kaplan 1995b. Research since that publication is documented in Kaplan 1996 and Kaplan 1997. The results of the new research suggest that moisture dependency (especially for uranium) may be more complex than previously thought (Kaplan 1996) and that colloidal transport will not be a concern at the Hanford Site (McGraw 1997).

\subsubsection{Natural Resources}

The Central Plateau of the Hanford Site has no important natural resources. No major mining operations exist in the Hanford Site area. Oil and gas exploration has occurred; however, no economically viable accumulations were found. Some local gravel processing is being done in the area. 


\section{DOE/RL-97-69}

\section{Rev. 0}

As noted in the hydrology section (Section 2.2.9), the unconfined aquifer is not a significant resource for water. Monitoring wells on the Hanford Site normally have screen lengths of $6.1 \mathrm{~m}(20 \mathrm{ft})$.

\subsubsection{Regional Background Contamination and Hanford Site Monitoring}

The Hanford Site has an extensive monitoring program. Studies have been directed at determining background levels of possible contaminants in the soil (DOE-RL 1994b and DOE-RL 1995b) and in the groundwater (Johnson 1993). Also, reports are issued annually covering general environmental conditions (Dirkes 1997) and groundwater monitoring (Dresel 1995).

2.2.12.1 Soil Background Levels. Low concentrations of ${ }^{238} U$ and ${ }^{137} \mathrm{Cs}$ were measured in samples of soil and vegetation during 1994 (Dirkes 1997-1). The levels were similar to those measured in previous years. No discernible increase in concentration could be attributed to current Hanford Site operations. DOE-RL 1995b summarizes all the measurements taken to determine radionuclide background levels at the Hanford Site. Table 2-2 displays the average of the measurements.

Table 2-2. Activity of Radionuclides in Hanford Sitewide Background Data Set. (The table is reproduced from DOE-RL 1995b).

\begin{tabular}{|l|l|l|l|l|l||}
\hline Nuclide & $\begin{array}{l}\text { Activity } \\
(\mathrm{pCi} / \mathrm{g})\end{array}$ & Nuclide & $\begin{array}{l}\text { Activity } \\
(\mathrm{pCi} / \mathrm{g})\end{array}$ & Nuclide & $\begin{array}{l}\text { Activity } \\
(\mathrm{pCi} / \mathrm{g})\end{array}$ \\
\hline${ }^{40} \mathrm{~K}$ & 15.4 & ${ }^{60} \mathrm{Co}$ & 0.00132 & ${ }^{90} \mathrm{Sr}$ & 0.0806 \\
\hline${ }^{137} \mathrm{Cs}$ & 0.417 & ${ }^{154} \mathrm{Eu}$ & 0.0083 & ${ }^{155} \mathrm{Eu}$ & 0.0234 \\
\hline${ }^{226} \mathrm{Ra}^{2}$ & 0.686 & ${ }^{232} \mathrm{Th}+\mathrm{D}$ & 0.687 & ${ }^{235} \mathrm{U}+\mathrm{D}$ & 0.0271 \\
\hline${ }^{238} \mathrm{U}+\mathrm{D}$ & 0.675 & ${ }^{238} \mathrm{Pu}$ & 0.00158 & ${ }^{239} / 240 \mathrm{Pu}$ & 0.00935 \\
\hline
\end{tabular}

" $+\mathrm{D}$ " indicates that daughters are included

${ }^{2}{ }^{226} \mathrm{Ra}$ is part of ${ }^{238} \mathrm{U}$ decay chain and is included in that entry.

2.2.12.2 Groundwater Background Levels. Sample results from environmental monitoring can vary depending on local operations, so a regional baseline study was conducted using these and other sitewide monitoring results (Johnson 1993). Groundwater background values and trigger threshold levels are shown in Table 2-3. 
DOE/RL-97-69

Rev. 0

Table 2-3. Provisional Background Values for Hanford Site Groundwater. ${ }^{2}$

\begin{tabular}{|c|c|c|}
\hline Constituent (Concentration) & $\begin{array}{c}\text { Groundwater Background } \\
\text { Values }^{b}\end{array}$ & $\begin{array}{c}\text { Provisional Threshold } \\
\text { Values }\end{array}$ \\
\hline Aluminum (ppb) & $<2$ & $<200$ \\
\hline Ammonium (ppb) & $<50$ & $<120$ \\
\hline Arsenic (ppb) & $3.9 \pm 2.4$ & 10 \\
\hline Barium (ppb) & $42 \pm 20$ & 68.5 \\
\hline Beryllium (ppb) & $<0.3$ & $<5$ \\
\hline Bismuth (ppb) & $<0.02$ & $<5$ \\
\hline Boron (ppb) & $<50$ & $<100$ \\
\hline Cadmium (ppb) & $<0.2$ & $<10$ \\
\hline Calcium (ppb) & $40,400 \pm 10,300$ & 63,600 \\
\hline Chloride (ppb) & $10,300 \pm 6,500$ & NC \\
\hline Chromium (ppb) & $4 \pm 2$ & $<30$ \\
\hline Copper (ppb) & $<1$ & $<30$ \\
\hline Fluoride (ppb) & $370 \pm 100$ & $1,340,775^{\mathrm{c}}$ \\
\hline Iron-mid (ppb) & NA & 291 \\
\hline Lead (ppb) & $<0.5$ & $<5$ \\
\hline Magnesium (ppb) & $11,800 \pm 3,400$ & 16,480 \\
\hline Manganese (ppb) & $7 \pm 5$ & $\mathrm{NC}$ \\
\hline Mercury (ppb) & $<0.1$ & $<0.1$ \\
\hline Nickel (ppb) & $<4$ & $<30$ \\
\hline Nitrate (ppb) & NA & 12,400 \\
\hline Phosphate (ppb) & $<1,000$ & $<1,000$ \\
\hline Potassium (ppb) & $4,950 \pm 1,240$ & 7,975 \\
\hline Selenium (ppb) & $<2$ & $<5$ \\
\hline Silver (ppb) & $<10$ & $<10$ \\
\hline Silicon (ppb) & NA & 26,500 \\
\hline Sodium (ppb) & $18,260 \pm 10,150$ & 33,500 \\
\hline
\end{tabular}


DOE/RL-97-69

Rev. 0

Table 2-3. Provisional Background Values for Hanford Site Groundwater. ${ }^{a}$

\begin{tabular}{|c|c|c|}
\hline Constituent (Concentration) & $\begin{array}{c}\text { Groundwater Background } \\
\text { Values }\end{array}$ & $\begin{array}{c}\text { Provisional Threshold } \\
\text { Values }\end{array}$ \\
\hline Strontium (ppb) & $236 \pm 102$ & 264.1 \\
\hline Sulfate (ppb) & $34,300 \pm 16,900$ & 90,500 \\
\hline Uranium $(\mathrm{pC} / / /)$ & $1.7 \pm 0.8$ & 3.43 \\
\hline Vanadium (ppb) & $17 \pm 9$ & 15 \\
\hline Zinc (ppb) & $6 \pm 2$ & NC \\
\hline Field alkalinity(ppb) & NA & 215,000 \\
\hline Laboratory alkalinity (ppb) & $123,000 \pm 21,000$ & 210,000 \\
\hline Field $\mathrm{pH}$ & NA & $(6.90,8.24)$ \\
\hline Laboratory $\mathrm{pH}$ & $7.64 \pm 0.16$ & $(7.25,8.25)$ \\
\hline Total organic carbon (ppb) & $586 \pm 347$ & $2,610,1,610^{c}$ \\
\hline Field conductivity $(\mu \mathrm{mho} / \mathrm{cm})$ & NA & 539 \\
\hline $\begin{array}{l}\text { Laboratory conductivity } \\
(\mu \mathrm{mho} / \mathrm{cm})\end{array}$ & $380 \pm 82$ & 530 \\
\hline TOX, LDL (ppb) & NA & $60.8,37.6^{c}$ \\
\hline Total carbon (ppb) & NA & 50,100 \\
\hline Gross alpha (pCi/l) & $2.5 \pm 1.4$ & $63,5.79^{c}$ \\
\hline Gross beta (pCi/l) & $19 \pm 12$ & $35.5,12.62^{c}$ \\
\hline Radium (pCi/l) & $<0.2$ & 0.23 \\
\hline
\end{tabular}

- From Tables 5-9 and 5-11 of DOE-RL 1992.

- Results shown are mean \pm one standard deviation, unless only an upper limit is given.

- Potential outlier observation(s) were removed.

LDL = lower detectability limit

NA $=$ not available.

$\mathrm{NC}=$ not calculated.

TOX $=$ total organic halides

2.2.12.3 Radiation Background Levels. Various natural and human-produced sources contribute to radiation doses. These sources include natural terrestrial and cosmic background radiation, medical treatment and $x$-rays, natural internal body radioactivity, and inhalation of naturally occurring radon. Figure 2-18 shows the national average dose from each of these 


\section{DOE/RL-97-69 \\ Rev, 0}

sources to an individual. Of the contributions shown in Figure 2-18, natural background contributes 300 mrem to the estimated per capita annual dose to individuals living near the Hanford Site. Human-produced sources contribute an additional 65 mrem. In contrast, annual Hanford Site environmental reports such as Dirkes and Hanf (Dirkes 1997-2) estimate that the maximum annual dose to an individual from Hanford Site operations in 1994 was about 0.05 mrem. This is similar to values seen over the last 4 years.

The public is exposed to radiation at or near the Hanford Site from industrial sources other than DOE operations. These sources include the low-level radioactive waste burial site operated by U.S. Ecology, the nuclear generating station operated by the Supply System, the nuclear fuel production plant operated by Siemans Nuclear Power Corporation, the low-level waste compacting facility operated by Allied Technology Corporation, and a decontamination facility operated by Pacific Nuclear Services. Based on information gathered from these companies, Dirkes and Hanf (Dirkes 1997-2) conservatively determined that the total 1994 annual dose for the hypothetical maximally exposed individual from those activities also was 0.05 mrem.

Figure 2-18. Averages for Natural and Human-Produced Sources of Radiation (NCRP 1987).

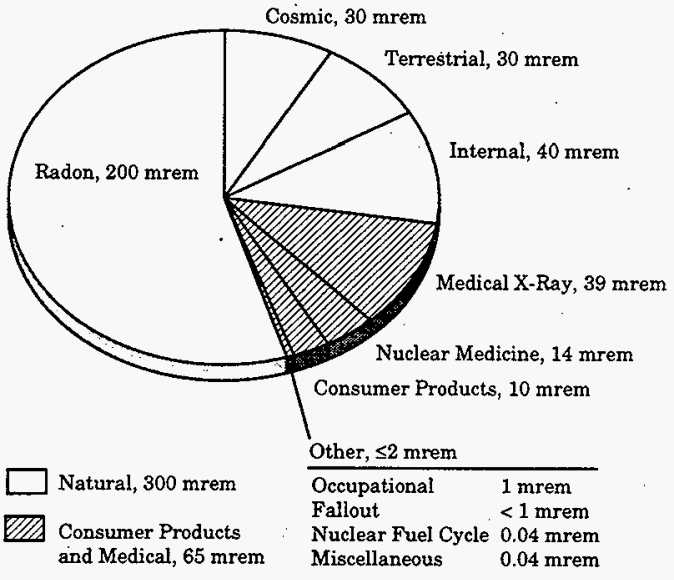

59203058.94 


\section{DOE/RL-97-69}

Rev. 0

\subsection{WASTE CHARACTERISTICS}

\subsubsection{Overview}

The source of the waste material to be incorporated into a solidified waste form is the waste currently stored in the Hanford Site's single- and double-shell tanks. This section covers the activities from the current storage of special material production wastes through the delivery of the treated waste at the disposal sites.

The TWRS record of decision (DOE 1997b) states that the waste will be retrieved from the tanks, then chemically separated to form the high-and low-activity radioactive waste streams. The high-activity radioactive waste stream will contain most of the radionuclides. This waste stream will be vitrified, and the product stored until it can be transferred to a licensed high-level waste repository. The low-activity radioactive waste stream contains the bulk of the non-radioactive chemicals and is predominantly the soluble components of the tank waste. This waste stream will be solidified in a glass or other form that meets the DOE specifications (DOE-RL 1996, reproduced in Appendix A). It is proposed to dispose of the immobilized lowactivity waste form on site in a manner that allows the waste to be retrievable for at least 50 years; although this time period has not been officially adopted. This overall strategy for the Hanford Tank Waste Remediation System is shown in Figure 2-19 (DOE-RL 1995a-1).

\subsubsection{Underground Tank Storage}

To store the liquid high-level radioactive waste generated by Hanford Site operations since 1944, 149 single-shell tanks and 28 double-shell underground tanks were built. The tanks are grouped into 18 tank farms containing over $209,000 \mathrm{~m}^{3}$ (54.3 Mgal) [Hanlon 1997-1] of waste. The consistency of the tank waste ranges from dilute aqueous solutions to thick paste to hard rock.

Four basic chemical processing operations generated the radioactive waste solutions. These operations were the bismuth phosphate process, the REDOX process, the PUREX process, and the Tributyl Phosphate process. The first three processes recovered plutonium from irradiated reactor fuels. The last process recovered uranium waste generated in the bismuth phosphate process. Other specialized campaigns recovered ${ }^{137} \mathrm{Cs},{ }^{90} \mathrm{Sr}$, and other special nuclear materials. The aqueous waste was made alkaline to control corrosion in the carbon-steel underground tanks. Anderson (1990) provides a history of the liquid waste generation and its subsequent handling and storage in the tank farms. 
•spinb!̣ גuequeurodns

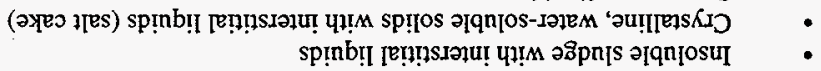

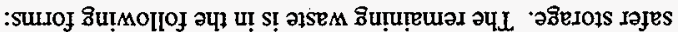

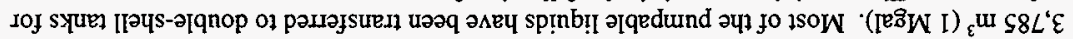

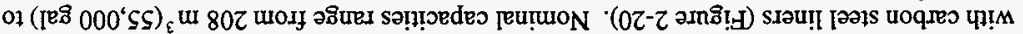

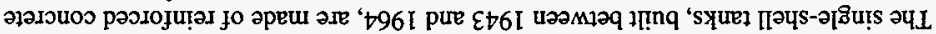

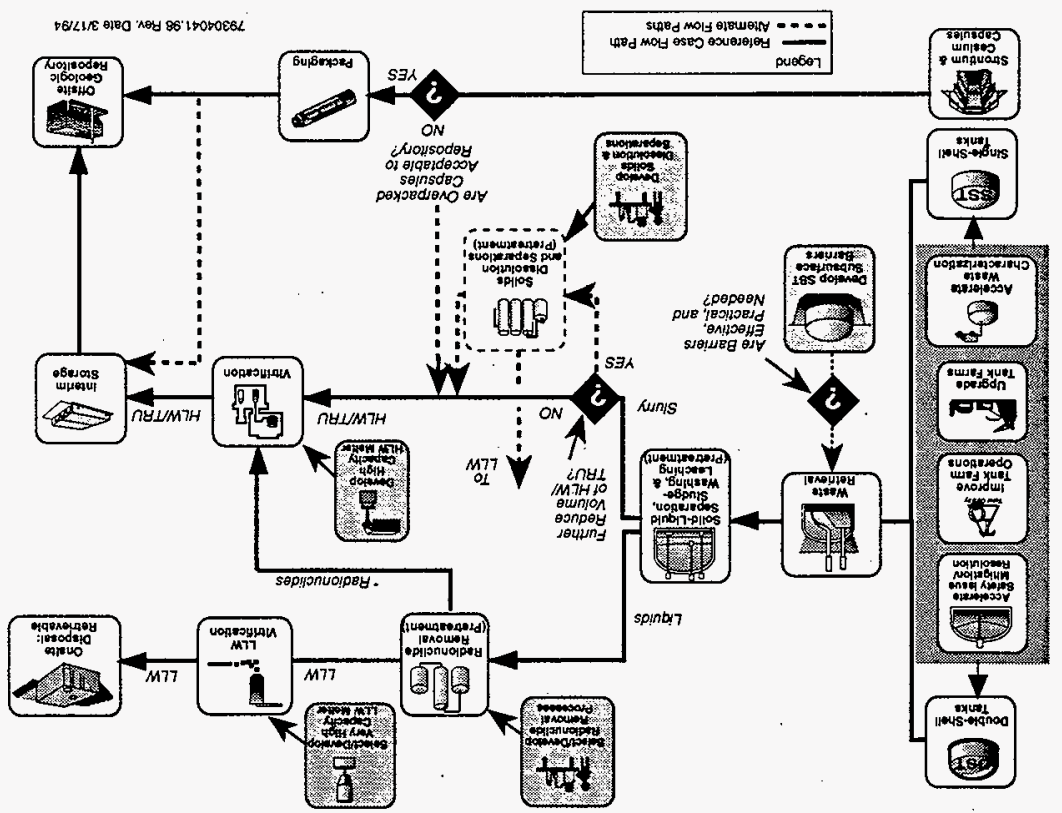

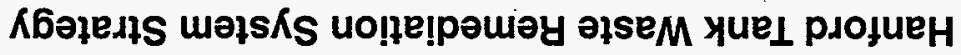

(I-ES66I T\&-تुOC

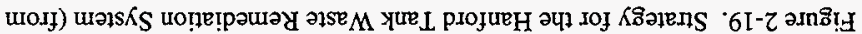


DOE/RL-97-69

Rev. 0

Sixty-seven single-shell tanks have leaked or are suspected to have leaked approximately $3,785 \mathrm{~m}^{3}$ (1 Mgal) of waste (Hanlon 1997-2).

Figure 2-20. Single-Shell Tank. For clarity, feed lines, risers, and instrumentation are not shown.

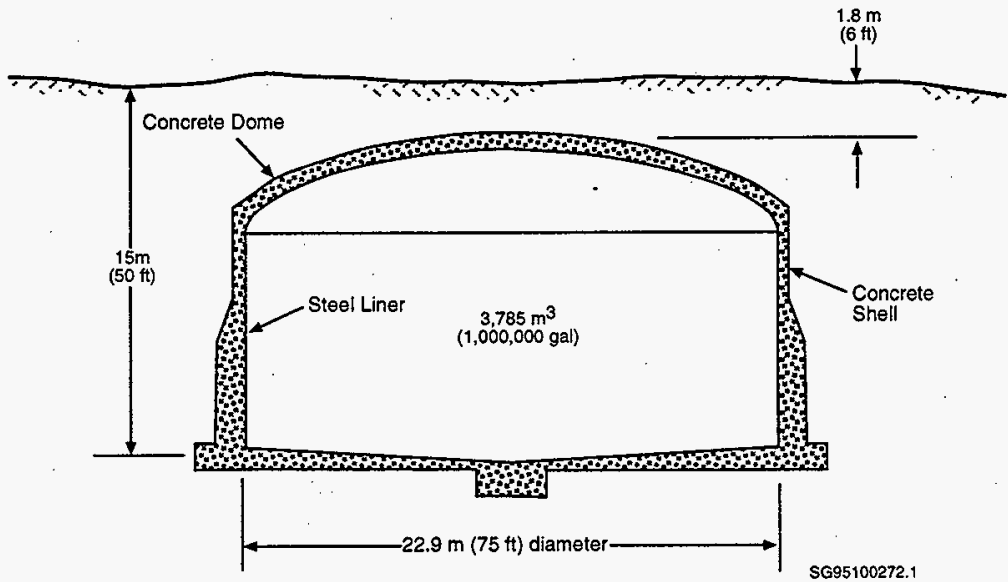

The double-shell tanks, first used in 1971, consist of a carbon steel primary tank, an annular space, and a secondary steel tank encased in reinforced concrete (Figure 2-21). Each double-shell tank has a capacity of $4,310 \mathrm{~m}^{3}(1.14 \mathrm{Mgal})$.

Most of the tank waste has undergone one or more treatment steps (for example, neutralization, precipitation, decantation, or evaporation). The neutralized waste contains sodium nitrate and nitrite, sodium hydroxide, sodium aluminate, sodium phosphate, various insoluble hydroxides and phosphates, usually small quantities of organic materials, and various radionuclides ( approximately $250 \mathrm{MCi}$ ). The main effect of the treatment steps other than neutralization was to reduce the water content of the waste. 
Figure 2-21. Double-Shell Tank.

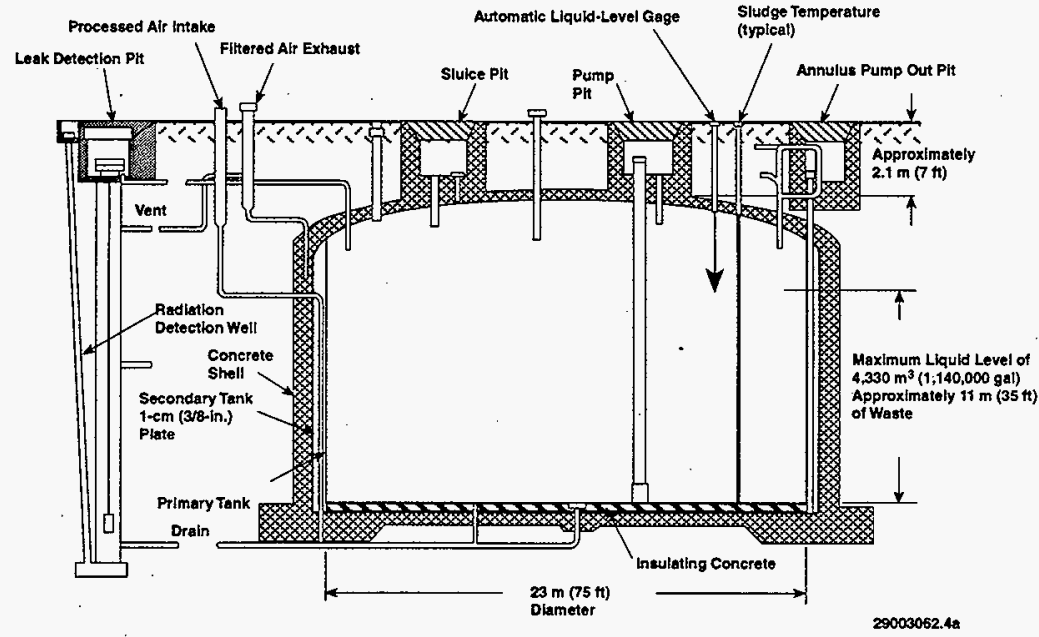

\subsubsection{Tank Waste Retrieval}

According to the Tri-Party Agreement (Ecology 1996-3), as much waste as possible given current technology must be removed from the tanks for treatment and immobilization. Unless limited by waste retrieval technology, the single-shell tank waste residues must not exceed $360 \mathrm{ft}^{3}$ (approximately $10 \mathrm{~m}^{3}$ ) in each 100 -series tank, which can hold $208 \mathrm{~m}^{3}$ (55,000 gallons) of waste. For the 200 -series tanks, which have volumes above $2,000 \mathrm{~m}^{3}$ (530,000 gallons), the limit is $30 \mathrm{ft}^{3}$ (approximately $1 \mathrm{~m}^{3}$ ). On a tank-by-tank basis, the DOE can request that the EPA and Ecology approve a higher residue limit.

\subsubsection{Separations}

The purpose of the separations step [DOE 1997b] is to separate the retrieved tank waste into the following two radioactive waste streams:

- A low-activity stream containing the bulk of the non-radioactive material and limited amounts of radionuclides. This waste will be immobilized and disposed of in the 200 Areas on the Hanford Site. 
- A much smaller high-activity stream containing most of the radionuclides. This waste will be immobilized, then stored until a licensed Federal high-level repository is ready to receive it.

This strategy is intended to achieve reasonable waste disposal costs in comparison with the costs of disposing of all of the tank waste at the proposed high-level repository, while providing adequate protection of the environment and the public. DOE plans to accomplish the treatment of tank waste in two phases. Phase 1 is planned to be a small scale demonstration with waste treatment and immobilization provided by private vendors. In phase 2 , private vendors would provide waste treatment and immobilization services in "full-scale" plants as well as retrieve wastes from the tanks. In both phases DOE would store and dispose of the immobilized product.

TWRS plans to use the following three-step approach during Phase 1 (2002 through about 2010).

1. Separate the soluble components from the insoluble components by means of intank "sludge washing" followed by settle-decant of the supernate.

2. Treat the soluble fraction to provide a feed to the low-activity waste immobilization facility that is in accordance with the U.S. Nuclear Regulatory Commission's "incidental waste" classification for Hanford Site waste (Berneo 1993, Paperiello 1997). The Nuclear Regulatory Commission requires that the waste meet the following criteria.

- The waste has been processed (or will further be processed) to remove key radionuclides to the maximum extent possible that is technically and economically practical.

- The waste will be incorporated in a solid physical form at a concentration level that does not exceed the applicable concentration limits for Class $\mathrm{C}$ low-level waste as set out in 10 CFR Part 61 (10 CFR.61-2).

- The waste is to be managed, pursuant to the Atomic Energy Act of 1954 (AEA 1954), so that safety requirements comparable to the performance objectives set out in 10 CFR Part 61 (10 CFR 61 - 3) are satisfied.

3. Wash the insoluble fraction in the tank, then use enhanced in-tank sludge washing (alkaline leaching) to remove more soluble non-radioactive material from the feed going to the high-level waste vitrification facility. Any additional separations required will be performed in the proposed high-level waste separations facility.

Performance details may differ during the second privatization production period, but equivalent separations are expected. 


\section{DOE/RL-97-69 \\ Rev. 0}

The NRC staff (Paperiello 1997) have indicated that such a separations activity along with an assessment consistent with NRC standards would allow the NRC to treat the lowactivity waste as "incidental waste."

\section{Section 3.1 provides the estimate of inyentory before and after separations}

\subsubsection{Immobilization of the Low-Activity Waste}

After separation, the waste will be immobilized. Only some external properties, including size, shape, the maximum radiation level, and the maximum contaminant release rate, have been set (DOE-RL 1996). None of the secondary waste streams from immobilization are expected to go into the proposed immobilized low-activity tank waste disposal facilities.

Based on the expected waste loading, about 100,000 containers will be generated (Burbank 1997). This corresponds to 260,000 cubic meters (337,000 cubic yards) of waste, or a football field covered with packages stacked 250 feet high. If the waste loading in the waste package is at the lower limit, the contractually allowed package count could be as high as 165,000 .

\subsubsection{Privatization}

The DOE is proceeding to privatize the immobilization functions currently assigned to TWRS. Under privatization, DOE would supply material retrieved from the tanks to private companies. The private companies would then return the high-level waste, the low-activity solidified waste, and various other waste streams. Specifications for the separation and immobilization of the first 6 to 13 percent of the retrieved waste (Phase 1B) are included in Appendix A. Contracts to actually proceed with Phase 1B are expected to be signed in the spring or summer of 1998.

\subsubsection{Packaging and Certification}

The physical, chemical, and radiological properties of the waste at the time of disposal have not been completely determined. Appendix A provides the requirements for the immobilized low-activity waste product. The waste form is expected to be contained in metal containers with external dimensions of 1.8 by 1.2 by 1.2 meters (about 6 by 4 by 4 feet) (DOE-RI 1996).

The TWRS Privatization contracts describe the product acceptance process in the requirements for the Products and Secondary Wastes Plan to be prepared by the private contractors during Phase 1A (September 1996 through January 1998) and implemented during Phase 1B. A product acceptance strategy has been prepared (Westsik 1997). Implementing the strategy requires a product acceptance process that includes developing and maintaining product 


\section{DOE/RL-97-69}

Rev. 0

specifications and conducting private contractor qualification testing and evaluation before production, DOE verification testing before production, private contractor certification testing and reporting during production, and DOE acceptance testing according to a not-yet-determined product acceptance procedure during production and operation of the disposal facilities.

\subsubsection{Transportation and Waste Emplacement}

After the DOE has approved a waste package for acceptance, DOE may choose to have the vendor store that package for up to 90 days. The details of this interim storage activity have not yet been defined. After the storage period has ended, DOE will transport the packages to the disposal site. Current plans call for the packages to be transported by a specialized truck. For remotely handled waste (all the waste considered in this performance assessment), cranes will remove the waste package from the vehicle and place it directly into the disposal facility.

The conceptual design report for the existing disposal vaults (Pickett 1997) calls for a remote crane to remove packages off the truck. The filled containers would be moved remotely once inside the facility. A remotely operated crane inside the facility would remove the waste container from the cart and place it into one of the vault bays.

\subsection{DISPOSAL TECHNOLOGY}

The design process for the disposal facilities is just beginning. A conceptual design report for the modification of the existing disposal vaults (Pickett 1997) has just been published. Because the new disposal facilities have not been designed yet, two conceptual designs were developed for use in the interim performance assessment. Both concepts are based on a vault disposal concept developed to estimate the costs for a disposal options configuration study (Mitchell 1995). The vault concept was enhanced by adding physical barriers to limit the amount of water entering the vault and a chemical barrier to reduce glass corrosion (Eiholzer 1995). Both concepts were based on the assumption that the waste would be in glass form. The difference between the two facility concepts is the approach taken to incorporate the enhancements. As part of an alternatives generation study (Burbank 1997), Eiholzer's Concept 2 design was modified, producing two sets of shorter rows. Section 2.4.1 outlines the current concepts and thinking for disposal technology for the immobilized low-activity tank waste disposal facility.

Future designs may include trench disposal, the reuse of processing canyon facilities, and the reuse of the storage tanks. The analyses of any of these options will be performed in future performance assessments, once plans are developed. 


\section{DOE/RL-97-69}

Rev. 0

\subsubsection{Current and Planned Disposal Units}

Sections 2.4.1.1 through 2.4.1.5 describe the existing disposal vaults and the preconceptual design for the first set of new concrete vaults.

2.4.1.1 Existing Vaults Design. Five concrete vaults were built for disposing of double-shell tank waste using a grouted waste form. The smallest vault (218-E-16-101) was filled with grouted phosphate/sulfate waste and closed. The grout disposal program was canceled before the other four vaults were filled. A conceptual design (Pickett 1997) exists for modifying these vaults to allow easier placement of packages.

Each existing vault (KEHC 1991) is $37.64 \mathrm{~m}$ long, $15.39 \mathrm{~m}$ wide, and $10.36 \mathrm{~m}$ high $(123.5 \times 50.5 \times 34.0 \mathrm{ft})$ inside. Figure $2-22$ shows a cutaway view of an existing disposal vault. The vault walls and floor are constructed on a cast-in-place reinforced concrete pad. The side walls are $1.37 \mathrm{~m}(4.5 \mathrm{ft})$ thick at the base, tapering to $0.61 \mathrm{~m}(2.0 \mathrm{ft})$ at the top. The end walls have a constant thickness of $0.76 \mathrm{~m}(2.5 \mathrm{ft})$. The concrete floor slab is $1.37 \mathrm{~m}(4.5 \mathrm{ft})$ thick and is flat and level. The vaults are designed to withstand an earthquake with a $0.25 \mathrm{G}$ horizontal and $0.17 \mathrm{G}$ vertical acceleration (DOE-RL 1990). The concrete mix includes a slag component to improve long-term durability with a low water/cement ratio to improve strength. The minimum compressive strength of this $\mathrm{mix}$ is $4,500 \mathrm{lb} / \mathrm{m}^{2}(31.03 \mathrm{MPa})$. Steel water stops are installed between the pour sections of the vault.

The concrete roof, made of 29 precast, prestressed concrete panels $1.22 \mathrm{~m}(4.0 \mathrm{ft})$ wide, is $0.66 \mathrm{~m}(2.17 \mathrm{ft})$ thick. Gaps between adjacent panels are filled with cement grout and the panels are topped with a concrete layer that slopes from $20.3-\mathrm{cm}$ (8-in) thick at the center of the vault to $5.1-\mathrm{cm}(2-\mathrm{in})$ thick at the edge.

The vaults are designed to meet RCRA requirements for double containment. The primary containment is the vault and a $1.32 \mathrm{~mm}$ ( $52 \mathrm{mil})$ thick, asphalt-based sealant applied to the interior walls and floor. The sealant thickness is increased to $1.9 \mathrm{~mm}$ ( $75 \mathrm{mil}$ ) near the top of the walls. The secondary containment is provided by a catch basin constructed of reinforced concrete with properties similar to the vault walls beneath each vault. The catch basin is lined with a $1.5 \mathrm{~mm}$ (60 mil) thick high-density polyethylene (HDPE) flexible membrane that meets RCRA requirements. The catch basin is filled with washed small gravel to a thickness of $0.30 \mathrm{~m}$ $(1 \mathrm{ft})$ near the edge and $1.2 \mathrm{~m}(4 \mathrm{ft})$ at the low point in the trough through the center of the catch basin. A geotile was laid over the gravel to prevent concrete from seeping into the gravel during construction of the vault floor. A perforated collection pipe runs through the catch basin trough to a sump. The liquid level in the sump will be monitored for at least 30 years after the vaults are filled, and any liquid collected will be removed for processing.

The exterior of the vault walls are surrounded by an HDPE drainage net and curtain. Insulation board is installed on the outside of the HDPE. High-density asphalt at least $1 \mathrm{~m}$ ( $3.3 \mathrm{ft}$ ) thick on the outside of the walls surrounds the vault. The catch basins lay atop a layer of $0.46 \mathrm{~m}$ ( $1.5 \mathrm{ft}$ ) thick layer of asphalt pavement that lays atop another $0.46 \mathrm{~m}$ (minimum) layer of asphalt-coated gravel. 


\section{DOE/RL-97-69}

Rev. 0

Figure 2-22. Existing Disposal Vaults, Cutaway View.

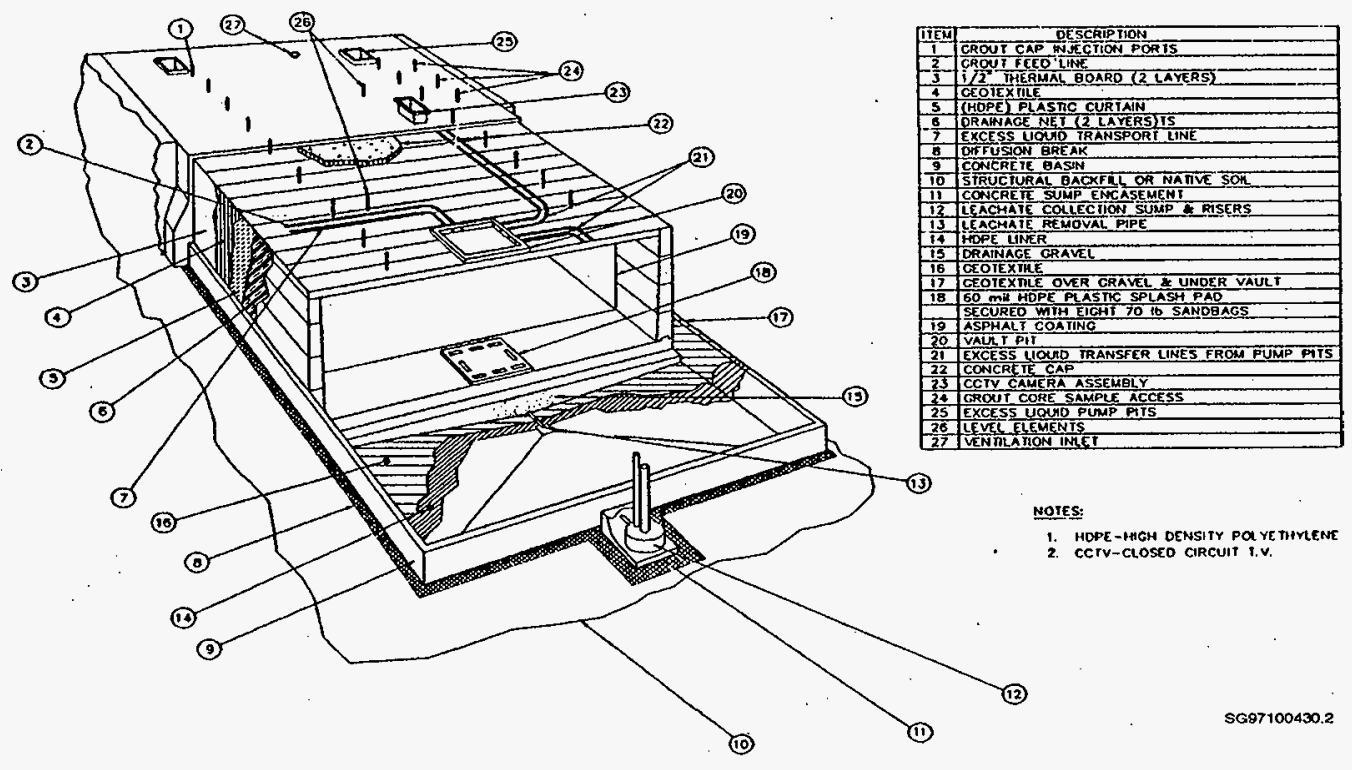




\section{DOE/RL-97-69}

Rev, 0

The conceptual design (Pickett 1997) for modifying the vaults (Project W-465) to allow roof access has just been completed. Definitive design is planned to start in October 1999 and finished in March 2001. Modification of the existing facility then commences with the completion scheduled for March 2002. The first packages are expected from the vendors in the summer of 2002 .

2.4.1.2 Preconceptual Design for New Concrete Vaults. Conceptual design for new concrete vaults is just now beginning. Detailed design is expected to be complete in September 2002 with construction completed in October 2004. The vaults would be ready for use in late 2005.

The resulting design is expected to be much simpler than the design used to construct the existing vaults. Eiholzer (1995) produced two similar preconceptual designs for the interim performance assessment. Burbank (1997) slightly modified this design for use in the disposal alternatives analysis where it is known as the remote-handled mixed waste disposal facility concept.

The vault bay is the basic unit used in all the disposal facility concepts. The overall concrete facility is divided into several sections called vault bays. The vault bays have concrete walls, floors, and ceilings. Six vault bays form a vault row. The number of vault bays depends on the size of the immobilized low-activity waste containers and the spacing between containers.

In the Eiholzer model, each vault bay has the same internal dimensions as an existing vault [ 38 by 19.5 by $9 \mathrm{~m}$ ( 125 by 64 by $29.5 \mathrm{ft})$ ]. Burbank optimized the interior dimensions around the presumed dimensions of the waste package, producing interior dimensions of $20 \times 20 \times 7.5 \mathrm{~m}(65.6 \times 65.6 \times 24.6 \mathrm{ft})$.

A significant difference between the preconceptual designs is the layout of the vault rows. In Eiholzer's first concept, the 10 vault rows are placed next to each other with one surface barrier covering the entire facility (see Figure 2-23). In her second concept, the vault rows are separated by equally wide rows of backfilled soil and separate barriers are placed over each vault row (see Figures 2-24 and 2-25). Burbank also separates the vault rows but in addition, places a road between the two sets of vault rows (see Figure 2-26). 
Figure 2-23. New Facility - Concept 1 of Eiholzer (1995).

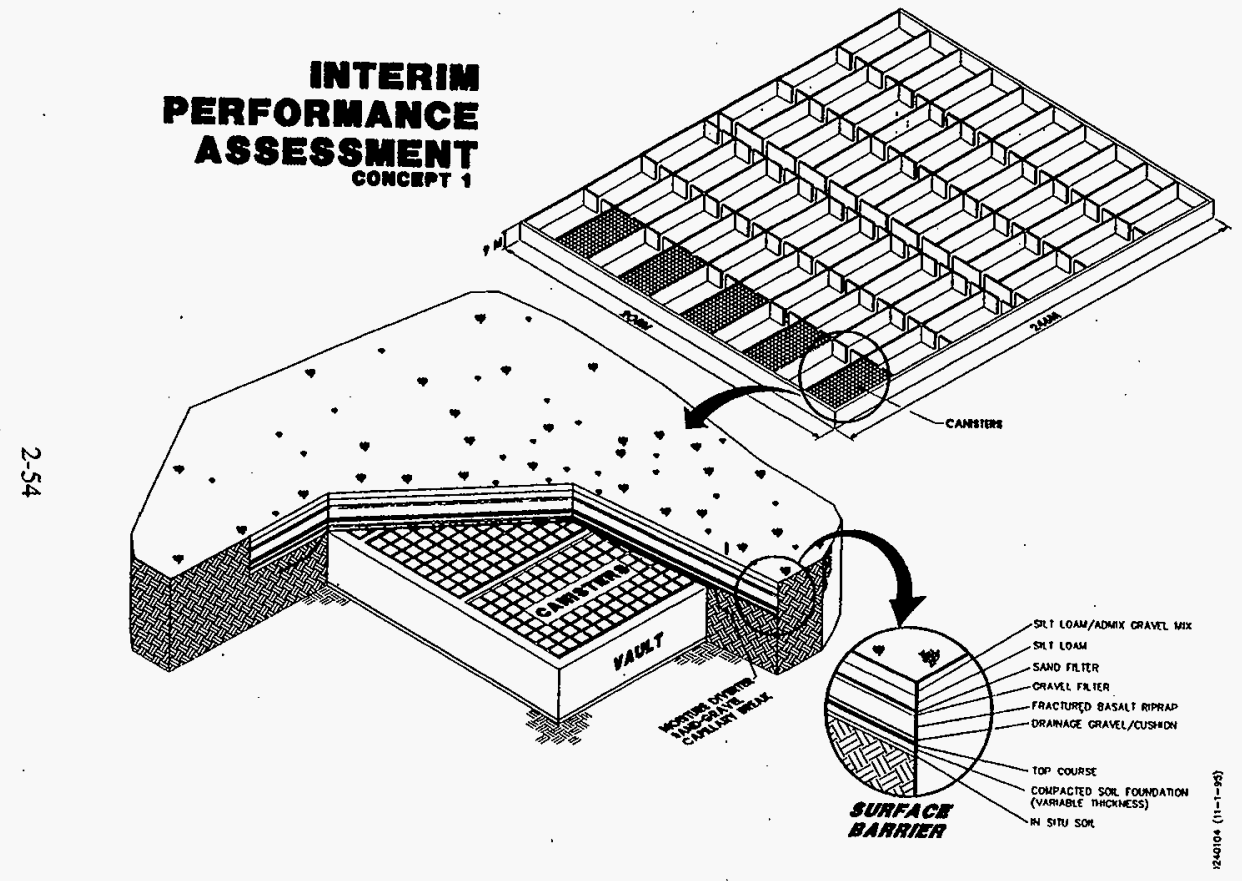

递菑 
Figure 2-24. New Facility - Concept 2 of Eiholzer (1995).

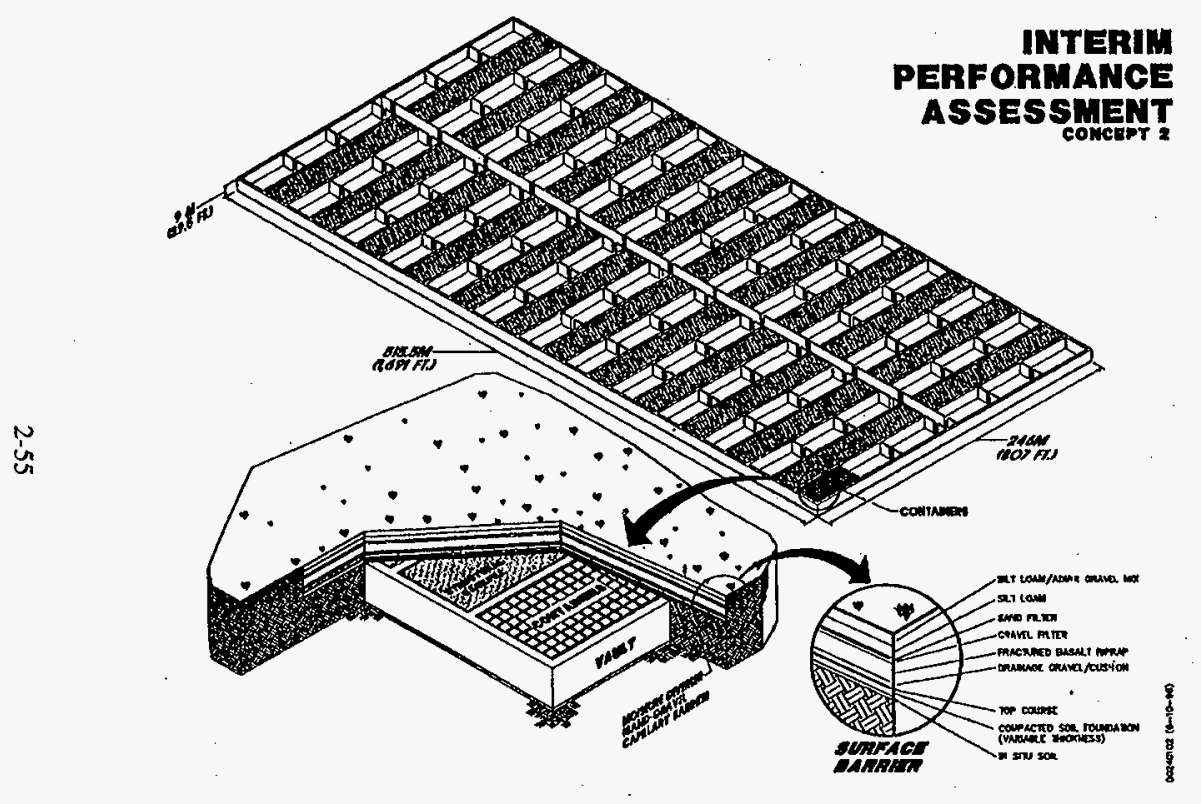

蛋 
Figure 2-25. Cross Section of Eiholzer Concept 2.

\section{INTERII PERFORMANGE ASSESSHENT}

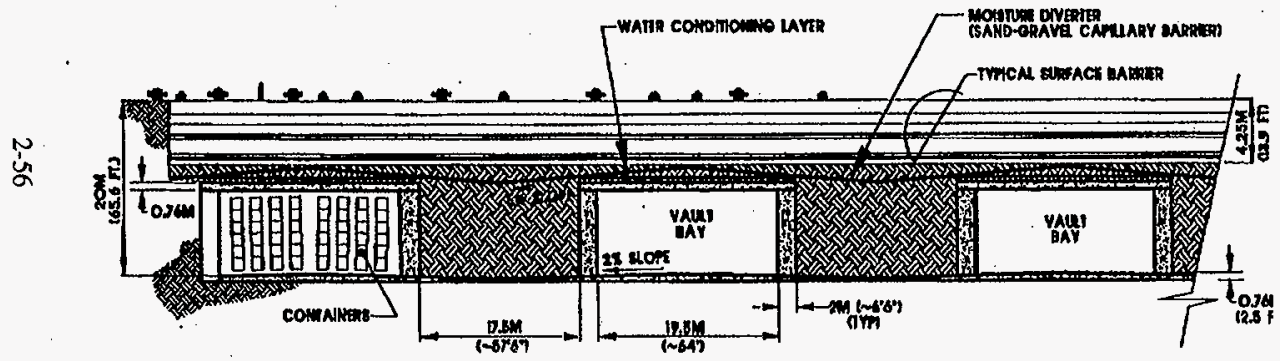

Mrysmis. 
DOE/RL-97-69

Rev. 0

Figure 2-26. New Facility Layout - Burbank (1997).

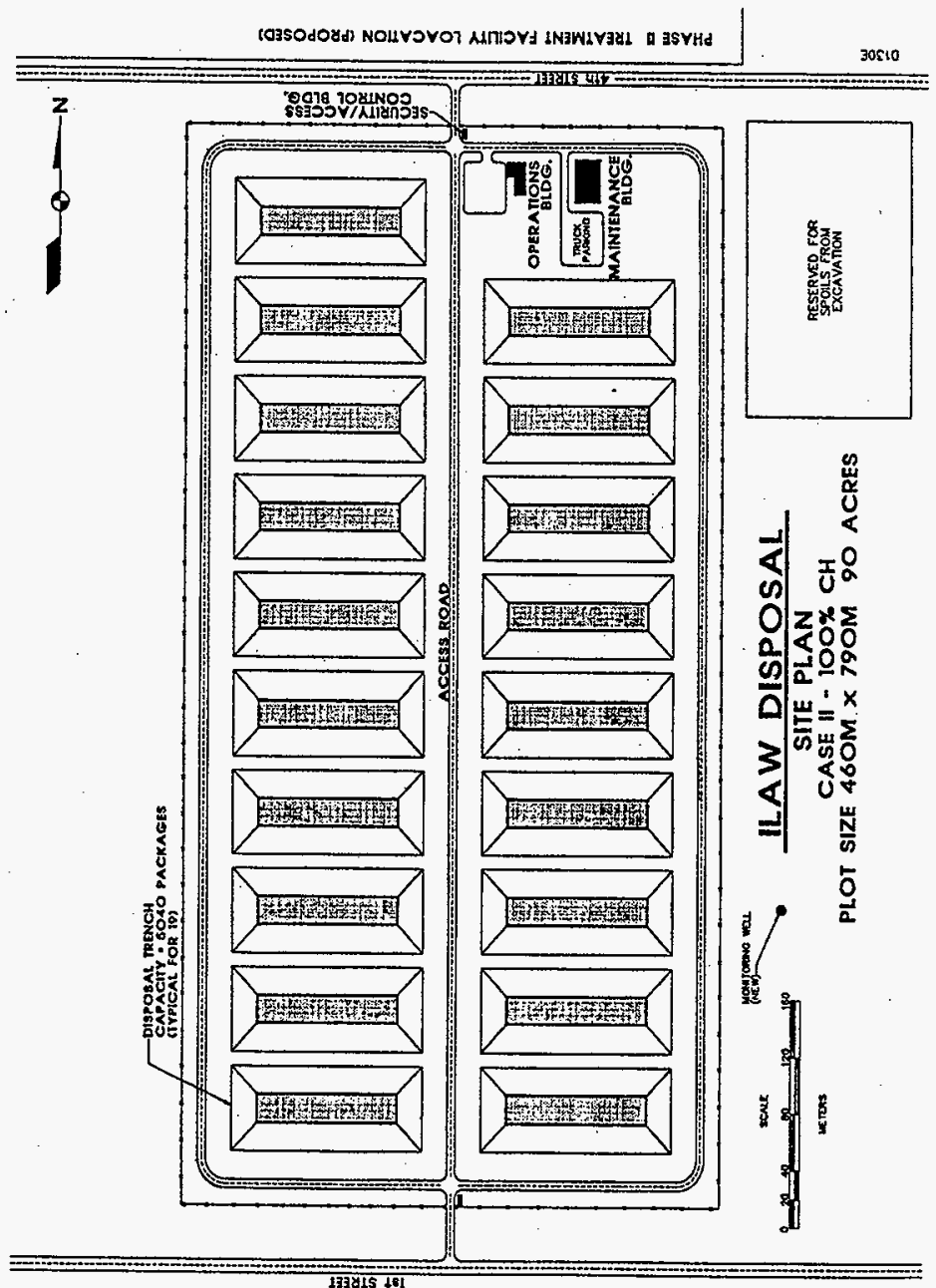




\section{DOE/RL-97-69}

Rev. 0

2.4.1.3 Vault Fill Material. Both Concepts 1 and 2 of Eiholzer (1995) and those of Burbank 1997 include backfilled soil around and on top of the waste containers in the facility. The soil was included in these concepts for the following three reasons:

- For structural support. The initial Mitchell 1995 design had void space between the immobilized low-activity waste containers and between the containers and the ceiling. Filling this space with soil would help prevent significant subsidence of the physical barriers when the concrete components of the system fail and collapse into the void space.

- To wick moisture away from the waste containers.

- To provide radiation shielding for the facility workers.

2.4.1.4 Disposal Unit Closure. All the concepts have-a similar barrier philosophy.' The uppermost barrier is the surface barrier designed to minimize intrusion and recharge. Beneath the surface barrier, a sand-gravel capillary break will divert any moisture that may come through the surface barrier away from the vault. These two barriers implement the goal of minimizing the amount of water that enters the vault. However, the extent of the barriers differs for the different concepts. In Eiholzer's first concept, only one surface barrier and capillary break covers the entire facility. However, a smaller capillary barrier performs better. In Eiholzer's second concept, a separate capillary break covers each vault row, but one continuous surface barrier covers the entire facility. In the Burbank concept, each vault row has a separate capillary break and surface barrier. Thus a series of hills and valleys would be present The Burbank concept would allow different types of disposal facilities (see following section) to be used in addition to the concrete vault.

Beneath the capillary break there could be a water-conditioning layer of crushed glass. This layer would increase the silica content of any moisture that penetrates the first two barriers. It has been well documented in water saturated tests with a wide variety of glass compositions that corrosion rates are much lower in water that is near saturation with respect to amorphous silica. However, as yet, no theoretical or direct laboratory evidence suggests that such preconditioning will be effective in reducing glass corrosion rates under the low moisture conditions expected in the disposal vault.

2.4.1.5 Disposal Site Closure. Disposal site closure is presumed to consist of applying the surface barrier and placing passive controls on the surface The intent of the surface barrier is to use evaporation and plant transpiration to minimize the influx of precipitation into the disposal system. The surface barrier, based on the Hanford Barrier (Myers 1994), includes a sand/gravel layer to work as another capillary break and a layer of basalt riprap to deter burrowing animals, plant root intrusion, and inadvertent intruders.

Passive controls are assumed to be used to deter inadvertent intrusion. However, the type of passive controls have not yet been selected. However, markers, rip/rap stone, fencing, and administrative controls are being considered. 


\section{DOE/RL-97-69}

Rev. 0

\subsubsection{Possible Future Disposal Concepts}

The disposal alternatives generation analysis (Burbank) investigated a series of possible disposal facilities. Besides the concrete vault mentioned in Section 2.4.1.2, the following were studied:

- A concrete vault with Resource Conservation and Recovery Act of 1976 (RCRAं) double containment

- A land-filled trench (with or without RCRA double containment)

- Existing large concrete buildings

- Existing underground tanks.

The existing tank waste contains listed hazardous waste and hence falls under the jurisdiction of RCRA. Unless such waste is treated to no longer be hazardous and is "delisted" (formally removed from regulation), the RCRA requirements (40 CFR 260-268) apply. In the State of Washington, these federal regulations are administrated by the Washington State Department of Ecology (WAC 173-303). An important requirement is that the waste be doubly contained and monitored. That is, the waste volume must be monitored and a second containment system must be in place to hold any leaked waste until it can be collected. The existing disposal facility has such a system. The production of the immobilized low-activity waste (ILAW) will destroy all significant quantities of listed hazardous wastes and the ILAW will have properties making it an extremely stable waste form. Thus ILAW should be able to be delisted. However, if the ILAW is not delisted, an RCRA-compliant facility would needed (see Figure 2-27). Such a facility is estimated to add about 3 to 4 million dollars in construction costs for each vault row over a base construction cost of about 25 million dollars.

Because of the significant variation in expected tank waste concentrations, many of the disposal packages may have radiation levels low enough to permit contact handling.

Burbank (1997) investigated the possibility of configuring some of the disposal rows as contacthandled waste disposal trenches. The construction costs for such facilities $(\$ 4.6$ million for a mixed waste trench and \$1.3 million dollars for a non-mixed waste trench) are significantly lower than for concrete structures. Lifetime operational costs for the trenches (approximately $\$ 11$ million per trench) would also be significantly lower than for the concrete facilities (approximately $\$ 21$ million per vault row). However, the number and production timing of such contact-handed packages cannot be determined until further information is available concerning individual tank inventories, the tank retrieval sequence, efficiencies of waste separation, and vendors' separation plans. The program is actively considering this option for waste received after 2005.

The Hanford Site's plateau has a number of facilities that are or soon will be considered surplused. Burbank 1997 investigated the use of both the very large process canyon buildings and the underground tanks presently storing the waste. The buildings might hold only as little as 24 percent of the IIAW packages in their interior. The per-package life-cycle cost of this 


\section{DOE/RI-97-69}

Rev. 0

option is about a factor of 2.5 higher than for new concrete structures primarily because these large radioactive facilities need extensive modifications and a large closure area. If waste packages were placed outside these facilities as well, the life-cycle cost per package would be comparable to the concrete facilities costs. In neither case have avoidance costs of demolishing the canyon buildings been considered. Note that none of the canyon buildings will be available for many years. However, the program is considering this option for waste received after 2010.

The use of single-shell tanks as the disposal facility for waste packages also was investigated by Burbank (1997). The conclusion was that the capital costs for opening the domes of the tanks to allow access for the current package shape was prohibitively expensive ( $\$ 100$ to $\$ 300$ million dollars per equivalent vault row). 


\section{DOE/RL-97-69}

\section{Rev. 0}

Figure 2-27. Cross Section of Burbank (1997) Concept. It is now expected that surface barrier will extend over all the vaults in the disposal facility and hence the slope shown in this figure will not be significant except for the outermost units.

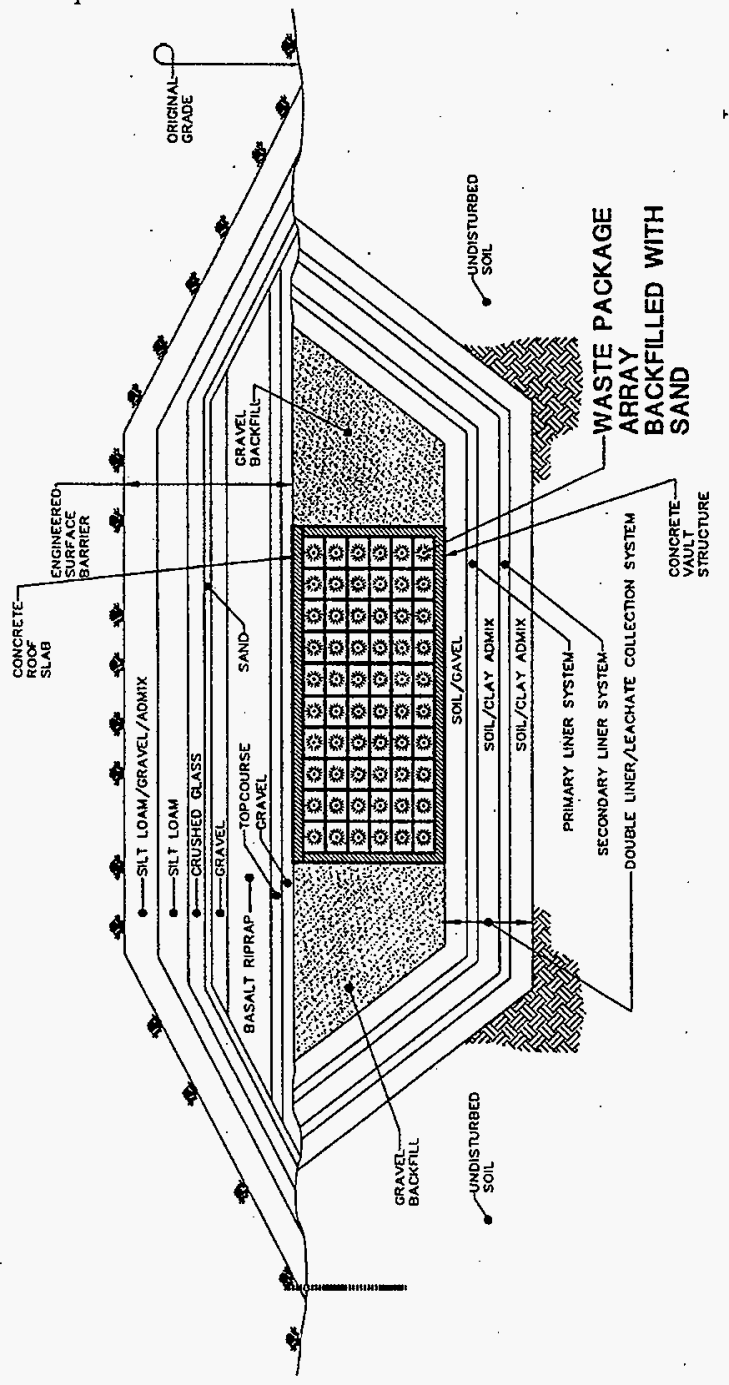


DOE/RL-97-69

Rev. 0

$2-62$ 
DOE/RL-97-69

Rev. 0

\subsection{ANALYSIS OF PERFORMANCE}

\subsection{OVERVIEW}

This chapter describes the models, computer codes, and input data used to analyze the long-term performance of the proposed disposal facilities. For the analyses, the information discussed in Chapter 2 is translated into a conceptual physical model, then into a numerical model. The data as well as the conceptual and numerical models are described and justified to the extent practicable. Stronger justification is expected in future performance assessments as more facility-, site-, and waste form-specific information is obtained.

The strategy for this assessment was to define and analyze both a base analysis case and sensitivity cases bracketing the base analysis case. The base analysis case was developed using best estimates of the environmental, waste form, and disposal facility parameters and how they will change with time. Following the recommendations of the Peer Review Panel (Case 1989), assumptions were intended to be "conservative but reasonable."

Most of the information in this chapter comes from previously released documents related to the interim performance assessment. Most of the data are from Data Packages for the Hanford Low-Level Tank Waste Interim Performance Assessment (Mann 1995a). The base analysis case was defined in Definition of the Base Analysis Case of the Interim Performance Assessment (Mann 1995b), which also contains a list of sensitivity cases.

This chapter shows, in the following manner, how the physical systems presented in Chapter 2 are translated into the numerical models that produce the results presented in Chapter 4. Chapter 5 presents the inadvertent intruder scenarios, data, and results.

1. Section 3.2 describes the source term radionuclide inventories.

2. Section 3.3 explains the pathways and scenarios that were analyzed.

3. Sections 3.4 and 3.5 present the assumptions and methodology used in the analyses, including the actual data used, respectively.

\subsection{SOURCE TERMS}

\subsubsection{Relevant Isotopes}

Relevant Isotopes

Screening analyses reduced the number of relevant radionuclides to 31 .

The anticipated tank waste inventories

were prescreened (Schmittroth 1995a) to determine which radionuclides are potential problems for the inadvertent intruder and groundwater pathway scenarios. This prescreening effort included the following: 


\section{DOE/RL-97-69}

Rev. 0

- Calculating the quantity of all isotopes produced during materials production at the Hanford Site

- Calculating, using a simple one-dimensional steady state model, the transport of such isotopes through Hanford's vadose zone (both with accepted Hanford Site geochemical retardation as well as with unretarded contaminant transport)

- Converting groundwater concentrations to drinking water doses

- Calculating inadvertent intrusion using the homesteader scenario.

The study indicated that the following radionuclides are the potentially most important ones for each scenario:

- $\quad{ }^{79} \mathrm{Se},{ }^{93} \mathrm{Nb}^{\mathrm{m}}$ (from ${ }^{93} \mathrm{Zr}$ and ${ }^{93} \mathrm{Mo}$ ), ${ }^{99} \mathrm{Tc},{ }^{129} \mathrm{I}$, and uranium isotopes and their daughters for the groundwater scenario

- Uranium, plutonium, neptunium, and americium isotopes and their daughters for the groundwater scenario in which geochemical retardation effects are ignored.

- $\quad{ }^{90} \mathrm{Sr},{ }^{99} \mathrm{Tc},{ }^{137} \mathrm{Cs},{ }^{126} \mathrm{Sn},{ }^{227} \mathrm{Ac},{ }^{239} \mathrm{Pu}$, and ${ }^{241} \mathrm{Am}$ for the inadvertent intruder scenario.

For this analysis, the top 12 contributors from the groundwater scenario, the top 14 contributors from the unretarded groundwater scenario, and the top 10 contributors from the inadvertent intruder scenario were used. These 28 isotopes contribute over 99 percent of the dose for the scenarios.

Previous Hanford Site performance assessments (Wood 1994 and Wood 1996) have shown that ${ }^{3} \mathrm{H},{ }^{14} \mathrm{C}$, and ${ }^{226} \mathrm{Rn}$ (from the decay of ${ }^{234} \mathrm{U}$ and ${ }^{238} \mathrm{U}$ ) are the main radionuclides of concern. Because radionuclides in Hanford Site surface waters come from groundwater, radionuclides important for surface water protection are taken from the groundwater selection analysis.

As noted in Section 3.4.7.5, the long-accepted values for the half-life of ${ }^{79} \mathrm{Se}$ and ${ }^{126} \mathrm{Sn}$ are now thought to be incorrect. However, the old values are used in the following sections to be consistent with the supporting documentation. Sensitivity studies using the new half-life values are presented in Section 3.5.5.2. 


\section{DOE/RL-97-69}

Rev. 0

\subsubsection{Inventory Values}

The inventory for this study is from Schmittroth $1995 \mathrm{~b}$ except where noted. Inventory values were not taken from the Grout Performance Assessment (Kincaid 1995) because those

Inventory

Inventory values are based on detailed reactor histories, and a conservative analysis of separations processes. estimates were for the waste from only the doubleshell tanks and because those estimates have been superseded. As the TWRS Standard Inventory Program (see Section 3.2.5) proceeds, new and better estimates are expected and will be used in future performance assessments.

Table 3-1 gives the inventories for the year 2010 for those radionuclides identified as being the most important for this performance assessment (see Section 3.2.1). The year 2010 is halfway through the treatment, immobilization, and disposal operations. Except for a few radionuclides (for example, ${ }^{90} \mathrm{Sr}$ and ${ }^{137} \mathrm{Cs}$ ), the inventory for radionuclides of concern does not change significantly during the treatment period. The column labeled "Percent to ILAW from Tanks" provides the current estimate of the fractional amount of material that will go into the waste form. This estimate comes primarily from the Process Design Group of the Disposal Engineering Section of the Westinghouse Hanford Company (Attachment 1 of Schmittroth 1995b). However, noted changes in Table 3-1 are from Petersen (1995). Better estimates will come from the private vendors who will treat the waste, but these are not yet available. Inventories for years other than 2010 and for all the radionuclides are given in Schmittroth (1995b). The following paragraphs summarize how the inventory was developed.

Table 3-1. Inventories for Performance Assessment. ${ }^{2}$ Inventory is decayed to 2010. Values for the half-lives for all radionuclides used in the analysis are given in Table B-6.

\begin{tabular}{|c|c|c|c|}
\hline Radionuclide & $\begin{array}{c}\text { Tank Inventory } \\
\text { (curies) }\end{array}$ & $\begin{array}{c}\text { Percent to ILAW } \\
\text { from Tanks }\end{array}$ & $\begin{array}{c}\text { Inventory in ILAW Decayed to 2010 } \\
\text { (curies) }\end{array}$ \\
\hline \hline${ }^{3} \mathrm{H}$ & $8.04 \times 10^{4}$ & 100 & 80400.0 \\
\hline${ }^{14} \mathrm{C}$ & $7.73 \times 10^{2}$ & 1 & 7.73 \\
\hline${ }^{79} \mathrm{Se}$ & $1.03 \times 10^{3}$ & $100^{\mathrm{c}}$ & 1030.0 \\
\hline${ }^{90} \mathrm{Sr}$ & $5.33 \times 10^{7}$ & $3^{\mathrm{e}}$ & $1610000.0^{\mathrm{e}}$ \\
\hline${ }^{93} \mathrm{Zr}$ & $4.87 \times 10^{3}$ & $1^{\mathrm{f}}$ & 48.7 \\
\hline${ }^{93} \mathrm{Nb}$ & $4.20 \times 10^{3}$ & $1^{\mathrm{f}}$ & 42.0 \\
\hline${ }^{99} \mathrm{Tc}$ & $2.72 \times 10^{4}$ & 82 & 223000.0 \\
\hline${ }^{126} \mathrm{Sn}$ & $1.58 \times 10^{3}$ & $100^{\mathrm{c}}$ & 1580.0 \\
\hline${ }^{129} \mathrm{I}$ & $6.62 \times 10^{1}$ & $10^{\mathrm{i}}$ & 6.62 \\
\hline${ }^{137} \mathrm{Cs}$ & $4.51 \times 10^{7} \mathrm{e}$ & $1^{8}$ & $451000.0^{e}$ \\
\hline${ }^{151} \mathrm{Sm}$ & $3.16 \times 10^{6}$ & $1^{\mathrm{f}}$ & 31600.0 \\
\hline
\end{tabular}


DOE/RL-97-69

Rev. 0

Table 3-1. Inventories for Performance Assessment. ${ }^{3}$ Inventory is decayed to 2010.

Values for the half-lives for all radionuclides used in the analysis are given in Table B-6.

\begin{tabular}{|c|c|c|c|}
\hline Radionuclide & $\begin{array}{c}\text { Tank Inventory } \\
\text { (curies) }\end{array}$ & $\begin{array}{c}\text { Percent to ILAW } \\
\text { from Tanks }\end{array}$ & $\begin{array}{c}\text { Inventory in ILAW Decayed to } 2010 \\
\text { (curies) }\end{array}$ \\
\hline${ }^{226} \mathrm{Ra}$ & $4.70 \times 10^{-3}$ & $50^{\mathrm{fh}}$ & 0.00235 \\
\hline${ }^{228} \mathrm{Ra}$ & 2.76 & $50^{f, h}$ & 1.38 \\
\hline${ }^{227} \mathrm{Ac}$ & 2.16 & $1^{\mathrm{f}, \mathrm{h}}$ & 1.08 \\
\hline${ }^{229} \mathrm{Th}$ & 0.98 & $1^{\mathrm{f}, \mathrm{h}}$ & 0.00979 \\
\hline${ }^{232} \mathrm{Th}$ & 2.68 & $1^{\mathrm{f}, \mathrm{h}}$ & 0.0268 \\
\hline${ }^{231} \mathrm{~Pa}$ & $1.45 \times 10^{2}$ & $100^{\mathrm{chh}}$ & 145.0 \\
\hline${ }^{233} \mathrm{U}$ & $4.30 \times 10^{2}$ & 6 & 25.8 \\
\hline${ }^{234} \mathrm{U}$ & $3.00 \times 10^{2}$ & 6 & 18.0 \\
\hline${ }^{235} \mathrm{U}$ & $1.23 \times 10^{1}$ & 6 & 0.736 \\
\hline${ }^{236} \mathrm{U}$ & 7.45 & 6 & 0.447 \\
\hline${ }^{238} \mathrm{U}$ & $2.97 \times 10^{2}$ & 6 & 17.8 \\
\hline${ }^{237} \mathrm{~Np}$ & $7.48 \times 10^{1}$ & 5 & 3.74 \\
\hline${ }^{239} \mathrm{Pu}$ & $3.72 \times 10^{4}$ & 6 & 2230.0 \\
\hline${ }^{240} \mathrm{Pu}$ & $7.18 \times 10^{3}$ & 6 & 431.0 \\
\hline${ }^{241} \mathrm{Am}$ & $5.31 \times 10^{4}$ & 8 & 4250.0 \\
\hline${ }^{243} \mathrm{Am}$ & $3.37 \times 10^{1}$ & 8 & 2.70 \\
\hline${ }^{245} \mathrm{Cm}$ & $1.03 \times 10^{-1}$ & $100^{c}$ & 0.103 \\
\hline
\end{tabular}

"Data are taken from Schmittroth 1995 b except as indicated by superscript "f."

' The fraction of tank waste going into the waste form was taken from Shelton 1995.

${ }^{c}$ Because of the absence of defensible data, no credit is taken for a reduction in the amount going to the low-level fraction.

23 percent of ${ }^{90} \mathrm{Sr}$ produced went into capsules rather than tanks.

${ }^{e}$ The daughters $\left({ }^{90} \mathrm{Y}\right.$ and $\left.{ }^{137} \mathrm{Ba}^{\mathrm{m}}\right)$ are in secular equilibrium with their parents and are included in exposure calculations. Their inventories are not included in the curie inventory shown.

${ }^{f}$ These values are based on the more recent work of Petersen (1995). Schmittroth (1995b) used values of 100 percent because of the lack of data.

${ }^{8} 45$ percent of ${ }^{137} \mathrm{Cs}$ produced went into capsules rather than tanks.

${ }^{\mathrm{h}}$ Also a decay product of other actinides.

Assumed in order to track significance. Most of ${ }^{129} \mathrm{I}$ is assumed to be trapped in off-gas stream and disposed elsewhere. 
DOE/RL-97-69

Rev. 0

\subsubsection{General Description of the Development of Estimated Immobilized Low-Activity Waste Radionuclide Inventory}

Tank-by-tank inventories of the radionuclides are generally not currently well known. However, reactor production records and nuclear fuel reprocessing records are reliable enough to establish accurate total tank waste inventory values for most of the fission products and uranium. The inventory of actinide nuclides is more uncertain because actinide production is sensitive to the time dependence of the neutron function and to processing transfers and losses. The estimated loss of fission products (particularly technetium and iodine) during processing or from tank leaks or discharges was used in adjusting the inventories.

Schmittroth et al. (Schmittroth 1995b) developed an inventory for the interim performance assessment. This inventory is based on the production of various radionuclides and the losses of the same radionuclides from processing and other factors. The process started by calculating radionuclide production values with the ORIGEN2 code (Croff 1980). (The detailed ORIGEN2 model is documented in Schmittroth 1995b.) Then, the calculated production values were corrected for known losses. Next, the reduction factors (splits) from the separated waste to an assumed glass waste form (Shelton 1995) are incorporated. Sections 3.2.3.1 through 3.2.3.4. summarize this strategy. Schmittroth (1995b) gives the details.

3.2.3.1 Calculated Radionuclide Production. The irradiation histories of the Hanford Site's production reactors are modeled as two conceptual reactors. The ORIGEN2 computer code (Croff 1980) is used for this modeling. One conceptual reactor represents all the singlepass irradiations. The other conceptual reactor explicitly models the $\mathrm{N}$ Reactor, the last production reactor at the Hanford Site. In both cases, detailed fuel types and irradiation histories are simplified, but still accurate. For example, although some enriched fuel was used in the single-pass irradiations, it was assumed that all the single-pass fuel was natural uranium. Likewise, although $\mathrm{N}$ Reactor produced some weapons-grade plutonium, a burnup of $2,000 \mathrm{MWd} / \mathrm{MTU}$, more typical of fuels-grade production, was used for the entire operating history. The consequences of these assumptions are more fully reported in Schmittroth (1995b).

Schmittroth et al. (1995b) modified an earlier radionuclide production calculation to obtain the current inventory. Two thorium campaigns were added to the model to account for ${ }^{233} \mathrm{U}$ production. $\mathrm{N}$ reactor fuel discharged to the $\mathrm{K}$ Basins was deleted from the production history because this fuel will not be processed. Cross section modifications also were included. The ${ }^{238} \mathrm{U}(\mathrm{n}, 2 \mathrm{n})$ cross section was adjusted to better account for ${ }^{237} \mathrm{~Np}$ production. The thorium capture cross section was changed to account for ${ }^{23} \mathrm{U}$ production.

The uncertainties of the ORIGEN2 results vary for different nuclides. For some, including the important fission products ${ }^{99} \mathrm{Tc},{ }^{90} \mathrm{Sr}$, and ${ }^{137} \mathrm{Cs}$, and ${ }^{129} \mathrm{I}$, these uncertainties are expected to be less than 10 percent. The results in these cases depend primarily on fissionproduct yields and the production reactor operating histories. Both of these areas are well known. The inventories of ${ }^{238} \mathrm{U}$ and ${ }^{239} \mathrm{Pu}$ before reprocessing also are well known. However, reprocessing efficiencies and other losses introduce significant uncertainties in the estimated tank waste inventories for these isotopes. Nevertheless, these uncertainties are less than a factor of 2 and are based on conservative reprocessing efficiencies; i.e., losses to waste were 
overestimated. Uncertainties for uranium, neptunium, and plutonium also may be significant. Calculations for the activation products ${ }^{3} \mathrm{H}$ and ${ }^{14} \mathrm{C}$ are only rough estimates that may be improved from additional tank waste characterization studies.

3.2.3.2 Hanford Production Processing and Storage. Recovery fractions from the processing of material from the Hanford Site production reactors were included in the ORIGEN2 model. These fractions were deducted from the reprocessed waste. The assumed uranium recovery fraction from reprocessing was 0.99 to give a more conservative (larger) value for the amount of uranium waste to be disposed. While efficiencies were higher for much of the reprocessing history, considerable uncertainty is associated with early operations. In the early operations, the uranium was discarded to tank waste, then later retrieved and extracted in $U$ plant recovery operations.

The separation fractions for technetium and neptunium also were large. Evidence exists that 20 percent or more of the technetium produced was lost to the waste stream; it was mainly co-processed with the $\mathrm{UO}_{3}$ and sent off site. Small amounts of technetium were lost to the environment as well. For most of the processing history at the Hanford Site, about 70 percent of the neptunium was recovered. Support for these values is provided in Section 4 of Schmittroth (1995b).

3.2.3.3 Separation and Vitrification Losses. The fractions of radionuclides that go to the low-level waste depend on evolving evaluations concerning the separation processes that will be used. The amount of separation is uncertain because the separation process has not yet been determined. Preliminary values were recently updated (Shelton 1995) with mainly minor changes from the 1994 estimate (Boldt 1994). The most significant change was an increase from 60 to 82 percent for the fraction of technetium that becomes part of the low-level glass waste. The estimate of the fraction of uranium going to the low-level waste stream (6 percent) was unchanged. However, a somewhat higher value is possible. All the tin was assumed to follow the low-level waste, although there is some indication that the amount may be less than 100 percent. In recognition of the potential importance of ${ }^{129}$, the fraction going to the lowlevel waste was given as 10 percent in a 1994 memo (Boldt 1994). In the most recent memo (Shelton 1995), this value was reduced to zero reflecting the expected volatilization of iodine in the melter. To ensure that ${ }^{129} \mathrm{~T}$ continues to be monitored in the performance assessment, the earlier value of 10 percent was maintained. Table 3-1 shows the specific values for separation fractions used in the present analyses.

Much of the total cesium and strontium produced in the reactors was separated in earlier chemical processing campaigns at the Hanford Site. This separated inventory, which currently resides in capsules, is not included in this low-level waste inventory. This assumption is consistent with the revised Tri-Party Agreement (Ecology 1996-2), which assumes that cesium and strontium in capsules will be disposed of as high-level waste.

Following separation of the tank waste, immobilization of the low-level waste stream is expected to volatilize some species, notably iodine, cesium, and potentially technetium. The present requirement (DOE-RL 1996) is to trap the volatile radionuclides and dispose of them in a separate facility. 


\section{DOE/RL-97-69}

Rev. 0

This discussion does not include any information from the private vendors, BNFL and Lockheed Martin Advanced Environmental Services, awarded the contracts to produce proposals for the processing of the waste. That information is expected to be available in May 1998. Their separation plans may be different from the plan outlined in Shelton (1995). Future performance assessments will be based on published information from the private vendors.

3.2.3.4 Modeling of Decay Chains. In general, the ORIGEN2 model represents the complete production history as well as the reprocessing operations and losses. Thus, the ORIGEN2 results provide total radionuclide inventories for both the single-shell and doubleshell tanks. For the most part, recovery fractions and losses expected during separation of the tank waste going to the low-level waste stream are treated separately. An exception was made for the uranium recovery fraction, assumed to be 6 percent, that was explicitly included in the ORIGEN2 calculation. The long half-lives associated with uranium and its daughters make it necessary to explicitly follow the decay chains after the separation split.

\subsubsection{TWRS Standard Inventory Effort}

Various estimates of inventories in the Hanford Site tanks have been made over the years. To update these estimates and better justify the resulting numbers, the TWRS Standard Inventory Effort was established to provide the best basis estimate of both global (Kupfer 1997) and tank-by-tank inventories (Washenfelder 1997). The effort is based on measurements in the tanks, as well as on tracking inventories from their source (reactor production or purchase) to their current location. The TWRS Standard Inventory Effort forms the source of information to demonstrate that compliance with the restrictions set in this performance assessment is to be "reasonably expected." Future performance assessments will use data from this effort for all phases of the analysis.

For the TWRS Standard Inventory estimate of the global inventory of radionuclides, the production of radionuclides is based on the work of Schmittroth et al described earlier (Watrous 1997). The Hanford Defined Waste Model [HDW] (Agnew 1997) was used to estimate separation histories for most of the radionuclides. For some radionuclides $\left({ }^{3} \mathrm{H},{ }^{9} \mathrm{Sr}\right.$, ${ }^{90} \mathrm{Y},{ }^{232} \mathrm{Th}$, and cesium and plutonium isotopes) the separation factors were taken from the code used to generate radionuclide waste streams from the production results. For the uranium isotopes, estimates were taken from accountability and tank sample results. Table 3-2 provides the best basis global radionuclide inventory for key isotopes. The second column of this table provides the value found in the Kupfer (1997) report, whereas the third column decays the value to the date of 1/1/2010 so that the comparison with the work of Schmittroth (1995b) can more easily be made. The last column provides comments from Kupfer (1997) on the use of the HDW model in their work.

The global inventory values given in Schmittroth (1995b) closely match those in Kupfer (1997). The ratio of inventories for most radionuclides is between 0.7 and 1.3. Although the production values for radionuclides used in the TWRS Standard Inventory values are based on the work of Schmittroth et al., the two analyses used very different models for separations and 


\section{DOE/RL-97-69}

Rev. 0

for tank tracking. The most important differences in terms of the results for this performance assessment are for ${ }^{99} \mathrm{Tc},{ }^{79} \mathrm{Se},{ }^{126} \mathrm{Sn}$, and ${ }^{137} \mathrm{Cs}$. The TWRS Standard Inventory value for ${ }^{99} \mathrm{Tc}$ ignores the amount of ${ }^{99} \mathrm{Tc}$ that was coextracted with uranium and sent off site. They choose to be conservative, partially because the amount coextracted is uncertain. Thus their value is about 20 percent higher than the value used in this analysis. The values for ${ }^{79} \mathrm{Se}$ and ${ }^{126} \mathrm{Sn}$ are about 25 percent lower in the TWRS Standard Inventory than used here; the reasons for the discrepancy are not obvious from the available documentation. The value for ${ }^{137} \mathrm{Cs}$ is about 30 percent lower in the TWRS Standard Inventory that results from a more extensive review of the various cesium separation campaigns performed at the Hanford Site.

The information concerning the tank-by-tank inventory is very uncertain because the waste in most tanks is largely heterogenous. Tank-by-tank estimates (Washenfelder 1997) have just been released. Tables 3-3 and 3-4 present tank-by-tank inventories for the most important radionuclides for those tanks where the radionuclide concentration is at least twice the average concentration value. Because of their recent publication and because new measurements and analyses are forthcoming, these values are expected to change. It should also be noted that waste from various tanks will be mixed, so the extreme variations seen here will be reduced in the actual waste form.

\subsubsection{Release Rate from Waste Form}

The radionuclide source term used in the transport calculations is based not only on the inventory, but also on the release rate of the radionuclides. The release rate is a function of the waste form, the disposal facility design, and the resulting chemical environment.

For an accurate determination of the source term, the chemical and physical models for contaminant release from the waste form must be explicitly modeled. However, because the waste form has not yet been determined and only specifications for its short-term release rate are known (DOE-RL 1996), simplified models are used in the base analysis case. More complete computer simulations of waste form corrosion and contaminant release are used as sensitivity calculations and will form the basis of future performance assessments. More complete computer simulations of waste form corrosion and contaminant release are planned similar to the simulations found in some of the sensitivity studies.

$\rightarrow \rightarrow \rightarrow$ The scenario for radionuclide release is described in Section 3.3 .3 (Contaminant Release Scenario).

$\rightarrow \rightarrow \rightarrow$ The release rates of radionuclides from the waste form actually used in the calculations are described in Section 3.4.4.3 (Waste Form Radionuclide Release Rate). 
DOE/RL-97-69

Rev. 0

Table 3-2. Best-Basis Global Radionuclide Inventory for Key Isotopes (curies) (after Kupfer 1997).

\begin{tabular}{|c|c|c|c|c|}
\hline \multirow[t]{2}{*}{ Nuclide } & \multicolumn{2}{|c|}{ Best-Basis } & \multirow{2}{*}{$\begin{array}{l}\text { Schmittroth } \\
\text { Decayed to } \\
1 / 1 / 2010 \\
\end{array}$} & \multirow{2}{*}{$\begin{array}{l}\text { Comments from Best-Basis Document } \\
\text { (Kupfer 1997) }\end{array}$} \\
\hline & $\begin{array}{c}\text { Decayed to } \\
1 / 1 / 1994 \\
\end{array}$ & $\begin{array}{l}\text { Decayed to } \\
1 / 1 / 2010 \\
\end{array}$ & & \\
\hline${ }^{3} \mathrm{H}-\mathbf{a}$ & $3.40 \times 10^{4}$ & $1.38 \times 10^{4}$ & $8.94 \times 10^{4}$ & $\begin{array}{l}\mathrm{HDW}^{\mathrm{c}} \text { model value is about a factor of } \\
2 \text { higher than best basis because HDW } \\
\text { ignores losses during processing }\end{array}$ \\
\hline${ }^{79} \mathrm{Se}$ & $7.73 \times 10^{2}$ & $7.73 \times 10^{2}$ & $10.3 \times 10^{2}$ & \\
\hline${ }^{90} \mathrm{Sr}$ - a & $7.16 \times 10^{7}$ & $4.86 \times 10^{7}$ & $5.37 \times 10^{7}$ & $\begin{array}{l}\mathrm{HDW}^{\mathrm{c}} \text { model value is } 14 \% \text { lower than } \\
\text { best basis value }\end{array}$ \\
\hline${ }^{99} \mathrm{Tc}$ & $3.26 \times 10^{4}$ & $3.26 \times 10^{4}$ & $2.72 \times 10^{4}$ & \\
\hline${ }^{126} \mathrm{Sn}$ & $1.19 \times 10^{3}$ & $1.19 \times 10^{3}$ & $1.58 \times 10^{3}$ & \\
\hline${ }^{129} \mathrm{I}$ & $6.30 \times 10^{1}$ & $6.30 \times 10^{1}$ & $6.62 \times 10^{1}$ & \\
\hline${ }^{137} \mathrm{Cs}-\mathrm{a}$ & $4.64 \times 10^{7}$ & $3.21 \times 10^{7}$ & $4.51 \times 10^{7}$ & $\begin{array}{l}\mathrm{HDW}^{\mathrm{c}} \text { model value is } 1.5 \% \text { higher } \\
\text { than best basis value }\end{array}$ \\
\hline${ }^{233} \mathrm{U}-\mathrm{b}$ & $4.76 \times 10^{2}$ & $4.76 \times 10^{2}$ & $4.30 \times 10^{2}$ & $\begin{array}{l}\mathrm{HDW}^{\mathrm{c}} \text { model value is about a factor of } \\
2 \text { higher; the HDW value is suspect. }\end{array}$ \\
\hline${ }^{234} \mathrm{U}-\mathrm{b}$ & $3.46 \times 10^{2}$ & $3.46 \times 10^{2}$ & $3.00 \times 10^{2}$ & $\begin{array}{l}\text { HDWc model value is about a factor of } \\
2.5 \text { higher; the HDW value is suspect. }\end{array}$ \\
\hline${ }^{235} \mathrm{U}-\mathrm{b}$ & $1.45 \times 10^{1}$ & $1.45 \times 10^{1}$ & $1.23 \times 10^{1}$ & $\begin{array}{l}\mathrm{HDW}^{\mathrm{c}} \text { model value is about a factor of } \\
2.5 \text { higher; the HDW value is suspect. }\end{array}$ \\
\hline${ }^{238} \mathrm{U}-\mathrm{b}$ & $3.22 \times 10^{2}$ & $3.22 \times 10^{2}$ & $2.97 \times 10^{2}$ & $\begin{array}{l}\text { HDWc model value is about a factor of } \\
3 \text { higher; the HDW value is suspect. }\end{array}$ \\
\hline${ }^{237} \mathrm{~Np}$ & $1.41 \times 10^{2}$ & $1.41 \times 10^{2}$ & $0.75 \times 10^{2}$ & \\
\hline${ }^{239} \mathrm{Pu}-\mathrm{a}$ & $3.91 \times 10^{4}$ & $3.91 \times 10^{4}$ & $3.72 \times 10^{4}$ & \\
\hline${ }^{241} \mathrm{Am}$ & $6.99 \times 10^{4}$ & $6.81 \times 10^{4}$ & $5.31 \times 10^{4}$ & $\begin{array}{l}\mathrm{HDW}^{\mathrm{c}} \text { model value is about } 20 \% \\
\text { higher }\end{array}$ \\
\hline
\end{tabular}

a Best estimate value is based on chemical separations information associated with DKPRO

b Best estimate values are based on accountability and tank samples.

c . The Hanford Defense Waste [HDW] model (Agnew 1997) was used to track the separations history of most of the items in the Best Basis Inventory. 


\section{DOE/RL-97-69}

Rev. 0

Table 3-3. Best Basis Tank by Tank Inventory for ${ }^{99} \mathrm{Tc},{ }^{12 \pi} \mathrm{Sn},{ }^{137} \mathrm{Cs},{ }^{97} \mathrm{Sr}$, and ${ }^{79} \mathrm{Se}$. Only those tanks where the concentration for at least one isotope is greater than twice the average for that isotope are presented. Radioisotopes decayed to 1/1/1994.

\begin{tabular}{|c|c|c|c|c|c|c|c|c|c|c|c|c|c|c|c|c|}
\hline \multirow[t]{2}{*}{ Tank Name } & \multirow{2}{*}{$\begin{array}{l}\text { Tank } \\
\text { Volume } \\
\text { (Kgal) }\end{array}$} & \multicolumn{3}{|c|}{ Technctium-99 } & \multicolumn{3}{|c|}{ Tin=126 } & \multicolumn{3}{|c|}{ Cesium-137 } & \multicolumn{3}{|c|}{ Strontium-90 } & \multicolumn{3}{|c|}{ Sclenium-79 } \\
\hline & & $\begin{array}{l}\text { Amount } \\
\text { (curies) }\end{array}$ & $\begin{array}{l}\text { Concentration } \\
\text { (curies/Kgal) }\end{array}$ & $\begin{array}{l}\text { Con. to } \\
\text { Average }\end{array}$ & $\begin{array}{l}\text { Amount } \\
\text { (curies) }\end{array}$ & $\begin{array}{l}\text { Concentralion } \\
\text { (curies/Kgal) }\end{array}$ & $\begin{array}{l}\text { Con to } \\
\text { Average }\end{array}$ & 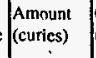 & $\begin{array}{l}\text { Concentration } \\
\text { (curics/Kgal) }\end{array}$ & $\begin{array}{l}\text { Con. to } \\
\text { Average }\end{array}$ & $\begin{array}{l}\text { Amnunt } \\
\text { (curics) }\end{array}$ & $\begin{array}{l}\text { Concentration } \\
\text { (curfes/Kgal) }\end{array}$ & \begin{tabular}{|l} 
Cont to \\
Average
\end{tabular} & \begin{tabular}{|l|} 
Amount \\
(curics)
\end{tabular} & \begin{tabular}{|} 
Concentration \\
(curies/Kgal)
\end{tabular} \mid & \begin{tabular}{|l|} 
Con. to \\
Average
\end{tabular} \\
\hline $241-A-102$ & 41 & 26. & 0.6439 & & 7.0 & 0.16951 & 9.00 & 31400 & 765.9 & & 135000 & 3292.7 & 3.00 & 4.4 & 0.10610 & 9.52 \\
\hline $241-\mathrm{A}-104$ & 28 & 8 & 0.2961 & & 8.7 & 0.31107 & 16.51 & 77700 & 2775.0 & 3.30 & 2930000 & 104642.9 & 95.30 & 5.3 & 0.19071 & 17.12 \\
\hline $241-\mathrm{A}-105$ & 19 & 12 & 0.6368 & & 12.5 & 0.65789 & 34.93 & 173000 & 9105.3 & 10.82 & 4710000 & 247894.7 & 225.9 & 8.0 & 0.42211 & 37.88 \\
\hline $241-\mathrm{A}-106$ & 125 & 97 & 0.7768 & 1.03 & 68.3 & 0.54640 & 29.01 & 108000 & 864.0 & 1.03 & 834000 & 6672.0 & 6.08 & 42.5 & 0.34000 & 30.51 \\
\hline $241-\mathrm{AN}-103$ & 953 & 456 & 0.4785 & & 18.8 & 0.01973 & 1.05 & 2310000 & 2423.9 & 2.88 & 8030 & 8.4 & & 12.3 & 0.01291 & 1.16 \\
\hline $241-\mathrm{AX}-102$ & 39 & 38 & 0.9667 & 1.28 & 8.4 & 0.21410 & 11.37 & 52000 & 1333.3 & 1.58 & 268000 & 6871.8 & 6.26 & 5.3 & 0.13564 & 12.17 \\
\hline $24 \mathrm{I}-\mathrm{AX}-103$ & 112 & 56 & 0.4982 & & 10.9 & 0.09732 & 5.17 & 134000 & 1196.4 & 1.42 & 3820000 & 34107.1 & 31.09 & 7.0 & 0.06286 & 5.64 \\
\hline 241-AX-104 & 7 & 4 & 0.6386 & & 4.6 & 0.65857 & 34.96 & 32596 & 4656.6 & 5.53 & 1580000 & 225714.3 & 205.75 & 3.0 & 0.42143 & 37.82 \\
\hline $241-\mathrm{AY}-101$ & 881 & 412 & 0.4677 & & 51.1 & 0.05800 & 3.08 & 442000 & 501.7 & & 3750000 & 4256.5 & 3.88 & 32.6 & 0.03700 & 3.32 \\
\hline $24 \mathrm{l}-\mathrm{AZ}-10 \mathrm{1}$ & 960 & 1100 & 1.1458 & 1.52 & 65.7 & 0.06844 & 3.63 & 7430000 & 7739.6 & 9.20 & 6360000 & 6625.0 & 6.04 & 41.3 & 0.04302 & 3.86 \\
\hline $241-\mathrm{AZ}-102$ & 963 & 599 & 0.6220 & & 35.4 & 0.03676 & 1.95 & 4320000 & 4486.0 & 5.33 & 3700000 & 3842.2 & 3.50 & 22.8 & 0.02368 & 2.12 \\
\hline $24 \mid-B-101$ & 113 & 4 & 0.0311 & & 7.8 & 0.06894 & 3.66 & 15900 & 140.7 & & 724000 & 6407.1 & 5.84 & 4.9 & 0.04354 & $3.9 !$ \\
\hline $241-C-105$ & 150 & 98 & 0.6540 & & 0.0 & 0.00018 & & 125000 & 833.3 & & 365000 & 2433.3 & 2.22 & 0.0 & 0.00012 & \\
\hline $241-C-106$ & 229 & 221] & 0.9651 & 1.28 & 30.2 & 0.13188 & 7.00 & 267000 & 1165.9 & 1.39 & 4770000 & 20829.7 & 18.99 & 18.5 & 0.08079 & 7.25 \\
\hline $241-C-107$ & 275 & 105 & 0.3818 & & 41.4 & 0.15055 & 7.99 & 30800 & 112.0 & & 1680000 & 6109.1 & 5.57 & 25.7 & 0.09345 & 8.39 \\
\hline $241-C-109$ & 66 & 1 & 0.0123 & & 0.1 & 0.00136 & & 237000 & 3590.9 & 4.27 & 221000 & $\mathbf{3 3 4 8 . 5}$ & 3.05 & 0.1 & 0.00087 & \\
\hline $241-C-111$ & 57. & 0 & 0.0038 & & 0.0 & 0.00018 & & 12000 & 210.5 & & 1140000 & 20000.0 & 18.23 & 0.0 & 0.00012 & \\
\hline $241-\mathrm{C}-112$ & 104 & 80 & 0.7663 & 1.01 & 0.1 & 0.00063 & & 246000 & 2365.4 & 2.81 & 1250000 & 12019.2 & 10.96 & 0.2 & 0.00230 & \\
\hline $241-\mathrm{C}-201$ & 2 & 0 & 0.0084 & & 0.0 & 0.00414 & & 42.7 & 21.4 & & 17100 & 8550.0 & 7.79 & 0.0 & 0.00261 & \\
\hline $241-5 X-107$ & 104 & 14 & 0.1365 & & 4.9. & 0.04663 & 2.48 & 53300 & 512.5 & & 198000 & 1903.8 & 1.74 & 3.7 & 0.03587 & 3.22 \\
\hline 241 -SX-108 & 87 & 8 & 0.0879 & & 3.2 & 0.03667 & 1.95 & 32500 & 373.6 & & 1090000 & 12528.7 & 11.42 & 2.5 & 0.02874 & 2.58 \\
\hline $241-\mathrm{SX}-109$ & 250 & 70 & 0.2788 & & 10.5 & 0.04200 & 2.23 & 258000 & 1032.0 & 1.23 & 1100000 & 4400.0 & 4.01 & 7.2 & 0.02876 & 2.58 \\
\hline $241-S X-110$ & 62 & 16 & 0.2629 & & 6.5 & 0.10532 & 5.59 & 31500 & 508.1 & & 116800 & 1883.9 & 1.72 & 5.0 & 0.08081 & 7.25 \\
\hline 241-SX-111 & 125 & 25 & 0.1976 & & 8.6 & 0.06904 & 3.67 & 63800 & 510.4 & & 240000 & 1920.0 & 1.75 & 6.6 & 0.05272 & 4.73 \\
\hline $241-\mathrm{SX}=112$ & 921 & 151 & 0.1663 & & 5,21 & 0.05663 & 3.01 & 47100 & 5120 & & 275000 & 1902.2 & 1.73 & 4.0 & 0.04326 & 3.88 \\
\hline
\end{tabular}




\section{DOE/RL-97-69}

Rev, 0

Table 3-3. Best Basis Tank by Tank Inventory for ${ }^{99} \mathrm{Tc},{ }^{12} \mathrm{Sn},{ }^{137} \mathrm{Cs},{ }^{97} \mathrm{Sr}$, and ${ }^{79} \mathrm{Se}$. Only those tanks where the concentration for at least one isotope is greater than twice the average for that isotope are presented. Radioisotopes decayed to 1/1/1994.

\begin{tabular}{|c|c|c|c|c|c|c|c|c|c|c|c|c|c|c|c|c|}
\hline \multirow[t]{2}{*}{ Tank Name } & \multirow{2}{*}{$\begin{array}{l}\text { Tank } \\
\text { Volume } \\
\text { (Kgal) }\end{array}$} & \multicolumn{3}{|c|}{ Technettum-99 } & \multicolumn{3}{|c|}{ Tin- 126} & \multicolumn{3}{|c|}{ Ccsium-137 } & \multicolumn{3}{|c|}{ Strontium-90 } & \multicolumn{3}{|c|}{ Selenium-79 } \\
\hline & & $\begin{array}{l}\text { Amount } \\
\text { (curtes) }\end{array}$ & $\begin{array}{l}\text { Concentration } \\
\text { (curics } / \mathrm{Kgal} \text { ) }\end{array}$ & $\begin{array}{l}\text { Con. 10 } \\
\text { Average }\end{array}$ & $\begin{array}{l}\text { Amount } \\
\text { (curies) }\end{array}$ & $\begin{array}{l}\text { Conicentration } \\
\text { (curic } / \text { /Kgal) }\end{array}$ & $\begin{array}{l}\text { Con. to } \\
\text { Average }\end{array}$ & $\begin{array}{l}\text { Amount } \\
\text { (curies) }\end{array}$ & $\begin{array}{l}\text { Concentration } \\
\text { (curies/Kgal) }\end{array}$ & $\begin{array}{l}\text { Con. to } \\
\text { Average }\end{array}$ & $\begin{array}{l}\text { Amount } \\
\text { (curics) }\end{array}$ & $\begin{array}{l}\text { Concentration } \\
\text { (curics/Kgal) }\end{array}$ & $\begin{array}{l}\text { Con. 10 } \\
\text { Average }\end{array}$ & $\begin{array}{l}\text { Amount } \\
\text { (curies) }\end{array}$ & $\begin{array}{l}\text { Concentration } \\
\text { (curies/Kgal) }\end{array}$ & $\begin{array}{l}\text { Con. to } \\
\text { Average }\end{array}$ \\
\hline $241-\$ X-114$ & 181 & 53 & 0.2906 & & 11.6 & 0.06409 & 3.40 & 72000 & 397.8 & & 267000 & 1475.1 & 1.34 & 8.4 & 0.04641 & 4.17 \\
\hline 241-SY-101 & 1100 & 14600 & 13.2727 & 17.58 & 30.6 & 0.02782 & 1.48 & 2210000 & 2009.1 & 2.39 & 125000 & 113.6 & & 20.3 & 0.01845 & 1.60 \\
\hline $241-T-105$ & 98 & 230 & 2.3469 & 3.11 & 0.0 & 0.00005 & & 30000 & 306.1 & & 170000 & 1734.7 & 1.58 & 0.0 & 0.00004 & \\
\hline Total & 60891 & 45984 & & & 1147.0 & & & 51231455 & & & 66798502 & & & 678.5 & & \\
\hline Avcrage & & & 0.7552 & & & 0.01884 & & & 841.4 & & & 1097.0 & & & 0.01114 & \\
\hline
\end{tabular}

The concentration ratio to the average value is not given if it is less than unity. 
DOE/RL-97-69

Rev. 0

Table 3-4. Best Basis Tank by Tank Inventory for ${ }^{23 !} \mathrm{Pa}, \mathrm{U}$ isotopes, ${ }^{239} \mathrm{Pu}$, and ${ }^{241} \mathrm{Am}$. Only those tanks where the concentration for at least one isotope is greater than twice the average for that isotope are presented.

Radioisotopes decayed to $1 / 1 / 1994$.

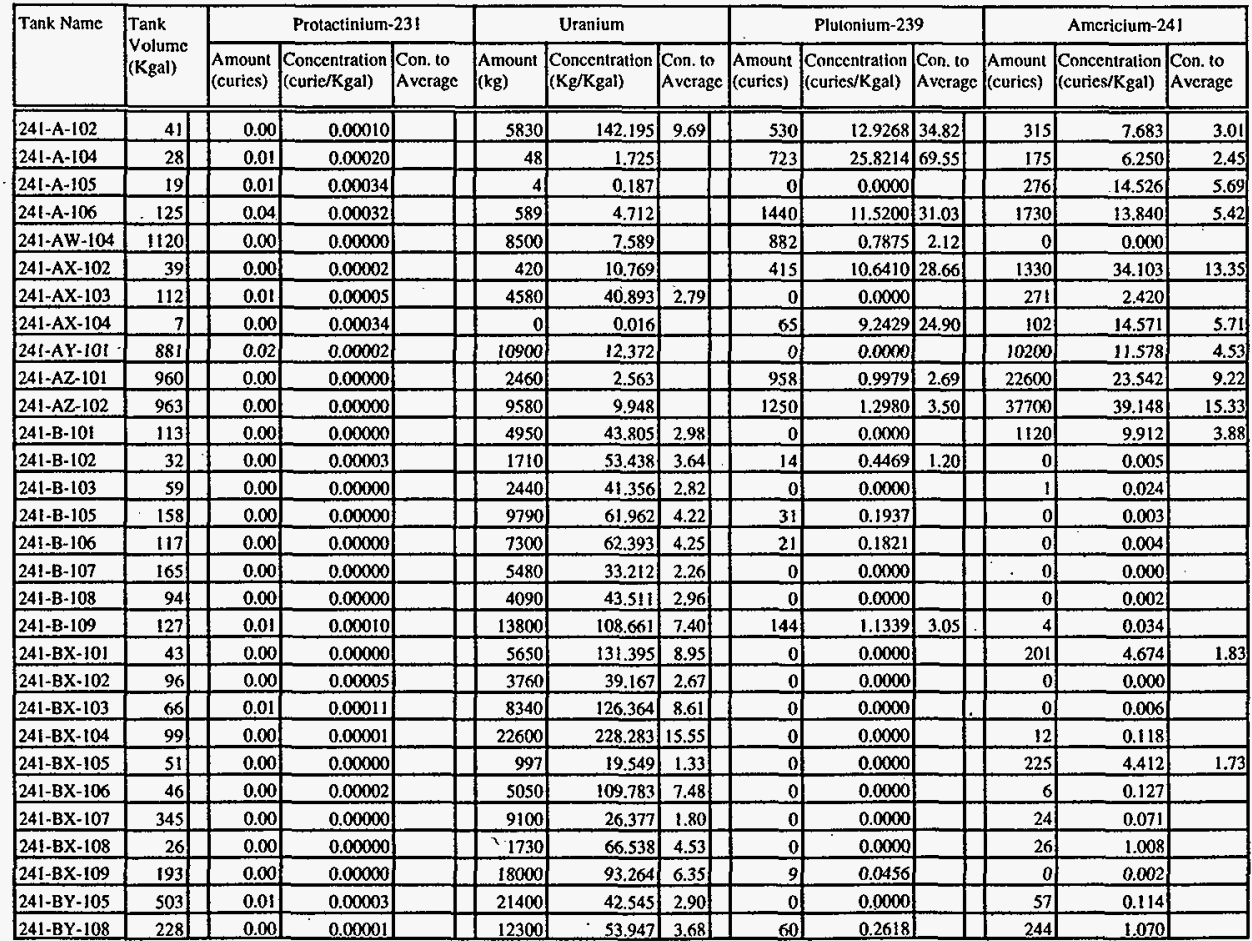




\section{DOE/RL-97-69}

\section{Rev, 0}

Table 3-4. Best Basis Tank by Tank Inventory for ${ }^{23} \mathrm{~Pa}, \mathrm{U}$ isotopes, ${ }^{230} \mathrm{Pu}$, and ${ }^{241} \mathrm{Am}$. Only those tanks where the concentration for at least one isotope is greater than twice the average for that isotope are presented.

Radioisotopes decayed to $1 / 1 / 1994$.

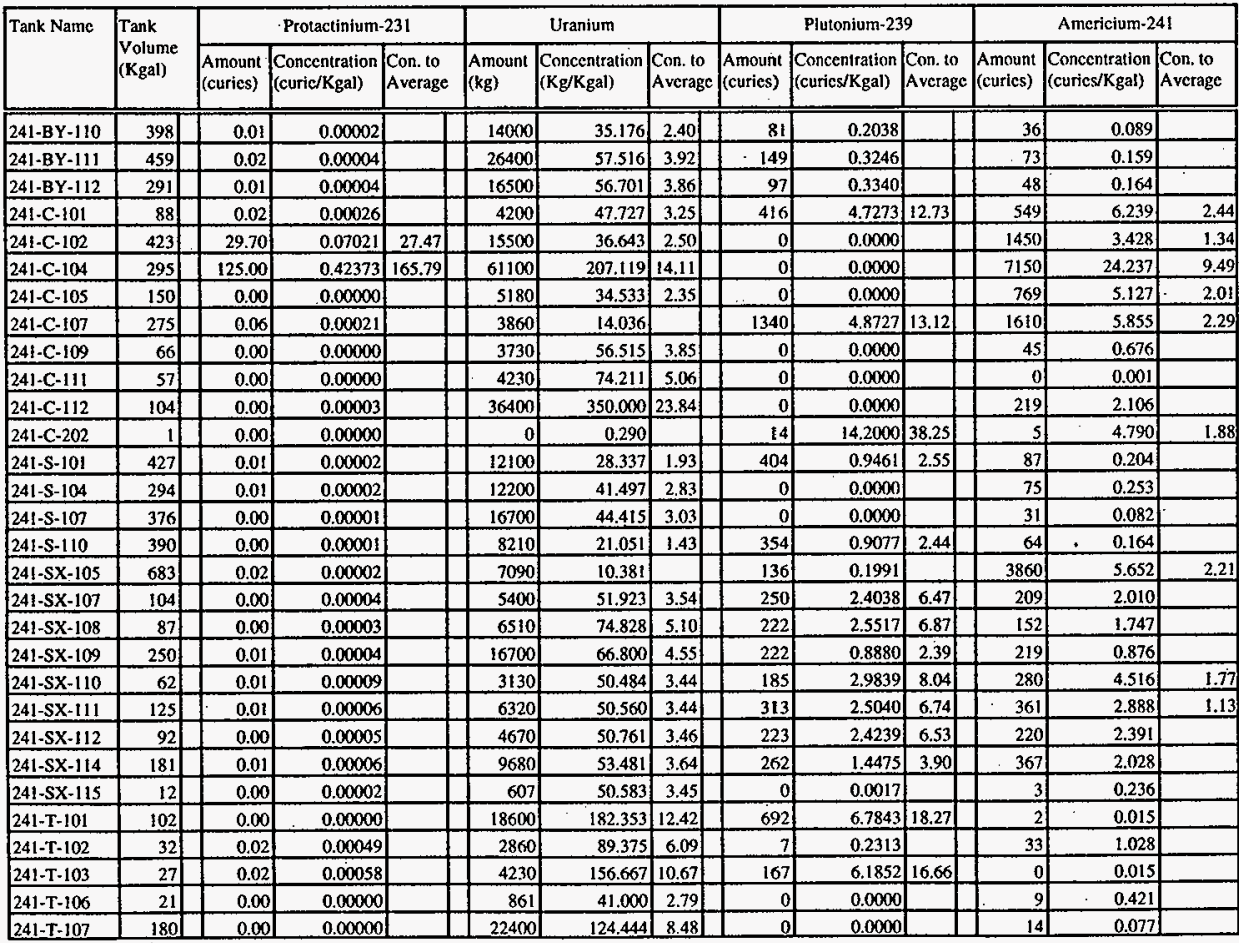

$$
3-13
$$




\section{DOE/RL-97-69}

\section{Rev. 0}

Table 3-4. Best Basis Tank by Tank Inventory for ${ }^{231} \mathrm{~Pa}, \mathrm{U}$ isotopes, ${ }^{239} \mathrm{Pu}$, and ${ }^{241} \mathrm{Am}$. Only those tanks where the concentration for at least one isotope is greater than twice the average for that isotope are presented.

Radioisotopes decayed to $1 / 1 / 1994$

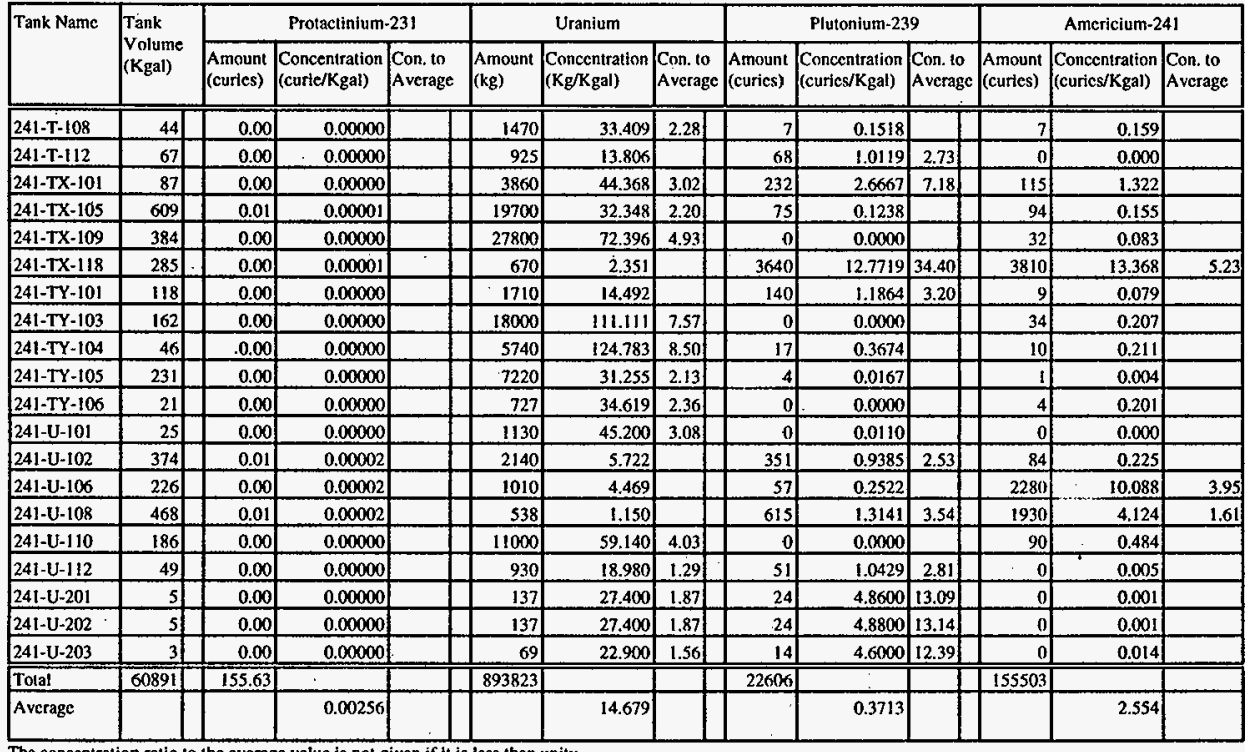

The concentration ratio to the average value is not given if it is less than unity. 


\section{DOE/RL-97-69}

Rev. 0

\subsection{PATHWAYS AND SCENARIOS}

This section discusses the selection criteria, the pathways chosen and not chosen, and the exposure pathways chosen and not chosen. Special emphasis is given to justifying the choices. In this discussion pathways refer to the environmental paths (for example, groundwater) by which contaminants move from the waste form to the human environment. Scenarios are the environmental and human-made events (for example, human intrusion or irrigation) that influence how contaminants move or affect humans.

\subsubsection{Selection Criteria}

Relevant pathways and scenarios for these analyses were selected mainly based on pathways and scenarios used in earlier Hanford Site long-term environmental analysis documents. Previous long-term environmental analyses have included performance assessments written to satisfy the requirements of DOE Order 5820.2a as well as environmental impact statements. As noted in Section 1.5.1, four Hanford Site performance assessments for the disposal of low-level waste have already been done (Kincaid 1995, Wood 1994b, Wood 1995, and Wood 1996). The most important environmental impact statements (EIS) have been the Hanford Defense Waste EIS (DOE 1987), the Tank Waste Remediation System EIS (DOE 1996b), and the Hanford Remedial Action EIS (DOE 1996c). These documents have been fairly consistent in their choice of pathways and scenarios.

After reviewing the relevant documents, reviews, and guidance, pathways and scenarios were selected for the interim performance assessment (PAT 1995b). Selection was based on the relevance of the pathway or scenarios to the current disposal action and performance objectives.

\subsubsection{Pathways}

3.3.2.1 Introduction. The selection of pathways for this performance assessment is covered more fully in Scenarios of the TWRS Low-Level Waste Disposal Program (WHC 1995). Possible scenarios were suggested by analyzing the performance objectives from Chapter 1 and determining which pathways could lead to a level of exposure that could equal or exceed the specified performance objective. Postulated land use was also studied to determine possible additional pathways. Finally, likely natural events were identified (such as catastrophic glacial age flooding).

In previous Hanford Site performance assessments and environmental impact statements, the dominant pathway was through groundwater. Infiltration of moisture from precipitation entered the engineered system, where the moisture may cause the contaminants (for example in a water-glass interaction) to be released or may simply carry away already released contaminants. The moisture and released contaminants travel downward through the vadose zone until the contaminants reach the unconfined aquifer where humans can encounter the radioisotopes 


\section{DOE/RL-97-69}

Rev. 0

through recovery of the groundwater resource for uses in residential and agricultural settings. From previous analyses (Rawlins 1994, Mann 1995b) supporting the Hanford Low-Level Tank Waste Program, this pathway again is expected to be dominant.

3.3.2.2 Future Land Use. In 1992 the Hanford Future Site Uses Working Group (HFSUWG) was charged to determine potential future uses of the various parts of the Hanford Site. This group consisted of local, state, and federal of ficials, representatives of affected Indian tribes and agricultural and labor organizations, as well as members of environmental and other special interest groups. The efforts of the HFSUWG form the basis of the Hanford Site Comprehensive Land Use plan (DOE 1996c). The HFSUWG summary report (HFSUWG 1992a-2) states

"In general, the Working Group desires that the overall cleanup criteria for the Central Plateau should enable general usage of the land and groundwater for other than waste management activities in the horizon of 100 years from the decommissioning of waste management facilities and closure of the disposal areas."

The following four general land uses can be envisioned for the Central Plateau over the time of interest to a performance assessment.

- Industrial/commercial
- $\quad$ Dry-land farming
- $\quad$ Irrigated.farming
Natural.

The present land use is heavy industrial. If this use is maintained, records of past activities (particularly the disposal of nuclear materials) are likely to be kept. In addition, in an industrial area, liquid discharges to the ground would be highly regulated and kept small.

Like the Central Plateau, the Horse Heaven Hills, south of the Hanford Site, are near, but at a significantly higher elevation than, the Columbia River. Although the amount of irrigation is increasing at certain locations, comparatively little irrigation occurs in the Horse Heaven Hills because of the relatively high energy cost (hence economic cost) of bringing water to the surface. Dry-land farming continues to be the main use for the land of the Horse Heaven Hills.

East of the Central Plateau, across the Columbia River, irrigated farming is extremely common. The water, however, does not come from the nearby stretches of the Columbia River. The water comes from the Columbia Basin Project, which derives its water from the Grand Coulee Dam, over $322 \mathrm{~km}$ ( $200 \mathrm{mi}$ ) upstream of the Hanford Site. The water is gravity-fed to the farms. The regional geography makes such a water delivery system unlikely for the Central Plateau.

Finally, west of the Central Plateau is the Fitzner/ Eberhardt Arid Lands Ecology Reserve, a nature preserve area.

For the base analysis case, the land use assumption was that knowledge of the disposal activities has been retained and that water discharges to the ground are minimized. These 


\section{DOE/RL-97-69}

Rev. 0

assumptions are consistent with the assumptions of the HFSUWG, the DOE, and the local planning authorities, all of whom are using a short-term (50-100 year) planning horizon.

\subsubsection{Land-Use-Driven Scenarios}

The pathways described here assume that some controls remain in place to prevent public intrusion into the disposal site. That is, the barriers and markers that are to be left will be effective in preventing open use of the land over the disposal site. The land surrounding the marked area, however, could be farmed and could contain wells.

Based on previous analyses at the Hanford Site, the main exposure pathway is expected to be the contamination of the underground aquifer leading to various exposure scenarios. Other pathways include the upward diffusion through the engineered system into the air.

$\rightarrow \rightarrow \rightarrow$ The scenario for contaminant release is given in Section 3.3 .3 .

$\rightarrow \rightarrow \rightarrow$ Exposure scenarios are described in Section 3.3 .5

3.3.2.3.1 Unconfined Aquifer Contamination. Contamination of the unconfined aquifer is caused by water (natural or human-caused penetrating through the ground surface layer, interacting with the engineered structure (including the waste), and then transporting contaminants down through the unsaturated sediments to the unconfined aquifer.

The main effects of land use on the analyses presented in this performance assessment are as follows:

- The amount of water penetrating through the ground surface layer above the disposal facility

- The direction and magnitude of flow of the unconfined aquifer from regional irrigation

- The amount of well water pumped to the surface.

Because the site of the disposal facility is assumed to be known to the surrounding population, it was assumed that the surface immediately above the disposal facility will not be used. Thus the only source of water would be natural rain or snowfall. The infiltration rate, the rate at which water actually penetrates through the surface layer and enters the sand-gravel capillary barrier, is described in Section 3.4 .6 and is expected to be small (less than $5 \mathrm{~mm} / \mathrm{year}$ ).

The second major consequence of land use is on the flow of groundwater in the unconfined aquifer. Analysis (ERDA 1975) of groundwater flow before the start of Hanford Site operations shows a predominantly west-to-east flow (Figure 2-12). Current calculations for post-operation conditions ( Lu 1996) predict a similar flow (Figure 3-1). These groundwater calculations form an important part in this analysis. 
DOE/RL-97-69

Rev. 0

Figure 3-1. Predicted Groundwater Flowlines for Post Hanford Conditions. (Lu 1996)

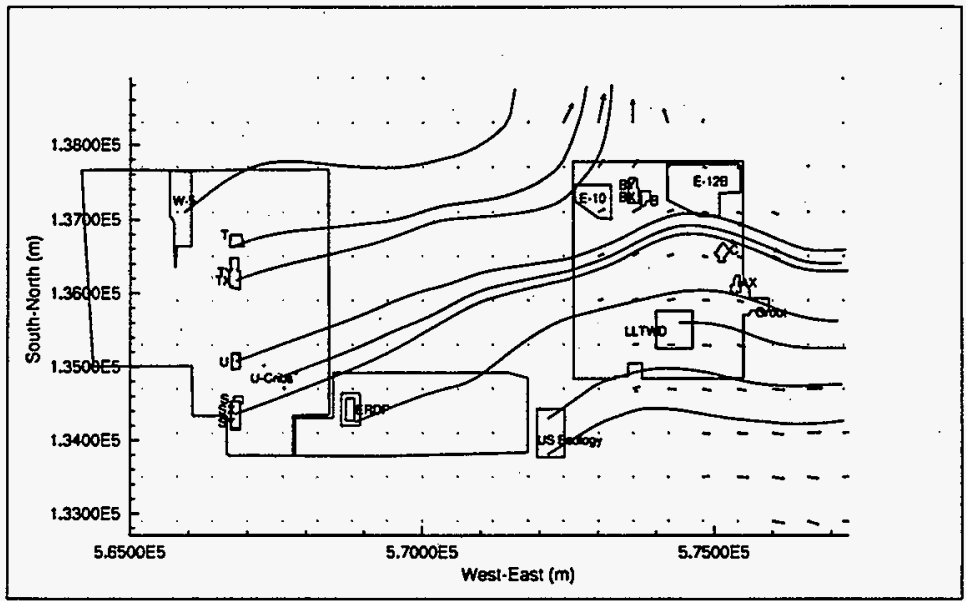

$\rightarrow \rightarrow \rightarrow$ The groundwater model is described in Section 3.53 .3 .

$\rightarrow \rightarrow \rightarrow$ The groundwater data are described in Section 3.5 .3$.

$\rightarrow \rightarrow \rightarrow$ The results of the groundwater modeling are described in Sections 4.2 through 4.7 and summarized in 49 .

The creation of ponds and the large amount of water discharged to the ground have altered the natural flow of groundwater (Dirkes 1997) (Figure 2-13). Possible irrigation on the Central Plateau which also would affect groundwater must be considered. No irrigation was assumed for the base analysis case because the energy requirements for irrigation in the Central Plateau are significantly higher than for other nearby regions and no known irrigation rights exist. However, irrigation on the plateau was considered in sensitivity cases to determine the effects of selected irrigation on the regional flow of the groundwater in the unconfined aquifer. Irrigation on the 200 Areas was considered unlikely because this area will be dedicated to waste disposal and irrigation would be considered an inadvertent intrusion. Each of the following sensitivity cases was considered separately:

- Irrigated farming in the area north of the 200 Areas

- Irrigated farming in the area west of the 200 Areas

- Irrigated farming in all areas on the plateau except the 200 West Area, the 200 East Area, and the region between these two areas . 


\section{DOE/RL-97-69 \\ Rev. 0}

The last major effect is the amount of water being taken from a well. At the locations of the proposed disposal facilities, the unconfined aquifer contains only a limited amount of water. Because the amount of water is so limited, either oniy a small amount would be pumped from the unconfined aquifer or the well would extend much deeper and tap the confined aquifer instead of the unconfined aquifer. Thus, minimum distortion of the groundwater flow field in the unconfined aquifer was assumed for the base analysis case. Sensitivity cases were considered, however, to determine the effect of the amount of pumping on the groundwater flowfield and the calculated doses.

3.3.2.3.2 Surface Water. The major surface water source in the region is the Columbia River. Here the main impact of land use is possible irrigation of land near the river. The Columbia River is a more likely source of water than the unconfined aquifer for farm land near the river because of the low elevation and nearness to the river. However, as part of the Washington State Growth Management Act, Benton County is planning to use the land downgradient from the Central Plateau for research and development or for uses not affecting the groundwater. Also, the Columbia River and the lands adjacent to the river are being considered for protected status under the Wild and Scenic Act of 1968.

For the base analysis case, the assumption was that no irrigation would occur downgradient from the plateau.

3.3.2.3.3 Air Resources. Gases and vapors could travel upward from the facility through the soil to the ground surface. This pathway is maximized with minimum downward water movement. No water flow is considered in the calculations for the protection of air resources.

3.3.2.4 Natural Event Scenarios. The main natural events to be expected are as follows:

- Wind erosion of the surface above the disposal facility

- Earthquakes

- Flooding caused by post-glacial events.

Wind erosion and earthquakes are considered as drivers for changes in the engineered structure as a function of time. They are described in Section 3.4.5.7. Massive regional flooding has occurred many times during the past 50,000 years (see Section 2.2.7.2). The flood in the scenario, which is caused by the release of water during glacial retreat from a receding ice dam removes 30 or more meters of ground, including the disposal units. In this scenario, the waste is assumed to be uniformly redeposited over the Hanford Site. Seasonal flooding or flooding caused by collapsed dams would not affect the disposal site (see Section 2.2.9.2). 


\section{DOE/RL-97-69}

Rev. 0

\subsubsection{Contaminant Release Scenario}

The actual waste form that will contain the contaminant is not yet officially known. Before the final request for proposal (RFP) for the privatization effort was released (DOE-RL

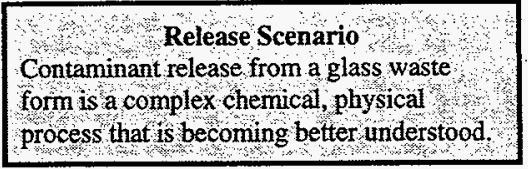

Release Scenario

Contaminant release from a glass wast form is a complex chemical, physical process that is becoming better understood 1996), the reference waste form was silicate glass. Until the Phase $1 \mathrm{~b}$ privatization contract is awarded (expected in May 1998), the waste form will be uncertain, although the private vendors have publicly indicated that a silicate glass waste form will be used. Section 3.3.3.1 gives a general description of the contaminant release scenario. Section 3.3.3.2 focuses on what occurs during the water/waste-form interaction if the waste form is a silicate glass.

$\rightarrow \rightarrow \rightarrow$ The contaminant release tate used in the base analysis case calculations is described insection 3.4 .3

3.3.3.1 General Description. The contaminant release scenario is based on a water/waste form interaction. Initially, the disposal facility design (Section 2.4) delays moisture from entering the vault bays. Eventually, water enters the vault bays and moves downward to the waste packages. When it reaches a waste package, the water first interacts with the container, aiding its corrosion. Once the container is breached, water is assumed to reach the waste form. The water starts interacting with and breaking down the waste form. The waste form then releases the contaminants into the available water. The release rate will depend on the material, temperature, and the local chemical environment. Then available water transports the contaminant from the waste package and through the disposal facility. If the vault bay contains a getter material that sorbs the contaminant, the contaminant takes longer to move through the disposal facility. Finally, the moisture and contaminants migrate to the vadose zone through cracks in the bottom of the disposal facility.

3.3.3.2 Contaminant Release Based on Glass Corrosion. If the waste form is a silicate glass, glass corrosion processes would control the initial release of the contaminants. Studies have shown (Cunnane 1994) that silicate glasses corrode in three stages.

The first stage occurs under dilute solution conditions. Under these conditions, the water does not contain significant concentrations of many elements released from the glass. The glass reacts at a characteristic initial rate (the "forward rate") that depends only on glass composition, temperature, and solution $\mathrm{pH}$. During this time the water/glass reaction releases components of the glass into the water.

The second stage occurs as the concentration of elements released from the glass in the contacting water increases. The rate of glass corrosion continually slows as the solution becomes more concentrated with glass components. The reaction may reach a point where the glass corrosion rate cannot be distinguished from zero. This rate has been called the saturation rate where apparent saturation occurs with respect to the glass phase. The solution is not saturated in a thermodynamic sense because glass is metastable. The solution is saturated in a kinetic sense in that the corrosion rate approaches a very low constant value. 


\section{DOE/RL-97-69 \\ Rev. 0}

The third stage of glass corrosion may occur if secondary mineral phases begin to precipitate from the "saturated" fluid. Precipitation of many of these mineral phases will cause the solution to become undersaturated with respect to the glass. This undersaturation affects the glass corrosion rate. Mass transfer between the solution and the mineral secondary phases will maintain undersaturation. The resulting glass corrosion rate will depend on the specific chemistry of the secondary mineral phases that are formed. Depending on the secondary mineral phase formed, glass corrosion could remain near the low rate attained during the second stage or could accelerate to a rate near the forward rate.

The glass corrosion process releases contaminants into the moisture in contact with the glass. However, the contaminant release rate is not necessarily proportional to the glass corrosion rate. Rather each contaminant is subject to a variety of chemical reactions that can significantly alter the concentration of the contaminants in the moisture that eventually exits the disposal vault. These reactions include oxidation/reduction, dissolution/precipitation, and adsorption. Experiments and numerical analysis are proceeding to better understand the actual contaminant release. Testing on reference low-level glasses has been completed. Testing has just begun on waste forms proposed by the TWRS privatization contractors.

\subsubsection{Contaminant Transport}

Previous analyses (Kincaid 1995, Mann 1995b, Wood 1994b, Wood 1995, Wood 1996)

have shown that contaminants are transported

Contaminant Transport

Outside the disposal vault, contaminant transport is treated as an extension of moisture movement using the $\mathrm{K}_{\mathrm{d}}$ model.

mainly by their movement in the aqueous phase.

Contaminant transport can occur as contaminants move with the water and diffuse through water. Other mechanisms involved vapor-phase transport of the gaseous contaminations and massive movements caused by catastrophic events such as glacial-age flooding. Sections 3.3.4.1 through 3.3.4.4 describe how the contaminant transport mechanisms were modeled. Appendix D contains the equations actually used in the models.

3.3.4.1 Moisture Movement. Two distinct moisture content regimes are present during contaminant transport: the unconfined aquifer and the vadose zone. In the unconfined aquifer, all the pore space of the porous sediment matrix is filled with water; the matrix is water saturated. In the vadose zone, the pore space is only partially filled with water; the vadose zone is unsaturated.

Water flow through a saturated porous medium, such as the unconfined aquifer, is governed by the empirical relationship known as Darcy's Law (Freeze 1979) and by the conservation of mass. Darcy's law defines the discharge of water through a cross section of a porous medium. However, in contamination transport, the average velocity of water flowing through the medium is needed. The average velocity of the pore water is determined by dividing the discharge or Darcy velocity of the water by the water-filled porosity of the medium. Total porosity is defined as the ratio of void space to total volume. 


\section{DOE/RL-97-69}

\section{Rev. 0}

In an unsaturated medium, the pores are not completely filled with water. For such a medium, moisture content is defined as the ratio of water-filled void space to the total volume and the average velocity of the pore water is determined by dividing the Darcy velocity by the moisture content. Additional effects (capillary forces, the dependence of hydraulic conductivity on moisture content, etc.) must be considered when analyzing an unsaturated medium. The Richards equation (Richards 1931) becomes the governing equation (see Appendix D).

The important parameters in these equations are the following:

- Matric potential (or pressure head) as a function of moisture content (water retention function)

- Hydraulic conductivity as a function of moisture content (relative permeability function)

- The source or sink of moisture.

Under extremely dry conditions, water vapor diffusion may be important. Water vapor diffuses through porous media along vapor pressure gradients. The presence of water-soluble components (in the waste form, for example) depresses the water vapor potential and causes the water vapor to diffuse from the surrounding soils. This water could then condense at the location of the water-soluble material and leach contamination from that surface. Important factors in this process are the level to which the water vapor pressure is depressed and the effective diffusion coefficient of water vapor.

3.3.4.2 Advective, Dispersive, and Diffusive Transport. The equation for the advective, dispersive, and diffusive transport of contaminants can be viewed as a mass balance on a differential volume.

The parameters important in this equation are

- The pore water velocity

- The dispersion coefficient

- The effective porosity of the soil layer

- The retardation factor that depends on the soil's density and wetted porosity and chemical distribution coefficient

- The effective diffusion coefficient

- The half-life for decay. 


\section{DOE/RL-97-69}

Rev. 0

An increase in the retardation factor increases the time for the contaminant to reach the aquifer. In the absence of an advective component, the diffusion process could bring water-soluble contaminants to the land surface via diffusion in a continuous liquid pathway.

Because of the very dry conditions present in Hanford Site soils and expected in the disposal facility, diffusive transport may be more important than advective movement under some conditions. Because of the large storage capacity of the surface soils, the effect of large transient storms is confined to the top few feet of soil.

3.3.4.3 Vapor Transport. Some contaminants may move upward from the disposal facility to the surface in the vapor phase. Such movement is governed by Fick's law.

3.3.4.4 Solid Transport. If another glacial-age catastrophic flood (such as the previous Missoula floods) occurs, the contaminants will be widely dispersed. For this case, the entire inventory is assumed to be mixed with soil to a depth of $20 \mathrm{~m}$ ( $66 \mathrm{ft}$ ) [the depth of the disposal facility] over the Hanford Site south of the Columbia River [an area of $906 \mathrm{~km}^{2}\left(350 \mathrm{mi}^{2}\right)$ ]. Past glacial-age catastrophic floods have deposited soils over a far greater area (even to the extent of carrying most of the soil all the way to the Pacific Ocean) and mixed the soil to greater depths. The all-pathways scenario described in Section 3.3.5 is then used to estimate the dose.

\subsubsection{Exposure Scenarios}

Two major exposure scenarios are considered: drinking contaminated water and living on a small farm. The details of these scenarios and the justification for all the parameters used in them are in Rittmann (1995).

$\rightarrow \rightarrow \rightarrow$ Values for the parameters used in these scenarios are discussed in Section 3.4 .7 and are given in Appendix $B$

The simplest case is exposure to contaminated drinking water pumped from a well. This well is assumed to be no closer to the disposal facility than $100 \mathrm{~m}(328 \mathrm{ft})$ and to be located to provide the maximal exposure. This location is the one recommended for analysis by the Performance Assessment Task Team (Wood 1994a) and required by the RL implementation directive (DOE-RL 1993) for DOE Order 5820.2A (DOE 1988b). The two major exposure parameters in this scenario are the amount of water consumed and the suite of dose conversion factors used.

The more complex scenario has a person not only drinking the well water, but also using it to irrigate a small farm. Exposure comes from drinking contaminated water, ingesting contaminated food, ingesting and inhaling contaminated soil, and from direct irradiation from the contaminated soil. The total exposure results in the all-pathways dose. 
DOE/RL-97-69

Rev. 0

\subsection{VALUES AND ASSUMPTIONS}

This section provides and justifies the conceptual models and data for those models that were used in the analyses. It covers the selection criteria and key assumptions for the conceptual models; describes the models and their associated data, the waste form, release rate, disposal facility, and moisture and moisture infiltration rate. It also covers the dosimetry parameters. The models actually used in the computer simulations were derived from these conceptual models and are described in Section 3.5. Sensitivity cases are gathered together in Section 3.5.5 and usually illustrate bounding conditions.

\subsubsection{Selection Criteria}

The following criteria are used to select among the alternatives:

- The ability to justify the choice

- The availability of experimental evidence

- The use of best calculational methods.

The overriding criterion was the ability to justify the data and calculational methods selected. The justification process requires that all data, assumptions, and processes be questioned for applicability. Does each selection realistically portray probable situations? This process quickly identifies errors, misunderstandings, and false assumptions that can be corrected. It also provides insight into the true requirements for methods and the true need for data.

Whenever possible, direct experimental evidence is the basis for selecting data or approaches for the conceptual models. However, in most cases, collecting direct experimental evidence is not possible. Sometimes collecting all the evidence could take too long (observing the behavior of glass for 10,000 years). Sometimes the amount of data is too large to obtain (determining hydrologic parameters for the entire vadose zone).

When direct experimental evidence is limited, the available data are used to support anaiytical simplifications. This approach has two major facets. The first is extrapolating laboratory-measured data to field conditions, as in the case of hydrologic parameters. The second is measuring various effects of the total process to form a complete picture, as was done to determine the infiltration rate. The infiltration rate was determined by combining short-term lysimetry with mid- and long-term tracer measurements and moisture movement simulation studies.

Because this analysis is being performed before key decisions on waste form and disposal facility design have been made, the amount of site-, facility-, and waste form-specific data to support this performance assessment is limited. However, significant amounts of experimental effort are planned to support future performance assessments (see Section 6.4). The statements of work (PAG 1994, PAG 1995, Mann 1997b) outline the experiments that will be performed to determine geology, hydrology, glass performance, other material performance, and infiltration rate. 


\section{DOE/RL-97-69}

Rev. 0

Analytic and calculational studies are a major part of the effort to provide data for processes, such as glass corrosion, that will be evolving over thousands of years. Analytical and computational tools were selected with the intention of using them to provide the most insight and accurate simulations of these processes.

\subsubsection{Key Assumptions}

Even though much of the site-, facility-, and waste form-specific data needed for a performance assessment have not yet been obtained, enough relevant data from other sources is known about the proposed disposal action that reasonable assumptions can be made. The key assumptions are in following areas:

- Location and layout of the disposal facilities (which dictates geology, stratigraphy, infiltration rate, and associated parameters)

- Waste form (which influences the release rate of contaminants)

- Inventory

- Disposal facility design.

As noted in Section 2.2.2, the location for the new disposal facility action has just been decided. However, determining the layout of the facilities on the reserved land is just beginning. Because most of the waste will be disposed of in the new site, this location is selected as the location for the base analysis case. However, because part of the waste is to be disposed of in the existing TWRS disposal facilities, a sensitivity case also is run for that site. Only limited characterization has been performed at either site. However, the central plateau area in which the preferred site rests has been well characterized. Therefore, rather good assumptions can be made about parameters that describe the proposed disposal site. A borehole (299-E17-20) just southwest of the new disposal site has been drilled to the underlying basalt layer at about $122 \mathrm{~m}$ $(400 \mathrm{ft})$. Both the borehole itself and samples taken from it will undergo significant characterization (Mann 1997b and Reidel 1997).

As noted in Section 2.3.5, the waste form has not been determined. However, the final specifications for the waste form are included in the RFP for privatization (DOE-RL 1996) and in the resulting contracts. The original waste stabilization program focused on silicate glass. Because of the knowledge and experience base that has been established for silicate glass, the private vendors have publicly indicated that silicate glass will be the waste form. However, even if the vendors do not choose silicate glass, the selected waste form is likely to have release properties similar to those of silicate glass to meet performance criteria. This assumption is based on the requested release rates given in the specifications for the waste form

(DOE-RL 1996). For the base analysis case of this performance assessment, the release rates for all elements from the waste form were assumed to be that given in the privatization specifications for all elements other than technetium. This means that the release rate assumed for technetium in the base analysis case is five times higher than that allowed in the RL 


\section{DOE/RL-97-69}

Rev: 0

specifications for the waste form. For some sensitivity cases, computer simulations of contaminant release rates under disposal conditions for a reference silicate glass were performed. As the actual waste form is better defined, short- and long-term experiments and analyses will be performed to better understand the release behavior as a function of time and environmental conditions (Mann 1997b).

The actual composition of the waste form (both radioactive and nonradioactive) is not known. For these analyses, only the mean composition based on the estimated total radionuclide inventory was used. As retrieval scenarios are better defined and individual tank contents become better known, composition variations in the waste form will be determined. These variations will be used in the analyses.

Finally, only conceptual ideas exist for the facility design (See Section 2.4). Important features have been identified and preliminary investigations have been done (Mann 1995b). Thus, certain design features can be included with some confidence. Much more work remains to be done as the conceptual design ideas are translated into preliminary and then final designs. An important part of such work will be experimental and analytical studies of how the design features behave over time.

\subsubsection{Site}

This section translates the geology, hydrogeology, and geochemistry described in Chapter 2 into a conceptual model and values that can be used in the analyses supporting this performance assessment. The location and stratigraphy of the disposal site are discussed first. Next, the hydrologic and geochemical properties of the vadose zone are addressed. Finally, the properties of the unconfined aquifer are examined.

\subsubsection{Location and Stratigraphy. As noted in} Section 2.2.2, the location of the disposal facility has just been determined (Rutherford 1997) to be in the south central part of the 200 East Area. The main strata at this location are the Hanford formation and the Ringold Formation. The existing TWRS Disposal Facility is about $1600 \mathrm{~m}$ (1 mile) east of this site.

The Hanford formation beneath the main disposal area consists of three layers. The upper $6 \mathrm{~m}(20 \mathrm{ft})$ is the Upper Gravel Sequence. The next $60 \mathrm{~m}(197 \mathrm{ft})$ consists of the Sand Sequence. The bottom, the Lower Gravel Sequence, is 25 to $40 \mathrm{~m}$ ( 82 to $131 \mathrm{ft}$ ) thick. For modeling purposes (Table 3-5) a mean thickness of this bottom sequence was taken as $35 \mathrm{~m}$ $(115 \mathrm{ft})$ making the Hanford formation $101 \mathrm{~m}(331 \mathrm{ft})$ thick in the model.

Below the Hanford formation at the main disposal site lies the Ringold Formation. Only Unit $E$ is of concern for these analyses. Unit $E$ is consolidated sandy gravel to muddy sandy gravel $30 \mathrm{~m}(98 \mathrm{ft})$ thick. 
DOE/RL-97-69

Rev. 0

Table 3-5. Stratigraphy Used for the Base Analysis Case (Reidel 1995).

\begin{tabular}{||l|l|}
\hline \multicolumn{1}{|c|}{ Formation } & \multicolumn{1}{|c|}{ Thickness and Location } \\
\hline \hline Hanford formation & starts at surface \\
Upper Gravel Sequence & $6 \mathrm{~m}(20 \mathrm{ft})$ (on surface) \\
Sand Sequence & $60 \mathrm{~m}(197 \mathrm{ft})$ \\
Lower Gravel Sequence & $35 \mathrm{~m}(115 \mathrm{ft})$ (bottom) \\
\hline Ringold Formation & starts just below Hanford formation, $101 \mathrm{~m}$ below the \\
& surface \\
Unit E & $30 \mathrm{~m}(98 \mathrm{ft})$ \\
\hline Unconfined aquifer & $103 \mathrm{~m}(338 \mathrm{ft})$ below surface, \\
& $118 \mathrm{~m}(387 \mathrm{ft})$ above mean sea level \\
\hline
\end{tabular}

The stratigraphy at the existing disposable facility site is quite similar. The main structure is the Hanford sandy sequence, which is between 50 and $70 \mathrm{~m}$ thick, overlying the lower Hanford gravel sequence which is between 20 and $30 \mathrm{~m}$ thick. However, this location has no upper Hanford sequence, making the total thickness of the Hanford formation between 75 and $90 \mathrm{~m}$. The Ringold Formation at the existing disposal site consists of the Unit A sequence, which is hydraulically very similar to the Unit $\mathrm{E}$ layer under the main disposal site.

The large discharge of water from Hanford Site operations has significantly affected the level and flow of the unconfined aquifer. However, DOE has agreed to severely limit such discharges; at the time of this analysis no discharges are expected. Based on calculations using the Environmental Restoration Contractor (ERC) Hanford Sitewide groundwater model (Law 1996), the present location of the aquifer at the new disposal site is $96 \mathrm{~m} \mathrm{(315} \mathrm{ft)} \mathrm{below} \mathrm{the}$

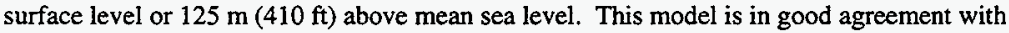
measurements. Computer simulations were used to define the level of the unconfined aquifer after Hanford Site operations cease. Current estimates of the post-Hanford water table (Law 1996) at either disposal site suggest this level as $103 \mathrm{~m}$ (338 ft) below the surface level or $118 \mathrm{~m}(387 \mathrm{ft})$ above mean sea level. This level was used for the base analysis case. The postHanford unconfined aquifer is expected to be in the Ringold Formation at both the existing and new disposal sites.

Two sensitivity cases were selected to determine the importance of the hydrologic parameters of each layer. All the analysis in this performance assessment assumes that the hydrologic parameters do not vary within a formation. Thus by changing the thicknesses of the formations, different hydrologic properties are used in the simulations. The first sensitivity case considers that all, rather than most, of the Hanford formation consists of the Sandy Sequence. The second sensitivity case assumes that the Lower Gravel Sequence starts at $50 \mathrm{~m}(164 \mathrm{ft})$ surface rather than $66 \mathrm{~m}(216 \mathrm{ft})$ below the surface. 
DOE/RL-97-69

Rev. 0

Two sensitivity cases will be studied to determine the importance of which formation contains the unconfined aquifer. In one sensitivity case, the top of the unconfined aquifer is at the 1997 position, $96 \mathrm{~m} \mathrm{(} 315 \mathrm{ft}$ ) below the surface (that is, the top of the aquifer is $7 \mathrm{~m}$ above the position of the base analysis case). In the other case, the top of the aquifer is lowered from the base analysis case by the amount it was raised in the first sensitivity case. Thus, for the second sensitivity case the top of the aquifer is at $110 \mathrm{~m}(361 \mathrm{ft})$ below the surface. In both cases the bottom of the aquifer remains at the same elevation below the surface.

\subsubsection{Vadose Zone Hydrologic Parameters.} Vadose zone hydrologic parameters (volumetric moisture content and hydraulic conductivity) for these analyses come from laboratory analyses of samples from the strata found near the disposal sites. Samples were taken from seven locations Hydrology
The vadose zone hydrology paraneters
are based on samples from boreholes
located near the disposal sites near the disposal site (Figure 3-2). Corrections were made for the gravel content and for primary drainage. This resulted in moisture retention data. A detailed discussion of the data and methods used to derive them can be found in the work of Khaleel and Freeman (Khaleel 1995). The following paragraphs summarize the methods and data.

The moisture retention data can be described in an empirical relationship following the methods of van Genuchten (1980). The moisture retention function is

$$
\theta(\Psi)=\theta_{r}+\left[\theta_{s}-\theta_{r}\right] *\left\{1+[\alpha \psi]^{n}\right\}^{-m}
$$

where $\theta(\psi)$ is the volumetric moisture content [dimensionless]

$\psi \quad$ is the matric potential or pressure head [m]

$\theta_{r}$. is the residual moisture content [dimensionless]

$\theta_{\mathrm{s}}$ is the saturated moisture content [dimensionless]

$\alpha \quad$ is a fitting parameter $\left(\mathrm{m}^{-1}\right)$

$\mathrm{n} \quad$ is a fitting parameter [dimensionless]

$\mathrm{m}$ is $1-1 / \mathrm{n}$.

Using the Mualam (1976) model and this form for moisture retention, the hydraulic conductivity is

$$
\mathrm{K}\left(\mathrm{S}_{\mathrm{e}}\right)=\mathrm{K}_{\mathrm{s}} * \mathrm{~S}_{\mathrm{e}}{ }^{n} *\left\{1-\left[1-\mathrm{S}_{\mathrm{e}}^{1 / \mathrm{m}}\right]^{\mathrm{m}}\right\}^{2}
$$

where $K\left(S_{e}\right)$ is the unsaturated hydraulic conductivity $[\mathrm{m} / \mathrm{t}]$

$\mathrm{K}_{\mathrm{s}} \quad$ is the saturated hydraulic conductivity $[\mathrm{m} / \mathrm{t}]$

$\mathrm{S}_{\mathrm{e}} \quad$ is effective saturation $=\left(\theta-\theta_{\mathrm{r}}\right) /\left(\theta_{\mathrm{s}}-\theta_{\mathrm{r}}\right)$

$\mathrm{n} \quad$ is the pore-connectivity parameter [dimensionless], estimated by Mualam to be about 0.5 for many soils. In this work, $\mathrm{n}$ is taken to be 0.5 . 


\section{DOE/RL-97-69}

Rev. 0

Figure 3-2. Hydrologic-Conductivity Sample Locations. Position 4 is the site of the existing disposal vaults.

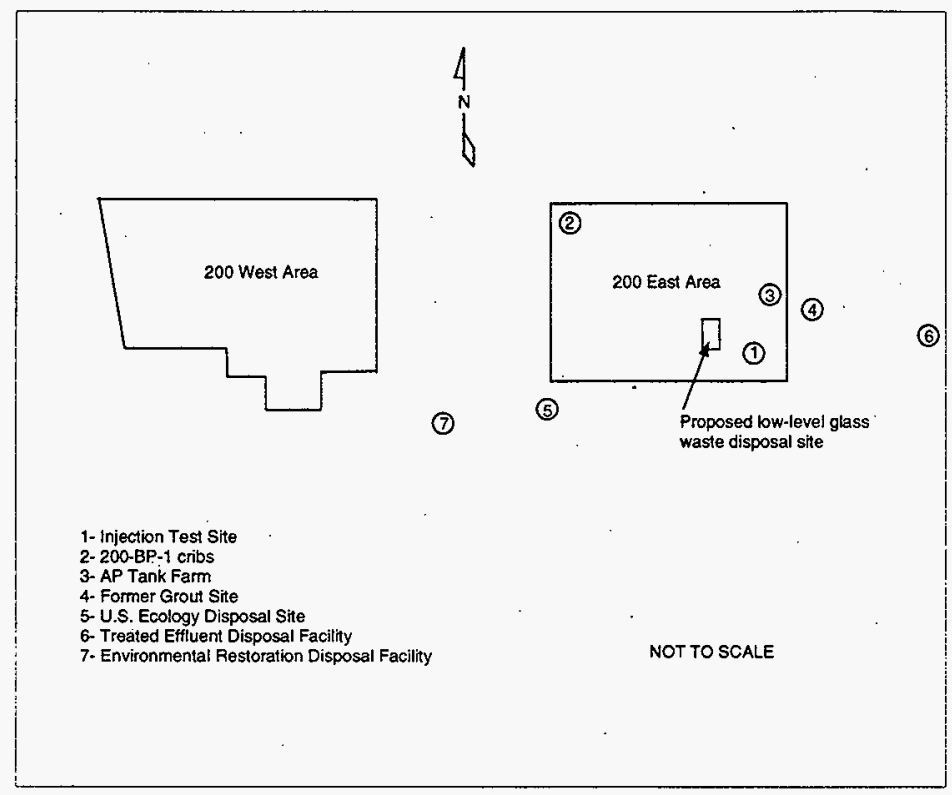

The RETC code (van Genuchten 1991) was used to determine values for $\theta_{r}, \theta_{s}, \alpha$, and $n$. Values for $\mathrm{K}_{\mathrm{s}}$ were determined by fitting laboratory data to a log-normal distribution. The resulting values are shown in Table 3-6.

The grout performance assessment (Kincaid 1995-2) relied on the work of Rockhold et al. (Rockhold 1993) to determine the unsaturated hydraulic conductivity in the vadose zone. Their procedure was similar to the Khaleel and Freeman approach. However, their data set was slightly smaller and did not include samples from near the new disposal site. The samples used by Rockhold et al. were mainly from the Grout Disposal Facility with some samples from the AP tank farm, the U.S. Ecology site, and the 200-BP-1 site. The residual moisture content $\left(\theta_{\mathrm{r}}=0.0234 \mathrm{~cm}^{3} / \mathrm{cm}^{3}\right)$ that Rockhold et al. determined for their 57 samples from the sandy sequence of the Hanford formation is similar to that found by Khaleel and Freeman $\left(\theta_{\mathrm{r}}=0.0246 \mathrm{~cm}^{3} / \mathrm{cm}^{3}\right)$. The residual moisture contents found by Rockhold et al. for the Hanford formation lower gravel sequence (14 samples yielding $\theta_{\mathrm{s}}=0.0213 \mathrm{~cm}^{3} / \mathrm{cm}^{3}$ ) and the Ringold Formation ( 5 samples yielding $\theta_{\mathrm{r}}=0.0283 \mathrm{~cm}^{3} / \mathrm{cm}^{3}$ ) is slightly higher than the values from the Khaleel and Freeman analysis $\left(\theta_{\mathrm{r}}=0.0126\right.$ and $0.0220 \mathrm{~cm}^{3} / \mathrm{cm}^{3}$, respectively). In general, the two analyses are in close agreement. 
DOE/RL-97-69

Rev. 0

Table 3-6. Values for Hydrologic Parameters for the Vadose Zone for the Base Analysis Case. ${ }^{2}$

\begin{tabular}{|c|c|c|c|c|c|c|}
\hline \multirow[t]{2}{*}{ Material } & \multirow{2}{*}{$\begin{array}{c}\text { Number of } \\
\text { Samples }\end{array}$} & \multicolumn{4}{|c|}{ van Genuchten Curve Fitting Parameters for Moisture Retention } & \multirow{2}{*}{$\begin{array}{c}\text { Saturated } \\
\text { Hydraulic } \\
\text { Conductivit } \\
(\mathrm{cm} / \mathrm{s})\end{array}$} \\
\hline & & $\begin{array}{c}\theta_{s}^{0 . d} \\
\left(\mathrm{~cm}^{3} / \mathrm{cm}^{3}\right)\end{array}$ & $\begin{array}{c}\begin{array}{c}\theta_{\mathrm{r}}^{\mathrm{c} d} \\
\left(\mathrm{~cm}^{3} / \mathrm{cm}^{3}\right)\end{array} \\
\end{array}$ & $\begin{array}{c}\alpha^{d} \\
\left(\mathrm{~cm}^{-1}\right)\end{array}$ & $\mathbf{n}^{d}$ & \\
\hline $\begin{array}{l}\text { Hanford } \\
\text { sands }\end{array}$ & 60 & 0.3578 & 0.0246 & 0.1566 & 2.1768 & $1.17 \times 10^{-2}$ \\
\hline $\begin{array}{l}\text { Hanford } \\
\text { gravel }\end{array}$ & 8 & 0.1312 & 0.0126 & 0.0125 & 1.530 & $1.32 \times 10^{-3}$ \\
\hline $\begin{array}{l}\text { Ringold } \\
\text { Formation }\end{array}$ & 15 & 0.1342 & 0.0220 & 0.0122 & 1.5865 & $8.74 \times 10^{-5}$ \\
\hline
\end{tabular}

- Parameters (from Khaleel 1995) are used to determine unsaturated hydraulic

conductivity, see text.

${ }^{b}$ The saturated volumetric moisture content.

' The residual volumetric moisture content.

'A van Genuchten curve fitting parameter.

The hydraulic properties for construction materials are taken from the work of Rockhold et al. (Rockhold 1993). The values are displayed in Table 3-7. Hydrologic parameters for sand, used in the sand-gravel capillary barrier and in the sensitivity cases, are assumed to be the same as for the sandy sequence of the Hanford formation. The hydrologic parameters for the water conditioning layer are assumed to be the same as for gravel.

For the calculations, the particle density of the soil was taken to be $2.72 \mathrm{~g} / \mathrm{cm}^{3}$.

Table 3-7. Values for Hydrologic Parameters for Construction Materials for the Base Analysis Case."

\begin{tabular}{|c|c|c|c|c|c|}
\hline & \multicolumn{4}{|c|}{$\begin{array}{l}\text { van Genuchten Curve Fitting Parameters for Moisture } \\
\text { Retention }\end{array}$} & \multirow{2}{*}{$\begin{array}{l}\text { Saturated Hydraulic } \\
\text { Conductivity } \\
(\mathrm{cm} / \mathrm{s})\end{array}$} \\
\hline Material & $\begin{array}{c}\theta_{s}^{\mathrm{b}, 0} \\
\left(\mathrm{~cm}^{3} / \mathrm{cm}^{3}\right)\end{array}$ & $\begin{array}{c}\Theta_{r}^{\mathrm{cdd}} \\
\left(\mathrm{cm}^{3} / \mathrm{cm}^{3}\right)\end{array}$ & $\begin{array}{c}\alpha^{\alpha} \\
\left(\mathrm{cm}^{-1}\right)\end{array}$ & $\mathbf{n}^{0}$ & \\
\hline Back-filled soil & 0.3710 & 0.0450 & 0.0683 & 2.080 & $3.00 \times 10^{-2}$ \\
\hline Gravel & 0.5180 & 0.0140 & 3.5366 & 2.661 & 1.85 \\
\hline Portland Concrete & 0.2258 & 0.0000 & $7.6 \times 10^{-6}$ & 1.393 & $3.75 \times 10^{-10}$ \\
\hline
\end{tabular}

- Parameters (from Rockhold 1993) are used to determine unsaturated hydraulic conductivity, see text.

${ }^{b}$ The saturated volumetric moisture content.

- The residual volumerric moisture content.

${ }^{-} \mathrm{A}$ van Genuchten curve fitting parameter. 


\section{DOE/RL-97-69}

Rev. 0

Simplistic, conservative values were chosen for dispersion (that is, the tendacity of the solute to spread from the advective path). The larger the value for dispersion, the sooner the contaminants will reach the receptor. The dispersion coefficient of the contaminations was taken to be one tenth of the travel length. The dispersion in the vadose zone in the horizontal direction was taken to be the same value. For aquifer transport, the dispersion in the horizontal direction perpendicular to the flow direction was also taken to be one-tenth of the travel length. The dispersion in the vertical direction for aquifer transport was taken as one-tenth the value of the dispersion coefficient in the horizontal direction.

The value of the diffusion coefficient in unsaturated sediments of the vadose zone, taken from the grout performance assessment (Kincaid 1995-3), using the model of Kemper and van Schaik (1966), is

$$
\mathrm{D}=1.25 \times 10^{-7} \mathrm{e}^{(-10 \theta)} \mathrm{cm}^{2} / \mathrm{s} ;
$$

where $\theta$ is the volumetric moisture content of the sediment.

To estimate the release of radon from the soil, radon's diffusivity must be estimated. Harris et al. (1992) summarized the measurements of gaseous diffusion performance on concrete materials. They concluded that, for dry materials, diffusivities ranged from $10^{-5}$ to $10^{-3} \mathrm{~cm}^{2} / \mathrm{s}$ $\left(10^{-6}\right.$ to $\left.10^{-4} \mathrm{in}^{2} / \mathrm{s}\right)$. The presence of moisture reduces the diffusivity value. Therefore, for these analyses, a value (corresponding to dry conditions) of $1.0 \times 10^{-3} \mathrm{~cm}^{2} / \mathrm{s}\left(1.6 \times 10^{-4}\right.$ in $\left.2 / \mathrm{s}\right)$ was used. A value 10 times larger, based on diffusion in air corrected for moisture and tortuosity, was used in the Hanford Solid Waste Performance Assessments (Wood 1994b and Wood 1996).

Sensitivity cases center around altering the presumed strata and hence their hydrologic properties. The strata changes (sensitivity) investigated in this performance assessment are given in Section 3.5.5.4.

\subsubsection{Vadose Zone Geochemical Retardation}

Factors. Chemical interactions with the soil in the vadose zone can greatly slow the transport of contaminants. The amount of slowing is described by a multiplicative factor known as the geochemical retardation factor. Geochemical retardation factors for these analyses are based on extensive laboratory work

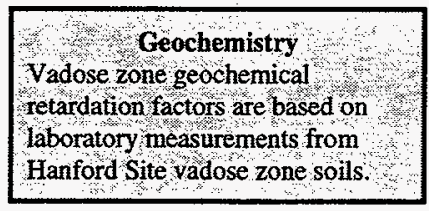
performed at the Hanford Site. This work is summarized in Kaplan (1995a and 1995b).

Geochemical retardation in unsaturated conditions is predicted to be

$$
\mathrm{R}_{\mathrm{f}}=1+\rho \mathrm{K}_{\mathrm{d}} / \theta
$$

where $R_{f}$ is the geochemical retardation factor (dimensionless)

$\rho \quad$ is the bulk density of the material $\left(\mathrm{g} / \mathrm{cm}^{3}\right)$

$\mathrm{K}_{\mathrm{d}} \quad$ is the chemical distribution coefficient (liter/g). 


\section{DOE/RL-97-69}

Rev. 0

$\theta \quad$ is the volumetric moisture content (dimensionless).

A deriyation from the general contaminant transport equation is given in Appendix $\mathrm{D}$, Section D.2.3. The chemical distribution coefficient $\left(\mathrm{K}_{\partial}\right)$ is measured in the laboratory by comparing the amount of material trapped in or on the soil matrix to the amount in the water phase.

The chemical distribution coefficients used in these analyses are based on the reports of Kaplan 1995a and Kaplan 1995b. Kaplan (1995a) investigates in detail best estimate $\mathrm{K}_{\mathrm{d}}$ values for the most important contaminants for our disposal conditions. For other contaminants, the "low $\mathrm{K}_{d}$ " values for neutral-to-high $\mathrm{pH}$, low salt, low organic, and oxic solutions from Table 6.1 of Kaplan (1995b) are the bases for the values used. The values are based on experiments using saturated Hanford Site soils (mainly the Hanford sandy sequence). Until planned experiments are completed, the chemical distribution coefficients are assumed independent of moisture and geologic layer.

For convenience in modeling, a subset of $\mathrm{K}_{\mathrm{d}}$ values was used in these analyses. The computer code PORFLOW (see Section 3.5.2.3) treats the chemical distribution coefficients as point-estimate values, not as probability functions. The code calculates the contaminant transport for only $4 \mathrm{~K}_{\mathrm{d}}$ values during a computer run. Therefore, the actual $\mathrm{K}_{\mathrm{d}}$ values were reduced to one of eight values (so only two PORFLOW runs per simulation had to be executed). Five of the values chosen are based on the $\mathrm{K}_{\mathrm{d}}$ values of the most important elements in these analyses. These elements with their corresponding $K_{d}$ values are technetium and selenium $\left(K_{d}=0\right.$ for both), uranium $\left(K_{d}=0.6 \mathrm{ml} / \mathrm{g}\right)$, iodine $\left(K_{d}=3 \mathrm{ml} / \mathrm{g}\right)$, carbon $\left(\mathrm{K}_{\mathrm{d}}=6 \mathrm{ml} / \mathrm{g}\right)$, and neptunium $\left(K_{d}=15 \mathrm{~m} / \mathrm{g}\right)$. Two higher $K_{d}$ values, 40 and $100 \mathrm{~m} / \mathrm{g}$, were chosen to represent more retarded elements. These higher values used for the chemical distribution coefficients for the less important elements in the computer simulations were selected to be conservative and are lower than the recommended values. Elements with such high $\mathrm{K}_{\mathrm{d}}$ values have little significance for vadose zone transport within the Hanford Site soils. Table 3-8 shows the recommended values and the values actually used in these analyses.

Because radionuclides spend significantly less time in the unconfined aquifer than in the vadose zone, no credit for increased travel time in the unconfined aquifer because of geochemical retardation was taken.

Sensitivity cases were used to judge the effects of different $K_{d}$ values. Two cases used different values for $K_{d}$ for uranium than are used in the base analysis case. One case used a $K_{d}$ value of zero for uranium. This was the conservative value used in earlier environmental assessments. The other sensitivity case used a $\mathrm{K}_{d}$ value of $100 \mathrm{~m} / \mathrm{g}$ for uranium in concrete (Krupka 1995) and $K_{d}$ value of 0 for uranium everywhere else in the system. New information indicates that the $\mathrm{K}_{\mathrm{d}}$ value for iodine proposed in Kaplan (1995a) is too large and that a value of $0.6 \mathrm{~m} \ell / \mathrm{g}$ may be more appropriate. The final geochemical sensitivity cases used $\mathrm{K}_{\mathrm{d}}=0.1 \mathrm{~m} / \mathrm{g}$ for technetium and selenium to determine whether small nonzero $\mathrm{K}_{\mathrm{d}}$ values would have a significant effect. 
DOE/RL-97-69

Rev. 0

Table 3-8. Chemical Distribution Coefficients $\left(\mathrm{K}_{\mathrm{d}}\right)$ for the Base Analysis Case. ${ }^{\mathrm{a}}$

\begin{tabular}{|l|l||l|l||l|l||}
\hline Element & \multicolumn{1}{|c|}{$\mathrm{K}_{d}(\mathrm{~m} / \mathrm{g})$} & Element & \multicolumn{1}{|c|}{$\mathrm{K}_{\mathrm{d}}(\mathrm{m} \mathrm{l} / \mathrm{g})$} & Element & \multicolumn{1}{|c||}{$\mathrm{K}_{\mathrm{d}}(\mathrm{m} \mathrm{l} / \mathrm{g})$} \\
\hline $\mathrm{Ac}$ & $67 \rightarrow 40$ & $\mathrm{Am}$ & $67 \rightarrow 40$ & $\mathrm{C}$ & 6 \\
\hline $\mathrm{Ce}$ & 100 & $\mathrm{Cm}$ & $106>100$ & $\mathrm{Co}$ & $1200 \rightarrow 100$ \\
\hline $\mathrm{Cs}$ & $540 \rightarrow 100$ & $\mathrm{Eu}$ & 100 & $\mathrm{I}$ & $3^{\mathrm{b}}$ \\
\hline $\mathrm{Nb}$ & $50 \rightarrow 40$ & $\mathrm{Ni}$ & $50 \rightarrow 40$ & $\mathrm{~Np}$ & $15^{\mathrm{b}}$ \\
\hline $\mathrm{Pa}$ & $10 \rightarrow 6$ & $\mathrm{~Pb}$ & $13000 \rightarrow 100$ & $\mathrm{Pu}$ & $80 \rightarrow 40$ \\
\hline $\mathrm{Ra}$ & $24 \rightarrow 15$ & $\mathrm{Se}$ & $0^{\mathrm{b}}$ & $\mathrm{Sn}$ & 100 \\
\hline $\mathrm{Sr}$ & $5 \rightarrow 3$ & $\mathrm{Tc}$ & $0^{\mathrm{b}}$ & Th & 40 \\
\hline $\mathrm{U}$ & $0.6^{\mathrm{b}}$ & $\mathrm{Zr}$ & $90 \rightarrow 40$ & others & 0 \\
\hline
\end{tabular}

${ }^{a}$ The number to the left of the arrow is the best estimate of the $\mathrm{K}_{\mathrm{d}}$ value, the number to the right of the arrow is a conservative estimate to minimize the number of computer simulations since the code only uses $4 \mathrm{~K}_{\mathrm{d}}$ values at a time.

b Data taken from Kaplan (1995a), others from Kaplan (1995b).

3.4.3.4 Unconfined Aquifer Properties. No data are available on the hydraulic parameters for the area immediately surrounding the disposal sites. The hydraulic parameters to be used are from the ERC sitewide model of the Hanford Site's unconfined aquifer (Law 1996). This model was created for use in the DOE's remedial restoration effort at the Hanford Site. Table 3-9 gives the hydraulic parameters immediately around the disposal site and the values used for them in these analyses.

For calculations involving a larger region of the Hanford Site, the ERC Hanford Sitewide Groundwater Model was used. This model contains 18 hydrogeologic material types. The material identification numbers for the upper and lower layers are shown in Figures 3-3 and 3-4, respectively. The hydrologic parameters are displayed in Table 3-10. Hydraulic conductivities for the 200 East and West Areas were obtained from Connelly et al. (1992a and 1992b); those for other areas were obtained from Thorne and Newcomer (1992). Because almost all the aquifer tests used to infer data contained in these compilations were single-well tests, no information is available for estimating the storage parameters. The aquifer test results were interpolated from point measurements to areal values using the software program EarthVision?

1 EarthVision is a registered trademark of Dynamic Graphics, Inc. 
DOE/RL-97-69

Rev. 0

Table 3-9. Hydraulic Parameters for Unconfined Aquifer Immediately Around the Disposal Site (Law 1996)

\begin{tabular}{|l|c|}
\hline \multicolumn{1}{|c|}{ Parameter } & Value \\
\hline \hline Saturated hydraulic conductivity $(\mathrm{cm} / \mathrm{s})$ & \\
Ringold Formation & 0.095 \\
Hanford formation & 3.6 \\
\hline Effective porosity & 0.1 \\
\hline Ringold aquifer thickness (m) & 20. \\
\hline
\end{tabular}

Although no formal study has been performed concerning seasonal variations in the groundwater underneath the Central Plateau, no evidence has been found to suggest that any significant seasonal variations will occur. The thickness of the vadose zone combined with the low rates of natural infiltration make any season variational very small. Because of variations of the water outflow from upstream dams, temporal variations occur in groundwater flow very near the Columbia River. However, such variations have been ignored in Hanford Site modeling. 
DOE/RL-97-69

Rev. 0

Table 3-10. Element Material-Zone Flow Properties. (Law 1996)

\begin{tabular}{|c|c|c|c|}
\hline \multirow[t]{2}{*}{ Zone } & $\begin{array}{c}\text { Horizontal } \\
\text { Saturated Conductivity }(\mathrm{cm} / \mathrm{s})\end{array}$ & \multirow[t]{2}{*}{ Storage } & \multirow[t]{2}{*}{ Effective Porosity } \\
\hline & $\begin{array}{c}\mathrm{K}_{\mathrm{xx}}=\mathrm{K}_{\mathrm{yy}} \\
\mathrm{K}_{\mathrm{zz}}=0.1 * \mathrm{~K}_{\mathrm{xx}} \\
\end{array}$ & & \\
\hline 1 & $2.53 \mathrm{e}-3$ & $1.0 \mathrm{e}-4$ & 0.10 \\
\hline 2 & $6.03 \mathrm{e}-3$ & $1.0 \mathrm{e}-4$ & 0.25 \\
\hline 3 & $1.59 \mathrm{e}-2$ & $1.0 \mathrm{e}-4$ & 0.10 \\
\hline 4 & $2.06 \mathrm{e}-2$ & $1.0 e-4$ & 0.10 \\
\hline 5 & $4.44 \mathrm{e}-2$ & $1.0 \mathrm{e}-4$ & 0.25 \\
\hline 6 & $2.29 \mathrm{e}-1$ & $1.0 \mathrm{e}-4$ & 0.25 \\
\hline 7 & $8.25 \mathrm{e}-2$ & $1.0 \mathrm{e}-4$ & 0.10 \\
\hline 8 & $9.52 \mathrm{e}-2$ & $1.0 \mathrm{e}-4$ & 0.25 \\
\hline 9 & $1.37 \mathrm{e}-1$ & $1.0 \mathrm{e}-4$ & 0.25 \\
\hline 10 & $1.75 \mathrm{e}-1$ & $1.0 \mathrm{e}-4$ & 0.25 \\
\hline 11 & $2.44 \mathrm{e}-1$ & $1.0 \mathrm{e}-4$ & 0.25 \\
\hline 12 & $2.85 \mathrm{e}-1$ & $1.0 \mathrm{e}-4$ & 0.25 \\
\hline 13 & $4.44 \mathrm{e}-1$ & $1.0 \mathrm{e}-4$ & 0.25 \\
\hline 14 & $9.52 \mathrm{e}-1$ & $1.0 \mathrm{e}-4$ & 0.25 \\
\hline 15 & 2.38 & $1.0 \mathrm{e}-4$ & 0.25 \\
\hline 16 & 3.59 & $1.0 \mathrm{e}-4$ & 0.25 \\
\hline 17 & 5.81 & $1.0 \mathrm{e}-4$ & 0.25 \\
\hline 18 & 6.76 & $1.0 \mathrm{e}-4$ & 0.25 \\
\hline
\end{tabular}


Figure 3-3. Zone Map for the Upper Layers of the ERC Hanford Sitewide Groundwater Model. See Table 3-10 for corresponding hydraulic parameters.

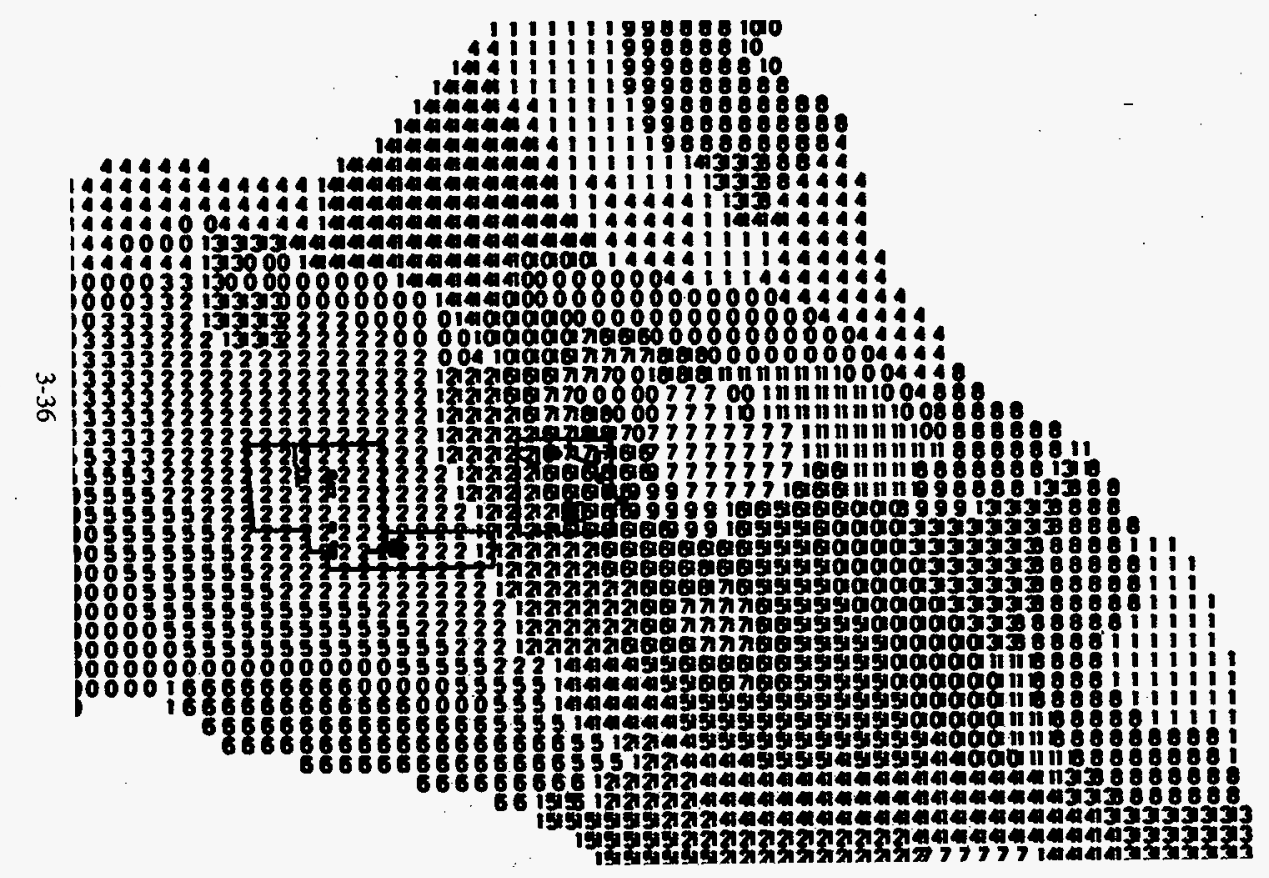


Figure 3-4. Zone Map for the Lower Layers of the ERC Hanford Sitewide Groundwater Model. See Table 3-10 for corresponding hydraulic parameters.

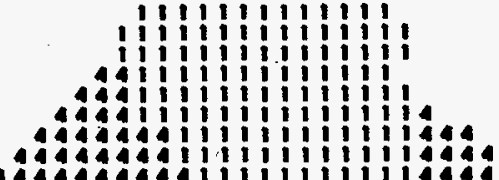

44444

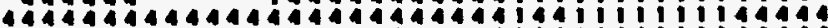

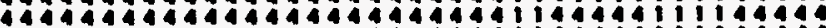

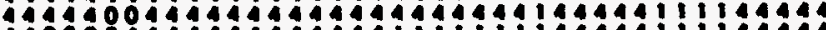

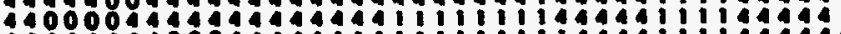

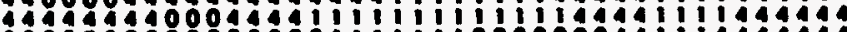

000033300000000911 I I I I

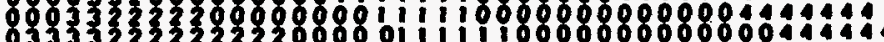

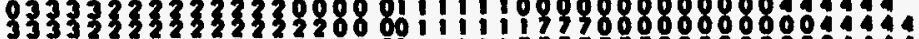

$\omega$

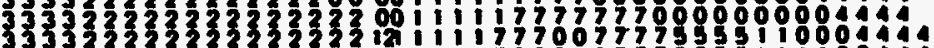

$\omega$

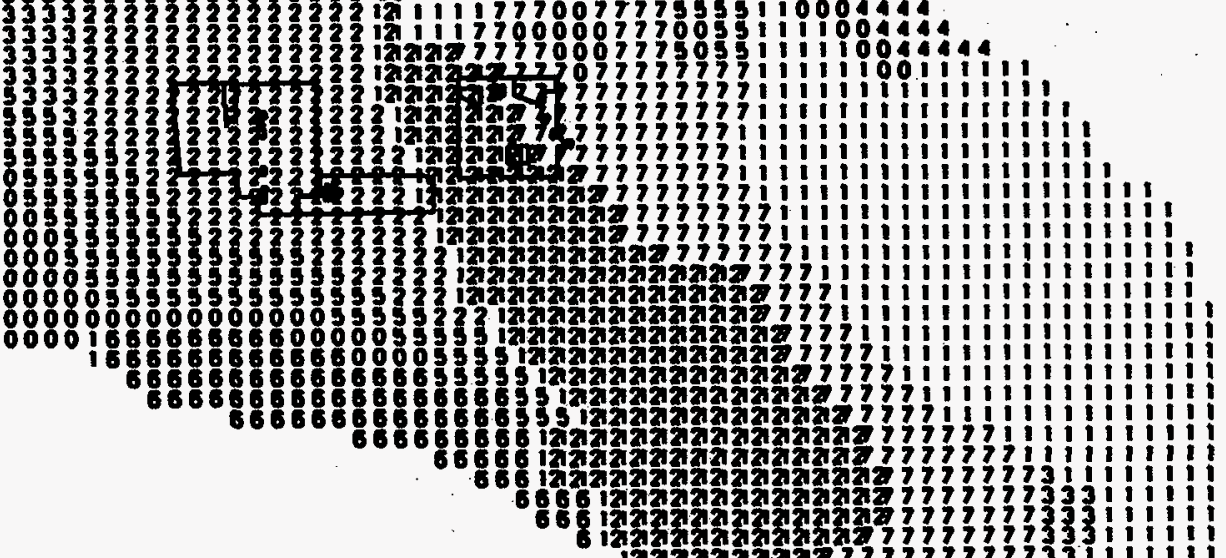




\section{DOE/RL-97-69 \\ Rev. 0}

\subsubsection{Waste Package}

This section describes the conceptual model for the waste package, which consists of the container and the waste form. The contents of the waste package are currently poorly known because an effort is under way to.privatize the immobilized waste function of TWRS (Section 2.3.5). Sections 3.4.4.1 through 3.4.4.4 describe what is known about the waste package components. This description includes the release rate from the waste form. The discussion also covers alternative waste forms and release rates that were used in sensitivity cases.

3.4.4.1 Container. The final TWRS privatization RFP (DOE-RL 1996) outlines the type of container that would be acceptable. The aspects of the container that affect the performance assessment are summarized here. The container would be made of an unspecified metal. The nominal outside dimensions of the package are 1.8 by 1.2 by $1.2 \mathrm{~m}$ (about 6 by 4 by $4 \mathrm{ft}$ ). The thickness depends on the type of metal used. The stacking height of the containers was assumed to be $7.2 \mathrm{~m}(23.6 \mathrm{ft})$, which is 6 containers high, consistent with the RFP. Filler material is to be added to reduced void space to less than 1 percent of the original container volume.

The conceptual model for the performance and degradation of the waste package ignores the presence of the container. The RFP (DOE-RL 1996) only specifies that the container be made out of metal. Thus, the container's material and durability are not yet known. For these analyses, the container material was assumed to have no effect on hydraulics, chemical retardation, or waste form performance. Once the container has been selected, testing on the container material and container-waste form interactions will be planned to determine the effect of the container degradation on waste form performance.

3.4.4.2 Waste Form. The TWRS privatization RFP (DOE-RL 1996) does not specify a waste form. The waste form will be based on the maximum package volume related to the sodium content of a gram-mole of waste and on release rates. For the base analysis case, the waste form is not defined. Only a release rate is prescribed (Section 3.4.4.3). The shape of the waste form is assumed to be nearly cubical. The inventory is also assumed to be evenly distributed among the waste packages produced. Because the waste form (combined with the local chemical conditions [amount of water presence, $\mathrm{pH}$, etc.]) will control the release rate of the radionuclide contaminants, Section 3.4.4.3 describes related sensitivity cases.

\subsubsection{Waste Form Radionuclide Release Rate.} Although neither the final TWRS privatization RFP (DOE-RL 1996) nor the resulting contracts specify a waste form, both specify initial (the first 7 days) fractional radionuclide release rates. The initial Radionuclide Release Rate The waste form radionuclide release rate is based on the specifications for the production of the waste form. fractional radionuclide release rate from the waste form averaged over all the containers as determined by the PCT test at $20^{\circ} \mathrm{C}$ and $\mathrm{pH}=.7$ shall not be greater than: 


\section{DOE/RL-97-69}

\section{Rev. 0}

- $\quad 1.4 \times 10^{-13} \mathrm{~s}^{-1}[4.4 \mathrm{ppm} / \mathrm{y}]$ for ${ }^{79} \mathrm{Se},{ }^{129} \mathrm{I},{ }^{237} \mathrm{~Np}$, and uranium isotopes

- $\quad 2.8 \times 10^{-14} \mathrm{~s}^{-1}[0.88 \mathrm{ppm} / \mathrm{y}]$ for ${ }^{99} \mathrm{Tc}$.

For the hypothetical waste form used in the base analysis case, the time dependence of the radionuclide release rate was calculated using the non-technetium initial fractional release rate of $4.4 \mathrm{ppm} / \mathrm{y}$ and the following assumptions:

1. The waste form corrosion rate is constant in time and does not vary with location in the vault.

2. The radionuclide release rate is proportional to the waste form corrosion rate and the inventory density at the surface.

3. The radionuclide release rate is proportional to the instantaneous surface area.

4. The radionuclides are uniformly spatially distributed in each waste form.

5. Each linear dimension of the waste form decreases at a constant rate.

6. The waste form has similar lengths in each dimension (for example, a sphere or a cube).

The first two assumptions contain most of the physics and chemistry of the problem (see Section 3.3.3.2). Waste form corrosion rates and, more importantly, contaminant release rates are strong nonlinear functions of the local physical and chemical environment. These properties are certain to vary as a function of time and space in the disposal facility. However, because of the large size of the vaults, spatial variations are likely to be most significant near the edges of the facility. Temporal variations will be more important than spatial variations because the large amounts of sodium that will be released from the waste form will affect the $\mathrm{pH}$ of the system, which is known to affect the glass corrosion rate. The second assumption implies that secondary phases will not be important. Secondary phases could trap important contaminants. (Testing at the Argonne National Laboratory has shown some evidence of this for the LD6-5412 low-level glass.) They also could act as a sink for silicon and hence accelerate glass corrosion, a condition that on-going screening tests are meant to identify if it exists. Nonetheless, if one uses a conservative enough glass corrosion rate, assumptions 1 and 2 are useful in bounding the problem. Only detailed computer simulations are sufficient to estimate actual future behavior. The computer simulations will be the foundation of the base analysis case in future performance assessments.

Using these assumptions, the time-dependent release rate is derived as follows. See Mann (1995b) for details. The first four assumptions yield

$$
\mathrm{RRR}(\mathrm{t})=\mathrm{C} * \mathrm{~S}(\mathrm{t}) * \mathrm{I}(\mathrm{t}) / \mathrm{V}(\mathrm{t})
$$


DOE/RL-97-69

Rev. 0

where
$\mathrm{RRR}(\mathrm{t})$ is the radionuclide release rate [Ci/y]
t is the time [y]
C is the corrosion rate [m/y], taken to be independent of time and chosen so
that the non-Tc rate given in the request for proposal is met
$S(t) \quad$ is the surface area of the waste form $\left[\mathrm{m}^{2}\right]$
I is the inventory in the waste form [Ci]
$\mathrm{V}(\mathrm{t}) \quad$ is the volume of the waste form. $\left[\mathrm{m}^{3}\right]$

Assumption 4 applies at the initial time $(t=0)$. Thus

$$
\mathrm{I}(\mathrm{t}) / \mathrm{V}(\mathrm{t})=\mathrm{I}(0) / \mathrm{V}(0)
$$

Then

$$
\mathrm{RRR}(\mathrm{t})=\mathrm{C} * \mathrm{~S}(\mathrm{t}) * \mathrm{I}(0) / \mathrm{V}(0)
$$

The shape of the waste form and Assumption 5 determine the rate at which the surface area decreases. For the base analysis case, the waste form was assumed to be nearly cubical. The surface area then becomes

$$
\begin{aligned}
\mathrm{S}(\mathrm{t}) & =\mathrm{K} 1 * \mathrm{x}(\mathrm{t})^{2}=\mathrm{K} 1 *[\mathrm{~K} 2 *(\mathrm{~T}-\mathrm{t})]^{2} \\
& =\mathrm{K} 3 *(\mathrm{~T}-\mathrm{t})^{2}
\end{aligned}
$$

where

$$
\begin{array}{ll}
\mathrm{x} & \text { is the time-dependent length [l] } \\
\mathrm{T} & \text { is the time for all the radionuclides to be released from the waste form [t] } \\
\mathrm{K} 1, \mathrm{~K} 2, \mathrm{~K} 3 & \text { are constants [various units]. }
\end{array}
$$

The radionuclide release rate for a cubical waste form then becomes

$$
\begin{aligned}
\mathrm{RRR}(\mathrm{t}) & =\mathrm{C} * \mathrm{~K} 3 *(\mathrm{~T}-\mathrm{t})^{2} * \mathrm{I}(0) / \mathrm{V}(0) \\
& =\mathrm{K} 4 *(\mathrm{~T}-\mathrm{t})^{2} * \mathrm{I}(0)
\end{aligned}
$$

The constant $\mathrm{K} 4$ is determined by the integral over time of the radionuclide release rate from 0 to $T$. The result of the integral is the total inventory, $I(0)$. Thus,

$$
\mathrm{K} 4=3 / \mathrm{T}^{3} \text {. }
$$

The radionuclide release rate becomes

$$
R R R(t)=3 * I(0) *(T-t)^{2} / T^{3}
$$

The value of $T$ can be determined at $t=0$. At $t=0, R R R(0) / I(0)$ is the initial fractional radionuclide release rate $[F R R R(0)]$. This rate is given in the RFP. Thus, the time for the waste 


\section{DOE/RL-97-69 \\ Rev, 0}

form to release all the radionuclides is

$$
\mathrm{T}=3 / \operatorname{FRRR}(0) \text {. }
$$

The last two equations were used in the base analysis case for the time-dependent radionuclide release rate from the waste form. Table 3-11 displays their simplified form.

Calculations (McGrail 1994) show using very conservative assumptions that the temperature rise from decay in the waste form in the disposal facility is less than $7{ }^{\circ} \mathrm{C}$. The soil above the disposal facility will provide a thermal shield. Thus, although the glass corrosion rate is temperature dependent, the release rate is assumed not to change because of the small temperature changes.

Table 3-11. Relative Radionuclide Release Rate-from the Waste Form for the Base Analysis Case.

Relative Radionuclide Release Rate from the Waste Form (ppm/year) =

$3 *[\mathrm{~T} \text { - time(years) }]^{2} / \mathrm{T}^{3}$, where $\mathrm{T}=6.8 \times 10^{5}$ years.

Several senisitivity calculations on contaminant release were performed because the release rate is important to the performance assessment. Some of the sensitivity cases are variations of the RFP specifications. Others involve a mechanistic estimation of the release rate as a function of space and time based on experimental data. Still others investigate the effects of different release rates caused by relatively small pieces of waste form.

Two sensitivity cases focused on variations of the RFP specifications. The base analysis case was based on a waste form that releases all radionuclides at a rate proportional to the inventory. However, the RFP specifies that the rate for technetium release be a factor of 5 slower based on initial inventories. Such a reduction can occur if the technetium is trapped or if 80 percent of the technetium is removed during waste separation. One sensitivity case based on the RFP analyzes the effect of trapping the technetium. The case of removing 80 percent of technetium from the inventory is treated as an inventory sensitivity case (Section 3.5.5.2). The other variation on the RFP was to assume that the waste form shape is not nearly cubical, but plate-like. This assumption leads to a constant surface area and a non-technetium release rate of $4.4 \mathrm{ppm}$ per year for 227,000 years. Such a sensitivity case also provides information concerning cracking of the waste form (and hence an increase in surface area over the base analysis case).

The base analysis case is built on a contract specification. Some sensitivity cases were built on how the waste form is expected to behave. In these cases, the waste form was assumed to be a well-studied silicate glass (LD6-5412). The release rate for these sensitivity cases results from the model discussed in Section 3.3.3.2 and implemented in the AREST-CT computer code (Section 3.5.2.2). 


\section{DOE/RL-97-69}

Rev. 0

3.4.4.4 Getter or Filler Material. The TWRS privatization RFP (DOE-RL 1996) states that the container may not have void space greater than 1 percent of the volume. This means that a getter or filler material may be part of the waste form. A getter material is a material that chemically combines or traps selected radionuclides. This restricts the radionuclides movement downward. Because the form of the waste package is not known, the base analysis case assumed that the waste container was completely filled with the stabilized waste form. No getter or special filler materials are used, only backfill soil separates the waste containers.

\subsubsection{Waste Disposal Facility}

The next-generation disposal facility concepts summarized in Section 2.4 and given in Eiholzer (1995) are used for the conceptual model. These concepts are based on and similar to the existing disposal facilities. The concepts of Burbank (1997) are similar to Eiholzer's Concept 2. Concept 1 (see Figure 2-23) was used for the base analysis case. Specific aspects of Concept 2 (see Figures 2-24 and 2-25) were used for sensitivity studies. These concepts were used because, although the actual disposal facility has not been designed, these concepts are thought to feature the components likely to be in the final design.

Sections 3.4.5.1 through 3.4.5.6 cover the specific key components of the disposal concepts. These components are the surface barrier, the capillary barrier, the water conditioning layer, and the vault layout. Values used for each component and any related sensitivity studies are discussed. Section 3.4.5.7 covers the degradation of the human-made portion of the disposal facility.

3.4.5.1 Surface Barrier. The surface barrier is the uppermost component of the waste disposal facility. The surface barrier is designed to store water from precipitation long enough for most of the water to evaporate or transpire through plants in the Hanford Site's arid climate. This barrier also serves to deter human, animal, and plant intrusion into the waste.

The surface bartier in the disposal facility concepts is expected to be a Hanford-type surface barrier (Myers 1994) without the asphalt layer. The top of the surface barrier will be flush with the soil surface, which is $221 \mathrm{~m}(725 \mathrm{ft})$ above sea level. The barrier covers the entire disposal facility. The barrier extends $1 \mathrm{~m}(3.3 \mathrm{ft})$ beyond the outside edge of the overall facility (Concept 1) and $8.75 \mathrm{~m}(28.7 \mathrm{ft}$ ) beyond each vault row (Concept 2 ). This is the distance that the sand-gravel capillary barrier (Section 3.4.5.2) extends beyond the edge.

The surface barrier is not explicitly modeled in the computer simulations. Rather, the rate of moisture moving through the surface barrier (or the degraded barrier) and passing into the soil beneath it is considered the top boundary condition for the computer simulation. The value for this rate of moisture movement (known as the infiltration rate) is discussed in Section 3.4.6. 


\section{DOE/RL-97-69 \\ Rev. 0}

3.4.5.2 Sand-Gravel Capillary Barrier. The disposal facility concepts include a sand-gravel capillary barrier beneath the surface barrier. The capillary barrier is designed to divert water away from the disposal vaults. The barrier is a pyramid with $1 \mathrm{~m}(3.3 \mathrm{ft})$ of sand on top of gravel (Figure 2-25): The pyramids for Facility Concepts 1 and 2 have approximately $2^{\circ}$ and $5^{\circ}$ slopes, respectively. The pyramids are 4 and $2 \mathrm{~m}$ (about 14 and $6.5 \mathrm{ft}$ ) high for Concepts 1 and 2 , respectively. The barriers will extend laterally beyond the vaults to mirror the surface barrier. Based on University of Washington experiments for the grout program (Kramer 1989), the sand is not expected to migrate into the gravel even under seismic shaking.

Disposal Facility Concept 1 includes a 1-m (3.3-ft)- thick gravel wall along the outside vertical concrete walls. This gravel wall is a side capillary barrier that encourages the moisture to remain in the soil and not pass through the gravel into the disposal facility. Mann (1995d) indicates that a gravel wall will improve the moisture movement around the facility.

Three sensitivity cases looked at the effects of the capillary barriers. The first case included the large capillary barrier over the top of the vault, but no side capillary barrier. The second case did not contain any sand-gravel capillary barriers. The last case looked at the influence of the size of the capillary barrier. In this case, the effects of the capillary barrier for Concept 2 were compared to the effects of the capillary barrier for Concept 1 . The widths of the capillary barriers for Concepts 1 and 2 are 208 and $41 \mathrm{~m}$ (682 and $134.5 \mathrm{ft}$ ), respectively.

\subsubsection{Water Conditioning Layer. Each disposal facility concept includes a water} conditioning layer. This layer, which is above the roof of the concrete disposal vaults, is designed to add silicon to any moisture that reaches the layer. If the waste form is a glass, silicon-enriched moisture could slow down glass corrosion. For these analyses, this water conditioning layer ( $1 \mathrm{~m}$ [3.3 ft] thick.) was considered to be only back-fill soil. The efficiency of such a water conditioning layer to change the chemical environment inside the disposal vault will be investigated in future analyses.

3.4.5.4 Vault. The total concrete structure containing the waste packages is termed a vault. As described in Section 2.4.1, the basic unit of the vault is the vault bay, consisting of four walls, a roof, and a floor (sometimes call a pad) made from concrete. For the conceptual design the concrete structure is assumed to be made from Portland cement. While steel structural reinforcement of the walls is likely to be used in the design, the impacts of the presence of steel were not considered in this study because an actual design is not available. The bottom of the vault bay floor is $20.75 \mathrm{~m}$ ( $68 \mathrm{ft}$ ) below grade and $(200 \mathrm{~m}$ [656 ft] above mean sea level). The dimensions of the vault bay are given in Table 3-12.

Six vault bays placed end to end make a vault row. For Concept 1 , the vault rows are next to each other, sharing a common wall. For Concept 2 , the vault rows are separated by backfilled soil a row wide. Such a row of soil would allow greater radiation protection for workers and a more robust sand-gravel capillary barrier. It also would use more land and cost more. Section 2.4.1 describes and shows the vault layouts. These are summarized in Table 3-13 and displayed in Figures 2-23 (Concept 1) and 2-24 (Concept 2). 


\section{DOE/RL-97-69}

Rev. 0

Section 3.5.5.5 describes the sensitivity cases analyzed. These cases focused on the effects of the design features, including vault layout and orientation as well as the effectiveness of various facility components.

Table 3-12. Dimension of a Vault Bay for Base Analysis Case. ${ }^{2}$

\begin{tabular}{|l|l|l|l|l|}
\hline Part of vault bay & $\begin{array}{c}\text { Height } \\
(\mathrm{m}[\mathrm{ft}])\end{array}$ & \multicolumn{1}{|c|}{$\begin{array}{c}\text { Length } \\
(\mathrm{m}[\mathrm{ft}])\end{array}$} & $\begin{array}{c}\text { Width } \\
(\mathrm{m}[\mathrm{ft}])\end{array}$ & $\begin{array}{c}\text { Thickness } \\
(\mathrm{m}[\mathrm{ft}])\end{array}$ \\
\hline roof (ceiling) & -- & $40(131)$ & $21.5(70.5)$ & $0.76(2.5)$ \\
\hline internal walls & $9(29.5)$ & depends on floor length or width & - & $1(3.3)$ \\
\hline $\begin{array}{l}\text { external walls (walls } \\
\text { next to soil) }\end{array}$ & $9(29.5)$ & depends on floor length or width & - & $2(6.6)$ \\
\hline floor (pad) & -- & $40(131)$ & $21.5(70.5)$ & $0.76(2.5)$ \\
\hline
\end{tabular}

${ }^{a}$ Data from Eiholzer (1995). Figures of the facility concepts are in Section 2.4.1.

Table 3-13. Vault Layout for Base Analysis Case. ${ }^{2}$

1. Six vault bays are laid out forming a vault row so that short sides are next to each other, resulting in a length of $246 \mathrm{~m}(807 \mathrm{ft})$. A vault row is oriented in the east-west direction.

2. Concept 1 (base analysis case)

a. Ten vault rows are placed parallel to each other, having a common internal wall. Total width is $208 \mathrm{~m}(682 \mathrm{ft})$, resulting in an area of $51,000 \mathrm{~m}^{2}$ (12.6 acres). (Eiholzer 1996)

3. Concept 2 (sensitivity)

a. Thirteen vault rows are placed parallel to each other. (Eiholzer 1996)

b. Vault rows are separated by $17.5 \mathrm{~m}(57.4 \mathrm{ft})$; walls on long side are exterior walls. Separations filled with compacted backfill soil created during excavation. The facility (vault rows plus separations) is 515.5 $\mathrm{m}(1,691.3 \mathrm{ft})$ wide, resulting in an area of $127,000 \mathrm{~m}^{2}$ (31 acres).

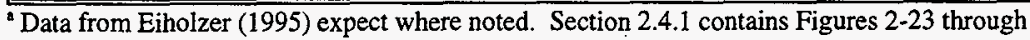
2-25 on the facility concepts. 
DOE/RL-97-69

Rev. 0

Figure 3-5. Waste Package Spacing for Disposal Facility Concepts 1 and 2 (from Eiholzer 1996).

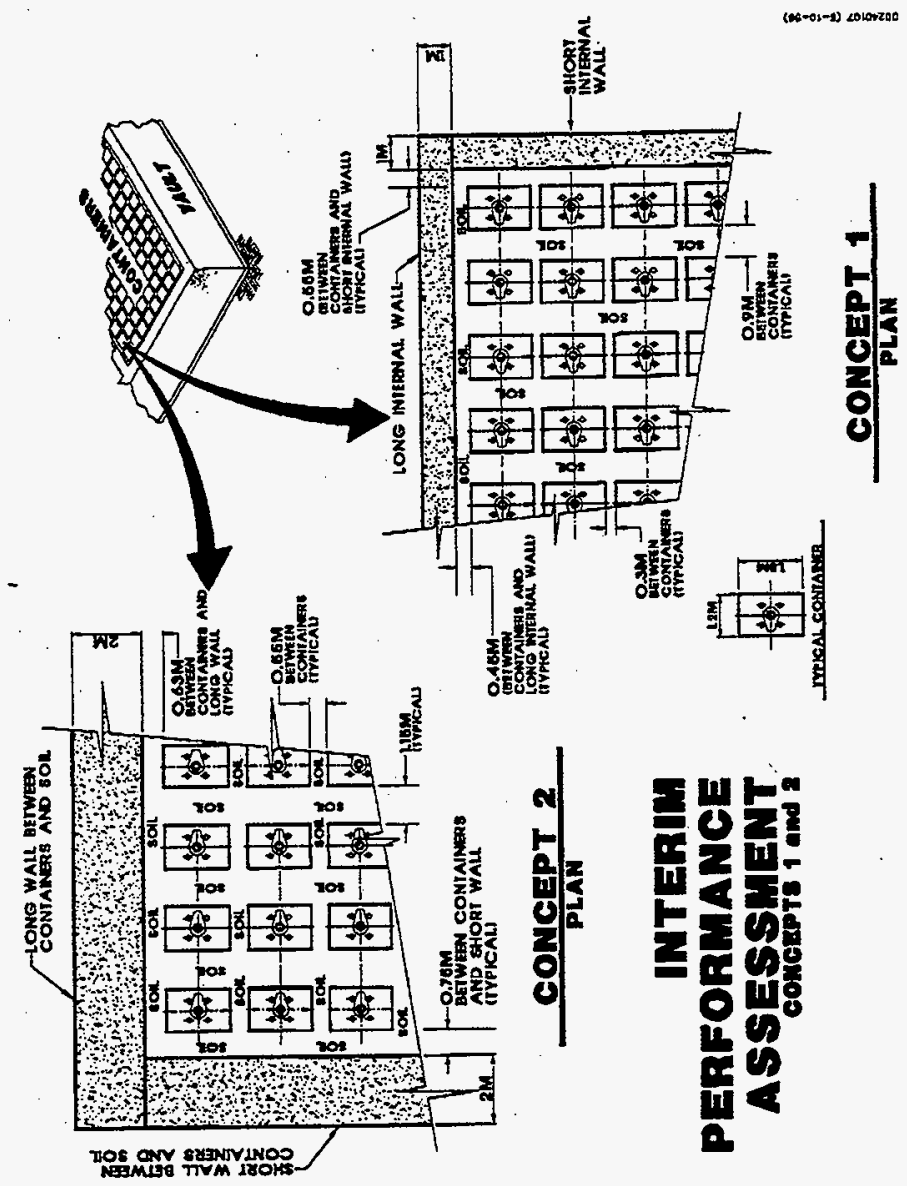




\section{DOE/RL-97-69}

Rev. 0

3.4.5.5 Filler Material. The disposal facility concepts include filler material between and above the stacks of waste packages inside the vault bays.

The type of filler material has not been chosen. Its main function is to fill the voids between containers and minimize subsidence. A secondary purpose can be to act as a higher conductivity path for moisture flow than the waste form packages. By performing such a role, less moisture would be available to erode the waste form.

The amount of filler material will depend on the stacking arrangement and number of waste packages. Because the actual arrangement is not known, an arrangement was developed for each concept. Figure 3-5 shows the spacing of the waste packages in the vault bays for both Concepts 1 and 2 (Eiholzer 1996). The arrangement for Concept 1 was used for the base analysis case. The arrangement for Concept 2 was used as a sensitivity case. The sensitivity case that used the Concept 2 arrangement determined the effect of a lower radionuclide concentration throughout the disposal facility. Different arrangements were used for each concept to examine if the spacing between waste containers affects the overall environmental outcome.

3.4.5.6 Existing TWRS Disposal Facilities Sensitivity Study. The four existing TWRS disposal vaults are assumed to be used for the disposal of the initial approximately 6 percent of the ILAW (Burbank 1997). These vaults, described in Performance Assessment of Grouted Double-Shell Tank Waste Disposal at Hanford (Kincaid 1995-4), are located about 1 kilometer east of the proposed disposal site. They could hold about 6 percent of the projected waste volume. Because the vaults are so close to the location of the new disposal site, the geology and associated data are similar. The design for the grout vaults is similar to the presumed facility design, except that the grout vaults have 0.5 to 1.0 meter of asphalt surrounding the concrete structure. No credit is taken for this asphalt, even though, as shown by Kincaid 1995, the asphalt greatly slowed the release of moisture and contaminants from the disposal facility. Closure plans for the existing and the new disposal facilities (capillary and surface barriers) are expected to be similar.

\subsubsection{Degradation of the Waste Disposal} Facility. The disposal facilities will degrade with time These analyses are based on the assumption that natural materials such as sand and gravel will not degrade, but that manufactured materials such as concrete and glass will. This section discusses components of the waste disposal facility and how they may degrade.

The Hanford surface barrier has a design life of at least 1,000 years (Myers 1994), with deterioration thought to come mainly from the effects of wind and animal intrusion. Although the actual lifetime of the surface barrier is not known, 1,000 years was used for these analyses. The infiltration rate through the barrier will change at the end of the barrier's lifetime (Section 3:4.6). Because the top of the Hanford-type surface barrier is at ground level, erosion should not pose the problem that it would if the barrier were above ground. Also, the facilities' locations are not in an area of sand dune formation (Section 2.2.7.2).
Facility Degradation This analysis included degradation of manufactured materials. 


\section{DOE/RL-97-69 \\ Rev. 0}

Because the capillary barrier is constructed of natural materials, it is assumed not to change from material degradation. Studies (Kramer 1989) have shown that the mixing of the sand and gravel should not significantly affect performance. However, the capillary barrier could fail if much subsidence occurs within the disposal facility. Large drops or gaps in the barrier would cause a discontinuity and possibly functional failure. However, calculations (Mann 1995b) indicate that large subsidence is required for the capillary barrier to fail. The subsidence aspect of the capillary barrier was examined in a sensitivity study.

The waste packages will degrade over time from the water-waste form interaction described in Section 3.4.4.3. The effect of the degradation of the waste containers is ignored in these 10,000-year analyses because these materials will degrade in such a comparatively short time that the container is assumed to have never existed. The possible effect of changed waste form release rates caused by chemical interactions of the waste form and container await the specifications for these materials.

All concrete structures are considered to be degraded at 500 years. Five hundred years was chosen because of a U.S. Nuclear Regulatory Commission staff's draft branch technical position (NRC 1997) recommending that no credit be taken for engineered physical components after at most 500 years. It is expected that future analysis will show that, because of the design specifications and climatic and geologic conditions on the Hanford Site, the concrete structures in the disposal facility will last longer than 500 years.

Earthquakes could accelerate the facility's degradation, particularly that of the concrete structures. However, earthquake analyses will not be performed as part of these analyses because not enough is known about the design of the disposal facility. As the facility design develops, the influence of earthquakes will be incorporated into future performance assessments.

Besides the influence of subsidence on the capillary barrier, the following sensitivity cases related to facility degradation were investigated:

- All the concrete was considered degraded at closure. This case indicates how important the concrete structure is to the disposal system.

- $\quad$ The concrete structure degrades at 2,000 years. This case examined the "bathtub" effect that occurs when water collects in the bottom of the disposal facility for a long time and is then immediately released. 


\section{DOE/RL-97-69}

Rev. 0

\subsubsection{Infiltration Rate}

The infiltration rate is the rate at which water leaves the near-surface zone (the zone affected by plant development, animal intrusion, and evaporation) and enters the sand-gravel capillary barrier. For the

Infiltration

The infilitration rate was based on specifications for the surface barrier and on natural conditions.

first 1,000 years, the near-surface zone is the Hanford-type barrier. That part of the infiltration rate not diverted by the sand-gravel capillary barrier provides the moisture that drives the corrosion of the waste form and carries the contaminants from the facility. This moisture and (starting at some depth into the vadose zone) the diverted water carry the contaminants into the aquifer. Table 3-14 displays the infiltration rates used in the base analysis case.

Table 3-14. Infiltration Rates for Base Analysis Case (Rockhold 1995).

\begin{tabular}{|c|c|}
\hline \multicolumn{1}{|c|}{ Parameter } & Recharge Rate Value \\
\hline \hline $\begin{array}{c}\text { At the Disposal Facility } \\
\text { First } 1,000 \text { years } \\
\text { Thereafter }\end{array}$ & $0.5 \mathrm{~mm} / \mathrm{y}(0.02 \mathrm{in} / \mathrm{y})$ \\
\hline
\end{tabular}

Normally, the infiltration rate is assumed to be equal to the recharge rate, the rate at which water enters the aquifer. This assumption is based on the separate assumption that little water is stored or converted in the vadose zone. Because of the equality of values, recharge rate and infiltration rate are often used interchangeably in performance assessments. In future performance assessments, the removal of water from the system during the corrosion processes will be explicitly included.

Rockhold et al. (Rockhold 1995) estimated the short-term and long-term recharge rates for the new disposal site. The short-term recharge rate $(0.5 \mathrm{~mm} / \mathrm{y}[0.02 \mathrm{in} / \mathrm{y}])$ was based on the design specifications of the Hanford surface barrier (Myers 1994 and described in Section 3.4.5.1). The long-term recharge rate $(3 \mathrm{~mm} / \mathrm{y}[0.12 \mathrm{in} / \mathrm{y}])$ was based on the data for the new disposal site from Fayer and Walters (Fayer 1995a). Fayer and Walters estimated recharge rates at locations throughout the Hanford Site based on vegetation cover and soil type. The estimated natural recharge rate at the existing disposal site is similar.

Because the specifications for the surface barrier (Myers 1994) cite 1,000 years for the design life, the base analysis case used the infiltration rate of $0.5 \mathrm{~mm} / \mathrm{y}$ for the first 1,000 years. Then the infiltration rate was immediately increased to $3 \mathrm{~mm} / \mathrm{y}$. The infiltration through the surface barrier is not expected to increase this quickly. However, the behavior of the Hanford Surface Barrier beyond 1,000 years has not been analyzed, so no information exists on which to base a slower rate of increase. The infiltration rate outside the region of the surface barrier for the first 1,000 years is expected to be the natural rate $(3 \mathrm{~mm} / \mathrm{y})$. However, this effect is ignored because the barrier covers most of the surface area important for contaminant transport. 


\section{DOE/RL-97-69}

Rev. 0

The following three sensitivity cases, based on natural conditions were selected to bracket the selected infiltration rates for the disposal facility:

- The first case does not consider the surface barrier. The $3 \mathrm{~mm} / \mathrm{y}$ recharge rate was used throughout the calculation.

- The second case used a lower time-independent rate $[1 \mathrm{~mm} / \mathrm{y}(0.04 \mathrm{in} / \mathrm{y})]$. This was also the recharge rate used in the grout performance assessment (Kincaid 1995).

- The third case used a very low recharge rate. The recharge rate of $0.1 \mathrm{~mm} / \mathrm{y}$ $(0.004 \mathrm{in} / \mathrm{y})$ was used. Preliminary tracer measurements indicate that if sagebrush persists at the disposal site, this recharge rate may be appropriate.

The infiltration rate used for the land-use sensitivity cases was $100 \mathrm{~mm} / \mathrm{y}(3.9 \mathrm{in} / \mathrm{y})$ to simulate irrigated farming.

\subsubsection{Exposure Parameters}

Data are needed to convert radionuclide concentrations into human dose. The first step is to decide which of several internal and external dose

Exposure Parameters Dosimetry parameters are based on Hanford Site practices. conversion libraries to use. The next step is to calculate dose conversion factors based on the exposure scenario pathways (Sections 3.3.2 and 3.3.5). Finally, significant data need to be determined for the inadvertent intrusion scenarios. The values for all the exposure parameters are those recommended in Rittmann 1995.

\subsubsection{Internal and External Dose Conversion Factors. Both DOE and the EPA} have published libraries of values to be used in converting radionuclide concentrations into human dose equivalent. In addition, the Hanford Site has developed its own library. This section describes the libraries available for internal and external dose conversion and explains the reasons for choosing particular libraries.

The internal dose conversion factors specify the effective dose equivalent (EDE) from a unit intake (ingested or inhaled). These dose factors reflect the committed dose over 50 years. This period was established by the International Commission for Radiological Protection (ICRP 1977) for determining internal dose and relating it to whole body exposure.

The three internal dose conversion libraries considered for this performance assessment were the ones developed by the DOE (DOE 1988d), the EPA (EPA 1988), and the Hanford Site. The Hanford Site values were based on the GENII computer code system (Napier 1988), which was last revised in 1993 (Rittmann 1993). In most cases, the three libraries have similar values. However, for technetium, a key radionuclide the values greatly differ. The GENII value for ${ }^{99} \mathrm{Tc}$ is 70 percent higher than the DOE value. The EPA value is 12 percent higher than the DOE value. The DOE library (DOE 1988d) was chosen for this performance assessment because of its widespread use in other DOE performance assessments. 


\section{DOE/RL-97-69 \\ Rev. 0}

External dose conversion factors give the expected dose equivalent to an individual standing in the center of a large contaminated area. The three sources of external dose factors used at the Hanford Site are from the DOE (DOE 1988c) and EPA (EPA 1993), and from the revised values based on GENII (Rittmann 1993). The values in the external dose factors libraries differ more than the values in the internal dose factors libraries. The DOE external dose factors library assumes that all radionuclides are at the surface and that no soil mixing has occurred. Thus, the values of the DOE library lead to larger dose estimates. The GENII and EPA models are similar to each other, but the EPA implementation uses a Monte Carlo approach while GENII uses a deterministic approach. For the key radionuclides important in external exposure, ${ }^{126} \mathrm{Sn}$ and ${ }^{137} \mathrm{Cs}$, the DOE dose factor is about four times larger than the EPA value. The GENII value is about 20 percent larger than the EPA value. Because of its modern database and methods, the EPA library was used in these analyses for external doses.

Although not the intent, the effect of these choices is to choose libraries with the lowest dose factors for the important radionuclides. Sensitivity cases were performed using each of the dose factor libraries.

\subsubsection{Drinking Water and All-Pathways Dose Conversion Factors. Parameters} other than the dose conversion factors are important in converting radionuclide concentrations into doses. This section covers the values needed for the drinking water exposure pathway and the all-pathways scenario, the two exposure scenarios considered in this performance assessment.

Water taken from a well is not taken just at the point of maximum contaminant concentration in the groundwater, but rather over a volume having a significant extent. Based on the grout performance assessment (Kincaid 1995-8], a well screen depth of $4.6 \mathrm{~m}(15 \mathrm{ft}$ ) is used. Screen lengths of Hanford Site monitoring wells use longer screen depths. Screen lengths on and off the Hanford Site will be documented in the near future. Hand calculations have shown that in the $100 \mathrm{~m}$ of travel in the groundwater, the contaminants will experience little vertical dispersion. Thus the screen depth is assumed to intercept all of the contaminants contained in the entire column of groundwater at the well location.

Pumping water up from the unconfined aquifer can distort the groundwater flow at high pumping rates and hence lower the concentration of radionuclides in the well water. A minimal pumping rate of 10 liters/day (10.6 quarts/day) [ 2 liters/day ( 2.1 quarts/day) per person for a family of 5] is assumed. To maximize the exposure at the 200 East Area boundary, the position of the vaults is assumed to be in the northeast quarter of the disposal area, the location nearest to the 200 East Area boundary and to the existing vaults.

For the drinking water scenario, the dosimetry parameter needed is the amount of water consumed. The value commonly used in performance assessments, 2 liters/day, is the value used in these analyses. This value is 35 percent higher than the 1.48 liters/day ( 1.56 qu/day) measured for the western United States by the EPA (Yang 1986). The resulting drinking water dose factors used for this performance assessment are displayed in Table B-1 in Appendix B. 


\section{DOE/RL-97-69 \\ Rev. 0}

As its name implies, the all-pathways scenario is more inclusive. This scenario includes drinking water, ingesting and inhaling soil, ingesting food, and receiving external radiation. Rittmann (1995) provides a complete description of all the parameters and the justification for the selected values. The resulting dose factors are displayed in Table B- 2 in Appendix B. The following paragraphs summarize these pathways and the values used in this performance assessment.

Soil is taken into the body by ingestion and by inhalation. Soil ingestion is assumed to occur through hand-mouth contact, licking the lips, and similar motions at the rate of 100 milligrams per day (0.0035 ounce/day) (EPA 1989a). Soil inhalation is based on the methods found in NUREG/CR-5512 (Kennedy 1992) and results in $2.3 \mathrm{mg} /$ day $(0.00008$ ounce/day) being inhaled.

Food ingestion exposure is based on the EPA's Exposure Factors Handbook (EPA 1989a), daily consumption factors for the western United States (Yang 1986), and animal, dairy, and plant intake rates (Kennedy 1992). However, water consumption is taken as 2 liters per day. For this calculation it is assumed that half of the person's meat is raised on irrigated fodder and 25 percent of the person's vegetables come from the garden.

Finally, the individual is exposed daily to radiation emitted by the contaminated soil. For these analyses, the time for external exposure was assumed to be 4,120 hours per year (Rittmann 1995).

The all-pathways dose factors found in Table B-2 are nearly the same as the drinking water dose factors found in Table B-1. The drinking water pathway is the largest contributor for most nuclides. Table B-2 shows the ratios between the all-pathways dose factors and the drinking water dose factors.

3.4.7.3 Other Scenarios. Two other scenarios (integrated dose estimate and the glacialage catastrophic flood) have additional parameters. For the cases where integrated doses are calculated, populations of 25 for a public drinking water system ( 40 CFR 141) and 5,000,000 for the number of people living on the Columbia River (Kincaid 1995-5) were used. The flow rate in the Columbia River was taken to be $1000 \mathrm{~m} / \mathrm{s}$ (the lower end of typical values, $1,000-3,000 \mathrm{~m}^{3} / \mathrm{s}$, cited by Woodruff 1992). For the catastrophic flood scenario, the waste is assumed to be redeposited uniformly to a depth of $20 \mathrm{~m}(65.6 \mathrm{ft}$, the depth of the bottom of the disposal facility) over an area equivalent to the Hanford Site $\left(1,450 \mathrm{~km}^{2}\left[560 \mathrm{mi}^{2}\right]\right)$.

It is realized that the exposure parameters chosen for the base analysis case may not be appropriate for Native American communities. Future performance assessments will treat these communities.

3.4.7.4 Half-lives. The half-lives and decay chain branching ratios are taken from Radioactive Decay Data Tables (Kocher 1981). The half-lives and other decay data used in this analysis are presented in Table B- 6 in Appendix B. Normally these data have very small uncertainties. 


\section{DOE/RL-97-69}

Rev. 0

However, for two key nuclides in this study $\left({ }^{79} \mathrm{Se}\right.$ and $\left.{ }^{126} \mathrm{Sn}\right)$, the half-lives were based on single measurements now thought to be incorrect. New measurements taken in China of the ${ }^{75 e}$ half-life (Yu 1993 and Chunseng 1997) indicate a much longer half-life $\left[(4.8 \pm 0.4) \times 10^{5}\right.$ years and $(11.3 \pm 1.7) \times 10^{5}$ years, respectively] than previously used ( $50.65 \times 10^{5}$ years). A new Chinese measurement (Zhang 1996) of the ${ }^{12} \mathrm{Sn}$ half-life increases that value from about 100,000 years to $(2.5 \pm 0.2) \times 10^{5}$ years. These new values are supported by unpublished data from the Pacific Northwest National Laboratory (Jenquin 1995) that indicates that the calculated values of reactor fuel yield in terms of curies/gram of fuel are a factor of 7 higher than the old value for ${ }^{79} \mathrm{Se}$ and a factor of 4.5 higher for ${ }^{126} \mathrm{Sn}$. An increase in the half-lives would imply a proportional decrease in the inventories (expressed in curies) used in this analysis.

\subsection{PERFORMANCE ANALYSIS METHODOEOGY}

This section describes how the performance of the system was determined. That is, this section explains how the data and conceptual models presented in Sections 3.2 through 3.4 are translated into a numerical model suitable for computer simulation. First the strategy of the computer simulation is introduced. Then the computer code selection criteria are summarized. The codes used are then described and their selection justified. Next the process of translating the disposal facility concepts and the natural system into computer models is described. Finally the parameters used in the computer simulations are given.

Calculations of relatively simple equations (for example, gaseous diffusion or glacial-age catastrophic flood consequences) were done by hand. These equations will be treated in Chapter 4 , where the results are discussed.

\subsubsection{Integration}

3.5.1.1 Strategy. Previous long-term environmental assessments at the Hanford Site have consistently shown that the groundwater pathway is the most important. This pathway also requires the most calculations. The conceptual model used for this and earlier Hanford Site performance assessments takes the following eight steps:

1. The water leaves the very-near-surface soil region at the infiltration rate.

2. The water moves toward the waste form, but most of it is diverted by any intact capillary barrier.

3. The water that is not diverted is chemically modified by the local environment, interacts with the waste form, accumulates contaminants, and again is chemically modified by the local environment. 


\section{DOE/RL-97-69}

Rev. 0

4. The water (possibly a reduced amount) leaves the disposal facility carrying contaminants with it. Some contaminants may interact with the material in the disposal facility, slowing the release of the contaminants to the surrounding natural environment.

5. The water moves through the undisturbed, unsaturated zone (vadose zone) below the disposal facility down to the unconfined aquifer. The contaminants also are transported through the vadose zone, again possibly undergoing some geochemical sorption.

6. The water and contaminants move and mix with the water in the unconfined aquifer until they are extracted from the aquifer and brought to the surface or until they reach the Columbia River.

7. Contaminants are normally extracted by being carried to the surface with groundwater being pumped through a well.

8. The radionuclide contaminants then result in human exposure through a variety of pathways (ingestion, inhalation, and external radiation).

Figure 3-6 shows these eight steps as a flow chart.

The results for each step are computed separately and used in the next step so that computations can be made more easily. Such an approach is taken to maximize computational efficiency. Some of the computer simulations take 100 hours of computer time; some take a few minutes. Each is a highly specialized calculation. However, the overall model is always considered at each step and consistent data are used throughout.

The strategy for the current computations is to define a base analysis case, then develop sensitivity cases derived from that base analysis case. In some instances the sensitivity cases are built on an alternative case, such as the one describing Disposal Facility Concept 2 . The results for the base analysis case and the sensitivity cases are presented in Chapter 4 . Chapter 5 combines the results of the computer simulations, the simpler calculations, and the other analyses to integrate and interpret how the contaminants will affect the environment in the long term.

3.5.1.2 Base Analysis Case. The base analysis case provides the "best" estimate of how the system may evolve given the information available. The base analysis case is not necessarily the way the system will behave. As more information concerning the waste form, the disposal facility design, and disposal site location is gathered, the definition of the base analysis case is expected to evolve. The approach used in the base analysis case is conservative, but reasonable. This approach was required by the DOE's Peer Review Panel. 
DOE/RL-97-69

Rev. 0

Figure 3-6. Eight Sequential Steps for the Groundwater Pathway

1) Water starts downward journey from the near-surface region.

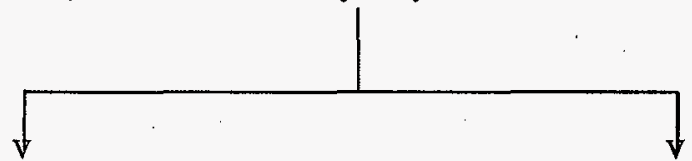

2) Most water diverted by the sand-gravel capillary barrier.

3) Water is chemically modified, interacts with waste form, and accumulates contaminants.

$$
\checkmark
$$

4) Water and contaminants leave the disposal facility, possibly chemically interacting with disposal facility components.

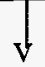

5) Water and contaminants move down thruugh the vadose zone.<smiles>[131In][131I]</smiles>

6) The contaminants move downgradient in the unconfined aquifer, mixing with the groundwater, diluting the contaminant concentration.<smiles>[131In][131I]</smiles>

7) Water and contaminants are pumped from a well to surface<smiles>C[V]</smiles>

8) Humans receive exposure from contaminants.

The major features of the base analysis case are as follows:

- The location of the facility is that selected for the new disposal facility (Rutherford 1997)

- The future land use of the 200 Areas is as a protected area, without artificial recharge (for example, no irrigated farming occurs)

- The design of the disposal facility is based on Concept 1 (Section 3.4.5) 


\section{DOE/RL-97-69 \\ Rev. 0}

- The long-term contaminant release rate from the waste form for all elements is that given in the TWRS Privatization specifications (DOE 1996a) for the shortterm release rate for all elements other than technetium. This means that the technetium release rate in the base analysis case is 5 times higher than the technetium release rate given in the RFP.

- The data for the natural system are those collected and interpreted for this performance assessment (Section 3.4.3).

Mann (1995b) describes the base analysis case in detail. The details of the models and related data for the base analysis case are presented in Sections 3.5.3 and 3.5.4, respectively.

\subsubsection{Computer Codes}

This section discusses the computer codes used for this performance assessment and justifies their technical adequacy. The general selection criteria used to select the major computer codes are first summarized. Sections 3.5.2.1 through 3.5.2.5 describe each major computer code used and the reason for its selection.

3.5.2.1 General Selection Criteria for Computer Codes. The large computer codes used for this assessment were selected based on meeting general code selection criteria and functional criteria related to the simulation being done. Large computer codes were needed for computing in the following two functional areas:

- Calculation of the contaminant release rate from glass (used only for sensitivity cases in this analysis)

- Calculation of water flow and contaminant transport.

The codes considered had to first meet the general code selection criteria.

The general code selection criteria were based on government code selection documents and the experience of others. The waste management code selection criteria of the DOE (Case 1988) and the NRC (Kozak 1989) were used to develop these selection criteria. The criteria were also shaped by the experience gained from other DOE performance assessments (WSRC 1992, Kincaid 1995-6) and codes selected for earlier Hanford Site risk assessments (DOE-RL 1991a). The general required selection criteria included the following:

- Having the appropriate scientific framework

- Having documentation covering the underlying theory, use, and verification

- Being under configuration control. 
General desirable criteria included the following:

- Suitable hardware requirements

- Suitable complexity

- Flexible interfaces with other codes

- A bias against proprietary codes

- Familiarity of the users with the code.

Mann (1995c) details the development of the general selection criteria and the complete criteria.

The actual codes selected also had to meet criteria related to the function being simulated. Sections 3.5.2.2 through 3.2.2.5 summarize the codes chosen and the reasons for their selection. References to specific functional criteria will be given in their sections or related appendices.

3.5.2.2 AREST-CT. The Analyzer for RadionuclidE Source-Term with Chemical Transport (AREST-CT) code is the sourceterm code used for some of the sensitivity Source Term Code The AREST:CT code is the source-term code used in the waste form sensitivity cases. cases in this performance assessment. The base analysis case and many of the sensitivity cases assume the release rate is based on the rates specified in the request for proposal for the waste form (DOE-RL 1996) which was not derived from a simulation of how a waste form would perform. AREST-CT calculates the timedependent flux of radionuclides released from the waste form. AREST-CT contains two important factors that allow the code to simulate the processes in the disposal facility. First, the code is based on basic principles of physics, chemistry, and thermodynamics which provides the best estimate of contaminant release over the spatial and long time periods of interest. Second, the model for the disposal facility can be coupled with a model for radionuclide release, thus providing the ability to couple the effects of facility design with waste form performance.

Using chemical reaction rates (including the glass corrosion rates) and moisture values in the vaults from PORFLOW (Section 3.5.2.3), AREST-CT provides the source term for the vadose zone calculations. AREST-CT calculates the following:

- The degradation of the waste form with corresponding release of radionuclides

- The chemical reactions that depend on time and space (including the formation of secondary mineral phases and the consumption of water)

- The transport of the water and contaminants through a vertical slice of the disposal facility.

3.5.2.2.1 Selection. AREST-CT was selected because it best meets the criteria and requirements for the disposal system release model (McGrail 1994) and the general code requirements (Mann 1995c). Ten source codes were considered (See Appendix C.3). Whereas some of the codes were comparable to AREST-CT in their ability to describe the physical 


\section{DOE/RL-97-69}

Rev. 0

processes important for the near field, their ability to describe chemical process was significantly inferior. Similarly, the codes whose strength was in their ability to model chemical processes were weak in their ability to model the physical processes. AREST-CT also scored high in numerical methods and functionality.

3.5.2.2.2 Code Description. AREST-CT calculates the total mass flux of radionuclides leaving the disposal facility by solving a coupled set of equations. The set describes the radionuclide release from the waste form and the mass transport of the radionuclides from the waste form through the disposal facility, constrained by chemical reactions. This coupled set of equations is commonly known as the reaction-transport equation. The value for radionuclide release from the waste form is taken from either an assumed constant release rate or a simulation using a mechanistic glass corrosion model. More detailed documentation of the design and models used in the AREST-CT code is found in Engel (1995) and Engel (1995a).

The governing equations are given in Appendix C.2.

3.5.2.2.3 Code History. The AREST-CT code was developed at the Pacific Northwest National Laboratory to analyze the engineered barrier system of a subsurface disposal site for storing nuclear waste. The engineered barrier system is the constructed or human-altered components of the disposal system. In this case, it is the disposal facility design starting with the water-conditioning layer.

The code was originally developed to support the engineered-system performance analyses for the proposed high-level waste repository at Yucca Mountain, Nevada. Specific capabilities that address the low-level waste disposal action have been included in AREST-CT.

3.5.2.2.4 Verification. A two-part verification test of AREST-CT, Version 1, was done to ensure that modules of the program were correctly implemented and worked together (Chen 1995). A summary is given here; more details are given in Appendix C.4.

First, specific portions or modules of AREST-CT were unit-tested to verify that the modules performed correctly. Individual code modules were evaluated against hand calculations, analytical solutions, or other existing numerical codes. Each module was unittested before being incorporated into AREST-CT. All modules were considered acceptable for current use.

Second, the entire integrated computer code was tested. At the time of verification, no analytical solutions existed for the reaction-transport problems designed for AREST-CT. The code was benchmarked against simulation results from other similar reaction-transport codes.

A one-dimensional idealization of a low-level-waste engineering system was run as a benchmark test case. The system consisted of 7 solids and 12 aqueous species. Two types of reactions were considered, equilibrium aqueous reactions and solid dissolution/precipitation reactions. The results of the test showed that AREST-CT simulations and the other codes were of similar quality. More details are given in Chen (1995). 


\section{DOE/RL-97-69}

Rev. 0

Additional testing and verification will be conducted as the AREST-CT code develops. Future testing will include integration testing for mechanisms of radioactive decay and decay chain in-growth, and for two-dimensional simulation. Plans for code development call for coupling with a multiphase flow solver so that it can model infiltration velocity changes with time-dependent porosity and permeability changes that result from solid dissolution/precipitation reactions and from the consumption of water that occurs during the hydrolysis of the glass waste form. Now, the program uses the water velocity from the separate moisture flow code.

\subsubsection{PORFLOW. The PORFLOW} code (ACRi 1994) was used to calculate the transport of contaminants from the waste packages in the disposal facility to

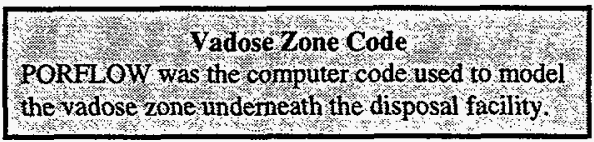
the unconfined aquifer. PORFLOW was also used to calculate the effect of possible disposal facility components on the amount of water that goes into the vaulted area then to the vadose zone.

PORFLOW interfaces with the two other major codes used in the analysis, AREST-CT (Section 3.5.2.2) and VAM3D-CG (Section 3.5.2.4). PORFLOW supplies AREST-CT with the moisture movement velocities into the vault, which drives the glass corrosion process. ARESTCT supplies PORFLOW with the contaminant source term at the bottom of the waste disposal facility. PORFLOW supplies VAM3D-CG, the code used for the unconfined aquifer, with the amount of moisture and contaminants entering the aquifer.

3.5.2.3.1 Selection. PORFLOW was given first consideration (Piepho 1995) for use as a flow and transport code because it was used in the analyses for the disposal action described in Performance Assessment of Grouted Double-Shell Tank Waste Disposal at Hanford (Kincaid 1995) and in earlier analyses of this disposal action (Rawlins 1994 and Mann 1995b). The capabilities of PORFLOW were compared to the capabilities of the VAM3D-CG (Huyakom 1994) and TRACR3D (Birdsell 1991) codes. All three codes met the flow and transport code requirements for this performance assessment (Mann 1995c).

Other codes, such as CFEST (Gupta 1987), MODFLOW (McDonald 1988), and SLAEMS (Strack 1989), were considered. However, they are aquifer codes and cannot be used for vadose zone transport. Code selection documents from the Yucca Mountain Project (Reeves 1994) and the Savannah River Saltstone effort (WSRC 1992) were also consulted for alternative codes.

PORFLOW was selected to simulate flow and transport in the vadose zone for the following reasons:

- It met all the requirements established for this performance assessment

- It had desired features that the other codes lacked

- It was used in the earlier phases of this project

- The analysts were familiar with PORFLOW 
DOE/RL-97-69

Rev. 0

Versions of the PORFLOW and VAM3D-CG codes available in 1990 were approved by Hanford Site regulators to support waste management and environmental remediation activities (DOE-RL 1991 a and 1991b).

3.5.2.3.2 Code Description. PORFLOW (ACRi 1994) calculates multi-phase fluid flow, heat transfer, and mass transport in unsaturated and saturated porous or fractured media. The code can simulate transient or steady-state problems in Cartesian or cylindrical geometry in two or three dimensions. The material, i.e., soil or concrete, that PORFLOW models can be either uniform or a mixture. The material can contain distinct elements such as discrete fractures or boreholes within a porous matrix.

In this performance assessment, PORFLOW is used to simulate the following (See Appendix D.2 for the governing equations):

- The moisture content distribution from the bottom of the surface barrier into and through the vault region

- The contaminant concentration distribution from the vault area down into the unconfined aquifer.

For the first simulation, the source rate of the moisture is the infiltration rate given in Section 3.4.6. PORFLOW tracks the moisture front through and around the sand-gravel capillary barrier, through the water conditioning layer, through the concrete structure, and into the vault bay with containers and filler material. PORFLOW simulates the moisture content distribution at the surface of the waste package. This distribution is an input used by AREST-CT.

Tracking the contaminants from the vault region down into the unconfined aquifer is a more complicated task. Again PORFLOW uses the infiltration rate from Section 3.4.6 and the various features of the disposal facility to establish moisture movement. For this problem, the vadose zone region below the disposal facility also is considered. The moisture content distribution within the vadose zone is predicted. Then PORFLOW tracks the movement of the radioactive contaminants down into the groundwater. The contaminants are assumed to be released from the surface of the waste package at the rate established in Section 3.4.4.3. Each PORFLOW run follows four sets of radionuclides, each set corresponding to a different $\mathrm{K}_{\mathrm{d}}$ value (Section 3.4.3.3): All the geologic layers (Section 3.4.4.1) with their different properties (Section 3.4.4.2) are treated in the same run.

3.5.2.3.3 Verification and Benchmarking. PORFLOW Version 2.394gr used in this analysis has been extensively verified and benchmarked (Piepho 1994). Verification and benchmarking efforts. were based on the following:

- Comparing the results of the Version 2.394gr with earlier versions of PORFLOW

- Reproducing the results of analytical solutions from verification problems

- Comparing the results with other codes used to solve complex problems. 


\section{DOE/RL-97-69}

Rev. 0

Additional details are given in Appendix D.4.1.

3.5.2.3.4 Field Testing. As this document is being written PORFLOW is being used to simulate the Sisson/Lu Injection Experiment and previous leaks from Tank T-106. The Sisson/Lu experiment (Sisson 1984) injected a known amount of water and radioactive tracers into a well just east of the proposed disposal site. The methods, tools, and boreholes were reevaluated recently (Fayer 1995c). The leak from Tank T-106 is the best characterized of the Hanford Site tank leaks.

\subsubsection{VAM3D-CG. VAM3D-CG Variably Saturated} Analysis Model in 3-Dimensions with Preconditioned Conjugate Gradient Matrix Solvers) (Huyakorn 1994) was used to calculate flow and contaminant transport in the unconfined aquifer from unit moisture flow and contaminant amounts at the bottom of the vadose zone.

Groundwater Code $7 \mathrm{AM} 3 \mathrm{D}-\mathrm{CG}$ was the computer code used to model groundwater.

3.5.2.4.1 Selection. Although PORFLOW was selected to be the flow and transport code in both the vadose zone and the unconfined aquifer (Piepho 1995), VAM3D-CG was the code actually used to calculate results in the aquifer. VAM3D-CG was chosen because of the need for a model to treat the entire Hanford Site, not just the area near the disposal facility. Although PORFLOW could perform such calculations, the model for the Hanford Site groundwater system already had been developed for the VAM3D-CG code (Law 1996) and successfully used in other Hanford Site performance assessments (Wood 1994b and Wood 1996).

Recommendation 94-2 of the Defense Nuclear Facilities Safety Board (DNFSB 1994) stressed the importance of calculating the environmental impact of all previous DOE actions on the points of compliance. This means that at the point where performance objectives must be met, the actions of all disposal and ground discharges besides the current proposed action must be included in the evaluation. Fortunately, the ERC Hanford Sitewide Groundwater Model (Law 1996) based on VAM3D-CG had been developed. Although other groundwater models of the Hanford Site (for example, Wurstner 1995) exist, this model has had boundary conditions optimized for future land uses. The Hanford Site is developing criteria for creating one accepted groundwater computer code and model. This code and model will be used in future performance assessments.

VAM3D-CG was selected for the Hanford Sitewide Groundwater Model (Law 1996) for the following reasons:

- The solution algorithms were robust

- The original developer, an internationally known expert, was available

- The VAM3D-CG code can deal with partially and fully saturated flow, thus efficiently simulating a fluctuating free water surface 


\section{DOE/RL-97-69}

Rev. 0

- The VAM3D-CG code supports the use of special grid shapes (transitional elements) for detailed simulation of small areas, thereby making computations more efficient

- The version of the VAM3D-CG code available in 1990 was approved by Hanford Site regulators to support waste management and environmental remediation activities (DOE-RL 1991a and DOE-RL 1991b).

The VAM3D-CG code is preferred over the PORFLOW code for Hanford sitewide groundwater modeling applications because it offers a curvilinear grid. A curvilinear grid can be set up to follow layering or other characteristic patterns. For example, the thickness of the aquifer at the Hanford Site varies from over $100 \mathrm{~m}$ (328 ft) to a few meters. A curvilinear grid was set up for the varying aquifer thickness, which allows faster input data preparations and faster code execution. The rectangular grid representations for varying formation thicknesses can lead to erroneous results when coarse grids are used or to prohibitively large matrices and computation times when fine grids are used.

3.5.2.4.2 Code Description. VAM3D-CG (Huyakorn 1994) calculates saturatedunsaturated groundwater flow and solute transport with variable water table positions and highly non-linear soil moisture conditions. The code can simulate transient or steady-state problems in one, two, or three dimensions using a finite element model. Special grid elements (in the shape of hexahedrals) are used to define discrete volumes with irregular geometry. The size of these elements can vary. Many "fine" elements can be used in places where the geometry varies quickly. Such finer elements allow a better description of regions in which the values of parameters and variables are changing rapidly. An orthogonal curvilinear grid can also be used to represent flow domains.

In this performance assessment, VAM3D-CG was used to forecast the contaminant movement in the groundwater. VAM3D-CG used the values for the hydrologic parameters from the ERC Hanford Sitewide Groundwater Model (Section 3.4.3.4). A normalized contaminant source term was used for the amount of contaminant entering the unconfined aquifer. Water flow and contaminant transport patterns were then distorted by the stress of pumping the water in the well. Thus VAM3D-CG calculated the contaminant concentration in the well relative to the normalized contaminant source term.

3.5.2.4.3 Verification and Benchmarking. Versions 2.4b (Lu 1994) and 3.1 (Lu 1995) of VAM3D-CG were tested in the following manner:

- Results of the installed version were compared to those published by the vendor (Huyakorn 1993)

- These versions were benchmarked against the results from PORFLO-3 Version 1.2 (Sagar 1990) for Hanford Site-relevant problems.

More details are given in Appendix D.4.2. 


\section{DOE/RL-97-69}

Rev. 0

3.5.2.4.4 Calibration and Validation. Calibration and validation tests were run for both Versions 2.4b and 3.1. The calibration and validation effort for Version 2.4b (Lu 1993) used data from the Hanford Injection Test experiment (Sisson 1984). The calibration and validation effort for Version 3.1 used data from the reevaluation of the Hanford Injection Test Experiment and from new experiments (Fayer 1995b). The Hanford Sitewide Groundwater Flow and Transport Calibration Report (Law 1996) describes in detail the various comparisons made using Hanford Site data.

\subsubsection{INTEG. INTEG (Mann 1996b)} calculates a specific impact (whether dose rate or concentration level) based on the inventory, vadose zone transport,

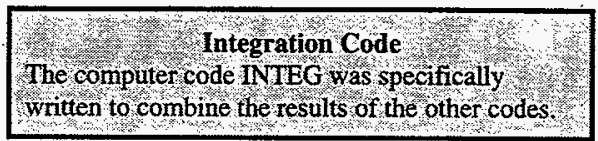
aquifer transport, and dosimetry factors.

The dose rate calculated depends on the type of dosimetry factor (i.e., all-pathways, drinking water). The program solves the following equation for each year under consideration.

$$
\text { Response }=\sum_{i} \frac{I_{i}(t) \Gamma_{i}(t) w_{i} D_{i}}{r A}
$$

where

$\mathrm{I}_{\mathrm{i}}$ is the amount (or inventory) of radionuclide $\mathrm{i}(\mathrm{Ci})$. The time-dependent value is calculated by INTEG based on the initial inventory and on decay and the ingrowth from other radionuclides.

$\Gamma_{i} \quad$ is the flux of contaminants at the bottom of the vadose zone normalized to an unit source inventory for radionuclide $\mathrm{i}([\mathrm{Ci} / \mathrm{y}] / \mathrm{Ci})$. The time-dependent value is calculated by PORFLOW.

$w_{i} \quad$ is the ratio of the concentration of radionuclide $i$ at the well location relative to the contaminant concentration at the bottom of the vadose zone (dimensionless). This quantity was called the well intercept factor in earlier Hanford performance assessments. The peak value as calculated by VAM3D-CG is used.

$D_{i} \quad$ is the dose rate factor $\left(\mathrm{mrem} / \mathrm{y}\right.$ per $\left.\mathrm{Ci} / \mathrm{m}^{3}\right)$. The values are taken from the tables in Appendix $B . D_{i}$ is unity when the response that is calculated is a concentration.

r is the recharge rate $(\mathrm{m} / \mathrm{y})$. The value at 10,000 years is used at all analysis times.

A is the area over which the contaminant flux enters the aquifer $\left(\mathrm{m}^{2}\right)$. The value used is the area of the disposal facility being modeled.

The program is modeled after GRTPA (Rittmann 1993), which served a similar function in earlier work (Rawlins 1994 and Mann 1995b). INTEG allows greater freedom in specifying data used in the integration. The code has been benchmarked against the results of GRTPA (Mann 1996b). 


\section{DOE/RL-97-69}

Rev. 0

3.5.2.6 Spreadsheets. Commercial spreadsheets were used in determining inadvertent intrusion doses. The Quattro ${ }^{2}$ Pro spreadsheet was used for developing the spreadsheet cells, while the Wingz ${ }^{3}$ spreadsheet was used for the actual runs. The spreadsheet calculations were compared with answers from the GENII computer program (Rittmann 1994). The spreadsheet formulas were verified as part of the review by the Hanford Environmental Dose Oversight Panel (HEDOP) (Rhoads 1996).

\subsubsection{Computer Models}

This section describes the numerical models used in the PORFLOW and VAM3D-CG computer simulations. Because the AREST-CT simulations of contaminant release rate are only used in sensitivity studies, its numerical models is discussed only in Appendix C.

For both the vadose zone and groundwater calculations, two slightly different models are used. These models are described in Sections 3.5.3.1 through 3.5.3.3. Each case has a computational complex model that describes the effect of many interacting features. These are the disposal facility models for the vadose zone calculations and the sitewide models for the groundwater calculations, respectively. Each case also has a much simpler calculational model that comprises the major features of the more complex models, but allows quicker runs. These simpler models are the unit cell model for the vadose zone calculations and the pumping model . for the groundwater calculations. The base analysis case was run using all the models. Most of the sensitivity cases were run using the simpler models.

3.5.3.1 Disposal Facility Model. This twodimensional model, shown-in Figure 3-7, treats an entire vault row (see Section 3.4.5) consisting of 10 vault bays by assuming centerline symmetry. See Piepho 1996 for more details. The model includes the sand-gravel capillary barrier, the water conditioning layer, the vault row, the waste packages, the filler material, and the vadose zone. The surface bartier is not treated. The water flux at the bottom of the surface barrier is considered a boundary condition. Source terms for contaminant release are considered to be at the surfaces of the waste containers.

A two-dimensional model (165 columns with 133 layers) is used. The sand-gravel capillary barrier is modeled with 28 layers. The water conditioning layer, the vault roof, walls, and floor were each modeled with 3 layers. Each of the five vault bays modeled was assumed to contain 9 sets of waste containers (each container being modeled by a $2 \times 9$ grid) separated by a $1 \times 9$ grid for the filler material. The vadose zone was modeled using 46 layers for the sandy sequence, 36 for the gravel sequence, and the bottom 4 modeled for the unconfined aquifer.

2 Quattro is a registered trademark of Corel Corporation

3 Wingz is a trademark of Investment Intelligence Systems Incorporated 


\section{DOE/RL-97-69}

Rev. 0

Symmetry is assumed about the center of the disposal facility with the last 10 columns separating adjacent vaults.

Figure 3-7. Zone Map for Disposal Facility Model. Symmetry around centerline is assumed.

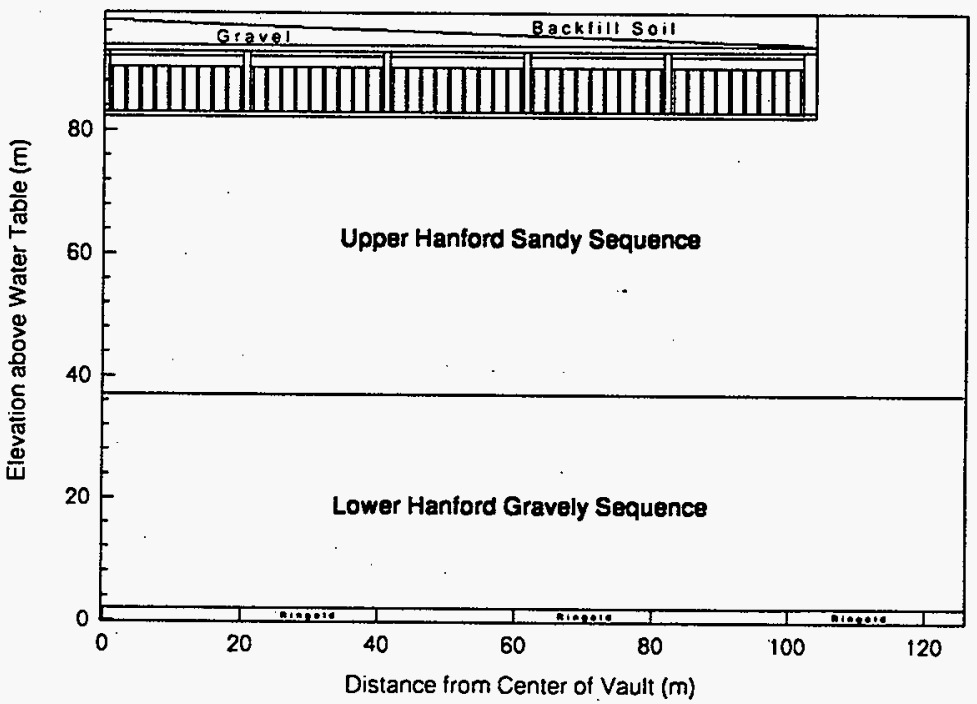

Earlier versions of this model were used in determining the effect of various disposal facility design options on long-term environmental performance (Mann 1995b).

The diffusion coefficient specified in Section 3.4.3.2 is based on the Kemper diffusion model (Kemper 1966). However, if the Kemper model is used in PORFLOW, dispersion cannot be calculated. Therefore the Scheidegger (1961) model was used and the parameters adjusted to obtain the same diffusion value for the moisture contents expected in the problem.

3.5.3.2 Unit Cell Model. The Unit Cell Model calculations focused on the calculations of sensitivity cases. Thus, the model is very much simpler than the disposal facility model just discussed. This two-

Vadose Zone Model -2 The unit cell model is a simpler model used for sensitivity cases. dimensional model treats a thin vertical slice one container $(1.8 \mathrm{~m})$ wide and six containers high of the disposal facility model. The sand-gravel capillary barrier and the concrete roof are not modeled. Kline (1996) gives full details. 


\section{DOE/RL-97-69}

Rev. 0

Figure 3-8 displays the geometry. The top of the model is the filler material atop the waste containers. The model continues with the waste containers and lateral filler material and with a degraded concrete floor. The vadose zone is below the engineered system with the unconfined aquifer at the very bottom of the model.

Figure 3-8. Zone Map for Unit Cell Model. $\mathrm{P}=$ head, $\mathrm{C}=$ concentration, $\mathrm{aq}=$ infiltration rate, and $\mathrm{x}$ and $\mathrm{z}$ are spatial directions.

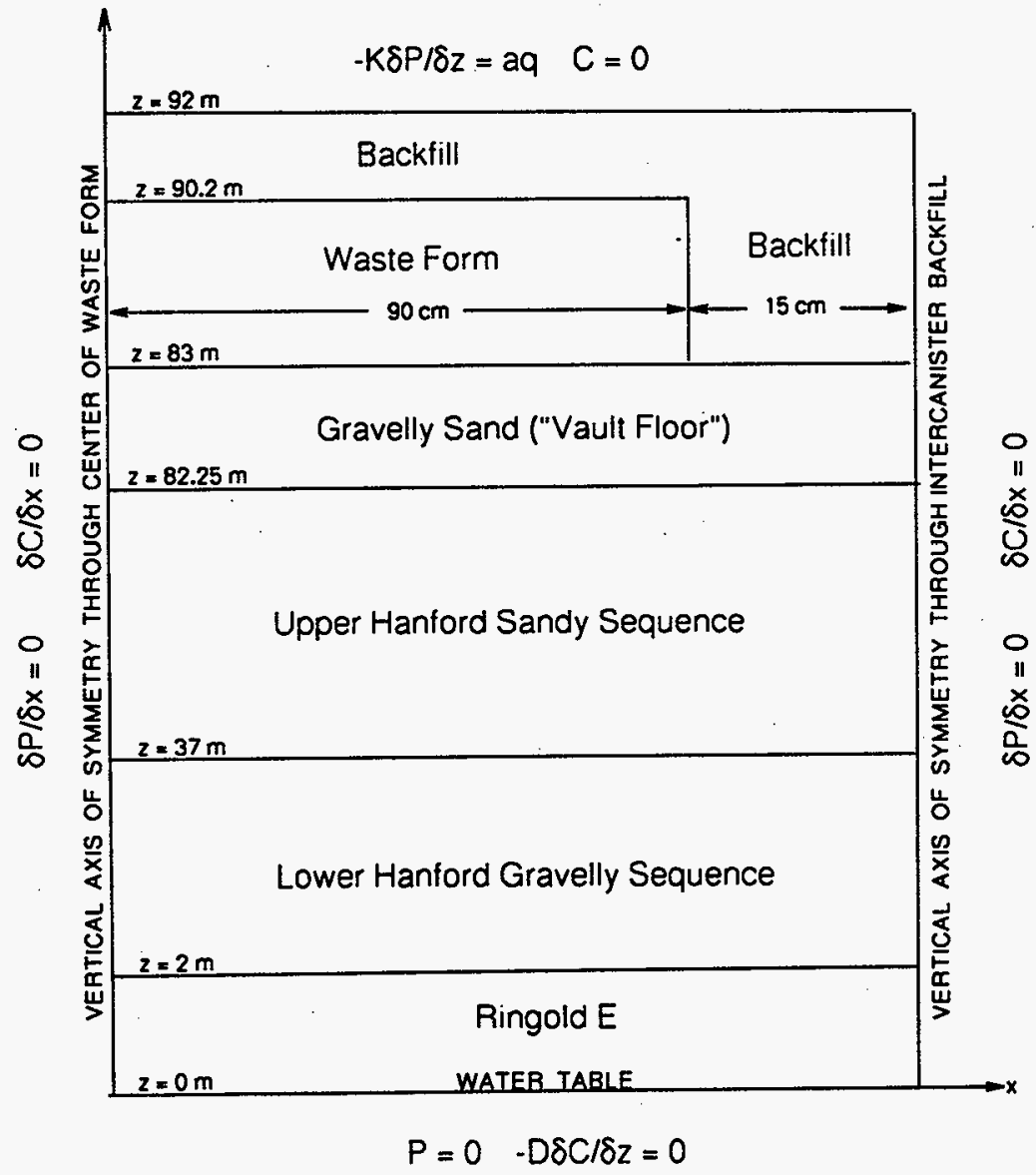




\section{DOE/RL-97-69}

Rev. 0

The grid spacing is 10 by 50 , resulting in Peclet numbers near unity. Nonuniform spacing that includes more detail in the disposal facility is used to minimize the number of nodes. The contaminant source terms $\left(6.82 \times 10^{-7} \mathrm{y}^{-1} \mathrm{~m}^{-3}\right)$ are given as a volumetric source inside the waste containers. Both vertical sides of the model are assumed to be reflective. The boundary condition at the top is the specified infiltration rate. The boundary condition at the water table is fully saturated.

An earlier use of this model (Kline 1995b) showed very good agreement with full disposal models (Mann 1995b).

\subsubsection{Sitewide Model. The aquifer was} analyzed using the ERC Hanford Sitewide Groundwater Model (Law 1996). A horizontal finite-element grid size of $600 \mathrm{~m}$ by $600 \mathrm{~m}$ $(1,962.5$ by $1,962.5 \mathrm{ft})$ was selected. Element

\section{Aquifer Model - 1}

The sitewide nodel treats groundwater fow over the entire Hanford Site. heights varied depending on the thickness of the aquifer and the thickness of the highconductivity Hanford formation. The model grid consists of 6 layers each with 2,474 elements and 2,611 nodes. Vertical discretization was performed using six layers. The top three are in the Hanford formation, and the bottom three are in the underlying Ringold Formation.

Boundary conditions reflect an arid environment with a few streams and rivers as water sources. Inflow along Cold Creek and Dry Creek are prescribed as hydraulic head conditions for model calibrations under 1979 conditions. For these calculations influx representing the recharge from Cold Creek and Dry Creek was used as flux boundary conditions, replacing the fixed head condition. Influx from the Yakima River is treated as a prescribed head. The recharge from the front of Rattlesnake Mountain or from precipitation is not included in the present model. The model treats the Columbia River as a boundary that is held constant in time but variable in distance along the river, with numerical values obtained by 5 river stage gauges over a 1-year period (1992-3). The data are undocumented, but were collected using the protocol described by Campell (1994). No flow is allowed into basalt outcrops or into the bottom of the model (corresponding to the top of the underlying basalt unit or to the lower mud unit of the Ringold Formation).

As noted in Section 3.5.2.4.1, versions of this Hanford sitewide groundwater model have been used for earlier Hanford Site performance assessments.

3.5.3.4 Pumping Model. This model is similar to the ERC Hanford Sitewide Groundwater Model, but on a smaller scale. This model calculates the effect of various pumping rates at the well on the groundwater flow. The element size is 25 by $20 \mathrm{~m}$ ( 82 by $66 \mathrm{ft}$ ) and consists of four layers (Figure 3-9). Each layer has 2,400 elements and 2,501 nodes. The bottom of the model is flat, using an average value for the top of the basalt zone. Values of the hydraulic head from the sitewide model were used as boundary conditions.
Aquifer Model - 2

The pumping model treats groundwater flow only near the disposal site. 


\section{DOE/RL-97-69}

Rev, 0

Figure 3-9. Zone Map for Pumping Model. (Material types 7 and 12 from Table 3-10 are used.)

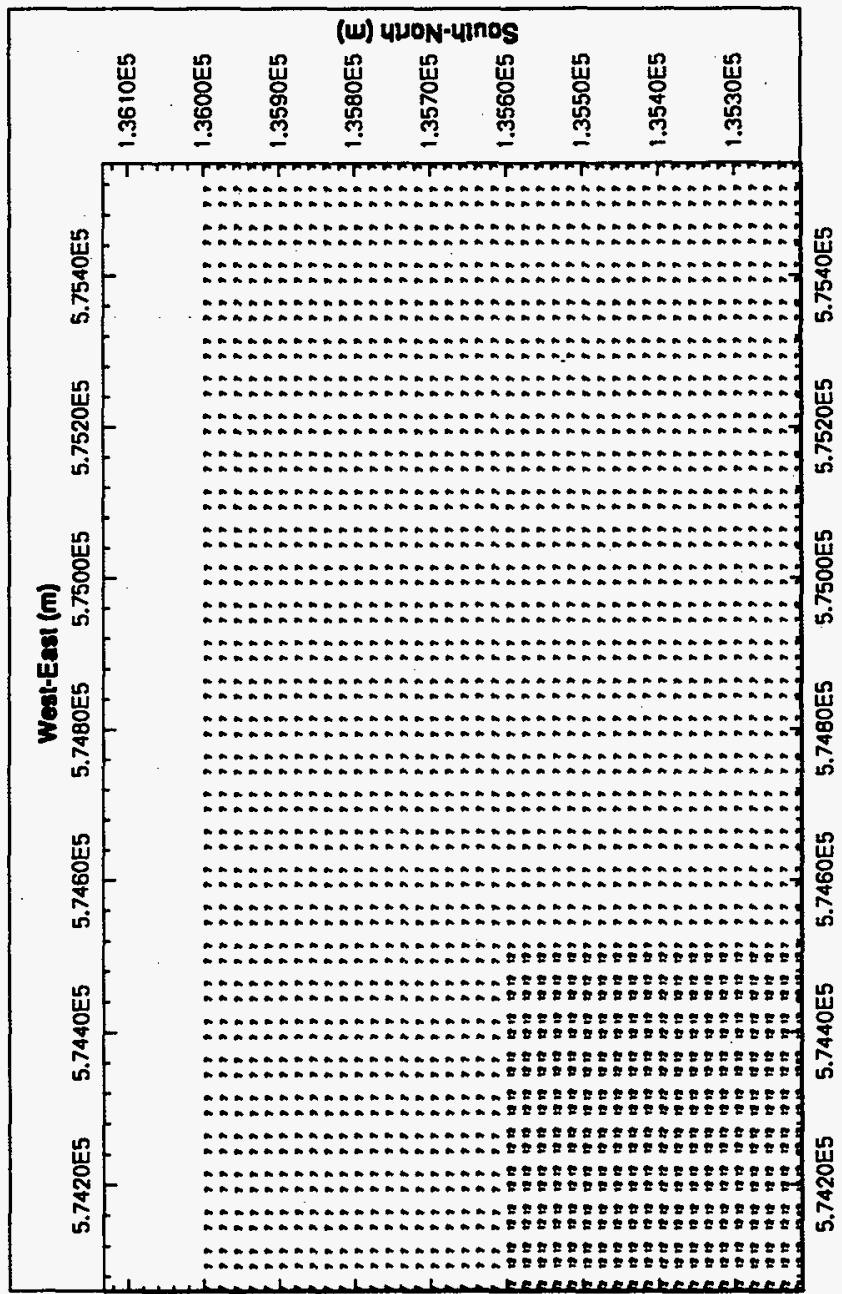


DOE/RL-97-69

Rev. 0

\subsubsection{Input Data}

This section specifies the data actually used in the computer models for the base analysis case. The intent is to follow the data given in Sections 3.2,3.3, and 3.4 as closely as possible. Data used in the sensitivity cases are given in Section 3.5.5.

Input Data

Table $3-15$ summarizes

the input data.

3.5.4.1 Contaminant Release Modeling. The contaminant release rate from the waste package is based on the request for proposal and on a time dependence derived in Section 3.4.4.

3.5.4.2 Vadose Zone Modeling. The same input data are used for both the disposal facility and the unit cell models. The input data used by both models for the base analysis case are summarized in Table 3-15. The actual input files for the base analysis case calculations are presented in Appendix D.5.

3.5.4.3 Aquifer Modeling. The aquifer models are based on a Hanford Site groundwater model (Law 1996). The hydrologic parameter data for the base analysis case are from Table 3-10 (Section 3.4.3.4). For the pump model, only material types 7 and 12 of the 18 types shown in Figures 3-3 and 3-4 were used.

The data set for the site model was calibrated and validated in three ways. The 1979 Hanford Site water tables were simulated using the known Hanford Site-related artificial recharges and assuming steady-state conditions. Second, the difference between the 1993 water table and the 1979 water table was calculated using a transient simulation. Finally, the movement of tritium plumes from 1979 to 1993 was simulated in a transient contaminant transport calculation. In all cases (Law 1996), good agreement was found between measured and simulated values.

3.5.4.4 Integration of Results. In addition to data already discussed, the input data for INTEG were taken from the output of the vadose zone and the aquifer models. Inventories were taken from Section 3.2.2. Dose conversion factors were taken from Section 3.3.5. 
DOE/RL-97-69

Rev, 0

Table 3-15. Base Analysis Case Input Data for the Disposal Facility and Unit Cell Models.

\begin{tabular}{|c|c|c|}
\hline Parameter & Value & $\begin{array}{l}\text { Section with Justification } \\
\text { for Using Value }\end{array}$ \\
\hline \multicolumn{3}{|l|}{ Soil Layering } \\
\hline $\begin{array}{l}\text { Hanford formation } \\
\text { Upper Gravel Sequence } \\
\text { Sand Sequence } \\
\text { Lower Gravel Sequence }\end{array}$ & $\begin{array}{l}6 \mathrm{~m}(20 \mathrm{ft}) \text { (on surface) } \\
60 \mathrm{~m}(197 \mathrm{ft}) \\
35 \mathrm{~m}(98 \mathrm{ft}) \text { (bottom) }\end{array}$ & Section 3.4.3.1 \\
\hline $\begin{array}{l}\text { Ringold Formation } \\
\text { Unit E }\end{array}$ & $30 \mathrm{~m}(98 \mathrm{ft})$, below Hanford formation & Section 3.4.3.1 \\
\hline \multicolumn{3}{|l|}{ Hydrologic Parameters } \\
\hline Vadose Zone Soil Layer & $\begin{array}{l}\text { Calculated based on curve-fitting parameters and } \\
\text { saturated hydraulic conductivity. See reference } \\
\text { section. }\end{array}$ & $\begin{array}{l}\text { Section } 3.4 .3 .2 \\
\text { (Values given in Table 3-6) }\end{array}$ \\
\hline Construction Material & $\begin{array}{l}\text { Calculated based on curve-fitting parameters and } \\
\text { saturated hydraulic conductivity. See reference } \\
\text { section. }\end{array}$ & $\begin{array}{l}\text { Section } 3.4 .3 .2 \\
\text { (Values given in Table 3-7) }\end{array}$ \\
\hline \multicolumn{3}{|l|}{ Infiltration Rate } \\
\hline $\begin{array}{l}\text { At the Disposal Facility } \\
\text { First } 1000 \text { years } \\
\text { After } 1000 \text { years }\end{array}$ & $\begin{array}{l}0.5 \mathrm{~mm} / \mathrm{y}(0.02 \mathrm{in} / \mathrm{y}) \\
3.0 \mathrm{~mm} / \mathrm{y}(0.12 \mathrm{in} / \mathrm{y})\end{array}$ & Section 3.4 .6 \\
\hline
\end{tabular}


DOE/RL-97-69

Rev. 0

Table 3-15. Base Analysis Case Input Data for the Disposal Facility and Unit Cell Models.

\begin{tabular}{|c|c|c|}
\hline Paramèter & Value & $\begin{array}{l}\text { Section with Justification } \\
\text { for Using Value }\end{array}$ \\
\hline \multicolumn{3}{|l|}{ Geochemical Parameters } \\
\hline $\begin{array}{l}\text { Chemical Distribution Coefficients }\left(\mathrm{K}_{\mathrm{d}}\right) \\
\mathrm{Se}, \mathrm{Tc}, \text { Others } \\
\mathrm{U} \\
\mathrm{Sr}, \mathrm{I} \\
\mathrm{Pa}, \mathrm{C} \\
\mathrm{Ra}, \mathrm{Np} \\
\mathrm{Ac}, \mathrm{Nb}, \mathrm{Am}, \mathrm{Ni}, \mathrm{Zr}, \mathrm{Pu}, \mathrm{Th} \\
\mathrm{Ce}, \mathrm{Cs}, \mathrm{Cm}, \mathrm{Eu}, \mathrm{Pb}, \mathrm{Co}, \mathrm{Sn}\end{array}$ & $\begin{array}{l}0.0 \mathrm{m \ell} / \mathrm{g} \\
0.6 \mathrm{m \ell} / \mathrm{g} \\
3.0 \mathrm{m \ell} / \mathrm{g} \\
6.0 \mathrm{m \ell} / \mathrm{g} \\
15 . \mathrm{m} \ell / \mathrm{g} \\
40 . \mathrm{m} \ell / \mathrm{g} \\
100 \mathrm{~m} \ell / \mathrm{g}\end{array}$ & Section 3.4 .3 .3 \\
\hline \multicolumn{3}{|l|}{ Contaminant Release Rate } \\
\hline $\begin{array}{l}\text { Relative Radionuclide } \\
\text { Release Rate }\end{array}$ & $\begin{array}{l}\text { Calculated release based on initial release rate and } \\
\text { time-dependent surface area. See reference } \\
\text { section. }\end{array}$ & $\begin{array}{l}\text { Section 3.4.4.3 } \\
\text { (Values given in Table } 3-11 \text { ) }\end{array}$ \\
\hline \multicolumn{3}{|l|}{ Disposal Facility Degradation } \\
\hline Concrete & degraded at 500 years & Section 3.4.5.7 \\
\hline Natural materials & $\begin{array}{l}\text { properties do not degrade, but system performance } \\
\text { changes because of materials rearrangement }\end{array}$ & Section 3.4.6.7 \\
\hline
\end{tabular}


Rev. 0

\subsubsection{Sensitivity Cases}

Sensitivity cases were run to determine the effect of various assumptions and data values. For most sensitivity cases, only one parameter or one set of parameters differs from the base analysis case or another sensitivity case. Thus, the change, if any, in the final answer will indicate the effect of that parameter on the overall answer. Table 3-16 summarizes the sensitivity cases. Sections 3.5.5.1 through 3.5.5.12 discuss the sensitivity cases and explain why each case was run.

3.5.5.1 Scenario-Dependent Sensitivity Cases. The scenario-dependent sensitivity cases are selected analyses to determine the extent to which results related to a scenario depend on selected values or assumptions. Several scenario-dependent cases were developed (Table 3-16). Land-use, drinking water, and catastrophic natural scenarios were considered (Section 3.3).

Predicting land use at the Hanford Site for the next 10,000 years is impossible. Natural conditions were assumed for the base analysis case (Section 3.3.2.2). For land-use sensitivity cases, the effect of various land uses were calculated. The following uses were examined:

- Irrigated farming on top of the disposal facility with an infiltration rate of $100 \mathrm{~mm} / \mathrm{y}(3.9 \mathrm{in} / \mathrm{y})$. Such irrigation is considered as an inadvertent intrusion. However, in this analysis such irrigation is calculated as part of the groundwater scenario, instead of part of the inadvertent intruder scenario.

- Irrigated farming in other parts of the Hanford Site Central Plateau with recharge rates of $100 \mathrm{~mm} / \mathrm{y}(3.9 \mathrm{in} / \mathrm{y})$. Such irrigation will distort the groundwater flow and change the water table height.

- Industrial use of the 200 Area, which is assumed to decrease the infiltration rate over the entire 200 Area by a factor of 2 , because water would be collected and then discharged at a point off the 200 Area Central Plateau.

The real value for the infiltration rate for irrigated farming is unknown. However, the value of $100 \mathrm{~mm} / \mathrm{y}(3.9 \mathrm{in} / \mathrm{y})$ is the lower value used in the Hanford Site grout performance assessment (Kincaid 1995) (the other value was $250 \mathrm{~mm} / \mathrm{y}$ ) and twice that used in the Hanford Site solid waste performance assessments (Wood 1994b and Wood 1996). These sensitivity cases treat only the effect of infittration on the unconfined aquifer; the effect of different water table heights (which could be caused by irrigation) is examined separately (See Section 3.5.5.4).

The drinking water scenario is based on the pumping rate and the location of the well. Minimal pumping $\left(0.01 \mathrm{~m}^{3} /\right.$ day $=10$ liters/day [2.6 gallons/day], corresponding to a family of five using the well only to obtain drinking water) is assumed for the base analysis case. As pumping is increased, water is taken from a wider area, resulting eventually in drawing in water that is uncontaminated. Pumping rates of 10 to $150 \mathrm{~m}^{3 / \text { day }}(2,640$ to 39,600 gallons/day) were used to determine the effect of the pumping rate on the overall drinking water dose. 


\section{DOE/RL-97-69}

Rev. 0

Table 3-16. List of Sensitivity Cases. Except for intrusion scenarios, the performance measures calculated were the drinking water dose and the all-pathways dose. For the intrusion scenarios, the acute and continuous doses were calculated.

\begin{tabular}{|c|c|c|}
\hline $\begin{array}{l}\text { Discussion } \\
\text { Section }\end{array}$ & $\begin{array}{l}\text { Sensitivity Case } \\
\text { (unless noted all cases treat groundwater scenario) }\end{array}$ & $\begin{array}{l}\text { Results } \\
\text { Presented in } \\
\text { Section }\end{array}$ \\
\hline \multicolumn{3}{|c|}{ Scenario } \\
\hline 3.5.5.1 & $\begin{array}{l}\text { Assume different parameters for intrusion scenario: Cases include garden size }=2,500 \mathrm{~m}^{2}\left[26,910 \mathrm{ft}^{2}\right] \text { rather } \\
\text { than } 500 \mathrm{~m}^{2}\left(5,382 \mathrm{ft}^{2}\right) \text { and diameter of the well }=0.2 \mathrm{~m}(8 \mathrm{in}) \text { rather than } 0.3 \mathrm{~m}(12 \mathrm{in}) \text {. }\end{array}$ & 4.2 .3 \\
\hline 3.5 .5 .1 & $\begin{array}{l}\text { Irrigated farming over the disposal facility, implying an infiltration rate of } 100 \mathrm{~mm} / \mathrm{y}(3.9 \mathrm{in} / \mathrm{y}) \text { forever, rather } \\
\text { than the base analysis case of } 0.5 \mathrm{~mm} / \mathrm{y}(0.02 \mathrm{in} / \mathrm{y}) \text { for first } 1,000 \text { years and } 3.0 \mathrm{~mm} / \mathrm{y}(0.12 \mathrm{in} / \mathrm{y}) \text { thereafter. }\end{array}$ & 4.7 .4 .3 \\
\hline 3.5 .5 .1 & $\begin{array}{l}\text { Assume irrigation occurs on Hanford Central Plateau. Cases studied are irrigation in all areas except } 200 \\
\text { Areas and region between } 200 \text { East and } 200 \text { West Areas, irrigation only north of } 200 \text { Areas, and irrigation } \\
\text { only west of } 200 \text { Areas. In base analysis case, no irrigation is assumed. }\end{array}$ & 4.8.3.3 \\
\hline 3.5 .5 .1 & Assume industry in 200 Areas (recharge reduced in 200 Areas by a factor of 2). & 4.8.3.3 \\
\hline 3.5.5.1 & $\begin{array}{l}\text { Assume different well locations, ranging from } 100 \mathrm{~m}(328 \mathrm{ft}) \text { downgradient from the disposal facility to the } \\
\text { Columbia River. Base analysis case assumes well is } 100 \mathrm{~m}(328 \mathrm{ft}) \text { downgradient. }\end{array}$ & 4.8.3.5 \\
\hline 3.5 .5 .1 & $\begin{array}{l}\text { Assume different pumping rates at the well, }\left(10 \mathrm{~m}^{3} / \mathrm{d}[2,640 \mathrm{gal} / \mathrm{day}], 50 \mathrm{~m}^{3} / \mathrm{d}[13,200 \mathrm{gal} / \mathrm{d}], 100 \mathrm{~m}^{3} / \mathrm{d}\right. \\
\left.[26,400 \mathrm{gal} / \mathrm{d}] \text {, and } 150 \mathrm{~m}^{3} / \mathrm{d}[39,600 \mathrm{gal} / \mathrm{d}]\right) \text { instead of the rate of } 0.01 \mathrm{~m}^{3} / \mathrm{d}[10 \mathrm{l} / \mathrm{d}=2.6 \mathrm{gal} / \mathrm{day}] \mathrm{used} \text { in the } \\
\text { base analysis case. }\end{array}$ & 4.8.3.6 \\
\hline 3.5.5.1 & Treat natural events, such as glacial-age flooding. & 4.11 \\
\hline
\end{tabular}




\section{DOE/RL-97-69}

Rev. 0

Table 3-16. List of Sensitivity Cases. Except for intrusion scenarios, the performance measures calculated were the drinking water dose and the all-pathways dose. For the intrusion scenarios, the acute and continuous doses were calculated.

\begin{tabular}{|c|c|c|}
\hline $\begin{array}{l}\text { Discussion } \\
\text { Section }\end{array}$ & $\begin{array}{l}\text { Sensitivity Case } \\
\text { (unless noted all cases treat groundwater scenario) }\end{array}$ & $\begin{array}{c}\text { Results } \\
\text { Presented in } \\
\text { Section }\end{array}$ \\
\hline \multicolumn{3}{|c|}{$\begin{array}{l}\text { Inventory } \\
\text { (The middle two sensitivity cases also affect the inadvertent intruder scenario) }\end{array}$} \\
\hline 3.5 .5 .2 & $\begin{array}{l}\text { Changes in inventory caused by TWRS Privatization Effort. Cases assumes that only } 20 \% \text { of the }{ }^{99} \mathrm{Tc} \\
\text { inventory of the base analysis case is disposed of in the facility. }\end{array}$ & 4.8 .2 \\
\hline 3.5.5.2 & Changes to reflect values in TWRS standard inventory $\left({ }^{137} \mathrm{Cs},{ }^{79} \mathrm{Se},{ }^{12} \mathrm{Sn},{ }^{99} \mathrm{Tc}\right.$, and U). & $4.2 .3,4.8 .2$ \\
\hline 3.5 .5 .2 & Changes to reflect new half-life values for ${ }^{79} \mathrm{Se}$ and ${ }^{12 \pi} \mathrm{Sn}$. & $4.2 .3,4.8 .2$ \\
\hline 3.5 .5 .2 & Arbitrary changes in inventory to determine sensitivity $\left({ }^{129},{ }^{79} \mathrm{Se}, \mathrm{U}\right)$. & 4.8 .2 \\
\hline \multicolumn{3}{|c|}{ Recharge } \\
\hline 3.5.5.3 & $\begin{array}{l}\text { Recharge rate }=3.0 \mathrm{~mm} / \mathrm{y}(0.12 \mathrm{in} / \mathrm{y}) \text { forever. The base analysis case used } 0.5 \mathrm{~mm} / \mathrm{y}(0.042 \mathrm{in} / \mathrm{y}) \text { for the first } \\
1,000 \text { years, and } 3.0 \mathrm{~mm} / \mathrm{y} \text { thereafter. }\end{array}$ & 4.7.4.2 \\
\hline 3.5 .5 .3 & Recharge rate $=1.0 \mathrm{~mm} / \mathrm{y}(0.04 \mathrm{in} / \mathrm{y})$ forever. & 4.7 .4 .2 \\
\hline 3.5.5.3 & Recharge rate $=0.1 \mathrm{~mm} / \mathrm{y}(0.004 \mathrm{in} / \mathrm{y})$ forever. & 4.7.4.2 \\
\hline \multicolumn{3}{|c|}{ Geology } \\
\hline 3.5 .5 .4 & $\begin{array}{l}\text { Top of unconfined aquifer is at } 96 \mathrm{~m}(315 \mathrm{ft}) \text { below the surface. In the base analysis case, the top of the } \\
\text { aquifer is at } 103 \mathrm{~m}(338 \mathrm{ft}) \text { below the surface. }\end{array}$ & 4.7 .2 .3 \\
\hline 3.5.5.4 & 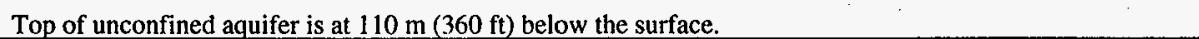 & 4.7 .2 .3 \\
\hline
\end{tabular}




\section{DOE/RL-97-69}

Rev, 0

Table 3-16. List of Sensitivity Cases. Except for intrusion scenarios, the performance measures calculated were the drinking water dose and the all-pathways dose. For the intrusion scenarios, the acute and continuous doses were calculated.

\begin{tabular}{|c|c|c|}
\hline $\begin{array}{l}\text { Discussion } \\
\text { Section }\end{array}$ & $\begin{array}{l}\text { Sensitivity Case } \\
\text { (unless noted all cases treat groundwater scenario) }\end{array}$ & $\begin{array}{c}\text { Results } \\
\text { Presented in } \\
\text { Section }\end{array}$ \\
\hline \multicolumn{3}{|c|}{ Facility } \\
\hline 3.5.5.5 & $\begin{array}{l}\text { Reduce radionuclide density in disposal facility by a factor of } 2 \text { by increasing the number of vault rows by a } \\
\text { factor of } 2 \text {. For example, this might result from having a lower waste loading in each of the packages. }\end{array}$ & 4.6.2.2 \\
\hline 3.5.5.5 & Rotate the disposal facility $90^{\circ}$. Long side now oriented north-south. & 4.6.2.3 \\
\hline 3.5.5.5 & Shorter sand-gravel capillary barrier (Concept 2 layout). Base analysis case used Concept 1 layout. & 4.6.2.4 \\
\hline 3.5.5.5 & Sand-gravel capillary barrier in facility design replaced with back-filled soil. & 4.6.3.2 \\
\hline 3.5.5.5 & Side sand-gravel capillary barrier in facility design replaced with back-filled soil. & 4.6.3.3 \\
\hline 3.5 .5 .5 & Sand used as filler material inside the disposal facility instead of back-filled soil. & 4.6.3.4 \\
\hline \multicolumn{3}{|c|}{ Degradation } \\
\hline 3.5.5.6 & $\begin{array}{l}\text { Concrete floors, walls, and ceiling degrade at } 2,000 \text { years to test "bath tub effect." Base analysis case has all } \\
\text { concrete degrading at } 500 \text { years. }\end{array}$ & 4.6 .4 \\
\hline 3.5 .5 .6 & $\begin{array}{l}\text { Degraded sand-gravel capillary barrier. (The degradation point is at } 2 / 3^{*} \ell \text { from the apex of the barrier where } \ell \\
\text { is half the width of the barrier.) }\end{array}$ & 4.6 .4 \\
\hline
\end{tabular}




\section{DOE/RL-97-69}

Rev. 0

Table 3-16. List of Sensitivity Cases. Except for intrusion scenarios, the performance measures calculated were the drinking water dose and the all-pathways dose. For the intrusion scenarios, the acute and continuous doses were calculated.

\begin{tabular}{|c|c|c|}
\hline $\begin{array}{l}\text { Discussion } \\
\text { Section }\end{array}$ & $\begin{array}{l}\text { Sensitivity Case } \\
\text { (unless noted all cases treat groundwater scenario) }\end{array}$ & $\begin{array}{c}\text { Results } \\
\text { Presented in } \\
\text { Section }\end{array}$ \\
\hline \multicolumn{3}{|c|}{ Hydrologic Parameters } \\
\hline 3.5.5.7 & $\begin{array}{l}\text { Change hydrologic parameters in vadose zone so that the entire zone has parameters corresponding to the } \\
\text { Hanford formation sandy sequence instead of the varying sequences. }\end{array}$ & 4.7.2.3 \\
\hline 3.5.5.7 & $\begin{array}{l}\text { Change hydrologic parameters in vadose zone so that the bottom half of the zone has parameters } \\
\text { corresponding to the Hanford formation gravelly sand sequence instead of the Ringold Formation. }\end{array}$ & 4.7.2.3 \\
\hline 3.5 .5 .7 & Change diffusion constant for the vadose zone to $1.00 \times 10^{-6} \mathrm{~cm}^{2} / \mathrm{sec}$ from $1.25 \times 10^{-7} \mathrm{~cm}^{2} / \mathrm{sec}$. & 4.7 .2 .3 \\
\hline \multicolumn{3}{|c|}{ Waste Form } \\
\hline 3.5.5.8 & Waste form is a thin plate, implying a time-independent radionuclide release rate. & 4.4 .3 .2 \\
\hline 3.5.5.8 & $\begin{array}{l}{ }^{99} \mathrm{Tc} \text { release rate reduced by a factor of } 5 \text { from the base analysis case. Thus, the technetium release rate is that } \\
\text { given in the request for proposal. }\end{array}$ & 4.4 .3 .3 \\
\hline 3.5 .5 .8 & All $K_{d}=0$ elements release rate reduced by factor of 5 . & 4.4.3.3 \\
\hline 3.5.5.8 & Release rate for all elements reduced by factor of 5 . & 4.4.3.3 \\
\hline 3.5.5.8 & $\begin{array}{l}\text { Contaminant release rate from glass (in the form of marbles) as calculated by mechanistic models, including } \\
\text { sodium ion exchange. Contaminants transported to floor of vault. }\end{array}$ & 4.4.3.4 \\
\hline 3.5.5.8 & $\begin{array}{l}{ }^{99} \mathrm{Tc} \text { release from glass marbles determined by mechanistic models, but with sodium ion exchange. } \\
\text { Contaminants transported to floor of vault. }\end{array}$ & 4.4.3.4 \\
\hline 3.5.5.8 & $\begin{array}{l}{ }^{99} \mathrm{Tc} \text { release from glass marbles determined by mechanistic model, with sodium ion exchange. Contaminants } \\
\text { transported to floor of vault with pore velocity of } 10 \mathrm{~cm} / \mathrm{y} \text {. }\end{array}$ & 4.4 .3 .4 \\
\hline
\end{tabular}




\section{DOE/RL-97-69}

Rev. 0

Table 3-16. List of Sensitivity Cases. Except for intrusion scenarios, the performance measures calculated were the drinking water dose and the all-pathways dose. For the intrusion scenarios, the acute and continuous doses were calculated.

\begin{tabular}{|c|c|c|}
\hline $\begin{array}{l}\text { Discussion } \\
\text { Section }\end{array}$ & $\begin{array}{l}\text { Sensitivity Case } \\
\text { (unless noted all cases treat groundwater scenario) }\end{array}$ & $\begin{array}{c}\text { Results } \\
\text { Presented in } \\
\text { Section }\end{array}$ \\
\hline \multicolumn{3}{|c|}{ Geochemical } \\
\hline 3.5 .5 .9 & For uranium: $\mathrm{K}_{\mathrm{d}}=0$ instead of $0.6 \mathrm{~m} / \mathrm{g}$ as was used in the base analysis case. & 4.7 .3 \\
\hline 3.5 .5 .9 & For uranium: $K_{d}=0$ in vadose zone and $K_{d}=100 \mathrm{~m} / \mathrm{g}$ in concrete. & 4.7 .3 \\
\hline 3.5.5.9 & For iodine, $K_{d}=0.6 \mathrm{ml} / \mathrm{g}$ instead of $3 \mathrm{ml} / \mathrm{g}$ in the base analysis case & 4.7 .3 \\
\hline 3.5 .5 .9 & For major elements (selenium and technetium): $\mathrm{K}_{d}=0.1 \mathrm{~m} / \mathrm{g}$ instead of 0 . & 4.7 .3 \\
\hline \multicolumn{3}{|c|}{ Exposure } \\
\hline 3.5.5.10 & $\begin{array}{l}\text { Different dose factor sets. The dose factor libraries from DOE, EPA, and GENII computer analyses were } \\
\text { used instead of taking internal dose factors from DOE and external dose factors from EPA. }\end{array}$ & 4.8 .4 \\
\hline 3.5.5.10 & Use different ingestion, inhalation, and time of exposure values from base analysis case. & 4.8 .4 \\
\hline \multicolumn{3}{|c|}{ Location of Facility } \\
\hline 3.5 .5 .11 & $\begin{array}{l}\text { Location of facility at existing TWRS disposal (grout) vaults which are east of the PUREX Facility, rather } \\
\text { than at the proposed location west of PUREX. }\end{array}$ & 4.8 .5 \\
\hline
\end{tabular}




\section{DOF/RL-97-69 \\ Rev. 0}

Table 3-16. List of Sensitivity Cases. Except for intrusion scenarios, the performance measures calculated were the drinking water dose and the all-pathways dose. For the intrusion scenarios, the acute and continuous doses were calculated.

\begin{tabular}{|l|l|l|}
\hline \multicolumn{1}{|c|}{$\begin{array}{c}\text { Discussion } \\
\text { Section }\end{array}$} & \multicolumn{3}{|c|}{$\begin{array}{c}\text { Sensitivity Case } \\
\text { (unless noted all cases treat groundwater scenario) }\end{array}$} & $\begin{array}{c}\text { Results } \\
\text { Presented in } \\
\text { Section }\end{array}$ & \multicolumn{2}{|c|}{ Calculations } \\
\hline 3.5 .5 .12 & Halved dispersion of base analysis case for vadose zone contaminant transport. & 4.7 .2 .3 \\
\hline 3.5 .5 .12 & Doubled dispersion of base analysis case for vadose zone contaminant transport. & 4.7 .2 .3 \\
\hline 3.5 .5 .12 & Doubled number of grid points from base analysis case for vadose zone flow and transport. & 4.8 .6 \\
\hline 3.5 .5 .12 & $\begin{array}{l}\text { Initial volumetric moisture content in the disposal facility = residual moisture content of material, rather than } \\
10 \% \text { as in the base analysis case. }\end{array}$ & 4.8 .6 \\
\hline 3.5 .5 .12 & Initial volumetric moisture content in disposal facility $=20 \%$. & 4.8 .6 \\
\hline
\end{tabular}




\section{DOE/RL-97-69}

Rev. 0

In the base analysis case, the well is assumed to be $100 \mathrm{~m}(328 \mathrm{ft})$ downgradient from the disposal facility. To determine the effect of the well position, the well was located as near as $50 \mathrm{~m}$ (164 ft) and at various other distances (including the 200 Area fence line) along flow lines down to the Columbia River.

Finally, the effects of catastrophic natural events were evaluated. The base analysis case does not evaluate a catastrophic natural event. Neither seasonal flooding nor even the collapse of the region's largest dam would cause water to reach the disposal facility. However, a catastrophic ice-age flood similar to those that occurred over 10,000 years ago, would affect the disposal facility and is analyzed.

3.5.5.2 Inventory-Dependent Sensitivity Cases. The inventory of radionuclides that will be in the waste form is uncertain. The inventory in the waste form depends on the amount and type of waste presently stored in the Hanford Site tanks, the process used to separate tank waste into low-activity and high-level waste streams, and the method of immobilization. At present, the separation process that the private vendors will use is unknown, as are the details of the immobilization method. These sensitivity cases are designed to evaluate the effect of different amounts of key radioisotopes.

One sensitivity case was based on a possible strategy for reducing technetium release rates. In the request for proposal, the total ${ }^{99} \mathrm{Tc}$ release rate is specified at a level five times lower than for other radionuclides. One strategy for achieving this reduced release rate is to reduce the amount of technetium by 80 percent. Such a sensitivity case was run.

The TWRS standard inventory effort has produced slightly different inventories for a number of key radionuclides: ${ }^{137} \mathrm{Cs},{ }^{79} \mathrm{Se},{ }^{126} \mathrm{Sn},{ }^{99} \mathrm{Tc}$, and uranium. The effect of using the TWRS standard inventory values was determined.

Because the accepted half-lives of ${ }^{79}$ Se and ${ }^{126} \mathrm{Sn}$ now have increased, their inventory values (when expressed as activity) have decreased. The effect of this decrease was determined.

The degree to which iodine will be volatilized in the immobilization operation (and hence not be in the final waste form) is unknown. For the base analysis case, it was assumed that 90 percent of the iodine will be volatilized. A sensitivity case of 50 percent of the iodine being volatilized was performed.

In the supporting document (WHC 1996) for the DOE petition to the NRC for the separated waste to be considered as non-high-level waste, various uncertainty bands are given. The amount of cesium separation may be different from what is assumed in the base analysis case. A sensitivity case increasing the amount of ${ }^{137} \mathrm{Cs}$ from $0.451 \mathrm{MCi}$ to $5.0 \mathrm{MCi}$ was performed.

3.5.5.3 Infiltration-Dependent Sensitivity Cases. The infiltration rate is one of the most important parameters of the calculation (Section 3.4.6). Besides the sensitivity case of $100 \mathrm{~mm} / \mathrm{y}(3.9 \mathrm{in} / \mathrm{y})$ mentioned in Section 3.5.5.1, three additional cases involving different recharge rates were run. The base analysis case used $0.5 \mathrm{~mm} / \mathrm{y}(0.02 \mathrm{in} / \mathrm{y})$ for the first 
1,000 years, followed by a rate of $3.0 \mathrm{~mm} / \mathrm{y}(0.12 \mathrm{in} / \mathrm{y})$. The furst sensitivity case models the case of extremely low recharge $(0.1 \mathrm{~mm} / \mathrm{y})[0.004 \mathrm{in} / \mathrm{y}]$. The second case uses the same rate as the Hanford Grout Performance Assessment (Kincaid 1995) $(1.0 \mathrm{~mm} / \mathrm{y})[0.04 \mathrm{in} / \mathrm{y}]$, allowing comparisons to be made with that analysis. The final case used a recharge rate of $3.0 \mathrm{~mm} / \mathrm{y}$ $(0.12 \mathrm{in} / \mathrm{y})$. This case shows the effectiveness of the surface barrier, because the difference between this sensitivity case and the base analysis case is the recharge rate for the first 1,000 years. The recharge rate in the latter case was based on the presence of the surface barrier.

3.5.5.4 Geology-Dependent Sensitivity Cases. An understanding of the geologic strata is the starting point for the vadose zone simulations. Most of the sensitivity studies that are partially derived from geologic considerations are described in Sections 3.5.5.7 and 3.5.5.9. The sensitivity cases considered in this section deal with the location of the top of the unconfined aquifer. The effects of contaminant transport in both the vadose zone and in the unconfined aquifer were calculated.

Sensitivity cases were developed that place the top of the unconfined aquifer above and below the position given in the base analysis case, $103 \mathrm{~m}$ ( $338 \mathrm{ft}$ ) below the surface. One case

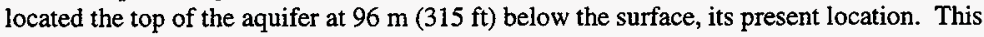
location is in the Hanford formation; the base analysis case had the aquifer in the Ringold Formation. This is an indirect way to study the influence of the hydrologic parameters.

The other sensitivity case located the top of the aquifer at $110 \mathrm{~m}(360 \mathrm{ft})$ below the surface. (In this case, the aquifer was deeper than the location used in the base analysis case by the same amount as the previous case was shallower than the value of the base analysis case. The deeper location results in a larger vadose zone, resulting in longer contaminant travel time through the vadose zone.

3.5.5.5 Facility-Dependent Sensitivity Cases. The design of the disposal facility has not yet started, so the model used in the base analysis case has significant uncertainties. Several sensitivity cases were studied to determine the importance of various design features.

Three sensitivity cases deal with the sand-gravel capillary barrier proposed for the top and sides of the disposal facility. The first case has no capillary barrier at all. The second case has the barrier only at the top of the facility. The third case used the Concept 2 layout (Section 3.4.5.2), which has a much shorter barrier.

Another case replaces the soil between the stacks of containers with sand to examine the effect of the hydrologic properties of the filler material. The hydrologic properties determine the "wicking" action of material.

Two additional sensitivity cases deal with the geometry of the disposal facility. In one case, the facility is rotated to determine the effect of facility orientation on contaminant concentration in the well compared to contaminant concentration at the bottom of the vadose zone. The second case doubles the area of the facility, while keeping the total inventory of radionuclides constant. This simulates a decrease in radionuclide density, which could result from lower waste loadings, different spacing between the containers, or other reasons. 


\section{DOE/RL-97-69 \\ Rev, 0}

3.5.5.6 Facility Degradation-Dependent Sensitivity Cases. Four sensitivity cases test the importance of assumptions made about facility degradation for the base analysis case. These assumptions were that natural materials do not degrade but that manufactured materials, such as concrete, degrade at 500 years (Section 3.4.5.7).

Two cases deal with the degradation of the concrete walls, floors, and ceilings. In the first case, the concrete degrades to gravelly sand at the time of closure. No credit is taken for concrete as a physical barrier. The second case determines the effect of the concrete structure trapping water then releasing it all at once. This so-called "bathtub effect" is modeled by having the concrete ceiling and the upper parts of the concrete walls degrade at 500 years but the concrete floor degrades at 2,000 years.

A group of sensitivity cases focuses on the effects of a degrading sand-gravel capillary barrier. The degradation of the capillary barrier is modeled by having the capillary barrier subside at a point two-thirds of the way down the length of the barrier. The cases run were based on different amounts of subsidence.

3.5.5.7 Hydrologic Parameter-Dependent Sensitivity Cases. Hydrologic properties are expected to vary spatially. To determine the importance of different hydrologic parameters, large changes in these parameters were made in the vadose zone calculation. For the base analysis case, the Hanford formation was assumed to have the hydrologic properties of gravelly sand for the top 6 percent, sand for the middle 60 percent, and gravelly sand for the bottom 34 percent. The first sensitivity case assumes that the entire formation has the properties of sand. The second assumes that the hydrologic properties correspond to gravelly sand for the top 6 percent, sand for the next 44 percent, and gravelly sand for the bottom 50 percent.

A separate sensitivity case looked at the importance of diffusion. The diffusion constant was changed from $1.27 \times 10^{-7} \mathrm{~cm}^{2} / \mathrm{s}$ to $1 \times 10^{-6} \mathrm{~cm}^{2} / \mathrm{s}$.

3.5.5.8 Waste Form-Dependent Sensitivity Cases. Waste form-dependent sensitivity cases were made to relate the effects of assumptions about the waste form on the overall source term component of the analysis. For the base analysis case, the contaminant release rate was based on the initial fractional radionuclide release rate (Section 3.4.4.3) given for elements other than technetium in the TWRS privatization specification (DOE-RL 1996). Also, because the waste form was unspecified, it was assumed to be a large cube that fits in the container. The related sensitivity cases focus on changes in the contaminant release rate and the waste form.

Two main sensitivity cases dealt with alternative interpretations of the waste form performance in the request for proposal (DOE-RL 1996). The first assumed the release rates were independent of time. This is equivalent to assuming that corrosion is only important in one dimension (for example if the waste form were a series of plates) or that the surface-to-volume ratio stays constant as a function of time. Because of the decrease in size of a waste form unit, the surface-to-volume ratio would normally decrease with size, unless cracking becomes important. The second sensitivity case assumes that, for some reason (for example, precipitation into a stable compound or incorporation into an altered glass phase), the release 


\section{DOE/RL-97-69 \\ Rev. 0}

rate for technetium was a factor of five less than for the other elements. The effect of a reduced release rate for all elements or for just $\mathrm{K}_{\mathrm{o}}=0$ elements also was calculated.

The final sensitivity cases used a mechanistic approach to determine the contaminant release rate, rather than using the specifications in the RFP. The AREST-CT computer code (Section 3.5.2.2) simulated the corrosion of LD6-5412 glass, the release of contaminants into the water, the formation of secondary mineral phases, and then the transport of contaminants out of the waste package. For these calculations (see Appendix $\mathrm{C}$ for details), spheres 1 centimeter in diameter surrounded by a sand matrix were used. The glass made up 70 percent of the volume. Such assumptions led to a surface area that is 27 times larger than the surface area of a nonfractured monolithic $1.2 \times 1.2 \times 1.8 \mathrm{~m}$ cube. An average pore velocity of $1 \mathrm{~cm} / \mathrm{y}$ was used for the transport calculations. Two additional sensitivity cases were performed around this sensitivity case. The first case assumed that the only reaction involving glass was the glass corrosion reaction (and that the sodium in the glass was not preferentially leached out). The second additional case involved a pore velocity of $10 \mathrm{~cm} / \mathrm{y}$. The results of these calculations (which yield time- and spatial-dependent release rates) are presented in Section 4.4.2.

3.5.5.9 Geochemical-Dependent Sensitivity Cases. The values for chemical distribution coefficients, $K_{d}$, can vary with environmental conditions (Kaplan 1995a). This means that as a contaminant moves from the disposal facility environment to the vadose zone, the $\mathrm{K}_{\mathrm{d}}$ value for the contaminant will change. However, in the base analysis case, the $\mathrm{K}_{\mathrm{d}}$ values were assumed not to vary as the contaminants move through the disposal system and the vadose zone. To determine the sensitivity to different $K_{d}$ values, a series of sensitivity cases for the most important elements was defined.

Two cases involve the $K_{d}$ for uranium. The first used a reduced value for the $K_{d}$ value for uranium. The value was reduced from $0.6 \mathrm{~m} / \mathrm{g}$ to 0 throughout the system. A uranium $\mathrm{K}_{\mathrm{d}}$ value of 0 has been used in other Hanford Site performance assessments (Wood 1994b, Kincaid 1995, Wood 1995, and Wood 1996). The other case used 0 as the $K_{d}$ value of uranium everywhere except in concrete, where the $\mathrm{K}_{\mathrm{d}}$ value was $100 \mathrm{~m} / \mathrm{g}$ (Krupka 1995).

Reanalysis of Hanford Site $\mathrm{K}_{\mathrm{d}}$ values for the Hanford Site Composite Analysis (Kincaid 1998) have reconfirmed most of the values used in the base analysis case. However, in the case of iodine, the $K_{d} v a l u e$ used in the base analysis case $(3 \mathrm{~m} / \mathrm{g})$ is now thought to be high and a lower value $(0.6 \mathrm{~m} / \mathrm{g})$ is more appropriate. A sensitivity case was run using this lower iodine $\mathrm{K}_{\mathrm{d}}$ value.

The best present knowledge for the chemical distribution coefficients for technetium and selenium is that these elements do not sorb on sediments present on the Hanford Site. This is why the $K_{d}$ value used in the base analysis case for each element was 0 . However, a sensitivity case using $0.1 \mathrm{~m} / \mathrm{g}$ was created to quantify the effect of a small amount of retardation to determine the value of on-going experiments to determine non-zero $\mathrm{K}_{\mathrm{d}}$ values for very mobile contaminants. 


\section{Rev, 0}

3.5.5.10 Exposure Parameter-Dependent Cases. Many dosimetry parameters have been proposed. To determine the sensitivity to the parameters chosen for the base analysis case, different parameter sets were used in sensitivity cases. Separate sensitivity runs were made with the dose factor sets from the DOE, EPA, and GENII computer analyses. The dose factor values are given in Rittmann (1995). In addition, the sensitivity to ingestion rates, inhalation rates, and time of exposure was calculated.

3.5.5.11 Location of the Facility. The base analysis case assumed that a single disposal facility would exist in the south central part of the 200 East Area. However, some of the immobilized waste will be placed in the existing vaults at the eastern edge of the 200 East Area. These vaults were built to hold grouted waste from the double-shell tanks. Sensitivity studies were made to determine the long-term impacts from placing part of the waste in these vaults.

3.5.5.12 Calculational Assumption-Dependent Sensitivity Cases. The previous sections addressed uncertainties related to data about natural and manufactured materials. However, uncertainties based on the calculational methods used must be addressed. Sensitivity cases were defined to address steady-state versus transient calculations and the effects of the number of grid points, dispersion, and initial moisture content.

In any computer representation, a finite number of spatial elements must represent an infinite number of points. A sensitivity case using double the number of grid points shows the effect of grid size and spacing.

Dispersion of contaminants, especially on the large scales represented in these analyses, is quite uncertain. A series of dispersion values was used to determine the sensitivity of the calculations to this parameter.

Finally, the initial moisture content in the disposal facility was varied to determined the importance of this initial condition. The base analysis case used 10-percent moisture content as the initial value. One sensitivity case used the residual moisture content $\left(\theta_{r}\right.$ from Section 3.4.4.2) as the initial moisture content for each soil type. The other sensitivity case used a value of 20 percent, twice that used in the base analysis case. 


\subsection{RESULTS OF ANALYSES}

\subsection{INTRODUCTION}

This chapter presents the results of the analyses described in Chapter 3. It also discusses the data and methods affecting those results. The emphasis of this chapter is not on the computational results per se, but rather on understanding the suite of analyses. Thus many of the numerical results will be found in Appendix E, "Detailed Results."

This chapter is divided into four parts, organized by scenario:

- The results from the groundwater scenarios, including the impact on surface water (Sections 4.2 - 4.9)

- The results of catastrophic events (Section 4.10)

- The ALARA analysis (Section 4.11)

- The results from the releases to air (Section 4.12)

For each scenario, the all-pathway dose is calculated.

\subsection{RESULTS OF GROUNDWATER SCENARIOS - BASE ANALYSIS CASE}

\subsubsection{Overview}

This section presents the results of the analyses for the base analysis groundwater contamination case. This section provides the results

\section{Groundwater Presentation}

The groundwater scenario is covered in many sections, so various key points can be emphasized in context. for the base analysis case. The following sections provide the sensitivity analyses:

- Section 4.3 (sensitivity cases on which other sensitivity cases are based)

- $\quad$ Section 4.4 (waste form sensitivity)

- Section 4.5 (facility design sensitivity)

- Section 4.6 (contaminant transport sensitivity)

- Section 4.7 (other factors).

Section 4.8 describes the effect of other Hanford Site activities on the groundwater affected by this disposal action. Section 4.9 puts into context the information given in Sections 4.2 through 4.8. 


\section{DOE/RL-97-69}

\section{Rev. 0}

Section 3.3 described the specific scenarios encompassed by the groundwater scenario. Section 3.4 presented the values used for the parameters.

Each analysis case depends on three key calculations:

- The release rate of contaminants from the waste form

- The transport of those contaminants to the aquifer.

- The transport through the aquifer to a person.

For the base analysis case, the release rate of contaminants from the waste form is derived from the TWRS Privatization Specifications (DOE-RL 1996). This section presents numerical simulation results for the transport of the contaminants through the vadose zone, the transport through the unconfined aquifer, and the integration of those simulation results.

\subsubsection{Vadose Zone Transport}

Once the contaminants are released from the waste form and the disposal facility, they slowly move

Vadose Zone

The vadose zone provides a delay of many thousands of years before the contaminants reach the groundwater downward through the unsaturated soil (the "vadose zone") beneath the disposal facility. At the Hanford Site this zone is characterized by very low moisture content (less than 10 percent of void volume).

4.2.2.1 Presentation of Vadose Zone Results. Vadose zone calculations were performed for a waste form containing a unit inventory (i.e. 1 curie). Such calculations assume that the interactions among different chemical constituents from the waste form are small in the vadose zone. Such an assumption is valid because of the low rate and small concentration of contaminants in the vadose zone.

Because the vadose zone calculations are based on a unit inventory, the results of the vadose zone transport calculations are a contaminant flux through the vadose zone to the groundwater normalized to a unit amount of inventory for that radionuclide. Because the calculations integrate over the area of the disposal facility, the units of the normalized flux become $\mathrm{yr}^{-1}$.

Because the radionuclide release from the waste form extends over many hundreds of thousands of years, the normalized contaminant flux at the bottom of the vadose zone appears to be a step function with a fairly sharp rise (see Figure 4-1). Such a curve can be characterized by three numbers:

- The maximum value of the normalized flux

- The time at which the curve reaches half the maximum value

- The time at which the contaminant flux first appears at the bottom of the vadose zone (taken here as the time the flux is $10^{-6}$ of the maximum value). 


\section{DOE/RL-97-69}

Rev. 0

These three values, along with the value for the compliance time of 10,000 years will be tabulated for each calculation. When a graphical comparison of different calculations yields insight, figures also will be displayed. Appendix E contains tables and figures that provide more information.

The curve has this shape because the length of time during which contaminants are released from the disposal facility is so much longer than the travel time for those contaminants in the vadose zone. Thus, the temporal shape of the contaminant flux at the bottom of the vadose zone is determined from the time dependence of the release from the waste form (or waste disposal facility) rather than from the time dependence of vadose zone transport. Appendix E.1 contains a mathematical justification of this effect. This "step" shape is different from the quickly rising, slowly decaying peaked shapes often seen in performance assessments. The shape of the rise of the "step" function is mainly governed by the same parameters (dispersion, travel time, and travel distance) that provide the width of typical vadose calculations.

Figure 4-1. General Characteristics of Vadose Zone Transport. The normalized contaminant flux to the aquifer is shown for the simulation of Concept 2 , constant release rate from waste form, full-facility model for a long-lived radionuclide that experiences no absorption.

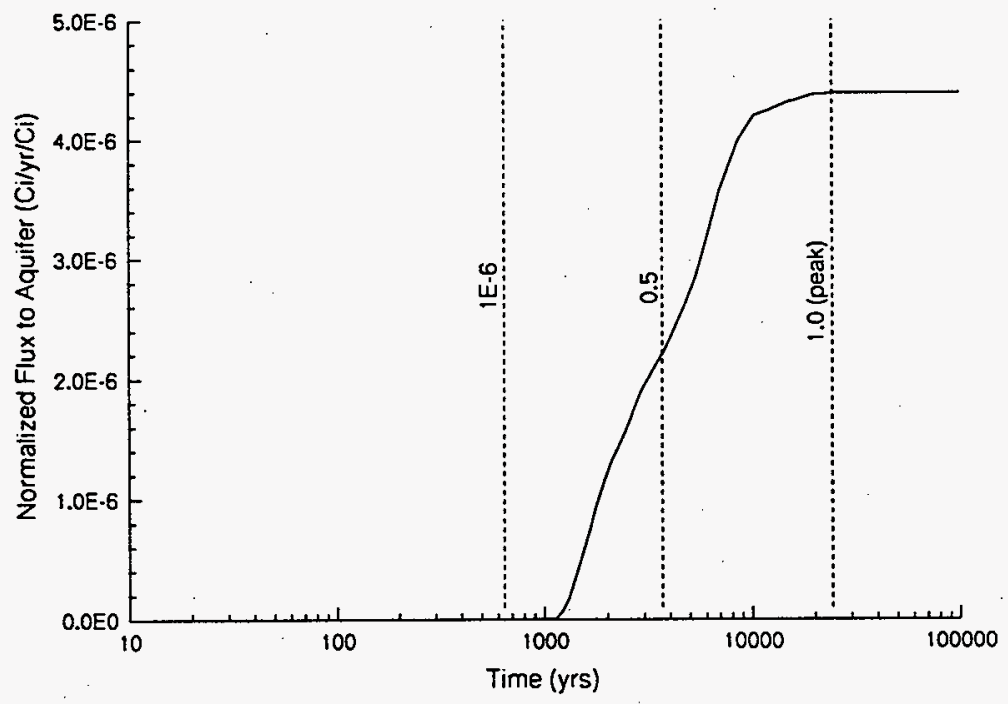




\section{DOE/RL-97-69}

Rev. 0

4.2.2.2 Comments on Computer Simulations. As noted in Chapter 3, two separate sets of analyses were performed for contaminant transport in the vadose zone. The results from the fullfacility model are documented in Piepho (1996). The results from the Unit Cell Model are documented in Kline (1996).

Because of the large size of the disposal facility and the significant depth of the vadose zone, the model for vadose zone transport is quite complex. The model has such a large number of spatial nodes and such small time steps that it strains computer resources. For the base analysis case, $4 \mathrm{~K}_{\mathrm{d}}$ bins were solved for over 70,000 time steps at 22,000 nodes. This run took about 100 hours on an IBM RS 6000 Model 580 UNIX computer. For the cases modeling Concept 2, where far fewer nodes are used, runs took 10 hours on a Pentium-based processor. Simulations of the Unit Cell Model, which used still fewer nodes took about 1 hour on the RS 6000 computer.

The mass balance errors for Concept 1 simulations (the largest ones experienced in the modeling) are shown in Table 4-1. Simulations for Concept 2 and the Unit Cell Model yielded fractional mass balance errors of less than 1 percent for all times. In addition, for the simulations of Concept 1 cases having a reduced release rate, the solution became unstable after 50,000 years. In such cases, values for times greater than 50,000 years were replaced by the maximum value at 50,000 years. This instability is thought to result from terminating the transient flow calculation before an equilibrium flow condition was reached. The value at 50,000 years is near the rate of contaminant release from the waste form and is a good approximation for later times.

Table 4-1. Fractional Mass Balance Error as a Function of Time for Modeling Concept 1 Simulations (Base Analysis Case).

\begin{tabular}{|c|c|}
\hline Time (years) & Fractional Mass Balance Error (\%) \\
\hline 21,500 & 0.5 \\
\hline 37,500 & 2.1 \\
\hline 53,500 & 3.5 \\
\hline
\end{tabular}

The Unit Cell Model calculations focused on the calculations of sensitivity cases. To simplify the model and conserve computer resources, the model did not include a hydraulic diverter above the vaults. Because of the assumed instantaneous step change in infiltration rate at 1,000 years and the step change in properties of the manufactured materials at 2,000 years, a pulse of contaminants occurs shortly after 2,000 years. Only unretarded contaminants $\left(\mathrm{K}_{\mathrm{d}}=0.0\right)$ showed this effect. Because the $K_{d}=0.1 \mathrm{~m} / \mathrm{g}$ group had nearly the same time dependence as the $\mathrm{K}_{\mathrm{d}}=0.0$ group (except for this pulse), all dose calculations reported for the Unit Cell Model use the $K_{d}=0.1 \mathrm{~m} / \mathrm{g}$ results for the unsetarded group. 


\section{DOE/RL-97-69}

Rev. 0

4.2.2.3 Base Analysis Case Simulation Overview. The following paragraphs discuss the simulated moisture content distribution within the disposal facility and the vadose zone as a function of time, the simulated flow paths within the vadose zone, and the contaminant transport within the vadose zone and the unconfined aquifer for the base analysis case.

4.2.2.4 Base Analysis Case Simulation of Moisture Flow in Vadose Zone. Contaminant transport depends strongly on the moisture content and flow in the vadose zone. Figure 4-2 shows the moisture content and a few flow lines at 1,000 years for the entire vadose zone. Figure 4-3 shows that information in more detail around the edge of the disposal facility. Figures 4-4 and 4-5 show similar information at 4,000 years (the time at which steady state flow occurs).

The effectiveness of the sand-gravel capillary barrier is clearly seen in the figures. The flow lines go around the hydraulic diverter, leaving a moisture shadow underneath. At 500 years, the moisture content [volume water $/$ volume soil $_{\text {] }}$ beneath the facility is $0.035 \mathrm{~cm}^{3} / \mathrm{cm}^{3}$. In the path of the diverted flow, the moisture content increases to $0.050 \mathrm{~cm}^{3} / \mathrm{cm}^{3}$, then declines to $0.042 \mathrm{~cm}^{3} / \mathrm{cm}^{3}$ moving away from the facility. Most of the shadowing effect disappears by the time the moisture reaches the bottom of the sandy sequence of the Hanford formation.

At 500 years, the simulation shows no indication of significant flow through the barrier. The moisture content in the backfill soil separating the canisters is $0.050 \mathrm{~cm}^{3} / \mathrm{cm}^{3}$ at the top of the canisters, increasing to only $0.053 \mathrm{~cm}^{3} / \mathrm{cm}^{3}$ at the bottom. These results remain almost constant (the relative change is less than 3 percent) moving horizontally outward from the center of the facility.

At longer times, the shadow remains intact but is smaller. At 4,000 years, the moisture content directly beneath the facility has increased to $0.038 \mathrm{~cm}^{3} / \mathrm{cm}^{3}$ at the edge of the facility. More significantly the large flow around the barrier has increased the moisture content just outside the facility to $0.078 \mathrm{~cm}^{3} / \mathrm{cm}^{3}$. The moisture content of the soil farthest from the facility increases (to $0.050 \mathrm{~cm}^{3} / \mathrm{cm}^{3}$, reflecting the $3 \mathrm{~mm} / \mathrm{y}$ recharge that occurs beginning at 1,000 years caused by the presumed return of the surface soil and vegetation to natural conditions.

At these Ionger times, the computer simulation shows somewhat poorer performance of the hydraulic diverter. Isolated sets of nodes show higher moisture contents $(0.016$ to $\left.0.028 \mathrm{~cm}^{3} / \mathrm{cm}^{3}\right)$ than the rest $\left(0.014 \mathrm{~cm}^{3} / \mathrm{cm}^{3}\right)$. However, the moisture content of the filler material between the canisters remains at about $0.05 \mathrm{~cm}^{3} / \mathrm{cm}^{3}$, with the bottom of the filler material still slightly moister than the top. 


\section{DOE/RL-97-69}

Rev. 0

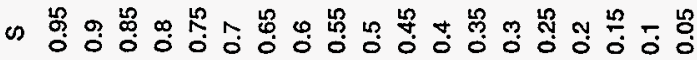
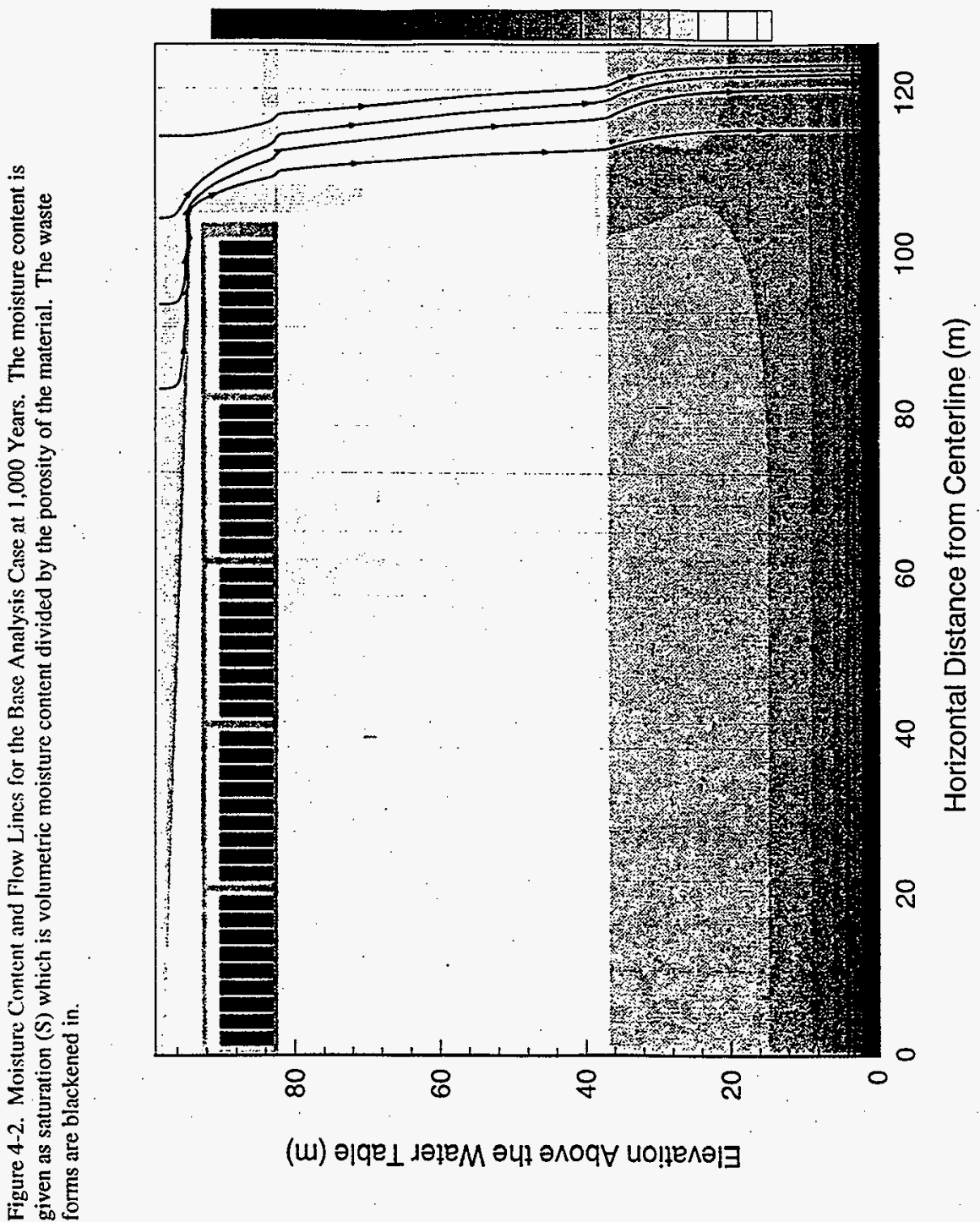


\section{Rev. 0}

Figure 4-3. Moisture Content and Flow Lines at 1,000 Years, Emphasizing the Edge of the Disposal Facility.

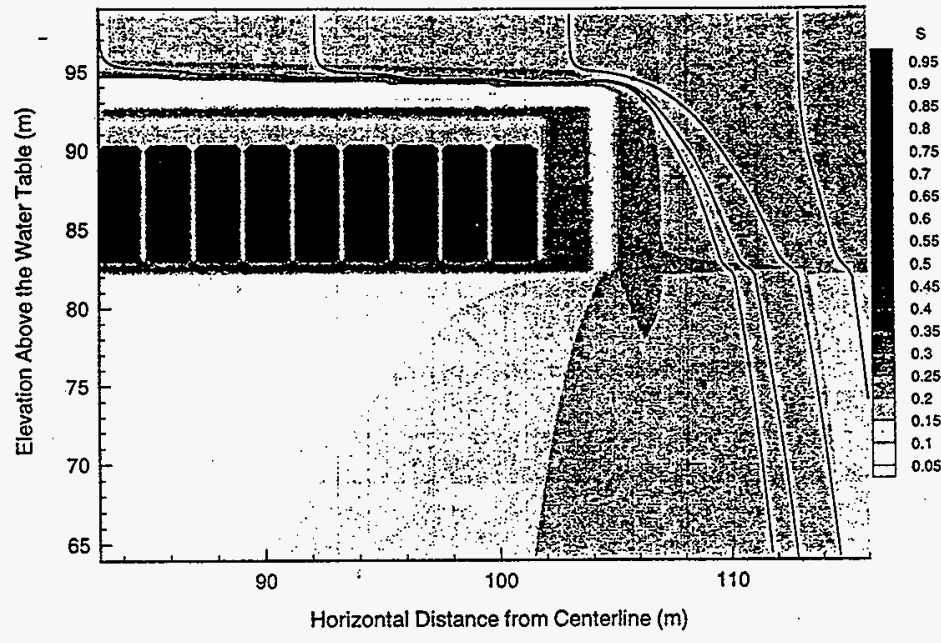

Figure 4-4. Moisture Content and Flow Lines at 4,000 Years (Steady State), Emphasizing the Edge of the Disposal Facility.

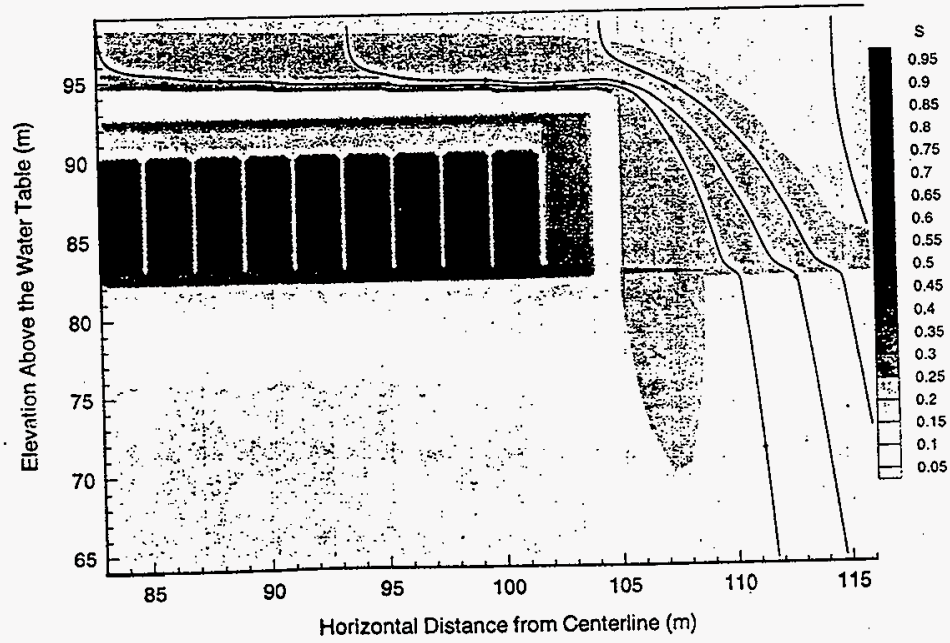


DOE/RL-97-69

Rev. 0

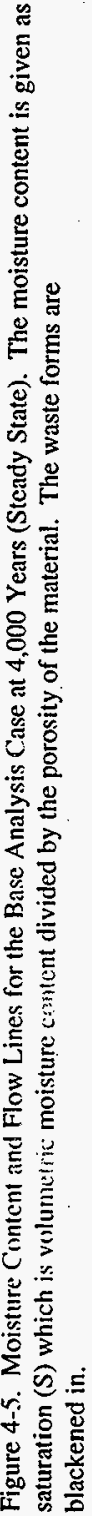

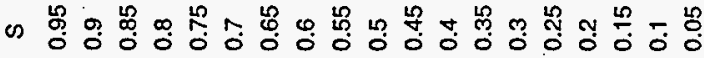

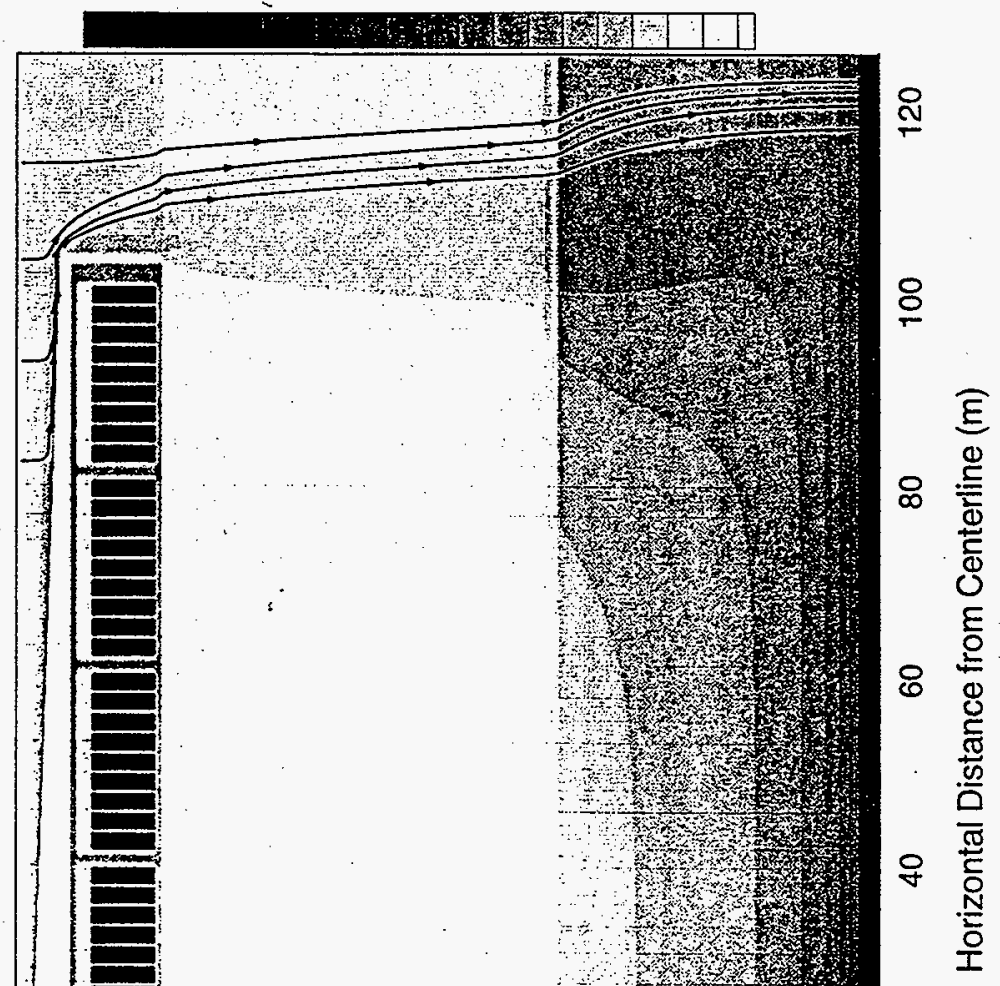

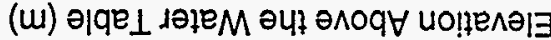




\section{DOE/RL-97-69}

Rev. 0

\subsubsection{Base Analysis Case Simulation of Contaminant Transport in Vadose Zone.}

Normalized contaminant fluxes to the aquifer [that is, contaminant fluxes normalized to 1 curie of inventory] were calculated using PORFLOW for 7 different $\mathrm{K}_{\mathrm{d}}$ values $\left(\mathrm{K}_{\mathrm{d}}=0,0.1,0.6,3.0\right.$, $15.0,40.0$, and $100.0 \mathrm{~m} / \mathrm{g}$ ) for up to 100,000 years.

Figure 4-6 shows the normalized contaminant flux to the aquifer for $\mathrm{K}_{d}=0,0.1$, and $0.6 \mathrm{~m} / \mathrm{g}$. Table $4-2$ shows the major parameters describing the normalized contaminant flux for each $\mathrm{K}_{\mathrm{d}}$ group calculated.

At 10,000 years, only the first $3 \mathrm{~K}_{d}$ groups are significant, having normalized flux values greater than $10^{-6}$ per year. The calculations. indicate that those radionuclides with $\mathrm{K}_{\mathrm{d}}=100.0 \mathrm{~m} / \mathrm{g}$ do not even reach the aquifer in 10,000 years. Because of the very conservative value used for dispersion, an extremely small amount of the $\mathrm{K}_{\mathrm{d}}=0$ group reaches the aquifer before 500 years.

Figure 4-6. Normalized Contaminant Flux to the Aquifer for $K_{d}=0,0.1$, and $0.6 \mathrm{~m} / \mathrm{g}$ - Base Analysis Case.

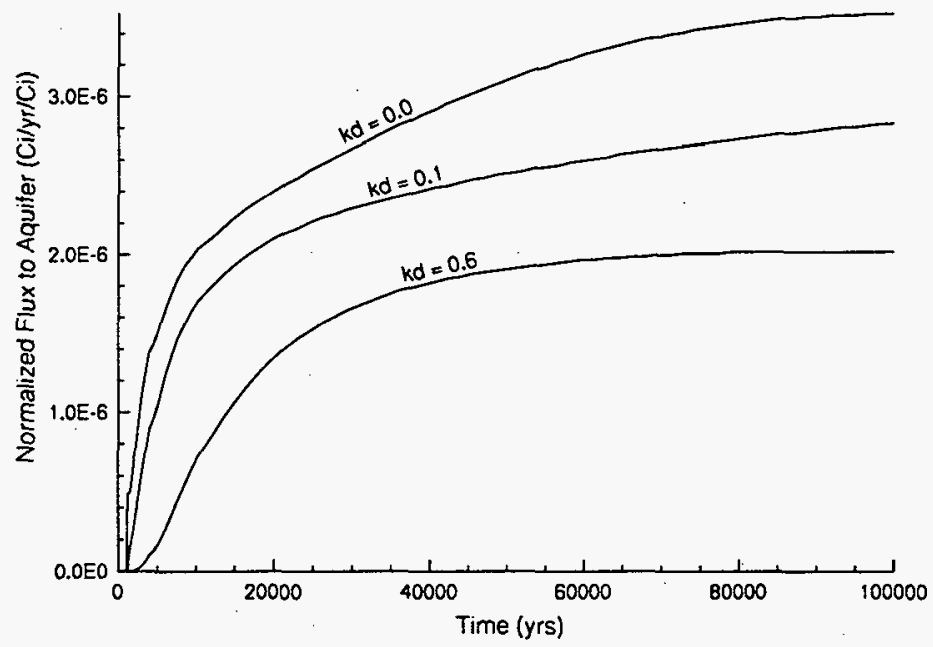


Rev. 0

Table 4-2. Major Parameters Describing the Normalized Contaminant Flux to the Aquifer for the Base Analysis Case. Decay is included later in the analysis.

\begin{tabular}{|c|c|c|c|c|c|}
\hline $\begin{array}{c}\mathrm{K}_{\mathrm{d}} \\
(\mathrm{m} / \mathrm{g})\end{array}$ & $\begin{array}{c}\text { Value at 10K } \\
\text { Years } \\
(\mathrm{Ci} / \mathrm{y} / \mathrm{Ci})\end{array}$ & $\begin{array}{c}\text { Peak Value } \\
\text { in First 100K } \\
\text { Years } \\
(\mathrm{Ci} / \mathrm{y} / \mathrm{Ci})\end{array}$ & $\begin{array}{c}\text { Time of True } \\
\text { Peak Value } \\
(\mathrm{y})\end{array}$ & $\begin{array}{c}\text { Time of } \\
0.5^{*} \text { True } \\
\text { Peak Value } \\
(\mathrm{y})\end{array}$ & $\begin{array}{c}\text { Time of } \\
10^{-6 *} \text { True } \\
\text { Peak Value } \\
(\mathrm{y})\end{array}$ \\
\hline \hline 0. & $2.04 \mathrm{e}-6$ & $3.53 \mathrm{e}-6$ & $>100,000$ & 12,000 & 450 \\
\hline 0.1 & $1.71 \mathrm{e}-6$ & $2.84 \mathrm{e}-6$ & $>100,000$ & 12,000 & 650 \\
\hline 0.6 & $0.72 \mathrm{e}-6$ & $2.02 \mathrm{e}-6$ & $>100,000$ & $>100,000$ & 1,300 \\
\hline 3.0 & $1.3 \mathrm{e}-09$ & $1.37 \mathrm{e}-6$ & $>100,000$ & $>100,000$ & 3,400 \\
\hline 15.0 & $9.3 \mathrm{e}-15$ & $0.20 \mathrm{e}-6$ & $>100,000$ & $>100,000$ & 17,000 \\
\hline 40.0 & $2.4 \mathrm{e}-23$ & $4.0 \mathrm{e}-09$ & $>100,000$ & $>100,000$ & 44,000 \\
\hline 100.0 & 0.0 & $2.1 \mathrm{e}-12$ & $>100,000$ & $>100,000$ & $>100,000$ \\
\hline
\end{tabular}

a The value given is for the peak value in the first 100,000 years.

b Unless a peak value was obtained in the first 100,000 years, the true peak value was taken as $4 \times 10^{-6} \mathrm{Ci} / \mathrm{y} / \mathrm{Ci}$.

The normalized flux to the unconfined aquifer reach its maximum before the computer simulations end at 100,000 years for any other the $K_{d}$ groups. However, based on the shape of the curve in Figure 4-6 and the contaminant release rate, the $K_{d}=0$ group is expected to be near its peak. Because the contaminant flux to the aquifer is expected to stay high (because the sustained release of contaminants from the waste form), calculations to longer times are needed to demonstrate the character of the full release and the magnitude of peak concentration and dose. The normalized flux to the aquifer can be approximately estimated based on the $\mathrm{K}_{\sigma}=0$ group. By assuming that the release rate continues indefinitely and that the travel in the vadose zone controls the temporal shape of the normalized flux, the normalized flux to the aquifer $(\Gamma)$ can be approximated by

$$
\Gamma\left(K_{d}, t \cdot\left[1+\alpha K_{d}\right]\right)=\Gamma\left(K_{d}=0, t\right),
$$

where $\alpha$ is a fitting parameter related to vadose zone thickness and moisture content. By comparing the time of occurrence for $\Gamma=10^{-6}$ per year for $K_{d}=0$ and $K_{d}=3 \mathrm{~m} \ell / g, \alpha$ is found to be $6.6 \mathrm{~g} / \mathrm{m}$. The Unit Cell Model produces values for $\alpha$ of about $35 \mathrm{~g} / \mathrm{m}$ ? where the effect of the moisture shadow of the facility is absent. The two methods are compared in Appendix E.2.2. Using equation 1, normalized fluxes were estimated out to 66 million years assuming that the flux never decreases from its maximum value. The value of 66 million years is derived $\left(=\alpha t_{\text {last }} K_{d \cdot \max }\right)$ from the last time $\left(t_{\text {lass }}\right)$ of the explicit calculation $(10,000 \mathrm{y}), \alpha(6.6 \mathrm{~g} / \mathrm{m} l)$, and the maximum $\mathrm{K}_{\mathrm{d}}$ value $\left(\mathrm{K}_{\mathrm{d}-\max }=100 \mathrm{~m} / \mathrm{g}\right)$. 


\section{DOE/RL-97-69}

Rev. 0

This is a conservative assumption, because the flux for groups with small $\mathrm{K}_{\mathrm{d}}$ values will show decreases in the range of a few million years as the release rate from the waste form goes to zero. Also some radionuclides with long half-lives will experienced significant decay over such long times. For example, 96 percent of ${ }^{99} \mathrm{Tc}$ will decay away in a million years.

\subsubsection{Base Analysis Case Simulation of Aquifer Transport}

These results are based on applying the Hanford site wide groundwater model described in Section 3.5.3.3. Two models were used, one with high spatial resolution near the disposal site and one with a lower Aquifer Transport
Significant contaminant dilution is obtained by
averaging over the weil screen height. Dispersion
of contaminants in the groundwater is relatively
small for well locations near the disposal sites. resolution describing the flow and transport all the way down to the Columbia River. Both models assume that the flux to groundwater from the vadose zone is a step function, i.e. 0 for times less than $t=0$ years, and a constant thereafter). A fuller description is given in Lu (1996), which assumed a recharge rate of $1 \mathrm{~mm} / \mathrm{y}$. The Lu (1996) results have been modified to reflect actual recharge rates (normally $3 \mathrm{~mm} / \mathrm{y}$ ) by multiplying them by the recharge rate.

The results for the close-in model are shown in Figures 4-7 and 4-8. Figure 4-7 shows the concentration ratio contours (concentration at the well relative to the concentration in the vadose zone beneath the disposal facility) 120 years after the flux starts to enter the aquifer at its surface. The plume is basically west to east with a slight northerly bias as suggested by the groundwater flows depicted in Figure 3-1. At 100 meters downgradient, the width of the plume is predicted to be about 25 meters (full width at the half maximum value), increasing to about 30 meters 900 meters downgradient. Figure 4-8 shows the time history of the concentration ratio at the well 100 meters down gradient from the disposal facility and at the 200 Area fence (about 900 meters downgradient). At the well 100 meters downgradient, the groundwater/vadose zone concentration ratio reaches a steady-state value $\left(5.31 \times 10^{-3}\right)$ after 30 years. At a well 900 meters downgradient (the 200 East Area boundary, a steady-state value $\left(4.08 \times 10^{-3}\right)$ is reached after about 60 years. The steady state values are summarized in Table 4-3.

Because two disposal sites are under consideration, plumes from the upgradient site (the new or main disposal site) can interact with plumes from the downgradient site (the existing disposal facility site). As shown in Figure 4-7, the concentration at the existing disposal vaults from the plume starting from the new disposal site would be about 0.2 of the concentration at the new disposal facility site (coordinates: N135,800 and E576,000). However, if the direction of the groundwater would shift to the northeast, the concentration could be as high as about 0.67 .

The flow paths for the distant well sites are displayed in Figure 4-9. The relative contamination levels for 400 years after the contaminants enter the aquifer are shown in Figure 4-10. Time histories for the eight wells shown in Figure 4-9 are displayed in Figure 4-11. Although some compression of the flow lines occurs, dispersion of the contaminants is much more important. The concentration ratio for a point near the river is less than $2 \times 10^{-4}$ for a unit 


\section{DOE/RL-97-69}

Rev. 0

Figure 4-7. Contamination Concentration in Well Water 120 Years After a Vadose Zone Flux of $1 \mathrm{Ci} / \mathrm{m}^{2}$ and a Recharge Rate of $1 \mathrm{~mm} /$ year Enter the Aquifer. Larger Square in the left hand quarter (labeled LLTWDS) is the site of the new disposal facilities. Smaller square in the upper right quarter of the larger square is the location of the modeled vaults (Lu 1996). Because the actual recharge rate is estimated to be $3 \mathrm{~mm} /$ year over most of the modeling period, actual concentrations will be 3 times higher than shown.

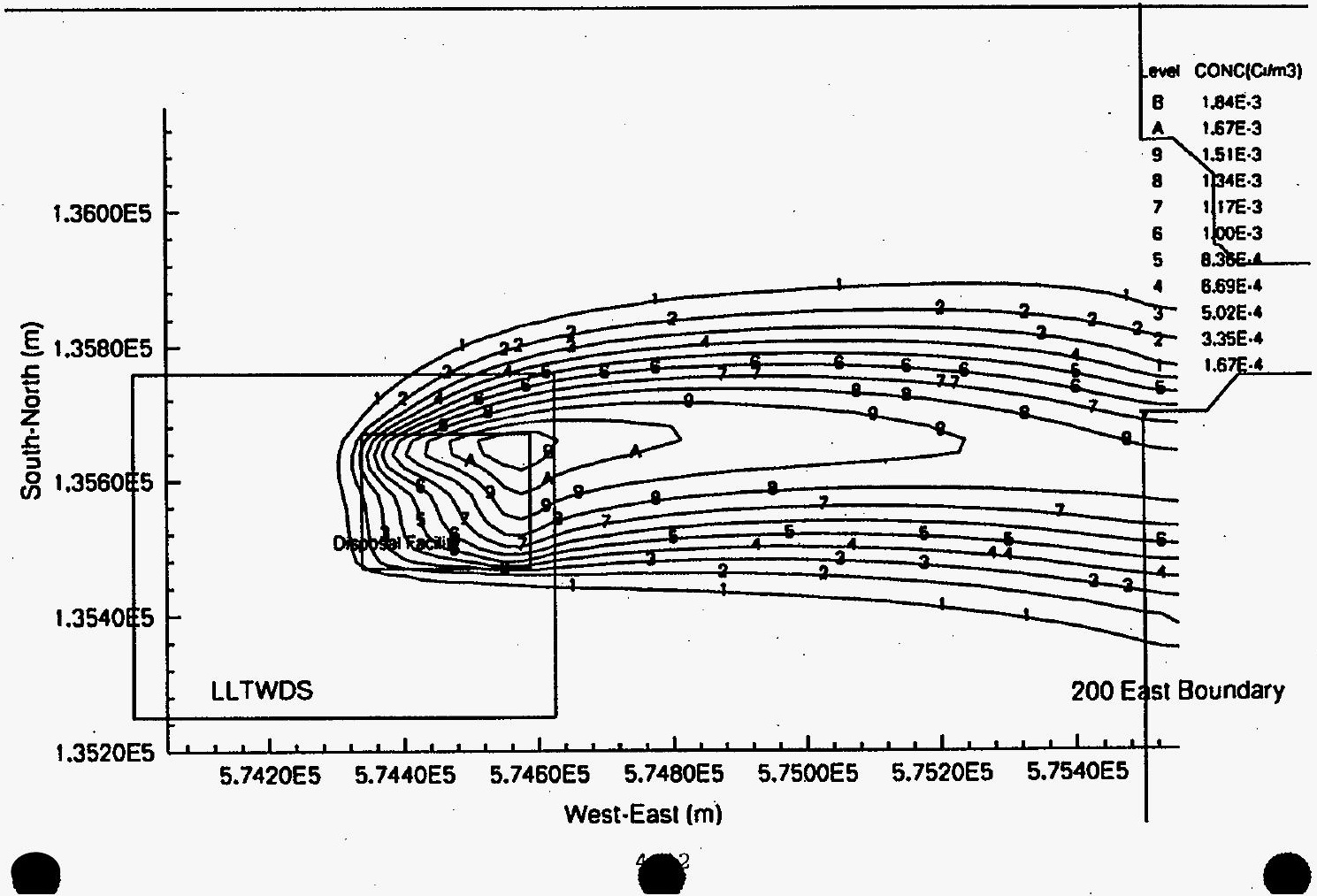


DOE/RL-97-69

Rev. 0

Figure 4-8. Concentration Ratios as a Function of Time at Points of Maximum Concentration 100 Meters Downgradient and at the 200 East Boundary (about 900 Meters Downgradient) (Lu 1996).

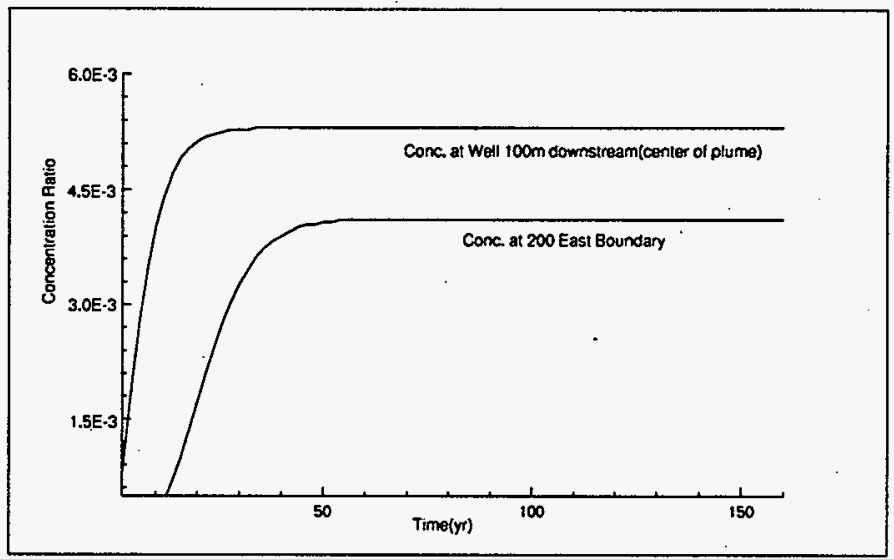

Table 4-3. Groundwater Concentration Ratios at Hypothetical Wells Relative to Unit Concentration Entering Aquifer Under Disposal Facility Under Steady State Conditions.

\begin{tabular}{|l|r|c|}
\hline \hline Well Number & Distance (meters) & Concentration Ratio \\
\hline \hline-- & 100.0 & $5.31 \times 10^{-3}$ \\
\hline h1 & $\sim 750.0$ & $4.89 \times 10^{-3}$ \\
\hline-- & 200 East Area Boundary $(\sim 900$ meters $)$ & $4.08 \times 10^{-3}$ \\
\hline h2 & $\sim 1,200.0$ & $3.27 \times 10^{-3}$ \\
\hline h3 & $\sim 1,750.0$ & $2.07 \times 10^{-3}$ \\
\hline h4 & $\sim 2,500.0$ & $1.79 \times 10^{-3}$ \\
\hline h5 & $\sim 6,000.0$ & $4.77 \times 10^{-4}$ \\
\hline h6 & $\sim 12,000.0$ & $2.91 \times 10^{-4}$ \\
\hline h7 & $\sim 15,000.0$ & $2.54 \times 10^{-4}$ \\
\hline h8 & $\sim 20,000.0$ & $1.86 \times 10^{-4}$ \\
\hline
\end{tabular}




\section{DOE/RL-97-69 \\ Rev. 0}

concentration entering the aquifer beneath the disposal site and it takes about 400 years to reach the Columbia River. The steady-state concentration ratios are summarized in Table 4-3.

The consistency of the two aquifer models can be judged by comparing the results of the models at the 200 East Area Boundary(about 900 meters downgradient from the disposal facility). The near model gives $4.08 \times 10^{-3}$, while the geometric interpolation of wells W1 (about 750 meters downgradient) and W2 (about 1200 meters downgradient) give $4.17 \times 10^{-3}$.

Large-scale Hanford Site groundwater modeling for conditions far in the future is just beginning to undergo extensive review. Some discrepancies are to be expected. For example, a study to evaluate the potential for transport of nickel radioisotopes from the 218-E-12B Burial Ground (Rhoads et al. 1994) postulated only unsaturated sediments beneath this site in the northern part of the 200 East Area in contrast to the 5 meters of saturated sediments used in this analysis. The postulation was based on two-dimensional CFEST (Gupta 1987) simulations under an assumption of a low recharge condition and supported by the measurements of adjacent wells. However, the desaturation condition should be limited to the vicinity of the 218-E-12B Burial Ground because the basalt structure is much nearer the surface at the burial ground.

\subsubsection{Integrated Simulation Results}

This section describes the result of combining the results of the vadose zone transport (Section 4.2.2) and the aquifer transport (Section 4.2.3), the amounts of the

Base Analysis Case Integrated Results Estimated drinking water doses in the first 10,000 years are 2 mrem in a year. All pathways doses are $6.4 \mathrm{mrem}$ in a year.

The computer program PORCON (described in Mann 1996) was used to combine the results of the PORFLOW runs. This permits a single file to contain all $\mathrm{K}_{\mathrm{d}}$ bins even though PORFLOW was limited to four bins per run. The program INTEG (described in Section 3.5.2.5) then combines the results of the transport simulations (vadose zone and aquifer) with inventory and exposure parameters to calculate the dose and radionuclide concentration at a well.

Concept 1 is the facility design used for the base analysis case. This section describes in detail the impacts of simulation results for this case. The impacts are estimated for water drawn from a well 100 meters downgradient of the disposal facility, from a well just before the groundwater mixes with the Columbia River, and from the Columbia River itself.

As shown in Table 4-4, the impacts estimated at a well 100 meters downgradient from the disposal facility are less than the performance objectives set in Section 1.6. The beta/photon and total drinking water doses are displayed as a function of time in Figure 4-12. Also shown in Figure 4-12 are the doses from ${ }^{99} \mathrm{Tc}$ and ${ }^{79} \mathrm{Se}$, the two biggest contributors to the dose. Table 4-5 shows the major contributors to the beta/photon dose at 10,000 years. Figure 4-13 shows the alpha-emitting radionuclide concentration as a function of time at the same well. Table 4-6 shows the major contributors to the alpha-emitting radionuclide concentration at 10,000 years. Figure 4-14 and Table 4-7 show the all-pathways dose and major contributors to that dose. 


\section{DOE/RL-97-69}

Rev. 0

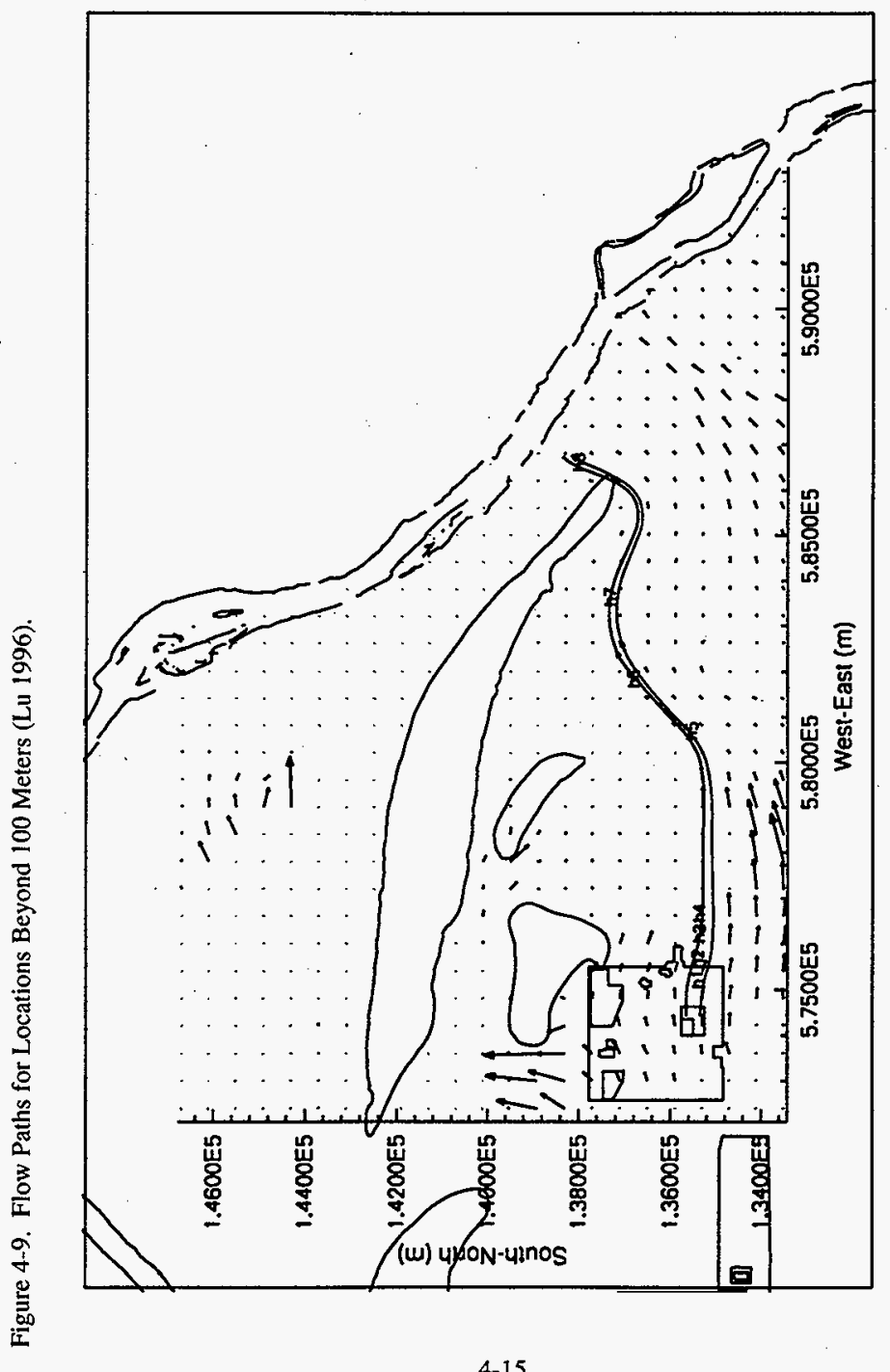


Figure 4-10. Contamination Concentration in Well Water 400 Years After a Vadose Zone Flux of $1 \mathrm{Ci} / \mathrm{m}^{2}$ and a Recharge Rate of $1 \mathrm{~mm} /$ year Enter the Aquifer. (Lu 1996). Because the actual recharge rate is estimated to be 3 $\mathrm{mm}$ /year over most of the modeling period, actual concentrations will be 3 times higher than shown.

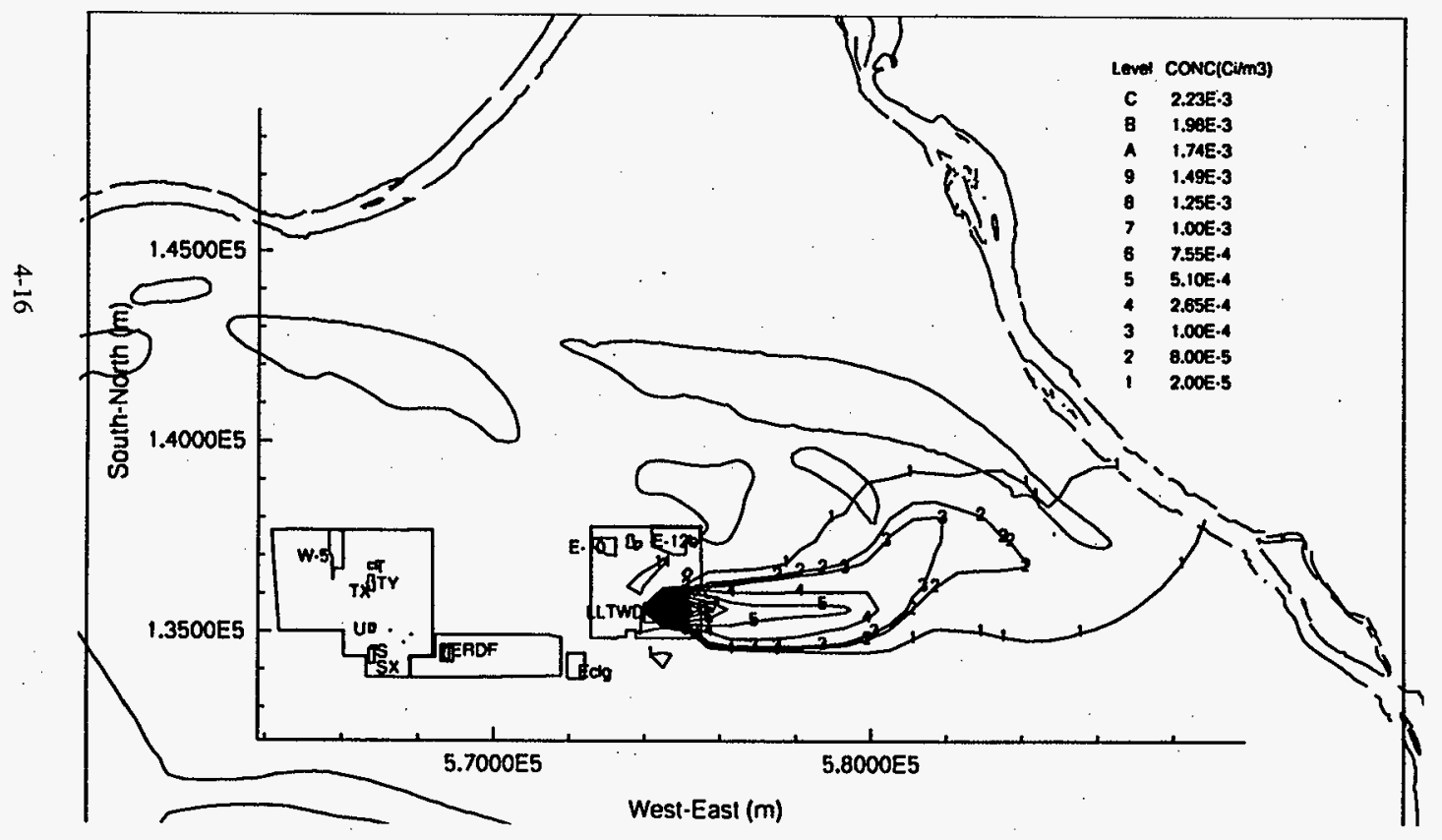




\section{DOE/RL-97-69}

Rev. 0

Figure 4-11. Concentration Ratio Histories at Downstream Hypothetical Wells. (Lu 1996) Locations h1 through h8 are shown in Figure 4-9 and defined in Table 4-3.
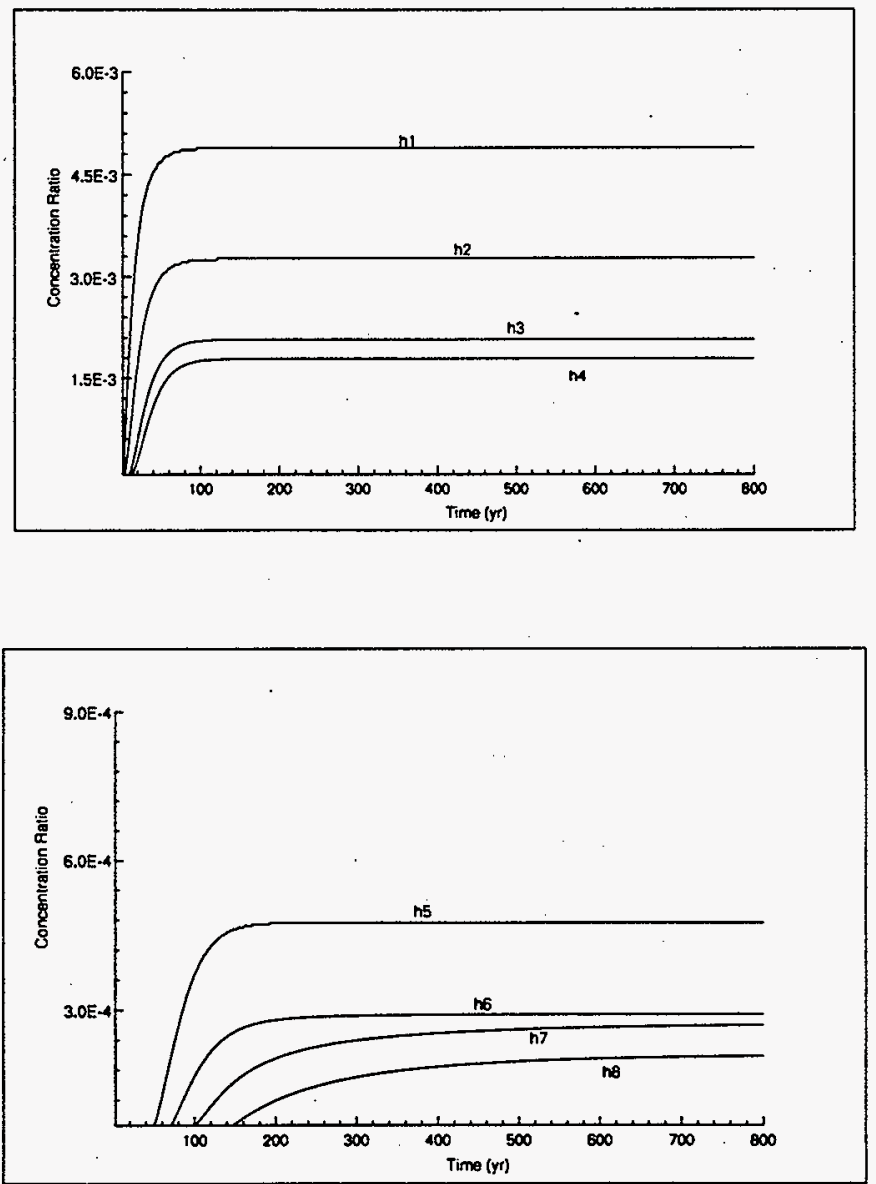


\section{DOE/RL-97-69}

\section{Rev. 0}

Doses and radionuclide concentrations also were calculated just before the radionuclides enter the Columbia River. Because the travel time in the unconfined aquifer is so short, the main difference between the impact 100 meters downgradient and the impact at the Columbia River (about 20,000 meters) is that more mixing occurs in the unconfined aquifer. Table 4-8 shows the estimated dose and radionuclide concentrations.

For all the impacts considered, the value of the impact is still rising at 10,000 years. As noted in Section 4.2.2.5, detailed computer simulations were carried out for each $\mathrm{K}_{\mathrm{d}}$ group for 100,000 years, while approximations were used out to $100,000,000$ years. Table $4-9$ presents the estimated maxima.

The last calculation for the base analysis case is the calculation of the integrated dose. Two cases are presented: a public drinking water system supplying 25 people located near the disposal facility and a population of 5 million drinking water from the Columbia River after the contaminants are mixed with the river. Although not realistic,-it is assumed that all the water consumed by the 5 million people comes from the well that intersects the groundwater just before the groundwater reaches the Columbia River. Even so, the estimated integrated dose of 0.05 person-rem/y and slightly less than 5 person-rem/y, respectively are far below the performance objective of 500 person-rem/y.

Table 4-4. Estimated Impact From Base Analysis Case at a Well 100 Meters Downgradient from the Disposal Facility at 10,000 years.

\begin{tabular}{||l|c|c|}
\hline Type of Impact & Value & $\begin{array}{c}\text { Performance } \\
\text { Objective }\end{array}$ \\
\hline \hline $\begin{array}{l}\text { Dose from beta/photon emitting radionuclides (mrem } \\
\text { in a year) }\end{array}$ & 2.0 & 4.0 \\
\hline All-pathways dose (mrem in a year) & 6.4 &. \\
\hline Concentration of alpha-emitting radionuclides (pCi/l) & 1.65 & 25. \\
\hline Radium concentration (pCi/l) & $<0.001$ & 15. \\
\hline Uranium concentration (pCi/l) & 1.65 & 3. \\
\hline
\end{tabular}




\section{DOE/RL-97-69}

Rev. 0

Figure 4-12. Drinking Water Doses for the Base Analysis Case at a Well 100 Meters Downgradient.

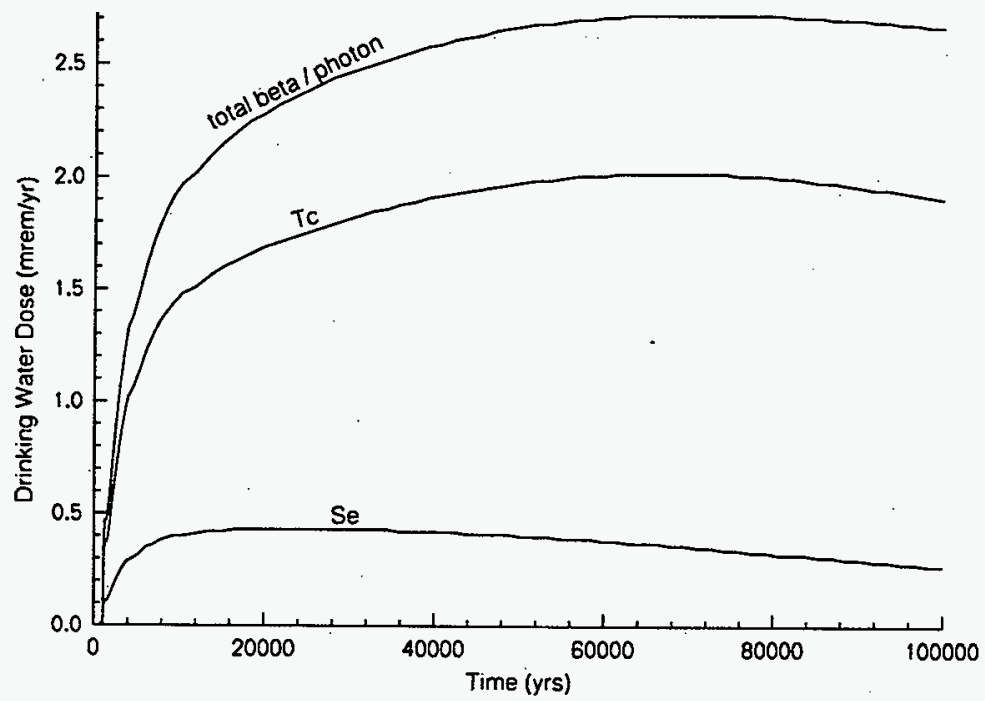

Table 4-5. Major Contributors at 10,000 Years to the Estimated Beta/Photon Drinking Water Dose at a Well 100 Meters Downgradient from the Disposal Facility for the Base Analysis Case.

\begin{tabular}{|l|c|c|}
\hline Radionuclide & Dose (mrem/year) & Concentration (pCi/l) \\
\hline \hline${ }^{99} \mathrm{Tc}$ & 1.48 & 1560. \\
\hline${ }^{79} \mathrm{Se}$ & 0.40 & 67. \\
\hline others ${ }^{2}$ & 0.09 & 2. \\
\hline total & 1.97 & 1630. \\
\hline
\end{tabular}

Mainly beta-emitting daughters of uranium 
DOE/RL-97-69

Rev. 0

Figure 4-13. Alpha-Emitting Radionuclide Concentrations for the Base Analysis Case at a Well 100 Meters Downgradient from the Disposal Facility.

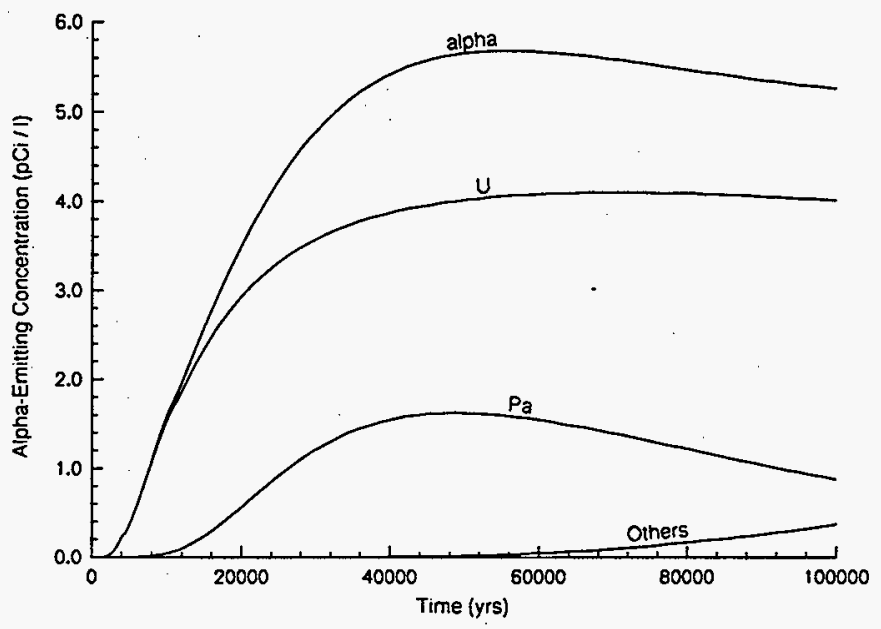




\section{DOE/RL-97-69}

Rev. 0

Table 4-6. Major Contributors at 10,000 Years to the Alpha-Emitting

Radionuclide Concentration at a Well 100 Meters Downgradient of the Disposal Facility for the Base Analysis Case.

\begin{tabular}{|l|c|c|}
\hline Radionuclide & Dose (mrem/year) & Concentration (pCi/l) \\
\hline \hline${ }^{226} \mathrm{Ra}$ & 0.00 & $4 . \times 10^{-12}$ \\
\hline${ }^{228} \mathrm{Ra}$ & 0.00 & $9 . \times 10^{-12}$ \\
\hline${ }^{231} \mathrm{~Pa}$ & 0.42 & 0.053 \\
\hline${ }^{232} \mathrm{U}$ & 0.01 & 0.013 \\
\hline${ }^{233} \mathrm{U}$ & 0.12 & 0.64 \\
\hline${ }^{234} \mathrm{U}$ & 0.08 & 0.47 \\
\hline${ }^{235} \mathrm{U}$ & 0.00 & 0.019 \\
\hline${ }^{236} \mathrm{U}$ & 0.00 & 0.014 \\
\hline${ }^{238} \mathrm{U}$ & 0.08 & 0.46 \\
\hline others & $<0.01$ & $<0.01$ \\
\hline total & 0.71 & 1.65 \\
\hline
\end{tabular}

Table 4-7. Major Contributors at 10,000 Years to the All-Pathways Dose at a Well 100 Meters Downgradient of the Disposal Facility for the Base Analysis Case.

\begin{tabular}{||l|c|}
\hline Radionuclide & Dose (mrem/year) \\
\hline \hline${ }^{99} \mathrm{Tc}$ & 4.86 \\
\hline${ }^{79} \mathrm{Se}$ & 0.73 \\
\hline${ }^{231} \mathrm{~Pa}$ & 0.46 \\
\hline${ }^{233} \mathrm{U}$ & 0.14 \\
\hline${ }^{234} \mathrm{U}$ & 0.10 \\
\hline${ }^{238} \mathrm{U}$ & 0.09 \\
\hline others & $<0.03$ \\
\hline total & 6.4 \\
\hline
\end{tabular}


DOE/RL-97-69

Rev. 0

Figure 4-14. All-Pathways Doses for the Base Analysis Case at a Well 100 Meters Downgradient.

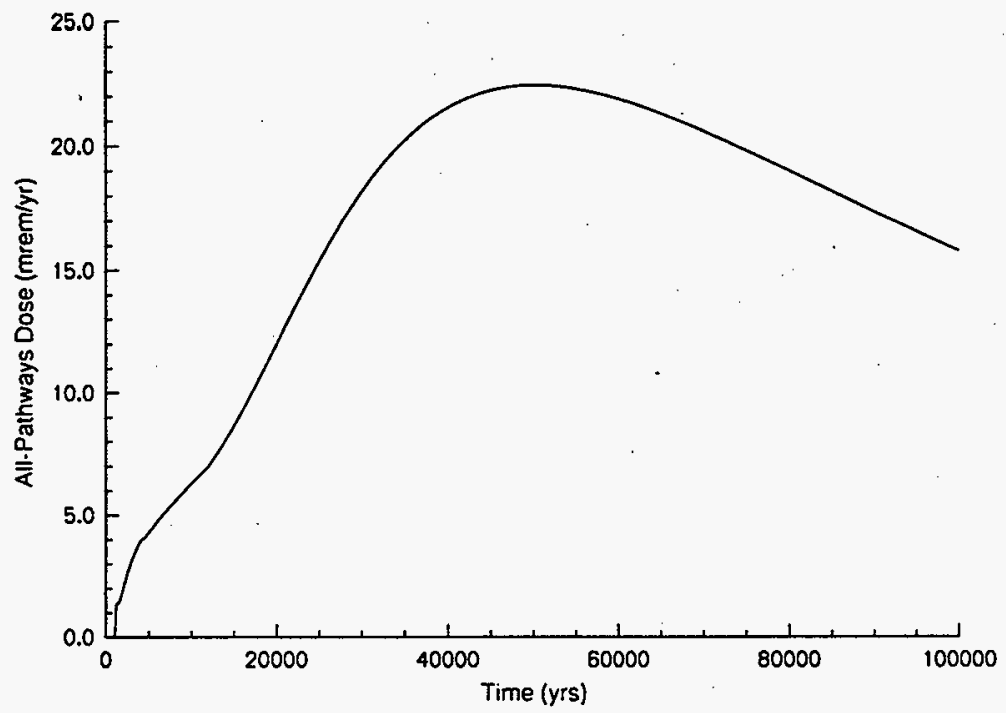

Table 4-8. Estimated Impact From Base Analysis Case from Groundwater Just Before Mixing with the Columbia River at 10,000 Years.

\begin{tabular}{||l|c|c|}
\hline Type of Impact & Value & $\begin{array}{c}\text { Surface Water } \\
\text { Performance } \\
\text { Objective }\end{array}$ \\
\hline \hline $\begin{array}{l}\text { Dose from beta/photon emitting radionuclides (mrem in a } \\
\text { year) }\end{array}$ & 0.069 & 1.0 \\
\hline All-pathways dose (mrem in a year) & 0.22 & 25. \\
\hline Concentration of alpha-emitting radionuclides (pCi/l) & 0.058 & 15. \\
\hline Radium concentration (pCi/ $\ell$ ) & $2 . \times 10^{-11}$ & 3. \\
\hline Uranium concentration (pCi/l) & 0.056 & $\ldots$ \\
\hline
\end{tabular}


DOE/RL-97-69

Rev. 0

Table 4-9. Estimated Maximum Impact From Base Analysis Case

Using the Groundwater Scenario.

\begin{tabular}{|c|c|c|c|c|}
\hline \multirow[t]{2}{*}{ Impact } & \multicolumn{2}{|c|}{$<10^{5}$ years $^{(a)}$} & \multicolumn{2}{|c|}{$<10^{8}$ years $^{(b)}$} \\
\hline & Value & Time & Value & Time \\
\hline $\begin{array}{l}\text { Maximum drinking water dose from } \\
\text { beta/photon emitting nuclides at a } \\
\text { nearby well ( } 100 \text { meters downgradient } \\
\text { from the disposal facility) }\end{array}$ & $\begin{array}{c}2.7 \\
\text { mrem/y }\end{array}$ & $\begin{array}{c}71 \times 10^{3} \\
\text { years }\end{array}$ & $\begin{array}{l}14^{(c)} \\
\mathrm{mrem} / \mathrm{y}\end{array}$ & $\begin{array}{c}65 \times 10^{6} \\
\text { years }\end{array}$ \\
\hline $\begin{array}{l}\text { Maximum all-pathways dose at a } \\
\text { nearby well }\end{array}$ & $\begin{array}{c}23 . \\
\mathrm{mrem} / \mathrm{y}\end{array}$ & $\begin{array}{c}50 \times 10^{3} \\
\text { years }\end{array}$ & $\begin{array}{c}23 . \\
\mathrm{mrem} / \mathrm{y}\end{array}$ & $\begin{array}{c}50 \times 10^{3} \\
\text { years }\end{array}$ \\
\hline $\begin{array}{l}\text { Maximum concentration of alpha- } \\
\text { emitting nuclides at a nearby well }\end{array}$ & $\begin{array}{c}5.7 \\
\mathrm{pC} \mathrm{C} / \mathrm{l} \ell \\
\end{array}$ & $\begin{array}{c}55 \times 10^{3} \\
\text { years }\end{array}$ & $\begin{array}{l}18 .^{(\mathrm{d})} \\
\mathrm{pC} \mathrm{i} / \ell\end{array}$ & $\begin{array}{c}51 \times 10^{6} \\
\text { years }\end{array}$ \\
\hline $\begin{array}{l}\text { Maximum concentration of radium } \\
\text { isotopes at a nearby well }\end{array}$ & $\begin{array}{l}0.075 \\
\mathrm{pCi} / \ell\end{array}$ & $\begin{array}{l}\text { @ } 10^{5} \\
\text { years }\end{array}$ & $\begin{array}{c}2.2 \\
\mathrm{pCi} / \ell\end{array}$ & $\begin{array}{c}10 \times 10^{6} \\
\text { years }\end{array}$ \\
\hline $\begin{array}{l}\text { Maximum concentration of uranium } \\
\text { isotopes at a nearby well }\end{array}$ & $\begin{array}{c}4.1 \\
\mathrm{pC} / / \ell \\
\end{array}$ & $\begin{array}{c}71 \times 10^{3} \\
\text { years }\end{array}$ & $\begin{array}{c}5.6 \\
\mathrm{pC} / / \ell \\
\end{array}$ & $\begin{array}{c}400 \times 10^{3} \\
\text { years }\end{array}$ \\
\hline $\begin{array}{l}\text { Maximum drinking water dose from } \\
\text { beta/photon emitting nuclides at the } \\
\text { Columbia River }\end{array}$ & $\begin{array}{c}0.10 \\
\mathrm{mrem} / \mathrm{y}\end{array}$ & $\begin{array}{l}71 \times 10^{3} \\
\text { years }\end{array}$ & $\begin{array}{c}0.49 \\
\mathrm{mrem} / \mathrm{y}\end{array}$ & $\begin{array}{c}65 \times 10^{6} \\
\text { years }\end{array}$ \\
\hline $\begin{array}{l}\text { Maximum all-pathways dose at the } \\
\text { Columbia River }\end{array}$ & $\begin{array}{c}0.79 \\
\mathrm{mrem} / \mathrm{y}\end{array}$ & $\begin{array}{c}50 \times 10^{3} \\
\text { years }\end{array}$ & $\begin{array}{c}0.79 \\
\text { mrem/y }\end{array}$ & $\begin{array}{c}50 \times 10^{3} \\
\text { years }\end{array}$ \\
\hline $\begin{array}{l}\text { Maximum concentration of alpha- } \\
\text { emitting nuclides at the Columbia } \\
\text { River }\end{array}$ & $\begin{array}{l}0.20 \\
\mathrm{pCi} / \ell\end{array}$ & $\begin{array}{l}55 \times 10^{3} \\
\text { years }\end{array}$ & $\begin{array}{l}0.65 \\
\mathrm{pCi} / \ell\end{array}$ & $\begin{array}{c}51 \times 10^{6} \\
\text { years }\end{array}$ \\
\hline $\begin{array}{l}\text { Maximum concentration of radium } \\
\text { isotopes at the Columbia River }\end{array}$ & $\begin{array}{l}0.003 \\
\mathrm{pCi} / \ell\end{array}$ & $\begin{array}{l}@ 10^{5} \\
\text { years }\end{array}$ & $\begin{array}{l}0.08 \\
\mathrm{pCi} / \ell\end{array}$ & $\begin{array}{c}11 \times 10^{6} \\
\text { years }\end{array}$ \\
\hline $\begin{array}{l}\text { Maximum concentration of uranium } \\
\text { isotopes at the Columbia River }\end{array}$ & $\begin{array}{l}0.14 \\
\mathrm{pCi} / \ell\end{array}$ & $\begin{array}{c}71 \times 10^{3} \\
\text { years }\end{array}$ & $\begin{array}{c}0.20 \\
\mathrm{pCi} / \ell\end{array}$ & $\begin{array}{c}400 \times 10^{3} \\
\text { years }\end{array}$ \\
\hline
\end{tabular}

${ }^{a}$ Detailed computer simulations were performed out to 100,000 years.

' Values between 100,000 years and $100,000,000$ years were inferred by using the $K=0$ results and adjusting the time by $\left(1 .+6.6 * \mathrm{~K}_{\mathrm{d}}\right)$.

' The drinking water dose from beta/photon emitters at a well 100 meters downgradient is estimated to exceed $4 \mathrm{mrem} / \mathrm{year}$ at about 750,000 years.

'The alpha-emitting nuclide concentration at a well 100 meters downgradient is estimated to exceed $15 \mathrm{pCi} / \ell$ at 2.5 million years. 


\subsection{RESULTS OF GROUNDWATER SCENARIOS - BASE SENSITIVITY CASES}

Beside the base analysis case, sensitivity cases were built around two other cases. The first case involved using the full-facility model from Concept 2. The second involved using the Unit Cell Model for vadose zone transport and the

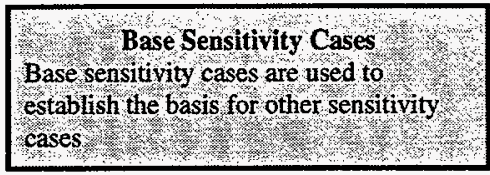
geometry for aquifer transport from Concept 1. These additional cases were chosen to highlight the differences between Concepts 1 and 2 and reduce computer resource requirements, respectively.

This section provides the results from these two base sensitivity case runs.

\subsubsection{Concept 2.}

Because Concept 2 forms the basis for many sensitivity runs, the

Concept 2 Base Sensitivity Case This base sensitivity case establishes the effect of having rows of soils between vault rows. estimated impacts are described here. The data and models used for this case (known as the Concept 2 base sensitivity case) are the same as for the base analysis case except that the Concept 2 design is used. The reasons for the differences between these results and those for the base analysis case (Concept 1) are explained in Section 4.5.2.1.

\subsubsection{Vadose Zone Transport Simulation of the Concept 2 Main Analysis Case.}

Figure 4-15 displays the normalized flux to the aquifer for the three fastest groups $\left(\mathrm{K}_{\mathrm{d}}=0,0.1\right.$, and $0.6 \mathrm{~m} / \mathrm{g}$ ). Table $4-10$ presents the relevant parameters for each $\mathrm{K}_{\mathrm{d}}$ group. Because the mean horizontal path from the side walls to the waste is only about 8 meters for the Concept 2 design compared to about 70 meters for the Concept 1 design, the moisture content in the disposal facility and below the disposal facility is higher for the Concept 2 design than for the base analysis case. This makes the hydraulic conductivity higher, so the contaminants reach the aquifer more quickly using the Concept 2 facility design

4.3.1.2 Integration of Vadose Zone and Other Data. Table 4-11 provides the estimated impacts at a well 100 meters downgradient at 10,000 years using Concept 2. Table 4-12 provides the estimated maximum impacts at the same well. The estimated impacts at the Columbia River are the same as for Concept 1 (Tables 4-8 and 4-9). 
DOE/RL-97-69

Rev. 0

Figure 4-15. Normalized Contaminant Flux to the Unconfined Aquifer for $\mathrm{K}_{\mathrm{d}}=0 ., 0.1$, and $0.6 \mathrm{~m} / \mathrm{g}$ for Concept 2 (Full-facility Model).

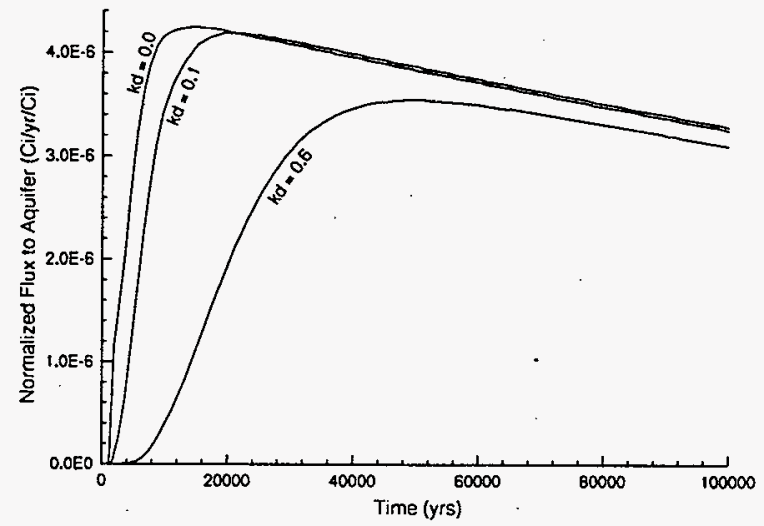

Table 4-10. Major Parameters Describing the Normalized Contaminant Flux to the Aquifer for Concept 2 (Full-facility Model).

\begin{tabular}{|c|c|c|c|c|c|}
\hline $\begin{array}{c}\mathrm{K}_{\mathrm{d}} \\
(\mathrm{m} / \mathrm{g})\end{array}$ & $\begin{array}{c}\text { Value at 10K } \\
\text { Years } \\
(\mathrm{Ci} / \mathrm{y} / \mathrm{Ci})\end{array}$ & $\begin{array}{c}\text { Peak Value in } \\
\text { First 100K } \\
\text { Years } \\
(\mathrm{Ci} / \mathrm{C} / \mathrm{Ci})\end{array}$ & $\begin{array}{c}\text { Time of True } \\
\text { Peak Value } \\
(\mathrm{y})\end{array}$ & $\begin{array}{c}\text { Time of } \\
0.5 * \text { True } \\
\text { Peak Value } \\
(\mathrm{y})\end{array}$ & $\begin{array}{c}\text { Time of } 10^{-6} \\
{ }^{*} \text { True Peak }^{(\mathrm{a})} \\
\text { Value }^{(\mathrm{b})} \\
(\mathrm{y})\end{array}$ \\
\hline 0. & $4.22 \mathrm{e}-6$ & $4.25 \mathrm{e}-6$ & 13,000 & 3,600 & 500 \\
\hline 0.1 & $3.69 \mathrm{e}-6$ & $4.19 \mathrm{e}-6$ & 21,000 & 6,600 & 900 \\
\hline 0.6 & $0.53 \mathrm{e}-6$ & $3.10 \mathrm{e}-6$ & $>100,000$ & 22,000 & 2,000 \\
\hline 3.0 & $4.6 \mathrm{e}-11$ & $2.80 \mathrm{e}-6$ & $>100,000$ & $>100,000$ & 8,000 \\
\hline 15. & $5.6 \mathrm{e}-22$ & $2.1 \mathrm{e}-8$ & $>100,000$ & $>100,000$ & 38,000 \\
\hline 40 & $6.9 \mathrm{e}-23$ & $3.2 \mathrm{e}-12$ & $>100,000$ & $>100,000$ & $>100,000$ \\
\hline 100. & $2.6 \mathrm{e}-24$ & $9.6 \mathrm{e}-20$ & $>100,000$ & $>100,000$ & $>100,000$ \\
\hline
\end{tabular}

The value given is for the peak value in the first 100,000 years.

b Unless an actual peak was obtained in the first 100,000 years, the true peak value was taken as $4 \times 10^{-6} \mathrm{Ci} / \mathrm{y} / \mathrm{Ci}$. 
DOE/RL-97-69

Rev. 0

Table 4-11. Estimated Impact Using Concept 2 Geometry at a Well 100 Meters

Downgradient from the Disposal Facility at 10,000 Years. (Full-facility Model).

\begin{tabular}{|l|l|}
\hline Type of Impact & \multicolumn{1}{|c|}{ Value } \\
\hline \hline Dose from beta/photon emitting radionuclides & $1.1 \mathrm{mrem} / \mathrm{y}$ \\
\hline All-pathways dose & $3.3 \mathrm{mrem} / \mathrm{y}$ \\
\hline Concentration of alpha-emitting radionuclides & $0.27 \mathrm{pCi} / \ell$ \\
\hline Radium concentration & $<1 . x 10^{-10} \mathrm{pCi} / \ell$ \\
\hline Uranium concentration & $0.27 \mathrm{pCi} / \ell$ \\
\hline
\end{tabular}

Table 4-12. Estimated Maximum Impact Using Concept 2 Geometry at 100 Meters Downgradient from the Disposal Facility. (Full-facility Model).

\begin{tabular}{||l|c|c|c|c||}
\hline \multirow{2}{*}{ Impact } & \multicolumn{2}{|c|}{$<10^{5}$ years ${ }^{(\mathrm{a})}$} & \multicolumn{2}{|c|}{$<10^{8}$ years $^{(\mathrm{b})}$} \\
\cline { 2 - 5 } & Value & Time & Value & Time \\
\hline \hline $\begin{array}{l}\text { Maximum drinking water dose from } \\
\text { beta/photon emitting nuclides } \\
\text { at a nearby well }\end{array}$ & $\begin{array}{c}1.12 \\
\mathrm{mrem} / \mathrm{y}\end{array}$ & $\begin{array}{c}15 \times 10^{3} \\
\text { years }\end{array}$ & $\begin{array}{c}5.0 .^{(\mathrm{c})} \\
\mathrm{mrem} / \mathrm{y}\end{array}$ & $\begin{array}{c}13 \times 10^{6} \\
\text { years }\end{array}$ \\
\hline $\begin{array}{l}\text { Maximum all-pathways dose at a } \\
\text { nearby well }\end{array}$ & $\begin{array}{c}7.9 \\
\mathrm{mrem} / \mathrm{y}\end{array}$ & $\begin{array}{c}72 \times 10^{3} \\
\text { years }\end{array}$ & $\begin{array}{c}7.9 \\
\mathrm{mrem} / \mathrm{y}\end{array}$ & $\begin{array}{c}72 \times 10^{3} \\
\text { years }\end{array}$ \\
\hline $\begin{array}{l}\text { Maximum concentration of alpha- } \\
\text { emitting nuclides at a nearby well }\end{array}$ & $\begin{array}{c}2.6 \\
\mathrm{pCi} / \ell\end{array}$ & $\begin{array}{c}62 \times 10^{3} \\
\text { years }\end{array}$ & $\begin{array}{c}6.9 \\
\mathrm{pCi} / \ell\end{array}$ & $\begin{array}{c}3 \times 10^{6} \\
\text { years }\end{array}$ \\
\hline $\begin{array}{l}\text { Maximum concentration of radium } \\
\text { isotopes at a nearby well }\end{array}$ & $\begin{array}{c}0.002 \\
\mathrm{pCi} / \ell\end{array}$ & $\begin{array}{c}\text { @ } 10^{5} \\
\text { years }\end{array}$ & $\begin{array}{c}0.78 \\
\mathrm{pCi} / \ell\end{array}$ & $\begin{array}{c}3 \times 10^{6} \\
\text { years }\end{array}$ \\
\hline $\begin{array}{l}\text { Maximum concentration of uranium } \\
\text { isotopes at a nearby well }\end{array}$ & $\begin{array}{c}2.1 \\
\mathrm{pCi} / \ell\end{array}$ & $\begin{array}{c}47 \times 10^{3} \\
\text { years }\end{array}$ & $\begin{array}{c}2.1 \\
\mathrm{pCi} / \ell\end{array}$ & $\begin{array}{c}47 \times 10^{3} \\
\text { years }\end{array}$ \\
\hline
\end{tabular}

"Detailed computer simulations were performed out to 100,000 years.

${ }^{b}$ Values between 100,000 years and $100,000,000$ years were inferred by using the $K=0$ results and adjusting the time by $\left(1 .+6.6 * \mathrm{~K}_{\mathrm{d}}\right)$.

c The drinking water dose from beta/photon emitters at a well 100 meters downgradient is estimated to exceed $4 \mathrm{mrem} /$ year at about 3 million years. 
Rev. 0

\subsubsection{Unit Cell Model.}

Because the Unit Cell Model is used in many of the sensitivity runs, the calculated impacts are described here. The Unit Cell Model takes a canister-wide slice of the Concept 1 facility concept, but without the sand-gravel capillary barrier (See Section 3.5.3.2 and Figure 3-8). This case, known as the Unit Cell Model base sensitivity case, retains the values used in the base analysis case. The reasons for the differences between these results and those for the base analysis case (Concept 1 ) are presented in Section 4.5.1.3.

\subsubsection{Vadose Zone Transport Simulation of the Unit Cell Model Main Analysis Case.}

Table 4-13 summarizes the calculated normalized fluxes to the unconfined aquifer. Figure 4-16 presents the normalized fluxes from the disposal facility to the vadose zone. Figure 4-17 displays the contaminant fluxes from the vadose zone to the aquifer as a function of time. Major features include a constant flux caused by the constant release rate and a faster rise caused by the absence of a hydraulic diverter than for the full-facility models. A more complete description is given in Kline (1996).

As mentioned in Section 4.2.2.1, the $\mathrm{K}_{\mathrm{o}}=0$ case shows a spike at early times caused by changing the infiltration rate at 1,000 years. Thus in the following results, the $\mathrm{K}_{\mathrm{d}}=0.1 \mathrm{~m} \ell / \mathrm{g}$, which do not show the spike, are used.

4.3.2.2 Integration of Vadose Zone Calculations and Other Data. Table 4-14 provides the estimated impacts at a well 100 meters downgradient at 10,000 years using the Unit Cell Model for the vadose zone calculations and the Concept 1 geometry for the aquifer calculations. Table 4-15 provides the estimated maximum impacts at the same well, 
Table 4-13. Major Parameters Describing the Normalized Contaminant Flux to the Aquifer Using the Unit Cell Model.

\begin{tabular}{|c|c|c|c|c|c|}
\hline $\begin{array}{c}\mathrm{K}_{\mathrm{d}} \\
(\mathrm{m} / \mathrm{g})\end{array}$ & $\begin{array}{c}\text { Value at 10K } \\
\text { Years } \\
(\mathrm{Ci} / \mathrm{y} / \mathrm{Ci})\end{array}$ & $\begin{array}{c}\text { Peak Value } \\
(\mathrm{Ci} / \mathrm{y} / \mathrm{Ci})\end{array}$ & $\begin{array}{c}\text { Time of Peak } \\
\text { Value } \\
(\mathrm{y})\end{array}$ & $\begin{array}{c}\text { Time of } \\
0.5^{*} \text { True } \\
\text { Peak Value }^{(\mathrm{b})} \\
(\mathrm{y})\end{array}$ & $\begin{array}{c}\text { Time of } 10^{-5} \\
{ }^{*} \text { True Peak }^{(2)} \\
\text { Value }^{(\mathrm{b})} \\
(\mathrm{y})\end{array}$ \\
\hline 0.0 & $4.37 \mathrm{e}-6$ & $6.9 \mathrm{e}-6^{\circ}$ & 2,150 & 1,200 & 170 \\
\hline 0.1 & $4.37 \mathrm{e}-6$ & $4.42 \mathrm{e}-6$ & 17,000 & 3,000 & 350 \\
\hline 0.6 & $2.65 \mathrm{e}-6$ & $4.42 \mathrm{e}-6$ & 39,000 & 9,100 & 1,500 \\
\hline 3.0 & $2.01 \mathrm{e}-9$ & $4.35 \mathrm{e}-6$ & $>100,000$ & 39,000 & 6,200 \\
\hline 6.0 & $1.6 \mathrm{e}-12$ & $3.26 \mathrm{e}-6$ & $>100,000$ & 76,000 & 11,000 \\
\hline 15.0 & $1.4 \mathrm{e}-18$ & $3.27 \mathrm{e}-7$ & $>100,000$ & $>100,000$ & $>100,000$ \\
\hline 40.0 & 0.0 & $2.9 \mathrm{e}-10$ & $>100,000$ & $>100,000$ & $>100,000$ \\
\hline 100.0 & 0.0 & $2.4 \mathrm{e}-15$ & $>100,000$ & $>100,000$ & $>100,000$ \\
\hline
\end{tabular}

${ }^{2}$ The value given is for the peak value in the first 100,000 years.

${ }^{\mathrm{b}}$ Unless a peak value was obtained in the first 100,000 years, the true peak value was taken as $4 \times 10^{-6} \mathrm{Ci} / \mathrm{y} / \mathrm{Ci}$.

'Value results from changing properties at 2,000 years.

Table 4-14. Estimated Impact at 10,000 Years from Groundwater at a Well 100 Meters Downgradient Using th: Unit Cell Model and Concept 1 Geometry.

The Unit Cell Micoel does not have a hydraulic diverter.

\begin{tabular}{|l|l|}
\hline Type of Impact & \multicolumn{1}{c|}{ Value } \\
\hline \hline Dose from beta/photon emitting radionuclides & $4.4 \mathrm{mrem} / \mathrm{y}$ \\
\hline All-pathways dose & $13.0 \mathrm{mrem} / \mathrm{y}$ \\
\hline Concentration of alpha-emitting radionuclides & $5.9 \mathrm{pCi} / \ell$ \\
\hline Radium concentration & $<10^{-6} \mathrm{pCi} / \ell$ \\
\hline Uranium concentration & $5.9 \mathrm{pCi} / \ell$ \\
\hline
\end{tabular}


DOE/RL-97-69

Rev, 0

Table 4-15. Estimated Maximum Impact from Groundwater at a Well 100 Meters Downgradient Using the Unit Cell Model for Concept 1 Design.

The Unit Cell Model does not have a hydraulic diverter.

\begin{tabular}{|l|c|c|}
\hline \multirow{2}{*}{ Impact } & \multicolumn{2}{|c|}{$<10^{5}$ years $\mathrm{s}^{(\mathrm{a})}$} \\
\cline { 2 - 4 } & Value & Time \\
\hline Maximum drinking water dose from beta/photon emitting & $\begin{array}{c}4.5^{(\mathrm{b})} \\
\text { mrem/y }\end{array}$ & $\begin{array}{c}15 \times 10^{3} \\
\text { years }\end{array}$ \\
\hline nuclides at a nearby well & $\begin{array}{c}63.0^{\circ} \\
\mathrm{mrem} / \mathrm{y}\end{array}$ & $\begin{array}{c}50 \times 10^{3} \\
\text { years }\end{array}$ \\
\hline Maximum all-pathways dose at a nearby well & $\begin{array}{c}15.0^{(\mathrm{d})} \\
\mathrm{pCi} / \ell\end{array}$ & $\begin{array}{c}49 \times 10^{3} \\
\text { years }\end{array}$ \\
\hline Mearby well concentration of alpha-emitting radionuclides at a & $\begin{array}{c}0.12 \\
\mathrm{pCi} / \ell\end{array}$ & $\begin{array}{c}@ 10^{5} \\
\text { years }\end{array}$ \\
\hline Maximum concentration of radium isotopes at a nearby well & $\begin{array}{c}9.5 \\
\mathrm{pCi} / \ell\end{array}$ & $\begin{array}{c}25 \times 10^{3} \\
\text { years }\end{array}$ \\
\hline
\end{tabular}

Detailed computer simulations were performed out to 100,000 years.

${ }^{b}$ The beta/photon drinking water dose is estimated to exceed 4 mrem in a year at 7,200 years.

' The all-pathways dose is estimated to exceed $25 \mathrm{mrem} /$ year at 22,000 years.

'The concentration of alpha-emitting radionuclides is estimated to exceed $15 \mathrm{mrem}$ in a year at 46,000 years. 
DOE/RL-97-69

Rev. 0

Figure 4-16. Normalized Contaminant Flux from the Disposal Facility to the Vadose Zone using the Unit Cell Model.

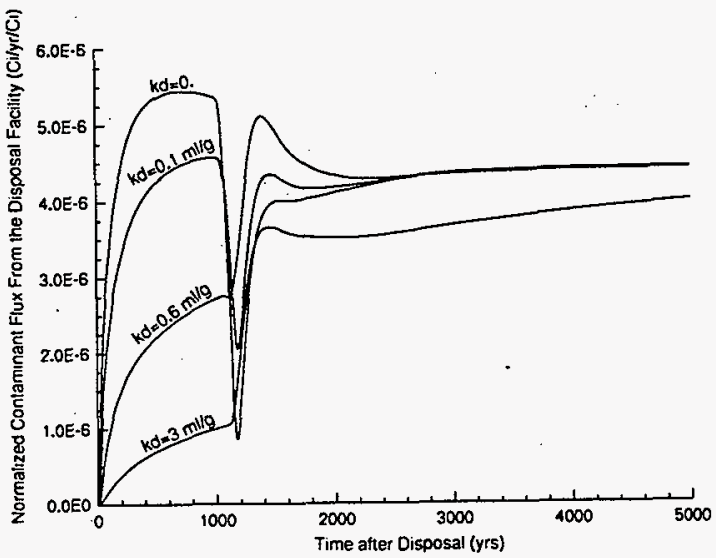

Figure 4-17. Normalized Contaminant Flux to the Unconfined Aquifer for $K_{d}=0,0.1,0.6$, and 3. $\mathrm{m} \ell / \mathrm{g}$ using the Unit Cell Model.

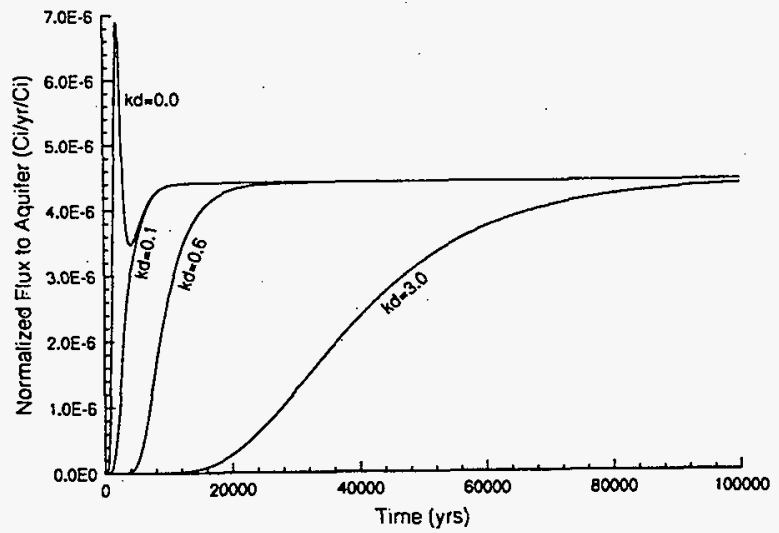


DOE/RL-97-69

Rev. 0

\subsection{RESULTS OF GROUNDWATER SCENARIOS - WASTE FORM SENSITIVITY CASES}

Waste form performance is one of the most important inputs to this performance assessment. However, the waste form has not been chosen; so the actual performance of the waste form is not yet known. For the base analysis case, the initial release of contaminants is assumed to happen at the same rate as the dissolution of the waste form for the non-technetium inventory as specified in the RFP for low-level tank waste immobilization (DOE-RL 1996). Subsequent release rates are established by using the same release rate per unit surface area and the available surface area. This section discusses the sensitivity of interpreting the RFP differently, as well as using more mechanistic approaches to determine glass performance.

\subsubsection{Contaminant Release Rates from Waste Form}

Although the contaminant release rate from the RFP forms the basis of the base analysis case, sensitivity runs were performed using a mechanistic model for glass corrosion and contaminant release. The AREST-CT computer code (Section 3.5.2.2 and Appendix C) simulated the dissolution of LD6-5412 glass, the release of contaminants from the glass, and the transport of those contaminants through the bottom of the disposal vaults. These simulations are discussed in Appendix E.

Because of current limitations of the model, certain effects were not modeled in this analysis that will be modeled in the future performance assessments. For example, water consumed during glass dissolution is not removed from the system in this analysis. Such water consumption is relatively unimportant for glass shapes having dimensions of a meter size but can be important for shapes which have a dimension a hundred times smaller. This analysis assumes that the surface area of the glass is proportional to the square of the effective radius of the glass and hence decreases as the glass dissolves. Processes that could increase the surface area, such as cracking after cooling, are not considered.

The simulations performed for this analysis show that the ion exchange of sodium for hydrogen in the glass waste form

$$
(\text { Glass }-0.4208 \mathrm{Na})+0.4208 \mathrm{H}^{+}=(\text {Glass }-0.4208 \mathrm{H})+0.4208 \mathrm{Na}^{+},
$$

is important at the low temperatures expected in the disposal vault. Because of this ion exchange reaction, the computed $\mathrm{pH}$ in the glass/water interface rises to over 12 . Because the glass LD6-5412 is much less stable at these high pH levels, the dissolution rate is significant (see Figure 4-18.). Using water-saturated, low-temperature, batch tests with LD6-5412 glass, the sodium ion-exchange reaction was identified only as a minor secondary reaction that contributed to an enhanced rate of sodium release compared to other major glass components, 


\section{DOE/RL-97-69}

Rev. 0

Figure 4-18. Glass Dissolution Rate as a Function of Time and Space in the Disposal Vault. For glass having a density of $2.7 \mathrm{~g} / \mathrm{cm}^{3}, 10^{-15} \mathrm{~m} / \mathrm{s}=2.3 \times 10^{-4} \mathrm{~g} /\left(\mathrm{m}^{2} \mathrm{~d}\right)$.

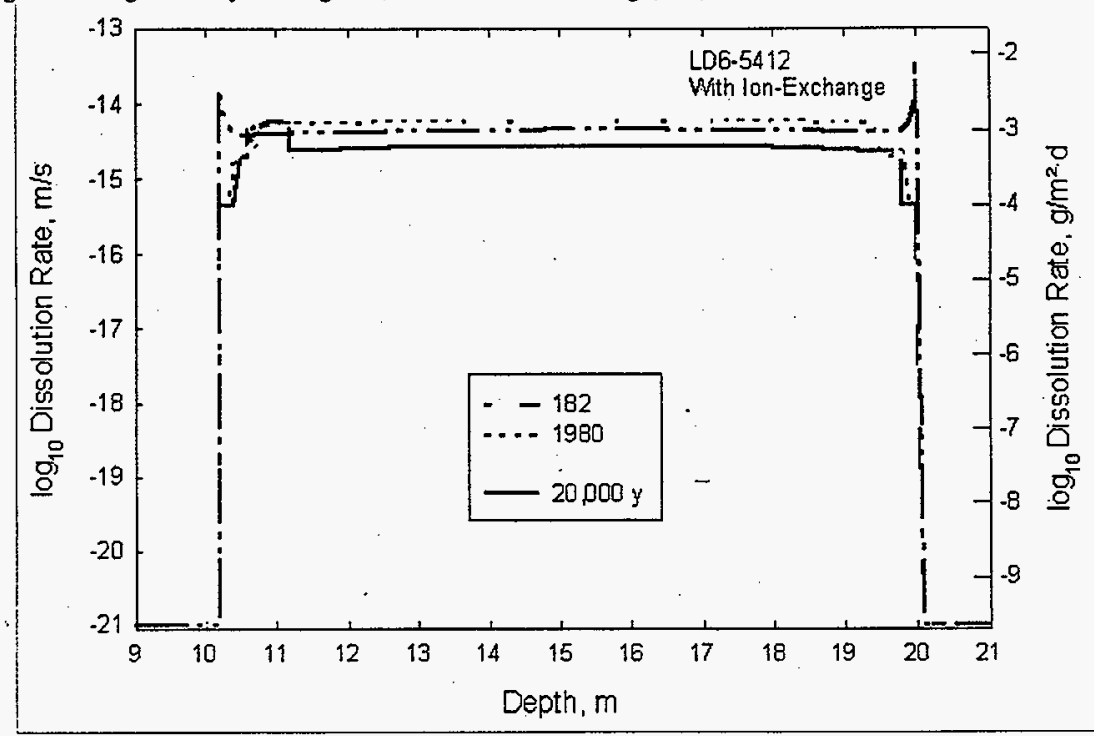

including boron and silicon. However, in an unsaturated environment where little water is present, the importance of this reaction mechanism was revealed through computer simulations that properly couple chemical reactions and transport.

The AREST-CT computer code also was used to transport the contaminants through the vault floor once they were released from the glass. The maximum release rate through the vault floor is shown in Table 4-16. Figure 4-19 displays the time dependence of the release rate through the floor. These calculations assume that the concrete floor has degraded and has the hydraulic parameters of gravel. Note that all the calculated release rates are smaller than those specified in the RFP (DOE-RL 1996).

To determine the actual importance of the ion exchange reaction, the technetium release rate was recalculated with the ion exchange reaction absent from the simulation. Without the sodium ion exchange reaction, the $\mathrm{pH}$ peaks at only about 10.5 . The lower $\mathrm{pH}$ reduces the glass corrosion rate by about a factor of 30 , resulting in a glass corrosion rate that is three or four orders of magnitude lower than the forward rate of reaction for LD6-5412. The maximum release rate is shown in Table 4-16 and the time dependence of the release rate through the floor is displayed in Figure 4-20. 
DOE/RL-97-69

Rev. 0

Table 4-16. Maximum Release Rate through Vault Floor as Calculated by AREST-CT.

\begin{tabular}{||l|c|}
\hline Element & Release Rate $(\mathrm{ppm} / \mathrm{y})$ \\
\hline \hline Base Analysis Case & 4.4 \\
\hline Selenium & 0.78 \\
\hline Technetium: & \\
full simulation & 0.50 \\
no sodium ion exchange & 0.02 \\
high pore velocity & 1.4 \\
\hline Iodine & 0.50 \\
\hline Uranium & 0.64 \\
\hline Plutonium & 0.50 \\
\hline
\end{tabular}

Figure 4-19. Estimated Release Rates through the Vault Floor.

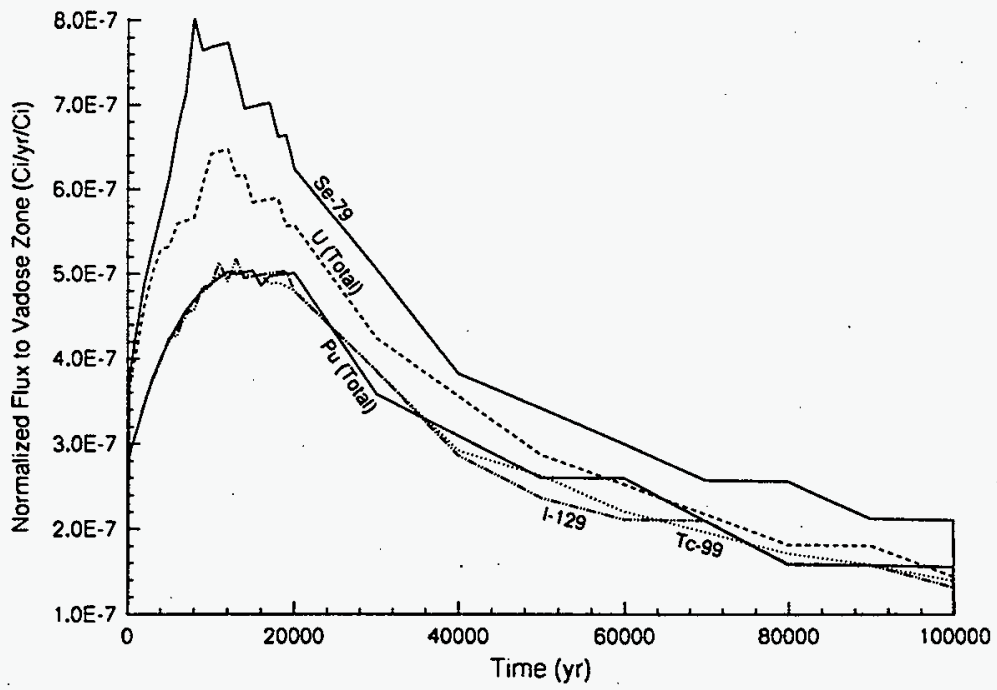




\section{DOE/RL-97-69}

Rev. 0

Figure 4-20. Normalized Technetium Fluxes Through the Vault Floor for Various Assumptions. The unit cell model base sensitivity case assumed the sodium ion-exchange reaction occurred and the pore velocity was $1.0 \mathrm{~cm} / \mathrm{y}$.

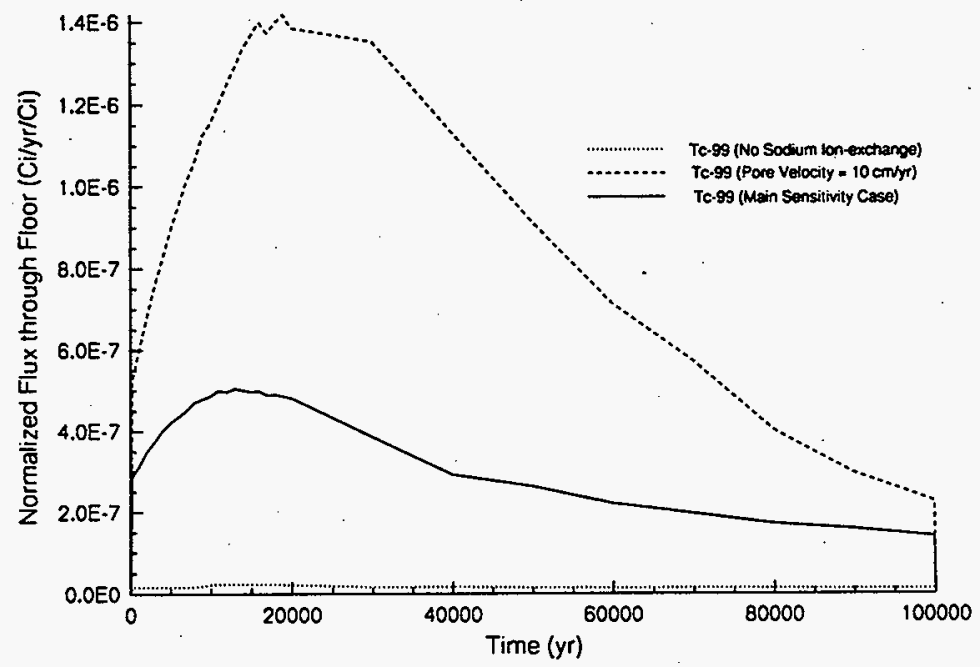

Finally, the AREST-CT calculation simulated a case with more water available in the vault system, resulting in an pore velocity of $10.0 \mathrm{~cm} / \mathrm{y}$ rather than $1.0 \mathrm{~cm} / \mathrm{y}$. The pore velocity is the rate of water which passes through the void spaces as contrasted to the infiltration rate which is the speed at which water passes through a unit volume of material. The pore velocity is the infiltration rate divided by the porosity. The technetium release rate increased by a factor of three as seen in Table 4-16 and Figure 4-20.

\subsubsection{Impact on Exposure Calculations}

This section describes the sensitivity of the estimated impacts to various assumptions made concerning the waste form. Included in the discussion are the effects caused by the treatment of the time dependence of the release rate, on the special treatment of technetium in the RFP, and the release rates calculated by the mechanistic model. 
DOE/RL-97-69

Rev. 0

4.4.2.1 Constant Mass Release. The base analysis case assumes that the rate of waste form dissolution (and contaminant release) is proportional to the surface area of the waste form. Thus the base analysis case has a declining amount of contaminants being released as a function of time. A sensitivity case was run to determine the effect of constant contaminant release at a rate of $4.4 \mathrm{ppm}$. This is equivalent to assuming that the waste form has the shape of a thin plate. Figure 4-21 displays the normalized flux to the aquifer for the $K_{\sigma}=0$ group for the Concept 2 base sensitivity case and the constant contaminant release case using Concept 2 . Table 4-17 presents the parameters for the curves of the various $\mathbf{K}_{d}$ groups. The results for the two cases are similar for the first 10,000 years. They then diverge as the results for the constant release case go to the expected value of $4.4 \times 10^{-6}$ per year and the results of the case with release proportional to surface area decline. The results for the constant release case go to the expected value, supporting the values calculated using the time-dependent release rate.

Because the normalized fluxes are so close for the constant release and the time-varying release, the estimated impacts differ little except after 50,000 years.

Figure 4-21. Normalized Flux to the Aquifer for $\mathrm{K}_{\mathrm{d}}=0$ for Concept 2 Simulations Using Constant Contaminant Release and Using Contaminant Release Proportional to Surface Area (Full-facility Model).

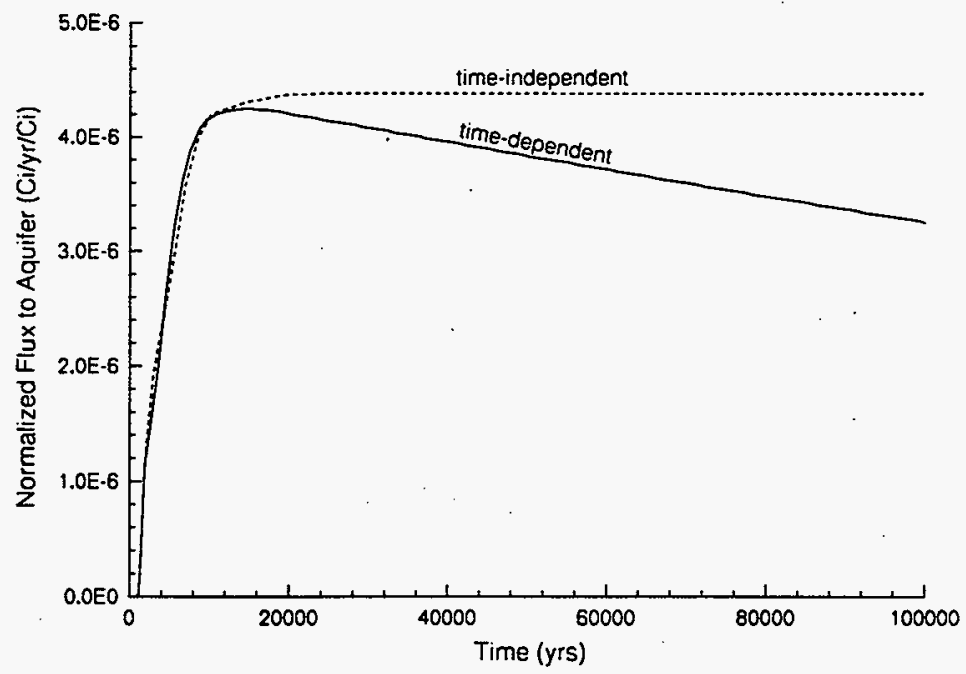


DOE/RL-97-69

Rev. 0

Table 4-17. Major Parameters Describing the Normalized Contaminant Flux to the Aquifer for Concept 2 Using Constant Contaminant Release (Full-facility Model).

\begin{tabular}{|c|c|c|c|c|c||}
\hline $\begin{array}{c}\mathrm{K}_{\mathrm{d}} \\
(\mathrm{m} / \mathrm{g})\end{array}$ & $\begin{array}{c}\text { Value at 10K } \\
\text { Years } \\
(1 / \mathrm{y})\end{array}$ & $\begin{array}{c}\text { Peak Value } \\
(1 / \mathrm{y})\end{array}$ & $\begin{array}{c}\text { Time of Peak } \\
\text { Value } \\
(\mathrm{y})\end{array}$ & $\begin{array}{c}\text { Time of } \\
0.5^{*} \text { Peak } \\
\text { Value } \\
(\mathrm{y})\end{array}$ & $\begin{array}{c}\text { Time of 10 } \\
\text { *Peak Value } \\
(\mathrm{y})\end{array}$ \\
\hline 0. & $4.21 \times 10^{-6}$ & $4.39 \times 10^{-6}$ & 35,000 & 3,700 & 650 \\
\hline 0.1 & $3.46 \times 10^{-6}$ & $4.35 \times 10^{-6}$ & 50,000 & 6,900 & 1,150 \\
\hline 0.6 & $0.42 \times 10^{-6}$ & $3.95 \times 10^{-6}$ & $>100,000$ & $22,000^{(b)}$ & $2,100^{(b)}$ \\
\hline
\end{tabular}

${ }^{3}$ The value given is for the peak value in the first 100,000 years. The true peak value is expected to be about $4 . x 10^{-6} \%$.

${ }^{b}$ Time of $\mathrm{K} *$ true peak value is about that listed.

4.4.2.2 Reduced Release Rate for Technetium. The RFP for tank waste immobilization (DOE-RL 1996) specified a lower release rate for technetium (by a factor of 5) than for the other radionuclides. This lower rate could be achieved by reducing the amount of technetium in the waste (and returning technetium to DOE) or by having a better performing waste form. For this section, the waste form is assumed to have a release rate that is five times better than the base analysis case. The results are similar to the base analysis case and to the Concept 2 base sensitivity case for the first 100,000 years except the normalized flux of the technetium to the aquifer is a factor of five lower.

Table 4-18 provides the effects of better performing waste forms, assuming that only technetium is affected and assuming that all $\mathrm{K}_{\mathrm{\sigma}}=0$ radionuclides are affected. The doses do not decrease by a factor of five from the base analysis case because other radionuclides become important. For example, if the improved factor of five performance only affects technetium, ${ }^{79} \mathrm{Se}$ is calculated to be the most important radionuclide. The beta/photon drinking water dose at 10,000 years is 50 percent from ${ }^{79} \mathrm{Se}$ and 47 percent from ${ }^{99} \mathrm{Tc}$. Alternatively, when the performance is improved for all the $K_{d}=0$ radionuclides, the impact of the $K_{d}=0.6 \mathrm{~m} / \mathrm{g}$ radioisotopes (mainly uranium and its daughters) is enough to provide one-third of the dose. 
DOE/RL-97-69

Rev. 0

Table 4-18. Sensitivity of Impacts Caused by Different Interpretations of Waste Immobilization Request for Proposal.

\begin{tabular}{|c|c|c|c|}
\hline Case & Time & $\begin{array}{c}\text { Beta/Photon } \\
\text { Drinking Water } \\
\text { Dose (mrem/y) }\end{array}$ & $\begin{array}{c}\text { All-Pathways } \\
\text { Dose } \\
\text { (mrem/y) } \\
\end{array}$ \\
\hline \multirow[t]{2}{*}{ Base Analysis Case } & $10 \mathrm{~K} \mathrm{y}$ & 2.0 & 6.4 \\
\hline & $\max$ & $2.7 @ 71 \mathrm{~K}$ & 23.@ $0 \mathrm{~K}$ \\
\hline \multirow{2}{*}{$\begin{array}{l}\text { Technetium has five times smaller release } \\
\text { rate }\end{array}$} & $10 \mathrm{Ky}$ & 0.87 & 2.8 \\
\hline & $\max$ & $1.20 @ 100 \mathrm{~K}$ & 18.@ 49K \\
\hline \multirow{2}{*}{$\begin{array}{l}\text { All } K_{d}=0 \text { radionuclides have five times } \\
\text { smaller release rates }\end{array}$} & $10 \mathrm{Ky}$ & 0.57 & 2.3 \\
\hline & $\max$ & $0.99 @ 100 \mathrm{~K}$ & 17.@49K \\
\hline \multirow{2}{*}{$\begin{array}{l}\text { All radionuclides have } 5 \text { times smaller } \\
\text { release rates }\end{array}$} & $10 \mathrm{Ky}$ & 0.40 & 1.3 \\
\hline & $\max$ & $0.54 @ 71 \mathrm{~K}$ & $4.6 @ 50 \mathrm{~K}$ \\
\hline \multirow[t]{2}{*}{ Concept 2 base sensitivity case } & $10 \mathrm{Ky}$ & 1.11 & 3.3 \\
\hline & $\max$ & $1.12 @ 15 \mathrm{~K}$ & $7.9 @ 72 \mathrm{~K}$ \\
\hline \multirow{2}{*}{$\begin{array}{l}\text { Technetium has five times smaller release } \\
\text { rate }\end{array}$} & $10 \mathrm{~K} \mathrm{y}$ & 0.42 & 1.05 \\
\hline & $\max$ & $1.34 @ 99 \mathrm{~K}$ & $8.9 @ 99 \mathrm{~K}$ \\
\hline \multirow{2}{*}{$\begin{array}{l}\text { All } K_{d}=0 \text { radionuclides have five times } \\
\text { smaller release rates }\end{array}$} & $10 \mathrm{Ky}$ & 0.24 & 0.72 \\
\hline & $\max$ & $1.43 @ 99 \mathrm{~K}$ & $9.0 @ 99 \mathrm{~K}$ \\
\hline \multirow{2}{*}{$\begin{array}{l}\text { All radionuclides have five times smaller } \\
\text { release rates }\end{array}$} & $10 \mathrm{~K} \mathrm{y}$ & 0.22 & 0.66 \\
\hline & $\max$ & $0.23 @ 15 \mathrm{~K}$ & $1.6 @ 72 \mathrm{~K}$ \\
\hline \multirow[t]{2}{*}{ Release rate constant at $4.4 \mathrm{ppm} / \mathrm{y}$} & $10 \mathrm{Ky}$ & 1.11 & 3.3 \\
\hline & $\max$ & $1.15 @ 25 \mathrm{~K}$ & $8.4 @ 74 \mathrm{~K}$ \\
\hline
\end{tabular}

4.4.2.3 Mechanistic Approaches to Waste Form Performance. Silicate glass is a leading candidate for the waste form. As described in Section 4.4.2, the AREST-CT code was used to estimate the release of contaminants from the waste form and the transport of those contaminants through the vault floor. This section presents the results of the Unit Cell Model following those contaminants through the vadose zone and the unconfined aquifer to the well. Table 4-19 displays the estimated impacts using the calculated glass release rates as a source term. Figure 4-22 shows the estimated beta/photon drinking water dose when sodium ion exchange is both included and excluded. 


\section{DOE/RL-97-69}

Rev. 0

Because the release rate for each element is reduced by about a factor of eight (Table 4-16), the impacts are reduced by about the same factor. Selenium-79 is a bit more important when a mechanistic model is used than when all elements have the same release rate, because it has a slightly higher calculated release rate than technetium. It contributes about 30 percent to the beta/photon drinking water dose in this case in contrast to about 20 percent for the base analysis case.

As noted in Section 4.4.2, sodium ion exchange significantly increases the $\mathrm{pH}$ level and hence the glass corrosion rate. If a glass were formulated and/or processed in such a way as to greatly decrease the sodium ion exchange reaction rate, then the $\mathrm{pH}$ of the system stays in the 8 and 9 region, resulting in a much slower glass dissolution rate [reaching a peak of $10^{-4} \mathrm{~g} /\left(\mathrm{m}^{2} \mathrm{~d}\right)$ rather than $\left.10^{-3} \mathrm{~g} /\left(\mathrm{m}^{2} \mathrm{~d}\right)\right]$. However, this peak release rate is achieved sooner because without the sodium exchange reaction, less time is needed to reach the peak $\mathrm{pH}$ (and peak release rate).

For the calculations shown in Table 4-19 and Figure 4-22, only the release rate for technetium is reduced. This makes the estimated impacts the result of the elements other than technetium, primarily selenium and uranium. If all elements were affected in a manner similar to technetium, the effects would drop by a factor of about 40 from the base analysis case.

These sets of calculations involve contaminant transport as well as release. However, AREST-CT was only used to model the interior of the vault, so its model is incomplete. As a sensitivity case, the pore velocity (that is, the infiltration rate divided by the porosity) was increased to $10.0 \mathrm{~cm} / \mathrm{y}$ (from $1.0 \mathrm{~cm} / \mathrm{y}$ ). The resulting release rate through the floor increases by a factor of only 2.7 .

Table 4-19. Estimated Impacts at 10,000 Years When Using Calculated Glass Release Rates at a Well 100 Meters Downgradient from a Concept 1 Facility (Unit Cell Model).

\begin{tabular}{|l|c|c|c|}
\hline Case & $\begin{array}{c}\text { Beta/Photon } \\
\text { Drinking Water } \\
\text { Dose } \\
\text { (mrem/y) }\end{array}$ & $\begin{array}{c}\text { Alpha-Emitting } \\
\text { Radionuclide } \\
\text { Concentration } \\
\text { (pCi//) }\end{array}$ & $\begin{array}{c}\text { All-Pathways } \\
\text { Dose } \\
\text { (mrem/y) }\end{array}$ \\
\hline Base sensitivity case & 4.4 & 5.9 & 13.4 \\
\hline $\begin{array}{l}\text { Glass mechanistic model (with } \\
\text { sodium ion exchange) }\end{array}$ & 0.53 & 0.63 & 1.5 \\
\hline $\begin{array}{l}\text { Glass mechanistic model } \\
\text { without sodium ion exchange - } \\
\text { technetium only }\end{array}$ & 0.20 & 0.63 & 0.5 \\
\hline $\begin{array}{l}\text { Glass mechanistic model } \\
\text { high pore velocity - technetium } \\
\text { only }\end{array}$ & 0.97 & 0.63 & 3.0 \\
\hline
\end{tabular}




\section{DOE/RL-97-69}

Rev. 0

Figure 4-22. Beta/Photon Drinking Water Dose When Using Glass Release as a Source Term for a Well 100 Meters Downgradient of a Concept 1 Facility (Unit Cell Model).

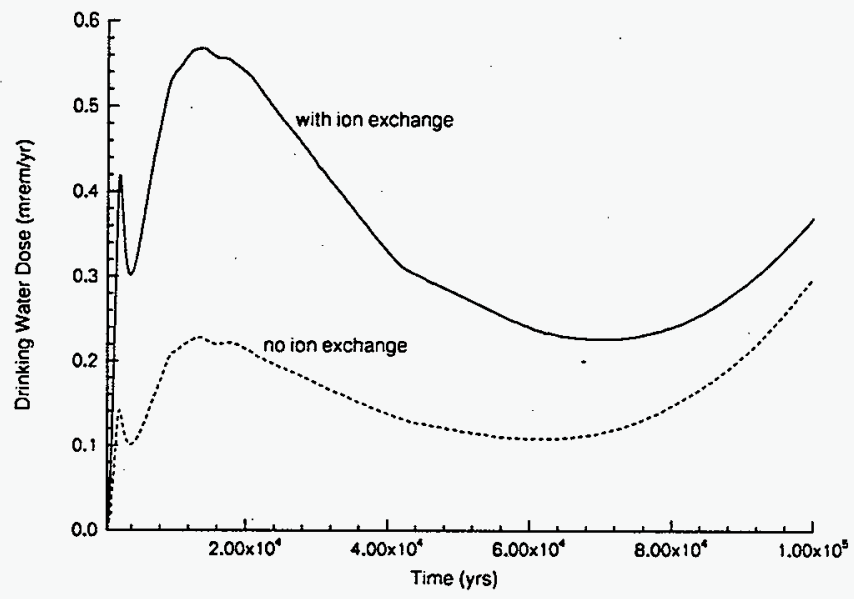

\subsection{RESULTS OF GROUNDWATER SCENARIOS - DISPOSAL FACILITY SENSITIVITY CASES}

At present no designs for the disposal facility have been developed. Concepts 1 and 2 are simply preconceptual ideas that reflect possible facility components, shapes, and sizes. For this performance assessment, the effect of vault layout and degradation and other effects were investigated.

\subsubsection{Vault Layout}

The following sections report the results for assuming different vault layouts. The study included increasing the number of rows of Concept 1 , rotating Concept 1 by $90^{\circ}$, and by inserting soil between the vault rows (Concept 2). 


\section{DOE/RL-97-69}

Rev. 0

4.5.1.1 Number of Vault Rows. The number of canisters that will be produced is uncertain because the vendors have to optimize a number of factors. The number of rows is not expected to be significantly fewer than in the base analysis case, but could be more depending on the choice of sodium loading and waste loading in the glass. Doubling the number of rows results in reducing the aquifer mixing factor (the well/vadose-zone concentration ratio) by 30 percent and increasing the area by 2 . Thus the estimated dose and contaminant concentrations in well water decrease by 65 percent.

4.5.1.2 Orientation. Because the shape of Concept 1 is nearly square ( 208 meters by 246 meters), rotating the facility $90^{\circ}$ has little effect. The calculations show a 2-percent increase in the well/vadose-zone concentration ratio and impacts. This is because the initial orientation of Concept 1 had the long side nearly perpendicular to the groundwater flow path. A larger effect would be seen if Concept 2 were rotated by $90^{\circ}$, because Concept 2 is less square in shape ( 246 meters by 515 meters).

However, as will be seen in Section 4.7.2.3, irrigation in other parts of the Hanford Site Central Plateau could change the direction slightly of groundwater flow. Thus, although the orientation of the vaults would affect the estimated doses, the exact effect is difficult to determine. The present orientation results in among the highest estimated impacts.

4.5.1.3 Concept 2. The major difference between the Concept 1 and Concept 2 facility design concepts is that in Concept 1 the vault rows share walls, while in Concept 2 the vault rows are separated by soil (Figures 2-24 and 2-25). This difference leads to two major effects and some minor ones. The major effects are an increased release rate from the facility for Concept 2 and a decrease in contaminant concentration in the groundwater because the disposal site area is larger. This section discusses these major effects caused by the differences in Concepts 1 and 2, the minor effects, and the effects produced by the Concept 2 vault layout.

In both Concepts 1 and 2, the hydraulic barrier above the waste is predicted to divert most of the water around the disposal facility (Figures 4-2 through 4-6). The moisture content of the filler material is predicted to be the same for both concepts, but the concepts differ in the magnitude of rain shadow beneath the disposal facility. Directly beneath the center of the facility, the moisture content increases from $0.035 \mathrm{~cm}^{3} / \mathrm{cm}^{3}$ in Concept 1 to $0.038 \mathrm{~cm}^{3} / \mathrm{cm}^{3}$ in Concept 2. At the edge of the facility, the increase is from $0.036 \mathrm{~cm}^{3} / \mathrm{cm}^{3}$ (Concept 1) to $0.041 \mathrm{~cm}^{3} / \mathrm{cm}^{3}$ (Concept 2). A similar increase is seen as one progresses down the vadose zone.

Figure 4-23 displays the normalized flux entering the aquifer for the unretarded group of chemicals $\left(\mathrm{K}_{\mathrm{d}}=0\right)$ for Concepts 1 and 2 . Although the normalized fluxes approach the same peak value (the rate at which contaminant is released from the waste form), the contaminants reach the aquifer much more quickly in Concept 2 (the flux reaches half its height in about 3,600 years in Concept 2 versus about 10,000 years in Concept 1). This faster travel time is caused by the higher hydraulic conductivity in the Concept 2 case resulting from the increased moisture content found for that case. 


\section{DOE/RL-97-69 \\ Rev. 0}

Figure 4-23. Normalized Flux to the Aquifer for $\mathrm{K}_{\mathrm{d}}=0$ Elements from Concepts 1 and Concept 2. The effects of increased area and a smaller groundwater/vadose zone concentration ratio, however, result in a smaller dose at 10,000 years from concept 2 (full-facility models).

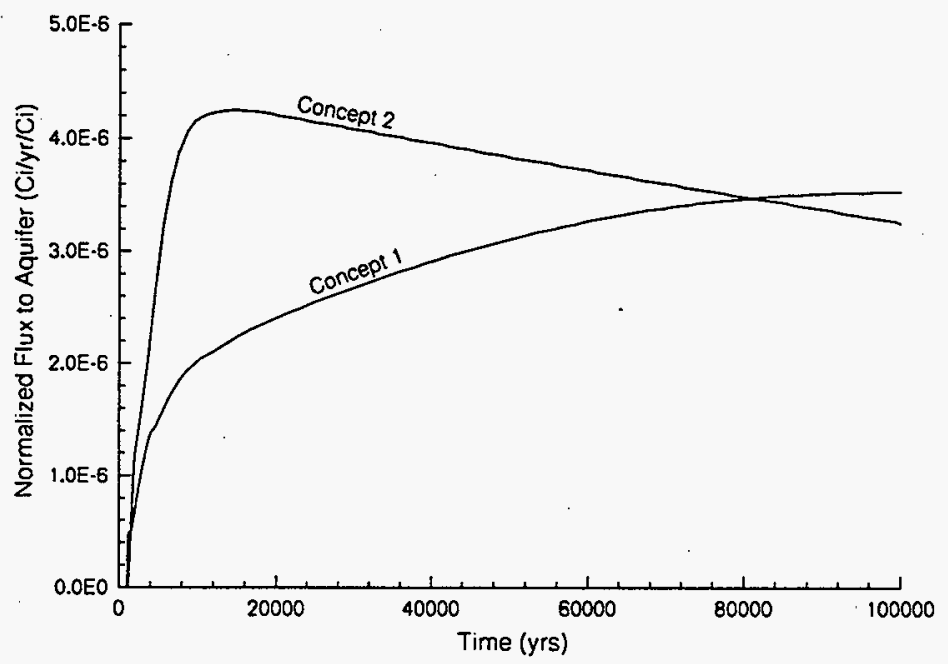

The waste is more dispersed in Concept 2 than in Concept 1 . Thus the flux entering the aquifer mixes with a larger volume of water. Modeling each row as a separate source, the aquifer mixing factor (or concentration ratio) is reduced to 0.00381 for Concept 2 (versus 0.00531 for Concept 1$)$. This yields a higher mixing factor $(0.00381$ versus 0.00309$)$ than would be indicated by just the increase in area, because the vadose zone fluxes are peaked over each row rather than being uniform over the entire area of the disposal facility. Because of lateral spreading in the vadose zone, which is not taken into account using the Unit Cell Model, the actual aquifer mixing factor will be between 0.00381 and 0.00309 .

Minor differences in effects caused by Concepts 1 and 2 relate to the effectiveness of the hydraulic barriers. The hydraulic barrier over Concept 1 is much longer and has a much shallower slope. The relative performance of such a shallower slope was not investigated separately in these analyses. Concept 1 also has a larger amount of water passing the side walls. The effect of this on degradation of the barrier or side walls also was not investigated.

Finally, the release rate of the contaminants was assumed to be independent of the moisture, but the corrosion rate of glass (and presumably other waste forms) does depend on the amount of water present. Because the interior of the Concept 2 facility is expected to have somewhat more moisture, the contaminant release rate should change. 


\section{DOE/RL-97-69 \\ Rev. 0}

4.5.1.4 Conceptual Design by Burbank (1997). No calculations were explicitly performed for the conceptual design in the disposal alternatives analysis as the vault shapes and layout are similar to those of Concept 2 .

\subsubsection{Facility Design Options}

Because only a preconceptual idea exists for the design of the new disposal facilities, relatively few sensitivity cases were run on vault components. The components examined were the sand-gravel capillary hydraulic barrier above the disposal vault, a similar barrier on the sides of the vault and the type of filler material between the canisters.

4.5.2.1 Hydraulic Diverter. Both the Concept 1 and 2 facilities have a sloping barrier above the disposal vaults and a barrier along the vault rows to divert moisture from the waste form. This diverter, also known as a sand-gravel capillary barrier, works on the principal that the overlying sand is forced to become nearly saturated before the water in the sand will drain into the gravel. Being near saturation, while not being at or above the air entry potential of the gravel, the relatively high unsaturated hydraulic conductivity of the sand layer when combined with its sloping configuration, offers the moisture an easier route downward by allowing it to move laterally until its comes to the edge of the capillary barrier and then downward through the vadose zone profile. The coarse gravel component of the barrier exhibits relatively large open pores that are not wet by the moisture until the overlying sand-layer reaches the air entry potential of the gravel.

The Unit Cell Model calculations did not model this diverter, so comparing the base analysis case (Concept 1) and the Unit Cell Model base sensitivity case for the Unit Cell Model provides an indication of the usefulness of the barrier. The beta/photon drinking water dose for Concept 1 increases by a factor of 2.2 with the alpha-emitting radionuclide concentration increasing a factor of 3.5. See Table 4-20.

The cause for this increase is that, when no diverter is present over the vault area, the sediments immediately below the vault area are more moist (See Figure 4-24). This makes the contaminants easier to flush from the vault zone and the vadose zone when no hydraulic diverter is present. This is reflected in the travel times, which are much faster in the Unit Cell Model (about 1,300 years for the unretarded group) than in the Concept 1 Full-facility Model (about 10,000 years).

For Concept 2 , the effect of the hydraulic diverter is only about 10 percent for the beta/photon drinking dose. However, the effect of the diverter on the concentration of alphaemitting radionuclides increases by a factor of 6.1 . The beta/photon dose does not significantly increase because the unretarded group for Concept 2 is already near its maximum value with a travel time being about 3,500 years. However, the effect of speeding the uranium group is significant. The travel time for Concept 2 Full-facility Model is about 20,000 years, for the Unit Cell Model about 10,000 years. 


\section{DOE/RL-97-69}

Rev. 0

The changes in the alpha-emitting radionuclide concentration are greater than the changes in the beta/photon drinking water dose when no hydraulic diverter is present. The flux of the unretarded group (selenium and technetium) is nearly at its maximum value even with a hydraulic barrier. However, with a hydraulic diverter, the flux in the $\mathrm{K}_{d}=0.6 \mathrm{~m} / \mathrm{g}$ group (uranium) is far below its maximum value. However, for a design without a hydraulic diverter, the flux for the $\mathrm{K}_{\mathrm{d}}=0.6 \mathrm{~m} / \mathrm{g}$ group (including uranium) is also near its peak. Thus the presence of the hydraulic barrier has a greater effect for the uranium group and, hence, for the impact from alpha-emitting nuclides.

Table 4-20. Effect of Facility Design Options on Estimated Impacts at 10,000 Years.

\begin{tabular}{|c|c|c|c|}
\hline Disposal Facility Feature & $\begin{array}{c}\text { Beta/Photon } \\
\text { Drinking Water } \\
\text { Dose } \\
(\mathrm{mrem} / \mathrm{y})\end{array}$ & $\begin{array}{l}\text { Alpha-Emitting } \\
\text { Radionuclide } \\
\text { Concentration } \\
\text { (pCi/l) }\end{array}$ & $\begin{array}{l}\text { All-Pathways Dose } \\
\text { (mrem/y) }\end{array}$ \\
\hline \multicolumn{4}{|c|}{ Concept 1 Geometry } \\
\hline $\begin{array}{l}\text { Full-facility Model with } \\
\text { hydraulic barrier } \\
\text { (base analysis case) }\end{array}$ & 2.0 & 1.7 & 6.4 \\
\hline $\begin{array}{l}\text { Unit Cell Model } \\
\text { which has no hydraulic } \\
\text { barrier }\end{array}$ & 4.4 & 5.9 & 13.4 \\
\hline $\begin{array}{l}\text { Unit Cell Model } \\
\text { when the material between } \\
\text { the containers is sand }\end{array}$ & 4.4 & 5.6 & 13.3 \\
\hline \multicolumn{4}{|c|}{ Concept 2 Geometry } \\
\hline $\begin{array}{l}\text { Full-facility Model with } \\
\text { hydraulic barrier }\end{array}$ & 1.11 & 0.27 & 3.3 \\
\hline $\begin{array}{l}\text { Unit Cell Model which } \\
\text { has no hydraulic barrier }\end{array}$ & 1.23 & 1.66 & 3.8 \\
\hline $\begin{array}{l}\text { Full-facility Model, but } \\
\text { without side gravel walls }\end{array}$ & 1.16 & 0.72 & 3.5 \\
\hline
\end{tabular}


Figure 4-24. Moisture Values of Unit Cell Model for steady state. The moisture content is given as saturation which is volumetric moisture content divided by the porosity of the material. The display on the right shows the top 15 meters.

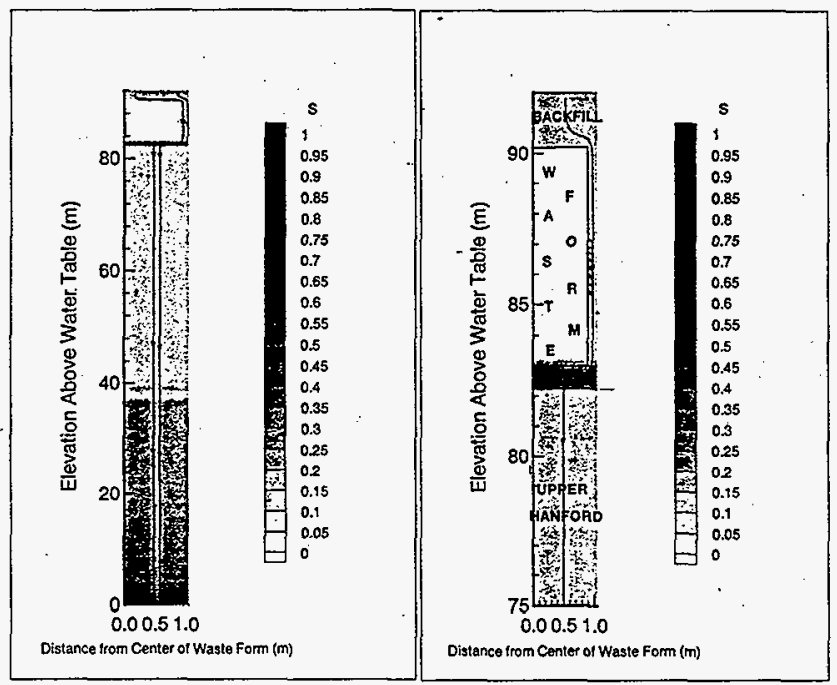

4.5.2.2 Side Hydraulic Diverter. Calculations were performed with a hydraulic diverter on top but not on the sides. The presence of the side hydraulic diverter for Concept 2 has about a 5-percent effect on performance for the beta/photon drinking water dose and about a 50-percent effect for the alpha-emitting radionuclide concentration. The cause of the performance change is the same for the top hydraulic barrier, but the effect is less because the moisture has to move horizontally rather than downward.

The effect of a side hydraulic diverter was not calculated for Concept 1 . However, because of its extended lateral dimensions, the effect of such a side hydraulic diverter should not be significant.

4.5.2.3 Filler Material. The base analysis case uses the hydraulic properties for the filler material between the canisters in the vaults. If hydraulic properties of sand are used instead of those of backfilled soil, the effects do not change significantly. The travel times are 2 percent longer causing some decrease in the alpha-emitting radionuclide concentration. 
DOE/RL-97-69

Rev. 0

\subsubsection{Degradation}

Relatively little analysis has been performed on degradation of the disposal facility because of the conceptual nature of the facility design and because much of the facility is presumed to be made of natural materials. However, the effect of the concrete floor remaining intact, trapping water, then failing has been investigated. The effect of having the hydraulic barrier above the waste fail in one location also was investigated.

The effect of trapping water in concrete for 2,000 years, then having the floor fail releasing the water was investigated for both concepts. The difference in the normalized flux at the aquifer for the different $K_{d}$ groups studied was less than 3 percent, with most groups having differences of less than 1 percent. Little difference ( $<1$ percent) showed up in the estimated impacts.

A failure in the hydraulic barrier was postulated in the Concept 2 design about two-thirds of the way down the barrier. Again, the normalized flux showed relatively little difference at the aquifer and in the dose (less than 5 percent).

Some additional simulations were made as part of an earlier study (Mann 1995d) to determine the sensitivity of design choices. According to these calculations, the barrier diverted water as long as the sand formed a continuous path and did not subside completely into the gravel.

\subsection{RESULTS FOR GROUNDWATER SCENARIOS - VADOSE ZONE SENSITIVITY CASES}

A number of sensitivity cases were run to determine the effect of using different values for the hydraulic parameters, the geochemical parameters, and the infiltration rate. Each of these parameters independently affects the rate at which the contaminants enter the unconfined aquifer.

\subsubsection{Hydraulic Parameters}

Hydraulic parameters are important in two distinct areas of the model: the disposal facility and the vadose zone.

4.6.1.1 Disposal Facility Hydraulic Properties. The disposal facility has not yet been designed. Therefore, sensitivity cases were run for the hydraulic and diffusion properties of the filler material between the canisters. 


\section{DOE/RL-97-69 \\ Rev. 0}

As noted in Section 4.5.3.3, a sensitivity run substituted the hydraulic properties of sand for back-filled soil. No significant change to the estimated impacts was noted.

The present philosophy conceming the design of the disposal facility is to keep the waste form and surrounding filler material as dry as possible to minimize waste form corrosion and transport of the released materials. In such a low-moisture facility, the transport of contaminants may be dominated more by diffusion (movement of contaminants through water) than by advection (movement of contaminants with water flow).

The simulations of Concepts 1 and 2 in the base analysis case used the Scheidegger diffusion model (see Section 3.5.3.1). As discussed in that section, the effective diffusion term could be lower. A sensitivity case with an effective value 20 times lower results in a much lower calculation of contaminant flux and dose. Figure 4-25 displays the normalized unretarded contaminant flux to the aquifer as a function of time for the two diffusion cases for Concept 1 . Table 4-21 shows the estimated beta/photon drinking water dose for the two diffusion cases for both Concepts 1 and 2 . The relative change is similar for other estimated impacts. Concept 2 shows a much smaller effect because the contaminant path out of the facility is shorter and because its filler material is more moist so more advection occurs.

4.6.1.2 Vadose Zone Hydraulic Properties. The sensitivity study also investigated the effects on dose rates of both vadose zone hydraulic properties (moisture retention and unsaturated conductivity relationships) and dispersion coefficients.

Because the hydraulic properties are so strongly correlated with stratigraphy, changing the positions of the strata in the vadose zone model changed the hydraulic properties of the simulation. The base analysis case assumed that the first 6 meters were from the upper gravel sequence, the next 60 meters were from the sandy sequence, and the bottom 35 meters were from the lower gravel sequence. The results of using different strata (and different moisture retention and conductivity curves) are shown in Table 4-22. Figure 4-26 shows the normalized unretarded contaminant flux entering the unconfined aquifer.

If the hydraulic parameters of the sandy sequence are used throughout the vadose zone, the bottom 35 meters are a bit drier and the contaminants travel faster (about 2,500 years versus about 5,000 years for the unretarded group, and about 5,400 years versus about 9,100 years for the uranium group). This does not result in much of a change in the beta/photon drinking water dose because selenium and technetium are on the plateau of the flux curve. However, the changes move the uranium isotopes to the plateau of the flux curve, resulting in a 50 percent increase in the estimated alpha-emitting radionuclide concentration. Note, however, that the travel times for the uranium group for Concept 1 (about 100,000 years) and for Concept 2 (about 20,000 years) are much longer than for the Unit Cell Model (see Tables 4.2, 4.10, and 4.13, respectively). A full-facility model simulation would show less of a change in alpha-emitting radionuclide concentration (or the all-pathway dose) than the unit cell model simulation. Using the full-facility model simulation, the steepest part of the contaminant curve would happen beyond 10,000 years. Even with a 50 percent increase predicted by the Unit Cell Model, the results would not exceed the performance objectives for either concept. 
DOE/RL-97-69

Rev. 0

Figure 4-25. Estimated Unretarded Contaminant Flux to Aquifer for Concept 1 for Different Diffusion Coefficients (Full-Facility Model).

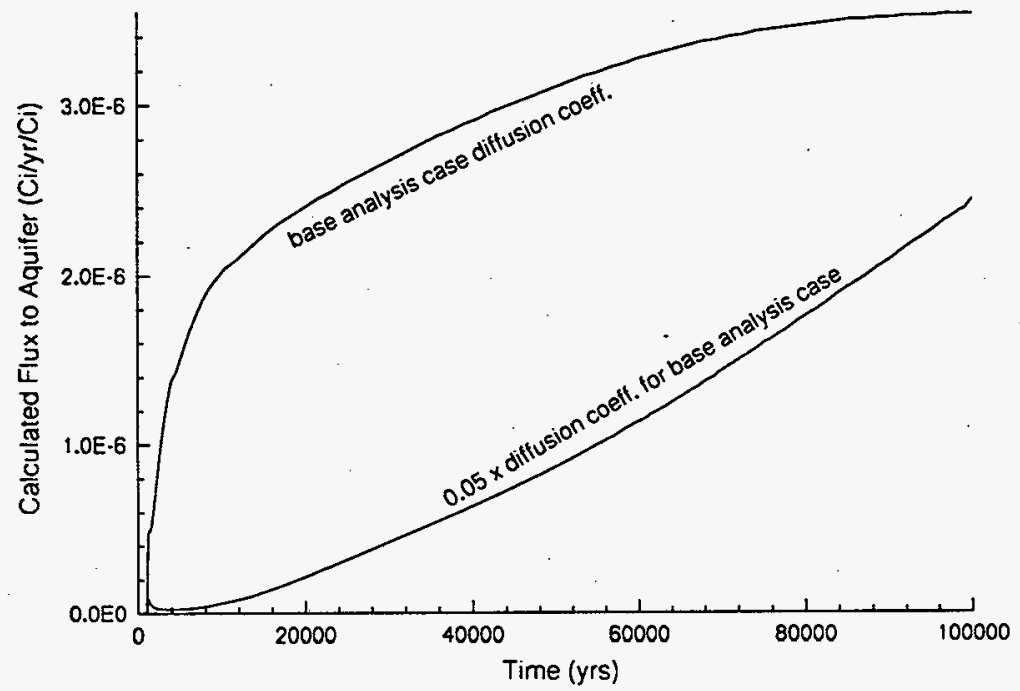

Table 4-21. Estimated Beta/Photon Drinking Water Dose at 10,000 Years at a Well 100 Meters Downgradient for Different Diffusion Coefficients.

\begin{tabular}{||l|l|c|}
\hline \multirow{2}{*}{ Concept } & Diffusion Coefficient & $\begin{array}{c}\text { Beta/Photon Dose at 10,000 Years } \\
\text { (mrem/y) }\end{array}$ \\
\hline \multirow{2}{*}{1} & Base analysis case & 1.97 \\
\cline { 2 - 3 } & $0.05 *$ base analysis case & 0.06 \\
\hline \multirow{2}{*}{2} & Base analysis case & 1.11 \\
\cline { 2 - 3 } & $0.05 *$ base analysis case & 0.20 \\
\hline
\end{tabular}


DOE/RL-97-69

Rev. 0

Table 4-22. Estimated Impact at 10,000 Years Assuming Different Strata (and Hydraulic Properties).

\begin{tabular}{||l|c|c|c|}
\hline Strata & $\begin{array}{c}\text { Beta/Photon } \\
\text { Drinking Water } \\
\text { Dose } \\
\text { (mrem/y) }\end{array}$ & $\begin{array}{c}\text { Alpha-Emitting } \\
\text { Radionuclide } \\
\text { Concentration } \\
\text { (pCi/l) }\end{array}$ & $\begin{array}{c}\text { All-Pathways } \\
\text { Dose } \\
\text { (mrem/y) }\end{array}$ \\
\hline $\begin{array}{l}\text { Base analysis case } \\
\text { vadose zone }= \\
6 \mathrm{~m} \text { gravel sequence } \\
60 \mathrm{~m} \text { sandy sequence } \\
35 \mathrm{~m} \text { gravel sequence }\end{array}$ & 2.0 & 1.7 & 6.4 \\
\hline $\begin{array}{c}\text { Unit Cell Model (no } \\
\text { hydraulic barrier) } \\
\text { vadose zone }=\text { same as } \\
\text { base analysis case }\end{array}$ & 4.4 & 5.9 & 13.4 \\
\hline $\begin{array}{c}\text { Unit Cell Model } \\
\text { vadose zone = } \\
101 \mathrm{~m} \text { sandy sequence }\end{array}$ & 4.6 & 9.9 & 18.8 \\
\hline $\begin{array}{l}\text { Unit Cell Model } \\
\text { vadose zone= } \\
6 \mathrm{~m} \text { gravel sequence } \\
45 \mathrm{~m} \text { sandy sequence } \\
50 \mathrm{~m} \text { gravel sequence }\end{array}$ & 4.1 & 4.2 & 12.5 \\
\hline
\end{tabular}

The second sensitivity case increased the thickness of the lower gravel sequence at the expense of the sandy sequence. The predicted impacts declined (to about 20 percent for the alpha-emitting radionuclide concentration). The reason for the asymmetry is that, in the Unit Cell Model, the unretarded group still reaches the unconfined aquifer before 10,000 years for both the Unit Cell Model base sensitivity case and the increased-gravel-layer case, and in neither case is the impact of the uranium group dominant.

The position of the water table also affects the amount of uranium $\left(\mathrm{K}_{\mathrm{d}}=0.6 \mathrm{~m} / \mathrm{g}\right)$ flux reaching the aquifer at 10,000 years, as seen in Table 4-23. The flux of the unretarded group (selenium and technetium) is near its maximum and does not change. However, with the travel time estimated by the Unit Cell Model close to 10,000 years, changes in the water table position matter. However, if a full-facility model is used, the sensitivity disappears because the travel time is significantly longer than 10,000 years. 
DOE/RL-97-69

Rev. 0

The dispersion coefficient describes the spreading of the contaminants as they move with the flow. Sensitivity cases were run for the full-facility model for Concept 2 with twice the value for the dispersion coefficient used in the base analysis case and one-half of the dispersion coefficient value used in the base analysis case. The difference in the calculated unretarded $\left(\mathrm{K}_{\mathrm{d}}=0\right)$ flux in both magnitude and time of arrival is only a few percent. However, for the uranium group $\left(\mathrm{K}_{\mathrm{d}}=0.6 \mathrm{~m} / \mathrm{g}\right)$, the fluxes change by 25 percent at 10,000 years, reflecting the wider spreading with higher dispersion values. As expected, the calculations show that the center of the contaminant flux and the peak value are unaffected. Thus, changing the dispersion coefficient results in very little change in either the beta/photon dose or all-pathways dose at 10,000 years or for peak doses, but there is a larger percentage change (about 10 percent) for the alpha-emitting radionuclide concentration at 10,000 years. A similar effect is seen for the Unit Cell Model as shown in Table 4-24. The travel time does not change much, but the slope of the curve changes significantly, becoming much sharper as the dispersion coefficient is lowered.

Figure 4-26. Normalized Unretarded Contaminant Flux Entering the Unconfined Aquifer for Three Different Sets of Hydraulic Properties in the Vadose Zone (Unit Cell Model).

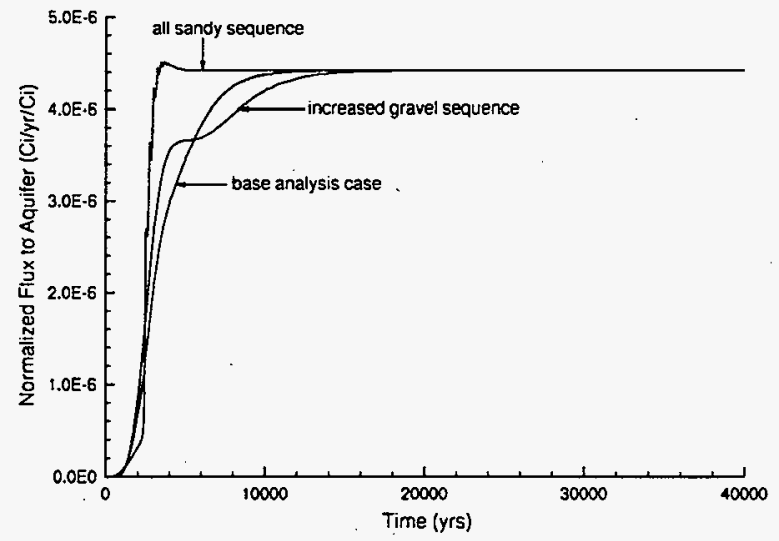


DOE/RL-97-69

Rev. 0

Table 4-23. Normalized Contaminant Flux Reaching the Unconfined Aquifer at 10,000 years as a Function of Water Table Position.

\begin{tabular}{||l|c|c|c|c||}
\hline \multirow{2}{*}{$\begin{array}{l}\text { Depth to } \\
\text { Water Table } \\
(\mathrm{m})\end{array}$} & \multicolumn{2}{|c|}{$\mathrm{K}_{\mathrm{d}}=0$} & \multicolumn{2}{c||}{$\mathrm{K}_{\mathrm{d}}=0.6 \mathrm{~m} / \mathrm{g}$} \\
\cline { 2 - 5 } & $\begin{array}{c}\text { Flux at } 10,000 \text { Years } \\
(1 / \mathrm{y})\end{array}$ & $\begin{array}{c}\text { Travel Time } \\
(\mathrm{y})\end{array}$ & $\begin{array}{c}\text { Flux at } 10,000 \text { Years } \\
(1 / \mathrm{y})\end{array}$ & $\begin{array}{c}\text { Travel Time } \\
(\mathrm{y})\end{array}$ \\
\hline 96 & $4.38 \mathrm{e}-6$ & 2,600 & $3.42 \mathrm{e}-6$ & 7,500 \\
\hline 101 & $4.37 \mathrm{e}-6$ & 3,000 & $2.65 \mathrm{e}-6$ & 9,100 \\
\hline 110 & $4.29 \mathrm{e}-6$ & 3,300 & $1.99 \mathrm{e}-6$ & 10,600 \\
\hline
\end{tabular}

Table 4-24. Effect of Dispersion on $\mathrm{K}_{\mathrm{d}}=0.6 \mathrm{~m} / \mathrm{g}$ Normalized Contaminant Fluxes to the Aquifer, Unit Cell Model.

\begin{tabular}{||l|c|c|c||}
\hline Dispersion Coefficient & $\begin{array}{c}\text { Flux value at } \\
10,000 \text { years } \\
\left(\mathrm{y}^{-1}\right)\end{array}$ & $\begin{array}{c}\text { Time When } \\
0.5 * \text { Peak Value } \\
\text { Occurs } \\
(\mathrm{y})\end{array}$ & $\begin{array}{c}\text { Time When } \\
10^{-6 * \text { Peak Value }} \\
\text { Occurs } \\
(\mathrm{y})\end{array}$ \\
\hline $0.1 *$ base analysis case & $2.54 \times 10^{-6}$ & 9,600 & 4,000 \\
\hline $0.5 *$ base analysis case & $2.51 \times 10^{-6}$ & 9,400 & 2,800 \\
\hline Base analysis case & $2.65 \times 10^{-6}$ & 9,100 & 1,500 \\
\hline $2.0 *$ base analysis case & $2.73 \times 10^{-6}$ & 8,700 & 850 \\
\hline
\end{tabular}

\subsubsection{Geochemical}

Retardation of contaminant transport greatly limits the number of isotopes that are important in the groundwater scenario. The cases described in this section investigate the sensitivity of the calculations to the geochemical parameters. Table 4-25 summarizes the effects on the beta/photon dose, the alpha-emitting radionuclide concentration, and the all-pathways dose at 10,000 years at a well 100 meters downgradient. 
DOE/RL-97-69

Rev. 0

Table 4-25. Effect of Geochemical Parameters on Impacts at a Well 100 Meters Downgradient at 10,000 Years.

\begin{tabular}{|c|c|c|c|}
\hline Geochemical Effect & $\begin{array}{l}\text { Beta/Photon } \\
\text { Dose } \\
\text { (mrem/y) }\end{array}$ & $\begin{array}{l}\text { Alpha-Emitting } \\
\text { Radionuclide } \\
\text { Concentration } \\
\text { (pCi/e) }\end{array}$ & $\begin{array}{c}\text { All-Pathways } \\
\text { Dose } \\
\text { (mrem/y) }\end{array}$ \\
\hline \multicolumn{4}{|c|}{ Concept 1 - Full-facility Model } \\
\hline Base analysis case & 1.97 & 1.65 & 6.4 \\
\hline $\mathrm{K}_{\mathrm{d}}$ for uranium $=0$ & 2.1 & 4.6 & 7.1 \\
\hline$K_{\mathrm{d}}$ for $S e$ and $T c=0.1 \mathrm{~m} / \mathrm{g}$ & 1.66 & 1.65 & 5.5 \\
\hline \multicolumn{4}{|c|}{ Concept 2 - Full-facility Model } \\
\hline Base sensitivity case & 1.11 & 0.27 & 3.3 \\
\hline $\mathrm{K}_{\delta}$ for uranium $=0$ & 1.23 & 2.6 & 3.8 \\
\hline$K_{d}$ for $S e$ and $T c=0.1 \mathrm{~m} / / \mathrm{g}$ & 0.94 & 0.27 & 2.8 \\
\hline \multicolumn{4}{|c|}{ Unit Cell Model - Concept 1 Geometry } \\
\hline Base sensitivity case & $\cdot 4.4$ & 5.9 & 13.4 \\
\hline $\mathrm{K}_{\mathrm{d}}$ for uranium $=0$ & 4.6 & 9.7 & 14.3 \\
\hline $\begin{array}{l}\mathrm{K}_{\mathrm{d}} \text { for uranium } \\
\text { concrete }=100 \mathrm{~m} \ell / \mathrm{g} \\
\text { vadose } z \text { one }=0\end{array}$ & 4.2 & 1.6 & 12.6 \\
\hline $\begin{array}{l}\mathrm{K}_{\mathrm{d}} \text { for technetium } \\
\text { concrete }=100 \mathrm{~m} \ell / \mathrm{g} \\
\text { vadose zone }=0\end{array}$ & 1.72 & 6.3 & 3.4 \\
\hline $\begin{array}{l}\mathrm{K}_{\mathrm{d}} \text { for } \mathrm{Se} \text { and } \mathrm{Tc} \\
\text { concrete }=100 \mathrm{~m} \ell / \mathrm{g} \\
\text { vadose zone }=0\end{array}$ & 0.98 & 6.3 & 4.7 \\
\hline
\end{tabular}

Previous Hanford Site performance assessments (Wood 1994b, Kincaid 1995, Wood 1995 , and Wood 1996) have assumed a conservative value for the uranium $K_{d}$ of 0 . Using such a value greatly increases the movement of uranium and its daughters. Thus, the alpha-emitting radionuclide concentration at 10,000 years increases by a factor of 3 for Concept 1 and by a factor of 10 for Concept 2 . The beta/photon dose increases by 10 percent because beta emitters are present in the decay chain. However, the estimated results are still below the performance objectives. 


\section{DOE/RL-97-69}

Rev. 0

Uranium is known to strongly absorb in concrete, having a chemical distribution coefficient $\left(\mathrm{K}_{\partial}\right)$ value of $100 \mathrm{~m} / \mathrm{g}$. Using this value in the floor of the Unit Cell Model increases the travel time for the uranium group by a factor of 4 (from 9,100 to 39,000 years) and reduces the alpha-emitting radionuclide concentration at 10,000 years by a factor of 3 from the case of assuming the $K_{d}$ of uranium is 0 and a factor of 2 from the case of assuming the value is $0.6 \mathrm{~m} / \mathrm{g}$.

Based on the work of Kaplan (1995a), the $\mathrm{K}_{\mathrm{d}}$ value for iodine was taken as $3.0 \mathrm{mg} / \mathrm{l}$ in the base analysis case. However, more recent work in support of the Hanford Site Composite Analysis indicates that the $\mathrm{K}_{\mathrm{d}}$ value for iodine in Hanford Site soils should be $0.6 \mathrm{mg} / \mathrm{l}$. At 10,000 years. shis lower $K_{d}$ value implies that the iodine concentration in groundwater would increase by a factor of 56, resulting in a beta/photon drinking water dose of $0.034 \mathrm{mrem}$ in a year and an all-pathways dose of 0.070 mrem in a year, values that still are not significant.

The base analysis case assumes that selenium and technetium move through the vadose zone without retardation. Major experiments on Hanford Site soils support this conclusion. However, to determine the sensitivity to the value of $\mathrm{K}_{\mathrm{d}}$ chosen, a sensitivity case with a slightly higher value $(0.1 \mathrm{~m} / \mathrm{g})$ was evaluated. Only a 15 -percent decrease was noted at 10,000 years in the beta/photon drinking water and all-pathways doses.

Finding a material that would chemically trap technetium and selenium would improve the performance of the disposal facility significantly. Assuming that the $\mathbf{K}_{\mathrm{d}}$ for technetium was $100 \mathrm{~m} / \mathrm{g}$ in the floor results in a 60-percent reduction in the beta/photon dose at 10,000 years. If both selenium and technetium could be trapped, the dose falls by 75 percent. It should be emphasized that such a material has not yet been found.

\subsubsection{Infiltration Rate}

In most performance assessments, the infiltration either greatly increases (for higher infiltration rates) or decreases (for lower infiltration rates) the impact relative to the base analysis case. For this performance assessment where the release time is long, the sensitivity to the infiltration rate is more one sided. For the base analysis case, the flux entering the unconfined aquifer is near its maximum (that is, the flux is rising but near the top of the plateau). Increasing the infiltration rate from the base analysis case moves the start of the plateau to early times which raises the value. However, because the value for the base analysis case is already near the value at the top of the plateau, the value for higher infiltration rates is not significantly greater. However, decreasing the infiltration rate moves the start of the plateau to much later times, causing the 10,000-year point to be significantly lower on the impact curve. Lower infiltration rates can greatly reduce the impacts at 10,000 years. However, the peak impact (at the top of the plateau) remains the same.

An important assumption of this analysis is that the contaminant release rate is independent of the moisture flux through the facility. As noted in Section 4.4.2, mechanistic simulations of contaminant release show an increase in release as the infiltration is increased. Moreover, because water is needed to corrode glass, at very low infiltration rates the glass 


\section{DOE/RL-97-69}

Rev. 0

dissolution rate also will be affected. These effects will be studied in future assessments as the waste form and facility design are determined.

4.6.3.1 Low Infiltration Rates. The base analysis case assumed that the infiltration rate would be $0.5 \mathrm{~mm} / \mathrm{y}$ for the first 1,000 years. The surface barrier is assumed to instantaneously degrade, resulting in a natural recharge rate of $3 \mathrm{~mm} / \mathrm{y}$ thereafter. A series of sensitivity cases investigated the result of other low infiltration rates. Table 4-26 summarizes the results.

Figure 4-27 shows the normalized contaminant flux at the unconfined aquifer as a function of time for various infiltration rates. Figure 4-28 shows the fluxes for the uranium group.

Assuming a steady-state infiltration rate of $3 \mathrm{~mm} / \mathrm{y}$ raised the impacts slightly. The calculated travel times for the unretarded group decreased to approximately 2,400 years from the Unit Cell Model base sensitivity case of about 3,000 years. (Concept 1 is about 10,000 years and Concept 2 is about 4,000 years). The travel time for the uranium group $\left(K_{d}=0.6 \mathrm{~m} / \mathrm{g}\right)$ also decreases to 8,600 years from 9,100 years. This puts both the unretarded contaminants and the next group of contaminants on the plateau so not much change is seen at 10,000 years using the Unit Cell Model for a surface barrier with a 1,000-year life.

Table 4-26. Effect of Infiltration Rates on Estimated Impacts at 10,000 Years for a Well 100 Meters Downgradient from the Facility.

\begin{tabular}{||l|c|c|c||}
\hline \hline Recharge Case & $\begin{array}{c}\text { Beta/Photon } \\
\text { Drinking Water } \\
\text { Dose } \\
\text { (mrem/y) }\end{array}$ & $\begin{array}{c}\text { Alpha-Emitting } \\
\text { Radionuclide } \\
\text { Concentration } \\
\text { (pCi/l) }\end{array}$ & $\begin{array}{c}\text { All-Pathways } \\
\text { Dose } \\
\text { (mrem/y) }\end{array}$ \\
\hline \multicolumn{4}{|c|}{ Concept 1 Geometry - Unit Cell Model } \\
\hline $\begin{array}{l}0.5 \mathrm{~mm} / \mathrm{y} \text { for 1000 years, } \\
3 . \mathrm{mm} / \mathrm{y} \text { thereafter }\end{array}$ & 4.4 & 5.9 & 13.4 \\
\hline $100 \mathrm{~mm} / \mathrm{y}$ (steady) & 5.0 & 31. & 194.0 \\
\hline $3.0 \mathrm{~mm} / \mathrm{y}$ (steady) & 4.4 & 5.9 & 13.4 \\
\hline $1.0 \mathrm{~mm} / \mathrm{y}$ (steady) & 3.5 & 0.19 & 10.3 \\
\hline $0.1 \mathrm{~mm} / \mathrm{y}$ (steady) & $<0.001$ & $<0.001$ & 0.001 \\
\hline & Concept 2-Full-facility Model & 3.3 \\
\hline $\begin{array}{l}0.5 \mathrm{~mm} / \mathrm{y} \text { for } 1000 \text { years, } \\
3 . \mathrm{mm} / \mathrm{y} \text { thereafter }\end{array}$ & 1.11 & 0.27 & 3.2 \\
\hline $100 \mathrm{~mm} / \mathrm{y}$ & 1.37 & 2.0 & \\
\hline \hline
\end{tabular}




\section{DOE/RL-97-69}

Rev. 0

If the surface barrier has a much longer life, the infiltration rate does not exceed $1 \mathrm{~mm} / \mathrm{y}$. The estimated beta/photon drinking water dose using the Unit Cell Model at 10,000 years decreases by 20 percent while the alpha-emitting radionuclide concentration declines by a factor of four. The beta/photon dose does not decline by much because the travel time for unretarded elements like selenium and technetium (about 6,500 years) is still small compared to 10,000 years. However, the travel time for the uranium group increases to about 24,000 years, yielding a significant decrease. If a hydraulic break is present (using the results for Concept 1 or 2), the unretarded groups also would show significant decreases. The travel times for unretarded elements for a constant 1-mm/y infiltration rate would increase to about 30,000 years for Concept 1 and about 11,000 years for Concept 2 .

If the infiltration rate is even less $(0.1 \mathrm{~mm} / \mathrm{y})$, the travel times become so long (about 25,000 years for $K_{d}=0$ and over 100,000 years for $K_{d}=0.6 \mathrm{~m} / \mathrm{g}$ ) that at 10,000 years no significant impacts are seen.

Figure 4-27: Normalized Contaminant Fluxes at the Unconfined Aquifer for Unretarded Contaminants for Various Infiltration Rates. (Unit Cell Model). Note that the curves approach the 4.4-ppm/y release rate from the waste form.

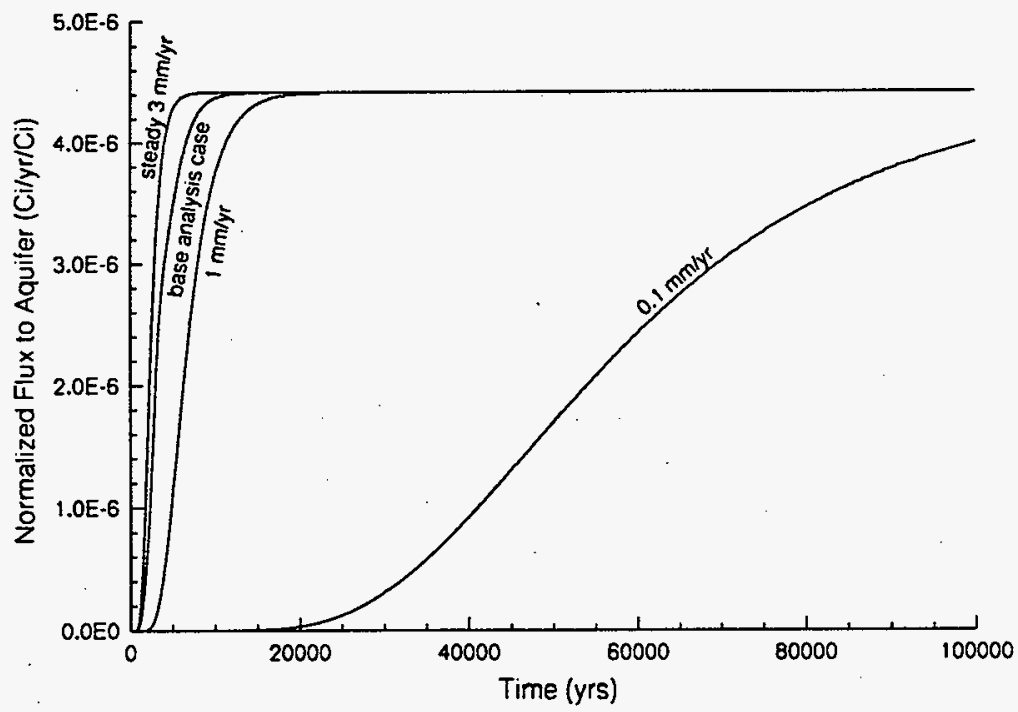


DOE/RL-97-69

Rev. 0

Figure 4-28. Normalized Contaminant Fluxes at the Unconfined Aquifer for $\mathrm{K}_{\mathrm{d}}=0.6 \mathrm{~m} / \mathrm{g}$ Contaminants for Various Infiltration Rates (Unit Cell Model).

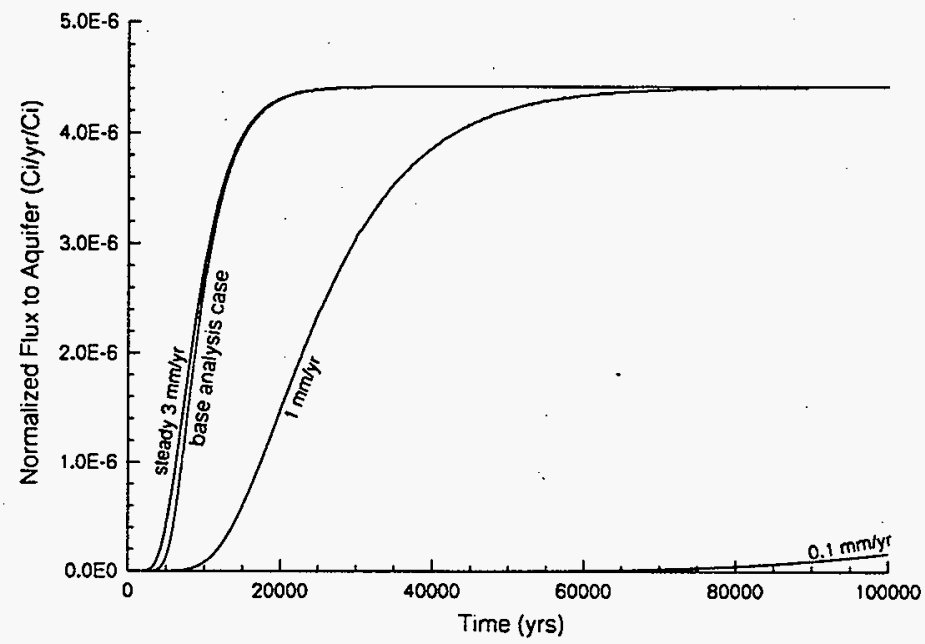

4.6.3.2 High Infiltration Rates. If the infiltration rate should increase, the contaminants would move much more quickly to the aquifer. Figure 4-29 shows the calculated normalized contaminant fluxes to the aquifer for the Concept 2 base sensitivity case and for the case of a $100 \mathrm{~mm} / \mathrm{y}$ infiltration rate. The peak value is somewhat higher $\left(4.8 \times 10^{-6} \mathrm{y}^{-1}\right.$ for the case of $100 \mathrm{~mm} / \mathrm{y}$ versus $4.2 \times 10^{-6} \mathrm{y}^{-1}$ for the base analysis case) because the release rate is higher at shorter times. However, because the contaminant flux is limited by the release rate from the waste form, the major effect of the high recharge rate is that the contaminants reach the aquifer sooner. The timing of the arrival is such that it is still long compared to the half-lives of ${ }^{13} \mathrm{Cs}$ and ${ }^{90} \mathrm{Sr}$, so these nuclides still do not contribute to the dose. However, at 10,000 years the contaminant flux for the uranium group $\left(\mathrm{K}_{\mathrm{d}}=0.6 \mathrm{~m} / \mathrm{g}\right)$ is nearer its peak, so the relative contribution by uranium isotopes and their daughters to the all-pathways dose is higher than for the base analysis case.

Table 4-26 presents the effects of the high infiltration rates. The estimated beta/photon drinking water dose at 10,000 years does increase, but only by about 20 percent. More importantly, the peak moves to 9,300 years. The alpha-emitting radionuclide concentration for the high infiltration case increases significantly from $0.92 \mathrm{pCi} / \ell$ to $2.7 \mathrm{pCi} / \ell$, which is still well below the performance objective of $15 \mathrm{pCi} / \ell$. Such a large increase is caused by the uranium isotopes arriving at the well inside the 10,000-year threshold. The magnitude of the increase in the all-pathways peak is similar to that of the beta/photon drinking water dose. 


\section{DOE/RL-97-69}

Rev. 0

Figure 4-29. Normalized Unretarded Contaminant Fluxes at the Unconfined Aquifer Using the Concept 2 Geometry For Infiltration Rates of $3 \mathrm{~mm} / \mathrm{y}$ and $100 \mathrm{~mm} / \mathrm{y}$ (Unit Cell Model).

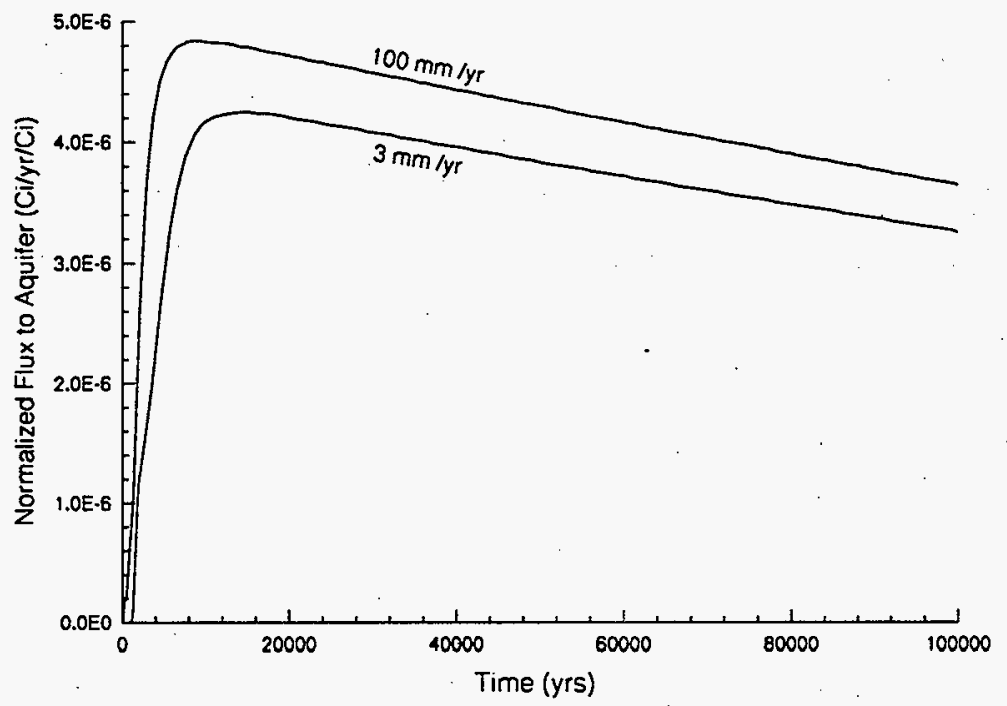

The importance of the hydraulic diverter is seen when comparing the Unit Cell Model results (no diverter) to the Concept 2 case). Without a diverter and with a $100-\mathrm{mm} / \mathrm{y}$ infiltration rate, the alpha-emitting radionuclide concentration and all-pathways dose increase by factors of 30 and 40 respectively. This is because the soil beneath the disposal facility stays relatively dry (moisture content $\equiv 0.041 \mathrm{~cm}^{3} / \mathrm{cm}^{3}$ ) even for an infiltration rate of $100 \mathrm{~mm} / \mathrm{y}$ with a hydraulic diverter, while it becomes almost saturated ( 43 percent saturation, implying a moisture content of $0.15 \mathrm{~cm}^{3} / \mathrm{cm}^{3}$ ) without a diverter. 
DOE/RL-97-69

Rev, 0

\subsection{RESULTS OF GROUNDWATER SCENARIOS - OTHER SENSITIVITY CASES}

This section describes the sensitivity to the amount of radionuclides in the waste (the inventory), the land use assumed, the library of dosimetry parameters chosen, the location of the facility, and calculational assumptions.

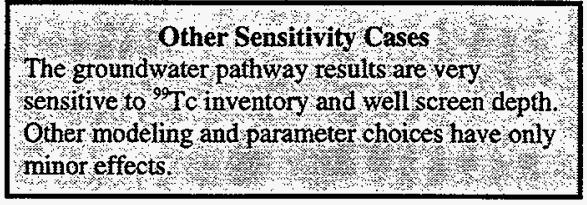

\subsubsection{Inventory}

As noted in Section 4.2.4, ${ }^{99} \mathrm{Tc},{ }^{79} \mathrm{Se}$, and uranium isotopes with their daughters are the largest contributors by far. This section describes the effect of changing the inventories of these materials.

The RFP requires that the release rate of ${ }^{99} \mathrm{Tc}$ be $0.88 \mathrm{ppm}$ (of the amount of ${ }^{99} \mathrm{Tc}$ supplied to the vendor) per year. This release rate, which is 5 times more restrictive than for other isotopes, can be met by separating out up to 80 percent of the ${ }^{99} \mathrm{Tc}$ and returning it to DOE for processing into high-level immobilized waste. Table 4-27 displays the results of assuming that the vendor returns 80 percent of the ${ }^{99} \mathrm{Tc}$ to the $\mathrm{DOE}$ and puts the remaining 20 percent into the low-level immobilized waste. The calculated results are very similar to those for the case (Section 4.4.2.2) where all the technetium is in the waste form, but where technetium is assumed to have a release rate five times lower than other materials. The beta/photon emitter dose at 10,000 years is nearly the same $(0.82 \mathrm{mrem} / \mathrm{y}$ for reduced inventory versus $0.90 \mathrm{mrem} / \mathrm{y}$ for the reduced release rate). The all-pathways dose at 10,000 years is the same for both cases. The doses do not decline in proportion to the ${ }^{99} \mathrm{Tc}$ inventory, because as the ${ }^{99} \mathrm{Tc}$ inventory is decreased, ${ }^{79} \mathrm{Se}$ becomes more important. If the ${ }^{99} \mathrm{Tc}$ inventory is reduced by a factor of five, ${ }^{99} \mathrm{Tc}$ would be responsible for less than half of the estimated beta/photon drinking water or allpathways dose.

As noted in Section 3.2.5, the Standard TWRS Inventory effort has produced new estimates for the contents of the tanks. Using their values, the estimate of the beta/photon drinking water dose increases 10 percent from 1.97 to $2.17 \mathrm{mrem}$ in a year, the concentration of alpha-emitting radionuclides increases 12 percent from 1.67 to $1.87 \mathrm{mrem}$ in a year, and the all-pathways dose increases 15 percent from 6.48 to $7.39 \mathrm{mrem}$ in a year. These increases result from the slightly higher inventory estimates for ${ }^{99} \mathrm{TC}$ and the uranium isotopes in the TWRS Standard Inventory. 
DOE/RL-97-69

Rev. 0

Table 4-27. Effect of Inventory Changes on Estimated Results at 10,000 Years at a Well 100 Meters Downgradient from the Facility (Concept 1 - Full-facility Model).

\begin{tabular}{||l|c|c|c||}
\hline Inventory Assumption & $\begin{array}{c}\text { Beta/Photon } \\
\text { Drinking Waster } \\
\text { Dose } \\
\text { (mrem/y) }\end{array}$ & $\begin{array}{c}\text { Alpha-Emitting } \\
\text { Radionuclide } \\
\text { Concentration } \\
\text { (pCi/l) }\end{array}$ & $\begin{array}{c}\text { All-Pathways } \\
\text { Dose } \\
\text { (mrem/y) }\end{array}$ \\
\hline Base analysis case & 1.97 & 1.65 & 6.4 \\
\hline $\begin{array}{l}\text { Technetium at 20\% of original } \\
\text { inventory }\end{array}$ & 0.79 & 1.65 & 2.5 \\
\hline $\begin{array}{l}\text { Using TWRS Standard } \\
\text { Inventory values }\end{array}$ & 2.17 & 1.87 & 7.4 \\
\hline Using updated ${ }^{79}$ Se half-life & 1.73 & 1.65 & 6.0 \\
\hline $\begin{array}{l}\text { Selenium at twice original } \\
\text { inventory }\end{array}$ & 2.4 & 1.65 & 7.1 \\
\hline $\begin{array}{l}\text { Iodine at five times the original } \\
\text { inventory }\end{array}$ & 1.97 & 1.65 & 6.4 \\
\hline $\begin{array}{l}\text { Uranium at twice original } \\
\text { inventory }\end{array}$ & 2.05 & 3.2 & 6.8 \\
\hline
\end{tabular}

As noted in Section 3.4.7.5, the half-life of ${ }^{78}$ Se is now expected to be a factor of 2.5 longer than the half-life used in the base analysis case. Using the longer half-life results in less activity and lower doses. The beta/photon drinking water dose decreases 12 percent from 1.97 to $1.73 \mathrm{mrem}$ in a year, while the all-pathways dose decreases 7 percent from 6.5 to $6.0 \mathrm{mrem}$ in a year. If the restricted performance for technetium demanded by the RFP is added to the longer half-life of ${ }^{79} \mathrm{Se}$, the drinking water dose estimate is only $0.55 \mathrm{mrem}$ in a year compared to a performance objective of 4.0 and the all-pathways dose is only $2.2 \mathrm{mrem}$ in a year compared to a performance objective of 25 .

Uncertainties for the selenium and uranium inventories in the waste form have not been established. Also, the exact amount of iodine that will escape from the melter and be trapped by filters is not yet known. Impacts of increasing the inventory of these elements by a factor of two for selenium and uranium and five for iodine are shown in Table 4-27.

Doubling the selenium inventory produces a 20-percent increase in the beta/photon drinking water dose and a 10-percent increase in the all-pathways dose. A five-fold increase in iodine has no calculated effect. Doubling the uranium inventory while keeping the same isotopic ratios increases the alpha-emitting radionuclide concentration by almost a factor of 2 and the all-pathways dose by 25 percent. 


\section{DOE/RL-97-69}

Rev. 0

Isotopes with short half-lives, such as ${ }^{137} \mathrm{Cs}$ and ${ }^{90} \mathrm{Sr}$, decay away before they reach the groundwater. Thus, even though the exact amount of these isotopes awaits NRC determination, these isotopes will not contribute to postulated doses for the groundwater pathway.

\subsubsection{Land Use}

Land use mainly affects the travel of contaminants in the unconfined aquifer. Land uses that could affect the infiltration rate are described in Section 4.6.3.2. Land uses that result in intrusion into the disposal facility itself are described in Section 4.2.3. This section describes land uses that affect the properties of the groundwater system beneath the Hanford Site. For more details, see Lu (1996).

4.7.2.1 Irrigation at the Disposal Facility. Even though lands on the Hanford Site's central plateau are not expected to be irrigated, lands near the Hanford Site currently are being irrigated. As described in Section 4.6.3.2, an infiltration rate of $100 \mathrm{~mm} / \mathrm{y}$ was used to describe the effects of possible irrigation at the disposal site.

4.7.2.2 Irrigation on the Hanford Central Plateau. Large areas of land surrounding the Hanford Site are under irrigation. Because radioactive plumes are present in the groundwater, irrigation is not expected to occur on the present Hanford Site, even after the land is released by the federal government. However, sensitivity cases based on irrigating large plots of land were simulated. In all cases an infiltration rate of $100 \mathrm{~mm} / \mathrm{y}$ was used.

The first case assumed that all the area immediately north of the Hanford Site 200 Areas would be irrigated. At the disposal site, the groundwater table would rise 2 meters and the direction of water flow would change to the southeast. The increase in water flux in this 2 meter interval would be significant because the interval is in the Hanford formation, a high permeability zone. Thus, the concentration ratio (and impacts) decreases by 42 percent.

The second case assumes that all the area immediately to the west of the 200 West Area would be irrigated. This would result in groundwater mounding just west of the 200 West Area and extending slightly into the 200 West Area. The result at the disposal site would be a small rise in the water table, but this higher water level would reside in the high permeability zone and so would experience greater dilution. For this case, the concentration ratio (and impacts) would be reduced to 80 percent of the value of the base analysis case.

The third and last irrigation case assumed that all the areas north, west, and south of the 200 Areas would be irrigated, but not the area between 200 West and 200 East Areas. Because of the large area south of the 200 Areas, the water table would rise significantly (about 8 meters at the disposal site) and the direction of flow would be northerly over almost all of the 200 Areas. The calculated concentration ratio and the impacts would drop by a factor of 5 . 


\section{DOE/RL-97-69 \\ Rev. 0}

Because of the uncertainty in the recharge rate, another sensitivity case was run with the recharge rate over the 200 Areas being reduced by a factor of 2 . No change was calculated for the aquifer mixing factor so no changes in the estimated impacts resulted. This is to be expected because the source of water for the unconfined aquifer lies significantly west of the 200 Areas with the infiltration of water from the 200 Areas making a very small contribution to the aquifer.

In summary, irrigation increases the amount of water in the unconfined aquifer. Because the bottom of the unconfined aquifer is fixed, added water forces an increase in the thickness of the aquifer, which in most cases will result in part of the unconfined aquifer being in the highly permeable Hanford formation. The result is a decrease in the calculated well to vadose-zone concentration ratio and hence in the estimated impacts. The amount of reduction in the estimated impacts depend on the amount of the aquifer residing in the high permeability zone. However, as noted, because of land-use restrictions, such irrigation is not expected to occur.

4.7.2.3 Level of the Water Table. For the base analysis case; the location of the top of the unconfined aquifer (the water table) is deeper than the current location because discharges at the Hanford Site of liquid effluents to the ground will have stopped. The level of the water table is expected to decline with time until it reaches a pre-Hanford-Site-operations level. However, the amount of contaminant mixing in the groundwater is sensitive to the level of the water table because the predicted level is near the interface of two geologic formations that have different hydraulic properties. Therefore, sensitivity cases were run using the pumping model: one raised the water table 7 meters to its current location and the other lowered it by 7 meters.

If the level of the water table is raised 7 meters, the upper portions of the groundwater lie within the Hanford formation, whose hydraulic conductivity is 37 times that of the base analysis case. Two effects are observed, the aquifer mixing factor (well to vadose-zone concentration ratio) is reduced by 85 percent to $2.64 \times 10^{-4}$ and the flow from the disposal site to the 200 East Area fence is east to southeast rather than almost due east, as in the base analysis case. Raising. the level of the water table 7 meters reduces all impacts by about an order of magnitude from the base analysis case.

Lowering the level of the water table 7 meters mainly reduces the thickness of the unconfined aquifer from 28 meters to 21 meters. Just as in the base analysis case, all of the unconfined aquifer is in the Ringold Formation. Thus, because the well uses only the water in the top 5 meters and the contaminants do not significantly mixed below that height, the contaminant concentration brought up through the well does not change.

4.7.2.4. Position of the Well. As discussed in Section 4.2.3, the transport within the aquifer was calculated for various well positions. The calculated dose or alpha-emitting radionuclide concentration is proportional to the relative concentrations in Table 4-5. As expected, as the distance from the disposal facility increases, the estimated impact declines. The estimated impact at a well at the 200 Area fence line is only 77 percent of the value at a well 100 meters downgradient of the disposal facility, assuming that the disposal facility is west of the PUREX facility. 


\section{DOE/RL-97-69}

Rev. 0

4.7.2.5. Pumping at the Well. The amount of pumping at the well can distort the groundwater flow field and change the predicted dose. Table 4-28 shows the effect of various pumping rates at a well 100 meters downgradient from the disposal facility normalized to a pumping rate of $0.01 \mathrm{~m}^{3}$ per day. This pumping rate corresponds to 10 liters per day. Thus, the base analysis case of a well supplying drinking water to 25 people would correspond to a pumping rate of $0.25 \mathrm{~m}^{3}$ per day. Such a small pumping rate has little impact on the groundwater flow patterns and practically no effect ( $<0.1$ percent) on the predicted dose rates. Much larger pumping rates would lower the predicted dose because more uncontaminated water would be used.

Table 4-28. Relative Impact of Pumping Rates on Aquifer Mixing Ratio at a Well 100 Meters Downgradient of the Facility.

\begin{tabular}{||l|l|l|l|l|l|}
\hline \multirow{2}{*}{} & \multicolumn{5}{|c|}{ Pumping Rate $\left(\mathrm{m}^{3} /\right.$ day $)$} \\
\cline { 2 - 6 } & 0.01 & 10. & 50. & 100. & 150. \\
\hline \hline \multirow{2}{*}{100 meter downgradient well } & 1.00 & 0.95 & 0.75 & 0.57 & 0.45 \\
\hline
\end{tabular}

4.7.2.6. Well Screen Height. Hand calculations indicate that relatively little dispersion occurs in the 100 meters between the disposal facility and the well. Also, as seen from the previous section, pumping at the expected rates does not significantly disturb the flow field. Thus, the volume of water over which the contaminant is averaged is proportional to the height of the well screen. Therefore the drinking-water and all-pathways doses are inversely proportional to the well screen height. Although the well screen height ( 4.6 meters) used in the base analysis case may seem large for sites in the Eastern United States, this well screen height is lower than typically used on Hanford Site wells.

\subsubsection{Dosimetry Parameters}

For the base analysis case (Section 3.4.7.2), the selection of dose factors was based on using the best data, rather than on using a common source. The internal dose factors were taken from the DOE and the external dose factors from the EPA. Other choices could be made. Table 4-29 shows the estimated doses at a well 100 meters downgradient at 10,000 years using various dosimetry libraries. The changes are relatively small for the variety of database choices; none of the results exceed performance objectives.

Assumptions concerning ingestion rates, inhalation rates, and times of exposure affect only the all-pathways dose. Most of the all-pathway dose comes from drinking water (53 percent) or from ingesting vegetable percent ( 34 percent). Therefore, the estimated allpathways dose is relatively insensitive to inhalation rates and times of exposure. The calculation is only moderately sensitive to ingestion rates or uptake factors with technetium uptake factors being the most important. 
DOE/RL-97-69

Rev. 0

Table 4-29. Effect of Different Dose Factor Libraries on the Beta/Photon Drinking Water Dose and All-Pathways Dose at a Well 100 Meters Down Gradient at 10,000 Years.

\begin{tabular}{|l|c|c||}
\hline Source & $\begin{array}{c}\text { Beta/Photon Dose } \\
(\mathrm{mrem} / \mathrm{y})^{\mathrm{a}}\end{array}$ & $\begin{array}{c}\text { All-Pathways } \\
\text { Dose } \\
(\mathrm{mrem} / \mathrm{y})^{\mathrm{a}}\end{array}$ \\
\hline Base analysis case & 1.97 & 6.4 \\
\hline U.S. Department of Energy & $\begin{array}{c}1.97 \\
(0 \%)\end{array}$ & $\begin{array}{c}6.4 \\
(0 \%)\end{array}$ \\
\hline U.S. Environmental Protection Agency & $\begin{array}{c}2.2 \\
(10 \%)\end{array}$ & $\begin{array}{c}7.0 \\
(9 \%)\end{array}$ \\
\hline $\begin{array}{l}\text { GENII (Hanford Site environmental computer } \\
\text { code) }\end{array}$ & $\begin{array}{c}3.0 \\
(52 \%)\end{array}$ & $\begin{array}{c}9.9 \\
(55 \%)\end{array}$ \\
\hline
\end{tabular}

${ }^{a}$ Numbers in parenthesis are percentage increases from the base analysis case

\subsubsection{Location of the Facility}

The base analysis case for this performance assessment assumes that the location of the disposal facility is just southwest of the PUREX Site. However, DOE is currently evaluating the option of disposing the first 6 percent of the waste in existing disposal vaults in the Grout Facility Area, which is just east of the PUREX site. Because the two sites are only a kilometer apart and the geology does not appear to vary significantly, vadose zone and aquifer transport are expected to be similar. The vadose zone transport runs discussed in Section 4.6.1 show a weak (less than 10 percent) dependence on the geologic layers.

A calculation of aquifer transport at the Grout Facility showed the same well to vadosezone concentration factor as for the base analysis case. The more important effect is that the grout facility is right next to the 200 East Area fence. This means that about 25 percent less mixing would take place before the contaminants hit the fence line than in the base analysis case.

\subsubsection{Calculational Assumptions}

A number of sensitivity runs using the Unit Cell Model were made to test calculational assumptions. These included increasing the number of nodes in the model, changing the initial amount of moisture in the construction materials, and rotating the canister so that the long (1.8 meters) rather than the short (1.2 meters) side was being modeled. None of the results differed significantly from the Unit Cell Model base sensitivity analysis case (see Table 4-30). 
DOE/RL-97-69

Rev. 0

Table 4-30. Test of Unit Cell Calculational Assumptions: Normalized Flux Entering Unconfined Aquifer $\left(K_{d}=0.1 \mathrm{~m} / \mathrm{g}\right)$.

\begin{tabular}{||l|c|c|c|c||}
\hline Case & $\begin{array}{c}\text { Value at } \\
10 \mathrm{~K} \text { Years } \\
(1 / \mathrm{y})\end{array}$ & $\begin{array}{c}\text { Peak } \\
\text { Value } \\
(1 / \mathrm{y})\end{array}$ & $\begin{array}{c}\text { Time of } \\
\text { Peak Value } \\
(\mathrm{y})\end{array}$ & $\begin{array}{c}\text { Time of 0.5* } \\
\text { Peak Value } \\
(\mathrm{y})\end{array}$ \\
\hline Base Sensitivity Case & $4.37 \mathrm{e}-6$ & $4.42 \mathrm{e}-6$ & 17,000 & 3,140 \\
\hline Double number of horizontal nodes & $4.37 \mathrm{e}-6$ & $4.42 \mathrm{e}-6$ & 17,000 & 3,150 \\
\hline $\begin{array}{l}\text { Initial moisture }=0.2 \mathrm{~cm}^{3} / \mathrm{cm}^{3} \text { in } \\
\text { construction materials }\end{array}$ & $4.37 \mathrm{e}-6$ & $4.42 \mathrm{e}-6$ & 17,000 & 3,100 \\
\hline $\begin{array}{l}\text { Initial moisture }=\text { residual level } \\
\text { in construction materials }\end{array}$ & $4.37 \mathrm{e}-6$ & $4.42 \mathrm{e}-6$ & 17,000 & $3,100$. \\
\hline Rotate canister orientation by $90^{\circ}$ & $4.37 \mathrm{e}-6$ & $4.42 \mathrm{e}-6$ & 17,000 & 3,150 \\
\hline
\end{tabular}

\subsubsection{Neglected Processes and Conditions.}

The major processes involved in contaminant transport have been modeled. However, the following processes also should be discussed:

- Preferential flow through the vadose zone

- Upward diffusion of contaminants

- Upward migration by capillary action

- Consumption of water in glass dissolution process.

Clastic dikes are localized vertical geologic features of the Hanford Site central plateau that exhibit enhanced flow under saturated conditions. Future work will characterize the hydraulic properties of these features and determine their effect (if any) at the disposal facility site.

Upward diffusion and upward migration only become important with extremely low infiltration rates. Both processes produce a characteristic time, $\mathrm{T}$, which depends on the soil diffusivity, $D$, and on the length to be traversed, $L$;

$$
\mathrm{T}=\mathrm{L}^{2} / \mathrm{D} \text {. }
$$

For the case of upward diffusion, the equation can be derived from Fick's law (see Section 4.12). For the case of capillary rise, the equation can be derived by ignoring the gravity term in the flow equation. Using a length of 6 meters (the total thickness of the sand-gravel capillary barrier, water-conditioning layer, and the vault roof) and a soil diffusivity of $1.25 \times 10^{-7} \mathrm{~cm} / \mathrm{s}$ (from Section 3.4.3.2), the characteristic time is almost 100,000 years. 
Moreover, as noted in Section 3.4.4.3, water must be present to dissolve the glass. Because the aquifer is so far below the disposal facility, capillary action could not bring water up to the waste. The only mechanism for providing the quantity of water needed to dissolve a significant amount of the waste form is infiltration. Therefore, under extremely dry conditions, there would be no mobile contaminants to move.

\subsection{IMPACT OF OTHER ACTIONS AT THE HANFORD SITE ON GROUNDWATER}

\subsubsection{Introduction}

The Defense Nuclear Facilities Safety Board recommended (DNFSB 1994) that, when evaluating of the impact of the disposal of radioactive waste, DOE consider not just the impact from the disposal action under consideration but also all other government actions that might affect those impacts. The Richland Operations Office is submitting a composite analysis (Kincaid 1998) that looks at all the Hanford Site's disposal and closure actions. The analysis presented here will focus on this disposal action using both the results of the aquifer models reported in Section 4.2.3 and the results of the composite analysis.

\subsubsection{Results from Base Analysis Case}

The main pathway affected in an integrated analysis is the groundwater pathway. Inadvertent intruder scenarios and releases to the air are controlled at the source point. As will be seen in Section 4.10, the impacts of catastrophic events on waste that has been disposed of are not significant.

Assuming that the disposal facility is placed just southwest of the PUREX facility, the previous Hanford Site actions that would affect groundwater downgradient of the disposal facility are those activities that are upgradient of the facility. From Figure 3-1, those actions are the operations at the S, SX, SY, and U tank farms and the disposal of waste at the Environmental Remediation Disposal Facility and the commercial low-level waste disposal site operated by a commercial firm (U.S. Ecology).

Using the aquifer model described in Section 3.5.3.3, mixing effects were calculated

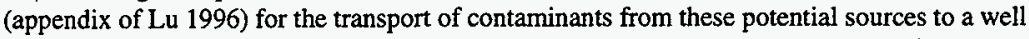
100 meters downgradient of the disposal facility. The mixing factors are displayed in Table 4-31. Because of the distance from the sources, the mixing factors are significantly less than from the low-level tank waste disposal site. 
DOE/RL-97-69

Rev. 0

Table 4-31. Mixing Factors* from Other Sources for a Well 100 Meters Downgradient of the Low-Level Tank Waste Disposal Site.

\begin{tabular}{||l|l|l|l|l|l||}
\hline & \multicolumn{5}{|c|}{ Upstream Sources } \\
\cline { 2 - 6 } & $\begin{array}{c}\text { Low-Level } \\
\text { Tank Waste } \\
\text { Site }\end{array}$ & ERDF Site & $\begin{array}{c}\text { S, SX, SY } \\
\text { Tank } \\
\text { Farm }\end{array}$ & $\begin{array}{c}\text { U Tank } \\
\text { Farm }\end{array}$ & $\begin{array}{c}\text { Commercial } \\
\text { LLW Disposal } \\
\text { Site }\end{array}$ \\
\hline Mixing Factor* & $1.77 \times 10^{-3}$ & $3.01 \times 10^{-4}$ & $2.08 \times 10^{-4}$ & $1.25 \times 10^{-4}$ & $8.91 \times 10^{-5}$ \\
\hline $\begin{array}{l}\text { Fraction of Base } \\
\text { Analysis Case }\end{array}$ & 1.00 & 0.17 & 0.12 & 0.07 & 0.05 \\
\hline \hline
\end{tabular}

Mixing factor is the contaminant concentration in well water divided by the contamination concentration at the bottom of the vadose zone.

Both the DOE (DOE 1988b) and the NRC (10 CFR 61-4) mandate a member of the general public can receive an exposure of no more than $25 \mathrm{mrem}$ in a year at the edge of a disposal facility. Assuming that the other sources have their maximum impact and ignoring any time factors that might reduce the effect of the overlap, the other sources could add no more than $10.3 \mathrm{mrem}$ in a year. Adding this to the amount estimated in Section 4.2.4, yields a total dose of less than 19 mrem in a year for the first 10,000 years. Moving the point of compliance to the 200 East Area fence will reduce the estimated compliance dose, by less than 25 percent.

Similar calculations have not been carried out for the TWRS existing disposal facility. Because potential upgradient sources (PUREX and the AP and AW double-shell tank farms) are relatively close, fine-scale modeling may be required.

\subsubsection{Hanford Site Composite Analysis}

A Composite Analysis (Kincaid 1998) is due for submittal to DOE-Headquarters that supports the active and planned low-level waste disposal on the 200 Area Plateau. It is a companion analysis to performance assessments for active and planned disposal, and remedial investigations and feasibility studies for remediation sites. With some limitations based primarily on available inventory data, this was a first iteration analysis to discover the long-term impacts to an offsite individual from all wastes to reside at the Hanford Site at the time of Site closure. For the Composite Analysis; the offsite individual resided outside the exclusive waste management area and buffer zone as defined by the Hanford Future Site Uses Working Group (HFSUWG 1992a). The analysis considered a 1500 year period and reached the following conclusions:

- Significant releases from the liquid discharge sites, tank leaks, losses from tanks during tank waste recovery operations, and pre-1988 solid waste burial grounds occurred prior to Site closure and were separated in time significantly from any discharges from the active or planned disposal. 


\section{DOE/RL-97-69}

Rev. 0

- Peak all-pathways dose to the maximally exposed individual outside the buffer zone after Site closure (assumed in 2050) was less than $6 \mathrm{mrem}$ in a year. This was the result of the agricultural scenario. Lesser doses resulted from the residential, industrial, and recreational scenarios. Despite high uncertainty in the inventories of past liquid discharges, tank leaks, tank losses, and pre-1988 burial grounds, this analyses indicated dose outside the buffer zone would not exceed the dose constraint of $30 \mathrm{mrem}$ in a year.

- Maximum doses are highest now and will decline with time. The doses are still associated with remnants of the existing plumes at the time of Site closure. Releases from liquid discharge sites, tank leaks, future tank losses, and pre-1988 burial grounds continue to enter the aquifer over the next few decades, but in general the rate of nuclide mass releasing to the aquifer will decline from now until Site closure and then continue to decline.

- No releases from the TWRS immobilized low-activity waste disposal facilities, the Environmental Restoration Disposal Facility trench, and the graphite cores of the production reactors is seen during the regulatory period of 1000 years or the full 1500 years analyzed.

Future iterations of the Composite Analysis will be based on a more fully consistent inventory for all post-closure waste sites including canyon buildings and associated facilities including permanent filters and the PUREX tunnels.

\subsection{SUMMARY OF GROUNDWATER SCENARIO}

Tables 4-4 and 4-8 show that the performance objectives for the groundwater scenario are met for the base analysis case. Table $4-10$ shows that the performance objectives also are met using Concept 2. However, for both Concepts 1 and 2, the estimated doses from beta/photon emitters at a well 100 meters downgradient from the facility $(2.0$ and $1.1 \mathrm{mrem}$ in a year, respectively) are only a factor of 2 to 4 lower than the performance objective of $4 \mathrm{mrem}$ in a year. Also the beta/photon doses are estimated to exceed $4 \mathrm{mrem}$ in a year at a time far in the future (about 750,000 years for Concept 1 and about 3 million years for Concept 2).

This section discusses the main causes for these results and provides a feeling for the robustness of the estimates. The next section presents the most important factors for the maximum value; Section 4.9.2 extends the discussion to the value at 10,000 years. 


\section{DOE/RL-97-69}

Rev. 0

\subsubsection{Maximum Impact of the Groundwater Scenario}

Although the performance objectives are for a time period up to 10,000 years, the maximum impact is of interest for three reasons,

- Considering the maximum value allows a determination of whether the disposal action has a significant impact at any time

- Comparing the impact at the time of compliance to the maximum impact allows a determination of how sensitive the result is to the choice of conceptual model and model parameters

- Examining the time history of doses allows identification of models and model parameters with the greatest overall impact.

This section describes the value of the maximum impact and those few parameters that determine that value.

4.9.1.1 Value of Maximum Impact. Table 4-32 shows the maximum impact at 10,000 years for Concept 1 assuming instantaneous transport through the vadose zone and a time-independent waste form release rate of 4.4 parts per million per year for all radionuclides. The corresponding values for Concept 2 would be 40 percent lower. Using the values in Table 4-32, only a few contaminants would be important, even if the vadose zone did not retard their movement. For the beta/photon drinking water dose, ${ }^{99} \mathrm{Tc},{ }^{126} \mathrm{Sn}$, and the daughters of the uranium isotopes are the most important contaminants. Selenium-79, neptunium and its daughters, and americium and its daughters are the next most important. For the alpha-emitting radionuclide concentration, the most important radiocontaminants are the uranium and plutonium isotopes and their daughters. For the all-pathways dose, the above radiocontaminants also are of the greatest concern. However, americium, plutonium, and tin are expected to be highly retarded (with $K_{d}$ values $\geq 40 \mathrm{~m} / \mathrm{g}$ ), resulting in travel times of millions of years, allowing for significant decay and making their impacts insignificant.

The main radiocontaminants of interest are ${ }^{99} \mathrm{Tc}$, the uranium isotopes and their daughters, and other $\mathrm{K}_{\mathrm{d}}=0$ contaminants, primarily ${ }^{79} \mathrm{Se}$. Thus at 10,000 years, assuming Concept 1 , a waste form release rate of $4.4 \mathrm{ppm} / \mathrm{y}$, and no effect of the vadose zone, the impacts from technetium, uranium, and selenium are as follows:

beta/photon drinking water dose

alpha-emitting radionuclide concentration

all-pathways dose
$<12.7$ mrem in a year $<25$. pCi/l

$<27.4$ mrem in a year.

Although these values are above the performance objectives, they are at most a factor of 3.5 above and are a worst case, ignoring the important known effects of facility design and vadose zone transport. Including these effects drops the estimated doses below the performance objectives, as already shown in Section 4.2 . 
DOE/RL-97-69

Rev. 0

Table 4-32. Maximum Contribution from Contaminants at 10,000 Years at a Well 100 Meters Downgradient from the Facility, Assuming Instantaneous Vadose Zone Transport, a Constant Waste Form Release Rate of $4.4 \mathrm{ppm} / \mathrm{y}$, and Concept 1.

\begin{tabular}{|c|c|c|c|c|}
\hline Contaminants ${ }^{(a, b)}$ & $\begin{array}{c}\mathrm{K}_{\mathrm{d}} \text { in } \\
\text { base case } \\
(\mathrm{m} \ell / \mathrm{g})\end{array}$ & $\begin{array}{c}\text { Beta/Photon } \\
\text { Drinking Water } \\
\text { Dose } \\
(\mathrm{mrem} / \mathrm{y}) \\
\end{array}$ & $\begin{array}{l}\text { Alpha-Emitting } \\
\text { Radionuclide } \\
\text { Concentration (pCi//) }\end{array}$ & $\begin{array}{c}\text { All-Pathways } \\
\text { Dose } \\
\text { (mrem/y) }\end{array}$ \\
\hline $\begin{array}{l}\text { Performance } \\
\text { Objective }\end{array}$ & $\ldots$ & 4.0 & 15.0 & 25. \\
\hline${ }^{79} \mathrm{Se}$ & 0. & 0.87 & 0. & 1.6 \\
\hline${ }^{93} \mathrm{Zr}+{ }^{93} \mathrm{Nb}^{\mathrm{m}}$ & 40.0 & 0.012 & 0. & 0.034 \\
\hline${ }^{99} \mathrm{Tc}$ & 0. & 3.2 & 0. & 10.5 \\
\hline${ }^{126} \mathrm{Sn}$ & 100.0 & 3.1 & 0. & 12.1 \\
\hline${ }^{129} \mathrm{I}$ & 3.0 & 0.21 & 0. & 0.42 \\
\hline $\begin{array}{l}\text { Thorium and } \\
\text { daughters }\end{array}$ & 40.0 & $0.008^{c}$ & $0.028^{c}$ & $0.018^{c}$ \\
\hline $\begin{array}{l}\text { Uranium and } \\
\text { daughters }\end{array}$ & 0.6 & 8.6 & 23.2 & 11.3 \\
\hline $\begin{array}{l}\text { Neptunium and } \\
\text { daughters }\end{array}$ & 15.0 & 1.67 & 0.65 & 1.83 \\
\hline $\begin{array}{l}\text { Plutonium and } \\
\text { daughters }\end{array}$ & 40.0 & 0.013 & $282.0^{\circ}$ & $966.0^{\circ}$ \\
\hline $\begin{array}{l}\text { Americium and } \\
\text { daughters }\end{array}$ & 40.0 & $1.03^{(d)}$ & $4.2^{(e)}$ & $15.0^{(c)}$ \\
\hline $\begin{array}{l}\text { Curium and } \\
\text { daughters }\end{array}$ & 100.0 & $0.001^{(\mathrm{d})}$ & $0.018^{(n)}$ & $0.06^{(\mathrm{i})}$ \\
\hline
\end{tabular}

$:{ }^{14} \mathrm{C},{ }^{90} \mathrm{Sr},{ }^{137} \mathrm{Cs}$, and ${ }^{151} \mathrm{Sm}$ have doses less than $0.001 \mathrm{mrem} / \mathrm{y}$.

${ }^{6}{ }^{226} \mathrm{Ra}$. ${ }^{228} \mathrm{Ra}$, and ${ }^{227} \mathrm{Ac}$ have alpha-emitting radionuclide concentrations less than $0.001 \mathrm{pCi} /$ l

' Peak value (shown) is at $\sim 8,000$ years.

${ }^{\mathrm{d}}$ Peak value (shown) is at $\sim 7,000$ years.

- Peak value (shown) is at $\sim 2,000$ years.

${ }^{i}$ Peak value (shown) is at $\sim 6,000$ years. 


\section{DOE/RL-97-69 \\ Rev. 0}

4.9.1.2 Important Parameters Determining Maximum Impact. Because the contaminant transport, not waste form release, sets the time scale in most performance assessments, the maximum response in those analyses depends on many variables. The total amount of contaminant reaching a point is fixed, and the peak response is inversely proportional to the width of the transport curve. In this analysis, the release rate of the waste form sets the time scale. The response mirrors the release rate and the maximum depends on only a few variables.

These few parameters can be found by using the equation described in Section 3.5.2.5

$$
\text { Response }=\sum_{i} \frac{I_{i} \Gamma_{i} w D_{i}}{r A}
$$

and noting that for the small amount of recharge characteristic of the Hanford Site that the aquifer mixing factor $w$ can be written as

$$
w(r)=w\left(r_{0}\right) \frac{r}{r_{0}} \frac{A}{A_{o}}=w_{0} \frac{r}{r_{o}} \frac{A}{A_{o}}=w_{0} r A
$$

and that for very-long-lived nuclides released very slowly from the waste form that

$$
\Gamma_{i}(t) \Rightarrow R_{i}\left(t-t_{0}\right)
$$

resulting in

$$
\text { Response }=\frac{w\left(r_{o}\right)}{r_{o} A_{o}} \sum_{i} I_{i} R_{i} D_{i}
$$

where

$I_{i}=\quad$ the inventory of contaminant $i$

$\Gamma_{\mathrm{i}}=$ the flux of contaminants at the bottom of the vadose zone

$\mathrm{w}=$ the ratio of contaminant concentration at the well to the concentration at the bottom of the vadose zone

$D_{i}=$ the dosimetry factor relating response to concentration of contaminant $i$

$\mathrm{r}=\quad$ is the recharge rate

$A_{0}=$ reference area over which the contaminants leave the vadose zone (taken to be the area of the disposal facility)

$r_{0}=$ reference recharge rate (taken as $1 \mathrm{~mm} / \mathrm{y}$ )

$R_{i}=$ the release rate of contaminant $i$ from the waste form at a time corrected for the vadose zone travel time, $t_{\mathrm{o}}$.

The second equation follows that for small recharge rates the concentration of contaminants in water in the vadose zone is proportional to the recharge and area but that the concentration of contaminants in water in the well depends only on the much larger amount of groundwater. The third equation reflects that the time dependence of the problem is driven by the slow release of the waste form rather than the travel in the vadose zone. For convenience, the effect of retardation on the aquifer mixing factor, $w$, is ignored, and one value is used for all elements. 


\section{DOE/RL-97-69}

Rev. 0

The maximum response depends on the inventory, waste form release rate, dosimetry factor for each long-lived contaminant, and a quantity that reflects the mixing in the unconfined aquifer. Each of these terms has an uncertainty associated with it.

The inventory of each major radionuclide taken as an upper limit is reasonably well known. As the result of the pretreatment and the immobilization processes, the amount of radionuclides may drop.

The waste form release rate used in this study comes from the RFP. This rate is defined at short times in the RFP and was extended to longer times using a simple model. As noted in Section 4.4.1, which describes a mechanistic approach to estimate the release rate, the release rate could be significantly different in magnitude and shape. However, how the vendors will proceed will not be known until the spring or summer of 1998.

The results show minor sensitivity to the different sets of dosimetry factors that exist.

The mixing of the contaminants in the groundwater depends on the flow rate and dispersion in the unconfined aquifer. Although some uncertainty (a factor of about 2) exists about what the flow rate will be thousands of years in the future, the values used in this study are probably near the low end.

Uncertainty remains in the calculated maximum, but this uncertainty mainly reflects a lack of knowledge of processes that will be selected in the next few years. Better information on the inventories and the flow of the unconfined aquifer also will help to increase our confidence.

\subsubsection{Impact of the Groundwater Scenario at 10,000 Years}

The time of compliance is for the first 10,000 years. Therefore, the values of the calculated responses during this time are the most important. Section 4.2 .4 describes the analysis for the base analysis case. This section will describe the general understanding of the calculated results for the first 10,000 years.

Unlike the maximum value, the value of an impact at 10,000 years depends on most of the input variables. However, the variables can be grouped by the manner in which they affect the results:

- The parameters affecting travel time

- The parameters affecting how quickly the estimated impact raises from small values to the maximum value

- The parameters affecting how the estimated impact decreases after the maximum value is reached. 


\section{DOE/RL-97-69}

\section{Rev. 0}

4.9.2.1 Travel Time. Travel time is important because it allows many radionuclides to decay before reaching the compliance point. It also allows the radionuclides to be grouped for easier analysis. For times significantly longer than the travel time for a group, the value of the response for that group is at its maximum and depends on only a few variables. For times much shorter than the travel time, that group contributes very little compared to groups that have already reached the maximum value. The exception is for the unretarded group, which is the first group to reach the unconfined aquifer. For times around the travel time, the response for the group is not only significant but changes quickly. The sensitivity cases have shown that the major parameters affecting the travel time are as follows:

- The vault layout (Section 4.5.1)

- The hydraulic diverter (Section 4.5.2.1)

- The hydraulic parameters of the disposal facility and of the vadose zone (Section 4.6.1)

- The infiltration rate (Section 4.6.3)

- The transport and hydraulic diffusion parameter in the filler material between canisters (Section 4.6.1.1)

- The geochemical $\mathrm{K}_{\mathrm{d}}$ values within the disposal system and in the natural environment (Section 4.6.2).

The first four parameters affect the moisture content in the disposal facility or in the vadose zone.

The vault layout is important because the vaults cast a moisture shadow if the design contains a hydraulic diverter. Water tends to move downward rather than horizontally, so that once the water is laterally displaced, relatively dry sediments exists beneath the engineered disposal system. The larger the engineered disposal system, the larger the shadow. The unretarded travel time is calculated to be four times longer when all the vaults are a single unit than when only vault rows are used. Such a longer travel time is caused by the lower hydraulic conductivity that results from the drier soil conditions in the moisture shadow.

The sand-gravel capillary barrier (hydraulic diverter) creates the moisture shadow. If no diverter is used, the flow is almost totally vertical. The unretarded travel time for the base analysis case is only 1,100 years without a barrier but about 10,000 years with one.

The hydraulic parameters establish how moisture flows and how wet (or dry) the soil is for a particular infiltration rate. Assuming various strata and different hydraulic properties, the travel time for the uranium isotopes can vary by about 15 percent.

The inside of the disposal facility is expected to be so dry that the movement of contaminants is likely to be by diffusion through the moisture rather than movement with the 


\section{DOE/RL-97-69}

Rev. 0

moisture. Which process is more important will be determined by the parameters describing diffusion and moisture transport inside the facility. In the base analysis case diffusion is more important than advection. If the diffusion parameter is decreased by 20 , the travel time to the aquifer increases by a factor of 6 .

The retardation of contaminant travel by geochemical processes allows most of the most troublesome isotopes to decay before they reach the aquifer. For example, ${ }^{9} \mathrm{Sr}$ is calculated to take 5,000 half-lives to reach the aquifer, ${ }^{137} \mathrm{Cs} 150,000$ half-lives, and ${ }^{239} \mathrm{Pu} 75$ half-lives.

4.9.2.2 Rise of the Response. The variables described in Section 4.9.2.1 will affect not only travel time, but also the amount of contamination spreading, both laterally and temporally. These effects combine to define the shape of the rise of the response at the water table. For the uranium group, the rise time from $10^{-6}$ of the peak value to half of the peak value ranges from 80 percent of the travel time for the base analysis case to 50 percent when the dispersion coefficient is decreased by an order of magnitude.

49.2.3 Fall of the Response After the Maximum Value is Reached. The fall of the response curve is important because doses from later retarded groups will add to the first maximum value: Without a falloff, the maximum dose would be a sum of the values shown in Table 4-32. In reality, combining effects (decay of the isotopes and reduced waste form release rate) greatly reduces the total.

Although the half-lives of the important unretarded radiocontaminants are long, they are short compared to the travel times for plutonium and americium. For example, the travel time of plutonium is about eight ${ }^{99} \mathrm{Tc}$ half-lives and the travel time for americium is about 20 . Thus ${ }^{99} \mathrm{Tc}$, the dominant isotope, at early times is not significant at the times when plutonium and americium contribute.

The waste form release rate is expected to decline significantly as time passes. Using either a release rate proportional to surface area or one resulting from the computer simulations from Section 4.4.1, shows that the release rate is approximately 25 percent (using surface area) or a factor of 4 (using the simulation) lower than the peak value reached just after 100,000 years.

\subsection{EFFECTS OF CATASTROPHIC EVENTS}

Based on the discussion presented in Section 3.3.2.4, the only scenario considered is that of an ice-age flood that scrapes away all material down to 20 meters (the depth of the disposal facility), then redeposits the material over the area of the Hanford Site. As noted in Section 2.2.5.4, the next such event might be expected in about 50,000 years. Using the farm scenario as the exposure scenario and assuming that all the waste is in a form that can be inhaled or ingested, the predicted dose is estimated to be $0.76 \mathrm{mrem}$ (EDE) in a year. Practically all the predicted dose (more than 98 percent) comes from the external exposure of ${ }^{126} \mathrm{~S} n$ and its daughters. If the glacier flood occurs as early as 10,000 years, the predicted dose
Effects of Catastrophic Events Catastrophic events are not expected to produce significant effects. 


\section{DOE/RL-97-69}

Rev. 0

increases to $1.01 \mathrm{mrem}$ (EDE) in a year. If the flood occurs at 100,000 years, the predicted dose is $0.53 \mathrm{mrem}$ (EDE) in a year. These values are much less than the $25 \mathrm{mrem}$ (EDE) in a year maximum established for the first 10,000 years for the all-exposure pathways. If the flood only redistributes the waste over an area equivalent to the 200 Areas $\left(78 \mathrm{~km}^{2}\right)$, the predicted dose at 50,000 years [14 mrem (EDE) in a year] is still less than the all-pathways limit.

\subsection{ALARA ANALYSIS}

To keep exposures $\underline{A}$ s Low

As Reasonably Achievable (ALARA) there must be close cooperation among design, operations, and analysis. The TWRS Immobilized Waste Program is committed to such integration.

Much of the early emphasis of the Immobilized Waste Program's performance assessment activity was to investigate the impact of various facility design options on long-term performance. These reports (Rawlins 1994 and Mann 1995d) helped guide early program thinking. The interim performance assessments (Mann 1996a and Mann 1997a) were used by the engineering staff in their alternatives generation analyses (for example, Burbank 1997) to investigate various disposal options, including the use of trenches and existing facilities as was discussed in Section 2.4.2.

The performance assessment activity was actively involved in the site selection of the new disposal site. Although many factors were considered (Shord 1995), the input from the performance assessment activity played a significant role.

Official design activities have just begun. Conceptual design for the modification of the existing disposal vaults has just been completed. The conceptual design for the first generation of the new disposal facilities has just begun. However, the design authority and the architect engineers are already using the principles learned by the performance assessment activity in their design requirement documents and designs, respectively. As the design matures, justification of design features will be made, as appropriate, on performance assessment results.

As planning for operations begin, those activities will be integrated with the performance assessment and design efforts. 
Rev. 0

\subsection{RESULTS OF SCENARIOS WITH RELEASES TO THE AIR}

In previous performance assessments, three radionuclides were considered $\left({ }^{3} \mathrm{H},{ }^{14} \mathrm{C}\right.$, and $\left.{ }^{222} \mathrm{Rn}\right)$ as candidates for atmospheric release. Gaseous release from a vitrified waste form is not a very credible scenario because the waste form is assumed to be stable over such a long time. The waste form is assumed to release less than $4.4 \times 10^{-6}$ of its initial inventory per year.
Releases to Air

Releases to air are not expected to be significant

As discussed in Section 3.3.4.3, the transport of vapors is governed by Fick's equation, the steady-state solution (Wood 1995) can be expressed as

$$
J=C \sqrt{\lambda D} \exp (-x \sqrt{\lambda / D})
$$

where

$$
\begin{aligned}
& \mathrm{J}=\quad \text { the flux at the surface }\left(\mathrm{Ci} \mathrm{m}^{-2} \mathrm{y}^{-1}\right) \\
& \mathrm{C}=\text { the concentration of the radionuclide in the ground }\left(\mathrm{Ci} / \mathrm{m}^{3}\right) \\
& \mathrm{x}=\text { the depth of the source }(\mathrm{m}) \\
& \lambda=\text { the mean life of the radionuclide }\left(=6.64 \times 10^{-2} \mathrm{y}^{-1} \text { for }{ }^{3} \mathrm{H}, 1.2 \times 10^{-4} \mathrm{y}^{-1} \text { for }{ }^{14} \mathrm{C}\right. \text { and } \\
& 65.9 \mathrm{y}^{-1} \text { for }{ }^{222} \mathrm{Rn} \text { ) } \\
& D=\text { the diffusion coefficient }\left(=10^{-3} \mathrm{~cm}^{2} / \mathrm{s}=3.14 \mathrm{~m}^{2} / \mathrm{y}\right) \text { [from Section 3.4.3.2]. }
\end{aligned}
$$

The concentration of ${ }^{14} \mathrm{C}$ is simply the inventory $(7.73 \mathrm{Ci})$ times the fractional amount release from the waste form (taken as $4.4 \times 10^{-6}$ in a year) divided by the waste volume $\left(3.2 \times 10^{5} \mathrm{~m}^{3}\right)$. However, the inventory of ${ }^{3} \mathrm{H}$ and ${ }^{222} \mathrm{Rn}$ changes as a function of time because of the short halflife of ${ }^{3} \mathrm{H}$ and the decay of ${ }^{222} \mathrm{Rn}$ 's parents (primarily ${ }^{234} \mathrm{U}$ and ${ }^{238} \mathrm{U}$ ). The inventory for ${ }^{3} \mathrm{H}$ is taken at 500 years after closure and the release fraction as $4.4 \times 10^{-6}$ in a year. The inventory for ${ }^{222} \mathrm{Rn}$ as a function of time is shown in Table 4-33. As expected, the ${ }^{222} \mathrm{Rn}$ inventory starts at the initial activity of its parent, ${ }^{226 \mathrm{Ra}}$, and builds until it reaches the activity of ${ }^{238} \mathrm{U}$.

Because the top of the waste form is more than 10 meters from the surface, the depth of the source will be taken to be 10 meters for these calculations. The calculated releases to the atmosphere are

$$
\begin{array}{ll}
{ }^{3} \mathrm{H}(500 \mathrm{y}): & 7.51 \times 10^{-19} \mathrm{Ci} \mathrm{m}^{-2} \mathrm{y}^{-1}=2.4 \times 10^{-14} \mathrm{pCi} \mathrm{m}^{-2} \mathrm{~s}^{-1} \\
{ }^{14} \mathrm{C:} & 1.95 \times 10^{-12} \mathrm{Ci} \mathrm{m}^{-2} \mathrm{y}^{-1}=6.2 \times 10^{-8} \mathrm{pCi} \mathrm{m}^{-2} \mathrm{~s}^{-1} \\
{ }^{222} \mathrm{Rn} \mathrm{(10,000y):} & 7.31 \times 10^{-25} \mathrm{Ci} \mathrm{m}^{-2} \mathrm{y}^{-1}=2.3 \times 10^{-20} \mathrm{pCi} \mathrm{m}^{-2} \mathrm{~s}^{-1} \\
\quad \text { (peak): } & 1.02 \times 10^{-23} \mathrm{Ci} \mathrm{m}^{-2} \mathrm{y}^{-1}=3.2 \times 10^{-19} \mathrm{pCi} \mathrm{m}^{-2} \mathrm{~s}^{-1}
\end{array}
$$

The small fluxes of ${ }^{222} \mathrm{Rn}$ result from the short half-life of ${ }^{222} \mathrm{Rn}$ and the very deep burial of the waste. Practically all the radon decays before it can reach the surface. 
DOE/RL-97-69

Rev. 0

Table 4-33. Inventory of ${ }^{222} \mathrm{Rn}$ as a Function of Time.

\begin{tabular}{|r|c||c|c||}
\hline \multicolumn{1}{|l|}{ Time $(\mathrm{y})$} & Inventory (Ci) & Time (y) & Inventory (Ci) \\
\hline 0. & $2.35 \mathrm{E}-03$ & $1,000$. & $3.27 \mathrm{E}-02$ \\
\hline $2,000$. & $1.10 \mathrm{E}-01$ & $3,000$. & $2.19 \mathrm{E}-01$ \\
\hline $5,000$. & $4.89 \mathrm{E}-01$ & $7,500$. & $8.74 \mathrm{E}-01$ \\
\hline $10,000$. & $1.28 \mathrm{E}+00$ & $20,000$. & $2.64 \mathrm{E}+00$ \\
\hline $30,000$. & $3.96 \mathrm{E}+00$ & $50,000$. & $6.27 \mathrm{E}+00$ \\
\hline $75,000$. & $8.63 \mathrm{E}+00$ & $100,000$. & $1.05 \mathrm{E}+01$ \\
\hline $200,000$. & $1.49 \mathrm{E}+01$ & $300,000$. & $1.66 \mathrm{E}+01$ \\
\hline $500,000$. & $1.76 \mathrm{E}+01$ & $750,000$. & $1.78 \mathrm{E}+01$ \\
\hline $1,000,000$. & $1.78 \mathrm{E}+01$ & & \\
\hline
\end{tabular}

To convert the ${ }^{3} \mathrm{H}$ and ${ }^{14} \mathrm{C}$ flux into a dose, the following equation is used

$$
\mathrm{D}=\mathrm{J} A(\mathrm{X} / \mathrm{Q}) \mathrm{B} \mathrm{F}
$$

where

$$
\begin{array}{ll}
D= & \text { the annual inhalation dose } \\
J= & \text { the flux at the surface } \\
A= & \text { the area of the facility [Concept 1] } \\
(X / Q)= & \text { normalized integrated exposure } \\
B= & \text { inhalation rate } \\
F= & \text { dose conversion factor }
\end{array}
$$

$(\mathrm{mrem} / \mathrm{y})$, (see above), $\left(4.45 \times 10^{4} \mathrm{~m}^{2}\right)$, $\left(1.0 \times 10^{-4} \mathrm{~s} / \mathrm{m}^{3}\right)$, $\left(2.67 \times 10^{-4} \mathrm{~m}^{3} / \mathrm{s}\right)$, $\left({ }^{3} \mathrm{H}: 9.5 \times 10^{4} \mathrm{mrem} / \mathrm{Ci}\right)$ $\left({ }^{14} \mathrm{C}: 2.1 \times 10^{6} \mathrm{mrem} / \mathrm{Ci}\right)$

The values for $(\mathrm{X} / \mathrm{Q}), \mathrm{B}$, and $\mathrm{F}$ are taken from the Performance Assessment for the Disposal of Low-Level Waste in the 200 West Area Burial Grounds (Wood 1994b-3). The resulting annual dose is $2.7 \times 10^{-12}$ mrem at 500 years for ${ }^{3} \mathrm{H}$ and $4.8 \times 10^{-9} \mathrm{mrem}$ (steady state) for ${ }^{14} \mathrm{C}$.

The predicted release of ${ }^{3} \mathrm{H},{ }^{14} \mathrm{C}$ and ${ }^{222} \mathrm{Rn}$ are far below the corresponding performance objectives (10 mrem in a year for ${ }^{3} \mathrm{H}$ and ${ }^{14} \mathrm{C}$ and $20 \mathrm{pCi} \mathrm{m}^{-2} \mathrm{y}^{-1}$ for ${ }^{222} \mathrm{Rn}$ ).

These calculations for ${ }^{3} \mathrm{H}$ are sensitive to the amount of ${ }^{3} \mathrm{H}$ in the waste form, taken to be 100 percent, and to the time of compliance taken as 500 years. Because of its short half-life, ${ }^{3} \mathrm{H}$ should decay long before the waste form releases any of the amount that will actually be in the waste form. 


\section{DOE/RL-97-69}

Rev. 0

The calculations for ${ }^{14} \mathrm{C}$ are relatively insensitive to the various parameters. However, the amount of ${ }^{14} \mathrm{C}$ might be as high as $100 \mathrm{Ci}$ (WHC 1996), compared with $7.73 \mathrm{Ci}$ of the base analysis case. Using the higher estimate of ${ }^{14} \mathrm{C}$ inventory would raise the predicted dose to $6.3 \times 10^{-8} \mathrm{mrem}$ in a year, still much lower than the performance objective of $10 \mathrm{mrem}$ in a year.

Because so much of the ${ }^{22} \mathrm{Rn}$ is predicted to decay by the time it reaches the surface, the ${ }^{222} \mathrm{Rn}$ calculation is extremely sensitive to the waste depth and the diffusion coefficient of radon in the soil. If the waste is only 5 meters deep rather than the 10 meters assumed or if the diffusion coefficient is $10^{-2} \mathrm{~cm}^{2} / \mathrm{s}$, the value used in the Hanford Site burial grounds performance assessment (Wood 1994b-3), the predicted flux increases by over 10 orders of magnitude. However, the predicted dose is still orders of magnitude less than the performance objective. 
DOE/RL-97-69

Rev. 0

\subsection{RESULTS FOR INADVERTENT INTRUDER SCENARIO}

\subsection{OVERVIEW}

The DOE intends to control the disposal sites for as long as the waste may be dangerous to an intruder. However, DOE recognizes that an inadvertent intruder may happen onto the site and not be discovered until after exposure has occurred.

As noted in Section 1.6.2.4, the time of compliance is 500 years after closure. However, results will be presented for the period of 100 years after closure to 1,000 years after closure. The performance objective for the driller scenario is $500 \mathrm{mrem}$ (EDE) for a one-time exposure, while the performance objective for the homesteader scenario is $100 \mathrm{mrem}$ (EDE) per year for a continuous exposure.

The time of closure is taken to be 2020 , although the final closure of all the vaults is not expected until 2028.

All the analyses presented in this section assume that the surface barrier is in place (Section 2.4.1). The significant thickness of rip-rap basalt is intended to deter any human, plant, or animal intrusion. All calculations were performed using a spreadsheet to calculate decay and to convert inventory concentrations into doses.

\subsection{INADVERTENT INTRUDER SCENARIOS}

The pathways described here assume that no memory of the disposal facility remains. Two principal cases of intruders were considered:

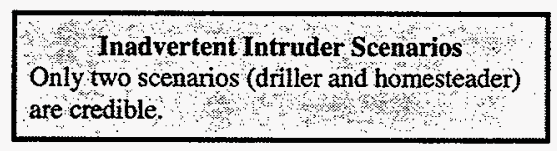

- The disposal facility is compromised by irrigation for commercial farming. A large amount of water enters the disposal facility, causing increased contaminant release and increased transport to the unconfined aquifer.

- An inadvertent intruder digs or drills into the disposal site and brings some of the waste to the surface, receiving an acute dose. Another intruder tills the waste into the soil and grows vegetables, receiving a continuous dose while engaged in various activities.

The scenario of irrigated farming on the disposal site is basically the same as the base analysis case for the groundwater. The difference is that instead of a small amount of water naturally infiltrating the disposal facility, a much larger amount of water enters the disposal facility (see Section 4.6.3). The larger amount of water may increase the contaminant release rate from the engineered facility. The increased amount of water certainly speeds the transport 
of the contaminants through the vadose zone into the unconfined aquifer but does not change the maximum dose rate (see Section 4.7.2).

The following three intruder scenarios that involve bringing waste from the disposal facility to the surface are usually considered in a performance assessment.

- Excavating for a basement or building foundation

- Drilling for groundwater or minerals

- Living where waste has been exhumed and scattered over the surface.

Scenario 1 is not considered credible because the top of the waste is over $10 \mathrm{~m}(32.8 \mathrm{ft})$ below the surface. Neither basements for home residence nor foundations for commercial structures are likely to extend this far below the surface. This scenario was not evaluated in these analyses.

Scenario 2 , the construction of small water wells, is quite possible. The driller scenario begins with the assumption that some time after the disposal practices have ended a well is drilled through the waste. Drilling at the disposal site is unintentional, and the waste is not recognized as a potential hazard, even though it is assumed to be in the form of glass chunks. The waste, along with uncontaminated soil taken from the well, is spread over a work area near the well. The dose to the worker is the sum of the contributions from inhalation of resuspended dust, ingestion of trace amounts of soil, and external exposure at the center of a slab of contaminated soil.

Scenario 3 considers a family planting a garden using the material taken from the well. Each individual of concern receives dose by direct exposure to the radiation field in the garden, by inhaling resuspended dust, by ingesting trace amounts of soil, and by consuming garden produce.

\subsection{DATA FOR INADVERTENT INTRUDER ANALYSIS}

Selecting values for parameters important in inadvertent intruder scenarios is very difficult. Because such intrusion is postulated to be in the future, the nature of the intrusion is ill-defined. Moreover, uncertainty abounds about the proper Inadvertent Intruder Data
More conservative data were used
than previous Hanford Site analyses. values to be used in a given scenario. This performance assessment looks at the driller and homesteader scenarios.

For the driller scenario, the most important parameters are the amount of waste taken from the site, the size of the area over which the waste is spread, and the physical integrity of the waste. 


\section{DOE/RL-97-69}

Rev. 0

The amount of waste material taken from the disposal site is assumed to be the stack height of the waste $(7.2 \mathrm{~m}$ [23.6 ft] from Section 3.4.5.4) times the area of the bore hole for the well. For this performance assessment, the diameter of the well is assumed to be $0.3 \mathrm{~m}(1 \mathrm{ft})$. Although consistent with the diameters used in earlier Hanford Site performance assessments, this value is larger than the range of diameters ( 10.2 to $25.4 \mathrm{~cm}$ [ 4 to $10 \mathrm{in}$ ]) commonly found in local communities. In future performance assessments, an estimate of the well diameter based on actual experience will be used.

The area over which the driller spreads the waste is $100 \mathrm{~m}^{2}$ (about $1,100 \mathrm{ft}^{2}$ ). This value has been historically used in Hanford Site performance assessments.

The integrity of the waste form becomes important in determining the amount of radionuclides available for inhalation or uptake by plants and animals. For the base case, 90 percent of the radionuclides exhumed is assumed to stay within the waste form: The importance of this assumption was investigated by sensitivity cases.

The worker at the well drilling site is exposed 8 hours a day for 5 days. The dose to the worker is the sum of the contributions from inhaling resuspended dust $\left(0.1 \mathrm{mg} / \mathrm{m}^{3}\right)$, ingesting trace amounts of soil ( $100 \mathrm{mg} / \mathrm{day})$, and external exposure at the center of a slab of contaminated soil for 40 hours. The dose factors for this scenario can be found in Appendix B, Table B-3.

The most important parameters in the second phase of the inadvertent intruder scenario, the homesteader scenario, are the volume of waste exhumed, the area over which it is spread, and the integrity of the waste form. For this scenario, the depth over which the waste is mixed with the soil and the parameters from the all-pathways scenario also are important.

The same amount of waste is exhumed as in the driller scenario. Because the waste is assumed to be tilled into the soil, the waste is spread over $500 \mathrm{~m}^{2}(0.124$ acre $)$. In all earlier Hanford Site performance assessments, the garden area has been $2,500 \mathrm{~m}^{2}(0.62$ acre $)$. The $500-\mathrm{m}^{2}$ garden was chosen for this performance assessment because the size represents an area large enough to supply a significant portion of a person's vegetable and fruit diet. Household gardens in the vicinity of the Hanford Site range in size from $10 \mathrm{~m}^{2}$ to $1,000 \mathrm{~m}^{2}\left(107 \mathrm{ft}^{2}\right.$ to 0.25 acre) (Napier 1984).

The value taken for the depth of the soil mixing is $15 \mathrm{~cm}$ ( $5.9 \mathrm{in}$.). This value has been used in other onsite performance assessments and is the typical depth of root systems of garden vegetables.

The values for other parameters for this scenario are taken from the driller scenario (immediately above) and the all-pathways exposure scenario (Section 3.4.7.2). The resulting dose factors are displayed in Appendix B, Table B-4. 
DOE/RL-97-69

Rev. 0

\subsection{INADVERTENT INTRUDER ANALYSIS RESULTS}

\subsubsection{Driller Scenario}

The results for the driller scenario are presented in Table 5-1 and displayed in Figure 5-1. The effect of waste form dissolution can be seen in Table 5-1 for the long-lived radionuclides. For these radionuclides (for example, ${ }^{99} \mathrm{Tc}$ ), the estimated dose increases as a function of time because more of the radionuclides are available for ingestion.

At all times calculated, the predicted dose is at least one order of magnitude less than $500 \mathrm{mrem}$, the performance objective at 500 years. The main radionuclide contributing to the dose initially is ${ }^{137} \mathrm{Cs}$. After about 200 years, ${ }^{126} \mathrm{Sn}$ becomes the most important nuclide.

None of the sensitivity cases change the conclusion that the driller scenario meets the performance objective. Even increasing the ${ }^{137} \mathrm{Cs}$ content to $5 \mathrm{MCi}$ (WHC 1996) results in increasing the predicted total driller dose only to $493 \mathrm{mrem}$ at 100 years and has no significant effect after 300 years. Changing other parameters (inventory of other radionuclides, waste density, size of the well, area over which the waste form is spread, the integrity of the waste form) modified the predicted exposures by at most a factor of two.

Figure 5-1. Inadvertent Intruder Results for the Driller Scenario - Base Intruder Case. The D in the legend represents "daughters."

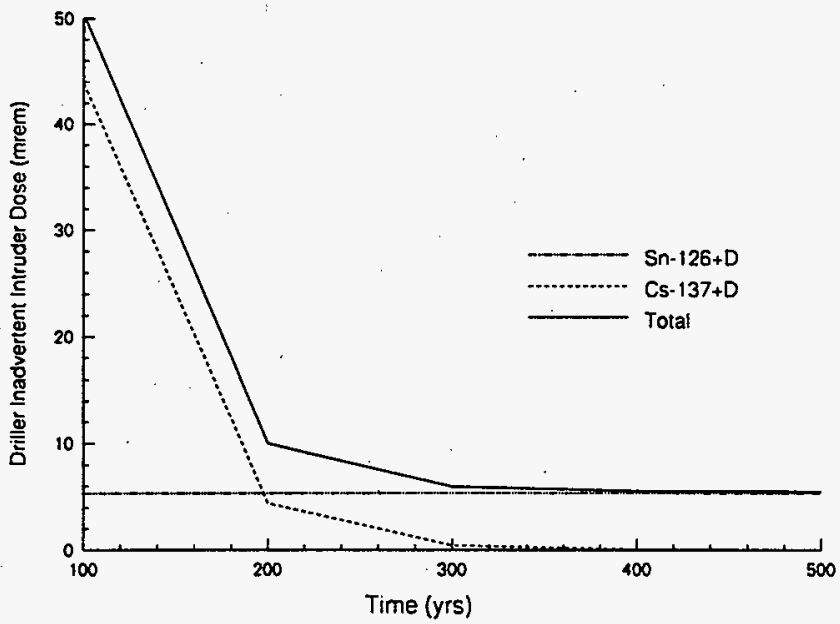


DOE/RL-97-69

Rev. 0

Table 5-1. Driller Intruder Dose (mrem) at Various Intrusion Times (years)a.

\begin{tabular}{|c|c|c|c|c|c|c|c|c|}
\hline Nuclide $^{b}$ & 100 & 200 & 300 & 400 & 500 & 600 & 800 & 1000 \\
\hline C-14 & 3.36E-08 & $3.39 \mathrm{E}-08$ & $3.41 \mathrm{E}-08$ & $3.44 \mathrm{E}-08$ & $3.46 \mathrm{E}-08$ & $3.49 \mathrm{E}-08$ & 3.53E-08 & $3.57 \mathrm{E}-08$ \\
\hline Se-79 & $6.50 \mathrm{E}-06$ & $6.86 \mathrm{E}-06$ & $7.21 \mathrm{E}-06$ & $7.57 \mathrm{E}-06$ & 7.93E-06 & $8.28 \mathrm{E}-0.6$ & $8.98 \mathrm{E}-06$ & $9.68 \mathrm{E}-06$ \\
\hline Sr-90+D & $1.06 \mathrm{E}+00$ & 9.38E-02 & 8.32E-03 & $7.38 \mathrm{E}-04$ & $6.54 \mathrm{E}-05$ & $5.80 \mathrm{E}-06$ & $4.56 \mathrm{E}-08$ & $3.59 \mathrm{E}-10$ \\
\hline $\mathrm{Zr}-93$ & $1.62 \mathrm{E}-06$ & 1.65E-06 & $1.66 \mathrm{E}-06$ & $1.67 \mathrm{E}-06$ & $1.68 \mathrm{E}-06$ & $1.69 \mathrm{E}-06$ & $1.71 \mathrm{E}-06$ & $1.74 \mathrm{E}-06$ \\
\hline $\mathrm{Nb}-93 \mathrm{~m}$ & $1.22 \mathrm{E}-08$ & $1.06 \mathrm{E}-10$ & $9.16 \mathrm{E}-13$ & $7.95 \mathrm{E}-15$ & $6.91 \mathrm{E}-17$ & $5.99 \mathrm{E}-19$ & $4.52 \mathrm{E}-23$ & $3.41 \mathrm{E}-27$ \\
\hline Tc-99 & 8.97E-04 & $8.98 \mathrm{E}-04$ & 8.99E-04 & $9.00 \mathrm{E}-04$ & $9.01 \mathrm{E}-04$ & $9.02 \mathrm{E}-04$ & $9.04 \mathrm{E}-04$ & $9.06 \mathrm{E}-04$ \\
\hline $\mathrm{Sn}-126+\mathrm{D}$ & $5.35 \mathrm{E}+00$ & $5.35 E+00$ & $5.34 \mathrm{E}+00$ & $5.34 \mathrm{E}+00$ & $5.33 \mathrm{E}+00$ & $5.33 \mathrm{E}+00$ & $5.32 \mathrm{E}+00$ & $5.32 \mathrm{E}+00$ \\
\hline I- 129 & $2.75 \mathrm{E}-05$ & $2.76 \mathrm{E}-05$ & $2.77 \mathrm{E}-0.5$ & $2.78 \mathrm{E}-05$ & $2.79 \mathrm{E}-05$ & $2.79 \mathrm{E}-05$ & $2.81 \mathrm{E}-05$ & $2.82 \mathrm{E}-05$ \\
\hline Cs-134 & $1.36 \mathrm{E}-20$ & 3.43E-35 & $8.64 \mathrm{E}-50$ & $2.17 \mathrm{E}-64$ & $5.48 \mathrm{E}-79$ & $1.38 \mathrm{E}-93$ & $8.74 \mathrm{E}-123$ & $5.54 \mathrm{E}-152$ \\
\hline Cs-137+D & $4.39 \mathrm{E}+01$ & $4.41 E+00$ & 4.44E-01 & $4.46 \mathrm{E}-02$ & $4.48 \mathrm{E}-03$ & $4.50 \mathrm{E}-04$ & $4.55 \mathrm{E}-06$ & $4.60 \mathrm{E}-08$ \\
\hline Sm-151 & $5.00 \mathrm{E}-06$ & $2.49 \mathrm{E}-06$ & $1.24 \mathrm{E}-06$ & $6.10 \mathrm{E}-07$ & $3.00 \mathrm{E}-07$ & $1.47 \mathrm{E}-07$ & $3.50 \mathrm{E}-08$ & $8.24 \mathrm{E}-09$ \\
\hline $\mathrm{Ra}-226+\mathrm{D}$ & $6.81 \mathrm{E}-06$ & 6.52E-06 & $6.24 \mathrm{E}-06$ & $5.98 \mathrm{E}-06$ & $5.73 \mathrm{E}-06$ & $5.48 \mathrm{E}-06$ & $5.03 \mathrm{E}-06$ & $4.61 \mathrm{E}-06$ \\
\hline $\mathrm{Ra}-228+\mathrm{D}$ & $4.47 \mathrm{E}-08$ & $2.60 \mathrm{E}-13$ & $1.51 \mathrm{E}-18$ & $8.81 \mathrm{E}-24$ & $5.12 \mathrm{E}-29$ & $2.98 \mathrm{E}-34$ & $1.01 \mathrm{E}-44$ & $3.41 \mathrm{E}-55$ \\
\hline $\mathrm{Ac}-227+\mathrm{D}$ & $2.73 \mathrm{E}-05$ & $1.14 \mathrm{E}-06$ & $4.74 \mathrm{E}-08$ & $1.98 \mathrm{E}-09$ & $8.24 \mathrm{E}-11$ & $3.43 \mathrm{E}-12$ & $5.95 \mathrm{E}-15$ & $1.03 \mathrm{E}-17$ \\
\hline Th- $229+\mathrm{D}$ & $4.59 \mathrm{E}-06$ & $4.56 \mathrm{E}-06$ & 4.53E-06 & 4.49E-06 & $4.46 \mathrm{E}-06$ & $4.43 \mathrm{E}-06$ & $4.36 \mathrm{E}-06$ & 4.30E-06 \\
\hline Th-232 & $1.14 \mathrm{E}-04$ & $1.14 \mathrm{E}-04$ & $1.14 \mathrm{E}-04$ & $1.14 \mathrm{E}-04$ & $1.14 \mathrm{E}-04$ & $1.14 \mathrm{E}-04$ & $1.14 \mathrm{E}-04$ & 1.14E-04 \\
\hline $\mathrm{Pa}-231$ & 9.32E-02 & $9.72 \mathrm{E}-02$ & $9.78 \mathrm{E}-02$ & $9.82 \mathrm{E}-02$ & $9.86 \mathrm{E}-02$ & $9.90 \mathrm{E}-02$ & $9.98 \mathrm{E}-02$ & $1.01 \mathrm{E}-01$ \\
\hline $\mathrm{U}-233$ & $1.28 \mathrm{E}-04$ & $2.44 \mathrm{E}-04$ & $3.59 \mathrm{E}-04$ & 4.73E-04 & $5.87 \mathrm{E}-04$ & $7.01 \mathrm{E}-04$ & $9.25 \mathrm{E}-04$ & $1.15 \mathrm{E}-03$ \\
\hline U-234 & 3.47E-06 & 4.64E-06 & $5.82 \mathrm{E}-06$ & $7.00 \mathrm{E}-06$ & $8.18 \mathrm{E}-06$ & $9.38 \mathrm{E}-06$ & $1.18 \mathrm{E}-05$ & $1.42 \mathrm{E}-05$ \\
\hline $\mathrm{U}-235+\mathrm{D}$ & $1.75 \mathrm{E}-04$ & $1.76 \mathrm{E}-04$ & $1.77 \mathrm{E}-04$ & $1.78 \mathrm{E}-04$ & $1.79 \mathrm{E}-04$ & $1.80 \mathrm{E}-04$ & $1.82 \mathrm{E}-04$ & $1.85 \mathrm{E}-04$ \\
\hline $\mathrm{U}-236$ & $5.71 \mathrm{E}-08$ & 8.37E-08 & $1.10 \mathrm{E}-07$ & 1.37E-07 & $1.63 \mathrm{E}-07$ & $1.90 \mathrm{E}-07$ & $2.43 \mathrm{E}-07$ & $2.95 \mathrm{E}-07$ \\
\hline
\end{tabular}


DOF/RL-97-69

Rev. 0

Table 5-1. Driller Intruder Dose (mrem) at Various Intrusion Times (years)

\begin{tabular}{||l|l|l|l|l|l|l|l|l|}
\hline \hline Nuclide $^{\mathrm{b}}$ & 100 & 200 & 300 & 400 & 500 & 600 & 800 \\
\hline \hline $\mathrm{U}-238+\mathrm{D}$ & $6.77 \mathrm{E}-04$ & $6.78 \mathrm{E}-04$ & $6.79 \mathrm{E}-04$ & $6.80 \mathrm{E}-04$ & $6.81 \mathrm{E}-04$ & $6.82 \mathrm{E}-04$ & $6.84 \mathrm{E}-04$ & $6.86 \mathrm{E}-04$ \\
\hline Np-237+D & $1.25 \mathrm{E}-03$ & $1.25 \mathrm{E}-03$ & $1.25 \mathrm{E}-03$ & $1.25 \mathrm{E}-03$ & $1.26 \mathrm{E}-03$ & $1.26 \mathrm{E}-03$ & $1.26 \mathrm{E}-03$ & $1.26 \mathrm{E}-03$ \\
\hline Pu-239 & $1.07 \mathrm{E}-03$ & $1.93 \mathrm{E}-03$ & $2.78 \mathrm{E}-03$ & $3.63 \mathrm{E}-03$ & $4.48 \mathrm{E}-03$ & $5.31 \mathrm{E}-03$ & $6.97 \mathrm{E}-03$ & $8.61 \mathrm{E}-03$ \\
\hline Pu-240 & $1.86 \mathrm{E}-04$ & $3.49 \mathrm{E}-04$ & $5.07 \mathrm{E}-04$ & $6.63 \mathrm{E}-04$ & $8.15 \mathrm{E}-04$ & $9.63 \mathrm{E}-04$ & $1.25 \mathrm{E}-03$ & $1.52 \mathrm{E}-03$ \\
\hline Am-241 & $5.22 \mathrm{E}-02$ & $4.58 \mathrm{E}-02$ & $4.01 \mathrm{E}-02$ & $3.51 \mathrm{E}-02$ & $3.07 \mathrm{E}-02$ & $2.68 \mathrm{E}-02$ & $2.05 \mathrm{E}-02$ & $1.56 \mathrm{E}-02$ \\
\hline Am-243+D & $7.47 \mathrm{E}-04$ & $7.41 \mathrm{E}-04$ & $7.35 \mathrm{E}-04$ & $7.30 \mathrm{E}-04$ & $7.24 \mathrm{E}-04$ & $7.18 \mathrm{E}-04$ & $7.07 \mathrm{E}-04$ & $6.96 \mathrm{E}-04$ \\
\hline Cm-245 & $1.12 \mathrm{E}-05$ & $1.14 \mathrm{E}-05$ & $1.15 \mathrm{E}-05$ & $1.16 \mathrm{E}-05$ & $1.17 \mathrm{E}-05$ & $1.18 \mathrm{E}-05$ & $1.19 \mathrm{E}-05$ & $1.20 \mathrm{E}-05$ \\
\hline \hline Total & $\mathbf{5 0 . 4 6}$ & 10.00 & 5.94 & 5.53 & 5.48 & 5.47 & 5.46 & 5.45 \\
\hline \hline
\end{tabular}

"Values in bold indicate highest contributor to dose

b Nuclides with " $+D$ " added to their name include the contributions from short-lived progeny, which are assumed to be in equilibrium at all times 
DOE/RL-97-69

Rev. 0

\subsubsection{Homesteader Scenario}

5.4.2.1 Results. The waste is assumed to be 7.2 meters ( 24 feet) thick and uniformly distributed in the disposal facility (i.e. the waste is averaged over the volume of the container and

Homesteader Dose At short times, ${ }^{137} \mathrm{C}$ predominates. At the time of compliance $126 \mathrm{~S}$ dominates, but the average base intruder case inventory results in a dose of $25 \mathrm{mrem}$ in a year: the filler material). This averaging method is consistent with the assumption that the well is randomly placed over the disposal vault. The well diameter is $0.30 \mathrm{~m}(12 \mathrm{in})$. Thus, the drilling operation brings 0.509 cubic meter of waste to the surface. This waste is spread over an area of $500 \mathrm{~m}^{2}\left(5,382 \mathrm{ft}^{3}\right)$ and mixed by tilling to a depth of $0.15 \mathrm{~m}(5.9 \mathrm{in})$. Because the garden volume is $75 \mathrm{~m}^{3}\left(2,649 \mathrm{ft}^{3}\right)$, the waste is diluted by a factor of 133. For dose factor generation, if the waste has an unit concentration of $1 \mathrm{Ci} / \mathrm{m}^{3}$, the final concentration in the garden soil is $4.52 \mu \mathrm{Ci} / \mathrm{kg}$.

The predicted doses for a hypothetical homesteader are presented in Table 5-2 and displayed in Figure 5-2. As in the driller scenario, estimated doses for long-lived radionuclides increase as a function of time because more waste is available for ingestion and inhalation as the waste form degrades.

Figure 5-2. Inadvertent Intruder Results for the Homesteader Scenario - Base Intruder.Case. The $\mathrm{D}$ in the legend represents daughters.

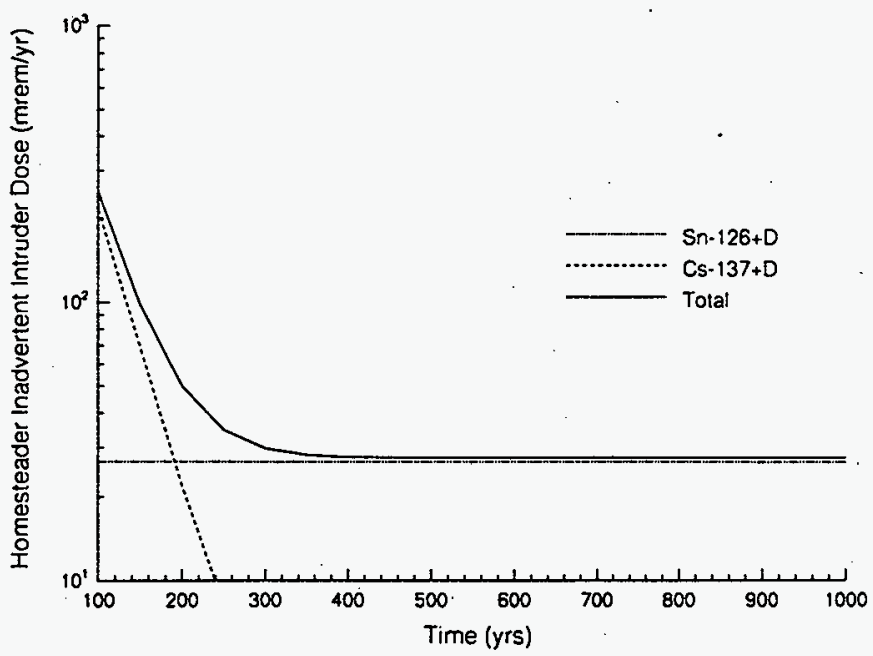




\section{DOE/RL-97-69}

Rev. 0

Initially, the main radionuclide contributing to the dose is ${ }^{137} \mathrm{Cs}$. After 200 years, ${ }^{126} \mathrm{Sn}$ becomes the most important radionuclide. Because the radionuclides are assumed to be trapped in the glass and unavailable for ingestion or inhalation, the dominant dose pathway is external radiation. Using the many (mostly conservative) assumptions of the base intruder case, the predicted dose is $27.5 \mathrm{mrem}$ in a year, over a factor of 3 lower than the performance objective of $100 \mathrm{mrem} / \mathrm{y}$ at 500 years. The estimated dose exceeds $100 \mathrm{mrem} / \mathrm{y}$ for times shorter than 150 years after the facility closes. The major parameters driving these results are the following:

- The initial inventory of ${ }^{137} \mathrm{Cs}$

- The initial inventory of ${ }^{126} \mathrm{Sn}$

- The assumption that the glass remains mainly in chunks which are too big to ingest

- The area over which the waste is spread on the surface

- The size of the hole drilled

- The areal density of the waste inside of the disposal facility.

The sensitivity of the results to these and other parameters is discussed in the following sections.

5.4.2,2 Cesium-137. At 100 years after closure, ${ }^{137} \mathrm{Cs}$ contributes over 88 percent of the predicted dose. Thus if the amount of ${ }^{137} \mathrm{Cs}$ is changed, the change in the predicted dose at 100 years follows the change in ${ }^{137} \mathrm{Cs}$. However, the amount of ${ }^{137} \mathrm{Cs}$ will not affect the predicted dose at the time of compliance ( 500 years after closure), because of its short 30 -year half-life. The predicted dose from ${ }^{137} \mathrm{Cs}$ decreases about an order of magnitude for every 100 years; thus, the predicted dose from ${ }^{137} \mathrm{Cs}$ at 500 years is $10^{-4}$ of the value at 100 years.

As part of the effort to determine the radioactive classification of the material taken from the single-shell tanks, whether it is high-level waste or incidental waste remaining after treatment (WHC 1996), an inventory as high as $5 \mathrm{MCi}$ of ${ }^{137} \mathrm{Cs}$ in the disposal facility has been proposed. This change by a factor of 11 implies the predicted dose of $9.8 \mathrm{rem}$ in a year 100 years after closure.

The TWRS Standard Inventory global value for ${ }^{137} \mathrm{Cs}$ (see Section 3.2.5) is 30 percent lower than that found in the base analysis case. This means if the TWRS Standard Inventory value is used, the homesteader dose at a 100 years decreases to 181 mrem in a year (a 25 percent decrease from ${ }^{137} \mathrm{Cs}$ and a further 3 percent decrease from ${ }^{126} \mathrm{Sn}$ ). The predicted dose from ${ }^{137} \mathrm{Cs}$ falls below that from ${ }^{126} \mathrm{Sn}$ at about 200 years. 
DOE/RL-97-69

Rev. 0

Table 5-2. Homesteader Intruder Dose (mrem in a year) at Various Intrusion Times (years) ${ }^{2}$.

\begin{tabular}{|c|c|c|c|c|c|c|c|c|c|c|c|c|c|}
\hline Nuclide ${ }^{b}$ & 100 & 150 & 200 & 250 & 300 & 350 & 400 & 500 & 600 & 700 & 800 & 900 & 1000 \\
\hline $\mathrm{H}-3$ & 2.34E-07 & $2.08 \mathrm{E}-08$ & $1.65 \mathrm{E}-00$ & $1.23 \mathrm{E}-10$ & $8.76 \mathrm{E}-12$ & $6.08 \mathrm{E}-13$ & $4.13 \mathrm{E}-14$ & $1.83 \mathrm{E}-16$ & $7.75 \mathrm{E}-19$ & $3.20 \mathrm{E}-21$ & $1.29 \mathrm{E}-23$ & $5.14 \mathrm{E}-26$ & $2.02 \mathrm{E}-$ \\
\hline $\mathrm{C}-14$ & $2.99 \mathrm{E}-06$ & $4.38 \mathrm{E}-06$ & $5.76 \mathrm{E}-06$ & $7.11 \mathrm{E}-06$ & $8.45 \mathrm{E}-06$ & $9.77 \mathrm{E}-06$ & $1.11 \mathrm{E}-0.5$ & $1.36 \mathrm{E}-05$ & 1.61E-05 & $1.86 \mathrm{E}-05$ & $2.09 \mathrm{E}-05$ & $2.32 \mathrm{E}-05$ & $2.55 \mathrm{E}-05$ \\
\hline Se-79 & $9.27 \mathrm{E}-05$ & $1.24 \mathrm{E}-04$ & $1.55 \mathrm{E}-04$ & $1.86 \mathrm{E}-04$ & $2.16 \mathrm{E}-04$ & $2.47 \mathrm{E}-04$ & $2.78 \mathrm{E}-04$ & $3.39 \mathrm{E}-04$ & $4.01 \mathrm{E}-04$ & 4.62E-04 & $5.23 \mathrm{E}-04$ & $5.84 \mathrm{E}-04$ & $6.44 \mathrm{E}-04$ \\
\hline$S r-90+D$ & $6.50 \mathrm{E}+00$ & $2.13 \mathrm{E}+00$ & $6.94 \mathrm{E}-01$ & $2.24 \mathrm{E}-0 \mathrm{l}$ & $7.20 \mathrm{E}-02$ & $2.30 \mathrm{E}-02$ & 7.31E-03 & 7.30E-04 & $7.20 \mathrm{E}-05$ & 7.02E-06 & $6.79 \mathrm{E}-07$ & $6.52 \mathrm{E}-08$ & $6.23 \mathrm{E}-09$ \\
\hline $\mathrm{Zr}-93$ & $8.28 \mathrm{E}-06$ & $8.47 \mathrm{E}-06$ & $8.60 \mathrm{E}-06$ & 8.72E-06 & $8.85 \mathrm{E}-06$ & $8.97 \mathrm{E}-06$ & $9.10 \mathrm{E}-06$ & $9.34 \mathrm{E}-06$ & $9.59 \mathrm{E}-06$ & $9.84 \mathrm{E}-06$ & $1.01 \mathrm{E}-05$ & 1.03E-05 & $1.06 \mathrm{E}-05$ \\
\hline Nb-93m & $5.98 \mathrm{E}-08$ & $5.59 \mathrm{E}-09$ & $5.23 \mathrm{E}-10$ & $4.89 \mathrm{E}-11$ & $4.57 \mathrm{E}-12$ & $4.27 \mathrm{E}-13$ & $3.99 \mathrm{E}-14$ & $3.49 \mathrm{E}-16$ & $3.05 \mathrm{E}-18$ & $2.67 \mathrm{E}-20$ & $2.33 \mathrm{E}-22$ & $2.04 \mathrm{E}-24$ & $1.78 \mathrm{E}-26$ \\
\hline Tc-99 & $1.06 \mathrm{E}-02$ & $1.46 \mathrm{E}-02$ & $1.86 \mathrm{E}-02$ & $2.26 \mathrm{E}-02$ & $2.66 \mathrm{E}-02$ & $3.06 \mathrm{E}-02$ & $3.46 \mathrm{E}-02$ & $4.25 \mathrm{E}-02$ & $5.05 \mathrm{E}-02$ & $5.84 \mathrm{E}-02$ & $6.64 \mathrm{E}-02$ & $7.43 \mathrm{E}-02$ & $8.22 \mathrm{E}-02$ \\
\hline Sn-126+D & $2.67 \mathrm{E}+01$ & $2.67 \mathrm{E}+01$ & $2.67 E+01$ & $2.67 \mathrm{E}+01$ & $2.66 \mathrm{E}+01$ & $2.66 \mathrm{E}+01$ & $2.66 \mathrm{E}+01$ & $2.66 \mathrm{E}+01$ & $2.66 \mathrm{E}+01$ & $2.66 \mathrm{E}+01$ & $2.66 \mathrm{E}+01$ & $2.65 \mathrm{E}+01$ & $2.65 \mathrm{E}+01$ \\
\hline I-129 & $1.43 \mathrm{E}-04$ & $1.54 \mathrm{E}-04$ & $1.66 \mathrm{E}-04$ & 1.77E-04 & $1.89 \mathrm{E}-04$ & $2.00 \mathrm{E}-04$ & $2.12 \mathrm{E}-04$ & $2.35 \mathrm{E}-04$ & $2.58 \mathrm{E}-04$ & $2.81 \mathrm{E}-04$ & $3.04 \mathrm{E}-04$ & $3.27 \mathrm{E}-04$ & $3.49 \mathrm{E}-04$ \\
\hline Cs-137+D & $2.17 \mathrm{E}+02$ & $6.87 \mathrm{E}+01$ & $2.18 \mathrm{E}+01$ & $6.91 \mathrm{E}+00$ & $2.19 \mathrm{E}+00$ & $6.95 \mathrm{E}-01$ & $2.20 \mathrm{E}-0 \mathrm{t}$ & $2.21 \mathrm{E}-02$ & $2.23 \mathrm{E}-03$ & $2.24 \mathrm{E}-04$ & $2.25 \mathrm{E}-05$ & $2.26 \mathrm{E}-06$ & $2.27 \mathrm{E}-07$ \\
\hline Sm-151 & $3.54 \mathrm{E}-05$ & $2.83 \mathrm{E}-05$ & $2.21 \mathrm{E}-05$ & $1.70 \mathrm{E}-05$ & $1.29 \mathrm{E}-05$ & $9.69 \mathrm{E}-06$ & $7.21 \mathrm{E}-06$ & $3.91 \mathrm{E}-06$ & $2.07 \mathrm{E}-06$ & $1.08 \mathrm{E}-06$ & $5.57 \mathrm{E}-07$ & $2.84 \mathrm{E}-07$ & $1.44 \mathrm{E}-07$ \\
\hline $\mathrm{Ra}-226+\mathrm{D}$ & $3.40 \mathrm{E}-05$ & 3.33E-05 & $3.26 \mathrm{E}-05$ & $3.19 \mathrm{E}-0.5$ & $3.13 \mathrm{E}-0 \mathrm{~S}$ & $3.06 \mathrm{E}-05$ & $3.00 \mathrm{E}-05$ & $2.87 \mathrm{E}-05$ & $2.75 \mathrm{E}-05$ & $2.64 \mathrm{E}-0.5$ & $2.53 \mathrm{E}-05$ & $2.43 \mathrm{E}-05$ & 2.33E-05 \\
\hline Ra-228+D & $2.11 \mathrm{E}-07$ & $5.08 \mathrm{E}-10$ & $1.23 \mathrm{E}-12$ & $2.96 \mathrm{E}-15$ & $7.13 \mathrm{E}-18$ & $1.72 \mathrm{E}-20$ & $4.15 \mathrm{E}-23$ & $2.42 \mathrm{E}-28$ & $1.41 \mathrm{E}-33$ & $8.18 \mathrm{E}-39$ & $4.76 \mathrm{E}-44$ & $2.77 \mathrm{E}-49$ & $1.61 \mathrm{E}-54$ \\
\hline Ac- $227+\mathrm{D}$ & $1.36 \mathrm{E}-04$ & $2.80 \mathrm{E}-05$ & $5.76 \mathrm{E}-06$ & $1.18 \mathrm{E}-06$ & $2,43 \mathrm{E}-07$ & $4.99 \mathrm{E}-08$ & $1.03 \mathrm{E}-08$ & $4.33 \mathrm{E}-10$ & $1.82 \mathrm{E}-11$ & $7.69 \mathrm{E}-13$ & $3.24 \mathrm{E}-14$ & $1.37 \mathrm{E}-15$ & $5.75 \mathrm{E}-17$ \\
\hline Th-229+D & $2.31 \mathrm{E}-05$ & $2.31 \mathrm{E}-05$ & $2.30 \mathrm{E}-05$ & $2.30 \mathrm{E}-0.5$ & $2.30 \mathrm{E}-05$ & $2.29 \mathrm{E}-05$ & $2.29 \mathrm{E}-0.5$ & $2,29 \mathrm{E}-05$ & $2.28 \mathrm{E}-0.5$ & $2.27 \mathrm{E}-05$ & $2.27 \mathrm{E}-05$ & $2.26 \mathrm{E}-05$ & $2.26 \mathrm{E}-05$ \\
\hline Th-232 & $5.70 \mathrm{E}-04$ & $5.71 \mathrm{E}-04$ & $5.71 \mathrm{E}-04$ & $5.71 \mathrm{E}-04$ & $5.71 \mathrm{E}-04$ & $5.72 \mathrm{E}-04$ & $5.72 \mathrm{E}-04$ & $5.72 \mathrm{E}-04$ & $5.73 \mathrm{E}-04$ & $5.73 \mathrm{E}-04$ & $5.74 \mathrm{E}-04$ & $5.74 \mathrm{E}-04$ & $5.75 \mathrm{E}-04$ \\
\hline $\mathrm{Pa}-231$ & 4.74E- 01 & $4.94 \mathrm{E}-01$ & $5.02 \mathrm{E}-01$ & $5.08 \mathrm{E}-01$ & $5.13 \mathrm{E}-01$ & $5.18 \mathrm{E}-01$ & $5.23 \mathrm{E}-01$ & 5.33E-01 & $5.43 \mathrm{E}-01$ & $5.53 \mathrm{E}-01$ & $5.63 \mathrm{E}-01$ & $5.73 \mathrm{E}-01$ & $5.83 \mathrm{E}-01$ \\
\hline U-233 & $6.70 \mathrm{E}-04$ & $9.76 \mathrm{E}-04$ & $1.28 \mathrm{E}-03$ & $1.59 \mathrm{E}-03$ & $1.90 \mathrm{E}-03$ & $2.21 \mathrm{E}-03$ & $2.52 \mathrm{E}-03$ & $3.14 \mathrm{E}-03$ & $3.76 \mathrm{E}-03$ & $4.39 \mathrm{E}-03$ & $5.01 E-03$ & $5.64 \mathrm{E}-03$ & $6.28 \mathrm{E}-03$ \\
\hline U-234 & $3.54 \mathrm{E}-05$ & $4.74 \mathrm{E}-05$ & $5.95 \mathrm{E}-05$ & $7.16 \mathrm{E}-05$ & $8.37 \mathrm{E}-05$ & $9.59 \mathrm{E}-05$ & $1.08 \mathrm{E}-04$ & $1.33 \mathrm{E}-04$ & $1.58 \mathrm{E}-04$ & $1.83 \mathrm{E}-04$ & $2.08 \mathrm{E}-04$ & $2.34 \mathrm{E}-04$ & $2.61 \mathrm{E}-04$ \\
\hline$U-235+D$ & 8.63E-04 & 8.67E-04 & $8.70 \mathrm{E}-04$ & $8.73 \mathrm{E}-04$ & $8.76 \mathrm{E}-04$ & $8.80 \mathrm{E}-04$ & $8.83 \mathrm{E}-04$ & $8.90 \mathrm{E}-04$ & $8.98 \mathrm{E}-04$ & $9.05 \mathrm{E}-04$ & $9.13 \mathrm{E}-04$ & $9.21 \mathrm{E}-04$ & $9.29 \mathrm{E}-04$ \\
\hline $\mathrm{U}-236$ & $7.06 \mathrm{E}-07$ & $9.83 \mathrm{E}-07$ & $1.26 \mathrm{E}-06$ & $1.54 \mathrm{E}-06$ & $1.81 \mathrm{E}-06$ & $2.09 \mathrm{E}-00$ & $2.37 \mathrm{E}-06$ & $2.92 \mathrm{E}-06$ & $3.48 \mathrm{E}-06$ & $4.03 \mathrm{E}-06$ & $4.58 \mathrm{E}-06$ & $5.13 \mathrm{E}-06$ & $5.69 \mathrm{E}-06$ \\
\hline
\end{tabular}




\section{DOE/RL-97-69}

Rev, 0

Table 5-2. Homesteader Intruder Dose (mrem in a year) at Various Intrusion Times (years)?

\begin{tabular}{|c|c|c|c|c|c|c|c|c|c|c|c|c|c|}
\hline Nuclide $^{b}$ & 100 & 150 & 200 & 250 & 300 & 350 & 400 & sod & 600 & 700 & 800 & 900 & 1000 \\
\hline$U-238+D$ & $3.36 \mathrm{E}-03$ & $3.37 \mathrm{E}-03$ & $3.38 \mathrm{E}-03$ & $3.39 \mathrm{E}-03$ & $3.40 \mathrm{E}-03$ & $3.42 \mathrm{E}-03$ & $3.4 .3 \mathrm{E}-0.3$ & 45E-03 & $3.47 \mathrm{E}-03$ & $3.49 \mathrm{E}-03$ & $3.51 \mathrm{E}-03$ & $3.54 \mathrm{E}-03$ & E-03 \\
\hline $\mathrm{Np}-237+\mathrm{D}$ & $6.09 \mathrm{E}-03$ & $6.11 \mathrm{E}-03$ & $6.13 \mathrm{E}-03$ & $6.15 \mathrm{E}-03$ & $6.17 \mathrm{E}-03$ & $6.19 \mathrm{E}-03$ & $6.21 \mathrm{E}-03$ & $6.25 \mathrm{E}-03$ & $6.29 \mathrm{E}-03$ & $6.33 \mathrm{E}-03$ & $6.37 \mathrm{E}-03$ & 6.41E-03 & $6.45 \mathrm{E}-03$ \\
\hline $\mathrm{Pu}-239$ & $1.72 \mathrm{E}-02$ & $2.52 \mathrm{E}-02$ & $3.33 \mathrm{E}-02$ & $4.13 \mathrm{E}-02$ & $4.92 \mathrm{E}-02$ & $5.72 \mathrm{E}-02$ & $6.51 \mathrm{E}-02$ & $8.09 \mathrm{E}-02$ & $9.66 \mathrm{E}-02$ & $1.12 \mathrm{E}-01$ & $1.28 \mathrm{E}-01$ & 1.43E-01 & $1.58 \mathrm{E}-01$ \\
\hline Pu-240 & $3.21 \mathrm{E}-03$ & $4.74 \mathrm{E}-03$ & $6.25 \mathrm{E}-03$ & $7.75 \mathrm{E}-03$ & $9.23 \mathrm{E}-03$ & $1.07 \mathrm{E}-02$ & $1.21 \mathrm{E}-02$ & $1.50 \mathrm{E}-02$ & $1.78 \mathrm{E}-02$ & $2.05 \mathrm{E}-02$ & $2.32 \mathrm{E}-02$ & $2.58 \mathrm{E}-02$ & 2.83E-02 \\
\hline $\mathrm{Am}-241$ & $2.81 \mathrm{E}-01$ & $2.72 \mathrm{E}-01$ & $2.63 \mathrm{E}-01$ & $2.54 \mathrm{E}-01$ & $2.44 \mathrm{E}-01$ & $2.35 \mathrm{E}-01$ & $2.26 \mathrm{E}-01$ & $2,07 \mathrm{E}-01$ & $1.89 \mathrm{E}-01$ & $1.72 \mathrm{E}-01$ & 1.55E-01 & $1.40 \mathrm{E}-01$ & $1.26 \mathrm{E}-0 \mathrm{I}$ \\
\hline$A m-243+D$ & $3.75 \mathrm{E}-03$ & $3.75 \mathrm{E}-03$ & $3.74 \mathrm{E}-03$ & $3.73 \mathrm{E}-03$ & $3.73 \mathrm{E}-03$ & 3.72E-03 & $3.71 \mathrm{E}-0.3$ & $3.70 \mathrm{E}-03$ & $3.68 \mathrm{E}-03$ & $3,67 \mathrm{E}-03$ & $3.65 \mathrm{E}-03$ & 3.64E-03 & 3.62E-03 \\
\hline $\mathrm{Cm}-245$ & $5.66 \mathrm{E}-05$ & $5.74 \mathrm{E}-05$ & $5.82 \mathrm{E}-0.5$ & $5.90 \mathrm{E}-05$ & $5.98 \mathrm{E}-05$ & $6.05 \mathrm{E}-05$ & $6.13 \mathrm{E}-05$ & $6.28 \mathrm{E}-0.5$ & 6.43E-05 & 6.57E-05 & $6.71 \mathrm{E}-05$ & $6.84 \mathrm{E}-05$ & 6.97E-05 \\
\hline Total & $2.51 \mathrm{E}+02$ & $0.98 E+02$ & $5.00 E+01$ & $3.47 \mathrm{E}+01$ & $2.98 \mathrm{E}+01$ & $2.82 \mathrm{E}+01$ & $2.77 \mathrm{E}+01$ & $2.75 E+01$ & $2.75 E+01$ & $2.75 E+01$ & $2.75 \mathrm{E}+01$ & $2.75 \mathrm{E}+01$ & $2.75 \mathrm{E}+01$ \\
\hline
\end{tabular}

Values in bold indicate highest contributor to dose

b Nuclides with " $+D$ " added to their name include the contributions from short-lived progeny, which are assumed to be in equilibrium at all times 


\section{DOE/RL-97-69}

Rev. 0

5.4.2.3 Tin-126. The dose at 500 years (the compliance time) is so dominated by ${ }^{12} \mathrm{Sn}$ (over 95 percent of the dose), that the change in the predicted dose is proportional to the change in the initial inventory of ${ }^{126} \mathrm{Sn}$. Because of the long half-life of ${ }^{126} \mathrm{Sn}$ (about 100,000 years), the predicted dose is relatively insensitive to the amount of time since closure.

It should be noted that the amount of ${ }^{126} \mathrm{Sn}$ to be placed in the waste form is highly uncertain. As was explained in Section 3.2.3, for these calculations all ${ }^{12} \mathrm{Sn}$ from the Hanford Site production reactors is assumed to go into the waste form. No credit is taken in this analysis for any separation that may have been done during the initial processing of the fuel or in the pretreatment of the waste following its retrieval from the Hanford Site tanks. Future efforts will use more realistic conservative assumptions, which are less conservative than those used here.

As for ${ }^{137} \mathrm{Cs}$, the TWRS Standard Inventory global value for ${ }^{126} \mathrm{Sn}$ is about 30 percent lower than the value used in the base analysis case. At 500 years, the TWRS Standard Inventory values would predict an estimated homesteader dose of 19.9 mrem in a year (resulting from a 29 percent decrease from ${ }^{126} \mathrm{Sn}$ and a 0.6 percent increase due to other components).

As noted in Section 3.4.7.5 on half-lives, the new measure of the ${ }^{12} \mathrm{Sn}$ half-life indicates a factor of 2 increase in the ${ }^{126} \mathrm{Sn}$ half-life. Thus, using only the new half-life information, the estimate intruder dose at 500 declines to $11.5 \mathrm{mrem}$ in a year ( 89 percent from ${ }^{12} \mathrm{Sn}$ ), significantly below the performance objective of $100 \mathrm{mrem}$ in a year. If, in addition, the TWRS Standard Inventory values are used, the estimated dose is only $8.6 \mathrm{mrem}$ in a year.

5.4.2.4 Stability of Waste Form. It is assumed that the waste form will not completely shatter into fine grains. Rather, most of the radionuclides would remain in the waste form and so much be unavailable for ingestion or inhalation. Sensitivity cases assuming that 10 and 100 percent of the radionuclides are available for ingestion or inhalation show that the predicted dose is relatively insensitive to this assumption. Figure 5-3 displays the ratio of the case assuming 10 percent of the waste available for ingestion to the case where none of the waste is available, as well as the ratio for the case of 100 percent availability to the case of 0 percent availability. Both ratios are displayed as a function of time since closure.

Figure 5-4 shows the radionuclides predicted to contribute to the dose at 100 years and at 500 years for the base intruder case where the amount of glass available is the amount of glass that has dissolved ( $<1$ percent) and the case where 100 percent is available for ingestion and inhalation. It can be seen that at 100 years, ${ }^{90} \mathrm{Sr}$ becomes significant when ingestion is allowed. However, ${ }^{137} \mathrm{Cs}$ still contributes over two-thirds of the predicted dose. At 500 years, with ingestion, ${ }^{126} \mathrm{Sn}$ contributes two-thirds of the predicted dose. However, ${ }^{99} \mathrm{Tc},{ }^{231} \mathrm{~Pa},{ }^{239} \mathrm{Pu}$, and ${ }^{241} \mathrm{Am}$ contribute noticeable amounts when ingestion is possible. In no case is inhalation a major exposure path.

5.4.2.5 Area of Homesteader Garden. The predicted dose depends on the area of the homesteader garden and the amount of time the homesteader spends in the garden. The homesteader receives dose from external radiation when he is in the garden or dose from internal exposure when he ingests produce from the garden. A homesteader is assumed to remain in a smaller garden for a shorter amount of time. 


\section{DOE/RL-97-69}

Rev. 0

The base intruder case assumes a much smaller area (500 square meters) than previous Hanford Site performance assessments (2500 square meters). The change in garden size proportionally increases the radionuclide soil concentration. The internal doses increase by the same factor, by a factor of five. However, the external doses from the larger garden are 10 to 25 percent less than the external dose from the smaller garden because of the shorter time spent in the smaller garden. Thus, the smaller garden gives only a 10 percent increase in the predicted dose for ${ }^{126} \mathrm{Sn}$ and only a 24 percent increase for ${ }^{137} \mathrm{Cs}$ than the larger garden. For radionuclides where ingestion is the main exposure pathway $\left({ }^{90} \mathrm{Sr},{ }^{99} \mathrm{Tc}\right.$, plutonium isotopes, $\left.{ }^{241} \mathrm{Am}\right)$, the ratio of the predicted dose is, in fact, nearly inversely proportional to the ratio of the garden areas. The ratio of effective dose rates for each radionuclide for the $500 \mathrm{~m}^{2}\left(5,382 \mathrm{ft}^{2}\right)$ garden to the $2,500 \mathrm{~m}^{2}\left(26,910 \mathrm{ft}^{2}\right)$ is shown in Appendix B, Table B-5.

5.4.2.6 Size of the Hole Drilled. The predicted dose is proportional to the amount of waste brought up from the disposal facility. For the base intruder case, the hole was conservatively estimated as $0.3 \mathrm{~m}$ (12 in). However, a more likely maximum diameter is $0.2 \mathrm{~m}(8 \mathrm{in})$. Such a smaller diameter hole would bring up only 42 percent of the waste that would come from the $0.3-\mathrm{m}(12-\mathrm{in})$ hole. This reduces the predicted dose by 42 percent.

Figure 5-3. Ratio of Predicted Homesteader Doses for Different Availability of Radionuclides for Ingestion and Inhalation.

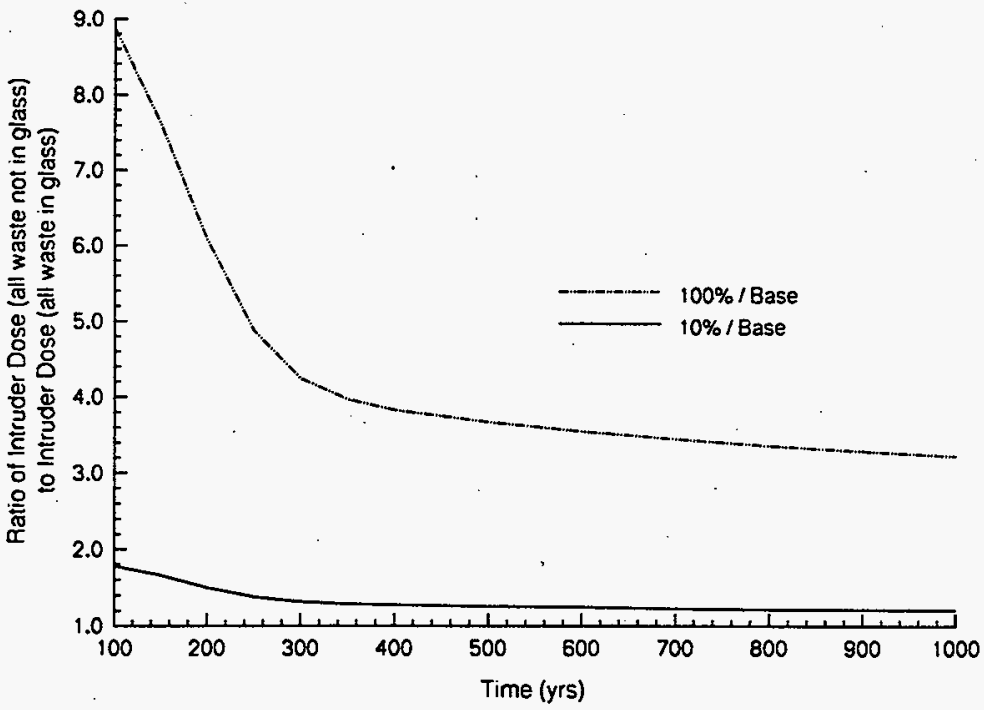


Figure 5-4. Contribution of Major Radionuclides for the Base Intruder Case and When Ingestion is Allowed.

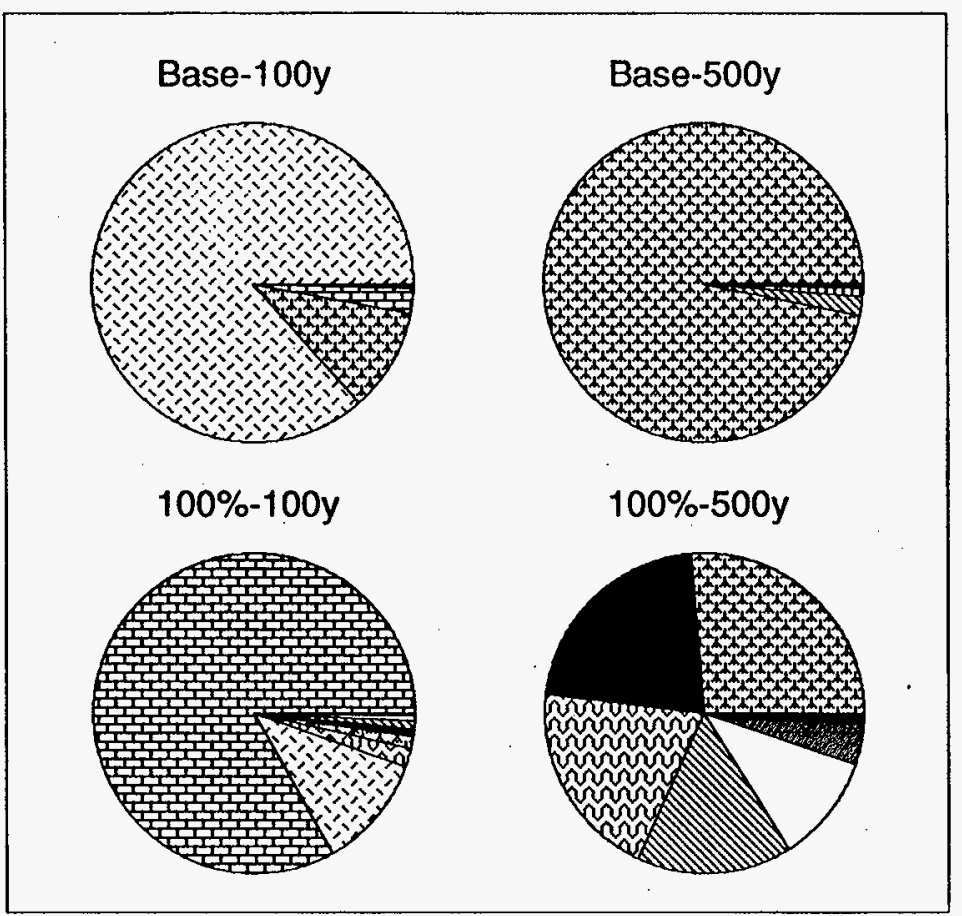

Sr-90+D

$\square$ Tc-99

㤨到 Sn-126+D

因 $\mathrm{Cs}-137+\mathrm{D}$

Pa-231

Du-239

Pu-240

Am-241

other 


\section{DOE/RL-97-69}

Rev. 0

5.4.2.7 Areal Density of the Waste. Because the predicted dose depends linearly on the amount of waste material brought to the surface, the predicted dose depends on the waste concentration. The waste is assumed to be averaged over both the container and the filler material. However, because the hole is assumed to go through the entire height of the disposal facility, the vertical dimension becomes unimportant. This makes the areal density (the volumetric density times the height) rather than the normal density important.

The areal density of the disposal facility could differ from the base intruder case for any of the following:

- A different design of the disposal facility (for example, the use of a dirt spacers between vault rows)

- Different ratios of waste material to filler material in a vault

- Different assumption of the total height of waste, causing a change in the area occupied by the waste itself

- Different waste loading (because of sodium content or other reasons).

If the area of the disposal facility increases by a factor of 2.5 (that is, the total area under Concept 2 [Section 3.4.5.4]), then the predicted dose decreases by 60 percent. If the sodium loading of the waste form decreases from 20 percent to 15 percent, the area increases by fourthirds (1.333) (assuming no change in facility height) and the predicted dose decreases by 25 percent.

5.4.2.8 Other Factors. Other factors are less important in determining the predicted dose. Such factors include the use of dose conversion factors and estimates of the amount of radionuclides other than ${ }^{126} \mathrm{Sn}$ and ${ }^{137} \mathrm{Cs}$ present.

The dose conversion factors important to the homesteader scenario are the external dose conversion factors. The factors used in the base intruder case are the ones from the EPA (EPA 1993). For ${ }^{126} \mathrm{Sn}$, the DOE external dose conversion factor (DOE 1988c) is a factor of 4.45 larger than the EPA factor. The DOE value is larger because it assumes all the radionuclides are on the surface of the soil and no shielding of the photon radiation occurs. The EPA factor, on the other hand, is based on the more realistic assumption of mixing (over a 15 centimeter layer). Previous Hanford Site performance assessments have used dose factors based on GENII (Napier 1988), which uses models similar to the EPA model. For ${ }^{126} \mathrm{Sn}$, the external dose conversion factor from GENII is 20 percent higher than the EPA value. For ${ }^{13} \mathrm{Cs}$, the ratios of the external dose conversion factors are similar to those for ${ }^{12} \mathrm{Sn}$.

Because ${ }^{126} \mathrm{Sn}$ and ${ }^{137} \mathrm{Cs}$ dominate the intruder dose results, changes in the amount of other radionuclides is relatively unimportant. Using different processing strategies, the amount of ${ }^{90} \mathrm{Sr}$ might be as much as twice the amount assumed in the base intruder case (3.4 MCi versus 1.6 MCi) (WHC 1996). Even using the maximum amount of ${ }^{90} \mathrm{Sr}$ would increase the total predicted dose at 100 years by less than 0.3 percent because ${ }^{90} \mathrm{Sr}$ does not significantly 
DOE/RL-97-69

Rev. 0

contribute to the estimated dose unless it is ingested. Changes in the amount of other isotopes are predicted to be less significant to the intruder dose.

\subsection{SUMMARY OF THE INADVERTENT INTRUDER SCENARIO}

The estimated exposures of the driller scenario easily meet the performance objectives by two orders of magnitude. The estimated exposures for the homesteader scenario are a factor of three lower than performance objectives.

Conservative values were taken for most of the parameters. Further analysis is expected to show that the diameter of the borehole should be smaller, the area over which the contamination is spread will be larger, and the amount of ${ }^{126} \mathrm{Sn}$ (the dominant isotope) will be smaller. Any of these factors will lead to smaller estimated doses. Also, once experiments on the half-life of ${ }^{126} \mathrm{Sn}$ are documented, the value taken for its half-life is likely to increase over the value used in this analysis, leading to lower estimated inventory values (when expressed in curies) and hence lower estimated dose values. 
DOE/RL-97-69

Rev. 0

5-16 


\subsection{PERFORMANCE EVALUATION}

\subsection{OVERVIEW}

This chapter compares the estimated impacts covered in Chapters 4 and 5 with the performance objectives established in Chapter 1. This chapter also defines those requirements, both on the acceptance of the waste form and on the disposal facility design, that are derived from long-term performance and shows that these requirements do not require heroic effort and so are likely to be met. The chapter concludes by describing the work planned to update the information contained in this performance assessment.

\subsection{COMPARISON OF ESTIMATED IMPACTS TO PERFORMANCE OBJECTIVES}

This section compares the estimated impacts to the performance objectives for each area of protection cited in Section 1.6:

Comparison to Performance Objectives The results from the base cases are all below the pefformance objectives.

- Protection of the general public

- Protection of the inadvertent intruder

- Protection of groundwater resources

- Protection of surface water resources

- Protection of air resources.

\subsubsection{Protection of General Public}

Table 6-1 compares the performance objectives for protecting the general public with the results from the base analysis case. The estimated all-pathways doses are significantly lower than the performance objectives during the first 10,000 years (the time of compliance). The sensitivity cases show that for the all-pathways performance objective to be exceeded would require one or more of the following:

- The waste form not meeting the specifications in the RFP for TWRS Privatization (DOE-RL 1996) or not performing at long times as modeled in this analysis

- A high infiltration rate and a disposal facility design without a hydraulic diverter

- A significantly larger inventory.

None of the performance measures (i.e impacts) are estimated to exceed the value of the performance objectives at any time. However, the maximum value of the all-pathways dose (23 mrem in a year estimated to occur at about 50,000 years) is just below the value of the performance objective ( 25 mrem in a year). The other two measures (all-pathways including other Hanford Site sources and ALARA) are estimated to remain significantly lower than the performance objectives at all times. 
DOE/RL-97-69

Rev. 0

Table 6-1. Comparison of Estimated Impacts with Performance Objectives for Protecting the Public. The time of compliance is 10,000 years. The point of compliance is well 100 meters downgradient of the facility.

\begin{tabular}{||l|c|c|}
\hline Performance Measure & $\begin{array}{c}\text { Performance } \\
\text { Objective }\end{array}$ & $\begin{array}{c}\text { Estimated } \\
\text { Impact }\end{array}$ \\
\hline All-pathways [mrem in a year] & 25.0 & 6.4 \\
\hline $\begin{array}{l}\text { All-pathways, including other Hanford Site sources } \\
\text { [mrem in a year] }\end{array}$ & 100.0 & $<19.0$ \\
\hline ALARA (all-pathways) [persons-rem/y] & 500.0 & 5.0 \\
\hline
\end{tabular}

\subsubsection{Protection of Inadvertent Intruders}

Table 6-2 compares the estimated impacts to the performance objectives for protecting the inadvertent intruder. The time of compliance starts at 500 years after closure. For both acute and continuous exposure, the performance objective is met by at least a factor of three. Tin-126 is the most important radionuclide. The estimated dose values for inadvertent intrusion are larger than expected because the well and garden size used in this analysis are conservative. Also, the actual inventory of ${ }^{126} \mathrm{~S} n$ will probably be smaller than modeled because much of it will go into the high-level waste fraction. Finally, indications are that the value for the half-life of ${ }^{126} \mathrm{Sn}$ used in this analysis is too small, which results in an overprediction of dose.

Table 6-2. Comparison of Estimated Impacts with Performance Objectives for Protecting the Inadvertent Intruder. The time of compliance starts at 500 years.

\begin{tabular}{||l|c|c||}
\hline Performance Measure & $\begin{array}{c}\text { Performance } \\
\text { Objective }\end{array}$ & $\begin{array}{c}\text { Estimated } \\
\text { Impact }\end{array}$ \\
\hline Acute exposure [mrem] & 500.0 & 5.5 \\
\hline Continuous exposure [mrem in a year] & 100.0 & 27.5 \\
\hline
\end{tabular}


DOE/RL-97-69

Rev. 0 :

\subsubsection{Protection of Groundwater Resources}

Table 6-3 compares the estimated impacts to the performance objectives for protecting the groundwater resources. The time of compliance is 10,000 years and the point of compliance is a well 100 meters down gradient of the disposal facility. The estimated impact is a factor of two less than the performance objectives for beta/photon emitters and a factor of nine less than the performance objectives for the alpha-emitting radionuclides. The concentration of radium is insignificant. The most important drivers are the inventories of technetium and uranium, the release rate from the waste form, and the amount of mixing in the aquifer. Retardation of uranium isotopes as they migrate through the engineered disposal system and natural vadose zone is important in achieving the alpha-emitting radionuclides performance measure.

Table 6-3. Comparison of Estimated Impacts with Performance Objectives for Protecting Groundwater Resources. Time of compliance is 10,000 years. Place of compliance is a well 100 meters downgradient of the facility.

\begin{tabular}{|l|c|c|}
\hline Performance Measure & $\begin{array}{c}\text { Performance } \\
\text { Objective }\end{array}$ & $\begin{array}{c}\text { Estimated } \\
\text { Impact }\end{array}$ \\
\hline Beta/Photon Emitters [mrem in a year] & 4. & 2.0 \\
\hline Alpha-emitting radionuclides [pCi/ $\ell]$ & 15. & 1.7 \\
\hline Ra [pCi/l] & 3. & $<0.001$ \\
\hline
\end{tabular}

\subsubsection{Protection of Surface Water Resources}

Table 6-4 compares of the estimated impacts to the performance objectives for protecting the surface water resources. The time of compliance is 10,000 years and the point of compliance is at a well intercepting the groundwater just before it mixes with the Columbia River. The estimated impacts are over an order of magnitude lower than the performance objectives.

Because of the large flow of the Columbia River and the tremendous mixing that occurs in a relatively few miles of the river, the predicted impacts from the use of water from the Columbia River would be far lower.

Table 6-4. Comparison of Estimated Impacts with Performance Objectives for Protecting Surface Water Resources. Time of compliance is 10,000 years. Place of compliance is a well intercepting the groundwater prior to entering the Columbia River.

\begin{tabular}{|l|c|c|}
\hline Performance Measure & $\begin{array}{c}\text { Performance } \\
\text { Objective }\end{array}$ & $\begin{array}{c}\text { Estimated } \\
\text { Impact }\end{array}$ \\
\hline Beta/Photon Emitters [mrem in a year] & 1.0 & 0.070 \\
\hline Alpha-emitting radionuclides [pCi/l] & 15.0 & 0.060 \\
\hline $\mathrm{Ra}[\mathrm{pCi} / \ell]$ & 3.0 & $<0.001$ \\
\hline
\end{tabular}


DOE/RL-97-69

Rev. 0

\subsubsection{Protection of Air Resources}

Table 6-5 compares the estimated impacts to the performance objectives for protecting air resources. The time of compliance is 10,000 years and the point of compliance is just above the disposal facility. The estimated impacts are over three orders of magnitude lower than the performance objectives.

Table 6-5. Comparison of Estimated Impacts with Performance Objectives for Protecting Air Resources. Time of compliance is 10,000 years. Place of compliance is just above the disposal facility.

\begin{tabular}{|l|c|c|}
\hline Performance Measure & $\begin{array}{c}\text { Performance } \\
\text { Objective }\end{array}$ & $\begin{array}{c}\text { Estimated } \\
\text { Impact }\end{array}$ \\
\hline Radon $\left[\mathrm{pCi} \mathrm{m}^{-2} \mathrm{~s}^{-1}\right.$ ] & 20.0 & $<0.001$ \\
\hline $\begin{array}{l}\text { Other radionuclides }\left({ }^{3} \mathrm{H} \text { and }{ }^{14} \mathrm{C}\right) \\
\text { [mrem in a year] }\end{array}$ & 10.0 & $<10^{-8}$ \\
\hline
\end{tabular}

\subsubsection{Application to Existing TWRS Disposal Facility}

Six percent of the low-level tank waste could be disposed of in four existing vaults just east of the PUREX facility. This waste could have a higher (at most a factor of 2) concentration of technetium than waste to be processed later. The present structures are similar to those described for Concept 2. Therefore, the impact of using the four existing vaults would meet the performance objectives for protecting the general public, groundwater, surface water, and air resources. Because the inventory of radiocontaminants such as ${ }^{12}{ }^{2} \mathrm{~S} n$ in the initial 6 percent of the low-level tank waste is not known, how such a disposal would affect inadvertent intruders also is not yet known, but is not expected to differ greatly from the forecast described in Section 5.4 .

The impact from disposing of the remainder of the waste in alternative facilities should closely follow the analysis presented. The inventory of waste not disposed of in the four existing vaults is nearly the same as the inventory assumed in this analysis.

\subsubsection{Summary}

Most of the estimated effects easily meet the performance objectives set out in Section 1.6. However, the estimated all-pathways dose, the continuous dose to a homesteader, beta/photon drinking water dose, and the concentration of alpha-emitting radionuclides in groundwater are less than a factor of 10 lower than the corresponding performance objective. As new information is obtained for the project, the estimated impacts are expected to decline, thereby increasing the margin of compliance with the performance objectives. 
DOE/RL-97-69

Rev. 0

\subsection{REQUIREMENTS SET BY PERFORMANCE ASSESSMENT}

\subsubsection{Introduction}

The analysis presented so far was designed to establish an understanding of how the engineered and natural systems behave. Based on this understanding, this section presents the requirements on the waste form and the disposal facilities based on long-term human health and safety and environmental considerations. Section 6.3.2 defines the methods and describes the parameters used to set those requirements. Those parameters that differ from the base analysis case and the base intruder case are emphasized. Sections 6.3.3 and 6.3.4 describe the calculations and the resulting requirements on waste form and the disposal facilities.

Section 6.3.5 describes why the requirements set in Sections 6.3.3 and 6.3.4 are likely to be met.

\subsubsection{Requirements Case}

Data and methods used to establish requirements on the waste form and the disposal facilities come mainly from the data and methods used in the base analysis case (Chapter 3 ) and the base intruder cases (Section 5.3). New data obtained since the publication of Data Packages for the Hanford Low-Level Tank Waste Interim Performance Assessment (Mann 1995a) and from the analyses contained in this document have been used to modify the data and methods. They are explained in the Sections 6.3.2.1 through 6.3.2.5.

6.3.2.1 Methods Used to Establish Requirements. The homesteader inadvertent intruder and groundwater scenarios are used to establish requirements for the waste form and the disposal facilities. Doses from the driller inadvertent intruder, the surface water, and the air release scenarios are insignificant compared to those from the groundwater and homesteader scenarios.

For the protection of the homesteader, the following equation can be used

or

$$
\Sigma \Sigma\left[I_{i j} / V_{j}\right] d_{i}^{h} k_{i}^{h} H_{j}<D^{h}
$$

$$
\Sigma \Sigma\left[\mathrm{I}_{\mathrm{ij}} / \mathrm{V}_{\mathrm{j}}\right] \mathrm{H}_{\mathrm{j}} / \mathrm{Y}_{\mathrm{j}}<1.0
$$

where the first sum is over contaminants $i$, the second sum is over containers $j$ in a vertical column emplaced within the disposal facility, and where

$I_{i j}=$ the inventory of contaminant $\mathrm{i}$ in container $\mathrm{j}(\mathrm{Ci})$

$\mathrm{V}_{\mathrm{j}}=$ the volume of container $\mathrm{j}\left(\mathrm{m}^{3}\right)$

$d_{i}^{h}=$ the dosimetry factor relating response to concentration of contaminant $i$ in the inadvertent homesteader scenario [(mrem $\left./ \mathrm{yr}) /\left(\mathrm{Ci} / \mathrm{m}^{3}\right)\right]$

$k_{i}^{h}=$ the factor that accounts for the fraction of waste exhumed during drilling, the mixing of the waste in the soil, and transport to point of exposure $(1 / \mathrm{m})$ 
$\mathrm{H}_{\mathrm{j}}=$ the height of container $\mathrm{j}(\mathrm{m})$

$\mathrm{D}^{\mathrm{h}}=$ the maximum dose allowable in the homesteader scenario (mrem/yr)

$Y_{i}=\left[D^{h} /\left(d_{i}^{h} k_{i}^{h}\right)\right]\left(C i / m^{2}\right)$.

The parameters $d_{i}^{h}, k_{i}^{h}$, and $D^{h}$ can be specified $\left(d_{i}^{h}\right.$ and $\left.D^{h}\right)$ or calculated $\left(k_{i}^{h}\right)$ from data already presented in this performance assessment. The TWRS Immobilized Waste Program will place restrictions on the quotient of inventory $\left(\mathrm{I}_{i j}\right)$ and container volume $\left(\mathrm{V}_{\mathrm{j}}\right)$. Although the height of an individual container is known, the number in a stack is not known. Therefore the program will also place restrictions on the summation over the vertical column.

The TWRS Immobilized Waste program also has decided to place additional restrictions on waste concentrations. To satisfy the Nuclear Regulatory Commission (Paperiello 1997) in their determination that the immobilized low-activity waste is not high-level waste, the concentration of all radionuclides will be below the Class C limits set in 10 CFR 61 (NRC 1982).

Also, the DOE has mandated concentration limits for ${ }^{90} \mathrm{Sr},{ }^{99} \mathrm{Tc}$, and ${ }^{137} \mathrm{Cs}$ (DOE-RL 1996) for the first phase of waste form production. All the waste slated to be placed in the existing disposal vaults will be produced under this contract. Therefore, these contract requirements also will be imposed on the waste to be placed in the existing disposal vaults. Although most of the waste in the first set of units in the new disposal facilities is expected to be produced under this contract, most of the waste that will be contained in the new disposal facilities will be produced under a different contract. Therefore, to provide maximum flexibility in future decisions, these contract limitations will not be placed on waste in the new disposal facilities.

The groundwater scenario (as discussed in Section 4.9.2) places the restriction that

$$
\Sigma I_{i} R_{i} d_{i}{ }^{g w} k_{i}{ }^{g w} / L<D^{g w}
$$

or

$$
\Sigma\left(\mathrm{I}_{\mathrm{i}} \mathrm{R}_{\mathrm{i}} / \mathrm{L}\right) / \mathrm{X}_{\mathrm{i}}<1.0
$$

where the sum is over all contaminations $i$ and where

$$
\begin{aligned}
& I_{i}=\text { the inventory of contaminant } i(C i) \\
& R_{i}=\text { the fractional release rate of contaminant } i \text { from the waste form }(1 / \mathrm{yr}) \\
& \mathrm{d}_{i}{ }^{\mathrm{gw}}=\text { the dosimetry factor relating response to concentration of contaminant } \mathrm{i} \text { in the } \\
& \text { groundwater scenario }\left[(\mathrm{mrem} / \mathrm{yr}) /\left(\mathrm{Ci} / \mathrm{m}^{3}\right)\right] \\
& \mathbf{k}_{i}{ }^{\mathrm{gw}}=\text { the factor which accounts for vadose zone and aquifer transport for contaminant } i \\
& \left(\mathrm{~m}^{2} / \mathrm{yr}\right) \\
& L=\text { the effective length of the disposal facility and accounts for the direction of }
\end{aligned}
$$




\section{DOE/RL-97-69}

Rev. 0

$\mathrm{D}^{g^{w}}=$ the maximum dose allowable in the groundwater scenario (mrem/yr)

$\mathrm{X}_{\mathrm{i}}=\left[\mathrm{D}^{\mathrm{gw}} /\left(\mathrm{d}_{\mathrm{i}}{ }^{\mathrm{g}^{w}} \mathrm{k}_{\mathrm{i}}{ }^{\mathrm{gw}}\right)\right][\mathrm{Ci} /(\mathrm{yr} \mathrm{m})]$.

The parameters $d_{i}{ }^{g w}, k_{i}{ }^{g w}$, and $D^{g w}$ can be specified $\left(d_{i}{ }^{g w}\right.$ and $\left.D^{g w}\right)$ or calculated $\left(k_{i}{ }^{g w}\right)$ from data already presented in this performance assessment. The TWRS Immobilized Waste Program will place restrictions on the product of the inventory $\left(I_{j}\right)$ and the release rate $\left(R_{j}\right)$. The effective disposal facility length $(\mathrm{L})$ is a special case. For the existing disposal vaults, $\mathrm{L}$ can be calculated. Because they have not yet been designed, for the new disposal facilities, the program will place restrictions on $\mathrm{L}$.

Table 6-6 summarizes the types of requirements which will be set.

Table 6-6. Types of Requirements to Be Set.

\begin{tabular}{|c|c|}
\hline Type of Requirement & Source \\
\hline \multicolumn{2}{|l|}{ Existing Disposal Facility } \\
\hline Limits on product of inventory and contaminant release rate & Present analysis : Table 6-8 \\
\hline Limits on inventory concentration times effective height & Present analysis : Table 6-7 \\
\hline Limits on inventory concentration & $\begin{array}{l}\text { Class C limits [NRC 1982] } \\
\text { Contract [DOE-RL 1996] }\end{array}$ \\
\hline \multicolumn{2}{|l|}{ New Disposal Facilities } \\
\hline $\begin{array}{l}\text { Limits on product of inventory and contaminant release rate } \\
\text { divided by effective disposal length }\end{array}$ & Present analysis : Table 6-8 \\
\hline Limits on inventory concentration times effective height & Present analysis : Table $6-7$ \\
\hline Limits on inventory concentration & Class C limits [NRC 1982] \\
\hline
\end{tabular}

6.3.2.2 Dosimetry Parameters Used to Set Requirements. Although the DOE library of internal dosimetry constants (DOE 1988d) and the EPA library of external dosimetry constants (EPA 1993) were used for the base analysis case, draft guidance (DOE 1997c) states that the EPA libraries (EPA 1989a and EPA 1993, respectively) be used. Therefore, the EPA libraries . will be used to set the inadvertent intruder and groundwater protection requirements. The DOE and EPA values are similar as seen in Appendix B, Table B-7.

6.3.2.3 Allowable Dose Used to Set Requirements. The performance objectives for protecting groundwater (all-pathways dose of $25 \mathrm{mrem}$ in a year, beta/photon drinking water dose of 4 mrem in a year, and alpha concentration limit of $15 \mathrm{pCi} / \mathrm{l}$ ) remain unchanged. However, the analysis (see Section 4.2.3) has shown that contaminants from the new disposal facilities could affect water taken from the existing disposal vaults. The analysis shows that, under the expected conditions, about 20 percent of the dose (or concentration) at a well 100 meters downgradient of the new disposal facilities would be present in the water taken from a well downgradient of the existing disposal vaults. If the groundwater direction changes, this fraction could reach 


\section{DOE/RL-97-69}

Rev. 0

67 percent. Therefore, to set limits to protect the groundwater resource, the limiting values will be based on $[1 /(1+0.67)]$ of the performance objectives (that is, an all-pathways dose of $15 \mathrm{mrem}$ in a year, a beta/photon drinking water dose of $2.4 \mathrm{mrem}$ in a year, and an alpha concentration limit of 9 mrem in a year).

The performance objective used to protect the homesteader (100 mrem in a year) will be used.

\subsubsection{Disposal Facility Parameters Used to Set Groundwater Protection Requirements. The following four disposal facility components are important in setting groundwater requirements.}

- The surface barrier establishes the recharge rate.

- The hydraulic barrier diverts moisture around the waste.

- The filler material between ILAW containers in the vaults to prevents subsidence.

- The effective disposal facility length is important in determining groundwater mixing.

The difference in the calculational results are small between the case using only natural recharge and the case using the surface barrier for a thousand years followed by natural recharge (presented in Section 4.6.3.1). Therefore, the capability of the surface barrier to reduce recharge from the natural rate will not be used in setting the requirements for groundwater protection. The sensitivity case that used the natural recharge rate at all times will be used. This choice will provide designers with greater flexibility in the design of the surface barrier.

The hydraulic diverter has been present in some conceptual designs (for example, Burbank 1997). However, this component may not survive through final design. Therefore, the properties of a hydraulic diverter were not included when establishing the requirements for setting groundwater protection requirements. Thus, the analysis performed for the Unit Cell calculations rather than the base analysis case form the basis for setting the requirements for groundwater protection (see Table 4-14).

The need to avoid subsidence requires that filler material be present and has long been a part of design. All of the cases run in this analysis assumed such filler material.

The effective disposal length (the volume of the disposal facility divided by the height of the waste and the length of the facility parallel to groundwater flow) obviously depends on the vault design and facility layout. For the existing disposal vaults, the facility length can be determined. However, for the new disposal facilities the allowable length will be treated as a specification.

6.3.2.5 Other Data Changes from Base Analysis Case. Only limited data have been collected since the issuance of Data Packages for the Hanford Low-Level Tank Waste Interim 


\section{DOE/RL-97-69}

Rev. 0

Performance Assessment (Mann 1995a). The only new information that would affect the setting of requirements is that the $\mathrm{K}_{\mathrm{d}}$ value for iodine is now thought to be $0.6 \mathrm{~m} / \mathrm{g}$ rather than the $3.0 \mathrm{~m} / \mathrm{g}$ used in the base analysis case. The new iodine $\mathrm{K}_{\mathrm{d}}$ will be used in setting requirements.

\subsubsection{Waste Acceptance Criteria}

Using the information in Section 6.3.2, waste acceptance criteria based on long-term human health and safety and environmental protection can be established based on protecting an inadvertent intruder and groundwater resources. The other scenarios do not imply any significant restrictions. Waste acceptance criteria for disposing ILAW should include

and

$$
\Sigma \Sigma\left[I_{i j} / V_{j}\right] H_{j} / Y_{i}<1
$$

(6.5 same as 6.2)

$$
\Sigma\left(I_{\mathrm{i}} \mathrm{R}_{\mathrm{i}} / \mathrm{L}\right) / \mathrm{X}_{\mathrm{i}}<1.0
$$

where the values of $Y_{i}$ are given in Table 6-7 and the values of $X_{i}$ are given in Table 6-8. The meaning of the other symbols is given in Section 6.3.2.1. Table 6-7 also presents the NRC Class maximum concentration limits $\left[\mathrm{I}_{\mathrm{ij}} / \mathrm{V}_{\mathrm{j}}\right]$, which apply to all waste disposed of, and the Phase 1 contract average concentration limits, which apply only to waste produced during Phase 1.

For inadvertent intruder protection, the dose values calculated from the base intruder case (Table 5-2) were multiplied by the ratio of the EPA value to the DOE value (where the internal dose dominates) or by unity (where the external dose dominates) to determine new estimates of the intruder doses. The values for $Y_{i}$ were then determined by increasing the value of $\left(\Sigma\left[I_{i j} / V_{j}\right] H_{j}\right)$ where the values are taken from the base intruder case)by the ratio of the allowed dose rate (100 mrem in a year) to the new estimate. Where daughters are important, the new estimated doses from the daughters were added to the parents before the ratio was taken. This procedure, basically using equation 6.5 , was used because it handles the cases of daughters more straight-forwardly than by determining $\mathrm{k}_{\mathrm{i}}{ }_{\mathrm{h}}$, which also has strong time dependencies when calculating intruder doses (i.e., than by using equation 6.1).

Table 6-7. Waste Acceptance Criteria Based on Protecting Inadvertent Intruder. $\Sigma \Sigma\left[I_{i j} / V_{j}\right] H_{j} / Y_{i}<1.0$. All waste disposed of also must meet the NRC Class $C$ limits, which also are treated as a sum of fractions rule. All waste produced during phase 1 must

\begin{tabular}{|c|c|c|c|c|}
\hline \multirow[t]{2}{*}{ Isotope } & \multirow{2}{*}{$\begin{array}{c}Y_{\mathrm{i}} \\
\underset{\left(\mathrm{Ci} / \mathrm{m}^{2}\right)}{\operatorname{Max}} \overline{\left.\mathrm{I}_{\mathrm{i}} / \mathrm{V}_{\mathrm{j}}\right] \mathrm{H}_{\mathrm{j}}} \\
\end{array}$} & \multicolumn{2}{|c|}{$\operatorname{Max}\left[I_{i j} / V_{j}\right] \quad\left(\mathrm{Ci} / \mathrm{m}^{3}\right)$} & \multirow{2}{*}{$\frac{\text { Avg }\left[I_{i j} / V_{j}\right]}{\text { Phase } 1 \text { Contract }}$} \\
\hline & & $\mathrm{Y}_{\mathrm{i}} * \Sigma \mathrm{H}_{\mathrm{j}}^{\mathrm{EDV}(\mathrm{I})}$ & NRC Class C & \\
\hline${ }^{3} \mathrm{H}$ & $1.6 \times 10^{18}$ & $2.2 \times 10^{17}$ & - & - \\
\hline${ }^{14} \mathrm{C}$ & $1.9 \times 10^{3}$ & $2.6 \times 10^{2}$ & 8.0 & - \\
\hline${ }^{79} \mathrm{Se}$ & $9.9 \times 10^{3}$ & $1.4 \times 10^{3}$ & - & - \\
\hline${ }^{90} \mathrm{Sr}$ & $7.2 \times 10^{6}$ & $1.0 \times 10^{6}$ & 7000.0 & 20.0 \\
\hline
\end{tabular}
have lower average concentration than shown in the last column. 


\section{DOE/RL-97-69}

Rev. 0

Table 6-7. Waste Acceptance Criteria Based on Protecting Inadvertent Intruder. $\Sigma \Sigma\left[I_{i j} / V_{j}\right] H_{j} / Y_{i}<1.0$. All waste disposed of also must meet the NRC Class $C$ limits, which also are treated as a sum of fractions rule. All waste produced during phase 1 must have lower average concentration than shown in the last column.

\begin{tabular}{|c|c|c|c|c|}
\hline \multirow[t]{2}{*}{ Isotope } & \multirow{2}{*}{$\begin{array}{c}Y_{\mathrm{i}} \\
\operatorname{Max} \Sigma\left[\mathrm{I}_{\mathrm{i}} / \mathrm{V}_{\mathrm{j}}\right]_{\mathrm{j}} \\
\left(\mathrm{Ci} / \mathrm{m}^{2}\right) \\
\end{array}$} & \multicolumn{2}{|c|}{$\operatorname{Max}\left[I_{i j} / V_{j}\right] \quad\left(\mathrm{Ci} / m^{3}\right)$} & \multirow{2}{*}{ Avg $\left[I_{i j} / V_{j}\right]$} \\
\hline & & $\mathrm{Y}_{\mathrm{i}} * \Sigma \mathrm{H}_{\mathrm{j}}^{\mathrm{EDV}(1)}$ & NRC Class C & \\
\hline${ }^{93} \mathrm{Zr}$ & $1.7 \times 10^{4}$ & $2.4 \times 10^{3}$ & - & - \\
\hline${ }^{99} \mathrm{Tc}$ & $1.5 \times 10^{3}$ & $2.1 \times 10^{2}$ & 3.0 & 0.3 \\
\hline${ }^{126} \mathrm{Sn}$ & $1.9 \times 10^{-1}$ & $2.6 \times 10^{-2}$ & - & - \\
\hline${ }^{129} \mathrm{I}$ & $9.2 \times 10^{1}$ & $1.3 \times 10^{1}$ & 0.08 & - \\
\hline${ }^{137} \mathrm{Cs}$ & $6.9 \times 10^{4}$ & $9.6 \times 10^{3}$ & 4600.0 & 3.0 \\
\hline${ }^{151} \mathrm{Sm}$ & $2.3 \times 10^{7}$ & $3.2 \times 10^{6}$ & - & - \\
\hline${ }^{226} \mathrm{Ra}$ & $2.6 \times 10^{-1}$ & $3.7 \times 10^{-2}$ & $2.7 \times 10^{-1(2)}$ & - \\
\hline${ }^{229} \mathrm{Th}$ & $1.4 \times 10^{\circ}$ & $1.9 \times 10^{-1}$ & $2.7 \times 10^{-1(2)}$ & - \\
\hline${ }^{232} \mathrm{Th}$ & $1.5 \times 10^{-1}$ & $2.1 \times 10^{-2}$ & $2.7 \times 10^{-1(2)}$ & - \\
\hline${ }^{231} \mathrm{~Pa}$ & $8.9 \times 10^{-1}$ & $1.2 \times 10^{-1}$ & $2.7 \times 10^{-1(2)}$ & - \\
\hline${ }^{233} \mathrm{U}$ & $2.6 \times 10^{1}$ & $3.7 \times 10^{0}$ & $2.7 \times 10^{-1(2)}$ & - \\
\hline${ }^{234} \mathrm{U}$ & $4.4 \times 10^{2}$ & $6.1 \times 10^{1}$ & $2.7 \times 10^{-1(2)}$ & - \\
\hline${ }^{235} \mathrm{U}$ & $2.7 \times 10^{0}$ & $3.7 \times 10^{-1}$ & $2.7 \times 10^{-1(2)}$ & - \\
\hline${ }^{236} \mathrm{U}$ & $5.0 \times 10^{2}$ & $6.9 \times 10^{1}$ & $2.7 \times 10^{-1(2)}$ & - \\
\hline${ }^{238} \mathrm{U}$ & $1.6 \times 10^{1}$ & $2.3 \times 10^{0}$ & $2.7 \times 10^{-1(2)}$ & - \\
\hline${ }^{237} \mathrm{~Np}$ & $1.9 \times 10^{0}$ & $2.7 \times 10^{-1}$ & $2.7 \times 10^{-1(2)}$ & - \\
\hline${ }^{239} \mathrm{Pu}$ & $1.1 \times 10^{2}$ & $1.5 \times 10^{0}$ & $2.7 \times 10^{-1(2)}$ & - \\
\hline${ }^{240} \mathrm{Pu}$ & $1.1 \times 10^{2}$ & $1.6 \times 10^{0}$ & $2.7 \times 10^{-1(2)}$ & - \\
\hline${ }^{241} \mathrm{Am}$ & $8.3 \times 10^{1}$ & $1.1 \times 10^{1}$ & $2.7 \times 10^{-1(2)}$ & - \\
\hline${ }^{243} \mathrm{Am}$ & $2.9 \times 10^{0}$ & $4.1 \times 10^{-1}$ & $2.7 \times 10^{-1(2)}$ & - \\
\hline${ }^{245} \mathrm{Cm}$ & $6.4 \times 10^{0}$ & $8.9 \times 10^{-1}$ & $2.7 \times 10^{-1(2)}$ & - \\
\hline
\end{tabular}

(1) A stacking height of 7.2 meters (6 packages) is used.

(2) NRC requirements are expressed in curies per gram. A density of $2.7 \mathrm{~g} / \mathrm{cm}^{3}$ was used for the waste form. 
Table 6-8. Waste Acceptance Criteria Based on Groundwater Protection. $\Sigma\left(I_{i} R_{i} / L\right) / X_{i}<1$. Other isotopes do not reach groundwater in 10,000 years or are daughters of those shown in which case they were considered in setting limits.

\begin{tabular}{|c|c|c|c|}
\hline Isotope & Limiting Quantity & $\begin{array}{c}\mathrm{X}_{\mathrm{i}} \\
\operatorname{Max} \mathrm{IR} / \mathrm{L} \\
\left(\mathrm{Ci} \mathrm{yr}^{-1} \mathrm{~m}^{-1}\right) \\
\end{array}$ & $\begin{array}{c}\mathrm{X}_{\mathrm{i}}{ }^{*} \mathrm{~L}_{\mathrm{EDF}}{ }^{(1,2)} \\
\begin{array}{c}\text { Max IR for Existing Vaults } \\
(\mathrm{Ci} / \mathrm{yr})\end{array} \\
\end{array}$ \\
\hline${ }^{79} \mathrm{Se}$ & $\beta \gamma$ Drinking Water Dose & $5.6 \times 10^{-5}$ & $3.5 \times 10^{-3}$ \\
\hline${ }^{99} \mathrm{Tc}$ & $\beta \gamma$ Drinking Water Dose & $3.2 \times 10^{-4}$. & $1.9 \times 10^{-2}$ \\
\hline${ }^{129} \mathrm{I}$ & $\beta \gamma$ Drinking Water Dose & $2.7 \times 10^{-6}$ & $1.7 \times 10^{-4}$ \\
\hline${ }^{231} \mathrm{~Pa}$ & All Pathways Dose ${ }^{(3)}$ & $1.1 \times 10^{-4}$ & $6.8 \times 10^{-3}$ \\
\hline${ }^{232} \mathrm{U}$ & All Pathways ${ }^{(4)}$ & $3.1 \times 10^{-6}$ & $1.9 \times 10^{-4}$ \\
\hline${ }^{233} \mathrm{U}$ & All Pathways ${ }^{(3,4)}$ & $1.7 \times 10^{-6}$ & $1.0 \times 10^{-4}$ \\
\hline${ }^{234} \mathrm{U}$ & All Pathways ${ }^{(4)}$ & $1.5 \times 10^{-5}$ & $9.5 \times 10^{-4}$ \\
\hline${ }^{235} \mathrm{U}$ & All Pathways ${ }^{(4)}$ & $1.6 \times 10^{-5}$ & $9.8 \times 10^{-4}$ \\
\hline${ }^{236} \mathrm{U}$ & All Pathways ${ }^{(4)}$ & $1.6 \times 10^{-5}$ & $1.0 \times 10^{-3}$ \\
\hline${ }^{238} \mathrm{U}$ & All Pathways ${ }^{(4)}$ & $1.6 \times 10^{-5}$ & $1.0 \times 10^{-3}$ \\
\hline
\end{tabular}

(1) Conversation factor is for drinking water or for all-pathways as appropriate

(2) Value used for $L$ for existing disposal vaults is 4 times the width (or 61.6 meters), thus ignoring the space in between the vaults

(3) Daughters were explicitly considered in setting limits. For other isotopes, daughters were not significant.

(4) Because uranium is not covered under the Federal Drinking Water guidelines, the all-pathways dose is used as limiting quantity. If uranium were to be included in groundwater, resulting limits would be about a factor of 10 lower.

For expected stacking heights (about 7.2 meters), the NRC Class $\mathrm{C}$ limits will be more restrictive than those found in this analysis for most isotopes. This is because the glass waste form makes ingesting or inhaling of the radioisotopes difficult even after they are brought to the surface. A few isotopes (mainly actinides) may be more restricted by this analysis than by the NRC restriction:

- $\quad{ }^{137} \mathrm{Cs}$ - if the stack of containers is higher than 15 meters (unlikely)

- $\quad{ }^{226} \mathrm{Ra}$, if the stack of containers is higher than 1 meter (very likely)

- $\quad{ }^{229} \mathrm{Th}$, if the stack of containers is higher than 5 meters (likely)

- $\quad{ }^{232} \mathrm{Th}$, if the stack of containers is higher than 0.6 meter (very likely)

- $\quad{ }^{231} \mathrm{~Pa}$, if the stack of containers is higher than 3 meters (very likely)

- $\quad{ }^{235} \mathrm{U} \quad$ - if the stack is higher than 9.9 meters (possible)

- $\quad{ }^{237} \mathrm{~Np}$ - if the stack is higher than 7.2 meters (possible)

- $\quad{ }^{243} \mathrm{Am}$ - if the stack height is greater than 10.9 meters (unlikely). 


\section{DOE/RL-97-69 \\ Rev. 0}

Note that the radioisotope of greatest concern for intruder protection $\left({ }^{12} \mathrm{Sn}\right)$ is not one of the radioisotopes restricted by the NRC.

For groundwater protection, the most restrictive limit based on beta/photon drinking water dose, alpha concentration, and all-pathways was used. The value of $\mathbf{k}_{i}{ }^{{ }^{w}}$ (for each contaminant $\mathrm{i}$ reaching the groundwater before 10,000 years) was determined by using equation 6.1, the dose calculated for the Unit Cell sensitivity case having $3.0 \mathrm{~mm} / \mathrm{yr}$ recharge, and the data (dosimetry, geotechnical, waste form) relevant to that case. New values for $\mathrm{d}_{\mathrm{i}}{ }^{\mathrm{gw}}$ were calculated by multiplying values for internal doses found in Table B-4 by the ratio of the EPA and DOE internal dosimetry values. Finally, values for $\mathrm{X}_{\mathrm{i}}$ were obtained from the definition of $\mathrm{X}_{\mathrm{i}}\left\{\mathrm{X}_{\mathrm{i}}=\left[\mathrm{D}^{\mathrm{g}^{\mathrm{w}}} /\left(\mathrm{d}_{\mathrm{i}}{ }^{\mathrm{gw}} \mathrm{k}_{\mathrm{i}}{ }^{\mathrm{gw}}\right)\right]\right\}$. The impacts of daughter isotopes were included by placing their doses with their long-lived parent. The effective length of the existing deposal vaults was determined by noting that the groundwater flow will be parallel to the long dimension of the vaults and ignoring the distance between the vaults. Thus, the effective length of the existing disposal vaults was conservatively taken to be four times the width of a vault or 61.6 meters, which ignores the backfill sediments separating the vaults).

\subsubsection{Disposal Facility Requirements}

Most of the requirements imposed by the performance assessment analysis are on the waste form. However, a few are imposed on the disposal facilities. The major facility requirements deal with subsidence, recharge rate, layout, interactions with the waste form, and intruder protection.

The performance assessment assumes that subsidence is small based on the slow degradation of the waste form and the use of filler materials to minimize voids in the disposal facility. This means that the facility must be constructed without significant void space. In addition, after waste is placed inside the facility, the spaces between the waste containers must be filled with a dry material. Note that the waste containers themselves must not have void spaces (see requirement 2.2.2.5 in Appendix A).

Because the waste form releases contaminants so slowly, the time dependence curve for exposure shows more of a plateau structure than a peaked shaped. Therefore, the major effect of the recharge rate is to delay the arrival of contaminants to the groundwater. If the second group of contaminants (i.e., those having $K_{d}=0.6 \mathrm{mg} /$, such as uranium) arrived before 10,000 years, the all-pathways dose performance objective would be violated and restrictions would have to be placed on the recharge rate. Based on the sensitivity analyses, the recharge rate must be limited to about $3.0 \mathrm{~mm} /$ year (i.e., the natural rate) if no hydraulic diverter is included in the design. If a hydraulic diverter is included, a recharge rate of $100 \mathrm{~mm} /$ year would not violate performance objectives. Therefore, if no hydraulic diverter is included in the design, the surface barrier must limit the recharge rate to the natural rate of $3 \mathrm{~mm} /$ year. Certainly, gravel surface barriers such as those used in the Hanford Site tank farms would not be suitable. Note that the surface barrier must also deter the inadvertent intruder.

The requirement for groundwater protection $\left[\Sigma\left(I_{i} R_{i} / L\right) / X_{i}<1\right]$ is actually on the disposal system. The designers of the disposal structures must ensure that materials are not used 


\section{DOE/RL-97-69}

Rev. 0

that would accelerate waste form degradation and that the vault layout is long enough in relationship to groundwater flow (L) so that the above equation holds. Alternatively, the designers can add components (for example, hydraulic diverters, getters) to minimize the requirements on the waste form.

Designers of the engineered system may wish to add components to provide greater defense-in-depth. The major components would be an improved surface barrier to the reduce recharge rate, a hydraulic barrier to divert moisture from the waste, concrete pads to trap uranium, and other getter materials to trap important radionuclides such as technetium. The recharge rate is the main driving function for the system. Having a surface barrier that could reduce this rate would lengthen the time the contaminants take to reach the groundwater. Diverting water away from the waste would likely reduce the contaminant release rate from the waste form and also create a greater moisture shadow under the disposal system that also would delay contaminant travel. Concrete is known to highly retard uranium isotopes, thus reducing its impact during the time of compliance. If an inexpensive getter could be found for technetium, such a material could also have important impacts.

\subsubsection{Likelihood of Meeting Requirements}

Because the base analysis case met the performance objectives and the sensitivity cases showed the robustness of the assumptions and data, this system can reasonably be expected to meet the requirements imposed in Section 6.3.3 and 6.3.4. This section demonstrates that compliance.

6.3.5.1 Changes from Base Analysis Case. To demonstrate such compliance, some of the data of the base analysis case will be altered to reflect the latest information, particularly the data on tank inventories.

The global tank inventories estimates of Schmittroth (1995) were used for both the base analysis case and in the base intruder case (in the form of average concentrations). However, the TWRS Standard Inventory group has recently determine the best global inventories (Kupfer 1997) and the best tank-by-tank inventories (Washenfelder 1997). These new values (see Section 3.2.4) are used to show that compliance is expected. For ${ }^{75} \mathrm{Se}$ and ${ }^{126} \mathrm{Sn}$, the inventories. were reduced by factors of 6.9 and 2.5 , respectively, because of the new half-life data (Section 3.4.7.4) not known to the TWRS Standard Inventory group when they were compiled their results. The separation factors used in the base analysis case (see Table 3-1) will continue to be used because better data are not available yet from the ILAW producers.

The base analysis case assumed that the long-term contaminant release rate would be the same as the short-term release rate specified in the contracts with the IlLAW producers (DOE-RL 1996). However, the release rate is known to be a function of space and time. Sensitivity cases were performed modeling the contaminant release from the well-studied 


\section{DOE/RL-97-69}

\section{Rev. 0}

LD6-5412 glass. For this compliance case, this modeling will be used with the peak values taken from Table 4-16.

The base analysis case used the preconceptual ideas from Eiholzer (1995). Since then, the decision to used the existing disposal vaults has been made (Shade 1997). The dimensions and layouts of the Existing Disposal Vaults will be used to determine compliance. Also, an alternatives-generation analysis using new data has been published (Burbank 1997). This new document is the basis of the design effort. Therefore, its vault layout will be used for the new disposal facilities, which implies an effective facility length of 200 meters, ignoring the backfill sediments separating the vault rows. This new document also will be used as the basis to convert tank waste volume into waste form volume $\left(55.3 \times 10^{6}\right.$ gallons of tank waste into $220,000 \mathrm{~m}^{3}$ of $\mathrm{LAW}$ volume).

6.3.5.2 Inadvertent Intruder Compliance Case. Table 6-9 presents the largest radionuclide concentration in a package assuming that each radionuclide is taken from the tank having the largest concentration of that radionuclide. The stack height is taken as 7.2 meters, or 6 containers, each with the maximum radionuclide concentration. Table 6-9 also displays the radionuclide concentration limitations for a 7.2 meter height given in Table 6-7.

For almost all the radionuclides, a stack of containers each with the maximum concentration would be of no concern, because the concentration values are far below the acceptance limits. For most of the remaining radionuclides $\left({ }^{90} \mathrm{Sr},{ }^{99} \mathrm{Tc},{ }^{13} \mathrm{Cs},{ }^{239} \mathrm{Pu},{ }^{240} \mathrm{Pu}\right.$, and ${ }^{24} \mathrm{Am}$ ) that are near or over the limiting values implied by equation 6.2 , the producers of the I.AW are required to have the waste form meet NRC Class C limits, which are the basis of waste acceptance for these radionuclides.

The only other radionuclide of concern in meeting the acceptance requirements based on inadvertent intruder protection is ${ }^{126} \mathrm{Sn}$. This radionuclide does not have a Class $\mathrm{Climit}$, so its waste acceptance limit is based on this performance assessment. If the ILAW containers having only waste from tanks A-105, A-106, or AX-104 were stacked on top of each other, the intruder dose would exceed the limit of $100 \mathrm{mrem}$ in a year. However, a number of alternatives exist.

- This performance assessment conservatively assumes that all tin would go to the ILAW product; actually, a significant fraction may be diverted to the high-level waste stream during separations and treatment.

- The three tanks of concern have small volumes of waste $(19,000$ gallons, 125,000 gallons, and 7,000 gallons). During retrieval, the tank contents are likely to be mixed with other tanks that have significantly lower ${ }^{126} \mathrm{Sn}$ concentrations.

- The operators of the disposal facility have the option of placing containers with low concentrations of ${ }^{126} \mathrm{~S} n$ on top of a container with a high concentration which would make the stack compliant with the disposal requirements.

Because these tanks are likely to be processed during the second phase of . immobilization, the DOE could by contract have the $\mathbb{L A W}$ producers separate 


\section{DOE/RL-97-69}

Rev. 0

the ${ }^{126} \mathrm{Sn}$ from the low-activity waste and ensure that the ${ }^{126} \mathrm{Sn}$ inventory is below the acceptance limits.

Table 6-9. Comparison of ILAW Inventory Concentrations to Maximum Concentration Limits.

\begin{tabular}{|c|c|c|c|c|}
\hline \multirow[t]{2}{*}{ Nuclide } & \multirow[t]{2}{*}{ Tank } & \multicolumn{2}{|c|}{ Maximum Concentration Limit $\left(\mathrm{Ci} / \mathrm{m}^{3}\right)$} & \multirow[t]{2}{*}{ Ratio } \\
\hline & & $\begin{array}{l}\text { From Tank Inventory } \\
\text { and Separations Data }{ }^{(1)}\end{array}$ & $\begin{array}{c}\text { From Waste Acceptance } \\
\text { Criteria }^{(2)}\end{array}$ & \\
\hline${ }^{3} \mathrm{H}$ & (3) & 0.63 & $2.2 \times 10^{7}$ & 0. \\
\hline${ }^{14} \mathrm{C}$ & (4) & 0.035 & 8.0 & 0.004 \\
\hline${ }^{79} \mathrm{Se}$ & AX-104 & 0.015 & $1.4 \times 10^{3}$ & 0. \\
\hline${ }^{90} \mathrm{Sr}$ & AX-104 & $5.7 \times 10^{4}$ & $7.0 \times 10^{3}$ & $8.1^{(6)}$ \\
\hline${ }^{93} \mathrm{Zr}$ & (4) & 0.22 & $2.4 \times 10^{3}$ & 0.000 \\
\hline${ }^{99} \mathrm{Tc}$ & SY-101 & 3.3 & 3.0 & $1.1^{(6)}$ \\
\hline${ }^{126} \mathrm{Sn}$ & AX-104 & 0.17 & 0.026 & 2.5 \\
\hline${ }^{129} \mathrm{I}$ & (3) & 0.002 & 0.08 & 0.036 \\
\hline${ }^{137} \mathrm{Cs}$ & A-105 & $2.3 \times 10^{3}$ & $4.6 \times 10^{3}$ & 0.50 \\
\hline${ }^{151} \mathrm{Sm}$ & (4) & 143.0 & $3.2 \times 10^{6}$ & 0. \\
\hline${ }^{226} \mathrm{Ra}$ & (4) & $2.1 \times 10^{-7}$ & 0.27 & 0. \\
\hline${ }^{229} \mathrm{Th}$ & (4) & $4.5 \times 10^{-5}$ & 0.27 & 0. \\
\hline${ }^{232} \mathrm{Th}$ & (4) & $1.2 \times 10^{-4}$ & 0.27 & 0. \\
\hline${ }^{231} \mathrm{~Pa}$ & (3) & 0.11 & 0.27 & 0.39 \\
\hline${ }^{233} \mathrm{U}$ & $\mathrm{C}-112^{(5)}$ & 0.022 & 0.27 & 0.080 \\
\hline${ }^{234} \mathrm{U}$ & $\mathrm{C}-112^{(5)}$ & 0.016 & 0.27 & 0.058 \\
\hline${ }^{235} \mathrm{U}$ & $\mathrm{C}-112^{(5)}$ & $6.6 \times 10^{-4}$ & 0.27 & 0.002 \\
\hline${ }^{236} \mathrm{U}$ & $\mathrm{C}-112^{(5)}$ & $3.4 \times 10^{-4}$ & 0.27 & 0.001 \\
\hline${ }^{238} \mathrm{U}$ & $\mathrm{C}-112^{(5)}$ & 0.015 & 0.27 & 0.054 \\
\hline${ }^{237} \mathrm{~Np}$ & (3) & $6.4 \times 10^{-3}$ & 0.27 & 0.024 \\
\hline${ }^{239} \mathrm{Pu}$ & C-202 & 3.6 & 0.27 & $13.3^{(6)}$ \\
\hline${ }^{240} \mathrm{Pu}$ & (4) & 0.33 & 0.27 & $1.2^{(6)}$ \\
\hline
\end{tabular}


DOE/RL-97-69

Rev. 0

Table 6-9. Comparison of ILAW Inventory Concentrations to Maximum Concentration Limits.

\begin{tabular}{|l|l|c|c|l|}
\hline \multirow{2}{*}{ Nuclide } & \multirow{2}{*}{ Tank } & \multicolumn{2}{|c|}{ Maximum Concentration Limit $\left(\mathrm{Ci} / \mathrm{m}^{3}\right)$} & \multirow{2}{*}{ Ratio } \\
\cline { 3 - 5 } & $\begin{array}{c}\text { From Tank Inventory } \\
\text { and Separations Data }\end{array}$ & $\begin{array}{c}\text { From Waste Acceptance } \\
\text { Criteria }^{(2)}\end{array}$ & \\
\hline${ }^{241} \mathrm{Am}$ & $\mathrm{C}-104$ & 6.1 & 0.27 & $22.6^{(6)}$ \\
\hline${ }^{243} \mathrm{Am}$ & ${ }^{(4)}$ & $1.5 \times 10^{-3}$ & 0.27 & 0.006 \\
\hline${ }^{245} \mathrm{Cm}$ & ${ }^{(4)}$ & $4.7 \times 10^{-6}$ & 0.27 & 0. \\
\hline
\end{tabular}

(1) See Section 3.2, particularly Tables 3-3 and 3-4 for tank-by-tank inventories.

(2) From RFP (DOE-RL 1996) and NRC Class C limits (10 CFR 61-2)

(3) Value taken from best-estimate global inventory (Kupfer 1997) and assuming that the maximum concentration was 10 times greater than the average concentration

(4) Value taken from base analysis case (Schmittroth 1995) and assuming that the maximum concentration was 10 times greater than the average concentration

(5) Value calculated using the largest peak concentration to average concentration for elemental uranium and then ratioing the best-estimate global inventory for each isotope.

(6) Although the calculated radionuclide concentration from the maximum tank is above the acceptance limit, the $\mathbb{L A W}$ producer is required to increase separation efficiency to ensure that each waste package is below the acceptawse limit as it is based on NRC Class C limits.

6.3.5.3 Groundwater Protection Compliance Case. Table 6-10 presents the expected disposal facility release rates from the existing disposal vaults and the new disposal facilities compared to the limitations given in Table 6-8. The two facilities are treated separately because of their different layouts. The existing disposal vaults are expected to take about 6 percent of the waste. It is not presently known how the waste will be distributed among the two facilities. A maximum inventory for the existing disposal vaults also can be calculated from the concentration limits from Table 6-7 and the volume of the vaults. However, this inventory is greater than the estimated ILAW inventory for all the radionuclides of Table 6-10, except for ${ }^{99} \mathrm{Tc}$. For ${ }^{99} \mathrm{Tc}$, the amount is limited because of the average $0.3 \mathrm{Ci} / \mathrm{m}^{3}$ requirement of the contract which allows less than 20 percent of the ${ }^{99} \mathrm{Tc}$ to be placed in the existing disposal vaults. For the other radionuclides, all waste is placed in each facility.

Even if all ILAW inventory is placed in each set of facilities, for each radionuclide, the $\left(I_{i} R_{i} / L\right)$ product is less than the requirement. The sum of $\left(I_{i} R_{i} / L\right)$ for the new disposal facility is 0.34 of the limit. Using the fact that the amount of $T c$ to be placed in the existing disposal vaults is limited (by concentrations specified in the RFP and by the volume of the vaults), the sum for the existing disposal vaults is 0.54 of the limit.

Thus, given the conservative assumptions the groundwater can be expected to be protected. In particular, the maximum release rate was used, but as seen from Figure 4-20, this 


\section{DOE/RL-97-69}

Rev. 0

maximum release rate is calculated not to occur until 10,000 years after disposal (i.e., at the time of compliance). However, it takes many thousands of years for the contaminants to reach groundwater, so the contamination level in the first 10,000 years will be lower.

The information in Table 6-10 also can be used to back out the maximum allowable contaminant release rate from the facility. For the new disposal facility, the maximum allowable release rate is $2.4 \mathrm{ppm} /$ year assuming that all the inventory of ${ }^{99} \mathrm{Tc}$ is placed in that facility. For the existing disposal vaults, the maximum allowable contaminant release rate is $3.8 \mathrm{ppm} / \mathrm{year}$ assuming that 5,000 curies of ${ }^{99} \mathrm{Tc}$ are placed in this facility.

\subsection{FURTHER WORK}

The TWRS Immobilized Waste Program is committed to providing information to the DOE and the public on the long-range human health and safety and the

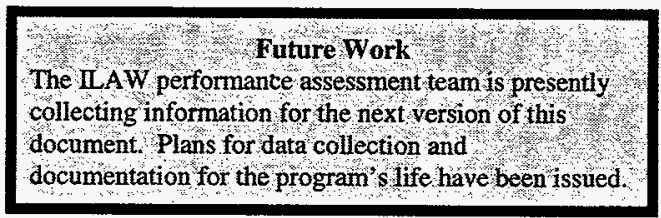
environmental impacts from the disposal of immobilized low-activity waste. The program realizes that this effort is just the beginning. The program realizes that although the analysis presented in this performance assessment is robust, it relies on much data that are not site-, facility-, and waste form-specific.

The program will provide further analyses based on new data and methods as they become available so that the decision makers can make the appropriate decisions. To support these assessments, an extensive data collection and interfacing effort is planned (Mann 1997b, DOE-RL 1997). The type and amount of new data will be guided by the uncertainty of current data and by the importance of such data to the results of future analyses. The major components of this data collection effort are as follows:

- Waste form data collection and model development

- Interactions with disposal facility designers

- Geotechnical data collection and model development

- ILAW inventory

- Other data collection (dosimetry, scenario development, performance objective selection).

\subsubsection{Future Performance Assessments}

As noted in Section 1.4 and presented in Table 1-2, a number of performance assessments will be produced that incorporate the latest data and information and that present the long-range impacts from disposal. These future performance assessments are expected to reaffirm the conclusions reached in this document. The next performance assessment is planned to be submitted in 2001 to support the start-up of the existing disposal vaults and the 


\section{DOE/RL-97-69}

Rev. 0

Table 6-10. Comparison of Expected Release Rates to Allowed Release Rates. The waste form is assumed to have release properties of LD6-5412 and all ILAW is placed in each facility.

IR is the inventory for nuclide times the release rate for that nuclide.

\begin{tabular}{|c|c|c|c|c|c|c|c|}
\hline \multirow[t]{2}{*}{ Nuclide } & \multirow{2}{*}{$\begin{array}{l}\text { Inventory } \\
\text { (Ci) }\end{array}$} & \multicolumn{3}{|c|}{ Existing Disposal Vaults ${ }^{(1)}$} & \multicolumn{3}{|c|}{ New Disposal Facilities ${ }^{(2)}$} \\
\hline & & $\begin{array}{c}\text { IR Limit } \\
(\mathrm{Ci} / \mathrm{yr})\end{array}$ & $\begin{array}{c}\text { Expected IR } \\
(\mathrm{Ci} / \mathrm{yr})\end{array}$ & $\frac{\text { Expected IR }}{\text { IR Limit }}$ & $\begin{array}{l}\text { IR Limit } \\
(\mathrm{Ci} / \mathrm{yr})\end{array}$ & $\begin{array}{c}\text { Expected IR } \\
(\mathrm{Ci} / \mathrm{yr})\end{array}$ & $\frac{\text { Expected IR }}{\text { IR Limit }}$ \\
\hline${ }^{79} \mathrm{Se}$ & 773. & $3.5 \times 10^{-3}$ & $6.0 \times 10^{-4}$ & 0.18 & $1.1 \times 10^{-2}$ & $6.0 \times 10^{-4}$ & 0.053 \\
\hline${ }^{99} \mathrm{Tc}$ & $\begin{array}{l}5.01 \times 10^{3(3)} \\
2.67 \times 10^{4}\end{array}$ & $1.9 \times 10^{-2}$ & $\begin{array}{l}2.5 \times 10^{-3} \\
1.3 \times 10^{-2}\end{array}$ & $\begin{array}{l}0.12 \\
0.68\end{array}$ & $6.4 \times 10^{-1}$ & $1.3 \times 10^{-2}$ & 0.21 \\
\hline${ }^{129} \mathbb{I}$ & 6.3 & $1.6 \times 10^{-4}$ & $3.2 \times 10^{-6}$ & 0.019 & $5.4 \times 10^{-4}$ & $3.2 \times 10^{-6}$ & 0.006 \\
\hline${ }^{231} \mathrm{~Pa}$ & $145 .^{(4)}$ & $6.8 \times 10^{-3}$ & $1.1 \times 10^{-4}$ & 0.017 & $2.2 \times 10^{.2}$ & $1.1 \times 10^{-4}$ & 0.005 \\
\hline${ }^{233} \mathrm{U}$ & 28.6 & $1.0 \times 10^{-4}$ & $1.8 \times 10^{-5}$ & 0.18 & $3.4 \times 10^{-4}$ & $1.8 \times 10^{-5}$ & 0.054 \\
\hline${ }^{234} \mathrm{U}$ & 20.8 & $9.5 \times 10^{-4}$ & $1.3 \times 10^{.5}$ & 0.014 & $3.0 \times 10^{-3}$ & $1.3 \times 10^{-5}$ & 0.004 \\
\hline${ }^{235} \mathrm{U}$ & 0.87 & $9.8 \times 10^{-4}$ & $5.6 \times 10^{-7}$ & 0.000 & $3.2 \times 10^{-3}$ & $5.6 \times 10^{-7}$ & 0.000 \\
\hline${ }^{236} \mathrm{U}$ & $0.045^{(4)}$ & $1.0 \times 10^{-3}$ & $2.9 \times 10^{-8}$ & 0.000 & $3.2 \times 10^{-3}$ & $2.9 \times 10^{-8}$ & 0.000 \\
\hline${ }^{238} \mathrm{U}$ & 19.3 & $1.0 \times 10^{-3}$ & $1.3 \times 10^{.5}$ & 0.012 & $3.2 \times 10^{-3}$. & $1.2 \times 10^{-5}$ & 0.004 \\
\hline
\end{tabular}

(1) For the existing disposal vaults, the effective length (L) is taken to be 61.6 meters.

(2) For the new disposal facilities, the effective length $(L)$ is taken to be 200 . meters.

(3) The lower inventory number of ${ }^{99} \mathrm{Tc}$ is for the existing disposal vaults and reflects that the average concentration must be less than $0.3 \mathrm{Ci} / \mathrm{m}^{3}$.

(4) Inventory values taken from the base analysis case. For other nuclides, inventory values taken from TWRS Standard Inventory. 


\section{DOE/RL-97-69}

Rev. 0

construction of the first set of new disposal facilities. Another performance assessment will be submitted in 2003 to support the startup of the new disposal facilities and the construction of a second set of new disposal facilities, if they are significantly different in design from the first set. At that time, performance assessments are scheduled on a 5-year cycle. These later performance assessments would support new designs, the startup of new facilities, and the closing of filled facilities.

As with the Hanford Low-Level Tank Waste Interim Performance Assessment (Mann 1996a and 1997a) and this document, a set of data packages will be published that will contain all data to be used in the performance assessment. Each data package will contain the best estimate of the information needed for the analysis (along with its uncertainties) along with reasonably bounding information so that the analysis can state what will not happen. Each data package will be reviewed and, in the more important cases, the review will be performed by outside experts. If new data not contained in the data packages are used in the performance assessment, they will be carefully documented and justified in the performance assessment itself. The performance assessment will carefully follow the guidance provided by the DOE and information from the technical reviews of other performance assessment documents and Hanford Site-relevant environmental analyses.

\subsubsection{Waste Form Data Collection and Model Development}

This analysis has shown that waste form behavior is the key parameter to the disposal of immobilized low-activity tank waste. Because of the projected slow release, the engineered system rather than the natural system will mainly determine the peak exposures.

In support of this performance assessment, a significant effort was spent to characterize the low-level waste glass LD6-5412. Based on this experience, a plan on how to estimate waste form performance thousands of years from now has been developed. This plan, presented in Appendix $\mathrm{G}$, forms the core of the performance assessment waste form task.

Estimating long-term waste form performance will be based on simulating the environment and waste form as a function of time and position in the disposal facility. To be successful, such a strategy depends on an understanding of the processes involved, on a powerful computer code that incorporates those processes, and on well-tested and -understood parameters for those processes.

As noted in Section 3.3.3.2, scientists believe they understand the major processes of glass dissolution and contaminant release. The release of contaminants from a glass waste form in a dry environment over thousands of years is very complex. Improvements on codes such as AREST-CT, which was used in this analysis on the behavior of LD6-5412, are expected. The improvements will allow the code to better incorporate not only the chemical effects of waste form release but also the hydraulic principles that govern the contaminant transport in the facility. 


\section{DOE/RL-97-69}

Rev. 0

Four major types of tests (SPFT, VHT, PCT, and PUF) will be used. The samples in the tests will be produced using the proposed formulations of the ILAW producers and radioactive wastes from Hanford Site tanks. These tests not only will provide parameters for the computer code analyses but will serve to validate the codes.

The single pass flow-through (SPFT) tests determine how the glass dissolves under constant environmental conditions (temperature, $\mathrm{pH}$, ion concentration). These tests pass a water solution of known ionic concentration at known temperatures. Because the dissolved glass never forms a significant fraction of the fluid, parameters such as the $\mathrm{pH}$ power law coefficient, the activation energy, and the rate law order can be determined. Also by investigating the entire data set, possible deviations from the model can be investigated and understood.

The vapor hydration tests (VHT) allow the determination of the formation of phases from the dissolved glass materials. Such phases could accelerate glass dissolution or could trap contaminants in a stable medium. These measurements are normally done at high temperatures higher than $100^{\circ} \mathrm{C}$ which greatly accelerates glass dissolution and formation of the phases. By performing the tests at different temperatures, scientists can investigate the temperature effects and extrapolate the measurements to temperatures typical of ILAW disposal. VHT also can supplement the results of the product consistency test (PCT), which is run at lower temperatures.

PCT is a well-established test to determine how glass will dissolve in a static environment. In these tests, the environmental conditions are established at the beginning of the test, then measured as the test proceeds. Because the $\mathbb{L} \mathrm{AW}$ waste contains so much sodium, the environmental conditions (particularly $\mathrm{pH}$ ) change significantly. PCT tests are run at a variety of temperatures and surface-to-volume ratios. Such measurements allow the pseudoequilibrium constant to be determined. These tests not only provide an integral check on the SPFT results, but can provide information on the importance of reactions such as the sodium ion exchange reaction.

The pressurized unsaturated flow (PUF) test is unique among the tests because it is the only test performed in an unsaturated-moisture environment. In this test, water is forced to flow through a porous medium of glass at a slow rate. Because the disposal facility is expected to be extremely dry, the PUF tests will be used to determine whether (or how) any of the parameters or processes change under such dry conditions. PUF test results have already been used to determine the change in hydraulic conductivity as the glass dissolves and other physical properties. The PUF tests, particularly those carried out over long periods, are expected to severely test the models and our understanding of them.

All this test information is being used to formulate, test, and calibrate the computer models, which are being modified to make them more robust and accurate. More chemical processes are being modeled. Our intent is to have a computer model that simulates the influx of water to the disposal facility, the corrosion of the glass, the release of the contaminants from the original glass waste form and its secondary mineral phases, and the transport of those contaminants out of the engineered disposal system. 


\subsubsection{Interactions with Disposal Facility Designers}

Disposal facility construction costs will be significant. The performance assessment team has been and will continue to work with the disposal facility designers to identify key components of the facility design so that cost-effective, safety-enhancing decisions can be made. The performance assessment team also will use these close contacts to determine the components that must be included in the models for future performance assessments.

To model the disposal facility, we need not only the design, but also the hydraulic and transport properties of the waste form and near-field environment. Movement of moisture through cracks in the waste form and the hydraulic and geochemical properties of the original and degraded materials will be investigated. Efforts to support design of moisture barriers (both surface and sand-gravel capillary), getter materials, and water conditioning layers are part of the multi-year plan.

\subsubsection{Geotechnical Data Collection and Model Development}

Geotechnical data describe the vadose zone and the unconfined aquifer. The vadose zone and the unconfined aquifer play an important role in the performance assessment because the vadose zone delays the arrival of contaminants and the aquifer supplies additional water with which the contaminants can mix. An integrated program covering all aspects of the Hanford Site's vadose zone and unconfined aquifer has just begun. The program should result in more efficient data collection and a more thorough method review.

In each of the next 3 years, one borehole will be drilled in the locations where the disposal facilities will be sited. The boreholes will provide samples for determining other geotechnical information and also will allow access to the vadose zone for in-situ moisture experiments and to the unconfined aquifer for groundwater testing.

The samples from the boreholes along with samples from other locations on the Hanford Central Plateau will be used to determine the geologic strata underlying the disposal facilities and the hydraulic and geochemical properties of those strata. In addition, the samples will be used to determine chlorine content as a function of depth, which will provide the recharge rate over the last 13,000 years).

Other analyses will use and support the determination of geotechnical data needed. For example, the computer simulations of moisture flow in Hanford Site surface sediments will combine the long-term time-varying infiltration rates determined by chlorine measurements (both total $\mathrm{Cl}$ and ${ }^{36} \mathrm{Cl}$ ) with short-term (a few decades) determination of the infiltration rate and with climate, soil, and vegetation studies. Enhanced contaminant transport through colloidal movement or in clastic dikes also will be studied. Studies of the spatial variability of soil hydraulics data and alternative conceptual models will be important for completing future performance assessments. 
DOE/RL-97-69

Rev. 0

Because of the thickness of the vadose zone, the size of the disposal facilities, and the distance separating the two sites, complex geotechnical computer codes and models are needed to forecast future moisture flow and contaminant transport. The performance assessment activity is committed to use the soon-to-be-selected Hanford Site standard groundwater code and model for future assessments. A similar selection effort is expected for vadose zone codes and models.

\subsubsection{ILAW Inventory}

The inventory in each ILAW package will depend on the radionuclide inventories of the 177 individual tanks, the order and method of retrieval from those tanks, the blending on the retrieved contents, and the separations and the immobilization processes used by the ILAW producers.

Until the ILAW packages are actually produced, the performance assessment team will continue its close interface with the TWRS Standard Inventory effort. The team also will closely interact with the TWRS Retrieval Group to incorporate their plans into the ILAW estimates. Finally, contacts with the ILAW producers will occur to determine their separations and immobilization plans to estimate better the fraction of the waste they receive that will end up in low-activity tank waste product. Such estimates also will be used for safety studies by the program.

Once the ILAW packages are produced, the performance assessment team will rely on product manifests. Thus, as ILAW packages are produced and product manifests become available, the complexity and uncertainty of the inventory estimate is expected to decrease.

\subsubsection{Other Data Collection}

Other information must be obtained for a successful performance assessment. Dosimetry data must be collected. Scenarios must be developed and reviewed. Performance objectives must be selected and reviewed.

The Hanford Site has a DOE-chartered group (the Hanford Environmental Dose Oversight Panel) to standardize dosimetry data and methods and to review the results of calculations. The performance assessment team will work closely with this group to ensure that its data and methods comply with Site standards. In particular, new data on scenarios and dosimetry values for Native American will be incorporated into future performance assessments.

The public have strong views concerning scenarios and performance objectives. The performance assessment team will review existing guidance, Hanford Site activities (especially the environmental impact statement activities), and other Hanford Site project efforts, such as the Hanford Tank Initiative, to determine the scenarios and performance objectives to be used in future performance assessments. 
DOE/RL-97-69

Rev. 0

\subsection{CONCLUSION}

This performance assessment analyzed the long-term environmental and human health impact of disposing of immobilized low-activity waste from Hanford Site tanks. Even though the amount of facility-, site-, and waste form-specific data is limited, the analysis demonstrates that an understanding of ILAW containment transport exists and that a base case can meet the performance objectives. Based on this expectation, requirements for waste acceptance and disposal facility performance were established. The final analysis of this performance assessment shows a "reasonable expectation" that these requirements will be met. Finally, this chapter concludes by explaining the additional effort which are planned and underway to confirm the data used in this assessment and to document the effects of new information and understanding on the long-term impact of the disposal of this waste. 
DOE/RL-97-69

Rev. 0

$6-24$ 
DOE/RL-97-69

Rev. 0

\subsection{QUALITY ASSURANCE}

\subsection{Overview}

This section describes the quality assurance activities associated with the performance assessment activity. Three separate areas are covered: experimental data collection, computer code use, and analyses. The following sections are arranged according to which organization performs the activity being discussed.

\subsection{Pacific Northwest National Laboratory.}

Pacific Northwest National Laboratory personnel conducted their work for the performance assessment according to the appropriate portions of the laboratory's quality assurance (QA) program plan. This program conforms to NQA-1, Quality Assurance Standard Requirements for Nuclear Facilities (ANSI/ASME 1989), as interpreted in Parts 1 and 3 of the Quality Assurance Manual (PNL 1994). Part 3 of this manual is a set of administrative procedures that define how the requirements of NQA-1 are implemented. The administrative procedures define controls, policies, and established methods for managing and conducting all aspects of work that affect quality.

Computer codes used for the performance assessment are documented, tested, and reviewed following the software control procedures established as part of the overall QA program. These software control procedures have been structured to address the requirements of NQA-1, Basic Requirements 3, and Supplement 3S-1, Supplemental Requirements for Design Control. The procedures cover all aspects of code development and use.

A key aspect of the QA program involves technical and peer reviews of procedures, test plans, data, calculations, and test results. The reviews range from verifying that calculations or data reduction have been performed correctly to evaluating the test methodology described in a proposed test plan.

This performance assessment did not include any audits. However, comprehensive audits are expected for the future performance assessments.

Records generated from all activities are indexed and managed according to QA program requirements. Record-holding facilities are used for long-term records retention and storage.

\subsection{Project Hanford Management Contractors}

The TWRS Immobilized Waste Program quality assurance activities are covered by the TWRS Quality Assurance Program Plan (LMHC 1998) and associated implementing procedures. This program addresses the requirements of the Quality Assurance Program Description of the Project Hanford Management Contractor (FDH 1997), which is based on 10 CFR 830.120 and DOE Order 5700.6C (DOE 1991). 
DOE/RL-97-69

Rev. 0

\subsection{Other Contractors}

Other organizations, such as Argonne National Laboratory and D.B. Stevens, Inc., worked on this activity. Their work was performed under either the Pacific Northwest National Laboratory or WHC QA plan.

\subsection{Hanford Environmental Dose Overview Panel}

The Richland Operations Office of DOE established the Hanford Environmental Dose Oversight Panel (Schreckhise 1993) to

- Ensure that appropriate radiological and nonradiological environmental and health dose assessment methods are used at the Hanford Site

- Ensure that all Hanford Site-related environmental and health dose assessments are technically consistent

- Foster communications among Hanford Site contractors regarding environmental and health dose assessments.

All dose calculations used in this performance assessment have been reviewed and approved for publication by a HEDOP reviewer (Rhoads 1996).

\subsection{Technical Reviews of Supporting Efforts}

External technical reviews by outside experts are being held on specialized topics because of the large amount of technical data used in performance assessments. These reviews are done to ensure that the proper methods, techniques, and resources are used in obtaining the data.

Some of the information used for the interim performance assessment has already been reviewed by external groups to ensure its acceptability by peers and stakeholders. The performance objectives and scenarios used in this performance assessment were reviewed by Hanford Site stakeholders. The results of the review were transmitted in a letter report (Muikowski 1995). The dosimetry results presented in this report were reviewed by members of the Hanford Environmental Dose Overview Panel. The results of the review were transmitted in a letter report (Rhodes 1996). The external review board for the Interim Performance Assessment (Appendix F.1) also reviewed the data packages.

A panel consisting of Mr. William E. Kennedy, Dr. Fred M. Phillips, Dr. Bridget Scanlon, Dr. Martinus Th. van Genuchten, and Dr. Peter J. Wierenga reviewed the efforts to determine the recharge rate (Honeyman 1995). They concluded that the recharge research performed at the Hanford Site over the past several decades was adequate for a preliminary performance assessment. However, additional effort would add credibility to the final performance assessment. 


\section{DOE/RL-97.69}

Rev. 0

Additional focused panel reviews are expected to occur for future performance assessments.

\subsection{Review of the Performance Assessment}

The Hanford Low-Level Tank Waste Interim Performance Assessment (Mann 1996a) used nearly the same data base and methods as this document. Many individuals and organizations commented on the first version of the interim performance assessment. Their comments (and the responses) are presented in Appendix F.

An external advisory board (Professor Lynn Gelhar, Dr. Louis Kovach, Todd Martin, Dr. Bill Prindle, and Elmer Wilhite with George Williamson serving as secretary) was especially formed to review the performance assessment activity and, in particular, the interim performance assessment. The board members' qualifications are given in Attachment A of Appendix F.1:3. Their report is shown in Appendix F.1.3, while the responses to their comments are in Appendix F.1.4.

Comments on the initial version of the interim performance assessment were provided by Phil LaMont and Doug Hildebrand of the Richland Operations Office of the Department of Energy, the staff of the Nuclear Regulatory Commission, the U.S. Department of the Navy, and four Hanford Site employees (Dewey Burbank, Dr. Kathleen Rhoads, Jeffrey Voogd, and Joseph Westsik). The comments from bodies not associated with the performance assessment and their responses also are documented in Appendix F. Revision 1 of the interim performance assessment (Mann 1997a) has incorporated all of the comments and the responses.

Copies of this document have been sent to various members of the Hanford technical and managerial staff for review. All received comments were considered and almost all were incorporated to yield a document that is easier to read. In addition, formal comments were received from the Richland Operations Office of the Department of Energy and from the Washington State Department of Ecology. These comments and the responses are displayed in Appendix F.5. 
DOE/RL-97-69

Rev. 0 
DOE/RL-97-69

Rev. 0

\subsection{RESUMES OF PREPARERS AND CONTRIBUTORS}

NEIL R. BROWN, Project Manager, TWRS-Low Level Waste Immobilization, U.S. Department of Energy, Richland Operations Office

B.S. Material Science and Engineering, Rice University

Ph.D. Material Science and Engineering,

Northwestem University

Before joining DOE, Dr. Brown was a post doctoral fellow at the Argonne National Laboratory where he studied corrosion characteristics of waste glass and soil remediation. At DOE, he has overseen technology development for the Low-Level Waste Program as well as the development of TWRS privatization specifications. Currently Dr. Brown is the DOE Contract Officer for British Nuclear Fuels, Limited's effort as part of TWRS privatization. He reviewed the interim performance assessment and this document.

YUETING CHEN, Research Scientist, Applied Geology and Geochemistry, Water and Land Resources Department, Pacific Northwest National Laboratory

B.S. Geochemistry, China University of Geosciences 1982

M.S. Geochemistry, China University of Geosciences 1985

Ph.D. Geochemistry, Indiana University

From 1985 to 1989, Dr. Chen worked as a lecturer at the China University of Geosciences. While earning his Ph.D. in geochemistry at Indiana University under Professor Peter Ortoleva, he developed a reactive-transport simulator CIRF.A. Since joining Pacific Northwest National Laboratory in 1994, he has been the principal developer of the AREST-CT code. His expertise is in reaction-transport modeling of subsurface systems. He is the co-author of one book and has published and presented more than 22 papers. Dr. Chen performed the AREST-CT calculations for this analysis.

MARY P CURRY, Technical Writer/Editor, Lockheed Martin Services, Incorporated.

B.S. Agriculture, Arizona State University

Ms. Curry has written and edited technical material for the aerospace and nuclear industry since 1982 and worked at the Hanford Site since 1991. She edited the interim performance assessment and this document. 
CHERYL R. EIHOLZER, Senior Research Engineer, Pacific Northwest National Laboratory.

B.N.E. Nuclear Engineering, Georgia Institute of Technology 1980

M.S. Metallurgical Engineering, University of Illinois, Champaign-Urbana 1985

Ms. Eiholzer was the main co-author of the interim performance assessment. She also produced the facility concepts used in this assessment and oversaw the material science research conducted for the overall performance assessment effort. She has more than 10 years experience in metallurgical related research and development, technical support, and project coordination on government, foreign, and private industry projects.

CHARLES T. KINCAID, Staff Scientist, Geosciences Department, Pacific Northwest National Laboratory

B.S. Civil Engineering, Humboldt State College

Ph.D. Engineering (Hydraulics), Utah State University

Dr. Kincaid is the Hanford representative on the DOE Peer Review Panel. He was the technical manager and key contributor to the Performance Assessment of Grouted Double-Shell Tank Waste Disposal at Hanford and is now leading the effort on the Hanford Site Composite Analysis. He has been the Technical Group Leader of the Soil Physics Group and of the Subsurface Transport Group. He was a key contributor in the development of contaminant transport codes and has contributed to various performance assessments. Dr. Kincaid reviewed this document and advised on its development. He also supplied the section on the results from the Hanford Site composite analysis.

RAZIUDDIN KHALEEL, Consulting Engineer, Nuclear and Environmental Initiatives, Flour Daniel Northwest Company

B.S. Civil Engineering, Bangladesh University of Engineering and Technology

M.S. Water Science and Engineering, Asian University of Technology

Ph.D. . Soil and Water Engineering, Texas A\&M University

Dr. Khaleel has over 25 years of experience in groundwater hydrology and numerical simulations of subsurface flow and transport. He was a key contributor to the Hanford Site solid waste performance assessments, particularly in the area of conceptual model development, direction of modeling, and in writing the document. For this document, he reviewed the approach, models, and results. 
DOE/RL-97-69

Rev. 0

NIALL W. KLINE, Fellow Software Engineer, Information and Scientific Systems, Lockheed Martin Services, Incorporated

B.A. Mathematics, Washington State University

M.S. Mathematics, Washington State University

Mr. Kline has been employed at the Hanford Site since January of 1978 . He has nearly 20 years of experience in mathematical modeling and numerical simulation of physical systems. For the past 15 years, $\mathrm{Mr}$. Kline has concentrated on modeling and simulation of isothermal and nonisothermal flow and transport in both groundwater and the vadose zone. For this performance assessment, he developed and tested the unit cell model and performed the unit cell simulations of vadose zone flow and transport.

PHIIP E. LAMONT, General Engineer, U.S. Department of Energy - Richland Operations Office

B.S. Chemical Engineering, Washington State University

M.S. Chemical Engineering, University of Idaho

Mr. LaMont is a project director in the Hanford Site Tank Waste Remediation System Office. $\mathrm{He}$ has more than 20 years of experience in nuclear waste management. Mr. LaMont reviewed this performance assessment as part of his responsibility for managing projects for storage and disposal of the immobilized waste products from the planned treatment of Hanford Site tank waste.

ALLEN H. LU, Fellow Scientist, Environmental Modeling Section, Westinghouse Hanford Company (retired).

B.S. Naval Navigation and Engineering, Chinese Naval Academy 1958

- M.S. Nuclear Physics, Tsin-Hua University, Taiwan 1964

Ph.D. Nuclear Physics, Renesselaer Polytechnic Institute 1969

Dr. Lu has been employed at the Hanford Site since 1979. He has worked on a variety of nuclear engineering projects. Most recently, he was in charge of various modeling studies using the VAM3D-CG flow and transport code. In particular, he was responsible for the source term and modeling for the Hanford Site solid waste performance assessments. He performed the aquifer calculations for this assessment. 
Rev. 0

FREDERICK M. MANN, Consulting Scientist, Nuclear and Environmental Initiatives, Flour Daniel Northwest Company

B.S. Physics, Stanford University

Ph.D. Physics, Califomia Institute of Technology

Dr. Mann is the team leader for the Tank Waste Performance Assessment Activity, which is charged with preparing this performance assessment. He has worked for over 20 years in the field of nuclear data and the application of that data to large energy facilities. He has advised the U.S. Department of Energy and the International Atomic Energy Agency. He is the main author of this document.

B. PETER MCGRAIL, Staff Scientist IV, Applied Geology and Geochemistry, Water and Land Resources Department, Pacific Northwest National Laboratory

B.S. Nuclear Engineering, University of Missouri

M.S. Nuclear Engineering, University of Missouri

Mr. McGrail has over 14 years of experience in fundamental and applied research on immobilization and disposal of hazardous and radioactive wastes. He is a principal investigator on performance assessment projects for high-level waste disposal in Japan and the United States, and for the Hanford Site low-level waste disposal project. He is a co-developer of the AREST-CT code, which is used to simulate the release and transport of contaminants modified by both kinetic- and equilibrium-controlled chemical reactions. He is the principal developer of the Tank Waste Simulator code, which is used to model coupled fluid, heat, and chemical mass transport processes in underground storage tanks. In addition to his modeling research, Mr. McGrail invented several novel experimental techniques to evaluate the kinetics and thermodynamics of waste form-water reactions including a two-phase single-pass flow-through method and the pressurized unsaturated flow (PUF) method. Mr. McGrail has published and presented more than 100 papers on all aspects of his waste management research. Mr. McGrail supervised the AREST-CT calculations for this analysis.

MEL G. PIEPHO, Senior Specialist, TRS, Inc.

B.S. Mathematics and Physics, Butler University

M.S. Physics, Indiana University

Ph.D. Physics, Indiana University

Dr. Piepho has over 20 years of mathematical modeling, numerical analysis, and computer science experience. For the last 10 years, he has concentrated on studying vadose zone flow and contaminant transport. He supplied the flow and transport calculations for the Hanford Site Grout performance assessment. He performed the vadose zone calculations for the facility model used in this assessment. 
DOE/RL-97-69

Rev. 0

RAYMOND J. PUIGH II, Manager, Environmental and Nuclear Initiatives, Fluor Daniel Northwest Company

B.S. Physics, Louisiana State University 1970

Ph.D. Physics, Florida State University 1976

Dr. Puigh has over 20 years of experience in nuclear fields ranging from nuclear data and testing to the impact of nuclear radiation on material properties. Relevant performance assessment experience includes metallurgy, tank waste inventory support, safety-assessment support for selected tank farm operation projects, and management of modeling staff. He is a major contributor to the writing of this document.

STEPHEN P. REIDEL, Staff Scientist IV, Applied Geology and Geochemistry, Water and Land Resources Department, Pacific Northwest National Laboratory

B.S. Geology, University of Cincinnati

M.S. Geology, University of Cincinnati 1972

Ph.D. Geology, Washington State University 1978

Dr. Reidel has been studying the geology and geohydrology of the Columbia Basin for over 25 years, with nearly 20 years spent at the Hanford Site. At the Site he has worked in the fields of commercial nuclear waste disposal, groundwater management and protection, waste management, site characterization, and natural phenomena hazards. He is a recognized expert on the geology of the Hanford Site. He is an Associate Adjunct Professor at Washington State University and a part time faculty member at Yakima Valley Community College. Dr. Reidel provided much of the geology for this assessment and reviewed the document.

PAUL D. RITTMANN, Process/Speciality Engineer II, Nuclear and Environmental Initiatives, Flour Daniel Northwest Company

B.A. Physics, University of Wisconsin

M.S. Physics, Purdue University

Ph.D. Physics, Purdue University

Dr. Rittmann has been employed at the Hanford Site since 1980 and has been using environmental transport and dose models since 1983. He is a member of the Hanford Environmental Dose Overview Panel. He was responsible for the dosimetry analyses for the Hanford Site solid waste performance assessments. He supplied the dosimetry data and equations for this performance assessment. 
FRANK SCHMITTROTH, Fellow Scientist, Criticality and Shielding, Westinghouse Hanford Company (retired)

B.S. Physics, Oregon State University

Dr. Schmittroth worked for Westinghouse Hanford Company from 1970 to 1996. His primary activities have supported nuclear data analysis, specifically nuclear cross sections, decay heat, and calculations of radionuclide inventories from both fast and thermal reactors. Recent activities have included groundwater modeling of the vadose zone and unconfined aquifers, statistical analyses, and Monte Carlo transport calculations of molecular flow. He reviewed the interim performance assessment.

ANN M. TALLMAN, Fellow Scientist, Liquid Effluent Services, Westinghouse Hanford Company (retired)

B.S. Chemistry, Ashland University (Ohio)

Dr. Tallman has 19 years of experience in geology and geotechnical studies and applications at the Hanford Site. Her work has been applied to site characterization and selection studies and to the design and construction of new facilities. She was the point of contact for the Hanford Site in matters relating to natural phenomena hazards (NPH) and NPH design criteria. Before coming to the Hanford Site, she was an assistant professor of geology at Smith College. Dr. Tallman provided the section on seismic analysis and reviewed the interim performance assessment.

JEFFRY A. VOOGD, Program Engineer, Tank Waste Remediation System Immobilized Waste Program, Lockheed Martin Hanford Company

B.S. Chemical Engineering, University of Washington, 1977

Mr. Voogd has programmatic responsibilities for storage and disposal of Hanford Site tank waste after treatment by private vendors. This role includes coordinating of cost, scope, and schedule among activities leading to final disposal of immobilized low activity waste. He has held positions in engineering management, low-activity waste disposal, high-level waste vitrification, and fuel reprocessing. These positions included previous assignments with performance assessments, waste disposal system design, waste form performance, and waste characterization. 


\section{DOE/RL-97-69}

Rev. 0

GEORGEF. WILLIAMSON, Project Manager, Storage and Disposal Subproject, Westinghouse Hanford Company (retired)

B.S. Metallurgical Engineering, Purdue University

M.S. Engineering, North Carolina State University

Mr. Williamson was the project manager for this activity until he retired in 1996. He has 30 years of technical and project management experience in the nuclear field associated with the fabrication of nuclear fuels for commercial power reactors and mixed waste treatment and disposal projects for defense wastes. He participated in the early development of the performance assessment for the grouting of Hanford Site tank wastes. Mr. Williamson reviewed this performance assessment. 
DOE/RL-97-69

Rev, 0

1 


\section{DOE/RL,-97-69}

Rev. 0

\subsection{REFERENCES}

10 CFR 61, "Licensing Requirements for the Land Disposal of Radioactive Waste," Code of Federal Regulations, Volume 10, Part 61, Section 55, U.S. Nuclear Regulatory Commission, Washington, D.C., December 27, 1982 as amended May 25, 1989. [1. Section 61.52(a)(2) mandates the protection for inadvertent intrusion for Class $\mathrm{C}$ wastes.]

[2. Section 61.55 describes waste classification. (May 1989)]

[3. Subpart C, sections 61.40 through 61.44 stated the performance objectives.]

[4. Section 61.41 mandates the protection for the general public.]

10 CFR 830.120, "Quality Assurance Requirements," Code of Federal Regulations, Volume 10, Part 830, Section 120, U.S. Nuclear Regulatory Commission, Washington, D.C., as amended January 1, 1997.

40 CFR 61H, Subpart H, "National Emission Standards for Emissions of Radionuclides Other than Radon from Department of Energy Facilities," Code of Federal Regulations, Volume 40, Part 61, Subpart H, Section 92, U.S. Environmental Protection Agency, Washington, D.C., December 15, 1989.

40 CFR 61Q, Subpart Q, "National Emission Standards for Radon Emissions from Department of Energy Facilities," Code of Federal Regulations, Volume 40, Part 61, Subpart Q, Section 192, U.S. Environmental Protection Agency, Washington, D.C., December 15, 1989.

40 CFR 141, "National Primary Drinking Water Regulations," Code of Federal Regulations, Volume 40, Part 141, Sections 15 and 16, U.S. Environmental Protection Agency, Washington, D.C., December 24, 1975.

40 CFR 143, "National Secondary Drinking Water Regulations," Code of Federal Regulations, Volume 40, Part 143, U.S. Environmental Protection Agency, Washington, D.C., July $19,1979$.

40 CFR 193, "Radiation Site Cleanup Regulation", proposed Code of Federal Regulations by the U.S. Environmental Protection Agency.

40 CFR 196, "Environmental Radiation Standards for Management and Disposal of Low-Level Waste", proposed Code of Federal Regulations by the U.S. Environmental Protection Agency.

40 CFR 260-268, RCRA regulations including "Hazard waster management system: General"

(40 CFR 260), "Standards for owners and operators of hazardous waste treatment, storage, and disposal facilities" (40 CFR 264), and "Land disposal restrictions" (40 CFR 268), Code of Federal Regulations, Volume 40, Parts 260-268, U.S. Environmental Protectional Agency, May 19, 1980 and as amended. 


\section{DOE/RL-97-69}

Rev. 0

ACRi, 1994a, PORFLOW User's Manual Version 2.50, Analytic and Computational Research, Inc., Bel Air, California, March 1994.

ACRi, 1994b, PORFLOW Validation Version 2.50, Analytic and Computational Research, Inc., Bel Air, California, 1994.

AEA 1954, Atomic Energy Act of 1954, 42 USC 2011 or 2014 et seq.

Agnew 1997, S.F. Agnew, R.A. Corbin, T.B. Duran, J.R. FitzPatrick, K.A. Jurgensen, T.P. Ortiz, and B.L. Young, Hanford Tank Chemical and Radionuclide Inventories: HDW Model Rev. 4, LA-UR-96-3860, Los Alamos National Laboratory, Los Alamos, New Mexico, 1997.

Alm 1997, A.L. Alm (Assistant Secretary for Environmental Management) "Critical Assumptions for Department of Energy Low-Level Waste Disposal Facility Assessments", attachment to letter dated March 7, 1997 to John T. Conway (Chairman, Defense Nuclear Facilities Safety Board), Department of Energy, Washington, D.C.

Anderson 1990, J.D. Anderson, A History of the 200 Area Tank Farms, WHC-MR-0132, Westinghouse Hanford Company, Richland, Washington, June 1990.

ANSI/ASME 1989, Quality Assurance Standard Requirements for Nuclear Facilities, ANSI/ASME NQA-1, American National Standards Institute/American Society of Mechanical Engineers, New York City, New York, 1989.

Boldt 1994, A.L. Boldt, "Source Terms", DSI to K.D. Boomer, Westinghouse Hanford Company, Richland, Washington, February, 9, 1994. Attachment 1 in Schmittroth 1995b.

Baca 1984, R.G. Baca, R.C. Amett, P.M. Clifton, and N.W. Kline, Chapter I-VII of Repository Horizon Identification Report, RHO-BW-ST-28P, Rockwell Hanford Operations, Richland, Washington, 1984.

Bauer 1990, H.H. Bauer and J.J. Vaccaro, Estimates of Ground Water Recharge to the Columbia Plateau Regional Aquifer System; Washington, Oregon and Idaho for Predevelopment and Current Land Use Conditions, WRIR 88-4108, U.S. Geological Survey, Tacoma, Washington.

Berger 1991, A. Berger, H. Gallee, and J.L. Melice, "The Earth's Future Climate at the Astronomical Timescale," In G.M. Goodess and J.P. Palutikof, Future Climate Change and Radioactive Waste Disposal: Proceedings of International Workshop, NSS/R257, U.K. Nirex Radioactive Waste Disposal, Ltd., Harwell, OX11 ORH, United Kingdom, pp. 148-165. 


\section{DOE/RL-97-69}

Rev. 0

Bernero 1993, "State of Washington and Oregon Denial of Petition for Rule Making", Bernero (Director, Office of Nuclear Materials Safety and Safeguards), 58 FR (Federal Register) 12342, U.S. Nuclear Regulatory Commission, Washington, D.C., March 4, 1993.

Bhuyan 1989, D. Bhuyan, Development of an Alkaline/Surfactant/Polymer Compositional Reservair Simulator (UT-CHEM), PhD Dissertation, University of Texas, Austin, Texas, 1989.

Birdsell 1991, K.H. Birdsell and B.J. Travis, TRACR3D: A Model of Flow and Transport in Porous Media, LA-11798-M, Los Alamos National Laboratory, Los Alamos, New Mexico, 1991.

Bjomstad 1984, B.N. Bjornstad, Suprabasalt Stratigraphy Within and Adjacent to the Reference Repository Location, SD-BWI-DP-039, Rockwell Hanford Operations, Richland, Washington.

Burbank 1996, D.A. Burbank, Jr., Alternatives Generation and Analysis for Immobilized LowLevel Waste Interim Storage Architecture, WHC-SD-W465-AGA-001, Rev. 0, Westinghouse Hanford Company, September 1996.

Burbank 1997, D.A. Burbank and M.J. Klem, Analysis of Alternatives for Immobilized LowActivity Waste Disposal, HNF-SD-TWR-AGA-004, Rev. 0, SGN Eurisys Services Corporation, Richland, Washington, October 1997.

Campbell 1994, M.D. Campbell, Monitoring Groundwater and River Interaction Along the Hanford Reach of the Columbia River, PNL-9437, Pacific Northwest Laboratory, Richland, Washington, 1994.

Carnahan 1986, C.L. Carnahan, "Simulation of Uranium Transport with Variable Temperature and Oxidation Potential: The Computer Program THCC (Thermo-Hydro-Chemical Coupling)," in Scientific Basis for Nuclear Waste Management X, eds. J.K. Bates and W.B. Seefeldt, Materials Research Society, Pittsburgh, Pennsylvania, 1986.

Case 1988, M.J. Case and M.D. Otis, Guidelines for Radiological Performance Assessments of DOE Low-Level Radioactive Waste Sites, DOE-LLW-62T (Section 4.5.2.5), U.S. Department of Energy, Idaho Operations Office, Idaho Falls, Idaho, July 1988.

Case 1989, M.J. Case, R.L. Dodge, T.G. Frangos, W.R. Hansen, W.E. Kennedy, Jr., D.W. Layton, D.W. Lee, and E.L. Wilhite, Recommended Format and Content for DOE LowLevel Waste Disposal Facility Radiological Performance Assessment Reports, DOE/LLW-81, Radioactive Waste Technical Support Program, Idaho National Engineering Laboratory, Idaho Falls, Idaho, April 1989.

CERCLA, Comprehensive Environmental Response, Compensation, and Liability Act of 1980, 42 U.S. C. 9601 , et seq. 


\section{DOE/RL-97-69 \\ Rev. 0}

Chatters 1991, J.C. Chatters, "Long-Term Climate Change Effects," L.L. Cadwell (editor), Hanford Site Protective Barrier Development Program: Fiscal Year 1990 Highlights, PNL-7831, Pacific Northwest Laboratory, Richland, Washington, pp. 2.23-3.1, September 1991.

Chatters 1992, J.C. Chatters and K.A. Hoover, "Response of the Columbia River Fluvial System to Holocene Climatic Change," Quaternary Research, Vol. 37, pp. $42-59$.

Chen 1994, Y. Chen, CIRF: A General Coupled Reaction-Transport Model and Simulator, $\mathrm{PhD}$ dissertation, Indiana University, Bloomington, Indiana, 1994.

Chen 1995, Y. Chen, D.W. Engel, B.P. McGrail, and K.S. Lessor, AREST-CT V1.0 Software Verification, PNL-10692, Pacific Northwest Laboratory, Richland, Washington, July 1995. [Also included as Appendix $\mathrm{H}$ in Mann 1995a.]

Chen 1996, Y. Chen, W. Chen, A. Park, J. Mu, and P. Orotleva, "A General Coupled ReactionTransport Model for Solute Transport and Porous Media Alternation with Both Kinetically Controlled and Equilibrium Controlled Chemical Reactions," submitted to the Journal of Hydrology.

Chunseng 1997, Li Chunsheng, Guo Jingru, and Li Daming, "A Procedure for the Separation of

${ }^{79}$ Se from Fission Products and Application to the Determination of the ${ }^{79} \mathrm{Se} \mathrm{Half-life",}$ Journal of Radioanalytical and Nuclear Chemistry, Vol. 220 (1997) 69-71.

Cleary 1978, R.W. Cleary and M.J. Ungs, "Two Dimensional Groundwater Transport Strip Source Model No. 4", Analytic Models for Groundwater Pollution and Hydrology Report, 78-WR-15, Water Resources Program, Department of Civil Engineering, Princeton, New Jersey, 1978.

Codell 1982, R.B. Codell, K.T. Key, and G. Whelan, A Collection of Mathematical Models for Dispersion in Surface Water and Groundwater, NUREG-0868, Nuclear Reactor Regulation, Nuclear Regulatory Commission, Washington, D.C., June 1982.

Connelly 1992a, M.P. Connelly, J.V. Borghese, C.D. Delaney, B.H. Ford, J.W. Lindberg, and S.J. Trent, Hydrogeologic Model for the 200 East Ground-Water Aggregate Area, WHC-SD-EN-TI-014, Westinghouse Hanford Company, Richland, Washington, April 1992.

Connelly 1992b, M.P. Connelly, J.V. Borghese, C.D. Delaney, B.H. Ford, J.W. Lindberg, and S.J. Trent, Hydrogeologic Model for the 200 West Ground-Water Aggregate Area, WHC-SD-EN-TI-003, Westinghouse Hanford Company, Richland, Washington, April 1992.

Conway 1997, J.G. Conway, R.J. Luxmore, J.M. Matuzek, and R.O. Patt, TWRS Vadose Zone Contamination Issue Expert Panel Status Report, DOE/RL-97-49, Rev. 0, U.S. Department of Energy, Richland, Washington, April 1997. 
DOE/RL-97-69

Rev. 0

Cowan 1996, S.P. Cowan, "Conditional Acceptance of the Hanford 200 West Area Burial Ground Performance Assessment", memorandum to Charles Hansen, U.S. Department of Energy, Washington, D.C., June 27, 1996.

Croft 1980, A.G. Croft, ORIGEN-2 - A Revised and Updated Version of the Oak Ridge Isotope Generation and Depletion Code, ORNL-5621, Oak Ridge National Laboratory, Oak Ridge, Tennessee, 1980.

Cropper 1986, J.P. Cropper and H.C. Fritts, 1986, A 360 Year Temperature and Precipitation Record for the Pasco Basin Derived from Tree Rings, DOE/RL-01830-T46, U.S. Department of Energy, Richland, Washington.

Cunnane 1994, J.C. Cunnane, J.K. Bates, W.L. Ebert, X. Feng, J.J. Mazer, D.J. Wronkiewicz, J. Sproul, W.L. Bourcier, B.P. McGrail, and M.K. Altenhofen, High-Level Waste Nuclear Waste Glass: A Compendium of Characteristics, DOE-EM-0177, U.S. Department of Energy, Washington, D.C., 1994.

Cushing 1995, C.E. Cushing (editor), Hanford Site National Environmental Policy Act (NEPA) Characterization, PNL-6415, Revision 7, Pacific Northwest Laboratory, Richland, Washington, September 1995.

[1. Section 4.7 .3 contains population data]

[2. Section 4.7 contains the discussion on socioeconomics]

[3. Section 4.3.1.5 describes flooding on the Hanford Site]

[4. Section 4.5 contains ecological data]

[5. Section 4.1 .5 describes severe weather]

Delaney 1991, C.N. Delaney, K.A. Lindsey, and S.P. Reidel, Geology and Hydrology of the Hanford Site: A Standardized Text for Use in WHC Documents and Reports, WHC-SD-ER-TI-003, Revision 0, Westinghouse Hanford Company, Richland, Washington, 1991.

Dirkes 1997, R.L. Dirkes and R.W. Hanf, Hanford Site Environmental Report for Calendar Year 1996, PNL-111472, Pacific Northwest Laboratory, Richland, Washington, August 1997.

[1. Section 4.6 describes soil and vegetation surveillance.]

[2. . Section 5.0 describes radiation doses from Hanford operations.]

DNFSB 1994, Defense Nuclear Facility Safety Board Recommendation 94-2, "Conformance with Safety Standards at DOE Low-Level Nuclear Waste and Disposal Sites," 59 Federal Register 47309 (1994).

DOC 1991, 1990 U.S. Census of Population and Housing, State and County Profiles, Washington (Summary Tape 1A for Washington State), Office of Financial Management, U.S. Department of Commerce, Washington, D.C., 1991. 


\section{DOE/RL-97-69}

Rev, 0

Dodge 1991, R.L. Dodge, W.R. Hansen, W.E. Kennedy, Jr., D.W. Layton, D.W. Lee, S.T. Maheras, S.M. Neuder, E.L. Wilhite, R.U. Curl, K.F. Grant, B.A. Heath, and K.H. Turner, Performance Assessment Review Guide for Low-Level Radioactive Waste Disposal Facilities, DOE/LLW-93, Radioactive Waste Technical Support Program, Idaho National Engineering Laboratory, Idaho Falls, Idaho, October 1991.

DOE 1986a, Environmental Assessment for the Grouting and Near-Surface Disposal of Low-

Level Radioactive Phosphate/Sulfate Wastes from N Reactor Operations, DOE/EA-0312, U.S. Department of Energy, Richland, Washington, December 1986.

DOE 1986b, Environmental Assessment Reference Repository Location, Hanford Site, Washington, DOE/RW-0070, U.S. Department of Energy, Washington, D.C.

DOE 1987, Final Environmental Impact Statement: Disposal of Hanford Defense High-Level, Transuranic and Tank Wastes, DOE/EIS-0113, Vol. 1-5, U.S. Department of Energy, Washington, D.C., December 1987.

[1. Section 4.2 and Appendix $O$ describe the Hanford Site geology.]

DOE 1988a, "Radioactive Waste Management", DOE Order 5820.2A, U.S. Department of Energy, Washington, D.C., September 26, 1988.

[1. Chapter III, section 3 describes the requirement and content of a performance assessment.]

DOE 1988b, Consultation Draft Site Characterization Plan. DOE/RW-0164, Vols. 1-9, Office of Civilian Radioactive Waste Management, U.S. Department of Energy, Washington, D.C.. 1988.

DOE 1988c, External Dose-Rate Conversion Factors for Calculation of Dose to the Public, DOE/EH-0070 (DE88-014297), U.S. Department of Energy, Washington, D.C., July 1988.

DOE 1988d, Internal Dose Conversion Factors for Calculation of Doses to the Public, DOE/EH-0071 (DE88-014297), U.S. Department of Energy, Washington, D.C., July 1988.

DOE 1991, "Quality Assurance", DOE Order 5700.6c, U.S. Department of Energy, Washington, D.C., August 21, 1991.

DOE 1993, "Radiation Protection of the Public and the Environment", DOE Order 5400.5, U.S. Department of Energy, Washington, D.C., January 7, 1993.

[1. Section 3 of Chapter 1 provides the DOE primary standard of $100 \mathrm{mrem}$ effective dose equivalent to members of the public in a year.] 


\section{DOE/RL-97-69}

Rev. 0

DOE 1995, Draft Waste Management Programmatic Environmental Impact Statement For Managing Treatment, Storage, and Disposal of Radioactive and Hazardous Waste, DOE/EIS-0200-D, U.S. Department of Energy, Washington, D.C., August 1995.

[Pages 34 to 43 of the summary provide information of the low-level waste in the DOE complex. Note that this EIS does not separate the Hanford tank waste into low- and high-level components.]

DOE 1996a, Implementation Plan, Defense Nuclear Facilities Safety Board Recommendation 94-2, Compliance with Safety Standards at Department of Energy Low-Level Nuclear Waste and Disposal Sites, Draft Revision 1, U.S. Department of Energy, Washington, D.C., March 11, 1996.

[The beginning of Section VII, "Radiological Assessment" discusses the use of DOE Order 5400.5 as the basis of the composite approach.]

DOE 1996b, Environmental Impact Statement for the Tank Waste Remediation System, DOE/EIS-0189, U.S. Department of Energy and the Washington State Department of Ecology, Washington, D.C., August 1996.

DOE 1996c, Draft Hanford Remediation.Action Environmental Impact Statement and Comprehensive Land Use Plan, DOE/EIS-0222D, U.S. Department of Energy, Washington, D.C., August 1996.

DOE 1997a, Radioactive Waste Management, DOE Order 435.1, U.S. Department of Energy, Washington, D.C., Draft order published February 28, 1997. The order is now expected to be issued in 1998 and become effective in 1999.

DOE 1997b, Record of Decision for the Tank Waste Remediation System, Hanford Site, Richland, Washington, Federal Register, Volume 62, page 8693, February 26, 1997.

DOE 1997c, "Format and Content Guide and Standard Review Plan for Performance Assessments", enclosure 1 of low-level waste management guidance for DOE Order 435.1, DOE G 435.1-5, Department of Energy, Washington, D.C., draft published February 25, 1997.

DOE-RL 1982, Site Characterization Report for the Basalt Waste Isolation Project, DOE/RL 82-3, U.S. Department of Energy, Richland, Washington, March 1982.

DOE-RL 1990, Grout Treatment Facility Dangerous Waste Permit Application, Rev. 1, U.S. Department of Energy, Richland, Washington, 1990. [Section 2.4.2 describes seismic specifications for the existing vaults.]

DOE-RL 1991a, Description of Codes and Models to Be Used in Risk Assessment, DOE/RL-91-44, U.S. Department of Energy, Richland, Washington, 1991.

DOE-RL 1991b, Ground-Water Development Plan in Support of Risk Assessment, DOE/RL-91-62, U.S. Department of Energy, Richland, Washington, 1991. 
DOE/RL-97-69

Rev. 0

DOE-RL 1992, Annual Report for RCRA Groundwater Monitoring Projects at Hanford Site

Facilities for 1991 - Progress Report, DOE/RL-92-03, U.S. Department of Energy,

Richland, Washington.

DOE-RL 1993a, "Radioactive Waste Management," RLID (Richland Operations Implementing

Directive) 5820.2A, U.S. Department of Energy, Richland, Washington,

November 23, 1993.

[Chapter III, Section 3a describes the requirements for a performance assessment.]

DOE-RL 1993b, Phase 1 Remedial Investigation Report for 200-BP-1 Operable Unit, DOE/RL-92-70, U.S. Department of Energy, Richland, Washington.

[1. p. 3-10]

DOE-RL 1993c, 200 East Groundwater Aggregate Area Management Study Report, DOE/RL-92-19, U.S. Department of Energy, Richland; Washington.

DOE-RL 1993d, Remedial Investigation and Feasibility Study Report for the Environmental Restoration Facility, DOE/RL-93-99, U.S. Department of Energy, Richland, Washington, October 1994.

DOE-RL 1994a, Phase I Remedial Investigation Report for the 300-FF-5 Operable Unit, DOE/RL 93-21, U.S. Department of Energy, Richland, Washington, January 1994.

DOE-RL 1994b, Hanford Site Background: Part 1, Soil Background for Nonradioactive Analytes, DOE/RL-92-94, Revision 2, 2 volumes, U.S. Department of Energy, Richland, Washington, March 1994.

DOE-RL 1995a, Tank Waste Remediation System Integrated Technology Plan, DOE/RL-92-61, Revision 2, U.S. Department of Energy, Richland, Washington, February 1995. [1. p. 1-6 contains figure for TWRS strategy.]

DOE-RL 1995b, Hanford Site Background: Evaluation of Existing Soil Radionuclide Data, DOE-RL-95-55, Rev. 0, U.S. Department of Energy, Richland, Washington, July 1995.

DOE-RL 1995c, Hanford Site Ground Water Protection Management Plan, DOE-RL-89-12, Rev. 2, U.S. Department of Energy, Richland, Washington, July 1995.

DOE-RL 1996, Request for Proposals (RFP) No. DE-RP06-96RL13308, letter from J.D. Wagoner to Prospective Offerors, Department of Energy, Richland, Washington, February 20, 1996.

DOE-RL 1997, Tank Waste Remediation System Fiscal Year 1998 Multi-Year Work Plan, WBS 1.1, HNF-SP-1230, Rev. 0, Project Hanford Management Contractor, Richland, Washington, September 1997. 


\section{DOE/RL-97-69}

Rev. 0

Dresel 1995; P.E. Dresel, P.D. Thorne, S.P. Luttrell, B.M. Gillespie, W.D. Webber, J.K. Merz, J.T. Rieger, M.A. Chamness, S.K. Wurstner, and B.E. Opitz, Hanford Site GroundWater Monitoring for 1994, PNL-10698, Pacific Northwest Laboratory, Richland, Washington, September 1995.

Ecology 1992, Water Quality Standards for Waters of the State of Washington, Washington Administrative Code, Chapter 173-201, Washington State Department of Ecology, Olympia, Washington, 1992.

Ecology 1996, Washington State Department of Ecology, United States Environmental Protection Agency, United States Department of Energy, Hanford Facility Agreement and Consent Order, Sixth Amendment, February 1996. The document is available from any of the parties.

[1.

Appendix D lists the activities and associated milestones. Activities 45 (closure of single-shell tanks), 50 (pretreatment processing), 60 (vitrification of Hanford low-level waste), and 90 (disposal of the immobilized low-activity waste) cover areas of concern for this performance assessment.l

[2. Activity $D$ lists the activities and associated milestones. Activity 50 deals with pretreatment processing.]

[3. Milestone 45-D in Appendix D describes retrieval criteria.]

Eiholzer 1995, C.R. Eiholzer, Disposal Facility Data for the Interim Performance Assessment, WHC-SD-RPT-159, Revision 0, Westinghouse Hanford Company, Richland, Washington, May 1995.

Eiholzer 1996, Internal Memo to F.M. Mann, "Changes to Facility Concepts due to Privatization Draft Specifications for Low-Activity Waste Package," January 15, 1996.

Engel 1995, D.W. Engel, B.P. McGrail, J.A. Fort, K.S. Lessor, R.E. Williford, and M.K. Altenhofen, Software Design Description for the AREST-CT Code Development, Pacific Northwest Laboratory, Richland, Washington, 1995.

Engel 1995a, D.W. Engel, B.P. McGrail, D.M. Elwood, W.J. Gray, R.E. Einziger, R.E Williford, W.E. Nichols, and M.K. Altenhofen, Mathematical Document for the AREST. CT Code Development, Number Pacific Northwest Laboratory, Richland, Washington, 1995.

EPA 1988, Limiting Values of Radionuclide Intake and Air Concentration and Dose Conversation Factors for Inhalation, Submersion, and Ingestion, EPA-520/1-88-020, U.S. Environmental Protection Agency Federal Guidance Report Number 11, U.S. Government Printing Office, Washington, D.C., 1988.

EPA 1989a, Exposure Factors Handbook, EPA/600/8-89/043, U.S. Environmental Protection Agency, Washington, D.C., 1989. 


\section{DOE/RL-97-69 \\ Rev. 0}

EPA 1989b, Risk Assessment Methodology: Environmental Impact Statement for NESHAPS Radionuclides. Volume I: Background Information Document, EPA/520/1-89/005, U.S. Environmental Protection Agency, Washington, D.C., January 1989.

EPA 1993, External Exposure to Radionuclides in Air, Water, and Soil, EPA-402-R-93-081, U.S. Environmental Protection Agency, Washington, D.C., 1993.

ERDA 1975, Final Environmental Statement Waste Management Operations, Hanford Reservation, Richland, Washington, ERDA 1538, Vol. 1-2, U.S. Energy Research and Development Administration, Washington, D.C., December 1975.

Eyler 1984, L.L. Eyler and M.J. Budden, Verification and Benchmarking of PORFLO: An Equivalent Porous Continuum Code for Repository Scale Analysis, PNL-5044, Pacific Northwest Laboratory, Richland, Washington, November 1984.

Fayer 1995a, M.J. Fayer and T.B. Walters, Estimated Recharge Rate at the Hanford Site, PNL-10285, Pacific Northwest Laboratory, Richland, Washington, March 1995.

Fayer 1995b, M.J. Fayer, R.E. Lewis, R. Engelman, A.L. Pearson, C.J. Murray, J.L. Smoot, R.R. Randall, W.H. Wegener, and A.H. Lu, Re-Evaluation of a Subsurface Injection Experiment for Testing Flow and Transport Models, PNL-10860, Pacific Northwest National Laboratory, Richland, Washington, December 1995.

FDH 1997, Quality Assurance Program Description, HNF-MP-599, Fluor Daniel Hanford, Inc. Richland, Washington, Octobe 1997.

Fecht 1987, K.R. Fecht, S.P. Reidel, and A.M. Tallman, "Paleodrainage of the Columbia River System on the Columbia Plateau of Washington State--A Summary," Selected Papers on the Geology of Washington, Division of Geology and Earth Resources, Bulletin 77, p. 219-248, edited by J.E. Schuster.

Freeze 1979, R.A. Freeze and J.A. Cherry, Groundwater, Prentice-Hall, Inc. Englewood Cliffs, New Jersey, 1979. [Section 2 discusses the principles of water flow.]

Frei 1996, M.W. Frei, "Issuance of Low-Level Waste Performance Assessment Guidance", letter from Mark W. Frei (Acting Associate Deputy Assistant Secretary for Waste Management, Department of Energy) dated November 1, 1996.

Frei 1997, M.W. Frei, "Conditional Acceptance of the Hanford 200 East Area Burial Ground Performance Assessment", letter from Mark W. Frei (Acting Deputy Assisstant Secretary for Waste Management, Department of Energy) to Charles Hansen (Assisstant Manager for Waste Management, Richland Operations Office) dated June 30, 1997.

Gee 1992, G.W. Gee, M.J. Fayer, M.L. Rockhold, and M.D. Campbell, "Variations in Recharge at the Hanford Site," Northwest Science 66(4):237-250. 


\section{DOE/RL-97-69}

Rev. 0

Geomatrix Consultants, Inc. 1996, Probablistic Seismic Hazard Analysis for DOE Hanford Site, Washington, WHC-SD-W236A-TI-002, Revision 1, Westinghouse Hanford Company, Richland, Washington, 1996.

Gephart 1979, R.E. Gephart, R.C. Amett, R.G. Baca, L.S. Leonhart, and F.A. Spane, Jr., Hydrologic Studies Within the Columbia Plateau, Washington: An Integration of Current Knowledge, RHO-BWI-ST-5, Rockwell Hanford Operations, Richland, Washington. 1979.

Gosman 1969, A.D. Gosman, W.M. Pun, A.K. Runchal, D.B. Spalding, and M. Wolfstein, Heat and Mass Transfer in Recirculating Flows, Academic Press, New York City, New York, 1969.

Gramulich 1987, L.H. Gramulich, "Precipitation Variation in the Pacific Northwest (1675-1975) as Reconstructed from Tree Rings," Annals of the Association of American Geographers, 77:19-29.

Graham 1981, M.J. Graham, M.D. Hall, S.R. Strait, and W.R. Brown, Hydrology of the Separations Area, RHO-ST-42, Rockwell Hanford Operations, Richland, Washington, July 1981.

Gupta 1987, S.K. Gupta, C.R. Cole, C.T. Kincaid, and A. Molti, Coupled Fluid, Energy, and Solute Transport (CFEST) Model: Formulation and User's Manual, BML/ONWI-660, Battelle Memorial Institute, Columbus, Ohio, October 1987.

Hajek 1966, B.F. Hajek, Soil Survey: Hanford Project in Benton County, Washington, BNWL-243, Pacific Northwest Laboratory, Richland, Washington.

Hanlon 1997, B.M. Hanlon, Waste Tank Summary Report for Month Ending August 31, 1997, HNF-EP-0182-113, Lockheed Martin Hanford Company, Richland, Washington, September 1997.

[1. Table E-1 summarizes the amount of waste in the tanks.]

[2. Appendix A provides the status of the tanks.]

Harris 1992, A.W. Harris, A. Atkinson, and P.A. Claisse, "Transport of Gases in Concrete Barriers," Waste Management, 12:155-178, 1992.

Haworth 1988, A. Haworth, S.M. Sharland, P.W. Tasker, and C.J. Tweed, A Guide to the Coupled Chemical Equilibria and Migration Code CHEQMATE, UK Nirex Lid. Report NSS/R113, United Kingdom, 1988. 


\section{DOE/RL-97-69}

Rev. 0

HFSUWG 1992a, The Future for Hanford: Uses and Cleanup, Summary of the Final Report of the Hanford Future Site Uses Working Group, Document number 0026618 ,

December 1992. This report is available through the Environmental Data Management Center, Lockheed Martin Services, Incorporated, Richland, Washington.

[1. Page 9 discusses use the central plateau wisely for waste management.]

[2. Page 23 discusses the future use options of the 200 Areas.]

[3. Page 25 discusses the cleanup scenario.]

HFSUWG 1992b, The Future for Hanford: Uses and Cleanup, the Final Report of the Hanford Future Site Uses Working Group, Document number 0026619, December 1992. This report is available through the Environmental Data Management Center, Lockheed Martin Services, Incorporated, Richland, Washington.

Hoitinik 1994, D.J. Hoitinik and K.W. Burk, Climatological Data Summary 1993 with Historical Data, PNL-9809, Pacific Northwest Laboratory, Richland, Washington, 1994.

Honeyman 1995, letter to Mr. L. Erickson, "Peer Review Comments on Hanford Recharge Workshop: May 22-23, 1995," Letter 9554648, Westinghouse Hanford Company, Richland, Washington, September 1995. [The letter has the full report of the panel as an attachment.]

Huyakorn 1993, P.S. Huyakorn and S. Panday, VAM3DCG - Variably Saturated Analysis Model in Three Dimensions with Preconditioned Conjugate Gradient Matrix Solvers: Version 2.4b, Documentation and User's Guide, Hydrogeologic, Inc, Hernadon, Virginia, 1993.

Huyakorn 1994, P.S. Huyakorn and S. Panday, VAM3DCG - Variably Saturated Analysis Model in Three Dimensions with Preconditioned Conjugate Gradient Matrix Solvers:

Documentation and User's Guide, Version 3.1, Hydrogeologic, Inc, Hernadon, Virginia, February 1994.

ICRP 1977, International Commission on Radiological Protection, ICRP Publication 26, Pergamon Press, New York, New York, 1977.

Jenquin 1995, U. Jenquin, "Comments on Se-79 Half-Life ", memo, Pacific Northwest Laboratory, Richland, Washington, December 6, 1995.

Johnson 1993, V.G. Johnson, Groundwater Status Report, WHC-EP-0595, Westinghouse Hanford Company, Richland, Washington, March 1993.

Kaplan 1995a, D.I. Kaplan and R.J. Serne, Distribution Coefficient Values Describing Iodine, Neptunium, Selenium, Technetium, and Uranium Sorption to Hanford Sediments, PNL10379, Sup. 1, Pacific Northwest Laboratory, Richland, Washington, March 1995. [Also included as Appendix Q of Mann 1995a.] 
DOE/RL-97-69

Rev. 0

Kaplan 1995b, D.I. Kaplan, R.J. Serne, and M.G. Piepho, Geochemical Factors Affecting Radionuclide Transport Through Near and Far Fields at a Low-Level Waste Disposal Site, PNL-10379, Pacific Northwest Laboratory, Richland, Washington, March 1995. [Also included as Appendix P of Mann 1995a.]

Kaplan 1996, D.I. Kaplan, R.J. Serne, A.T. Owen, J. Conca, T.W. Wietsma, and T.L. Gervais, Radionuclide Adsorption Distribution Coefficients Measured in Hanford Sediments for the Low-Level Waste Performance Assessment Project, PNNL-11385, Pacific Northwest National Laboratory, Richland, Washington, August 1996.

KEHC 1991, Drawings for "Grout Vault Pair (218-E-16-102 \& 103)”, Drawing Number H-2-77573 for Project B-714, Kaiser Engineers Hanford Company, dated January 30, 1991.

Kemper 1966, W.D. Kemper and J.C. van Schaik, "Diffusion of Salts in Clay-Water Systems", Soil Sci. Am. Proc. 30:534-540, 1966.

Kennedy 1992, W.E. Kennedy and D.L. Strenge, Residual Radioactive Contamination from Decommissioning, Volume 1, NUREG/CR-5512, Pacific Northwest Laboratory, Richland, Washington, October 1992.

Kervevan 1994, C. Kervevan, R. Fabriol, A. Guillen, and J.-P. Sauty, "A Sequential-ParalleI Approach for Coupling Chemistry and Transport in Groundwater Quality Modelling," High-Performance Computing and Networking Proceedings, Volume I: Applications, eds W. Gentzch and U. Harms, Springer-Verlag, Berlin, Germany, 1994.

Khaleel 1995, R. Khaleel and E.J. Freeman, A Compilation of Hydrologic Properties for LowLevel Tank Waste Disposal Facility Performance Assessment, WHC-SD-WM-RPT-0165, Revision 0, Westinghouse Hanford Company, Richland, Washington, June 1995. [Also included as Appendix O in Mann 1995a.]

Khaleel 1997, R. Khaleel and J.F. Relyea, "Correcting Laboratory Measured Moisture Retention Data for Gravels”, Waster Resources Research, Vol. 33, 1875-1878, August 1997. 
Kincaid 1995, C.T. Kincaid, J.W. Shade, G.A. Whyatt, M.G. Piepho, K. Rhoads, J.A. Voogd, J.H. Westsik, Jr., K.A. Blanchard, and B.G. Lauzon, Performance Assessment of Grouted Double-Shell Tank Waste Disposal at Hanford, WHC-SD-WM-EE-004, Revision 1, Westinghouse Hanford Company, Richland, Washington, May 1995.

[1. Section 1.5.1, page 1.15 explains the reason for the selection of 10,000 years as the general time of compliance and of 500 years as the time of inadvertent intruder compliance.]

[2. Sections 3.4 .12 on page 3.69 and 3.4 .13 starting on page 3.70 describe the vadose zone hydrologic parameters.]

[3. Section 3.3.6.6 on page 3.62 describes the effective diffusion constant for the vadose zone.]

[4. Section 2.6 describes the Grout Disposal Facility.]

[5. The population along the Columbia River is found as footnote $f$ to Table 4.2 on page 4.12.]

[6. Appendix G.1 describes code selection.]

[7. Appendix $H$ describes the benchmarking of PORFLOW 2.394gr against TRACR3D.]

[8. The footnote to Table 3.20 uses a screen depth of 4.6 meter.]

Kincaid 1998, C.T. Kincaid, M.P. Bergeron, C.R. Cole, M.D. Freshley, D.L. Strenge, P.D. Thorne, L.W. Vail, and S.K. Wurnster, Composite Analysis for the Low-Level Waste Disposal in the 200 Area Plateau of the Hanford Site, PNNL-11800, Pacific Northwest National Laboratory, Richland, Washington, expected to be published March 1998.

Kline 1983, N.W. Kline, A.K. Runchal, and R.G. Baca, PORFLO Computer Code: Users Guide, RHO-BW-CR-138P, Rockwell Hanford Operations, Richland, Washington, December 1983.

Kline 1995a, N.W. Kline and R. Khaleel, "Effect of Moisture-Dependent Anisotropy and Enhanced Recharge Around Underground Storage Tanks," Proceedings of the International Conference on Mathematics and Computations, Reactor Physics, and Environmental Analyses, pp. 181-191, American Nuclear Society, Inc., La Grange Park, IL; also WHC-SA-2680-FP, Westinghouse Hanford Company, Richland, Washington, 1995.

Kline 1995b, N.W. Kline, Development of a Unit Cell Model for Interim Performance Assessment of Vitrified Low Level Waste Disposal, WHC-SD-WM-RPT-189, Revision 1, Westinghouse Hanford Company, Richland, Washington, September 1995.

Kline 1996, N.W. Kline, Unit Cell Modeling in Support of the Interim Performance Assessment for Low Level Tank Waste Disposal, WHC-SD-WM-RPT-225, Rev. 0, Westinghouse Hanford Company, Richland, Washington, August 1996.

Kocher 1981, D.C. Kocher, Radioactive Decay Data Tables, DOE/TIC-11026, U.S. Government Printing Office, Washington, D.C. 1981. 


\section{DOE/RL-97-69 \\ Rev. 0}

Kozak 1989, M.W. Kozak, M.S.Y. Chu, C.P. Harlan, and P.A. Mattingly, Background Information for the Development of a Low-Level Waste Performance Assessment Methodology, NUREG/CR-5453 [SAND89-2509], Volume 4 (Section 2.0), U.S. Nuclear Regulatory Commission, Washington, D.C., 1989.

Kramer 1989, S.L. Kramer and R.D. Holtz, Experimental Investigation of Seismically-Induced Particle Migration, contained in letter from R.D. Holtz to P.L. Brockman, University of Washington, Seattle, Washington, August 1989.

Krupka 1995, K.M. Krupka and R.J. Serne, Performance Assessment of Low-Level Radioactive Waste Disposal Facilities: Effects on Radionuclide Concentrations by Cement/GroundWater Interactions, NUREG/CR-6637, U.S. Nuclear Regulatory Commission, Washington, DC, May 1995.

[Table 5.1 provides $\mathrm{K}_{\mathrm{d}}$ values for selected radionuclide elements for concrete environments.]

Kupfer 1997, M.J. Kupfer, A.L. Boldt, B.A. Higley, K.M. Hodgson, L.W. Shelton, B.C.

Simpson, R.A. Watrous, M.D. LeClair, G.L. Borsheim, R.T. Winward, R.M. Orme, N.G. Colton, S.L. Lambert, D.E. Place, and W.W. Schulz, Standard Inventories of Chemicals and Radionuclides in Hanford Site Tank Wastes, HNF-SD-WM-TI-740, Rev. 0 , Lockheed Martin Hanford Corporation, Richland, Washington, August 1997.

Law 1996, A. Law, S. Panday, C. Denslow, K. Fetch, A. Knepp, Hanford Sitewide Groundwater Flow and Transport Model Calibration Report, BHI-00608, Rev. 0, Bechtel Hanford Inc., Richland, Washington, April 1996. Further work on calibration has been done and has been documented as Rev. 1, issued in September 1997.

LMHC 1998, "Quality Assurance Program Plan," HNF-IP-0842, Volume XI, Section 1.1, Revision 0, Lockheed Martin Hanford Company, Richland, Washington, January 1998.

Lindberg 1993, J.W. Lindberg, J.V. Borghese, B.N. Bjornstad, and M.P. Connelly, Geology and Aquifer Characteristics of the Grout Treatment Facility, WHC-SD-EN-TI-071, Rev. 0, Westinghouse Hanford Company, Richland, Washington, January 1993.

[Paper is reproduced as Appendix C of Kincaid 1995].

Lindsey 1989, K.A. Lindsey and D.R. Gaylord, Sedimentology and Stratigraphy of the MiocenePliocene Ringold Formation, Hanford Site, South-Central Washington, WHC-SA-0740-FP, Westinghouse Hanford Company, Richland, Washington, 1989.

Lindsey 1991, K.A. Lindsey, Revised Stratigraphy for the Ringold Formation, Hanford Site, South-central Washington, WHC-SD-EN-EE-004, Revision 0, Westinghouse Hanford Company, Richland, Washington, 1991.

Lindsey 1992, K.A. Lindsey, B.N. Bjornstad, J.W. Lindberg, and K.M. Hoffmann, Geologic Setting of the 200 East Area: An Update, WHC-SD-EN-TI-012, Rev. 0, Westinghouse Hanford Company, Richland, Washington, 1992. 


\section{DOE/RL-97-69}

Rev. 0

Lowe 1993, S.S. Lowe, W.C. Carlos, J.J. Irwin, R. Khaleel, N.W. Kline, J.D. Ludowise, R.M. Marusich, and P.D. Rittmann, Engineering Study of Tank Leaks Related to Hydraulic Retrieval of Sludge from Tank 241-C-106, WHC-SD-WM-ES-218, Revision 1, Westinghouse Hanford Company, Richland, Washington, June 1993.

Lu 1993, A.H. Lu and R. Khaleel, "Calibration/Validation of VAM3D Model Using Injection Test Data at Hanford," in Vadose Zone Modeling Workshop Proceedings, March 29-30, 1993, R. Khaleel (ed.), p. 99 - 111, WHC-MR-0420, Westinghouse Hanford Company, Richland, Washington, August 1993.

Lu 1994, A.H. Lu and D.W. Langford, Verification and Benchmark Testing of the VAM3D-CG Flow and Transport Code for Use in Performance Assessment at Hanford, WHC-SDER-CSWD-005, Westinghouse Hanford Company, Richland, Washington, July 1994.

Lu 1995, A.H. Lu and D.W. Langford, Verification and Benchmark Testing of Version 3.1 of the VAM 3DCG Flow and Transport Computer Code for Use in Performance Assessment at Hanford, WHC-SD-ER-CSWD-007, Westinghouse Hanford Company, Richland, Washington, 1995.

Lu 1996, A.H. Lu, Contaminant Transport in the Unconfined Aquifer, Input to the Low Level Tank Waste Interim PA, WHC-SD-WM-RPT-241, Westinghouse Hanford Company, Richland, Washington, June 1996.

Lytle 1995, Headquarters Review of the "Performance Assessment of Grouted Double-Shell Tank Waste at Hanford, "memorandum from J.L. Lytle to J. Kinzer, U.S. Department of Energy, Washington, D.C., June 1, 1995.

MacKinnon 1994, R.J. MacKinnon, T.M. Sullivan, C.J. Suen, and S.A. Simonson, BLT-EC (Breach, Leach, Transport, and Equilibrium Chemistry), a Finite Element Model for Assessing the Release of Radionuclides from Low-Level Waste Disposal Units: Background, Theory, and Model, Description, Brookhaven National Laboratory, Upton, New York, 1994.

Magnuson 1990, S.O. Magnuson, K.G. Baca, and A.J. Sondrup, Independent Verification and Benchmark Testing of the PORFLO-3 Computer Code, Version 1.0, EGG-86-9175, EG\&G Idaho, Inc., Idaho Falls, Idaho, 1990.

Mangold 1991, D.C. Mangold and C.F. Tsang, "A Summary of Subsurface Hydrological and Hydrochemical Models" Review of Geophysics, Vol. 29, 51-79, 1991. 


\section{DOE/RL-97-69}

Rev. 0

Mann 1995a, F.M. Mann, Data Packages for the Hanford Low-Level Tank Waste Interim Performance Assessment, WHC-SD-WM-RPT-166, Revision 0, Westinghouse Hanford Company, Richland, Washington, July 1995.

Mann 1995b, F.M. Mann, C.R. Eiholzer, R. Khaleel, N.W. Kline, A.H. Lu, B.P. McGrail, P.D. Rittmann, and F. Schmittroth, Definition of the Base Analysis Case of the Interim Performance Assessment, WHC-SD-WM-RPT-200, Revision 0, Westinghouse Hanford Company, Richland, Washington, December 1995.

Mann 1995c, F.M. Mann, Computer Code Selection Criteria and Considerations for the Hanford Tank Low-Level Waste Interim Performance Assessment, WHC-SD-WMCSWD-073, Westinghouse Hanford Company, Richland, Washington, March 1995. [Also included as Appendix D in Mann 1995a.]

Mann 1995d, F.M. Mann, C.R. Eiholzer, N.W. Kline; B.P. McGrail, and M.G. Piepho, Impacts of Disposal System Design Options on Low-Level Glass Waste Disposal System Performance, WHC-EP-0810, Revision 1, Westinghouse Hanford Company, Richland, Washington, September 1995.

Mann 1996a, F.M. Mann, C.R. Eiholzer, A.H. Lu, P.D. Rittmann, N.W. Kline, Y. Chen, B.P. McGrail, G.F. Williamson, and N.R. Brown, Hanford Low-Level Tank Waste Interim Performance Assessment, WHC-EP-0884, Rev. 0, Westinghouse Hanford Company, Richland, Washington, September 1996.

Mann 1996b, F.M. Mann, INTEG: A Program to Calculate Groundwater Contamination and Human Doses, WHC-SD-WM-RPT-219, Westinghouse Hanford Company, Richland, Washington, June 1996.

Mann 1997a, F.M. Mann, C.R. Eiholzer, A.H. Lu, P.D. Rittmann, N.W. Kline, Y. Chen, B.P. McGrail, G.F. Williamson, J.A. Voogd, N.R. Brown, and P.E. LaMont, Hanford LowLevel Tank Waste Interim Performance Assessment, HNF-EP-0884, Rev. 1, Project Hanford Management Contractor, Richland, Washington, September 1997.

Mann 1997b, F.M. Mann, Statements of Work for FY 1998 to 2003 for the Hanford Low-Level Tank Waste Performance Assessment Project, HNF-SD-WM-PAP-062, Revision 2, Lockheed Martin Hanford Company, Richland, Washington, June 1997.

[1. Section 1.2.C.iv describes plans for recharge rate determination.]

[2. Section 1.2.C.ii describes the integrated borehole activity. Other activities described in the SOW will obtain samples from these boreholes.]

McDonald 1988, M.G. McDonald and A.W. Harbaugh, "A Modular Three-Dimensional Finite Difference Groundwater Flow Model," Techniques of Water Resources Investigations, 06-A1, United States Geological Survey, Washington, D.C., 1988. 
DOE/RL-97-69

Rev. 0

McGrail 1994, B.P. McGrail and L.A. Mahoney, Selection of a Computer Code for Hanford Low-Level Waste Engineered-System Performance Assessment, PVTD-C95-04-01E, Revision 1, Pacific Northwest Laboratory, Richland, Washington, December 1994. [Also included as Appendix G in Mann 1995a]

McGrail 1995, B.P. McGrail and D.K. Peeler, Evaluation of the Single-Pass Flow-Through Test to Support a Low-Activity Waste Specification, PNL-10746, Pacific Northwest Laboratory, Richland, Washington, September 1995.

McGraw 1997, M.A. McGraw and D.I. Kaplan, Colloid Suspension Stability and Transport Through Unsaturated Porous Media, PNNL-11565, Pacific Northwest National Laboratory, Richland, Washington, April 1997.

Mitchell 1995, D.E. Mitchell, Immobilized Low-Level Waste Disposal Options Configuration Study, WHC-SD-WM-TI-686, Revision 0, Westinghouse Hanford Company, Richland, Washington, February 1995.

Mualem 1976, Y. Mualem, "A New Model for Predicting the Hydraulic Conductivity of Unsaturated Porous Media," Water Resources Research, 12 (1976) 513.

Murkowski 1995, letter from R.J. Murkowski to L. Erickson, "Performance Objectives and Scenario for the Glass Low-Level Waste Interim Performance Assessment," Correspondence Number 9550371, Westinghouse Hanford Company, Richland, Washington, January 27, 1995.

Myers 1979, C.W. Myers, S.M. Price, J.A. Caggiano, M.P. Cochran, W.J. Czimer, N.J. Davidson, R.C. Edwards, K.R. Fecht, G.E. Holmes, M.G. Jones, J.R. Kunk, R.D. Landon, R.K. Ledgerwood, J.T. Lillie, P.E. Long, T.H. Mitchell, E.H. Price, S.P. Reidel, and A.M. Tallman, Geologic Studies of the Columbia Plateau: A Status Report, RHO-BWI-ST-4, Rockwell Hanford Operations, Richland, Washington, October 1979.

Myers 1981, C.W. Myers and S.M. Price. "Bedrock Structure of the Cold Creek Syncline Area," in Subsurface Geology of the Cold Creek Syncline, RHO-BWI-ST-14 [see Tallman 1981], Rockwell Hanford Operations, Richland, Washington, July 1981.

Myers 1994, D.R. Myers and D.A. Duranceau, Prototype Hanford Surface Barrier: Design Bases Document, BHI-0007, Bechtel Hanford Company, Richland, Washington, November 1994.

Napier 1984, B.A. Napier, R.A. Peloquin, W.E. Kennedy Jr., and S.M. Neuder, Intruder Dose Pathway Analysis for the Onsite Disposal of Radioactive Wastes: The ONSITE/MAXII Computer Program, NUREG/CR-3620, U.S. Nuclear Regulatory Commission, Washington, DC, 1984. 


\section{DOE/RL-97-69}

Rev. 0

Napier 1988, B.A. Napier, R.A. Peloquin, D.L. Strenge, and J.V. Ramsdell, GENII - The Hanford Environmental Radiation Dosimetry Software System, PNL-6584, Pacific Northwest Laboratory, Richland, Washington, December 1988.

NCRP 1987, Ionizing Radiation Exposure of the Population of the United States, Report No. 93, National Council on Radiation Protection, Bethesda, Maryland, 1987.

NEPA, National Environmental Policy Act of 1969, 42 U.S.C. 4321 et seq, 1969.

Newcomb 1958, R.C. Newcomb, "Ringold Formation of the Pleistocene Age in the Type Locality, the White Bluffs, Washington," American Journal of Science, 33(1):328-340.

Newcomb 1972, R.C. Newcomb, J.R. Strand, and F.J. Frank, Geology and Groundwater Characteristics of the Hanford Reservation of the U.S. Atomic Energy Commission, Washington, Geological Survey Professional Paper 717, U.S. Geological Survey, Washington, D.C. 1972.

NLLWMP 1992, Proceedings of the Department of Energy Performance Assessment Briefing, Denver, Colorado, October 29, 1991, DOE/LLW-138, National Low-Level Waste Management Program, Idaho National Engineering Laboratory, Idaho Falls, Idaho, February 1992.

Noorishad 1987, J. Noorishad, C.L. Carnahan, and J.V. Benson, Development of the NonEquilibrium Reactive Chemical Transport Code CHMTRNS, LBL-22361, Lawrence Berkeley Laboratory, Berkeley, California, 1987.

NRC 1997, Branch Technical Position on a Performance Assessment Methodology for Low-

Level Radioactive Waste Disposal Facilities (draft for public comment). NUREG-1573.

Low-Level Waste Management Branch, U.S. Nuclear Regulatory Commission, Washington, D.C., May 1997.

[1. Section 3.2.3 describes the time frame for performance assessment analyses.]

[2. Sections 3.2.2 and 3.3.4 discusses the role and timing assumptions for engineered systems.]

[3. Section 3.2.1.2 discusses site conditions to be used in performance assessment]

OFM 1994, Office of Financial Management, 1994 Population Trend for Washington State, Office of Financial Management, Forecasting Division, Olympia, Washington, 1994.

PAG 1994, Hanford Tank Low-Level Waste Performance Assessment Group, Statements of Work for FY 1995 to 2000, WHC-SD-WM-PAP-062, Revision 0, Westinghouse Hanford Company, Richland, Washington, June 1994. 


\section{DOE/RL-97-69 \\ Rev. 0}

Paperiello 1997, C.J. Paperiello (Director of Office of Nuclear Material Safety and Safeguards), letter dated June 1997 to Jackson Kinzer (Assistant Manager, Office of Tank Waste Remediation Systems) "Classification of Hanford Low-Activity Tank Waste Fraction", U.S. Nuclear Regulatory Commission, Washington, D.C.

\{Letter is given in Appendix F.2.3\}.

PAT 1994, Performance Assessment Team, Performance Objectives of the Tank Waste Remediation Systems Low-Level Waste Disposal Program, WHC-EP-0826, Revision 0, Westinghouse Hanford Company, Richland, Washington, December 1994.

PAT 1995a, Performance Assessment Team, Performance Objectives of the Tank Waste Remediation Systems Low-Level Waste Disposal Program, WHC-EP-0826, Revision 1, Westinghouse Hanford Company, Richland, Washington, January 1995. [Included as Appendix B in Mann 1995a.]

PAT 1995b, Performance Assessment Team, Scenarios of the TWRS Low-Level Waste Disposal Program, WHC-EP-0828, Revision 1, Westinghouse Hanford Company, Richland, Washington, January 1995. [Included as Appendix C in Mann 1995a.]

Petersen 1995, C.A. Petersen, "Radionuclide Solubility," DSI to G.F. Williamson, Westinghouse Hanford Company, Richland, Washington, November 27, 1995.

Pickett 1997, W.W. Pickett, Immobilized Low-Activity Waste Interim Storage Facility, Project W-465 Conceptual Design Report, HNF-1975, Rev. 0, Fluor Daniel Northwest Company, Richland, Washington, December 1997.

Piepho 1991, M.G. Piepho and A.K. Runchal, "A Comparison of Three Methods for Solving Flow Equations of Two Immiscible Fluids in Variably Saturated Media," Proceedings of the Third Symposium on Multiphase Transport in Porous Media, American Society of Mechanical Engineers; also WHC-SA-1289-FP, Westinghouse Hanford Company, Richland, Washington, 1991.

Piepho 1994, M.G. Piepho, W.H. Sutherland and P.D. Rittmann, The Grout/Glass Performance Assessment Code System (GPACS) with Verification and Benchmarking, WHC-SD-WMUM-019, Revision 0, Westinghouse Hanford Company, Richland, Washington, December 1994. [Also included as Appendix F in Mann 1995a.]

Piepho 1995, M.G. Piepho, Selection of Flow and Transport Code for the Hanford Low-Level Tank Waste Interim Performance Assessment, WHC-SD-WM-CSWD-074, Revision 0, Westinghouse Hanford Company, Richland, Washington, February 1995.

[Also included as Appendix $\mathrm{E}$ in Mann 1995a.]

Piepho 1996, M.G. Piepho, Low-Level-Vitrification-Waste Performance Assessment Flow and Transport Modelling, DBSA-PNWB-967-42, Daniel B. Stevens \& Associates, Inc., Richland, Washington, May 1996. 
DOE/RL-97-69

Rev. 0

PNL 1994, Quality Assurance Plan, PNL-MA-70, Pacific Northwest Laboratory, Richland, Washington, August 1994.

Power 1981, M.S. Power, K.J. Coppersmith, R.R. Youngs, D.P. Schwratz, and F.H. Swam III, Final Safety Analysis Report WNP-2, Amendment N.18, Appendix 2.5K, "Seismic Exposure Analysis for the WNP-2 and WNP-1/4 Site," Washington Public Power Supply System, Richland, Washington, 1981.

Prych 1995, E.A. Prych, Estimating Deep Percolation Rates at Selected Locations on the USDOE Hanford Site, WA, Using Two Chloride-Tracer Methods, Open File 94-514, U.S. Geological Survey, Tacoma, Washington, 1995.

PSPL 1982, Skagit/Hanford Nuclear Project, Preliminary Safety Analysis Report, Vol. 4, App. 20, Amendment 23, Puget Sound Power and Light Company, Bellevue, Washington, 1982.

Rawlins 1994, J.A. Rawlins, R.A. Karnesky, R. Khaleel, A.H. Lu, F.M. Mann, B.P. McGrail, W.J. McMahon, M.G. Piepho, P.D. Rittmann, and F. Schmittroth, Impacts of Disposal System Design Options on Low.Level Glass Waste Disposal System Performance, WHC-EP-0810, Revision 0, Richland, Washington, September 1994.

RCRA, Resource Conservation and Recovery Act of 1976, 42 U.S.C. 6901, et seq.

Reeves 1994, M. Reeves, N.A. Baker, and J.O. Duguid, Review and Selection of Unsaturated Flow Models, B00000000-01425-2200-00001, Revision 0, INTERA, Inc., Las Vegas, Nevada, 1994.

Reidel 1989, S.P. Reidel and P.R. Hooper, editors, "Volcanism and Tectonism in the Columbia River Flood-Basalt Province," Special Paper 239, Geological Society of America, Boulder, Colorado, p. 386, plate 1, 1989.

Reidel 1993, S.P Reidel., V.G. Johnson and N.W. Kline, Groundwater Impact Assessment for the 216-U-17 Crib, 200 West Area, WHC-EP-0664, Westinghouse Hanford Company, Richland, Washington, June 1993.

Reidel 1995, S.P. Reidel, A.M. Tallman, V.G. Johnson, C.J. Chou, S.M. Narbutovski, and J.P. Kiesler, TWRS Complex Site Characterization Plan, Westinghouse Hanford Company, Richland, Washington, June 1995.

[Section 2.2 contains the geologic information for the new disposal facilities site and is reproduced as Appendix I of Mann 1995a].

Reidel 1997, S.P. Reidel, Characterization Plan for the Immobilized Low-Activity Waste Borehole, PNNL-11802, Pacific Northwest National Laboratory, Richland, Washington, December 1997. 


\section{DOE/RL-97-69 \\ Rev. 0}

Rhoads 1994, K. Rhoads, B.N. Bjornstad, R.E. Lewis, S.S. Teel, K.J. Cantrell, R.J. Serne, L.H. Sawyer, J.L. Smoot, J.E. Szecsody, M.S. Wigmosta, and S.K. Wumster, Estimation of the Release and Migration of Nickel Through Soils and Groundwater at the Hanford Site 218-E-12B Burial Ground, PNL-9791, Pacific Northwest Laboratory, Richland, Washington, 1994.

Rhoads 1996, Kathleen Rhoads, "HEDOP Review of LL Tank Waste PA", memo from K. Rhoads to Fred Mann, Pacific Northwest National Laboratory, Richland, Washington, September 1996.

Richards 1931, L.A. Richards, "Capillary Conduction of Liquids Through Porous Mediums," Physics, 1 (1931) 318.

Rittmann 1993, P.D. Rittmann, GRTPA - A Program to Calculate Human Dose from PORFLOW Output, WHC-SD-WM-UM-018, Westinghouse Hanford Company, Richland, Washington, November 1993.

Rittmann 1994, P.D. Rittmann, Dose Estimation for the Solid Waste Performance Assessment, WHC-SD-WM-TI-616, Westinghouse Hanford Company, Richland, Washington, August 1994.

Rittmann 1995, P.D. Rittmann, Data and Assumptions for Estimates of Radiation Doses for the Glass Low-Level Waste Interim Performance Assessment, WHC-SD-WM-TI-707, Revision 0, Westinghouse Hanford Company, Richland, Washington, June 1995. [Also included as Appendix R in Mann 1995a.]

Rockhold 1993, M.L. Rockhold, M.J. Fayer, and P.R. Heller, Physical and Hydraulic Properties of Sediments and Engineered Materials Associated with Grouted Double-Shell Tank Waste Disposal at Hanford, PNL-8813, Pacific Northwest Laboratory, Richland, Washington, September 1993. [Also Appendix J of Kincaid 1995.]

Rockhold 1995, M.L. Rockhold, M.J. Fayer, C.T. Kincaid, and G.W. Gee, Estimate of the Natural Ground Water Recharge for the Performance Assessment of a Low-Level Waste Disposal Facility at the Hanford Site, PNL-10508, Pacific Northwest Laboratory, Richland, Washington, March 1995. [Also included as Appendix K in Mann 1995a.]

Routson 1990, R.C. Routson and V.G. Johnson, "Recharge Estimates for the Hanford Site 200 Area Plateau," Northwest Science, 64:150-158, 1990.

Runchal 1979, A.K. Runchal and T. Maini, "Regional Groundwater Flow Near a High-Level Radioactive Waste Repository," Engineering Bulletin 50, pp. 11-20, Dames and Moore, 1979.

Runchal 1985, A.K. Runcal, B. Sagar, R.G. Baca, and N.W. Kline, PORFLO - A Continuum Model for Fluid Flow, Heat Transfer, and Mass Transport in Porous Media, RHO-BW-CR-150P, Rockwell Hanford Operations, Richland, Washington, 1985. 


\section{DOE/RL-97-69}

Rev. 0

Runchal 1992, A.K. Runchal, B. Sagar and N.W. Kline, PORFLO-3: A Mathematical Model for Fluid Flow, Heat, and Mass Transport in Variably Saturated Geologic Media; Users Manual, Version 1.2, WHC-EP-0385, Westinghouse Hanford Company, Richland, Washington, December 1992.

Rutherford 1997, W.A. Rutherford (Director, Site Infrastructure Division), letter 97-SID-285 to H.J. Hatch (President of Fluor Daniel Hanford, Inc.), "Contract DE-AC06-96RL113200 Approval of Tank Waste Remediation System Complex Site Evaluation Report", dated July 10, 1997, Department of Energy, Richland, Washington.

RWTSP 1994, A Compilation of DOE Performance Assessment Peer Review Panel Review Comments and Recommendations, DOE/LLW-216, Radioactive Waste Technical Support Program, Idaho National Engineering Laboratory, Idaho Falls, Idaho, 1994.

Sagar 1990, B. Sagar and A.K. Runchal, PORFLO-3: A Mathematical Model for Fluid Flow, Heat, and Mass Transport in Variably Saturated Geologic Media; Theory and Numerical Methods, Version 1.0, WHC-EP-0042, Westinghouse Hanford Company, Richland, Washington, March 1990.

Schreckhise 1993, R.G. Schreckhise, K. Rhoads, J.S. Davis, B.A. Napier, and J.V. Ramsdell, Recommended Environmental Dose Calculation Methods and Hanford Specific Parameters, PNL-3777, Rev. 2, Pacific Northwest Laboratory, Richland, Washington, 1993.

Schmittroth 1995a, F.A. Schmittroth and T.H. DeLorenzo, Consequence Ranking of Radionuclides in Hanford Tanks Waste, WHC-SD-WM-RPT-163, Revision 0, Westinghouse Hanford Company, Richland, Washington, September 1995.

Schmittroth 1995b, F.A. Schmittroth, T.H. DeLorenzo, D.W. Wootan, and D.Y. Garbrick, Inventories for Low-Level Tank Waste, WHC-SD-WM-RPT-164, Revision 0, Westinghouse Hanford Company, Richland, Washington, June 1995. [Also included as Appendix J in Mann 1995a.]

Serne 1990, R.J. Serne and M.I. Wood, Hanford Waste-Form Release and Sediment Interaction, A Status Report with Rationale and Recommendations for Further Studies, PNL-7297, Pacific Northwest Laboratory, Richland, Washington, May 1990.

Serne 1993, R.J. Serne, "Solid-Waste Leach Characteristics and Contaminant-Sediment Interactions, Volume 1: Batch Leach and Adsorption Tests and Sediment Characterization", PNL-8889, Vol. 1, Pacific Northwest Laboratory, Richland, Washington, 1993.

Shade 1997, J.W. Shade, TWRS Retrieval and Disposal Mission: Immobilized Low-Activity Waste Disposal Plan, HNF-1517, Rev. 0, Fluor Daniel Hanford, Inc., Richland, Washington, December 1997. 
Sheiton, 1995, L.W. Shelton, DSI to F. Schmittroth and A. L. Boldt, Westinghouse Hanford Company, Richland, Washington, May 22, 1995. [Attachment 1 to Schmittroth 1995b.]

Shord 1995, A.L. Shord, Tank Waste Remediation System Complex Site Evaluation Report, WHC-SD-WM-SE-021, Revision 0, Westinghouse Hanford Company, Richland, Washington, May 1995.

Simunek 1993, J. Simunek and D.L. Suarez, UNSATCHEM-2D Code for Simulating Saturated Water Flow, Heat Transport, Carbon Dioxide Production and Transport, and Multicomponent Solute Transport with Major Ion Equilibrium and Kinetic Chemistry, Research Report No. 128, U.S. Salinity Laboratory, Riverside, California, 1993.

Singleton 1994, K.M. Singleton and K.A. Lindsey, Groundwater Impact Assessment Report for the 216-U-14 Ditch, WHC-EP-0698, Westinghouse Hanford Company, Richland, Washington, January 1994.

Sisson 1984, J.B. Sisson and A.H. Lu, Field Calibration of Computer Models for Applications to Buried Liquid Discharges: A Status Report, RHO-ST-46p, Rockwell Hanford Company, Richland, Washington, August 1984.

Skaggs 1981, R. L. Skaggs and W. H. Walters, Flood Analysis of Cold Creek Near the Hanford Site, RHO-BWI-C-120/PNL-4219, Rockwell Hanford Operations, Richland, Washington, 1981.

Smith 1990, R.M. Smith and W.R. Gorst, RCRA Ground-Water Monitoring Projects for Hanford Facilities: Annual Progress Report for 1989, PNL-7215, Pacific Northwest Laboratory, Richland, Washington, 1990.

Stewart 1987, G.H. Stewart, W.T. Farris, D.G. Huizenga, A.H. McMakin, G.P. Streile, and R.L. Treat, Long-Term Performance Assessment of Grouted Phosphate/Sulfate Waste from $N$ Reactor Operations, PNL-6512, Pacific Northwest Laboratory, Richland, Washington, . April 1987.

Stone 1983, W.A. Stone, J.M. Thorp, O.P. Gifford, and D.J. Hoitink, Climatological Summary for the Hanford Area, PNL-4622, Pacific Northwest Laboratory, Richland, Washington, June 1983.

Strack 1989; O.D.L. Strack, Groundwater Mechanics, Prentice-Hall, Englewood Cliffs, New Jersey, 1989.

Tallman 1979, A.M. Tallman, K.R. Fecht, M.C. Marratt, and G.V. Last, Geology of the Separation Areas Hanford Site, South Central Washington, RHO-ST-23, Rockwell Hanford Operations, Richland, Washington, 1979. 


\section{DOE/RL-97-69}

Rev. 0

Tallman 1981, A.M. Tallman, J.T. Lillie, K.R. Fecht, C.W. Myers, and S.M. Price, "Suprabasalt Sediments of the Cold Creek Syncline Area," Subsurface Geology of the Cold Creek Syncline, RHO-BWI-ST-14, Rockwell Hanford Operations, Richland, Washington, 1981.

Thome 1992, P.D. Thome and D.R. Newcomer, Summary and Evaluation of Available Hydraulic Property. Data for the Hanford Site Unconfined Aquifer System, PNL-8337, Pacific Northwest Laboratory, Richland, Washington, November 1992.

Travis 1991, B.J. Travis and K.H. Birdsell, TRACR3D: A Model of Flow and Transport in Porous Media, LA-11798-M, Los Alamos National Laboratory, Los Alamos, New Mexico, 1991.

van Genuchten 1980, M.Th. van Genuchten, "A Closed Form Equation for Predicting the Hydraulic Conductivity of Unsaturated Soils," Journal of the American Soil Science Society, 44 (1980) 892 .

van Genuchten 1991, M.Th. van Genuchten, F.J. Leij, and S.R. Yates, The RETC Code for Quantifying the Hydraulic Functions of Unsaturated Soils, EPA/000/0-91/000, U.S. Environmental Protection Agency, Washington, D.C. 1991.

WAC 173-200, "Water Quality Standards for Ground Waters of the State of Washington," Washington State Administrative Code, 173-200, Section 170, Washington State Department of Ecology, Olympia, Washington, December 1, 1990.

WAC 173-201A, "Water Quality Standards for Surface Waters of the State of Washington," Washington State Administrative Code 173-201A, Washington State Department of Ecology, Olympia, Washington, December 22, 1992.

WAC 173-303, "Dangerous Waste Regulations", Washington State Administrative Code 173303, Washington State Department of Ecology, March 3, 1991.

WAC 173-480, "Ambient Air Quality Standards and Emission Limits for Radionuclides," Washington State Administrative Code 173-480, Section 040, Washington State Department of Ecology, Olympia, Washington, July 7, 1986.

WAC 246-247, "Radiation Protection - Air Emissions," Washington State Administrative Code 246-247, Section 040, Washington State Department of Ecology, Olympia, Washington, January 31, 1991.

Warrick 1976, A.W. Warrick and D.O. Homer, "Time Dependent Linearized Infiltration: III. Strip and Disc Sources," Science Soc. Amer. Proc. 40, 639-643, 1976.

Washenfelder 1997, "Contract Number DE-AC06-96RL13200; Completion of Milestone T24-97-158, Contractor Letter to Department of Energy, Richland Operations Office, Reporting Completion of Standard Inventory Estimates for All Tanks," letter FDH-9757750 from D.J. Washenfelder to J.K. McClusky, dated August 29, 1997. 


\section{DOE/RL-97.69}

Rev. 0

Watrous 1997, R.A. Watrous and D.W. Wootan, Activity of Fuel Batches Processed Through Hanford Separations Plants, 1944 Through 1989, HNF-SD-WM-T1-794, Rev. 0, Lockheed Martin Hanford Corporation, Richland, Washington, July 1997.

Watson 1984, E.C. Watson, C.D. Becker, R.E. Fitzner, K.A. Gano, K.L. Imhoff, R.F. McCallum, D.A. Myers, T.L. Page, K.R. Price, J.V. Ramsdell, D.G. Rice, D.L. Schreiber, L.A. Skumatz, D.J. Sommer, J.J. Tawil, R.W. Wallace, and D.G. Watson, Environmental Characterization of Two Potential Locations at Hanford for a New Production Reactor, PNL-5275, Pacific Northwest Laboratory, Richland, Washington, September 1984.

WCC 1989, Evaluation of Seismic Hazard for N-Reactor Facilities, Hanford Reservation, Hanford, Washington, WHC-MR-0023, Prepared for Westinghouse Hanford Company by Woodward-Clyde Consultants, Oakland, California.

Westsik 1997, J.H. Westsik, Jr. and P.L. Miller, "Preliminary Product Acceptance Strategy for ILAW, IHLW, Intermediate Products, and Secondary Wastes," WIT-097-036, Pacific Northwest National Laboratory, Richland, Washington, January 1997.

WHC 1990, Liquid Effluent Study Final Project Report, WHC-EP-0367, Westinghouse Hanford Company, Richland, Washington, August 1990.

WHC 1994, Overview of the Performance Objectives and Scenarios of the TWRS Low-Level Waste Disposal Program, WHC-EP-0827, Revision 0, Westinghouse Hanford Company, 'Richland, Washington, October 1994.

[Based on comments on Revision 0, Revision 1 was issued in January 1995. Revision 1 is included as Appendix A in Mann 1995a.]

WHC 1995, Scenarios of the TWRS Low-Level Waste Disposal Program, WHC-EP-0828, Revision 1, Westinghouse Hanford Company, Richland, Washington, January 1995. [Also included as Appendix C in Mann 1995a.]

WHC 1996, Technical Basis for Classification of Low-Activity Waste Function from Hanford Site Tanks, WHC-SD-WM-TI-699, Revision 1, Westinghouse Hanford Company, Richland, Washington, July 1996.

Wilhite 1994, Performance Assessment Peer Review Panel Recommendations on the "Performance Assessment of Grouted Double-Shell Tank Waste Disposal at Hanford" WHC-SD-WM-EE-004, Revision O (U), letter from E.L. Wilhite to J.A. Turi, SRT-WED-94-0112, Westinghouse Savannah River Company, Aiken, South Carolina, October 4, 1994.

Wolery 1992, T.J. Wolery, EQ3NR, A Computer Program for Geochemical Aqueous SpeciationSolubility Calculations: Theoretical Manual, User's Guide, and Related Documentation, UCRL-MA-110662-PT-III, Lawrence Livermore Laboratory, Livermore, California, 1992. 


\section{DOE/RL-97-69}

Rev. 0

Wood 1994a, D.E. Wood (Chairman), R.U. Curl (Technical Secretary), D.R. Armstrong, J.R. Cook, M.R. Dolenc, D.C. Kochner, K.W. Owens, E.P. Regnier, G.W. Roles, R.R. Seitz, and M.I. Wood, Performance Assessment Task Team Progress Report, DOE/LLW-157, Revision 1, Idaho National Engineering Laboratory, Idaho Falls, Idaho, May, 1994.

Wood, 1994b, M.I. Wood, R. Khaleel, P.D. Rittmann, A.H. Lu, S.H. Finfrock, R.J. Serne, and K.J. Cantrell, Performance Assessment for the Disposal of Low-Level Waste in the 200 West Area Burial Grounds, WHC-EP-0645, Westinghouse Hanford Company, Richland, Washington, November, 1994.

[1. Section 1.6 discusses the time of compliance.]

[2. P. 3-31 provides the discussion of the radon diffusivity coefficient.]

[3. Section 4.3.1 provides the calculation of the release of contaminants to air]

Wood 1995, M.I. Wood, R. Khaleel, P.D. Rittmann, A.H. Lu, S.H. Finfrock, and T.H. DeLorenzo, Environmental Remediation Disposal Facility Performance Assessment, BHI-00169, Revision 00, Bechtel Hanford Company, Richland, Washington, August 1995.

Wood 1996, M.I. Wood, Performance Assessment for the Disposal of Low-Level Waste in the 200 East Area Burial Grounds, WHC-EP-0875, Westinghouse Hanford Company, Richland, Washington, September 1996.

[1. Section 1.6 discusses the time of compliance.]

Woodruff 1992, R.K. Woodruff, R.W. Hanf, and R.E. Lundgren, Hanford Site Environmental Report for Calendar Year 1991, PNL-8148, Pacific Northwest Laboratory, Richland, Washington, 1992.

WSRC 1992, Radiological Performance Assessment for the Z-Area Saltstone Disposal Facility, WSRC-RP-92-1360 (Appendix B.10), Westinghouse Savannah River Company, Aiken, South Carolina, December 1992.

Wurstner 1995, S.K. Wurstner, P.D. Thorne, M.A. Chamness, M.D. Freshley, and M.D. Williams, Development of a Three-Dimensional Ground-Water Model of the Hanford Site Unconfined Aquifer System: FY 1995 Status Report, PNL-10886, Pacific Northwest National Laboratory, Richland, Washington, December 1995.

Yang 1986, Y. Yang and C.B. Nelson, "An Estimate of Daily Food Usage Factors for Assessing Radionuclide Intakes in the U.S. Population," Health Physics, $\underline{50}$ (1986) 245.

Yeh 1990, G.T. Yeh and V.S. Tripathi, HYDROGEOCHEM: A Coupled Model of Hydrologic Transport and Geochemical Equilibria in Reactive Multicomponent. Systems, DE91007825, Oak Ridge National Laboratory, Oak Ridge, Tennessee, 1990.

Yu 1993, R. Yu, J. Guo, and A. Cui, Chinese Joumal of Nuclear Radiochemistry, Vol. 15 (1993) 240. 
DOE/RL-97-69

Rev, 0

Zhang 1996, Shengdong Zhang, Jingru Guo, Anzhi Cui, Daming Li, and Daming Liu,

"Measurement of the Half-life of ${ }^{126} \mathrm{Sn}$ Using a Radiochemical Method", J. Radioanal. Nucl. Chem., Letters 212 (1996) 93. 
DOE/RL-97-69

Rev, 0

\section{APPENDIX A \\ SPECIFICATIONS FOR IMMOBILIZATION \\ (DOE/RL 1996)}

[References are given in Section 2.2.1

and not necessarily in Chapter 9.]

[These specifications have been incorporated into the contracts with British Nuclear Fuels Limited, Inc. (DE-RP06-96RL13308) and with Lockheed Martin Advanced Environmental Systems (DE-RP06-96RL13309)

Specification 2: Immobilized Low-Activity Waste

2.1 Scope: This Specification defines the requirements for the Immobilized Low-Activity Waste (ILAW) product, one of the final waste products identified in Section C.4 of this Statement of Work.

\subsection{Requirements:}

\subsubsection{References:}

2.2.1.1 10 CFR 61. Licensing Requirements for Land Disposal of Radioactive Waste, Code of Federal Regulations. U.S. Nuclear Regulatory Commission, Washington, D.C.

2.2.1.2 40 CFR 268. Land Disposal Restrictions. Code of Federal Regulations. U.S. Environmental Protection Agency, Washington, D.C.

2.2.1.3 49 CFR 172.101. Table 2-Radionuclides. Code of Federal Regulations. U.S. Department of Transportation, Washington, D.C.

2.2.1.4 49 CFR 173. Shippers-General Requirements for Shipments and Packaging. Subpart I - Radioactive Materials, Code of Federal Regulations. U.S. Department of Transportation, Washington, D.C.

2.2.1.5 ANSI Standard N14.5. January 16, 1987. American National Standard for Radioactive Materials - Leakage Tests on Packages for Shipment. American National Standards Institute, New York, New York.

2.2.1.6 ANSI/ANS-16.1. April 14, 1986. Measurement of the Leachability of Solidified Low-Level Radioactive Wastes by a Short Term Test Procedure. American National Standards Institute/American Nuclear Society, La Grange Park, Illinois.

2.2.1.7 ANSI/ANS-55.1. July 28, 1992. American National Standard for Solid Radioactive Waste Processing System for Light-Water-Cooled Reactor Plants; Appendix B - Testing for Free Liquids in Solidified Matrices. American National Standards Institute/American Nuclear Society, La Grange Park, Illinois.

2.2.1.8 ASTM B553-79. May 25, 1979. Standard Test Methods of Electroplated Plastics. American Society for Testing and Materials. Easton, Maryland. 
2.2.1.9 ASTM C39-94. November 15, 1994. Standard Test Method for Compressive Strength of Cylindrical Concrete Specimens. American Society for Testing and Materials, Easton, Maryland.

2.2.1.10 ASTM C1285-94. October 15, 1994. Standard Test Methods for Determining Chemical Durability of Nuclear Waste Glasses: Product Consistency Test $(P C T)$. American Society for Testing and Materials, Easton, Maryland.

2.2.1.11 ASTM G21-90. October 26, 1990. Standard Practice for Determining Resistance of Synthetic Polymeric Materials to Fungi. American Society for Testing and Materials. Easton, Maryland.

2.2.1.12 ASTM G22-76. November 26, 1976. Standard Practice for Determining Resistance of Plastics to Bacteria. American Society for Testing and Materials, Easton, Maryland.

2.2.1.13 DOE Order 5820.2A. September 26, 1988. Radioactive Waste Management. U.S. Department of Energy, Washington, D.C.

2.2.1.14 NRC. January 1995. Branch Technical Position on Concentration Averaging and Encapsulation. Division of Waste Management, Office of Nuclear Material Safety and Safeguards, U.S. Nuclear Regulatory Commission, Washington, D.C.

2.2.1.15 NRC. January 1991. Technical Position on Waste Form, Rev. 1, Low-Level Waste. Division Management Branch, Office of Nuclear Material Safety and Safeguards, U. S. Nuclear Regulatory Commission, Washington, D.C.

2.2.1.16 NUREG/BR-0204. April 1995. Instructions for Completing NRC's Uniform LowLevel Radioactive Waste Manifest. U.S. Nuclear Regulatory Commission, Washington, D.C.

2.2.1.17 NUREG-1293. Rev. 1. April 1991. Pittiglio, C. L., Jr., and D. Hedges. Quality Assurance Guidance for a Low-Level Radioactive Waste Disposal Facility. Division of Low-Level Waste Management and Decommissioning, Office of Nuclear Material Safety and Safeguards, U.S. Nuclear Regulatory Commission, Washington, D.C.

2.2.1.18 SW-846, Method 9095. Rev. 0. September 1986. Paint Filter Liquids Test. In Test Methods for Evaluating Solid Waste, Volume 1C: Laboratory Manual Physical/Chemical Methods, U.S. Environmental Protection Agency, Office of Solid Waste and Emergency Response, Washington, D.C.

2.2.1.19 WA 7890008967. Rev. 2. August 1995 (as modified). Dangerous Waste Portion of the Resource Conservation and Recovery Act Permit for the Treatment, Storage and Disposal of Dangerous Waste. Hanford Facility, Washington State Department of Ecology, Olympia, Washington.

2.2.1.20 WAC 173-303. 1995. Dangerous Waste Regulations, Washington Administrative Code, as amended. 


\section{DOE/RL-97-69 \\ Rev. 0}

\subsubsection{Product Requirements:}

2.2.2.1 Package Description: The ILAW products shall be in the form of a package. The constituent parts of each package are: a sealed metal container enclosing a waste form, in which the ILAW product is emplaced; an optional matrix material, which may be used to encapsulate the waste form; and an optional filler material, which may be used to fill void spaces in the container before it is closed.

2.2.2.2 Waste Loading: For every gram-mole of sodium provided to the Contractor in Waste Envelopes A and C, the Contractor may produce up to $100 \mathrm{~cm}^{3}$ of ILAW product (based on the external dimensions of the package). For every gram-mole of sodium in Waste Envelope B, the Contractor may produce up to $250 \mathrm{~cm}^{3}$ of ILAW product (based on the extemal dimensions of the package).

2.2.2.3 Size and Configuration: The package shall be a rectangular metal container and shall have an external dimension, including all appurtenances, of $1.8 \mathrm{~m}$ (length) $\mathrm{x}$ $1.2 \mathrm{~m}$ (width) $\times 1.2 \mathrm{~m}$ (height) $\pm 0.2 \mathrm{~m}$. Once a package size is selected, the dimension of all packages shall be constant and have a dimensional tolerance of $\pm 0.01 \mathrm{~m}$.

2.2.2.4 Mass: The mass of each package shall not exceed $10,000 \mathrm{~kg}$.

2.2.2.5 Void Space: The head space in the fully loaded package shall not exceed 1 percent of the total internal volume of the container. A non-compactible filler material (screened to 4 mesh size or smaller) may be used to meet this requirement. If the waste form and matrix materials are loaded into the container in a manner that results in void spaces between the emplaced pieces, the filler material shall be used to fill the void spaces. If a filler material is used, it shall be compatible with the other materials in the package.

2.2.2.6 Chemical Composition Documentation: The Contractor shall identify in the Products and Secondary Wastes Plan the chemical composition of the waste form, matrix material, and filler material for each package. The reported composition shall include elements (excluding oxygen) present in concentrations greater than 0.5 percent by weight. Crystalline and noncrystalline phases expected to be present shall be identified and the amount of each phase shall be estimated for the waste form, matrix material, and filler material.

2.2.2.7 Radiological Composition Documentation: The Contractor shall identify the individual package inventory of radionuclides that are significant as defined in NUREG/BR-0204 and 49 CFR 172.101 (Table 2), in the Products and

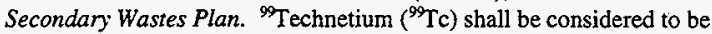
significant at concentrations greater than $0.003 \mathrm{Cj} / \mathrm{m}^{3}$ in the ILAW form. The inventories shall be indexed to the year 2000 . The documentation shall be consistent with the Radiological Description format described in NUREG/BR0204. 


\section{DOE/RL-97-69 \\ Rev. 0}

2.2.2.8 Radionuclide Concentration Limitations: The radionuclide concentration of the ILAW form shall be less than Class C limits as defined in 10 CFR 61.55 and as described in Branch Technical Position on Concentration Averaging and Encapsulation. In addition, the average concentrations of ${ }^{137} \mathrm{Cesium}\left({ }^{137} \mathrm{Cs}\right)$, ${ }^{90}$ Strontium $\left({ }^{90} \mathrm{Sr}\right)$, and ${ }^{99} \mathrm{Tc}$ shall be limited as follows: ${ }^{137} \mathrm{Cs}<3 \mathrm{Ci} / \mathrm{m}^{3},{ }^{90} \mathrm{Sr}<20$ $\mathrm{Ci} / \mathrm{m}^{3}$ and ${ }^{99} \mathrm{Tc}<0.3 \mathrm{Ci} / \mathrm{m}^{3}$. The average concentrations shall be calculated by adding the inventories of each of the above radionuclides in the packages that have been presented to date for acceptance and dividing by the total volume of waste in these packages.

2.2.2.9 Surface Dose Rate Limitations: The dose rate at any point on the external surface of the package shall not exceed $1,000 \mathrm{mRem} / \mathrm{hr}$.

2.2.2.10 Surface Contamination Limitations: Removable contamination on the extemal surfaces of the package shall not exceed $367 \mathrm{~Bq} / \mathrm{m}^{2}$ for alpha and $3670 \mathrm{~Bq} / \mathrm{m}^{2}$ for beta-gamma contamination when measured using the method described in 49 CFR 173.443(a).

2.2.2.11 Labeling and Manifesting: Each package shall have a label attached or stamped on the outer surfaces of at least two sides of the container in a readily accessible location. The label shall contain a unique identification (e.g., serial number) which shall be assigned to each package and the corresponding documentation. Labels and markings shall have a predicted service life of 50 years assuming that the packages are stored in a ventilated enclosure at ambient temperatures.

The Contractor shall prepare a shipping manifest for delivery with each shipment of ILAW product. Information on the manifest shall satisfy the requirements in DOE Order 5820.2A, Chapter III, Section 3.d, and NUREG/BR-0204. Any package containing dangerous waste must be labeled and manifested in accordance with WAC 173-303-370 and the Dangerous Waste Portion of the Resource Conservation and Recovery Act Permit for the Treatment, Storage, and Disposal of Dangerous Wastes (Permit No. WA 7890008967).

2.2.2.12 Closure and Sealing: The fully loaded package shall be closed, sealed, and a Tamper Indicating Device applied. The closure system shall be leak tight as defined by ANSI Standard N14.5. The closure system shall be designed to ensure that the seal remains intact for a storage period of 50 years in an ambienttemperature, ventilated enclosure.

2.2.2.13 External Temperature: The temperature of the accessible external surfaces of the package shall not exceed $50^{\circ} \mathrm{C}$ when returned to DOE. This temperature constraint shall assume a shaded, still air environment at an ambient temperature of $38^{\circ} \mathrm{C}$.

2.2.2.14 Free Liquids: The package shall contain no detectable free liquids as prescribed in ANSI/ANS-55.1 or SW-846 Method 9095. 


\section{DOE/RL-97-69 \\ Rev. 0}

2.2.2.15 Pyrophoricity or Explosivity: The package contents shall not be pyrophoric, readily capable of detonation, or readily capable of explosive decomposition or reaction (including reaction with water) at normal pressure and temperature. The waste form and any optional matrix and filler materials shall not be ignitable or reactive as defined in WAC 173-303-090(5) and WAC 173-303-090(7).

2.2.2.16 Explosive or Toxic Gases: The package shall not contain or be capable of generating quantities of explosive (e.g., hydrogen) or toxic gases, vapors, or fumes harmful to persons handling the waste.

2.2.2.17 Radionuclide Release Rate: The average fractional release rates for the waste form or waste form/matrix combination shall be the following: For ${ }^{9 \%} \mathrm{Tc}$, the average fractional release rate $\left(R_{T}\right)$ shall be less than $2.8 \mathrm{E}-14\left(\mathrm{~s}^{-1}\right)$; and for, ${ }^{79}$ Selenium $\left({ }^{79} \mathrm{Se}\right),{ }^{129} \mathrm{Iodine}\left({ }^{129} \mathrm{I}\right),{ }^{237} \mathrm{Neptunium}\left({ }^{237} \mathrm{~Np}\right)$, and uranium isotopes, the average fractional release rate $(\mathrm{R})$ shall be less than $1.4 \mathrm{E}-13\left(\mathrm{~s}^{-1}\right)($ see Sections 2.2.2.17.1 and 2.2.2.17.2). The basis for fractional release rate determination shall be the radionuclide inventory remaining in the liquid fraction of waste processed following solid separation.

2.2.2.17.1 Silicate Glass Waste Forms: For silicate glass waste forms, compliance with the fractional release rate requirements shall be established by showing that the average value of the product of the glass corrosion rate, the glass surface area to volume ratio, and the fraction of the processed inventory of technetium that is solidified in the glass satisfies the following constraints:

$$
\begin{aligned}
\text { Equation TS 2.1 } & R_{T C}=\left(\frac{C_{g}}{\rho}\right) \times\left(\frac{s_{g}}{V_{8}}\right) \times F<.2 .8 E-14\left(s^{-1}\right) \\
\text { Equation TS 2.2 } & R=\left(\frac{C_{g}}{\rho}\right) \times\left(\frac{s_{g}}{V_{8}}\right)<1.4 E-13\left(s^{-1}\right)
\end{aligned}
$$

where:

$\mathrm{C}_{\mathrm{B}}$ is the corrosion rate of the glass $\left(\mathrm{kg} /\left(\mathrm{m}^{2}-\mathrm{s}\right)\right)$

$\rho$ is the glass density $\left(\mathrm{kg} / \mathrm{m}^{3}\right)$

$S_{8}$ is the surface area of the glass in the package that is available for corrosion $\left(\mathrm{m}^{2}\right)$

$\mathrm{V}_{g}$ is the glass volume in the package $\left(\mathrm{m}^{3}\right)$

$F$ is the fraction of the soluble inventory (residual inventory in the solution after solid/liquid separation) of technetium that is solidified in the glass. $\mathrm{F}$ is calculated by dividing the technetium inventory solidified in each package by the average inventory to date of technetium processed per package. F shall be estimated by either sampling and analyzing the feed and glass products or from process knowledge. 


\section{DOE/RL-97-69 \\ Rev. 0}

The average values for $R$ and $R_{\pi c}$ shall be calculated by maintaining a running summation of the $R$ and $R_{T C}$ values of the packages presented to date for acceptance (excluding any that have not been accepted) and dividing by the number of packages accepted to date.

The corrosion rate $\left(C_{\varepsilon}\right)$ shall be the average rate determined to occur at $20^{\circ} \mathrm{C}$ over a period of 7 -days when statistical product inventory information of the waste form is tested using the Product Consistency Test (PCT) (ASTM C1285-94). The $20^{\circ} \mathrm{C}$ rates shall be determined as follows:

- The normalized release of sodium, silicon, and boron (if present as a constituent in the glass) shall be measured using a 7-day PCT run at $20^{\circ} \mathrm{C}$ (ASTM C1285-94). Alternatively, the normalized releases may be measured at any temperature in the range of $20^{\circ} \mathrm{C}$ to $90^{\circ} \mathrm{C}$ provided the Contractor develops and applies an empirical correlation to relate the elevated temperature results to those at $20^{\circ} \mathrm{C}$.

- The normalized release of $\mathrm{Si}$ shall be used to calculate the average corrosion rate of the glass $\left(\mathrm{kg} /\left(\mathrm{m}^{2}-\mathrm{s}\right)\right)$ over the 7-day test period. Secondary mineral formation and phase separation shall not affect the PCT.

The surface area to volume ratio $\left(S_{g} N_{g}\right)$ of the glass product shall be the average surface area to volume ratio of the products expected based on information obtained from destructive examination of prototypical non-radioactive products produced during product qualification.

2.2.2.17.2 Waste Forms Other Than Silicate Glass: The Contractor shall identify how the fractional release rates, $R_{\mathrm{TC}}$ and $\mathrm{R}$, are to be determined for waste forms and waste form/matrix combinations other than silicate glass if applicable. The Contractor shall be responsible for identifying an appropriate approach and testing method to show that the waste form products proposed will meet or exceed the specified radionuclide release requirements when immersed in deionized water at $20^{\circ} \mathrm{C}$. The approach and testing methods do not necessarily require direct measurement of the radionuclides identified in this specification; measurement of a waste form characteristic (e.g., the corrosion rate for silicate glass waste forms) to which the radionuclide release rate can be related may be more appropriate.

2.2.2.18 Compressive Strength: The Contractor shall determine the mean compressive strength of the waste form (and any optional matrix and filler materials) by testing representative non-radioactive samples. The compressive strength shall be at least $3.45 \mathrm{E} 6 \mathrm{~Pa}$ when tested in accordance with ASTM C39-94 or an equivalent testing method. 


\section{DOE/RL-97-69 \\ Rev. 0}

2.2.2.19 Thermal, Radiation, Biodegradation and Immersion Stability: The ILAW product shall be resistant to thermal, radiation, biodegradation and immersion degradation, as described in NRC Technical Position on Waste Form. Resistance to each of these types of degradation shall be established by showing that the mean compressive strength of representative samples shall be equal to or greater than 3.45E06 $\mathrm{Pa}$ and not less than 75 percent of the initial compressive strength after subjecting the samples to the following:

2.2.2.19.1 Thermal degradation: 30 thermal cycles between a high of $60^{\circ} \mathrm{C}$ and a low of $-40^{\circ} \mathrm{C}$ in accordance with the ASTM B553-79 or an equivalent testing method.

2.2.2.19.2 Radiation degradation: Exposure to a minimum radiation dose of $1.0 \mathrm{E} 08 \mathrm{rad}$ or to a dose equivalent to the maximum level of exposure expected from self-irradiation during storage, transportation and disposal if this is greater than 1.0E08 rad.

2.2.2.19.3 Biodegradation: No evidence of culture growth when representative samples are tested in accordance with ASTM G21-90, ASTM G22-76, or equivalent methods.

2.2.2.19.4 Immersion degradation: Immersion for 90 days under the ANSI/ANS16.1 testing conditions.

2.2.2.20 Waste Form Leach Testing: The waste form shall have a sodium leachability index greater than 6.0 when tested for 90 days in deionized water using the ANSI/ANS-16.1 procedure.

2.2.2.21 Dangerous Waste Limitations: The ILAW product shall be acceptable for land disposal under the State of Washington Dangerous Waste Regulations, WAC 173-303 and 40 CFR 268. The Contractor shall perform sampling and testing necessary to support designation of the ILAW product for dangerous waste characteristics, dangerous waste criteria and dangerous waste sources as specified in WAC 173-303-070. Information needed to show that the treated waste in the ILAW product is not prohibited from land disposal pursuant to WAC 173-303-140 and 40 CFR 268 shall be provided by the Contractor. Also, information specified in WAC 173-303-072 to pursue an exemption or categorical exclusion from the dangerous waste requirements shall be provided by the Contractor in the Products and Secondary Wastes Plan. The sampling, preparation and testing methods shall conform to the requirements in WAC 173303-110.

2.2.2.22 Compression Testing: Each fully loaded package shall be able to withstand a compression load of $50,000 \mathrm{~kg}$ force. Compliance with this specification shall be established by using the compression test described in 49 CFR 173.465(d). The Contractor shall demonstrate the integrity of the package by showing that the dimensions of the tested packages are within the tolerance range and by showing that the seal remains intact in accordance with Section 2.2.2.12. 


\section{DOE/RL-97-69 \\ Rev. 0}

2.2.2.23 Container Material Degradation: The container shall be resistant to degradation by microbial action, moisture, radiation effects, or chemical reactions with the container contents under the expected storage conditions that may reasonably occur during storage (in an ambient-temperature, ventilated enclosure) and handling and disposal operations. The container and handling appurtenances shall be designed to allow safe lifting and movement (in accordance with Section 2.2.3.1) after a storage period of 50 years. The integrity of the container shall not be jeopardized by wind, blowing sand, precipitation, sunlight, or extreme temperatures $\left(+60^{\circ} \mathrm{C},-40^{\circ} \mathrm{C}\right)$.

\subsubsection{Handling Requirements:}

2.2.3.1 Package Handling: The package shall be compatible with forklift and crane lifting and movement. The package shall be equipped with lifting and other handling appurtenances designed to allow safe lifting, movement, and stacking of the packages when fully loaded. The package shall maintain its integrity during handling, transportation, and stacking. The package shall allow for vertical stacking of six packages.

2.3 Inspection and Acceptance: The Products and Secondary Wastes Plan provided as a Part A deliverable in Standard 3, Waste Products and Secondary Wastes, shall define the content and delivery of Contractor documentation required to demonstrate compliance with the requirements of this specification. Product inspection and acceptance requirements will be performed in accordance with Section E, Inspection and Acceptance and NUREG-1293. In addition to Section E requirements for ILAW, the Contractor shall conform to the Contractor Certification Program as described in DOE Order 5820.2A, Chapter 3, Section 3.E.(4). 
DOE/RL-97-69

Rev. 0

\section{APPENDIX B \\ DOSIMETRY DOSE FACTORS}

This appendix provides tables of factors to convert radionuclide concentrations to dose rates. The exposure scenarios are described in Section 3.3.5; the underlying exposure parameters are described in Section 3.4.7. Table B-1 through B-7 provide the dose factors and half-life and other decay information.

Table B-1. Drinking Water Scenario Dose Factors ${ }^{a}$

\begin{tabular}{|c|c|c|c|}
\hline Nuclide & $\begin{array}{c}\text { Drinking Water } \\
\text { Dose Factor } \\
\text { (mrem/y per pCi/l) }\end{array}$ & Nuclide & $\begin{array}{l}\text { Drinking Water } \\
\text { Dose Factor } \\
\text { (mrem/y per pCi/l) }\end{array}$ \\
\hline $\mathrm{H}-3$ & 4.60E-05 & Eu-155 & $9.49 \mathrm{E}-04$ \\
\hline $\mathrm{Be}-10$ & 3.07E- 03 & Gd-152 & $1.10 \mathrm{E}-01$ \\
\hline $\mathrm{C}-14$ & $1.53 \mathrm{E}-03$ & Ho-166m & $5.69 \mathrm{E}-03$ \\
\hline $\mathrm{Na}-22$ & $8.76 \mathrm{E}-03$ & Re-187 & $6.06 \mathrm{E}-06$ \\
\hline $\mathrm{Cl}-36$ & 2.19E-03 & $\mathrm{Tl}-204$ & $2.34 \mathrm{E}-03$ \\
\hline $\mathrm{K}-40$ & $1.39 \mathrm{E}-02$ & $\mathrm{~Pb}-210+\mathrm{D}$ & $4.92 E+00$ \\
\hline $\mathrm{Mn}-54$ & $1.97 \mathrm{E}-03$ & $B i-207$ & $3.58 \mathrm{E}-03$ \\
\hline Fe-55 & 4.23E-04 & Po-209 & $1.46 \mathrm{E}+00$ \\
\hline Co- 60 & $1.90 \mathrm{E}-02$ & $\mathrm{Ra}-226+\mathrm{D}$ & 8.04E-01 \\
\hline $\mathrm{Ni}-59$ & $1.46 \mathrm{E}-04$ & $\mathrm{Ra}-228+\mathrm{D}$ & $8.77 \mathrm{E}-01$ \\
\hline $\mathrm{Ni}-63$ & 3.94E-04 & $A c-227+D$ & $1.07 \mathrm{E}+01$ \\
\hline Se-79 & $6.06 \mathrm{E}-03$ & Th-228+D & $5.50 \mathrm{E}-01$ \\
\hline $\mathrm{Rb}-87$ & $3.50 \mathrm{E}-03$ & Th-229+D & $2.85 \mathrm{E}+00$ \\
\hline Sr-90+D & $1.02 \mathrm{E}-01$ & Th-230 & $3.87 \mathrm{E}-01$ \\
\hline Zr-93 & 1.17E-03 & Th-232 & $2.04 \mathrm{E}+00$ \\
\hline $\mathrm{Nb}-93 \mathrm{~m}$ & 3.87E-04 & $\mathrm{Pa}-231$ & $8.03 \mathrm{E}+00$ \\
\hline $\mathrm{Nb}-94$ & $3.72 \mathrm{E}-03^{\circ}$ & U-232 & $9.49 \mathrm{E}-01$ \\
\hline Mo-93 & $9.49 \mathrm{E}-04$ & $\mathrm{U}-233$ & $1.97 \mathrm{E}-01$ \\
\hline Tc-99 & $9.49 \mathrm{E}-04$ & U-234 & $1.90 \mathrm{E}-01$ \\
\hline
\end{tabular}


DOE/RL-97-69

Rev. 0

Table B-1. Drinking Water Scenario Dose Factors ${ }^{2}$

\begin{tabular}{|c|c|c|c|}
\hline Nuclide & $\begin{array}{c}\text { Drinking Water } \\
\text { Dose Factor } \\
\text { (mrem/y per pCi/ } / \text { ) } \\
\end{array}$ & Nuclide & $\begin{array}{c}\text { Drinking Water } \\
\text { Dose Factor } \\
\text { (mrem/y per pCi/l) } \\
\end{array}$ \\
\hline Ru-106+D & $1.53 \mathrm{E}-02$ & $\mathrm{U}-235+\mathrm{D}$ & $1.83 \mathrm{E}-01$ \\
\hline Pd-107 & $1.02 \mathrm{E}-04$ & $\mathrm{U}-236$ & $1.83 \mathrm{E}-01$ \\
\hline $\mathrm{Ag}-108 \mathrm{~m}+\mathrm{D}$ & $5.48 \mathrm{E}-03$ & $U-238+D$ & $1.77 \mathrm{E}-01$ \\
\hline Cd-109 & $8.76 \mathrm{E}-03$ & $\mathrm{~Np}-237+\mathrm{D}$ & $2.85 \mathrm{E}+00$ \\
\hline $\mathrm{Cd}-113 \mathrm{~m}$ & 1.10E-01 & $\mathrm{Pu}-236$ & $9.49 \mathrm{E}-01$ \\
\hline In-115 & $1.02 \mathrm{E}-01$ & $\mathrm{Pu}-238$ & $2.77 \mathrm{E}+00$ \\
\hline$S n-121 m+D$ & $1.45 \mathrm{E}-03$ & Pu-239 & $3.14 \mathrm{E}+00$ \\
\hline Sn-126+D & $1.34 \mathrm{E}-02$ & $\mathrm{Pu}-240$ & $3.14 \mathrm{E}+00$ \\
\hline Sb- $125+D$ & $2.51 \mathrm{E}-03$ & $\mathrm{Pu}-241+\mathrm{D}$ & $6.28 \mathrm{E}-02$ \\
\hline I-129 & $2.04 \mathrm{E}-01$ & $\mathrm{Pu}-242$ & $2.99 \mathrm{E}+00$ \\
\hline Cs. 134 & $5.40 \mathrm{E}-02$ & Pu-244+D & $2.92 \mathrm{E}+00$ \\
\hline Cs-135 & $5.18 \mathrm{E}-03$ & Am-241 & $3.29 \mathrm{E}+00$ \\
\hline Cs $-137+D$ & $3.65 \mathrm{E}-02$ & $\mathrm{Am}-242 \mathrm{~m}+\mathrm{D}$ & $3.13 \mathrm{E}+00$ \\
\hline $\mathrm{Ba}-133$ & $2.34 \mathrm{E}-03$ & $A m-243+D$ & $3.29 \mathrm{E}+00$ \\
\hline $\mathrm{Pm}-147$ & $6.94 \mathrm{E}-04$ & $\mathrm{Cm}-243$ & $2.12 \mathrm{E}+00$ \\
\hline $\mathrm{Sm}-147$ & $1.31 \mathrm{E}-01$ & $\mathrm{Cm}-244$ & $1.68 \mathrm{E}+00$ \\
\hline$S \mathrm{~m}-151$ & $2.48 \mathrm{E}-04$ & Cm-245 & $3.29 \mathrm{E}+00$ \\
\hline Eu-150 & $4.53 \mathrm{E}-03$ & Cm-246 & $3.29 \mathrm{E}+00$ \\
\hline Eu-152 & $4.38 \mathrm{E}-03$ & $\mathrm{Cm}-247+\mathrm{D}$ & $2.99 \mathrm{E}+00$ \\
\hline Eu-154 & $6.64 \mathrm{E}-03$ & $\mathrm{Cm}-248$ & $1.17 \mathrm{E}+01$ \\
\hline
\end{tabular}

" Nuclides with " $+\mathrm{D}$ " added to the name include the contributions from short-lived progeny, which are assumed to be in equilibrium at all times. 
DOE/RL-97-69

Rev. 0

Table B-2. All-Pathways Dose Factors ${ }^{2}$ (Well Water).

\begin{tabular}{|c|c|c|c|c|c|}
\hline Nuclide & $\begin{array}{c}\text { All-Pathways } \\
\text { Dose Factor } \\
\text { (mrem/y per } \mathrm{pCi} / \ell \text { ) }\end{array}$ & $\begin{array}{c}\text { Ratio to } \\
\text { Drinking Water } \\
\text { Dose Factor }\end{array}$ & Nuclide & $\begin{array}{c}\text { All-Pathways } \\
\text { Dose Factor } \\
\text { (mrem/y per } \mathrm{pCi} / \ell)\end{array}$ & $\begin{array}{c}\text { Ratio to } \\
\text { Drinking } \\
\text { Water } \\
\text { Dose Factor }\end{array}$ \\
\hline$H-3$ & $5.30 \mathrm{E}-05$ & 1.15 & $\mathrm{Eu}-155$ & $1.36 \mathrm{E}-03$ & 1.43 \\
\hline $\mathrm{Be}-10$ & $3.41 \mathrm{E}-03$ & 1.11 & $\mathrm{Gd}-152$ & $1.28 \mathrm{E}-01$ & 1.17 \\
\hline C.14 & $1.79 \mathrm{E}-03$ & 1.17 & $\mathrm{Ho}-166 \mathrm{~m}$ & $1.85 \mathrm{E}-02$ & 3.25 \\
\hline $\mathrm{Na}-22$ & $5.71 \mathrm{E}-02$ & 6.52 & $\operatorname{Re}-187$ & $8.56 \mathrm{E}-06$ & 1.41 \\
\hline $\mathrm{Cl}-36$ & $3.40 \mathrm{E}-02$ & 15.5 & Tl-204 & 4.95E-03 & 2.12 \\
\hline$K-40$ & $3.06 \mathrm{E}-02$ & 2.21 & $\mathrm{~Pb}-210+\mathrm{D}$ & $5.50 \mathrm{E}+00$ & 1.12 \\
\hline $\mathrm{Mn}-54$ & $6.48 \mathrm{E}-03$ & 3.29 & $\mathrm{Bi}-207$ & $1.44 \mathrm{E}-02$ & 4.02 \\
\hline $\mathrm{Fe}-55$ & $6.57 \mathrm{E}-04$ & 1.55 & Po-209 & $1.69 \mathrm{E}+00$ & 1.15 \\
\hline Co- 60 & $4.84 \mathrm{E}-02$ & 2.55 & $\mathrm{Ra}-226+\mathrm{D}$ & $9.20 \mathrm{E}-01$ & 1.14 \\
\hline $\mathrm{Ni}-59$ & $1.90 \mathrm{E}-04$ & 1.30 & $\mathrm{Ra}-228+\mathrm{D}$ & $9.98 \mathrm{E}-01$ & 1.14 \\
\hline $\mathrm{Ni}-63$ & $5.13 \mathrm{E}-04$ & 1.30 & $A c-227+D$ & $1.16 \mathrm{E}+01$ & 1.09 \\
\hline $\mathrm{Se}-79$ & $1.09 \mathrm{E}-02$ & 1.80 & Th-228+D & $6.08 \mathrm{E}-01$ & 1.11 \\
\hline $\mathrm{Rb}-87$ & 7.75E-03 & 2.21 & $T h-229+\mathrm{D}$ & $3.11 E+00$ & 1.09 \\
\hline $\mathrm{Sr}-90+\mathrm{D}$ & $1.26 \mathrm{E}-01$ & 1.24 & Th-230 & $4.22 \mathrm{E}-01$ & 1.09 \\
\hline $\mathrm{Zr}-93$ & $1.42 \mathrm{E}-03$ & 1.21 & Th-232 & $2.23 E+00$ & 1.09 \\
\hline $\mathrm{Nb}-93 \mathrm{~m}$ & $3.15 \mathrm{E}-03$ & 8.14 & $\mathrm{~Pa}-231$ & $8.75 \mathrm{E}+00$ & 1.09 \\
\hline $\mathrm{Nb}-94$ & $4.12 \mathrm{E}-02$ & 11.1 & $\mathrm{U}-232$ & $1.09 E+00$ & 1.15 \\
\hline Mo-93 & $1.28 \mathrm{E}-03$ & 1.35 & U-233 & $2.26 \mathrm{E}-01$ & 1.15 \\
\hline Tc-99 & $3.12 \mathrm{E}-03$ & 3.29 & U-234. & $2.18 \mathrm{E}-01$ & 1.15 \\
\hline $\mathrm{Ru}-106+\mathrm{D}$ & $1.85 \mathrm{E}-02$ & 1.20 & $\mathrm{U}-235+\mathrm{D}$ & $2.12 \mathrm{E}-01$ & $i .15$ \\
\hline Pd-107 & $1.99 \mathrm{E}-04$ & 1.95 & $\mathrm{U}-236$ & $2.10 \mathrm{E}-01$ & 1.15 \\
\hline $\mathrm{Ag}-108 \mathrm{~m}+\mathrm{D}$ & $2.57 \mathrm{E}-02$ & 4.70 & $\mathrm{U}-238+\mathrm{D}$ & $2.04 \mathrm{E}-01$ & 1.15 \\
\hline $\mathrm{Cd}-109$ & $1.04 \mathrm{E}-02$ & 1.19 & $\mathrm{~Np}-237+\mathrm{D}$ & $3.11 \mathrm{E}+00$ & 1.09 \\
\hline $\mathrm{Cd}-113 \mathrm{~m}$ & $1.30 \mathrm{E}-01$ & 1.19 & $\mathrm{Pu}-236$ & $1.03 E+00$ & 1.09 \\
\hline In-115 & $1.31 \mathrm{E}-01$ & 1.28 & $\mathrm{Pu}-238$ & $3.02 \mathrm{E}+00$ & 1.09 \\
\hline
\end{tabular}


DOE/RL-97-69

Rev. 0

Table B-2. All-Pathways Dose Factors ${ }^{2}$ (Well Water).

\begin{tabular}{|c|c|c|c|c|c|}
\hline Nuclide & $\begin{array}{c}\text { All-Pathways } \\
\text { Dose Factor } \\
\text { (mrem/y per pCi/l) }\end{array}$ & $\begin{array}{c}\text { Ratio to } \\
\text { Drinking Water } \\
\text { Dose Factor }\end{array}$ & Nuclide & $\begin{array}{c}\text { All-Pathways } \\
\text { Dose Factor } \\
\text { (mrem/y per pCi/l) }\end{array}$ & $\begin{array}{c}\text { Ratio to } \\
\text { Drinking } \\
\text { Water } \\
\text { Dose Factor } \\
\end{array}$ \\
\hline$S n-121 m+D$ & $4.28 \mathrm{E}-03$ & 2.94 & $\mathrm{Pu}-239$ & $3.42 \mathrm{E}+00$ & 1.09 \\
\hline Sn-126+D & $5.29 \mathrm{E}-02$ & 3.96 & Pu-240 & $3.42 \mathrm{E}+00$ & 1.09 \\
\hline Sb-125+D & $5.52 \mathrm{E}-03$ & 2.20 & $\mathrm{Pu}-241+\mathrm{D}$ & $6.84 \mathrm{E}-02$ & 1.09 \\
\hline $1-129$ & 4.13E-01 & 2.02 & Pu-242 & $3.26 \mathrm{E}+00$ & 1.09 \\
\hline Cs-134 & $1.22 \mathrm{E}-01$ & 2.25 & $\mathrm{Pu}-244+\mathrm{D}$ & $3.18 \mathrm{E}+00$ & 1.09 \\
\hline Cs-135 & 1.09E-02 & 2.09 & Am-241 & $3.58 \mathrm{E}+00$ & 1.09 \\
\hline Cs- $137+D$ & $8.02 \mathrm{E}-02$ & 2.20 & $A m-242 m+D$ & $3.41 \mathrm{E}+00$ & 1.09 \\
\hline $\mathrm{Ba}-133$ & $4.93 \mathrm{E}-03$ & 2.11 & $A m-243+D$ & $3.58 \mathrm{E}+00$ & 1.09 \\
\hline Pm-147 & 8.31E-04 & 1.20 & $\mathrm{Cm}-243$ & $2.31 \mathrm{E}+00$ & 1.09 \\
\hline Sm-147 & $1.58 \mathrm{E}-01$ & 1.20 & $\mathrm{Cm}-244$ & $1.83 \mathrm{E}+00$ & 1.09 \\
\hline Sm-151 & $2.98 \mathrm{E}-04$ & 1.20 & $\mathrm{Cm}-245$ & $3.58 \mathrm{E}+00$ & 1.09 \\
\hline Eu-150 & $1.54 \mathrm{E}-02$ & 3.39 & $\mathrm{Cm}-246$ & $3.58 \mathrm{E}+00$ & 1.09 \\
\hline Eu-152 & $1.28 \mathrm{E}-02$ & 2.93 & $\mathrm{Cm}-247+\mathrm{D}$ & $3.27 \mathrm{E}+00$ & 1.09 \\
\hline Eu-154 & $1.61 \mathrm{E}-02$ & 2.43 & $\mathrm{Cm}-248$ & $1.27 \mathrm{E}+01$ & 1.09 \\
\hline
\end{tabular}

${ }^{2}$ Nuclides with " $+\mathrm{D}$ " added to the name include the contributions from short-lived progeny, which are assumed to be in equilibrium at all times. 
DOE/RL-97-69

Rev. 0

Table B-3. Drilling Scenario Dose Factors ${ }^{2}$ (Soil).

(Assumes that waste height is $8 \mathrm{~m}$, actual height is $7.2 \mathrm{~m}$.)

\begin{tabular}{|c|c|c|c|}
\hline Nuclide & $\begin{array}{l}\text { Drilling Dose Factor } \\
\left(\mathrm{mrem} / \mathrm{y} \text { per } \mathrm{Ci} / \mathrm{m}^{3}\right)\end{array}$ & Nuclide & $\begin{array}{l}\text { Drilling Dose Factor } \\
\text { (mrem/y per } \mathrm{Ci} / \mathrm{m}^{3} \text { ) }\end{array}$ \\
\hline $\mathrm{H}-3$ & $3.63 E-03$ & Eu-155 & $2.08 \mathrm{E}+01$ \\
\hline Be-10 & $2.16 \mathrm{E}-01$ & $\mathrm{Gd}-152$ & $3.08 \mathrm{E}+01$ \\
\hline C-14 & $2.82 \mathrm{E}-02$ & Ho-166m & $1.04 \mathrm{E}+03$ \\
\hline $\mathrm{Na}-22$ & $1.34 \mathrm{E}+03$ & Re-187 & $1.10 \mathrm{E}-04$ \\
\hline $\mathrm{Cl}-36$ & $3.00 \mathrm{E}-01$ & $\mathrm{~T} 1-204$ & $4.98 \mathrm{E}-01$ \\
\hline$K-40$ & $9.75 \mathrm{E}+01$ & $\mathrm{~Pb}-210+\mathrm{D}^{*}$ & $8.79 \mathrm{E}+01$ \\
\hline $\mathrm{Mn}-54$ & $5.11 \mathrm{E}+02$ & $\mathrm{Bi}-207$ & $9.24 \mathrm{E}+02$ \\
\hline $\mathrm{Fe}-55$ & $7.60 \mathrm{E}-03$ & Po-209 & $2.84 \mathrm{E}+01$ \\
\hline $\mathrm{Co}-60$ & $1.54 \mathrm{E}+03$ & $\mathrm{Ra}-226+\mathrm{D}$ & $1.09 \mathrm{E}+03$ \\
\hline $\mathrm{Ni}-59$ & $2.67 \mathrm{E}-03$ & $\mathrm{Ra}-228+\mathrm{D}$ & $5.84 \mathrm{E}+02$ \\
\hline $\mathrm{Ni}-63$ & $7.15 \mathrm{E}-03$ & $A c-227+D$ & $1.21 \mathrm{E}+03$ \\
\hline $\mathrm{Se}-79$ & $1.07 \mathrm{E}-01$ & Th- $228+\mathrm{D}$ & $9.90 \mathrm{E}+02$ \\
\hline $\mathrm{Rb}-87$ & $7.67 \mathrm{E}-02$ & Th- $229+\mathrm{D}$ & $4.61 \mathrm{E}+02$ \\
\hline Sr $-90+\mathrm{D}$ & $4.42 \mathrm{E}+00$ & Th-230 & $4.54 \mathrm{E}+01$ \\
\hline $\mathrm{Zr}-93$ & $5.87 \mathrm{E}-02$ & Th-232 & $2.28 \mathrm{E}+02$ \\
\hline $\mathrm{Nb}-93 \mathrm{~m}$ & $2.19 \mathrm{E}-02$ & $\mathrm{~Pa}-231$ & $3.16 \mathrm{E}+02$ \\
\hline $\mathrm{Nb}-94$ & $9.65 \mathrm{E}+02$ & $\mathrm{U}-232$ & $9.73 \mathrm{E}+01$ \\
\hline Mo-93 & $8.70 \mathrm{E}-02$ & $\mathrm{U}-233$ & $1.92 \mathrm{E}+01$ \\
\hline Tc-99 & $3.15 \mathrm{E}-02$ & $\mathrm{U}-234$ & $1.90 E+01$ \\
\hline $\mathrm{Ru}-106+\mathrm{D}$ & $1.31 \mathrm{E}+02$ & $\mathrm{U}-235+\mathrm{D}$ & $1.02 \mathrm{E}+02$ \\
\hline Pd-107 & $3.33 \mathrm{E}-03$ & $\mathrm{U}-236$ & $1.76 E+01$ \\
\hline Ag- $108 m+D$ & $9.83 \mathrm{E}+02$ & $\mathrm{U}-238+\mathrm{D}$ & $3.11 \mathrm{E}+01$ \\
\hline Cd-109 & $1.84 \mathrm{E}+00$ & $\mathrm{~Np}-237+\mathrm{D}$ & $2.27 \mathrm{E}+02$ \\
\hline $\mathrm{Cd}-113 \mathrm{~m}$ & $2.13 E+00$ & $\mathrm{Pu}-236$ & $3.57 \mathrm{E}+01$ \\
\hline In-115 & $2.21 \mathrm{E}+00$ & $\mathrm{Pu}-238$ & $1.03 E+02$ \\
\hline
\end{tabular}


DOE/RL-97-69

Rev. 0

Table B-3. Drilling Scenario Dose Factors ${ }^{2}$ (Soil).

(Assumes that waste height is $8 \mathrm{~m}$, actual height is $7.2 \mathrm{~m}$.)

\begin{tabular}{|c|c|c|c|}
\hline Nuclide & $\begin{array}{l}\text { Drilling Dose Factor } \\
\left(\mathrm{mrem} / \mathrm{y} \text { per } \mathrm{Ci} / \mathrm{m}^{3}\right)\end{array}$ & Nuclide & $\begin{array}{l}\text { Drilling Dose Factor } \\
\left(\mathrm{mrem} / \mathrm{y} \text { per } \mathrm{Ci} / \mathrm{m}^{3}\right)\end{array}$ \\
\hline $\mathrm{Sn}-121 \mathrm{~m}+\mathrm{D}$ & $2.67 \mathrm{E}-01$ & $\mathrm{Pu}-239$ & $1.16 \mathrm{E}+02$ \\
\hline $\mathrm{Sn}-126+\mathrm{D}$ & $1.20 \mathrm{E}+03$ & $\mathrm{Pu}-240$ & $1.16 E+02$ \\
\hline Sb-125+D & $2.52 \mathrm{E}+02$ & $\mathrm{Pu}-241+\mathrm{D}$ & $2.29 \mathrm{E}+00$ \\
\hline $1-129$ & $5.02 \mathrm{E}+00$ & $\mathrm{Pu}-242$ & $1.09 \mathrm{E}+02$ \\
\hline Cs-134 & $9.53 E+02$ & $\mathrm{Pu}-244+\mathrm{D}$ & $3.12 \mathrm{E}+02$ \\
\hline Cs-135 & $9.41 \mathrm{E}-02$ & $\mathrm{Am}-241$ & $1.24 \mathrm{E}+02$ \\
\hline $\mathrm{Cs}-137+\mathrm{D}$ & $3.45 \mathrm{E}+02$ & $\mathrm{Am}-242 \mathrm{~m}+\mathrm{D}$ & $1.23 \mathrm{E}+02$ \\
\hline $\mathrm{Ba}-133$ & $2.10 \mathrm{E}+02$ & $\mathrm{Am}-243+\mathrm{D}$ & $2.19 \mathrm{E}+02$ \\
\hline Pm-147 & $2.17 \mathrm{E}-02$ & $\mathrm{Cm}-243$ & $1.43 E+02$ \\
\hline Sm-147 & $1.08 \mathrm{E}+01$ & $\mathrm{Cm}-244$ & $6.15 \mathrm{E}+01$ \\
\hline$S m-151$ & $7.88 \mathrm{E}-03$ & $\mathrm{Cm}-245$ & $1.60 \mathrm{E}+02$ \\
\hline Eu-150 & $8.90 \mathrm{E}+02$ & $\mathrm{Cm}-246$ & $1.22 E+02$ \\
\hline Eu-152 & $6.86 \mathrm{E}+02$ & $\mathrm{Cm}-247+\mathrm{D}$ & $3.07 \mathrm{E}+02$ \\
\hline Eu-154 & $7.50 \mathrm{E}+02$ & $\mathrm{Cm}-248$ & $4.30 \mathrm{E}+02$ \\
\hline
\end{tabular}

"Nuclides with " $+\mathrm{D}$ " added to the name include the contributions from short-lived progeny, which are assumed to be in equilibrium at all times. 
DOE/RL-97-69

Rev. 0

Table B-4. Intruder Scenario Dose Factors. ${ }^{a}$ (Soil)

(Assumes waste height is $8 \mathrm{~m}$, actual height is $7.2 \mathrm{~m}$.)

\begin{tabular}{|c|c|c|c|c|c|c|}
\hline \multirow[t]{2}{*}{ Nuclide } & \multirow{2}{*}{$\begin{array}{c}\text { External } \\
\text { (mrem/y per } \\
\left.\mathrm{Ci} / \mathrm{m}^{3}\right) \\
\end{array}$} & \multicolumn{4}{|c|}{ Internal (mrem/y per $\mathrm{Ci} / \mathrm{m}^{3}$ ) } & \multirow{2}{*}{$\begin{array}{c}\text { Total } \\
\left(\mathrm{mrem} / \mathrm{y} \text { per } \mathrm{Ci} / \mathrm{m}^{3}\right)\end{array}$} \\
\hline & & Inhalation & Soil Ingestion & Vegetables & Subtotal & \\
\hline $\mathrm{H}-3$ & 0.0 & $4.00 \mathrm{E}-04$ & 5.93E-04 & $2.85 \mathrm{E}-01$ & $3.26 \mathrm{E}-01$ & $3.26 \mathrm{E}-01$ \\
\hline $\mathrm{Be}-10$ & $5.43 \mathrm{E}-01$ & $1.02 \mathrm{E}+00$ & $7.71 \mathrm{E}-01$ & $1.67 \mathrm{E}+00$ & $3.46 \mathrm{E}+00$ & $4.00 \mathrm{E}+00$ \\
\hline $\mathrm{C}-14$ & $6.73 \mathrm{E}-03$ & 5.95E-03 & $3.76 \mathrm{E}-01$ & $1.63 \mathrm{E}+02$ & $1.64 \mathrm{E}+02$ & $1.64 \mathrm{E}+02$ \\
\hline $\mathrm{Na}-22$ & $5.30 \mathrm{E}+03$ & $2.04 \mathrm{E}-02$ & $1.93 \mathrm{E}+00$ & $7.15 \mathrm{E}+01$ & $7.34 \mathrm{E}+01$ & $5.37 \mathrm{E}+03$ \\
\hline $\mathrm{Cl}-36$ & $1.07 \mathrm{E}+00$ & $5.32 \mathrm{E}-02$ & $5.05 \mathrm{E}-01$ & $2.23 \mathrm{E}+04$ & $2.23 \mathrm{E}+04$ & $2.23 E+04$ \\
\hline $\mathrm{K}-40$ & $4.34 \mathrm{E}+02$ & $3.45 \mathrm{E}-02$ & $3.46 \mathrm{E}+00$ & $1.19 \mathrm{E}+03$ & $1.19 \mathrm{E}+03$ & $1.63 \mathrm{E}+03$ \\
\hline Mn-54 & $1.57 \mathrm{E}+03$ & $1.27 \mathrm{E}-02$ & $3.39 \mathrm{E}-01$ & $6.14 \mathrm{E}+01$ & $6.18 \mathrm{E}+01$ & $1.63 \mathrm{E}+03$ \\
\hline $\mathrm{Fe}-55$ & 0.0 & $6.65 \mathrm{E}-03$ & $9.38 \mathrm{E}-02$ & $1.79 \mathrm{E}-01$ & $2.79 \mathrm{E}-01$ & $2.79 \mathrm{E}-01$ \\
\hline Co-60. & $6.49 \mathrm{E}+03$ & $4.07 \mathrm{E}-01$ & $4.46 \mathrm{E}+00$ & $3.59 \mathrm{E}+01$ & $4.08 \mathrm{E}+01$ & $6.53 E+03$ \\
\hline $\mathrm{Ni}-59$ & 0.0 & $3.77 \mathrm{E}-03$ & $3.67 \mathrm{E}-02$ & $9.68 \mathrm{E}-01$ & $1.01 \mathrm{E}+00$ & $1.01 E+00$ \\
\hline $\mathrm{Ni}-63$ & 0.0 & $8.68 \mathrm{E}-03$ & $9.88 \mathrm{E}-02$ & $2.61 \mathrm{E}+00$ & $2.72 \mathrm{E}+00$ & $2.72 \mathrm{E}+00$ \\
\hline $\mathrm{Se}-79$ & $9.53 \mathrm{E}-03$ & $2.58 \mathrm{E}-02$ & $1.52 \mathrm{E}+00$ & $2.51 \mathrm{E}+01$ & $2.67 \mathrm{E}+01$ & $2.67 \mathrm{E}+01$ \\
\hline $\mathrm{Rb}-87$ & $7.18 \mathrm{E}-02$ & $9.55 \mathrm{E}-03$ & $8.78 \mathrm{E}-01$ & $3.95 \mathrm{E}+01$ & $4.04 \mathrm{E}+01$ & $4.05 \mathrm{E}+01$ \\
\hline $\mathrm{Sr}-90$ & $1.16 \mathrm{E}+01$ & $6.74 \mathrm{E}-01$ & $2.51 \mathrm{E}+01$ & $4.11 \mathrm{E}+03$ & $4: 14 E+03$ & $4.15 \mathrm{E}+03$ \\
\hline $\mathrm{Zr}-93$ & $1.25 \mathrm{E}-03$ & $9.31 \mathrm{E}-01$ & $2.96 \mathrm{E}-01$ & $4.42 \mathrm{E}-01$ & $1.67 \mathrm{E}+00$ & $1.67 \mathrm{E}+00$ \\
\hline $\mathrm{Nb}-93 \mathrm{~m}$ & $5.21 \mathrm{E}-02$ & $7.93 \mathrm{E}-02$ & 9.49E-02 & $4.20 \mathrm{E}-01$ & $5.95 \mathrm{E}-01$ & $6.47 \mathrm{E}-01$ \\
\hline $\mathrm{Nb}-94$ & $4.34 \mathrm{E}+03$ & $9.57 \mathrm{E}-01$ & $9.35 \mathrm{E}-01$ & 4.10E+00 & $5.99 \mathrm{E}+00$ & $4.34 \mathrm{E}+03$ \\
\hline
\end{tabular}


DOE/RL-97-69

Rev. 0

Table B-4. Intruder Scenario Dose Factors. ${ }^{\text {" }}$ (Soil)

(Assumes waste height is $8 \mathrm{~m}$, actual height is $7.2 \mathrm{~m}$.)

\begin{tabular}{|c|c|c|c|c|c|c|}
\hline \multirow[t]{2}{*}{ Nuclide } & \multirow{2}{*}{$\begin{array}{c}\text { External } \\
\text { (mrem/y per } \\
\left.\mathrm{Ci} / \mathrm{m}^{3}\right)\end{array}$} & \multicolumn{4}{|c|}{ Internal (mrem/y per $\mathrm{Ci} / \mathrm{m}^{3}$ ) } & \multirow{2}{*}{$\begin{array}{c}\text { Total } \\
\left(\mathrm{mrem} / \mathrm{y} \text { per } \mathrm{Ci} / \mathrm{m}^{3}\right)\end{array}$} \\
\hline & & Inhalation & Soil Ingestion & Vegetables & Subtotal & \\
\hline Mo-93 & $2.99 \mathrm{E}-01$ & $8.19 \mathrm{E}-02$ & $2.37 \mathrm{E}-01$ & $9.43 \mathrm{E}+00$ & $9.75 \mathrm{E}+00$ & $1.00 \mathrm{E}+01$ \\
\hline Tc-99 & $3.80 \mathrm{E}-02$ & $1.29 \mathrm{E}-02$ & $1.41 \mathrm{E}-01$ & $1.58 \mathrm{E}+02$ & $1.58 \mathrm{E}+02$ & $1.58 \mathrm{E}+02$ \\
\hline $\mathrm{Ru}-106$ & $4.25 \mathrm{E}+02$ & $9.22 \mathrm{E}-01$ & $2.78 \mathrm{E}+00$ & $3.65 \mathrm{E}+01$ & $4.02 \mathrm{E}+01$ & $4.65 \mathrm{E}+02$ \\
\hline Pd-107 & 0.0 & $3.76 \mathrm{E}-02$ & $2.56 \mathrm{E}-02$ & $6.88 \mathrm{E}-01$ & $7.51 \mathrm{E}-01$ & $7.51 \mathrm{E}-01$ \\
\hline $\mathrm{Ag}-108 \mathrm{~m}$ & $4.40 \mathrm{E}+03$ & $5.78 \mathrm{E}-01$ & $1.37 \mathrm{E}+00$ & $6.51 \mathrm{E}+01$ & $6.71 \mathrm{E}+01$ & $4.47 \mathrm{E}+03$ \\
\hline Cd-109 & $5.80 \mathrm{E}+00$ & $2.23 \mathrm{E}-01$ & $1.69 \mathrm{E}+00$ & $1.82 \mathrm{E}+02$ & $1.84 \mathrm{E}+02$ & $1.90 \mathrm{E}+02$ \\
\hline $\mathrm{Cd}-113 \mathrm{~m}$ & $3.18 \mathrm{E}-01$ & $3.95 \mathrm{E}+00$ & $2.67 \mathrm{E}+01$ & 2.63E+03 & $2.66 \mathrm{E}+03$ & $2.66 \mathrm{E}+03$ \\
\hline In-115 & $2.03 \mathrm{E}-01$ & $9.87 \mathrm{E}+00$ & $2.57 \mathrm{E}+01$ & $3.72 \mathrm{E}+01$ & $7.27 \mathrm{E}+01$ & $7.29 \mathrm{E}+01$ \\
\hline Sn-121m & $1.07 \mathrm{E}+00$ & $2.67 \mathrm{E}-02$ & $3.63 \mathrm{E}-01$ & $1.85 E+00$ & $2.24 \mathrm{E}+00$ & $3.32 \mathrm{E}+00$ \\
\hline Sn-126 & $5.41 \mathrm{E}+03$ & $2.19 \mathrm{E}-01$ & $3.36 \mathrm{E}+00$ & $1.71 \mathrm{E}+01$ & $2.07 \mathrm{E}+01$ & $5.43 E+03$ \\
\hline Sb-125 & $9.98 \mathrm{E}+02$ & $2.93 \mathrm{E}-02$ & $5.56 \mathrm{E}-01$ & $7.45 \mathrm{E}+00$ & $8.03 \mathrm{E}+00$ & $1.01 \mathrm{E}+03$ \\
\hline $1-129$ & $5.79 E+00$ & $4.56 \mathrm{E}-01$ & $4.48 \mathrm{E}+01$ & $1.49 \mathrm{E}+03$ & $1.54 \mathrm{E}+03$ & $1.54 \mathrm{E}+03$ \\
\hline Cs:134 & $3.64 \mathrm{E}+03$ & $1.16 \mathrm{E}-01$ & $1.15 \mathrm{E}+01$ & $3.64 \mathrm{E}+02$ & $3.75 \mathrm{E}+02$ & $4.01 E+03$ \\
\hline $\mathrm{Cs}-135$ & $1.96 \mathrm{E}-02$ & $1.31 \mathrm{E}-02$ & $1.30 \mathrm{E}+00$ & $3.85 \mathrm{E}+01$ & $3.98 \mathrm{E}+01$ & $3.98 \mathrm{E}+01$ \\
\hline $\mathrm{Cs}-137$ & $1.53 \mathrm{E}+03$ & $9.18 \mathrm{E}-02$ & $9.07 \mathrm{E}+00$ & $2.69 \mathrm{E}+02$ & $2.78 \mathrm{E}+02$ & $1.81 \mathrm{E}+03$ \\
\hline $\mathrm{Ba}-133$ & $9.13 E+02$ & $1.93 \mathrm{E}-02$ & $5.67 \mathrm{E}-01$ & $6.75 \mathrm{E}+00$ & $7.33 \mathrm{E}+00$ & $9.20 \mathrm{E}+02$ \\
\hline Pm-147 & $2.25 \mathrm{E}-02$ & 8.67E-02 & $1.53 \mathrm{E}-01$ & $5.94 \mathrm{E}-01$ & $8.34 \mathrm{E}-01$ & $8.56 \mathrm{E}-01$ \\
\hline
\end{tabular}


DOE/RL-97-69

Rev. 0

Table B-4. Intruder Scenario Dose Factors." (Soil)

(Assumes waste height is $8 \mathrm{~m}$, actual height is $7.2 \mathrm{~m}$.)

\begin{tabular}{|c|c|c|c|c|c|c|}
\hline \multirow[t]{2}{*}{ Nuclide } & \multirow{2}{*}{$\begin{array}{c}\text { External } \\
\text { (mrem/y per } \\
\mathrm{Ci} / \mathrm{m}^{3} \text { ) } \\
\end{array}$} & \multicolumn{4}{|c|}{ Internal (mrem/y per $\left.\mathrm{Ci} / \mathrm{m}^{3}\right)$} & \multirow{2}{*}{$\begin{array}{c}\text { Total } \\
\left(\mathrm{mrem} / \mathrm{y} \text { per } \mathrm{Ci} / \mathrm{m}^{3}\right)\end{array}$} \\
\hline & & Inhalation & Soil Ingestion & Vegetables & Subtotal & \\
\hline $\mathrm{Sm}-147$ & 0.0 & $2.06 \mathrm{E}+02$ & $3.30 \mathrm{E}+01$ & $1.22 \mathrm{E}+02$ & $3.61 \mathrm{E}+02$ & $3.61 \mathrm{E}+02$ \\
\hline $\mathrm{Sm}-151$ & $5.03 \mathrm{E}-04$ & $8.38 \mathrm{E}-02$ & $6.21 \mathrm{E}-02$ & $2.29 \mathrm{E}-01$ & $3.75 \mathrm{E}-01$ & $3.76 \mathrm{E}-01$ \\
\hline Eu-150 & $3.96 \mathrm{E}+03$ & $7.76 \mathrm{E}-01$ & $1.13 E+00$ & $4.16 \mathrm{E}+00$ & $6.06 \mathrm{E}+00$ & $3.97 \mathrm{E}+03$ \\
\hline Eu-152 & $3.01 \mathrm{E}+03$ & $6.23 \mathrm{E}-01$ & $1.07 \mathrm{E}+00$ & $3.99 \mathrm{E}+00$ & $5.69 \mathrm{E}+00$ & $3.01 \mathrm{E}+03$ \\
\hline Eu-154 & $3.24 \mathrm{E}+03$ & $7.26 \mathrm{E}-01$ & $1.61 \mathrm{E}+00$ & $6.00 \mathrm{E}+00$ & $8.34 \mathrm{E}+00$ & $3.25 \mathrm{E}+03$ \\
\hline Eu-155 & 8.71E+01 & $1.06 \mathrm{E}-01$ & $2.23 \mathrm{E}-01$ & 8.43E-01 & $1.17 \mathrm{E}+00$ & $8.83 \mathrm{E}+01$ \\
\hline Gd-152 & 0.0 & $6.97 \mathrm{E}+02$ & $2.75 \mathrm{E}+01$ & $1.01 \mathrm{E}+02$ & $8.25 \mathrm{E}+02$ & $8.25 \mathrm{E}+02$ \\
\hline $\mathrm{Ho}-166 \mathrm{~m}$ & $4.69 \mathrm{E}+03$ & $2.09 \mathrm{E}+00$ & $1.43 \mathrm{E}+00$ & $5.26 \mathrm{E}+00$ & $8.78 \mathrm{E}+00$ & $4.70 \mathrm{E}+03$ \\
\hline $\operatorname{Re}-187$ & 0.0 & $1.41 \mathrm{E}-04$ & $1.51 \mathrm{E}-03$ & $3.44 \mathrm{E}-01$ & $3.46 \mathrm{E}-01$ & $3.46 \mathrm{E}-01$ \\
\hline $\mathrm{Tl}-204$ & $1.88 \mathrm{E}+00$ & $6.10 \mathrm{E}-03$ & 5.37E-01 & 8.05E-01 & $1.35 \mathrm{E}+00$ & $3.23 \mathrm{E}+00$ \\
\hline $\mathrm{Pb}-210$ & $3.01 E+00$ & $6.13 \mathrm{E}+01$ & $1.22 \mathrm{E}+03$ & $5.05 \mathrm{E}+03$ & $6.32 \mathrm{E}+03$ & $6.33 E+03$ \\
\hline $\mathrm{Bi}-207$ & $4.11 E+03$ & $4.02 \mathrm{E}-02$ & $8.89 \mathrm{E}-01$ & $4.05 \mathrm{E}+00$ & $4.98 \mathrm{E}+00$ & $4.11 \mathrm{E}+03$ \\
\hline Po-209 & $8.86 \mathrm{E}+00$ & $2.90 \mathrm{E}+01$ & $3.66 \mathrm{E}+02$ & $8.25 \mathrm{E}+02$ & $1.22 \mathrm{E}+03$ & $1.23 \mathrm{E}+03$ \\
\hline Ra-226 & $4.83 E+03$ & $2.39 \mathrm{E}+01$ & $2.21 \mathrm{E}+02$ & $6.64 \mathrm{E}+02$ & $9.09 \mathrm{E}+02$ & $5.74 \mathrm{E}+03$ \\
\hline $\mathrm{Ra}-228$ & $3.07 \mathrm{E}+03$ & $1.53 \mathrm{E}+02$ & $2.29 \mathrm{E}+02$ & $6.74 \mathrm{E}+02$ & $1.06 \mathrm{E}+03$ & 4.12E+03 \\
\hline Ac-227 & $9.56 \mathrm{E}+02$ & $1.92 \mathrm{E}+04$ & $2.64 \mathrm{E}+03$ & $3.74 \mathrm{E}+03$ & $2.56 \mathrm{E}+04$ & $2.65 \mathrm{E}+04$ \\
\hline Th-228 & $3.56 \mathrm{E}+03$ & $7.63 E+02$ & $1.16 \mathrm{E}+02$ & $1.57 \mathrm{E}+02$ & $1.04 \mathrm{E}+03$ & $4.60 \mathrm{E}+03$ \\
\hline
\end{tabular}

B-9 


\section{DOE/RL-97-69}

Rev. 0

Table B-4. Intruder Scenario Dose Factors. ${ }^{2}$ (Soil)

(Assumes waste height is $8 \mathrm{~m}$, actual height is $7.2 \mathrm{~m}$.)

\begin{tabular}{|c|c|c|c|c|c|c|}
\hline \multirow[t]{2}{*}{ Nuclide } & \multirow{2}{*}{$\begin{array}{c}\text { External } \\
\text { (mrem/y per } \\
\left.\mathrm{Ci} / \mathrm{m}^{3}\right) \\
\end{array}$} & \multicolumn{4}{|c|}{ Internal (mrem/y per $\mathrm{Ci} / \mathrm{m}^{3}$ ) } & \multirow{2}{*}{$\begin{array}{c}\text { Total } \\
\left(\mathrm{mrem} / \mathrm{y} \text { per } \mathrm{Ci} / \mathrm{m}^{3}\right)\end{array}$} \\
\hline & & Inhalation & Soil Ingestion & Vegetables & Subtotal & \\
\hline Th-229 & $7.57 \mathrm{E}+02$ & $5.86 \mathrm{E}+03$ & $7.17 \mathrm{E}+02$ & $9.05 E+02$ & $7.48 \mathrm{E}+03$ & $8.24 \mathrm{E}+03$ \\
\hline Th-230 & $1.66 \mathrm{E}+00$ & $9.29 \mathrm{E}+02$ & $9.73 \mathrm{E}+01$ & $1.23 \mathrm{E}+02$ & $1.15 \mathrm{E}+03$ & $1.15 \mathrm{E}+03$ \\
\hline Th-232 & $1.76 \mathrm{E}+02$ & $4.65 E+03$ & $5.28 \mathrm{E}+02$ & $6.71 \mathrm{E}+02$ & $5.85 \mathrm{E}+03$ & $6.03 \mathrm{E}+03$ \\
\hline $\mathrm{Pa}-231$ & $1.07 \mathrm{E}+02$ & $4.08 \mathrm{E}+03$ & $2.06 \mathrm{E}+03$ & $2.74 E+03$ & $8.88 \mathrm{E}+03$ & $8.99 \mathrm{E}+03$ \\
\hline $\mathrm{U}-232$ & $6.76 \mathrm{E}+02$ & $2.06 \mathrm{E}+03$ & $2.57 \mathrm{E}+02$ & $8.38 \mathrm{E}+02$ & $3.16 \mathrm{E}+03$ & $3.83 \mathrm{E}+03$ \\
\hline $\mathrm{U}-233$ & $7.22 \mathrm{E}-01$ & $3.74 \mathrm{E}+02$ & $4.91 \mathrm{E}+01$ & $1.70 \mathrm{E}+02$ & $5.93 \mathrm{E}+02$ & $5.94 \mathrm{E}+02$ \\
\hline U-234 & 2.03E-01 & $3.73 E+02$ & $4.72 \mathrm{E}+01$ & $1.64 \mathrm{E}+02$ & $5.84 \mathrm{E}+02$ & $5.85 \mathrm{E}+02$ \\
\hline $\mathrm{U}-235$ & $3.74 \mathrm{E}+02$ & $3.45 \mathrm{E}+02$ & $4.57 \mathrm{E}+01$ & $1.58 \mathrm{E}+02$ & $5.49 \mathrm{E}+02$ & $9.22 \mathrm{E}+02$ \\
\hline $\mathrm{U}-236$ & $1.08 \mathrm{E}-01$ & $3.45 \mathrm{E}+02$ & $4.54 \mathrm{E}+01$ & $1.57 \mathrm{E}+02$ & $5.48 \mathrm{E}+02$ & $5.48 \mathrm{E}+02$ \\
\hline$U-238$ & $6.02 \mathrm{E}+01$ & $3.45 \mathrm{E}+02$ & $4.41 \mathrm{E}+01$ & $1.53 \mathrm{E}+02$ & $5.42 \mathrm{E}+02$ & $6.02 \mathrm{E}+02$ \\
\hline $\mathrm{Np}-237$ & $5.17 \mathrm{E}+02$ & $1.38 \mathrm{E}+03$ & $6.94 \mathrm{E}+02$ & $2.74 \mathrm{E}+03$ & $4.81 E+03$ & $5.33 E+03$ \\
\hline $\mathrm{Pu}-236$ & $2.21 \mathrm{E}+00$ & $4.21 \mathrm{E}+02$ & $2.13 E+02$ & $2.69 \mathrm{E}+02$ & $9.04 E+02$ & $9.06 \mathrm{E}+02$ \\
\hline $\mathrm{Pu}-238$ & $7.70 \mathrm{E}-02$ & $1.33 \mathrm{E}+03$ & $6.95 \mathrm{E}+02$ & $8.36 \mathrm{E}+02$ & $2.86 \mathrm{E}+03$ & $2.86 \mathrm{E}+03$ \\
\hline $\mathrm{Pu}-239$ & $1.46 \mathrm{E}-01$ & $1.48 \mathrm{E}+03$ & $7.89 \mathrm{E}+02$ & $9.48 \mathrm{E}+02$ & $3.22 \mathrm{E}+03$ & $3.22 \mathrm{E}+03$ \\
\hline $\mathrm{Pu}-240$ & $7.51 \mathrm{E}-02$ & $1.48 \mathrm{E}+03$ & $7.89 \mathrm{E}+02$ & $9.48 \mathrm{E}+02$ & $3.22 \mathrm{E}+03$ & $3.22 \mathrm{E}+03$ \\
\hline $\mathrm{Pu}-241$ & $2.70 \mathrm{E}-02$ & $2.95 \mathrm{E}+01$ & $1.61 \mathrm{E}+01$ & $1.92 \mathrm{E}+01$ & $6.48 \mathrm{E}+01$ & $6.48 \mathrm{E}+01$ \\
\hline $\mathrm{Pu}-242$ & $6.56 \mathrm{E}-02$ & $1.39 \mathrm{E}+03$ & $7.53 \mathrm{E}+02$ & $9.04 \mathrm{E}+02$ & $3.05 E+03$ & $3.05 E+03$ \\
\hline
\end{tabular}


DOE/RL.-97-69

Rev. 0

Table B-4. Intruder Scenario Dose Factors. "(Soil)

(Assumes waste height is $8 \mathrm{~m}$, actual height is $7.2 \mathrm{~m}$.)

\begin{tabular}{|c|c|c|c|c|c|c|}
\hline \multirow[t]{2}{*}{ Nuclide } & \multirow{2}{*}{$\begin{array}{c}\text { External } \\
\text { (mrem/y per } \\
\mathrm{Ci} / \mathrm{m}^{3} \text { ) }\end{array}$} & \multicolumn{4}{|c|}{ Internal (mrem/y per $\mathrm{Ci} / \mathrm{m}^{3}$ ) } & \multirow{2}{*}{$\begin{array}{c}\text { Total } \\
\left(\mathrm{mrem} / \mathrm{y} \text { per } \mathrm{Ci} / \mathrm{m}^{3}\right)\end{array}$} \\
\hline & & Inhalation & Soil Ingestion & Vegetables & Subtotal & \\
\hline $\mathrm{Pu}-244$ & $9.15 \mathrm{E}+02$ & $1.39 \mathrm{E}+03$ & $7.35 \mathrm{E}+02$ & $8.83 \mathrm{E}+02$ & $3.01 \mathrm{E}+03$ & $3.93 E+03$ \\
\hline Am-241 & $2.24 \mathrm{E}+01$ & $1.51 \mathrm{E}+03$ & $8.25 \mathrm{E}+02$ & $1.03 E+03$ & $3.37 \mathrm{E}+03$ & $3.39 \mathrm{E}+03$ \\
\hline$A m-242 m$ & $3.35 \mathrm{E}+01$ & $1.48 \mathrm{E}+03$ & $7.88 \mathrm{E}+02$ & $9.84 \mathrm{E}+02$ & $3.25 \mathrm{E}+03$ & $3.29 \mathrm{E}+03$ \\
\hline Am-243 & $4.46 \mathrm{E}+02$ & $1.51 \mathrm{E}+03$ & $8.27 \mathrm{E}+02$ & $1.03 E+03$ & $3.37 \mathrm{E}+03$ & $3.81 \mathrm{E}+03$ \\
\hline $\mathrm{Cm}-243$ & $2.86 \mathrm{E}+02$ & $1.00 \mathrm{E}+03$ & $5.26 \mathrm{E}+02$ & $6.35 \mathrm{E}+02$ & $2.16 \mathrm{E}+03$ & $2.45 \mathrm{E}+03$ \\
\hline $\mathrm{Cm}-244$ & $6.34 \mathrm{E}-02$ & $7.69 \mathrm{E}+02$ & $4.14 \mathrm{E}+02$ & $5.01 \mathrm{E}+02$ & $1.69 \mathrm{E}+03$ & $1.69 \mathrm{E}+03$ \\
\hline $\mathrm{Cm}-245$ & $1.72 \mathrm{E}+02$ & $1.57 E+03$ & $8.26 \mathrm{E}+02$ & $9.92 \mathrm{E}+02$ & $3.39 E+03$ & $3.56 \mathrm{E}+03$ \\
\hline $\mathrm{Cm}-246$ & $5.96 \mathrm{E}-02$ & $1.57 \mathrm{E}+03$ & $8.26 \mathrm{E}+02$ & $9.92 \mathrm{E}+02$ & $3.39 E+03$ & $3.39 \mathrm{E}+03$ \\
\hline $\mathrm{Cm}-247$ & $8.83 \mathrm{E}+02$ & $1.42 \mathrm{E}+03$ & $7.53 \mathrm{E}+02$ & $9.04 \mathrm{E}+02$ & $3.08 \mathrm{E}+03$ & $3.96 \mathrm{E}+03$ \\
\hline $\mathrm{Cm}-248$ & $4.50 \mathrm{E}-02$ & $5.52 \mathrm{E}+03$ & $2.94 \mathrm{E}+03$ & $3.53 \mathrm{E}+03$ & $1.20 \mathrm{E}+04$ & $1.20 \mathrm{E}+04$ \\
\hline
\end{tabular}

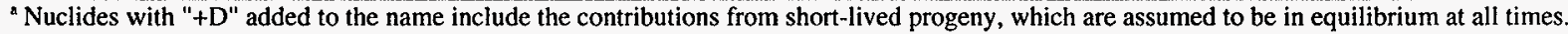


DOF/RL-97-69

Rev, 0

Table B-5. Ratio of Intruder Dose Factors for $2500 \mathrm{~m}^{2}$ Garden Relative to $500 \mathrm{~m}^{2}$ Garden. ${ }^{a}$

\begin{tabular}{|c|c|c|c|c|c|}
\hline Nuclide & Ratio & Nuclide & Ratio & Nuclide & Ratio \\
\hline $\mathrm{H}-3$ & 4.88 & $S n-126+D$ & 1.10 & Th-230 & 4.97 \\
\hline $\mathrm{Be}-10$ & 3.37 & $\mathrm{Sb}-125+\mathrm{D}$ & 1.10 & Th-232 & 4.53 \\
\hline C-14 & 5.00 & $1-129$ & 4.93 & $\mathrm{~Pa}-231$ & 4.80 \\
\hline $\mathrm{Na}-22$ & 1.10 & Cs-134 & 1.18 & $\mathrm{U}-232$ & 3.07 \\
\hline $\mathrm{Cl}-36$ & 5.00 & $\mathrm{Cs}-135$ & 4.99 & U-233 & 4.98 \\
\hline $\mathrm{K}-40$ & 2.56 & Cs $-137+D$ & 1.24 & $\mathrm{U}-234$ & 4.99 \\
\hline $\mathrm{Mn}-54$ & 1.13 & $B a-133$ & 1.10 & $\mathrm{U}-235+\mathrm{D}$ & 2.04 \\
\hline Fe-55 & 5.00 & Pm-147 & 4.57 & U-236 & 5.00 \\
\hline Co-60 & 1.10 & Sm-147 & 5.00 & $\mathrm{U}-238+\mathrm{D}$ & 3.68 \\
\hline $\mathrm{Ni}-59$ & 5.00 & $\mathrm{Sm}-151$ & 4.98 & $\mathrm{~Np}-237+\mathrm{D}$ & 3.71 \\
\hline $\mathrm{Ni}-63$ & 5.00 & Eu-150 & 1.09 & $\mathrm{Pu}-236$ & 4.96 \\
\hline $\mathrm{Se}-79$ & 4.99 & Eu-152 & 1.09 & Pu-238 & 5.00 \\
\hline $\mathrm{Rb}-87$ & 4.97 & Eu-154 & 1.09 & $\mathrm{Pu}-239$ & 5.00 \\
\hline Sr-90+D & 4.95 & Eu-155 & 1.10 & $\mathrm{Pu}-240$ & 5.00 \\
\hline $2 r-93$ & 4.99 & Gd-152 & 5.00 & $\mathrm{Pu}-241+\mathrm{D}$ & 4.99 \\
\hline $\mathrm{Nb}-93 \mathrm{~m}$ & 3.88 & $\mathrm{Ho}-166 \mathrm{~m}$ & 1.09 & $\mathrm{Pu}-242$ & 5.00 \\
\hline $\mathrm{Nb}-94$ & 1.09 & $\operatorname{Re}-187$ & 5.00 & $\mathrm{Pu}-244+\mathrm{D}$ & 2.73 \\
\hline Mo-93 & 4.52 & TI-204 & 1.62 & Am-241 & 4.88 \\
\hline
\end{tabular}




\section{DOE/RL-97-69}

Rev. 0

Table B-5. Ratio of Intruder Dose Factors for $2500 \mathrm{~m}^{2}$ Garden Relative to $500 \mathrm{~m}^{2}$ Garden. ${ }^{a}$

\begin{tabular}{|c|c|c|c|c|c|}
\hline Nuclide & Ratio & Nuclide & Ratio & Nuclide & Ratio \\
\hline Тс-99 & 5.00 & $\mathrm{~Pb}-210+\mathrm{D}$ & 4.99 & Am- $242 m+D$ & 4.82 \\
\hline $\mathrm{Ru}-106+\mathrm{D}$ & 1.17 & $\mathrm{Bi}-207$ & 1.09 & Am-243+D & 3.52 \\
\hline $\mathrm{Pd}-107$ & 5.00 & Po-209 & 4.87 & $\mathrm{Cm}-243$ & 3.53 \\
\hline$A g-108 m+D$ & 1.11 & $\mathrm{Ra}-226+\mathrm{D}$ & 1.25 & $\mathrm{Cm}-244$ & 5.00 \\
\hline $\mathrm{Cd}-109$ & 4.51 & $\mathrm{Ra}-228+\mathrm{D}$ & 1.37 & $\mathrm{Cm}-245$ & 4.26 \\
\hline $\mathrm{Cd}-113 \mathrm{~m}$ & 5.00 & $\mathrm{Ac}-227+\mathrm{D}$ & 4.43 & $\mathrm{Cm}-246$ & 5.00 \\
\hline In-115 & 4.95 & Th-228+D & 1.33 & $\mathrm{Cm}-247+\mathrm{D}$ & 2.78 \\
\hline $\mathrm{Sn}-121 \mathrm{~m}+\mathrm{D}$ & 2.31 & Th-229+D & 3.76 & $\mathrm{Cm}-248$ & 5.00 \\
\hline
\end{tabular}

"Nuclides with " $+\mathrm{D}$ " added to the name include the contributions from short-lived progeny, which are assumed to be in equilibrium. 
Rev. 0

Table B-6. Half-Life and Other Decay Information.

\begin{tabular}{|c|c|c|c|c|}
\hline Parent & Half-Live (y) & $\begin{array}{c}\text { Next Long-Lived } \\
\text { Daughter }\end{array}$ & $\begin{array}{c}\text { Number of } \\
\text { Alpha Emitters } \\
\end{array}$ & $\begin{array}{c}\begin{array}{c}\text { Branching } \\
\text { Ratio }\end{array} \\
\end{array}$ \\
\hline${ }^{3} \mathrm{H}$ & 12.28 & & 0 & 1.0 \\
\hline${ }^{10} \mathrm{Be}$ & $1.60 \times 10^{6}$ & & 0 & 1.0 \\
\hline${ }^{14} \mathrm{C}$ & $5,730.0$ & & 0 & 1.0 \\
\hline${ }^{22} \mathrm{Na}$ & 2.602 & & 0 & 1.0 \\
\hline${ }^{36} \mathrm{Cl}$ & $301,000.0$ & & 0 & 1.0 \\
\hline${ }^{40} \mathrm{~K}$ & $1.277 \times 10^{9}$ & & 0 & 1.0 \\
\hline${ }^{54} \mathrm{Mn}$ & 0.856 & & 0 & 1.0 \\
\hline${ }^{55} \mathrm{Fe}$ & 2.7 & & 0 & 1.0 \\
\hline${ }^{60} \mathrm{Co}$ & 5.271 & & 0 & 1.0 \\
\hline${ }^{59} \mathrm{Ni}$ & $75,000.0$ & . & 0 & 1.0 \\
\hline${ }^{63} \mathrm{Ni}$ & 100.1 & & 0 & 1.0 \\
\hline${ }^{79} \mathrm{Se}$ & $65,000.0^{\mathrm{a}}$ & & 0 & 1.0 \\
\hline${ }^{87} \mathrm{Rb}$ & $4.73 \times 10^{10}$ & & 0 & 1.0 \\
\hline${ }^{90} \mathrm{Sr}$ & 28.6 & & 0 & 1.0 \\
\hline${ }^{93} \mathrm{Zr}$ & $1.53 \times 10^{6}$ & ${ }^{93} \mathrm{Nb}^{\mathrm{m}}$ & 0 & 1.0 \\
\hline${ }^{93} \mathrm{Nb}^{\mathrm{m}}$ & 14.6 & & 0 & 1.0 \\
\hline${ }^{94} \mathrm{Nb}$ & $20,300.0$ & & 0 & 1.0 \\
\hline${ }^{93} \mathrm{Mo}$ & $3,500.0$ & & 0 & 1.0 \\
\hline${ }^{99} \mathrm{Tc}$ & $213,000.0$ & & 0 & 1.0 \\
\hline${ }^{106} \mathrm{Ru}$ & 1.01 & & 0 & 1.0 \\
\hline${ }^{107} \mathrm{Pd}$ & $6.50 \times 10^{6}$ & & 0 & 1.0 \\
\hline${ }^{108} \mathrm{Ag}^{\mathrm{m}}$ & 127.0 & & 0 & 1.0 \\
\hline${ }^{109} \mathrm{Cd}$ & 1.2704 & & 0 & 1.0 \\
\hline${ }^{113} \mathrm{Cd}^{\mathrm{m}}$ & 13.7 & & 0 & 1.0 \\
\hline${ }^{115} \mathrm{In}$ & $4.6 \times 10^{15}$ & & 0 & 1.0 \\
\hline${ }^{121} \mathrm{Sn}^{\mathrm{m}}$ & 55.0 & & 0 & 1.0 \\
\hline
\end{tabular}


DOE/RL-97-69

Rev. 0

Table B-6. Half-Life and Other Decay Information.

\begin{tabular}{|c|c|c|c|c|}
\hline Parent & Half-Live (y) & $\begin{array}{c}\text { Next Long-Lived } \\
\text { Daughter }\end{array}$ & $\begin{array}{c}\text { Number of } \\
\text { Alpha Emitters }\end{array}$ & $\begin{array}{c}\text { Branching } \\
\text { Ratio } \\
\end{array}$ \\
\hline${ }^{126} \mathrm{Sn}$ & $100,000.0^{\mathrm{a}}$ & & 0 & 1.0 \\
\hline${ }^{125} \mathrm{Sb}$ & 2.77 & & 0 & 1.0 \\
\hline${ }^{129} \mathrm{I}$ & $1.57 \times 10^{7}$ & & 0 & 1.0 \\
\hline${ }^{134} \mathrm{Cs}$ & 2.062 & & 0 & 1.0 \\
\hline${ }^{135} \mathrm{Cs}$ & $2.30 \times 10^{6}$ & & 0 & 1.0 \\
\hline${ }^{137} \mathrm{Cs}$ & 30.17 & & 0 & 1.0 \\
\hline${ }^{133} \mathrm{Ba}$ & 10.5 & & 0 & 1.0 \\
\hline${ }^{147} \mathrm{Pm}$ & 2.6234 & & 0 & 1.0 \\
\hline${ }^{147} \mathrm{Sm}$ & $1.06 \times 10^{11}$ & & 1 & 1.0 \\
\hline${ }^{151} \mathrm{Sm}$ & 90.0 & & 0 & 1.0 \\
\hline${ }^{150} \mathrm{Eu}$ & 36.0 & & 0 & 1.0 \\
\hline${ }^{152} \mathrm{Eu}$ & 13.6 & & 0 & 1.0 \\
\hline${ }^{154} \mathrm{Eu}$ & 8.8 & & 0 & $1.0^{\circ}$ \\
\hline${ }^{15 s} \mathrm{Eu}$ & 4.96 & & 0 & 1.0 \\
\hline${ }^{152} \mathrm{Gd}$ & $1.10 \times 10^{14}$ & & 1 & 1.0 \\
\hline${ }^{166} \mathrm{Ho}^{\mathrm{m}}$ & $1,200.0$ & & 0 & 1.0 \\
\hline${ }^{187} \mathrm{Re}$ & $4.7 \times 10^{10}$ & & 0 & 1.0 \\
\hline${ }^{204} \mathrm{Tl}$ & 3.779 & & 0 & 1.0 \\
\hline${ }^{210} \mathrm{~Pb}$ & 22.26 & & 1 & 1.0 \\
\hline${ }^{226} \mathrm{Ra}$ & $1,600.0$ & ${ }^{210} \mathrm{~Pb}$ & 4 & 1.0 \\
\hline${ }^{228} \mathrm{Ra}$ & 5.75 & ${ }^{228} \mathrm{Th}$ & 0 & 1.0 \\
\hline${ }^{227} \mathrm{Ac}$ & 21.773 & & 5 & 1.0 \\
\hline${ }^{228} \mathrm{Th}$ & 1.9132 & ${ }^{208} \mathrm{~Pb}$ & 5 & 1.0 \\
\hline${ }^{229} \mathrm{Th}$ & 7340.0 & & 5 & 1.0 \\
\hline${ }^{230} \mathrm{Th}$ & 77000.0 & ${ }^{226} \mathrm{Ra}$ & 1 & 1.0 \\
\hline${ }^{232} \mathrm{Th}$ & $1.405 \times 10^{10}$ & ${ }^{228} \mathrm{Ra}$ & 1 & 1.0 \\
\hline
\end{tabular}


DOE/RL-97-69

Rev. 0

Table B-6. Half-Life and Other Decay Information.

\begin{tabular}{|c|c|c|c|c|}
\hline Parent & Half-Live (y) & $\begin{array}{c}\text { Next Long-Lived } \\
\text { Daughter }\end{array}$ & $\begin{array}{c}\text { Number of } \\
\text { Alpha Emitters }\end{array}$ & $\begin{array}{c}\text { Branching } \\
\text { Ratio } \\
\end{array}$ \\
\hline${ }^{231} \mathrm{~Pa}$ & $32,764.0$ & ${ }^{227} \mathrm{Ac}$ & 1 & 1.0 \\
\hline${ }^{232} \mathrm{U}$ & 72.0 & ${ }^{228} \mathrm{Th}$ & 1 & 1.0 \\
\hline${ }^{233} \mathrm{U}$ & 159200.0 & ${ }^{229} \mathrm{Th}$ & $\mathrm{i}$ & 1.0 \\
\hline${ }^{234} \mathrm{U}$ & $244,500.0$ & ${ }^{230} \mathrm{Th}$ & 1 & 1.0 \\
\hline${ }^{235} \mathrm{U}$ & $7.038 \times 10^{8}$ & ${ }^{231} \mathrm{~Pa}$ & 1 & 1.0 \\
\hline${ }^{236} \mathrm{U}$ & $2.34 \times 10^{7}$ & ${ }^{232} \mathrm{U}$ & 1 & 1.0 \\
\hline${ }^{238} \mathrm{U}$ & $4.468 \times 10^{9}$ & ${ }^{234} \mathrm{U}$ & 1 & 1.0 \\
\hline${ }^{237} \mathrm{~Np}$ & $2.14 \times 10^{6}$ & ${ }^{233} \mathrm{U}$ & 1 & 1.0 \\
\hline${ }^{236} \mathrm{Pu}$ & 2.851 & ${ }^{232} \mathrm{U}$ & 1 & 1.0 \\
\hline${ }^{238} \mathrm{Pu}$ & 87.75 & ${ }^{234} \mathrm{U}$ & 1 & 1.0 \\
\hline${ }^{239} \mathrm{Pu}$ & $24,131.0$ & ${ }^{235} \mathrm{U}$ & 1 & 1.0 \\
\hline${ }^{240} \mathrm{Pu}$ & $6,569.0$ & ${ }^{236} \mathrm{U}$ & 1 & 1.0 \\
\hline${ }^{241} \mathrm{Pu}$ & 14.4 & ${ }^{241} \mathrm{Am}$ & 0 & $1.0^{\circ}$ \\
\hline${ }^{242} \mathrm{Pu}$ & $375,800.0$ & ${ }^{238} \mathrm{U}$ & 1 & 1.0 . \\
\hline${ }^{244} \mathrm{Pu}$ & $8.26 \times 10^{7}$ & ${ }^{240} \mathrm{Pu}$ & 1 & 1.0 \\
\hline${ }^{241} \mathrm{Am}$ & 432.2 & ${ }^{237} \mathrm{~Np}$ & 1 & 1.0 \\
\hline${ }^{242} \mathrm{Am}^{\mathrm{m}}$ & $152.0^{\circ}$ & ${ }^{238} \mathrm{Pu}$ & 1 & $0.82782^{\mathrm{b}}$ \\
\hline${ }^{243} \mathrm{Am}$ & $7,380.0$ & ${ }^{239} \mathrm{Pu}$ & 1 & 1.0 \\
\hline${ }^{243} \mathrm{Cm}$ & 28.5 & ${ }^{239} \mathrm{Pu}$ & 1 & 1.0 \\
\hline${ }^{244} \mathrm{Cm}$ & 18.11 & ${ }^{240} \mathrm{Pu}$ & 1 & 1.0 \\
\hline${ }^{245} \mathrm{Cm}$ & $8,500.0$ & ${ }^{241} \mathrm{Pu}$ & 1 & 1.0 \\
\hline${ }^{246} \mathrm{Cm}$ & $4,750.0$ & ${ }^{242} \mathrm{Pu}$ & 1 & 1.0 \\
\hline${ }^{247} \mathrm{Cm}$ & $1.56 \times 10^{7}$ & ${ }^{243} \mathrm{Am}$ & 1 & 1.0 \\
\hline${ }^{248} \mathrm{Cm}$ & $339,000.0$ & ${ }^{244} \mathrm{Pu}$ & 1 & $0.9174^{\circ}$ \\
\hline
\end{tabular}

Value is suspected to be in error, see text.

${ }^{b}$ Remainder goes to ${ }^{242} \mathrm{Cm}$

- Remainder undergoes spontaneous fission 


\section{DOE/RL-97-69}

Rev. 0

Table B-7. Ratios of EPA Internal Dose Factors to DOE Values.

Differences of Less than 10 Percent are Not Shown.

\begin{tabular}{|l|c|c||c|c|c|}
\hline Nuclide & Ingestion & Inhalation & Nuclide & Ingestion & Inhalation \\
\hline \hline${ }^{79} \mathrm{Se}$ & & 1.11 & ${ }^{228} \mathrm{Ra}$ & 1.20 & 1.13 \\
\hline${ }^{99} \mathrm{Tc}$ & 1.12 & 1.11 & ${ }^{237} \mathrm{~Np}$ & 1.14 & \\
\hline${ }^{126} \mathrm{Sn}$ & 1.15 & 1.34 & ${ }^{239} \mathrm{Pu}$ & 0.82 & 0.84 \\
\hline${ }^{151} \mathrm{Sm}$ & & 1.14 & ${ }^{240} \mathrm{Pu}$ & 0.82 & 0.84 \\
\hline${ }^{207} \mathrm{Bi}$ & 1.12 & 1.43 & ${ }^{241} \mathrm{Am}$ & 0.81 & 0.85 \\
\hline${ }^{209} \mathrm{Po}$ & 1.19 & 1.17 & ${ }^{243} \mathrm{Am}$ & 0.80 & 0.85 \\
\hline${ }^{226} \mathrm{Ra}$ & 1.20 & & ${ }^{245} \mathrm{Cm}$ & 0.83 & 0.84 \\
\hline
\end{tabular}


DOE/RL-97-69

Rev. 0

B-18 
DOE/RL-97-69

Rev. 0

\section{APPENDIX C \\ WASTE FORM RELEASE COMPUTER CODES}

\section{C.1 Overview}

This section briefly summarizes the waste form release modeling for those sensitivity cases involving computer simulation of the release. More information is given than is justified by the importance of the three sensitivity cases because later performance assessments will probably be based heavily on this type of simulation:

\section{C.2 Governing Equations}

\section{C.2.1 Mass Conservation of Aqueous Solutes}

Based on the continuum theory, the model can be represented by a set of partial differential equations (PDEs) that describe the mass conservation of solutes in pore fluids. Assuming that the rock matrix does not deform, the mass conservation law of solutes can be written as

$$
\frac{\partial\left(\phi S_{w} \rho_{w} C_{i}\right)}{\partial t}=-\vec{\nabla} \cdot \vec{J}_{i}+\sum_{j=1}^{N_{r}} v_{i j} W_{j}, \quad i=1,2, \ldots
$$

where $\phi$ denotes the porosity,

$S_{w}$ denotes the water saturation,

$\rho_{w}$. the density of the aqueous solution,

$\mathrm{C}_{\mathrm{i}} \quad$ is the molal concentration of solute $\mathrm{i}$.

$J_{i} \quad$ is the flux of species $i$,

$v_{i j}$ is the stoichiometric coefficient of species $i$ in reaction $j$,

$\mathrm{N}_{\mathrm{r}}$ is the number of total reactions, and

$\mathrm{w}_{j} \quad$ is the rate of reaction $\mathrm{j}$.

In general, the reaction rate is a non-linear function of the concentrations. Through the term $\mathrm{W}_{p}$ one solute species is non-linearly coupled with other species. The non-linear partial differential equation [equation (C.1)] simply states that the time rate of change of aqueous species concentrations consists of two parts; one is the contribution of transport and the other is the contribution of all reactions. Assuming the phenomenon of hydrodynamic dispersion can be represented by a Fickian type law, the first term on the right-hand side can be expanded into

$$
-\vec{\nabla} \cdot \vec{J}_{i}=-\vec{\nabla} \cdot\left(-\phi S_{w} \rho_{w} D_{i} \vec{\nabla} C_{i}+\vec{u} \phi S_{w} \rho_{w} C_{i}\right),
$$

where $D_{i} \quad$ is the dispersion coefficient of $i$ and

u is the velocity of pore fluid. 


\section{DOE/RL-97-69}

Rev. 0

The second term at the right-hand side of equation (C.1) represents all types of reactions, including aqueous speciation, redox reactions, solid precipitation and dissolution, and adsorption. In general, chemical reactions can be treated as either equilibrium-controlled or kinetic-controlled. Several of the available reaction-transport models can only treat equilibrium reactions (Mangold 1991). In this case, the non-linear equation (C.1) can be transformed into a linear equation, making it numerically easier to solve. However, many reactions are kinetically controlled, especially solid dissolution and precipitation reactions. Consequently, both equilibrium and kinetic reactions are included in the model used here. To emphasize this, the reaction term in equation (C.1) is split into two parts: one represents the contributions from equilibrium reactions, the other contributions from kinetic reactions

$$
\sum_{j=1}^{N_{f}} v_{i j} W_{j}=\sum_{j=1}^{N_{e}} v_{i j}^{e} W_{j}^{e}+\sum_{j=1}^{N_{k}} v_{i j}^{k} W_{j}^{k},
$$

where $v_{i j}{ }^{\circ}$ and $v_{i j}{ }^{\mathrm{k}}$ are the stoichiometric coefficients in equilibrium reactions and kinetic reactions, respectively, while $\mathrm{W}_{j}{ }^{\mathrm{a}}$ and $\mathrm{W}_{\mathrm{j}}{ }^{\mathrm{k}}$ are the rates of equilibrium and kinetic reactions, respectively.

To define the mathematical form of the $W$ 's, note that for any kinetic reaction $j$ involving aqueous and solid species $m$ with the form

$$
\sum v_{m j} B_{m}=0
$$

using the law of mass-action, with activity corrections, the rate can be expressed as

$$
W_{j}^{k}=A_{j} k_{j}\left[\prod_{v_{i j}<0}\left(\gamma_{i} C_{i}\right)^{N_{i j} j^{\prime}}-\prod_{v_{i j}>0}\left(\gamma_{i} C_{i}\right)^{v_{i j} / K_{j}^{e q}}\right]
$$

where $A_{j}$ is a factor. For aqueous reactions, $A_{j}=1$. For solid dissolution and precipitation reactions, $A_{j}$ is the effective reaction surface in unit volume of the porous medium. If we further assume that all solids are spherical grains or can be represented as equivalent spherical grains with radii of $R_{1}$, and that the effective reaction surface is proportional to water saturation then,

$$
W_{j}=4 \pi R_{l(j)}^{2} n_{l(j)} S_{w} k_{j}\left[\prod_{v_{i j}<0}\left(\gamma_{i} C_{i}\right)^{l v_{i j} /}-\prod_{v_{i j}>0}\left(\gamma_{i} C_{i}\right)^{v_{i j} / K_{j}^{e q}}\right]
$$

where $n_{1} \quad$ denotes the number of grains in unit volume of porous medium

$k_{j}$. is the rate constant

$\gamma_{i} \quad$ is the activity coefficient, which is a function of the concentrations of all species.

Several formulas, such as Davies equation, B-dot equation, and Pitzer's model, can be used to calculate $\gamma_{\mathrm{i}}$. The B-dot equation with modifications for neutral species adopted by Wolery (1992) is computationally economic and stable, and can handle moderate salinity; making it the most suitable for reaction-transport problems. Although Pitzer's model can handle high ionic strength, computationally it is not feasible for reaction-transport simulations because of its complicated structure and the lack of Pitzer constants for all but a few aqueous species. 
Rev, 0

\section{C.2.2 Texture Dynamics}

Dissolution and precipitation reactions can change the volume fractions of solids as a function of time. For spherical grains, the change rate is

while

$$
\frac{\partial V_{l}}{\partial t}=4 \pi R_{l}^{2} n_{l} \frac{\partial R_{l}}{\partial t},
$$

$$
\frac{\partial R_{l}}{\partial t}=\sum_{j} k_{j}\left[\prod_{v_{i}<0}\left(\gamma_{i} C_{i}\right)^{j v_{i j} \prime}-\prod_{v_{i j}>0}\left(\gamma_{i} C_{i}\right)^{v_{i j} / K_{j}^{e q}}\right] / \rho_{j},
$$

where $V_{1}$. is the volume fraction of solid 1

$R_{t} \quad$ is the change rate in radius of solid 1

$\rho_{1} \quad$ is the molar density of 1 .

Equation (C.8) serves as the bridge between the aqueous phase and solid phases so the whole system is mass-conserved.

\section{C.2.3 Contaminant Release Rate From Glass}

The equation for the contaminant release rate from glass is taken as

$$
J_{i}=v_{i} a_{H^{-}}^{-n(n)} k_{o} e^{\frac{E_{a}}{R T}}\left[1-\left(\frac{Q}{K}\right)^{\sigma}\right]
$$

where $\mathbf{J}_{\mathrm{i}} . \quad$ is the flux of element $\mathrm{i}$

$v_{i}$ is the stoichmetric coefficient of element $i$

$\mathrm{a}_{\mathrm{H}+} \quad$ is the activity of $\mathrm{H}^{+}$

$\eta \quad$ is the $\mathrm{pH}$ power law coefficient

$T$ is the temperature

$k_{o}$ is the intrinsic rate constant

$E_{a} \quad$ is the activation energy

$R \quad$ is the gas constant

$\mathrm{Q}$ is the ion activity product

$\mathrm{K}$ is the pseudoequilibrium constant

$\sigma \quad$ is the average stoichiometric parameter for the overall reaction. 


\section{Rev. 0}

\section{C.2.4 Reactions Considered}

Three types of reactions are considered:

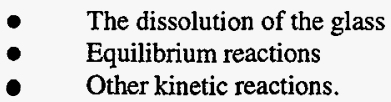

The glass considered in our simulations is LD6-5412, with a formula of the major glass components of $\mathrm{Al}_{0.1535} \mathrm{~B}_{0.094} \mathrm{Ca}_{0.046} \mathrm{~K}_{0.0202} \mathrm{Na}_{0.4208} \mathrm{Si}_{0.6068} \mathrm{O}_{1.8514}$. Flow-through experiments show that two reaction mechanisms are involved in the glass dissolution (McGrail 1995). One is the network dissolution reaction

$$
\begin{aligned}
\text { Glass }+ & 0.5 \mathrm{OH}^{-}+0.45 \mathrm{H}_{2} \mathrm{O}= \\
& 0.0202 \mathrm{~K}^{+}+0.4208 \mathrm{Na}^{+}+0.046 \mathrm{Ca}++0.094 \mathrm{BO}_{2}^{+}+ \\
& 0.154 \mathrm{Al}(\mathrm{OH})_{3}(\mathrm{aq})+0.2712 \mathrm{HSiO}_{3}^{-}+0.3348 \mathrm{H}_{2} \mathrm{SiO}_{4}{ }^{2-}+ \\
& 2.28 \times 10^{-8} \mathrm{SeO}_{3}{ }^{2-}+1.62 \times 10^{-6} \mathrm{TcO}_{4}^{-}+3.83 \times 10^{-8} \mathrm{IO}_{3}^{-}+ \\
& \left.2.72 \times 10^{-5} \mathrm{U}^{-} \mathrm{OH}\right)_{4}(\mathrm{aq})+1.93 \times 10^{-9} \mathrm{Pu}(\mathrm{OH})_{5}^{-}+ \\
& 2.73 \times 10^{-9} \mathrm{NpO}_{2}(\mathrm{OH})(\mathrm{aq})
\end{aligned}
$$

the other is an ion-exchange reaction

$$
\text { Glass } .0 .4208 \mathrm{Na}+0.4208 \mathrm{H}^{+}=0.4208 \mathrm{Na}^{+}+\text {Glass } \cdots .0 .4208 \mathrm{H}
$$

The measured rate constant for reaction (C.10) at $14^{\circ} \mathrm{C}$ is $3.03 \times 10^{-14} \mathrm{~mol} \cdot \mathrm{m}^{-2} \cdot \mathrm{s}^{-1}=$

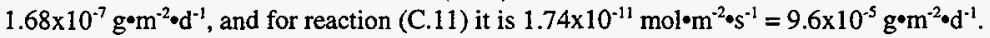
Radionuclide release is assumed to only occur via reaction (C.10); the release of all radionuclides is assumed to be congruent.

Thirty-eight aqueous species, 14 solid species plus glass were considered in the simulations. The selection of species is based on speciation calculations and observations from glass testing experiments. Table $\mathrm{C}-1$ lists all reactions considered in the simulations, including 21 equilibrium reactions and 16 kinetic reactions.

Table C-1. List of Reactions Considered in Glass Performance

\begin{tabular}{|l|l|}
\hline Number & Reaction \\
\hline \multicolumn{2}{|l|}{} \\
\hline 1. & $\mathrm{H}_{2} \mathrm{O}=\mathrm{H}^{+}+\mathrm{OH}^{-}$ \\
\hline 2. & $\mathrm{CO}_{2}(\mathrm{aq})+\mathrm{H}_{2} \mathrm{O}=\mathrm{H}^{+}+\mathrm{HCO}_{3}^{\circ}$ \\
\hline 3. & $\mathrm{HCO}_{3}=\mathrm{H}^{+}+\mathrm{CO}_{3}^{2-}$ \\
\hline 4. & $\mathrm{Al}(\mathrm{OH})_{4}+\mathrm{H}^{+}=\mathrm{Al}(\mathrm{OH})_{3}+\mathrm{H}_{2} \mathrm{O}$ \\
\hline 5. & $\mathrm{H}_{2} \mathrm{SiO}_{4}^{2}+2 \mathrm{H}^{+}=\mathrm{SiO}_{2}(\mathrm{aq})+\mathrm{H}_{2} \mathrm{O}$ \\
\hline 6. & $\mathrm{HSSO}_{3}+\mathrm{H}^{+}=\mathrm{SiO}_{2}(\mathrm{aq})+\mathrm{H}_{2} \mathrm{O}$ \\
\hline
\end{tabular}


DOE/RL-97-69

Rev. 0

Table C-1. List of Reactions Considered in Glass Performance

\begin{tabular}{|c|c|}
\hline 7. & $\mathrm{BO}_{2}^{-}+\mathrm{H}^{+}=\mathrm{B}(\mathrm{OH})_{3}(\mathrm{aq})$ \\
\hline 8. & $\mathrm{CaCO}_{3}(\mathrm{aq})+\mathrm{H}^{+}=\mathrm{Ca}^{2+}+\mathrm{HCO}_{3}$ \\
\hline 9. & $\mathrm{CaHCO}_{3}{ }^{+}=\mathrm{Ca}^{2+}+\mathrm{HCO}_{3}^{-}$ \\
\hline 10. & $\mathrm{CaOH}^{+}+\mathrm{H}^{*}=\mathrm{Ca}^{2+}+\mathrm{H}_{2} \mathrm{O}$ \\
\hline 11. & $\mathrm{UO}_{2} \mathrm{CO}_{3}(\mathrm{OH})_{3}^{+}+4 \mathrm{H}^{+}=2 \mathrm{UO}_{2}^{+}+\mathrm{HCO}_{3}^{-}+3 \mathrm{H}_{2} \mathrm{O}$ \\
\hline 12. & $\mathrm{UO}_{2} \mathrm{CO}_{3}(\mathrm{aq})+\mathrm{H}^{*}=\mathrm{HCO}_{3}{ }^{-}+\mathrm{UO}_{2}{ }^{2+}$ \\
\hline 13. & $\mathrm{UO}_{2}\left(\mathrm{CO}_{3}\right)_{2}{ }^{2+}+2 \mathrm{H}^{+}=\mathrm{UO}_{2}{ }^{2+} 2 \mathrm{HCO}_{3}{ }^{-}$ \\
\hline 14. & $\mathrm{UO}_{2}\left(\mathrm{CO}_{3}\right)_{3}{ }^{4}+3 \mathrm{H}^{+}=\mathrm{UO}_{2}{ }^{1+}+3 \mathrm{HCO}_{3}^{-}$ \\
\hline 15. & $\mathrm{UO}_{2} \mathrm{OH}^{*}+\mathrm{H}^{+}=\mathrm{UO}_{2}^{2+}+\mathrm{H}_{2} \mathrm{O}$ \\
\hline 16. & $\mathrm{UO}_{2}(\mathrm{OH})_{2}(\mathrm{aq})+2 \mathrm{H}^{+}=\mathrm{UO}_{2}^{2+}+2 \mathrm{H}_{2} \mathrm{O}$ \\
\hline 17. & $\mathrm{UO}_{2}(\mathrm{OH})_{3}+3 \mathrm{H}^{+}=\mathrm{UO}_{2}{ }^{2+}+3 \mathrm{H}_{2} \mathrm{O}$ \\
\hline 18. & $\mathrm{U}(\mathrm{OH})_{4}(\mathrm{aq})+0.5 \mathrm{O}_{2}(\mathrm{aq})+2 \mathrm{H}^{+}=\mathrm{UO}_{2}{ }^{2+}+3 \mathrm{H}_{2} \mathrm{O}$ \\
\hline 19. & $\mathrm{NpO}_{2} \mathrm{OH}(\mathrm{aq})=\mathrm{OH}+\mathrm{NpO}_{2}^{*}$ \\
\hline 20. & $\mathrm{NpO}_{2}\left(\mathrm{CO}_{3}\right)^{-}=\mathrm{NpO}_{2}{ }^{+}+\mathrm{CO}_{3}{ }^{2 *}$ \\
\hline 21. & $\mathrm{HSeO}_{3}=\mathrm{H}^{*}+\mathrm{SeO}_{3}^{2-}$ \\
\hline & Kinetic Reactions \\
\hline 1. & 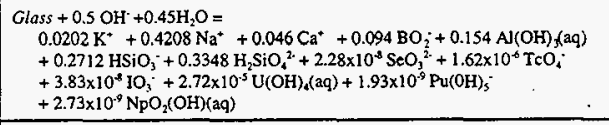 \\
\hline 2. & Glass. $0.4208 \mathrm{Na}+0.4208 \mathrm{H}^{+}=0.4208 \mathrm{Na}^{+}+$Glass .0 .4208 \\
\hline 3. & Quarz $+\mathrm{OH}=\mathrm{HSiO}_{3}^{-}$ \\
\hline 4. & Calcire $=\mathrm{Ca}^{2+}+\mathrm{CO}_{3}$ \\
\hline 5. & Albite $($ high $)+2 \mathrm{OH}^{*}=\mathrm{Na}^{+}+\mathrm{Al}(\mathrm{OH})_{3}(\mathrm{aq})+3 \mathrm{HSiO}_{3}$ \\
\hline 6. & $\mathrm{~K}$-feldspar $+2 \mathrm{OH}=\mathrm{K}^{+}+\mathrm{Al}(\mathrm{OH})_{3}(\mathrm{aq})+3 \mathrm{HSiO}_{3}$ \\
\hline 7. & Illite $+2.4 \mathrm{OH}^{-}=0.6 \mathrm{~K}^{+}+0.25 \mathrm{Mg}^{2+}+2.3 \mathrm{Al}(\mathrm{OH}) 3(\mathrm{aq})+3.5 \mathrm{HSiO}_{3}^{-}$ \\
\hline 8. & Analcime $+0.96 \mathrm{H}^{+}=0.96 \mathrm{Na}^{+}+0.96 \mathrm{AL}(\mathrm{OH})_{3}(\mathrm{aq})+2.04 \mathrm{SiO}_{2}(\mathrm{aq})+5.04 \mathrm{H}_{2} \mathrm{O}$ \\
\hline 9. & Chalcedony $=\mathrm{SiO}_{2}(\mathrm{aq})$ \\
\hline 10. & $\mathrm{NaAlSi}{ }_{2} \mathrm{O}_{6} 6 \mathrm{H} 2 \mathrm{O}+\mathrm{OH}=\mathrm{Na}^{+}+\mathrm{Al}(\mathrm{OH})_{3}(\mathrm{aq})+2 \mathrm{HSiO}_{3}{ }^{-}+4 \mathrm{H}_{2} \mathrm{O}$ \\
\hline 11. & Phillipsite $+3 \mathrm{H}^{*}=\mathrm{K}^{+}+\mathrm{Ca}^{2+} 3 \mathrm{Al}(\mathrm{OH})_{3}(\mathrm{aq})+5 \mathrm{SiO}_{2}(\mathrm{aq})+3 \mathrm{H}_{2} \mathrm{O}$ \\
\hline 12. & Tobermorite $+10 \mathrm{H}^{+}=5 \mathrm{Ca}^{2+}+6 \mathrm{SiO}_{2}(\mathrm{aq})+10.5 \mathrm{H}_{2} \mathrm{O}$ \\
\hline 13. & Gobbinsile $+6 \mathrm{H}^{+}=4 \mathrm{Na}^{+}+\mathrm{Ca}^{2+}+6 \mathrm{Al}(\mathrm{OH})_{3}(\mathrm{aq})+10 \mathrm{SiO}_{2}(a q)+8 \mathrm{H}_{2} \mathrm{O}$ \\
\hline 14. & Haiweeite $+6 \mathrm{H}^{*}=\mathrm{Ca}^{2+}+6 \mathrm{SiO}_{2}(\mathrm{aq})+2 \mathrm{UO}_{2}^{2+}+8 \mathrm{H}_{2} \mathrm{O}$ \\
\hline 15. & Schoepite $+2 \mathrm{H}^{+}=\mathrm{UO}_{2}^{2+}+3 \mathrm{H}_{2} \mathrm{O}$ \\
\hline 16. & $\mathrm{PuO}_{2}(\mathrm{~s})+3 \mathrm{H}_{2} \mathrm{O}=\mathrm{H}^{+}+\mathrm{Pu}(\mathrm{OH})^{s}$ \\
\hline
\end{tabular}




\section{DOE/RL-97-69}

Rev. 0

\section{C.3 Code Selection}

The selection of AREST-CT for modeling the release rate of contaminants from the glass waste form was based on meeting the criteria and requirements for the disposal system release model (McGrail 1994). The 10 codes considered were

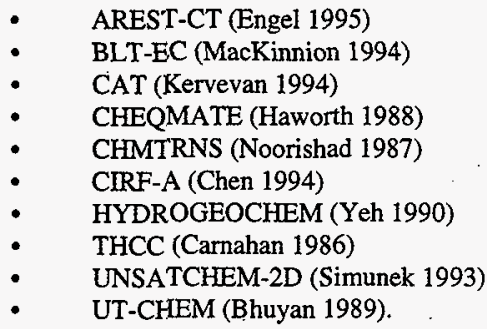

To be considered, a code must have met the criteria and requirements given in Mann $1995 \mathrm{c}$ and at least 50 percent of all requirements given in McGrail 1994. Briefly, the criteria were that the codes would be
- Based on scientific principles
- Documented
- Maintained under a software quality management program
- Able to use Site- and facility-specific data
- Capable of monitoring long simulations.

The requirements given in Mann 1995c were based on the capabilities of the code. The source term codes needed to be capable of the following:

- Simulating radionuclide release from unstable and stable vitrified waste

- Modeling various chemical processes

- Simulating radionuclide releases controlled by solubility limits or adsorption

- Accepting specific release rates then simulating the disposal facility release until the inventory was depleted.

The additional requirements listed in McGrail (1994) fit into one of four groups -- physical processes, chemical processes, numerical methods, and functionality. The first two groups contained a list of related principal processes. These processes were expected to affect low-level waste glass corrosion and the mobility of radionuclides. The numerical method group contained a list of related numerical methods needed to solve the related equations in the first two groups. Functionality covered a variety of program options such as a graphical users interface and a software quality management program. 
DOE/RL-97-69

Rev, 0

All the requirements in McGrail (1994) were given a merit score. This score was based on the importance of the process to modeling the performance of the disposal facility and on the degree of difficulty in adding the capability to an existing code. Codes having a specific capability were assigned the merit score for that capability. All the merit scores for each code were tabulated for a total merit score for the code. AREST-CT was chosen over the nine other codes because, based on the totals, AREST-CT had the largest merit score of 361. The next code had a total score of 264. For the scores of other codes, see McGrail 1994.

\section{C.4 Verification and Benchmarking}

Because AREST-CT is still being developed, its verification, benchmarking, and validation history are short. However, the comparisons between experimental results produced for this interim performance assessment and the AREST-CT calculations for this document give confidence to the validity of the AREST-CT code.

The verification of AREST-CT, Version 1, was done to ensure that modules of the program were correctly implemented and worked together (Chen 1995). The verification had two parts. First, specific portions or modules of AREST-CT were unit tested to verify that the modules were performing correctly. Unit testing consists of evaluating individual code modules against hand calculations, analytical solutions, or other existing numerical codes. Each module was unit tested before being implemented into AREST-CT. All modules were considered acceptable for current use.

The second part of the verification of AREST-CT consisted of testing the computer code as a whole object. At the time of verification, no analytical solutions existed for solving the reaction-transport problems designed for AREST-CT. The code was benchmarked against simulation results from a similar reaction-transport code.

The benchmark test case that was a one-dimensional idealization of a low-level waste engineered system. The system consisted of 7 solids and 12 aqueous species. Two types of reactions were considered: equilibrium aqueous reactions and solid dissolution/precipitation reactions. More details on the testing are given in Chen (1995). The results of the test showed that AREST-CT simulations quantitatively compared well with the analytical solutions and other reactive-transport codes.

Further testing and verification tests will be conducted as the AREST-CT code develops. Future testing will include integration testing for mechanisms of radioactive decay and decay chain in growth, and for two-dimensional simulation. Plans for code development include increasing the number of grid nodes and decreasing the size of time steps for the onedimensional transport case to improve convergence. Also the program will be coupled with an unsaturated flow solver. Currently, the program uses the water velocity data from PORFLOW. With the flow solver, AREST-CT will model infiltration velocity changes with porosity as a result of solid dissolution/precipitation reactions. 
DOE/RL-97-69

Rev. 0

$c-8$ 
DOE/RL-97-69

Rev. 0

\section{APPENDIX D \\ MOISTURE FLOW AND CONTAMINANT TRANSPORT COMPUTER CODES}

\section{D.1 Overview}

This appendix provides detailed information about the moisture flow and transport codes [PORFLOW (ACRi 1994a) and VAM3D-CG (Huyakorn 1994)] used in this performance assessment. The following sections cover the governing equations, the detailed reasons for code selection; verification, benchmarking, and validation efforts; and the input decks for the base analysis case.

\section{D.2 Governing Equations}

\section{D.2.1 Overview}

This section discusses the equations important in calculating moisture flow and contaminant transport. The first section presents the equations on which the water flow calculations are based. The next section discusses contaminant transport associated with moisture flow. The final section describes moisture movement under diffusive conditions.

\section{D.2.2 Moisture Flow}

Two distinct moisture content regimes are present during contaminant transport: the unconfined aquifer and the vadose zone. In the unconfined aquifer, all the pore spaces are filled with water; that is, the medium is saturated with water. In the vadose zone the pore spaces between the soil particles are only partially filled with water. The vadose zone is unsaturated.

Water flow through a saturated porous medium, such as the unconfined aquifer, is governed by the empirical relationship known as Darcy's Law (Freeze 1979) and by the conservation of mass. Darcy's law can be expressed as

$$
\overrightarrow{\mathrm{v}}=-\overrightarrow{\mathrm{K}} \nabla \mathrm{h}
$$

where $\mathrm{v}$ is the velocity vector $(\mathrm{m} / \mathrm{yr})$

$\mathrm{K}$ is the hydraulic conductivity tensor $(\mathrm{m} / \mathrm{yr})$

h is the hydraulic head vector $(\mathrm{m})$.

By using the conservation of water entering and leaving a volume and by using Darcy's law to relate the hydraulic gradient to the rate at which water enters and leaves the same volume, transient water flow in a saturated porous media can be expressed as 
where $S$ is the specific storage $\left(\mathrm{m}^{-1}\right)$ and

$\mathrm{Q}$ is the source or sink of moisture $\left(\mathrm{y}^{-1}\right)$.

Darcy's law defines the discharge of water through a cross section of porous media. However, in contamination transport, the average velocity of water flowing through the medium is important. This is because contaminants that are not geochemically retarded move with the water. The average velocity of the pore water is determined by dividing the velocity of the water by the porosity of the medium. Porosity is defined as the ratio of void space to total volume.

In an unsaturated medium, the pores are not completely filled with water. Additional effects (capillary forces, the dependence of hydraulic conductivity on moisture content) must be considered. Richards equation (Richards 1931) becomes the governing equation:

$$
\nabla[\mathrm{K}(\psi) \nabla \psi]+\partial \mathrm{K}_{\mathrm{zz}}(\psi) / \partial \mathrm{z}=(\mathrm{d} \theta / \mathrm{d} \psi)(\partial \psi / \partial \mathrm{t})+\mathrm{Q}
$$

where $\mathrm{K}$ is again the hydraulic conductivity tensor $(\mathrm{m} / \mathrm{y})$, but now depends on the pressure head

$\psi \quad$ is the pressure head ( $\mathrm{m})$, which depends on the moisture content $\theta$

$\theta \quad$ is the moisture content (dimensionless)

$\mathrm{z}$ is the vertical column of moisture (m).

The relationship between the pressure head and the hydraulic head is simply

$$
h=\psi+z
$$

For the performance assessment calculations, the hydraulic conductivity tensor is reduced to a single function, with

$$
\begin{gathered}
\mathrm{K}_{\mathrm{ij}}=\mathrm{K}, \text { for } \mathrm{i}=\mathrm{j} \text { and } \\
\mathrm{K}_{\mathrm{ij}}=0, \text { for } \mathrm{i} \neq \mathrm{j} .
\end{gathered}
$$

The functional dependence of the pressure head on moisture content and of the hydraulic conductivity on pressure head and ultimately on moisture content is discussed in Section 3.4.3.2.

For extremely dry conditions, vapor diffusion may be important. In such conditions, water does not move as a collective body, but rather as single molecules. Such diffusion can be described by Fick's equation,

$$
\mathrm{dm} / \mathrm{dt}=-\mathrm{D}_{\mathrm{v}} \mathrm{AdC} / \mathrm{dx}
$$




\section{DOE/RL-97-69}

Rev. 0

where $\mathrm{dm} / \mathrm{dt}$ is the mass rate of water vapor diffusion $(g / \mathrm{y})$

$D_{v} \quad$ is the effective vapor diffusion coefficient $\left(\mathrm{m}^{2} / \mathrm{y}\right)$

A is the cross section area $\left(\mathrm{m}^{2}\right)$

C is the water vapor mass concentration in the gas phase $\left(\mathrm{g} / \mathrm{m}^{3}\right)$

$\mathrm{dC} / \mathrm{dx}$ is the water vapor mass concentration gradient $\left(\mathrm{g} / \mathrm{m}^{4}\right)$.

\section{D.2.3 Advective and Diffusive Transport}

The equation for the advective and diffusive transport of contaminants can be viewed as a mass balance on a differential volume. The advective-dispersive equation for solute movement through a porous medium with a constant, steady-state flow velocity was developed (Codell 1982) for the limiting case of unidirectional advective transport with three-dimensional dispersion in a homogeneous, saturated aquifer,

$$
\begin{gathered}
n_{e} \frac{\partial C}{\partial t}+\left(n-n_{e}\right) \frac{\partial G}{\partial t}+(1-n) \frac{\partial P}{\partial t}+n_{e} u \frac{\partial C}{\partial x}= \\
n_{e}\left[E_{x} \frac{\partial^{2} C}{\partial x^{2}}+E_{y} \frac{\partial^{2} C}{\partial y^{2}}+E_{z} \frac{\partial^{2} C}{\partial z^{2}}\right]+ \\
\left(n-n_{e}\right)\left[E_{x}^{1} \frac{\partial^{2} G}{\partial x^{2}}+E_{y}^{1} \frac{\partial^{2} G}{\partial y^{2}}+E_{z}^{1} \frac{\partial^{2} G}{\partial z^{2}}\right]- \\
n_{e} \lambda C-(1-n) \lambda P-\left(n-n_{e}\right) \lambda G
\end{gathered}
$$

where $\mathrm{C}$ is the dissolved concentration in the liquid phase in voids that are interconnected and allow flow [flowing voids] $\left(\mathrm{g} / \mathrm{m}^{3}\right.$ or $\left.\mathrm{Ci} / \mathrm{m}^{3}\right)$

$\mathrm{G}$ is the dissolved concentration in the liquid phase in voids that are not interconnected and do not allow flow [non-flowing voids] $\left(\mathrm{g} / \mathrm{m}^{3}\right.$ or $\left.\mathrm{Cj} / \mathrm{m}^{3}\right)$

$\mathrm{p} \quad$ is the particulate concentrations on the solid phase $(\mathrm{g} / \mathrm{g}$ or $\mathrm{Ci} / \mathrm{g})$

$\mathrm{n} \quad$ is the total porosity (dimensionless)

$n_{e} \quad$ is the effective porosity (dimensionless)

$\mathrm{t} \quad$ is the time $(\mathrm{y})$

$u \quad$ is the $x$-component of groundwater or pore water velocity $(\mathrm{m} / \mathrm{y})$

$E_{\mathrm{i}} \quad$ is the dispersion coefficient in the flowing voids in the $\mathrm{i}$-th (where $\mathrm{i}=\mathrm{x}, \mathrm{y}$, or $\mathrm{z}$ ) direction $\left(\mathrm{m}^{2} / \mathrm{y}\right)$ 


\section{DOE/RL-97-69}

Rev. 0

$\mathrm{E}_{\mathrm{i}}^{\cdot} \quad$ is the diffusion coefficient in the non-flowing voids in the $\mathrm{i}$-th direction $\left(\mathrm{m}^{2} / \mathrm{y}\right)$

$\lambda \quad$ is the decay constant $[=(\ln 2) /$ half life $]\left(y^{-1}\right)$.

Each term in the equation represents some aspect of the solute movement through the porous medium. The first term on the left of the equal sign is the accumulation (storage) of the solute in the liquid phase in the flowing void. The second term is the accumulation in the liquid phase in the non-flowing void. The third term is the accumulation in the solid phase; and the term to the left of the equal sign is $\mathrm{x}$-direction advective transport in the flowing voids in the liquid phase. The first term to the right of the equal sign represents the dispersive transport in the flowing voids in the liquid phase in each direction. The second term represents the diffusive transport in the non-flowing voids in the liquid phase in each direction. The last terms are the chemical degradation or radioactive decay in the liquid phase in the flowing void, in the solid phase, and in the liquid phase in the nonflowing void respectively.

Using the following assumptions:

- . The dissolved concentration in the non-flowing flows (G) equals the dissolved concentration in the flowing voids $(\mathrm{C})$ for each time and position

- The contaminant absorption process can be described by a constant $\left(K=\rho^{*} K_{d}(1-n)\right)$ representing the ratio between the contaminant absorbed to the soil matrix $(\mathrm{P})$ and the contaminant dissolved in solution $(\mathrm{C})$

- The diffusion in the nonflowing void $\left(E_{\nu}^{\prime}\right)$ is comparable with the dispersion in the flowing void $\left(E_{j}\right)$,

the equation (D.6) can be simplified to

$$
\frac{\partial C}{\partial t}+\frac{u}{R_{f_{1}}} \frac{\partial C}{\partial x}=\frac{D_{x}}{R_{f_{1}} \partial x^{2} C}+\frac{D_{y}}{R_{f_{1}}} \frac{\partial^{2} C}{\partial y_{2}}+\frac{D_{z}}{R_{f_{1}}} \frac{\partial^{2} C}{\partial z^{2}}-\lambda C
$$

in which

$$
\mathrm{D}_{\mathrm{i}}=\mathrm{n} \mathrm{E}_{\mathrm{i}} / \mathrm{n}_{\mathrm{e}}
$$

and

$$
R_{f}=n / n_{c}+\left(\rho * K_{d}\right) / n_{c}
$$

and where

$D_{i} \quad$ is the pseudodispersion coefficient $\left(\mathrm{m}^{2} / \mathrm{y}\right)$

$R_{f} \quad$ is the retardation factor (dimensionless)

$\rho \quad$ is the bulk density $\left(\mathrm{g} / \mathrm{m}^{3}\right)$

$\mathrm{K}_{\mathrm{d}} \quad$ is the equilibrium (partition or distribution) coefficient $\left(\mathrm{m}^{3} / \mathrm{g}\right.$ ).

The retardation factor $\left(R_{f}\right)$ is used as a measure of the mobility of constituents in a porous medium. 


\section{DOE/RL-97-69}

Rev. 0

By making the following substitutions,

$$
\mathrm{u}^{*}=\mathrm{u} / \mathrm{R}_{\mathrm{f}}
$$

and

$$
D_{i}^{*}=D_{i} / R_{f},
$$

the contaminant transport equation can be written as

$$
\frac{\partial C}{\partial t}+u^{*} \frac{\partial C}{\partial x}=D_{x}^{*} \frac{\partial^{2} C}{\partial x^{2}}+D_{y}^{*} \frac{\partial^{2} C}{\partial y^{2}}+D_{z}^{*} \frac{\partial^{2} C}{\partial z^{2}}-\lambda C
$$

The first equation of this section [equation (D.1)] specifically addresses the general conditions for saturated flow and solute movement. However, it also can be applied to the unsaturated zone if minor modifications are made:

- The porosities ( $\mathrm{n}$ and $\mathrm{n}_{\mathrm{e}}$ ) are assumed to be equal to the soil matrix moisture content

- The one-dimensional flow is in the vertical direction.

For this case, the retardation factor is defined by

$$
R_{f}=1+\left(\rho * K_{d}\right) / \theta
$$

where $\theta$ is the moisture content of the partially saturated zone and dispersion is considered only in the flow direction.

\section{D.2.4 Vapor Transport}

Some contaminants may move upward from the disposal facility to the surface because they are in the vapor phase. Such movement is governed by Fick's second law,

$$
D \frac{\partial^{2} C}{\partial^{2} Z}=\frac{\partial C}{\partial t}
$$

where

$C$ is the concentration $\left(\mathrm{g} / \mathrm{m}^{3}\right.$ or $\left.\mathrm{Ci} / \mathrm{m}^{3}\right)$

$z$ is the distance $(\mathrm{m})$

$t$ is time ( $y$ )

$D$ is the diffusion coefficient $\left(\mathrm{m}^{2} / \mathrm{y}\right)$. 
The solution for concentration $\mathrm{C}$ in the $\mathrm{z}$ direction over time $\mathrm{t}$ is given by:

$$
\frac{C}{C_{o}}=\operatorname{erfc}\left(\frac{z}{2 \sqrt{D t}}\right)
$$

where erfc is the complimentary error function and $\mathrm{C} / \mathrm{C}_{0}$ is the relative concentration. The mass transport across the surface becomes

$$
\frac{\partial C}{\partial t}=\frac{C_{0}}{\sqrt{4 \pi D T}} \frac{z}{t} \exp \left[-z^{2} /(4 D t)\right]
$$

\section{D.3 Code History}

\section{D.3.1 PORFLOW}

Many versions of PORFLOW codes have been adapted for a variety of problems over the past 15 years. The bibliography of reports describing the code developments and problems to which they have been applied has grown to include about 100 documents. A partial listing of these reports is contained in the user documentation for the newest releases

(ACRi 1994a, 1994b). Many of the available references give detailed technical descriptions of the mathematical modeling, numerical methods, and computational algorithms embodied in the various computer code versions along with pointed discussions of complex engineering problems to which they are applied. This section will provide a brief and accessible description of what the PORFLOW computer code is, what it does, and how it is used for the interim performance assessment of low-level tank waste disposal.

The PORFLOW code allows simulation of flow of two fluids and a passive air phase, conductive and convective heat transfer, and transport of up to four dissolved contaminant species in a variably saturated, heterogeneous, anisotropic, fractured porous continuum. The remaining paragraphs in this section chronicle a few major steps in the development of the PORFLOW codes series and exemplify typical past and present use.

About 30 years ago, Gosman et al. (1969) developed the Nodal Point Integration technique for use in simulating heat transfer and mass transport in a circulating fluid. Nodal Point Integration is used to render a discrete system of simultaneous linear equations from a continuous mathematical model involving coupled partial differential equations. The advantage of Nodal Point Integration over classical finite difference schemes is the assurance that the discrete model is conservative at every point of interest (i.e., errors in the amounts of fluid volume, heat, and mass of transported species are sufficiently small at every point in space as well as in the global totals). Use of Nodal Point Integration is one of the defining characteristics of the PORFLOW series of codes. 


\section{DOE/RL-97-69}

Rev. 0

In the 1970's the Nodal Point Integration technique was used to develop a model for simulating thermally disturbed groundwater movement in the vicinity of a high-level radioactive waste repository (Runchal 1979). The computer code was called GWTHERM and was a forerunner to the PORFLOW codes. In the 1980's during the Basalt Waste Isolation Project (BWIP), the two-dimensional PORFLO code (Kline 1983, Eyler 1984, Runchal 1985) was developed from the GWTHERM prototype for use in assessing performance of a deep geologic repository for high-level nuclear waste. The PORFLO code was used principally to calculate near-field estimates of water flow (seepage) rates in the vicinity of the proposed repository, temperature distribution around the repository, and contaminant mass release rates to the farfield and/or accessible environment (e.g., in DOE-RL 1982 and Baca 1984). The PORFLO code was limited to saturated media (e.g., a repository at depth, below the water table) and transport of a single dissolved contaminant species.

The PORFLO-3 computer code (Sagar 1990,Runchal 1992) is a three-dimensional generalization of the PORFLO code. In addition to being fully three-dimensional, the PORFLO-3 code is tailored for simulation of flow and transport in saturated and unsaturated media. The PORFLO-3 code also has the conduction and convection heat transfer capabilities, but thermal disturbance is typically not a condition in many of the unsaturated flow modeling applications where the code has been used. For instance, PORFLO-3 has been used in threedimensional predictive modeling of saturated flow and transport of tracers and residual contaminants in support of the remedial investigation process for the 300-FF-5 groundwater operable unit (DOE-RL 1994a). Travel times through the vadose (unsaturated) zone from various surface facilities (cribs and trenches) to groundwater for discharged water and contaminants and of relative arrival concentrations have been estimated with PORFLO-3 models in support of the Liquid Effluent program (WHC 1990, Reidel 1993, Singelton 1994). Singleshell tank (SST) leaks during waste retrieval operations have been analyzed with PORFLO-3 models to provide the approximate impact on groundwater (Lowe 1993) and later to quantify the umbrella effect of SST's on infiltrating precipitation (Kline 1995a) and further refine estimates of vertical penetration and lateral spreading of leaked contaminants in the vadose zone. The PORFLO-3 code also has been used in analysis of the effectiveness of capillary barriers (Kline 1995b), particularly to assess diversion capacity of a capillary barrier used to limit infiltration of precipitation into a near-surface disposal facility for low-level waste.

The most recent PORFLOW codes (Versions 2.0 and higher) comprise extension of PORFLO-3 to allow two fluids (such as water and $\mathrm{CCl}_{4}$ ) or two phases (such as liquid water and water vapor), in addition to a passive air phase in variably saturated media. These code versions also allow simulation of multiple contaminant species transport, including chain decay. While the capability of simulating simultaneous seepage of two distinct fluids has undergone preliminary testing by Piepho and Runchal (Piepho 1991), some of the newer features (e.g., phase changes, decay chains) implemented in the PORFLOW codes have not been used extensively at the Hanford Site. Most notably PORFLOW has been used to simulate seepage of infiltrating precipitation and simultaneous transport (advection and diffusion) of several dissolved contaminant species through a near-surface disposal facility and underlying vadose zone to groundwater. Contaminant fluxes to groundwater are subsequently postprocessed by an auxiliary computer code to provide dose estimates through various pathways (e.g., intrusion, drinking water) as was done in the performance assessment by Kincaid et al. (Kincaid 1995) for 


\section{DOE/RL-97-69 \\ Rev. 0}

Hanford Site grouted tank waste. The same simulation capabilities were used to calculate dose estimates as a means of evaluating impacts of disposal system design options on low-level glass waste disposal system performance (Rawlins 1994, Mann 1995d, Kline 1995a). The PORFLOW code used in those grout and glass waste disposal analyses is designated Version 2.394gr and has been tested extensively by Piepho et al (Piepho 1994). Version 2.394gr of PORFLOW also is the code version used for the present interim performance assessment of lowlevel tank waste disposal.

\section{D.3.2 VAM3D-CG}

Earlier versions of VAM3D-CG (VAM2D and VAM3D) have been used for Hanford Site risk assessments. Version 2.4b of VAM3D-CG was used in the 200 West Area Burial Grounds Performance Assessment (Wood 1994b). Version 3.1 of VAM3D-CG was obtained because of the greater model complexity required for the model for the Environmental Restoration Disposal Facility Performance Assessment (Wood 1995) and for the Hanford Sitewide groundwater model (Law 1996). Version 3.1 was used in this interim performance assessment and also was used in the 200 . East Area Burial Ground Performance Assessment (Wood 1996).

\section{D.4 Verification and Benchmarking}

\section{D.4.1 PORFLOW-Verification and Benchmarking}

The version of PORFLOW used in this analysis, Version $2.394 \mathrm{gr}$, has been extensively verified and benchmarked (Piepho 1994). Verification and benchmarking efforts were based on

- $\quad$ Comparing the results of the Version 2.394gr of PORFLOW with earlier versions of PORFLOW

- Reproducing the results of analytical solutions from other verification problems

- Comparing the results with other codes for complex problems.

PORFLOW Version $2.394 \mathrm{gr}$ was used to run the following five cases that were used in an extensive verification effort of PORFLOW at the Idaho National Engineering Laboratory (Magnuson 1990),

- Transient unsaturated flow in a one-dimensional vertical column (denoted as problem vt1 by Magnuson)

- Transient drawdown of pressure head caused by pumping a confined aquifer of constant thickness that is fully penetrated by a well (denoted as vt2)

- Steady-state two-dimensional saturated-unsaturated flow (denoted as bt1), 


\section{DOE/RL-97-69}

Rev, 0

- Transient two-dimensional unsaturated flow simulating the infiltration of water into relatively dry, heterogeneous soils (bt2)

- Steady-state saturated flow in a porous medium with two distinct fractures (bt3).

In each case, the results of Magnuson et al. Agree closely with those using PORFLOW 2.394gr.

The results of PORFLOW 2.394gr could be compared against analytical solutions for the following four cases:

- $\quad$ Case vt1 of Magnuson (1990)

- $\quad$ Case vt2 of Magnuson (1990)

- Two-dimensional nonuniform infiltration into dry homogenous soil (Warrick 1976)

- Mass transport in a two-dimensional groundwater model with a strip source (Cleary 1978).

Again, the results agreed closely.

Finally, as part of the Hanford Site grout performance assessment (Kincaid 1995-7), the results of PORFLOW 2.394gr and another code, TRACR3D (Travis 1991), were compared for models of the Hanford Site grouted waste. Again, the results show good agreement. Piepho (1994) provides the details.

\section{D.4.2 VAM3D-CG - Verification and Benchmarking}

Version 2.4b of VAM3D-CG (Lu 1994) and Version 3.1 (Lu 1995) were tested by

- Comparing the results of the installed version against those published by the vendor (Huyakorn 1993)

- Benchmarking these versions against results of PORFLO-3 Version 1.0 (Sagar 1990) for problems relevant to the Hanford Site.

The tests against the vendor-supplied results included

- Transient one-dimensional horizontal flow in a soil slab

- Transient vertical infiltration in a soil column

- Transient two-dimensional flow in a rectangular soil slab

- Transient two-dimensional transport in a rectangular soil slab

- Three-dimensional transport in uniform groundwater flow. 
Rev. 0

The benchmarking tests consisted of

- Modeling the 217-U-17 crib in the 200 West Area

- Modeling a clay cap.

In all cases, agreement was good.

\section{D.5 Field Testing}

\section{D.5.1 PORFLOW-Field Testing}

Testing of PORFLOW against Hanford field experiments (Hanford Injection Test) and accidents (T106 Tank Leak) is now being performed.

\section{D.5.2 VAM3D-CG - Field Testing}

Field testing efforts were performed for both Versions $2.4 \mathrm{~b}$ and 3.1. The calibration/validation effort for Version 2.4b (Lu 1993) used data from the Hanford Injection Test (Sisson 1984). The calibration/validation effort for Version 3.1 used data from the reevaluation of the Hanford Injection Test and from new experiments (Fayer 1995b). 


\section{DOE/RL-97-69 \\ Rev. 0}

\section{D.6 Input for Base Analysis Case}

\section{D.6.1 Disposal Facility Model (Concept 1) - PORFLOW}

TITL base 1-1d - base case w .2Dw diffusion(20x base 1-1n) for concept 1 LLVW disposal facility with 50 sources (45 canisters)

USER PIEHPO - Mel Piepho of Daniel B. Stephens \& Assoc., Richland, WA 99352; 509-946-6627

I

GRID 166 by $133 \$$ Including PORFLO-3 boundary cells

I

/2345678911234567892123456789312345678941234567895123456789612345678971234567899/

I

COOR X user specfied

I The following numbers represent the actual PORFLOW grid lines in the $\mathrm{X}$

/ direction. It includes 45 canisters, each with a $1.8 \mathrm{~m}$ width

\begin{tabular}{|c|c|c|c|c|c|c|c|}
\hline-0.25 & 0.25 & 0.75 & 1.15 & 2.6 & 3.2 & 4.7 & \\
\hline 5 & 5.3 & 6.87 & 7.17 & 7.48 .9 & $\begin{array}{lll}9 & 9.29 .\end{array}$ & & \\
\hline 11 & 11.3 & 11.6 & 13.1 & 13.4 & $13.7 \quad 15.2$ & 15.5 & \\
\hline 15.8 & 17.3 & 17.6 & 17.9 & 19.35 & 19.75 & & \\
\hline 20.25 & 20.75 & 21.25 & 21.65 & $5 \quad 23.1$ & 23.4 & 25.2 & \\
\hline 25.5 & 25.8 & 27.3 & 27.6 & 27.9 & $29.4 \quad 29.7$ & 30 & \\
\hline 31.5 & 31.8 & 32.1 & 33.6 & 33.9 & 34.2 & 36 & \\
\hline 36.3 & 37.8 & 38.1 & 38.4 & 39.85 & 40.25 & & \\
\hline 40.75 & 41.25 & 41.75 & 42.15 & $5 \quad 43.6$ & 43.944 & .245 .7 & \\
\hline 46 & 46.3 & 47.8 & 48.1 & 48.4 & $49.9 \quad 50.2$ & 50.5 & \\
\hline 52 & 52.3 & 52.6 & 54.1 & 54.4 & 56.2 & 56.5 & \\
\hline 56.8 & 58.3 & 58.6 & 58.9 & 60.35 & 60.75 & & \\
\hline 61.25 & 61.75 & 62.25 & 62.65 & $\begin{array}{ll}5 & 64.1\end{array}$ & $64.4 \quad 64$ & .766 .2 & \\
\hline 66.5 & 66.8 & 68.3 & 68.6 & 68.9 & $70.4 \quad 70.7$ & 71 & \\
\hline 72.5 & 72.8 & 73.1 & 74.6 & 74.9 & 75.2 & 77 & \\
\hline 77.3 & 78.8 & 79.1 & 79.4 & 80.85 & 81.25 & & \\
\hline 81.75 & 82.25 & 82.75 & 83.15 & $5 \quad 84.6$ & 84.985 & $\begin{array}{ll}2 & 86.7\end{array}$ & \\
\hline 87 & 87.3 & 88.8 & 89.1 & 89.4 & $90.9 \quad 91.2$ & 91.5 & \\
\hline 93 & 93.3 & 93.6 & 95.1 & 95.4 & 97.2 & 97.5 & \\
\hline 97.8 & 99.3 & 99.6 & 99.9 & 101.35 & 101.75 & & \\
\hline 102.25 & 103. & 103.75 & 5104 & .25104 & .75105 .25 & 105.75 & 106.25 \\
\hline 107.25 & 108 & 110 & 112 & 115 & $118 \quad 122$ & 126 & \\
\hline
\end{tabular}

SCALE by 0.01

COOR Y user specfied

-25. 25. 75. 165. 235. 305. 385. ! 1

485. 585. 685. 785. 885. 985. 1085.1185.

1285. 1385. 1485. 1585. 1685. 1785. 1885. 1985. ! 3

2085. 2185. 2285. 2385. 2485. 2585. 2685. 2785. !4

2885. 2985. 3085. 3185. 3285. 3385. 3485. !5

3585. 3665. 3735. 3805. 3905. 4005. 4105. 4205. 16

4305. 4405. 4505. 4605. 4705. 4805, 4905. 5005. ! 7

5105. 5205. 5305. 5405. 5505. 5605. 5705. 5805. 18

5905. 6005. 6105. 6205. 6305. 6405. 6505. 19

6605. 6705. 6805. 6905. 7005. 7105. 7205. 110

7305. 7405. 7505. 7605. 7705. 7805. 7905. 8005. !11

8105. 8205. 8245. 8285. 8315. 8355. 8455. 8555. 112

8655. 8755. 8855. 8955. 9000. 9040. 9100. 9180. $\quad ! 13$

9220. 9255. 9295. 9325. 9355.9395. 9410.9425. 114

9440. 9455. 9470. 9485. 9500. 9515. 9530.9545. 115

9560. 9575. 9590. 9605. 9620. 9635. 9650. 9665. 116 
DOE/RL-97-69

Rev. 0

9680. 9695. 9710. 9725. 9740. 9755. 9795. 9850.

117

9900.

I

DATUM $0 ., 0$.

GRAVITY vector: $0,-1$

READ 'base0-0.arc' START in UNFOrmatted mode TIME $=0$.

1

/ Zone definitions from TRACER-3D material type map.

1

ZONE 1 from $(1,87)$ to $(166,133) \$$ Backfill Soil

ZONE 2 from $(1,41)$ to $(166,86) \$$ Hanford-Sandy Seq.

ZONE 3 from $(1,5)$ to $(166,40) \$$ Fanford-Gravel Seq.

ZONE 4 from $(1,1)$ to $(166,4) \$$ Ringold

ZONE 5 from $(1,130)$ to $(7,130) \$$ GRAVEL

ZONE 5 from $(1,129)$ to $(13,129) \$$ GRAVEL

ZONE 5 from $(1,128)$ to $(19,128) \$$ GRAVEL

ZONE 5 from $(1,127)$ to $(25,127) \$$ GRAVEL

ZONE 5 from $(1,126)$ to $(31,126) \$$ GRAVEL

ZONE 5 from $(1,125)$ to $(37,125) \$$ GRAVEL

ZONE 5 from $(1,124)$ to $(43,124) \$$ GRAVEL

ZONE 5 from $(1,123)$ to $(49,123) \$$ GRAVEL

ZONE 5 from $(1,122)$ to $(55,122) \$$ GRAVEL

ZONE 5 from $(1,121)$ to $(61,121) \$$ GRAVEL

ZONE 5 from $(1,120)$ to $(67,120) \$$ GRAVEL

ZONE 5 from $(1,119)$ to $(73,119) \$$ GRAVEL

ZONE 5 from $(1,118)$ to $(79,118) \$$ GRAVEL

ZONE 5 from $(1,117)$ to $(85,117) \$$ GRAVEL

ZONt 5 from $(1,116)$ to $(91,116) \$$ GRAVEL

ZONE 5 from $(1,115)$ to $(97,115) \$$ GRAVEL

ZONE 5 from $(1,114)$ to $(103,114) \$$ GRAVEL

ZONE 5 from $(1,113)$ to $(109,113) \$$ GRAVEl

ZONE 5 from $(1,112)$ to $(115,112) \$$ GRAVEL

ZONE 5 from $(1,111)$ to (121,111) \$ GRAVEL

ZONE 5 from $(1,110)$ to $(127,110) \$$ GRAVEL

ZONE 5 from $(1,109)$ to $(133,109) \$$ GRAVEL

ZONE 5 from $(1,108)$ to $(140,108) \$$ GRAVEL

ZONE 5 from $(1,107)$ to $(147,107) \$$ GRAVEl

ZONE 5 from $(1,106)$ to $(154,106) \$$ GRAVEi

ZONE 5 from $(154,87)$ to $(155,105) \$$ GRAVEI

ZONE 6 from $(1,103)$ to $(153,105) \$$ Crushed Glass between gravel and cement top of vault

ZONE 7 from $(2,101)$ to $(150,102) \$$ Top CONCRETE

ZONE 9 from $(1,98)$ to $(150,100) \$$ BF Soil (matrix) above canisters

I

1

ZONE 10 from $(4,89)$ to $(5,97) \$$ glass canisters ZONE 10 from $(7,89)$ to $(8,97) \$$ glass canisters ZONE 10 from $(10,89)$ to $(11,97) \$$ glass canisters ZONE 10 from $(13,89)$ to $(14,97) \$$ glass canisters ZONE 10 from $(16,89)$ to $(17,97) \$$ glass canisters ZONE 10 from $(19,89)$ to $(20,97) \$$ glass canisters ZONE 10 from $(22,89)$ to $(23,97) \$$ glass canisters ZONE 10 from $(25,89)$ to $(26,97) \$$ glass canisters ZONE 10 from $(28,89)$ to $(29,97) \$$ glass canisters I

ZONE 10 from $(34,89)$ to $(35,97) \$$ glass canisters ZONE 10 from $(37,89)$ to $(38,97) \$$ glass canisters 
DOE/RL-97-69

Rev. 0

ZONE 10 from $(40,89)$ to $(41,97) \$$ glass canisters ZONE 10 from $(43,89)$ to $(44,97) \$$ glass canisters ZONE 10 from $(46,89)$ to $(47,97) \$$ glass canisters ZONE 10 from $(49,89)$ to $(50,97) \$$ glass canisters ZONE 10 from $(52,89)$ to $(53,97) \$$ glass canisters ZONE 10 from $(55,89)$ to $(56,97) \$$ glass canisters ZONE 10 from $(58,89)$ to $(59,97) \$$ glass canisters 1

ZONE 10 from $(64,89)$ to $(65,97) \$$ glass canisters ZONE 10 from $(67,89)$ to $(68,97) \$$ glass canisters ZONE 10 from $(70,89)$ to $(71,97) \$$ glass canisters ZONE 10 from $(73,89)$ to $(74,97) \$$ glass canisters ZONE 10 from $(76,89)$ to $(77,97) \$$ glass canisters ZONE 10 from $(79,89)$ to $(80,97) \$$ glass canisters ZONE 10 from $(82,89)$ to $(83,97) \$$ glass canisters ZONE 10 from $(85,89)$ to $(86,97) \$$ glass canisters ZONE 10 from $(88,89)$ to $(89,97) \$$ glass canisters 1

ZONE 10 from $(94,89)$ to $(95,97) \$$ glass canisters ZONE 10 from $(97,89)$ to $(98,97) \$$ glass canisters ZONE 10 from $(100,89)$ to $(101,97) \$$ glass canisters ZONE 10 from $(103,89)$ to $(104,97) \$$ glass canisters ZONE 10 from $(106,89)$ to $(107,97) \$$ glass canisters ZONE 10 from $(109,89)$ to $(110,97) \$$ glass canisters ZONE 10 from $(112,89)$ to $(113,97) \$$ glass canisters ZONE 10 from $(115,89)$ to $(116,97) \$$ glass canisters ZONE 10 from $(118,89)$ to $(119,97) \$$ glass canisters 1

ZONE 10 from $(124,89)$ to $(125,97) \$$ glass canisters ZONE 10 from $(127,89)$ to $(128,97) \$$ glass canisters ZONE 10 from $(130,89)$ to $(131,97) \$$ glass canisters ZONE 10 from $(133,89)$ to $(134,97) \$$ glass canisters ZONE 10 from $(136,89)$ to $(137,97) \$$ glass canisters ZONE 10 from $(139,89)$ to $(140,97) \$$ glass canisters ZONE 10 from $(142,89)$ to $(143,97) \$$ glass canisters ZONE 10 from $(145,89)$ to $(146,97) \$$ glass canisters ZONE 10 from $(148,89)$ to $(149,97) \$$ glass canisters 1

ZONE 12 from $(1,87)$ to $(153,88) \$$ Bottom CONCRETE 1

ZONE 13 from $(1,89)$ to $(2,102) \$$ Vertical CONCRETE

ZONE 13 from $(31,89)$ to $(32,102) \$$ Vertical CONCRETE

ZONE 13 from $(61,89)$ to $(62,102) \$$ Vertical CONCRETE

ZONE 13 from $(91,89)$ to $(92,102) \$$ Vertical CONCRETE

ZONE 13 from $(121,89)$ to $(122,102)$ \$ vertical CONCRETE ZONE 13 from $(151,89)$ to $(153,102) \$$ Vertical CONCRETE 1

ZONE 14 from $(3,89)$ to $(3,97) \$$ BF soil matrix ZONE 14 from $(6,89)$ to $(6,97) \$$ BF soil matrix ZONE 14 from $(9,89)$ to $(9,97) \$$ BF soil matrix ZONE 14 from $(12,89$ ) to $(12,97) \$$ BF soil matrix ZONE 14 from $(15,89)$ to $(15,97) \$$ BF soil matrix ZONE 14 from $(18,89)$ to $(18,97) \$$ BF soil matrix ZONE 14 from $(21,89)$ to $(21,97) \$$ BF soil matrix ZONE 14 from $(24,89)$ to $(24,97) \$$ BF soil matrix ZONE 14 from $(27,89)$ to $(27,97) \$$ BF soil matrix ZONE 14 from $(30,89)$ to $(30,97) \$$ BF soil matrix 
I

ZONE 14 from $(33,89)$ to $(33,97) \$$ BF soil matrix ZONE 14 from $(36,89)$ to $(36,97) \$$ BF soil matrix ZONE 14 from $(39,89)$ to $(39,97) \$$ BF soil matrix ZONE 14 from $(42,89)$ to $(42,97) \$$ BF soil matrix ZONE 14 from $(45,89)$ to $(45,97) \$$ BF soil matrix ZONE 14 from $(48,89)$ to $(48,97) \$$ BF soil matrix ZONE 14 from $(51,89)$ to $(51,97) \$$ BF soil matrix ZONE 14 from $(54,89)$ to $(54,97) \$$ BF soil matrix ZONE 14 from $(57,89)$ to $(57,97) \$$ BF soil matrix ZONE 14 from $(60,89)$ to $(60,97) \$$ BF soil matrix 1

ZONE 14 from $(63,89)$ to $(63,97) \$$ BF soil matrix ZONE 14 from $(66,89)$ to $(66,97) \$$ BF soil matrix ZONE 14 from $(69,89)$ to $(69,97) \$$ BF soil matrix ZONE 14 from $(72,89)$ to $(72,97) \$$ BF soil matrix ZONE 14 from $(75,89)$ to $(75,97) \$$ BF soil matrix ZONE 14 from $(78,89)$ to $(78,97) \$$ BF soil matrix ZONE 14 from $(81,89)$ to $(81,97) \$$ BF soil matrix ZONE 14 from $(84,89)$ to $(84,97) \$$ BF soil matrix ZONE 14 from $(87,89)$ to $(87,97) \$$ BF soil matrix ZONE 14 from $(90,89)$ to $(90,97) \$$ BF soil matrix I

ZONE 14 from $(93,89)$ to $(93,97) \$$ BF soil matrix ZONE 14 from $(96,89)$ to $(96,97) \$$ BF soil matrix ZONE 14 from $(99,89)$ to $(99,97) \$$ BF soil matrix ZONE 14 from $(102,89)$ to $(102,97) \$$ BF soil matrix ZONE 14 from $(105,89)$ to $(105,97) \$$ BF soil matrix ZONE 14 from $(108,89)$ to $(108,97)$ \$ BF soil matrix ZONE 14 from $(111,89)$ to $(111,97) \$$ BF soil matrix ZONE 14 from $(114,89)$ to $(114,97) \$$ BF soil matrix ZONE 14 from $(117,89)$ to $(117,97)$ \$ BF soil matrix ZONE 14 from $(120,89)$ to $(120,97) \$$ BF soil matrix 1

ZONE 14 from $(123,89)$ to $(123,97) \$$ BF soil matrix ZONE 14 from $(126,89)$ to $(126,97) \$$ BF soil matrix ZONE 14 from $(129,89)$ to $(129,97) \$$ BF soil matrix ZONE 14 from $(132,89)$ to $(132,97) \$$ BF soil matrix ZONE 14 from $(135,89)$ to $(135,97) \$$ BF soil matrix ZONE 14 from $(138,89)$ to $(138,97) \$$ BF soil matrix ZONE 14 from $(141,89)$ to $(141,97) \$$ BF soil matrix ZONE 14 from $(144,89)$ to $(144,97) \$$ BF soil matrix ZONE 14 from $(147,89)$ to $(147,97) \$$ BF soil matrix ZONE 14 from $(150,89)$ to $(150,97) \$$ BF soil matrix

1

IZONE 1 - SOIL G-1

/ ZONE 2 - SOLL G-2, Hanford-Sandy Seg. I ZONE 3 - SOIL G-3, Hanford-Gravel Seq. I ZONE 4 - SOIL G-4, Ringold-Upper

ROCK rbo $=2.720$ tot $=3 * 0.371:$ ZONE 1

ROCK rho $=2.720$ tot $=3^{*} 0.3578:$ ZONE 2

ROCK rho $=2.720$ tot $=3^{*} 0.1312:$ ZONE 3

ROCK rho $=2.720 \quad t o t=3 * 0.1342:$ ZONE 4

ROCK rho $=2.720$ tot $=3 * 0.518$ ZONE 5 
DOE/RL-97-69

Rev. 0

ROCK tho $=2.720$ tot $=3 * 0.518:$ ZONE 6

ROCK tho $=2.720$ tot $=3 * 0.2258$ ZONE 7

ROCK tho $=2.720$ tot $=3 * 0.371:$ ZONE 9

ROCK tho $=2.720$ tot $=3 * 0.0001$ ZONE 10

ROCK rho $=2.720$ tot $=3^{*} 0.2258$ ZONE 12

ROCK rho $=2.720$ tot $=3 * 0.2258$ ZONE 13

ROCK rbo $=2.720$ tot $=3 * 0.371:$ ZONE 14

1

HYDRaulic properties: SS=1.e-5 $(\mathrm{Kx}, \mathrm{Ky}, \mathrm{Kz})=3 * 9467.28(\mathrm{~m} / \mathrm{yr}) \quad$ : ZONE 1

HYDRaulic properties: $S S=1 . e-5(\mathrm{Kx}, \mathrm{Ky}, \mathrm{Kz})=3 * 3690.0(\mathrm{~m} / \mathrm{yr}) \quad$ :ZONE 2

HYDRaulic properties: $\mathrm{SS}=1 . \mathrm{e}-5(\mathrm{Kx}, \mathrm{Ky}, \mathrm{Kz})=3 * 417.0(\mathrm{~m} / \mathrm{yr}) \quad: \mathrm{ZONE} 3$

HYDRaulic properties: SS=1.e-5 $(\mathrm{Kx}, \mathrm{Ky}, \mathrm{Kz})=3 * 27.6(\mathrm{~m} / \mathrm{yr}) \quad:$ ZONE 4

HYDRaulic properties: $S S=1 . e-5(\mathrm{Kx}, \mathrm{Ky}, \mathrm{Kx})=3 * 583816.0(\mathrm{~m} / \mathrm{yr}) \quad:$ ZONE 5

HYDRaulic properties: $S S=1 . e-5(\mathrm{Kx}, \mathrm{Ky}, \mathrm{Kz})=3 * 583816.0(\mathrm{~m} / \mathrm{yr}) \quad: \mathrm{ZONE} 6$

HYDRaulic properties: $S S=1 . \mathrm{e}-5(\mathrm{Kx}, \mathrm{Ky}, \mathrm{Kz})=3 * 1.1834 \mathrm{e}-4(\mathrm{~m} / \mathrm{yr}): \mathrm{ZONE} 7$

/HYDRaulic properties: SS=1.e-5 (Kx,Ky,Kz) $=3 * 9467.28(\mathrm{~m} / \mathrm{yr}) \quad:$ ZONE 7

HYDRaulic properties: $S S=1 . e-5(\mathrm{Kx}, \mathrm{Ky}, \mathrm{Kz})=3 * 9467.28(\mathrm{~m} / \mathrm{yr}) \quad$; ZONE 9

HYDRaulic properties: SS=1.e-5 $(\mathrm{Kx}, \mathrm{Ky}, \mathrm{Kx})=3 * 1 . \mathrm{E}-30(\mathrm{~m} / \mathrm{yr}) \quad: \mathrm{ZONE} 10^{-}$

HYDRaulic properties: SS=1.e-5 $(\mathrm{Kx}, \mathrm{Ky}, \mathrm{Kz})=3 * 1.1834 \mathrm{e}-4(\mathrm{~m} / \mathrm{yr}): \mathrm{ZONE} 12$

HYDRaulic properties: SS=1.e-5 (Kx,Ky,Kz) $=3 * 1.1834 \mathrm{e}-4(\mathrm{~m} / \mathrm{yr}): \mathrm{ZONE} 13$

/HYDRaulic properties: $S S=1 . e-5(\mathrm{Kx}, \mathrm{Ky}, \mathrm{Kz})=3 * 9467.28(\mathrm{~m} / \mathrm{yr}) \quad:$ ZONE 12

/HYDRaulic properties: $S S=1 . e-5(\mathrm{Kx}, \mathrm{Ky}, \mathrm{Kz})=3 * 9467.28(\mathrm{~m} / \mathrm{yr}) \quad: \mathrm{ZONE} 13$

HYDRaulic properties: $S S=1 . e-5(\mathrm{Kx}, \mathrm{Ky}, \mathrm{Kz})=3 * 9467,28(\mathrm{~m} / \mathrm{yr}) \quad: \mathrm{ZONE} 14$

1

MULTiphase: MINImum relative CONDuctivity is $1 . E-20$ for ZONEs 1 to 14 step 1

MULTiphase: VAN MUAL $\mathrm{n}=2.08$ alpha $=6.83 \mathrm{sr}=.1213 \quad 0 .: \mathrm{ZONE} 1$

MULTiphase: VAN MUAL $n=1.868$ alpha $=15.66 \mathrm{~s} s=.06875 \quad 0 .:$ ZONE 2

MULTiphase: VAN MUAL $n=1.613$ alpha $=1.25 \mathrm{sr}=.09604 \quad 0 .:$ ZONE 3

MULTiphase: VAN MUAL $n=1.338$ alpha=1.22 sr=.1639 $0 .:$ ZONE 4

MULTiphase: VAN MUAL $\mathfrak{n}=2.661$ atpha $=353.66 \mathrm{~s} r=2.703 \mathrm{e}-2 \quad 0 .:$ ZONE 5

MULTiphase: VAN MUAL $\mathrm{n}=2.661$ alpha=353.66 sr=2.703e-2 $0 .:$ ZONE 6

/MULTiphase: VAN MUAL $\mathrm{n}=2.08$ alpha $=6.83 \quad \mathrm{sr}=.1213 \quad 0 .:$ ZONE 6

MULTiphase: VAN MUAL $n=1.393$ alpha $=7.61 \mathrm{e}-4 \mathrm{~s}=0.00$. $:$ ZONE 7

MULTiphase: VAN MUAL $n=2.08$ alpha $=6.83 \quad s t=1213 \quad 0 .: Z O N E 7$

MULTiphase: VAN MUAL $n=2.08$ alpha $=6.83 \quad s r=.1213 \quad 0 .:$ ZONE 9

MULTiphase: VAN MUAL $n=1.393$ alpha $=7.61 \mathrm{e}-4 \mathrm{sr}=0.00$. $: Z O N E 10$

MULTiphase: VAN MUAL $n=1.393$ alpha $=7.61 \mathrm{e}-4 \mathrm{~s}=0.00 .:$ ZONE 12

MULTiphase: VAN MUAL $n=1.393$ alpha $=7.61 \mathrm{e}-4 \mathrm{~s}=0.00$. : ZONE 13

MULTiphase: VAN MUAL $n=2.08 \quad$ alpha $=6.83 \quad \mathrm{~s} r=.1213 \quad 0 .:$ ZONE 12

MULTiphase: VAN MUAL $n=2.08$ alpha $=6.83 \quad s r=.1213 \quad 0 .: Z O N E 13$

MULTiphase: VAN MUAL $n=2.08$ alpha=6.83 $s 5=.1213 \quad 0 .: Z$ ZNE 14

I

TRANsport C $K d=0 . \quad D a b=1.5779 e-2 \quad a=0.00 \quad b=0.0: Z O N E 1$

TRANspor. $C \mathrm{Kd}=0$. $D a b=1.5779 \mathrm{e}-2 \quad a=8.500 \quad b=.85:$ ZONE 2

TRANsport C Kd=0. Dab=1.5779e-2 a=8.500 b=.85: ZONE 3

TRANsport C Kd=0. Dab=1.5779e-2 $a=8.500 \quad b=.85:$ ZONE 4

TRANsport C Kd=0. Dab=1.5779e-2 $a=0.000 \quad b=0 .:$ ZONE 5

TRANsport C Kd=0. Dab=1.5779e-2 $a=0.000 \quad b=0 . ;$ ZONE 6

TRANsport C Kd=0. Dab=1.57788e-2 $a=0.000 \quad b=0 .:$ ZONE 7

TRANsport C Kd=0. Dab=1.5779e-2 $a=0.000 \quad b=0 .:$ ZONE 9

TRANsport C Kd=0. Dab=7.88940e-30 a=0.000 b=0.: ZONE 10

TRANsport C Kd=0. Dab $=1.57788 \mathrm{e}-2 \cdot a=0.000 \quad b=0 .:$ ZONE 12

TRANsport C Kd=0. Dab=1.57788e-2 $a=0.000 \quad b=0 .:$ ZONE 13

TRANsport $C \mathrm{Kd}=0$. Dab=1.5779e-2 $a=0.000 \quad b=0 .:$ ZONE 14 
DOE/RL-97-69

Rev. 0

I

TRANsport C2 Kd=0.0 Dab=1.5779e-2 a= $0.00 \quad b=0.0:$ ZONE 1

TRANsport C2 $\mathrm{Kd}=0.0 \mathrm{Dab}=1.5779 \mathrm{e}-2 \quad \mathrm{a}=8.500 \quad \mathrm{~b}=.85:$ ZONE 2

TRANsport C2 Kd=0.0 Dab=1.5779e- $2 \quad a=8.500 \quad b=.85:$ ZONE 3

TRANsport C2 Kd=0.0 Dab=1.5779e-2 a=8.500 $b=.85:$ ZONE 4

TRANsport C2 Kd=0.0 Dab=1.5779e-2 $a=0.000 \quad b=0 .:$ ZONE 5

TRANsport C2 Kd=0.0 Dab=1.5779e-2 $a=0.000 \quad b=0 .:$ ZONE 6

TRANsport C2 Kd=0.0 Dab=1.57788e-2 $a=0.000 \quad b=0,:$ ZONE 7

TRANsport C2 $\mathrm{Kd}=0.0 \mathrm{Dab}=1.5779 \mathrm{e}-2 \quad \mathrm{a}=0.000 \quad \mathrm{~b}=0 .:$ ZONE 9

TRANsport C2 $\mathrm{Kd}=0.0 \mathrm{Dab}=7.88940 \mathrm{e}-30 \mathrm{a}=0.000 \quad \mathrm{~b}=0 .:$ ZONE 10

TRANsport C2 Kd=0.0 Dab=1.57788e-2 $a=0.000 \quad b=0 .:$ ZONE 12

TRANspor C2 Kd=0.0 Dab=1.57788e-2 $a=0.000 \quad b=0 .:$ ZONE 13

TRANsport C2 Kd=0.0 Dab=1.5779e-2 $a=0.000 \quad b=0 .:$ ZONE 14

1

TRANsport C3 $\mathrm{Kd}=0.1 \mathrm{Dab}=1.5779 \mathrm{e}-2 \quad a=0.00 \quad b=0.0:$ ZONE 1

TRANsport C3 Kd=0.1 Dab=1.5779e-2 $a=8.500 \quad b=.85:$ ZONE 2

TRANsport C3 Kd=0.1 Dab=1.5779e-2 $a=8.500 \quad b=.85:$ ZONE 3

TRANsport C3 Kd=0.1 Dab=1.5779e-2 $a=8.500 \quad b=.85:$ ZONE 4

TRANspor C3 Kd=0.1 Dab=1.5779e-2 $a=0.000 \quad b=0 .:$ ZONE 5

TRANsport C3 $\mathrm{Kd}=0.1 \mathrm{Dab}=1.5779 \mathrm{e}-2 \mathrm{a}=0.000 \quad b=0 .:$ ZONE 6

TRANsport C3 Kd=0.1 Dab=1.57788e-2 $a=0.000 \quad b=0 .:$ ZONE 7

TRANsport C3 Kd=0.1 Dab=1.5779e-2 $a=0.000 \quad b=0 .:$ ZONE 9

TRANsport C3 Kd=0.1 Dab=7.88940e-30 $a=0.000 \quad b=0 .:$ ZONE 10

TRANsport C3 Kd=0.1 Dab=1.57788e-2 $a=0.000 \quad b=0 .:$ ZONE 12

TRANsport C3 Kd=0.1 Dab=1.57788e-2 $a=0.000 \quad b=0 .:$ ZONE 13

TRANsport C3 Kd=0.1 Dab=1.5779e-2 $a=0.000 \quad b=0 . ;$ ZONE 14

I

TRANsport C4 Kd=0.6 Dab=1.5779e-2 a=0.00 b=0.0:ZONE 1

TRANsport C4 Kd=0.6 Dab=1.5779e-2 $a=8.500 \quad b=.85:$ ZONE 2

TRANsport C4 Kd=0.6 Dab=1.5779e-2 $a=8.500 \quad b=.85:$ ZONE 3

TRANsport C4 Kd=0.6 Dab $=1.5779 \mathrm{e}-2 \quad \mathrm{a}=8.500 \quad \mathrm{~b}=.85:$ ZONE 4

TRANsport C4 Kd=0.6 Dab=1.5779e-2 $a=0.000 \quad b=0 .:$ ZONE 5

TRANsport C4 Kd=0.6 Dab=1.5779e-2 $a=0.000 \quad b=0:$ : ZONE 6

TRANsport C4 Kd=0.6 Dab=1.5778e-2 $a=0.000 \quad b=0 .:$ ZONE 7

TRANsport C4 Kd=0.6 Dab=1.5779e-2 $a=0.000 \quad b=0 .:$ ZONE 9

TRANspor C4 Kd=0.6 Dab $=7.88940 \mathrm{e}-30 \quad a=0.000 \quad b=0 .:$ ZONE 10

TRANsport C4 Kd=0.6 Dab=1.57788e- $2 \quad a=0.000 \quad b=0 .:$ ZONE 12

TRANsport C4 Kd=0.6 Dab=1.57788e-2 $a=0.000 \quad b=0 .:$ ZONE 13

TRANsport C4 Kd=0.6 Dab=1.5779e $-2 \quad a=0.000 \quad b=0 .: Z O N E 14$

1

1

INITIAL H=-.7487 IN ZONE 1 !!! Soil G-1

INITIAL H=-.8227 IN ZONE 2 !!! Soil G-2

INITIAL H=-3.9454 IN ZONE 3 !!! Soil G-3

ANITIAL $\mathrm{H}=-2.05473$ IN ZONE $4 \quad$ !! ! Soil G-4

INITIAL $\mathrm{H}==.7487$ IN ZONE 5 !!! Gravel above engineered vault system

INITIAL H=-.7487 IN ZONE 6 !!! Crushed Glass on top of concrete vault roof

INITIAL H=-.7487 IN ZONE 7 !!! Top concrete

INITIAL $\mathrm{H}=-.7487$ IN ZONE 9 !!! BF Soil on top of canisters

INITIAL $\mathrm{H}=-.7487$ IN ZONE $10 \quad$ !! Canisters

INITIAL $\mathrm{H}=-.7487$ IN ZONE 12 !!! Bottom concrete

INITIAL H $=-7487$ IN ZONE 13 !!! Vertical concrete

INITIAL H=-.7487 IN ZONE $14 \quad$ !!! BF Soil in vertical spacings

INITIAL $H=0.0$ from $(1,1)$ to $(166,1)$ ! bottom 


\section{I}

INITIAL $C$ is 0 everywhere

INITIAL $C 2$ is 0 everywhere

INITIAL $\mathrm{C} 3$ is 0 everywhere

INITIAL $\mathrm{C} 4$ is 0 everywhere

I

BOUN P west index $=-1$ GRAD $=0$

BOUN P east index $=1 \mathrm{GRAD}=0.0$

BOUN P bottom index $=-2$ VALUe $=-0.25$ water table

BOUN P top index $=2 \mathrm{FLUX}=-5.0 \mathrm{E}-4 \mathrm{~m} / \mathrm{year}$

I

BOUN $C$ west index $=-1$ GRAD $=0.0$

BOUN C east index $=1$ GRAD $=0.0$

BOUN $C$ bottom index $=-2$ GRAD $=0.0$

BOUN C top index $=2$ VALUe $=0.0$

I

BOUN C2 west index $=-1 \mathrm{GRAD}=0.0$

BOUN C2 east index $=1$ GRAD $=0.0$

BOUN C2 bottom index $=-2$ GRAD $=0.0$

BOUN C2 top index $=2$ VALUe $=0.0$

I

BOUN C3 west index $=-1 \mathrm{GRAD}=0.0$

BOUN C3 east index $=1$ GRAD $=0.0$

BOUN C3 bottom index $=-2$ GRAD $=0.0$

BOUN C3 top index $=2$ VALUe $=0.0$

I

BOUN C4 west index $=-1$ GRAD $=0.0$

BOUN C4 east index $=1$ GRAD $=0.0$

BOUN C4 bottom index $=-2$ GRAD $=0.0$

BOUN C4 top index $=2$ VALUe $=0.0$

1

PROPERTIES FOR P BY GEOMEtric MEAN

PROPERTIES FOR C BY HARMOnic MEAN

PROPERTIES FOR C2 BY HARMOnic MEAN

PROPERTIES FOR C3 BY HARMOnIC MEAN

PROPERTIES FOR C4 BY HARMonic MEAN

I

1

LOCATE SOURCE 1 from $(3,89)$ to $(3,97) \$$ BF soil matrix LOCATE SOURCE 2 from $(6,89)$ to $(6,97) \$$ BF soil matrix LOCATE SOURCE 3 from $(9,89)$ to $(9,97) \$$ BF soil matrix LOCATE SOURCE 4 from $(12,89)$ to $(12,97) \$ \mathrm{BF}$ soil matrix LOCATE SOURCE 5 from $(15,89)$ to $(15,97) \$$ BF soil matrix LOCATE SOURCE 6 from $(18,89)$ to $(18,97) \$$ BF soil matrix LOCATE SOURCE 7 from $(21,89)$ to $(21,97) \$$ BF soil matrix LOCATE SOURCE 8 from $(24,89)$ to $(24,97) \$$ BF soil matrix LOCATE SOURCE 9 from $(27,89)$ to $(27,97) \$$ BF soil matrix LOCATE SOURCE 10 from $(30,89)$ to $(30,97) \$ B F$ soil matrix I

LOCATE SOURCE 11 from $(33,89)$ to $(33,97) \$$ BF soil matrix LOCATE SOURCE 12 from $(36,89)$ to $(36,97) \$$ BF soil matrix LOCATE SOURCE 13 from $(39,89)$ to $(39,97) \$$ BF soil matrix LOCATE SOURCE 14 from $(42,89)$ to $(42,97) \$$ BF soil matrix LOCATE SOURCE 15 from $(45,89)$ to $(45,97) \$$ BF soil matrix LOCATE SOURCE 16 from $(48,89)$ to $(48,97) \$$ BF soil matrix LOCATE SOURCE 17 from $(51,89)$ to $(51,97) \$$ BF soil matrix LOCATE SOURCE 18 from $(54,89)$ to $(54,97) \$$ BF soil matrix 
LOCATE SOURCE 19 from $(57,89)$ to $(57,97) \$$ BF soil matrix LOCATE SOURCE 20 from $(60,89)$ to $(60,97) \$ \mathrm{BF}$ soil matrix 1

LOCATE SOURCE 21 from $(63,89)$ to $(63,97) \$$ BF soil matrix LOCATE SOURCE 22 from $(66,89)$ to $(66,97) \$$ BF soil matrix LOCATE SOURCE 23 from $(69,89)$ to $(69,97) \$$ BF soil matrix LOCATE SOURCE 24 from $(72,89)$ to $(72,97) \$$ BF soil matrix LOCATE SOURCE 25 from $(75,89)$ to $(75,97) \$ \mathrm{BF}$ soil matrix LOCATE SOURCE 26 from $(78,89)$ to $(78,97) \$$ BF soil matrix LOCATE SOURCE 27 from $(81,89)$ to $(81,97) \$$ BF soil matrix LOCATE SOURCE 28 from $(84,89)$ to $(84,97) \$$ BF soil matrix LOCATE SOURCE 29 from $(87,89)^{\circ}$ to $(87,97) \$$ BF soil matrix LOCATE SOURCE 30 from $(90,89)$ to $(90,97) \$$ BF soil matrix I

LOCATE SOURCE 31 from $(93,89)$ to $(93,97) \$$ BF soil matrix LOCATE SOURCE 32 from $(96,89)$ to $(96,97) \$$ BF soil matrix LOCATE SOURCE 33 from $(99,89)$ to $(99,97) \$$ BF soil matrix LOCATE SOURCE 34 from $(102,89)$ to $(102,97) \$ B F$ soil matrix LOCATE SOURCE 35 from $(105,89)$ to $(105,97) \$$ BF soil matrix LOCATE SOURCE 36 from $(108,89)$ to $(108,97) \$$ BF soil matrix LOCATE SOURCE 37 from $(111,89)$ to $(111,97) \$$ BF soil matrix LOCATE SOURCE 38 from $(114,89)$ to $(114,97) \$$ BF soil matrix LOCATE SOURCE 39 from $(117,89)$ to $(117,97) \$$ BF soil matrix LOCATE SOURCE 40 from $(120,89)$ to $(120,97) \$$ BF soil matrix 1

LOCATE SOURCE 41 from $(123,89)$ to $(123,97) \$$ BF soil matrix LOCATE SOURCE 42 from $(126,89)$ to $(126,97) \$$ BF soil matrix LOCATE SOURCE 43 from $(129,89)$ to $(129,97) \$ B F$ soil matrix LOCATE SOURCE 44 from $(132,89)$ to $(132,97) \$ B F$ soil matrix LOCATE SOURCE 45 from $(135,89)$ to $(135,97) \$$ BF soil matrix LOCATE SOURCE 46 from $(138,89)$ to $(138,97) \$$ BF soil matrix LOCATE SOURCE 47 from $(141,89)$ to $(141,97) \$$ BF soil matrix LOCATE SOURCE 48 from $(144,89)$ to $(144,97) \$$ BF soil matrix LOCATE SOURCE 49 from $(147,89)$ to $(147,97) \$$ BF soil matrix LOCATE SOURCE 50 from $(150,89)$ to $(150,97) \$$ BF soil matrix

I

I

// TIME STRENGTH $\left(\mathrm{m}^{* *} 3 / \mathrm{m} * * 3-\mathrm{yr}\right)$

ISOUR\# 1 FLOW , 4 set: $(0 ., 0 ., 121 ., 7.29 \mathrm{e}-5,20000 ., 2.92 \mathrm{e}-4,40000 ., 2.92 \mathrm{e}-3)$

/ $\mathrm{C}=0.0, \mathrm{C} 2=0.0, \mathrm{C} 3=0.0, \mathrm{C} 4=0.0$

SCALE 0012346

SOUR\# 1 for $C 39$ pairs on file 'rfprate.dat'

IC2 is for Tc- 99 which has a release rate that is 5 times smaller than $\mathrm{C}^{\prime} \mathrm{s}, \mathrm{C} 3{ }^{\prime} \mathrm{s}, \mathrm{C} 4$ 's, / hence the scale factor is reduced by a factor of 5 if same release file is used.

SCALE 00024691

SOUR\# 1 for $\mathrm{C} 25$ pairs on file 'rfptcx5.dat'

SCALE .0012346

SOUR\# 1 for C3 39 pairs on file 'Ifprate.dat'

SCALE .0012346

SOUR\# 1 for C4 39 pairs on file 'rfprate.dat' SCALE 0024691

SOUR\# 2 for C 39 pairs on file 'rfprate.dat' SCALE 00049384

SOUR\# 2 for C2 5 pairs on file 'rfptcx 5 .dat'

SCALE .0024691

SOUR\# 2 for $\mathrm{C} 339$ pairs on file 'rfprate.dat'

SCALE 0024691 
Rev. 0

SOUR\# 2 for C4 39 pairs on file 'rfprate.dat' SCALE .0024691

SOUR\# 3 for C 39 pairs on file 'rfprate.dat' SCALE .00049384

SOUR\# 3 for $\mathrm{C} 25$ pairs on file ' $r$ fptcx 5 .dat' SCAIE 0024691

SOUR\# 3 for C3 39 pairs on file 'rfprate.dat' SCALE .0024691

SOUR\# 3 for C4 39 pairs on file 'rfprate.dat' SCALE .0024691

SOUR\# 4 for C 39 pairs on file 'rfprate.dat' SCALE 00049384

SOUR\# 4 for C2 5 pairs on file 'rfptcx 5 .dat' SCALE 0024691

SOUR\# 4 for C3 39 pairs on file 'rfprate.dat' SCALE 0024691

SOUR\# 4 for C4 39 pairs on file 'rfprate.dat' SCALE .0024691

SOUR\# 5 for $C 39$ pairs on file 'rfprate.dat' SCALE 00049384

SOUR\# 5 for $\mathrm{C} 25$ pairs on file 'rfptcx 5 .dat' SCALE 0024691

SOUR\# 5 for C3 39 pairs on file 'rfprate.dat' SCALE 0024691

SOUR\# 5 for C4 39 pairs on file 'rfprate.dat' SCALE .0024691

SOUR\# 6 for C 39 pairs on file 'rfprate.dat' SCALE 00049384

SOUR\# 6 for $\mathrm{C} 25$ parrs on file 'rfptex 5 .dat' SCALE 0024691

SOUR\# 6 for C3 39 pairs on file 'rfprate.dat' SCALE .0024691

SOUR\# 6 for $\mathrm{C} 439$ pairs on file 'rfprate.dat' SCALE .0024691

SOUR\# 7 for C 39 pairs on file 'rfprate.dat' SCALE 00049384

SOUR\# 7 for C2 5 pairs on file 'rfptex5.dat' SCALE .0024691

SOUR\# 7 for C339 pairs on file 'rfprate.dat' SCALE 0024691

SOUR\# 7 for C4 39 pairs on file 'rfprate.dat' SCALE 0024691

SOUR\# 8 for C 39 pairs on file 'rfprate.dat' SCALE 00049384

SOUR\# 8 for $\mathrm{C} 25$ pairs on file 'rfptcx S.dat' SCALE 0024691

SOUR\# 8 for $\mathrm{C} 339$ pairs on file 'rfprate.dat' SCALE 0024691

SOUR\# 8 for C4 39 pairs on file 'rfprate.dat' SCALE .0024691

SOUR\# 9 for C 39 pairs on file 'rfprate.dat' SCALE 00049384

SOUR\# 9 for C2 5 pairs on file 'rfptcx 5 .dat' SCALE 0024691

SOUR\# 9 for C 339 pairs on file 'rfprate.dat' SCALE .0024691

SOUR\# 9 for C4 39 pairs on file 'rfprate.dat' 
SCALE 0012346

SOUR\# 10 for C 39 pairs on file 'rfprate.dat' SCALE 00024691

SOUR\# 10 for C2 5 pairs on file 'rfptex5.dat' SCALE .0012346

SOUR\# 10 for C3 39 pairs on file 'rfprate.dat' SCALE .0012346

SOUR\# 10 for $\mathrm{C} 439$ pairs on file 'rfprate.dat' SCALE .0012346

1

SOUR\# 11 for C 39 pairs' on file 'rfprate.dat' SCALE .00024691

SOUR\# 11 for C2 5 pairs on file 'rfptcx5.dat' SCALE .0012346

SOUR\# 11 for $C 339$ pairs on file 'rfprate.dat' SCALE .0012346

SOUR\# 11 for $\mathrm{C} 439$ pairs on file 'rfprate.dat' SCALE .0024691

SOUR\# 12 for C 39 pairs on file 'rfprate.dat' SCALE .00049384

SOUR\# 12 for C2 5 pairs on file 'rfptcx5.dat' SCALE .0024691

SOUR\# 12 for C3 39 pairs on file 'rfprate.dat' SCALE 0024691

SOUR\# 12 for $\mathrm{C} 439$ pairs on file 'rfprate.dat' SCALE 0024691

SOUR\# 13 for C 39 pairs on file 'rfprate.dat' SCALE .00049384

JUUR\# 13 for $\mathrm{C} 25$ pairs on file 'rfptcx5.dat' SCALE 0024691

SOUR\# 13 for C3 39 pairs on file 'rfprate.dat' SCALE 0024691

SOUR\# 13 for $\mathrm{C} 439$ pairs on file 'rfprate.dat' SCALE .0024691

I

SOUR\# 14 for C 39 pairs on file 'tfprate.dat' SCALE 00049384

SOUR\# 14 for C2 5 pairs on file 'rfptcx5.dat' SCALE .0024691

SOUR\# 14 for C3 39 pairs on file 'rfprate.dat' SCALE .0024691

SOUR\# 14 for $\mathrm{C} 439$ pairs on file 'rfprate.dat' SCALE .0024691

SOUR\# 15 for C 39 pairs on file 'rfprate.dat' SCALE .00049384

SOUR\# 15 for $\mathrm{C} 25$ pairs on file 'rfptcx5.dat' SCALE .0024691

SOUR\# 15 for C3 39 pairs on file 'rfprate.dat' SCALE .0024691

SOUR\# 15 for C4 39 pairs on file 'rfprate.dat' SCALE 0024691

SOUR\# 16 for C 39 pairs on file 'rfprate.dat' SCALE .00049384

SOUR\# 16 for C2 5 pairs on file 'rfptex5.dat' SCALE 0024691

SOUR\# 16 for C3 39 pairs on file 'rfprate.dat' SCALE 0024691 
SOUR\# 16 for C4 39 pairs on file 'rfprate.dat' SCALE .0024691

SOUR\# 17 for C 39 pairs on file 'rfprate.dat' SCALE .0049384

SOUR\# 17 for C2 5 pairs on file 'rfptcxS.dat' SCALE .0024691

SOUR\# 17 for C3 39 pairs on file 'rfprate.dat' SCALE .0024691

SOUR\# 17 for C4 39 pairs on file 'rfprate.dat' SCALE 0024691

SOUR\# 18 for C 39 pairs on file 'rfprate.dat' SCALE 00049384

SOUR\# 18 for C2 5 pairs on file 'rfptcx 5,dat' SCALE .0024691

SOUR\# 18 for C3 39 pairs on file 'rfprate.dat' SCALE .0024691

SOUR\# 18 for C4 39 pairs on file 'rfprate.dat' SCALE 0024691

SOUR\# 19 for C 39 pairs on file 'rfprate.dat' SCALE .00049384

SOUR\# 19 for C2 5 pairs on file 'rfptex 5 .dat' SCALE .0024691

SOUR\# 19 for C3 39 pairs on file 'rfprate.dat' SCALE .0024691

SOUR\# 19 for C4 39 pairs on file 'rfprate.dat' SCALE .0012346

SOUR\# 20 for C 39 pairs on file 'rfprate.dat' SCALE .00024691

SOUR\# 20 for C2 5 pairs on file 'Ifptex 5.dat' SCALE 0012346

SOUR\# 20 for C3 39 pairs on file 'rfprate.dat' SCALE .0012346

SOUR\# 20 for $\mathrm{C} 439$ pairs on file 'rfprate.dat' SCALE .0012346

1

SOUR\# 21 for C 39 pairs on file 'rfprate.dat' SCALE .00024691

SOUR\# 21 for C2 5 pairs on file 'rfptcx 5.dat' SCALE .0012346

SOUR\# 21 for C3 39 pairs on file 'rfprate.dat' SCALE 0012346

SOUR\# 21 for C4 39 pairs on file 'rfprate.dat' SCALE .0024691

SOUR\# 22 for C 39 pairs on file 'rfprate.dat' SCALE .00049384

SOUR\# 22 for C2 5 pairs on file 'rfptcx5.dat' SCALE .0024691

SOUR\# 22 for C3 39 pairs on file 'rfprate.dat' SCALE .0024691

SOUR\# 22 for $\mathbf{C} 439$ pairs on file 'rfprate.dat' SCALE .0024691

SOUR\# 23 for C 39 pairs on file 'rfprate.dat' SCALE .00049384

SOUR\# 23 for C2 5 pairs on file 'Ifptcx 5.dat' SCALE .0024691

SOUR\# 23 for C3 39 pairs on file 'rfprate.dat' SCALE .0024691 
DOE/RL-97-69

Rev. 0

SOUR\# 23 for $\mathrm{C} 439$ pairs on file 'rfprate.dat' SCALE .0024691

SOUR\# 24 for C 39 pairs on file 'rfprate.dat' SCALE 00049384

SOUR\# 24 for $\mathrm{C} 25$ pairs on file 'rfptex5.dat' SCALE .0024691

SOUR\# 24 for C3 39 pairs on file 'rfprate.dat' SCALE 0024691

SOUR\# 24 for C4 39 pairs on file 'rfprate.dat' SCALE 0024691

SOUR\# 25 for $C 39$ pairs on file 'rfprate.dat' SCALE .00049384

SOUR\# 25 for C2 5 pairs on file 'Ifptex5.dat' SCALE 0024691

SOUR\# 25 for C3 39 pairs on file 'rfprate.dat' SCALE .0024691

SOUR\# 25 for C4 39 pairs on file 'rfprate.dat SCALE .0024691

SOUR\# 26 for C 39 pairs on file 'rfprate.dat' SCALE 00049384

SOUR\# 26 for $\mathrm{C} 25$ pairs on file 'rfptex 5 .dat' SCALE .0024691

SOUR\# 26 for C3 39 pairs on file 'rfprate.dat' SCALE .0024691

SOUR\# 26 for $\mathrm{C} 439$ pairs on file 'rfprate.dat' SCALE .0024691

SOUR\# 27 for C 39 pairs on file 'rfprate.dat' SCALE 00049384

SOUR\# 27 for $\mathrm{C} 25$ pairs on file 'rfptexs.dat' SCALE .0024691

SOUR\# 27 for C3 39 pairs on file 'rfprate.dat' SCALE .0024691

SOUR\# 27 for $\mathrm{C} 439$ pairs on file 'rfprate.dat' SCALE .0024691

SOUR\# 28 for C 39 pairs on file 'rfprate.dat' SCALE .00049384

SOUR\# 28 for C2 5 pairs on file 'rfptex5.dat' SCALE .0024691

SOUR\# 28 for C3 39 pairs on file 'rfprate.dat' SCALE 0024691

SOUR\# 28 for C4 39 pairs on file 'rfprate.dat' SCALE .0024691

SOUR\# 29 for C 39 pairs on file 'rfprate.dat' SCALE .00049384

SOUR\# 29 for C2 5 pairs on file 'ffptex5.dat' SCALE .0024691

SOUR\# 29 for C3 39 pairs on file 'rfprate.dat' SCALE .0024691

SOUR\# 29 for $\mathrm{C} 439$ pairs on file 'rfprate.dat' SCALE .0012346

SOUR\# 30 for C 39 pairs on file 'rfprate.dat' SCALE .00024691

SOUR\# 30 for C2 5 pairs on file 'rfptex5.dat' SCALE .0012346

SOUR\# 30 for C3 39 pairs on file 'rfprate.dat' SCALE .0012346

SOUR\# 30 for $\mathrm{C} 439$ pairs on file 'rfprate.dat' 
SCALE .0012346

I

SOUR\# 31 for C 39 pairs on file 'rfprate.dat' SCALE .00024691

SOUR\# 31 for C2 5 pairs on file 'rfptcx5.dat' SCALE 0012346

SOUR\# 31 for C3 39 pairs on file 'rfprate.dat' SCALE .0012346

SOUR\# 31 for $\mathrm{C} 439$ pairs on file 'rfprate.dat' SCALE 0024691

SOUR\# 32 for C 39 pairs on file 'rfprate.dat' SCALE 00049384

SOUR\# 32 for C2 5 pairs on file 'rfptex5.dat' SCALE .0024691

SOUR\# 32 for C3 39 pairs on file 'rfprate.dat' SCALE 0024691

SOUR\# 32 for $\mathrm{C} 439$ pairs on file 'rfprate.dat' SCALE 0024691

SOUR\# 33 for C 39 pairs on file 'Ifprate.dat' SCALE 00049384

SOUR\# 33 for $\mathrm{C} 25$ pairs on file 'rfptex5.dat' SCALE .0024691

SOUR\# 33 for C3 39 pairs on file 'rfprate.dat' SCALE .0024691

SOUR\# 33 for $\mathrm{C} 439$ pairs on file 'rfprate.dat' SCALE .0024691

SOUR\# 34 for C 39 pairs on file 'rfprate.dat' SCALE 00049384

SOUR\# 34 for $\mathrm{C} 25$ pairs on file 'rfptex5.dat' SCALE 0024691

SOUR\# 34 for C3 39 pairs on file 'rfprate.dat' SCALE 0024691

SOUR\# 34 for $\mathrm{C} 439$ pairs on file 'rfprate.dat' SCALE .0024691

SOUR\# 35 for $C 39$ pairs on file 'rfprate.dat' SCALE 00049384

SOUR\# 35 for C2 5 pairs on file 'rfptcx5.dat' SCALE 0024691

SOUR\# 35 for C3 39 pairs on file 'rfprate.dat' SCALE .0024691

SOUR\# 35 for C4 39 pairs on file 'rfprate.dat' SCALE 0024691

SOUR\# 36 for C 39 pairs on file 'rfprate.dat' SCALE 00049384

SOUR\# 36 for $\mathrm{C} 25$ pairs on file 'rfptcx5.dat' SCALE .0024691

SOUR\# 36 for C3 39 pairs on file 'rfprate.dat' SCALE .0024691

SOUR\# 36 for $\mathrm{C} 439$ pairs on file 'rfprate.dat' SCALE 0024691

SOUR\# 37 for C 39 pairs on file 'rfprate.dat' SCALE .0024691

SOUR\# 37 for C2 5 pairs on file 'rfptcx5.dat' SCALE 0024691

SOUR\# 37 for C3 39 pairs on file 'rfprate.dat' SCALE .0024691

SOUR\# 37 for C4 39 pairs on file 'rfprate.dat' 
SCALE .0024691

SOUR\# 38 for C 39 pairs on file 'rfprate.dat' SCALE .00049384

SOUR\# 38 for $\mathrm{C2} 5$ pairs on file 'ffptcx5.dat' SCALE .0024691

SOUR\# 38 for C3 39 pairs on file 'rfprate.dat' SCALE .0024691

SOUR\# 38 for C4 39 pairs on file 'rfprate.dat' SCALE .0024691

SOUR\# 39 for C 39 pairs on file 'rfprate.dat' SCALE 00049384

SOUR\# 39 for C2 5 pairs on file 'rfptcx5.dat' SCALE 0024691

SOUR\# 39 for C3 39 pairs on file 'rfprate.dat' SCALE .0024691

SOUR\# 39 for $C 439$ pairs on file 'rfprate.dat' SCALE 0012346

SOUR\# 40 for C 39 pairs on file 'rfprate.dat' SCALE .00024691

SOUR\# 40 for $\mathrm{C} 25$ pairs on file 'rfptex5.dat' SCALE .0012346

SOUR\# 40 for C3 39 pairs on file 'rfprate.dat' SCALE 0012346

SOUR\# 40 for $\mathrm{C} 439$ pairs on file 'rfprate.dat' SCALE .0012346

I

SOUR\# 41 for C 39 pairs on file 'rfprate.dat' SCALE .00024691

SOUR\# 41 for $C 25$ pairs on file 'rfptex5.dat' SCALE .0012346

SOUR\# 41 for C3 39 pairs on file 'rfprate.dat' SCALE .0012346

SOUR\# 41 for $\mathrm{C} 439$ pairs on file 'Ifprate.dat' SCALE .0024691

I

SOUR\# 42 for C 39 pairs on file 'rfprate.dat' SCALE .00049384

SOUR\# 42 for $\mathrm{C} 25$ pairs on file 'rfptcx5.dat' SCALE .0024691

SOUR\# 42 for C3 39 pairs on file 'rfprate.dat' SCALE .0024691

SOUR\# 42 for C4 39 pairs on file 'rfprate.dat' SCALE 0024691

SOUR\# 43 for C 39 pairs on file 'rfprate.dat' SCALE .00049384

SOUR\# 43 for C2 5 pairs on file 'rfptex5.dat' SCALE .0024691

SOUR\# 43 for C3 39 pairs on file 'Ifprate.dat' SCALE .0024691

SOUR\# 43 for C4 39 pairs on file 'rfprate.dat' SCALE .0024691

SOUR\# 44 for C 39 pairs on file 'rfprate.dat' SCALE 00049384

SOUR\# 44 for C2 5 pairs on file 'rfptcxS.dat' SCALE .0024691

SOUR\# 44 for C3 39 pairs on file 'rfprate.dat' SCALE .0024691 
DOE/RL-97-69

Rev. 0

SOUR\# 44 for C4 39 pairs on file 'rfprate.dat' SCALE .0024691

SOUR\# 45 for $\mathrm{C} 39$ pairs on file 'rfprate.dat' SCALE 00049384

SOUR\# 45 for $\mathrm{C2} 5$ pairs on file 'rfptex5.dat' SCALE .0024691

SOUR\# 45 for C3 39 pairs on file 'rfprate.dat' SCALE .0024691

SOUR\# 45 for $\mathrm{C} 439$ pairs on file 'rfprate.dat' SCALE 0024691

SOUR\# 46 for $C 39$ pairs on file 'rfprate.dat' SCALE 00049384

SOUR\# 46 for $\mathrm{C2} 5$ pairs on file 'rfptex5.dat' SCALE .0024691

SOUR\# 46 for $\mathrm{C} 339$ pairs on file 'rfprate.dat' SCALE .0024691

SOUR\# 46 for $\mathrm{C} 439$ pairs on file 'rfprate.dat' SCALE .0024691

SOUR\# 47 for $C 39$ pairs on file 'rfprate.dat' SCALE .00049384

SOUR\# 47 for $C 25$ pairs on file 'rfptcx5.đat' SCALE 0024691

SOUR\# 47 for C3 39 pairs on file 'rfprate.dat' SCALE .0024691

SOUR\# 47 for $\mathrm{C} 439$ pairs on file 'rfprate.dat' SCALE 0024691

SOUR\# 48 for C 39 pairs on file 'rfprate.dat' SCALE 00049384

SOUR\# 48 for $\mathrm{C} 25$ pairs on file 'rfptcx 5 .dat' SCALE .0024691

SOUR\# 48 for C3 39 pairs on file 'rfprate.dat' SCALE .0024691

SOUR\# 48 for $\mathrm{C} 439$ pairs on file 'rfprate.dat' SCALE .0024691

SOUR\# 49 for C 39 pairs on file 'rfprate.dat' SCALE .00049384

SOUR\# 49 for $\mathrm{C} 25$ pairs on file 'rfptcx5.dat' SCALE .002469!

SOUR\# 49 for C3 39 pairs on file 'rfprate.dat' SCALE .0024691

SOUR\# 49 for C4 39 pairs on file 'rfprate.dat' SCALE .0012346

SOUR\# 50 for C 39 pairs on file 'rfprate.dat' SCALE 00024691

SOUR\# 50 for C2 5 pairs on file 'rfptex 5 .dat' SCALE .0012346

SOUR\# 50 for C3 39 pairs on file 'rfprate.dat' SCALE .0012346

SOUR\# 50 for C4 39 pairs on file 'rfprate.dat'

I

1

FIXEd $P$ from $(4,89)$ to $(5,97) \$$ glass canisters

FIXEd $P$ from $(7,89)$ to $(8,97) \$$ glass canisters

FIXEd $P$ from $(10,89)$ to $(11,97) \$$ glass canisters

FIXEd $P$ from $(13,89)$ to $(14,97) \$$ glass canisters

FIXEd P from $(16,89)$ to $(17,97) \$$ glass canisters

FIXEd $P$ from $(19,89)$ to $(20,97) \$$ glass canisters 
DOE/RL-97-69

Rev. 0

FlXEd $P$ from $(22,89)$ to $(23,97) \$$ glass canisters

FLXEd $P$ from $(25,89)$ to $(26,97) \$$ glass canisters FLXEd P from $(28,89)$ to $(29,97) \$$ glass canisters $l$

FiXEd $P$ from $(34,89)$ to $(35,97) \$$ glass canisters FIXEd $P$ from $(37,89)$ to $(38,97) \$$ glass canisters FIXEd P from $(40,89)$ to $(41,97) \$$ glass canisters FIXEd $P$ from $(43,89)$ to $(44,97) \$$ glass canisters FLXEd $P$ from $(46,89)$ to $(47,97) \$$ glass canisters FIXEd $P$ from $(49,89)$ to $(50,97) \$$ glass canisters FIXEd $P$ from $(52,89)$ to $(53,97) \$$ glass canisters FlXEd $P$ from $(55,89)$ to $(56,97) \$$ glass canisters FIXEd $P$ from $(58,89)$ to $(59,97) \$$ glass canisters I

FIXEd P from $(64,89)$ to $(65,97) \$$ glass canisters FIXEd $P$ from $(67,89)$ to $(68,97) \$$ glass canisters FIXEd $P$ from $(70,89)$ to $(71,97) \$$ glass canisters FIXEd P from $(73,89)$ to $(74,97) \$$ glass canisters FIXEd $P$ from $(76,89)$ to $(77,97) \$$ glass canisters FIXEd $P$ from $(79,89)$ to $(80,97) \$$ glass canisters FLXEd P from $(82,89)$ to $(83,97) \$$ glass canisters FIXEd $P$ from $(85,89)$ to $(86,97) \$$ glass canisters FIXEd $P$ from $(88,89)$ to $(89,97) \$$ glass canisters I

FIXEd P from $(94,89)$ to $(95,97) \$$ glass canisters FLXEd $P$ from $(97,89)$ to $(98,97) \$$ glass canisters FIXEd P from $(100,89)$ to $(101,97) \$$ glass canisters FIXEd P from $(103,89)$ to $(104,97) \$$ glass canisters FIXEd P from $(106,89)$ to $(107,97) \$$ glass canisters FLXEd P from $(109,89)$ to $(110,97) \$$ glass canisters FLXEd $P$ from $(112,89)$ to $(113,97) \$$ glass canisters FIXEd $P$ from $(115,89)$ to $(116,97) \$$ glass canisters FIXEd $P$ from $(118,89)$ to $(119,97) \$$ glass canisters I

FIXEd $P$ from $(124,89)$ to $(125,97) \$$ glass canisters FIXEd P from $(127,89)$ to $(128,97) \$$ glass canisters FIXEd $P$ from $(130,89)$ to $(131,97) \$$ glass canisters FIXEd $P$ from $(133,89)$ to $(134,97) \$$ glass canisters FIXEd $P$ from $(136,89)$ to $(137,97) \$$ glass canisters FLXEd P from $(139,89)$ to $(140,97) \$$ glass canisters FIXEd $P$ from $(142,89)$ to $(143,97) \$$ glass canisters FIXEd $P$ from $(145,89)$ to $(146,97) \$$ glass canisters FIXEd P from $(148,89)$ to $(149,97) \$$ glass canisters 1

1

CONVergence for $P$ LOCAL eps $=5.0 \mathrm{e}-6$ TTERations $=12$

METHod is PICARD

MATRIX for $P=2$ using $A D I$

MATRIX for $C=2$ using $A D I$

MATRIX for $\mathrm{C} 2=2$ using $\mathrm{ADI}$

MATRIX for $\mathrm{C} 3=2$ using $A D I$

MATRIX for $C 4=1$ using $A D I$

//RELAX $\mathrm{P}=0.32$ !!!!!! $\mathrm{S}=0.5, \mathrm{KR}=0.5, \mathrm{SE}=0.5$

I

FLUX B ALANCE FOR C ON 'base 1-1d.flx' FROM (1,1) TO (166,133) EVERY 2000 STEPSS

FLUX BALANCE for $C$ from $(1,87)$ to $(153,101)$ every 2000 steps

FLUX BALANCE for C from $(1,87)$ to $(166,133)$ every 2000 steps 


\section{DOE/RL-97-69 \\ Rev. 0}

FLUX BALANCE for C from $(1,5)$ to $(166,86)$ every 2000 steps

FLUX BALANCE for C from $(3,89)$ to $(3,97)$ every 2000 steps FLUX BALANCE for C from $(148,89)$ to $(149,97)$ every 2000 steps FLUX BALANCE for C from $(150,89)$ to $(150,97)$ every 2000 steps /HISTORY $(2,2),(20,2),(40,2),(60,2),(78,2)$ on 'base 1-1d.his' eve 200 1

FLUX BALANCE for $P$ from $(1,1)$ to $(166,133)$ every 1000 steps FLUX BALANCE for $P$ from $(1,87)$ to $(153,101)$ every 1000 steps FLUX BALANCE for $P$ from $(1 ; 87)$ to $(166,133)$ every 1000 steps FLUX BAIANCE for $P$ from $(1,1)$ to $(166,86)$ every 1000 steps FLUX for $C$ from $(1,87)$ to $(166,87)$ every 200 steps FLUX for $C$ from $(1,2)$ to $(166,2)$ every 200 steps FLUX for C2 from $(1,2)$ to $(166,2)$ every 200 steps FLUX for C3 from $(1,2)$ to $(166,2)$ every 200 steps FLUX for C4 from $(1,2)$ to $(166,2)$ every 200 steps DIAGnostic node at $(46,2)$ every 20 steps DEBUg leve 1 at step 90000

1

WINDOW from $(1,1)$ to $(165,133)$

SOLVE AUTO 200 YEARS,STEPS=1.e-1 FAC=1.1 MAX 20.0 1.e-15 3.0 85000 CONVergence for P LOCAI eps $=1.0 \mathrm{e}-5$ ITERations $=12$

SOLVE AUTO 300 YEARS,STEPS=1.e-1 FAC=1.1 MAX 20.0 1.e-153.0 85000

SAVE U, V, C, C2, C3, C4, H, S, MOIS on 'basel-1d.arc' NOW

OUTPUT U, V, C, H, S, MOIS NOW

Degrade the concrete here after 500 years

CONVergence for P LOCAL eps $=5.0 \mathrm{e}-5$ TTERations $=12$

HYDRaulic properties: $S S=1 . e-5(\mathrm{Kx}, \mathrm{Ky}, \mathrm{Kz})=3 * 417.0(\mathrm{~m} / \mathrm{yr}) \quad:$ ZONE 7

HYDRaulic properties: $S S=1 . \mathrm{e}-5(\mathrm{Kx}, \mathrm{Ky}, \mathrm{Kz})=3 * 417.0(\mathrm{~m} / \mathrm{yr}) \quad:$ ZONE 12

HYDRaulic properties: $S S=1 . e-5(\mathrm{Kx}, \mathrm{Ky}, \mathrm{Kz})=3 * 417.0(\mathrm{~m} / \mathrm{yr}) \quad$ : ZONE 13

MULTiphase: VAN MUAI $n=1,613$ alpha $=1,25 \mathrm{~s}=096040 .:$ ZONE 7

MULTiphase: VAN MUAL $n=1.613$ alpha $=1.25 \mathrm{sr}=.096040 .:$ ZONE 12

MULTiphase: VAN MUAL $n=1.613$ alpha $=1.25 \mathrm{sr}=.096040 .:$ ZONE 13

MULTiphase: VAN MUAL $\mathrm{n}=1.613$ alpha $=1.25 \mathrm{~s}=.896040 .:$ ZONE 7

MULTiphase: VAN MUAL $\mathrm{n}=1.613$ alpha $=1.25 \mathrm{~s} r=.89604 \quad 0$. : ZONE 12

MULTiphase: VAN MUAL $\mathrm{n}=1.613$ alpha=1.25 $\mathrm{sr}=.89604 \quad 0 .:$ ZONE 13

INITIAL $\mathrm{H}=-.001$ IN ZONE 7 !!! Top horizontal concrete

INITIAL $\mathrm{H}=-.001$ IN ZONE 12 !!! Bottom horizontal concrete

INITIAL $\mathrm{H}=-.001$ IN ZONE 13 !!! Vertical concrete

SOLVE AUTO 500.0 YEARS,STEPS=1.e-1 FAC=1.1 MAX 20.0 1.e-153.0 85000

SAVE U, V, C, C2, C3, C4, H, S, MOIS NOW

OUTPUT U, V, C, H, S, MOIS NOW

/ Increase the recharge rate from $0.05 \mathrm{~cm} / \mathrm{yr}$ to $.3 \mathrm{~cm} / \mathrm{yr}$ at $1000 \mathrm{yrs}$

CONVergence for P LOCAL eps $=5.0 \mathrm{e}-5$ ITERations $=12$

BOUN $P$ west index $=-1$ GRAD $=0$

BOUN $P$ east index $=1$ GRAD $=0.0$

BOUN $P$ bottom index $=-2$ VALUe $=-0.25$ water table

BOUN P top index $=2 \mathrm{FLUX}=-3.0 \mathrm{E}-3 \mathrm{~m} / \mathrm{year}$

$I$

SOLVE AUTO 3000 YEARS,STEPS=1.e-8 FAC=1.1 MAX 10.01. e- 153.085000

SAVE U, V, C, C2, C3, C4, H, S, MOIS NOW

OUTPUT $U, V, C, H, S$, MOIS NOW

1

DISABLE FLOW

I

SOLVE AUTO 6000 YEARS,STEPS=3.e-1 FAC=1.1 MAX 4.0 1.e-153.0 85000

OUTPUT U, V, C, H, S, MOIS NOW

SAVE U, V, C, C2, C3, C4, H, S, MOIS NOW 


\section{DOE/RL-97-69}

Rev. 0

SOLVE AUTO 90000 YEARS,STEPS=4.e-0 FAC=1.1 MAX $8.0 \quad 1 . e-143.085000$

END

QUIT 
DOE/RL-97-69

Rev. 0

\section{D.6.2 Unit Cell Model - PORFLOW}

TITLe Performance Based on a Single Canister: Concept 1 Base Case

1

I Units: length in meters (m)

I mass in kilograms $(\mathrm{kg})$

$f$ time in years $(\mathrm{yr})$

1

GRID $10 \times 44$

I

COORdinates in $\mathrm{X}$ direction: -0.050 .050 .150 .30 .50 .70 .850 .951 .0251 .075$

1

COORdinates in $Y$ direction: $-1.0 \quad 1.0 \quad 3.0 \quad 6.0 \quad 10.0 \quad 15.0 \quad 21.0 \quad 26.0$

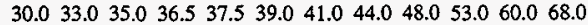

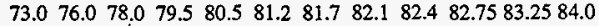

$85.0 \quad 86.0 \quad 87.0 \quad 88.0 \quad 88.7589 .5 \quad 90.0 \quad 90.490 .991 .491 .8592 .15$

1

ZONE 1 from $(1,1)$ to $(10,2) \$$ Ringold $E$

ZONE 2 from $(1,3)$ to $(10,12) \$$ Lower Hanford Gravels (Sandy gravel)

ZONE 3 from $(1,13)$ to $(10,28) \$$ Upper Hanford Sands

ZONE 4 from $(1,29)$ to $(10,30) \$$ Concrete Vault Floor (Degraded at $t=0)$

ZONE 5 from $(1,31)$ to $(10,44) \$$ Vault Interior (Backfill)

ZONE 6 from $(1,31)$ to $(7,39) \$$ Canister Stack (Waste Form)

ZONE 7 from $(2,43)$ to $(9,43) \$$ Artificial diffusion barrier

1

MULTiphase: VAN MUAL $n=1.5865, a=1.22 / \mathrm{m}, \mathrm{S} r=0.164,0$ Zone 1

MULTiphase: VAN MUAL $n=1.530, a=1.25 / \mathrm{m}, \mathrm{S} r=0.096,0$ Zone 242

MULTiphase: VAN MUAL $n=2.1768, a=15.66 / \mathrm{m}, \mathrm{S} r=0.069,0$ Zone 3

MULTiphase: VAN MUAL $n=2.080, a=6.83 / \mathrm{m}, S \mathrm{r}=0.121,0$ Zone 572

MULTiphase: VAN MUAL $\mathrm{n}=2.661, \mathrm{a}=353.66 \mathrm{Sr}=0.027,0$ Zone 6

I

MULTiphase: MINImum kr = 1e-20

1

HYDRaulic Ss $0.1 \mathrm{~K} 3 * 27.58 \mathrm{~m} / \mathrm{yr}$ for Zone 1

HYDRaulic Ss 0.1 K $3 * 416.56$ for Zone 242

HYDRaulic Ss 0.1 K 3*3592.24 for Zone 3

HYDRaulic Ss 0.1 K 3*9467.28 for Zone 572

HYDRaulic Ss 0.1 K 3*\$83815.6 for Zone 6

I

SOIL Rho 2720 Por $0.1122 * 0.1342$ for Zone 1

SOIL Rho 2720 Por $0.1192 * 0.1312$ for Zone 242

SOIL Rho 2720 Por $0.3332 * 0.3578$ for Zone 3

SOIL Rho 2720 Por $0.3262 * 0.371$ for Zone 572

SOIL Rho 2620 Por $0.5042 * 0.518$ for Zone 6

I

DATUm 00

GRAVity $0-1$

1

READ 22

TIME $=0$

1

BOUN P-1 GRAD =0 \$ Symmetry: center of canister

BOUN $P+1$ GRAD $=0 \quad \$$ Symmetry: center of intercanister filler

BOUN P -2 VALUe $=-1.0 \mathrm{~m} \$$ Water Table

BOUN P +2 FLUX $=-0.0005 \mathrm{~m} / \mathrm{yr} \$$ Assumed recharge of $0.5 \mathrm{~mm} / \mathrm{yr}$

1

PROPerties for P: GEOMetric mean at cell interfaces 
DOE/RL-97-69

Rev. 0

MATRix sweeps in $X$ and $Y$ directions: $P=2$ iterations of $A D I$

METHod for nonlinearity of $P$ is PICArd

CONVergence of $\mathrm{P}$ : LOCAL mode with epsilon $=0.0005$ and maxiter $=30$

1

/ Transport Properties: $\mathrm{C}=\mathrm{Kd}=0$

/ $\quad \mathrm{C}_{2}=\mathrm{Kd}=0.1 \mathrm{ml} / \mathrm{gr}$

$f \quad \mathrm{C} 3=\mathrm{Kd}=0.6 \mathrm{ml} / \mathrm{gr}$

f $\mathrm{C} 4=\mathrm{Kd}=3 \mathrm{ml} / \mathrm{gr}$

TRAN C $\mathrm{Kd}=0 \quad \mathrm{Dm}=7.889 \mathrm{e}-4 \mathrm{aL}=8.225 \mathrm{aT}=0.8225$ for Zone 151

TRAN C $\mathrm{Kd}=0 \quad \mathrm{Dm}=7.889 \mathrm{e}-4$ aL $=8.225 \mathrm{aT}=0.8225$ for Zone 6

TRAN C2 $\mathrm{Kd}=0.0001 \mathrm{Dm}=7.889 \mathrm{e}-4$ aL $=8.225 \mathrm{aT}=0.8225$ for Zone 151

TRAN C2 Kd=0 Dm=7.889e-4 aL=8.225 aT=0.8225 for Zone 6

TRAN C3 Kd=0.0006 Dm=7.889e-4 al=8.225 aT=0.8225 for Zone 151

TRAN C3 $\mathrm{Kd}=0 \quad \mathrm{Dm}=7.889 \mathrm{e}-4$ aL $=8.225$ aT $=0.8225$ for Zone 6

TRAN C4 $\mathrm{Kd}=0.003 \mathrm{Dm}=7.889 \mathrm{e}-4$ al $=8.225 \mathrm{aT}=0.8225$ for Zone 151

TRAN C $4 \mathrm{Kd}=0 \quad \mathrm{Dm}=7.889 \mathrm{e}-4 \mathrm{aL}=8.225 \mathrm{aT}=0.8225$ for Zone 6

I

/ Artificial diffusion barrier - next to top row of nodes

1

TRAN C 4*07

TRAN C2 $4 * 07$

TRAN C3 $4 * 07$

TRAN C4 4*0 7

I

INITial $\mathrm{C}=0$ everywhere

INITial $\mathrm{C} 2=0$ everywhere

INITial C3 $=0$ everywhere

INITial $\mathrm{C} 4=0$ everywhere

I

BOUN C west index $=-1 \mathrm{GRAD}=0.0$

BOUNC east index $=1$ GRAD $=0.0$

BOUN $C$ bottom index $=-2$ GRAD $=0.0$

BOUNC top index $=2$ VALUe $=0.0$

I

BOUN C2 west index $=-1$ GRAD $=0.0$

BOUN C2 east index $=1$ GRAD $=0.0$

BOUN C2 bottom index $=-2$ GRAD $=0.0$

BOUN C2 top index $=2$ VALUe $=0.0$

I

BOUN C3 west index $=-1 \quad \mathrm{GRAD}=0.0$

BOUN C3 east index $=1$ GRAD $=0.0$

BOUN $C 3$ bottom index $=-2$ GRAD $=0.0$

BOUNC3 top index $=2 \mathrm{VALUe}=0.0$

I

BOUN C4 west index $=-1$ GRAD $=0.0$

BOUN C4 east index $=1$ GRAD $=0.0$

BOUN $C 4$ bottom index $=-2$ GRAD $=0.0$

BOUN C4 top index $=2$ VALUe $=0.0$

I

PROPERTIES FOR C BY HARMOnic MEAN

PROPERTIES FOR C2 BY HARMonic MEAN

PROPERTIES FOR C3 BY HARMonic MEAN

PROPERTIES FOR C4 BY HARMONIC MEAN

1

LOCATE SOURCE 1 at $(2,31)$ to $(7,39)$

LOCATE SOURCE 2 at $(2,31)$ to $(7,39)$ 
LOCATE SOURCE 3 at $(2,31)$ to $(7,39)$

LOCATE SOURCE 4 at $(2,31)$ to $(7,39)$

1

$/$ Constant initial maximum volumetric fractional release rate:

1

SOURce number 1 for $\mathrm{C}$ is VOLUmetric with 2 pairs of the form $(\mathrm{t}, \mathrm{f})$;

$(0.0,6.82 \mathrm{e}-7),(226343.5,6.82 \mathrm{e}-7)$

I

SOUR 2 C2 VOLU $2(0.0,6.82 \mathrm{e}-7)(226343.5,6.82 \mathrm{e}-7)$

SOUR 3 C3 VOLU $2(0.0,6.82 \mathrm{e}-7)(226343.5,6.82 \mathrm{e}-7)$

SOUR 4 C4 VOLU $2(0.0,6.82 \mathrm{e}-7)(226343.5,6.82 \mathrm{e}-7)$

I

MATRIX for $\mathrm{C}=2$ using $\mathrm{ADI}$

MATRIX for $\mathrm{C} 2=2$ using $A D I$

MATRIX for $\mathrm{C} 3=1$ using $\mathrm{ADI}$

MATRIX for $\mathrm{C} 4=1$ using $\mathrm{ADI}$

I

FLUX of $P$ from $(2,43)$ to $(9,43)$ every 200 steps

FLUX of $P$ from $(2,28)$ to $(9,28)$ every 200 steps

FLUX of $P$ from $(2,2)$ to $(9,2)$ every 200 steps

1

FLUX of $\mathrm{C}$ from $(2,28)$ to $(9,28)$ every 100 steps

FLUX of C2 from $(2,28)$ to $(9,28)$ every 100 steps

FLUX of C3 from $(2,28)$ to $(9,28)$ every 100 steps

FLUX of C4 from $(2,28)$ to $(9,28)$ every 100 steps

1

FLUX OFC FROM (2.2) TO (9,2) EVERY 100 STEPS

FLUX OF C2 FROM $(2,2)$ TO $(9,2)$ EVERY 100 STEPS

FLUX OF C 3 FROM $(2,2)$ TO $(9,2)$ EVERY 100 STEPS

FLUX OF C4 FROM $(2,2)$ TO $(9,2)$ EVERY 100 STEPS

$f$

DIAGnostic node at $(5,33)$ every 50 steps $\$$ History node in the waste form

WINDOW from $(1,1)$ to $(10,44)$

SAVE U,V,H,P,S,MOIS, C,C2,C3,C4 NOW \$ I.C.

1

SOLVE AUTO 100 YEARS,STEPS=1.e-5 FAC=1.02 MAX 0.01 1.e-9 3.05000000

SAVE U,V,H,P.S,MOIS, C,C2,C3,C4,NOW

I

SOLVE AUTO 100 YEARS IN STEPS OF 1.e-4 FAC 1.02 MAX 0.05 1.e-8 3.0

SAVE U,V,H,P,S,MOIS, C,C2,C3,C4 NOW

I

SOLVE AUTO 300 YEARS IN STEPS OF 1.e-3 FAC 1.02 MAX 0.1 1.e-7 3.0

SAVE NOW \$ At 500 years

I

SOLVE AUTO 500 YEARS IN STEPS OF 1.e-6 FAC 1.02 MAX 0.1 $1 . e-123.0$

SAVE NOW $\$$ At 1000 years

1

/ Step Change in Recharge Rate from $0.5 \mathrm{~mm} / \mathrm{yr}$ to $3 \mathrm{~mm} / \mathrm{yr}$

I

BOUN P $+2 \mathrm{FLUX}=-0.003 \mathrm{~m} / \mathrm{yr}$

I

SOLVE AUTO S00 YEARS IN STEPS OF 1.e-6 FAC 1.01 MAX 0.1 1.e-15 3.0

SAVE NOW

SOLVE AUTO 500 YEARS IN STEPS OF 1.e-4 FAC 1.02 MAX $0.2 \quad 1 . e-15 \quad 3.0$

SAVE NOW

I

SOLVE AUTO 500 YEARS IN STEPS OF 1.e-3 FAC 1.02 MAX 0.4 1.e-15 3.0 
DOE/RL-97-69

Rev. 0

SAVE NOW

SOLVE AUTO 500 YEARS IN STEPS OF 0.002 FAC 1.02 MAX $0.5 \quad 1 . e-15 \quad 3.0$ SAVE NOW

SOLVE AUTO 1000 YEARS IN STEPS OF 0.005 FAC 1.02 MAX 0.8 $1 . e-153.0$ SAVE NOW

SOLVE AUTO 1000 YEARS IN STEPS OF 0.01 FAC 1.02 MAX 1.0 1.e-15 3.0 SAVE NOW

I

SOLVE AUTO 2000 YEARS IN STEPS OF 0.02 FAC 1.02 MAX 1.0

SAVE NOW

SOLVE AUTO 3000 YEARS IN STEPS OF $0.05 \quad 1.02 \quad 1.0$

SAVE NOW

I

SOLVE AUTO 5000 YEARS IN STEPS OF 0.1 FAC 1.02 MAX 2.0

SAVE NOW

SOLVE AUTO 5000 YEARS IN STEPS OF $0.2 \quad 1.022 .0$

SAVE NOW

SOLVE AUTO 5000 YEARS IN STEPS OF 0.4 fac $1.02 \max 2$.

SAVE NOW

SOLVE AUTO 5000 YEARS IN STEPS OF 0.51 .024$.

SAVE NOW

SOLVE AUTO 70000 YEARS IN SIEPS OF 0.5 fac $1.01 \max 5$.

I

END

QUIT 
DOE/RL-97-69

Rev. 0

\section{D.6.3 Pump Model - VAM3D-CG}

Because of the size of the input file, the file is not listed.

\section{D.6.4 Site Groundwater Model}

Because of the size of the input file, the file is not listed.

\section{D.6.5 INTEG}

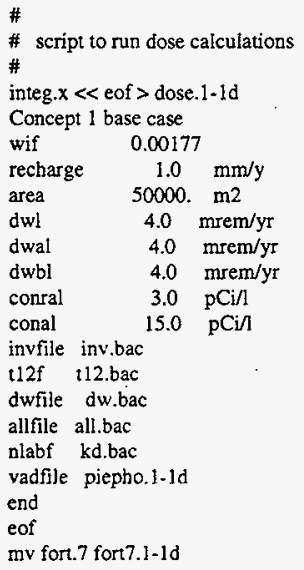


DOE/RL-97-69

Rev. 0

$D-34$ 
DOE/RL-97-69

Rev. 0

\section{APPENDIX E DETAILED RESULTS}

\section{E.1 OVERVIEW}

This appendix presents more information concerning the results of the simulations. The four sections cover vadose zone simulations, unconfined aquifer simulations, the calculation of dose, and simulations of glass dissolution.

Because of the long-time of release from the waste form, the time-dependence of the vadose zone transport, and the impacts of the disposal action looks more like a step function than a peak function. The following section provides a mathematical justification for this shape.

For a point source in an infinite one-dimensional homogeneous media, the concentration of contaminants $\mathrm{C}$ can be expressed as

$$
C(z, t)=\int_{0}^{t} f(T) G(z, t-T) d T
$$

where $t$

is the time (s) since release

$z$

$f(T)$

$G(z, t-T)$

is the distance $(\mathrm{cm})$ from release

is the source term of contaminants

is the Green's function for transport

$$
G(z, t)=\left(\frac{1}{4 \pi D_{2} t}\right)^{\frac{1}{2}} \exp (-\lambda t) \exp \left[-\frac{(z-u t)^{2}}{4 D_{z} t}\right]
$$

where $D_{2}$ is the retardation-corrected pseudodispersion coefficient $\left(\mathrm{cm}^{2} / \mathrm{s}\right)$

$\lambda$ is the decay constant $\left(\mathrm{s}^{-1}\right)$ of the contaminant

u is the retardation-corrected pore velocity $(\mathrm{cm} / \mathrm{s})$.

Both $\mathrm{D}_{\mathbf{z}}$ and $\mathrm{u}$ depend on the moisture content.

For the unretarded contaminants (in our case, technetium and selenium), the release rate for the base analysis case is almost constant, changing less than 1 percent in 20,000 years. Thus, the slowly varying release function $f(T)$ can be removed from the integrand, leaving just the integral over the Green's function. This integral results in a step function with the first wave of contaminants followed by hundred of thousands of years of succeeding contaminants.

For the more typical case where the release from the waste form is quick relative to the travel through the vadose zone, the Green's function can be removed from the integrand, resulting in a integral that is just the inventory. The time dependence is a skewed bell-shaped curve. 


\section{E.2 VADOSE ZONE SIMULATIONS}

\section{E.2.1 Overview}

This appendix provides more details concerning the computer simulations that were run to determine the contaminant flux to the underground aquifer. The next section briefly discusses the calculation for very long times. The last section summarizes the fluxes for all the computer simulations (Table E-1) and provides figures displaying the contaminant fluxes.

\section{E.2.2 Extension of Calculation to Long Times}

To determine the peak impact, calculations of the vadose zone flux must be made for millions of years. However, computer simulations for such long times would not justify their cost. Therefore, a simpler approach was used.

As has been shown in previous calculations for Hanford Site conditions, the normalized flux to the aquifer can be approximately calculated based on the $\mathrm{K}_{\mathrm{d}}=0$ group. By assuming that the release rate continues indefinitely and the waste form release controls the temporal shape, the normalized flux to the aquifer can be approximated by

$$
\Gamma\left(\mathrm{K}_{\mathrm{d}}, \mathrm{t} \cdot\left[1+\alpha \mathrm{K}_{\mathrm{d}}\right]\right)=\Gamma\left(\mathrm{K}_{\mathrm{d}}=0, \mathrm{t}\right) .
$$

By comparing the time of occurrence for $\Gamma=10^{-6}$ per year for $K_{\widetilde{\sigma}}=0$ and $K_{d}=3 \mathrm{mg} / \mathrm{l}, \alpha$ is found to be $6.6 \mathrm{l} / \mathrm{mg}$. Figure $\mathrm{E}-1$ compares the $\mathrm{K}_{\mathrm{d}}=3 \mathrm{mg} / \mathrm{l}$ group as found by computer simulations and as predicted using the above simple formula [equation (E.3)].

\section{E.2.3 Values}

The results of all the vadose zone simulations are displayed in Table E-1 (where cases beginning with 1 were performed with the Concept 1 Full Facility Model, cases beginning with 2 were performed with the Concept 2 Full Facility Model, and cases beginning with 3 were performed with the Unit Cell Model.). The results for each simulation are ordered by the value of the $\mathrm{K}_{\mathrm{d}}$ parameter. Because for most of the simulations, the peak value occurs after the simulations end at 100,000 years, values in the table for half height and for $1 \mathrm{ppm}$ height are given both for the actual peak value and for the peak value in the first 100,000 years.

No figures are given in this section, because the curve shapes are so similar. Please see the figures in Sections 4.3 through Section 4.6 of the main document. The results are explained more thoroughly in Kline (1996) and Piepho (1996). 


\section{DOE/RL-97-69}

Rev. 0

Figure E-1. Comparison of $\mathrm{K}_{\mathrm{d}}=3 \mathrm{mg} / \mathrm{l}$ Using Computer Simulations and An Approximation.

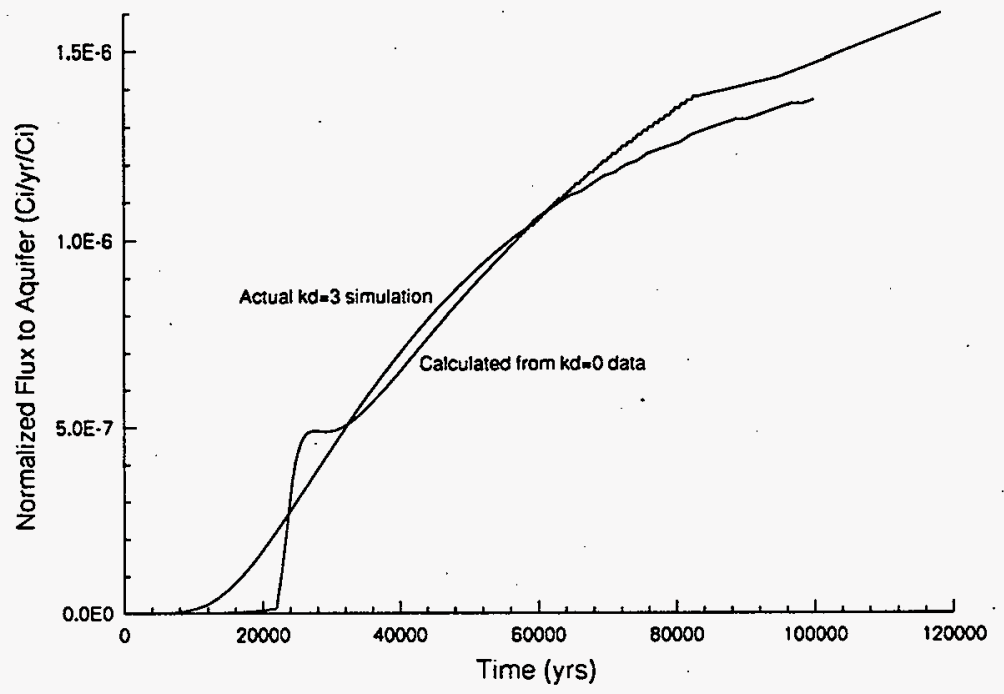


DOE/RL-97-69

Rev. 0

Table E-1. Summary of Vadose Zone Simulations for the Normalized Contaminant Flux Reaching the Unconfined Aquifer.

Case numbers reflect archival filenames.

(Values with * Assume Peak Value is $4 \times 10^{-6} \mathrm{y}^{-1}$ )

(Values with \#, Calculated only to 40,000 Years)

(Values in Parentheses Reflect Peak Values in First 100k Years)

\begin{tabular}{|c|c|c|c|c|c|c|}
\hline Case & Subcase. & $\begin{array}{c}\text { Value at } \\
10,000 \text { Years }\end{array}$ & $\begin{array}{l}\text { Peak Value in } \\
100,000 \text { Years }\end{array}$ & $\begin{array}{c}\text { Time of Peak } \\
\text { Value }\end{array}$ & $\begin{array}{c}\text { Time of } \\
0.5 * \text { Peak }\end{array}$ & $\begin{array}{c}\text { Time of } \\
10^{-6 * \text { Peak }}\end{array}$ \\
\hline \multirow{8}{*}{$\begin{array}{l}1-1 d \text {, } \\
\text { Base Analysis } \\
\text { Case }\end{array}$} & $K_{d}=0$ & 2.04 e- 6 & 3.53 e- 6 & $100,000^{*}$ & $\begin{array}{r}12,000^{*} \\
(6,900) \\
\end{array}$ & $\begin{array}{r}450^{*} \\
(400) \\
\end{array}$ \\
\hline & $\mathrm{K}_{\mathrm{d}}=0.1 \mathrm{mg} / \ell$ & $1.71 e-6$ & 2.84 e- 6 & $100,000^{*}$ & $\begin{array}{r}12,000^{*} \\
(7,000) \\
\end{array}$ & $\begin{array}{r}650 * \\
(620) \\
\end{array}$ \\
\hline & $K_{d}=0.6 \mathrm{mg} / \ell$ & 0.724 e- 6 & 2.02 e- 6 & $100,000^{*}$ & $\begin{array}{r}>100,000 \\
(15,000) \\
\end{array}$ & $\begin{array}{r}1,300^{*} \\
(1,250) \\
\end{array}$ \\
\hline & $K_{d}=3.0 \mathrm{mg} / \ell$ & $0.0013 e-6$ & 1.37 e-6 & $100,000^{*}$ & $\begin{array}{r}>100,000 \\
(23,000) \\
\end{array}$ & $\begin{array}{r}3,400 * \\
(3,100) \\
\end{array}$ \\
\hline & $K_{d}=15 . \mathrm{mg} / \ell$ & 9.3 e- 15 & $0.202 \mathrm{e}-6$ & $100,000^{*}$ & $\begin{array}{r}>100,000 \\
(79,000) \\
\end{array}$ & $\begin{array}{l}17,000^{*} \\
(13,500)\end{array}$ \\
\hline & $\mathrm{K}_{\mathrm{d}}=40 . \mathrm{mg} / \ell$ & 2.4 e-23 & 0.004 e- 6 & $100,000^{*}$ & $\begin{array}{r}>100,000 \\
(91,000) \\
\end{array}$ & $\begin{array}{l}44,000^{*} \\
(25,000) \\
\end{array}$ \\
\hline & $\mathrm{K}_{\mathrm{d}}=100 . \mathrm{mg} / \mathrm{l}$ & 0.0 & $2.1 \mathrm{e}-12$ & $100,000 *$ & $\begin{array}{r}>100,000 \\
(94,000) \\
\end{array}$ & $\begin{array}{r}>100,000 \\
(25,000) \\
\end{array}$ \\
\hline & $\begin{array}{l}K_{d}=0 \text {, factor of } 5 \\
\text { reduced release rate }\end{array}$ & $0.526 \mathrm{e}-6$ & $0.802 \mathrm{e}-6$ & $40,000 \#$ & $\begin{array}{l}8,500^{*} \\
(5,500)\end{array}$ & $\begin{array}{l}450 * \\
(400)\end{array}$ \\
\hline
\end{tabular}




\section{DOE/RL-97-69}

Rev. 0

Table E-1. Summary of Vadose Zone Simulations for the Normalized Contaminant Flux Reaching the Unconfined Aquifer.

Case numbers reflect archival filenames.

(Values with * Assume Peak Value is $4 \times 10^{-6} \mathrm{y}^{-1}$ )

(Values with \#, Calculated only to 40,000 Years)

(Values in Parentheses Reflect Peak Values in First 100k Years)

\begin{tabular}{|c|c|c|c|c|c|c|}
\hline Case & Subcase & $\begin{array}{c}\text { Value at } \\
10,000 \text { Years }\end{array}$ & $\begin{array}{l}\text { Peak Value in } \\
100,000 \text { Years }\end{array}$ & $\begin{array}{c}\text { Time of Peak } \\
\text { Value }\end{array}$ & $\begin{array}{c}\text { Time of } \\
0.5^{*} \text { Peak }\end{array}$ & $\begin{array}{c}\text { Time of } \\
10^{-6 * \text { Peak }} \\
\end{array}$ \\
\hline \multirow{8}{*}{$\begin{array}{l}2-1 d, \\
\text { Concept } 2\end{array}$} & $K_{d}=0$ & 4.22 e- 6 & 4.25 e- 6 & 13,000 & 3,600 & 500 \\
\hline & $\mathrm{K}_{\mathrm{d}}=0.1 \mathrm{mg} / \ell$ & $3.69 \mathrm{e}-6$ & 4.19 e- 6 & 21,000 & 6,600 & 900 \\
\hline & $\mathrm{K}_{\mathrm{d}}=0.6 \mathrm{mg} / \ell$ & $0.534 \mathrm{e}-6$ & 3.10 e- 6 & $100,000 *$ & $\begin{array}{c}22,000^{*} \\
(17,000) \\
\end{array}$ & $\begin{array}{r}2,000^{*} \\
(1,900) \\
\end{array}$ \\
\hline & $\mathrm{K}_{\mathrm{d}}=3.0 \mathrm{mg} / \mathrm{l}$ & $4.6 \mathrm{e}-11$ & 2.80 e- 6 & $100,000^{*}$ & $\begin{array}{r}>100,000 \\
(86,000)\end{array}$ & $\begin{array}{r}8,000 \\
(8,000) \\
\end{array}$ \\
\hline & $\mathrm{K}_{\mathrm{d}}=15 . \mathrm{mg} / \mathrm{l}$ & $5.6 \mathrm{e}-22$ & $2.1 \mathrm{e}-8$ & $100,000^{*}$ & $\begin{array}{r}>100,000 \\
(89,000) \\
\end{array}$ & $\begin{array}{r}38,000 \\
(27,000) \\
\end{array}$ \\
\hline & $\mathrm{K}_{\mathrm{d}}=40 . \mathrm{mg} / \mathrm{l}$ & $6.9 \mathrm{e}-23$ & $3.2 \mathrm{e}-12$ & $100,000^{*}$ & $\begin{array}{r}>100,000 \\
(95,000) \\
\end{array}$ & $\begin{array}{r}>100,000 \\
(46,000) \\
\end{array}$ \\
\hline & $\mathrm{K}_{\mathrm{d}}=100 . \mathrm{mg} / \mathrm{l}$ & $2.6 \mathrm{e}-24$ & 9.6 e-20 & $100,000^{*}$ & $\begin{array}{r}>100,000 \\
\quad(97,000) \\
\end{array}$ & $\begin{array}{r}>100,000 \\
(17,000) \\
\end{array}$ \\
\hline & $\begin{array}{l}\mathrm{K}_{\mathrm{d}}=0 \text {, reduced } \\
\text { release rate }\end{array}$ & 0.855 e- 6 & 0.871 e- 6 & 17,000 & 3,600 & 500 \\
\hline
\end{tabular}




\section{DOE/RL-97-69}

Rev, 0

Table E-1. Summary of Vadose Zone Simulations for the Normalized Contaminant Flux Reaching the Unconfined Aquifer.

Case numbers reflect archival filenames.

(Values with * Assume Peak Value is $4 \times 10^{-6} \mathrm{y}^{-6}$ )

(Values with \#, Calculated only to 40,000 Years)

(Values in Parentheses Reflect Peak Values in First 100k Years)

\begin{tabular}{|c|c|c|c|c|c|c|}
\hline Case & Subcase & $\begin{array}{c}\text { Value at } \\
10,000 \text { Years }\end{array}$ & $\begin{array}{l}\text { Peak Value in } \\
100,000 \text { Years }\end{array}$ & $\begin{array}{c}\text { Time of Peak } \\
\text { Value }\end{array}$ & $\begin{array}{c}\text { Time of } \\
0.5 * \text { Peak }\end{array}$ & $\begin{array}{l}\text { Time of } \\
10^{-6 *} \text { Peak }\end{array}$ \\
\hline \multirow{8}{*}{$\begin{array}{l}\text { 1-1de, } \\
K_{d}=0 \text { extend } \\
\text { to other } K_{d} \text { 's }\end{array}$} & $\mathrm{K}_{d}=0$. & $2.02 \mathrm{e}-6$ & $3.52 \mathrm{e}-6$ & 100,000 & 6,900 & 450 \\
\hline & $\mathrm{K}_{\mathrm{d}}=0.1 \mathrm{mg} / \mathrm{\ell}$ & $1.65 \mathrm{e}-6$ & $2.52 \mathrm{e}-6$ & 166,000 & 11,400 & 700 \\
\hline & $K_{d}=0.6 \mathrm{mg} / \ell$ & 0.693 e- 6 & 3.52 e- 6 & 496,000 & 34,000 & 2,080 \\
\hline & $\mathrm{K}_{\mathrm{d}}=3 . \mathrm{mg} / \mathrm{l}$ & $1.4 \mathrm{e}-11$ & 3.52 e- 6 & $2,080,000$ & 143,000 & $8 ; 700$ \\
\hline & $\mathrm{K}_{\mathrm{d}}=6 . \mathrm{mg} / \mathrm{l}$ & $1.6 \mathrm{e}-14$ & 3.52 e- 6 & $4,060,000$ & 279,000 & 17,000 \\
\hline & $\mathrm{K}_{\mathrm{d}}=15 . \mathrm{mg} / \mathrm{l}$ & $1.7 \mathrm{e}-16$ & 3.52 e- 6 & $10,000,000$ & 688,000 & 42,000 \\
\hline & $K_{d}=40 . \mathrm{mg} / \mathrm{l}$ & 0.0 & $3.52 \mathrm{e}-6$ & $26,500,000$ & $1,820,000$ & 110,000 \\
\hline & $K_{d}=100 . \mathrm{mg} / \mathrm{l}$ & 0.0 & 3.52 e- 6 & $66,000,000$ & $4,550,000$ & 275,000 \\
\hline \multirow{4}{*}{$\begin{array}{l}1-1 n \text {, } \\
\text { smaller diff. } \\
\text { coef. }\end{array}$} & $\mathrm{K}_{\mathrm{d}}=0$ & $0.200 e-6$ & 2.44 e- 6 & $100,000 *$ & $\begin{array}{r}93,000^{*} \\
(63,000) \\
\end{array}$ & $\begin{array}{l}560^{*} \\
(550) \\
\end{array}$ \\
\hline & $\mathrm{K}_{\mathrm{d}}=0.1 \mathrm{mg} / \mathrm{l}$ & $0.025 e-6$ & $1.01 \mathrm{e}-6$ & $100,000^{*}$ & $\begin{array}{r}>100,000^{*} \\
(55,000) \\
\end{array}$ & $\begin{array}{r}940^{*} \\
(900) \\
\end{array}$ \\
\hline & $\mathrm{K}_{\mathrm{d}}=0.6 \mathrm{mg} / \mathrm{l}$ & $0.0015 e-6$ & $0.281 \mathrm{e}-6$ & $100,000^{*}$ & $\begin{array}{r}>100,000^{*} \\
(65,000)\end{array}$ & $\begin{array}{r}1350 * \\
(1250) \\
\end{array}$ \\
\hline & $\begin{array}{l}\mathrm{K}_{\mathrm{d}}=0 ., \text { reduced } \\
\text { release rate }\end{array}$ & 0.018 e- 6 & $0.177 \mathrm{e}-6$ & $40,000 \#$ & $\begin{array}{l}>40,000^{*} \\
(>40,000)\end{array}$ & $\begin{array}{l}560^{*} \\
(500)\end{array}$ \\
\hline
\end{tabular}




\section{DOE/RL-97-69}

Rev. 0

Table E-1. Summary of Vadose Zone Simulations for the Normalized Contaminant Flux Reaching the Unconfined Aquifer.

Case numbers reflect archival filenames.

(Values with * Assume Peak Value is $4 \times 10^{-6} \mathrm{y}^{-1}$ )

(Values with \#, Calculated only to 40,000 Years)

(Values in Parentheses Reflect Peak Values in First 100k Years)

\begin{tabular}{|c|c|c|c|c|c|c|}
\hline Case & Subcase & $\begin{array}{c}\text { Value at } \\
10,000 \text { Years }\end{array}$ & $\begin{array}{l}\text { Peak Value in } \\
100,000 \text { Years }\end{array}$ & $\begin{array}{c}\text { Time of Peak } \\
\text { Value }\end{array}$ & $\begin{array}{r}\text { Time of } \\
0.5 * \text { Peak }\end{array}$ & $\begin{array}{l}\text { Time of } \\
10^{-6 *} \text { Peak }\end{array}$ \\
\hline \multirow{4}{*}{$\begin{array}{l}1-2 d \text {, } \\
\text { Concept } 1 \text {, } \\
\text { concrete floor } \\
\text { degrades at } \\
2000 \text { years }\end{array}$} & $\mathrm{K}_{\mathrm{d}}=0$. & $2.06 e-6$ & 3.60 e- 6 & $100,000^{*}$ & $\begin{array}{r}14,700^{*} \\
(7,400) \\
\end{array}$ & $\begin{array}{l}420^{*} \\
(420)\end{array}$ \\
\hline & $\mathrm{K}_{\mathrm{d}}=0.1 \mathrm{mg} / \ell$ & 1.70 e- 6 & 2.88 e- 6 & $100,000^{*}$ & $\begin{array}{r}25,000^{*} \\
(7,500) \\
\end{array}$ & $\begin{array}{l}475^{*} \\
(470) \\
\end{array}$ \\
\hline & $\mathrm{K}_{\mathrm{d}}=0.6 \mathrm{mg} / \mathrm{l}$ & $0.715 e-6$ & $2.03 e-6$ & $100,000^{*}$ & $\begin{array}{r}>100,000^{*} \\
(15,000) \\
\end{array}$ & $\begin{array}{r}1,280^{*} \\
(1,250) \\
\end{array}$ \\
\hline & $\begin{array}{l}K_{d}=0, \text { reduced } \\
\text { release rate }\end{array}$ & $0.532 \mathrm{e}-6$ & $0.802 \mathrm{e}-6$ & $40,000 \#$ & $\begin{array}{r}7,800^{*} \\
(5,500)\end{array}$ & $\begin{array}{l}420^{*} \\
(420)\end{array}$ \\
\hline \multirow{4}{*}{$\begin{array}{l}2-1 \mathrm{n}, \\
\text { concept } 2, \\
\text { reduced } \\
\text { diffusion coef. }\end{array}$} & $K_{c}=0$. & $0.852 \mathrm{e}-6$ & 3.31 e- 6 & 81,000 & 17,500 & 650 \\
\hline & $\mathrm{K}_{\mathrm{d}}=0.1 \mathrm{mg} / \mathrm{\ell}$ & 0.310 e- 6 & 3.04 e- 6 & $100,000^{*}$ & $\begin{array}{r}39,000^{*} \\
(25,000) \\
\end{array}$ & $\begin{array}{r}1,150^{*} \\
(1,150) \\
\end{array}$ \\
\hline & $\mathrm{K}_{\mathrm{d}}=0.6 \mathrm{mg} / \ell$ & $0.0074 e-6$ & 1.74 e- 6 & $100,000^{*}$ & $\begin{array}{r}>100,000 \\
(55,000) \\
\end{array}$ & $\begin{array}{l}2,600^{*} \\
(2,600) \\
\end{array}$ \\
\hline & $\begin{array}{l}K_{d}=0, \text { reduced } \\
\text { release rate }\end{array}$ & $0.171 \mathrm{e}-6$ & 0.609 e- 6 & $40,000 \#$ & $\begin{array}{r}25,000^{*} \\
(17,000)\end{array}$ & $\begin{array}{l}650^{*} \\
(650)\end{array}$ \\
\hline
\end{tabular}


DOE/RI_-97-69

Rev. 0

Table E-1. Summary of Vadose Zone Simulations for the Normalized Contaminant Flux Reaching the Unconfined Aquifer.

Case numbers reflect archival filenames.

(Values with * Assume Peak Value is $4 \times 10^{-6} \mathrm{y}^{-1}$ )

(Values with \#, Calculated only to 40,000 Years) (Values in Parentheses Reflect Peak Values in First 100k Years)

\begin{tabular}{|c|c|c|c|c|c|c|}
\hline Case & Subcase & $\begin{array}{c}\text { Value at } \\
10,000 \text { Years }\end{array}$ & $\begin{array}{l}\text { Peak Value in } \\
100,000 \text { Years }\end{array}$ & $\begin{array}{c}\text { Time of Peak } \\
\text { Value }\end{array}$ & $\begin{array}{l}\text { Time of } \\
0.5^{*} \text { Peak }\end{array}$ & $\begin{array}{c}\text { Time of } \\
10^{-6 * \text { Peak }} \\
\end{array}$ \\
\hline \multirow{4}{*}{$\begin{array}{l}2-2 \mathrm{~d}, \\
\text { Concept } 2 \text {, } \\
\text { constant waste } \\
\text { form release } \\
\text { rate }\end{array}$} & $\mathrm{K}_{\mathrm{d}}=0$. & $4.21 \mathrm{e}-6$ & $4: 39$ e- 6 & 35,000 & 3,700 & 650 \\
\hline & $\mathrm{K}_{\mathrm{d}}=0.1 \mathrm{mg} / \mathrm{l}$ & $3.46 \mathrm{e}-6$ & $4.39 \mathrm{e}-6$ & 50,000 & 6,900 & 1,150 \\
\hline & $\mathrm{K}_{\mathrm{d}}=0.6 \mathrm{mg} / \ell$ & 0.415 e- 6 & 3.95 e- 6 & $100,000^{*}$ & $\begin{array}{l}23,000^{*} \\
(22,000) \\
\end{array}$ & 2,100 \\
\hline & $\begin{array}{l}K_{d}=0, \text { reduced } \\
\text { release rate }\end{array}$ & $0.841 \mathrm{e}-6$ & $0.878 \mathrm{e}-6$ & 35,000 & 3,700 & 650 \\
\hline \multirow{4}{*}{$\begin{array}{l}2-2 \mathrm{n}, \\
2-2 \mathrm{~d} \text { with } \\
\text { reduced } \\
\text { diffusion coef. }\end{array}$} & $K_{d}=0$ & 0.846 e- 6 & $4.08 \mathrm{e}-6$ & $100,000^{*}$ & $\begin{array}{l}25,000 * \\
(24,000) \\
\end{array}$ & $\begin{array}{r}650^{*} \\
(650) \\
\end{array}$ \\
\hline & $\mathrm{K}_{\mathrm{d}}=0.1 \mathrm{mg} / \mathrm{l}$ & 0.315 e- 6 & 3.67 e-6 & $100,000 *$ & $\begin{array}{r}40,000^{*} \\
(32,000) \\
\end{array}$ & $\begin{array}{r}1,150^{*} \\
(1,150) \\
\end{array}$ \\
\hline & $\mathrm{K}_{\mathrm{d}}=0.6 \mathrm{mg} / \mathrm{l}$ & $0.0082 e-6$ & $1.96 \mathrm{e}-6$ & $100,000^{*}$ & $\begin{array}{r}100,000^{*} \\
(58,000) \\
\end{array}$ & $\begin{array}{l}2,200^{*} \\
(2,200) \\
\end{array}$ \\
\hline & $\begin{array}{l}K_{d}=0, \text { reduced } \\
\text { release rate }\end{array}$ & 0.170 e- 6 & $0.816 \mathrm{e}-6$ & $100,000 *$ & $\begin{array}{l}25,000^{*} \\
(24,000)\end{array}$ & $\begin{array}{l}650 * \\
(650)\end{array}$ \\
\hline
\end{tabular}




\section{DOE/RL-97-69}

Rev. 0

Table E-1. Summary of Vadose Zone Simulations for the Normalized Contaminant Flux Reaching the Unconfined Aquifer.

Case numbers reflect archival filenames.

(Values with * Assume Peak Value is $4 \times 10^{-6} \mathrm{y}^{-1}$ )

(Values with \#, Calculated only to 40,000 Years)

(Values in Parentheses Reflect Peak Values in First 100k Years)

\begin{tabular}{|c|c|c|c|c|c|c|}
\hline Case & Subcase & $\begin{array}{c}\text { Value at } \\
10,000 \text { Years } \\
\end{array}$ & $\begin{array}{l}\text { Peak Value in } \\
100,000 \text { Years }\end{array}$ & $\begin{array}{c}\text { Time of Peak } \\
\text { Value } \\
\end{array}$ & $\begin{array}{r}\text { Time of } \\
0.5 * \text { Peak } \\
\end{array}$ & $\begin{array}{c}\text { Time of } \\
10^{-6 * \text { Peak }}\end{array}$ \\
\hline \multirow{4}{*}{$\begin{array}{l}2-2 \mathrm{dc}, \\
\text { Concept } 2 \\
\text { concrete } \\
\text { degrades at } \\
2000 \text { years }\end{array}$} & $K_{d}=0$ & 4.27 e- 6 & 4.30 e- 6 & 15,600 & 2,100 & 660 \\
\hline & $\mathrm{K}_{\mathrm{d}}=0.1 \mathrm{mg} / \mathrm{l}$ & $3.76 \mathrm{e}-6$ & 4.24 e- 6 & 21,600 & 5,300 & 1,150 \\
\hline & $K_{d}=0.6 \mathrm{mg} / \mathrm{l}$ & $0.606 \mathrm{e}-6$ & 3.59 e- 6 & 50,000 & 19,600 & 2,000 \\
\hline & $\begin{array}{l}K_{d}=0 \text {, reduced } \\
\text { release rate }\end{array}$ & $0.866 \mathrm{e}-6$ & $0.882 e-6$ & 17,600 & 2,100 & 660 \\
\hline \multirow{4}{*}{$\begin{array}{l}2-3 \mathrm{~d} \text {, Concept } \\
2 \text {, failed } \\
\text { hydraulic } \\
\text { barrier }\end{array}$} & $K_{d}=0$ & $4.14 \mathrm{e}-6$ & 4.19 e- 6 & 14,000 & 4,000 & 640 \\
\hline & $\mathrm{K}_{\mathrm{d}}=0.1 \mathrm{mg} / \mathrm{l}$ & $3.54 \mathrm{e}-6$ & $4.14 \mathrm{e}-6$ & 20,000 & 6,100 & 1,140 \\
\hline & $K_{d}=0.6 \mathrm{mg} / \mathrm{l}$ & $0.433 \mathrm{e}-7$ & 3.50 e- 6 & 48,000 & 18,000 & 2,140 \\
\hline & $\begin{array}{l}\mathrm{K}_{\mathrm{d}}=0 \text {, reduced } \\
\text { release rate }\end{array}$ & 0.839 e -6 & 0.859 e- 6 & 18,000 & 4,000 & 640 \\
\hline \multirow{4}{*}{$\begin{array}{l}2-4 d, \\
\text { Concept } 2 \\
\text { no side barrier }\end{array}$} & $K_{d}=0$ & 4.31 e-6 & 4.31 e- 6 & 10,000 & 1,900 & 640 \\
\hline & $\mathrm{K}_{\mathrm{d}}=0.1 \mathrm{mg} / \ell$ & $4.21 \mathrm{e}-6$ & $4.26 \mathrm{e}-6$ & 15,000 & 4,000 & 1,180 \\
\hline & $\mathrm{K}_{\mathrm{d}}=0.6 \mathrm{mg} / \mathrm{l}$ & $1.39 \mathrm{e}-6$ & 3.67 e- 6 & 35,000 & 13,000 & 2,600 \\
\hline & $\begin{array}{l}\mathrm{K}_{\mathrm{d}}=0 \text {, reduced } \\
\text { release rate }\end{array}$ & $0.876 e-6$ & 0.877 e- 6 & 13,000 & 1,900 & 640 \\
\hline
\end{tabular}




\section{DOE/RL-97-69}

Rev. 0

Table E-1. Summary of Vadose Zone Simulations for the Normalized Contaminant Flux Reaching the Unconfined Aquifer.

Case numbers reflect archival filenames.

(Values with * Assume Peak Value is $4 \times 10^{-6} \mathrm{y}^{-1}$ )

(Values with \#, Calculated only to 40,000 Years)

(Values in Parentheses Reflect Peak Values in First 100k Years)

\begin{tabular}{|c|c|c|c|c|c|c|}
\hline Case & Subcase & $\begin{array}{c}\text { Value at } \\
10,000 \text { Years }\end{array}$ & $\begin{array}{l}\text { Peak Value in } \\
100,000 \text { Years }\end{array}$ & $\begin{array}{c}\text { Time of Peak } \\
\text { Value } \\
\end{array}$ & $\begin{array}{c}\text { Time of } \\
0.5 * \text { Peak }\end{array}$ & $\begin{array}{c}\text { Time of } \\
10^{-6 *} \text { Peak } \\
\end{array}$ \\
\hline \multirow{4}{*}{$\begin{array}{l}2-5 \mathrm{~d}, \\
\text { Concept } 2,10 \\
\mathrm{~cm} / \mathrm{y} \text { recharge } \\
\text { rate }\end{array}$} & $\mathrm{K}_{\mathrm{d}}=0$ & 4.83 e- 6 & $4.84 \mathrm{e}-6$ & 9,300 & 2,000 & 15 \\
\hline & $\mathrm{K}_{\mathrm{d}}=0.1 \mathrm{mg} / \mathrm{l}$ & 4.76 e- 6 & 4.79 e- 6 & 13,000 & 2,800 & 28 \\
\hline & $\mathrm{K}_{\mathrm{d}}=0.6 \mathrm{mg} / \mathrm{l}$ & 3.19 e- 6 & 4.12 e- 6 & 29,000 & 6,000 & 135 \\
\hline & $\begin{array}{l}K_{d}=0 \text {, reduced } \\
\text { release rate }\end{array}$ & $0.985 \mathrm{e}-6$ & 0.985 e- 6 & 12,000 & 2,000 & 15 \\
\hline \multirow{4}{*}{$\begin{array}{l}2-6 \mathrm{~d}, \\
\text { Concept } 2 \text {, } \\
0.5 * \\
\text { dispersion } \\
\text { coef. }\end{array}$} & $K_{d}=0$ & $4.17 \mathrm{e}-6$ & $4.24 \mathrm{e}-6$ & 15,000 & 4,000 & 750 \\
\hline & $\mathrm{K}_{\mathrm{d}}=0.1 \mathrm{mg} / \mathrm{l}$ & $3.52 \mathrm{e}-6$ & $4.17 \mathrm{e}-6$ & 21,000 & 6,700 & 1,300 \\
\hline & $\mathrm{K}_{\mathrm{d}}=0.6 \mathrm{mg} / \mathrm{l}$ & $0.418 \mathrm{e}-6$ & $3.52 \mathrm{e}-6$ & 51,000 & 19,000 & 3,000 \\
\hline & $\begin{array}{l}\mathrm{K}_{\mathrm{d}}=0 \text {, reduced } \\
\text { release rate }\end{array}$ & $0.846 \mathrm{e}-6$ & 0.870 e- 6 & 19,000 & 4,000 & 750 \\
\hline \multirow{4}{*}{$\begin{array}{l}2-7 d \\
\text { concept } 2 \\
2 * \text { dispersion } \\
\text { coef. }\end{array}$} & $K_{d}=0$ & $4.24 \mathrm{e}-6$ & $4.26 \mathrm{e}-6$ & 13,000 & 3,600 & 600 \\
\hline & $\mathrm{K}_{\mathrm{d}}=0.1 \mathrm{mg} / \mathrm{\ell}$ & $3.79 \mathrm{e}-6$ & 4.20 e- 6 & 21,000 & 6,000 & 700 \\
\hline & $\mathrm{K}_{\mathrm{d}}=0.6 \mathrm{mg} / \mathrm{l}$ & $0.676 \mathrm{e}-6$ & 3.55 e- 6 & 50,000 & 19,000 & 1,600 \\
\hline & $\begin{array}{l}\mathrm{K}_{\mathrm{d}}=0 \text {, reduced } \\
\text { release rate }\end{array}$ & $0.860 e-6$ & $0.872 \mathrm{e}-6$ & 17,000 & 3,600 & 600 \\
\hline
\end{tabular}




\section{DOE/RL-97-69}

Rev. 0

Table E-1. Summary of Vadose Zone Simulations for the Normalized Contaminant Flux Reaching the Unconfined Aquifer.

Case numbers reflect archival filenames.

(Values with * Assume Peak Value is $4 \times 10^{-6} \mathrm{y}^{-1}$ )

(Values with \#, Calculated only to 40,000 Years)

(Values in Parentheses Reflect Peak Values in First 100k Years)

\begin{tabular}{|c|c|c|c|c|c|c|}
\hline Case & Subcase & $\begin{array}{c}\text { Value at } \\
10,000 \text { Years }\end{array}$ & $\begin{array}{l}\text { Peak Value in } \\
100,000 \text { Years }\end{array}$ & $\begin{array}{c}\text { Time of Peak } \\
\text { Value }\end{array}$ & $\begin{array}{c}\text { Time of } \\
0.5^{*} \text { Peak }\end{array}$ & $\begin{array}{c}\text { Time of } \\
10^{-6 * \text { Peak }}\end{array}$ \\
\hline \multirow{8}{*}{$\begin{array}{l}3, \\
\text { Unit Cell } \\
\text { Model Main } \\
\text { Analysis Case }\end{array}$} & $K_{d}=0$ & 4.37 e- 6 & $\begin{array}{r}6.90 \text { e- } 6 \\
(4.42 \text { e- } 6) \\
\end{array}$ & $\begin{array}{r}2,150 \\
(17,000) \\
\end{array}$ & $\begin{array}{r}1,350 \\
(1,100) \\
\end{array}$ & $\begin{array}{c}175 \\
(167) \\
\end{array}$ \\
\hline & $\mathrm{K}_{\mathrm{d}}=0.1 \mathrm{mg} / \mathrm{l}$ & 4.37 e- 6 & 4.42 e- 6 & 17,000 & 3,000 & 350 \\
\hline & $\mathrm{K}_{\mathrm{d}}=0.6 \mathrm{mg} / \mathrm{l}$ & $2.65 e-6$ & $4.42 \mathrm{e}-6$ & 39,000 & 9,100 & 1,550 \\
\hline & $\mathrm{K}_{\mathrm{d}}=3 . \mathrm{mg} / \ell$ & $2.01 \mathrm{e}-9$ & $4.35 \mathrm{e}-6$ & $100,000 *$ & $\begin{array}{r}39,000 \\
(39,000) \\
\end{array}$ & $\begin{array}{r}6,200 \\
(6,200) \\
\end{array}$ \\
\hline & $\mathrm{K}_{\mathrm{d}}=6 . \mathrm{mg} / \ell$ & $1.60 \mathrm{e}-12$ & $3.26 \mathrm{e}-6$ & $100,000^{*}$ & $\begin{array}{r}76,000 \\
(65,000) \\
\end{array}$ & $\begin{array}{c}11,000 \\
(11,000) \\
\end{array}$ \\
\hline & $\mathrm{K}_{\mathrm{d}}=15 . \mathrm{mg} / \mathrm{l}$ & $1.44 \mathrm{e}-18$ & 0.327 e- 6 & $100,000^{*}$ & $\begin{array}{r}>100,000 \\
(87,000) \\
\end{array}$ & $\begin{array}{r}>100,000 \\
(21,000) \\
\end{array}$ \\
\hline & $\mathrm{K}_{\mathrm{d}}=40 . \mathrm{mg} / \mathrm{l}$ & 0 & $2.9 \mathrm{e}-10$ & $100,000^{*}$ & $\begin{array}{r}>100,000 \\
(94,000) \\
\end{array}$ & $\begin{array}{r}>100,000 \\
(30,000) \\
\end{array}$ \\
\hline & $\mathrm{K}_{\mathrm{d}}=100 . \mathrm{mg} / \ell$ & 0 & $2.4 \mathrm{e}-15$ & $100,000^{*}$ & $\begin{array}{r}>100,000 \\
(96,000)\end{array}$ & $\begin{array}{r}>100,000 \\
(45,000) \\
\end{array}$ \\
\hline
\end{tabular}




\section{DOE/RL-97-69}

Rev. 0

Table E-1. Summary of Vadose Zone Simulations for the Normalized Contaminant Flux Reaching the Unconfined Aquifer.

Case numbers reflect archival filenames.

(Values with * Assume Peak Value is $4 \times 10^{-6} \mathrm{y}^{-1}$ )

(Values with \#, Calculated only to 40,000 Years)

(Values in Parentheses Reflect Peak Values in First 100k Years)

\begin{tabular}{|c|c|c|c|c|c|c|}
\hline Case & Subcase & $\begin{array}{c}\text { Value at } \\
10,000 \text { Years }\end{array}$ & $\begin{array}{l}\text { Peak Value in } \\
100,000 \text { Years }\end{array}$ & $\begin{array}{c}\text { Time of Peak } \\
\text { Value }\end{array}$ & $\begin{array}{c}\text { Time of } \\
0.5^{*} \text { Peak }\end{array}$ & $\begin{array}{c}\text { Time of } \\
10^{-6 * \text { Peak }} \\
\end{array}$ \\
\hline \multirow{4}{*}{$\begin{array}{l}3 \mathrm{a}, \\
\text { Unit Cell } \\
\text { Model, } 3 \mathrm{~mm} / \mathrm{y} \\
\text { recharge rate }\end{array}$} & $K_{d}=0$ & 4.42 e- 6 & 4.42 e- 6 & 4,400 & 1,100 & 170 \\
\hline & $K_{\mathrm{d}}=0.1 \mathrm{mg} / \ell$ & 4.42 e- 6 & 4.42 e- 6 & 10,000 & 2,400 & 355 \\
\hline & $K_{d}=0.6 \mathrm{mg} / \mathrm{l}$ & $2.81 \mathrm{e}-6$ & $4.42 \mathrm{e}-6$ & 40,000 & 8,600 & 1,200 \\
\hline & $\mathrm{K}_{\mathrm{d}}=3 . \mathrm{mg} / \mathrm{l}$ & 3.0 e- 9 & $4.36 \mathrm{e}-6$ & $100,000^{*}$ & $\begin{array}{c}38,000 \\
(38,000)\end{array}$ & $\begin{array}{r}5,400 \\
(5,400)\end{array}$ \\
\hline \multirow{4}{*}{$\begin{array}{l}3 \mathrm{~b} \text {, } \\
\text { Unit Cell } \\
\text { Model, } \\
1 \mathrm{~mm} / \mathrm{y} \\
\text { recharge rate }\end{array}$} & $K_{d}=0$ & $4.41 \mathrm{e}-6$ & 4.42 e- 6 & 12,000 & 3,000 & 460 \\
\hline & $\mathrm{K}_{\mathrm{d}}=0.1 \mathrm{mg} / \mathrm{l}$ & $3.75 \mathrm{e}-6$ & 4.42 e- 6 & 25,000 & 6,500 & 980 \\
\hline & $\mathrm{K}_{\mathrm{d}}=0.6 \mathrm{mg} / \mathrm{l}$ & $8.40 \mathrm{e}-8$ & 4.42 e- 6 & 100,000 & 24,000 & 3,400 \\
\hline & $\mathrm{K}_{\mathrm{d}}=3 . \mathrm{mg} / \mathrm{l}$ & $2.0 \mathrm{e}-14$ & 1.90 e- 6 & $100,000^{*}$ & $\begin{array}{r}>100,000 \\
(77,000)\end{array}$ & $\begin{array}{c}15,000 \\
(13,000)\end{array}$ \\
\hline
\end{tabular}




\section{DOE/RL-97-69}

Rev. 0

Table E-1. Summary of Vadose Zone Simulations for the Normalized Contaminant Flux Reaching the Unconfined Aquifer.

Case numbers reflect archival filenames.

(Values with * Assume Peak Value is $4 \times 10^{-6} \mathrm{y}^{-1}$ )

(Values with \#, Calculated only to 40,000 Years)

(Values in Parentheses Reflect Peak Values in First 100k Years)

\begin{tabular}{|c|c|c|c|c|c|c|}
\hline Case & Subcase & $\begin{array}{c}\text { Value at } \\
10,000 \text { Years }\end{array}$ & $\begin{array}{l}\text { Peak Value in } \\
100,000 \text { Years }\end{array}$ & $\begin{array}{c}\text { Time of Peak } \\
\text { Value }\end{array}$ & $\begin{array}{c}\text { Time of } \\
0.5^{*} \text { Peak }\end{array}$ & $\begin{array}{l}\text { Time of } \\
10^{-6 *} \text { Peak }\end{array}$ \\
\hline \multirow{4}{*}{$\begin{array}{l}3 \mathrm{~d} \text {, } \\
\text { Unit Cell } \\
\text { Model, } \\
0.1 \mathrm{~mm} / \mathrm{y} \\
\text { recharge rate }\end{array}$} & $\mathrm{K}_{d}=0$ & 5.9 e- 08 & 4.48 e- 6 & 68,000 & 24,500 & 3,600 \\
\hline & $\mathrm{K}_{\mathrm{d}}=0.1 \mathrm{mg} / \mathrm{l}$ & $7.5 \mathrm{e}-11$ & 4.00 e- 6 & $100,000^{*}$ & $\begin{array}{r}54,000 \\
(54,000) \\
\end{array}$ & $\begin{array}{r}7,800 \\
(7,800) \\
\end{array}$ \\
\hline & $\mathrm{K}_{\mathrm{d}}=0.6 \mathrm{mg} / \mathrm{l}$ & 8.8 e- 19 & $0.166 \mathrm{e}-6$ & $100,000^{*}$ & $\begin{array}{r}>100,000 \\
(88,000) \\
\end{array}$ & $\begin{array}{r}28,000 \\
(18,500) \\
\end{array}$ \\
\hline & $\mathrm{K}_{\mathrm{d}}=3 . \mathrm{mg} / \ell$ & 0. & $1.4 \mathrm{e}-13$ & $100,000^{*}$ & $\begin{array}{r}>100,000 \\
(95,000)\end{array}$ & $>100,000$ \\
\hline \multirow{4}{*}{$\begin{array}{l}3 \mathrm{e}, \\
\text { Unit Cell } \\
\text { Model, } \\
100 \mathrm{~mm} / \mathrm{y} \\
\text { recharge rate }\end{array}$} & $\mathrm{K}_{\mathrm{d}}=0$ & 4.44 e- 6 & $4.73 e-6$ & 600 & 66 & 8 \\
\hline & $\mathrm{K}_{\mathrm{d}}=0.1 \mathrm{mg} / \mathrm{l}$ & 4.44 e- 6 & 4.45 e-6 & 670 & 127 & 17 \\
\hline & $\mathrm{K}_{\mathrm{d}}=0.6 \mathrm{mg} / \mathrm{l}$ & 4.44 e- 6 & 4.44 e-6 & 2,500 & 384 & 57 \\
\hline & $\mathrm{K}_{\mathrm{d}}=3.0 \mathrm{mg} / \ell$ & 4.44 e- 6 & 4.44 e- 6 & 4,900 & 1,600 & 240 \\
\hline \multirow{4}{*}{$\begin{array}{l}\text { 3f, } \\
\text { Unit Cell } \\
\text { Model, } \\
\text { Sandy } \\
\text { sequence only }\end{array}$} & $\mathrm{K}_{\mathrm{d}}=0$ & $4.42 \mathrm{e}-6$ & $6.25 e-6$ & 2,500 & 2,250 & 170 \\
\hline & $\mathrm{K}_{\mathrm{d}}=0.1 \mathrm{mg} / \ell$ & 4.42 e- 6 & 4.49 e- 6 & 3,900 & 2,500 & 275 \\
\hline & $\mathrm{K}_{\mathrm{d}}=0.6 \mathrm{mg} / \mathrm{l}$ & 4.23 e- 6 & 4.42 e- 6 & 21,000 & 5,400 & 1,100 \\
\hline & $\mathrm{K}_{\mathrm{d}}=3 \mathrm{mg} / \mathrm{l}$ & $0.126 e-6$ & 4.42 e- 6 & 84,000 & 21,000 & 3,900 \\
\hline
\end{tabular}


DOE/RL-97-69

Rev. 0

Table E-1. Summary of Vadose Zone Simulations for the Normalized Contaminant Flux Reaching the Unconfined Aquifer.

Case numbers reflect archival filenames.

(Values with * Assume Peak Value is $4 \times 10^{-6} \mathrm{y}^{-1}$ )

(Values with \#, Calculated only to 40,000 Years)

(Values in Parentheses Reflect Peak Values in First 100k Years)

\begin{tabular}{|c|c|c|c|c|c|c|}
\hline Case & Subcase & $\begin{array}{c}\begin{array}{c}\text { Value at } \\
10,000 \text { Years }\end{array} \\
\end{array}$ & $\begin{array}{l}\text { Peak Value in } \\
100,000 \text { Years }\end{array}$ & $\begin{array}{c}\text { Time of Peak } \\
\text { Value }\end{array}$ & $\begin{array}{r}\text { Time of } \\
0.5 * \text { Peak } \\
\end{array}$ & $\begin{array}{c}\text { Time of } \\
10^{-6 *} \text { Peak }\end{array}$ \\
\hline \multirow{4}{*}{$\begin{array}{l}3 \mathrm{~g}, \\
\text { Unit Cell } \\
\text { Model, } \\
\text { filler is } \\
\text { Hanford } \\
\text { formation } \\
\text { sand }\end{array}$} & $K_{d}=0$ & 4.37 e- 6 & 7.38 e- 6 & 2,150 & $\begin{array}{r}1 ; 320 \\
(1,075) \\
\end{array}$ & 182 \\
\hline & $\mathrm{K}_{\mathrm{d}}=0.1 \mathrm{mg} / \mathrm{l}$ & 4.37 e- 6 & 4.42 e- 6 & 17,000 & 3,200 & 375 \\
\hline & $\mathrm{K}_{\mathrm{d}}=0.6 \mathrm{mg} / \mathrm{l}$ & $2.51 \mathrm{e}-6$ & 4.42 e- 6 & 40,000 & 9,400 & 1,600 \\
\hline & $K_{d}=3 . \mathrm{mg} / \mathrm{l}$ & $1.36 \mathrm{e}-9$ & 4.35 e- 6 & $100,000^{*}$ & $\begin{array}{r}40,000 \\
(40,000)\end{array}$ & $\begin{array}{r}6,500 \\
(6,500)\end{array}$ \\
\hline \multirow{4}{*}{$\begin{array}{l}3 \mathrm{~h} \text {, } \\
\text { Unit Cell } \\
\text { Model, } \\
\text { Thicker } \\
\text { Hanford } \\
\text { formation } \\
\text { gravel layer }\end{array}$} & $K_{d}=0$ & 4.20 e- 6 & 8.53 e-6 & 2,000 & $\begin{array}{c}1,300 \\
(1,000)\end{array}$ & 200 \\
\hline & $\mathrm{K}_{\mathrm{d}}=0.1 \mathrm{mg} / \ell$ & 4.20 e- 6 & 4.42 e- 6 & 22,000 & 2,750 & 396 \\
\hline & $\mathrm{K}_{\mathrm{d}}=0.6 \mathrm{mg} / \mathrm{l}$ & $1.88 \mathrm{e}-6$ & 4.42 e- 6 & 44,000 & 10,800 & 1,700 \\
\hline & $\mathrm{K}_{\mathrm{d}}=3 . \mathrm{mg} / \mathrm{l}$ & 2.71 e- 10 & 4.29 e- 6 & $100,000 *$ & $\begin{array}{r}45,000 \\
(45,000) \\
\end{array}$ & 7,500 \\
\hline
\end{tabular}




\section{DOE/RL-97-69}

Rev, 0

Table E-1. Summary of Vadose Zone Simulations for the Normalized Contaminant Flux Reaching the Unconfined Aquifer.

Case numbers reflect archival filenames.

(Values with * Assume Peak Value is $4 \times 10^{-6} \mathrm{y}^{-1}$ )

(Values with \#, Calculated only to 40,000 Years)

(Values in Parentheses Reflect Peak Values in First 100k Years)

\begin{tabular}{|c|c|c|c|c|c|c|}
\hline Case & Subcase & $\begin{array}{c}\text { Value at } \\
10,000 \text { Years } \\
\end{array}$ & $\begin{array}{l}\text { Peak Value in } \\
100,000 \text { Years }\end{array}$ & $\begin{array}{c}\text { Time of Peak } \\
\text { Value }\end{array}$ & $\begin{array}{c}\text { Time of } \\
0.5 * \text { Peak }\end{array}$ & $\begin{array}{c}\text { Time of } \\
10^{-6 *} \text { Peak }\end{array}$ \\
\hline \multirow{4}{*}{$\begin{array}{l}3 \mathrm{i}, \\
\text { Unit Cell } \\
\text { Model, } \\
\text { lower water } \\
\text { table }\end{array}$} & $K_{d}=0$ & 4.29 e- 6 & 7.08 e- 6 & 2,200 & $\begin{array}{r}1,400 \\
(1,200) \\
\end{array}$ & 200 \\
\hline & $\mathrm{K}_{\mathrm{d}}=0.1 \mathrm{mg} / \mathrm{\ell}$ & $4.29 \mathrm{e}-6$ & 4.42 e- 6 & 20,000 & 3,300 & 435 \\
\hline & $\mathrm{K}_{\mathrm{d}}=0.6 \mathrm{mg} / \mathrm{l}$ & $1.99 \mathrm{e}-6$ & 4.42 e- 6 & 43,000 & 10,600 & 1,900 \\
\hline & $\mathrm{K}_{\mathrm{d}}=3 . \mathrm{mg} / \mathrm{l}$ & $2.31 \mathrm{e}-10$ & 4.29 e- 6 & $100,000^{*}$ & 45,000 & 7,700 \\
\hline \multirow{4}{*}{$\begin{array}{l}3 \mathbf{j} \\
\text { Unit Cell } \\
\text { Model, } \\
\text { higher water } \\
\text { table }\end{array}$} & $K_{d}=0$ & 4.38 e- 6 & 7.29 e- 6 & 2,000 & $\begin{array}{l}1,200 \\
1,000 \\
\end{array}$ & 142 \\
\hline & $\mathrm{K}_{\mathrm{d}}=0.1 \mathrm{mg} / \mathrm{l}$ & 4.38 e- 6 & 4.42 e- 6 & 17,000 & 2,600 & 295 \\
\hline & $\mathrm{K}_{\mathrm{d}}=0.6 \mathrm{mg} / \mathrm{\ell}$ & 3.42 e- 6 & 4.42 e- 6 & 33,000 & 7,500 & 1,200 \\
\hline & $\mathrm{K}_{\mathrm{d}}=3 \mathrm{mg} / \mathrm{l}$ & $1.56 \mathrm{e}-8$ & 4.40 e -6 & $100,000 *$ & 31,000 & 5,200 \\
\hline \multirow{4}{*}{$\begin{array}{l}3 \mathrm{k} \\
\text { Unit Cell } \\
\text { Model, } \\
\text { moisture }=0.2 \\
\text { in construction } \\
\text { materials }\end{array}$} & $\mathrm{K}_{\mathrm{d}}=0$. & $4.38 \mathrm{e}-6$ & 6.90 e- 6 & 2,150 & $\begin{array}{l}1,350 \\
1,120 \\
\end{array}$ & 172 \\
\hline & $\mathrm{K}_{\mathrm{d}}=0.1 \mathrm{mg} / \mathrm{l}$ & $4.37 \mathrm{e}-6$ & 4.42 e- 6 & 17,000 & 3,100 & 305 \\
\hline & $\mathrm{K}_{\mathrm{d}}=0.6 \mathrm{mg} / \mathrm{l}$ & $2.65 \mathrm{e}-6$ & $4.42 \mathrm{e}-6$ & 41,000 & 9,100 & 1,500 \\
\hline & $\mathrm{K}_{\mathrm{d}}=3 \mathrm{mg} / \mathrm{l}$ & $2.01 \mathrm{e}-9$ & $4.35 e-6$ & $100,000 *$ & 39,000 & 6,300 \\
\hline
\end{tabular}


DOE/RL-97-69

Rev. 0

Table E-1. Summary of Vadose Zone Simulations for the Normalized Contaminant Flux Reaching the Unconfined Aquifer.

Case numbers reflect archival filenames.

(Values with * Assume Peak Value is $4 \times 10^{-6} \mathrm{y}^{-1}$ )

(Values with \#, Calculated only to 40,000 Years)

(Values in Parentheses Reflect Peak Values in First 100k Years)

\begin{tabular}{|c|c|c|c|c|c|c|}
\hline Case & Subcase & $\begin{array}{c}\text { Value at } \\
10,000 \text { Years }\end{array}$ & $\begin{array}{l}\text { Peak Value in } \\
100,000 \text { Years }\end{array}$ & $\begin{array}{c}\text { Time of Peak } \\
\text { Value }\end{array}$ & $\begin{array}{c}\text { Time of } \\
0.5 * \text { Peak }\end{array}$ & $\begin{array}{c}\text { Time of } \\
10^{-6 *} \text { Peak } \\
\end{array}$ \\
\hline \multirow{4}{*}{$\begin{array}{l}31 \\
\text { Unit Cell } \\
\text { Model, } \\
\text { moisture = } \\
\text { residual in } \\
\text { construction } \\
\text { materials }\end{array}$} & $\mathrm{K}_{d}=0$ & 4.37 e- 6 & 6.90 e- 6 & 2,150 & $\begin{array}{l}1,350 \\
1,120 \\
\end{array}$ & 172 \\
\hline & $\mathrm{K}_{\mathrm{d}}=0.1 \mathrm{mg} / \ell$ & 4.37 e- 6 & 4.42 e- 6 & 17,000 & 3,100 & 364 \\
\hline & $\mathrm{K}_{\mathrm{d}}=0.6 \mathrm{mg} / \mathrm{l}$ & $2.65 e-6$ & 4.42 e- 6 & 40,000 & 9,100 & 1,550 \\
\hline & $\mathrm{K}_{\mathrm{d}}=3 . \mathrm{mg} / \mathrm{l}$ & $2.01 \mathrm{e}-9$ & 4.36 e- 6 & $100,000^{*}$ & 39,000 & 6,300 \\
\hline \multirow{4}{*}{$\begin{array}{l}3 \mathrm{~m} \\
\text { Unit Cell } \\
\text { Model, } \\
\text { canister } \\
\text { rotated } 90 \\
\text { degrees }\end{array}$} & $K_{d}=0$ & $4.37 \mathrm{e}-6$ & 7.29 e- 6 & 2,200 & $\begin{array}{l}1,330 \\
1,080 \\
\end{array}$ & 175 \\
\hline & $K_{d}=0.1 \mathrm{mg} / \mathrm{l}$ & $4.37 \mathrm{e}-6$ & 4.42 e- 6 & 17,000 & 3,150 & 365 \\
\hline & $\mathrm{K}_{\mathrm{d}}=0.6 \mathrm{mg} / \mathrm{\ell}$ & $2.59 \mathrm{e}-6$ & 4.42 e- 6 & 40,000 & 9,200 & 1,500 \\
\hline & $\mathrm{K}_{\mathrm{d}}=3 . \mathrm{mg} / \mathrm{l}$ & $1.63 \mathrm{e}-9$ & 4.35 e- 6 . & $100,000^{*}$ & $39,000^{*}$ & 6,400 \\
\hline \multirow{4}{*}{$\begin{array}{l}3 \mathrm{n} \\
\text { Unit Cell } \\
\text { Model, } \\
\text { increased } \\
\text { number of } \\
\text { nodes }\end{array}$} & $\mathrm{K}_{\mathrm{d}}=0$ & 4.37 e- 6 & $6.84 e-6$ & 2,150 & $\begin{array}{l}1,350 \\
1,140 \\
\end{array}$ & 173 \\
\hline & $\mathrm{K}_{\mathrm{d}}=0.1 \mathrm{mg} / \ell$ & 4.37 e- 6 & $4.42 \mathrm{e}-6$ & 17,000 & 3,150 & 305 \\
\hline & $\mathrm{K}_{\mathrm{d}}=0.6 \mathrm{mg} / \mathrm{\ell}$ & $2.65 e-6$ & $4.42 \mathrm{e}-6$ & 40,000 & 9,100 & 1,560 \\
\hline & $K_{d}=3 . \mathrm{mg} / \ell$ & 2.00 e- 9 & 4.35 e- 6 & $100,000^{*}$ & 39,000 & 6,300 \\
\hline
\end{tabular}


DOE/RL-97-69.

Rev. 0

Table E-1. Summary of Vadose Zone Simulations for the Normalized Contaminant Flux Reaching the Unconfined Aquifer.

Case numbers reflect archival filenames.

(Values with * Assume Peak Value is $4 \times 10^{-6} \mathrm{y}^{-1}$ )

(Values with \#, Calculated only to 40,000 Years)

(Values in Parentheses Reflect Peak Values in First 100k Years)

\begin{tabular}{|c|c|c|c|c|c|c|}
\hline Case & Subcase & $\begin{array}{c}\text { Value at } \\
10,000 \text { Years } \\
\end{array}$ & $\begin{array}{l}\text { Peak Value in } \\
100,000 \text { Years }\end{array}$ & $\begin{array}{c}\text { Time of Peak } \\
\text { Value } \\
\end{array}$ & $\begin{array}{c}\text { Time of } \\
0.5^{*} \text { Peak } \\
\end{array}$ & $\begin{array}{c}\text { Time of } \\
10^{-6 *} \text { Peak }\end{array}$ \\
\hline \multirow{4}{*}{$\begin{array}{l}\text { 3o } \\
\text { Unit Cell } \\
\text { Model, } \\
\text { waste form is } \\
\text { sand }\end{array}$} & $K_{d}=0$ & 4.37 e- 6 & 5.72 e- 6 & 2,200 & $\begin{array}{l}1,380 \\
1,240 \\
\end{array}$ & 172 \\
\hline & $\mathrm{K}_{\mathrm{d}}=0.1 \mathrm{mg} / \ell$ & 4.37 e- 6 & 4.42 e-6 & 17,000 & 3,300 & 305 \\
\hline & $\mathrm{K}_{\mathrm{d}}=0.6 \mathrm{mg} / \ell$ & 2.65 e- 6 & 4.42 e- 6 & 40,000 & 9,100 & 1,590 \\
\hline & $\mathrm{K}_{\mathrm{d}}=3 . \mathrm{mg} / \mathrm{l}$ & 2.00 e- 6 & 4.36 e- 6 & $100,000^{*}$ & 39,000 & 6,300 \\
\hline \multirow{4}{*}{$\begin{array}{l}3 p \\
\text { Unit Cell } \\
\text { Model, } \\
\text { reduced } \\
\text { diffusion } \\
\text { coefficient }\end{array}$} & $K_{d}=0$ & 4.37 e- 6 & $6.91 \mathrm{e}-6$ & 2,150 & $\begin{array}{l}1,350 \\
1,120 \\
\end{array}$ & 210 \\
\hline & $\mathrm{K}_{\mathrm{d}}=0.1 \mathrm{mg} / \mathrm{\ell}$ & $4.37 \mathrm{e}-6$ & $4.42 \mathrm{e}-6$ & 17,000 & 3,150 & 365 \\
\hline & $\mathrm{K}_{\mathrm{d}}=0.6 \mathrm{mg} / \ell$ & $2.65 \mathrm{e}-7$ & $4.42 \mathrm{e}-6$ & 40,000 & 9,100 & 1,560 \\
\hline & $\mathrm{K}_{\mathrm{d}}=3 . \mathrm{mg} / \mathrm{\ell}$ & $2.00 \mathrm{e}-9$ & $4.36 \mathrm{e}-6$ & $100,000 *$ & 39,000 & 6,300 \\
\hline \multirow{4}{*}{$\begin{array}{l}3 q \\
\text { Unit Cell } \\
\text { Model, } \\
\text { twice } \\
\text { dispersion } \\
\text { coefficient }\end{array}$} & $K_{d}=0$ & 4.37 e- 6 & 5.89 e- 6 & 1,990 & $\begin{array}{r}1,125 \\
980 \\
\end{array}$ & 107 \\
\hline & $\mathrm{K}_{\mathrm{d}}=0.1 \mathrm{mg} / \mathrm{\ell}$ & $4.37 \mathrm{e}-6$ & 4.42 e- 6 & 17,000 & 2,750 & 355 \\
\hline & $\mathrm{K}_{\mathrm{d}}=0.6 \mathrm{mg} / \mathrm{\ell}$ & 2.73 e- 6 & $4.42 \mathrm{e}-6$ & 54,600 & 8,700 & 842 \\
\hline & $\mathrm{K}_{\mathrm{g}}=3 . \mathrm{mg} / \mathrm{l}$ & $2.90 \mathrm{e}-8$ & 4.27 e- 6 & $100,000^{*}$ & $37,000 *$ & 6,300 \\
\hline
\end{tabular}




\section{DOE/RL-97-69}

Rev. 0

Table E-1. Summary of Vadose Zone Simulations for the Normalized Contaminant Flux Reaching the Unconfined Aquifer.

Case numbers reflect archival filenames.

(Values with * Assume Peak Value is $4 \times 10^{-6} \mathrm{y}^{-1}$ )

(Values with \#, Calculated only to 40,000 Years)

(Values in Parentheses Reflect Peak Values in First 100k Years)

\begin{tabular}{|c|c|c|c|c|c|c|}
\hline Case & Subcase & $\begin{array}{c}\text { Value at } \\
10,000 \text { Years }\end{array}$ & $\begin{array}{l}\text { Peak Value in } \\
100,000 \text { Years }\end{array}$ & $\begin{array}{c}\text { Time of Peak } \\
\text { Value }\end{array}$ & $\begin{array}{c}\text { Time of } \\
0.5 * \text { Peak }\end{array}$ & $\begin{array}{c}\text { Time of } \\
10^{-6 * \text { Peak }}\end{array}$ \\
\hline \multirow{4}{*}{$\begin{array}{l}3 r \\
\text { Unit Cell } \\
\text { Model, } \\
\text { half dispersion } \\
\text { coefficient }\end{array}$} & $K_{d}=0$ & $4.37 \mathrm{e}-6$ & 8.01 e-6 & 2,270 & $\begin{array}{l}1,546 \\
1,256 \\
\end{array}$ & 250 \\
\hline & $\mathrm{K}_{\mathrm{d}}=0.1 \mathrm{mg} / \mathrm{l}$ & 4.37 e- 6 & 4.42 e- 6 & 17,000 & 3,400 & 540 \\
\hline & $\mathrm{K}_{\mathrm{s}}=0.6 \mathrm{mg} / \mathrm{l}$ & 2.51 e- 6 & 4.42 e -6 & 29,000 & 9,400 & 2,800 \\
\hline & $\mathrm{K}_{\mathrm{d}}=3 . \mathrm{mg} / \mathrm{l}$ & $5.4 \mathrm{e}-11$ & 4.41 e-6 & $100,000^{*}$ & $40,000^{*}$ & 9,900 \\
\hline \multirow{4}{*}{$\begin{array}{l}3 \text { s } \\
\text { Unit Cell } \\
\text { Model, } \\
0.1 * \\
\text { dispersion } \\
\text { coefficient }\end{array}$} & $K_{d}=0$ & $4.37 \mathrm{e}-6$ & 10.2 e- 6 & 2,350 & $\begin{array}{l}1,725 \\
1,380 \\
\end{array}$ & 375 \\
\hline & $\mathrm{K}_{\mathrm{d}}=0.1 \mathrm{mg} / \mathrm{l}$ & 4.37 e- 6 & 4.42 e- 6 & 17,000 & 3,600 & 830 \\
\hline & $\mathrm{K}_{\mathrm{d}}=0.6 \mathrm{mg} / \mathrm{l}$ & $2.54 \mathrm{e}-6$ & 4.42 e- 6 & 22,000 & 9,600 & 4,000 \\
\hline & $\mathrm{K}_{\mathrm{d}}=3.0 \mathrm{mg} / \mathrm{l}$ & $3.5 \mathrm{e}-13$ & 4.42 e- 6 & 94,000 & 41,000 & 11,600 \\
\hline
\end{tabular}




\section{DOE/RL-97-69}

Rev. 0

Table E-1. Summary of Vadose Zone Simulations for the Normalized Contaminant Flux Reaching the Unconfined Aquifer.

(Values with * Assume Peak Value is $4 \times 10^{-6} \mathrm{y}^{\cdot 1}$ )

Case numbers reflect archival filenames.

(Values in Parentheses Reflect Peak Values in First 100k Years)

\begin{tabular}{|c|c|c|c|c|c|c|}
\hline Case & Subcase & $\begin{array}{c}\text { Value at } \\
10,000 \text { Years }\end{array}$ & $\begin{array}{l}\text { Peak Value in } \\
100,000 \text { Years }\end{array}$ & $\begin{array}{c}\text { Time of Peak } \\
\text { Value }\end{array}$ & $\begin{array}{r}\text { Time of } \\
0.5 * \text { Peak }\end{array}$ & $\begin{array}{l}\text { Time of } \\
10^{-6 *} \text { Peak }\end{array}$ \\
\hline \multirow{4}{*}{$\begin{array}{l}3 \mathrm{t} \\
\text { Unit Cell } \\
\text { Model, } \\
\mathrm{K}_{\mathrm{d}}=100 \mathrm{mg} / \ell \\
\text { in floor }\end{array}$} & $K_{d}=0$ & 0.805 e- 7 & 3.99 e- 6 & $100,000 *$ & $\begin{array}{c}31,000 \\
(27,000)\end{array}$ & 385 \\
\hline & $\mathrm{K}_{\mathrm{d}}=0.1 \mathrm{mg} / \mathrm{l}$ & $0.691 \mathrm{e}-7$ & 3.98 e- 6 & $100,000^{*}$ & $\begin{array}{r}32,000 \\
(28,000) \\
\end{array}$ & 782 \\
\hline & $\mathrm{K}_{\mathrm{d}}=0.6 \mathrm{mg} / \mathrm{l}$ & $0.198 \mathrm{e}-7$ & 3.89 e- 6 & $100,000^{*}$ & $\begin{array}{r}39,000 \\
(34,000) \\
\end{array}$ & 3,000 \\
\hline & $\mathrm{K}_{\mathrm{d}}=3 . \mathrm{mg} / \mathrm{l}$ & 1.13 e- 10 & $3.19 \mathrm{e}-6$ & $100,000^{*}$ & $\begin{array}{r}72,000 \\
(59,000)\end{array}$ & 7,700 \\
\hline \multirow{4}{*}{$\begin{array}{l}\text { 3u, } \\
\text { Unit Cell, } \\
\text { Model, } \\
\text { time- } \\
\text { dependent } \\
\text { waste form } \\
\text { release rate }\end{array}$} & $K_{d}=0$ & $4.26 \mathrm{e}-6$ & $\begin{array}{l}6.87 \text { e-6 } \\
4.26 \text { e- } 6 \\
\end{array}$ & $2,150 \quad 11,400$ & $\begin{array}{l}1,350 \\
1,110 \\
\end{array}$ & 175 \\
\hline & $\mathrm{K}_{\mathrm{d}}=0.1 \mathrm{mg} / \mathrm{\ell}$ & $4.27 \mathrm{e}-6$ & $4.28 \mathrm{e}-6$ & 11,200 & 3,100 & 360 \\
\hline & $\mathrm{K}_{\mathrm{d}}=0.6 \mathrm{mg} / \mathrm{l}$ & 2.62 e- 6 & 4.19 e- 6 & 23,500 & 9,000 & 1,540 \\
\hline & $\mathrm{K}_{\mathrm{d}}=3.0 \mathrm{mg} / \mathrm{l}$ & $2.00 \mathrm{e}-9$ & 3.73 e- 6 & 82,000 & 37,000 & 6,300 \\
\hline
\end{tabular}




\section{DOE/RL-97-69}

Rev. 0

Table E-1. Summary of Vadose Zone Simulations for the Normalized Contaminant Flux Reaching the Unconfined Aquifer.

(Values with * Assume Peak Value is $4 \times 10^{-6} \mathrm{y}^{-1}$ )

Case numbers reflect archival filenames.

(Values in Parentheses Reflect Peak Values in First 100k Years)

\begin{tabular}{|c|c|c|c|c|c|c|}
\hline Case & Subcase & $\begin{array}{c}\text { Value at } \\
10,000 \text { Years }\end{array}$ & $\begin{array}{l}\text { Peak Value in } \\
100,000 \text { Years }\end{array}$ & $\begin{array}{c}\text { Time of Peak } \\
\text { Value } \\
\end{array}$ & $\begin{array}{c}\text { Time of } \\
0.5^{*} \text { Peak }\end{array}$ & $\begin{array}{c}\text { Time of } \\
10^{-6 * \text { Peak }} \\
\end{array}$ \\
\hline \multirow{8}{*}{$\begin{array}{l}3 \mathrm{v} \\
\text { Unit Cell } \\
\text { Model } \\
\text { waste form } \\
\text { release rates } \\
\text { calculated by } \\
\text { AREST-CT }\end{array}$} & $\mathrm{Tc}$, main & $0.470 \mathrm{e}-6$ & $0.502 \mathrm{e}-6$ & 14,600 & 1,630 & 240 \\
\hline & $\begin{array}{l}\mathrm{Tc} \text {, no } \mathrm{Na} \text { ion } \\
\text { exchange }\end{array}$ & 0.019 e- 6 & 0.028 e- 6 & 18,200 & 1,600 & 215 \\
\hline & $\begin{array}{l}\text { Tc, increased pore } \\
\text { velocity }\end{array}$ & $1.08 \mathrm{e}-6$ & 1.38 e- 6 & 18,000 & 2,000 & 225 \\
\hline & $\mathrm{Se}$ & 0.767 e- 6 & $0.767 \mathrm{e}-7$ & 9,700 & 1,730 & 210 \\
\hline & $\mathrm{U}$ & $0.286 e-6$ & $0.591 \mathrm{e}-6$ & 22,000 & 10,400 & 1,900 \\
\hline & I & $1.37 \mathrm{e}-10$ & $0.344 \mathrm{e}-6$ & 60,000 & 34,000 & 7,400 \\
\hline & $\mathrm{Np}$ & $9.3 \mathrm{e}-17$ & $2.32 \mathrm{e}-5$ & $100,000 *$ & $\begin{array}{r}>100,000 \\
(85,000) \\
\end{array}$ & $(21,000)$ \\
\hline & $\mathrm{Pu}$ & 0.0 & $2.72 \mathrm{e}-11$ & $100,000^{*}$ & $\begin{array}{r}>100,000 \\
(94,000)\end{array}$ & \\
\hline
\end{tabular}




\section{E.3 UNCONFINED AQUIFER SIMULATIONS}

Because only a few numbers are used from these simulations, only figures (Figures E-2 through E-7) will be given to give an indication of the breath of the results. For more detailed explanation see Lu 1996.

Figure E-2. Simulated Post-Hanford Operations Water Table and Well Location.

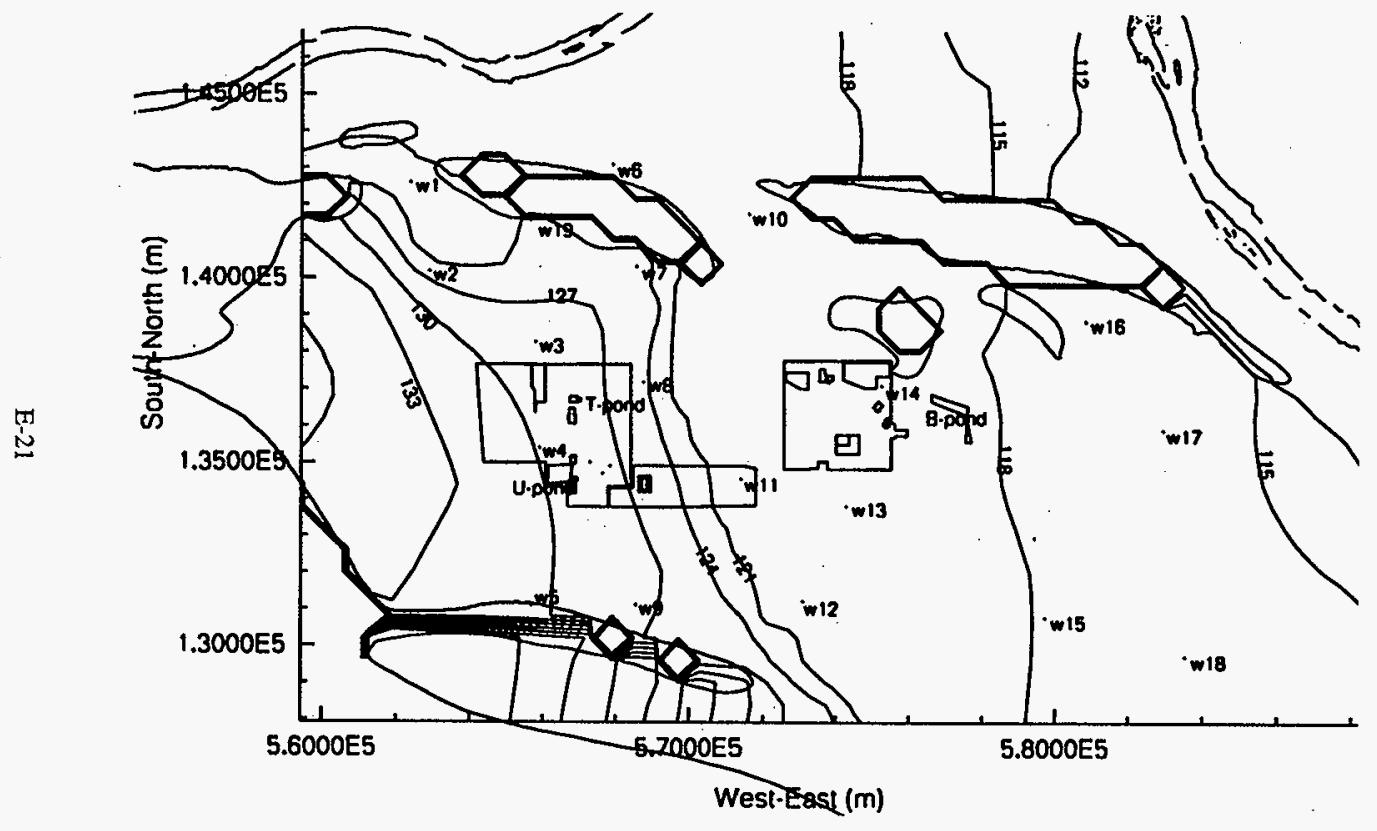


DOE/RL-97-69

Rev. 0

量

co<o o t

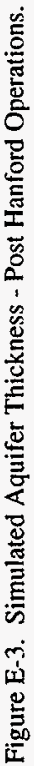

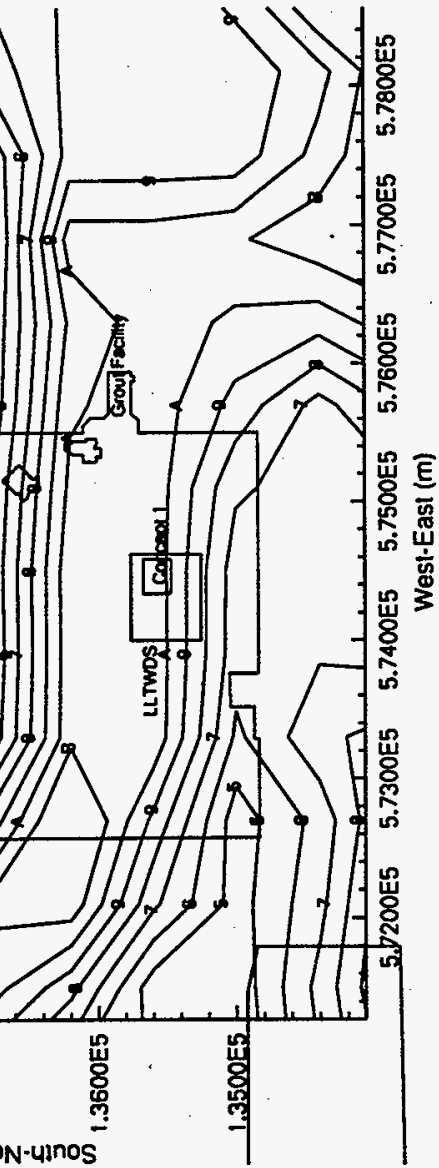


DOE/RL-97-69

Rev. 0
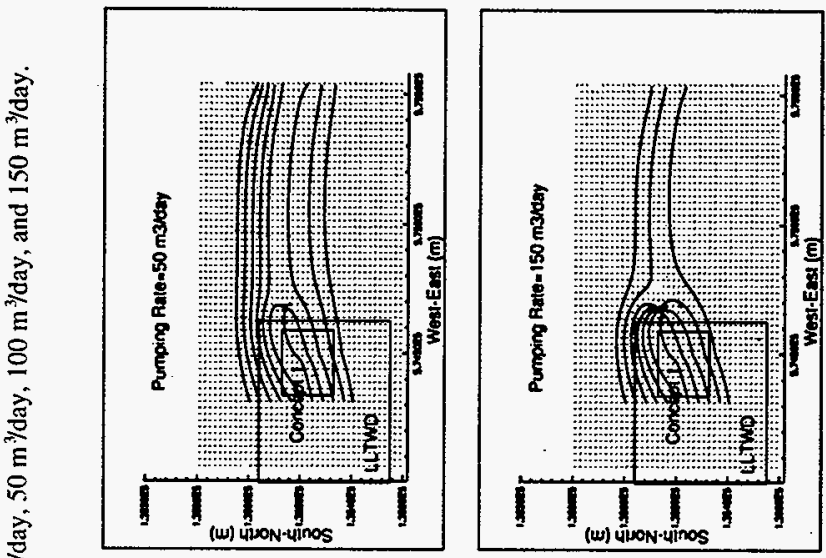

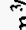

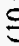

:
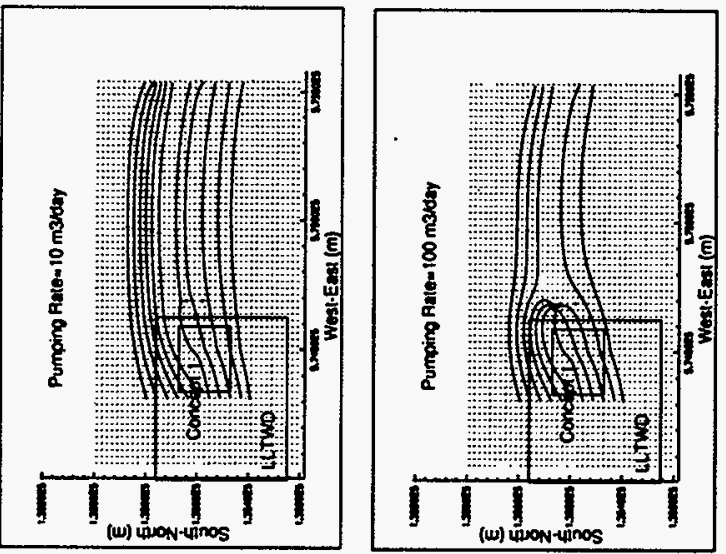

E-23 
Figure E-5. Simulated Concentration Contour from New Disposal Facility for Concept 2. Assumes concentration of 1 $\mathrm{Ci} / \mathrm{m}^{3}$ in the vadose zone and a recharge rate of $1 \mathrm{~mm} / \mathrm{y}$. Since actual recharge is $3 \mathrm{~mm} / \mathrm{y}$, actual concentrations will be 3 times higher than shown.

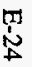

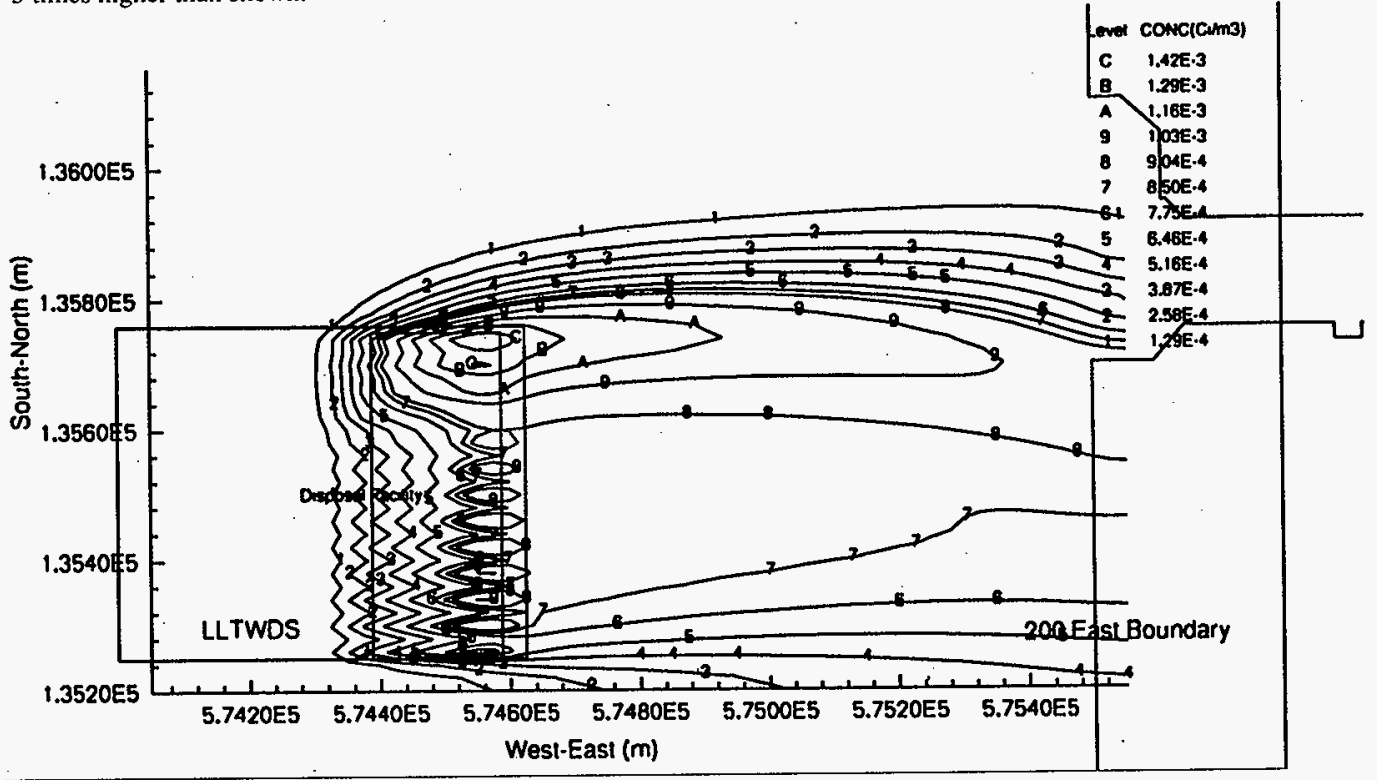


Figure E-6. Simulated Concentration Contour from the New Disposal Facility for Irrigation North of the 200 Area. Assumes concentration of $1 \mathrm{Ci} / \mathrm{m}^{3}$ in the vadose zone and a recharge rate of $1 \mathrm{~mm} / \mathrm{y}$. Since actual recharge is $3 \mathrm{~mm} / \mathrm{y}$, actual concentrations will be 3 times higher than shown.

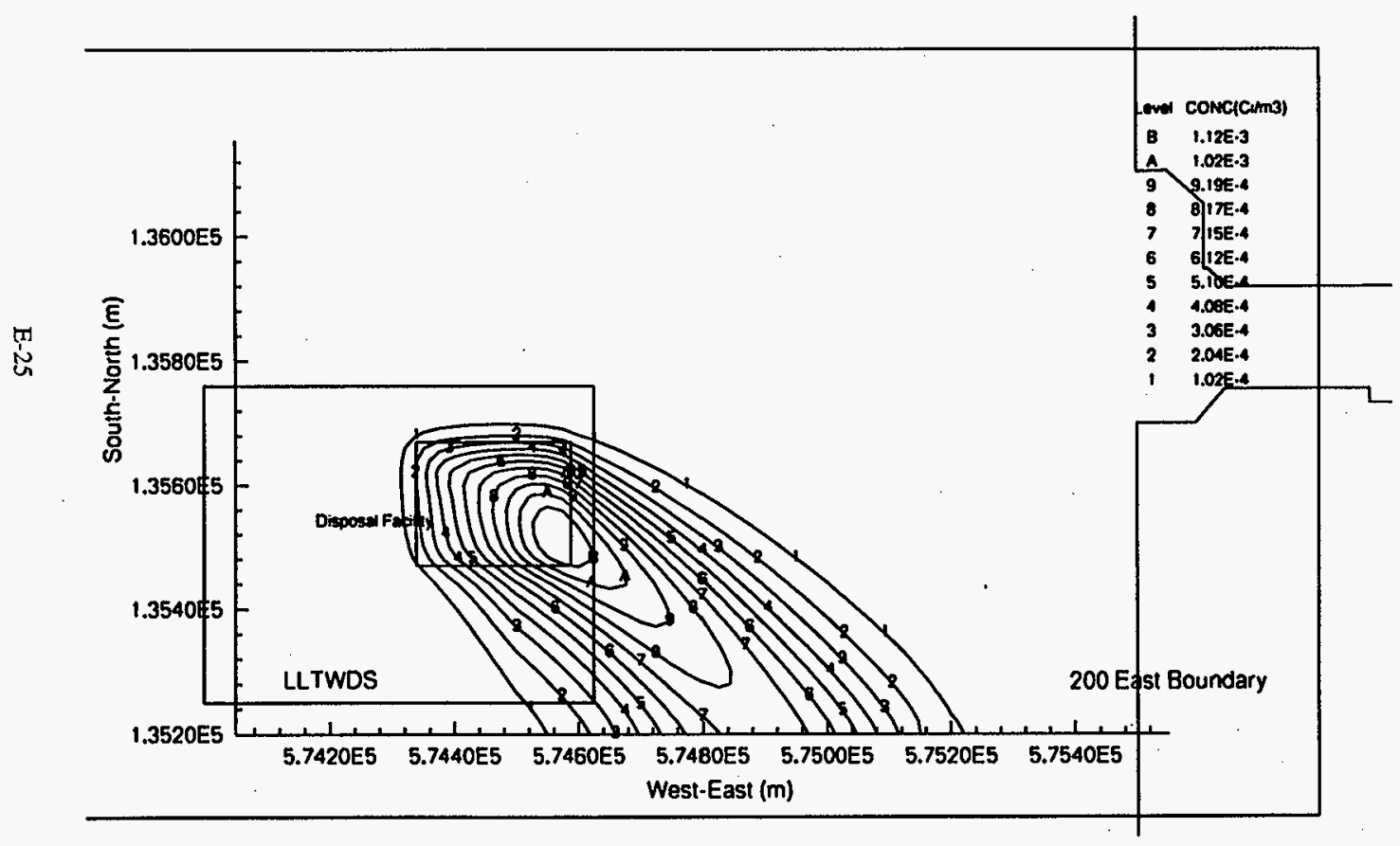


Figure E-7. Simulated Concentration Contour for Existing TWRS Disposal Facilities. Assumes concentration of $1 \mathrm{Ci} / \mathrm{m}^{3} \mathrm{in}$ the vadose zone and a recharge rate of $1 \mathrm{~mm} / \mathrm{y}$. Since actual recharge is $3 \mathrm{~mm} / \mathrm{y}$, actual concentrations will be 3 times higher than shown.

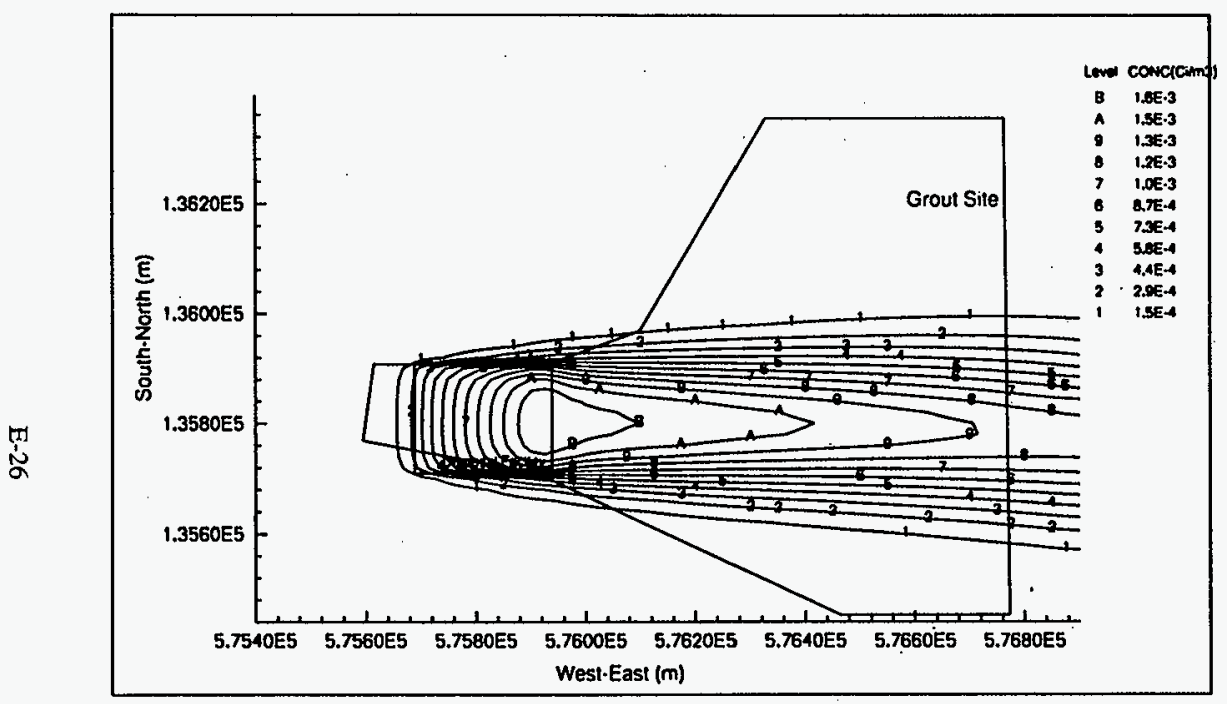


DOE/RL-97-69

Rev. 0

\section{E.4 CALCULATION OF DOSE}

Table E-2 summarizes the calculation of the beta/photon drinking water dose, the alpha concentration in well water, and the all-pathway dose. Because the time dependence of these impacts follows the time dependence of the vadose simulations, please refer to those figures in Sections 4.2 through 4.7 . Rows with " $10 \mathrm{~K} \mathrm{y}$ " have the maximum exposure values during the first 10,000 years; rows with "limit" have the time (in years) at which the performance objectives are reached; rows with "max" have the maximum exposure values along with the year that the maximum value was reached.

Table E-2. Summary of Dose Calculations. Case numbers reflect archival filenames.

\begin{tabular}{|c|c|c|c|c|}
\hline Case & Time & $\begin{array}{c}\text { Beta Dose } \\
\text { (mrem/y) }\end{array}$ & $\begin{array}{l}\text { Alpha } \\
\text { Conc. } \\
\text { (pCi/l) }\end{array}$ & $\begin{array}{c}\text { All- } \\
\text { Pathways } \\
\text { Dose } \\
(\mathrm{mrem} / \mathrm{y})\end{array}$ \\
\hline Performance Objectives & $10 \mathrm{~K} \mathrm{y}$ & 4.0 & 15.0 & 25.0 \\
\hline \multirow[t]{3}{*}{ 1-1d Base Analysis Case } & $10 \mathrm{~K} \mathrm{y}$ & 1.97 & 1.65 & 6.4 \\
\hline & limit & $>100,000$ & $>100,000$ & $>100,000$ \\
\hline & $\max$ & $\begin{array}{c}2.7 \\
@ 71,000\end{array}$ & $\begin{array}{c}5.7 \\
\text { @ } 55,000\end{array}$ & $\begin{array}{c}23.0 \\
@ 50,000\end{array}$ \\
\hline \multirow{3}{*}{$\begin{array}{l}\text { 1-1de Base Analysis Case, } \\
\text { vadose zone flux } \\
\text { extended to } 66 \\
\text { million years }\end{array}$} & $10 \mathrm{Ky}$ & 1.96 & 1.53 & 5.9 \\
\hline & limit & @ 750,000 & @ 2.2M & $>66 \mathrm{M}$ \\
\hline & $\max$ & $\begin{array}{c}14.0 \\
@ 65 \mathrm{M}\end{array}$ & $\begin{array}{c}18.0 \\
@ 51 \mathrm{M}\end{array}$ & $\begin{array}{c}22.0 \\
@ 55,000\end{array}$ \\
\hline \multirow{3}{*}{$\begin{array}{l}\text { 1-1dz Concept } 1 \\
\text { flux }=0 \text { for } K_{d}>0.7\end{array}$} & $10 \mathrm{Ky}$ & 1.97 & 1.60 & 5.9 \\
\hline & limit & $\geq 100,000$ & $>100,000$ & $>100,000$ \\
\hline & $\max$ & $\begin{array}{c}2.6 \\
\text { @ } 60,000\end{array}$ & $\begin{array}{c}4.1 \\
@ 71,000\end{array}$ & $\begin{array}{c}8.3 \\
@ 63,000\end{array}$ \\
\hline \multirow{3}{*}{$\begin{array}{l}\text { 1-1di Concept } 1, \\
\mathrm{Tc} \text { inv }=0.2 \text { of base } \\
\text { analysis case }\end{array}$} & $10 \mathrm{~K} \mathrm{y}$ & 0.79 & 1.65 & 2.5 \\
\hline & limit & $>100,000$ & $>100,000$ & $>100,000$ \\
\hline & $\max$ & $\begin{array}{c}1.14 \\
@ 100,000\end{array}$ & $\begin{array}{c}5.7 \\
\text { @ } 55,000\end{array}$ & $\begin{array}{c}17.2 \\
@ 49,000\end{array}$ \\
\hline
\end{tabular}


DOE/RL-97-69

Rev. 0

Table E-2. Summary of Dose Calculations. Case numbers reflect archival filenames.

\begin{tabular}{|c|c|c|c|c|}
\hline Case & Time & $\begin{array}{l}\text { Beta Dose } \\
\text { (mrem/y) }\end{array}$ & $\begin{array}{l}\text { Alpha } \\
\text { Conc. } \\
\text { (pCi/l) }\end{array}$ & $\begin{array}{l}\text { All- } \\
\text { Pathways } \\
\text { Dose } \\
\text { (mrem/y) }\end{array}$ \\
\hline Performance Objectives & $10 \mathrm{Ky}$ & 4.0 & 15.0 & 25.0 \\
\hline \multirow{3}{*}{$\begin{array}{l}\text { 1-1dis, Concept } 1 \\
\text { double Se inventory } \\
\text { from base analysis } \\
\text { case }\end{array}$} & $10 \mathrm{~K} \mathrm{y}$ & 2.4 & 1.65 & 7.1 \\
\hline & limit & $>100,000$ & $>100,000$ & $>100,000$ \\
\hline & $\max$ & $\begin{array}{c}3.1 \\
@ 62,000\end{array}$ & $\begin{array}{c}5.7 \\
@ 55,000\end{array}$ & $\begin{array}{c}23.0 \\
@ 50,000\end{array}$ \\
\hline \multirow{3}{*}{$\begin{array}{l}\text { 1-1 diu, Concept } 1 \\
\text { double U inventory } \\
\text { from base analysis } \\
\text { case }\end{array}$} & $10 \mathrm{~K} \mathrm{y}$ & 2.05 & 3.2 & 6.8 \\
\hline & limit & $>100,000$ & $>100,000$ & $>100,000$ \\
\hline & $\max$ & $\begin{array}{c}3.0 \\
\Leftrightarrow 82,000\end{array}$ & $\begin{array}{c}9.7 \\
\text { @ } 62,000\end{array}$ & $\begin{array}{c}23.0 \\
@ 50,000\end{array}$ \\
\hline \multirow{3}{*}{$\begin{array}{l}1-1 \text { dii, Concept } 1 \\
5 * \text { I inventory from } \\
\text { base analysis case }\end{array}$} & $10 \mathrm{Ky}$ & 1.97 & 1.65 & 6.4 \\
\hline & limit & $>100,000$ & $>100,000$ & $>100,000$ \\
\hline & $\max$ & $\begin{array}{l}3.0 \\
@ 81,000\end{array}$ & $\begin{array}{l}5.7 \\
\text { @ } 55,000\end{array}$ & $\begin{array}{l}23.0 \\
\text { @ } 50,000\end{array}$ \\
\hline \multirow{3}{*}{$\begin{array}{l}1-1 \mathrm{dr}, \text { Concept } 1, \\
\text { Tc release rate } \\
\text { reduced by factor } \\
\text { of } 5 \text { from } \\
\text { base analysis case }\end{array}$} & $10 \mathrm{~K} \mathrm{y}$ & 0.87 & 1.65 & 2.8 \\
\hline & limit & $>100,000$ & $>100,000$ & $>100,000$ \\
\hline & $\max$ & $\begin{array}{c}1.20 \\
@ 41,000\end{array}$ & $\begin{array}{l}5.7 \\
\text { @ } 55,000\end{array}$ & $\begin{array}{c}17.6 \\
@ 49,000\end{array}$ \\
\hline \multirow{3}{*}{$\begin{array}{l}\text { 1-1 dra Concept } 1, \\
\text { release rate reduced by } \\
\text { factor of } 5 \text { from } \\
\text { base analysis case } \\
\text { for all } \\
\mathrm{K}_{\mathrm{d}}=0 \text { contaminants }\end{array}$} & $10 \mathrm{~K} \mathrm{y}$ & 0.57 & 1.65 & 2.3 \\
\hline & limịt & $>100,000$ & $>100,000$ & $>100,000$ \\
\hline & $\max$ & $\begin{array}{l}0.99 \\
\text { @ } 100,000\end{array}$ & $\begin{array}{l}5.7 \\
\text { @ } 55,000\end{array}$ & $\begin{array}{c}17.1 \\
\text { @ } 49,000\end{array}$ \\
\hline
\end{tabular}


DOE/RL-97-69

Rev. 0

Table E-2. Summary of Dose Calculations. Case numbers reflect archival filenames.

\begin{tabular}{|c|c|c|c|c|}
\hline Case & Time & $\begin{array}{l}\text { Beta Dose } \\
\text { (mrem/y) }\end{array}$ & $\begin{array}{l}\text { Alpha } \\
\text { Conc. } \\
\text { (pCi/l) }\end{array}$ & $\begin{array}{c}\text { All- } \\
\text { Pathways } \\
\text { Dose } \\
\text { (mrem/y) } \\
\end{array}$ \\
\hline Performance Objectives & $10 \mathrm{Ky}$ & 4.0 & 15.0 & 25.0 \\
\hline \multirow{3}{*}{$\begin{array}{l}\text { 1-1 dku Concept } 1 \text {, } \\
K_{d}=0 \text { for uranium }\end{array}$} & $10 \mathrm{~K} \mathrm{y}$ & 2.1 & 4.6 & 7.1 \\
\hline & limit & $>100,000$ & $>100,000$ & $>100,000$ \\
\hline & $\max$ & $\begin{array}{c}2.9 \\
\text { @ } 76,000\end{array}$ & $\begin{array}{c}8.4 \\
@ 71,000\end{array}$ & @ $\begin{array}{ll}23.0 \\
50,000\end{array}$ \\
\hline \multirow{3}{*}{$\begin{array}{l}1-1 \mathrm{dk} 0 \text {, Concept } 1 \text {, } \\
\mathrm{K}_{\mathrm{d}}=0.1 \mathrm{mg} / \ell \text { for } \mathrm{Se} \\
\text { and } \mathrm{Tc}\end{array}$} & $10 \mathrm{Ky}$ & 1.66 & 1.65 & 5.5 \\
\hline & limit & $>100,000$ & $>100,000$ & $>100,000$ \\
\hline & $\max$ & $\begin{array}{c}2.2 \\
@ 100,000\end{array}$ & $\begin{array}{ll} & 5.7 \\
\text { @ } & 55,000\end{array}$ & $\begin{array}{l}21 . \\
@ 49,000 .\end{array}$ \\
\hline \multirow{3}{*}{$\begin{array}{l}\text { 1-1ddoe Concept } 1 \text {, } \\
\text { DOE dose factors }\end{array}$} & $10 \mathrm{Ky}$ & 1.97 & 1.65 & 6.4 \\
\hline & limit & $>100,000$ & $>100,000$ & $>100,000$ \\
\hline & $\max$ & $\begin{array}{l}2.7 \\
\text { @ } 71,000\end{array}$ & $\begin{array}{l}5.7 \\
\text { @ } 55,000 \\
\end{array}$ & $\begin{array}{l}23.0 \\
@ 50,000 \\
\end{array}$ \\
\hline \multirow{3}{*}{$\begin{array}{l}\text { 1-1 depa Concept } 1, \\
\text { EPA dose factors }\end{array}$} & $10 \mathrm{Ky}$ & 2.2 & 1.65 & 7.0 \\
\hline & limit & $>100,000$ & $>100,000$ & $>100,000$ \\
\hline & $\max$ & $\begin{array}{l}3.0 \\
@ 71,000\end{array}$ & $\begin{array}{l}5.7 \\
\text { @ } 55,000\end{array}$ & $\begin{array}{c}23.0 \\
@ 52,000\end{array}$ \\
\hline \multirow{3}{*}{$\begin{array}{l}\text { 1-1dgen, Concept } 1 \\
\text { GENII dose factors }\end{array}$} & $10 \mathrm{Ky}$ & 3.0 & 1.65 & 9.9 \\
\hline & limit & $@ 41,000$ & $>100,000$ & @ 38,000 \\
\hline & $\max$ & $\begin{array}{c}4.2 \\
@ 70,000\end{array}$ & $\begin{array}{c}5.7 \\
@ 55,000 \\
\end{array}$ & $\begin{array}{c}27.0 \\
\text { @ } 50,000\end{array}$ \\
\hline \multirow{3}{*}{$\begin{array}{l}\text { 1-1n. Concept } 1 \\
\text { Diffusion constant } \\
\text { reduced by factor of } \\
20 \text {. }\end{array}$} & $10 \mathrm{~K} \mathrm{y}$ & 0.060 & 0.056 & 0.64 \\
\hline & limit & $>100,000$ & $>100,000$ & $>100,000$ \\
\hline & $\max$ & $\begin{array}{c}1.80 \\
@ 100,000\end{array}$ & $\begin{array}{c}1.85 \\
@ 58,000\end{array}$ & $\begin{array}{c}16.4 \\
@ 54,000\end{array}$ \\
\hline
\end{tabular}


DOE/RL-97-69

Rev. 0

Table E-2. Summary of Dose Calculations. Case numbers reflect archival filenames.

\begin{tabular}{|c|c|c|c|c|}
\hline Case & Time & $\begin{array}{l}\text { Beta Dose } \\
\text { (mrem/y) }\end{array}$ & $\begin{array}{l}\text { Alpha } \\
\text { Conc. } \\
\text { (pCi/l) }\end{array}$ & $\begin{array}{c}\text { All- } \\
\text { Pathways } \\
\text { Dose } \\
\text { (mrem/y) } \\
\end{array}$ \\
\hline Performance Objectives & $10 \mathrm{~K} \mathrm{y}$ & 4.0 & 15.0 & 25.0 \\
\hline \multirow{3}{*}{$\begin{array}{l}\text { 1-2d, Concept } 1 \text {, } \\
\text { concrete degrades at } \\
2000 \text { years }\end{array}$} & $10 \mathrm{Ky}$ & 1.96 & 1.56 & 6.4 \\
\hline & limit & $>100,000$ & $>100,000$ & $>100,000$ \\
\hline & $\max$ & $\begin{array}{c}2.8 \\
\text { @ } 73,000\end{array}$ & $\begin{array}{c}5.7 \\
@ 57,000\end{array}$ & $\begin{array}{c}23.0 \\
@ 50,000\end{array}$ \\
\hline \multirow{3}{*}{$\begin{array}{l}\text { 1-1dukd, Concept } 1 \\
\mathrm{U} \text { daughters have } \mathrm{K}_{\mathrm{d}} \text { of } \\
\text { uranium }\end{array}$} & $10 \mathrm{~K} \mathrm{y}$ & 35.0 & 22.0 & 68.0 \\
\hline & limit & @ 3,400 & @ 8,200 & @ 5,600 \\
\hline & $\max$ & $\begin{array}{c}57.0 \\
\text { @ } 26,000\end{array}$ & $\begin{array}{c}39.0 \\
@ 30,000\end{array}$ & $\begin{array}{c}107.0 \\
@ 26,000\end{array}$ \\
\hline \multirow{3}{*}{$\begin{array}{l}\text { 1-dCR, Concept } 1, \\
\text { impacts at Columbia } \\
\text { River }\end{array}$} & $10 \mathrm{~K} \mathrm{y}$ & 0.069 & 0.058 & 0.22 \\
\hline & limit & $>100,000^{*}$ & $>100,000$ & $>100,000$ \\
\hline & $\max$ & $\begin{array}{c}0.095 \\
@ 71,000\end{array}$ & $\begin{array}{c}0.20 \\
\text { @ } 55,000\end{array}$ & $\begin{array}{c}0.79 \\
@ 50,000\end{array}$ \\
\hline \multirow{3}{*}{$\begin{array}{l}\text { 1-1deCR, Concept } 1 \\
\text { impacts at Columbia } \\
\text { River, vadose zone } \\
\text { flux extended to } 66 \\
\text { million years }\end{array}$} & $10 \mathrm{Ky}$ & 0.068 & 0.054 & 0.21 \\
\hline & limit & $>100,000^{*}$ & $>100,000$ & $>100,000$ \\
\hline & $\max$ & $\begin{array}{c}0.49 \\
@ 66 \mathrm{M}\end{array}$ & $\begin{array}{c}0.65 \\
@ 51 \mathrm{M} \\
\end{array}$ & $\begin{array}{c}0.56 \\
@ 66,000\end{array}$ \\
\hline \multirow{3}{*}{$\begin{array}{l}\text { 2-1d, Concept } 2 \text { Main } \\
\text { Analysis Case }\end{array}$} & $10 \mathrm{~K} \mathrm{y}$ & 1.11 & 0.27 & 3.3 \\
\hline & limit & $>100,000$ & $>100,000$ & $>100,000$ \\
\hline & $\max$ & $\begin{array}{c}1.12 \\
@ 15,000\end{array}$ & $\begin{array}{c}2.6 \\
@ 62,000\end{array}$ & $\begin{array}{c}7.9 \\
@ 72,000\end{array}$ \\
\hline
\end{tabular}


DOE/RL-97-69

Rev. 0

Table E-2. Summary of Dose Calculations. Case numbers reflect archival filenames.

\begin{tabular}{|c|c|c|c|c|}
\hline Case & Time & $\begin{array}{l}\text { Beta Dose } \\
\text { (mrem/y) }\end{array}$ & $\begin{array}{l}\text { Alpha } \\
\text { Conc. } \\
\text { (pCi/l) }\end{array}$ & $\begin{array}{l}\text { All. } \\
\text { Pathways } \\
\text { Dose } \\
(\text { mrem/y) }\end{array}$ \\
\hline Performance Objectives & $10 \mathrm{~K} \mathrm{y}$ & 4.0 & 15.0 & 25.0 \\
\hline \multirow{3}{*}{$\begin{array}{l}\text { 2-1de, Concept } 2 \text { Main } \\
\text { Analysis Case, vadose } \\
\text { zone flux extended } \\
\text { to } 66 \mathrm{M} \text { years }\end{array}$} & $10 \mathrm{~K} y$ & 1.14 & 0.78 & 3.4 \\
\hline & limit & @3.3M & $>66 \mathrm{M}$ & $>66 \mathrm{M}$ \\
\hline & $\max$ & $\begin{array}{c}5.0 \\
\text { @ } 13 \mathrm{M}\end{array}$ & $\begin{array}{c}6.9 \\
\text { @ } 2.7 \mathrm{M}\end{array}$ & $\begin{array}{c}10.3 \\
\text { @ } 51,000\end{array}$ \\
\hline \multirow{3}{*}{$\begin{array}{l}\text { 2-1 di, Concep } t 2 \\
\text { Inventory of } \mathrm{Tc}=0.2 \\
\quad \text { *base case }\end{array}$} & $10 \mathrm{~K} \mathrm{y}$ & 0.42 & 0.27 & 1.04 \\
\hline & limit & $>100,000$ & $>100,000$ & $>100,000$ \\
\hline & $\max$ & $\begin{array}{l}0.45 \\
@ 25,000\end{array}$ & $\begin{array}{c}2.6 \\
62,000\end{array}$ & $\begin{array}{l}6.3 \\
\text { @ } 74,000\end{array}$ \\
\hline \multirow{3}{*}{$\begin{array}{l}2-1 \mathrm{dr} \text {, Concept } 2 \text {, } \\
\text { Tc release rate reduced by factor of } \\
5 \text { from base analysis case }\end{array}$} & $10 \mathrm{~K} \mathrm{y}$ & 0.42 & 0.27 & 1.05 \\
\hline & limit & $>100,000$ & $>100,000$ & $>100,000$ \\
\hline & $\max$ & $\begin{array}{c}1.34 \\
@ 99,000\end{array}$ & (a) $\begin{array}{l}2.6 \\
62,000\end{array}$ & $\begin{array}{c}8.9 \\
@ 99,000\end{array}$ \\
\hline \multirow{3}{*}{$\begin{array}{l}\text { 2-1dra, Concept } 2, \\
\text { release rate for } \mathrm{K}_{\mathrm{d}}=0 \\
\text { reduced by factor } \\
\text { of } 5 \text { from base } \\
\text { analysis case }\end{array}$} & $10 \mathrm{~K} \mathrm{y}$ & 0.24 & 0.27 & 0.72 \\
\hline & limit & $>100,000$ & $>100,000$ & $>100,000$ \\
\hline & $\max$ & $\begin{array}{l}1.43 \\
@ 99,000\end{array}$ & $\begin{array}{l}2.6 \\
@ 62,000\end{array}$ & $\begin{array}{c}9.0 \\
\text { @ } 99,000\end{array}$ \\
\hline \multirow{3}{*}{$\begin{array}{l}\text { 2-1dku, Concept } 2 \text {, } \\
\text { uranium has } \mathrm{K}_{\mathrm{d}}=0\end{array}$} & $10 \mathrm{~K} y$ & 1.23 & 2.6 & 3.8 \\
\hline & limit & $>100,000$ & $>100,000$ & $>100,000$ \\
\hline & $\max$ & $\begin{array}{l}1.24 \\
@ 11,000\end{array}$ & @ $\begin{array}{l}2.7 \\
58,000\end{array}$ & $\begin{array}{l}7.9 \\
\text { @ } 72,000\end{array}$ \\
\hline
\end{tabular}


DOE/RL-97-69

Rev. 0

Table E-2. Summary of Dose Calculations. Case numbers reflect archival filenames.

\begin{tabular}{|c|c|c|c|c|}
\hline Case & Time & $\begin{array}{c}\text { Beta Dose } \\
(\mathrm{mrem} / \mathrm{y})\end{array}$ & $\begin{array}{l}\text { Alpha } \\
\text { Conc. } \\
\text { (pCi/l) }\end{array}$ & $\begin{array}{l}\text { All- } \\
\text { Pathways } \\
\text { Dose } \\
\text { (mrem/y) } \\
\end{array}$ \\
\hline Performance Objectives & $10 \mathrm{~K} \mathrm{y}$ & 4.0 & 15.0 & 25.0 \\
\hline \multirow{3}{*}{$\begin{array}{l}2-1 \mathrm{dk} 0 \text {, Concept } 2 \\
\text { Tc and Se have } \mathrm{K}_{\mathrm{d}}=0.1 \\
\mathrm{ml} / \mathrm{g}\end{array}$} & $10 \mathrm{Ky}$ & 0.94 & 0.27 & 2.8 \\
\hline & limit & $>100,000$ & $>100,000$ & $>100,000$ \\
\hline & $\max$ & $\begin{array}{c}1.11 \\
@ 21,000\end{array}$ & $\begin{array}{c}2.6 \\
@ 62,000\end{array}$ & $\begin{array}{c}7.9 \\
\text { @ } 72,000\end{array}$ \\
\hline \multirow{3}{*}{$\begin{array}{l}2-1 \mathrm{n} \text {, Concept } 2 \\
\text { Diffusion coefficient } \\
\text { reduced by factor } \\
\text { of } 20\end{array}$} & $10 \mathrm{~K} \mathrm{y}$ & 0.20 & 0.004 & 0.59 \\
\hline & limit & $>100,000$ & $\geq 100,000$ & $>100,000$ \\
\hline & $\max$ & $\begin{array}{c}0.72 \\
@ 65,000\end{array}$ & $\begin{array}{c}1.5 \\
@ 99,000\end{array}$ & $\begin{array}{c}7.4 \\
\text { @ } 75,000 .\end{array}$ \\
\hline \multirow{3}{*}{$\begin{array}{l}\text { 2-2d, Concept } 2 \\
\text { Release rate } \\
\text { independent of time }\end{array}$} & $10 \mathrm{~K} \mathrm{y}$ & 1.11 & 0.24 & 3.3 \\
\hline & limit & $>100,000$ & $>100,000$ & $>100,000$ \\
\hline & $\max$ & $\begin{array}{c}1.15 \\
@ 25,000\end{array}$ & $\begin{array}{c}2.9 \\
@ 12,000\end{array}$ & $\begin{array}{c}8.4 \\
@ 74,000 \\
\end{array}$ \\
\hline \multirow{3}{*}{$\begin{array}{l}2-2 \mathrm{dc}, \text { Concept } 2 \\
\text { Concrete degrades at } \\
2000 \text { years }\end{array}$} & $10 \mathrm{Ky}$ & 1.12 & 0.29 & 3.3 \\
\hline & limit & $>100,000$ & $>100,000$ & $>100,000$ \\
\hline & $\max$ & @ 1.14 & $\begin{array}{c}2.6 \\
\text { @ } 62,000\end{array}$ & $\begin{array}{c}7.9 \\
@ 72,000\end{array}$ \\
\hline \multirow{3}{*}{$\begin{array}{l}\text { 2-3d, Concept } 2 \\
\text { Failed hydraulic } \\
\text { barrier }\end{array}$} & $10 \mathrm{~K} \mathrm{y}$ & 1.10 & 0.27 & 3.3 \\
\hline & $\underline{\text { limit }}$ & $>100,000$ & $>100,000$ & $>100,000$ \\
\hline & $\max$ & $\begin{array}{c}1.11 \\
@ 14,000\end{array}$ & $\begin{array}{c}2.6 \\
\text { @ } 62,000\end{array}$ & $\begin{array}{c}7.8 \\
\text { @ } 72,000\end{array}$ \\
\hline \multirow{3}{*}{$\begin{array}{r}2-4 \mathrm{~d}, \text { Concept } 2 \\
\text { No side barrier }\end{array}$} & $10 \mathrm{~K} \mathrm{y}$ & 1.16 & 0.72 & 3.5 \\
\hline & limit & $>100,000$ & $>100,000$ & $>100,000$ \\
\hline & $\max$ & $\begin{array}{l}1.17 \\
@ 13,000\end{array}$ & $\begin{array}{c}2.6 \\
\text { @ } 59,000\end{array}$ & $\begin{array}{c}7.8 \\
\text { @ } 72,000\end{array}$ \\
\hline
\end{tabular}


DOE/RL-97-69

Rev. 0

Table E-2. Summary of Dose Calculations. Case numbers reflect archival filenames.

\begin{tabular}{|c|c|c|c|c|}
\hline Case & Time & $\begin{array}{l}\text { Beta Dose } \\
(\mathrm{mrem} / \mathrm{y})\end{array}$ & $\begin{array}{l}\text { Alpha } \\
\text { Conc. } \\
\text { (pCi/l) }\end{array}$ & $\begin{array}{c}\text { All- } \\
\text { Pathways } \\
\text { Dose } \\
(\mathrm{mrem} / \mathrm{y})\end{array}$ \\
\hline Performance Objectives & $10 \mathrm{~K} \mathrm{y}$ & 4.0 & 15.0 & 25.0 \\
\hline \multirow{3}{*}{$\begin{array}{l}2-5 \mathrm{~d}, \text { Concept } 2 \\
100 \mathrm{~mm} / \mathrm{y} \text { recharge rate }\end{array}$} & $10 \mathrm{~K} \mathrm{y}$ & 1.37 & 2.0 & 4.2 \\
\hline & limit & $>100,000$ & $>100,000$ & $>100,000$ \\
\hline & $\max$ & $\begin{array}{c}1.37 \\
\text { @ } 9,300\end{array}$ & $\begin{array}{l}2.8 \\
\text { @ } 58,000\end{array}$ & $\begin{array}{l}8.1 \\
071,000\end{array}$ \\
\hline \multirow{3}{*}{$\begin{array}{l}2-6 \mathrm{~d}, \text { Concept } 2 \text {, } \\
0.5 * \text { dispersion coefficient }\end{array}$} & $10 \mathrm{~K} \mathrm{y}$ & 1.09 & 0.20 & 3.2 \\
\hline & limit & $>100,000$ & $>100,000$ & $>100,000$ \\
\hline & $\max$ & @ 1.12 & $\begin{array}{l}2.6 \\
\text { @ } 63,000\end{array}$ & $\begin{array}{c}7.9 \\
\text { @ } 72,000\end{array}$ \\
\hline \multirow{3}{*}{$\begin{array}{l}2-7 \mathrm{~d} \text {, Concept } 2 \\
2 * \text { dispersion coefficient }\end{array}$} & $10 \mathrm{Ky}$ & 1.12 & 0.35 & 3.3 \\
\hline & limit & $>100,000$ & $>100,000$ & $>100,000$ \\
\hline & $\max$ & $\begin{array}{ll} & 1.13 \\
\text { @ } & 15,000\end{array}$ & $\begin{array}{l}2.6 \\
\text { @ } 61,000\end{array}$ & $\begin{array}{c}7.9 \\
@ 72,000\end{array}$ \\
\hline \multirow{3}{*}{$\begin{array}{l}\text { 2-1dCR, Concept } 2 \\
\text { impacts at Columbia } \\
\text { River }\end{array}$} & $10 \mathrm{~K} \mathrm{y}$ & 0.054 & 0.013 & 0.161 \\
\hline & limit & $>100,000^{*}$ & $>100,000$ & $>100,000$ \\
\hline & $\max$ & $\begin{array}{c}0.055 \\
@ 15,000\end{array}$ & $\begin{array}{c}0.126 \\
@ 62,000\end{array}$ & $\begin{array}{l}0.38 \\
\text { @ } 74,000\end{array}$ \\
\hline \multirow{3}{*}{$\begin{array}{l}\text { 2-1deCR, Concept } 2 \\
\text { impacts at Columbia } \\
\text { River, vadose zone } \\
\text { flux extended to } \\
\text { long times }\end{array}$} & $10 \mathrm{~K} \mathrm{y}$ & 0.056 & 0.011 & 0.167 \\
\hline & limit & $>100,000^{*}$ & $>100,000$ & $>100,000$ \\
\hline & $\max$ & $\begin{array}{c}0.25 \\
(13 \mathrm{M}\end{array}$ & $\begin{array}{c}0.34 \\
@ 2.7 \mathrm{M}\end{array}$ & $\begin{array}{c}0.50 \\
@ 51,000\end{array}$ \\
\hline
\end{tabular}


DOE/RL-97-69

Rev. 0

Table E-2. Summary of Dose Calculations. Case numbers reflect archival filenames.

\begin{tabular}{|c|c|c|c|c|}
\hline Case & Time & $\begin{array}{l}\text { Beta Dose } \\
(\mathrm{mrem} / \mathrm{y})\end{array}$ & $\begin{array}{l}\text { Alpha } \\
\text { Conc. } \\
\text { (pCi/l) }\end{array}$ & $\begin{array}{l}\text { All- } \\
\text { Pathways } \\
\text { Dose } \\
\text { (mrem/y) }\end{array}$ \\
\hline Performance Objectives & $10 \mathrm{Ky}$ & 4.0 & 15.0 & 25.0 \\
\hline \multirow{3}{*}{$\begin{array}{l}\text { 3, Unit Cell Model, } \\
\text { Main analysis case }\end{array}$} & $10 \mathrm{k} \mathrm{y}$ & 4.4 & 5.9 & 13.4 \\
\hline & limit & @ 7,200 & @ 46,000 & @ 22,000 \\
\hline & $\max$ & (@) $\begin{array}{l}4.5 \\
15,000\end{array}$ & $\begin{array}{c}15.0 \\
@ 49,000\end{array}$ & $\begin{array}{c}63.0 \\
@ 50,000\end{array}$ \\
\hline \multirow{3}{*}{$\begin{array}{l}\text { 32, Unit Cell Model, } \\
\text { Concept } 2\end{array}$} & $10 \mathrm{~K} \mathrm{y}$ & 1.23 & 1.66 & 3.8 \\
\hline & limit & $>100,000$ & $>100,000$ & $>100,000$ \\
\hline & $\max$ & $\begin{array}{l}1.26 \\
@ 15,000\end{array}$ & $\begin{array}{l}4.3 \\
\text { @ } 49,000\end{array}$ & $\begin{array}{ll} & 17.8 \\
@ & 50,000\end{array}$ \\
\hline \multirow{3}{*}{$\begin{array}{l}\text { 3a, Unit Cell Model, } \\
3.0 \mathrm{~mm} / \mathrm{y} \text { recharge rate }\end{array}$} & $10 \mathrm{Ky}$ & 4.4 & 8.6 & 6.2 \\
\hline & limit & @ 4,600 & (@) 46,000 & $@ 22,000$ \\
\hline & $\max$ & $\begin{array}{l}4.5 \\
@ 14,000\end{array}$ & $\begin{array}{l}15.0 \\
\text { @ } 49,000\end{array}$ & $\begin{array}{ll} & 63.0 \\
\text { @ } & 50,000 \\
\end{array}$ \\
\hline \multirow{3}{*}{$\begin{array}{l}\text { 3b, Unit Cell Model, } \\
3.0 \mathrm{~mm} / \mathrm{y} \text { recharge rate with initial } \\
\text { drainage }\end{array}$} & $10 \mathrm{~K} \mathrm{y}$ & 4.4 & 5.9 & 13.4 \\
\hline & limit & @ 7,200 & $@ 49,000$ & @22,000 \\
\hline & $\max$ & $\begin{array}{l}4.5 \\
@ 15,000\end{array}$ & $\begin{array}{l}15.0 \\
\text { @ } 49,000\end{array}$ & $\begin{array}{c}63.0 \\
@ 50,000\end{array}$ \\
\hline \multirow{3}{*}{$\begin{array}{l}\text { 3c, Unit Cell Model, } \\
1.0 \mathrm{~mm} / \mathrm{y} \text { recharge rate }\end{array}$} & $10 \mathrm{~K} \mathrm{y}$ & 3.5 & 0.19 & 10.3 \\
\hline & limit & $@ 16,000$ & $>100,000$ & $>100,000$ \\
\hline & $\max$ & $\begin{array}{c}4.1 \\
\text { @ } 25,000\end{array}$ & $\begin{array}{c}10.0 \\
98,000\end{array}$ & $\begin{array}{l}21.0 \\
\text { @ } 96,000\end{array}$ \\
\hline \multirow{3}{*}{$\begin{array}{l}\text { 3d, Unit Cell Model, } \\
0.1 \mathrm{~mm} / \mathrm{y} \text { recharge rate }\end{array}$} & $10 \mathrm{Ky}$ & $<0.001$ & $<0.001$ & 0.001 \\
\hline & limit & $>100,000$ & $>100,000$ & $>100,000$ \\
\hline & $\max$ & $\begin{array}{l}2.5 \\
100,000\end{array}$ & $\begin{array}{l}0.33 \\
100,000\end{array}$ & $\begin{array}{c}7.7 \\
100,000\end{array}$ \\
\hline
\end{tabular}


DOE/RL-97-69

Rev. 0

Table E-2. Summary of Dose Calculations. Case numbers reflect archival filenames.

\begin{tabular}{|c|c|c|c|c|}
\hline Case & Time & $\begin{array}{l}\text { Beta Dose } \\
(\mathrm{mrem} / \mathrm{y})\end{array}$ & $\begin{array}{l}\text { Alpha } \\
\text { Conc. } \\
(\mathrm{pCi} / 1)\end{array}$ & $\begin{array}{l}\text { All- } \\
\text { Pathways } \\
\text { Dose } \\
\text { (mrem/y) }\end{array}$ \\
\hline Performance Objectives & $10 \mathrm{~K} \mathrm{y}$ & 4.0 & 15.0 & 25.0 \\
\hline \multirow{3}{*}{$\begin{array}{l}\text { 3e, Unit Cell Model, } \\
10 . \mathrm{cm} / \mathrm{y} \text { recharge rate }\end{array}$} & $10 \mathrm{~K} \mathrm{y}$ & 4.8 & 28.0 & 176.0 \\
\hline & limit & @ 192 & @ 1,100 & @ 800 \\
\hline & $\max$ & @ 5.0 .200 & $\begin{array}{c}30.0 \\
\text { @ } 4,200\end{array}$ & $\begin{array}{c}194.0 \\
@ 4,200\end{array}$ \\
\hline \multirow{3}{*}{$\begin{array}{l}\text { 3f, Unit Cell Model, } \\
\text { entire vadose zone has properties. } \\
\text { of sandy sequence }\end{array}$} & $10 \mathrm{~K} \mathrm{y}$ & 4.6 & 9.9 & 18.8. \\
\hline & limit & @ 3,000 & @ 18,000 & @ 11,800 \\
\hline & $\max$ & $\begin{array}{l}4.6 \\
@ 9,500\end{array}$ & $\begin{array}{c}19.3 \\
@ 32,000\end{array}$ & $\begin{array}{c}99.0 \\
@ 33,000\end{array}$ \\
\hline \multirow{3}{*}{$\begin{array}{l}\text { 3g, Unit Cell Model, } \\
\text { Filler material } \\
\text { between canisters is } \\
\text { Hanford formation sand }\end{array}$} & $10 \mathrm{~K} \mathrm{y}$ & 4.4 & 5.6 & 13.3 \\
\hline & limit & $@ 7,400$ & $>100,000$ & @ 23,000 \\
\hline & $\max$ & $\begin{array}{l}4.5 \\
@ 15,000\end{array}$ & $\begin{array}{c}14.9 \\
@ 50,000\end{array}$ & $\begin{array}{l}61.0 \\
\text { @ } 51,000 \\
\end{array}$ \\
\hline \multirow{3}{*}{$\begin{array}{l}\text { 3h, Unit Cell Model, } \\
\text { Lower Hanford gravel } \\
\text { is } 50 \text { meters thick }\end{array}$} & $10 \mathrm{Ky}$ & 4.1 & 4.2 & 12.5 \\
\hline & limit & @ 9,200 & $>100,000$ & @26,000 \\
\hline & $\max$ & $\begin{array}{ll} & 4.4 \\
0 & 17,000\end{array}$ & $\begin{array}{c}14.2 \\
\text { @ } 54,000\end{array}$ & $\begin{array}{l}55.0 \\
\text { @ } 55,000\end{array}$ \\
\hline \multirow{3}{*}{$\begin{array}{l}\text { 3i, Unit Cell Model, } \\
\text { Water table at } 110 \text { meters }\end{array}$} & $10 \mathrm{~K} \mathrm{y}$ & 4.2 & 4.4 & 12.7 \\
\hline & limit & @ 8,600 & $>100,000$ & @ 26,000 \\
\hline & $\max$ & $\begin{array}{l}4.4 \\
\text { @ } 16,000\end{array}$ & $\begin{array}{c}14.2 \\
\text { @ } 54,000\end{array}$ & $\begin{array}{c}56.0 \\
@ 55,000\end{array}$ \\
\hline \multirow{3}{*}{$\begin{array}{l}\text { 3j, Unit Cell Model, } \\
\text { water table at } 96 \\
\text { meters }\end{array}$} & $10 \mathrm{~K} \mathrm{y}$ & 4.5 & 7.7 & 14.2 \\
\hline & limit & @ 6,700 & @ 29,000 & @ 17,000 \\
\hline & $\max$ & $\begin{array}{ll} & 4.5 \\
\text { @ } 13,000\end{array}$ & $\begin{array}{c}16.5 \\
@ 42,000\end{array}$ & $\begin{array}{c}75.0 \\
\text { @ } 42,000\end{array}$ \\
\hline
\end{tabular}


DOE/RL-97-69

Rev. 0

Table E-2. Summary of Dose Calculations. Case numbers refiect archival filenames.

\begin{tabular}{|c|c|c|c|c|}
\hline Case & Time & $\begin{array}{l}\text { Beta Dose } \\
\text { (mrem/y) }\end{array}$ & $\begin{array}{l}\text { Alpha } \\
\text { Conc. } \\
\text { (pCi/l) }\end{array}$ & $\begin{array}{c}\text { All- } \\
\text { Pathways } \\
\text { Dose } \\
\text { (mrem/y) }\end{array}$ \\
\hline Performance Objectives & $10 \mathrm{~K} \mathrm{y}$ & 4.0 & 15.0 & 25.0 \\
\hline \multirow{3}{*}{$\begin{array}{l}\text { 3k, Unit Cell Model, } \\
\text { Initial moisture at } 0.2 \text { in for } \\
\text { construction materials }\end{array}$} & $10 \mathrm{~K} \mathrm{y}$ & 4.4 & 5.9 & 13.4 \\
\hline & limit & $@ 7,200$ & $@ 46,000$ & @ 22,000 \\
\hline & $\max$ & @ 15,000 & $\begin{array}{l}15.0 \\
\text { @ } 49,000\end{array}$ & $\begin{array}{l}63.0 \\
\text { @ } 50,000\end{array}$ \\
\hline \multirow{3}{*}{$\begin{array}{l}\text { 31, Unit Cell Model } \\
\text { Initial moisture is residual in } \\
\text { construction materials }\end{array}$} & $10 \mathrm{~K} \mathrm{y}$ & 4.4 & 5.9 & 13.4 \\
\hline & limit & $@ 7,200$ & $@ 46,000$ & @22,000 \\
\hline & $\max$ & $\begin{array}{l}4.5 \\
@ 15,000\end{array}$ & $\begin{array}{c}15.0 \\
49,000\end{array}$ & $\begin{array}{c}63.0 \\
@ 50,000\end{array}$ \\
\hline \multirow{3}{*}{$\begin{array}{l}\text { 3m, Unit Cell Model } \\
\text { canisters rotated by } 90 \text { degrees }\end{array}$} & $10 \mathrm{~K} \mathrm{y}$ & 4.4 & 5.7 & 13.4 \\
\hline & limit & $@ 5,200$ & $>100,000$ & @ 22,000 \\
\hline & $\max$ & $\begin{array}{l}4.5 \\
\text { @ } 15,000\end{array}$ & $\begin{array}{l}15.0 \\
050,000\end{array}$ & $\begin{array}{l}62.0 \\
@ 50,000\end{array}$ \\
\hline \multirow{3}{*}{$\begin{array}{l}\text { 3n, Unit Cell Model } \\
\text { doubled number of lateral nodes }\end{array}$} & $10 \mathrm{~K} \mathrm{y}$ & 4.4 & 5.9 & 13.4 \\
\hline & limit & @ 7,200 & $@ 46,000$ & @ 22,000 \\
\hline & $\max$ & $\begin{array}{l}4.5 \\
@ 15,000\end{array}$ & $\begin{array}{l}15.0 \\
49,000\end{array}$ & $\begin{array}{l}63.0 \\
50,000\end{array}$ \\
\hline \multirow{3}{*}{$\begin{array}{l}\text { 3o, Unit Cell Model, } \\
\text { waste form has hydraulic } \\
\text { properties of sand }\end{array}$} & $10 \mathrm{~K} \mathrm{y}$ & 4.4 & 5.8 & 13.4 \\
\hline & limit & @ 7,200 & @ 46,000 & $@ 22,000$ \\
\hline & $\max$ & $\begin{array}{l}4.5 \\
\text { @ } 15,000\end{array}$ & $\begin{array}{l}15.0 \\
\text { @ } 49,000\end{array}$ & $\begin{array}{l}63.0 \\
50,000\end{array}$ \\
\hline
\end{tabular}


DOE/RL-97-69

Rev. 0

Table E-2. Summary of Dose Calculations. Case numbers reflect archival filenames.

\begin{tabular}{|c|c|c|c|c|}
\hline Case & Time & $\begin{array}{c}\text { Beta Dose } \\
\text { (mrem/y) }\end{array}$ & $\begin{array}{l}\text { Alpha } \\
\text { Conc. } \\
\text { (pCi/l) }\end{array}$ & $\begin{array}{c}\text { All- } \\
\text { Pathways } \\
\text { Dose } \\
(\mathrm{mrem} / \mathrm{y})\end{array}$ \\
\hline Performance Objectives & $10 \mathrm{~K} \mathrm{y}$ & 4.0 & 15.0 & 25.0 \\
\hline \multirow{3}{*}{$\begin{array}{l}\text { 3p, Unit Cell Model, } \\
\text { diffusion coefficient } \\
\text { reduced to } 10^{-8} \mathrm{~cm}^{2} / \mathrm{s}\end{array}$} & $10 \mathrm{~K} \mathrm{y}$ & 4.4 & $5.9^{\circ}$ & 13.4 \\
\hline & limit & @ 7,200 & @ 46,000 & @ 22,000 \\
\hline & $\max$ & $\begin{array}{c}4.5 \\
\text { @ } 15,000\end{array}$ & $\begin{array}{l}15.0 \\
\text { @ } 49,000\end{array}$ & $\begin{array}{c}63.0 \\
@ 50,000\end{array}$ \\
\hline \multirow{3}{*}{$\begin{array}{l}\text { 3q, Unit Cell Model, } \\
\text { doubled dispersion } \\
\text { coefficient }\end{array}$} & $10 \mathrm{Ky}$ & 4.4 & 6.2 & 14.4 \\
\hline & limit & @ 7,100 & @ 44,000 & $@ 17,000$ \\
\hline & $\max$ & $\begin{array}{l}4.5 \\
@ 15,000\end{array}$ & $\begin{array}{c}15.0 \\
@ 45,000\end{array}$ & $\begin{array}{c}62.0 \\
@ 46,000\end{array}$ \\
\hline \multirow{3}{*}{$\begin{array}{l}\text { 3r, Unit Cell Model, } \\
\text { halved dispersion } \\
\text { coefficient }\end{array}$} & $10 \mathrm{Ky}$ & 4.3 & 5.7 & 13.3 \\
\hline & limit & @ 7,400 & @ 45,000 & @ 26,000 \\
\hline & $\max$ & $\begin{array}{ll} & 4.5 \\
@ & 14,000\end{array}$ & @ $\begin{array}{c}15.2 \\
52,000\end{array}$ & $\begin{array}{l}65.0 \\
\text { @ } 52,000\end{array}$ \\
\hline \multirow{3}{*}{$\begin{array}{l}\text { 3s, Unit Cell Model, } \\
\text { One-tenth dispersion } \\
\text { coefficient }\end{array}$} & $10 \mathrm{~K} \mathrm{y}$ & 4.3 & 5.6 & 13.3 \\
\hline & limit & (a) 7,700 & @ 45,000 & @ 30,000 \\
\hline & $\max$ & $\begin{array}{l}4.5 \\
\text { @ } 14,000\end{array}$ & $\begin{array}{c}15.6 \\
@ 53,000\end{array}$ & $\begin{array}{c}69.0 \\
\text { @3,000 }\end{array}$ \\
\hline \multirow{3}{*}{$\begin{array}{c}\text { 3tu0, Unit Cell Model, } \\
\text { U has } K_{d}=0 \\
\text { everywhere }\end{array}$} & $10 \mathrm{~K} \mathrm{y}$ & 4.6 & 9.7 & 14.2 \\
\hline & limit & @ 5,800 & @22,000 & @ 46,000 \\
\hline & $\max$ & $\begin{array}{c}4.6 \\
\text { @ } 10,800\end{array}$ & $\begin{array}{c}15.0 \\
@ 48,000\end{array}$ & $\begin{array}{ll} & 63.0 \\
\text { @ } 50,000\end{array}$ \\
\hline
\end{tabular}


DOE/RL-97-69

Rev. 0

Table E-2. Summary of Dose Calculations. Case numbers reflect archival filenames.

\begin{tabular}{|c|c|c|c|c|}
\hline Case & Time & $\begin{array}{l}\text { Beta Dose } \\
\text { (mrem/y) }\end{array}$ & $\begin{array}{l}\text { Alpha } \\
\text { Conc. } \\
(\mathrm{pCi} / 1)\end{array}$ & $\begin{array}{c}\text { All- } \\
\text { Pathways } \\
\text { Dose } \\
\text { (mrem/y) } \\
\end{array}$ \\
\hline Performance Objectives & $10 \mathrm{~K} \mathrm{y}$ & 4.0 & 15.0 & 25.0 \\
\hline \multirow{3}{*}{$\begin{array}{l}\text { 3t, Unit Cell Model, } \\
\text { U has } K_{d}=0 \text { everywhere } \\
\text { but in floor where } K_{d}=100 \mathrm{mg} / \ell\end{array}$} & $10 \mathrm{Ky}$ & 4.2 & 1.6 & 12.6 \\
\hline & limit & @ 4,600 & $>100,000$ & @ 22,000 \\
\hline & $\max$ & $\begin{array}{c}4.2 \\
@ 7,700\end{array}$ & $\begin{array}{c}12.3 \\
@ 59,000\end{array}$ & $\begin{array}{c}62.0 \\
@ 50,000\end{array}$ \\
\hline \multirow{3}{*}{$\begin{array}{l}\text { 3ttc, Unit Cell Model, } \\
\mathrm{Tc} \text { has } \mathrm{K}_{\mathrm{d}}=100 \mathrm{mg} / \mathrm{in} \text { floor }\end{array}$} & $10 \mathrm{Ky}$ & 1.72 & 6.3 & 4.7 \\
\hline & limit & $>100,000$ & @ 46,000 & @ 24,000 \\
\hline & $\max$ & $\begin{array}{c}3.5 \\
\text { @ } 100,000\end{array}$ & $\begin{array}{c}15.0 \\
\text { @ } 49,000\end{array}$ & $\begin{array}{c}60.0 \\
@ 51,000\end{array}$ \\
\hline \multirow{3}{*}{$\begin{array}{l}\text { 3t0, Unit Cell Model, } \\
\text { Se and } \mathrm{Tc} \text { have } \mathrm{K}_{\mathrm{d}}=100 \mathrm{mg} / \mathrm{l} \text { in } \\
\text { floor }\end{array}$} & $10 \mathrm{Ky}$ & 0.98 & 6.3 & 3.4 \\
\hline & limit & $>100,000$ & @ 46,000 & $@ 25,000$ \\
\hline & $\max$ & $\begin{array}{c}3.4 . \\
@ .100,000\end{array}$ & $\begin{array}{c}15.0 \\
@ 49,000\end{array}$ & $\begin{array}{c}60.0 \\
@ 51,000\end{array}$ \\
\hline \multirow{3}{*}{$\begin{array}{l}\text { 3u, Unit Cell Model, } \\
\text { release rates proportional to } \\
\text { surface area }\end{array}$} & $10 \mathrm{Ky}$ & 4.3 & 5.8 & 13.1 \\
\hline & limit & @ 7,500 & $>100,000$ & @ 22,000 \\
\hline & $\max$ & $\begin{array}{c}4.3 \\
@ 13,000\end{array}$ & $\begin{array}{c}13.8 \\
\text { @ } 45,000\end{array}$ & $\begin{array}{c}59.0 \\
\text { @ } 48,000\end{array}$ \\
\hline \multirow{3}{*}{$\begin{array}{l}\text { 3v, Unit Cell Model } \\
\text { release rates as calculated by } \\
\text { AREST-CT }\end{array}$} & $10 \mathrm{Ky}$ & 0.53 & 0.63 & 1.54 \\
\hline & limit & $>100,000$ & $>100,000$ & $>100,000$ \\
\hline & $\max$ & $\begin{array}{c}0.56 \\
\text { @ } 14,000\end{array}$ & $\begin{array}{c}1.49 \\
@ 32,000\end{array}$ & $\begin{array}{c}6.0 \\
@ 47,000\end{array}$ \\
\hline
\end{tabular}


DOE/RL-97-69

Rev. 0

Table E-2. Summary of Dose Calculations. Case numbers reflect archival filenames.

\begin{tabular}{|c|c|c|c|c|}
\hline Case & Time & $\begin{array}{c}\text { Beta Dose } \\
(\mathrm{mrem} / \mathrm{y})\end{array}$ & $\begin{array}{l}\text { Alpha } \\
\text { Conc. } \\
(\mathrm{pCi} / \mathrm{l})\end{array}$ & $\begin{array}{l}\text { All- } \\
\text { Pathways } \\
\text { Dose } \\
\text { (mrem/y) }\end{array}$ \\
\hline Performance Objectives & $10 \mathrm{~K} \mathrm{y}$ & 4.0 & 15.0 & 25.0 \\
\hline \multirow{3}{*}{$\begin{array}{l}\text { 3vxi, Unit Cell Model } \\
\text { release rates as calculated by } \\
\text { AREST-CT, but no ion exchange } \\
\text { for TC }\end{array}$} & $10 \mathrm{~K}$ & 0.20 & 0.63 & 0.47 \\
\hline & limit & $>100,000$ & $>100,000$ & $>100,000$ \\
\hline & $\max$ & $\begin{array}{c}0.30 \\
@ 100,000\end{array}$ & $\begin{array}{c}1.49 \\
@ 32,000\end{array}$ & $\begin{array}{c}5.4 \\
\text { @ } 48,000\end{array}$ \\
\hline \multirow{3}{*}{$\begin{array}{l}\text { 3vpor, Unit Cell Model, } \\
\text { release rates as calculated by } \\
\text { AREST-CT, but increased pore } \\
\text { velocity }\end{array}$} & $10 \mathrm{Ky}$ & 0.97 & 0.63 & 3.0 \\
\hline & limit & $>100,000$ & $>100,000$ & $>100,000$ \\
\hline & $\max$ & $\begin{array}{c}1.18 \\
@ 20,000\end{array}$ & $\begin{array}{c}1.49 \\
\text { @ } 32 ; 000\end{array}$ & $\begin{array}{c}7.7 \\
@ 44,000\end{array}$ \\
\hline
\end{tabular}

* Limit for beta/photon drinking water dose at Columbia River is $1 \mathrm{mrem} / \mathrm{y}$. 
DOE/RL-97-69

Rev. 0

\section{E.5 WASTE FORM RELEASE CALCULATIONS}

\section{E.5.1 Simulation Domain and Physical Conditions}

Figure E-8. Glass Simulation Domain.

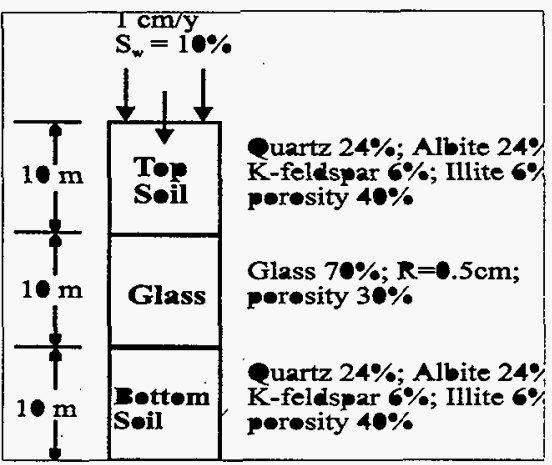

The proposed disposal facility will be located in the vadose zone; it will be about 10 meters high and about 10 meters beneath the ground. Average pore-water velocity in the vadose zone is $1 \mathrm{~cm} /$ year, with a water saturation of 10 percent (Kline 1995b). The average temperature is about $14^{\circ} \mathrm{C}$. The surrounding soil contains $24 \%$ quartz, $24 \%$ high albite, $6 \% \mathrm{~K}$-feldspar, and $6 \%$ illite, with a porosity of 40 percent (Serne 1993). The glass is assumed to be spherical with a radius of $0.5 \mathrm{~cm}$, and it occupies 70 percent of the volume of the waste vault. The facility is modeled as a one-dimensional column as shown in Figure E-8.

\section{E.5.2 Glass Composition and Dissolution Kinetics}

The stoichiometric coefficients for the radioactive elements given in reaction (C.10) of Appendix C.2.4 were calculated from the total waste inventory, assuming a uniform glass composition is produced totaling $210,000 \mathrm{~m}^{3}$ (Schmittroth $1995 \mathrm{~b}$ ). For historical reasons, the glass waste shapes were taken as marbles with a radius of $0.5 \mathrm{~cm}$.

\section{E.5.3 Key Results}

Figure $\mathrm{E}-9$ shows the calculated $\mathrm{pH}$ in the vault as a function of time and space where the ion-exchange reaction [reaction (C.10)] of Appendex C.2.4 was not considered. Peak pH values occur at the edges of the vault because this is. where the glass reaction rate is largest, as is shown in Figure E-10. Glass reaction rates are largest at the interface between the vault and the surrounding soil because diffusive and advective mass transfer lowers the concentration of silicon and other glass components in the aqueous phase. Consequently, the chemical affinity for the network dissolution reaction [reaction (C.10)] is larger, resulting in a faster dissolution kinetics. Figure E-10 shows the complex time and spatial dependence of the glass reaction rate that results from the complex interaction between mass transport and chemical reactions. In general, however, the calculations indicate an overall low rate of glass corrosion, as much as three or four orders of magnitude lower than the forward rate of reaction for LD6-5412 glass at this temperature and average $\mathrm{pH}$ in the vault. 
DOE/RL-97-69

Rev. 0

Figure E-9. Computed pH when Ion Exchange Reaction is NOT Considered.

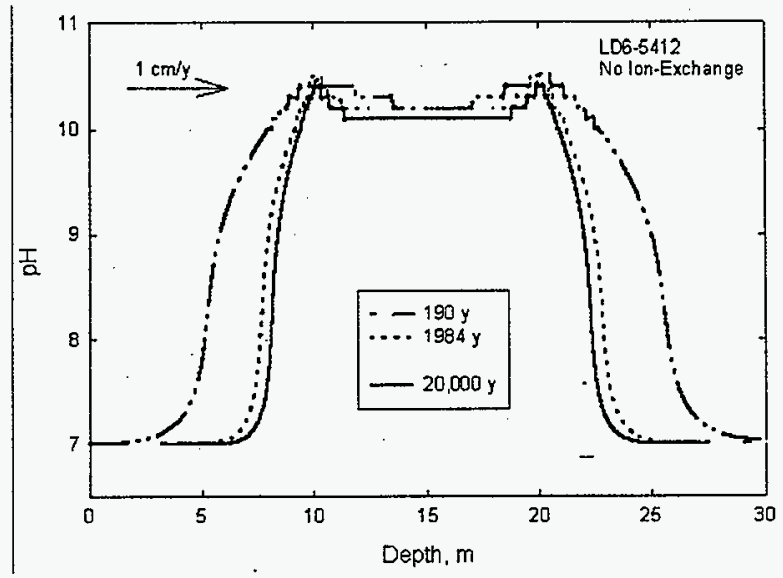

Figure E-10. Glass Dissolution Rate as a Function of Time and Space when NOT Considering Ion Exchange Reaction.

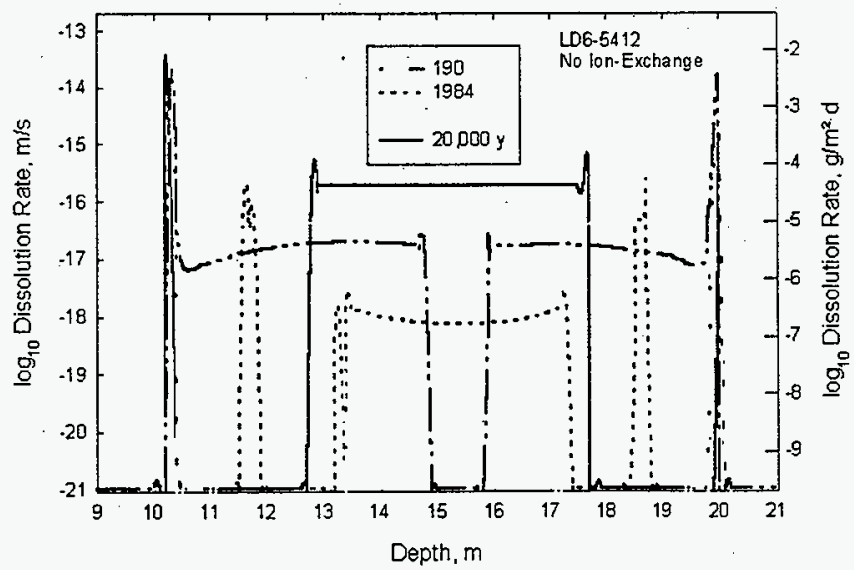


Figure E-11 shows the calculated ${ }^{99} \mathrm{Tc}$ concentrations as a function of time and space. Unlike the complex time and spatial dependence found for the glass corrosion rate, the ${ }^{99} \mathrm{Tc}$ concentrations appear smooth and regular, with only a slight peak near the vault edges where the glass reaction rate is highest. The smooth spatial profile for ${ }^{99} \mathrm{Tc}$ results because under the oxidizing conditions in the vault, ${ }^{99} \mathrm{Tc}$ is highly soluble as a pertechnitate $\left(\mathrm{TcO}_{4}\right)$ anion. With no solid phase precipitation to affect the concentration profile, the radionuclide is subject to dispersion by diffusion and advection, which tends to smooth concentration gradients.

The simulation results presented in Figures E-8 through E-11 ignored the ion-exchange reaction [reaction (C.11)]. Including this reaction dramatically affects the computed $\mathrm{pH}$ profile in the vault, as illustrated in Figure E-12. With ion exchange included, the computed $\mathrm{pH}$ in the vault rises to over 12 , nearly two $\mathrm{pH}$ units higher than in the simulations without the reaction (Figure E-9). LD6-5412 glass is less stable at $\mathrm{pH}>12$; this is reflected by a marked increase in the calculated glass corrosion rate, as shown in Figure 4-22. With ion exchange included in the simulation, the overall rate of glass corrosion in the vault increases by several orders of magnitude. Although not shown here, the increase in glass corrosion rate increases proportionately the release rate of an element such as ${ }^{99} \mathrm{Tc}$, which is highly soluble under these conditions. The release rates of less soluble radionuclides can increase or even decrease depending on whether the solubility of any secondary phases that contain the elements increase or decrease at the higher $\mathrm{pH}$.

The large increase in the computed glass corrosion rate in the vault from the ionexchange reaction mechanism is a clear example in which a computer simulation has identified a significant performance assessment issue that is not observable from laboratory test results. In typical water-saturated, low-temperature, batch tests with LD6-5412 glass, the sodium ionexchange reaction was identified as a minor secondary reaction that contributed to an enhanced rate of sodium release as compared with the other major glass components, including boron and silicon. The importance of this reaction mechanism to the overall performance of the disposal system was only revealed through computer simulations that properly couple chemical reactions and transport. Now that the importance of this mechanism has been identified, new glasses can be formulated that either eliminate or minimize the sodium ion exchange, and thus significantly improve the overall performance of the disposal system.

In contrast with the results from the base analysis case where a fixed dissolution rate for the LAW glass is assumed, the AREST-CT simulations show that increasing pore water velocity through the vault linearly increases the release rate of ${ }^{99} \mathrm{Tc}$ (Figure E-13), especially when ion exchange is included. This occurs because the higher flux of fresh water into the vault reduces the ion activity product $(Q)$ causing the glass to dissolve faster in accordance with the dissolution rate law given in (C.2.3, Equation 9). Increasing the relative water content while holding the pore water velocity constant at $1 \mathrm{~cm} / \mathrm{y}$ also increases the release rate of ${ }^{99} \mathrm{Tc}$ (Figure E-12). Again the effect is much more pronounced when ion exchange is included. Increasing the water content at a fixed pore velocity again increases the total volumetric influx of fresh water entering the vault, which increases the glass dissolution rate to compensate. For a particular unsaturated porous medium, increases in water content would be accompanied by increases in pore water velocity, which would make the increase in ${ }^{99} \mathrm{Tc}$ flux even more 
DOE/RL-97-69

Rev. 0

pronounced.

Figure E-11. Calculated Total Aqueous ${ }^{99} \mathrm{Tc}$ Concentration as a Function of Time and Space.

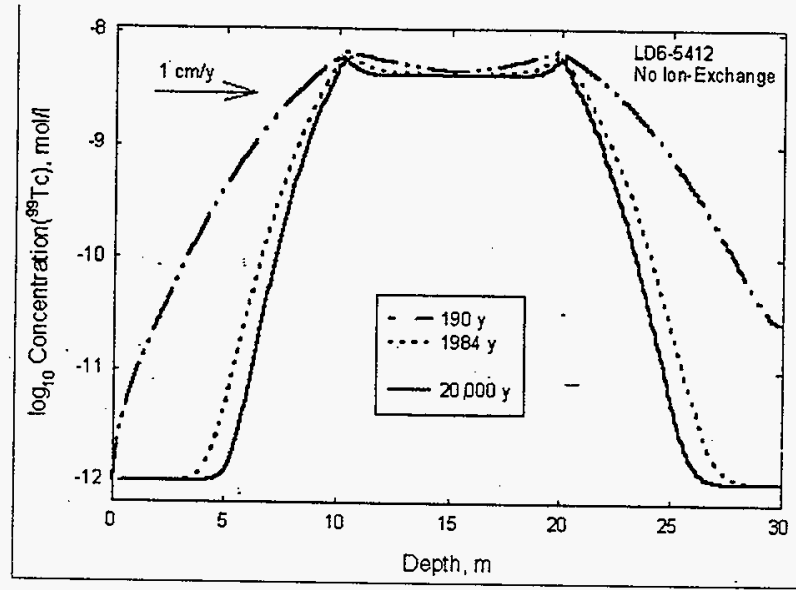

Figure E-12. Computed pH in Disposal Vault When Ion Exchange Is Included.

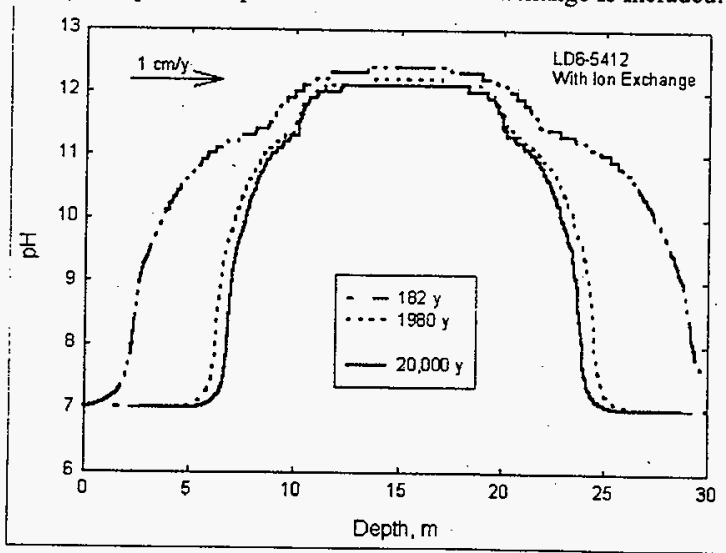

$E-43$ 


\section{DOE/RL-97-69}

Rev, 0

Figure E-13. Effect of Varying Pore Water Velocity on Normalized Flux of ${ }^{99} \mathrm{Tc}$ to the Vadose Zone. Equilibrium with atmospheric $\mathrm{CO}_{2}$ is assumed.

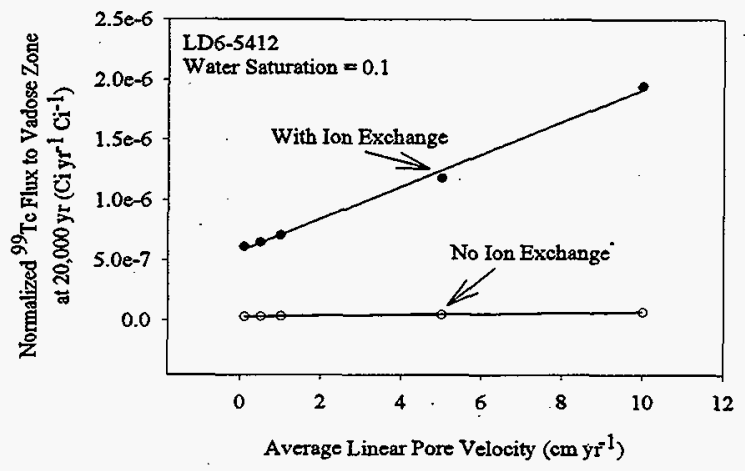


DOE/RL-97-69

Rev. 0

\section{APPENDIX F \\ COMMENTS BY REVIEWERS}

This document builds heavily on the data, methods, and results of the Hanford LowLevel Yank Waste Interim Performance Assessment (Mann 1996a). The interim performance assessment document was sent to various groups and organizations. Written comments coming from outside of the tank waste programs are included in this appendix along with the responses to those comment).

\section{F.1 EXTERNAL REVIEW BOARD}

With the concurrence of the Department of Energy, an external review board was appointed to review the interim performance assessment (Mann 1996a) and the performance assessment activity in general.

\section{F.1.1 Members}

The members of the board were

$\begin{array}{ll}\text { - } & \text { Lynn Gelhar } \\ \text { - } & \text { Louis Kovach } \\ \text { - } & \text { Bodd Martin Prindle } \\ \text { - } & \text { Elmer Wilhite } \\ & \text { George Williamson (secretary). }\end{array}$

Short biographies are contained in the Appendix A of their report which is reproduced in Section F.1.3.

\section{F.1.2 Board Materials}

The board was supplied with the published version of the Interim Performance Assessment (Mann 1996a), the data on which the performance assessment was based (Mann 1995a), and the definition of the analyses cases (Mann 1995b). The board was also sent the introductory sections of the draft statements of work for FY 1998 through 2003 (the final version being published as Mann 1997).

The board met in Richland, Washington on April 15 and 16. They had previously submitted their comments on the Interim Performance Assessment to the secretary of the board. At the meeting, presentations were made to the board concerning how the Interim Performance Assessment was generated and what were the plans for the performance assessment activity. The performance assessment team responded (see Section F.1.4) to the questions posed by the board. The report of the board is reproduced in the next section. 
DOE/RL-97-69

Rev. 0

\section{F.1.3 Report of the External Review Board}

The report is reproduced as provided by the review board with the exception of page numbers and some minor formatting changes. Comments in curly brackets \{\} are not in the original report, but are included to aid the reader. A number in a curly bracket is a pointer to the response found in Section F.1.4. Section numbers in straight brackets [] refer to the section number in this performance assessment as the structure of the current document has slightly changed from the interim performance assessment.

\section{COMMENTS AND FINDINGS FROM THE EXTERNAL REVIEW PANEL for the \\ HANFORD LOW-LEVEL TANK WASTE INTERIM PERFORMANCE ASSESSMENT \\ May 1997 \\ External Performance Assessment Review Panel}

1.0 PURPOSE

TABLE OF CONTENTS

2.0 BACKGROUND

3.0 REVIEW PANEL

4.0 DISCUSSION

4.1 PERFORMANCE OBJECTIVES

4.2 PERFORMANCE SCENARIOS

4.3 RADIONUCLIDE INVENTORY

4.4 WASTE FORM PROPERTIES

4.4.1 Glass Compositions

4.4:2 Glass Shape

4.4.3 Void Space Filler

4.4.4 Water-conditioning Layer of Crushed Glass

4.4.5 Glass LD6-5412

4.4.6 Single-pass Flow-through and Pressurized

Unsaturated Flow

4.5 DISPOSAL SYSTEM DESIGN AND LOCATION

- 4.6 GEOTECHNICAL ASPECTS

4.7 INTERACTION WITH OTHER HANFORD SITES

4.8 DOE PA APPROVAL

4.9 PUBLIC ACCEPTANCE

4.10 PROGRAMMATIC/GENERAL COMMENTS

5.0 CONCLUSIONS

APPENDIX A HANFORD LOW-LEVEL TANK WASTE PA REVIEW PANEL MEMBERS

APPENDIX B COMMENTS ON GEOTECHNICAL ASPECTS OF THE INTERIM PA APPENDIX C SPECIFIC COMMENTS ON INTERIM PA AND SUPPORTING DOCUMENTS

APPENDIX D QUESTIONS AND ANSWERS 
DOE/RL-97-69

Rev. 0

COMMENTS AND FINDINGS FROM THE EXTERNAL REVIEW PANEL for the

HANFORD LOW-LEVEL TANK WASTE

INTERIM PERFORMANCE ASSESSMENT

\subsection{PURPOSE}

This report will document the results of the external panel review of performance assessment (PA) documentation and a workshop conducted on April 15-16, 1997, in Richland, Washington, regarding the treatment and disposal of Hanford low-level tank waste. The panel conducted the review both from a technical and management point of view to provide comments, and recommendations for efficient and cost-effective completion of the PA for disposal of tank waste. Documentation reviewed by the panel included the document Hanford Low-Level Tank Waste Interim Performance Assessment (referred to as interim PA) (WHC-EP-0884), and its major supporting documents, Data Packages for the Hanford Low-Level Tank Waste Interim Performance Assessment (referred to as Data Packages) (WHC-SD-WM-RPT-166), and Definition of the Base Analysis Case of the Interim Performance Assessment (WHC-SD-WM-RPT-200). Also reviewed was the document, Statements of Work for FY 1998 to 2003 for the Hanford Low-Level Tank Waste Performance Assessment Activity, dated March $31,1997$.

\subsection{BACKGROUND}

Over the past 50 years, radioactive and mixed wastes from the production of national defense materials have been stored on the Hanford Site, primarily in below-grade single- and double-shell tanks in the 200 Areas. During the late 1980 s and early 1990s, the U.S. Department of Energy (DOE) initiated significant mission changes to proceed with plans to permanently immobilize and dispose of the low-activity fraction of these tank wastes in near-surface low-level tank waste disposal facilities. Current planning envisions the production of immobilized low-activity wastes (LAW) by private companies under contract to the DOE followed by storage and disposal of LAW by the DOE on the Hanford Site in the 200 Area Plateau. Over 200,000 cubic meters of LAW will be disposed of under this plan during the next two to three decades.

DOE Order 5820.2A, Management of Radioactive Wastes, requires that a PA be written and approved before commencement of disposal activities. 


\subsection{REVIEW PANEL}

An independent external review panel was contracted by Lockheed Martin Hanford Corporation consisting of the following six individuals. Additional background information is provided in Appendix A.

Lynn Gelhar - Dr. Gelhar of the Massachusetts Institute of Technology is an internationally-recognized expert in groundwater modeling.

Louis Kovach - Dr. Kovach is a private consultant on nuclear waste management.

Todd Martin - Mr. Martin of the Hanford Education Action League serves on the Hanford Advisory Board.

Bill Prindle - Dr. Prindle is a private consultant and recognized expert on glasses and vitrification.

Elmer Wilhite - Mr. Wilhite is an advisory scientist at the Savannah River Site and serves as chairman of the U.S.. Department of Energy - Headquarters peer review panel.

George Williamson - Mr. Williamson, the former Hanford Low-Level Waste Disposal Project manager, serves as the secretary of the review panel.

\subsection{DISCUSSION}

Based on the review of documentation provided to panel members and the workshop held in Richland, Washington, on April 15-16, 1997, the panel generally agrees that the interim PA addresses many of the issues important in the quantifying the long-term performance of the facility, but that some significant scenarios and processes are not adequately addressed.

Consequently, the interim PA findings may be overly optimistic regarding the likelihood that the performance objectives will be met, and may not provide an adequate basis for setting priorities regarding possible additional data collection needed to enhance the reliability of the PA. Furthermore, in some cases, the content and form of the technical documentation needs to be improved to assure technical defensibility. The discussion that follows will be grouped under subjects covering the information needed to prepare, review, and accept a PA. Comments of a general nature that are believed to influence the PA preparation and approval are listed under the "Programmatic/General Comment" section.

Detailed technical editorial and clarification comments regarding specific sections of the interim PA are listed in Appendices B and C. 
DOE/RL-97-69

Rev. 0

\subsection{PERFORMANCE OBJECTIVES}

The performance objectives used in the PA (described on pages 1-7 and 1-8) are largely appropriate for compliance with DOE Orders. However, two of the performance objectives should be reconsidered due to the revision of DOE Order, Management of Radioactive Wastes. They are as follows:

- Protection of groundwater resources $\{1\}$

The revised groundwater protection performance objective is tied to the Site's groundwater protection management plan. The discussion of groundwater protection on pages 1-12 and 1-13 should be revised to include a discussion of the Hanford groundwater protection management plan and to show how the selected groundwater protection performance objective was derived from the plan.

- As low as reasonably achievable (ALARA) $\{2\}$

Guidance for ALARA determinations will be provided in the new DOE Order 435.1, Radioactive Waste Management. This guidance should be followed as the PA is revised.

\subsection{PERFORMANCE SCENARIOS}

A critical step in PAs is the development of scenarios. It is important that these scenarios be both realistic and bounding; requirements that are often at odds with one another. The ability to effectively meet both of these requirements is extremely important. Clear communication of exactly how these two requirements are met is of equal importance. $\{3\}$

With the above in mind, the PA should include a best estimate scenario. This scenario would be based on the most probable performance of waste form, disposal facility, transport through the vadose zone, etc. The PA would take credit for reasonable assumptions (such as performance of the waste form) and dismiss those for which there is less surety (such as using a 15-foot well screen).

The selection of assumption is necessarily a subjective process. Mitigation measures should be taken to assure that the assumptions are reasonable. These include broad and rigorous review. $\{4\}$

Another important mitigation measure is to ensure the PA does not rest too heavily on the accuracy of the best estimate scenario. Given the significant nature of uncertainty in any PA stretching over thousands of years, too much reliance on accuracy in the best estimate scenario is dangerous. To avoid this, the PA should include other scenarios as bounding cases. One of these would be a reasonable worst-case scenario, the other a reasonable best-case scenario. The bounding cases would serve several purposes. First, they bound the analysis in the PA, answering the inevitable questions, "How bad/good can it get?" Second, the broad range of scenarios can help bound the program itself. The tank waste treatment and disposal program has 


\section{DOE/RL-97-69 \\ Rev. 0}

experienced many changes over the years, and will undoubtedly experience more. A PA that could weather these changes with minimal modifications would expedite the program, saving time and money. $\{5\}$

The three outlined scenarios form only the basic analytical skeleton for the PA. The PA should have more iterative scenarios between the extreme cases. Other scenarios would be useful for sensitivity purposes, and to give more insight into the risks posed by a broader range of potential outcomes. $\{6\}$

The difference between limited sensitivity cases and sensitivity cases involving change in several parameters or assumptions is important. The most effective, understandable, and analytically sound way to approach the PA is through full scenarios. The current interim PA considers changes of variables in isolation; it does not contain sensitivity cases in which multiple variables deviate. That such multiple deviations are likely emphasizes the importance of considering entire scenarios in sensitivity cases. Isolated variations are appropriate for identifying important variables and their relative sensitivity in PA results, however, such consideration is not sufficient or defensible in making overall PA conclusions. $\{7\}$

One specific scenario that is given little consideration in the current interim PA is catastrophic flooding. Many may summarily dismiss this scenario because of the profound and far-reaching impacts the region would experience over and above exposure to this waste. Still, it is likely that in the time frame under consideration in the interim PA a catastrophic flood is indeed likely. Location of waste, disposal design, and other variables could impact the exposure as a result of catastrophic flood. Other variants of the flood scenario presented in the PA should be considered. For example, could a modified flood scenario provide substantially greater infiltration through the waste without exposing the waste and redistributing it? $\{8\}$

\subsection{RADIONUCLIDE INVENTORY}

This subject was not discussed at length in the workshop, however, knowledge of the actual inventory to be placed in the LAW disposal facilities is important, and generally will have a linear relationship on the PA calculation results. The source of Hanford tank inventory information has been a subject of concern for years. It is recommended that the PA work utilize the Kupfer data as the best estimate of the tank waste inventory as soon as possible. $\{9\}$

In addition, consideration of additional inventory sensitivity cases would strengthen the PA. For example, consideration of inhomogeneities in the waste tanks could be done by exploring the impact on groundwater concentrations of simulating more than one row of vaults. $\{10\}$ 


\section{DOE/RL-97-69}

Rev. 0

\subsection{WASTE FORM PROPERTIES}

\subsubsection{Glass Compositions}

There are some dangers inherent in dealing with average in-tank waste compositions and average glass compositions. While some blending of waste from tank-to-tank can be done, it is fairly certain that there will be some considerable composition variation in the waste streams to be fed into the immobilization process. Different glass compositions will be required to accommodate these waste stream variations in order to meet the waste product criteria. $\{11\}$

\subsubsection{Glass Shape}

With regard to the shape of the waste glass product inside the disposal package, a minimum surface to volume ratio is desired to reduce the concentration of undesirable constituents released to the environment through leaching. Accordingly, wherever possible when producing glass waste form for disposal, making small particles or fragments of glass should be avoided in favor of larger pieces. The worst case is to "frit" or dribble the molten glass into water; this raises the definite possibility of creating a radioactive aqueous secondary waste. Spheres of 2-4 $\mathrm{cm}$. diameter can be readily formed from the molten glass using marble machines without the need for water quenching.

Very large spheres become difficult to make as they require a very long cooling cycle to reduce the stresses that otherwise would cause shattering. Pouring glass "monoliths" by casting the molten glass directly into the disposal package require the cylindrical alloy steel canisters proposed for high-level waste (HLW) disposal; square mild steel boxes would not be suitable as they would soften and sag out of shape. The glass cast into the HLW type of canister is going to crack into blocks, but will still have less surface-to-volume ratio than a package filled with $1 \mathrm{~cm}$. diameter spheres. The costs of glass manufacture and final shaping or sizing will dictate to a large extent the methods chosen by the private companies for final product content and shaping to achieve performance specification requirements. $\{12\}$

\subsubsection{Void Space Filler}

If a sulfur-polymer is to be used to fill the void space around the glass waste form, then some study of sulfur-polymer degradation would seem to be in order. $\{13\}$

\subsubsection{Water-conditioning Layer of Crushed Glass}

It would probably be useful to verify by experiment that a water-conditioning layer of crushed glass in the vault cover would reduce glass corrosion rates under low moisture conditions. $\{14\}$

\subsubsection{Glass LD6-5412}

There is no real assurance that glass LD6-5412 is a "best estimate.". It would seem advisable to run simulation studies, also, on some of the other glasses that have been proposed as promising for disposing of the Hanford wastes to clarify the bounds. $\{15\}$ 
DOE/RL-97-69

Rev. 0

\subsubsection{Single-pass Flow-through and Pressurized Unsaturated Flow}

The single-pass flow-through (SPFT) and the pressurized unsaturated flow (PUF) tests are real contributions and better simulate the Hanford disposal site conditions than other tests (i.e., the regular ASTM/ANSI and product consistency test [PCT]). However, they seem too complicated and require too much judgement to be run as routine product acceptability tests. Some further refinements that would make the tests easier to use by the average technician would seem necessary. $\{16\}$

Much more data is needed on standard waste disposal glasses using the SPFT and PUF tests so the results can be compared with rankings obtained by the traditional glass durability tests. Product leaching tests (i.e., PUF) should be cross-correlated with possible product quality assurance tests (i.e., PCT) for the specific product used. While this may be difficult for a large group of glass forms, it should be attempted for an individual glass form. $\{16\}$

\subsection{DISPOSAL SYSTEM DESIGN AND LOCATION}

Current planning envisions placement of the initial immobilized LAW packages in the four existing vaults constructed by the former Hanford Grout Program followed by construction, operations, and closure of additional facilities located in a site west of PUREX for the majority of the immobilized LAW. Conceptual designs for the disposal facilities have not been developed to date. This subject was not discussed much during the workshop since its overall impact on long-term performance is small compared to other components of the disposal system.

The PA review panel cited a few points for consideration which include the following:

- Look and see what others are doing regarding disposal facilities for LAW both nationally and internationally (i.e., the French). $\{17\}$

- Verify that it is cost effective to utilize the existing four vaults for the initial storage/disposal of the LAW which may contain the bulk of the 99Tc inventory. $\{18\}$

- It was discovered during an off-line conversation that some of the immobilized LAW product packages produced by the private vendors may have a small enough radionuclide inventory to allow contact handling compared to the specification limits which would dictate remote handling. This has significant potential cost savings from both a disposal facility design and material handling view point. It may be possible to develop and operate two types of facilities; those that require remote handling and shielding, and those that could be handled in a conventional manner and placed in simple earthen trenches. Future negotiations with the private vendors and appropriate contract language could result in significant future savings to the project. Continued investigation of the merits and risks of this approach should be pursued. $\{19\}$ 


\section{DOE/RL-97-69}

Rev. 0

\subsection{GEOTECHNICAL ASPECTS}

Numerous comments and discussion are provided in this report regarding radionuclide transport pathways, analysis concerns, and recommendations for future plans, In addition to the concern that the impacts of glacial flooding is not addressed, comments are provided on recharge and infiltration, performance of a capillary barrier over the disposal site, flow and diffusion in the disposal facility, water vapor diffusion, modeling of the vadose zone, hydraulic properties and dispersion in the vadose zone, aquifer flow and contaminant transport, and source term including decay chain effects. This discussion is provided in Appendix B.

In view of the major uncertainties with key processes and/or parameters as discussed in Appendix B, it is likely that the conclusions presented in the interim PA are optimistic in assessing the likelihood that the disposal action will meet the performance objectives. $\{20\}$

Suggestions to improve the accuracy of the PA process and assure cost effective data collection activities include the following:

- Modify models to address issues discussed in Appendix B.

- Update the integrated site characterization plan with a focus on PA modeling needs also taking advantage of existing geotechnical data (i.e., existing borehole data). $\{21\}$

- Perform expert review of the updated site characterization plan to determine scope of data collection needs, if any. $\{22\}$

\subsection{INTERACTION WITH OTHER HANFORD SITES}

The interim PA is based on early guidance that indicated that the consideration of other sources of radioactive material should be in the PA. Current guidance, however, directs that a separate analysis called a "composite analysis," must be performed to account for other sources of radioactive material. The $\mathrm{PA}$ should be revised to remove the consideration of these other sources. Alternatively, the composite analysis could be incorporated into the PA. If the latter course is the one chosen, it should be made clear the performance objectives and point of compliance is different for the PA and the composite analysis. \{23\}

As the other sources are considered, it is important to keep in mind that the inventory of radionuclides should be consistent from one source to another. For example, the interim PA indicates that essentially all the I-129 produced at Hanford was trapped from the off gas systems of reprocessing facilities; thus, only a fraction is expected to be in the low-level waste (LLW) analyzed in the interim PA. That would mean that the composite analysis should account for all the I- 129 produced by assuming that the trapping medium is buried in one of the burial grounds. 
DOE/RL-97-69

Rev. 0

\subsection{DOE PA APPROVAL}

The U.S. Department of Energy - Headquarters (DOE-HQ) process for approval of PAs is changing. Heretofore, each PA was reviewed for technical quality and consistency by the Peer Review Panel (PRP), a group of technical experts in the PA field, At this time, DOE has formed a review group of Federal employees. Initially, the Federal group was to review composite analyses and direct the work of the PRP in reviewing PAs. Recently, however, the Federal group has indicated that it will review both the composite analyses and PAs. It is not clear at this time whether the PA review criteria will change. It would be helpful if the PA team could find opportunity to present the PA methodology to the Federal group to get an early indication of whether it will be viewed as acceptable. $\{24\}$

\subsection{PUBLIC ACCEPTANCE}

Public acceptability of the PA is enormously important. The public can be a stumbling block to the PA approval or an effective lobbyist for PA approval. This PA has a particularly ripe opportunity to gain and utilize public support. The public was instrumental in the selection of glass as the low-level tank waste form. If the PA process is carried out with adequate public involvement, it could bolster public support of the PA and the program. $\{25\}$

Following are critical items for gaining public support of the PA.

- The PA should not delay the program. It should be funded and conducted to support the time line currently envisioned for tank waste treatment and disposal. \{26\}

- The PA should be conservative enough to bound the program, and reasonable enough to give some realistic expectations of the disposal system's performance. Ideally, the PA would be able to weather almost any programmatic changes with minimal modifications. $\{27\}$

- The PA must be a credible, defensible document. This aspect of the PA must be emphasized as the public is extremely suspicious of any DOE document that predicts exposure risks. $\{28\}$

- The PA must be effective in communicating its assumptions, analyses, results and uncertainties. If the public is unable to understand the document, acceptance is highly unlikely. $\{29\}$

There are few public concerns for which the PA will not stand more rigorous tests in the DOE approval process. The two exceptions may be the effective communication and the delay to the program. Based on past concerns, the northwest stakeholder community is probably more sensitive to these two issues than DOE.

As the PA is an iterative process internally, so should it be in the public arena. Obtaining public involvement early and substantively throughout the development of the PA is critical. Sound 


\section{DOE/RL-97-69 \\ Rev. 0}

public involvement helps ensure that the public acceptability items listed above are accomplished by identifying and resolving potential stumbling blocks early. It is not critical to have extensive public involvement programs built into the PA. The Hanford Advisory Board's Major Safety and Waste Management Committee is the appropriate body by which to keep stakeholders involved in the development of the PA. The committee is particularly useful as a gauge of stakeholder interest, allowing PA personnel to judge the need for public workshops, public meetings or focused consultations. It is likely that, if involved early, the public involvement may amount to little more than continued dialogue and review cycles with the committee. $\{30\}$.

It is worth noting the public's tank waste treatment and disposal values as they relate to the PA. The public has clearly stated its desire for "getting on with" tank waste disposal. Included in this umbrella value is the desire for DOE to proceed with the most practical, timely available technology. This value is balanced with the desire for an environmentally safe waste form. The public has deemed glass to be the waste form most responsive.to these values.

Implicit in the above values is the public's recognition that leaving the waste in the tanks is an unacceptable alternative. If the best that can be done with practical, timely, available technology (a sound glass in a well-engineered disposal facility) may still result in a relatively significant dose, it will still likely be accepted. In short, to a certain extent, the best that can be done has to be acceptable.

The possibility that the currently envisioned disposal action will result in a dose that is, indeed, so high as to be publically unacceptable, cannot be dismissed. This would likely throw the program into an intensive and extended technology development phase. However, given public values which value retrieval, treatment, and disposal over study, this scenario is highly unlikely.

\subsection{PROGRAMMATIC/GENERAL COMMENTS}

- It is unfortunate that final waste form and acceptance criteria are still unresolved, as this means, even with the specifications put forth in the Request for Proposal, there are still a number of uncertainties that could cause surprises or less than optimum solutions to disposal issues. In the absence of firm criteria, it is important to supply vendors with as much information about the site and wastes as possible, and it seems that this is being done.

The PA program assumes that the final PA will not be prepared until after the first immobilized waste is produced. This seems to be counter to a new direction that DOE is taking in the revised DOE Order, Management of Radioactive Wastes. In the revised DOE Order, a new requirement has been developed for a "Life Cycle Waste Management Plan." For a new facility, such as the Hanford low-level tank waste disposal facility, the "Life Cycle Waste Management Plan" must be completed before construction of the facility can begin. The "Life Cycle Waste Management Plan" is intended to ensure that a viable path to disposal exists for each waste stream produced by DOE. Thus, an 


\section{DOE/RL-97-69 \\ Rev. 0}

approved PA would be an essential component of the "Life Cycle Waste Management Plan." It would seem to be beneficial to review your program and schedule with DOE-HQ to ensure that the program meshes well with the new DOE Order requirements. $\{31\}$

- The PA program should establish what are the technical goals of the project, i.e., when is the information good enough for the intended purpose. A predictive methodology for the next 10,000 years has an uncertainty by itself. Continuously refining current data input may have only limited uncertainty improvement in the out years. Any additional new data generation should be evaluated on this sensitivity basis. $\{32\}$

- The PA has manifold customers, but the PA development team should not try to customize based on assumed needs. What is important is that the PA should be technically defensible, the rest will take care of itself. \{33\}

- Additional data generation needs should be culled whether they add only additional data with the same scatter, in which case they are not useful or if the new data will significantly reduce current uncertainty, in which case they are important. $\{34\}$

- The PA should indicate both best estimate and bounding information. The relationship between these two values is also a good indication where additional data, if any, will improve the final PA. $\{35\}$

- The waste characterization source information should be switched to the Kupfer data as soon as possible. $\{36\}$

- Conservatism should be properly used (i.e., the current assumption that all of the Se will be in the LAW fraction is far too conservative while the assumption for future wells to have a 15 -foot well screen is an undefendable non-conservatism). $\{37\}$

- All assumptions should be clearly identified and justified at the beginning of the PA, and not buried in the body of the PA. $\{38\}$

- The current privatization vendor inputs and activity should be more closely integrated with the PA development. $\{39\}$

The possible "unitization" of the PA should be considered along unit operation basis. Release from glass, release from storage facility, transport in vadose zone and transport in ground water are examples. As additional information becomes available, the adjustments can be made easier on a unitized basis than for the entire PA as a whole. $\{40\}$

The possibility of a third waste form for separated volatiles and semivolatiles should be considered. As an example, the separated $\mathrm{T} c$ may have a much better PA result when co-alloyed to form a binary then reintroduced into the melter feed stream. $\{41\}$ 
- Selenium partitioning is near-identical to the sulfur partitioning during pretreatment and other processing activity. The current assumption that all of the Se would be in the LAW is not only over-conservative, but unrealistic. $\{42\}$

- Volatiles and semivolatiles are not well treated in the PA. In the current processing paths, the off gas scrubbers will collect most of these, and what actually goes out in the stack is not identical to what leaves the melter. As mentioned above, whether these should be continuously reintroduced into the melter feed should be an option (if justified), but not a given. \{43\}

- The grout vaults would have to be significantly modified for use as an LAW storage facility. The cost of using a modified versus a new specific facility should be justified based on requirements. $\{44\}$

- While there was indication that the site vadose zone and groundwater studies are starting to be coordinated, the actual picture is still that there are many duplicated uncoordinated efforts in this aspect. Neither the vadose zone nor the ground water will differentiate in isotope transport based on the exact source of the isotopes. $\{45\}$

- It is not clear if other Site's PA reports have been reviewed for comparison of detail, assumptions, and indicated uncertainties. $\{46\}$

\subsection{CONCLUSIONS}

The preparation, review and approval of a PA is a complex and challenging undertaking. The panel members generally agree that many of the issues important to long-term performance of the planned disposal action have been addressed. A notable caveat to this conclusion is the lack of a clear presentation of assumptions and the difficulty a reader has in understanding the sources and reasonableness of data used for the PA preparation since much of the information is in other references or not well justified. Information must be presented in the next issue of the PA justifying the assumptions and subjective choices that have been made.

Future LLW disposal project activities including the preparation and review of the PA need to consider and incorporate the following:

- Develop and present a best estimate case as well as bounding cases. This would serve to portray the best estimate of long-term performance of this disposal action as well as presenting how good or bad things could get. $\{47\}$

The waste form characteristics currently have a great deal of uncertainty due to the preliminary nature of the DOE privatization plans for the production of immobilized LAW. The low-level waste disposal project/technical personnel, DOE, and the private companies need to communicate and share information as much as possible within contract limitations to assure cost-effective success for waste treatment and disposal. $\{48\}$ 


\section{DOE/RL-97-69}

Rev. 0

- The lack of long-term geologic stability, as reflected in the likelihood of catastrophic glacial flooding during the period in which the waste will remain hazardous, make the currently proposed site vulnerable to regulatory disqualification for such long-term wastes. $\{49\}$

- The geotechnical aspects of the PA, that is, the analysis describing the release and transport of contaminants through the disposal site, vadose zone, and groundwater needs considerable work to enable an informed reader to clearly understand the assumptions and modeling parameters employed to project the impact of the disposal action over time. The "Integrated Site Characterization Plan" should be updated and reviewed to determine the scope of future data collection needs, if any. $\{50\}$.

- The DOE PA review and approval process has recently changed. Project personnel and the PA team should contact the new federal group responsible for reviewing PAs to get an early indication if current plans will be successful for obtaining PA approval. \{51\}

- The project should develop a dialogue with the Hanford Advisory Board as the primary means to assure public participation and acceptance. $\{52\}$

- Project planning needs to consider the new DOE requirements for "Life Cycle Waste Management Plan." \{53\} 
DOE/RL-97-69.

Rev. 0

\title{
APPENDIX A \\ HANFORD LOW-LEVEL TANK WASTE PA REVIEW PANEL MEMBERS
}

Lynn Gelhar

\author{
Ralph M. Parsons Laboratory \\ Department of Civil Engineering \\ Massachusetts Institute of Technology \\ Cambridge, MA 02139 \\ (617) 253-7121 \\ fax: (617) $258-8850$ \\ email: gelhar@mit.edu
}

Professor Gelhar is a nationally and internationally-recognized expert in groundwater modeling. $\mathrm{He}$ is currently a professor at the Department of Civil and Environmental Engineering at the Massachusetts Institute of Technology. Dr. Gelhar has been awarded numerous research grants in the area of groundwater hydrology by the U.S. Environmental Protection Agency, the National Science Foundation, the U.S. Nuclear Regulatory Commission (NRC), the U.S. Geologic Survey, the American Petroleum Institute, the National Institute of Environmental Health, and the Tennessee River Authority. He has received several highly-prestigious awards and honors from technical and professional societies. Dr. Gelhar has published extensively in peer-reviewed journals such the Water Resources Journal, American Society of Civil Engineers, and the Ground Water. He is knowledgeable concerning Hanford modeling efforts as he served on the expert panel at the Hanford vadose zone modeling workshop held March 1993.

Louis Kovach

$$
\begin{aligned}
& 7000 \text { Huntley Road } \\
& \text { Columbus, OH } 43229 \\
& \text { (614) } 846-5710 \\
& \text { fax: (614) } 431-0858 \\
& \text { email: Louis_kovach@rl.gov }
\end{aligned}
$$

Dr. Kovach is a private consultant on nuclear. waste management and the president of NUCON International, Inc. He has been involved in various radiochemical processing activities starting in 1968 with consulting for the Atomic Energy Commission, and later to the NRC and the Advisory Committee on reactor safety. Dr. Kovach has chaired various Organization for Economic Cooperation and Development and Internal Atomic Energy Agency safety groups on post-accident and post-sever accident recovery plans. He is a member of the Hanford Tank Advisory Panel. Dr. Kovach chaired the independent review team for the Tank Waste Remediation System (TWRS) environmental impact statement and the Hanford HLW volume reduction independent review. Dr. Kovach is the author of numerous articles and book chapters on nuclear waste management and other pollution control processes.

Dr. Kovach is a visiting lecturer at the Harvard School of Public Heath, a position he has held for 14 years. 


\title{
DOE/RL-97-69
}

Rev. 0

Todd Martin

\author{
Hanford Education Action League \\ 1408 West Broadway Avenue \\ Spokane WA 99201-1902 \\ (509) 326-3370 \\ fax: (509) 326-2932 \\ email: healtm@aol.com
}

Mr. Martin has been a knowledgeable critic of Hanford activities for a number of years, and serves on the Hanford Advisory Board. He is also a member of the Hanford Science and Technology Coordination Group. The disposal of immobilized LAW is a subject of particular interest to Mr. Martin, and his insight would aid the successful deployment of this project.

Bill Prindle

1556 Crestline Drive
Santa Barbara CA 93105
(805) 687-0446
fax: (805) 682-6476
email: wprindle@aol.com

Dr. Prindle is a private consultant. He is retired from Corning Glass where he was the Vice President and Associate Director of Technology (1990-1992), and Associate Director of Research, Development, and Engineering (1987-1990). Dr. Prindle was the vitrification expert' member on the Hanford Waste Management Technology Advisory Committee, and chaired the External Advisory Panel for the Phase I Source Evaluation Board for LLW melter testing.

Dr. Prindle is a Fellow of the American Ceramic Society and was president of the Society in 1980-1981. He was also president of the International Glass Congress XII (1980), and the International Commission on Glass in 1985-1988. He is also a Fellow of the Society of Glass Technology.

Elmer Wilhite

\author{
Westinghouse Savannah River Company \\ Post Office Box 616 \\ Aiken SC 29802 \\ (803) $725-5800$ \\ fax: (803) 725-4704 \\ email: elmer.wilhite@srs.gov
}

Mr. Wilhite is an advisory scientist at the Savannah River Technology Center. He serves as the chairman of the DOE-HQ PRP. This panel, chartered in DOE Order 5820.2A, performs the technical review of all LLW PAs submitted to the DOE for approval. In addition, Mr. Wilhite has taken an active role in waste management at the Savannah River Site. 
DOE/RL-97-69

Rev. 0

George Williamson

254 Rockwood Drive

Richland WA 99352

(509) 627-4924

email: gwillia524@aol.com

Before retiring from the Westinghouse Hanford Company in 1996, Mr. Williamson was the Project manager of the TWRS Low-Level Waste Disposal Project. He has many years of experience researching and managing the disposal of Hanford low-level tank waste. Mr.

Williamson has the unique perspective of understanding the needs of the project as well as the constraints of the TWRS organization. 


\section{DOE/RL-97-69}

Rev. 0

\section{APPENDIX B \\ COMMENTS ON GEOTECHNICAL ASPECTS OF THE INTERIM PA \\ by Dr. Lynn Gelhar}

\section{GEOTECHNICAL ASPECTS}

\section{Geologic Stability and Glacial Flooding Scenario}

The proposed waste inventory includes substantial amounts of long-lived nuclides which will remain hazardous for tens of thousands of years, and within that time frame it is likely that the proposed site will be inundated by glacial flooding, as has occurred frequently in the very recent geologic past (as recent as 13,000 years ago). The consequences of the likely event of catastrophic glacial flooding are not being taken very seriously (only a short paragraph at the end of Chapter 4). The flooding could result in erosion which exhumes the waste storage facility, making it directly accessible at the surface. For example, what would be the consequences of a child adopting a waste marble as a plaything? The 200 Area seems that it could be particularly vulnerable to flooding effects being just downstream from the gap between Gable Mountain and Gable Butte. $\{101\}$

It would seem sensible that areas of the Hanford Site which may be less vulnerable to flooding effects be considered in siting the facility. Another approach would be to alter the waste composition so that the waste material would produce minimal hazard after 1,000 years. It is important for management to recognize that the lack of long-term geologic stability, as reflected in the catastrophic flooding potential, makes the currently proposed site vulnerable to regulatory disqualification for such long-lived wastes. $\{102\}$

\section{Form of Presentation and Technical Defensibility}

The overall organization of the documents seems well thought-out and logical, but in several places, the intended message does not come through very well. The documents are very uneven in the degree of details that is provided; in many places, crucial facts are left out, whereas other parts seem to be unnecessarily detailed. The interim PA and supporting documents (Data Packages and Definition of Base Analysis Case) rely too heavily on references to other documents without offering any explanation or assessment of the information from those sources. There seems to be many assumptions, ambiguities, uncertainties, and subjective choices which are hidden away in secondary or tertiary references. This makes it extremely difficult for the reader to develop any independent judgement about the adequacy of the assumptions regarding processes and parameters incorporated in the interim PA. In many cases, the form of the graphical presentation of the modeling results is not at all useful to a reader trying to assess the reliability of the results and the likely controlling process. Some specific suggestions about how the document could be improved are noted in the technical comments that follow, but technical editing is not part of the panel's responsibility. In many cases the Grout Program PA is cited as a basis for parameter values adopted, without any explicit justification. This would not seem to be a technically-defensible approach since the Grout PA 


\section{DOE/RL-97-69}

Rev, 0

apparently was found to be inadequate. The individual contributors to the documents need to think carefully about what information a technically-informed reader needs in order to be able to assess the soundness of the results. This information must be provided in the interim PA and supporting documents with explicit discussions acknowledging and justifying the assumptions and subjective choices that have been made. The natural tendency of modelers is to avoid or suppress such ambiguities in favor of the precise mathematical details of a computer code. A formal internal technical review process should be instituted to assure that adequate technical information is included in the PA documents. Such critical reviews need to be done by peers in the same technical specialty to assure that the nuances of the discipline are understood and appropriate technical information is included. $\{103\}$

\section{Geotechnical Issues and Concerns}

The key geotechnical concerns regarding the interim PA are discussed by reference to the path that water may take through the waste facility and the surrounding natural subsurface environment. The discussion focuses on process and parameter uncertainties which may not be adequately reflected in the interim PA.

\section{Recharge and Infiltration}

The source of water which could enter the facility and transport waste to the water table is precipitation which has averaged around $160 \mathrm{~mm} / \mathrm{yr}$ over the last 50 years. In the interim PA, it was assumed, based on the recommendation of Rockhold (1995), that the near-surface Hanford Barrier would effectively limit the water infiltration rate above the waste facility to $0.5 \mathrm{~mm} / \mathrm{yr}$ over the next 1,000 years, after which the rate is assumed to increase to $3 \mathrm{~mm} / \mathrm{yr}$. The recommendation of Rockhold (1996) which is based on eight years of lysimeter measurements complemented by computer simulations, seems to represent the most favorable vegetative cover (deep-rooted sagebrush), and presumes that the Barrier's 1,000 year design life will assure that infiltration is limited to $0.5 \mathrm{~mm} / \mathrm{yr}$ over that period. No explicit consideration of changes in climate, vegetation, or soils (wind erosion) are included though such changes are likely in the 1,000 year period; it would seem that the infiltration rate could easily increase an order of magnitude or more as a result of such changes during that period. In view of such uncertainties, it does not seem reasonable to describe the $0.5 \mathrm{~mm} / \mathrm{yr}$ value as conservative (p. 13, Data Packages). The value of $3 \mathrm{~mm} / \mathrm{yr}$ used after 1,000 years (out to 100,000 years or more) also is not conservative; Rockhold (1996) recommends a natural recharge of 5 to $25 \mathrm{~mm} / \mathrm{yr}$ for vegetation ranging from sagebrush to grasses under current climatic conditions. Major climate changes can be anticipated over the next 100,000 years. At the extreme, glacial flooding could produce an infiltration rate on the order of the saturated hydraulic conductivity $\left(10^{7} \mathrm{~mm} / \mathrm{yr}\right.$ for the backfill soil). Even under current climatic conditions, the effects of plausible transient infiltration events could also produce greatly increased infiltration. If a major winter snow accumulation (say, $100 \mathrm{~mm}$ water content) melts over a few days when there is essentially no evapotranspiration, this would correspond to an infiltration rate on the order of $104 \mathrm{~mm} / \mathrm{yr}$. How does the Hanford Barrier and the gravel capillary break function under such transient conditions? $\{104\}$ 
Contrary to the recommendation of Rockhold (1996), the interim PA assumes that the infiltration rate of $0.5 \mathrm{~mm} / \mathrm{yr}$ applies over the entire modeled surface area extending beyond the Hanford Barrier to the edge of the modeled area. Rockhold (1996) recommends using $75 \mathrm{~mm} / \mathrm{yr}$ at the edge of the Hanford Barrier, but only in the Data Packages (p. 13) do we find an attempt to justify the assumption to disregard this recommendation. It is very likely that there will be some surface runoff and/or lateral subsurface flow from the barrier which increases the infiltration rate at the edge of the barrier. Certainly there is no justification for neglecting the increased infiltration corresponding to natural recharge outside of the barrier-covered area. Moisture entering from the natural surroundings can have a crucial influence on the rate of transport from the waste facility because of the natural tendency for lateral flow in these heterogeneous stratified sediments, as discussed in more detail below. Even in the backfill material beneath the Hanford Barrier but above the capillary break, such lateral flow could be significant because typical construction would likely create some layering in the soil. On p. 44 of the Definition of Base Analysis Case we find, inappropriately identified as a "calculational assumption," the statement (Table 14-1) that the initial moisture content of the natural vadose zone soils was determined by the initial recharge rate. What initial recharge rate was actually used and what are the corresponding initial moisture contents in each zone? $\{105\}$

\section{Capillary Barrier}

The gravel capillary break/barrier above the waste storage vault is intended to function as a sloping roof which diverts infiltrating water around the stored waste. Though the numerical modeling indicates that this capillary barrier is quite effective, there is little field experience with large facilities of this kind that establishes the effectiveness of such barriers of the long periods involved here. This flow configuration with fine soil over coarse soil is one that is known to be particularly susceptible to flow instabilities which create narrow channels through which water moves rapidly and once such channels are established, water tends to enter the preferential flow paths repeatedly (e.g., see Glass, 199i). This mechanism of flow channeling is not represented in the vadose zone flow numerical model which considers only homogeneous zones. The possibility of failure of the capillary barrier by flow in preferential channels is not even mentioned in the PA documents. Such failures of the capillary barrier system would be most likely under transient high infiltration events as noted above. The interim PA claims to look at a sensitivity case representing failure of the capillary barrier, but that case is so poorly described as to make it impossible to judge whether the tested situation is meaningful. Even if one looks into Piepho (1996) (p. 8), it is not possible to discover what configuration and condition was actually tested. Which half of the gravel was replaced by backfill soil $2 / 3$ of the way down from the apex? What is the actual configuration used and why does this make sense? The functioning of the capillary barrier likely will be very sensitive to the contrasting unsaturated flow properties of the backfill and gravel soils used in the model, but there is no discussion of the basis for selecting the adopted parameters of those materials (Table 3-4) in the interim PA documents. It is unacceptable to simply refer to the Grout PA for justification of the parameter values selected without any discussion of the rationale for or limitations of the selections. The interim PA should include and discuss graphs contrasting the unsaturated hydraulic characteristics of the different materials represented in the vadose zone model (Tables 3-3 and 3-4); plots of both tension versus moisture content and conductivity versus tension are very helpful to understand the behavior of the flow at the interfaces between different materials. 
DOE/RL-97-69

Rev. 0

What happens to the gravel capiliary barrier under saturated conditions that could be produced by glacial flooding? It is likely that the interim PA modeling results are an overly optimistic representation of the long-term effectiveness of the capillary barrier. $\{106\}$

\section{Flow and Diffusion in the Facility}

The vadose zone flow modeling seems to be predicting that very little liquid water will flow into the waste storage vaults, judging from the strong sensitivity of the transport result to the molecular diffusion coefficient (Figure 4-23). Because of the very limited graphical presentation of the results (Figure 4-9), it is not possible for the reader to sense of how much flow is passing through and around the storage facility. A graph showing the vertical water flux distribution into the facility across the top of the waste vaults should be included. Streamline patterns should also be used more effectively to quantitatively demonstrate the flow conditions; uniformly spaced streamlines originating at the top of the model, where a uniform flux of $0.5 \mathrm{~mm} / \mathrm{yr}$ was applied, would portray the portion of the inflow which is diverted around the waste. Figures 4-6 through 4-9 present only the uninteresting part of the flow pattern; closely spaced streamlines originating very near the apex (left boundary) would illustrate how much water enters the waste vaults and how it moves through the vaults. The graphs should also present both moisture content, tension, and concentration as this makes it easier for the reader to visualize the influence of discontinuities in the hydraulic characteristics. Detailed plots for the Concept 2 simulations mentioned on p. $4-36$ should also be included. Saturation plots such as Figure $4-9$ can be misleading because they do not show the absolute amount of moisture which controls solute transport via molecular diffusion according to the unnumbered equation at the bottom of p. 3-25 of the interim PA. That equation seems to be incorrect; the minus sign preceding the 10 is wrong according to p. E-A-4 of the Data Packages. This error is repeated on p. 27 of the Definition of Base Analysis Case. Certainly, the diffusion coefficient does not decrease with increasing moisture content as indicated by the equation on p. 3-25. This equation is presented with no justification other than a nonspecific reference to the Grout PA. There must be some discussion of the basis for the diffusion relationship adopted, and its limitations and uncertainties. There seems to be some mix-up in the sensitivity analysis on the diffusion coefficient. In Table 3-15 (p. 3-74) it is indicated that the diffusion coefficient was increased from $1.25 \times 10-7$ to $1 \times 10-6 \mathrm{~cm} 2 / \mathrm{sec}$ whereas the results in Figure 4-23 indicate a decrease to 0.05 times the base case. Judging from the strong sensitivity seen in Figure 4-23, the increase could produce adverse results. Why aren't the results for the increased diffusion coefficient presented? The diffusion coefficient issue is further confused by the fact that two different definitions of dispersion/diffusion coefficient are implied by the discussions in D.2.3 (interim PA, Appendix) and p. E-A-3 of the Data Packages. Effectively, they differ by a moisture content multiplier, and because moisture content is apparently very small in the vaults, this can be an important difference. The code kludge mentioned on p. 3-63 and discussed on p. 2 of Piepho (1996) does not clarify this matter. Which form of the diffusion coefficient is represented by the equation on p. 3-25? \{107\}

\section{Water Vapor Diffusion}

Because the vadose zone modeling indicates that the capillary barrier is very effective in diverting infiltrating liquid water around the waste, it is important to consider the possibility of 


\section{DOE/RL-97-69}

Rev. 0

diffusive transport of water vapor into the facility through the soil gas. Under isothermal conditions, water vapor will diffuse through the medium from areas of low tension to areas of high tension if there is gas-filled pore space. This water vapor transport can be represented, to first approximation, by simply modifying the unsaturated hydraulic conductivity at high tension. Appendix D of the interim PA (p. D-2) briefly mentions the mechanism of water vapor diffusion, but does not indicate that this effects has been incorporated in the model. Certainly, the adopted van Genuchten relationship for the unsaturated hydraulic conductivity (p. 3-24) does not represent this effect. Increased moisture in the facility would lead to increased diffusion of solutes because of the increase of the effective molecular diffusion coefficient and increased gravity-driven advection because the unsaturated hydraulic conductivity is increased. $\{108\}$

\section{Vadose Zone Modeling}

The description of the finite difference grid used in the vadose zone simulations is inadequate. Only by ferreting out Piepho (1996, p. 3) can one find a graphic showing the grid used, but in that figure the crucial detail of the grid in and above the waste vaults can not be seen. Information on the grid detail, particularly in areas of sharp contrast in hydraulic properties, is crucial for the reader to be able to judge the potential accuracy of the simulations. Graphics which show the grid detail in areas of the capillary barrier and the waste vault are absolutely essential to supplement the limited word descriptions on p. 3-62. The graphics should show grid detail in relation to a clear delineation of all of the different material zones actually represented in the model, along with a table that lists the flow and transport properties of all of the different zones. It is certainly not reasonable or appropriate to expect the reader to decipher the input file listings in Appendix D. A particular concem is the grid resolution in the backfill material between the waste canisters. On p. 3-62, it is indicated that a $1 \times 9$ (horizontal to vertical?) grid was used in the backfill between the canisters and that the contaminant releases are, in some unspecified fashion, "...considered to be at the surface of the waste containers." Is this a flux boundary condition? It is difficult to see how one can expect much accuracy in representing diffusive transport calculations using only a single grid point. Apparently, sensitivity to grid spacing has been tested only for the less realistic cell model (Table 4-32); Piepho (1996) does not say anything about testing for grid effects for the full facility models. Graphics showing the grid and a table specifying the flow and transport parameters actually used in each zone are also required in the case of the cell model (Figure 3-8). Why is the contaminant source volumetrically distributed (p. 3-65); is the waste form taken to be permeable; how is its permeability arrived at? Also, it is unclear how the PORFLOW code was actually interfaced with AREST-CT (p. 3-56). What is the basis for the AREST-CT setup described on p. 3-81? What is the flow configuration and what does the grid look like? What is the basis for the assumed "pore velocity" of $1 \mathrm{~cm} / \mathrm{yr}$ ? Appendix $\mathrm{C}$ tells nothing about what was actually done and why. $\{109\}$

\section{Vadose Zone Hydraulic Properties}

As water moves down through and around the waste facility, it enters the undisturbed Hanford formation, a heterogeneous imperfectly layered system of predominantly sand and gravel formed as a result of glacial flooding. The interim PA represents this heterogeneous layered system as two thick homogenized layers, an upper sandy zone and a lower gravely zone, each of which is 


\section{DOE/RL-97-69}

Rev. 0

assumed to be hydraulically homogeneous and isotropic. The actual data in Appendix I of Appendix $\mathrm{O}$ of the Data Packages show large variations of hydraulic properties within the two thick layers. Many studies, including work at the Hanford Site (Kline and Khaleel, 1995), have shown that such layered heterogeneous soils behave anisotropically in bulk, with the hydraulic conductivity parallel to the layers (horizontal) being larger than that in the vertical. Furthermore, the degree of anisotropy is found to increase rapidly with increasing tension or decreasing moisture content, becoming very large in dry soil of the kind encounter under natural conditions at Hanford. Consequently, the infiltrating water diverted around the waste by the capillary barrier is very likely to move back beneath the vaults, creating moist conditions under the waste facility which will reduce the travel time through the vadose zone. In contrast, the interim PA simulations show the diverted water moving primarily moves downward (see Figure 4-9) leaving a dry wake below the facility and slowing the migration of contaminants through the vadose zone. It is difficult to understand why this effect of the fine-scale layering in the vadose zone was not considered in the interim PA. An option to handle tension-dependent anisotropy is already available in PORFLOW (Kline and Khaleel, 1995), so that it should be relatively simple to test the influence of lateral flow under the facility. Kline and Khaleel (1995, Figure 1) indicate anisotropy ratios of over 1,000 even for relatively moist soils (tensions less than $50 \mathrm{~cm}$ ). It may not be possible to precisely predict the degree of anisotropy, but there are some data on the variability of unsaturated conductivity that could be used to get a plausible estimate. That would certainly seem better than to ignore a mechanism that is know to influence vadose zone water movement at Hanford. When anisotropy effects are included, it will likely be necessary to extend the modeled domain to encompass more undisturbed terrain (with its larger infiltration [recharge] rate) because water from that wetter environment will also tend to be drawn in under the facility. Because of subtle layering in the backfill material, some water may also tend to move back under the Hanford Barrier. A vertical capillary break extending down from the end of the Hanford Barrier may need to be constructed to prevent this. $\{110\}$

There are substantial unacknowledged uncertainties in the vadose zone hydraulic data presented in Appendix O (Data Packages) which form the basis for Table 3-3 of the interim PA. First, it is likely that recovery and disturbance of samples is more of a problem with gravely materials than with sands. Open-work gravels are likely to be destroyed or filled with fines during sample processing. This may greatly decrease the permeability relative to in situ values in the gravels. Second, the gravel correction procedure (p. O-6) adopted from Bouwer and Rice (1983) likely is suitable only for a limited amount of gravel. What evidence is there that these corrections are suitable for the very high gravel content of the Hanford gravel samples? These corrections can significantly reduce saturated conductivity and porosity; possibly the unusually low values of porosity and saturated conductivity used for the Hanford gravel (Table 3-3) are related to this potential problem. The uncorrected values of saturated conductivity and porosity should also be include in Appendix 1 of Appendix $O$ to allow the reader to judge the importance of this effect. Third, the van Genuchten method which was used to predict unsaturated hydraulic conductivity from moisture retention curves and saturated conductivity has been demonstrated to be quite unreliable for a variety of soils (Yates et al., 1992, Figure 1C) and for Hanford formation soils (Khaleel et al., 1995, Figure 6); predicted unsaturated conductivities can range over at least 4 orders of magnitude relative to observed unsaturated conductivity with the largest errors occurring for the dry conditions of interest in the interim PA. It would be better to put much more weight on samples where unsaturated conductivity was measured directly in the range of 


\section{DOE/RL-97-69}

Rev. 0

tension or moisture content of interest. The samples for which direct measurements of unsaturated conductivity are available should be identified in Appendix 1 of Appendix $O$. Finally, the recommend values (Table 3-3) for the homogenized zones where obtained by taking arithmetic averages of the van Genuchten parameters. Why is this a sensible procedure when dealing with nonlinear processes of this type? Stochastic upscaling analysis leading to macro anisotropy is a more defensible way of aggregating the data. In that context, the crosscorrelation between the parameters will play a significant role; the univariate statistics discussed in Appendix $\mathrm{O}$ only partly characterize the variability the vadose zone flow properties. Obviously the sensitivity analysis in the interim PA (p. 459), involving the interchange of the properties of the thick homogenized layers only for the cell model, is practically meaningless as far as reflecting the large uncertainties in the unsaturated hydraulic properties. $\{111\}$

\section{Dispersion in the Vadose Zone}

Field-scale dispersive mixing in the vadose zone can be an important process producing dilution which can decrease concentrations and early arrival which, in the case of decay species, can lead to higher concentrations. The interim PA is devoid of any discussion of the basis for selecting the dispersion parameters. There is a passing reference on p. 3-25 to "the dispersion coefficient of the contamination was taken to 0.1 *travel length in the direction of travel," but we are not told what value was actually used and why. The statement is incorrect on first principles; apparently they have in mind the longitudinal dispersivity, which, when multiplied by the velocity, produces the longitudinal dispersion coefficient, and have adopted an old, largely discredited, rule-of-thumb which has been used for saturated fluw.. There is no discussion of whether this choice is appropriate for the dry unsaturated conditions of the Site or what the uncertainties may be in this choice. Yet the sensitivity analyses considered only a minor change in dispersion coefficient (by a factor of 2) only for Concept 2, and the less realistic cell model ( $\mathrm{p}$ 4-61), and even in those cases no graphical results are presented to show the influence on the breakthrough curve. The data summary for unsaturated longitudinal dispersivity in Chapter 5 of Gelhar (1993) could serve as a guide to the selection of appropriate values, though those field studies likely are for smaller scale, wetter conditions. $\{112\}$

Based on theoretical analysis of macrodispersion in unsaturated media, it is predicted that the longitudinal dispersivity could increase dramatically as the soil become drier. Only in Piepho (1996) do we discover that a longitudinal dispersivity (p. 2, improperly called the longitudinal dispersion coefficient) of $8.5 \mathrm{~m}$ was apparently used in the Definition of the Base Analysis Case, but on p. 9, we find statements that for sensitivity cases of $1 / 2$ and 2 times the base case, values of $42.5 \mathrm{~m}$ and $170 \mathrm{~m}$ respectively were used. What was actually used in the base case? In the Definition of the Base Analysis Case, "values for dispersion" (p. 44) are ludicrously classified as "calculational assumptions;" by this logic every numerical value used in the model could be described as a calculational assumption. In Piepho (1996, p. 2), we discover that dispersion was actually neglected entirely in the disposal facility itself because "...these relatively large values of dispersion would overstate the release from the disposal facility...". The dispersivity for the backfill may indeed be smaller than that of the more heterogeneous natural materials, but that is no reason to neglect a real phenomenon which may increase the release. A defensible approach would be to assign a dispersivity that is an order of magnitude lower in the backfill material, and see how the results are altered. Because the dispersion coefficient is the product of the velocity 


\section{DOE/RL-97.69}

\section{Rev. 0}

and the dispersivity, if the velocity in the waste facility is very small there will be little effect. This would be much better than neglecting the process entirely; velocities need not be very large before dispersion dominates diffusion.

All of the machinations in the interim PA regarding the dispersion coefficient leave an impression of a lack of familiarity with even the most rudimentary concepts of field-scale dispersive transport in porous media and a lack of proper attention to detail, thereby serving to discredit the work. The interim PA simulations presume that the dispersivity is the same for all of the transported species. Recent theoretical developments and field experiments have shown that the dispersivity of solutes undergoing heterogeneous linear equilibrium sorption can be significantly larger than the dispersivity of a nonsorbing (conservative) solutes. The aquifer tracer experiment reported by Garabedian et al., (1987) indicates that the dispersivity for a sorbed tracer is an order of magnitude larger than that of the non-sorbed tracer. Simulations of solute transport in the context of performance assessment for a low-level radioactive waste disposal site (Talbott and Gelhar, 1994) show that, for Sr90, the concentration at an offsite point of potential exposure would be 10 orders of magnitude larger when heterogeneous sorption enhancement of dispersion is included as compared with the traditional case of an unaffected dispersivity. Though it is not known how important this dispersion enhancement mechanism is in the vadose zone, it seems prudent to consider the possibility of such dispersivity enhancement. There is no mention of the possibility of dispersion enhancement for sorbed species in the interim PA or supporting documents. This is a serious omission because this mechanism could produce larger releases to the groundwater in the cases where the half-life of the species is of the same magnitude as their travel time to the water table.

\section{Sorption in the Vadose Zone}

The adopted Kd values (Table 3-5) do not reflect some effects and uncertainties inherent in the information of Appendix $Q$ of the Data Packages. Different interpretations of this information could lead to significantly different best estimate values as illustrated by the following examples.

Looking first at $U$, which dominates the alpha release (Figure 4-17), we see from Table 6.1 that there is an important decrease of $\mathrm{Kd}$ with moisture content. Regardless of whether the "\% saturated" means saturation or moisture content, the lowest value (seven percent) is most appropriate for the dry conditions under the waste facility. This suggests that best estimate of $0.1 \mathrm{ml} / \mathrm{g}$ rather than 0.6 used in the simulations, and that does not take into account the gravel correction recommended on p. Q-iii. For the Hanford gravel which has well over 50 percent gravel in most sample (Appendix $\mathrm{O}$ ) it would be reasonable to reduce the $\mathrm{Kd}$ to 0.05 , and in view of the fact the Trench 8 soil, a loamy sand, likely contains a fair amount of fines, a further reduction in the Hanford sand may also be appropriate. The very high value of $\mathrm{Kd}(79.3 \mathrm{ml} / \mathrm{g})$ reflects the high silt and clay content of this soil and indicates the likely importance of soil grain size distribution in affecting $\mathrm{Kd}$. Appendix $\mathrm{Q}$ should include actual grain size distributions (or at least summary textural information as in Appendix 1 of Appendix $O$ ) for all of the samples, so that the reader could more explicitly assess such effects. Looking at I (Table 2.1), it becomes evident that there are two populations represented there, one eolian surface material, Rupert sand, tested with synthetic aqueous phase (the last six samples), and the other three samples of subsurface materials, tested with formation water which are more likely to be representative of 


\section{DOE/RL-97-69}

Rev. 0

soil beneath the waste facility. The average of the first three samples gives an average $\mathrm{Kd}$ of 1.1 $\mathrm{ml} / \mathrm{g}$ (compared with $3 \mathrm{ml} / \mathrm{g}$ in Table 3.3), and this does not take any account of unsaturation effects. Judging from the $U$ unsaturated column experiments, this reduction could be a factor of 5 , so we have $0.2 \mathrm{ml} / \mathrm{g}$ and for the Hanford gravel this would gravel correct to $0.1 \mathrm{ml} / \mathrm{g}$. \{113\}

These examples show that equally plausible, technically-defensible interpretations of the data can yield $\mathrm{Kd}$ best estimate values that are an order of magnitude lower than those used in the interim PA calculations. Of course, there are large uncertainties in all of the estimates because of the small sample size and the limited understanding of the unsaturated and gravel effects, among other things. Appendix P reviews of the many of the complications in determining appropriate field $\mathrm{Kd}$ values and lays out some general plans to resolve some of the issues. However, this material does not address what is likely the most important and difficult issue, i.e., how to representatively sample and analyze this highly heterogeneous medium to arrive at bulk $\mathrm{Kd}$ that will properly reflect the sorptive properties of an entire zone or geologic layer in the model. This issue has been addressed in the case of saturated flow via stochastic upscaling theory (Gelhar, 1993, Section 5.4); it is found that the effective bulk Kd should be simply the arithmetic mean, and that spatial variability of $\mathrm{Kd}$ can dramatically enhance the longitudinal dispersivity of a heterogeneously-sorbed contaminant, particularly when there is a negative correlation between $\mathrm{Kd}$ and hydraulic conductivity variations. The key point is that in order to predict the dispersivity enhancement, one must appropriately measure the $\mathrm{Kd}$ and hydraulic conductivity on the same laboratory samples so that this correlation can be evaluated. The picture is more complicated in the unsaturated flow case because the variation in velocity is affected by the flow conditions (moisture content) and the variation in $\mathrm{Kd}$ is, according to the $\mathrm{U}$ column experiments, also dependent on moisture content.

Furthermore, a dry vadose zone may be sorptively advantaged in the sense that water may tend to be moving primarily through the finer grained more sorptive materials because coarse materials tend to have lower unsaturated conductivity at high tension or low moisture content. Such effects can not be represented without information on the interrelationship between unsaturated flow and sorptive properties. It would seem to be a relatively simple matter to modify the unsaturated sorption column experiments to be able to simultaneously determine unsaturated hydraulic conductivity and moisture retention relationships.

\section{Aquifer Flow and Contaminant Transport}

The degree of mixing and dilution as contaminants move into and with the groundwater flow to the well at $100 \mathrm{~m}$ is a very important element of the PA calculations; in the interim PA, almost 3 orders of magnitude concentration reduction is attributed to processes in this zone. One of the reasons for this concentration reduction is the dilution caused by assuming that contaminated water is mixed with clean water at the well as a result of withdrawing water from the aquifer through a $5 \mathrm{~m}$ long well screen. The fact that a $5 \mathrm{~m}$ well screen was assumed it is not stated in the interim PA or supporting documents; it was ascertained through discussions with Fred Mann. This well screen length seems to be much longer than would be required to supply the amount of water used by a single household from this very permeable aquifer; a $1 \mathrm{~m}$ long screen is more plausible. The consequence of decreasing the screen length to $1 \mathrm{~m}$ would be roughly a five-fold increase in concentrations. Another important factor which controls the degree of mixing in the 
aquifer (not in the well), is the vertical transverse dispersivity used in the transport calculations in the aquifer. The dispersivities used in the aquifer transport calculations do not seem to be specified in the interim PA, Data Packages, or Definition of Base Analysis Case; the only dispersivities given for the aquifer model seem to be in Lu $(1996, \mathrm{p}$. 17) based on fitting the large tritium plumes extending to the Columbia (longitudinal dispersivity $30.5 \mathrm{~m}$, transverse horizontal $3.0 \mathrm{~m}$, transverse vertical $3.0 \mathrm{~m}$ ). It is very doubtful that there is any justification for using such an extremely large vertical dispersivity in these stratified sediments; all reliable field experiments indicate vertical transverse dispersivities in such materials are on the order of a $\mathrm{mm}$ or less (Gelhar et al., 1992; Van der Kamp et al., 1994). Larger values usually represent inadequate vertical resolution of sampling (in-well mixing which is likely the case in the longscreened monitoring wells at Hanford) or inadequate vertical resolution in the numerical transport model. Vertical discretization may be a problem in the interim PA work, but since the grid spacing in the vertical is not given, one can't tell. The vertical transverse dispersivity is an important parameter because it is the dominant in situ mixing and dilution mechanism in this situation with slowly varying contaminant input. Due to vertical dispersion, the solute will $\mathrm{mix}$ over a zone with thickness on the order of the square root of the product of the vertical dispersivity and the distance traveled ( $100 \mathrm{~m}$ to the well). If the vertical dispersivity is $3 \mathrm{~mm}$ the mixed zone is around $0.6 \mathrm{~m}$; if the vertical dispersivity is $3 \mathrm{~m}$, as was apparently used in the interim PA calculations, the mixed zone would be represented as being 30 times thicker, and because the mass flux into the aquifer is fixed, the in situ concentration is 30 times lower than the realistic case. The $30.5 \mathrm{~m}$ longitudinal dispersivity is probably too high, judging from the Columbus experiment; $a$ value of around $10 \mathrm{~m}$ would be reasonable for this heterogeneous aquifer. However, longitudinal dispersion is not likely to be very important because of the quasi-steady nature of the plume. Enhancement of longitudinal dispersion for heterogeneouslysorbed species, as discussed above in the vadose zone, is also likely in the aquifer. Another factor that has an important influence on the amount of dilution in the aquifer is the ratio of the vertical flux of contaminated water (from the vadose zone) to the horizontal specific discharge in the aquifer. Because the hydraulic gradient is decently known the main source of uncertainty regarding aquifer flow characteristics is the horizontal hydraulic conductivity in the site area. The unusually low effective porosity used in the interim PA calculation (0.1, Table 3-6) may be artificially accelerating the arrival of contaminants at the well, but this is not likely to significantly affect the overall results because the travel time in the aquifer is so small compared to the vadose zone. The calculations of aquifer contaminant transport were based on the assumption of a uniform input flux of contaminant over the area of the facility $(\mathrm{Lu}, 1996, \mathrm{p} .32)$ aquifer. A graph showing the spatial distribution of the modeled contaminant flux from the vadose zone is needed to judge the appropriateness of this assumption. The effects of the aquifer contaminant transport factors discussed here are not addressed in the sensitivity studies in the interim PA. $\{114\}$

\section{Source Term and Decay Chains}

The numerical coefficient (4.4) in Table 3-8 seems to be incorrect; it should be 3 . Half-lives and curies remaining at 1,000 and 10,000 years should be included in Table 3-1 to better portray the long-term hazard reflected in the waste inventory. From the discussion in the interim PA (3.5.1, 4.3.4), it is not entirely clear how the normalized response results from each of the flow and transport modeling components are brought together to produce the final concentration or dose 


\section{DOE/RL-97-69 \\ Rev. 0}

result, and why this is a sensible approach. There should be a more explicit description of what is done in the interim PA calculations as represented by the response equation on p. 3-61. What is the rationale for using elaborate flow and transport models which provide spatial distributions of water and contaminant fluxes (strictly the term flux should be used for per unit area per unit of time quantities) and then average out this information in using the response equation? It seems that significant numerical dilution could be introduced through this approach. This approach would seem to have difficulty consistently handling the more realistic case in which recharge rate is not uniform over the entire surface and the higher natural recharge is drawn in under the facility to some degree. What recharge rate does one divide by in that case and what area should be used? What is the rationale for dividing by the recharge rate at 10,000 years ( $3 \mathrm{~mm} / \mathrm{yr}$, p. 3-61)? Does this mean that the concentrations calculated in the first 1,000 years (recharge $=0.5 \mathrm{~mm} / \mathrm{yr}$ ) are effectively diluted by six times the actual amount of water? It also seems that the approach being used, which apparently does all of the decay chain calculation external to the flow and transport simulations, may have some limitations in cases where the daughters and parents have significantly different decay rates,.Kds and dispersivities, or when the Kd changes in space (say, differs between the Hanford sand and the Hanford gravel). Some limitations of this type seem to be alluded to on p. 15 of Mann (1996). There may not be significant approximations involved, but because it is difficult to see exactly how this is being done, one can't be sure. It might be helpful to illustrate, in a brief appendix, how this works for a simple decay chain example with 1D transport equations in which transport parameters are different for each species. If there are significant limitations to the approach, it would not seem wise to build the entire PA effort around this framework. $\{115\}$

\section{Overall Assessment and Future Plans}

In view of the major uncertainties with key processes and/or parameters as discussed in Section 3 of this appendix, it is felt that the conclusions of Chapter 5 may be overly optimistic in assessing the likelihood that the facility will meet the performance objectives. It is very likely that the results of these calculation are largely determined by a number of assumptions and subjective choices, most of which are hidden from scientific purview by the shear volume and dispersed, ill-focused nature of the substantive technical support information. The sensitivity analyses in Chapter 4 provide some interesting insights about what factors affect the outcome of the models. The altemative vadose zone models of different complexity are helpful in providing some insight into possible model behavior, but if a potentially pertinent process is not represented in any of the models, it will be difficult to say much about the importance of that process. The interim PA makes an effort to use the modeling results and their sensitivities to guide the planning of data collection activities. This overall approach, of course, makes sense, but in the present form may be providing misguided direction if the models do not incorporate processes that will actually dominate the behavior of the system. $\{116\}$

The full characterization plan (Reidel, 1995, only Section 2 is in the Data Package, Appendix I), which apparently is the basis for current data collection plans, makes frequent reference to Piepho (1995) as the basis for setting priorities in terms of data collection. Piepho (1995) presents a statistical methodology based on regression for ranking the importance of selected transport parameters, but these results are not meaningful because of the limited number of parameters considered, and because the resulting rankings will depend on subjectively assigned 


\section{DOE/RL-97-69}

Rev. 0

PDFs (Table 1) which may not derive explicitly from lab or field data (as in the case of the dispersivity), or represent the ranges seen in lab data (as for $\mathrm{Kd}$ ). A fundamental conceptual flaw in this approach is the failure to recognize that the parameters needed in the model are aggregated effective quantities representing the overall effect (say sorption) of a large block or zone of soil that internally involves very complex heterogeneity which can never feasibly be characterized in full detail. In the case of sorption in a saturated system we know, from stochastic upscaling theory, that the effective $\mathrm{Kd}$ is the arithmetic average, and then the appropriate estimate of the effective $\mathrm{Kd}$ would be just the average of the pertinent lab $\mathrm{Kd}$ values from that zone and the uncertainty in the model parameter is the uncertainty in the estimate of the mean. Regardless of what the probability distribution of $\mathrm{Kd}$, the uncertainty in the mean is proportional to the standard deviation divided by the square root of the number of independent sample. Thus, we have a basis for judging how further sampling will reduce the uncertainty in a given model parameter. This, coupled with the sensitivity of the pertinent model output to the model parameter, gives a systematic basis for setting priorities in data collection. In the traditional deterministic approach to modeling, as taken in the interim PA, the link between data collection and model parameters is ad hoc or, at best, tenuous (as in the unsaturated hydraulic properties where arithmetic averages of the van Genuchten parameters are arbitrarily adopted). Some technically defensible upscaling procedure (stochastic or otherwise) is required to provide this link.

The following short-term (one year) steps are suggested to improve the accuracy and effectiveness of the PA process and to assure cost effectiveness of the data collection activities:

The PA modeling should be modified to address the process and parameter issues identified in Section 3 of this appendix, and the sensitivity work expanded to treat these factors. Some of the issues can be addressed simply by changing some input characteristics (e.g., vapor diffusion); these changes could be incorporate in the September 1997 version of the interim PA. Other cases may require changes to the code and grid (e.g., lateral moisture inflow from the surroundings); these should be approached as relatively simple screening calculations which are used to assess the importance of the process in defining data gaps, and to decide whether the refinements are need for the preliminary PA.

(2) In parallel with the above modeling modifications, an updated integrated site characterization plan, focusing specifically on the PA modeling needs, should be developed using the existing geotechnical data. Judging from Figure 2-5 of Reidel (1995), there are many boreholes in the general 200 East Area which should be usable at least to define the range of hydrogeologic conditions that could be expected at the site. This report should be a self-contained integrated presentation of the field and laboratory information (geologic, hydrologic and geochemical) and its use to parameterize the PA model. The report should consider the interim PA modeling results with the modifications in 1) above and should develop updated recommendations regarding the data collection needs for PA and cost thereof. This report should be reviewed by a panel of outside geotechnical experts familiar with vadose zone characterization and its use in parameterizing models. This report along with the panel's recommendations would form the basis decisions on the scope and cost of the data collection program. 


\section{DOE/RL-97-69}

Rev. 0

\section{4. $\quad$ References}

Garabedian, S.P., L.W. Gelhar and M.A. Celia, "Large-Scale Dispersive Transport in Aquifers: Field Experiments and Reactive Transport Theory," Parsons Lab Report 315, R88-01, MIT, dated January 1988.

Gelhar, Lynn W., "Stochastic Subsurface Hydrology," Prentice Hall, 390 pp., dated 1993.

Glass, R. J., Laboratory research program to aid in developing and testing the validity of conceptual models of flow and transport in unsaturated porous media, SAND 89-2359C, Sandia National Laboratory, Albuquerque, NM, dated 1991.

Khaleel, Raziuddin, John F. Relyea, and James L. Conca, "Evaluation of van GenuchtenMualem Relationship to Estimate Unsaturated Hydraulic Conductivity at Low Water Contents," Water Resources Research, Section 31(11), pages 2659-2668, dated 1995.

Talbott, M. E., and L. W. Gelhar, "Performance Assessment of a Hypothetical Low-level Waste Facility: Groundwater Flow and Transport Simulation," U.S. Nuclear Regulatory Commission . Report NUREG/CR-6114, Vol. 3, dated 1994.

Van der Kamp, G., L. D. Luba, J. A. Cherry, and H. Maathuis, "Field Study of a Long and Very Narrow Contaminant Plume," Ground Water, Section 32(6), pages 1008-1016, dated 1994.

Yates, S. R., M. T. Van Genuchten, A. W. Warrick, and F. J. Leij, "Analysis of Measured, Predicted, and Estimated Hydraulic Conductivity Using the RETC Computer Program," Soil Science Society of American Journal, Section 56, pages 347-354, dated 1992. 
DOE/RL-97-69

Rev. 0

\section{APPENDIX C \\ SPECIFIC COMMENTS ON INTERIM PA AND SUPPORTING DOCUMENTS}

by Dr. Louis Kovach

(comments by others specifically noted)

The review has been performed on a sequential basis as the information is presented in document WHC-EP-0884 Rev. 0, dated September 1996, Hanford Low-Level Tank Waste Interim Performance Assessment, and its Data Packages for the Hanford Low-Level Tank Waste Interim Performance Assessment, document WHC-SD-WM-RPT-166, Rev. 0, dated August 3, 1995. When the review of the main document includes background information from the Data Packages, it is so indicated.

\section{Interim PA Comments}

Section 1 Review

\section{$\underline{1.5 .2 .5}\{$ Section 1.6.2.5 of present document $\}$}

It is not clear from the description whether the disposal facility is analyzed by itself or for its contribution to the existing ground water contamination. While this may be covered later, it would be important to state here which method is used. $\{201\}$

Section 1.5.2.6 \{Section 1.6.2.6 of present document\}

Same comment as above. $\{202\}$

\section{Section 2 Review}

Section 2.2.3.2 \{Section 2.2.3 of present document\}

The demography numbers and forecasts are inconsistent with the TWRS Environmental Impact Statement (EIS). $\{203\}$

Section 2.2.3.4 [Section 2.2.4.2 of present document\}

The proposed TWRS complex will have at least two low-level facilities and the high level facility may be combined with one of the low-level facilities. $\{204\}$

Section 2.2.5.4.2 \{Section 2.2.7.5.2 of the present document\}

Is the Geomatrix 1966 data use appropriate? \{205\} 


\section{DOE/RL-97-69}

\section{Rev. 0}

Section 2.2.6.4 \{Section 2.2.93 of present document\}

Are the groundwater hydrology descriptions for the time of operation of the disposal facility, and are they consistent with other current predictions (e.g., TWRS EIS)? $\{206\}$

Section 2.3.3 \{Section 2.3.3 of present document\}

The waste removal values appear to be different than in the TWRS EIS. $\{207\}$

Section 2.3.4. Subpoints 1 and 3 \{Section 2.3.4 of present document\}

The current TWRS scenario for Phase II of privatization is out of tank sludge washing. $\{208\}$

Section 2.3.7 (Bill Prindle) (section 2.3.7 of present document

Why shouldn't the certification process address product testing in addition to monitoring the waste immobilization process? It would seem that a case could be made that meeting the waste product criteria is more important than monitoring how the product was prepared. \{209\}

Section 2.4.2 \{Section 2.4.1 of present document\}

While the reference case is a glass-type LAW form, it does not have to be glass. $\{210\}$

\section{Section 3 Review}

\section{Section 3.2.1 (Elmer Wilhite) \{Section 3.2.1 of present document\}}

The process (i.e., radionuclide screening) of deciding which radionuclides should be considered. in the PA is not described. The PA must document the full set of radionuclides considered and any processes used to reduce that set to a smaller one for detailed calculations. $\{211\}$

\section{Sections 3.2.2 and 3.2.3 \{Sections 3.2.2 and 3.2.3 of present document\}}

These values should be eventually replaced by the data from the best basis inventory estimates (Kupfer, et al.) being compiled, in the mean time, several isotope concentration estimates should be cross checked against the current Kupfer values. $\{212\}$

Section 3.2.3.4 \{Section 3.2.3.3 of present document\}

The melter volatilization and off gas capture values are continuously mishandled at the site. \{213\}

Neither continuous recycle from the off gas scrubbers nor assumption of total loss from the scrubbers is correct. It should be evaluated, whether captured in the scrubber, volatiles and 


\section{DOE/RL-97-69}

Rev. 0

semivolatiles should be reincorporated into one or the other proposed waste forms or solidified in a separate manner (e.g., Tc alloyed to metal, I-129 converted to AgI, PbI). $\{214\}$

Section 3.2.4 \{section removed, replaced by Section 3.2.4 in present document

A current program of preparing best estimates for tank by tank inventory should be available by the end of fiscal year 1997. $\{215\}$

Section 3.3.3.3 \{section 3.3.2.3 of present document

Land use scenarios should be cross checked against and be consistent with the TWRS EIS. $\{216\}$

Has any evaluation been made in regard to Native American water usage? (See DOE Environmental Justice Regulations). $\{217\}$

Section 3.3.4.2 (Elmer Wilhite) \{Section 3.3.3.2 of present document

The glass corrosion mechanism is discussed. It is not clear whether the forward rate or the saturated rate is used in the source term calculations. If the saturated rate is used, there should be a discussion of the saturation of the infiltrating water as a function of infiltration rate. In other words, is the infiltration rate used in the PA slow enough that saturation occurs? $\{218\}$

Section 3.3 .6 \{ Section 3.3 .5 of present document \}

Is this section consistent with the TWRS EIS? $\{219\}$

Section 3.4 .4 .3 \{Section 3.4.3.2 of present document\}

There are current studies in regard to transport in the Hanford vadose zone. Are any of those findings being included in this evaluation? How is the existing vadose zone contamination included in the evaluation? $\{220\}$

Section 3.4.4.4 and Table 3-5 (Section 3.4.3.3 and Table 3-8 of present document

These values do not appear to be consistent with the values used in the TWRS EIS. $\{221\}$

Section 3.4.5.5 \{Section 3.4.4.4 of present document \}

It is unlikely that a LAW container can be filled to less than one percent void volume. If necessary, the void volume definition should be given. Some vendors may propose a liner for the container to help prevent glass cracking. $\{222\}$ 
DOE/RL-97-69

Rev. 0

Section 3.4 .6 \{Section 3.4.5 of present document $\}$

Has there been a review of any other countries' experience with LLW disposal facility design? $\{223\}$

From the reference materials, it appears that all of the discussed design features are based on Site postulations. Is it implied that there is no international experience in this area. If the other Site experience has been reviewed, where is a lessons learned description and comparison with Site based design features? $\{224\}$

Section 3.4.6.7 \{Section 3.4.5.6 of present document\}

Are these the same vaults that are being proposed for storing spent nuclear fuel? $\{225\}$

Section 3.4.6.8 \{Section 3.4.5.7 of present document\}

If the NRC assumption is that concrete structures degrade in 500 years, why is the sensitivity study uses immediate and 2,000 year degradation? $\{226\}$

Section 3.4 .7 \{Section 3.4 .6 of present document\}

If the particular disposal site is undisturbed for long periods of time, one would expect natural vegetation to reach an equilibrium level, such vegetation equilibrium, if anything should decrease the recharge rate rather than increase it. Of course, natural events such as range fires would also occur periodically so the recharge rate may vary also on the basis of natural occurrences. $\{227\}$

Section 3.4.8.2 \{Section 3.4.7.1 of present document\}

Sentence problem in last paragraph on page 3-43. $\{228\}$

Section 3.4.8.2 \{Section 3.4.7.1 of present document\}

There should be an explanation for the great divergence for $\mathrm{T} c$ in the site GENII value and that of the DOE library. More widespread use is not a technical explanation. $\{229\}$

Section 3.4.8.3 \{Section 3.4.7.2 of present document\}

Has the Native American all pathways dose conversion factor been considered? $\{230\}$

Section 3.4.8.4 \{Section 5.3 of present document

Is this consistent with the values given in the TWRS EIS? \{231\} 


\section{DOE/RL-97-69}

Rev. 0

Section 3.4.8.6 \{Section 3.4.7.4 of present document \}

Typo in second sentence. "Are" should be "and." $\{232\}$

Section 3.4.8.6 \{Section 3.4.7.4 of present document\}

Jenquin data. I am puzzled by the description. Why are the increased "calculated over measured" yield values cause changes in half life? $\{233\}$

Sections 3.5.2.2.5 and 3.5.2.3.4 (Sections 3.5.2.2.4 and 3.5.2.3.3 in the present document\}

At least for codes that we are using for NRC licensed facilities, an extensive and formal QA program defined validation is required. Considering that there will be NRC involvement with this project also, does the validation methodology satisfies current NRC criteria? $\{234\}$

Section 3.5.2.3.6 \{Section 3.5.2.3.4 of present document $\}$

Was this code involved in the estimation of the $S$ farm leakage? Do the recent vadose zone isotope movement issue, and the commensurate studies have any lessons learned impacts? $\{235\}$

Section 3.5.2.4.2 \{Section 3.5.2.4.1 of present document\}

This section answers one of the earlier questions (1.5.2.5), however, the recent vadose zone isotope transport problems have to be considered before finalization of the code(s) for this application. $\{236\}$.

\section{Section 3.5.5.2 \{Section 3.5.5.1 of present document\}}

The Native American impact scenarios seem to missing in all cases. DOE has a special requirement to include such impact analysis for all environmental documentation. \{237\}

Section 3.5.5.3 \{Section 3.5.5.2 of present document\}

What is the basis for assuming that the melter volatilized I-129 will be or can be released to the atmosphere? With the particular sensitivity toward iodine releases at the Site, how can one justify to purposefully release iodine, even if calculated concentrations would be minimal? It should also be kept in mind that the scrubber solution will most likely accumulate the iodine (and some other halides), and any release would take place from such, more concentrated sources. Has the release mechanism assumption been checked with SRP, West Valley, and other international melter operations where actual operating data is available? \{238\}

Section 3.5.5.3 \{Section 3.5.5.2 of present document\}

From a long term PA standpoint, what is the specific concern with Cs-137 content? $\{239\}$ 


\section{DOE/RL-97-69}

Rev. 0

Section 3.5.5.6 \{Section 3.5.5.5 of present document\}

There are operating LLW repositories around the world. Is there any information from those operations that can be used to compare or even validate the codes on real systems? $\{240\}$

Section 3.5.5.9 \{Section 3.5.5.8 of present document \}

One of the issues I am aware of that affects the surface area of the glass and, therefore, the release rate, is cooling related cracking of the waste form in the metal storage container. Has anyone looked at the possibility of using a chemically inert liner (such as graphite or carbon felt). which would permit better relief of expansion or contraction stresses, and reduce the potential of the increase in glass surface area? $\{241\}$

\section{Section 3.5.5.10 \{Section 3.5.5.9 of present document]}

The OECD has performed in the near past an international exercise in Kd evaluation. Was information from that activity used to cross-check Kd values used at the Site? $\{242\}$

Section 3.5.5.10 \{Section 3.5.5.9 of present document\}

Are the Kd values used in this exercise consistent with that used in the TWRS EIS? $\{243\}$.

Section 3.6.2 \{Section 7.2 of present document $\}$

I have recently participated in the assessment of an activity at PNNL (C-106 vendor sample preparation), and my personal findings in that case indicate that the QA program that followed is not well instilled in the personnel using it. I would feel much more comfortable if the QA program used in this exercise is audited. Such audit should not only be "expected," but a basic requirement for any safety related code and methodology development. As an example, the PNNL QA program requires the development of a $Q A$ plan for special projects which involve non-routine work. If that QA program is, in fact, followed there should be a QA plan for this project. I would like to review the specific QA plan relating to the ongoing performance assessment work. $\{244\}$

\section{Section 3.6 .7 . Section 7.2 of present document $\}$.}

I am troubled by the wording in this paragraph. It states that an advisory board will be created in the future, and in the following sentence it states that this document has been reviewed by such a panel and the document revised on the basis of their comments. I would be interested in looking at their comments and the comment resolution. $\{245\}$ 
DOE/RL-97-69

Rev. 0

Section 4 Review \{Chapters 4 and 5 of present document

Section 4.2 \{Section 5.4 in the present document $\}$

How do these scenario effects compare to the values in the TWRS EIS? The Native American scenario is missing. $\{246\}$

Section 4.2.3.2 \{Section 5.4.2.2 in present document $\}$

It appears that the Sn-126 contribution falls below the Cs-137 at 200 years and not 300 years. $\{247\}$

\section{Section 4.2.3.4 \{Section 5.4.2.4 of present document\}}

The relative potential contribution of $S n 126$ to the dose begs the question: Are there realistic technically feasible and cost effective methods of removing this isotope from the LAW waste feed prior to vitrification. It is greatly troubling that the major contributors to the dose (i.e., Tc and $\mathrm{Sn}$ ) are the least characterized from the tank waste and cause the greatest uncertainty in the PA. $\{248\}$

There are several ways that this problem can be addressed. One way is to get as much available international experience data as possible. Another way is to better scrutinize available processes knowledge for the removal of these isotopes either from the liquid phase process or the off gas scrubber system.

It is also questionable if these isotopes should be included in the LAW waste form if they can be separated from the rest of the material. The site is stuck on the two waste form groove, even if there are numerous indications of problems with such assumption. Anything that shows limiting PA should be evaluated for separation and possible inclusion in less release prone matrix or potential inclusion in the HLW waste form. This is also true for $\mathrm{Tc}$ and Se-79 in the groundwater impact.

Thus, what is the sensitivity of the PA to these possible reductions of the limiting isotopes and what is the cost trade off of going to the removal path? $\{249\}$

Sections 4.6.2.2 and 4.6.3 \{Section 4.5.1.1 and 4.5.2 in present document\}

The question is, again, how much of the international experience has been reviewed and what are the lessons learned? $\{250\}$

\section{Section 4, General Comment}

The scaling of the figures can be misleading. In such presentations, the ere should be a broken line indicating that the discontinuity in the data presentation (starting with zero and then switching to log scale). $\{251\}$ 
Section 4.7 \{Section 4.6 of present document\}

There should a be a best estimate also given in addition to the sensitivity studies. It is not clear if the base case represents the best estimate or not. $\{252\}$

\section{Section 4.8.2 \{Section 4.7.1 of present document\}}

This is indicative of what feedback is important for the appropriate process design and what impacts need to better defined to reduce the uncertainty of the PA. How is this data integrated into the overall TWRS process? What are immediately definable steps? Example could be immediate additional characterization data for the critical analytes Tc, Sn-126, Se-79, etc. How does one prioritize needs which could be included in TFA or science studies financed outside the current TWRS budget? There is data from power reactor accident evaluation studies with simultaneous release of iodine and cesium, and the potential pool scrubbing effect in BWRs and alkali sprays for PWRs. Has this data been reviewed and incorporated into the estimates of scrubber collection efficiency? Has data been obtained from operating melters from other countries in regard to iodine scrubbing efficiency or accumulation in the off gas system scrubbers from which better best case estimates can be prepared, and the overall uncertainty of . the PA reduced? $\{253\}$

Section 4.9 \{Section 4.8 of present document $\}$

Is this still correct based on the recent issues with the groundwater contamination? $\{254\}$

Section 4.10 \{Section 4.9 of present document

What is the relationship of the base case to the best current estimate? $\{255\}$

Section 5 Review \{Chapter 6 of present document\}

\section{Section 5, General Comment}

In addition to the performance objective and single value estimated impact, the range of reasonably possible should also be shown. The uncertainty in some of the scenarios is too large to present only a single value "estimated" impact. \{256\}

\section{Section 5.2.4 (Elmer Wilhite) \{section 6.2.4 of present document\}}

Table 5-3 does not seem to correspond with the data presented in Table 4-34 on page 4-78. For example, in Table 4-34, the sum of doses from fission products is about $7.4 \mathrm{mrem} / \mathrm{year}$ while the same value in Table $5-3$ is $2.0 \mathrm{mrem} / \mathrm{year}$. $\{257\}$ 


\section{DOE/RL-97-69}

\section{Rev. 0}

Section 5.2.4 \{Section 6.2 .4 of present document\} .

It is obvious that the uncertainty affects most strongly the groundwater scenario, which currently is approximately estimated at one half of the performance objective, but the well screen length assumption is difficult to defend. $\{258\}$

Section 5.5.3 \{section completely rewritten in new document, now in Section 6.4\}

I strongly recommend the collection and utilization of the relevant international experience based technical data. $\{259\}$

On page 16 of the Data Packages, the important parameters for intruder doses are described. Two of the values used do not correspond to those used in other Hanford PAs. The well diameter of $12 \mathrm{~cm}$. is smaller than the $30 \mathrm{~cm}$. value used in other PAs, and the garden size of 500 square meters is smaller than the 2,500 square meters used in other Hanford PAs. The rationale for using different values in the various Hanford PAs should be clearly stated. (Elmer Wilhite) $\{260\}$

In the Definition of the Base Analysis Case of the Interim Performance Assessment, on page 21, it is stated that the container material is assumed to have no effects on hydraulics or on chemical retardation. As it should be expected that the containers will, in fact, degrade with time, consideration should be given to consider the effect of container degradation (i.e., rust) on the migration of contaminants from the disposal site. (Elmer Wilhite) $\{261\}$

On page 24 , it is stated that all concrete structures degrade to gravelly sand at 500 years. This assumption seems to be conservative. However, if the hydraulic properties of the concrete are changed to be consistent with gravelly sand after 500 years, is there a possibility that this will, in effect, act as if a capillary break had been installed around the waste? (Elmer Wilhite) (262)

On page 31 , a glass corrosion rate is stated at $\mathrm{pH} 9.5$. Does $\mathrm{pH} 9.5$ match the expected condition the disposal unit? (Elmer Wilhite) $\{263\}$ 
DOE/RL-97-69

Rev. 0

\section{APPENDIX D \\ QUESTIONS AND ANSWERS}

\section{Response to Questions Posed by Jeff Voogd During the Meeting}

Can you recommend methods to balance conservatism in the assumptions and scenarios needed for technical and public acceptance with desires to present results that represent best estimates?

Present a set of cases which span the range from best estimates to reasonably conservative to strongly conservative or worst case. Interpret the results, taking into account the relative uncertainties.

Can you provide recommendations to balance the drive to collect data versus the ability to use assumptions or sensitivity studies to reduce costs?

A minimum set of data must be collected to provide assurance that the simulation of the site is reasonably realistic. Beyond that, sensitivity analyses should be used to aid in the decision making process as to what additional data, if any, are needed.

Does the board have a set of recommended end points for data collection?

It is difficult to develop end points for data collection a priority. As stated above, it should be expected that a minimum set of data would be needed to ensure that the site is being reasonably represented. Because many potentially important process and parameter uncertainties are not incorporated, it is not appropriate to use the interim PA results to draw conclusions regarding data needs. 


\section{DOE/RL-97-69}

Rev. 0

\section{F.1.4 Responses to Board Comments}

Responses to the items noted in the panel's report follow.

1. When the performance objectives were determined for this performance assessment, there was no guidance to use the site's groundwater protection management plan as a source of information. The latest version (1995) of the "Hanford Site Ground-Water Protection Management Plan" (DOE-RL-89-12, Revision 2) is silent on protection of groundwater in the future. The new "Hanford Site Ground-Water Protection Management Plan" (due September 1998) should set standards for future groundwater protection.

2. The performance assessment activity will follow the guidance of draft DOE Order 435.1 (the successor to DOE Order 5820.2A) as far as practicable.

3. A major finding of the expert review panel is the need to provide both best estimate analyses as well as suitable bounding analyses. The performance assessment team agrees that this is the correct approach and the performance assessment activity is being modified accordingly.

Data collection efforts for the performance assessment activity are being modified so that data can be gathered that support both types of analyses. In future performance assessment, separate scenarios will be chosen as best-estimates and as reasonably bounding.

4. The performance assessment team agrees that broad and rigorous review is important. The document which describes the tasks in the performance assessment activity, "Statements of Work for FY 1998 to 2003 of the Hanford Low-Level Tank Waste Performance Assessment Activity" (HNF-SD-WM-PAP-062, Rev. 2), requires that each document (including those defining and justifying data to be used in the performance assessment) have a separate review activity. In addition, a separate independent review panel is planned.

5. As noted in item 3, having separate bounding cases will be adopted by the performance assessment team. Providing an indication of "what will not happen" will give many a better basis for decision than attempting to predict exactly events many thousands of years in the future.

6. As the interim performance assessment was the furst performance assessment performed for immobilized low-activity tank waste, only a limited number of scenarios were considered. With the understanding of these analyses, a better definition of scenarios can be performed in the future. Future performance assessments will use more scenarios in order to provide the reader with greater insight. 


\section{DOE/RL-97-69}

Rev. 0

7. Isolated variations of parameters was emphasized in the interim performance assessment as this was the first performance assessment to study waste having a time of release significantly longer than the travel time of the most mobile radionuclides. Thus the intent was to identify important variables and their relative sensitivity in performance assessment results. Multiple variations (for example, changing the description of the vadose zone stratigraphy) were limited because of the lack of prior knowledge to select the most meaningful set of sensitivity scenarios.

With the knowledge gained from this analysis, future performance assessments will rely more on changing scenarios or systems, rather than varying parameters.

8. As shown in Section 2.2.6.3 of the Performance Assessment, even if the largest dam on the Columbia River (Grand Coulee Dam) collapses, the resulting catastrophic flood would not reach the disposal site. However, such a collapse would have extremely dire conditions in the Pacific Northwest, killing tens of thousands of people if not more. In order for a catastrophic flood to reach the disposal site, then a volume of water that. would reshape the topography of the entire region is necessary. The consequences of such an event on the disposal site (Section 4.10) compared to the consequences for the entire region of related events is beyond the scope of this analysis.

Recent guidance from the Department of Energy is to focus on the next 1,000 years with the results for a period out to 10,000 years used to optimize design. Thus the effects of a catastruphic flood which may occur many tens of thousands of years in the future were not fully analyzed. The amount of effort to be expended for such a scenario will be based on guidance from the Department of Energy and the feedback from the Northwest public.

Although there is the likelihood of catastrophic glacial flooding this alone should not disqualify the currently proposed site. Because of the uncertainties in any statements about the future, regulatory bodies stress the continuation of present conditions unless there are convincing arguments. For example, in the NRC's branch technical position on performance assessment methodology (NRC 1997 - 3], "the staff recommends that new site conditions that may arise directly from significant changes to existing natural conditions, processes, and events do not need to be quantified in LLW performance assessment modeling." Thus the Nuclear Regulatory Commission in their regulation of the commercial low-level waste disposal site which lies nearby on the Hanford plateau just southwest of the proposed site and the Department of Energy in their regulation of the low-level radioactive waste burial grounds just north of the proposed site have not considered such catastrophic floods.

9. The performance assessment effort has committed to use the effort of the TWRS Characterization Program as the official estimate of the inventory of wastes in the Hanford Site tanks. For this performance assessment, the values supplied by the TWRS Characterization Program (Kupfer 1997 and Washenfelder 1997) were used to show that "reasonable expectation" exists that requirements based on the performance assessment analyses could be achieved. Future performance assessments will use the values from 


\section{DOE/RL-97-69}

Rev. 0

the TWRS Characterization Program in all aspects of the performance assessment.

10. Future revisions of the performance assessment will model the inhomogeneities of inventories. With the tank by tank estimates from the TWRS Characterization Program combined with the order of retrieval, inventory in the immobilized low-level waste as a function of time of immobilization will be determined. The analysis in this performance assessment suffers because the necessary retrieval and vendor separations and immobilization plans are not yet available. However, tank by tank estimates were used to show that "reasonable expectation" exists that requirements based on the performance assessment analyses could be achieved.

11. It is recognized that there will be variations in waste compositions and waste form formulations as the immobilization spans many years. For this first analysis of the immobilized waste form, the simplest approach was used. Future performance assessments will contain scenarios involving a larger variety of waste forms as information about them is obtained.

12. The glass shape will be determined by the vendors. The performance assessment team will maintain communications with the vendors to determine what glass shapes that they will be supplying to the Department of Energy.

13. The vendors will determine what filler material will be used around the glass waste form inside the metal container. The disposal facility operators will determine what fill material will go around the metal containers inside the disposal facility. Sulfur-polymer cement is no longer being considered for either situation. The performance assessment team will analyze likely filler materials based on conversations with the vendors and with the disposal facility design team.

14. An experimental verification of the usefulness of a water-conditioning layer of crushed glass is contained in the "Statements of Work for FY 1998 to FY2003 of the Hanford Low-Level Tank Waste Performance Assessment" as activity S1W03384.

15. LD6-5412 was not treated as a "best-estimate" for the waste form. Discussions with the vendors of the waste form indicate that they will NOT be using LD6-5412. The LD6-5412 glass was used in the sensitivity cases to provide an indication of how a lowlevel glass waste form might behave in the disposal facility. LD6-5412 glass was also chosen to show likely compliance with the restrictions based on the performance assessment.

LD6-5412 was chosen as there exists more publicly available data on this low-level waste glass than for any other. Activities (particularly the.waste form activities S1W03000 - S1W03160) in the "Statements of Work for FY 1998 to FY2003 of the Hanford Low-Level Tank Waste Performance Assessment" are designed to accumulate the similar level of information for the various vendor glasses as was achieved for LD6-5412. 


\section{DOE/RL-97-69}

Rev, 0

16. The determination of what tests are to be used in product acceptance testing is neither a performance assessment nor a Project Hanford Management Contractor activity. Rather product acceptance is the responsibility of the Waste Integration Team under DOE. The DOE Tank Focus Area has identified the need to standardize such tests and to determine the cross-correlation of such tests with more standard PCT tests.

The performance assessment activity takes pride that significant development of the SPFT and PUF tests were done with performance assessment funding.

17. The Systems Engineering activity which is responsible for engineering studies is investigating various low-activity waste disposal options both nationally and internationally. In particular, the French experience is being extensively investigated.

18. "The Alternatives Generation and Analysis Report for Immobilized Low-Level Interim Storage Architecture" (Burbank 1996) clearly showed that the grout vaults were the most cost effective solution for the storage of the immobilized low-activity waste that is produced. An alternatives and generation analysis report on disposal of the waste (Burbank 1997) has recently been released.

19. These concepts are being pursued through "The Alternatives Generation and Analysis Report for Immobilized Low-Activity Waste Disposal" (Burbank 1997) which has been recently released.

20. The travel time in the vadose zone for the most important radionuclides for dose is so much less than the expected release time from the waste. Thus the plateau value for the dose is determined not from geotechnical considerations but rather from waste form processes. Therefore, although there are improvements that need to be made in the geotechnical area, such improvements are unlikely to increase the estimated maximum dose.

21. Although the activities for vadose zone characterization are still heavily based on the integrated site characterization plan ("Characterization Plan for the Proposed TWRS Complex", Reidel July 1995), information from the interim performance assessment analysis and from other Hanford vadose zone efforts have changed priorities as given in the newest statement of work document. In addition, the Hanford Site is in the process of coordinating all of the vadose zone and groundwater activities.

22. There are plans for an independent review of the coordinated TWRS vadose zone characterization activities. Separate review tasks are included in the statements of work.

23. The Hanford Composite Analysis is scheduled to be released in March 1998. To provide an indication of what such an analysis might show, an analysis of interacting sources was included in this document. Future performance assessments will reference the results of the current revision of the Hanford Site Composite Analysis. 
24. Following this recommendation, DOE-RL staff have already made contacts with headquarter staff to determine a path forward given the proposed change from DOE Order 5820.2A to DOE Order 435.1. Additional routes to determine how to transition from one order to the other are being pursued.

25. The performance assessment team will strengthen its effort to increase public involvement and the public's understanding of the issues underlying immobilized lowactivity tank waste disposal.

26. The performance assessment activity is being structured so that it should not delay the program. Novel approaches.are being considered to ensure that the performance assessment document does not hinder privatization or disposal.

27. The performance assessment activity will follow both a best-estimate approach as well as a reasonably bounding approach. In addition, future performance assessments will be written so that analyses identify key features and determine the limitations of such features.

28. Defensibility of the performance assessment is extremely important to the performance assessment team. Defensibility of the data and approach was a major goal for this performance assessment. In producing this performance assessment, the performance assessment team found that certain data (waste form release rates, well screen height) need better justification and that certain methods (using the base analysis case, emphasizing parameter variation) must be replaced (using both best-estimate and reasonably bounding cases, emphasizing scenario variations).

29. Because of its regulatory nature, the performance assessment is highly restricted in its format. The performance assessment team attempted to make the document more readable for the lay reader. The team realizes that it has a very long way to go.

30. The performance assessment team has encouraged DOE to present Hanford low-level tank waste performance assessment information to the Safety and Waste Management Committee of the Hanford Advisory Board. A few presentations have been made. The team will recommend that more presentations be made.

31. The strategy for writing and submitting performance assessments to DOE has been rethought. Thus, this performance assessment has taken the approach that sufficient information exists a) to understand how the natural and manmade systems will behave, b) to establish the bases for the setting of waste acceptance criteria of disposal facility design features, and c) to show that "reasonable expectation" exists that waste acceptance criteria and facility design features can be met. Hence, this performance assessment is being submitted in Spring 1998 rather than in 2001 as had been planned in the interim performance assessment or in early planning documents. The program is, however, committed to gather more data and in revising the performance assessment based on new information. 


\section{DOE/RL-97-69 \\ Rev. 0}

32. The performance assessment team agrees that gathering more data without significantly reducing uncertainty is unacceptable. The approach taken in determining what data should be collected was a) to identify the questions that needed to be answered b) to determine what information was needed to answer those questions, and c) to determine whether information already existed for that area. As the analyses have proceeded, new areas for data collection have been discovered, but many more have been closed.

33. As noted in item 28 , defensibility of the document is key to the program.

34. Agreed, see note 32 .

35. Agreed, see note 27.

36. Agreed, see note 9.

37. The goal of the performance assessment activity is to define the values of all parameters used in the performance assessment. It is recognized that certain parameters (for example, the well screen height) are not defended adequately in this document while others (for example, the partitioning of Se between high-activity and low-activity waste) are being investigated so that values can be justified.

38. The order of presentation was our interpretation of the format guidance given by the Department of Energy. We agree with the comments that a discussion of the major assumptions belongs in the first chapter and added a section on data sources (Section 1.7). In future performance assessments, we will strive to make it easier for the reader to understand the large amount of information in the performance assessment, while still following the requirements of DOE.

39. Members of the performance assessment team are already receiving training to allow them greater access to vendor information. There is a commitment both at the DOE and contractor level to increase communication between the performance assessment team and the vendors. Also members of the performance assessment team are aiding DOE in the initial screening of waste form performance.

40. An attempt was made to "unitize" the analysis in this performance assessment (discussions of inventory, transport through the vadose zone, transport through groundwater, and dosimetry effects were each treated separately in Chapter 4). However, the presentation was not sufficiently orientated toward this philosophy so that the reader realized this approach. Succeeding performance assessments will attempt to better modulize not only the analysis but also its presentation.

41. A third waste form is being considered by DOE. However, the present plan is to dispose of such a waste form as immobilized high-activity waste and therefore is not subject to the analysis done for the immobilized low-activity waste. 


\section{DOE/RL-97-69 \\ Rev. 0}

42. When the performance assessment activity started, the importance of selenium was not known to the engineering staff. Therefore, they could provide little guidance as to how selenium would partition between the high-activity and low-activity waste streams. Information is now being obtained that will allow an accurate representation of how selenium will split. Such information will be used in future performance assessments. The refocusing of staff effort on determining how selenium partitions should be viewed as a success of the iterative performance assessment approach where conservative assumptions are used where knowledge is weak or lacking, the consequence determined, and if necessary, more information is gathered to better define the answer.

43. The offgas issue is one that has to be worked with the vendors. It is unknown at present whether the vendors will recycle such material, return it to DOE, produce a third waste form (see note 41), or treat it as waste (in which case they have the responsibility for disposal). The performance assessment team will be actively working with the vendors on determining a path forward.

44. An analysis has been performed. See item 18 .

45. The performance assessment team is working actively in making both the integrated Hanford Site groundwater activity and the integrated Hanford Site vadose zone activity a success. We admit that much more coordination is needed.

46. Other sites' performance assessments have been used, particularly those of Savannah River Site. For example, performance objectives of each of the sites were used. Although not shown in the performance assessment, experience of other sites has been used in our data collection activities. For example, the work at the Savannah River Site on Tc getters was followed up as was the work at the Nevada Test Site on no-flow zones. The use of $\mathrm{Cl}$ tracers to estimate recharge is another area which grew from investigating the approaches of others.

47. Agreed, see item 27.

48. Agreed, see item 39.

49. Disagree. See note 8.

50. The preparation and review of the performance assessment made clear limitations in the present analysis and presentation. The performance assessment team will attempt to better present and justify paradigms, models, and data values in the next version so that both the informed and general reader can understand what was done.

The characterization plan has been redone (Reidel 1997) as part of the planning activity for the borehole drilling activity. In addition, as part of the Hanford Site integrated vadose zone activity, data quality objective activities are occurring.

51. Agreed, see item 24. 
DOE/RL-97-69

Rev, 0

52. Agreed, see item 30 .

53. Agreed. Efforts to understand the implications of the proposed DOE Order 435.1, "Radioactive Waste Management", are underway.

101. See note 8 .

102. As noted in the response to comment 8, there already exists a commercial low-level radioactivity waste burial ground just southwest of the proposed site and DOE low-level burial grounds to the north. In addition, the staff of the NRC has also reviewed this performance assessment and have not raised this issue. Thus vulnerabilities due to regulatory disqualification are thought to be minimal.

It should be recognized that any location in the entire Columbia Basin with the exception of basalt interiors will undergo extreme destruction if another catastrophic flood occurs. Past catastrophic floods locally move 100 's of cubic miles of soils, creating channels hundreds of feet deep.

The performance assessment team is committed to analyze all risks that the public and the regulatory system deem important.

103. The performance assessment team recognizes that the presentation of material can be improved. The team will strive to be sure that the improvement occurs.

Because of the large amount of information needed for a performance assessment, it is difficult to judge how much detail should be included in a document and how much should be referenced. The present approach was to put as much as possible in the "Data Packages for the Hanford Low-Level Tank Waste Interim Performance Assessment." Because this approach was used for the first time, the next version of the "Data Packages" should be a significant improvement in both form and content. The performance assessment team will certainly use the comments in improving the documents.

Presenting modeling results is difficult because of the amount of information that could be portrayed. We will use the comments to attempt to provide more useful information to the reader.

Because this performance assessment was produced early in the program's life, there was little time to independently obtain all the data needed for the performance assessment. Therefore the grout performance assessment was used as a source of data. Although the Peer Review Panel could not formally find the grout performance assessment "technically adequate" because it lacked a best-estimate case, the data in the grout performance assessment were of high quality. 


\section{DOE/RL-97-69 \\ Rev. 0}

Formal internal reviews will be part of the succeeding performance assessments. The current program planning document has a formal internal review step for each document that will be part of the next set of data packages. For some activities, a formal external review is also included.

104. The recharge rate for the first 1,000 years was based on the design specifications of the Hanford surface barrier. The proposed design, now being tested, was created to meet the design specifications considering all of the various events outlined in the comment. The performance assessment team will follow the results of both the continuing design effort and the research/development effort to better understand how the surface barrier is likely to work.

The value of natural recharge after the first 1,000 years may be a bit too low. However, it is unlikely to be as high as $25 \mathrm{~mm} /$ year. Lysimetry, tracer, and simulations along with plant studies will be used to produce better estimates of recharge which will be used in future performance assessments. However, the effect of recharge rates as high as 100 $\mathrm{mm}$ /years were calculated and are discussed in Section 4.6.3.

The guidance on producing performance assessments is to use current climate conditions. Although the climate is likely to change significantly in the future, it is beyond the scope of the performance assessment to analyze such changes.

Recharge at the Hanford Site occurs because of quick melting after a major winter snow accumulation. Actual recharge events occur only a few days every decade. Thus the Hanford Barrier was designed with this process as the main driving force. Testing so far indicates that the constructed prototype is working very well during the potential recharge events we have experienced since its construction.

105. Rockhold (1996) assumes that the Hanford Barrier would be built atop the disposal facility and would have sloping regions to fit with the surface features. This is the design of the prototype. However, conceptual designs for the disposal facility which were the basis for this performance assessment have no such slopes. Even the Alternatives Generation Analysis for disposal (Burbank 1997) shows a raised surface barrier, current plans are to have a surface barrier that is parallel with the ground surface.

The Hanford Barrier does not work by diverting the water around a region. Rather the barrier works by storing the moisture until the vegetation can evapotranspire the moisture. Therefore, it was acceptable not to use the high-recharge areas of the sloped features.

The performance assessment team will use the information on disposal facility design, actual Hanford Barrier experience, and recharge research to estimate the expected recharge. As disposal facility layout becomes better known, the treatment of end effects will be performed. 


\section{DOE/RL-97-69}

Rev. 0

The initial moisture content, unfortunately, was not presented in the performance assessment. Because changing the initial moisture content had so little effect on the simulated results, the authors chose not to present the information.

106. The authors of the performance assessment recognize the limitations of the sand-gravel capillary barrier. Much more research/development is needed for such a disposal facility component. Although not extensively presented in the performance assessment, reference was made to calculations (Piepho 1996) that showed the rather small effect of preferential flows on estimated contaminant fluxes.

As noted above (note 103), the grout performance assessment was a source of data because the interim performance assessment was done early in the life of the program. The planned data collection efforts do include extensive efforts on measurements and understanding of near-field materials.

Because the sand-gravel capillary barrier is untested, sensitivity cases were performed without such a disposal facility component.

Comments concerning the presentation of materials (in particular, the use of graphs to display unsaturated conductivity and moisture retention data) will be seriously considered in future performance assessments.

107. The performance assessment team has learned much in performing the analyses. Some data were not explicitly collected during the modeling process (for example, flux into the disposal facility) which it is now clear should have been captured and presented. A better understanding of the moisture flow and its presentation in the document is highly desirable. In addition, future versions of the performance assessment will have fuller depictions of moisture flow and contaminant transport inside the vault area.

The role of diffusion inside the disposal facility is uncertain. Efforts are continuing to bound the question and define an approach to measure the data necessary to resolve it. Such understanding and data will be used in future performance assessments.

108. The performance assessment agrees the water vapor may be an important mechanism for transferring water into the disposal facility. The same effort mentioned in note 107 is looking at this possibility. It is also attempting to discover the importance of the mechanism for outflow.

109. Graphics showing the model simulations will be improved in the future performance assessment. In addition, more sensitivity cases will be run to determine the adequacy of modeling assumptions (such as grid spacing and number of elements used). Because the approach for the base analysis case for waste form release was based on the specifications of the RFP (hence implying the same release rate for all time and for all spatial points), little effort was spent in justifying the model. 


\section{DOE/RL-97-69}

Rev. 0

The AREST-CT modeling of the waste form release rate (as sensitivity cases) assumed an infiltration rate $(1 \mathrm{~mm} / \mathrm{yr}$ or $10 \mathrm{~mm} / \mathrm{yr})$ and glass waste forms the size of marbles in a porous media. These calculations supplied a time-dependent flux condition to the PORFLOW unit cell calculations.

Future performance assessments will be based on more realistic modeling which will simulate the waste form produced by the vendor as it degrades over time.

110. The effect of tension-dependent anisotrophy will be included in future performance assessments. As part of the plan code selection process, the ability to handle this process will be mandated. An option of vertical capillary break is being considered in facility design.

111. Hydraulic data collection activities for future performance assessments will use the information supplied to provide better estimate of hydraulic properties. Already, data have been obtained for more gravelly soils and compared with the Bouwer and Ricer correction procedure (Khaleel 1997). Values for unsaturated conductivity and moisture retention will be based on new measurements and will result from simultaneous fitting of such measurements for all moisture contents of interest. Stochastic upscaling leading to macroanistropy (with cross-correlations between parameters) will be used in data collection activities for future performance assessments.

112. Little is known about dispersive mixing at Hanford. An on-going effort should provide a better documented basis for future performance assessments. This performance assessment simply varied the value to determine its effect.

113. The moisture dependence of $K_{d}$ was found after values were recommended for use in the performance assessment. This dependency has not been previously observed and requires confirmation before integrating into performance assessment calculations. It is believed that the $\mathrm{K}_{d}$ used in the performance assessment for $\mathrm{U}$ is appropriate for the conditions expected. However, this is an area which the performance assessment is funding and better answers will be forthcoming.

114. As noted in the comment, the justification of the 5 meter well screen height is nonexistent in the performance assessment. This is the value normally used in Hanford performance assessments and its lack of justification demonstrates complacency in not documenting the experience of local drillers and of local health departments. In future performance assessments, this important number will be defended. (A nonscientific sampling indicates that a 40 foot height might, in fact, be more typical).

Future versions of groundwater flow and contaminant transport will rely on to-beselected Hanford Site groundwater model that is to be used on all Hanford analyses. These concerns will be passed on. 


\section{DOE/RL-97-69 \\ Rev. 0}

115. Agreed, the numerical coefficient is incorrect. It should be 3. This is a typo.

The suggested revision to the inventory table will be considered for future performance assessments.

Because the travel time in the groundwater from one side of the disposal facility is so small compared to the vadose zone travel time which itself is small compared to the waste form release time, spatial variations in the flux entering the groundwater are integrated out when performing the effective time integral.

The "module" or "unitized" approach used in this performance assessment was obviously not communicated clearly enough. Future performance assessments will be written to more clearly explain the approach, the approximations, and their effect. Because the contaminant flux reaches a plateau after many thousands of years independent of whether the recharge rate is $0.5 \mathrm{~mm} /$ year or $3.0 \mathrm{~mm} /$ year, it seems most appropriate to use the 3 $\mathrm{mm} /$ year value. However, the point is well taken, the amount of water passing through the plane between the vadose zone and the groundwater should be explicitly calculated and used.

The non-explicit calculation of daughters is a limitation of this approach. Calculations in future performance assessments will explicitly take the effect of daughters into account. Because of the uranium $K_{d}$ is so low compared to other actinide $K_{d} s$, the effect will be small before 10,000 years.

116. The criticism of the geotechnical data and modeling is valid. However, as shown in the analysis because of the very long release times given for the waste form, the travel in the vadose zone provides delay rather than a change in contaminant flux (and hence dose). Therefore the conclusion of the performance assessment is fairly robust. A major caveat on this is the amount of dilution caused by groundwater flow and extraction. If, indeed, atypical well screen heights are used, then the results would be nonconservative.

201: The performance objectives are for an added burden. The last sentence in the paragraph mentioning Table 1:3 has been modified, "Performance Objectives presented in Table 1-3 are values in addition to any existing amounts or background." Footnote b to Table 1-3 has been modified has been modified to read. "... Values given are in addition to any existing amounts or background."

202. See note 201 .

203. The 1990 Census figures used for Benton and Franklin Counties are the same (Figure 2-4 of the PA and Table 4.6.2 of the EIS). The differences come in how the information is broken down. The PA gives populations of the various cities and towns in 1990 and estimated in 1993 whereas the EIS provides an estimate of the total Tri-Cities population from 1890 to 1994 . The figures are consistent for 1993 if the EIS figure for total 


\section{DOE/RL-97-69}

Rev. 0

Tri-Cities population is the sum of the population in Benton and Franklin Counties. Since the EIS does not forecast population, the PA and EIS forecasted populations are not different. Although the data are presented in different ways and stress different subcategories, the information in the two documents are consistent.

204. The statement contained in the performance assessment refiected thinking prior to the privatization. The paragraph has been deleted.

205. The citation in the reference section is misspelled. It has been corrected.

206. Both the TWRS EIS and this performance assessment use the VAM moisture flow and contaminant transport computer code (although different versions). Both documents are based on the Hanford Site groundwater model developed by the Hanford Site Environmental Restoration contractor.

207. The retrieval fractions are expressed differently. The wording in the performance assessment (volumes for each series of single-shell tank) is directly out of the TPA Agreement. The wording in the EIS (per cent retrieved) translates those volumes to an . approximate percentage.

208. The text has been changed to indicate that the three steps are for the first phase of processing (2002 through 2010) and that the second phase ( -2010 through 2025$)$ may be different.

209. The product acceptance section has been rewritten reflecting the current strategy. Note that it is likely that there will be some product testing in the product acceptance process.

210. The water conditioning layer depends not only on whether the waste form is a glass but also on its performance. The paragraph has been rewritten to indicate that this component is only a possibility.

211. After the first sentence of Section 3.2.1, the following section was added to explain the screening performed by Schmittroth 1995 .

"This prescreening effort included the calculation of the quantity of all isotopes produced during materials production at Hanford (see Section 3.2.3), a simple one-dimensional steady state calculation of the transport of such isotopes through Hanford's vadose zone (both with accepted Hanford-relevant $\mathrm{K}_{\mathrm{d}} \mathrm{s}$ as well as $\mathrm{K}_{\mathrm{d}}=0$ ), the conversion of groundwater concentrations to drinking water doses (see Section 3.3.5), and the calculation of inadvertent intrusion using the homesteader scenario (see Section 3.3.2.4).

212. Agreed, see note 9. 


\section{DOE/RL-97-69}

\section{Rev. 0}

213. The only use of off-gas was in the inventory of I-129. Although the position of the engineering staff is that there will be little I-129 due to volatilization during $\mathrm{Pu}$ separation, tank storage, and immobilization, the performance assessment assumes that $10 \%$ of the original produced amount is disposed in the immobilized waste form. This assumption was made (as stated in the text) to determine whether I-129 is important to disposal impacts. It was not.

The performance assessment team will better treat volatilization once the vendors' plans become known.

214. The present performance assessment assumes that volatilization is unimportant, hence putting a higher amount of radionuclides into the immobilization waste than may actually occur. The methods used to handle volatiles and semivolatile materials will be established by the private vendors. The performance assessment team will incorporate such methods into the models used in subsequent performance assessments.

215. The interim performance assessment did not use tank by tank inventories generated by the TWRS Characterization Program as they were not available. However, this performance assessment did use the tank by tank inventory data in the analysis to show that there exists "reasonable expectation" that the requirements suggested by this performance assessment can be met. Future performance assessments will used the information provided by the TWRS Characterization Program in all phases of the analyses.

216. Future Hanford land-use scenarios are in a state of flux. The "Draft Hanford Remediation Action Environmental Impact Statement and Comprehensive Land Use Plan", DOE/EIS-0222D, dated August 1996 provides the Hanford Site's future land use plan. However, due to public feedback, the plan is undergoing revision. The performance assessment team is attempting to follow all of the activities in land use planning (including both local zoning and federal designation of the Hanford Reach as a wild and scenic river). The scenarios used in the current performance assessment are consistent with scenarios used in other Hanford performance assessments with the use of the 200 Area in the future.

217. The issue of environmental justice is treated explicitly in environmental impact statements (see Section 5.19 of the TWRS Final EIS). Future performance assessments will, however, investigate the impact on Native Americans now that scenarios for that community are being standardized.

218. As stated in the introduction to these paragraphs (Section 3.3.3), the contaminant release rate used in the calculations is specified elsewhere. The reference has been changed to Section 3.3.3.2 so to eliminate one link in the pointer chain. 


\section{DOE/RL-97-69}

Rev. 0

Simulations and experiments indicate that the first phase of glass corrosion is relatively quick (using the time scale of the performance assessment). Thus, it is the "saturated" rate which will dominate the performance assessment as shown in the sensitivity case which simulated glass corrosion from first principles rather than using the RFP values. An additional sensitivity study was done to determine the impact of changing the infiltration rate.

219. Both the EIS and the PA used drinking water standards as performance objectives for protecting groundwater. Procedures, codes, and data are somewhat different but are consistent.

220. On-going studies of vadose zone contamination studies are not explicitly included in this performance assessment. Existing vadose zone contaminants will be covered under the Hanford Site Composition Analysis which is scheduled to be published in March 1998.

However, such studies have been and will be used in the Hanford Site data collection activities. Some (for example, remeasurement and reanalysis of the 1980's injection experiment) are being funded and lead by the performance assessment team.

221. The TWRS EIS did use different geochemical values than this performance assessment. The values used in this performance assessment were the result of a study funded by the performance assessment to obtain the best estimated values for chemical effects that would impact low-activity tank waste disposal. The EIS team choose to use earlier, less complete data. Subsequent analysis for the Hanford Site Composite Analysis shows that the $\mathrm{K}_{\mathrm{d}} \mathrm{s}$ used in this performance assessment are still valid with the exception of I-129 whose $K_{d}$ value would be reduced by 5 . Recent studies conducted for this performance assessment activity (Kaplan 1996) essentially doubled the number of iodine $\mathbf{K}_{\mathrm{d}}$ values that have measured using Hanford sediments, resulting in values consistent with previously reported values summarized in Kaplan (1995a). A reduction of the I $\mathrm{K}_{d}$ value does not materially affect the conclusions of the performance assessment as seen by the results presented in section 4.6.2.

222. The vendors indicate that they do intend to meet the void requirement by using small particle non-waste form material. Future performance assessments will use the information supplied by the vendors on their waste forms to better model the waste form and package.

223. The system engineering and design staff are investigating designs from other countries, particularly those of France. (See response to comment 17.)

224. The disposal facility concepts were developed by the performance assessment team based on engineering studies for the grout facility, solid waste facilities, and for vitrified waste (in sulfur-cement) disposal facilities. Now that the program is entering into the phase where the engineering staff is joining with architect-engineers, the performance assessment team will be able to rely on more formal designs. 


\section{DOE/RL-97-69}

Rev. 0

225. The Canister Storage Building in the northwest corner of the 200 Area will be used to store spent fuel. The grout vaults on the far eastern side of the 200 East Area were to be used to dispose of low-level grouted double-shell tank waste. The facilities are different in structure and location.

226. Varying the effective life of concrete walls serve different purposes. The case of modeling the concrete walls. with no effective life provides the engineering staff with information concerning the value of the concrete walls for long-term environmental impact. Thus designs with different types of walls can be envisioned.

Modeling the effective life as much longer than 500 years was to determine whether water trapped in a vault could act as a strong driving function once the water is released.

The simulations show little sensitivity to either situation.

227. Agree. Recharge events at the Hanford Site occur only a few times each decade. This performance assessment thus uses an average rate over many decades. Once the nearsurface zone is passed, then such a more continuous process describes the moisture flow.

228. Agreed, the phrase "over 50 years" was repeated. It has been fixed.

229. GENII treats the stomach wall and the stomach as separate organs (thus adding doses) whereas other dosimetry models treat them as an unit.

230. Native American scenarios were not included in this performance assessment as standardized scenarios have not been developed. As part of the Columbia River Comprehensive Impact Assessment such scenarios are being developed and will be available for future performance assessments.

231. No discussion of inadvertent intrusion could be found in EIS. The EIS [Appendix D (Anticipated Risk)] covers operational scenarios, atmospheric release scenarios, and ground/surface water exposures.

232. Agreed, fixed.

233. Calculations using fission yields provide atoms of Se-79 per atom of U-235. Based on systematics, this quantity is probably known to $30 \%$. To express the results of the calculation in units of Curies of Se-79 to grams of U-235 (the units normally used in measurement), the half-life of Se-79, the atomic weight of U-235, and Avogadro's number must be known. The latter two are well known. Thus the discrepancy between fission yield calculations and measurements is likely to result from an incorrect half-life. New Chinese measurements (Guo 1993 and Chunseng 1997) indicate that the half-life of ${ }^{79} \mathrm{Se}$ is much longer than is normally used. 


\section{DOE/RL-97-69 \\ Rev. 0}

234. NUREG-1199 ("Standard Format and Content of a license application for a Low-Level Radioactive Waste Disposal Facility"), NUREG-1200 ("Standard Review Plan for the review of a license application for a Low-Level Radioactive Waste Disposal Facility"), and draft NUREG-1573 ("Branch Technical Position on a Performance Assessment Methodology for a Low-Level Radioactive Waste Disposal Facilities") are silent on the extent of validation. Because the codes are used to simulate conditions thousands of years into the future, validation in the strict sense is impossible. The best that can be done is to compare simulation results to short-term experiments. Both the AREST-CT and PORFLOW codes have undergone such testing. The codes that will be used in future performance assessments will have more testing as the performance assessment team expands the experimental data base.

235. No. The STOMP code, rather than the PORFLOW code, was used for the SX Tank Farm simulations. These simulations show the importance of understanding what processes must be modeled. In particular, the SX Tank Farm experience showed the importance of near-field chemical and physical conditions on the vadose zone from tank leaks. For example, the fluid leaking from the SX tank had a high density and high temperature. The ionic content of the waste may have overcome the geochemical properties of the vadose zone. The performance assessment team is closely following the lessons learned from the SX modeling as well as other modeling being performed on the Hanford Site.

236. Agreed.

237. Agreed. Future performance assessments will include Native American scenarios, especially as the parameters for those scenarios are now obtaining wide-spread acceptance.

238. The volatilization of iodine was provided by the engineering staff to the performance assessment team. The performance assessment team, in order not to overlook a potential issue, increased the amount of iodine estimated by the engineering staff. The performance assessment team will interact with the private vendors to determine the actual amount of iodine going into the waste form. If the iodine is not recycled to the waste form, then the vendors will be responsible for disposing of it as with other secondary radioactive waste. There is no assumption that the iodine will be released to the atmosphere, just that it will not be in the immobolized low-activity product.

239. The sensitivity case for increased Cs-137 inventory was included for inadvertent intruder scenarios, where Cs-137 is important in the few hundred year time frame.

240. The major uncertainties in the facility design referred to in Section 3.5.5.5 are not the computer codes but the lack of the design. Sensitivity cases were performed to provide the design staff information on the importance of various features to long-term impacts.

International experience will be used to better validate the computer codes used. However, such experience is very limited and usually not very applicable to the disposal of low-level glass waste forms in an arid environment. 


\section{DOE/RL-97-69 \\ Rev, 0}

241. With the privatization of the immobilization, the vendors will determine the best way to reduce cracking. The performance assessment team will follow their efforts to determine the viability of their estimates and the effects on the long-term durability of the waste form.

242. Because of the local nature of $\mathrm{K}_{d} s$, the OECD report (although reviewed for relevance) was not used in establishing $\mathrm{K}_{\mathrm{d}}$ values. Rather the extensive Hanford experimental data base was used for the expected conditions (low ionic content, neutral to slightly basic, low organic content but high carbonate content.)

243. The $\mathrm{K}_{d} s$ used in the PA come from a more complete data base than the ones used in the EIS. The major difference is that the $K_{d}$ for uranium in the EIS was taken to be 0 , while in the PA it was taken to be $0.6 \mathrm{mg} / \mathrm{l}$ based on the experimental data base.

244. The work being performed at PNNL for the performance assessment activity is covered under a general quality assurance plan. For future performance assessments, the data collected will be performed at QA level 2 with supporting calculations at QA level 3. Note that previous data collected by PNNL for the performance assessment activity was done at QA level 3.

The waste form effort at Argonne National Laboratory supporting the performance assessment activity was just audited (April 1997) and was found to be compliant.

245. The external review board mentioned in section 7.7 is the board which provided the comments in this section (Appendix F.1). The sentence was incorrectly written in the original release with the board having already provided their review. As the board has now provided their review, the sentence is now correct.

246. As noted in response 321, the EIS did not present inadvertent scenarios. No Native American scenarios were included in this performance assessment because of a lack of standardized scenarios. Because their "traditional activities" would not intrude on the waste, the residential scenario should be bounding for Native Americans.

247. Agreed. Number changed from " 300 " to " 200 ".

248. The value for an iterative set of performance assessments is that they can be used to identify problems and concerns so that these problems and concerns can be addressed. One of the main purposes of this performance assessment was to identify concems as early as possible. Thus the finding that $\mathrm{Sn}-126$ could be a problem should be seen as a strength of this effort.

249. The Department of Energy as well as the systems engineering staff of the Site's contractor are using the performance assessment to address these questions.

250. As noted above (response 223), the design staff is using international experience. 


\section{Rev. 0}

251. The comment on axes presentation will be considered in future performance assessments. The aim is NOT to mislead the reader.

252. Because of the lack of knowledge on the disposal facility design and the waste form performance, the terminology of "best estimate" was not used. Also by having one case (rather than the two suggested by this review board), some parameters (for example, certain $\mathrm{K}_{d} \mathrm{~s}$ ) were conservatively chosen rather than best-estimates. Future performance assessments will have a true best-estimate case as well as a reasonably bounding case.

253. The initial version of the performance assessment is already being used in a number of areas involving TWRS, including characterization, facility design, and relationship to vendors. The performance assessment is not seen just as a regulatory compliance tool, but as a document that has wide and important impact on many different TWRS areas.

254. The brief compliance analysis here was intended to provide an indication of what a full analysis (expected in March 1998) will show. This analysis assumes that each tank farm will be compliant with the all-pathways dose requirements. Thus changes in tank farm compliance would change the calculated results in this section.

255. Because data are being gathered (particularly waste form information), it is difficult to provide a snapshot that is more valid than the one documented in the performance assessment. Information gathered since the initial release of the performance assessment do not significantly change any of the calculated results.

256. Agreed. The performance assessment team in future documents will produce both a bestestimate and reasonably possible cases.

257. Table 4-32 (Table 4-34 in the interim performance assessment) provides an estimate of the dose assuming that the waste was placed directly in the groundwater. Thus no retardation due to the vadose zone is included. Table 6-3 (Table 5-3 of the interim performance assessment) includes the effect of the vadose zone (including retardation).

258. The well screening height was not well defended in this performance assessment. Future performance assessments will provide relevant local practice to justify the value used in such future documents. However, based on conversations the value used in this performance assessment is conservative considering local practices.

259. Agreed.

260. Comments on earlier Hanford Site performance assessments suggested that the values used for borehole diameters and garden sizes were not conservative enough. To determine the sensitivity of these values, less conservative values than previously used in Hanford performance assessments were used. The well diameter will be based on documented local experience. The area of the garden farm is more difficult since most farms in the region are fairly large. However, this value too will be based on documented local experience. 


\section{DOE/RL-97-69}

Rev. 0

261. Container degradation will be included in future performance assessments. Since the material to be used in the containers is not known (the request for proposal only states metal), it was premature to perform detailed estimates. The effect, however, is thought to be small.

262. Because the facility designs were only conceptual, detailed degradation scenarios were not developed. Data collection efforts are planned to obtain information on how expected materials will degrade.

It is expected that the degraded concrete will act hydraulically different from the filler material surrounding the waste forms and will act as a sort of a capillary barrier. That is why current data collection activities are striving to understand how the components of the disposal facility will degrade and what influence each component will have on the others.

263. The $\mathrm{pH}$ inside the disposal facility will be spatially and temporally dependent. It will depend on the amount of infiltration as well as on the rate of the sodium-hydrogen ion exchange reaction for the particular waste form. Based on various calculations, an estimate of 9.5 is not inappropriate. 


\section{F.2 Nuclear Regulatory Commission}

As part of the NRC's ruling on the classification of the tank waste, the Engineering and Geosciences Branch of the Division of Waste Management read the document. By letter (see Section F.2.1), the staff first requested a meeting to address a series of questions. By receiving a response to their letter (see Section F.2.2), the request for the meeting was dropped. In June 1997, the Department of Energy received a letter from the Director, Office of Nuclear Material Safety and Safeguards of the Nuclear Regulatory Commission, (see Section F.2.3) that given the preliminary nature of the interim performance assessment the preliminary finding of the NRC staff was that safety requirements comparable to the performance objectives set out in $10 \mathrm{CFR}$ Part 61 Subpart $\mathrm{C}$ would be satisfied.

\section{F.2.1 Letter from NRC Requesting Additional Information}

February 1997

Mr. Donald D. Wodrich

Office of Tank Waste Remediation System

U. S. Department of Energy

Richland Operations Office

P. O. BOX 550 MSIN $57-50$

Richland, WA 99352

\section{SUBJECT: REQUEST FOR ADDITIONAL INFORMATION - HANFORD INCIDENTAL WASTE CLASSIFICATION}

Dear Mr. Wodrich:

U.S. Nuclear Regulatory Commission staff along with our contractor, the Center for Nuclear Waste Regulatory Analyses, are in the process of reviewing the "Technical Basis for Classification of Low-Activity Waste Fraction from Hanford Site Tanks" (Technical Basis), WHC-SE-WM-TI-699, Rev. w, as requested in the November 7, 1996, letter from J. Kinzer, U.S. Department of Energy (DOE), to C. Paperiello, U.S. Nuclear Regulatory Commission. In the process of reviewing the Technical Basis, we have also examined several of the supporting references, including the "Hanford Low-Level Tank Waste Interim Performance Assessment" (Interim PA), WHC-EP-0884, dated September 16, 1996. With respect to the Interim PA, we have identified several issues that need to be resolved before NRC staff can fully evaluate your request for agreement that the Hanford tank waste planned for disposal on-site is incidental waste that would not be subject to NRC licensing authority. These comments address the effects of certain assumptions, models, or parameters on dose calculations with respect to meeting the third of the incidental waste classification criteria set forth in the March 2, 1993, letter from R. Bernero, NRC, to J. Lytle, DOE. The comments are listed in the Enclosure.

In order to facilitate the expedited review schedule requested in the November 7 letter, we would like to attempt to resolve these issues in a meeting (face-to-face, or through telecon or videocon) 


\section{DOE/RL-97-69}

\section{Rev. 0}

with you and with the PA staff that authored the Interim PA document. Please contact either Jennifer Davis at (301) 415-5874, or Richard Weller at (301) 415-7287 to set up a meeting. We would appreciate it if the meeting could be held very soon, as we are working to meet your scheduled completion date of April 1997.

\section{Sincerely,}

Michael J. Bell, Chief

Engineering and Geosciences Branch

Division of Waste Management

Office of Nuclear Material Safety And Safeguards

Enclosure: As stated

cc: J. Kinzer (w/encl) 
DOE/RL-97-69

Rev. 0

\section{SPECIFIC COMMENTS FROM REVIEW OF THE "HANFORD LOW-LEVEL TANK WASTE INTERIM PERFORMANCE ASSESSMENT," WHC-EP-0884, REVISION 0}

1. The Interim PA provides a value of an initial fractional radionuclide release rate of $4.4 \times 10^{6}$ for all radionuclides except ${ }^{99} \mathrm{Tc}$. Which has a rate of $8.8 \times 10^{7}$ (Pp. iv and 3-32). These values for the fractional radionuclide release rate may be unrealistically low for the disposal facility. The Interim PA assumes that the fractional radionuclide release rates are limited by the fractional bulk dissolution rate of the glass. However, it is not clear how the fractional release rates for ${ }^{99} \mathrm{Tc}$. A highly soluble nuclide, could be much smaller than the other isotopes in the glass. These values should be justified. For example, Kerrisk (1984) presents a detailed model for calculating fractional radionuclide release rates for vitrified pressurized water reactor high-level waste for 10 important radionuclides expected in the waste, based on nuclide solubilities, recharge rates, background concentrations of silica, and other factors. A similar evaluation would be appropriate for the Tank Waste Remediation System waste.

Additionally, the bulk dissolution rate for glass does not necessarily determine the dissolution rate for high-solubility fission products in the glass (such as ${ }^{99} \mathrm{Tc}$ and ${ }^{129} \mathrm{~T}$ ), because many of these nuclides may have the ability to diffuse out of the glass, and may, therefore, have high release rates. These processes are not included in the Interim PA.

2. The $K_{d}$ value for $I$ (p. 3-27, Table 3-5) appears to be nonconservative. As standard practice, $I$ is generally considered to be unretarded, i.e., $K_{d}-1 \mathrm{~L} / \mathrm{kg}$. (See also Sheppard and Thibault, 1990.) The value presented in the Interim PA, $\mathrm{K}_{d}-3 \mathrm{~L} / \mathrm{kg}$ is somewhat higher. This difference is expected to significantly affect the results. The value used should be altered or justified.

3. Some of the all-pathways dose conversion factors (DCFs) in the Interim PA (p. B-56, Table B-3) appear to be low compared with DCFs for other arid sites (LaPlante, et al., 1995). The Interim PA should include a more detailed technical justification for the selection of the CFS, because evaluation of disposal facility performance are expected to be very sensitive to the values selected.

4. The derivation of the relative radionuclide release rate (pp. 3-33 and 3-34) may require modification. The equation in the center of page 3-33 describes the absolute radionuclide release rate (in $\mathrm{Ci} / \mathrm{yr}$ ) for the waste form as :

Where:

$$
R R R(t)=S(t)=I(t) / V(t)
$$

$R R R(t)=$ the radionuclide release rate $(C 1 / t)$

$\mathrm{T}=$ the time

C = the constant corrosion rate $(\mathrm{I} / \mathrm{t})$

$S(t) \quad=$ the surface area of the waste form as a function of time (13)

$I(t) \quad=$ the radionuclide inventory in the waste form as a function of time (Ci)

$V(t) \quad=$ the volume of the waste form as a function of time $\left(1^{3}\right)$ 


\section{DOE/RL-97-69}

Rev. 0

Assuming that this equation is correct, the reiative (or fractional) radionuclide release rate, $\operatorname{FRRR}(T)$, i.e., the fraction of radionuclide inventory release rate per unit time would be given by:

$$
\operatorname{FRRR}(T)=\operatorname{RRR}(\mathrm{t}) / I(t)-C * S(t) / V(t)
$$

The waste area to volume ration is expected to increase with time due to corrosion of the waste form and cracking due to formation of corrosion products. Because FRRR(t) is directly proportional to the waste area to volume ration, this quantity would be expected to increase with time. On page 3-34, there is an expression for FRRR $(t)$ that decreases with time. This consideration should be included in the Interim PA, because performance is likely to be highly sensitive to radionuclide release rate.

5. The Interim PA methodology is deterministic, and single values (sometimes best values) of parameters are used. The reviewers are concerned that if the range of measured parameter values were incorporated into the Interim PA, some performance limits might be exceeded. Uncertainty analyses should be performed in addition to the sensitivity analyses presented in the Interim PA.

6. There is insufficient justification for the assumption that the capillary barrier will be intact for 1000 years. The performance of this barrier will degrade with time. Similarly, the Interim PA assumes that the concrete vaults will be intact for 500 years. This assumption seems to be based on a U:S. Nuclear Regulatory Commission Branch Technical Position which specifies that the maximum credit that can be allowed for concrete structures is 500 years. A site-specific justification should be provided for this assumption, since occurrence of earthquakes and other natural events must be accounted for.

7. The infiltration rate of $0.5 \mathrm{MM} / \mathrm{yr}$ for the first 1000 years and $3 \mathrm{~mm} / \mathrm{yr}$ thereafter has not been adequately justified. These values may be unrealistically low, and contribution from lateral subsurface flow during storms has been neglected.

8. The release rate calculation appears unrealistic in that the dissolution time for the entire inventory is based on dissolution in still water. In flowing water, waste dissolution will be faster because the fresh water will provide for continuous attack on the waste form. The Interim PA acknowledges that performance results are dependent upon the release rate (pp. 3-32 and 3-35). The dissolution time calculations should be justified or altered.

9. The Interim PA uses an equation which appears to consider that the quantity of radionuclides transported to the base of the vades zone is dissolved in a volume of water equal to the annual recharge (p. 3-61). This would be unrealistic and nonconservative, particularly for the second design option in which the vaults are interspersed by soil. The volume of water will be the portion of annual recharge that actually flows over the waste. The concentration calculated by the flow and transport code would appear to be more justifiable. 


\section{DOE/RL-97-69}

Rev, 0

10. Flow and transport modeling neglects heterogeneity within layers, thereby omitting consideration of spatially distributed flow.

\section{REFERENCES}

Kerrisk, J.F., "Solubility Limits on Radionuclide Dissolution at a Yucca Mountain Repository." LA-9995-M5, Los Alamos National Laboratory, Los Alamos, NM, 1984.

LaPlante, P.A., S.J. Maheras, and M.S. Jarzemba, "Initial Analysis of Selected Site Specific Dose Assessment Parameters and Exposure Pathways Applicable to the Groundwater Release Scenario at Yucca Mountain," CNWRA 95-018, Center for Nuclear Waste Regulatory Analyses, San Antonio, TX. 1995.

Sheppard, M.I., and D.H. Thibault, "Default Soil/Solid Liquid Partition Coefficients, K, for Four Major Soil Types: A Compendium, "Health Physics, Vol. 59, No. 4, pp. 471-482, 1990. 
DOE/RL-97-69

Rev. 0

\title{
F.2.2 Response to NRC Letter
}

The following letter was sent to the NRC.

\author{
Department of Energy \\ Richland Operations Office \\ P.O. Box 550 \\ Richland, Washington 99352
}

97-TWR-003

February 1997

Michael J. Bell, Chief

Engineering and Geosciences Branch

Division of Waste Management

Office of Nuclear Material Safety

and Safeguards

U.S. Nuclear Regulatory Commission

Washington, D.C. 20555

Dear Mr. Bell:

REQUEST FOR ADDITIONAL INFORMATION - HANFORD INCIDENTAL WASTE CLASSIFICATION

Reference: $\quad$ NRC letter from Michael J. Bell, to Donald D. Wodrich, RL, "Request for Additional Information - Hanford Incidental Waste Classification," dated February 6, 1997.

As requested in the above reference, attached is our response to your review comments of the "Hanford Low-Level Tank Waste Interim Performance Assessment," WHC-EP-0884, Revision 0, dated September 16, 1996. On February 12, 1997, copies of the document referenced in the attached responses, "Data Package for the Hanford Low-Level Tank Waste Interim Performance Assessment, "WHC-SD-WM-RPT-166, Revision 0, dated August 1994, were transmitted.

It is my understanding that this information meets your needs and that a meeting on this subject is not needed at this time. If you have any questions or need additional information, please contact me on (509) 376-6550.

Sincerely,

Don Wodrich, Senior Technical Advisor Office of Tank Waste Remediation System

TWR:DDW

Attachment

cc w/attach:

C. Peterson, NHC 
Response to Specific Comments from the Review of the "Hanford Low-Level Tank Waste Interim Performance Assessment," WHC-EP-0884, Revision 0

(Comments contained in the letter from Michael J. Bell, NRC)

1a. The comments suggest that the initial fractional release rate of $4.4 \times 10^{-6}$ for all radionuclides except ${ }^{99} \mathrm{Tc}$, which has a rate of $8.8 \times 10^{-7}$ may be unrealistically low.

The actual waste form to be disposed is undergoing negotiation between the Department of Energy and two private vendors selected for phase 1 immobilization. Since the waste form is unknown, the base analysis case of the interim performance assessment used the specifications that were included in the request for proposal [RFP] (and now included in the contracts). Please note that for the base case, the release rate for $\mathrm{Tc}$ is taken as $4.4 \times 10^{-6}$.

Although this release rate is very low, experiments at the Argonne and Pacific Northwest National Laboratories have shown for a variety of low-level radioactive glass waste forms, this rate can be achieved for the temperatures and $\mathrm{pHs}$ expected in the disposal facility.

The initial rate will be determined by a 7-day PCT test and hence should be indicative of the forward rate of glass dissolution. Multi-year experiments at Argonne and Pacific Northwest Laboratories on LD6-5412, a typical low-level waste glass, show that the initial rate is indeed conservative for both. Stage II and III of the glass dissolution process.

In addition, to using the release rate specifications, computer simulations based on experimental data for LD6-5412 were performed. These calculations documented in the interim performance assessment show that the predicted release rate is much lower than required in the RFP.

1b. The comments state that the release rate for Tc may not be lower than for other components. For the base case of the interim performance assessment, the release rate for Tc was assumed to be the same as for other elements. The lower rate for Tc release in the RFP could be met in a variety of ways. The most likely way is to separate the Tc from the waste to be immobilized, as the specifications require the release rate calculated relative to the amount of material supplied to the vendor and not to the amount in the waste form. However, from the perspective of a performance assessment, the effect is the same as shown by the sensitivity cases.

1c. The comments suggest that bulk glass dissolution does not necessarily determine the dissolution rate for high-solubility nuclides, which may be released at much higher rates by diffusion. The only element that has been observed in experiments at Argonne and Pacific Northwest National Laboratories to be released faster than bulk dissolution is sodium. Experiments with actual vendor glasses are planned to determine whether the 
Rev. 0

fission product nuclides are also subject to this release mechanism. Recent experiments at Argonne National Laboratory suggest that $\mathrm{Tc}$ may be bound in some of the secondary phases that are formed from dissolution of LD6-5412 and FLLW-1.

2. The comments note that the Kd for iodine is usually taken to be 0 and that the interim performance assessment used $3 \mathrm{~L} / \mathrm{kg} . \mathrm{K}_{\mathrm{d}}$ values for the important elements are based on experiments using Hanford soils (see "Distribution Coefficient Values Describing Iodine, Neptunium, Selenium, Technetium, and Uranium Sorption to Hanford Sediments" by D.I. Kaplan and R.J. Serne, PNL-10379, Sup. 1 - March 1995. This document as well as others forming the data base for the interim performance assessment are contained in "Data Packages for the Hanford Low-Level Tank Waste Interim Performance Assessment," WHC-SD-WM-RPT-166, Rev. 0 - August 1995). Subsequent measurements and reanalysis confirmed that a non-zero $\mathrm{K}_{\mathrm{d}}$ is appropriate for Hanford soils, although the value of 3 may be a bit too high.

Argonne National Laboratory is measuring Tc release from LD6-5412 glass this year. Both Argonne and Pacific Northwest National Laboratories will measure release rates of actual vendor glasses made using actual Hanford tank waste starting next year.

3. The comments state that dose conversion factors in the interim performance assessment appear to be low compared to other arid sites and should be documented. The dose conversion factors are documented in "Data and Assumptions for Estimates of Radiation Doses for the Glass Low-Level Waste Interim Performance Assessment, P.D. Roadman, WHC-SD-WM-TI-707 - June 1995. This document as well as others forming the data base for the interim performance assessment are contained in "Data Packages for the Hanford Low-Level Tank Waste Interim Performance Assessment," WHC-SD-WMRPT-166, Rev. 0 - August 1995. The values used are consistent with the values used in other Hanford risk assessments. Both the values and methods used were reviewed by the Hanford Environmental Dose Oversight Panel.

4. The comments note that the surface area to volume of the waste form should increase with time due to corrosion and cracking. As noted in the performance assessment, the simple assumption of uniform decrease in dimensions was used. As more is known about the waste form and its processing, cracking and other events will be included into the performance assessments.

5. The comments note that interim performance assessment used point values and provided sensitivity studies. The comments suggest that an uncertainty analysis be performed. The interim performance assessment was produced in order to provide confidence that the disposal of Hanford low-activity tank waste could be performed. Because it was produced so early in the project, many items (waste form, disposal facility location and design) were not known. Reasonable assumptions based on other projects were used for the estimation of values for the base case. Sensitivity cases were defined to determine the impact of these assumptions. For the performance assessments to be submitted for regulatory review, uncertainty analyses will be done. 


\section{DOE/RL-97-69 \\ Rev, 0}

6. The comments note that the surface barrier is assumed to be intact for 1,000 years and that the concrete structure for 500 years. Neither the surface barrier nor the concrete structures have been designed. The results from sensitivity studies assuming no credit for such structures are very little different from the base case where credit for such structures is taken. The parameters (including design life) for the surface barrier come from work on the Hanford barrier ("Prototype Hanford Surface Barrier: Design Basis Document," D.R. Myers and D.A. Duranceau, BHI-0007 - November 1994). Research on the Hanford surface barrier is continuing. As the design of the disposal facility progresses, analyses to determine the degradation of the structure will occur. However, until design does start, assumptions based on other projects were thought suitable for the interim performance assessment.

7. The comments suggest that the infiltration rates are not adequately justified. The effect of lateral subsurface flow during storms has been neglected. The rates were taken from "Estimate of the Natural Ground Water Recharge for the Performance Assessment of a Low-Level Waste Disposal Facility at the Hanford Site" by M.L. Rockhold, M.J. Fayer, C.T. Kincaid, and G.W. Gee, PNL-10508, March 1995. (This document as well as others forming the data base for the interim performance assessment are contained in "Data Packages for the Hanford Low-Level Tank Waste Interim Performance Assessment," WHC-SD-WM-RPT-166, Rev. 0 - August 1995). The value for the first 1,000 years is based on the design specifications of the Hanford surface barrier. Testing of this surface barrier is continuing at Hanford and so far is meeting its specifications (even under a separate test having precipitation rates of three times normal). The long-term infiltration rates are based on an extensive program at Hanford which has been very favorably reviewed by outside groups. The results of a program including long-term tracer measurements, lysimeter measurements, and computer simulations will be used in the performance assessments created for regulatory review.

The cause of infiltration at the Hanford Site has been extensively studied. Lateral flow is seen at Hanford but its cause is suspected to be from geologic and hydraulic phenomena (non-horizontal layers, anisotropic hydraulic tensors) rather than storm related events. Once a disposal site is selected, characterization of vadose zone properties will allow a better answer to these concerns.

8. The comments indicate that the release calculations are unrealistic because they are based on dissolution is [sic] still water. Because of the low infiltration rates, the waste if not in still water is in an environment in which the water hardly moves. The base analysis case assumes the forward rate of glass dissolution provides the maximum rate since it is based on distilled water. Moreover, the simulations of glass dissolution do assume flowing water but at rates consistent with water infiltration. These calculations show that the system is diffusion dominated with a very small advective component.

9. The comments note that the contaminants are assumed to be diluted using the area of the disposal facility, not of the waste packages. The computer model used in the base analysis case was a full facility model. The results of these simulations clearly show that 


\section{DOE/RL-97-69}

Rev. 0

the water and contaminants do spread laterally enough to cover the gaps between vaults in the alternate layout design. In fact, the calculations are conservative, since the lateral dispersion will extend beyond the area of the disposal facility.

10. The comments note that the vadose zone modeling neglects heterogeneity within layers. This is true. The site of the disposal action has not yet been determined. Once the site(s) have been determined, then site characterization will be performed. The effect of any preferred flow paths will be determined. 
DOE/RL-97-69

Rev. 0

\section{F.2.3 Letter from NRC on Classification of Hanford Low-Activity Tank Waste Fraction}

June 1997

Mr. Jackson Kinzer, Assistant Manager

Office of Tank Waste Remediation System

U.S. Department of Energy

Richland Operations Office

P.O. Box 550

Richland, WA 99352

SUBJECT: CLASSIFICATION OF HANFORD LOW-ACTIVITY TANK WASTE FRACTION

Dear Mr. Kinzer:

The U.S. Regulatory Commission has received your letter dated November 7, 1996 requesting NRC agreement that the Hanford tank waste planned for removal from the tanks and disposal . on-site is incident waste [i.e., not high-level waste (HLW)] and, therefore, would not be subject to NRC licensing authority. In response to your request, NRC and contractor staff [Center for Nuclear Waste Regulatory Analyses (CNWRA)] have reviewed the "Technical Basis for Classification of Low-Activity Waste Fraction from Hanford Site Tanks" (Technical Basis Report) and supporting documents, including the "Hanford Low-Level Tank Waste Interim Performance Assessment" [Interim Performance Assessment (PA)] to determine whether there is reasonable assurance that the tank waste slated for disposal as low-activity waste (LAW) meets the incident waste classification specified in the March 2, 1993 letter from R. Bernero, NRC, to J. Lytle, U.S. Department of Energy (DOE).

Criterion One from the March 1993 letter specifies that “... wastes have been processed (or will be further processed) to remove key radionuclides to the maximum extent that is technically and economically practical." To comply with this criterion, available separation technologies were identified for each of the major radionuclides of interest and individually evaluated to determine the status of the technology and the radionuclide removal efficiency. Three separate technologies were deemed both technically and economically practical. Currently, it is expected that all three will be used. The three technologies include a simple solids-liquids separation removal of transuranic waste from selected tanks and single-cycle ion exchange removal of cesium- 137 from certain wastes. Approximately $3.1 \times 10^{17} \mathrm{~Bq}(8.5 \mathrm{MCi})$ of activity will remain in the $\mathrm{LAW}$, which corresponds to about 2 percent of the estimated $15.6 \times 10^{18} \mathrm{~Bq}(422 \mathrm{MCi})$ generated at the Hanford Site (based on a December 31, 1999 decay date).

NRC staff concludes that the available separation processes have been extensively examined to determine those that are both technically and economically practical, and that the residual 2 percent of the activity generated at the Hanford Site represents the maximum amount of separation currently technically and economically practical for this case. It is considered that Criterion One for classifying the Hanford site LAW fraction as incidental waste will be met if the waste management plan presented in the Technical Basis report is followed. Note that if actual radionuclide inventories, either in the tanks or following separation, are significantly 
DOE/RI,-97-69

Rev. 0

higher than or different in character from those projected, compliance with this criterion will require re-evaluation by $\mathrm{NRC}$.

Compliance with Criterion Two, “... waste will be incorporated in a solid physical form at a concentration that does not exceed the applicable concentration limits for Class $\mathbf{C}$ [low-level waste] as set out in 10 CFR Part 61." was determined using the estimated total vitrified waste volume $\left(158,000 \mathrm{~m}^{3}\right)(42,000,000$ gallons $)$ in conjunction with projected radionuclide activities. From these calculations, which NRC staff verified, the vitrified waste form is expected to meet the limits for Class $\mathrm{C}$ or less, as specified. Note that molten metal processing is also considered for the LAW form. This method would considerably decrease the total waste form volume such that the waste classification could be affected. If the radionuclide inventories in the LAW are significantly higher than those projected in the Technical Basis report, or if the waste form type or total volume are altered, reevaluation of conformance with this criterion will be necessary.

To evaluate Criterion Three "... wastes are to be managed, pursuant to the Atomic Energy Act, so that safety requirements comparable to the performance objectives set out in $10 \mathrm{CFR}$ Part 61 , Subpart C are satisfied.", an Interim PA was prepared. The DOE PA was performed to the requirements of DOE Order 5820.2A, "Radioactive Waste Management," dated September 26, 1988. This order is similar to the 10 CFR Part 61 performance objectives.

The Interim PA is the first of three PAs planned and is somewhat preliminary; it was conducted before selection of a disposal facility site and design, specific treatment alternatives, LAW form, or a complete and verified radiological and chemical characterization of the contents of the Hanford tanks. Our review identified a number of specific issues and concerns associated with the Interim PA, documented in the February 6, 1997 Request for Additional Information (RAI) from M. Bell, NRC, to D. Wodrich, DOE, (note added: this letter is reproduced in Section F.2.1 and discussed in the enclosed CNWRA report. DOE's responses to the RAI constitute Appendix B to the CNWRA report \{note added: this letter is reproduced in Section F.2.2 . Many of the RAI comments cannot be fully resolved until the site, facility design, and solidification process are selected. It is expected that uncertainties and concerns identified with respect to the Interim PA can be satisfactorily addressed in subsequent PAs.

Although the Interim PA is preliminary it indicates that the performance objectives of Part 61 will be met. Consistent with the preliminary nature of this Interim PA, the staff's preliminary finding is that Criterion Three appears to be satisfied. As the disposal facility is chosen, the disposal facility design is completed, treatment alternatives are selected, the LAW form is determined, and proper characterization of the contents of the tanks is confirmed, the various assumptions and input parameters are likely to be further refined. Please submit future PAs as supplements to the Technical Basis report so that they can be reviewed to confirm the current analysis and resolve any outstanding issues.

Based on the preliminary information provided in the DOE Technical Basis report and the Interim PA, the staff's preliminary finding is a provisional agreement that the LAW portion of the Hanford tank waste planned for removal from the tanks and disposal on-site is incidental waste and is, therefore, not subject to NRC licensing authority. Staff considers that the information presented is not sufficient to make an absolute determination at this time. Note that 


\section{DOE/RL-97-69}

Rev, 0

if Hanford tank waste is not managed using a program comparable to that set forth in the Technical Basis report, or the current characterization of tank contents is not confirmed, the incidental waste characterization must be revisited by DOE and the NRC consulted. As a fundamental element of the incident waste classification, DOE must ensure the contractors perform LAW separation and disposal do so in accordance with the criterion set forth in the March 1993 letter and the approved Technical Basis report.

Successive PAs should be submitted as supplements to the Technical Basis report so that they can be reviewed to confirm the current analysis and resolve any outstanding issues. Other specific changes that would necessitate DOE re-evaluation and further consultation include, but are not limited to, the following:

1) Continuing characterization of tank waste results in a determination that the radionuclide inventory in the HIW tanks is higher than or different from that used to develop the Technical Basis Report and the Interim PA. This would affect the resolution of all three criteria.

2) The LAW fraction of the Hanford tank waste is not vitrified, or the final volume of waste is significantly different from that projected in the Technical Basis report. The waste form is a determining factor in classification of waste as Class A, B, or C (Criterion Two) and would also impact PA (Criterion Three).

3) Final selection of the LAW disposal site, or changes to site characterization parameters will affect the resolution of Criterion Three.

If you have any questions about the details of this letter, please contact Michael Bell of my staff at (301) $415-7286$.

Sincerely,

Carl J. Paperiello, Director

Office of Nuclear Material Safety and Safeguards 


\title{
DOE/RL-97-69
}

Rev. 0

\section{F.3 U.S. Department of Navy}

Reactor compartments from decommissioned submarines from the U.S. Navy are disposed in the northern part of the 200 East Area. Because of this disposal action, the U.S. Navy has performed a series of environmental studies in that region.

\section{F.3.1 Letter from US Navy}

July 1996

5090

Ser $2310 / 1118$

\section{U. S. Department of Energy}

Richland Operations Office

Attn: T. K. Teynor.

Director, Waste Programs Division

P.O. Box 550, MSIN S7-55

Richland, WA 99352

Gentlemen:

Puget Sound Naval Shipyard has reviewed a copy of the Hanford Low-Level Tank Waste Interim Performance Assessment, WHC-EP-0884 (Tank Waste PA) and provides comments in enclosure (1). Comments are provided per reference (a) which requested a response by March 30, 1997. Comment 4. of enclosure (1) is intended to provide consistency with the Draft 200 East Area Low level Burial Ground Performance Assessment (Woods 1996), and the Shipyard requests to be informed of specific text changes in resolution to this comment. Faxing of revised pages is sufficient. I can be reached at (360)-476-8544.

Sincerely

\author{
J. R. WRZESKI \\ Head, Reactor Engineering Division \\ Nuclear Engineering and Planning Department \\ By direction of the Shipyard Commander
}

Ref:

(a) WHC letter 9654293 of September 24, 1996

Encl:

(1) Comments to Hanford Low-Level Tank Waste Performance Assessment 
DOE/RL-97-69

Rev. 0

\section{COMMENTS TO HANFORD LOW-LEVEL TANK WASTE INTERIM PERFORMANCE ASSESSMENT}

\section{Ref (a): NAVSHIPYD PUGET ltr 5090/5 Ser 2300.1/1 188 of 5 Jul 96}

1. Section 3.4.5.4 on page 3-32 specifies a $1.4 \mathrm{E}-13\left(\mathrm{~s}^{-1}\right)$ initial fractional radionuclide release rate for non- ${ }^{99} \mathrm{Tc}$ isotopes for use in the base case analysis. This rate is equated to a initial radionuclide release rate of $4.4 \mathrm{p} . \mathrm{m} . / \mathrm{yr}$ in the subject section (first bullet). Table $3-8$ on page 3-34 provides a formula which results in an initial radionuclide release rate of [4.4/T] p.m./yr (at time $=0$ ), vice $4.4 \mathrm{p} . \mathrm{m} . / \mathrm{yr}$. The constant $\mathrm{T}$ is a large value, and so the formula does not appear to be consistent with the earlier text. Please clarify.

2. In section 4.3.2.5 on page 4-21 at the beginning of third paragraph, " 10,00 years" is a typographical error which probably should be " 10,000 years".

3. In Appendix D, section D.3.2 (page D-8) at the end of the first (and only) paragraph, "Hanford East Area" appears to be a typographical error which probably should be "Hanford 200 East Area".

4. In Appendix E, Figure E-2 on page E-20 depicts a 119-120 meter elevation above mean sea level for the water table at the 218-E-12B Burial Ground. This corresponds to a de-saturated condition under Trench 94 consistent with predictions from Rhoads et al., 1994. In 1995, groundwater monitoring wells adjacent to the trench were either dry or showed aquifer thickness of less than 1 meter, at about 122 meters above mean sea level. This is not consistent with the 5 meter thick aquifer predicted for this site in Figure E-3 on page E-21. Comment 1.a of enclosure (1) of reference (a) noted a similar inconsistency in the Draft 200 East Area Low level Burial Ground Performance Assessment (Wood, 1996). This comment was resolved by Westinghouse Hanford Company in proposed text changes provided to the Shipyard on July 31,1996 . Similar text is proposed below for addition as a footnote to Figure E-3 of the Tank Waste Performance Assessment with the footnote keyed to the 218-E-12B Burial Ground:

"A study to evaluate the potential for transport of nickel radioisotopes from the 218-E-12B Burial Ground (Rhoads et al. 1994) postulated unsaturated sediments beneath this site, rather than the 5 meter thickness predicted in this analysis. The postulation was based on twodimensional CFEST simulations under an assumption of a low recharge condition and supported by the measurements of adjacent wells. However, the desaturation condition should be limited to the vicinity of the 218-E-12B Burial Ground. Further details can be found in Wood 1996." 
DOE/RL-97-69

Rev. 0

\section{F.3.2 Response to letter}

1. The commenter is correct. The multiplicative factor in Table 3.8 is incorrect, it should be 3 . The calculations were performed with the proper value, as can be determined by comparing the cases with constant release rate with the cases using the formula given in Table 3.8 .

2. The commenter is correct. "10,00" should be " $10,000 "$ ".

3. The commenter is correct. "Hanford East Area Burial Ground" should be "Hanford 200 East Area Burial Ground"

4. The commenter's point is noted. However, rather than placing the comment as a footnote to a figure caption in an appendix, the following text was added in the main body of the text at the end of section of Section 4.3.3.

"Large-scale Hanford groundwater modeling for conditions far in the future is just beginning to undergo extensive review. Some discrepancies are to be expected. For example, a study to evaluate the potential for transport of nickel radioisotopes from the 218E-12B Burial Ground (Rhoads et al, 1994) postulated unsaturated sediments beneath this site located in the northern part of the 200 East Area (as contrasted to the 5 meters predicted in this analysis). The postulation was based on two-dimensional CFEST (Gupta 1987) simulations under an assumption of a low recharge condition and supported by the measurements of adjacent wells. However, the desaturation condition should be limited to the vicinity of the 218-E-12B Burial Ground, because of the basalt structure being much nearer the surface at the burial ground."

The reference Rhoads 1994 will be added

Rhoads 1994, K. Rhoads, B.N. Bjomstad, R.E. Lewis, S.S. Teel, K.J. Cantrell, R.J. Serne, L.H. Sawyer, J.L. Smoot, J.E. Szecsody, M.S. Wigmosta, and S.K. Wurnster, Estimation of the Release and Migration of Nickel Through Soils and Groundwater at the Hanford Site 218-E12B Burial Ground, PNL-9791, Pacific Northwest Laboratory, Richland, Washington, 1994. 


\section{DOE/RL-97-69}

Rev. 0

\section{F.4 Kathleen Rhoads}

Kathleen Rhoads is a Senior Research Scientist at the Pacific Northwest National Laboratory. She performed the Hanford Environmental Dose Oversight Panel review [Rhoads 1996] of the interim performance assessment as required by the local Department of Energy office.

Her comments were the following (with the responses in italics):

1) The PA analysis needs to tie the results to "standard" methods adopted by HEDOP (including Paul as a member of the panel). In the case of this document, the demonstration that the methods used for the PA were equivalent to those previously approved by HEDOP are in the technical background document rather than in the PA itself, which makes the connection less visible than would be desirable. However, I don't consider that a serious enough flaw that I would refuse to approve the calculations. Paul [Rittmann] is aware that I have some concerns about his use of the spreadsheet approach (although as yet, he hasn't been concemed enough about them to mend his ways!). In the end, the quality of the results is the bottom line, and he has demonstrated in several documents that there aren't any substantial differences between his method and those approved by the panel. I've been willing to approve them on that basis, and because these documents usually come to me as an afterthought when the opportunity for substantial reworking is past.

Comment is noted. An attempt will be made to better tie the efforts for succeeding performance assessments to "standard" methods.

2) The use of DOE dose factors for internal exposure pathways and the EPA FGR 12 dose factors for external exposure pathways (sec. 4.8.4) is inconsistent, but again not a fatal flaw since both sets are based on essentially the same models (and in fact, were developed by the same organization). However, in the future, DOE is recommending use of the EPA FGR 11 and FGR 12 dose factors for 10 CFR 834 compliance calculations, and the site should standardize on those just to avoid confusion. Although I don't think this is a serious enough issue to request that it be changed before your impending publication date, I would recommend revising the calculations to use EPA dose factors throughout in your next version of the document. That should be straightforward because Paul has them in a database that he uses with his spreadsheet.

Before calculations for the interim performance assessment were begun, an evaluation was performed to find the best library of conversion coefficients. Sensitivity calculations were performed to demonstrate the effect of using different libraries.

Guidance from the Department of Energy seems to be solidifying around the EPA library. Therefore, once the guidance becomes official, we will use such guidance. 
DOE/RL-97-69

Rev. 0

\section{F.5 Comments on this Document}

Copies of this document have been sent to various members of the Hanford technical and managerial staff for review. All received comments were considered and almost all were incorporated to yield a document that is easier to read. In addition, formal comments were received from the Richland Operations Office of the Department of Energy and from the Washington State Department of Ecology. These formal comments are displayed in Sections F.5.1 and F.5.2, respectively, along with the responses of the program, and the cementers' acceptance. 
DOE/RL-97-69

Rev. 0

F.5.1 Richland Operations Office of the Department of Energy

CORRESPONDENCE DISTRIBUTION COVERSHEET

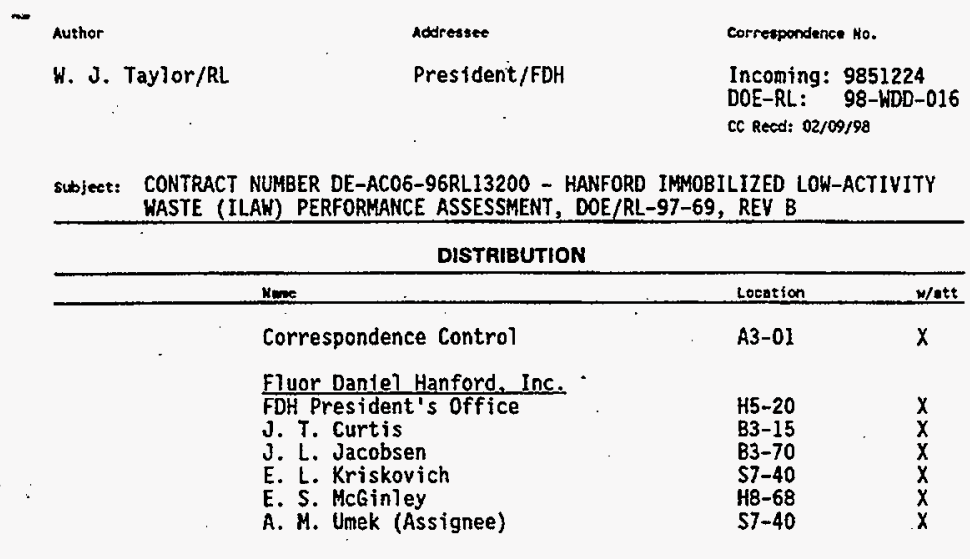

PHAC CORRESPOWDENCE CONTROL

For avestions or Distribution/Wsih Corrections

Contact: Chris Hough $9376-8111$ of Glems Lenz a 372-3931

CC:MAIL AOORESS: ACORRESPONOENCE CONTROL-PHMC

54-6000-117 (9/88) (EF) EFF008 - Distribution Coversheet 
DOE/RL-97-69

Rev. 0

9851224

CC RECD: 02/09/98

\section{Department of Energy}

Richland Operations Office

P.O. Box 550

Richland, Washington 99352

98-WDO-016

\section{FEB O 91998}

Mr. H. J. Hatch, President

Fiuor Daniel Hanford, Inc.

Richland, Washington 99352

Dear $\mathrm{Mr}$. Hatch:

CONTRACT NUMBER DE-ACO6-96RL13200 - HANFORD IMMOBILIZED LOW-ACTIVITY WASTE (ILAW) PERFORMANCE ASSESSMENT, DOE/RL-97-69, REV B

Reference: Letter from A. M. Umek, FDH, to W. J. Taylor, RL, same subject, FDH-9850347, dated January 20, 1998.

The U. S. Department of Energy, Richland Operations Office (RL) has reviewed the subject draft Performance Assessment enclosed with the reference letter. The draft Revision $B$ clearly refiects considerable effort to address comments of the External Review Board and other reviewers of the previous draft to the extent feasible at this time.

We are providing the enclosed comments on Review Comment Record forms for your disposition in accordance with the Fiscal Year 1998 Performance Agreement TWR6.1,1. The final comment addresses additional minor editorial notes in the text. A copy of the markup will be provided directiy to Fred Mann of Fluor Daniel Northwest, inc.

If any direction is provided by a contracting Officer's Representative (COR) which your company bel ieves exceeds the COR's authority, you are to immediately notify the Contracting officer and request clarification prior to complying with the direction.

If you have any questions, please contact P. E. LaMont, of my staff, on 376-6117.

WDO:PEL

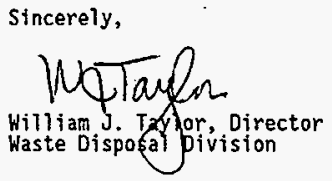

\section{Enctosure}

CC W/encl:

A. H. Umek, FDH

F. M. Mann, FDNW

H. L. Boston, LMHC

R. J. Murkowski, LMHC 


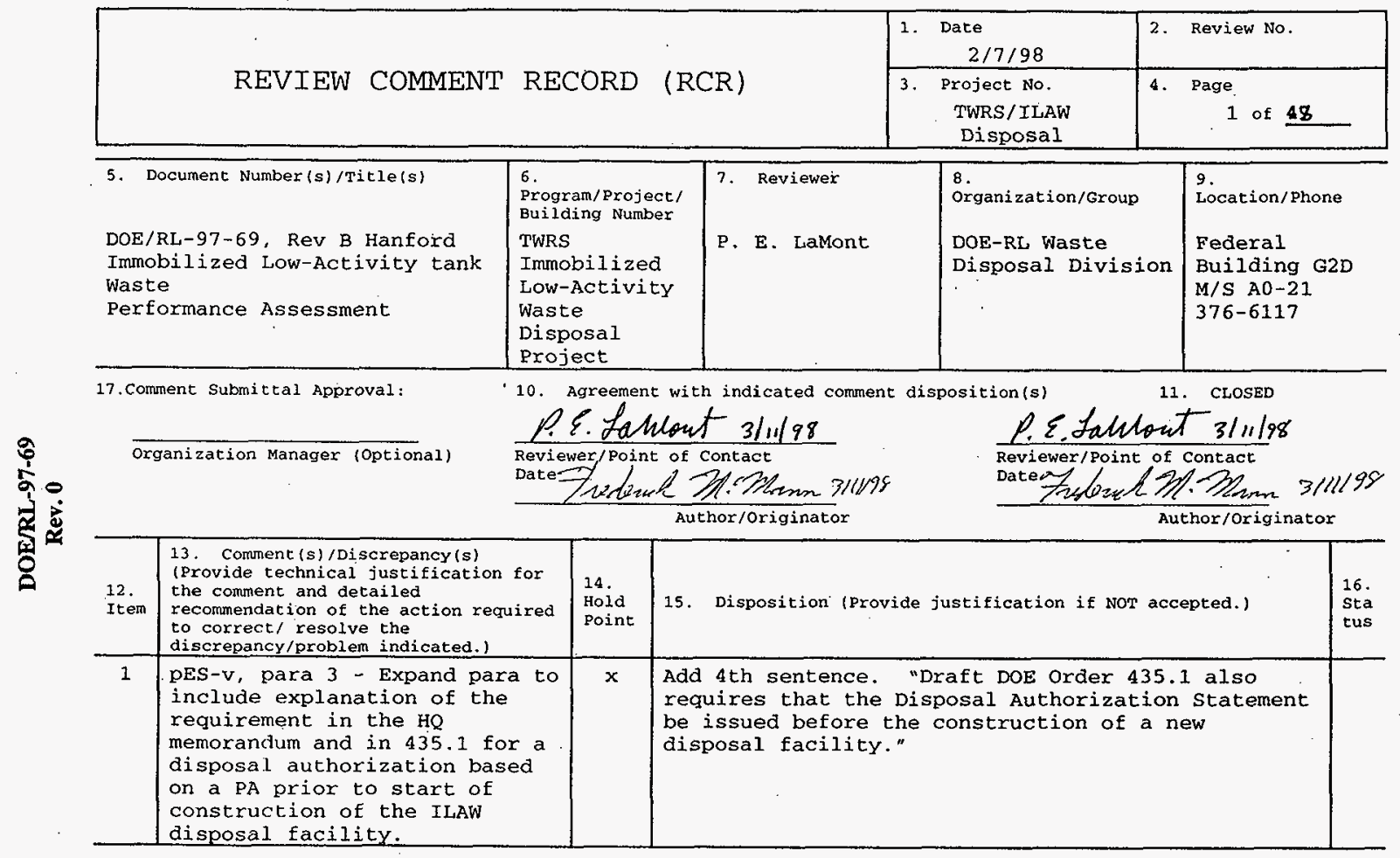




\begin{tabular}{|c|c|c|c|c|c|c|}
\hline & \multirow{2}{*}{\multicolumn{2}{|c|}{ REVIEW COMMENT RECORD }} & \multirow[b]{2}{*}{ ( $\mathrm{RCR})$} & $\begin{array}{l}\text { 1. Date } \\
2 / 7 / 98 \\
\end{array}$ & \multicolumn{2}{|l|}{ 2. Review No. } \\
\hline & & & & $\begin{array}{l}\text { 3roject No. } \\
\text { TWRS/ILAW } \\
\text { Disposal }\end{array}$ & 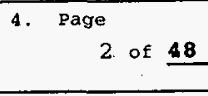 & \\
\hline $\begin{array}{l}12 . \\
\text { Item }\end{array}$ & $\begin{array}{l}\text { 13. Comment(s)/Discrepancy (s) } \\
\text { (Provide technical justification for } \\
\text { the comment and detailed } \\
\text { recommendation of the action reguired } \\
\text { to correct/ resolve the } \\
\text { discrepancy/problem indicated.) }\end{array}$ & $\begin{array}{l}14 \\
\text { Hoid } \\
\text { Point }\end{array}$ & 15. Disp & ide justification & accepted.) & $\begin{array}{l}16 . \\
\text { Sta } \\
\text { tus }\end{array}$ \\
\hline 2 & $\begin{array}{l}\text { pEs-vii/viii - Add a brief } \\
\text { explanation of the source of } \\
\text { the requirements before } \\
\text { presenting the results. }\end{array}$ & $\mathrm{x}$ & $\begin{array}{l}\text { No chang } \\
\text { The per } \\
\text { discuss } \\
\text { not pre: } \\
\text { need to } \\
\text { and the }\end{array}$ & $\begin{array}{l}\text { bjectives ("reg } \\
\text { top of page ES- } \\
\text { page ES-vi, bec } \\
\text { ed on pages ES- } \\
\text { summary is alr }\end{array}$ & $\begin{array}{l}\text { nents") are } \\
\text { Details are } \\
\text { they would } \\
\text { irough Es-xii } \\
\text { fairly long. }\end{array}$ & \\
\hline 3 & $\begin{array}{l}\text { pES-viii, para } 2 \text { - Explain the } \\
\text { rationale for extrapolation to } \\
65 \mathrm{M} \text { years. This surely } \\
\text { exceeds the expected geologic } \\
\text { life of the site. }\end{array}$ & $x$ & $\begin{array}{l}\text { Change } \\
\text { "to lon } \\
\text { Such a } \\
\text { executi } \\
\text { NRC gui } \\
\text { time of } \\
\text { conveni } \\
\text { to } 100, \\
\text { time fr }\end{array}$ & $\begin{array}{l}\text { from "to } 65 \mathrm{mi} \\
\text { should not appe } \\
\text { DOE Order } 58 \\
\text { io CFR } 61 \text { is to } \\
\text { sure. } 65 \text { milli } \\
\text { int as the expl } \\
\text { can easily be } \\
\text { the } \mathrm{K}_{\mathrm{d}} \mathrm{s} \text { of inter }\end{array}$ & $\begin{array}{l}\text { years" to } \\
\text { the } \\
\text { guidance and } \\
\text { ulate to the } \\
\text { ears was a } \\
\text { calculations } \\
\text { led to that }\end{array}$ & \\
\hline 4 & $\begin{array}{l}\text { pES-ix, para } 2 \text {, etc. - Explain } \\
\text { the "time of compliance" in } \\
\text { more detail, i.e. source of } \\
\text { numbers and why different. } \\
\text { Also, explain differences in } \\
\text { time of compliance as required } \\
\text { by DoE and other sources. }\end{array}$ & $x$ & $\begin{array}{l}\text { 2nd sen } \\
10,000 \\
\text { recommer } \\
\text { (referer } \\
\text { to be } \\
\text { perform } \\
\text { reguire }\end{array}$ & $\begin{array}{l}\text { d. "A time of } \\
\text { chosen instead } \\
\text { of 1,000 years } \\
\text { indicated for } \\
\text { dental waste" } \\
\text { sment must also }\end{array}$ & $\begin{array}{l}\text { Liance of } \\
\text { le DOE } \\
\text { ause the NRC } \\
\text { LLAW product } \\
\text { the } \\
\text { their }\end{array}$ & \\
\hline
\end{tabular}




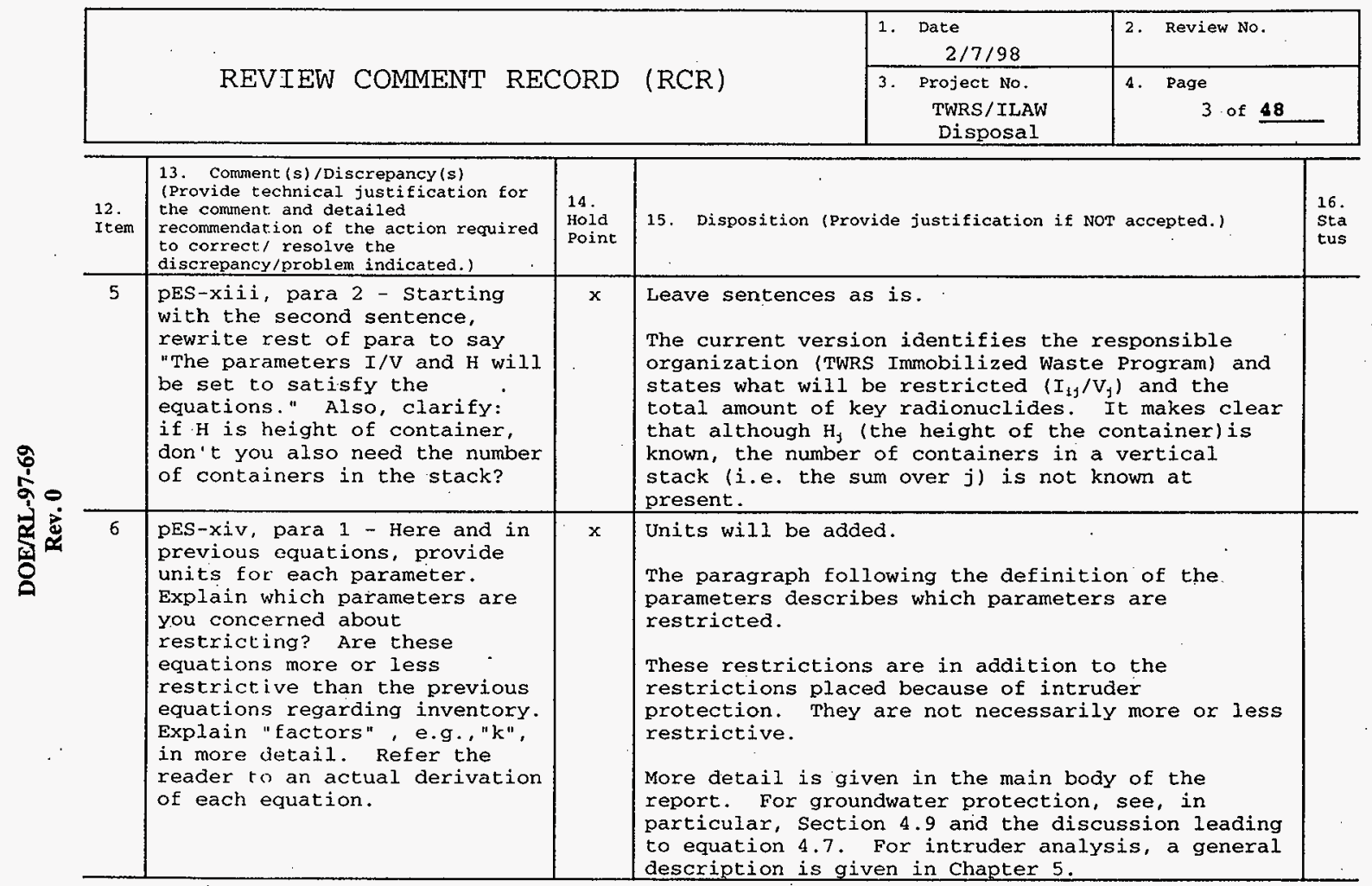




\begin{tabular}{|c|c|c|c|c|}
\hline \multirow{2}{*}{ REVIEW COMMENT RECORD (RCR) } & $\begin{array}{c}\text { 1. Date } \\
2 / 7 / 98\end{array}$ & Review No. \\
\cline { 2 - 5 } & $\begin{array}{c}\text { 3. Project No. } \\
\text { TWRS/ILAW } \\
\text { Disposal }\end{array}$ & $\begin{array}{c}\mathbf{4 .} \text { Page } \\
4 \text { of }\end{array}$ \\
\hline
\end{tabular}

\begin{tabular}{|c|c|c|c|c|}
\hline $\begin{array}{l}12 . \\
\text { Item }\end{array}$ & $\begin{array}{l}\text { 13. Comment(s)/Discrepancy (s) } \\
\text { (Provide technical justification for } \\
\text { the comment and detailed } \\
\text { recommendation of the action required } \\
\text { to correct/ resolve the } \\
\text { discrepancy/problem indicated.) }\end{array}$ & $\begin{array}{l}14 . \\
\text { Hold } \\
\text { Point }\end{array}$ & 15. pisposition (Provide justification if NOT accepted.) & $\begin{array}{l}16 . \\
\text { Sta } \\
\text { tus }\end{array}$ \\
\hline 7 & $\begin{array}{l}\text { pES-xv, para } 4 \text { - Explain the } \\
\text { effective length parameter in } \\
\text { more detail so that it is more } \\
\text { clear exactly how an increase } \\
\text { in } L \text { affects performance. }\end{array}$ & $x$ & $\begin{array}{l}\text { On page ES-xiv, after definition } L \text { is given, the } \\
\text { following is added: "L is obtained by dividing the } \\
\text { volume of the waste by the product of the waste } \\
\text { column height and of the disposal facility extent } \\
\text { parallel to the path of groundwater flow. When } \\
\text { the groundwater flow is parallel to an edge of the } \\
\text { facility (which it is in this instance), then } L \text { is } \\
\text { the length of the disposal facility perpendicular } \\
\text { to groundwater flow." }\end{array}$ & \\
\hline 8 & $\begin{array}{l}\text { pES-xvi, para } 2 \text { - Text is } \\
\text { unclear. It seems to say that } \\
\text { some radionuclides could } \\
\text { exceed the "acceptance limit", } \\
\text { which appears to mean a Iimit } \\
\text { derived from equations ES.3 } \\
\text { and ES. } 4 \text { or similar } \\
\text { perrformance-based equations. } \\
\text { If a limit is lower than what } \\
\text { is allowed in the ILAw } \\
\text { specifications, including } \\
\text { class c. for the private } \\
\text { vendor, then this is a } \\
\text { problem. }\end{array}$ & $x$ & $\begin{array}{l}\text { Replace paragraph } 2 \text { with the following: } \\
\text { "If the waste packages have the maximum } \\
\text { concentrations estimated from the best basis tank } \\
\text { by tank inventories (reference) and anticipated } \\
\text { separation efficiencies (reference), then almost } \\
\text { all the radionuclides will meet the requirements } \\
\text { imposed by equations ES. } 1 \text { through ES. } 4 \text {. However, } \\
\text { the producers of the ILAW packages are required to } \\
\text { meet NRC Class C limits, which for the remaining } \\
\text { radionuclides are more restrictive than the limits } \\
\text { found here. Thus the immobilized waste accepted . } \\
\text { by DoE wili meet the requirements set here." } \\
\text { Only in the case of }{ }^{126} \text { Sn is there a concern. This } \\
\text { concern is addressed in the 3rd paragraph and is } \\
\text { shown not to be significant. }\end{array}$ & \\
\hline
\end{tabular}




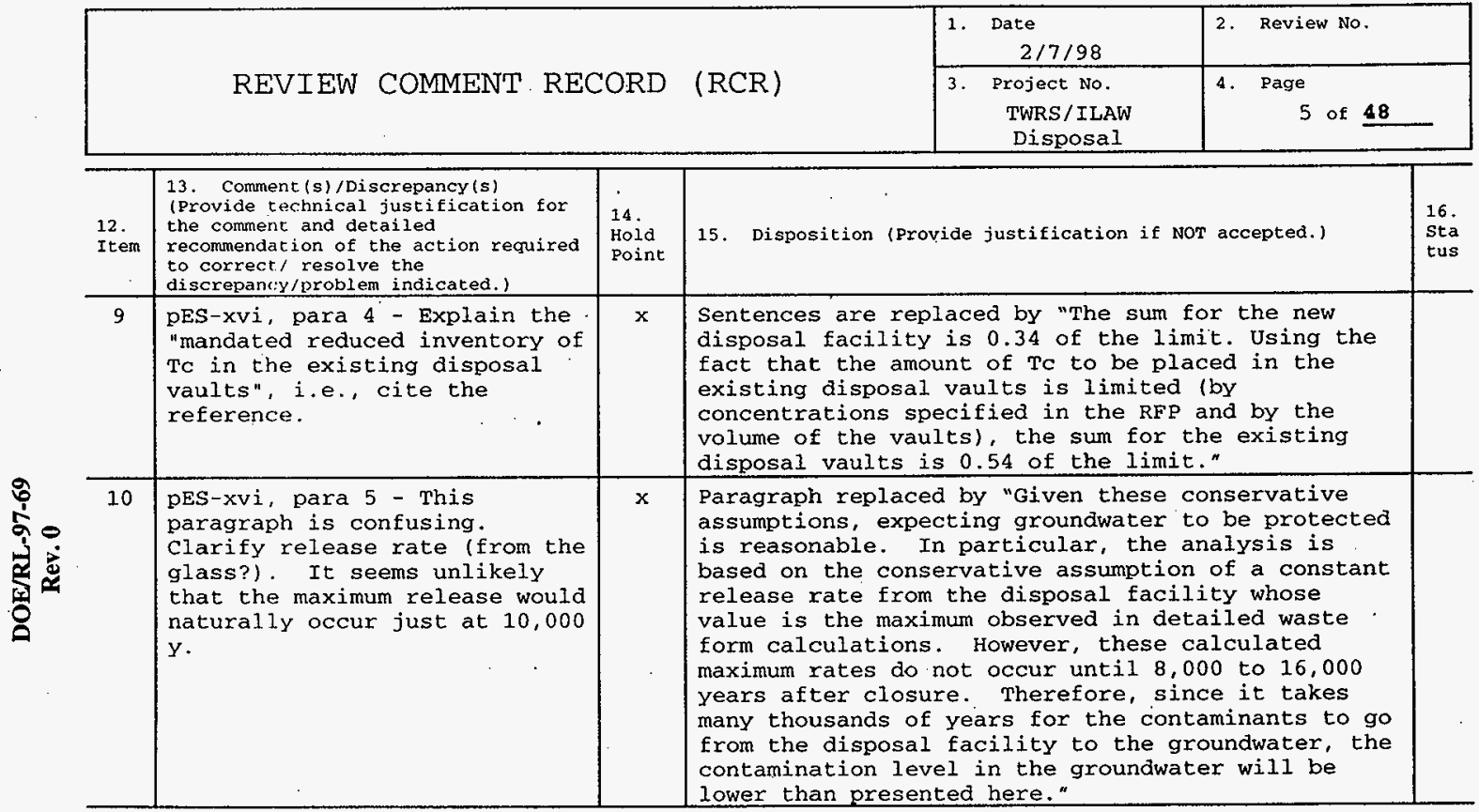




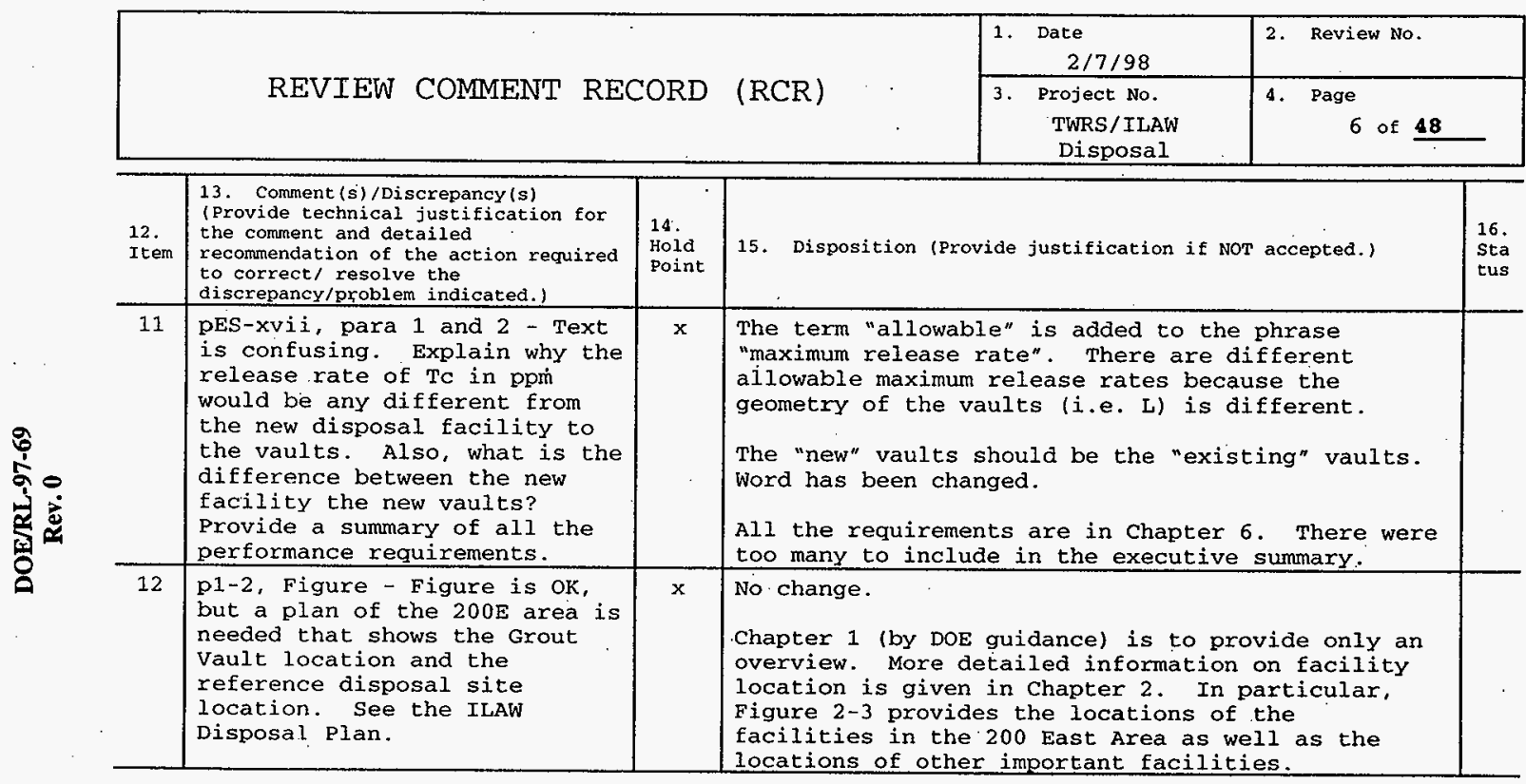




\begin{tabular}{|l|l|c|c|}
\hline REVIEW COMMENT RECORD (RCR) & $\begin{array}{c}1 . \\
\text { Date } \\
2 / 7 / 98\end{array}$ & $\begin{array}{c}\text { Review No. } \\
\text { Project No. } \\
\text { TWRS/ILAW } \\
\text { Disposal }\end{array}$ & $\begin{array}{c}\text { 4. Page } \\
7 \text { of } 48\end{array}$ \\
\hline
\end{tabular}

\begin{tabular}{|c|c|c|c|c|}
\hline $\begin{array}{l}12, \\
\text { Item }\end{array}$ & $\begin{array}{l}\text { 13. Comment (s)/Discrepancy(s) } \\
\text { (Provide technical justification for } \\
\text { the comment and detailed } \\
\text { recommendation of the action required } \\
\text { to correct/ resolve the } \\
\text { discrepancy/problem indicated.) }\end{array}$ & $\begin{array}{l}14 . \\
\text { Hoid } \\
\text { Point }\end{array}$ & 15. Disposition (Provide justification if NoT accepted.) & $\begin{array}{l}16 \\
\text { Sta } \\
\text { tus }\end{array}$ \\
\hline 13 & $\begin{array}{l}\text { p1-3, para } 5 \text { - Provide } \\
\text { additional explanation of the } \\
\text { Grout vaults. Indicate that } \\
\text { they are currently being } \\
\text { modified for use as an ILAW } \\
\text { storage facility and explain } \\
\text { why, but the performance } \\
\text { assessment activity will } \\
\text { address use of the vaults as a } \\
\text { disposal facility along with } \\
\text { the new disposal facility in } \\
\text { the reference disposal } \\
\text { facility location. Explain } \\
\text { the reason why and that the } \\
\text { function of the grout vaults } \\
\text { for storage versus disposal is } \\
\text { expected to be re-evaluated } \\
\text { and it is deemed likely that } \\
\text { the mission of the grout } \\
\text { vaults will be changed from } \\
\text { storage to disposal. }\end{array}$ & $x$ & $\begin{array}{l}\text { The following sentences are added to the end of } \\
\text { the first paragraph on page } 1-4 \text { : "This project } \\
\text { (W- } 465 \text { ) was started based on the assumption that } \\
\text { these vaults would be used as interim storage } \\
\text { facilities for ILAW. However, the project is } \\
\text { evaluating the impacts of a change to a disposal } \\
\text { mission." }\end{array}$ & \\
\hline
\end{tabular}




\begin{tabular}{|c|c|c|c|c|c|c|}
\hline & \multirow{2}{*}{\multicolumn{2}{|c|}{ REVIEW COMMENT RECORD }} & \multirow[b]{2}{*}{ (RCR) } & $\begin{array}{l}\text { 1. Date } \\
2 / 7 / 98 \\
\end{array}$ & \multicolumn{2}{|l|}{ 2. Review No. } \\
\hline & & & & $\begin{array}{l}\text { 3roject No. } \\
\text { TWRS/ILAW } \\
\text { Disposal }\end{array}$ & $\begin{array}{l}\text { 4. page } \\
8 \text { of } 48\end{array}$ & \\
\hline $\begin{array}{l}12 . \\
\text { Item }\end{array}$ & $\begin{array}{l}\text { 13. Comment (s)/Discrepancy(s) } \\
\text { (Provide technical justification for } \\
\text { the comment and detailed } \\
\text { recommendation of the action required } \\
\text { to correct/ resolve the } \\
\text { discrepancy/problem indicated.) }\end{array}$ & $\begin{array}{l}14 . \\
\text { Hold } \\
\text { Point }\end{array}$ & 15. Disp & vide justification & accepted.) & $\begin{array}{l}16 . \\
\text { Sta } \\
\text { tus }\end{array}$ \\
\hline 14 & $\begin{array}{l}\text { p1-4, para } 2 \text { - Verify the } \\
\text { capacity of the existing } \\
\text { vaults in terms of the percent } \\
\text { of projected need. This } \\
\text { reviewer believes they would } \\
\text { hold more like } 5 \text { percent of } \\
\text { the total expected ILAW. }\end{array}$ & $\mathbf{x}$ & $\begin{array}{l}\text { No chan } \\
\text { Burbank } \\
\text { However } \\
\text { (length } \\
\text { details) } \\
\text { percent } \\
\text { is to sl } \\
\text { Whether } \\
\text { waste pa } \\
\text { that suc }\end{array}$ & $\begin{array}{l}\text { es that the bas } \\
\text { ends on a numbe } \\
\text {, waste loadin } \\
\text { ore the phrase } \\
\text { The purpose } \\
\text { aditional facil } \\
\text { cilities hold } \\
\text { not significan } \\
\text { lities are nee }\end{array}$ & $\begin{array}{l}\text { is } 68 . \\
\text { assumptions } \\
\text { peration } \\
\text { than } 10 \\
\text { information } \\
\text { are needed. } \\
\text { ar of the } \\
\text { the point }\end{array}$ & \\
\hline
\end{tabular}




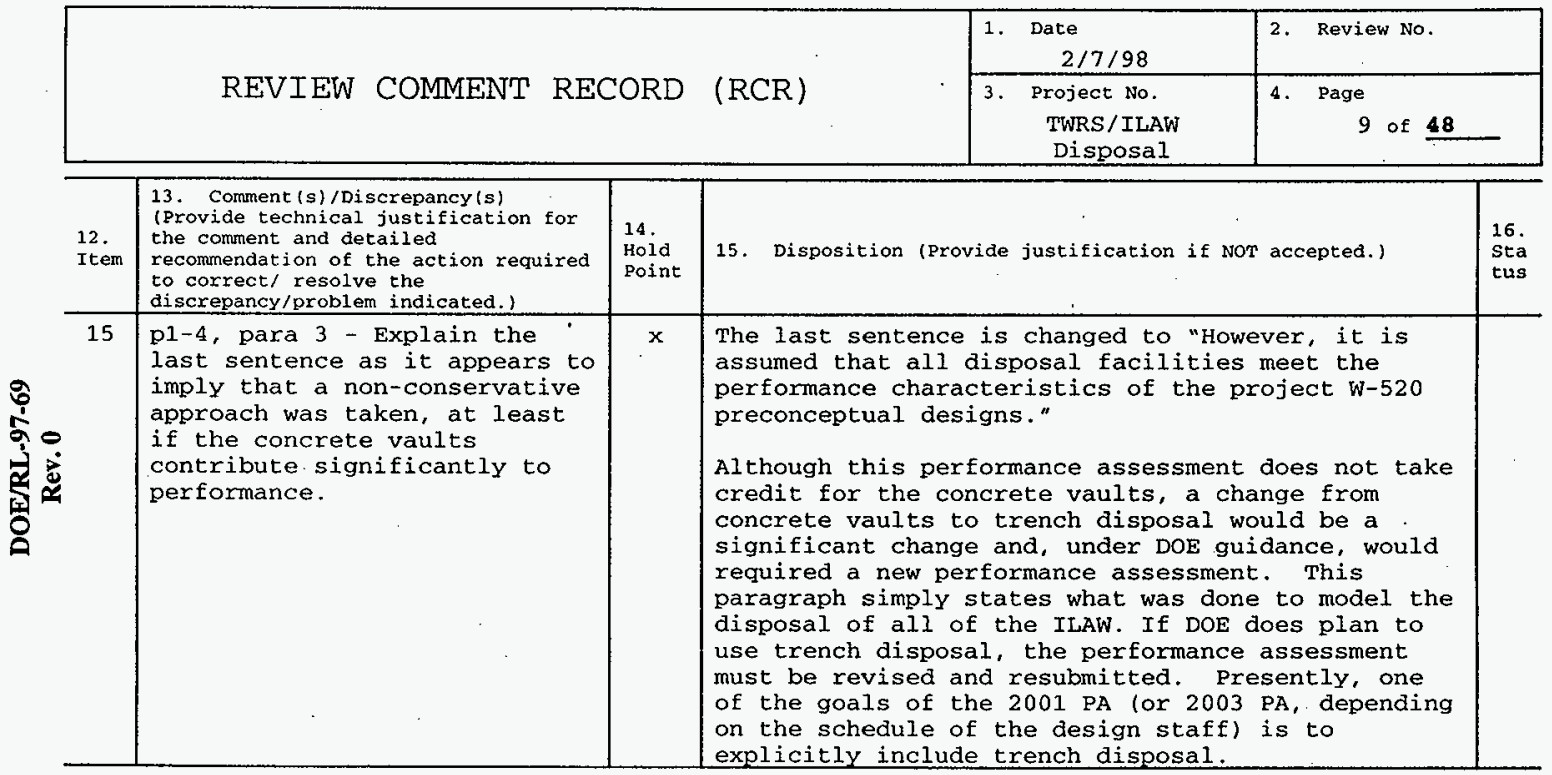




\begin{tabular}{|c|c|c|c|c|c|c|}
\hline & \multirow{2}{*}{\multicolumn{2}{|c|}{ REVIEW COMMENT RECORD }} & \multirow[b]{2}{*}{ (RCR) } & $\begin{array}{l}\text { 1. Date } \\
2 / 7 / 98\end{array}$ & \multicolumn{2}{|l|}{ 2. Review No: } \\
\hline & & & & $\begin{array}{l}\text { 3. Project No. } \\
\text { TWRS/ILAW } \\
\text { Disposal } \\
\end{array}$ & $\begin{array}{l}\text { 4. Page } \\
10 \text { of } 48\end{array}$ & \\
\hline $\begin{array}{l}12 . \\
\text { Item }\end{array}$ & $\begin{array}{l}\text { 13. Comment (s)/Discrepancy (s) } \\
\text { (Provide technical justification for } \\
\text { the comment and detailed } \\
\text { recommendation of the action required } \\
\text { to correct/ resolve the } \\
\text { discrepancy/problem indicated.) }\end{array}$ & $\begin{array}{l}14 . \\
\text { Hoid } \\
\text { Point }\end{array}$ & 15. Disp & fide justification $i$ & accepted.) & $\begin{array}{l}16 . \\
\text { sta } \\
\text { tus }\end{array}$ \\
\hline 16 & $\begin{array}{l}\text { p1-7, Figure 1-2 - Logic of } \\
\text { figure is not good, even if } \\
\text { commentor was responsible. In } \\
\text { particular, if the PA isn't } \\
\text { approved, it is not clear that } \\
\text { storage would be a viable } \\
\text { alternative, although this may } \\
\text { depend on why the PA was not } \\
\text { approved. The logic should } \\
\text { show approval of a PA before } \\
\text { start of production and a } \\
\text { separate PA approval before } \\
\text { start of the construction of } \\
\text { the disposal facility. }\end{array}$ & $\mathbf{x}$ & $\begin{array}{l}\text { The dia } \\
\text { project } \\
\text { clarify }\end{array}$ & $\begin{array}{l}\text { tended to give a } \\
\text { odifications wil } \\
\qquad\end{array}$ & $\begin{array}{l}\text { verview of the } \\
\text { made to }\end{array}$ & \\
\hline 17 & $\begin{array}{l}\text { p1-10, para } 6 \text { - Some of the } \\
\text { more relevant non-Hanford PA's } \\
\text { should also have been } \\
\text { reviewed, and possible Yucca } \\
\text { Mountain Project unsaturated } \\
\text { zone transport studies. } \\
\text { Explain. }\end{array}$ & $\mathbf{x}$ & $\begin{array}{l}\text { The sen } \\
\text { DOE sit } \\
\text { also re } \\
\text { and met } \\
\text { on page } \\
\text { DOE gui } \\
\text { environ } \\
\text { perform } \\
\text { continu } \\
\text { other s }\end{array}$ & $\begin{array}{l}\text { formance assessn } \\
\text { comments on tho } \\
\text { understand diffe } \\
\text { added to the end } \\
\text { o provide a back } \\
\text { essments at this } \\
\text { sment activity } \\
\text { itor environment } \\
\text { uding Yucca Mour }\end{array}$ & $\begin{array}{l}\text { s from other } \\
\text { studies are } \\
\text { t approaches } \\
\text { section } 1.5 .4 \\
\text { und of other } \\
\text { E Site. The } \\
\text { and is } \\
\text { assessments at } \\
\text { n). }\end{array}$ & \\
\hline
\end{tabular}




\begin{tabular}{|l|l|l|l|}
\hline \multirow{2}{*}{. REVIEW COMMENT RECORD (RCR) } & $\begin{array}{c}1 . \text { Date } \\
2 / 7 / 98\end{array}$ & $2 . \quad$ Review No. \\
\cline { 2 - 5 } & $\begin{array}{c}\text { 3. Project No. } \\
\text { TWRS/ILAW } \\
\text { Disposal }\end{array}$ & $\begin{array}{c}4 . \quad \text { Page } \\
11 \text { of } 48\end{array}$ \\
\hline
\end{tabular}

\begin{tabular}{|c|c|c|c|c|}
\hline $\begin{array}{ll}12 . \\
\text { Item }\end{array}$ & $\begin{array}{l}\text { 13. Comment (s)/Discrepancy(s) } \\
\text { (Provide technical justification for } \\
\text { the comment and detailed } \\
\text { recommendation of the action required } \\
\text { to correct/ resolve the } \\
\text { discrepancy/problem indicated.) }\end{array}$ & $\begin{array}{l}14 . \\
\text { Hold } \\
\text { Point }\end{array}$ & 15. Disposition (Provide justification if NOT accepted.) & $\begin{array}{l}16 . \\
\text { Sta } \\
\text { tus }\end{array}$ \\
\hline 18 & $\begin{array}{l}\text { p1-11, para } 2 \text { - Explain the } \\
\text { specific weaknesses in the } \\
\text { performance assessment in the } \\
\text { EIS and how those are being } \\
\text { addressed in this and later } \\
\text { PA's. In particular, explain } \\
\text { where the EIS may or may not } \\
\text { be conservatively bounding. }\end{array}$ & $x$ & $\begin{array}{l}\text { No change. } \\
\text { The purpose of the TWRS Environmental Impact } \\
\text { Statement is quite different than of this } \\
\text { performance assessment. As noted in this } \\
\text { paragraph the data and models used in the EIs were } \\
\text { less complete and detailed. Since the RoD has } \\
\text { been issued, it is beyond the scope of this } \\
\text { performance assessment to document improvements } \\
\text { over every previous Hanford site environmental } \\
\text { analysis. }\end{array}$ & \\
\hline 19 & $\begin{array}{l}\text { pl-15, para } 1 \text { - Explain the } \\
\text { performance objectives that } \\
\text { were in place prior to } 435.1 \text {, } \\
\text { i.e., } 5480.2 \mathrm{~A} \text {, and how these } \\
\text { might evolve. Also, because } \\
\text { of the NRC incidental waste } \\
\text { question, explain all the } \\
\text { performance requirements in } \\
\text { locFR61, not just the } 1,000 \text { yr } \\
\text { compliance time and compare } \\
\text { these with DoE's. Then } \\
\text { indicate which ones were used } \\
\text { in this pA. }\end{array}$ & $x$ & $\begin{array}{l}\text { No change. } \\
\text { As stated in the paragraph (part of the summary), } \\
\text { draft DOE order } 435.1 \text { ( } 2 / 28 / 97 \text { version) only } \\
\text { introduced two significant changes. The following } \\
\text { sections go into the details of the performance } \\
\text { objectives and how they were selected. } \\
\text { It is difficult to judge or predict how } \\
\text { performance objectives will evolve. } \\
10 \mathrm{CFR} 61 \text { requirements are discussed in detailed } \\
\text { under each category of protection. }\end{array}$ & \\
\hline
\end{tabular}




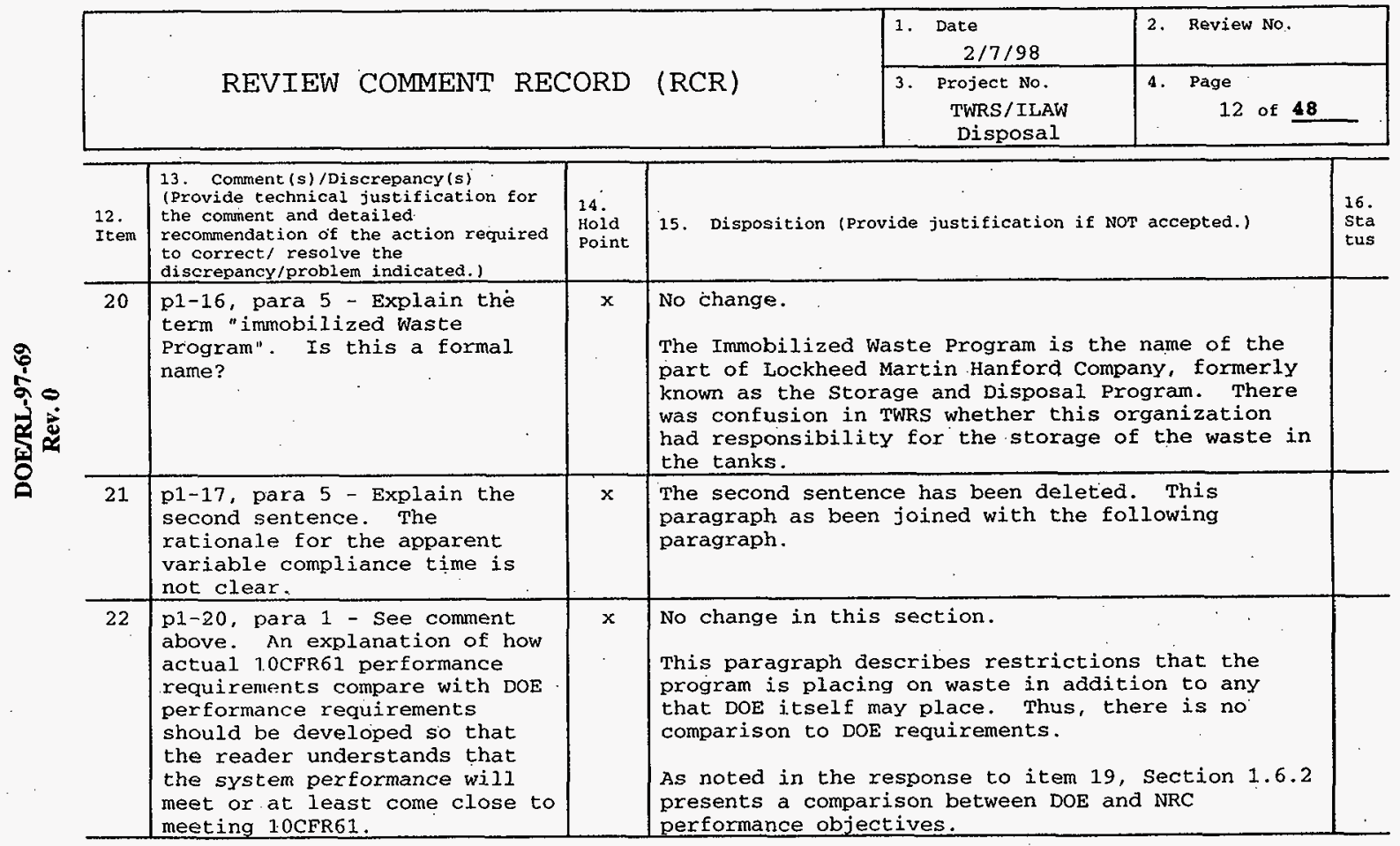




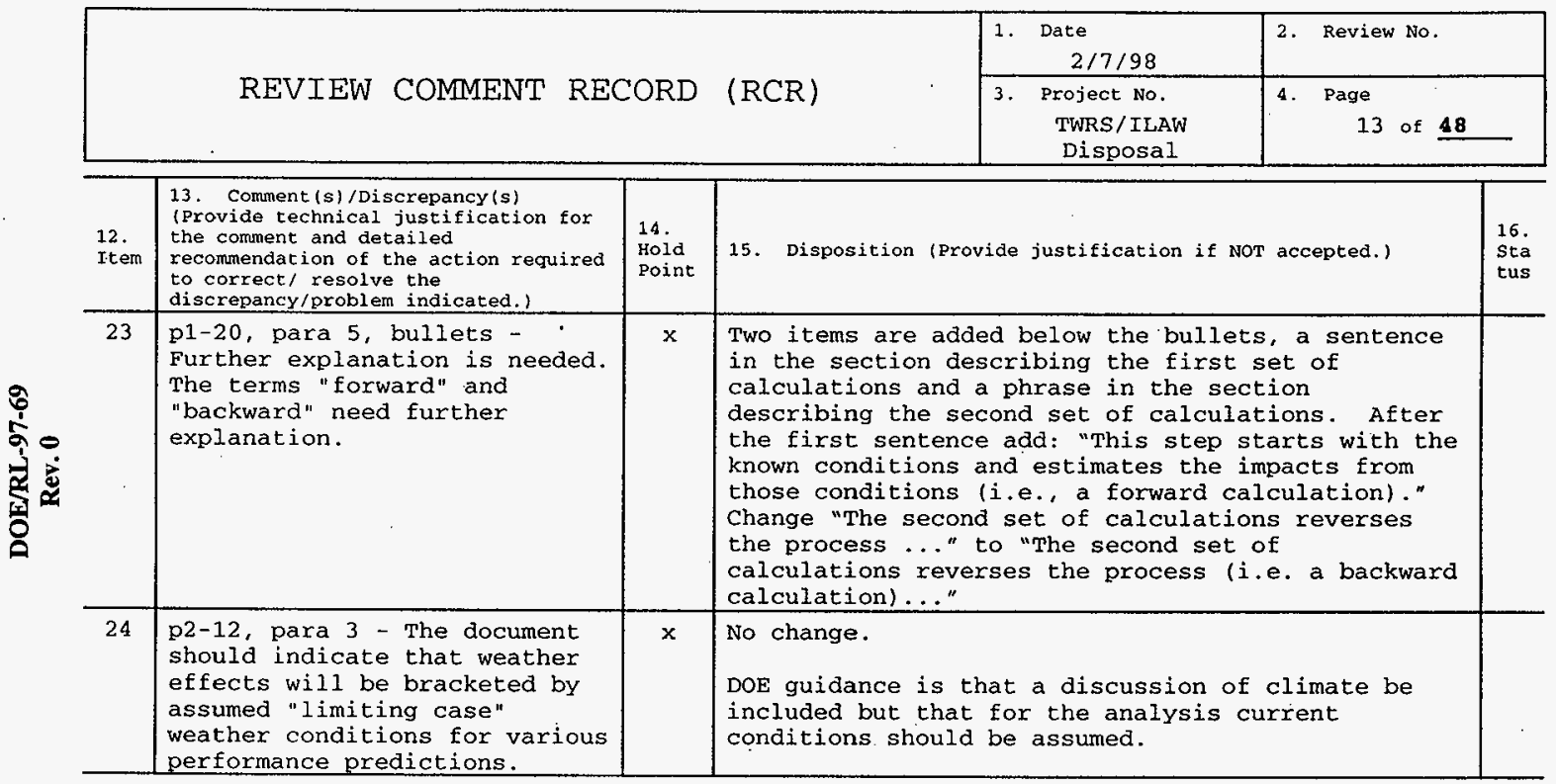




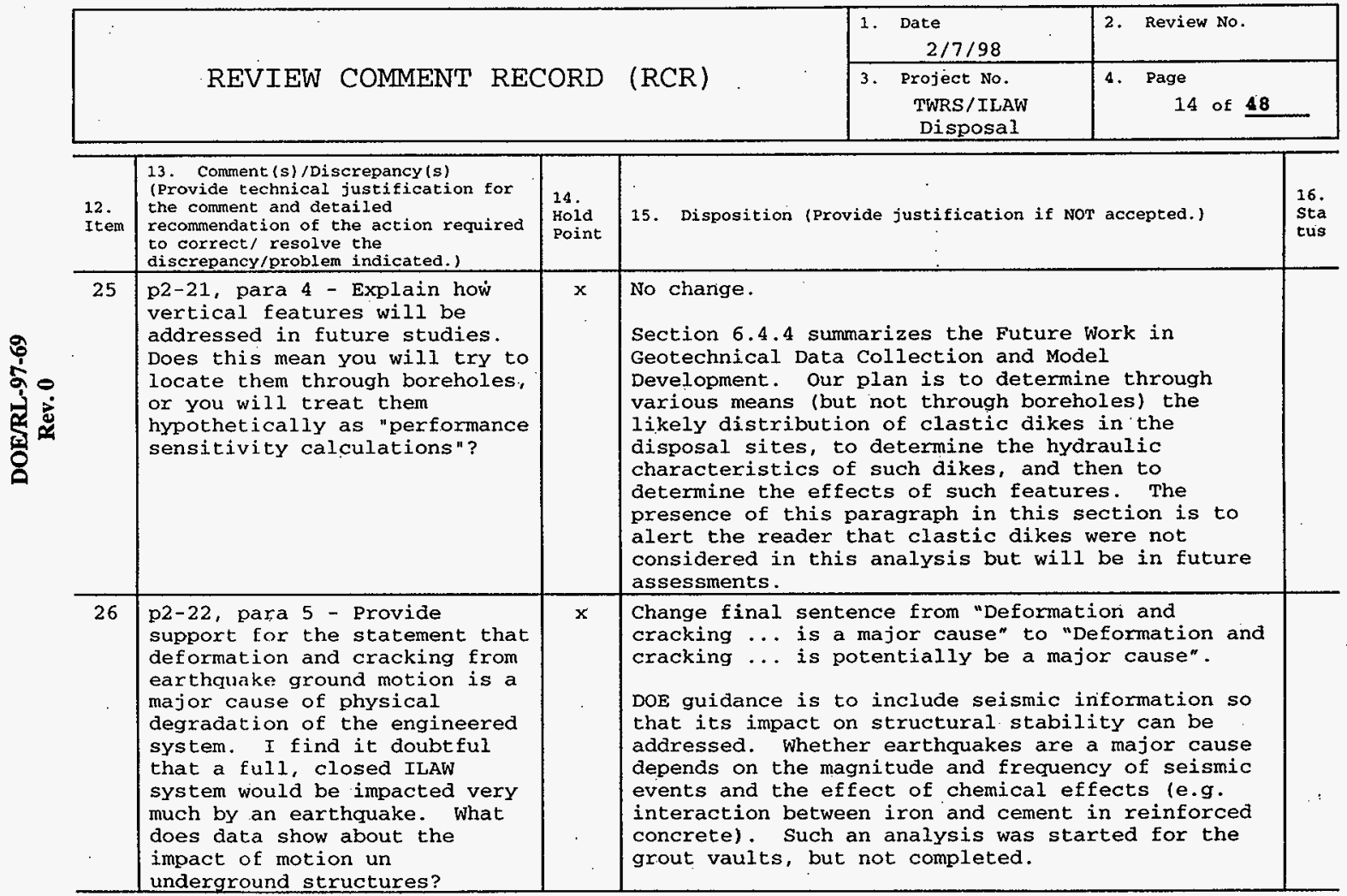




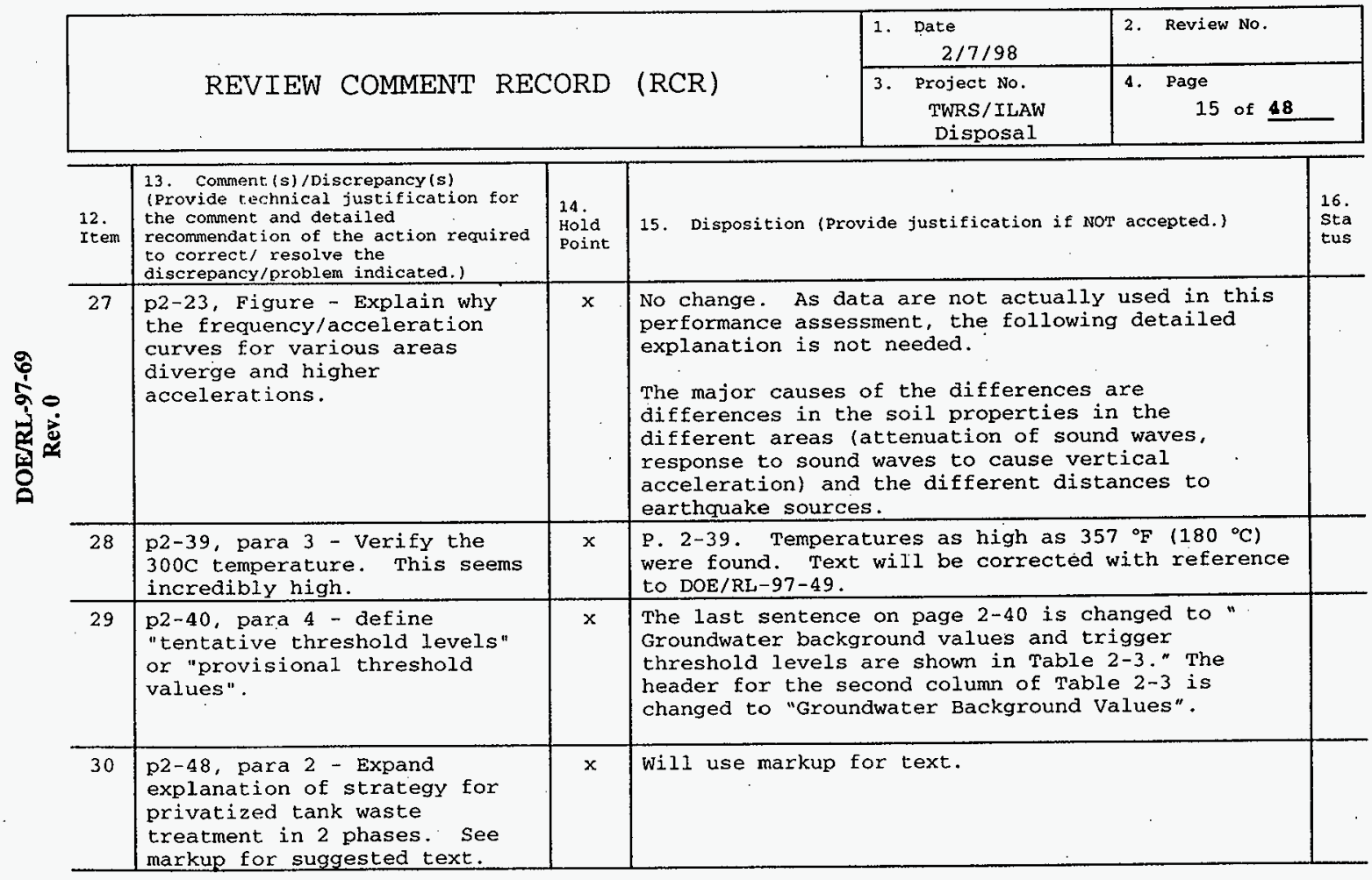




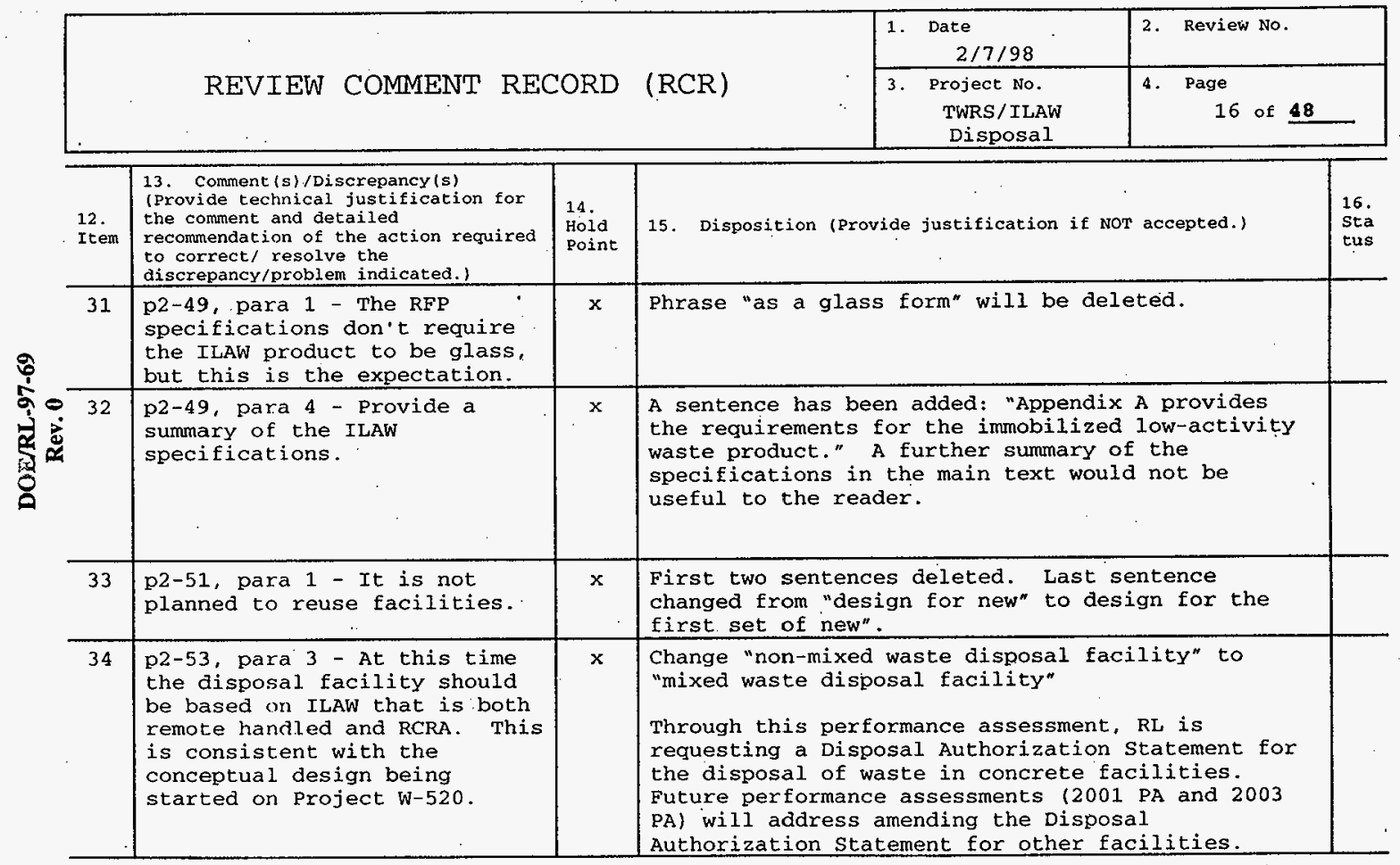




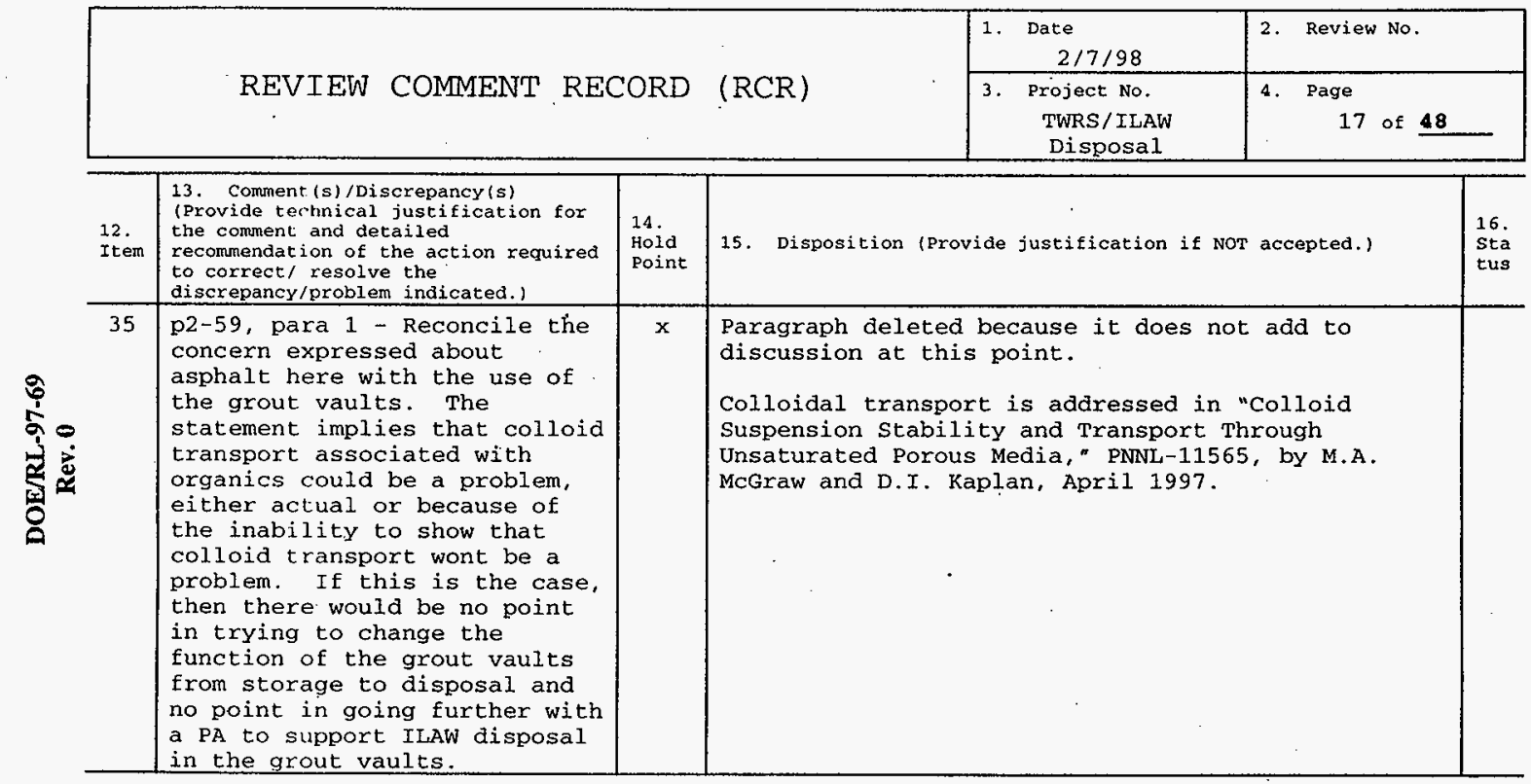




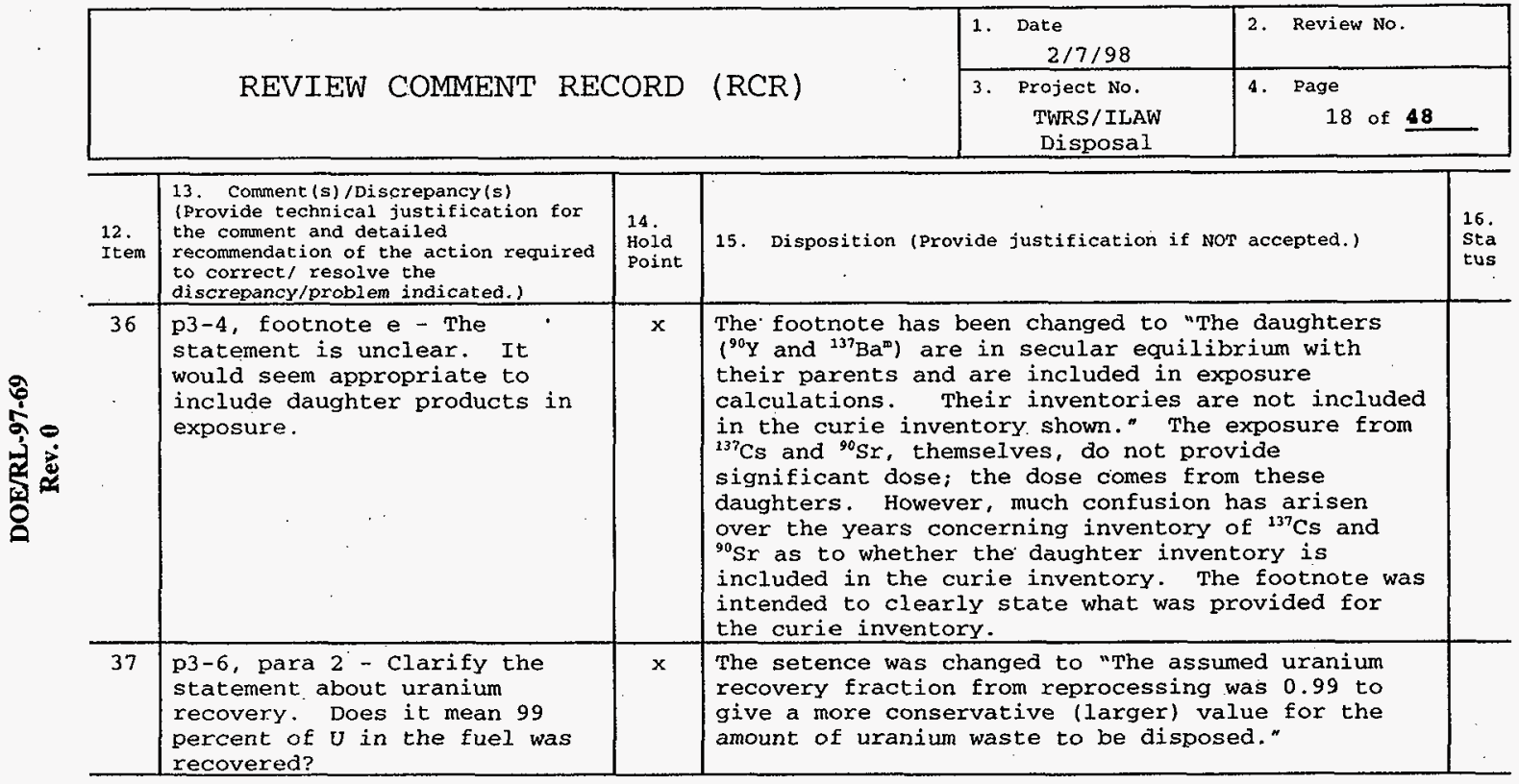




\begin{tabular}{|c|c|c|c|c|c|c|}
\hline & & & & $\begin{array}{l}\text { 1. Date } \\
2 / 7 / 98\end{array}$ & 2. Review No. & \\
\hline & REVIEW COMMENT REC & ORD & ( $R C R$ ) & $\begin{array}{l}\text { 3. Project No. } \\
\text { TWRS/ILAW } \\
\text { Disposal }\end{array}$ & $\begin{array}{l}\text { 4. Page } \\
19 \text { of } 18\end{array}$ & \\
\hline $\begin{array}{l}12 . \\
\text { Item }\end{array}$ & $\begin{array}{l}\text { 13. Comment (s)/Discrepancy (s) } \\
\text { (Provide technical justification for } \\
\text { the comment and detailed } \\
\text { recommendation of the action required } \\
\text { to correct/ resolve the } \\
\text { discrepancy/problem indicated.) }\end{array}$ & $\begin{array}{l}14 \text { Hold } \\
\text { Point }\end{array}$ & 15. Disg & ide justification & accepted.) & $\begin{array}{l}16 . \\
\text { Sta } \\
\text { tus }\end{array}$ \\
\hline 38 & $\begin{array}{l}\text { p3-6, para } 4 \text { - Explain where } \\
\text { I-129 would go. If it isn't } \\
\text { in the ILAW (or HLW), then } \\
\text { does it go to the ground } \\
\text { somewhere else? Therefore, } \\
\text { its performance should be } \\
\text { dealt with elsewhere. This PA } \\
\text { should show "integration" with } \\
\text { other PA's to achieve closure } \\
\text { on the species that "get } \\
\text { around". It appears that ILAW } \\
\text { is unilaterally taking } \\
\text { responsibility for } 10 \text { percent } \\
\text { of the I-129, but there should } \\
\text { be reference to someone else } \\
\text { taking responsibility for the } \\
\text { rest of it in a PA. }\end{array}$ & $\mathbf{x}$ & $\begin{array}{l}\text { No chan } \\
\text { To be b } \\
\text { that } 10 \\
\text { up in I } \\
\text { the iod } \\
\text { process } \\
\text { Further } \\
\text { The pur } \\
\text { compani } \\
\text { is to s } \\
\text { importa }\end{array}$ & $\begin{array}{l}\text { he performance } \\
\text { 'I produced by } \\
\text { s likely that m } \\
\text { ated during the } \\
\text { released short } \\
\text { on probably occ } \\
\text { e composite Ana } \\
\text { to this perfo } \\
\text { nal resting pla } \\
\text { clides. }\end{array}$ & $\begin{array}{l}\text { isment assumes } \\
\text { eactors ends } \\
\text { (if not all) of } \\
\text { ial } \\
\text { hereafter. } \\
\text { in storage. } \\
\text { (the } \\
\text { ce assessment) } \\
\text { of all the }\end{array}$ & \\
\hline
\end{tabular}




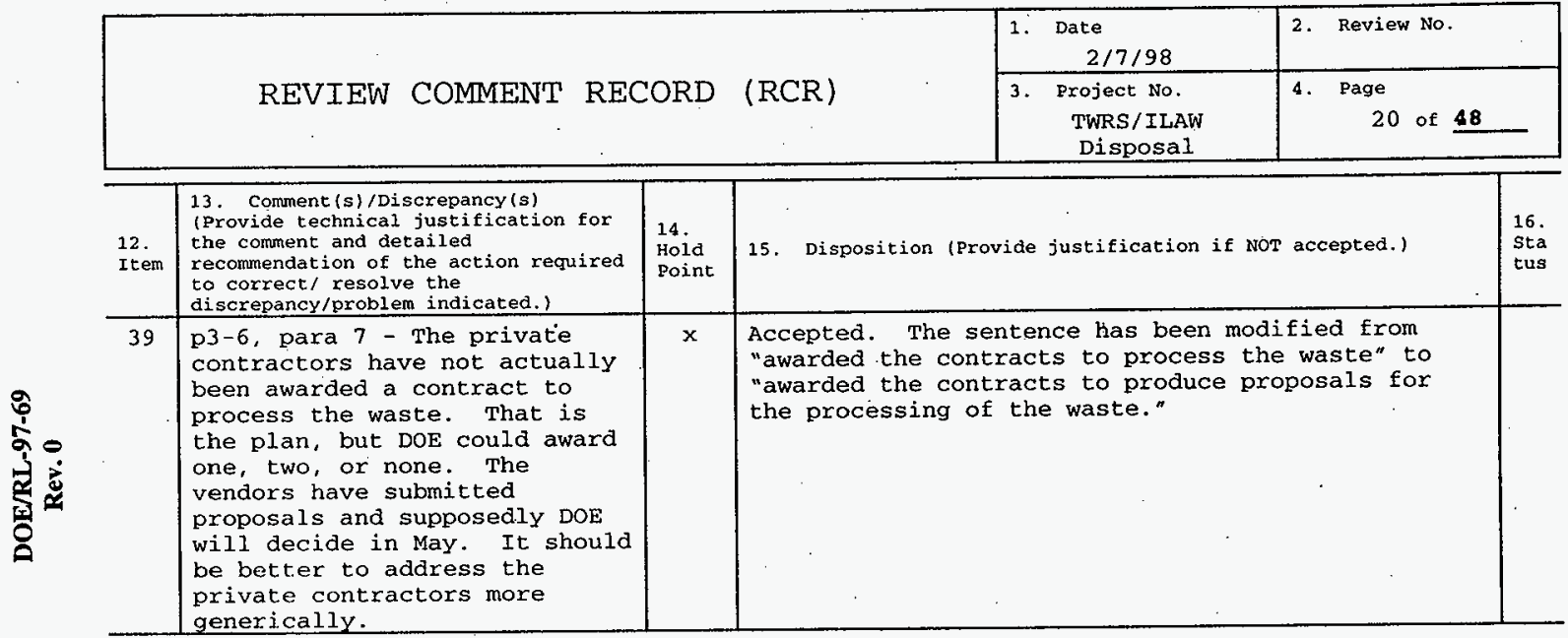




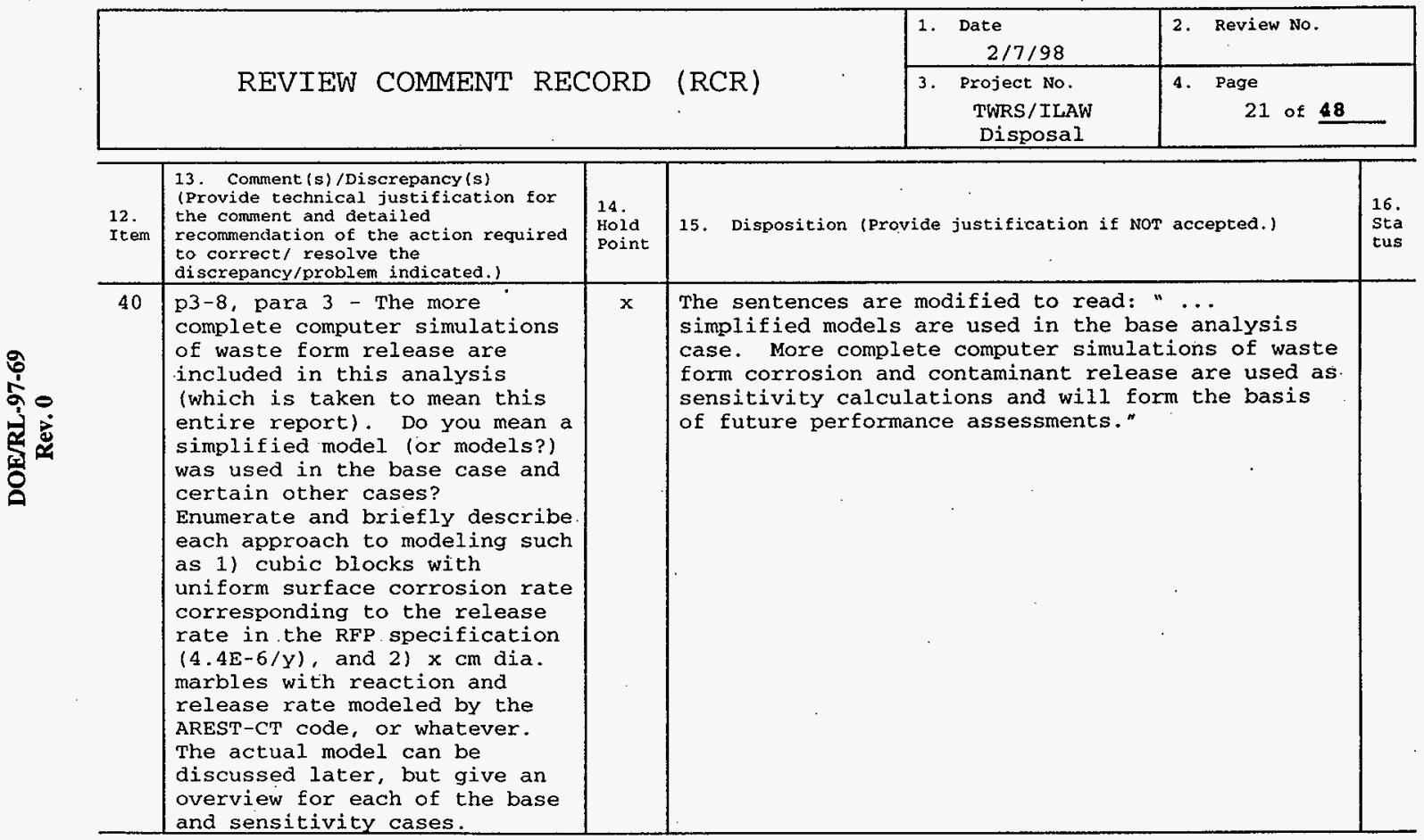




\begin{tabular}{|c|c|c|c|c|c|c|}
\hline & \multirow{2}{*}{\multicolumn{2}{|c|}{ REVIEW }} & \multirow[b]{2}{*}{ ( $\mathrm{RCR}$ ) } & $\begin{array}{l}\text { 1. Date } \\
2 / 7 / 98 \\
\end{array}$ & \multicolumn{2}{|l|}{ 2. Review No. } \\
\hline & & & & $\begin{array}{l}\text { 3roject No. } \\
\text { TWRS / ILAW } \\
\text { Disposal }\end{array}$ & \multicolumn{2}{|l|}{$\begin{array}{l}\text { 4. Page } \\
22 \text { of } 48\end{array}$} \\
\hline $\begin{array}{l}12 . \\
\text { Item }\end{array}$ & $\begin{array}{l}\text { 13. Comment(s)/Discrepancy (s) } \\
\text { (Provide technical justification for } \\
\text { the comment and detailed } \\
\text { recommendation of the action required } \\
\text { to correct / resolve the } \\
\text { discrepancy/problem indicated.) } \\
\end{array}$ & $\begin{array}{l}14 \text {. } \\
\text { Hoid } \\
\text { Point }\end{array}$ & \multicolumn{3}{|c|}{ 15. Disposition (Provide justification if NOT accepted.) } & $\begin{array}{l}16 . \\
\text { Sta } \\
\text { tus }\end{array}$ \\
\hline 41 & $\begin{array}{l}\text { p3-9, Table (and text on p3- } \\
7 / 8 \text { ) - Point of showing two } \\
\text { different sources of inventory } \\
\text { is a little unclear. Explain } \\
\text { which inventory was used and } \\
\text { how in this study. Is the } \\
\text { point of showing two sources } \\
\text { intended provide reader some } \\
\text { perspective on the potential } \\
\text { variability of the inventory } \\
\text { values? }\end{array}$ & $\mathbf{x}$ & \multicolumn{3}{|c|}{$\begin{array}{l}\text { A sentence will be added to the first paragraph of } \\
\text { Section } 3.2 .4 \text { (TWRS Standard Inventory Effort). } \\
\text { "This effort forms the source of information to } \\
\text { demonstrate that compliance with the restrictions } \\
\text { set in this performance assessment is to be } \\
\text { "reasonably expected." Future performance } \\
\text { assessments will used data from this effort for } \\
\text { all phases of the analysis." }\end{array}$} & \\
\hline 42 & $\begin{array}{l}\text { p3-20/21 Contaminant Release } \\
\text { (Section } 3.3 .3)- \text { It is not } \\
\text { clear how the text on in this } \\
\text { section differs in purpose } \\
\text { from the text on p3-8, Section } \\
3.2 .5 \text {. } \\
\end{array}$ & $\mathbf{x}$ & \multicolumn{3}{|c|}{$\begin{array}{l}\text { No change. } \\
\text { The purpose is the same. DOE guidance has the } \\
\text { source term (i.e, contaminant release rate) as } \\
\text { part of the inventory section. Section } 3.2 .5 \text { was } \\
\text { inserted so that reviewers (for example, Peer } \\
\text { Review panel members) would find a discussion of } \\
\text { the source term (and a pointer to more detailed } \\
\text { information) at the location that they expected. }\end{array}$} & \\
\hline
\end{tabular}




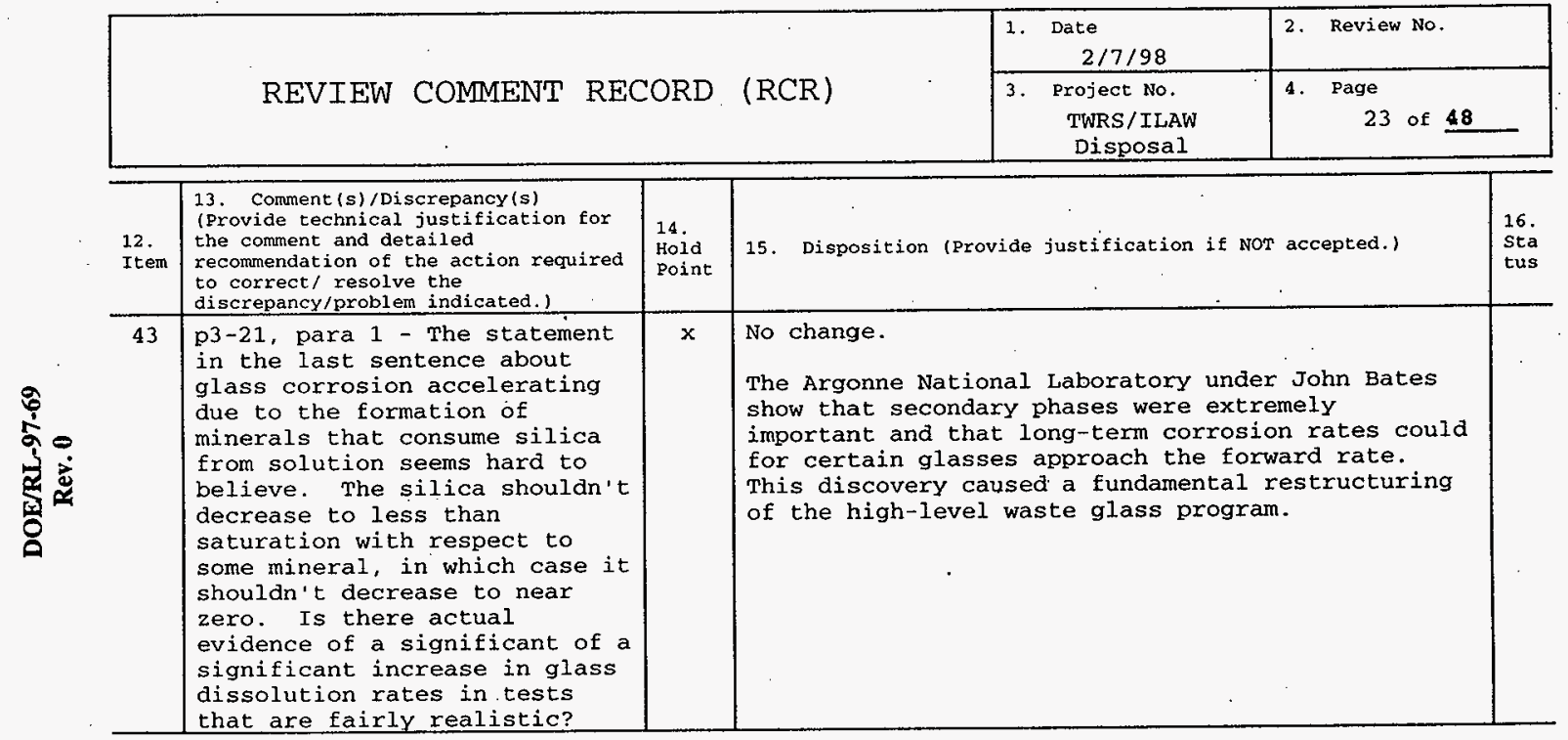




\begin{tabular}{|c|c|c|c|}
\hline \multirow{2}{*}{ REVIEW COMMENT RECORD (RCR) } & $\begin{array}{c}\text { 1. Date } \\
2 / 7 / 98\end{array}$ & 2. Review No. \\
\cline { 3 - 5 } & $\begin{array}{c}\text { 3. Project No. } \\
\text { TWRS/ILAW } \\
\text { Disposal }\end{array}$ & $\begin{array}{c}4 . \text { Page } \\
24 \text { of }\end{array}$ \\
\hline
\end{tabular}

\begin{tabular}{|c|c|c|c|c|}
\hline $\begin{array}{l}12 . \\
\text { Item }\end{array}$ & $\begin{array}{l}\text { 13. Comment(s)/Discrepancy (s) } \\
\text { (Provide technical justification for } \\
\text { the comment and detailed } \\
\text { recommendation of the action reguired } \\
\text { to correct/ resolve the } \\
\text { discrepancy/problem indicated.) }\end{array}$ & $\begin{array}{l}14 . \\
\text { Hold } \\
\text { Point }\end{array}$ & 15. Disposition (Provide justification if NOT accepted.) & $\begin{array}{l}16 . \\
\text { Sta } \\
\text { tius }\end{array}$ \\
\hline 44 & $\begin{array}{l}\text { p3-23, para } 4 \text { - It is not } \\
\text { clear why uniform distribution } \\
\text { of contaminants over the } \\
\text { Hanford site in the event of a } \\
\text { catastrophic flood is remotely } \\
\text { reasonable. Justify further. } \\
\text { If the blocks of glass are } \\
\text { still most1y intact in } 10,000 \\
\text { years, this reviewer would } \\
\text { expect the floods to scatter } \\
\text { the blocks around with some } \\
\text { abrasion. If the glass is } \\
\text { mostly alteration products } \\
\text { when the flood hits then } \\
\text { uniform distribution may be } \\
\text { more appropriate, except for } \\
\text { soluble material which would } \\
\text { be washed away. }\end{array}$ & $x$ & $\begin{array}{l}\text { No change. } \\
\text { The catastrophic Colombia River floods released } \\
\text { tremencous amounts of energy and moved many tens } \\
\text { cubic miles of soil to the sea. The scenario } \\
\text { presented here is simply to provide the reader a } \\
\text { possible effect of another such flood. Section } \\
4.10 \text { provides the results of the analysis. }\end{array}$ & \\
\hline
\end{tabular}




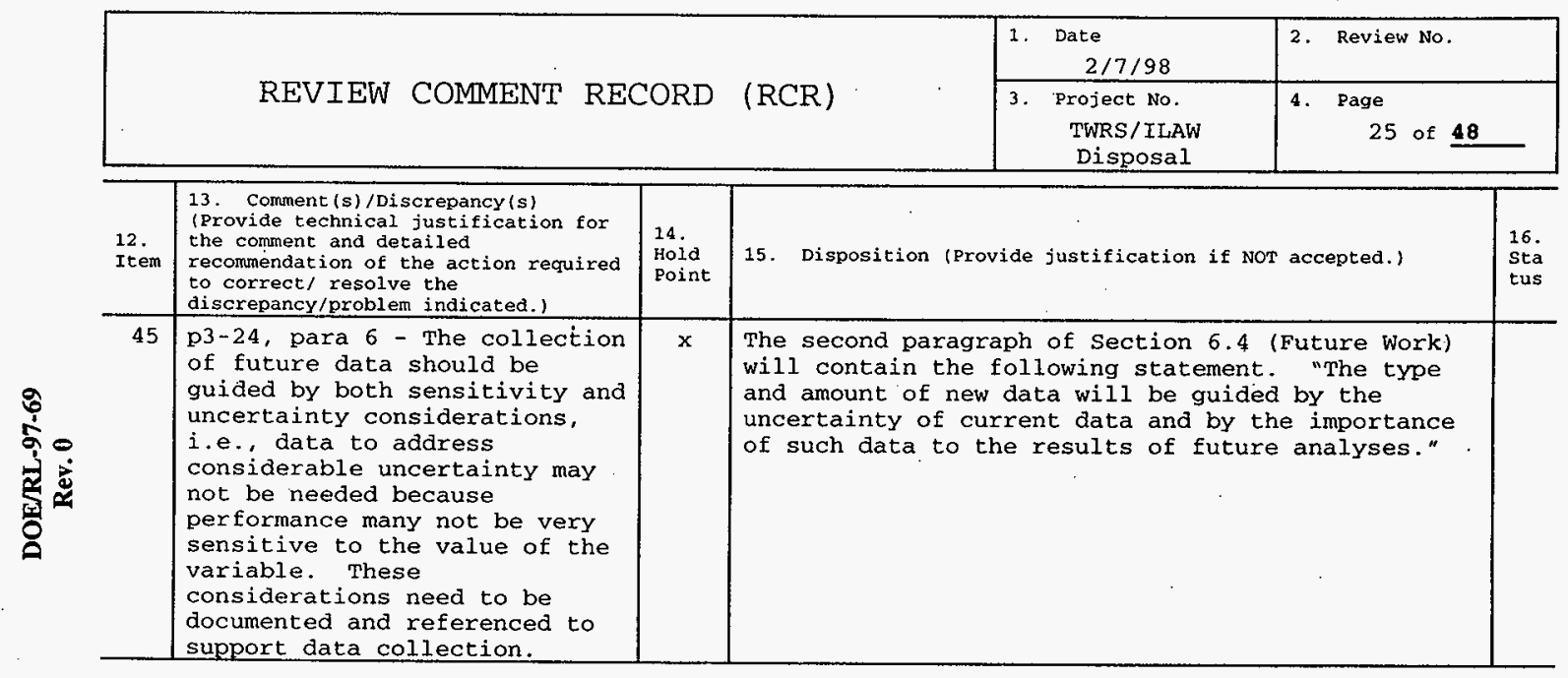




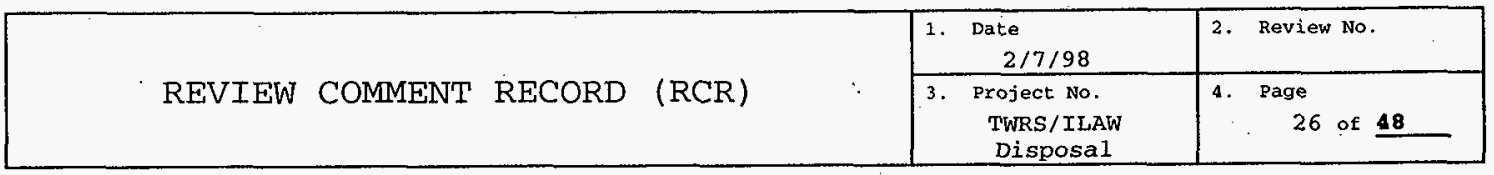

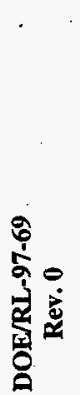

\begin{tabular}{|c|c|c|c|c|}
\hline $\begin{array}{l}12 . \\
\text { Item }\end{array}$ & $\begin{array}{l}\text { 13. Comment }(s) / D i s c r e p a n c y(s) \\
\text { (Provide techical justification for } \\
\text { the comment and detailed } \\
\text { recommendation of the action required } \\
\text { to correct/ resolve the } \\
\text { discrepancy/problem indicated.) }\end{array}$ & $\begin{array}{l}14 . \\
\text { Hoid } \\
\text { Point }\end{array}$ & 15. Disposition (Provide justification if NOT accepted.) & $\begin{array}{l}16 . \\
\text { Sta } \\
\text { tus }\end{array}$ \\
\hline 46 & $\begin{array}{l}\text { p3-25, para } 2 \text { - Text implies } \\
\text { that this PA is inadequate for } \\
\text { intended purpose, i.e. } \\
\text { obtaining a "disposal } \\
\text { authorization" from HQ for } \\
\text { start of construction of } \\
\text { Project w- } 465 \text {. An explanation } \\
\text { is needed as to why this. } \\
\text { report is good enough to } \\
\text { justify construction of the } \\
\text { grout vaults. Note: This } \\
\text { reviewer believes that it is } \\
\text { impractical to have a "final" } \\
\text { pA completed before start of } \\
\text { construction; therefore, there } \\
\text { will inherently more } \\
\text { uncertainty in the system } \\
\text { performance at that time than } \\
\text { expected later after further } \\
\text { data collection and analyses. } \\
\text { The approach in this report of } \\
\text { a base case and sensitivity } \\
\text { cases helps off-set some of } \\
\text { the uncertainty. }\end{array}$ & $x$ & $\begin{array}{l}\text { Disagree that the text implies that this PA is } \\
\text { inadequate. } \\
\text { The first and second sentences are modified to } \\
\text { state: "Even though much of the site-, facility-, } \\
\text { and waste form-specific data. needed for a } \\
\text { performance assessment have not yet been obtained, } \\
\text { enough relevant data from other sources is known } \\
\text { about the proposed disposal action that reasonable } \\
\text { assumptions can be made.". }\end{array}$ & \\
\hline
\end{tabular}




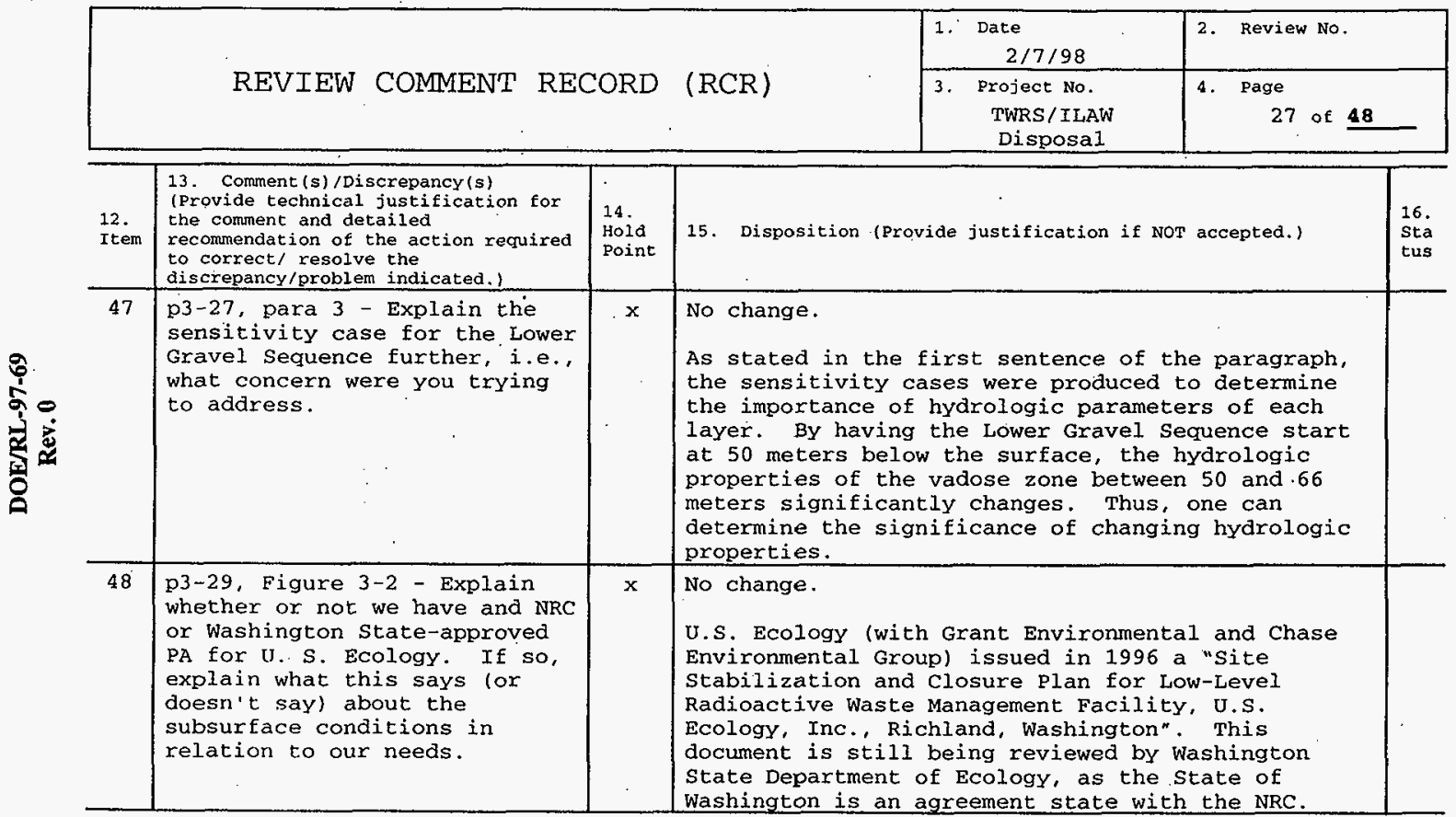




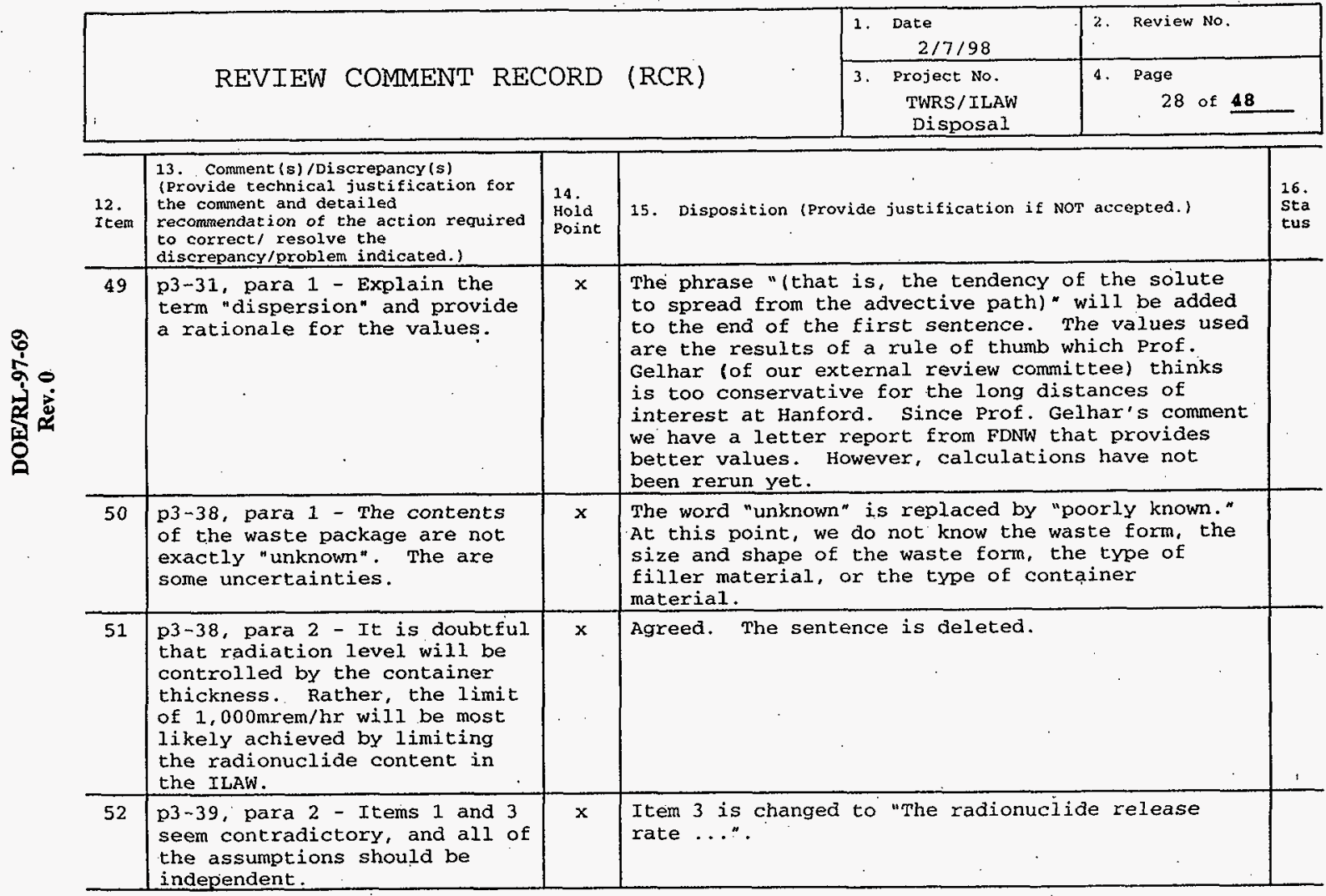

A-6400-090.1 (03:92) WEF011 


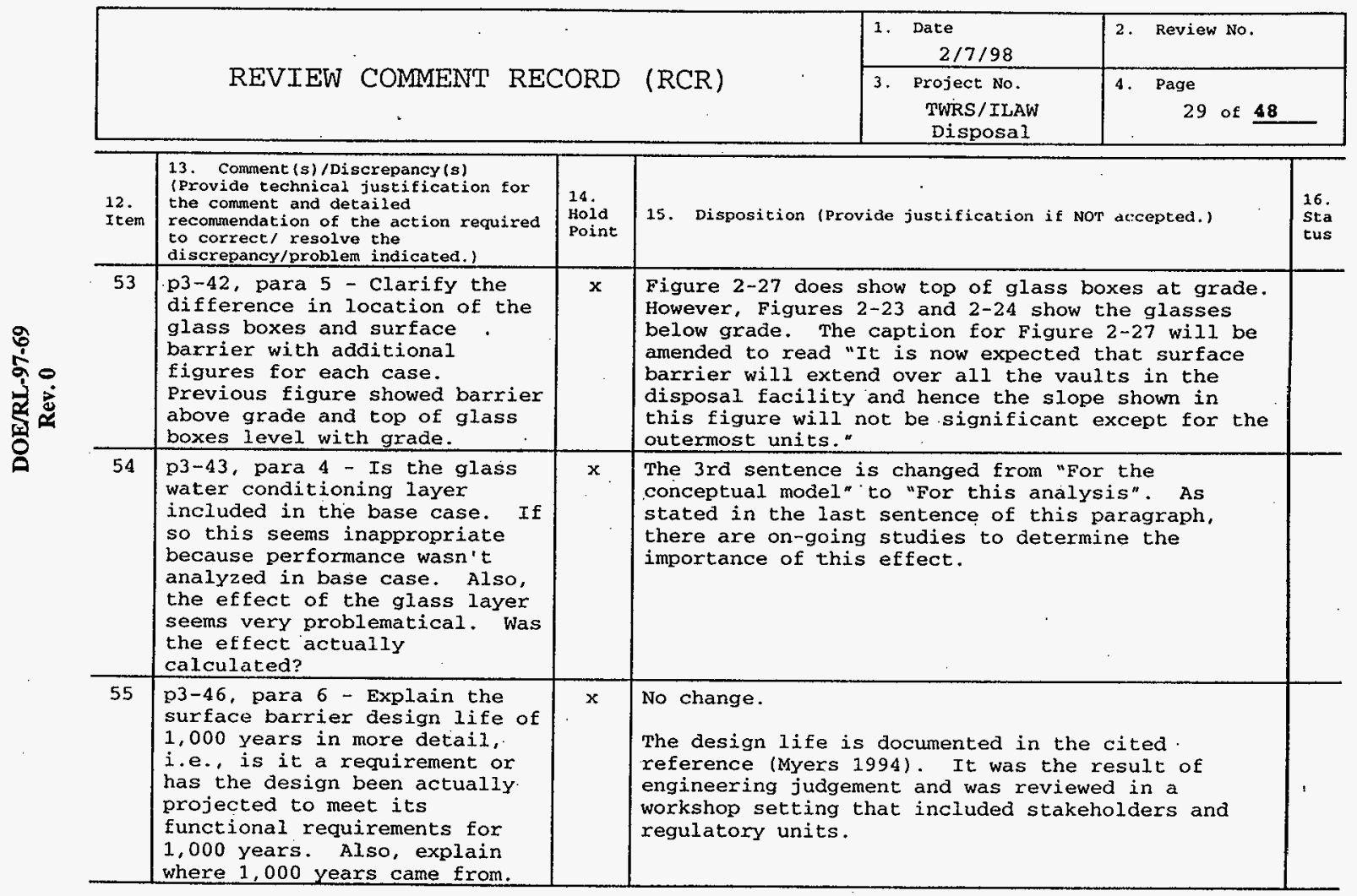

A-6400-090.1 (0) 192) WEF011 


\begin{tabular}{|c|c|c|c|c|c|c|}
\hline & \multirow{2}{*}{\multicolumn{2}{|c|}{ REVIEW COMMENT RECORD }} & \multirow[b]{2}{*}{ ( RCR) } & $\begin{array}{l}\text { 1. Date } \\
2 / 7 / 98 \\
\end{array}$ & \multicolumn{2}{|l|}{ 2. Review No. } \\
\hline & & & & $\begin{array}{l}\text { 3. Project No. } \\
\text { TWRS/ILAW } \\
\text { Disposal }\end{array}$ & \multicolumn{2}{|l|}{$\begin{array}{l}\text { 4. Page } \\
30 \text { of } \mathbf{4 8}\end{array}$} \\
\hline $\begin{array}{l}12 . \\
\text { Item }\end{array}$ & $\begin{array}{l}\text { 13. Comment (s)/Discrepancy (s) } \\
\text { (Provide technical justification for } \\
\text { the comment and detailed } \\
\text { recommendation of the action required } \\
\text { to correct/ resolve the } \\
\text { discrepancy/prablem indicated.) } \\
\end{array}$ & $\begin{array}{l}14 \\
\text { Hold } \\
\text { Point }\end{array}$ & \multicolumn{3}{|c|}{ 25. Disposition (Provide justification if NOT accepted.) } & $\begin{array}{l}16 . \\
\text { Sta } \\
\text { tus }\end{array}$ \\
\hline 56 & $\begin{array}{l}\text { p3-48, para } 2 \text { - Perform a } \\
\text { simple estimate of rate of } \\
\text { water depletion by reaction } \\
\text { with glass to determine if } \\
\text { this is significant compared } \\
\text { with infiltration in the } 0.5 \text { - } \\
3.0 \mathrm{~mm} / \text { year range. }\end{array}$ & $\mathrm{x}$ & \multicolumn{3}{|c|}{$\begin{array}{l}\text { No change. } \\
\text { At this recharge rate, there is not significant } \\
\text { water consumption. However, the infiltration rate } \\
\text { into the vault interior will be significantly } \\
\text { lower than this, especially if a sand-gravel } \\
\text { capillary barrier is used. In that case, a } \\
\text { significant fraction of the water will be } \\
\text { consumed. }\end{array}$} & \\
\hline
\end{tabular}




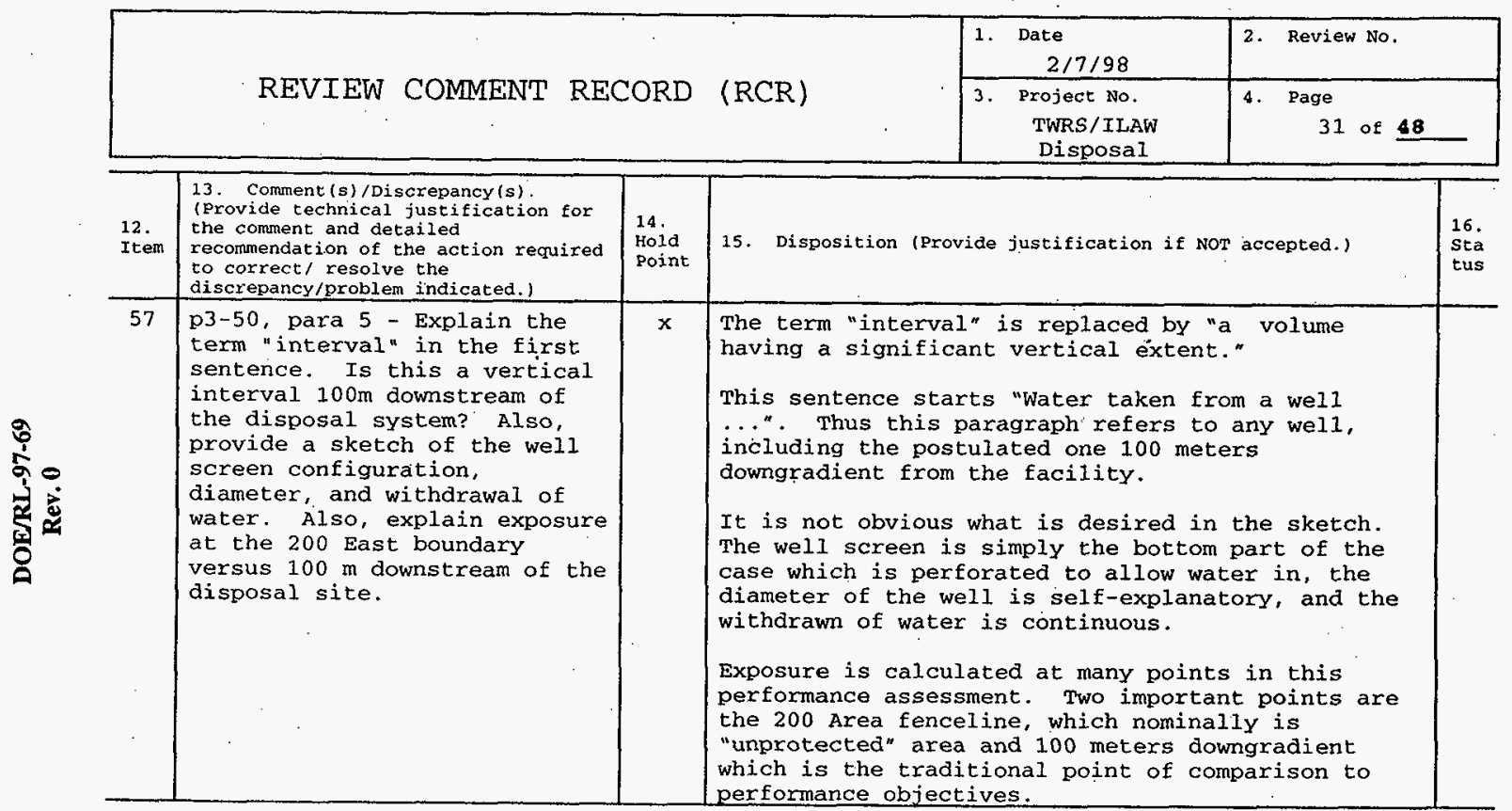




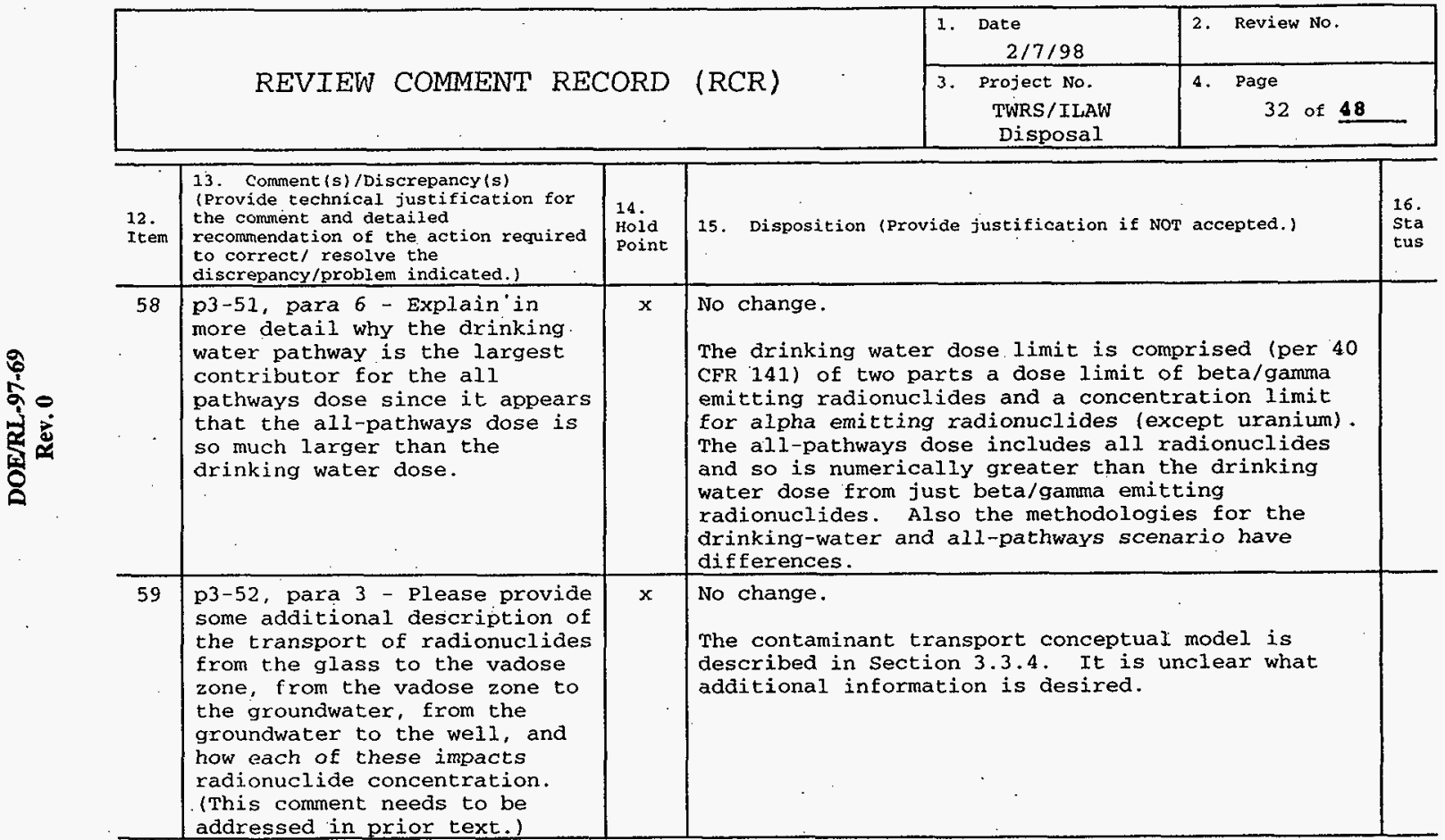




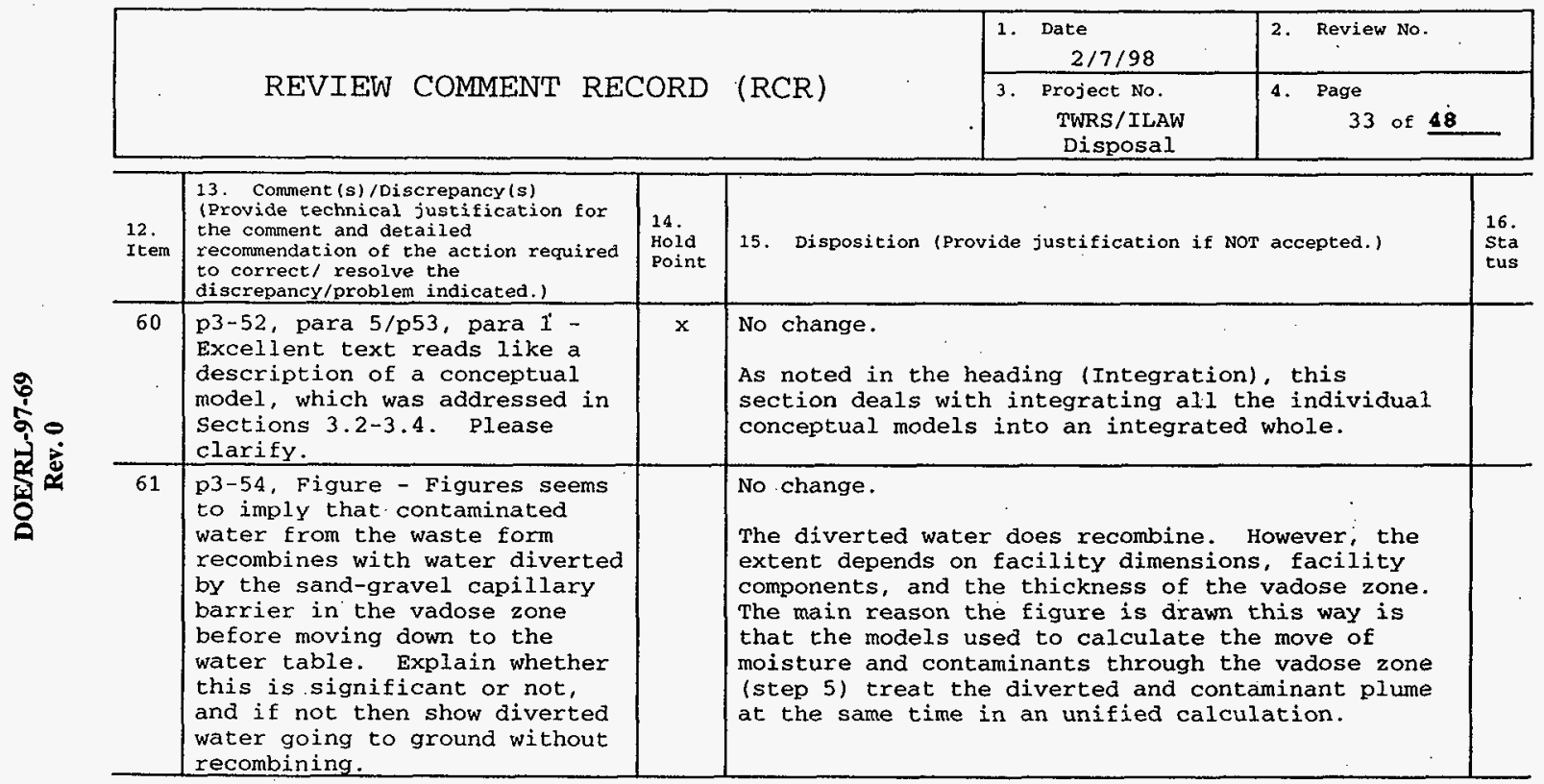




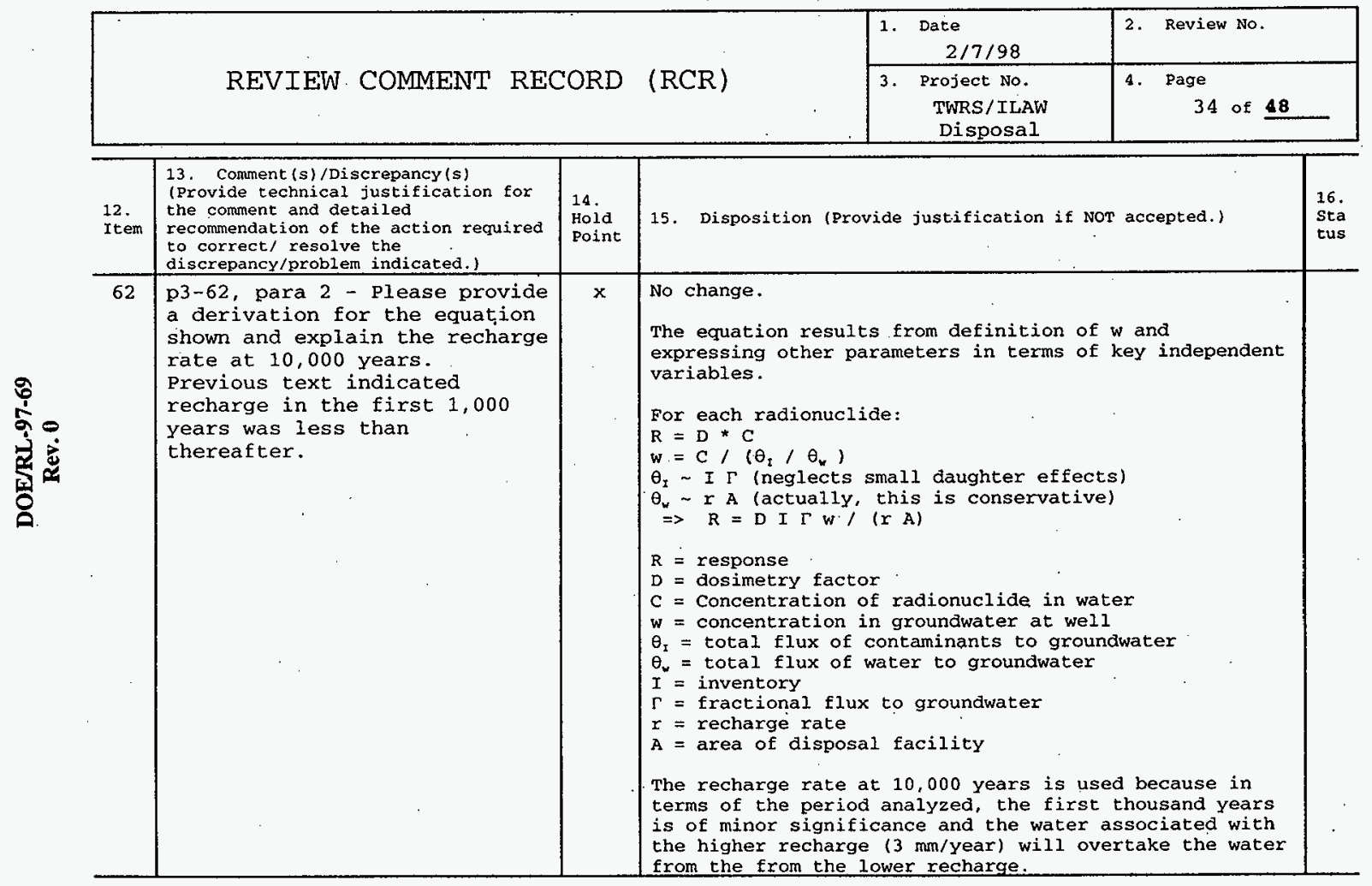




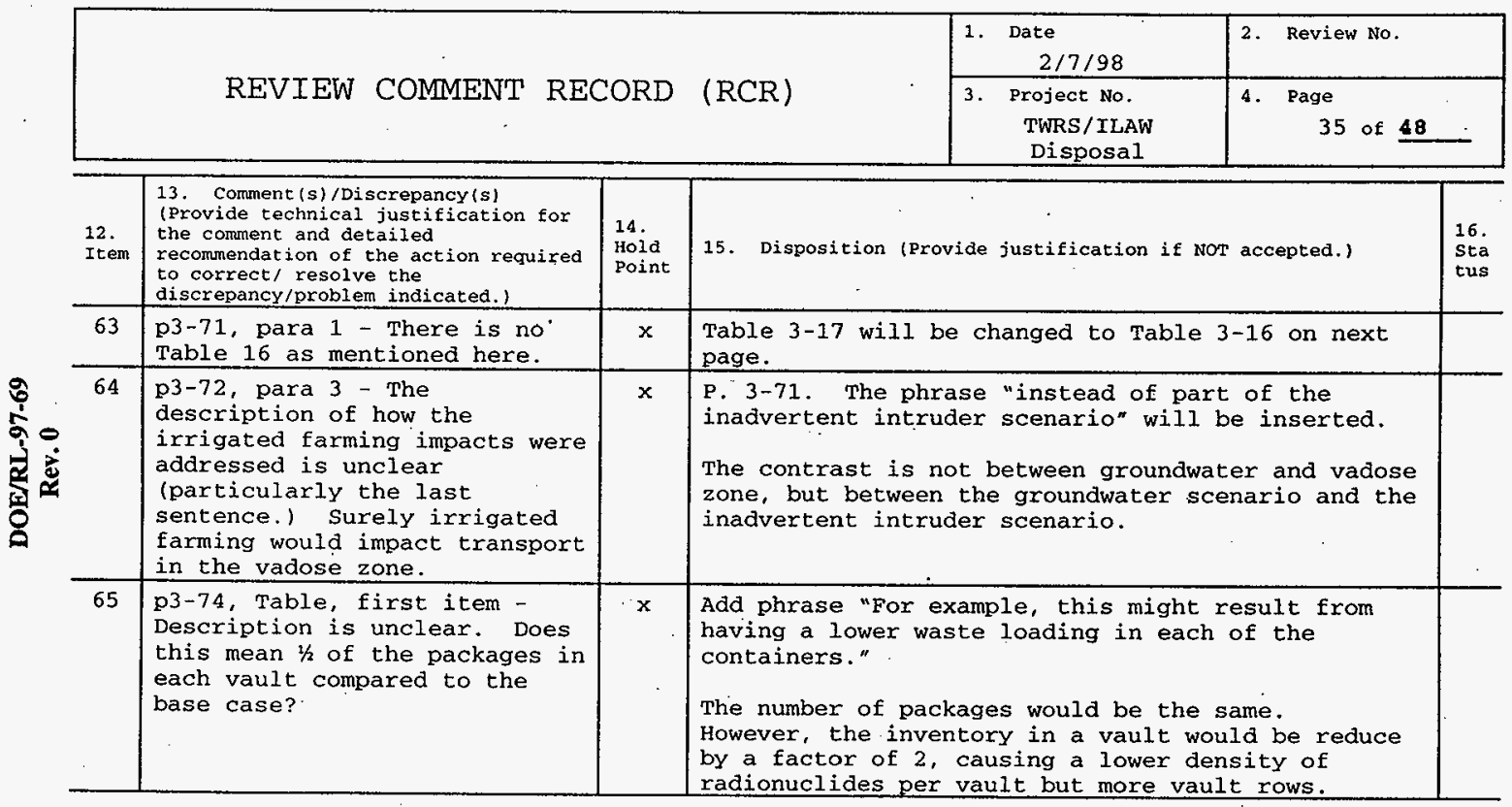




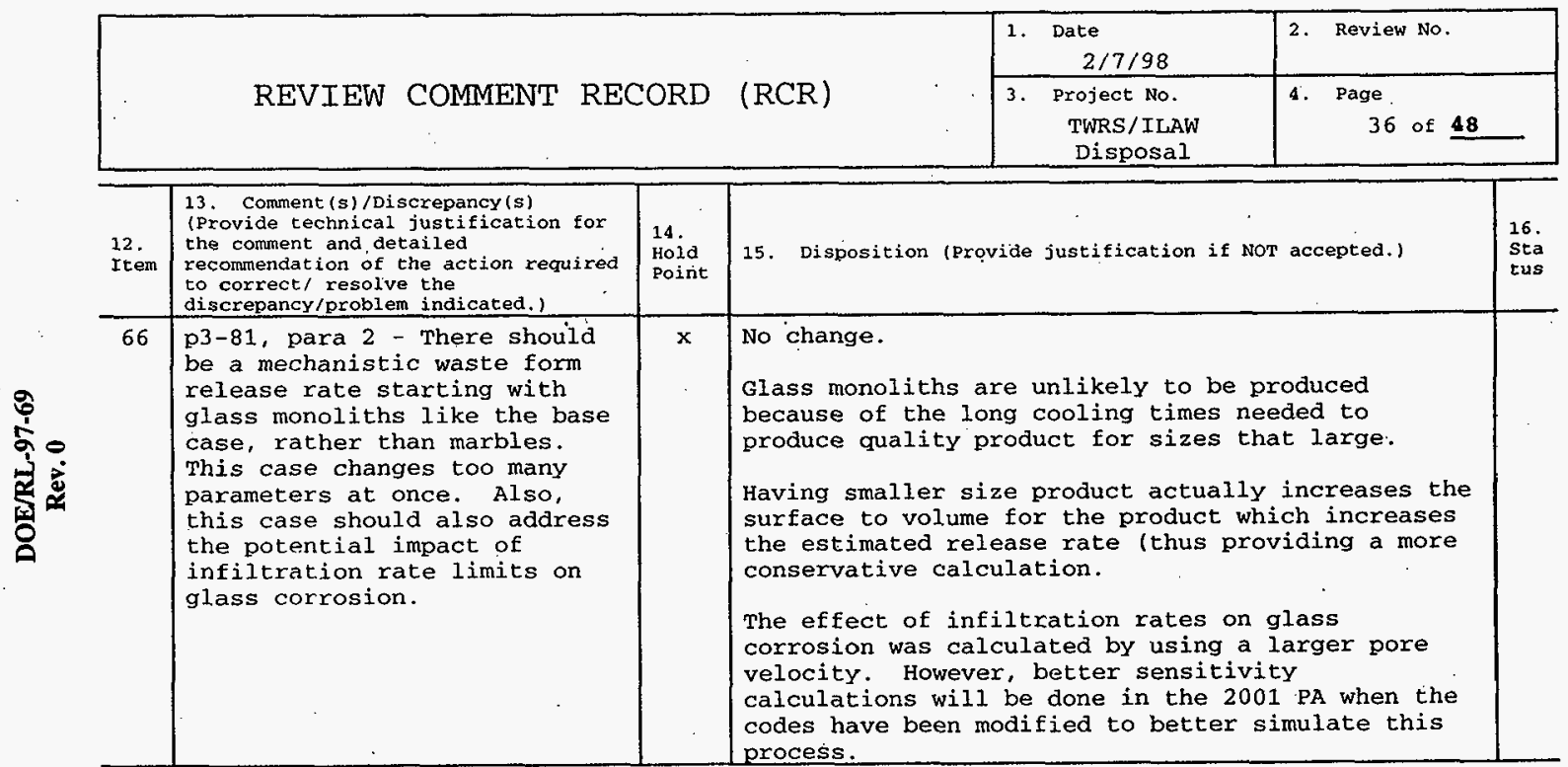




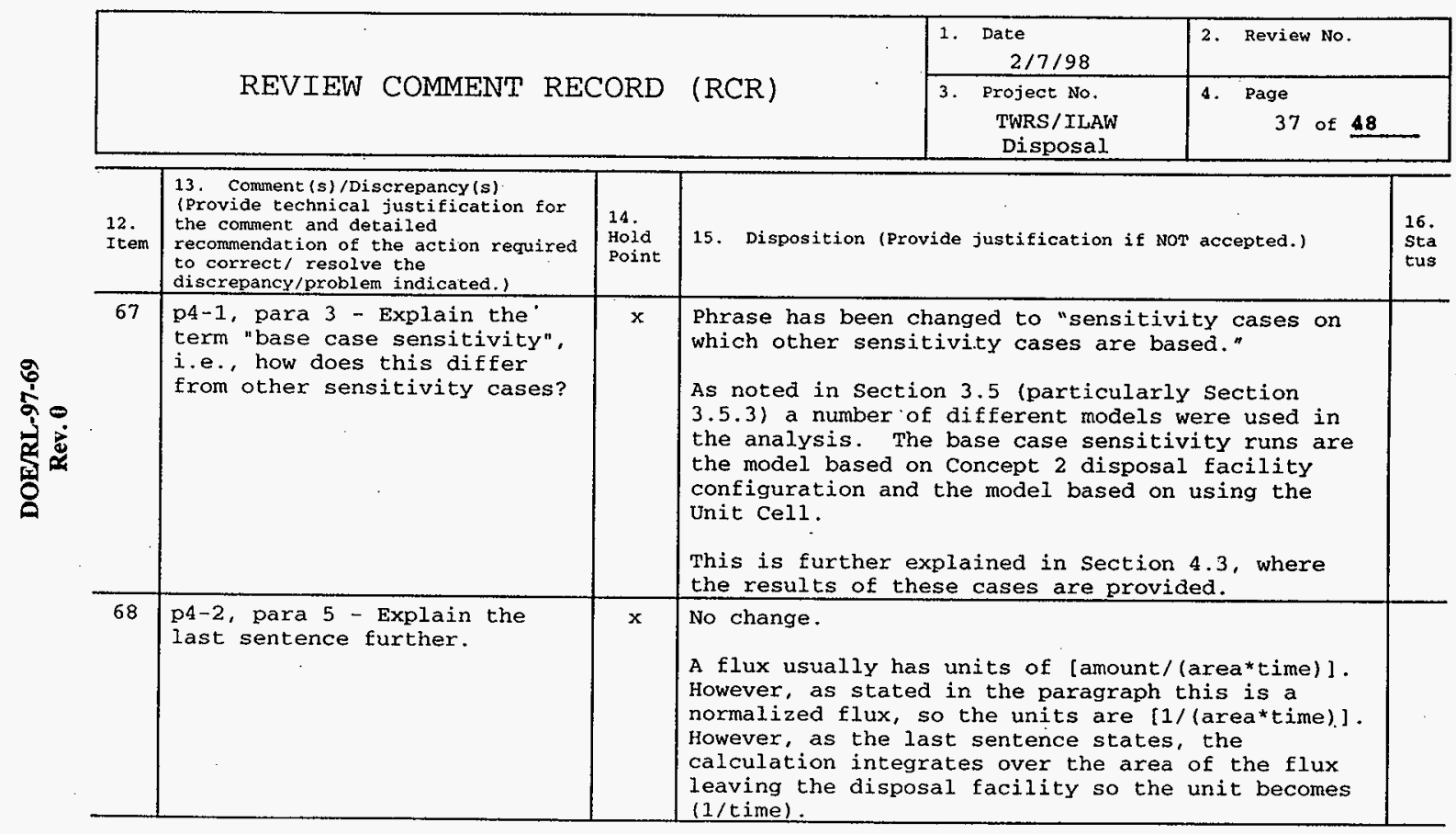




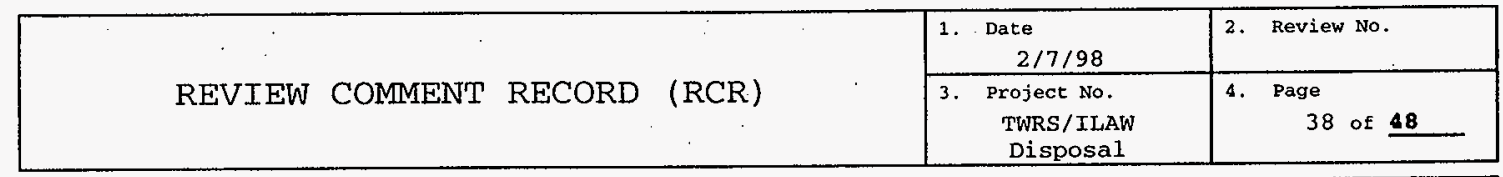

\begin{tabular}{|c|c|c|c|c|}
\hline $\begin{array}{l}12 . \\
\text { Item }\end{array}$ & $\begin{array}{l}\text { 13. Conment (s)/Discrepancy (s). } \\
\text { (provide technical justification for } \\
\text { the comment and detailed } \\
\text { recommendation of the action required } \\
\text { to correct/ resolve the } \\
\text { discrepancy/problem indicated.) }\end{array}$ & $\begin{array}{l}14, \\
\text { Hold } \\
\text { Point }\end{array}$ & 15. Disposition (Provide justification if NOT accepted.) & $\begin{array}{l}16, \\
\text { Sta } \\
\text { tus }\end{array}$ \\
\hline 69 & $\begin{array}{l}\text { p4.3, Figure 4-1 - Explain } \\
\text { whether figure only applies to } \\
\text { a non-sorbed radionuclide (and } \\
\text { one with a long half-life. } \\
\text { Also, address whether } \\
\text { solubility limits are exceeded } \\
\text { at the selected recharge rate. }\end{array}$ & $\mathbf{x}$ & $\begin{array}{l}\text { Caption will be changed by adding a phrase "for a } \\
\text { long-lived radionuclide that experiences no } \\
\text { absorption." }\end{array}$ & \\
\hline 70 & $\begin{array}{l}\text { p4-6, Figure } 4-2 \text { - It is } \\
\text { unclear how this figure fits } \\
\text { with the base-case } \\
\text { infiltration assumptions of } \\
0.5 \mathrm{~mm} / \mathrm{y} \text { in } 1 \text { st } 1,000 \text { years } \\
\text { and } 3.0 \mathrm{~mm} / \mathrm{y} \text { after. Show } \\
\text { infiltration stream lines. } \\
\text { Also, show streamlines below } \\
\text { waste form. }\end{array}$ & $\mathbf{x}$ & $\begin{array}{l}\text { No change to figures } 4-2 \text {. through } 4-5 \text {. } \\
\text { The ability to recreate these figures with the } \\
\text { source points desired is gone. } \\
\text { By definition, a streamline follows where most of } \\
\text { the water goes. Most of the water is calculated } \\
\text { to be diverted because of the capillary barrier. } \\
\text { Hence the streamlines are as shown. }\end{array}$ & \\
\hline 71 & $\begin{array}{l}\text { p4-9, Figure } 4-6-\text { Explain why } \\
\text { the normalized flux for the } \\
0.0 \text { k curve at } 10,000 y \text { seems } \\
\text { to be substantially less than } \\
\text { the general normalized flux } \\
\text { curve in Figure } 4-1 \text {. } \\
\text { Shouldn't these two curves be } \\
\text { the same? }\end{array}$ & $\mathrm{x}$ & $\begin{array}{l}\text { No. There are two major differences. Figure } 4-1 \\
\text { uses concept } 2 \text { and a constant release rate ( } 4 \\
\text { ppm/year), while } 4-6 \text { uses concept } 1 \text { and the time- } \\
\text { dependent release rate (which depends on surface } \\
\text { area). As explained in Sections } 4.3 \text { and } 4.5 \text {, } \\
\text { because of the moisture shadow, there is a } \\
\text { significant difference between having one big } \\
\text { vault (or closely packed set of vaults) and vaults } \\
\text { separated by rows of dirt. }\end{array}$ & \\
\hline
\end{tabular}




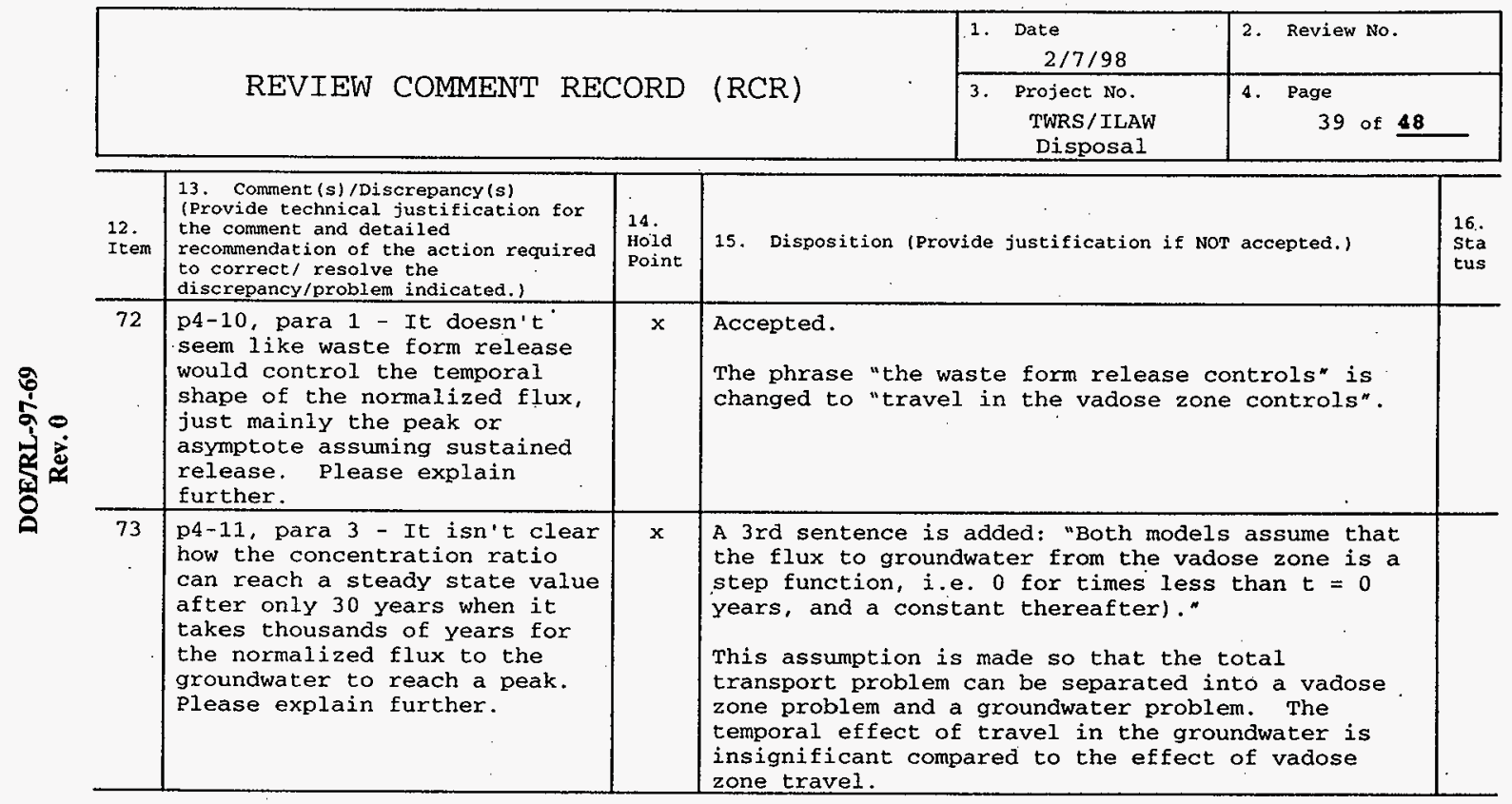




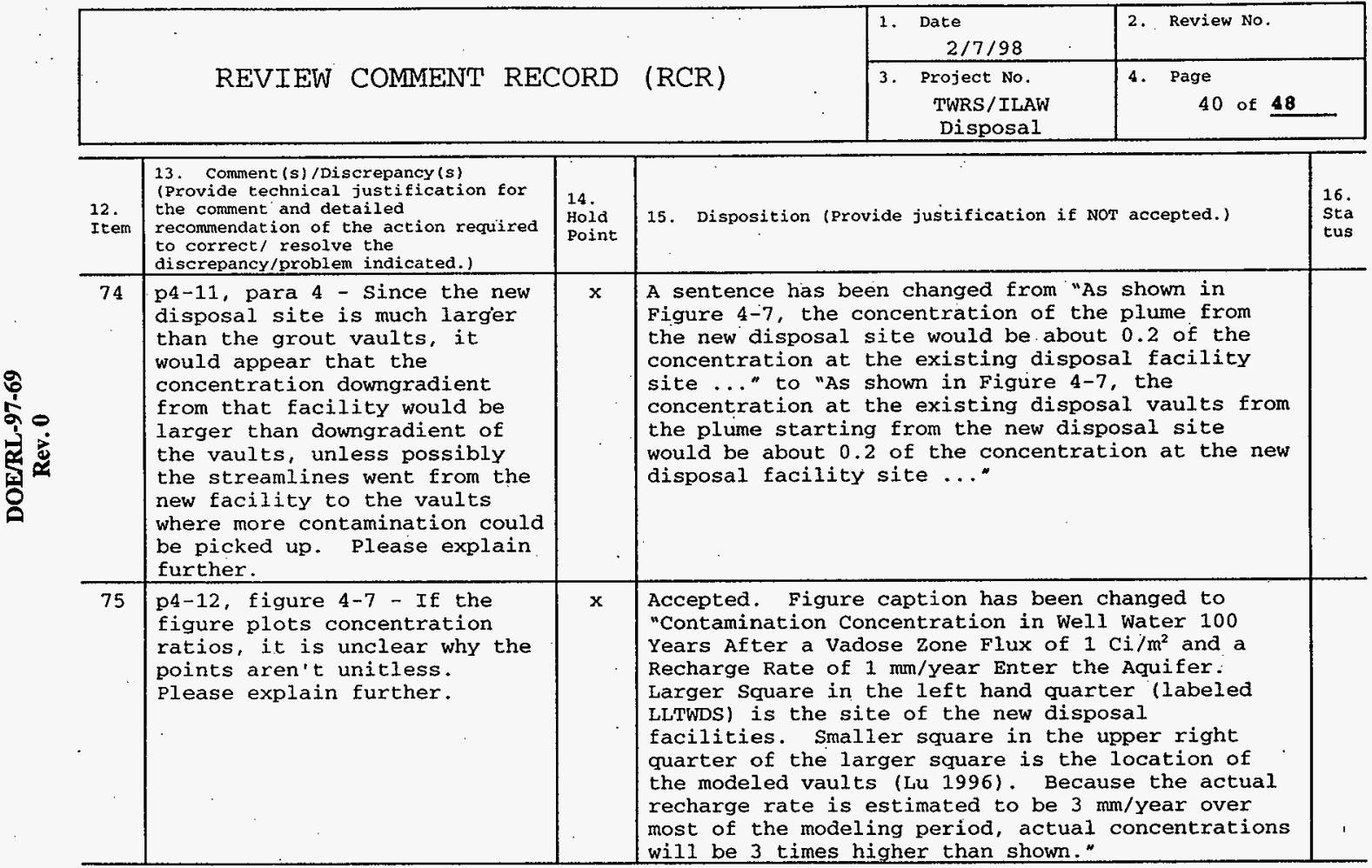




\begin{tabular}{|c|c|c|c|c|c|}
\hline & & \multirow{2}{*}{\multicolumn{2}{|c|}{ REVIEW COMMENT RECORD }} & \multirow[b]{2}{*}{ (RCR) } & 2. Review No. \\
\hline & & & & & \\
\hline & $\begin{array}{l}12 . \\
\text { Item }\end{array}$ & $\begin{array}{l}\text { 13. Comment(s)/Discrepancy(s) } \\
\text { (Provide technical justification for } \\
\text { the comment and detailed } \\
\text { recommendation of the action required } \\
\text { to correct/ resolve the } \\
\text { discrepancy/problem indicated.) }\end{array}$ & $\begin{array}{l}14 . \\
\text { Hold } \\
\text { Point }\end{array}$ & 15. Disp & $\begin{array}{l}16 . \\
\text { Sta } \\
\text { tus }\end{array}$ \\
\hline 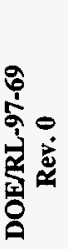 & 76 & $\begin{array}{l}\text { p4-13, Table } 4-3 \text { - The first } \\
\text { entry shows a concentration } \\
\text { ratio of } 5.31 \text { E-3 at } 100 \mathrm{~m} \text {. } \\
\text { Does this small number reflect } \\
\text { a "step change" in dilution } \\
\text { when the water from the vadose } \\
\text { zone mixes with the water in } \\
\text { the unconfined aquifer. } \\
\text { please explain further. }\end{array}$ & $x$ & $\begin{array}{l}\text { No chan } \\
\text { Because } \\
\text { groundw } \\
\text { about } 5 \\
\text { mixed i } \\
\text { mixed i }\end{array}$ & \\
\hline & 77 & $\begin{array}{l}\text { p4-24, para } 4 \text {, last sentence - } \\
\text { Explain why the arrival times } \\
\text { in Table } 4-10 \text { are longer than } \\
\text { the base case in Table } 4-2 \\
\text { even if the hydraulic } \\
\text { conductivity in concept } 2 \text { is } \\
\text { higher. }\end{array}$ & $x$ & $\begin{array}{l}\text { No chan } \\
\text { Trave } \\
\text { half th } \\
\text { travel } \\
4-10 . \\
K_{d}=0 \\
K_{d}=0.1 \\
K_{d}=0.6 \\
\text { Times f } \\
\text { effect } \\
\text { used as }\end{array}$ & i \\
\hline
\end{tabular}




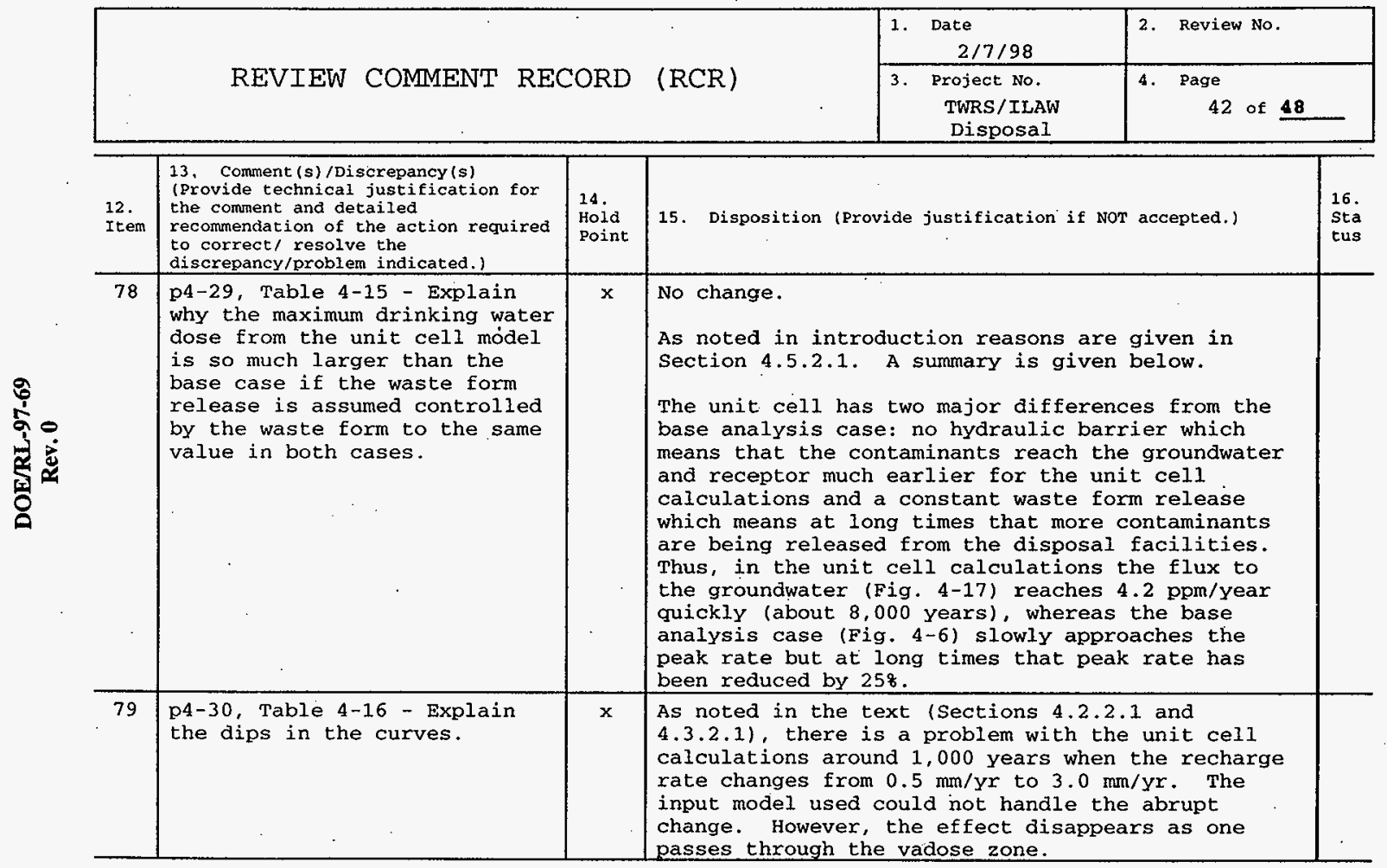




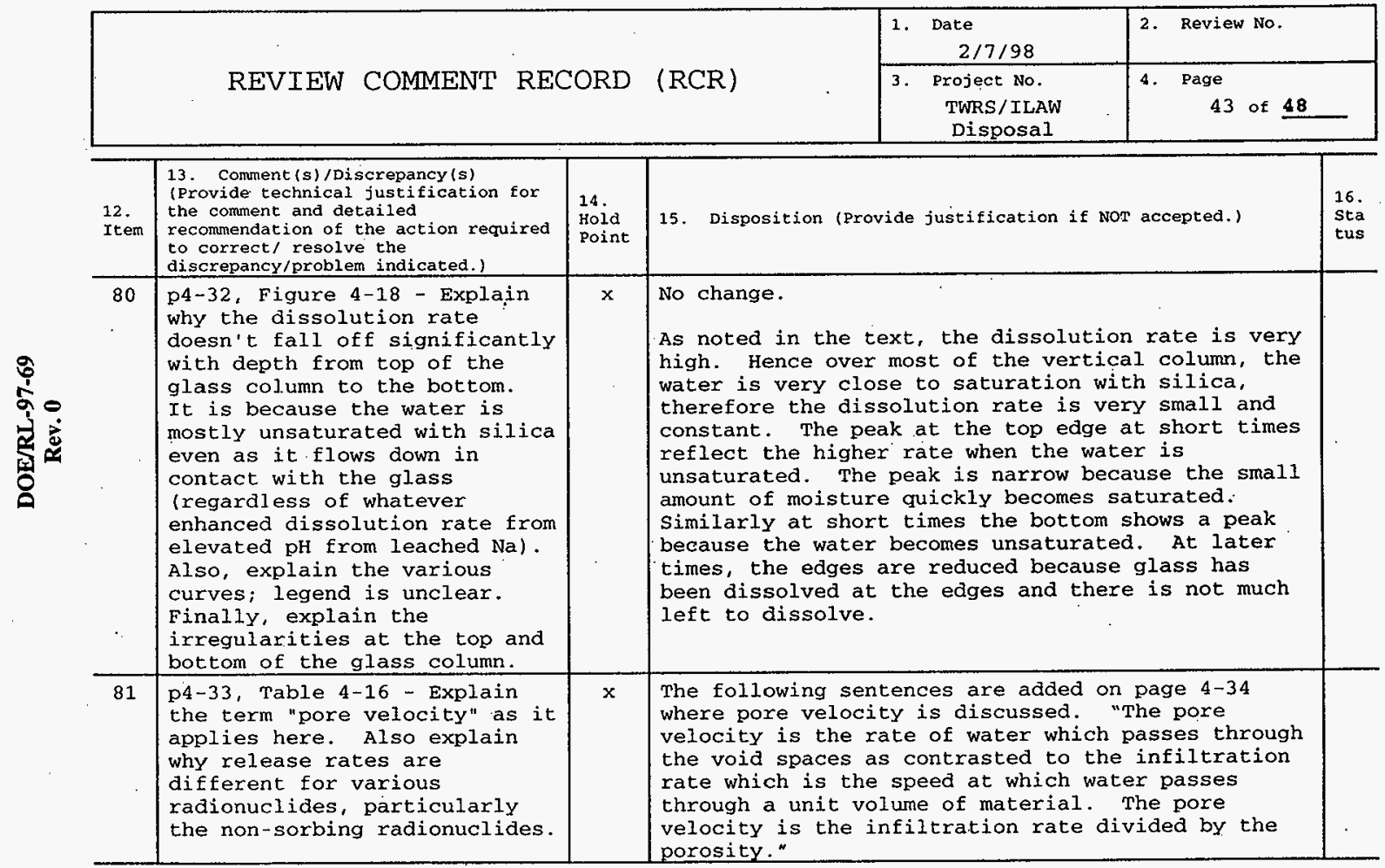




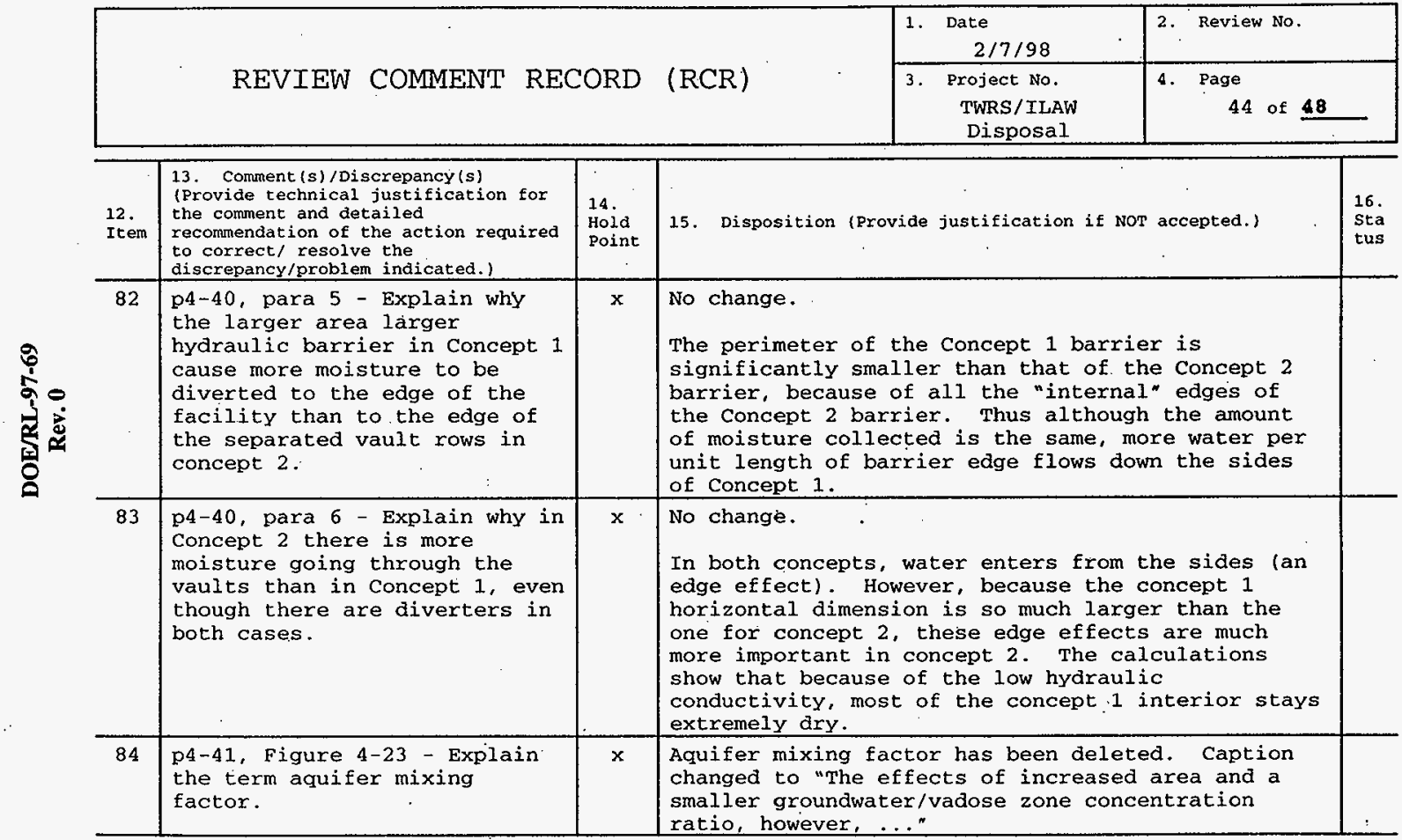




\begin{tabular}{|c|c|c|c|c|c|c|}
\hline & & & & & $\begin{array}{l}\text { 1. Date } \\
2 / 7 / 98\end{array}$ & \\
\hline & & COMMENT REC & ORD & ( $\mathrm{RCR})$ & $\begin{array}{l}\text { 3. Project No. } \\
\text { TWRS/ILAW } \\
\text { Disposal }\end{array}$ & \\
\hline & $\begin{array}{l}12 . \\
\text { Item }\end{array}$ & $\begin{array}{l}\text { 13. Comment (s)/Discrepancy (s) } \\
\text { (Provide technical justification for } \\
\text { the comment and detailed } \\
\text { recommendation of the action required } \\
\text { to correct/ resolve the } \\
\text { discrepancy/problem indicated.) }\end{array}$ & $\begin{array}{l}14 \\
\text { Hold } \\
\text { Point }\end{array}$ & 15. Disp & ide justification if NOT accepted.) & $\begin{array}{l}16 . \\
\text { Sta } \\
\text { tus }\end{array}$ \\
\hline$\frac{1}{8}$ & 85 & $\begin{array}{l}\mathrm{p} 4-62 \text {, para } 2 \text { - If the well to } \\
\text { vadose zone concentration } \\
\text { factor is the same, wouldn't } \\
\text { the dose impact also be the } \\
\text { same. please explain further. }\end{array}$ & $x$ & $\begin{array}{l}\text { No chan } \\
\text { concent } \\
\text { from th } \\
\text { meters } \\
\text { or the } \\
200 \text { Eas } \\
\text { downgra } \\
\text { whereas } \\
\text { the bou }\end{array}$ & $\begin{array}{l}\text { own in Table } 4-3 \text { the groundwater } \\
\text { ios are a function of distance } \\
\text { facility. Thus, the ratios } 100 \\
\text { nt for either the new facilities } \\
\text { aults at the same. However, the } \\
\text { ndary is about } 900 \text { meters } \\
\text { the new disposal facilities } \\
\text { ing facilities are basically at }\end{array}$ & \\
\hline & 86 & $\begin{array}{l}\text { p4-67, para } 3 \text { - Explain the } \\
\text { phrase "no effect of the } \\
\text { vadose zone", i.e. what is } \\
\text { the effect of the vadose zone } \\
\text { besides delaying radionuclide } \\
\text { arrival at the aquifer? }\end{array}$ & $x$ & $\begin{array}{l}\text { No chan } \\
\text { Because } \\
\text { form, t } \\
\text { arrival } \\
\text { with sh } \\
\text { zone is } \\
\text { which h } \\
\text { concent }\end{array}$ & $\begin{array}{l}\text { ag release times from the waste } \\
\text { the vadose zone is to delay } \\
\text { andwater. For disposal actions } \\
\text { leases, the effect of the vadose } \\
\text { the contaminant peak out in time } \\
\text { ect of reducing the maximum }\end{array}$ & \\
\hline
\end{tabular}




\begin{tabular}{|c|c|c|c|c|c|c|}
\hline & & & & $\begin{array}{l}\text { 1. Date } \\
2 / 7 / 98 \\
\end{array}$ & 2. Review No. & \\
\hline & REVIEW COMMENT REC & ORD & $(\mathrm{RCR})$ & $\begin{array}{l}\text { 3. Project No. } \\
\text { TWRS/ILAW } \\
\text { Disposal }\end{array}$ & $\begin{array}{r}\text { 4. Page } \\
.46 \text { of } 48 \\
\end{array}$ & \\
\hline $\begin{array}{l}12 . \\
\text { Item }\end{array}$ & $\begin{array}{l}\text { 13. Comment (s)/Discrepancy (s) } \\
\text { (Provide technical justification for } \\
\text { the comment and detailed } \\
\text { recommendation of the action required } \\
\text { to correct/. resolve the } \\
\text { discrepancy/problem indicated.) }\end{array}$ & $\begin{array}{l}\text { Poid } \\
\text { Point }\end{array}$ & 15. Dis & ide justification $i$ & accepted.) & $\begin{array}{l}16 . \\
\text { Sta } \\
\text { tus }\end{array}$ \\
\hline 87 & $\begin{array}{l}\text { p5-14, para } 2 \text { - Reasoning is } \\
\text { unclear. If the intruder hits } \\
\text { glass in a vault, the dose } \\
\text { should be the same as before, } \\
\text { but if he misses, the dose } \\
\text { should be zero (other factors } \\
\text { being the same). }\end{array}$ & $x$ & $\begin{array}{l}\text { The fir } \\
\text { "If the } \\
\text { a facte } \\
\text { Concept } \\
\text { dose de } \\
\text { This pe } \\
\text { radiont } \\
\text { contair } \\
\text { radion } \\
\text { are a } \\
\text { less ar }\end{array}$ & $\begin{array}{l}\text { after the bull } \\
\text { he disposal faci } \\
\text { that is, the tot } \\
3.4 .5 .43) \text {, the } \\
60 \text { percent." } \\
\text { scusses the effe } \\
\text { ntory density in } \\
\text { he intruder brin } \\
\text { s exposure will } \\
\text { reasons why the } \\
\text { listed. }\end{array}$ & $\begin{array}{l}\text { is changed to } \\
\text { increases by } \\
\text { area under } \\
\text { le predicted } \\
\text { w } \\
\text { waste } \\
\text { less. There } \\
\text { ity could be }\end{array}$ & \\
\hline 88 & $\begin{array}{l}\text { p6-4, para } 2 \text { - Explain further } \\
\text { the point about the impact of } \\
\text { the length to width ratio. }\end{array}$ & $\mathrm{x}$ & $\begin{array}{l}\text { The ser } \\
\text { does no } \\
\text { The int } \\
\text { reader } \\
\text { introdu }\end{array}$ & $\begin{array}{l}\text { "long sides" is } \\
\text { hing. } \\
\text { sentence was to } \\
\text { of the size of } \\
\text { next section. }\end{array}$ & $\begin{array}{l}\text { leted as it } \\
\text { ovide the } \\
\text { which is }\end{array}$ & \\
\hline 89 & $\begin{array}{l}\text { p6-7, Table } 6-6 \text { - Explain the } \\
\text { term "present analysis". It } \\
\text { implies this report contains } \\
\text { limits on inventory times } \\
\text { contamination release rate. } \\
\text { Explain where these are } \\
\text { located. }\end{array}$ & $x$ & $\begin{array}{l}\text { Senten } \\
\text { invent } \\
\text { Actual }\end{array}$ & $\begin{array}{l}\text { op of the page } \\
\text { ictions of the } \\
\text { ns are in Tables }\end{array}$ & $\begin{array}{l}\text { be changed to } \\
\text { uct of the } \\
7 \text { and } 6-8 \text {. }\end{array}$ & \\
\hline
\end{tabular}




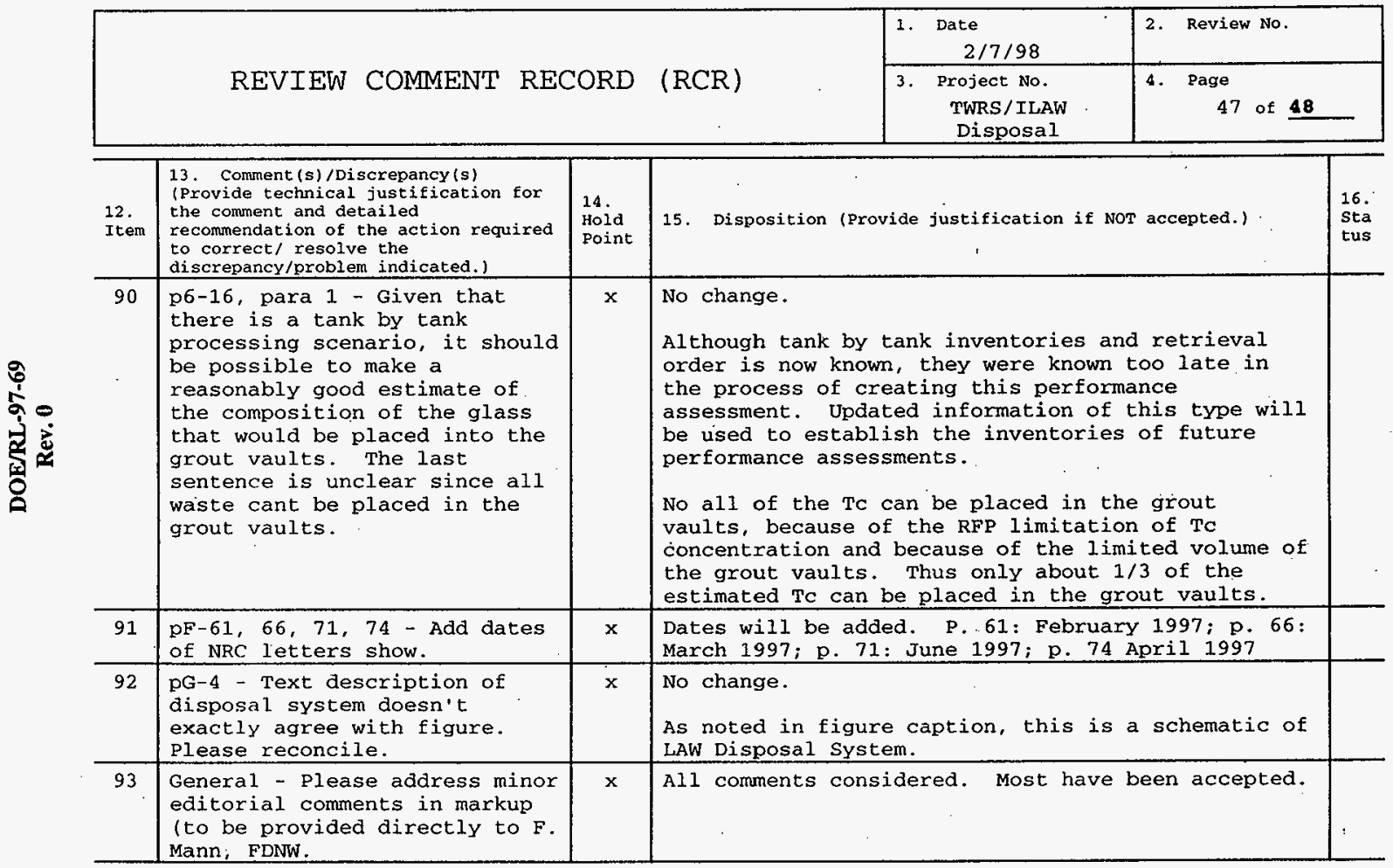




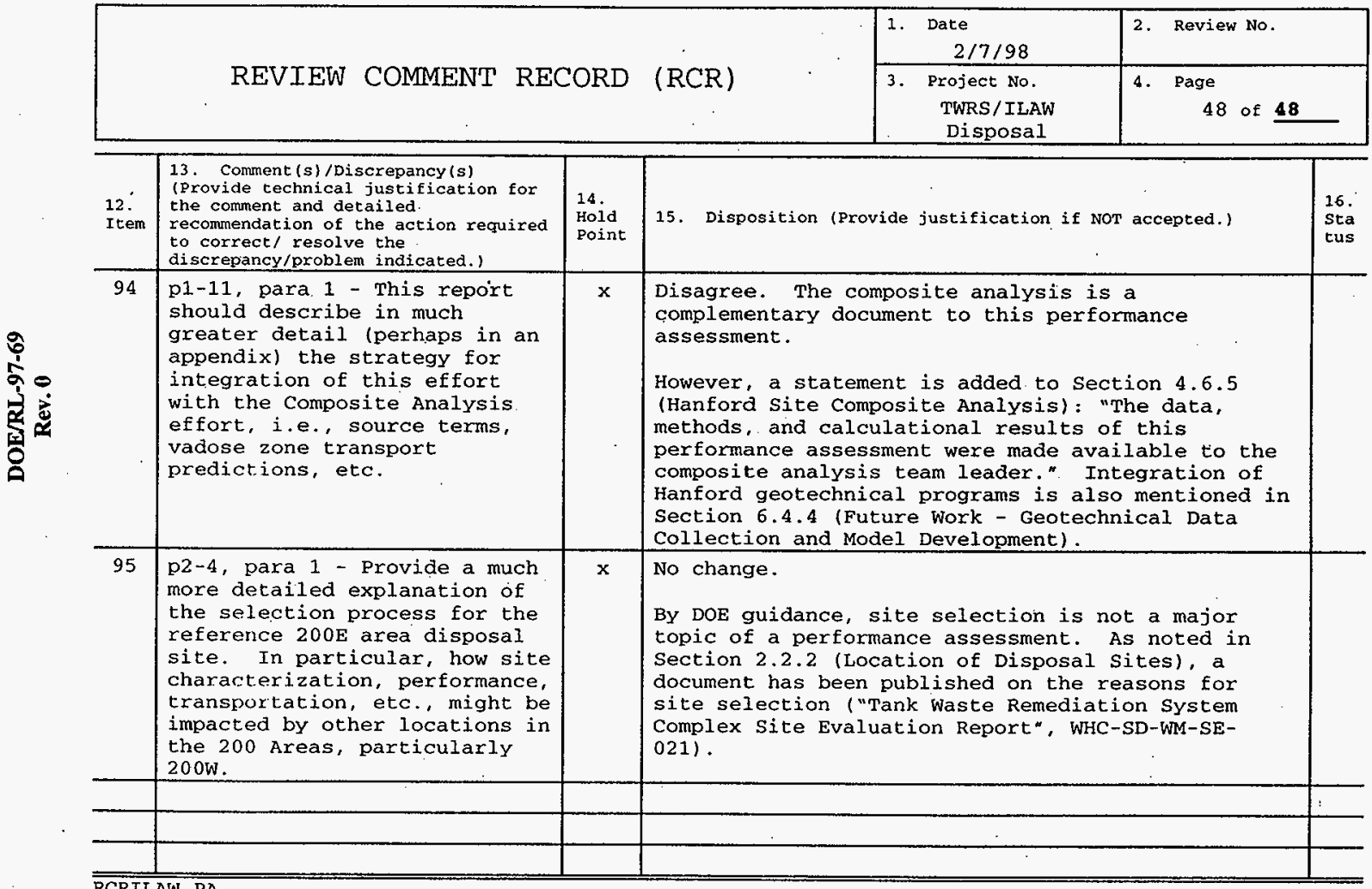


DOE/RL-97-69

Rev. 0

F.5.2 Washington State Department of Ecology

\title{
CORRESPONDENCE DISTRIBUTION COVERSHEET
}

\author{
Muthor \\ Addressee \\ Correspondence No. \\ W. J. Taylor/RL \\ President/FDH \\ Incoming: $9851711 \mathrm{~A}$ \\ DOE-RL: $98-W D D-022$ \\ CC Recd: 02/25/98
}

subject: CONTRACT NUMBER DE-AC06-96RL13200 - DISPOSITION OF COAMENTS FROM THE STATE OF WASHINGTON DEPARTMENT OF ECOLOGY (ECOLOGY) ON THE HANFORD IMMOBILIZED LOW-ACTIVITY WASTE (ILAW) PERFORMANCE ASSESSMENT, DOE $/ R L-97-69$, REV B

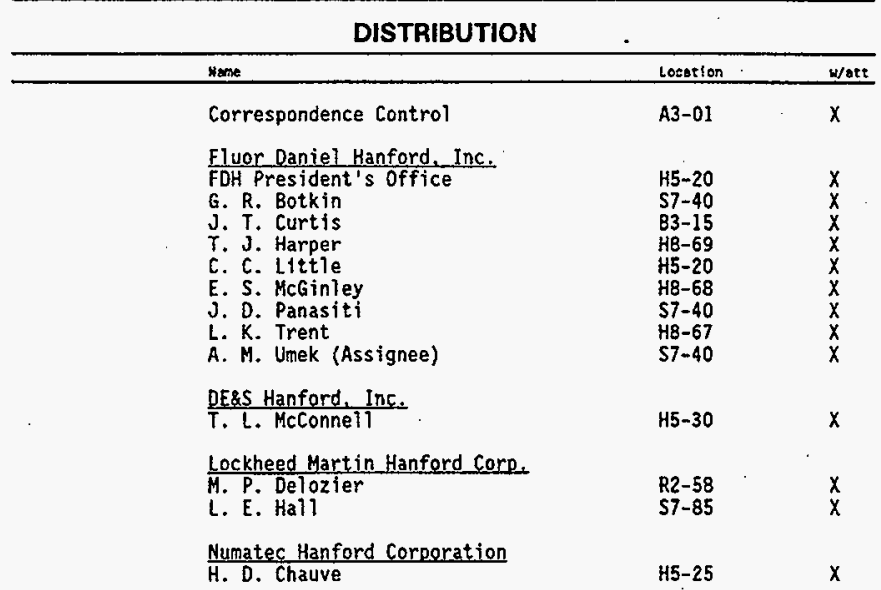

PHMC contespondente control

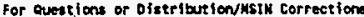

Contuct: Chris Hough a 376-811t or Gleme Lenz $\$ 372-3931$

CC:MAIL ADDRESS: ACORRESPONDENCE CONTROL-PHMC

- 54-6000-117 (9/88) (EF) Wef000 - O! stribution coverehett 
DOE/RL-97-69

Rev. 0

$9851711 \mathrm{~A}$

Department of Energy

CE RECD: 02/25/98

Richland Operations Office

P.O. Box 550

Richland, Washington 99352

\section{FEB 251998}

98-WDD-022

Mr. H. J. Hatch, President

Fluor Daniel Hanford, Inc.

Richland, Washington 99352

Dear Mr. Hatch:

CONTRACT NUMBER DE-AC06-96RI 13200 - DISPOSITION OF COMMENTS FROM THE STATE OF WASHINGTON DEPARTMENT OF ECOLOGY (ECOLOGY) ON THE HANFORD IMMOBILIZED LOW-ACTIVITY WASTE (ILAW) PERFORMANCE ASSESSMENT, DOE/RL-97-69, REV B

References: 1) Letter, A. M. Umek, LMHC, to W. J. Taylor, RL, "CONTRACT NUMBER DE-AC06-96RL13200 - HANFORD IMMOBILIZED LOWACTIVITY TANK WASTE PERFORMANCE ASSESSMENT, DOE/RL-96-69, REV B," FDH-9850347, dated January 20, 1998.

2) Letter, W. J. Taylor, RL, to H. J. Hatch, FDH, "CONTRACT NUMBER DE-AC06-96RL13200 - HANFORD IMMOBILIZED LOW-ACTIVITY WASTE (ILAW) PERFORMANCE ASSESSMENT, DOERI-97-69, REV B," 98-WDD-016, dated February 9, 1998.

3) Letter, S. Dahl, Ecology to C. Banks, RL, "Comments on Hanford Immobilized Low Activity Tank Waste Performance Assessment (DOF/RL-97-69, Rev B) March 1998", dated February 13, 1998.

The subject draft Performance Assessment was transmitted to the U.S. Department of Energy (DOE), Richland Operations Office (RL) for review with the Reference 1 letter, and comments from DOE-RL were returned with the Reference 2 letter within 15 days in accordance with the Fiscal Year 1998 Performance Agreernent TWR6.1.1. Subsequently, comments on the draft performance assessment were provided by Ecology with the enclosed Reference 3 letter three days ater the designated review period. These were passed on to Fred Mann of Fluor Daniel Northwest Services for a preliminary evaluation.

It was DOE's intention to request that the comments from Ecology be dispositioned if there were no significant impact on the scheduled completion of the Performance Assessment. However, it is our understanding that the comments have been dispositioned already in the course of their evaluation. DOE-RL appreciates the expeditious and efficient handling of this matter. In order to respond to Ecology, DOE would aiso appreciate receiving a copy of the completed Review Comment Record forms when available. 


\section{DOE/RL-97-69}

Rev. 0

Mr. H. J. Hatch

$-2-$

98-WDD-022

If any direction is provided by a Contracting Officer's Representative (COR) which your company believes exceeds the COR's authority, you are to immediately notify the Contracting Officer and request clarification prior to complying with the direction.

If you have any questions, please contact P. E. LaMont, of my staff on 376-6117.

Sincerely,

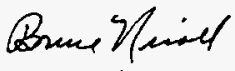

WDD:PEL

William J. Taylor, Director

Enclosure

Waste Disposal Division

cc w/encl:

A. J. Umek, FDH

T. B. Veneziano, FDH

F. M. Mann, FDNW

R. J. Murkowski, LMHC 
DOE/RL-97-69

Rev. 0

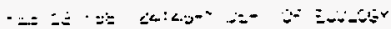

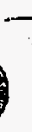

STATE OF WASHAN

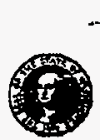

DEPARTMENT OF ...........

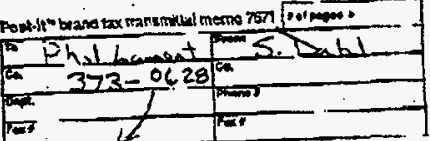

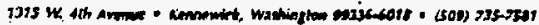

Fobruary 13,1998

Mr. Clarenoo Barks

U.S. Department of Energy

P.O. BOX S50. MSN; $A 0-21$

Richland W 195352

Dear Mr. Banks;

Re: Comments on Ilanford loumolsilized Low Activity I2nk Wasu Performance Assescmout (DUERL-97-69, Rev B) Mandi 1998

The Washington State Lepertineat of Ecoingy (F.culugy), has completed the rewlow of the

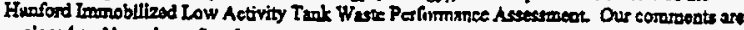
enclosed and have bees faxad to your

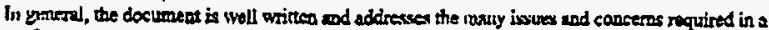

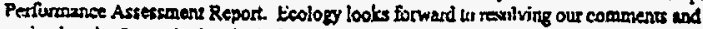
teviewing the furture drafts of this doenencat.

If you have any questions or concerts. pleose contact Bot Julien at (509) 736-5702.
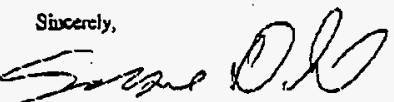

Stranne Drhl, TWRS Project Manager

Nuclear Waste Prugram

SD:ch

Einclosure

cc: Administrive Reund (TWRS) 


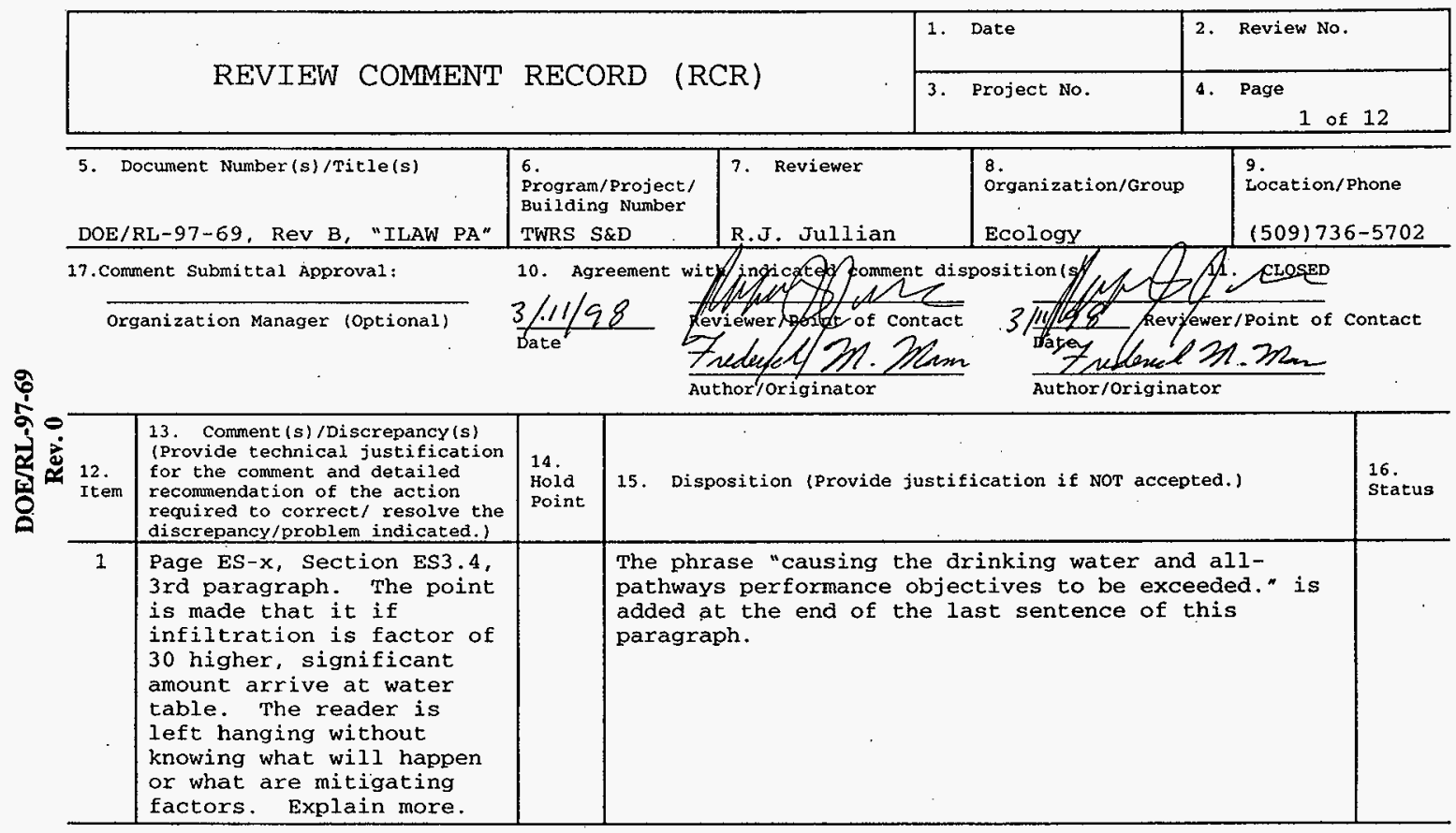




\begin{tabular}{|l|l|l|l|}
\hline \multirow{2}{*}{ REVIEW COMMENT RECORD (RCR) } & $\begin{array}{l}\text { 1. Date } \\
\text { 2. Review No. }\end{array}$ & \\
\cline { 3 - 4 } & 3. & project No. & 4. Page 2 of 12 \\
\hline
\end{tabular}

\begin{tabular}{|c|c|c|c|c|c|}
\hline - & $\begin{array}{l}12 . \\
\text { Item }\end{array}$ & $\begin{array}{l}\text { 13. Comnent (s) / Discrepancy (s) } \\
\text { (Provide technical justification } \\
\text { for the comment and detailed } \\
\text { recommendation of the action } \\
\text { required to correct/ resolve the } \\
\text { discrepancy/problem indicated.) }\end{array}$ & $\begin{array}{l}14 \text {. } \\
\text { Hold } \\
\text { Point }\end{array}$ & 15. Disposition (Provide justification if NOT accepted.) & $\begin{array}{l}16 . \\
\text { Status }\end{array}$ \\
\hline 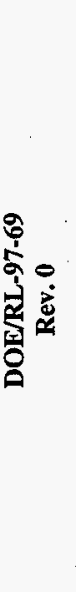 & 2 & $\begin{array}{l}\text { Page ES-xiii, Section } \\
\text { ES4.1, 3rd and 4th } \\
\text { paragraphs. A discussion } \\
\text { on concentration limits } \\
\text { due to contract and } \\
\text { stacking height for class } \\
\text { C and by radionuclide is } \\
\text { presented. The reader is } \\
\text { confused as to what, } \\
\text { when, and the } \\
\text { relationships. Need more } \\
\text { information to clarify } \\
\text { what is being said. }\end{array}$ & & 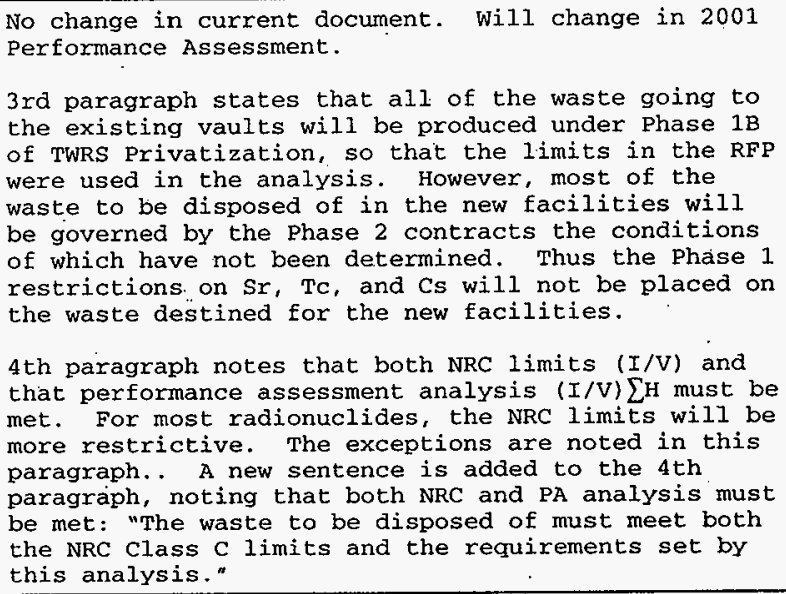 & \\
\hline & 3 & $\begin{array}{l}\text { Page } 1-3 \text {, Section } 1.2, \\
3 \text { rd paragraph. } 200,000 \mathrm{~m}^{3} \\
\text { conversion in Executive } \\
\text { Summary is } 7 \times 10^{6} \mathrm{ft}^{3} . \\
\text { Make them equal. }\end{array}$ & & $\begin{array}{l}\text { Actual conversion is } 7.06 \times 10^{6} \text {. Therefore the page } \\
1-3 \text { conversion is changed to } 7,000,000 \mathrm{ft}^{3} \text {. }\end{array}$ & \\
\hline
\end{tabular}




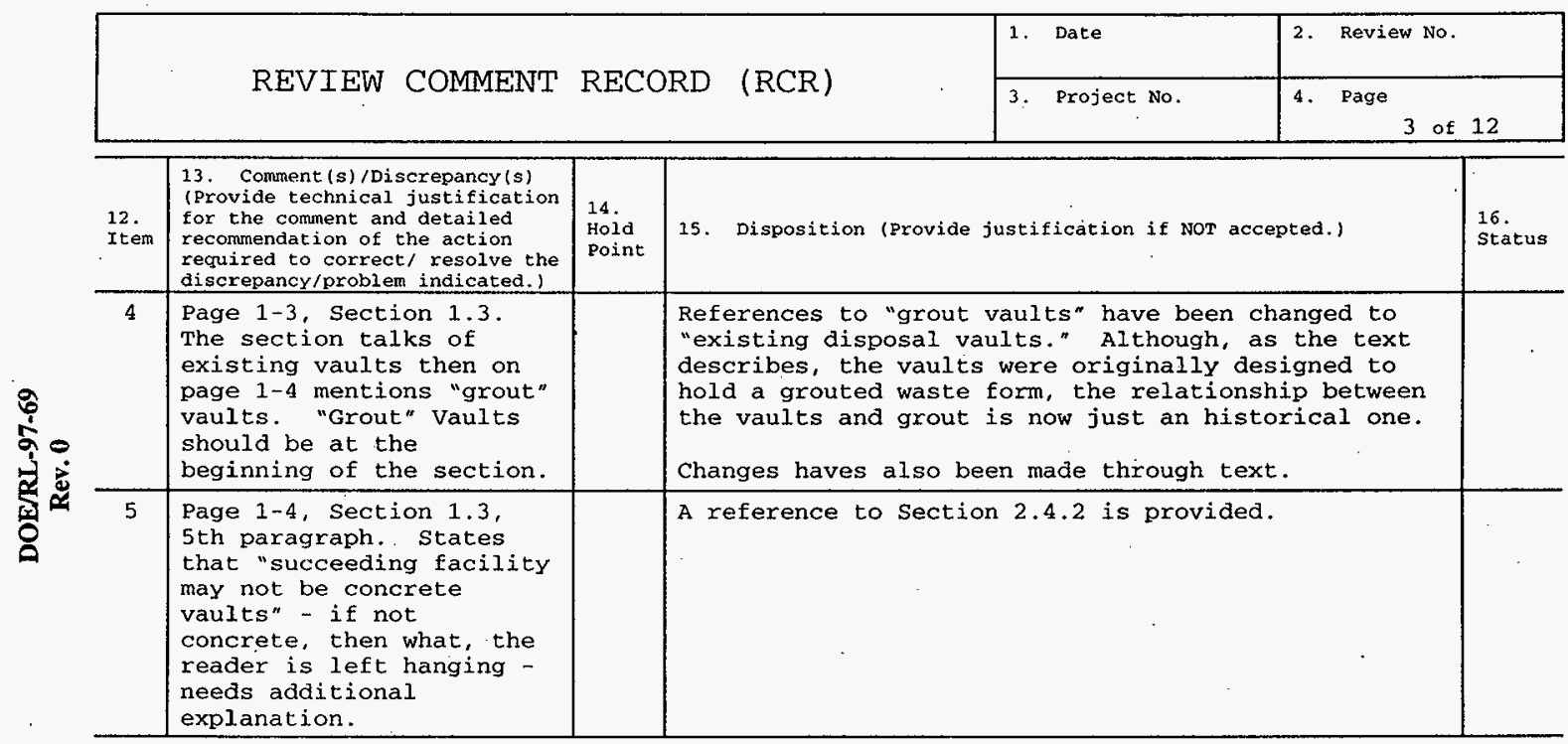




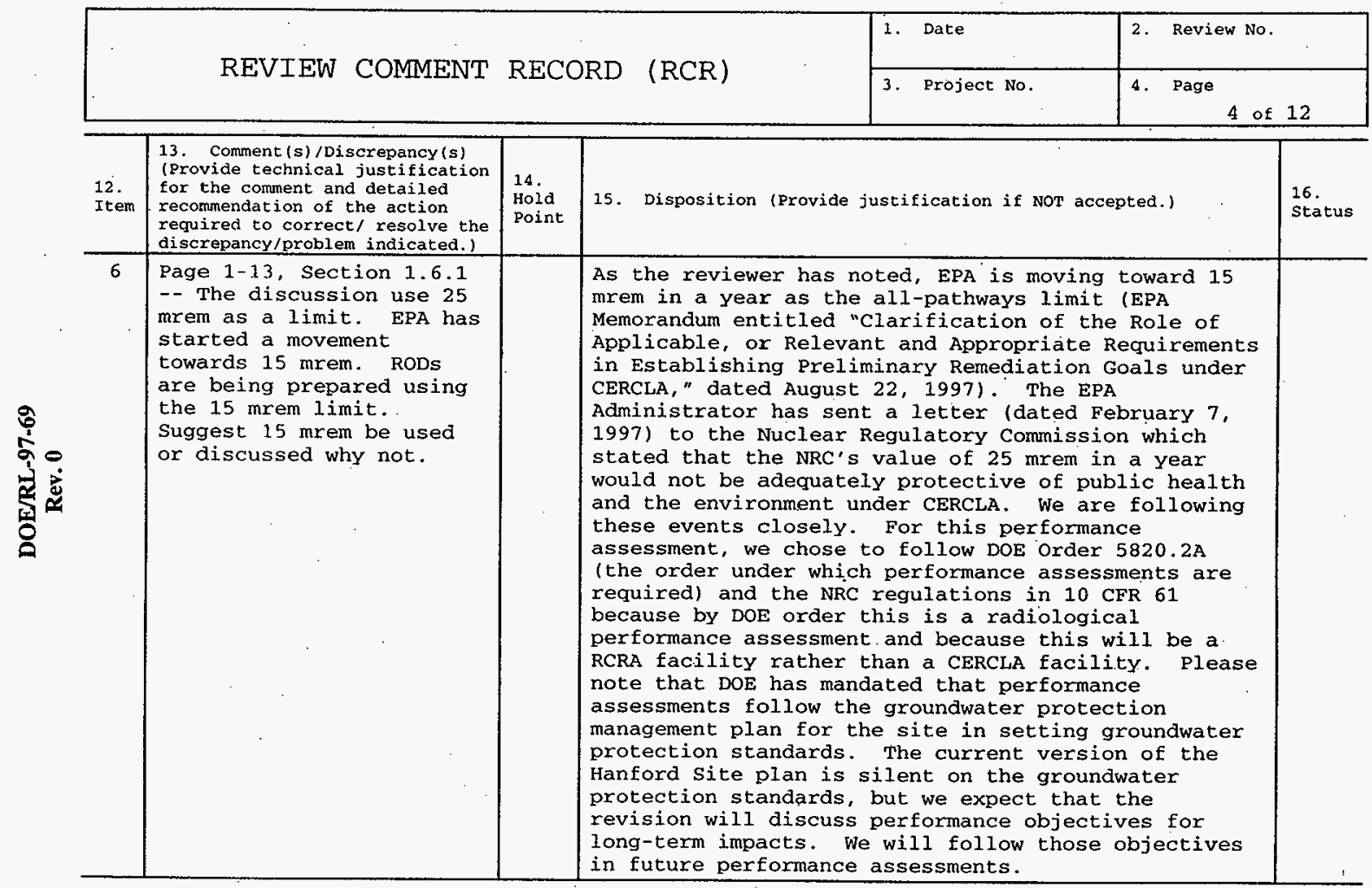




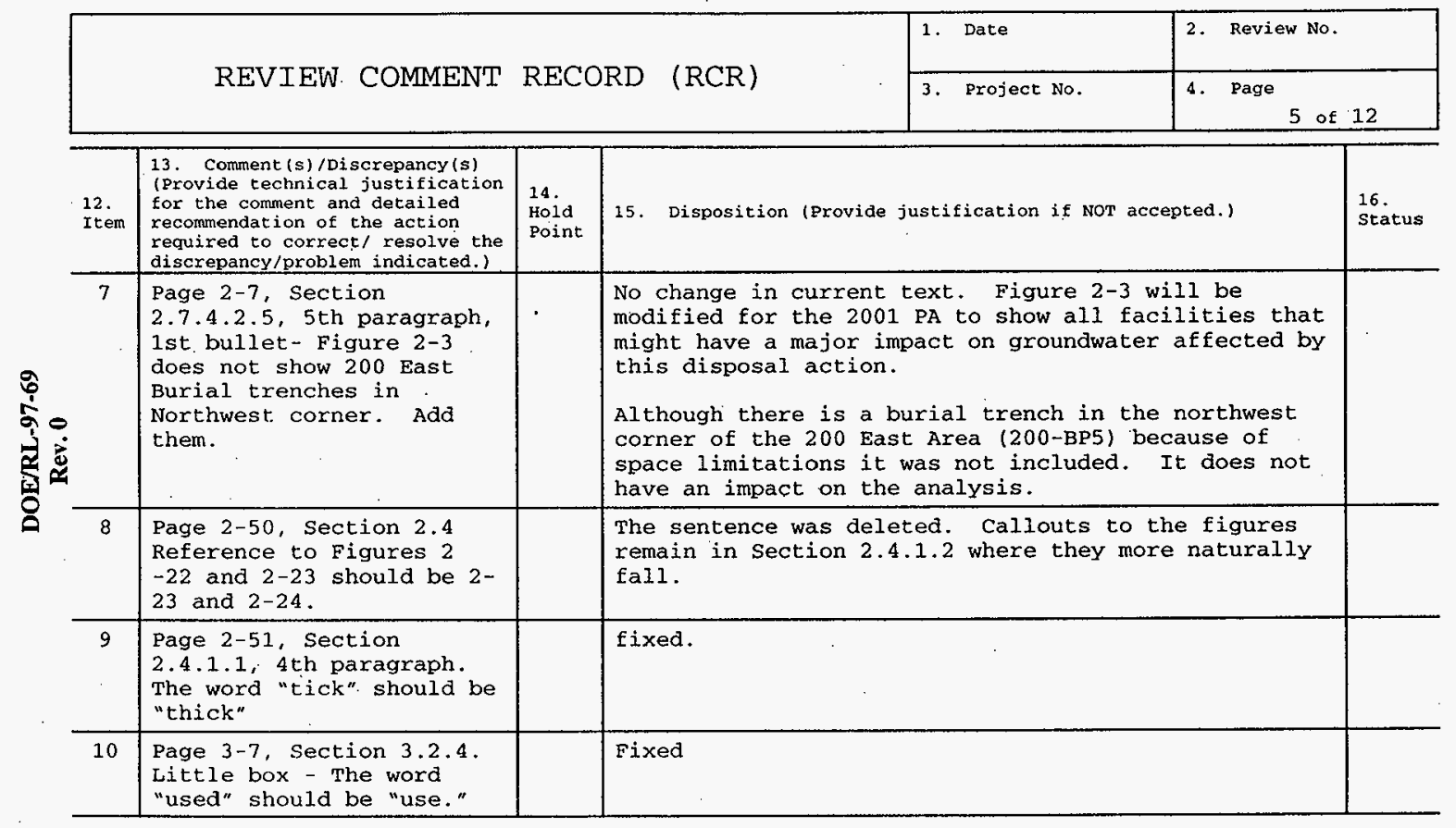




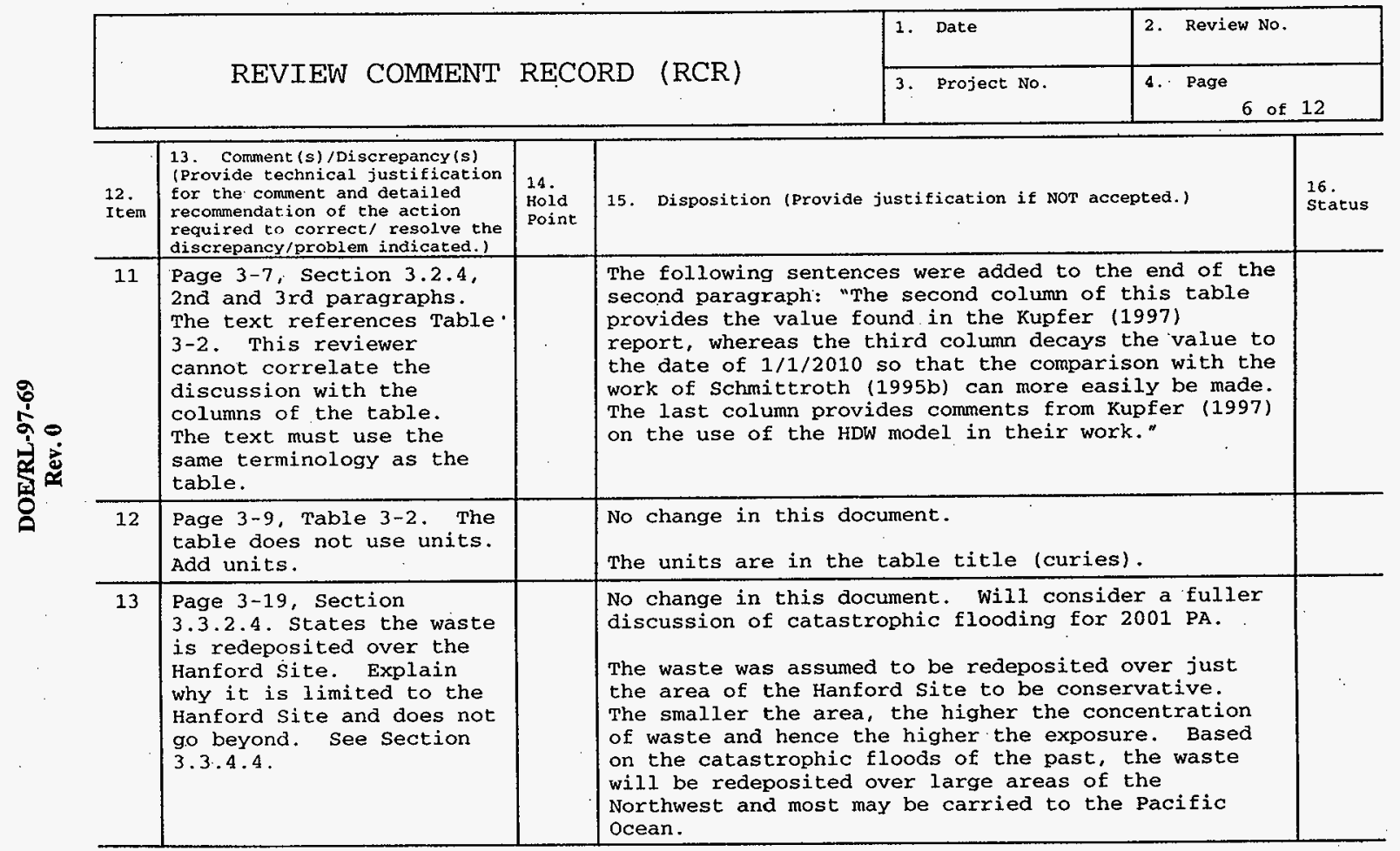




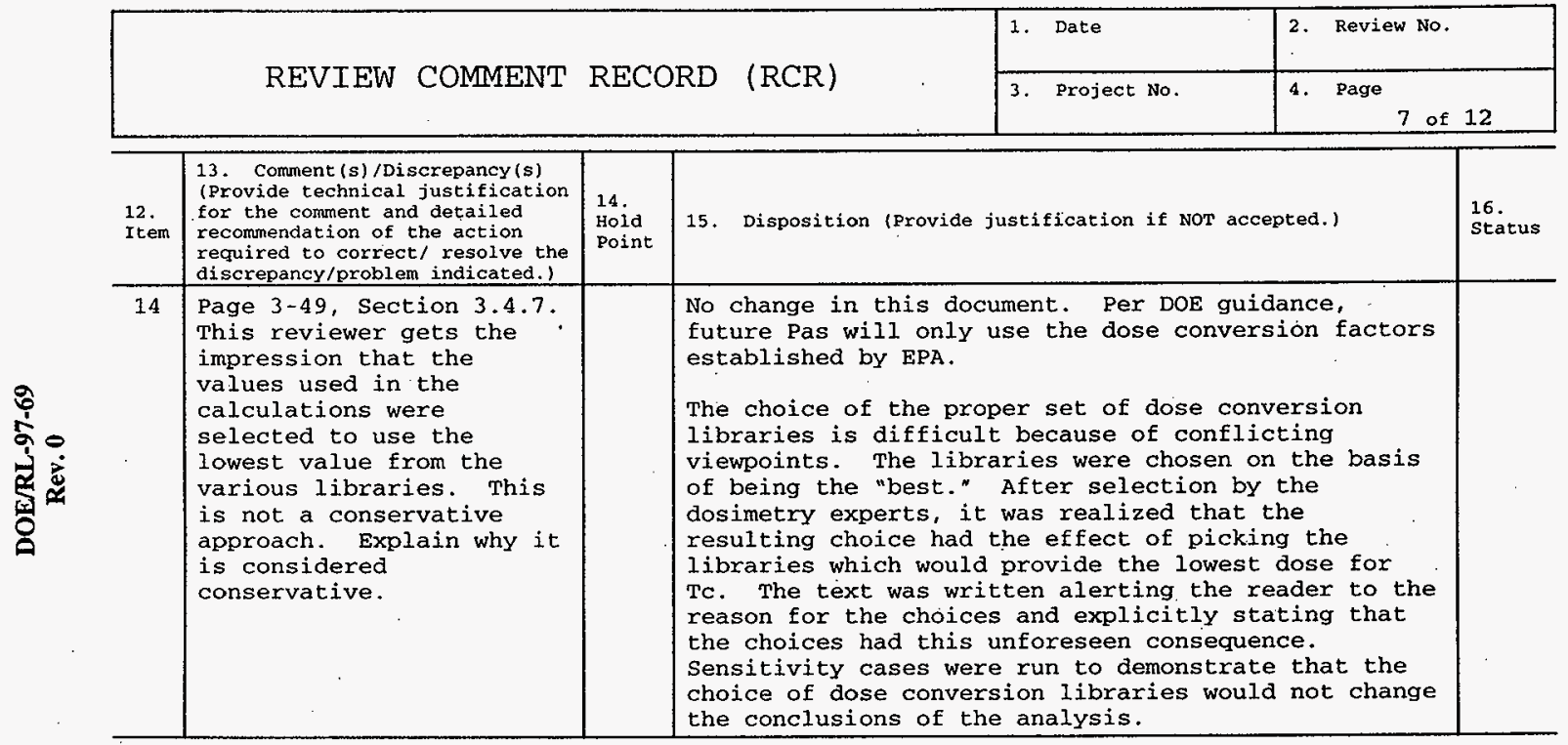




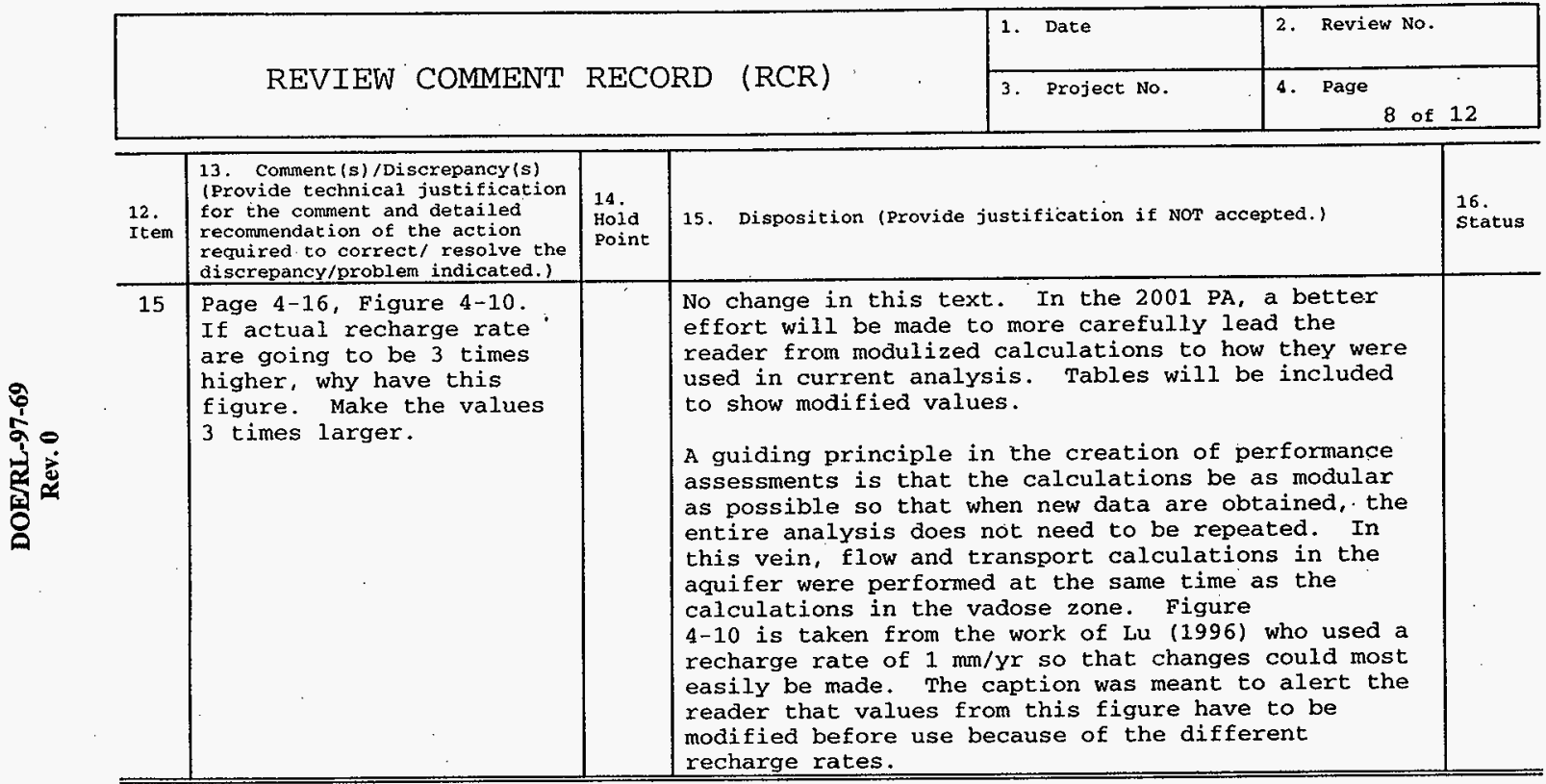




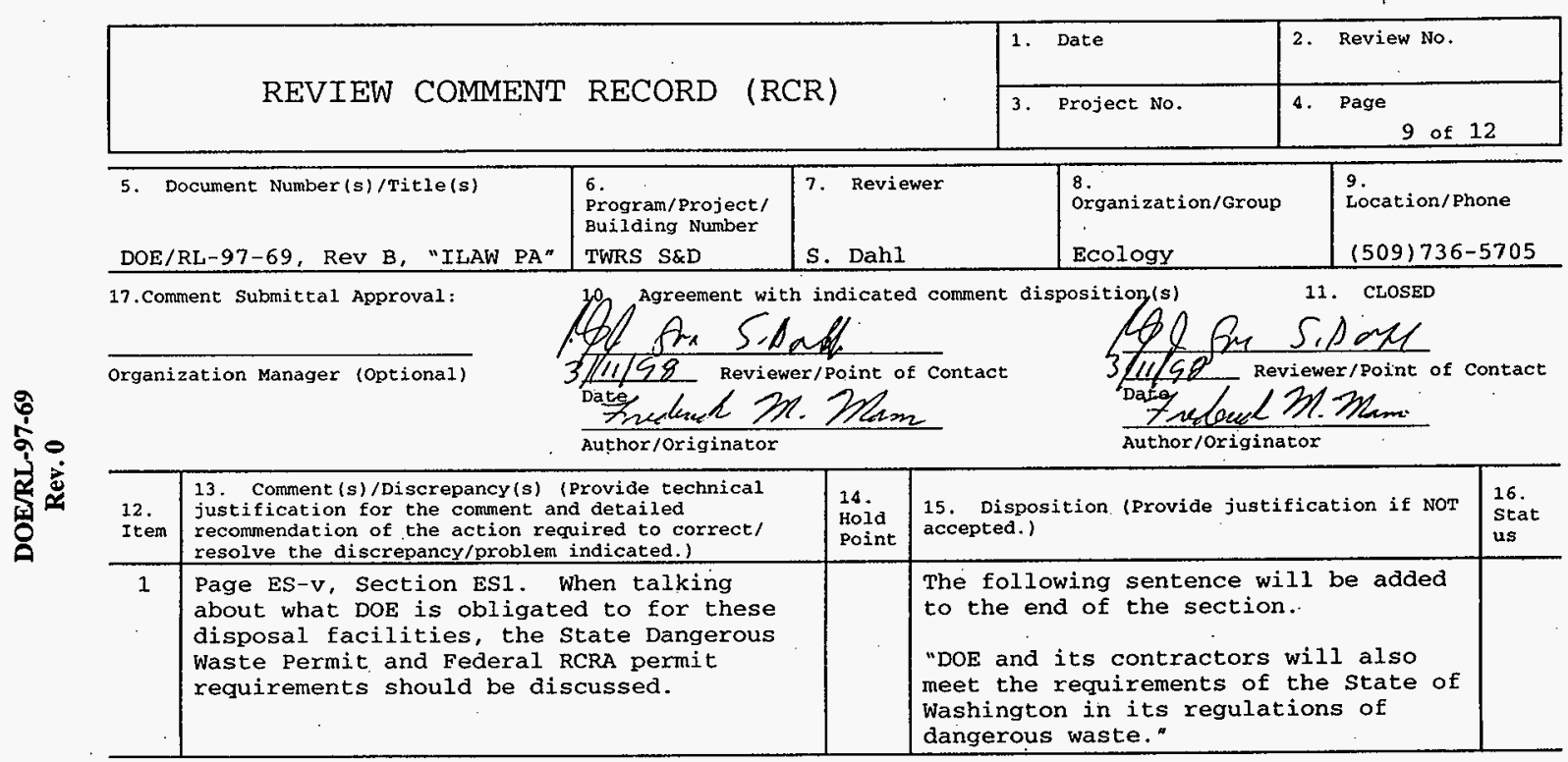




\begin{tabular}{|l|l|l|l|l|}
\hline \multirow{2}{*}{ REVIEW COMMENT RECORD (RCR) } & $\begin{array}{c}\text { 1. Date } \\
\vdots\end{array}$ & Review No. \\
\cline { 3 - 5 } & 3. Project No. & $4 . \quad$ Page \\
\end{tabular}

\begin{tabular}{|c|c|c|c|c|}
\hline $\begin{array}{l}12 . \\
\text { Item }\end{array}$ & $\begin{array}{l}\text { 13. Comment (s)./Discrepancy (s) (Provide technical } \\
\text { justification for the comment and detailed } \\
\text { recommendation of the action required to correct/ } \\
\text { resolve the discrepancy/problem indicated.) }\end{array}$ & $\begin{array}{l}14 . \\
\text { Hold } \\
\text { Point }\end{array}$ & $\begin{array}{l}\text { 15. Disposition (Provide justification if NOT } \\
\text { accepted.) }\end{array}$ & $\begin{array}{l}16 . \\
\text { stat } \\
\text { us }\end{array}$ \\
\hline 2 & $\begin{array}{l}\text { Page ES-vi, Section ES2. Please discuss } \\
\text { Dangerous Waste/RCRA design parameters in } \\
\text { executive summary and appropriate sections } \\
\text { in the report. }\end{array}$ & & $\begin{array}{l}\text { No change to Executive Summary. } \\
\text { However, on page } 2-59 \text { mention and } \\
\text { reference the dangerous waste } \\
\text { regulations of the State of } \\
\text { Washington (WAC } 173-303 \text { ). } \\
\text { The performance assessment is a } \\
\text { document required by the Department } \\
\text { of Energy in its granting of a } \\
\text { Disposal Authorization statement. } \\
\text { The performance assessment is to be a } \\
\text { study of the impacts from the } \\
\text { disposal of radioactive materials. } \\
\text { The more extensive discussion of } \\
\text { Dangerous waste/RCRA design } \\
\text { parameters will be done through the } \\
\text { on-going permitting activities with } \\
\text { the State of washington. }\end{array}$ & \\
\hline
\end{tabular}




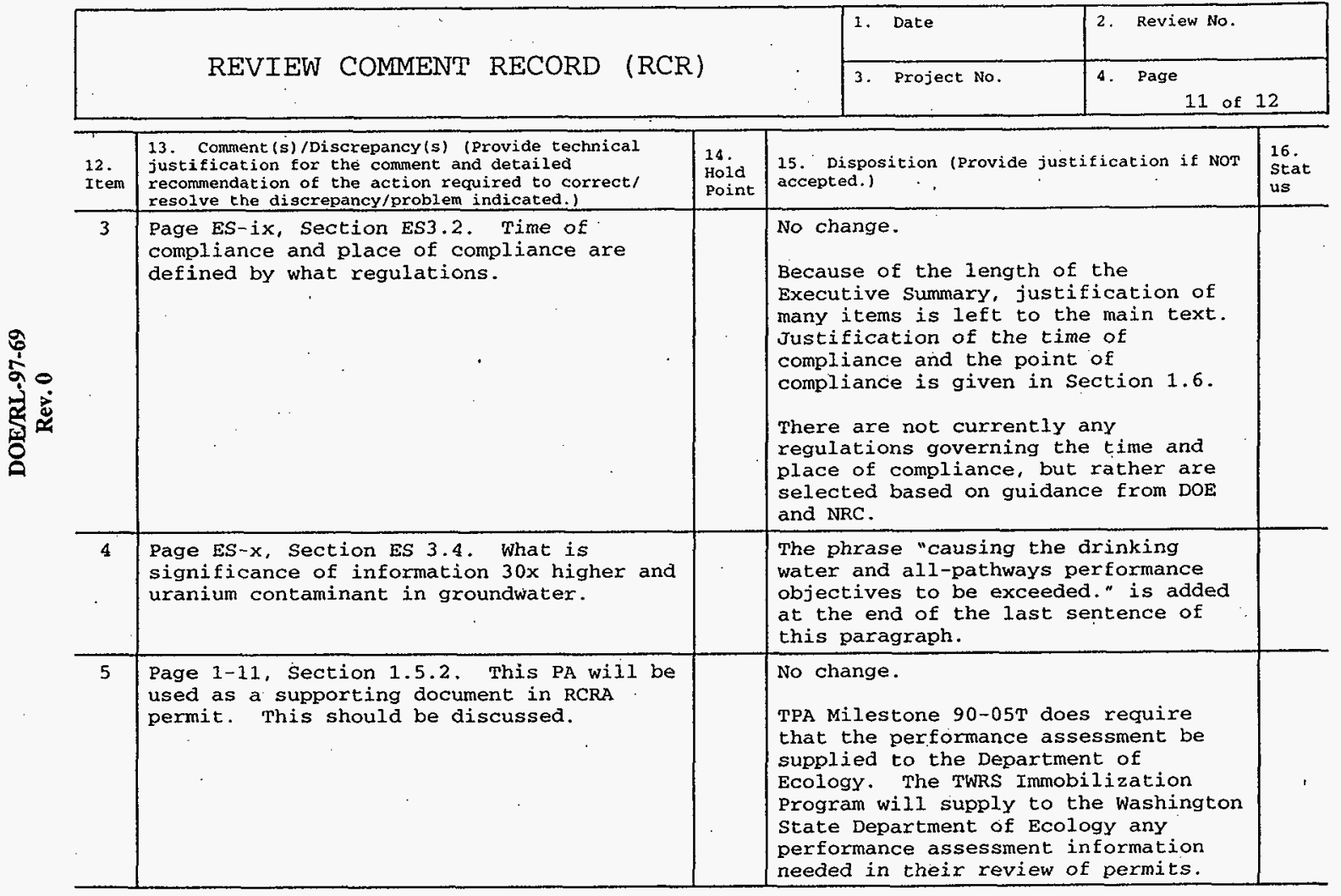

A-6400-090.1 (03/92) WEF011 


\begin{tabular}{|c|c|c|c|c|c|}
\hline \multirow{2}{*}{\multicolumn{3}{|c|}{ REVIEW COMMENT RECORD (RCR) }} & \multicolumn{3}{|c|}{ 2. Review No. } \\
\hline & & & \multicolumn{2}{|c|}{ 3. Project No. } & 4. Page \\
\hline $\begin{array}{l}12 . \\
\text { Ittem }\end{array}$ & $\begin{array}{l}\text { 13. Comment (s)/Discrepancy (s) (Provide technical } \\
\text { justification for the comment and detailed } \\
\text { recomendation of the action required to correct/ } \\
\text { resolve the discrepancy/problem indicated.) }\end{array}$ & $\begin{array}{l}14 . \\
\text { Hold } \\
\text { Point }\end{array}$ & \multicolumn{2}{|c|}{$\begin{array}{l}\text { 15. Disposition (Provide justification if NOT } \\
\text { accepted.) }\end{array}$} & $\begin{array}{l}16 . \\
\text { Stat } \\
\text { us }\end{array}$ \\
\hline 6 & $\begin{array}{l}\text { Page } 1-13 \text {, section } 1.6 .1 \text {. How were } \\
\text { stakeholders involved and what was the } \\
\text { result of compiling their values. }\end{array}$ & & \multicolumn{2}{|c|}{$\begin{array}{l}\text { Section } 1.6 .4 \text { discusses stakeholder } \\
\text { involvement. Each bullet in section } \\
1.6 .1 \text { refers, to one of the remaining } \\
\text { subsections under section } 1.6 \text {. The } \\
\text { section numbers were added to aid the } \\
\text { reader. }\end{array}$} & \\
\hline 7 & $\begin{array}{l}\text { Page 1-14. It is not clear to me how } \\
\text { performance objectives were developed and } \\
\text { how they are at least as conservative as } \\
\text { state, federal, and DoE regulations. }\end{array}$ & & \multicolumn{2}{|c|}{$\begin{array}{l}\text { No change in current text. A section } \\
\text { comparing various regulations will be } \\
\text { added for the } 2001, \text { PA. } \\
\text { Table } 1-3 \text { is in the summary part of } \\
\text { the section on performance } \\
\text { objectives. The justification of the } \\
\text { performance objectives are given in } \\
\text { the following subsections. The } \\
\text { intent of providing the. "main driver" } \\
\text { is to alert those readers int only } \\
\text { use the summary sections what are the } \\
\text { main regulations that drive the } \\
\text { particular choice. }\end{array}$} & \\
\hline 8 & $\begin{array}{l}\text { Page } 1-16 \text {. What is citation for } 25 \text { mrem. } \\
\text { Who says this is the right number. Please } \\
\text { justify. }\end{array}$ & & \multicolumn{2}{|c|}{$\begin{array}{l}\text { References to DOE Order } 5820.2 \mathrm{~A} \text { and } \\
\text { NRC regulation } 10 \text { CFR } 61 \text { will added. }\end{array}$} & \\
\hline
\end{tabular}


DOE-RL-97-69

Rev. 0

APPENDIX G

\begin{abstract}
A Strategy to Conduct an Analysis of the Long-Term Performance of Low-Activity Waste Glass in a Shallow Subsurface Disposal System at Hanford
\end{abstract}
B. P. McGrail
W. L. Ebert ${ }^{(2)}$
D. H. Bacon
D. M. Strachan ${ }^{(2)}$

December 1997 
DOE/RL-97-69

Rev. 0

G-2 
DOE/RL-97-69, Rev. 0

Based on PNNL Report (PNNL-11834) To Be Published

\section{A Strategy to Conduct an Analysis of the Long-Term Performance of Low-Activity Waste Glass in a Shallow Subsurface Disposal System at Hanford}
B. P. McGrail
W. L. Ebert ${ }^{(a)}$
D. H. Bacon
D. M. Strachan ${ }^{(a)}$

February 1998

Prepared for

the U.S. Department of Energy

under Contract DE-AC06-76RLO 1830

Pacific Northwest National Laboratory

Richland, Washington 99352

(a) Argonne National Laboratory, Argonne, II 60439 


\section{DOE/RL-97-69, Rev. 0 \\ Based on PNNL Report (PNNL-11834) To Be Published}

\section{DISCLAIMER}

This report was prepared as an account of work sponsored by an agency of the United States Government. Neither the United States Government nor any agency thereof, nor Battelle Memorial Institute, nor any of their employees, makes any warranty, expressed or implied, or assumes any legal liability or responsibility for the accuracy, completeness, or usefulness of any information, apparatus, product, or process disclosed, or represents that its use would not infringe privately owned rights. Reference herein to any specific commercial product, process, or service by trade name, trademark, manufacturer, or otherwise does not necessarily constitute or imply its endorsement, recommendation, or favoring by the United States Government or any agency thereof, or Battelle Memorial Institute. The views and opinions of authors expressed herein do not necessarily state or reflect those of the United States Government or any agency thereof.

\section{PACIFIC NORTHWEST NATIONAL LABORATORY operated by BATTELLE MEMORIAL INSTITUTE for the UNITED STATES DEPARTMENT OF ENERGY under Contract DE-AC06-76RLO 1830}

Printed in the United States of America

Avallable to DOE and DOE contractors from the Office of Scientific and Technical Information, P.O. Box 62, Oak Ridge, TN 37831; prices available from (615) $576-8401$.

Available to the public from the National Technical Information Service, U.S. Department of Commerce, 5285 Port Royal Rd., Springfield, VA 22161 


\section{DOE/RL-97-69, Rev, 0 \\ Based on PNNL Report (PNNL-11834) To Be Published}

\section{SUMMARY}

Privatized services are being procured to vitrify low-activity tank wastes for eventual disposal in a shallow subsurface facility at the Hanford Site. Over 500,000 metric tons of low-activity waste glass will be generated, which is among the largest volumes of waste within the U.S. Department of Energy (DOE) complex and is one of the largest inventories of long-lived radionuclides planned for disposal in a low-level waste facility. Before immobilized waste can be disposed of, DOE must approve a "performance assessment," which is a document that describes the impacts of the disposal facility on public health and environmental resources. Because the release rate of radionuclides from the glass waste form is a key factor determining these impacts, a sound scientific basis for determining their long-term release rates must be developed if this disposal action is to be accepted by regulatory agencies, stakeholders, and the public. In part, the scientific basis is determined from a sound testing strategy.

The foundation of the proposed testing strategy is a well accepted mechanistic model that is being used to calculate the glass corrosion behavior over the geologic time scales required for performance assessment. This model requires that six parameters be determined, and the testing program is defined by an appropriate set of laboratory experiments to determine these parameters, and is combined with a set of field experiments to validate the model as a whole.

Three general classes of laboratory tests are proposed in this strategy: 1) characterization, 2) accelerated, and 3) service condition. Characterization tests isolate and provide specific information about processes or parameters in theoretical models. Accelerated tests investigate corrosion behavior that will be important over the regulated service life of a disposal system within a laboratory time frame of a few years or less. Service condition tests verify that the techniques used in accelerated tests do not change the alteration mechanisms. The recommended characterization tests are single-pass flow-through tests using a batch reactor design. Accelerated and service conditions tests include product consistency and pressurized unsaturated flow (PUF) tests. Nonradioactive glasses will be used for the majority of the laboratory testing $(\sim 80 \%)$, with the remainder performed with glasses containing a selected set of key radionuclides.

Additionally, a series of PUF experiments with a natural analog of basaltic glass is recommended to confirm that the alteration products observed under accelerated conditions in the PUF tests are similar to those found associated with the natural analog. This will provide additional confidence in using the PUF test results to infer long-term corrosion behavior. 


\section{Based on PNNL Report (PNNL-11834) To Be Published}

Field tests are proposed as a unique way to validate the glass corrosion and contaminant transport models being used in the performance assessment. To better control the test conditions, the field tests are to be performed in lysimeters (corrugated steel containers buried flush with the ground surface). Lysimeters provide a way to combine a glass, Hanford soil, and perhaps other engineered materials in a well-controlled test, but on a scale that is not practicable in the laboratory. The recommended field tests include some experiments where a steady flow rate of water is artificially applied. These tests use a glass designed to have a high corrosion rate so that it is easier to monitor contaminant release and transport. Existing lysimeters at the Hanford Site can be used for these experiments or new lysimeters that have been equipped with the latest in monitoring equipment and located near the proposed disposal site. 


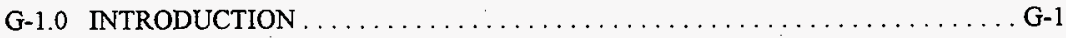

G-2.0 DISPOSAL SYSTEM DESCRIPTION $\ldots \ldots \ldots \ldots \ldots \ldots \ldots \ldots \ldots \ldots$ G-3

G-2.1 WATER INFILTRATION $\ldots \ldots \ldots \ldots \ldots \ldots \ldots \ldots \ldots \ldots \ldots \ldots \ldots$, G-3

G-2.2 FACILITY DESCRIPTION $\ldots \ldots \ldots \ldots \ldots \ldots \ldots \ldots \ldots \ldots \ldots \ldots \ldots \ldots$

G-3.0 MODELING APPROACH $\ldots \ldots \ldots \ldots \ldots \ldots \ldots \ldots \ldots \ldots \ldots \ldots \ldots$ G-6

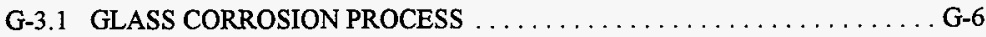

G-3.1.1 Importance of Secondary Phases $\ldots \ldots \ldots \ldots \ldots \ldots \ldots \ldots \ldots \ldots \ldots$

G-3.1.2 Effect of Ion Exchange $\ldots \ldots \ldots \ldots \ldots \ldots \ldots \ldots \ldots \ldots \ldots$ G-7

G-3.2 GLASS CORROSION MODEL $\ldots \ldots \ldots \ldots \ldots \ldots \ldots \ldots \ldots \ldots \ldots \ldots \ldots$

G-3.2.1 Rate Law for Hydrolysis and Dissolution $\ldots \ldots \ldots \ldots \ldots \ldots$ G-8

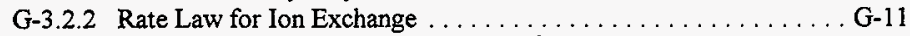

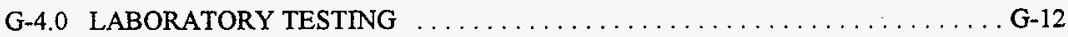

G-4.I SINGLE-PASS FLOW-THROUGH TEST $\ldots \ldots \ldots \ldots \ldots \ldots \ldots \ldots$ G-13

G-4.1.1 Well-mixed Batch Reactor $\ldots \ldots \ldots \ldots \ldots \ldots \ldots \ldots \ldots \ldots \ldots \ldots \ldots$

G-4.1.2 Packed Bed Reactor . . . . . . . . . . . . . . . . . . . G-13

G-4.1.3 Fluidized Bed Reactor . . . . . . . . . . . . . . . .

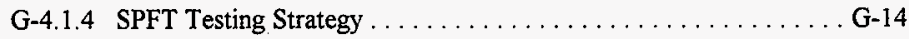

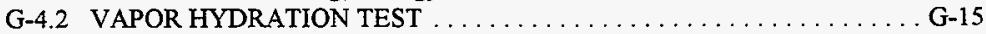

G-4.3 PRODUCT CONSISTENCY TEST $\ldots \ldots \ldots \ldots \ldots \ldots \ldots \ldots \ldots \ldots \ldots \ldots$

G-4.4 PRESSURIZED UNSATURATED FLOW TEST $\ldots \ldots \ldots \ldots \ldots \ldots \ldots$ G- 18

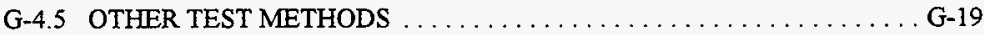

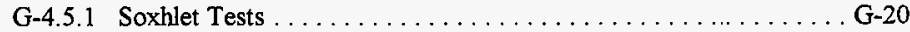

G-4.5.2 MCC-1 Test ......................... G-20

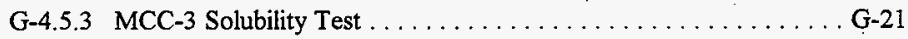

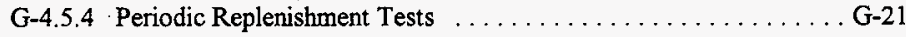

G-4.5.5 Unsaturated or "Drip" Test $\ldots \ldots \ldots \ldots \ldots \ldots \ldots \ldots \ldots, \mathrm{G}-22$

G-4.5.6 Accelerated Dissolution Test . . . . . . . . . . . . . . G-22

G-4.6 REQUIRED TESTS WITH RADIOACTIVE GLASSES $\ldots \ldots \ldots \ldots \ldots$ G-23

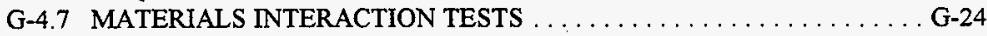

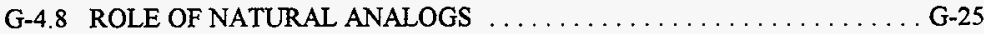

G-4.9 LABORATORY. TESTING STRATEGY SUMMARY ........... G-26

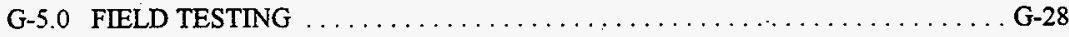

G-6.0 MODELING THE DISPOSAL SYSTEM $\ldots \ldots \ldots \ldots \ldots \ldots \ldots \ldots \ldots$ G-30

G-6.1 SUBPROCESS MODEL DEVELOPMENT $\ldots \ldots \ldots \ldots \ldots \ldots \ldots$ G-31

G-6.1.1 Adaptive Reaction Network ................. G-31

G-6.1.2 Composition-Dependent Hydraulic Property Model . . . . . . . . G-31

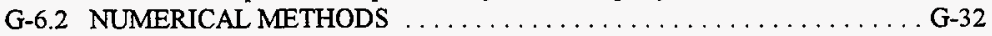

G-6.3 DISPOSAL SYSTEM SIMULATIONS FOR THE PERFORMANCE

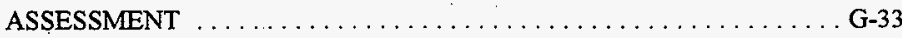




\section{FIGURES}

G-2.1. Schematic of ILAW Disposal System. . . . . . . . . . . . . . . . . . G-4

G-3.1. "Top-Down" Strategy for LAW Glass Testing G-7

G-3.2. Release of Na in Excess of that Released by Matrix Dissolution in Static Tests with LD6-5412, a Reference LAW Glass ...

G-4.1. Schematic of Batch Flow-Through Reactor.

G-4.2. Normalized Si Release Rate as a Function of $\mathrm{pH}$ and Temperature for LD6-5412 Glass. G-14

G-4.3. Schematic of VHT .

\section{TABLE}




\section{DOE/RL-97-69, Rev. 0 \\ Based on PNNL Report (PNNL-11834) To Be Published \\ GLOSSARY}

$\begin{array}{ll}\text { ADT } & \text { accelerated dissolution test } \\ \text { ALT } & \text { accelerated leach test } \\ \text { ANL } & \text { Argonne National Laboratory } \\ \text { AREST-CT } & \text { Analyzer of RadionuclidE Source Term with Chemical Transport } \\ \text { ASTM } & \text { American Society for Testing and Materials } \\ \text { CPU } & \text { central processing unit } \\ \text { DLT } & \text { dynamic leach test } \\ \text { DOE } & \text { U.S. Department of Energy } \\ \text { EMSP } & \text { Environmental Management Science Program } \\ \text { GFLOPS } & \text { giga floating point operations per second } \\ \text { HLW } & \text { high-level waste } \\ \text { ILAW } & \text { immobilized low-activity waste } \\ \text { ISO } & \text { International Standards Organization } \\ \text { LAW } & \text { low-activity waste } \\ \text { MIIT } & \text { Materials Interface Interaction Test } \\ \text { PCT } & \text { product consistency test } \\ \text { PNNL } & \text { Pacific Northwest National Laboratory } \\ \text { PUF } & \text { pressurized unsaturated flow } \\ \text { RH } & \text { relative humidity } \\ \text { SPFT } & \text { single-pass flow-through test } \\ \text { STOMP } & \text { a nonisothermal, multiphase flow simulator } \\ \text { STORM } & \text { Subsurface Transport Over Reactive Multiphases } \\ \text { S/V } & \text { surface area-to-soiution volume ratio } \\ \text { VHT } & \text { vapor hydration test } \\ \text { WIPP } & \text { Waste Isolation Pilot Plant }\end{array}$




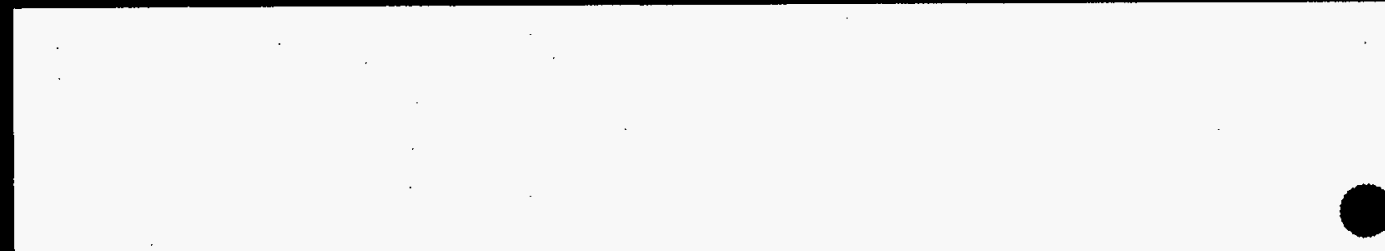

•

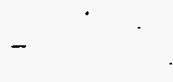




\section{DOE/RL-97-69, Rev, 0 \\ Based on PNNL Report (PNNL-11834) To Be Published}

\section{G-1.0 INTRODUCTION}

The Hanford Site in southeastern Washington State has been used extensively to produce nuclear materials for the U.S. strategic defense arsenal by the U.S. Department of Energy (DOE) and its predecessors, the U.S. Atomic Energy Commission and the U.S. Energy Research and Development Administration. A large inventory of radioactive and mixed waste has accumulated in 177 buried single- and double-shell tanks. The DOE is proceeding with plans to permanently dispose of this waste (Ecology 1996; 62 FR 8693). Liquid waste recovered from the tanks will be pretreated to separate the low-activity fraction from the high-level and transuranic wastes. The small volume of high-level immobilized waste and the much larger volume of low-activity waste (LAW) will be disposed of in different locations. The high-level waste (HLW) will be stored on the Hanford Site until sent to a federal geologic repository. The immobilized low-activity waste (IIAW) will be placed in a near-surface disposal system on the Hanford Site.

Privatized services are being procured ${ }^{2}$ for treating and immobilizing the tank waste. The leading processing option for waste immobilization is vitrification. Vitrifying the LAW is expected to generate over 500,000 metric tons or $200,000 \mathrm{~m}^{3}\left(6,000,000 \mathrm{ft}^{3}\right)$ of LAW glass that will be disposed of under this plan. This is among the largest volumes of waste within the DOE complex and is one of the largest inventories of long-lived radionuclides planned for disposal in a low-level waste facility.

Before the immobilized waste can be disposed of, DOE must approve a "performance assessment," which is a document that describes the long-term impacts of the disposal facility on public health and environmental resources. Results from an interim performance assessment have recently been published (Mann et al. 1997). A major conclusion from this study is that the release rate of radionuclides from the glass waste form by reaction with water is one of the key parameters that determines the impacts of the disposal action and is the most uncertain. Consequently, a sound scientific basis for determining the long-term release rates of radionuclides from these glasses must be developed if this disposal action is to be accepted by regulatory agencies, stakeholders, Native Americans, and the public.

A general approach for the evaluation of materials behavior in a disposal site has been developed that outlines logical steps to validate and confirm the corrosion behavior of materials whose life expectancies must greatly exceed the length of time over which experimental data can be obtained (ASTM 1991). These steps include determining the likely range of environmental factors in the disposal system, identifying and characterizing materials that are likely to be present in the disposal system, performing tests under site-relevant conditions to determine important alteration processes for those materials, developing models for key alteration processes, and performing tests that accelerate those processes. The ASTM protocol also recommends tests to confirm the corrosion model and to utilize information provided by analog materials or systems. Many steps in this approach relevant to waste glass behavior in general have been completed in studies conducted for deep geologic disposal systems and can be directly applied to the Hanford

${ }^{2}$ Request for Proposals (RFP) No. DE-RP06-96RL-3308. Letter from J.D. Wagoner to Prospective Offerors, Department of Energy, Richland, Washington, February 20, 1996. 
DOE/RL-97-69, Rev, 0

\section{Based on PNNL Report (PNNL-11834) To Be Published}

system. For example, the processes that control glass corrosion are well understood, and rate expressions have been developed and tested. What remains is primarily to characterize the specific corrosion behavior of actual LAW glasses. This includes identifying (or confirming) the corrosion processes that will control the long-term behavior of the glasses and release of radionuclides, measuring parameters needed to perform model calculations for performance assessment, and conducting accelerated and service condition tests to confirm and provide confidence in those calculations.

The purpose of this report is to document a technical strategy developed by Pacific Northwest National Laboratory (PNNL) ${ }^{2}$ and Argonne National Laboratory that the ILAW disposal program will pursue over the next several years to evaluate the long-term radionuclide release behavior of the LAW glass(es) under development by the private contractors. As such, this document is intended to serve as the technical basis for the glass testing program that is needed to complete the performance assessment for the ILAW disposal facility. Specific matrices of tests will not be developed in this report; these are to be provided in separate test plans for each test method. However, this document will define the general classes of tests for which test plans will need to be developed and provide a general range of appropriate conditions for these tests. We begin the discussion of the technical strategy with a brief overview of the disposal system design and expected environmental conditions at the site.

'Pacific Northwest National Laboratory is operated for the U.S. Department of Energy by Battelle under Contract DE-AC06-76RLO 1830. 
DOE/RL-97-69, Rev. 0

Based on PNNL Report (PNNL-11834) To Be Published

\section{G-2.0 DISPOSAL SYSTEM DESCRIPTION}

The Hanford Site is a $1450 \mathrm{~km}^{2}$ area of semi-arid land located in southeastern Washington state. Average annual precipitation is $16 \mathrm{~cm}$, with $44 \%$ of this total occurring during November, December, and January. Daytime high temperatures in summer can exceed $40^{\circ} \mathrm{C}$, while outbreaks of arctic air masses in winter can cause temperatures to drop below $-18^{\circ} \mathrm{C}$. Plans call for the disposal system to include a protective surface barrier with design elements to minimize root intrusion, animal intrusion, and water infiltration. The use of silt-loam soils when combined with a representative community of shrub-steppe vegetation has been shown to cause most precipitation falling on the region to be lost through evapotranspiration. Consequently, the disposal facility is to be located in relatively dry, unsaturated soil, and performance assessment models must be applicable to the specific physics and chemistry of this type of system.

\section{G-2.1 WATER INFILTRATION}

Water flow in the near-surface unsaturated zone is transient because of intermittent precipitation events. Transient water flow begins when water enters at the ground surface and infiltrates downward into the soil column. At some distance from the ground surface, transient effects will dampen out, and the downward flowing water will reach a steady infiltration rate. The distance at which steady infiltration occurs is sometimes referred to as the penetration depth (Eagleson 1978; Salvucci, 1993). Thus, the unsaturated zone essentially comprises two regions: an unsteady-flow region between the ground surface and penetration depth, and a steady-flow region between the penetration depth and the saturated zone water table. The steady flux in the lower unsaturated region is equal to the annual rate of ground-water recharge and therefore is composed of contributions not only from the most recent pulse, but from previous precipitation events as well.

The ILAW disposal facility will be situated below the penetration depth in the region of steady flow. The natural rate of moisture infiltration is approximately $3.0 \mathrm{~mm} /$ year (Fayer and Waiters 1995). However, the natural rate of moisture infiltration cannot be relied upon because construction of the disposal system will destroy the natural soil-sediment profile and remove surface vegetation. Consequently, a protective surface barrier will be engineered with sediment layers and a capillary barrier to prevent or minimize infiltration. The design basis for the Hanford barrier (Myers and Duranceau 1994) specifies that less than $0.5 \mathrm{~mm} /$ year will pass through the barrier for the first 1,000 years. Infiltration beyond the root zone is controlled at the soil/atmosphere interface where surface soils and sediments, and vegetation, interact with the climate. The frequency, duration, and magnitude of precipitation and runoff events determine the infiltration rate. Infiltration into the disposal facility will be controlled by the physics described above, the unsaturated hydraulic properties of the surface and subsurface barriers to infiltration, the vault and surrounding soil, and the matric and gravity potential gradients. 


\section{Based on PNNL Report (PNNL-11834) To Be Published}

\section{G-2.2 FACLITY DESCRIPTION}

A detailed design for the ILAW disposal facility is not yet available. However, Burbank (1997) has performed preconceptual engineering studies of alternative designs. The basic design unit for all the disposal facility concepts is a vault bay. The vault bays have concrete walls, floors, and ceilings. Six vault bays form a vault row. The number of vault bays depends on the size of the immobilized LAW containers and the spacing between containers. Burbank optimized the interior dimensions around the presumed dimensions of the waste package, $1.8 \mathrm{~m} \times 1.2 \mathrm{~m} \times 1.2 \mathrm{~m}$ $\pm 0.2 \mathrm{~m}$ (DOE-RL 1996), producing interior dimensions of $20 \times 20 \times 7.5 \mathrm{~m}$. He also separates the vault rows and places a road between the two sets of vault rows (see Figure G-2.1). This design accommodates a single vault capacity of 5040 waste packages in an array 10 wide $\times 6$ high $\times 84$ rows, with 19 vaults total at the disposal site.

All the concepts include backfilled soil around and on top of the waste containers in the facility. The soil was included in these concepts 1) for structural support, 2) to wick moisture away from the waste containers, and 3 ) to provide radiation shielding for the facility workers. They also have a similar barrier philosophy. The uppermost barrier is the surface barrier, which consists of sand/gravel layers to work as a capillary break, a layer (that may or may not be included in the final design) for conditioning the chemistry of the water to help minimize the rate of glass corrosion and/or radionuclide release, and a layer of basalt riprap to deter burrowing animals, plant root intrusion, and inadvertent intruders. Beneath the surface barrier, another sandgravel capillary break will divert moisture coming through the surface barrier away from the vault. This barrier combination minimizes the amount of water that enters the vault.

Figure G-2.1. Schematic of IIAW Disposal System.

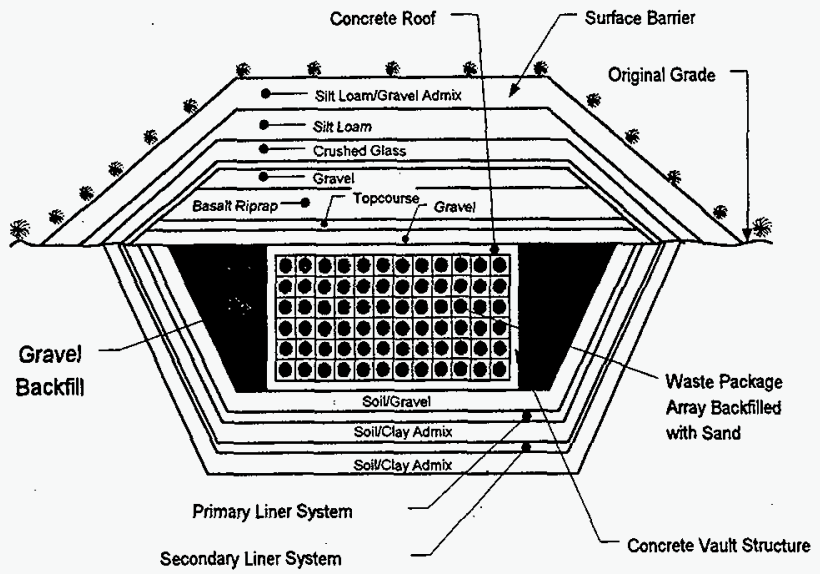




\section{Based on PNNL Report (PNNL-11834) To Be Published}

The disposal vaults are to be located approximately $15 \mathrm{~m}$ below the top of the surface barrier. At this depth, the ambient temperature is approximately $15^{\circ} \mathrm{C}$, and temperature fluctuations are less than $2^{\circ} \mathrm{C}$. Also, because the LAW generates a small amount of heat from radioactive decay (McGrail and Mahoney 1995), the disposal system can be treated adequately as an isothermal system. The waste packages are expected to consist of a rectangular steel container that holds the glass and possibly a filler material. The glass will likely not be annealed and thus will be thermally stress fractured to some extent. The extent of fracturing is important because it increases the available surface area for possible contact by water and thus can potentially increase the radionuclide release rate from the disposal system.

Based on this disposal system concept, small amounts of water are expected to percolate through the disposal system and eventually penetrate the steel containers and contact the glass. The goal of the glass testing program then, is to provide the necessary supporting data so that the radionuclide release behavior of this system can be modeled with sufficient confidence to support an overall performance assessment for disposal of ILAW at the Hanford Site. 


\section{DOE/RL-97-69, Rev. 0 \\ Based on PNNL Report (PNNL-11834) To Be Published}

\section{G-3.0 MODELING APPROACH}

Because it is impossible to formulate a rationale and a defensible testing program without understanding the physical and chemical processes that govern glass corrosion and radionuclide release as well as the conceptual models that describe these processes, we briefly review these concepts below.

\section{G-3.1 GLASS CORROSION PROCESS}

Fortunately, much is known about glass/water reaction processes. Glass forms ranging from simple binary and ternary silicate glasses to complex waste glasses with 30 or more components have been studied for 35 years. Much of this work relevant to silicate waste glasses has recently been compiled and criticaliy reviewed (Bates et al. 1994). A general picture of the glass corrosion process in water has emerged that can be summarized as follows: upon initial contact by water, alkali is extracted by ion exchange in what is thought to be a diffusioncontrolled process. Simultaneously, hydrolysis and dissolution of the glass network occurs. In unsaturated disposal systems where water content and flow rate are expected to be very low, the rate of ion exchange and dissolution decrease, but for different reasons. The ion-exchange rate slows in accordance with a diffusion-controlled process as a reaction layer builds up on the glass over time. A reaction layer builds up as a result of silanol condensation reactions that reform $\mathrm{Si}-\mathrm{O}$ bonds. The dissolution rate of the glass network slows because of the common ion effect, i.e., as the solution becomes more concentrated in glass components, the difference in chemical potential between the glass and aqueous phase decreases, which decreases the dissolution rate. The dissolution rate cannot become zero because silicate glasses are thermodynamically unstable in water.

\section{G-3.1.1 Importance of Secondary Phases}

As a solution in contact with a dissolving glass becomes more and more concentrated in glass components, solubility limits for alteration phases begin to be exceeded. Although no generally accepted theory has been proposed to describe the factors controlling nucleation and growth, ultimately, the glass transforms into a paragenetic assemblage of alteration products or minerals. Also, no generally accepted theory exists that can be used to predict which specific phases should form or the sequence of their formation: However, from the Simplexity Principle (Goldsmith 1953), we know that the most disordered phase should form from a random system of components first. We know from the Ostwald Step Rule (Ostwald 1897) that subsequent transformations to more stable phases should occur in steps where the reaction products obtained at each step lay near the previous state in free energy. These governing principles have extremely important implications for the testing strategy because at the low temperatures $\left(15^{\circ} \mathrm{C}\right)$ relevant for the LAW disposal system, metastable and/or amorphous phases may persist for long periods of time. Consequently, a means must be found for accelerating the transformation process during laboratory testing without altering the fundamental transformation process itself. 


\section{DOE/RL-97-69, Rev. 0 Based on PNNL Report (PNNL-11834) To Be Published}

The secondary phases that form from the glass/water reaction process are expected to depend principally on the composition of the glass and not on other components in the disposal system because the glass supplies the majority of the elements to the fluid from which the secondary phases precipitate. However, the water conditioning layer, filler material in and/or between waste packages, and the concrete used in vault construction may also impact the formation of secondary phases; especially in localized regions. Glasses that are stable with respect to the formation of alteration products will maintain a slow but finite rate of network hydrolysis and dissolution indefinitely. Many existing natural glasses exhibit these characteristics, having withstood weathering over geologic time scales. Laboratory tests have generally reproduced the same types of alteration products that have been found on these glasses (Grambow et al. 1986; Luo et al. 1997), confirming their long-term stability with respect to forming alteration phases. However, glasses that are unstable with respect to alteration product formation exhibit autocatalytic reactivity, i.e., a very rapid increase in dissolution rate that is limited only by the availability of water or the forward reaction rate of the glass, whichever is the rate limiting process. High-level waste glasses (Van Iseghem and Grambow 1988 have exhibited this phenomenon and so has a representative LAW glass, LD6-5412 (McGrail et al. 1997a). Consequently, the laboratory testing program must ensure that the LAW glass(es) being produced by the private vendors fall into the former, stable category. If not, then the tests should provide guidance for modifying the glass composition into a region with known long-term stability.

\section{G-3.1.2 Effect of Ion Exchange}

Because of the large effect that secondary phase formation has on glass dissolution rates, recent work on glass/water interactions has focused on understanding this process and incorporating it into models (Ebert and Bates 1993). The ion-exchange process has been largely ignored because it has been thought to be a short duration, secondary, or tertiary process that had little or no bearing on long-term corrosion or radionuclide release rates from glasses. The only significant effect identified in the literature that is attributed to alkali ion exchange is an increase in solution $\mathrm{pH}$ in static laboratory tests conducted at high surface area-to-volume ratios (Strachan et al. 1990; Bourcier and Feng 1993).

The discovery of the significance of ion exchange to long-term radionuclide release rates was only very recently made possible by the development of computational tools that can simulate the coupled processes of glass dissolution, mass transport, and chemical reactions in a complex disposal system (Chen, McGrail, and Engel 1997). By comparing simulations where $\mathrm{Na}$ ion exchange was included versus those where it was excluded, Chen, McGrail, and Engel (1997) showed that the ion-exchange reaction increased the $\mathrm{pH}$ in a conceptual design for a LAW disposal vault from approximately 9.8 to over 12.5 , which increased the radionuclide release rate by over 3 orders of magnitude. Thus, the overall performance of the disposal system can be significantly improved if improved glasses are developed that minimize alkali ion exchange. Formulation of such glasses can be rationally accomplished only through development of a fundamental scientific understanding of the ion-exchange process. Such a study is currently being supported under DOE's Environmental Management Science Program (EMSP), and the results and conclusions from this work will be closely coordinated with the testing program described in this report. 
DOE/RL-97-69, Rev. 0

Based on PNNL Report (PNNL-11834) To Be Published

\section{G-3.2 GLASS CORROSION MODEL}

It is impossible to develop a rationale testing program without thoroughly understanding the model that is being used to calculate the glass corrosion behavior over the geologic time scales required for performance assessment. In fact, the testing program is directly linked and derived from the data requirements of this model. Figure G-3.1 illustrates the basic linkage between modeling and testing. At the top of the pyramid is the conceptual model that describes the glass corrosion process. The parameters that make up this model are abstracted at the mid-level of the pyramid. Once the parameter set is known, the testing program is determined by the appropriate experiments needed to obtain each parameter in the set. This strategy is consistent with American Society for Testing and Materials guidelines (ASTM 1991), but we emphasize the "model driven" approach here because, ultimately, the credibility of the performance assessment rests on the credibility of the models and supporting data, not on a specific test. Following this approach, the conceptual model for glass corrosion planned for use in the performance assessment is discussed in the next section.

\section{G-3.2.1 Rate Law for Hydrolysis and Dissolution}

The literature on modeling glass dissolution is extensive. However, Strachan, Bourcier, and McGrail (Strachan et al.1994) published a recent review of the subject. An interested reader should consult this paper and the references cited therein for additional details. The conclusion from this study was that of all the models that have been developed to describe glass dissolution behavior, the general kinetic rate law proposed by Aagaard and Helgeson (Aagaard and Helgeson 1982) and later adapted by Grambow (Grambow 1985), best describes the majority of the experimental data that has been gathered over 35 years of studying glass/water reaction processes. Consequently, this model has been selected for use on the LAW disposal project. The corrosion of silicate glasses in water can be represented as a special type of irreversible dissolution reaction. The reaction is irreversible because the glass cannot be reformed by precipitation from aqueous solution.

A conventional transition state kinetic rate equation can be used to compute the flux of any element $i$ released from the glass into the aqueous phase and is given by

$$
J_{t}^{a}=v_{i} k e^{-\frac{E_{a}}{R T}}\left[1-\left(\frac{Q}{K}\right)^{\sigma}\right] \prod_{j} a_{j}^{-\eta}, i=1,2, \ldots N ; j=1,2, \ldots M
$$

where

$a_{j} \quad=\quad$ activity of $j$ th aqueous species 
DOE/RL-97-69, Rev. 0

\section{Based on PNNL Report (PNNL-11834) To Be Published}

$\begin{array}{lll}\mathbf{k}^{\cdot} & =\quad \text { intrinsic rate constant, } \mathrm{g} / \mathrm{m}^{2} \cdot \mathrm{s} \\ \mathrm{E}_{\mathrm{a}}= & \text { activation energy, } \mathrm{J} / \mathrm{mol} \\ \mathrm{J}_{\mathrm{i}}^{\mathrm{a}} & = & \text { flux of element } i \text { to the aqueous phase, } \mathrm{g} / \mathrm{m}^{2} \cdot \mathrm{s} \\ K & = & \text { equilibrium constant of rate controlling reaction } \\ \mathrm{M} & = & \text { number of species directly affecting the rate } \\ \mathrm{N} & = & \text { number of elements } \\ Q & = & \text { ion-activity product of rate controlling reaction } \\ \mathrm{R} & = & \text { gas constant, } 8.314 \mathrm{~J} / \mathrm{mol} \cdot \mathrm{K} \\ \mathrm{T} & = & \text { temperature, } \mathrm{K} \\ v_{t} & = & \text { stoichiometric coefficient of element } i \text { in the glass } \\ \sigma \quad= & \text { net reaction order } \\ \eta & = & \text { stoichiometric coefficient for the } j \text { th reactant species. }\end{array}$

Equation (G.1) is a constitutive relationship that relates temperature and the composition of water contacting the glass to the corrosion rate. Currently, $\mathrm{H}^{+}$is the only aqueous species that has been found to directly influence the rate via the activity product term (Bourcier et al. 1992).

Consequently, Equation (G.1) can be simplified to

$$
J_{i}^{a}=v_{i} k e^{-\frac{E_{c}}{R T}} a_{H}^{-\eta} \cdot\left[1-\left(\frac{Q}{K}\right)^{\sigma}\right], \quad i=1,2, \ldots N
$$

where $a_{\mathrm{H}}+$ is the hydrogen ion activity. Because the temperature is assumed to be a known constant, and $v$, values are determined from the glass composition, application of Equation (G.2) for modeling glass corrosion in a disposal system requires the determination of six parameters; $\mathrm{k}, \mathrm{E}_{\mathrm{a}}, \eta, \sigma, K$, and $Q$. In accordance with the strategy illustrated in Figure G-3.1 and the ASTM 1174 approach, the testing program is then defined by an appropriate set of experiments that determines these parameters.

G-3.2.1.1 Experiments for Kinetic Rate Law Parameters. If a glass is placed in a dilute solution that is refreshed at an infinite rate, the chemical affinity term $\left[1-(Q / K)^{\circ}\right]$ in Equation (G.2) equals 1, and the corrosion rate of the glass is determined only by the three traditional kinetic rate law parameters, $k, E_{2}$, and $\eta$. Experimentally, the single-pass flow-through (SPFT) test is used to approximate these conditions. By adjusting glass surface area and flow rate, the solution remains dilute, but not so dilute that the solution concentrations cannot be determined with standard analytical techniques. The SPFT test has been used to measure reaction rates of minerals (Knauss and Wolery 1986; Dove and Crerar 1990) and glasses (Knauss et al. 1990; McGrail and Olson 1992; McGrail et al. 1997c). By monitoring the change in dissolution rate over a sufficient range of temperature and $\mathrm{pH}$ values, $\mathrm{k}, \mathrm{E}_{2}$, and $\eta$ can be easily obtained by applying standard nonlinear regression techniques to (G.2). Details of the recommended experimental procedure and tests are given in Section G-4.1. 


\section{DOE/RL-97-69, Rev, 0 \\ Based on PNNL Report (PNNL-11834) To Be Pubished}

G-3.2.1.2 Experiments for Affinity Term Parameters. By definition, $\sigma$ and $K$ are the parameters of the chemical affinity term $\left[1-(Q / K)^{\circ}\right]$ and so are usually obtained from laboratory experiments. The ion activity product $(Q)$ is a variable and must be computed as a function of time and space for the disposal system (McGrail and Mahoney 1995; Bacon and McGrail 1997). Computation of $Q$ is complex and depends on physical properties of the system, such as flow rate and glass surface area, and chemical properties, such as solubility products and the amounts and types of alteration products formed (see Section G-3.1.1). Because transport and chemical processes interact, or more precisely are coupled, a special type of computational model, called a reactive chemical transport model, is required for simulations. ${ }^{(2)}$ The key inputs to this model derived from the glass testing program are the parameters $\sigma$ and $K$, and the identification of glass alteration products. These data are extremely important because they can affect the calculated long-term corrosion rate of the glass by 3 to 4 orders of magnitude.

The pseudoequilibrium constant $(K)$ and reaction order parameter $(\sigma)$ are probably the most difficult parameters to obtain in the rate law, and, unfortunately, are also the most poorly documented in terms of experimental techniques and methods för obtaining them. Unlike for a crystalline or amorphous phase, the assignment of $K$ for a glass is ambiguous, because by definition, equilibrium between the glass and water does not exist. Assigning $K$ to a hypothetical phase including all the glass elements has not proven successful in modeling laboratory test data (Bourcier 1989; Advocat et al. 1990). Consequently, an approximation is used where $K$ is associated with a reversible microscopic reaction that is rate limiting and not the macroscopic glass/water reaction itself. Good agreement with laboratory test data for most glasses has been obtained by assigning $K$ to a simple $\mathrm{SiO}_{2}$ polymorph, such as chalcedony, or mixtures of simple hydroxides and silicate phases (Bourcier et al. 1990; Gin 1996).

Unfortunately, the "agreement" typically reported in the literature lacks a statistical basis and is usually just trial and error reckoning of batch test data to calculated curves (Bourcier et al. 1990). The situation for determining the parameter $\sigma$ is even poorer with most studies of silicate mineral and glass dissolution simply assuming $\sigma=1$. In other cases (Bourcier et al. 1994), $\sigma$ and/or $K$ have been regressed using data from batch tests. Batch tests introduce additional difficulties in accurately obtaining these parameters because $\mathrm{pH}$ and solution concentrations change continuously throughout the test, requiring "corrections". derived from the rate law itself. This introduces the possibility of inseparable causality errors. In a recent paper, McGrail et al. (1997c) illustrated how the SPFT test can be used to obtain $\sigma$ and $K$ by varying the flow rate over a sufficiently wide range. Their technique has the advantage of being performed at fixed $\mathrm{pH}$ and steady-state solution concentrations and does not require data "corrections" derived from the rate law. Consequently, the experimental techniques and formal mathematics developed by McGrail et al. will be used to obtain these parameters (see Section G-4.1).

Because there is no single test that can reliably evaluate the effects of secondary phases on the long-term corrosion rate of a glass, our approach is to employ a range of accelerated experimental techniques. By doing so, a range of physical and environmental factors can be

\footnotetext{
(a)The interested reader should consult McGrail and Mahoney (1995), Chen et al. (1997), and Bacon and McGrail (1997) for details.
} 


\section{DOE/RL-97-69, Rev, 0 \\ Based on PNNL Report (PNNL-11834) To Be Published}

examined that affect the rate and type of secondary phases formed. The use of different tests to accelerate glass corrosion provides added confidence that the artifacts associated with each test method are understood and properly taken into account and that long-term corrosion behavior of the glass is understood. Three types of long-term experiments are recommended for the majority of the testing: 1) vapor hydration tests, 2) product consistency tests (PCTs), and 3) pressurized unsaturated flow (PUF) tests. Each of these tests, and alternative tests, are discussed in detail in Section G-4.0.

\section{G-3.2.2 Rate Law for Ion Exchange}

Although ion exchange has been largely ignored in the recent literature on the glass/water reactions, the process has been the subject of numerous early studies. In fact, the traditional idea of glass "leaching" involves the basic mechanism of ion exchange in which an $\mathrm{H}^{+}$or $\mathrm{H}_{3} \mathrm{O}^{+}$ion exchanges for an alkali ion $\left(\mathrm{M}^{+}\right)$in the glass, thereby generating a hydrated layer on the glass surface. The overall chemical reaction describing the process can be written as:

or

$$
\equiv \mathrm{Si}-\mathrm{O}-\mathrm{M}+\mathrm{H}^{+} \rightarrow=\mathrm{Si}-\mathrm{OH}+\mathrm{M}^{+}
$$

$$
\equiv \mathrm{Si}-\mathrm{O}-\mathrm{M}+\mathrm{H}_{3} \mathrm{O}^{+} \rightarrow \equiv \mathrm{Si}-\mathrm{OH}+\mathrm{M}^{+}+\mathrm{H}_{2} \mathrm{O} \text {. }
$$

Rana and Douglas (Rana and Douglas 1961a and $1961 \mathrm{~b}$ ) were among the first to report on this mechanism. Boksay, Bouquet, and Dobos (Boksay 1968) and Doremus (Doremus 1975; Doremus 1977; Lanford et al. 1979) pioneered the idea that ion counter-diffusion or interdiffusion is the rate limiting process for the exchange reaction. Recent data on a representative LAW glass, LD6-5412, is also consistent with a diffusion-controlled release mechanism. Figure $\mathrm{G}-3.2$ shows that $\mathrm{Na}$ is being released, presumably by ion exchange, at a linear rate with respect to $t^{1 / 2}$ in excess of the rate of matrix dissolution.

Detailed studies of the ion exchange process(es) are being conducted under the EMSP program. Once these studies are complete, an appropriate rate equation for ion exchange will be developed. The parameters that make up this model (possibly diffusion coefficients) will need to be determined from laboratory tests on the vendor glass compositions. However, until the EMSP studies are further along, it is premature to identify specific test methods and conditions.
Figure G-3.2. Release of $\mathrm{Na}$ in Excess of that Released by Matrix Dissolution in Static Tests with LD6-5412, a Reference LAW Glass

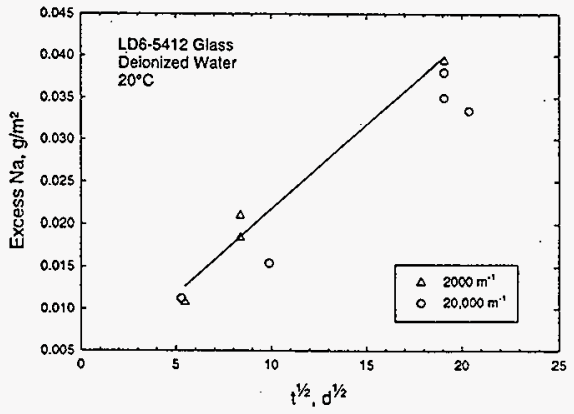




\section{DOE/RL-97-69, Rev. 0 \\ Based on PNNL Report (PNNL-11834) To Be Published}

\section{G-4.0 LABORATORY TESTING}

Waste glasses are laboratory tested to identify important corrosion processes under siterelevant conditions and to measure parameter values needed to model long-term behavior (see Section G-3.0). Three general classes of tests are proposed in this strategy: 1) characterization, 2) accelerated, and 3) service condition. Characterization tests are used isolate and provide specific information about processes or parameters in theoretical models. Test conditions are usually very different from expected service conditions to highlight a particular process and minimize or hold constant other effects. Examples of such tests include measuring basic material properties, such as density and compressive strength. Characterization tests proposed in this plan related to glass corrosion are SPFT tests used to measure kinetic rate law parameters.

Accelerated tests are used to investigate corrosion behavior that will be important over the regulated service life of a disposal system within a laboratory time frame of a few years or less. Therefore, it is important to know likely site conditions over long times to determine what aspects of glass corrosion need to be considered in the performance assessment. Elevated temperatures and high glass surface area-to-solution volume ratio $(\mathrm{S} / \mathrm{V})$ are often used to accelerate the reactions and processes that lead to glass dissolution. It is important to verify that the technique. used to accelerate a reaction or process does not cause a change in the rate-limiting step or mechanism of the process, or if it does, the change must be taken into account. For example, water diffusion, ion exchange, and hydrolysis will be affected to a different degree by changes in the temperature, and the overall temperature dependence of glass corrosion will include contributions from all three processes, although it may be dominated by one process under particular test conditions. Accelerated test methods that will be used to study the advanced stages of glass dissolution include the PCT, the vapor hydration test (VHT), and the PUF test. Tests will be conducted over a range of conditions to link the dissolution behavior under disposal conditions with that under accelerating test conditions.

Service condition tests are conducted to verify that the techniques used in accelerated tests do not change the alteration mechanisms. They are designed to approximate, to the extent possible in the laboratory, the physical and chemical environment of the disposal system. Because of the low temperature of $\mathbb{L A W}$ disposal system and the very slow rate of moisture flow expected in the disposal facility, laboratory tests approximating these conditions are unlikely to yield meaningful data in reasonable time periods. Consequently, no specific service condition tests are proposed in this plan. Rather, the parameter values for some tests are selected so as to reflect service conditions. For example, some PUF experiments may be performed with fractured glass monoliths instead of ground glass to provide service condition information on water flow paths and glass aiteration processes in fractures. However, solution flow rate and temperature adopted for these tests will likely be higher than the expected conditions. Again, the purpose of the testing program is to demonstrate a scientific understanding of the processes controlling longterm glass corrosion so that the models describing these processes can be used with confidence in extrapolating to the expected service conditions.

Having described the general types of tests to be performed, the specific characterization and accelerated tests proposed under this plan are discussed in Sections G-4.1 through G-4.9. 


\section{G-4.1 SINGLE-PASS FLOW-THROUGH TEST}

The SPFT test is an open system test where a solution at a known flow rate and constant temperature flows through a reaction cell that contains the sample. The configuration precludes recirculation of a portion of the effluent and so makes a "single-pass" through the reaction cell. Many different SPFT apparatuses have been developed, but these can all be classified as three basic types: 1) well-mixed batch, 2) packed bed, and 3) fluidized bed. The advantages and disadvantages of each design are discussed below.

\section{G-4.1.1 Well-mixed Batch Reactor}

Figure G-4.1 shows a schematic of a typical batch flow through cell. Fluid and, optionally, a gas or gas mixture is pumped into the cell. Fluid exits the cell and is collected in a separate container for later chemical analysis. Mixing is accomplished by convection from the solution flow and (optionally) gas flow into the reactor. Some researchers have used a mechanical stirrer as well. The key advantages to using this type of reactor include the ability to use powdered or monolithic samples, use and control a gas or gas mixture during the test, and eliminate the need to control bubble formation in the fluid inlet, as is necessary with a packed bed reactor (see below). The only disadvantage to using a batch reactor is the need to ensure that when using powdered samples, sufficient mixing occurs to prevent agglomeration of the particles or formation of a stagnant solution around the sample.

\section{G-4.1.2 Packed Bed Reactor}

In a typical packed-bed type reactor, a porous bed of the test material is packed between two frits that have a nominal pore size smaller than the particle size of the sample. Solution flows through the porous bed and is collected in the same manner as with the batch reactor. The key advantage to using this type of reactor is that it eliminates the possibility of a stagnant solution layer as is possible with a batch reactor. However, this design has several important disadvantages. Care must be exercised to ensure that gas bubbles do not form in the inlet lines, which can become entrained in the porous bed. Entrained bubbles could exclude part of the sample surface from contact with the fluid. McGrail and Olson (1992) reported that it was impossible to prevent bubble formation in their fluid inlet lines at $90^{\circ} \mathrm{C}$, despite vigorous attempts to degas the solution. This limited the effective operating temperature to $70^{\circ} \mathrm{C}$ or less. The second disadvantage is that by the nature of the design, a concentration gradient will exist across the bed. However, depending on the specifics of the corrosion mechanism, this may or may not be of concern. Finally, the option of imposing a fixed gas partial pressure in the reaction cell is not available as with the batch type of reactor. 


\section{Based on PNNL Report (PNNL-11834) To Be Published}

\section{G-4.1.3 Fluidized Bed Reactor}

The fluidized bed reactor is similar to the packed bed reactor except that much less sample is used so that when sufficiently high flow rates are used, the sample particles are suspended or "fluidized" in the cell. The advantages of this design are that it eliminates the concentration gradient inherent with the packed bed reactor and ensures complete exposure of the entire particle surface area to the fluid. However, this test configuration has numerous disadvantages. First, depending on the particle size and density difference between the sample and the fluid, a relatively high flow rate is required to fluidize the bed. The flow rate required can often be sufficiently high that the solution exiting the reactor does not differ enough from background concentrations to be statistically significant. This is particularly problematic at lower temperatures because the flow rate required to fluidize the bed will change only slightly with temperature, but the dissolution rate of the test material may decrease by 2 to 3 orders of magnitude over the temperature range of 90 to $20^{\circ} \mathrm{C}$, thus compounding detection limit problems. Second, the high flow rates required generate large volumes of effluent. This can present an expensive waste disposal problem, especially when testing radioactive materials. Third, because the particles are in motion and collide with one another, particle abrasion may cause a change in surface area during the test, which may be difficult to quantify. Fourth, the reactor must be carefully engineered and tested to prevent particles from settling in quiescent pockets and from transporting out of the reactor to the collection system.

\section{G-4.1.4 SPFT Testing Strategy}

Based on the discussion of SPFT testing methods in Sections G-4.1.1 through G-4.1.3, the advantages of the batch reactor are sufficient to select it as the preferred test apparatus design. Testing must then be performed over an appropriate range of conditions. The $\mathrm{pH}$ of the water percolating through a LAW disposal system will almost certainly be between $\mathrm{pH} 6$ and 13, so the pH dependence of the rate must be determined over this range. Collecting SPFT data over the acidic $\mathrm{pH}$ range is not required. The activation energy $\left(E_{2}\right)$ is another important parameter in the model, and SPFT tests must be run over a sufficient range of temperatures to accurately determine this parameter. A typical data set that provides the three parameters, $k, E_{2}$, and $\eta$, is shown in Figure G-4.2.

Figure G-4.2. Normalized Si Release Rate as a Function of pH and Temperature for LD6-5412 Glass.

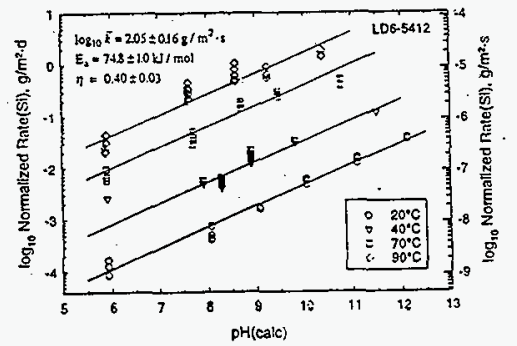




\section{DOE/RL-97-69, Rev. 0 \\ Based on PNNL Report (PNNL-11834) To Be Published}

The procedures outlined in McGrail et al. (1997c) should also be followed in running SPFT tests over a sufficient range of flow rates to evaluate the parameters $\sigma$ and $K$. Although $K$ should be independent of $\mathrm{pH}$ and perhaps $\sigma$ as well, at least one additional experiment at another $\mathrm{pH}$ should be performed for confirmation. Finally, test results (McGrail et al. 1997c) on LD6-5412 glass indicated the possibility that an additional element (besides $\mathrm{Si}$ ), such as $\mathrm{Al}$, may need to be included in the affinity term. If a similar conclusion is reached based on the SPFT test results for the vendor glass compositions, then a series of tests should be performed where the concentrations of the test element(s) are varied independently. An analytical solution for a mixed $\mathrm{Si}-\mathrm{Al}$ kinetic rate law model was developed by $\mathrm{McGrail}$ et al. (1997c) and can be used to develop a statistical design for these tests.

\section{G-4.2 VAPOR HYDRATION TEST}

The VHT is the simplest accelerated test to be used in the recommended testing strategy because there is only one degree of freedom in test parameters that can be varied, temperature, excluding test duration and humidity. The principle use of the test is as a convenient means of generating alteration phases for analysis within a short period, but it is also useful for a qualitative measure of the effect of alteration phase formation on the

Figure G-4.3. Schematic of VHT

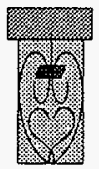
corrosion rate. The VHT is a static test in which a monolithic sample is exposed to water vapor in a sealed vessel, as illustrated in Figure $\mathrm{G} * 4.3$. At relative humidity (RH) above about $80 \%$, a thin film of water condenses on the sample. The thickness of the film increases with the RH, and it is in this film that the glass corrodes. The thickness of the film determines the effective $S / V$ ratio of the system; for a uniform layer, the $\mathrm{S} / \mathrm{V}$ ratio is simply the inverse of the thickness of the film. Most VHTs have been performed in $100 \%$ relative humidity at temperatures above $100^{\circ} \mathrm{C}$, although tests have been conducted at lower humidities and temperatures. At the completion of a test, the sample is removed from the vessel, and the reacted surface is analyzed with highresolution electron microscopy. Discrete precipitated crystalline phases usually form when the sample corrodes. The solution evaporates from the sample when the test is terminated and is not available for analysis. This precludes using the test to evaluate and test models of glass corrosion behavior, which require detailed measurements of the solution composition in contact with the glass.

Vapor hydration has been used by archaeologists to replicate the weathering observed on obsidian artifacts recovered from terrestrial sites (Friedman and Long 1976). The method has also been used to simulate the long-term weathering of tektite (Mazer et al. 1992) and basaltic glasses (Byers et al. 1986). Because the test method produces the same alteration phases that form during the weathering of natural glasses over long periods, the test has also been used to accelerate the corrosion of waste glasses. High-level waste glasses commonly form clay layers in VHTs. Glasses having compositions relevant to anticipated LAW for Hanford form zeolite phases similar to analcime, gobbinsite, and phillipsite. 


\section{DOE/RL-97-69, Rev. 0 \\ Based on PNNL Report (PNNL-11834) To Be Published}

To extract kinetic information, VHTs will be run over a minimum of four temperatures, all at $100 \% \mathrm{RH}$. However, it is important to recognize that the rate measured in VHTs is not the glass dissolution rate, but the rate at which alteration phases are formed. It is presumed that precipitation rates of the alteration phases are much faster than the glass dissolution rate. Tests with radioactive glasses will be used to measure the distribution of radionuclides between alteration phases and residual phases (see Section G-4.6).

\section{G-4.3 PRODUCT CONSISTENCY TEST}

The PCT has been standardized as an ASTM standard procedure (ASTM 1994). The ASTM standard includes two methods: PCT Method A was developed specifically for verifying process control of vitrified HLW forms and is conducted with specific values of test parameters; PCT Method B does not specify the values of test parameters. Because the PCT Method B encompasses commonly used variations of test parameters, we refer to all static dissolution tests with crushed glass generically as PCTs.

The PCTs are conducted by reacting an aliquot of crushed glass that has been sieved to isolate the desired size fraction with an aliquot of a solution in a sealed vessel at the desired temperature. The glass $\mathrm{S} / \mathrm{V}$ can be calculated from the glass/solution mass ratio and the specific surface area of the crushed glass to determine the average dissolution rate during the test. Tests are conducted as batch tests wherein a separate test is run for each duration. At the end of the test, the solution is analyzed for $\mathrm{pH}$ and the concentrations of dissolved glass components. The latter are used to calculate the amount of glass that has reacted and the dissolution rate. The reacted glass surface can also be analyzed to help characterize the reaction mechanism, such as when an alkali-depleted layer or alteration phases form.

Because the test conditions in PCTs are water-saturated and static (closed-system), which are not consistent with expected disposal system conditions, including a significant number of PCTs in this plan requires explanation. Traditionally, PCTs are used as a means to study advanced stages of corrosion at high glass/solution mass ratio (or $\mathrm{S} / \mathrm{V}$ ), high temperature, and long test duration. It is argued that the reaction conditions in the PCTs are similar in several regards to the conditions expected in a disposal site. Although waste glasses will not be crushed, the $S / V$ values commonly used in PCTs are similar to the effective $S / V$ values when a small volume of water contacts a glass. The static conditions of the PCTs are also probably not too different from the very low water infiltration rates anticipated. Therefore, PCTs probably provide a fair simulation of the corrosion behavior after a small amount of water has contacted a waste package and reveal key reaction processes. While each of these statements is true to some extent, they provide insufficient justification for running PCTs as they establish only heuristic connections with modeling.

Consistent with the model-centered approach used in this plan, the PCT is used to calibrate the substantial set of supporting geochemical data that are required for modeling the dynamic evolution in solution chemistry that occurs as a consequence of glass/water reactions.

The term "calibration" in this context refers to a complex iterative process whereby the evolution in solution composition and secondary phase formation observed in PCTs is reproduced, with a 


\section{DOE/RL-97-69, Rev, 0 \\ Based on PNNL Report (PNNL-11834) To Be Published}

reasonable level of uncertainty, in a geochemical model of the system. The process is complex because during a closed-system test, like the PCT, changes in the concentrations of dissolved glass components, the solution $\mathrm{pH}$, and, in some cases, dissolved air components must be modeled simultaneously. Fortunately, the geochemical simulator selected for modeling this system, the EQ3/6 code (Wolery and Daveler 1992), has capabilities for handling these complexities.

The calibration process requires, among other things, estimating solubility product values for secondary minerals that are identified in the PCTs, but for which thermodynamic data are not available. These values can be generated by fitting to the PCT data or by using empirical methods, such as with a polymer model (Mattigod and McGrail 1998). However, if a particular phase is found to have an important effect on long-term glass corrosion rates, it is recommended that independent measurements of its solubility product be performed. Once the geochemical model has been calibrated against the PCT data, the significant aqueous speciation and dissolution-precipitation reactions in the model can be identified. This reaction set and supporting thermodynamic data then make up the reaction network that is used in the reactive transport model to compute radionuclide release from the disposal system (Bacon and McGrail 1997).

Because the dissolution behavior of glasses in PCTs are usually strongly affected by the affinity term, PCT results can also be used to measure of the values of the saturation concentration $(K)$ and the net reaction order variable $(\sigma)$. However, the effect of a changing $\mathrm{pH}$ and solution composition complicates the extraction of these values. Instead, the results of PCTs conducted for long durations can be used to confirm the values of $K$ and $\sigma$ that are derived from the SPFT tests (see Section G-4.1.4).

There are two degrees of freedom for parameter variation in PCTs, temperature and $S / V$, excluding test duration. It is.recommended that PCTs be performed at a minimum of four separate temperatures between 20 and $90^{\circ} \mathrm{C}$ and at two $\mathrm{S} / \mathrm{V}$ ratios. Tests at elevated temperatures are needed to measure the trends in the corrosion behavior as a function of temperature and to determine if the corrosion mechanism changes with temperature. Use of higher $\mathrm{S} / \mathrm{V}$ ratios provides another means of accelerating the extent of reaction. However, there are limits to the values of $\mathrm{S} / \mathrm{N}$ that are practicable. At $\mathrm{S} / \mathrm{V}$ ratios $>20,000 \mathrm{~m}^{-1}$, test artifacts become important. Initial alkali ion exchange and dissolution of fines can increase leachate ionic strength and $\mathrm{pH}$ to values that are unrealistic for a disposal system subject to open-system mass transport. In PCTs conducted in containers impermeable to air, the available $\mathrm{CO}_{2}(\mathrm{~g})$ can also be consumed, which compounds the $\mathrm{pH}$ excursion from the ion-exchange and limits the formation of important carbonate minerals. Consumption of water from hydrolysis of the glass becomes an important consideration, as the $\mathrm{S} / \mathrm{V}$ could be a steeply time-varying function. This makes interpretation of the test data much more difficult. Consequently, it is recommended that the $\mathrm{S} / \mathrm{V}$ be limited to a maximum of $20,000 \mathrm{~m}^{-1}$. 


\section{G-4.4 PRESSURIZED UNSATURATED FLOW TEST}

The PUF test is a new technique developed at PNNL for testing waste forms (McGrail et al. 1997a and 1997b). The experimental design provides a novel way to study waste form corrosion behavior under unsaturated conditions, subject to open-system flow and transport. Like the SPFT test, the PUF test provides three degrees of freedom for parameter variation: temperature, glass surface area, and flow rate.

The basic test apparatus consists of a column packed with glass particles (or other material) of a known size and density, and a computer data acquisition and control system (see Figure G-4.4). The column is fabricated from a chemically inert material so that dissolution reactions are not influenced by interaction with the column. A porous titanium plate of proprietary design is sealed in the bottom of the column to ensure an adequate pressure differential for the conductance of fluid while operating under unsaturated conditions (Wierenga et al. 1993). Titanium was chosen because it is highly corrosion resistant

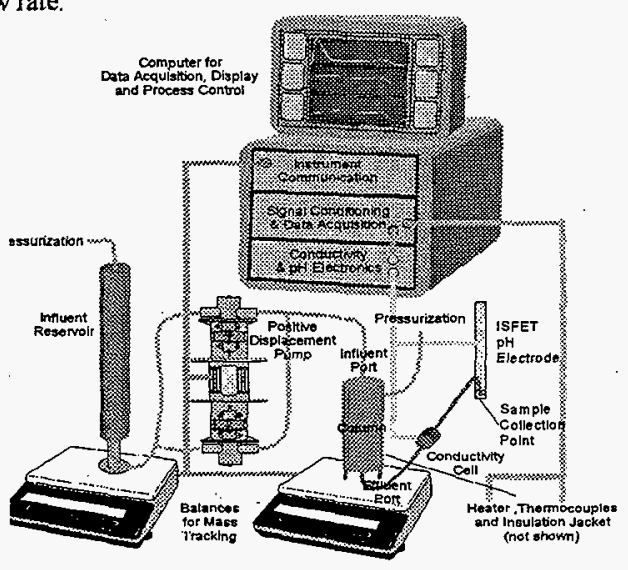

Figure G-4,4. Schematic of PUF Apparatus and has excellent wetting properties. When water saturated, the porous plate allows water but not air to flow through it, as long as the applied pressure differential does not exceed the air entry relief pressure or "bubble pressure" of the plate. The computer control system runs LabVIEWTM (National Instruments Corporation) software for logging test data to disk from several thermocouples, pressure sensors, inline sensors for effluent $\mathrm{pH}$ and conductivity, and column weight from an electronic balance to accurately track water mass balance and saturation level.

Several important findings have resulted from PUF experiments that have been performed on LD6-5412 glass and SRL-202 glass, a reference HWW glass for the Defense Waste Processing Facility. With LD6-5412 glass, precipitation of zeolitic secondary phases was correlated with an acceleration of the glass reaction rate, exactly as was found in PCTs conducted at a high surface area-to-volume ratio $(\mathrm{S} / \mathrm{V})$ of $20,000 \mathrm{~m}^{-1}$ and the same $90^{\circ} \mathrm{C}$ temperature. However, in the PCTs, the accelerated reaction stage did not occur before about 120 to 240 days: In the PUF test, the accelerated reaction stage was reached after only about 12 days. This is an acceleration factor of about 10 to 20 , even though the specific surface area of the glass used in the PUF test was about 10 times smaller than the specific surface area of the glass used in the PCTs. In the PUF test with SRL-202 glass, precipitation of an aluminosilicate phase, pianlinite $\left[\mathrm{Al}_{2} \mathrm{Si}_{2} \mathrm{O}_{6}(\mathrm{OH})_{2}\right]$, was correlated with a $50 \%$ decrease in volumetric water content, indicating a change in the hydraulic properties of the sample. This is this first evidence ever reported that corrosion and secondary phase precipitation can induce changes in the unsaturated hydraulic 


\section{Based on PNNL Report (PNNL-11834) To Be Published}

properties of a glass waste form. Experiments with $\mathrm{Pu}$-containing glass packed in a thin layer between two layers of SRL-202 glass (not containing Pu) have also shown that $>90 \%$ of the $\mathrm{Pu}$, brought into solution from corrosion of the Pu glass, exits the column as a colloid. This is important because to exit the column as a colloid in this experiment, the colloids must have been transported approximately half the column length through a layer of crushed SRL-202 glass. Consequently, the PUF test provides a means to study the formation and transport of radiocolloids under unsaturated flow conditions.

Based on the findings from the PUF experiments that have been run to date, the test will play an important role in the overall testing strategy. First, because the test combines glass corrosion, unsaturated flow, and mass transport processes under controlled conditions, it is ideally suited to provide data for validation of the reactive transport model being used for long-term performance calculations for the disposal system (Bacon and McGrail 1997). Second, the demonstrated ability to accelerate the transformation of the glass into alteration products means that the test will provide critical information on these phases, and the stability of the glass with respect to the formation of these phases, in relatively short periods of time. Third, aged samples from the test can be independentiy evaluated for changes in unsaturated hydraulic properties, thereby providing critical data for modeling fluid flow through the disposal system. Fourth, the flow-through configuration allows for different engineered-barrier materials to be tested in combination to evaluate interactive effects on glass corrosion rates and/or radionuclide release (see Section G-4.7).

Although the PUF test is assigned a key role in the overall testing strategy for the ILAW program, it must be recognized that because of the complex apparatus required, the number of PUF experiments that can be performed is constrained by relatively high costs per test, equipment availability, and access to skilled technicians to run the test. Consequently, it is recommended that PUF tests be performed at three different temperatures only. Also, because very little information currently exists on the effect of flow rate on the PUF test results, a series of tests should be performed on one vendor glass formulation that covers a range of flow rates. These experiments should be designed to examine whether the corrosion rates can be correlated with a reduced parameter, such as the ratio of volumetric flow rate to glass surface area, a well-defined correlating parameter in SPFT tests (McGrail et al. 1997c). Finally, tests are recommended with radioactive glasses (see Section G-4.6) and a series of materials interaction experiments with at least cement and glass combinations, but perhaps including iron or iron corrosion products as well (see Section G-4.7).

\section{G-4.5 OTHER TEST METHODS}

Other test methods have been used to measure the values of model parameters and to study glass corrosion behavior under site-relevant conditions. Some of the more commonly used test methods are described below. The reasons why these tests are not included in the testing strategy for Hanford LAW are also discussed. Basically, the other test methods described below provide little or no additional relevant information when compared with the tests proposed in Sections G-4.1 through G-4.4. 


\section{DOE/RI-97-69, Rev. 0 \\ Based on PNNL Report (PNNL-11834) To Be Published}

\section{G-4.5.1 Soxhlet Tests}

Soxhlet tests provide a method for measuring the glass corrosion rates under highly dilute conditions. Soxhlet tests are performed by reacting a sample with condensed fluid in a refluxing apparatus. Water is boiled from a reservoir, condensed in a reflux tube, then allowed to drip into a small cup that contains the sample. The solution in the sample cup is refreshed as condensate drips into the sample cup. Complete volume replacement of the fluid in the cup typically occurs every few minutes but the precise replenishment time depends on the sample cup volume and refluxing conditions. The refluxing action provides an effective flow rate that can be varied by controlling the applied heat flux to the device. Tests are usually run to attain a flow rate sufficiently high that the solution in the sample cup remains highly dilute. The corrosion rate can be measured by periodically removing a sample of the solution in the reservoir for analysis. The Materials Characterization Center Soxhlet test (MCC-5) specifies the use of a monolithic sample and an all-Teflon apparatus (Strachan et al. 1981), although crushed samples and stainless steel apparatuses have also been used.

Soxhlet tests have been utilized to measure the initial corrosion rate of glasses as a function of the temperature, particularly for European HLW glasses (Delage and Dussossoy 1991; Tovena et al. 1994). Unfortunately, because the system operates with condensed vapor, the dissolution rate can only be easily measured at the $\mathrm{pH}$ of distilled water at the test temperature. . Because the dissolution rate is required over a pH range of 6 to 13, the SPFT technique (see Section G-4.1) is preferred for these measurements.

\section{G-4.5.2 MCC-1 Test}

The MCC-1 static leach test method was developed to compare the durabilities of candidate waste forms developed to stabilize high-level nuclear wastes (DOE 1982). The test procedure has been standardized by the ASTM (ASTM 1992). The method calls for placing a monolithic specimen of known geometric surface area into a volume of solution such that the $S / V$ is $10 \mathrm{~m}^{-1}$. The test may be performed with demineralized water, a reference silicate solution, or a reference brine. The reference temperature and time are $90^{\circ} \mathrm{C}$ and 28 days, although temperatures of 40 or $70^{\circ} \mathrm{C}$ and other durations can be used. (a) The MCC-1 test typically provides a solution-dominated system in that the leachate remains dilute as the glass dissolves. However, tests conducted for long time periods may be affected by changes in solution chemistry. Samples corroded in MCC-1 tests show details of the chemical and physical alteration of the glass surface and have provided insight into mechanisms controlling the initial stages of corrosion (Bates et al. 1991; Oversby and Phinney 1992).

While the MCC-1 method was originally designed to compare the relative chemical durabilities of candidate waste forms, the test can be used to characterize several aspects of the corrosion process in conjunction with a corrosion mechanism. Tests conducted for short time periods provide a simple means of measuring the glass corrosion rate under dilute conditions.

\footnotetext{
(a) The MCC-2 test procedure is a.variation of the MCC-1 procedure that permits reaction temperatures of 110,150 , and $190^{\circ} \mathrm{C}$.
} 
DOE/RL-97-69, Rev. 0

\section{Based on PNNL Report (PNNL-11834) To Be Published}

Tests have been performed in buffer solutions or solutions spiked with various glass components to determine the effects of the leachate chemistry on the glass corrosion rate (Advocat et al. 1991). Longer term tests can be run to monitor the alteration of the glass surface during corrosion to investigate the corrosion mechanism (Strachan 1983; Bates et al. 1991). However, because each of these processes is covered in greater depth using SPFT and PCTs, there is no. compelling need to include MCC-1 tests in the testing strategy for LAW glass.

\section{G-4.5.3 MCC-3 Solubility Test}

The MCC-3 test was designed to measure the maximum solubility of a waste form in the solution of interest (MCC 1984). This test method formed the basis of the PCT. Tests were to be conducted until the solution composition did not vary with the reaction time (i.e., until the glass "saturated" the solution). However, application (Shade and Strachan 1986) of the test method showed that 1) constant solution compositions were not achieved within a few weeks, and 2) the solution composition depended on the particle size of the glass used. The first observation is a direct result of the glass reactivity, while the second is due to the different $\mathrm{S} / \mathrm{V}$ that results from the different total surface areas of different sieve fractions. Tests conducted at higher S/Vs usually generate more concentrated solutions. The MCC-3 procedure was subsequently modified such that 1) a single size fraction is specified, and 2) the test vessel is continuously agitated during the test, usually by placing the vessel on a roller. The PCT has effectively replaced the MCC-3 test in most laboratories, although all of the complications associated with the use of crushed glass found during development of the MCC-3 tests are common to the PCT procedure.

\section{G-4.5.4 Periodic Replenishment Tests}

Several test methods have been developed in which leachate solution is periodically removed from an ongoing static test and replaced with an equal volume of fresh solution. Such replacement tests have been used to simulate very low flow rates that cannot be attained using mechanical pumps (Barkatt et al. 1983 and 1984). Either monolithic or crushed samples can be used, and different starting solution compositions can be used. Specific test methods have different replacement schedules and replace different fractions of the total solution volume. For example, the test designated by the International Standardization Organization (ISO) calls for replacing the entire solution volume daily for the first week, every week for eight weeks, monthly for six months, and twice yearly thereafter (Hespe 1971). The American Nuclear Society test method ANS 16.1 and variations of the ANS 16.1, such as the Dynamic Leach Test (DLT) and the Accelerated Leach Test (ALT), are similar total volume exchange tests. They differ primarily in the replacement schedules. These tests were developed to characterize materials from which contaminants are assumed, a priori, to be released by a diffusion-controlled process, such as with grouts and cements. Although the ANS 16.1 test is required for LAW in the Phase 1 Hanford Privatization Contracts, this type of test provides little insight to the long-term corrosion behavior of glass waste forms. This is because concentrations of the waste form components and solution $\mathrm{pH}$ change over time in the fluid contacting the waste form until the fresh fluid is injected, which then causes a sudden and abrupt change in the solution chemistry. Such conditions are extremely difficult to interpret and cannot be treated adequately with conventional geochemical computer codes. Consequently, no periodic replenishment tests are proposed in this plan. 


\section{DOE/RL-97-69, Rev. 0 \\ Based on PNNL Report (PNNL-11834) To Be Published}

\section{G-4.5.5 Unsaturated or "Drip" Test}

The Unsaturated Test or "drip test" was developed at ANL to simulate the corrosion of a waste glass that is intermittently contacted by transient water in an unsaturated geologic environment, such as that at Yucca Mountain (Bates and Gerding 1986). A sample of the waste form and possibly other engineering or geologic materials is placed in the center of a reaction cell. A small amount of liquid water is injected through a septum and allowed to drip from the feed tube onto the upper surface of the sample. Initial aliquots of added water are vaporized until the air is saturated; subsequent aliquots drip onto the sample. Solution that drips from the sample during the test and collects in the bottom of the test vessel can be analyzed to quantify the amount of glass that has dissolved and been transported away from the waste form. The corroded glass can also be analyzed to assess the corrosion mechanism, study materials interactions, and identify any alteration phases that form (Woodland et al. 1991). Unsaturated tests are being used as one of the primary sources of radionuclide release data in a total system performance assessment for the Yucca Mountain Site (Stout and Leider 1996).

Unfortunately, the "drip test" has several drawbacks with respect to evaluating LAW glass behavior relevant to disposal at the Hanford Site. First, the drip test is a quasi-static method, similar to the periodic replenishment tests discussed in Section G-4.5.4. Consequentiy, the same difficulties exist in applying conventional modeling tools for modeling the experiment as were previously described for these tests. Second, the exact amount of fluid in contact with the sample at any given time is not known (and likely variable), so the effective $\mathrm{S} / \mathrm{V}$, a key parameter needed in modeling, is poorly defined. Finally, the drip test was originally designed as a service condition test corresponding to a particular scenario at the Yucca Mountain Site where fluid may periodically drip on the waste packages from fluid-filled fractures. This "drip" scenario does not represent a possible hydrodynamic condition for the $\mathrm{LAW}$ disposal system, which is located in a shallow, sandy soil. The PUF method is preferred for unsaturated testing because it applies a steady unsaturated hydraulic condition on the sample, and the total amount of water in contact with the sample is continuously monitored. ${ }^{\text {(a) }}$ These features make the PUF test amenable to modeling using standard computational methods and tools.

\section{G-4.5.6 Accelerated Dissolution Test}

The accelerated dissolution test (ADT) was designed to measure the dissolution rate of a glass in the presence of its alteration phases and in a solution that is in near equilibrium with those phases. The alteration phases are generated by vapor hydration of a sample of the glass being evaluated, and the nearly saturated solution is generated in a PCT conducted at high S/V and at the temperature at which the dissolution rate is to be measured. The dissolution rate is measured by mass loss of a fresh monolithic sample. To date, the ADT has only been applied to measure the dissolution rate of the LD6-5412 glass (Ebert et al. 1996). The rate measured with ADTs was consistent with that estimated from long-term PCTs and that extrapolated from VHTs. However, an inoculation period existed in which the dissolution rate was at first very low and then increased

(a) The capability to monitor spatial variations in moisture distribution during a PUF test will be available shortly at PNNL with the installation of an X-ray computed microtomography system. 
DOE/RL-97-69, Rev. 0

\section{Based on PNNL Report (PNNL-11834) To Be Published}

because of the effects of the alteration phases. The occurrence of this period, which was of different durations in replicate tests, is not fully understood, but may be related to time needed for the solution and alteration phases to equilibrate. A specific role for the ADT has not been identified in this plan, but the test will likely continue to be used periodicaliy to confirm long-term dissolution rates measured in VHTs and PCTs.

\section{G-4.6 REQUIRED TESTS WITH RADIOACTIVE GLASSES}

In Sections G-4.1 through G-4.5, no distinction was made with regards to testing "cold" or fully radioactive glasses. Because the ultimate goal of the testing program is to evaluate longterm radionuclide release rates, and not glass corrosion rates per se, some testing must obviously be performed with radionuclide-containing materials. However, it is not required that all testing be performed with radioactive materials. This is because the radionuclides found to be of most concern in the performance assessment (Mann et al. 1997) for the LAW disposal system are ${ }^{99} \mathrm{Tc}$, ${ }^{79} \mathrm{Se}$, and ${ }^{129} \mathrm{I}$. These radionuclides are extremely soluble under the oxidizing conditions that are expected at the site. Consequently, the rate of glass corrosion ultimately determines the rate of release for these important elements. However, at very long times, $\mathrm{Pu}$ and $\mathrm{U}$ isotopes also contribute to the computed doses from the groundwater pathway (Mann et al. 1997). These elements are expected to form sparingly soluble precipitates in the disposal vault and may also be transported as colloids, so the release rates will not depend directly on the corrosion rate of the glass. For these elements, experiments with radioactive glasses are needed to identify the solubility-controlling phases. Release rates of the soluble radionuclides also need to be checked for congruency with the rate of glass corrosion to eliminate the possibility of a mechanism, such as ion exchange, that could selectively enhance release rates.

Because only very limited data have been obtained with a single LAW glass (LD6-5412) doped with ${ }^{99} \mathrm{Tc}$, it is difficult at this time to define what amount of testing with radioactive glasses is required. The level of testing also depends strongly on future funding levels for the LAW disposal program. A reasonable conjecture includes a reduced set of VHT, PCT, and PUF tests with a fully radioactive glass containing each radionuclide of interest. The reduced set may include VHTs at one temperature, PCTs at two temperatures but only the highest $\mathrm{S} / \mathrm{V}$, and PUF experiments; also at two temperatures, but at two flow rates and one glass surface area. Concentrations of the radionuclides in the test glasses likely should not reflect the expected activity levels in the actual glass product. Consideration should be given to doping the test glasses at significantly higher.levels than expected so that it is easier to identify secondary solids containing the radionuclides. Because the radionuclide concentrations and radioactivity levels of LAW glass are very low, there is little or no concern regarding radiolysis-induced experimental artifacts or having the radioactive glasses exhibit different long-term corrosion behavior when compared with nonradioactive glasses. 


\section{DOE/RL-97-69, Rev. 0 \\ Based on PNNL Report (PNNL-11834) To Be Published}

\section{G-4.7 MATERIALS INTERACTION TESTS}

The LAW disposal system will include the following additional materials, besides glass, that are used in construction or as part of the waste package: 1) concrete used in the vault walls, ceiling, and floor; 2) carbon or stainless steel containers used to hold the glass; and 3) filler material used inside the containers to consume void space. Of these materials, the concrete is of the most interest because of the anticipated volume required, approximately 320,000 metric tons (Burbank 1997), and the chemical effect of the concrete in increasing $\mathrm{pH}$ and $\mathrm{Ca}, \mathrm{Na}$, and $\mathrm{K}$ concentrations. Corrosion of the metal containers will generate iron oxyhydroxides that are known to adsorb or coprecipitate with $\mathrm{Si}$ (Harder 1978). This can act as an additional sink for Si, resulting in enhanced rates of glass corrosion (McVay and Buckwalter 1983; McGrail 1986).

However, iron hydroxide precipitates may also have a beneficial effect in that they are well known adsorbents for a wide variety of metals, and so could lower release rates for some radionuclides. No specific filler material has been identified, so the significance of this material to glass corrosion behavior cannot be assessed at this time.

Because the concrete is used exclusively on the exterior of the vaults, the interactive effects of the concrete on the glass (if any) will most likely be confined to a region at the "interface" between the two materials. This is because diffusion and/or advection limit the total mass flux of $\mathrm{OH}^{-}, \mathrm{Ca}^{2+}$, etc. from the concrete that is available for reaction with the glass. To properly test this mass transport rate limited process in the laboratory, a technique is required where mass transport by diffusion and/or advection from the concrete into the glass can be controlled. Batch experimental methods, such as the VHT or PCT, are intentionally designed to be well-mixed systems to avoid mass transport constraints on the reaction processes.

Consequently, these methods are unsuited for this materials interaction study. Fortunately, the PUF technique provides a means to control mass transfer and transport rates by the particle size and flow rate used in the test. The concrete and glass can be configured sequentially, such that the water can "equilibrate" with the concrete before entering the porous glass bed. By comparing differences in corrosion rates and radionuclide release, with and without the concrete, and by examining the alteration products formed, especially at the interface between the two materials, a good understanding of the interactions between the materials can be developed.

Interactive effects with the container or iron corrosion products are more difficult to assess because the material will be distributed throughout the disposal system, including the interior region of each vault. In this case, the mass transport limitations discussed above for the concrete do not apply, at least on a scale larger than a single waste package. A highly localized assessment of the interactive effect could be obtained by running a VHT where the container material and glass are "sandwiched" together. An alternative would be to run PCT or PUF experiments where the glass and container material particles are mixed together in volume percentages equivalent to what is expected in the current disposal system design. Glass corrosion rates would then be directly compared with and without the metal present to obtain a direct assessment of the interactive effects, if any. Care must be exercised in these tests to ensure that the available $\mathrm{O}_{2}$ is not consumed from oxidation of the steel. 


\section{Based on PNNL Report (PNNL-11834) To Be Published}

\section{G-4.8 ROLE OF NATURAL ANALOGS}

Analogy is a scientific method that uses inference from certain resemblances to imply a probable further similarity (Ewing and Jercinovic 1987; Petit 1992). The term natural analog refers to a material or process that resembles those expected in a waste disposal system or the methodology used to study and assess them. The analysis of analog materials has been used to enhance confidence in the validity of long-term predictions made with mechanistic models, as well as assisting in the development of those models (ASTM 1991). By studying the alteration of natural materials that has occurred over millions of years due to weathering in a range of terrestrial environments, insight has been gained into the long-term corrosion behavior of waste glasses in a disposal environment. This is done by characterizing the natural alteration of the analog material and comparing it to alteration produced in laboratory tests with naturally occurring or chemically identical synthetic materials. In addition to studying the natural alteration of a material, it is also important to identify the alteration mode(s) that controls corrosion of the analog material and to verify that the same process that controls the rate in the short-term testing also controls the long-term behavior that is being modeled. Applications of natural analogs include

- comparing alteration products generated during long-term corrosion of natural glasses to those generated in accelerated laboratory tests to verify experimental methods of accelerating glass corrosion

- $\quad$ studying specific reaction processes that are important in waste glass corrosion and are highlighted in the corrosion mechanism of a natural material

studying the relationship between the kinetics of natural glass corrosion measured in short-term laboratory tests and the known long-term durability of the glass to verify that the appropriate reactions and processes are modeled for long-term calculations

- calibrating the degree to which a laboratory test accelerates a corrosion mode.

The use of natural analogs to extract kinetic information is usually limited to bounding estimates because of the uncertain and changing conditions to which the analog material has been subjected, including wet/dry cycling, variations in temperature and water composition, etc., and uncertainty regarding the age of the sample itself. In most cases, kinetic information must be extracted by examining reacted solids that are usually incomplete assemblages of alteration phases. Nevertheless, corroded natural glasses provide valuable insight regarding corrosion processes that are important to long-term corrosion and confidence in the accelerating properties of laboratory tests.

Geologists have studied samples of basaltic glasses recovered from marine, geothermal, and subglacial environments. Corrosion of basaltic glasses results in the formation of palagonite, which is a generic term for an assemblage of alteration phases that includes clays and zeolites. The same phases have been observed to form in nature and in laboratory tests (Lutze 1985; Byers et al. 1985). In both natural settings and in laboratory tests, the amounts and in some cases the 
identities of phases that are formed depend both on the glass composition and the environmental conditions (e.g., the temperature, chemistry, and volume of the solution contacting the glass). Waste glasses have been shown to react similarly to basalt glasses in laboratory tests and to transform to many of the same phases. This provides evidence that 1) the laboratory test accelerates the corrosion behavior of basalt glasses and leads to the same phases formed in nature over very long time periods and 2) the same processes that control long-term basalt glass corrosion in terrestrial sites (and under terrestrial conditions) also control the long-term corrosion of waste glasses.

Long-term testing of natural analog glasses using VHT and PCT methods is being funded at ANL through separate DOE programs. Consequently, there are no current plans to support additional VHT and PCT testing of natural analogs through the LAW disposal project. However, the PUF method has only recently been developed, and no natural materials have been examined using this test method. Consequently, a small number of long-term PUF tests should be performed using a selected natural analog. The preferred material would have a much higher alkali content than is typical of rhyolitic or basaltic glasses and would have been subjected to environmental weathering conditions analogous to those expected for the disposal system. One possible site for such samples is the obsidian flows at Newberry Crater, Oregon (25 miles south of Bend, Oregon), which range in age from 1,200 to about 6,700 years B.P. This area has an arid environment similar to that of the Hanford Site and potentially provides similar analogs at different ages within a short distance of each other. Regardless, the selected natural analog sample for study must be as well-characterized as possible in terms of the sample age and weathering conditions if it is to be useful for comparing against data from PUF experiments.

\section{G-4.9 LABORATORY TESTING STRATEGY SUMMARY}

Table 4.1 represents a compilation of the recommended testing discussed in Sections G4.1 through G-4.6. To the best of the authors' current knowledge, this is the minimum matrix of laboratory tests required to fully characterize the long-term corrosion and radionuclide release behavior of a glass waste form for disposal at the Hanford Site. A duration limit of 2000 days was selected because the major decisions regarding acceptable glass compositions and disposal system design need to be made in approximately the next 5 years. Consequently, tests beyond this time frame will have little impact on the overall program.

A key issue not discussed in the strategy up to this point is variability. Variability in the waste stream delivered to the private vendors will result in variability in the composition of the glass product; i.e., no single glass composition represents the entire inventory of glasses to be produced during the vitrification campaigns. Glass compositional variability must also be addressed in evaluating the long-term performance of the disposal system. One approach is to identify a selected set of glasses that represent compositional extremes and then perform a reduced set of experiments on these glasses. The results from these tests can then be used to bound the release rate behavior for entire compositional space. Once data are available on the reference vendor glass compositions and the variability expected during processing is quantified, specific compositions and tests can be proposed. 
DOE/RL-97-69, Rev, 0

Based on PNNL Report (PNNL-11834) To Be Published

Table G-4.1. Master Test Matrix for Long Term Performance Evaluation of a Glass

\begin{tabular}{|c|c|c|c|c|c|c|}
\hline Test Method & Temp & $\mathrm{pH}$ & $\begin{array}{l}\text { Flow } \\
\text { Rate }\end{array}$ & $\begin{array}{l}\text { Surf. } \\
\text { Area }\end{array}$ & $\begin{array}{l}\text { Sol. } \\
\text { Vol. }\end{array}$ & $\begin{array}{c}\text { Duration Range } \\
\text { (days) }\end{array}$ \\
\hline SPFT $\left(k, E_{2}, \eta\right)$ & 4 & 6 & Var.(1) & 1 & & $14-30$ \\
\hline $\operatorname{SPET}(K \sigma)$ & 1 & 2 & 15 & 1 & & $14-30$ \\
\hline VHT & $\frac{1}{4}$ & & & & & $1-2000$ \\
\hline PCT & 4 & & & $2^{(2)}$ & $1^{(2)}$ & $30-2000$ \\
\hline PUF & 3 & & 3 & 2 & & $30-2000$ \\
\hline Rad_Glasses & & & & & & \\
\hline $\begin{array}{r}\text { VHT } \\
\text {. }\end{array}$ & 1 & & & & & $1-365$ \\
\hline PCT & 2 & & & $1^{(2)}$ & $1^{(2)}$ & $30-2000$ \\
\hline PUF & 2 & & 2 & 1 & & $30-2000$ \\
\hline
\end{tabular}

(1) Flow rate sufficiently high so that $Q / K \approx 0$.

(2) Varied as S/V. 


\section{DOE/RL-97-69, Rev. 0 \\ Based on PNNL Report (PNNL-11834) To Be Published}

\section{G-5.0 FIELD TESTING}

Field testing provides a unique opportunity to obtain site-relevant data on the corrosion behavior of waste forms under conditions that more closely approximate service conditions than is possible in the laboratory. Recognizing this fact, several burial studies with glass waste forms have been conducted in the United States and abroad. One of the first studies involving glasses was carried out in the early 1980 s at the Stripa Site in Sweden. The Stripa Site is an abandoned iron mine located in a granitic formation approximately $350 \mathrm{~m}$ below the surface. Specimens were fabricated in a "pineapple slice" geometry and stacked into assemblies that were either heated to $90^{\circ} \mathrm{C}$ or maintained at ambient mine temperatures $\left(8\right.$ to $\left.10^{\circ} \mathrm{C}\right)$. Samples were extracted at predetermined intervals $(0.25,0.5,1$, and 2 years) for extensive characterization using surface spectroscopic and microscopic analytical techniques. In the United States, a comprehensive field test involving HLW glasses was performed for the Materials Interface Interaction Tests (MIITs) at the Waste Isolation Pilot Plant (WIPP) in Carlsbad, New Mexico. Located approximately $650 \mathrm{~m}$ below the surface in the Salvo salt formation, a wide array of glasses and waste package materials were tested for 5 years. Pineapple slices of test samples were stacked on heated Teflon assemblies in such a manner as to test a variety of interfacial reactions. The United States also has participated in burial studies conducted at the Mol Site in Belgium (clay geology) and Ballidon Site in the United Kingdom (limestone) in an effort to test the performance of a simulated $\mathrm{HLW}$ glass (SRL-165) in other geologies.

At the Hanford Site, grout waste forms have been field tested in lysimeters at the Grout Waste Test Facility located in the 300 Area (Last et al. 1995). A lysimeter essentially consists of a corrugated steel container buried flush with the ground surface. Lysimeters can range in size from small soil-filled cans, a few centimeters in diameter and a few centimeters deep, to large caissons that are several meters wide and tens of meters deep. Lysimeters can be simply designed with little or no peripheral instrumentation, or they can be designed with extensive monitoring features, including devices for monitoring temperature, water content and matric potential and devices for extracting samples of water for chemical analysis. Lysimeters have been built and used at the Hanford Site for a variety of reasons, including the assessment of recharge rates, biointrusion studies, radionuclide transport studies, evapotranspiration studies, and field-scale waste-form performance tests (Gee and Jones 1985; Rockhold et al. 1995).

Although lysimeters have several disadvantages, they are a logical choice for field testing of the glass corrosion and contaminant transport models being developed for the LAW disposal system. The devices provide a way to combine a LAW glass, Hanford soil, and perhaps other engineered materials in a well-controlled test but on a scale that is not practicable in the laboratory. The test is controlled because the walls of the lysimeter form a physical boundary in the system being studied that defines a fixed volume for calculating water storage and tracer mass balance and restricting the geometry of flow within the lysimeter to essentially one dimension. Interpretation of complex temporal variations in tracer release and transport is much simpler in one spatial dimension. The field scale affords the opportunity to monitor contaminant release and transport in time and space that is not possible in laboratory experiments, such as with the PUF test (see Section G-4.4). This is especially true when operating under low moisture content conditions where the volume of solution available per cubic meter for collection of samples is small. 


\section{Based on PNNL Report (PNNL-11834) To Be Published}

Lysimeter experiments should be used as a tool to confirm the coupled glass corrosion and contaminant transport model described in Section G-3.0. For this purpose, there is no need to exclusively test glasses similar in composition to the vendor's formulation or to simulate natural conditions as much as possible. Instead, some experiments should be run with an applied steady flow rate of water and with a glass designed to have high corrosion rate so that it is easier to monitor contaminant release and transport during the test. It is also important that these experiments be designed and instrumented appropriately so that data can be collected to support validation studies of other key models being used on the $\mathrm{LAW}$ disposal program, such as a multiphase flow simulator. 
DOE/RL-97-69, Rev. 0

Based on PNNL Report (PNNL-11834) To Be Published

\section{G-6.0 MODELING THE DISPOSAL SYSTEM}

The previous discussion of the testing strategy would not be complete without a discussion of the linkage to modeling the disposal system, as this is the ultimate use of the data generated by the testing program. The fundamental objective of the performance assessment for disposing of $\mathrm{LAW}$ is to calculate the radiation dose to a future population as a result of any release and transport of radionuclides to the unconfined aquifer located approximately $70 \mathrm{~m}$ below the disposal facility. Computer models will be used to simulate the processes controlling the release and transport of radionuclides to the unconfined aquifer. The computer codes must perform three major simulation functions: 1) release of contaminants from the vitrified waste, 2) transport of those contaminants through the engineered system, and 3) transport through the vadose zone to the groundwater. In Section G-3.2, we presented the kinetic rate law for glass corrosion:

$$
J_{i}^{a}=v_{i} k e^{-\frac{E_{a}}{R T}}\left[1-\left(\frac{Q}{K}\right)^{0}\right] \prod_{j} a_{j}^{-\eta j}, \quad i=1,2, \ldots N ; j j=1,2, . . M
$$

Assuming that $\mathrm{k}, \mathrm{E}_{\mathrm{a}}, \eta, K$, and $\sigma$ are all known parameters developed from the laboratory testing program, to determine the mass flux of any component $i$ released from the glass to the aqueous phase, it is necessary to calculate the $\mathrm{pH}$ and ion activity product, $Q$. Because the calculation of these chemical variables depends on both the physical properties of the system, such as flow rate and glass surface area, and chemical properties, such as solubility products and the amounts and types of alteration products formed, functions (1) and (2) discussed above cannot be decoupled. A special type of computational model, called a reactive chemical transport model, is required for simulations.

In 1995, the Hanford Low-Activity.Waste Disposal Project selected a reactive transport code to calculate contaminant release rates from the engineered components of the disposal system (McGrail and Mahoney 1995). The Analyzer of RadionuclidE Source Term with Chemical Transport (AREST-CT) code describes multicomponent reactive transport in an isothermal, partially saturated, porous medium. The model includes chemical reactions between aqueous, gaseous, and solid phases. Reactions involving minerals are described through appropriate kinetic rate laws, along with a special option for treating irreversible reactions (such as glass corrosion) via the kinetic rate, Equation (G.2). Homogeneous reactions within the aqueous phase are assumed to be reversible with their reaction rates controlled by transport and local equilibrium mass action relations. Local equilibrium between a gas or gas mixture and the aqueous phase is treated through Henry's law. Solute transport includes contributions from advection, diffusion, dispersion, and radioactive decay.

Because of evidence from PUF experiments that significant changes in bydraulic properties may occur as a result of precipitation of secondary phases, it was decided in 1997 to incorporate a multiphase flow and transport capability into AREST-CT so that these property changes could be coupled to the flow field. The specific mechanisms incorporated in the code are changes in porosity, and hence hydraulic conductivity, caused by mineral precipitation/dissolution and changes in water saturation caused by water consumption/production in chemical reactions. 


\section{DOE/RL-97-69, Rev. 0 \\ Based on PNNL Report (PNNL-11834) To Be Published}

This was accomplished by coupling AREST-CT with STOMP, a nonisothermal, multiphase flow simulator (White and Oostrom 1996). The new coupled code is called STORM, Subsurface Transport Over Reactive Multiphases.

As it is currently configured, the STORM code represents a relatively complete model of the physical and reactive chemical transport processes that are required for simulating radionuclide release rates from the disposal system. However, several improvements to the code are needed to support long-term performance calculations, especially in more than one spatial dimension. These improvements can be classified in terms of 1) subprocess models and 2) numerical methods.

\section{G-6.1 SUBPROCESS MODEL DEVELOPMENT}

STORM has two subprocess models requiring further development: 1) adaptive reaction network and 2) composition-dependent hydraulic property model.

\section{G-6.1.1 Adaptive Reaction Network}

The set of reactions to be considered in a single STORM run, the reaction network, is fixed as specified in the input file. Consequently, careful consideration must be given to including all important solid and solution species that may be important in the system. This is extremely difficult because the system being modeled is usually changing chemically in time and space, often in ways that cannot be predicted a priori. Consequently, solid and solution species that were important at the start of a nun can become unimportant components in the reaction network and vice versa. A subprocess model is needed in STORM that adapts the reaction network periodically. This can be accomplished by conducting a phase boundary search at each node. The phase boundary search is a numerical implementation of the mineralogic phase rule. It operates by querying a general thermodynamic database and computing an ion activity product for each solid that could exist in the current system based on the elements being considered. Supersaturated phases are added to the reaction network, and undersaturated phases can be deleted. However, because the dissolution rate of a phase is finite, deletion of the phase from the network is constrained until the total mass falls below some specified value.

\section{G-6.1.2 Composition-Dependent Hydraulic Property Model}

Unsaturated flow experiments with glass waste forms have shown that the dissolution of the glass and subsequent formation of secondary minerals, such as zeolites and clays, can change the unsaturated flow properties of the glass (McGrail et al. 1997c.). Constitutive equations are used in computational modeling of multiphase flow to relate changes in flow properties, such as hydraulic conductivity and permeability, to changes in primary variables, such as matric potential or volumetric water content (Tietje and Tapkenhinrichs 1993). For example, a water-retention function developed by van Genuchten (1980) is commonly used in modeling unsaturated flow in porous media

$$
\theta=\theta_{r}+\left(\theta_{s}-\theta_{r}\right) /\left[1+(\alpha \psi)^{n}\right]^{m}
$$




\section{DOE/RL-97-69, Rev. 0 \\ Based on PNNL Report (PNNL-11834) To Be Published}

where $\theta, \theta_{n}$ and $\theta_{s}$ are water content, residual water content, and saturated water content, respectively, $\psi$ is matric potential, and $\alpha, n$, and $m$ are fitted parameters that are related to the physical properties of the porous medium. Physical properties, such as porosity, tortuosity, air entry matric potential, residual moisture content, etc., are typically assumed as invariant properties of the matrix, and so $\alpha, n$, and $m$ are assumed to be constant as well. Such assumptions are invalid in chemically reactive systems where macroscopic changes in physical and chemical properties can be induced by interphase mass transfer reactions that affect the pore scale. In general, the most important mass-transfer reactions involve dissolution of primary solid phases and concomitant precipitation of secondary solid phases.

A fundamental physicochemical basis for modifying the empirical fitting coefficients used in constitutive relationships, like the van Genuchten function, for multiphase flow through a system containing fractured glass should be developed. One possible approach to develop an appropriate model is to conduct experiments where hydraulic and physicochemical property data are obtained on uncorroded and corroded glass samples, possibly obtained from PCT and PUF experiments. This data set will form the basis for developing physicochemical constitutive relationships for unsaturated flow. These relationships can then be tested by comparing computer simulations with measurements of the solid phase and moisture distribution during PUF tests (see Section G-4.4).

\section{G-6.2 NUMERICAL METHODS}

The vitrified waste may be in the form of large glass blocks riddled with stress fractures. Berkowitz, Bear, and Braester (1988) suggested that solute transport in fractured media can be considered at a number of different scales. A near-field scale would include a few discrete fractures near the source. At a far-field scale, the fractured media could be treated as a continuum that is representative of an equivalent porous medium in which the repeating fractures behave as large pores. Their work focused on a contaminant source surrounded by a fractured porous medium. The fractured glass waste packages emplaced in a vault

(Figure G-2.1) presents a different situation; the contaminants are already distributed within the glass matrix and are released as the glass dissolves. Given the low flow rates through the vault, the contaminants will be mixed by diffusion within each fracture. If stress fractures in the glass waste form are numerous and closely spaced, a continuum approach to modeling flow and transport through the vault will likely be adequate. Consequently, developing a model capable of handling flow and transport in discrete fractures is not warranted at this time.

Currently, STORM executes on a fixed, 2-D cartesian finite grid. This makes the code inefficient when handling sharp concentration fronts that commonly develop in reactive transport simulations. Consequently, implementing an adaptive gridding algorithm is recommended. Adaptive gridding provides a means to increase the number of computational cells in regions where sharp concentration fronts exist and coarsens the grid where concentrations are uniform. This refinement better captures the movement of these fronts with less numerical dispersion and increases execution speed by putting extra grids at only those locations where they are needed. 
DOE/RL-97-69, Rev. 0

\section{Based on PNNL Report (PNNL-11834) To Be Published}

Two-dimensional simulations of coupled unsaturated flow and reactive transport with STORM require significant computing resources. A two-dimensional simulation with 22 aqueous species, 9 solid species, 10 equilibrium reactions, and 10 kinetic reactions on a 30 by 35 grid requires 1 week to reach a simulation time of 20,000 years running on a Sun Ultra 1 . A sensitivity analysis consisting of multiple two-dimensional runs would therefore take years to complete.

Several alternatives exist for decreasing the execution time of the code. The simplest is to execute the simulations on a workstation with a faster scalar central processing unit (CPU). Workstations are available that are several times faster than a Sun Ultra 1; within 5 years, workstations will be available that are 10 to 100 times faster than a Sun Ultra 1. A second alternative is to adapt STORM for execution on a machine with multiple, parallel processors. Currently, an effort is underway at PNNL to develop a parallel multiphase flow and reactive transport code, targeted for execution on an IBM NWMPP1 computer, capable of 247 GFLOPS. However, the reactive transport algorithm used in this code, operator-splitting, is likely to be restricted to much smaller time steps than the global-implicit algorithm used in STORM. Once this new code is available, testing will be performed to determine the relative efficiency of two codes in running an actual LAW disposal system simulation. If significant improvements in execution time are demonstrated on a realistic simulation, then the techniques and algorithms developed from the research program on parallel multiphase flow and reactive transport codes may be implemented in a parallel version of the STORM code so that it may be used to solve the larger problems required for the LAW disposal system performance assessment.

\section{G-6.3 DISPOSAL SYSTEM SIMULATIONS FOR THE PERFORMANCE ASSESSMENT}

The ultimate objective of the laboratory and field testing, and model development activities discussed in the previous sections of this report is to provide technically credible calculations of radionuclide release and transport in support of a formal performance assessment for the חLAW disposal system. The general methodology (Mann et al. 1998) is to divide the problem into logical parts that correspond to the computer simulation tools that will be applied in different parts of the problem domain. Figure G-6.1 illustrates the recommended overall computational strategy. The very-near-surface infiltration rate provides a key boundary condition for the remainder of the simulations. The coupled unsaturated flow, chemical reactions, and contaminant transport simulator (see Section G-6.0) is applied from just below the root zone to some distance into the soil (probably several meters) below the floor of the disposal vault. This region is defined as the near field. Water exiting the region near the vault is expected to be of high ionic strength and $\mathrm{pH}$ and this plume will migrate down into the soil column for some distance until dispersion and chemical interactions with the soil components attenuate it. Beyond this depth, the chemical composition of the migrating fluid will likely change very little. Consequently, it is possible to limit the domain over which computationally intensive reactive chemical transport simulations must be performed by switching to a relatively simple vadose zone flow and transport simulation in the far-field domain. The radionuclide flux exiting the vadose zone to the unconfined aquifer is computed with this model and is used as a boundary condition for the unconfined aquifer flow and transport simulator. The final step in the methodology is to compute the impacts, if any, from ingestion, inhalation, and external radiation to humans exposed to the contaminants by withdrawing water from the aquifer and using it for drinking, farming, and 


\section{Based on PNNL Report (PNNL-11834) To Be Published}

other purposes.

The methodology outlined in

Figure 6.1 is remarkably robust for conducting a performance assessment. Each simulation tool is based on basic principles of physics, chemistry, and thermodynamics. No ad hoc assumptions are made about the performance of the waste form or other components of the engineered and natural system. Consequently, changes in boundary conditions, such as infiltration rate, or scenarios, such as an assumed failure of the capillary break, can be quantitatively assessed in terms of their overall impacts on system performance. Of course, the database needed to support the mechanistic models used in the selected simulation tools is substantial. In this report, we have attenipted to define the minimum required data set to support the coupled unsaturated flow, chemical reactions, and contaminant transport simulator (see Section G-4.0). Although a considerable amount of testing is required, it is not intractable. Similar statements can be made about the other parts of the methodology.

Consequently, the approach outlined in Figure G-6.1, and especially the laboratory and field testing required to support it, are not unreasonable or unrealistic, assuming current programmatic funding levels and schedule are maintained

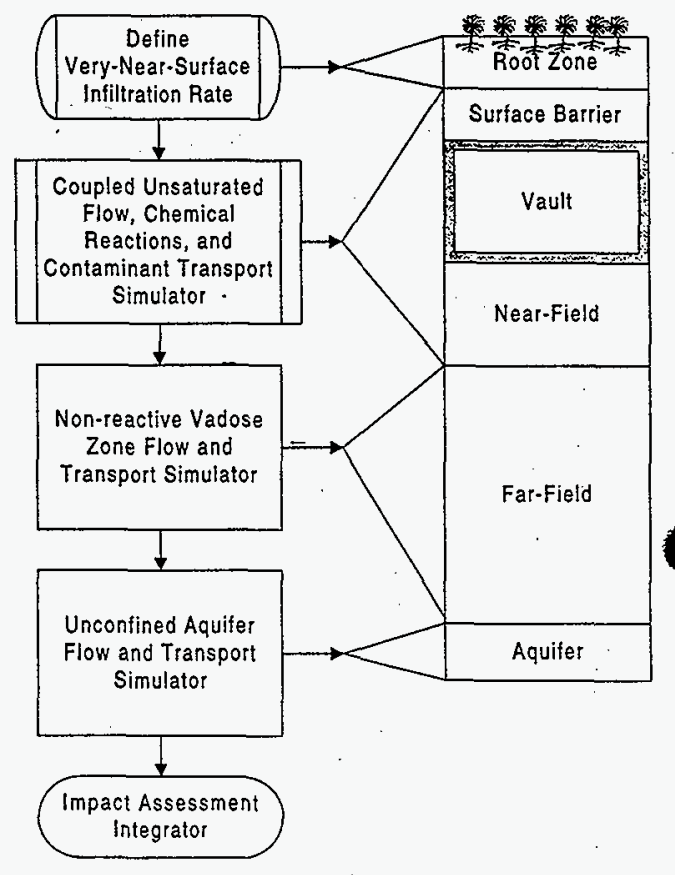

Figure G-6.1. Modeling Strategy for Assessing ILAW Disposal System Impacts 


\section{DOE/RL-97-69, Rev. 0 \\ Based on PNNL Report (PNNL-11834) To Be Published}

\section{G-7.0 CONCLUSION}

An overall strategy for evaluating the long-term performance of a low-activity waste glass at Hanford has been presented. The strategy combines laboratory testing and field testing into an overall plan for demonstrating a scientific understanding of the processes controlling long-term glass corrosion. Models describing these processes can then be used with confidence in extrapolating to the disposal system conditions and calculating radionuclide release rates in a formal performance assessment.

The recommended laboratory testing includes single-pass flow-through (SPFT), product consistency (PCT), and pressurized unsaturated flow (PUF) tests. The majority of the laboratory testing $(\sim 80 \%)$ is to be conducted using nonradioactive glasses, with the remainder performed with glasses containing a selected set of key radionuclides. Additionally, a series of PUF experiments with a natural analog of basaltic glass are recommended to confirm that the alteration products observed under accelerated conditions in the PUF tests are similar to those found associated with the natural analog. This will provide additional confidence in using the PUF test results to infer long-term corrosion behavior.

The final component of the strategy is a set of field experiments using both vendor glasses and specially formulated highly reactive glasses. The purpose of these experiments is to validate the models for glass corrosion and reactive chemical transport that form the technical basis for calculating radionuclide release rates in the disposal system. These experiments can be performed in existing lysimeters at the Hanford Site, or in new lysimeters that have been equipped with the latest in monitoring equipment and located near the proposed disposal site. The field tests will be closely coordinated with other tasks on the $I \mathrm{LAW}$, so that may serve to validate other key model inputs to the performance assessment. 
DOE/RL-97-69, Rev, 0

Based on PNNL Report (PNNL-11834) To Be Published

\section{G-8.0 REFERENCES}

Aagaard, P., and H. C. Helgeson. 1982. "Thermodynamic and Kinetic Constraints on Reaction Rates Among Minerals and Aqueous Solutions. I. Theoretical Considerations." Am. J. Sci. 282:237-285.

Advocat, T., J. L. Crovisier, B. Fritz, and E. Vernaz. 1990. "Thermokinetic Model of Borosilicate Glass Dissolution." Mat. Res. Soc. Symp. Proc. 176:241-248.

Advocat, T., J. L. Crovisier, E. Vernaz, G. Ehret, and H. Charpentier. 1991. "Hydrolysis of R7T7 Nuclear Waste Glass in Dilute Media: Mechanisms and Rate as a Function of pH." Mat. Res. Soc. Symp. Proc. 212:57-64.

American Society for Testing and Materials (ASTM). 1991. Standard Practice for Prediction of the Long-Term Behavior of Waste Package Materials Including Waste Forms Used in Geologic Disposal of High-Level Nuclear Waste. ASTM C1174, Philadelphia, Pennsylvania.

American Society for Testing and Materials (ASTM). 1992. Test Method for Static Leaching of Monolithic Waste Forms for Disposal of Radioactive Waste. ASTM Standard C1220-92, American Society for Testing and Materials, Philadelphia, Pennsylvania.

American Society for Testing and Materials (ASTM). 1994. Standard Test Methods for Determining Chemical Durability of Nuclear Waste Glasses: The Product Consistency Test (PCT). ASTM C1285, Philadelphia, Pennsylvania.

Bacon, D. H., and B. P. McGrail. 1997. "Source Term Analysis for Hanford Low-Activity Tank Waste Using the STORM Code: A Coupled Unsaturated Flow And Reactive Transport Model." Am. Chem. Soc. Proc. (in press).

Barkatt, Aa., P. B. Macedo, W. Sousanpour, A. Barkatt, M. A. Boroomand, C. F. Fisher, J. J. Shirron, P. Szoke, and V.L. Rogers. 1983. "The Use of a Flow Test and a Flow Model in Evaluating the Durability of Various Nuclear Waste-Form Materials." Nucl. Chem. Waste Mgmt. 4:153-169.

Barkatt, Aa., W. Sousanpour, Al. Barkatt, M. A. Boroomand, and P. B. Macedo. 1984. "Leach Behavior of SRL TDS-131 Defense Waste Glass in Water at High/Low Flow Rates." Mat. Res. Soc. Symp. Proc. 26:643-653.

Bates, J. K. C. R. Bradley, E. C. Buck, J. C. Cunnane, W. L. Ebert, X. Feng, J. J. Mazer, D. J. Wronkiewicz, J. Sproull, W. L. Bourcier, B. P. McGrail, and M. K. Altenhofen. 1994. High-Level Waste Borosilicate Glass: A Compendium of Corrosion Characteristics. DOE-EM-0177, U.S. Department of Energy, Office of Waste Management, Washington, D.C. 
DOE/RL-97-69, Rev. 0

\section{Based on PNNL Report (PNNL-11834) To Be Published}

Bates, J. K., and T. J. Gerding. 1986. One-Year Results of the NNWSI Unsaturated Test Procedure: SRL 165 Glass Application. ANL-85-41, Argonne National Laboratory, Argonne, Illinois.

Bates, J. K., W. L. Ebert, J. J. Mazer, J. P. Bradley, C. R. Bradley, and N. L. Dietz. 1991. "The Role of Surface Layers in Glass Leaching Performance." Mat. Res. Soc. Symp. Proc. 212:77-87.

Berkowitz, B., J. Bear, and C. Braester. 1988. "Continuum Models for Contaminant Transport in Fractured Porous Formations." Water Resour. Res. 24(8):1225-1236.

Boksay, Z., G. Bouquet, and S. Dobos. 1968. "The Kinetics of the Formation of Leached Layers on Glass Surfaces." Phys. Chem. Glasses 9(2):69-71.

Bourcier, W. L. 1989. Geochemical Modeling of Radioactive Waste Glass Dissolution Using EQ3/6: Preliminary Results and Data Needs. UCDD-21869, Lawrence Livermore National Laboratory, Livermore, California.

Bourcier, W. L., D. W. Peiffer, K. G. Knauss, K. D. McKeegan, and D. K. Smith. 1990. A Kinetic Model for Borosilicate Glass Dissolution Based on the Dissolution Affinity of a Surface Alteration Layer." Mat. Res. Soc. Symp. Proc. 176:209-216.

Bourcier, W. L., H. C. Weed, S. N. Nguyen, J. K. Nielsen, L. Morgan, L. Newton, and K. G. Knauss. 1992. Proc. Seventh Anmual Water-Rock Interaction Conf., Balkema, Rotterdam, pp. 81-84.

Bourcier, W. L., S. A. Carroll, and B. L. Phillips. 1994. "Constraints on the Affinity Term for Modeling Long-Term Glass Dissolution Rates." Mat. Res. Soc. Symp. Proc. 333:507512.

Bourcier, W. L., W. L. Ebert, and X: Feng. 1993. "Modeling Surface Area to Volume Effects on Borosilicate Glass Dissolution." Mat. Res. Soc. Symp. Proc. 294:577-582.

Burbank, D. A., Jr. 1997. Analysis of Alternatives for Immobilized Low-Activity Waste Disposal. HNF-SD-TWR-AGA-004, Rev. 0, SGN Eurisys Services Corporation, Richland, Washington.

Byers, C. D., M. J. Jercinovic, and R. C. Ewing. 1986. A Study of Natural Glass Analogues as Applied to Alteration of Nuclear Waste Glass. NUREG/CR-4842, Nuclear Regulatory Commission,

Byers, C. D., M. J. Jercinovic, R. C. Ewing, and K. Keil. 1985. "Basalt Glass: An Analogue for the Evaluation of the Long-Term Stability of Nuclear Waste Form Borosilicate Glasses." Mat. Res. Soc. Symp. Proc. 44:583-590. 


\section{Based on PNNL Report (PNNL-11834) To Be Published}

Chen, Y., B. P. McGrail, and D. W. Engel. 1997. "Source-Term Analysis for Hanford LowActivity Tank Waste Using the Reaction-Transport Code AREST-CT." Mat. Res. Soc. Symp. Proc. 465:1051-1058.

Delage, F., and J. L. Dussossoy. 1991. "R7T7 Glass Initial Dissolution Rate Measurements Using a High-Temperature Soxhlet Device." Mat. Res. Soc. Symp. Proc. 212:41-47.

DOE 1982 (see U.S. Department of Energy 1982)

DOE 1997 (see U.S. Department of Energy 1997)

Doremus, R. H. 1975. "Interdiffusion of Hydrogen and Alkali Ions in a Glass Surface." J. Noncrystalline Solids 19(2):137-44.

Doremus, R. H. 1977. "Diffusion in Glasses and Melts." J. Noncrystalline Solids 25:261-292.

Dove, P. M, and D. A. Crerar. 1990. "Kinetics of Quartz Dissolution in Electrolyte Solutions Using a Hydrothermal Mixed Flow Reactor." Geochim. Cosmochim. Acta 54:955-969.

Eagleson, P. S. 1978. “Climate, Soil and Vegetation, A Simplified Model of Soil Moisture Movement in the Liquid Phase." Water Resour. Res. 14(5):722-730.

Ebert, W. L., A. J. Bakel, and N. R. Brown. 1996. "Measurement of the Glass Dissolution Rate in the Presence of Alteration Phases." Proceedings International Topical Meeting on Nuclear and Hazardous Waste Management, Spectnum '96, Seattle, Washington, pp. $569-575$.

Ebert, W. L., and J. K. Bates. 1993. "A Comparison of Glass Reaction at High and Low Glass Surface/Solution Volume." Nuc. Tech. 104:372-384.

Ecology. 1996. Washington State Department of Ecology, United States Environmental Protecion Agency, United States Department of Energy. Hanford Facility Agreement and Consent Order, Sixth Amendment, February 1996.

Ewing, R. C., and M. J. Jercinovic. 1987. "Natural Analogues: Their Applications to the Prediction of the Long-Term Behavior of Nuclear Waste Forms." Mat. Res. Symp. Proc. 84:67-83.

Fayer, M. J., and T. B. Walters. 1995. Estimated Recharge Rate at the Hanford Site. PNL10285, Pacific Northwest Laboratory, Richland, Washington.

Friedman, I., and W. Long. 1976. "Hydration Rate of Obsidian." Science 191:347-352.

Gee, G. W., and T. L. Jones. 1985. Lysimeters at the Hanford Site: Present and Future Needs. PNL-5578, Pacific Northwest National Laboratory, Richland, Washington. 


\section{DOE/RL-97-69, Rev. 0}

\section{Based on PNNL Report (PNNL-11834) To Be Published}

Gin, S. 1996. "Control of R7T7 Nuclear Glass Alteration Kinetics Under Saturation Conditions." Mat. Res. Soc. Symp. Proc. 412:189-196.

Goldsmith, J. R. 1953. “A 'Simplexity Principle' and Its Relation to 'Ease' of Crystallization." J. Geol. 61:439-451.

Grambow, B. E. 1985. "A General Rate Equation for Nuclear Waste Glass Corrosion." Mat. Res. Soc. Symp. Proc. 44:15-27.

Grambow, B., M. J. Jercinovic, R. C. Ewing, and C. D. Byers. 1986. "Weathered Basalt Glass: A Natural Analogue for the Effects of Reaction Progress on Nuclear Waste Glass Alteration." Mat. Res. Soc. Symp. Proc. 50:263-272.

Harder, H. 1978. "Synthesis of Iron Layer Silicate Minerals under Natural Conditions." Cloys and Clay Minerals 26(1):65-72.

Hespe, E. D. 1971. "Leach Testing of Immobilized Radioactive Waste Solids: A Proposal for a Standard Method." In Atomic Energy Review 9(1):195-207, International Atomic Energy Agency, Vienna.

Knauss, K. G., and T. J. Wolery. 1986. "Dependence of Albite Dissolution Kinetics on pH and Time at $25^{\circ} \mathrm{C}$ and $70^{\circ} \mathrm{C}$." Geochim. Cosmochim. Acta 50:2481-2497.

Knauss, K. G., W. L. Bourcier, K. D. McKeegan, C. I. Merzbacher, S. N. Nguyen, F. J. Ryerson, D. K. Smith, H. C. Weed, L. Newton. 1990. "Dissolution Kinetics of a Simple Analogue Nuclear Waste Glass as a Function of pH, Time and Temperature." Mat. Res. Soc. Symp. Proc. 176:371-381.

Lanford, W. A., K. Davis, P. Lamarche, T. Laursen, R. Groleau, and R. H. Doremus. "Hydration of Soda-Lime Glass." 1979. J. Noncrystalline Solids 33(2):249-266.

Last, G. V., R. J. Serne, and V. L. LeGore. 1995. Field Lysimeter Studies for Performance Evaluation of Grouted Hanford Defense Wastes. PNL-10166, Pacific Northwest National Laboratory, Richland, Washington.

Luo, J. S., W. L. Ebert, J. J. Mazer, and J. K. Bates. 1997. "Simulation of Natural Corrosion by Vapor Hydration Test: Seven-Year Results." Mat. Res. Soc. Symp. Proc. 465:157-163.

Lutze, W., and G. G. Malow. 1985. "Alteration of Basalt Glasses: Implications for Modeling the Long-Term Stability of Nuclear Waste Glasses." Nature 314(21):252-255.

Mann, F. M., C. R. Eiholzer, A. H. Lu, P. D. Rittmann, N.W. Kline, Y. Chen, B.P. McGrail, G. F. Williamson, J. A. Voogd, N. R. Brown, and P. E. LaMont. 1997. Hanford Low-Level Tank Waste Interim Performance Assessment. HNF-EP-0884, Rev. 1, Project Hanford Management Contractor, Richland, Washington. 
DOE/RL-97-69, Rev. 0

\section{Based on PNNL Report (PNNL-11834) To Be Published}

Materials Characterization Center. 1984. MCC-3 Agitated Powder Leach Test. PNL-3990, Pacific Northwest Laboratory, Richland, Washington.

Mattigod, S. V. and B. P. McGrail. 1998. "Estimating the Standard Free Energy of Formation of Zeolites Using the Polymer Model." Zeolites (in press).

Mazer, J. J., J. K. Bates, C. M. Stevenson, and C. R. Bradley. 1992. “Obsidians and Tektites: Natural Analogues for Water Diffusion in Nuclear Waste Glasses." Mat. Res. Soc. Symp. Proc. 257:513-520.

McGrail, B. P. 1986. "Waste Package Component Interactions with Savannah River Defense Waste Glass in a Low-Magnesium Salt Brine." Nuc. Tech. 75(2):168-186.

McGrail, B. P., and K. M Olson. 1992. Evaluating Long-term Performance of In-situ Vitrified Waste Forms: Methodology and Results. PNL-8358, Pacific Northwest Laboratory, Richland, Washington.

McGrail, B. P., and L. A. Mahoney. 1995. Selection of a Computer Code for Hanford LowLevel Waste Engineered-System Performance Assessment. PNL-10830, Pacific Northwest Laboratory, Richland, Washington.

McGrail, B. P., C. W. Lindenmeier, P. F. Martin, and G. W. Gee. 1997a. "The Pressurized Unsaturated Flow (PUF) Test: A New Method for Engineered-Barrier Materials Evaluation." In Transactions of the American Ceramic Society Vol. 72, eds. V. Jain and D. K. Peeler, Columbus, Ohio.

McGrail, B. P., P. F. Martin, and C. W. Lindenmeier. 1997b. "Accelerated Testing of Waste Forms Using a Novel Pressurized Unsaturated Flow (PUF) Method.” Mat. Res. Soc. Symp. Proc. 465:253-260.

McGrail, B. P., W. L. Ebert, A. J. Bakel, and D. K. Peeler. 1997c. "Measurement of Kinetic Rate Law Parameters on a Na-Ca-Al Borosilicate Glass for Low-Activity Waste." J. Nuc. Mat. 249:175-189.

McVay, G. L., and C. Q. Buckwalter. 1983. "Effect of Iron on Waste Glass Leaching." J. Am. Ceram. Soc. 66(3):170-174.

Myers, D. R., and D. A. Duranceau. 1994. Prototype Hanford Surface Barrier: Design Bases Document. BHI-007, Bechtel Hanford Company, Richland, Washington.

Ostwald, W. Z. 1897. "Studien über die Bildung und Umwaldung fester Korper. 1. Abhandlung: Ubersattigung and Uberkaltung." Zeitschr. Physik Chemie 22:289-330.

Oversby, V. L., and D. L. Phinney. 1992. "The Development of Surface Alteration Layers on SRL-165 Nuclear Waste Glass." J. Nuc. Mat. 190:247-268. 


\section{Based on PNNL Report (PNNL-11834) To Be Published}

Petit, J. C. 1992. "Reasoning by Analogy: Rational Foundation of Natural Analogue Studies." Appl. Geochem., Suppl. Issue 1:9-11.

Rana, M. A., and R. W. Douglas. 1961a. "The Reaction Between Glass and Water. Part 1. Experimental Methods and Observations." Phys. Chem. Glasses 2(6):179-195.

Rana, M. A., and R. W. Douglas. 196lb. "The Reaction Between Glass and Water. Part 2. Discussion of the Results." Phys. Chem. Glasses 2(6):196-204.

Rockhold, M. L., M. J. Fayer, C. T. Kincaid, and G. W. Gee. 1995. Estimation of Natural Ground Water Recharge for the Performance Assessment of a Low-Level Waste Disposal Facility at the Hanford Site. PNL-10508, Pacific Northwest National Laboratory, Richland, Washington.

Salvucci, G. D. 1993. “An Approximate Solution for Steady Vertical Flux of Moisture Through an Unsaturated Homogeneous Soil." Water Resour. Res. 29(11):3749-3753.

Shade, J. W., and D. M. Strachan. 1986. "Effect of High Surface Area to Solution Volume Ratios on Waste Glass Leaching." Am. Ceram. Soc. Bull. 65(12):1568-1573.

Stout, R. B., and H. Leider. 1996. Waste Form Characteristics Report, Version 1.2. UCRL-D108314, Rev. 1.2, Lawrence Livermore National Laboratory, Livermore, California.

Strachan, D. M., B. P. McGrail, M. J. Apted, D. W. Engel, and P. W. Eslinger. 1990. Preliminary Assessment of the Controlled Release of Radionuclides from Waste Packages Containing Borosilicate Waste Glass. PNL-7591, Pacific Northwest Laboratory, Richland, Washington.

Strachan, D. M., W. L. Bourcier, and B. P. McGrail. 1994. "Toward a Consistent Model for Glass Dissolution." Radioactive Waste Management and Environmental Restoration 19:129-145.

Strachan, D.M. 1983. "Results from Long-Term Use of the MCC-1 Static Leach Test Method." Nucl. Chem: Waste Mgmt. 4:177-188.

Strachan, D.M., B.O. Bames, and R.P. Turcotte. 1981. "Standard Leach Tests for Nuclear Waste Materials." Mat. Res. Soc. Symp. Proc. 3:347-354.

Tietje, O., and M. Tapkenhinrichs. 1993. "Evaluation of Pedo-Transfer Functions." Soil Sci. Soc. Am. J. 57:1088-1095.

Tovena, I., T. Advocat, D. Ghaleb, E. Vernaz, and F. Larche. 1994. "Thermodynamic and Structural Models Compared with the Initial Dissolution Rates of "SON" Glass Samples." Mat. Res. Soc. Symp. Proc. 333:595-602. 
DOE/RL-97-69, Rev. 0

Based on PNNL Report (PNNL-11834) To Be Published

U.S. Department of Energy (DOE). 1982. Nuclear Waste Materials Handbook: Test Methods. Technical Information Center report, DOE/TIC-11400.

U.S. Department of Energy (DOE). 1997. Record of Decision for the Tank Waste Remediation System, Hanford Site, Richland, Washington. Federal Register, Volume 62, page 8693, February 26, 1997.

van Genuchten. 1980. "A Closed-Form Equation for Predicting the Hydraulic Conductivity of Unsaturated Soils." Soil Sci. Soc. Am. J. 44:892-898.

Van Iseghem, P. and B. Grambow. 1988. "The Long-Term Corrosion and Modelling of Two Simulated Belgian Reference High-Level Waste Glasses." Mat. Res. Soc. Symp. Proc. 112:631-639.

White, M. D., and M. Oostrom. 1996. STOMP: Subsurface Transport Over Multiple Phases, Theory Guide. PNNL-1 1217, Pacific Northwest Nationàl Laboratory, Richland, Washington.

Wierenga, P. J., M. H. Young, G. W. Gee, R. G. Hills, C. T. Kincaid, T. J. Nicholson, and R. E. Cady. 1993. Soil Characterization Methods for Unsaturated Low-Level Waste Sites. PNL-8480, Pacific Northwest National Laboratory, Richland, Washington.

Wolery, T. J., and S. A. Daveler. 1992. EQ6, A Computer Program for Reaction Path Modeling of Aqueous Geochemical Systems: Theoretical Manual, User's Guide and Related Documentation. UCRL-MA-110662 PT IV, Lawrence Livermore Laboratory, Livermore, California.

Woodland, A. B., J. K. Bates, and T. J. Gerding. 1991. Parametric Effects on Glass Reaction in the Unsaturated Test Method. ANL-91-36, Argonne National Laboratory, Argonne, Ilinois. 
DOE/RL-97-69

Rev. 0

\section{APPENDIX H \\ CORRESPONDENCE BETWEEN DOE GUIDANCE AND THIS DOCUMENT}

This appendix provides a crosswalk between the February 28, 1997 guidance (DOE 1997c) for Draft DOE Order 435.1 (DOE 1997a) and the location of those sections in this document.

\begin{tabular}{|c|c|c|}
\hline Guidance $^{(1)}$ & Description & $\begin{array}{l}\text { Location in this } \\
\text { Document }{ }^{(2)}\end{array}$ \\
\hline \multirow[t]{4}{*}{ B.1 } & \multicolumn{2}{|l|}{ EXECUTIVE SUMMARY } \\
\hline & $\begin{array}{l}\text { Highlight features that are important to understanding } \\
\text { the document and its results }\end{array}$ & \\
\hline & $\begin{array}{l}\text { Summary comparison of the results (with } \\
\text { uncertainties) to performance measures }\end{array}$ & \\
\hline & Constraints on acceptance of waste & \\
\hline B. 2 & \multicolumn{2}{|l|}{ INTRODUCTION } \\
\hline \multirow[t]{3}{*}{ B.2.1 } & \multicolumn{2}{|l|}{ General Approach } \\
\hline & General approach used in preparing document & 1.1 \\
\hline & $\begin{array}{l}\text { Descriptive information about the disposal facility and } \\
\text { site }\end{array}$ & 1.2 \\
\hline \multirow[t]{5}{*}{ B.2.2 } & \multicolumn{2}{|l|}{ General Facility Description } \\
\hline & $\begin{array}{l}\text { General description of waste disposal facility and } \\
\text { location (major design philosophy, facility features, } \\
\text { and disposal concept) }\end{array}$ & 1.3 \\
\hline & Land use patterns (including future uses) & $1.2,2.2 .4$ \\
\hline & Waste certification process & 2.3 .7 \\
\hline & Movement of waste through disposal operations & 2.3 .8 \\
\hline
\end{tabular}


DOE/RL-97-69

Rev. 0

\begin{tabular}{|c|c|c|}
\hline Guidance $^{(1)}$ & Description & $\begin{array}{l}\text { Location in this } \\
\text { Document }\end{array}$ \\
\hline \multirow[t]{2}{*}{ B.2.3 } & \multicolumn{2}{|l|}{ Schedules } \\
\hline & Schedule for facility life cycle & 1.4 \\
\hline \multirow[t]{3}{*}{ B.2.4 } & \multicolumn{2}{|l|}{ Related Documents } \\
\hline & Documents for site-regulation (e.g. EISs) & 1.5 .1 \\
\hline & Regulatory Agreements & 1.5 .2 \\
\hline \multirow[t]{4}{*}{ B.2.5 } & \multicolumn{2}{|l|}{ Performance Criteria } \\
\hline & Applicable criteria to judge performance - numeric & 1.6 \\
\hline & ALARA performance objectives & 1.6 .2 .2 \\
\hline & Institutional control & 1.6 .2 .4 \\
\hline \multirow[t]{2}{*}{ B.2.6 } & \multicolumn{2}{|l|}{ Summary of Key Assessment Assumptions } \\
\hline & Highlight key assumptions & 1.7 \\
\hline B.3 & \multicolumn{2}{|l|}{ DISPOSAL FACILITY CHARACTERISTICS } \\
\hline B.3.1 & \multicolumn{2}{|l|}{ Site Characteristics } \\
\hline B.3.1.1 & \multicolumn{2}{|l|}{ Geography and Demography } \\
\hline \multirow[t]{6}{*}{ B.3.1.1.1 } & \multicolumn{2}{|l|}{ Disposal Site Location } \\
\hline & Include regional map & Fig. 2-2, 2-2 \\
\hline & Location of DOE Site and disposal facility & 2.2 .2 \\
\hline & Indicate boundaries of disposal site on map & Fig. 2-3 \\
\hline & Indicate future boundary on maps & Fig. 2-2 \\
\hline & Future expansion should be indicated & 2.2 .2 \\
\hline
\end{tabular}


DOE/RL-97-69

Rev. 0

\begin{tabular}{|c|c|c|}
\hline Guidance $^{(1)}$ & Description & $\begin{array}{l}\text { Location in this } \\
\text { Document }{ }^{(2)}\end{array}$ \\
\hline \multirow[t]{2}{*}{ B.3.1.1.2 } & \multicolumn{2}{|l|}{ Disposal Site Description } \\
\hline & General desciption of site and surrounding areas & 2.2 .2 \\
\hline \multirow[t]{2}{*}{ B.3.1.1.3 } & \multicolumn{2}{|l|}{ Population Distribution } \\
\hline & Existing and projected population & 2.2 .3 \\
\hline \multirow[t]{2}{*}{ B.3.1.1.4 } & \multicolumn{2}{|l|}{ Uses of Adjacent Lands } \\
\hline & Summary of historical and current land uses & 2.2 .4 \\
\hline \multirow[t]{5}{*}{ B.3.1.2 } & \multicolumn{2}{|l|}{ Meteorology and Climatology } \\
\hline & Regional and site-specific climate & 2.2 .5 \\
\hline & Local meterology and microclimate & 2.2 .5 \\
\hline & Regional severe weather (tomados, etc) & 2.2.5.5 \\
\hline & $\begin{array}{l}\text { Basis for weather including location of weather } \\
\text { stations }\end{array}$ & $\begin{array}{l}2.2 .5 .2, \\
\text { Fig. } 2-2\end{array}$ \\
\hline \multirow[t]{2}{*}{ B.3.1.3 } & \multicolumn{2}{|l|}{ Ecology } \\
\hline & Plant and animal species & 2.2 .6 \\
\hline B.3.1.4 & \multicolumn{2}{|l|}{ Geology, Seismology, and Volcanology } \\
\hline \multirow[t]{6}{*}{ B.3.1.4.1 } & \multicolumn{2}{|l|}{ Regional and Site-Specific Geology and Topography } \\
\hline & Structural geology of the region & 2.2 .7 \\
\hline & Maps and geologic profiles & $\begin{array}{l}\text { Fig. } 2-5,2-6,2- \\
7,2-8\end{array}$ \\
\hline & Topography & 2.2.7.2 \\
\hline & Soil characteristics & 2.2.7.4 \\
\hline & Erosin, landslides, slumping & 2.2.7.2 \\
\hline
\end{tabular}


DOE/RL-97-69

Rev. 0

\begin{tabular}{|c|c|c|}
\hline Guidance $^{(1)}$ & Description & $\begin{array}{l}\text { Location in this } \\
\text { Document }{ }^{(2)}\end{array}$ \\
\hline \multirow[t]{4}{*}{ B.3.1.4.2 } & \multicolumn{2}{|l|}{ Seismology } \\
\hline & Identification of faults & 2.2 .7 .5 \\
\hline & Relationship of vaults to stress fields & 2.2 .7 .5 \\
\hline & Seismic investigations & 2.2 .7 .5 \\
\hline \multirow[t]{3}{*}{ B.3.1.4.3 } & \multicolumn{2}{|l|}{ Volcanology } \\
\hline & geophysical and geodetic monitoring description & 2.2 .7 .6 \\
\hline & Volcanic flows & 2.2 .7 .6 \\
\hline B.3.1.5 & Hydrology & \\
\hline \multirow{4}{*}{$\begin{array}{r}\text { B.3.1.5.1 } \\
.\end{array}$} & \multicolumn{2}{|l|}{ Surface Water } \\
\hline & Disposal site drainage & 2.2 .9 .1 \\
\hline & Location, size, and shape of surface water features & 2.2 .9 .1 \\
\hline & Flood potential & 2.2 .9 .2 \\
\hline \multirow[t]{10}{*}{ B.3.1.5.2 } & \multicolumn{2}{|l|}{ Groundwater } \\
\hline & Unsaturated Zone: conceptual model & 3.5.3.1, 3.5.3.2 \\
\hline & : data & 3.5 .4 .2 \\
\hline & : code & $3.5 .2 .3,3.4 .3 .2$ \\
\hline & Saturated Zone : description of extent & $3.5 .3 .3,3.5 .3 .4$ \\
\hline & : data & 3.5.4.3, 3.4.3.4 \\
\hline & : seasonal flucations & 3.4.3.4 \\
\hline & : code & 3.5 .2 .4 \\
\hline & Results from monitoring wells and boreholes & 2.2 .9 .3 \\
\hline & Concentrations of radionuclides in groundwater & 2.2 .12 .2 \\
\hline
\end{tabular}


DOE/RL-97-69

Rev. 0

\begin{tabular}{|c|c|c|}
\hline Guidance $^{(1)}$ & Description & $\begin{array}{l}\text { Location in this } \\
\text { Document }(2)\end{array}$ \\
\hline \multirow[t]{8}{*}{ B.3.1.6 } & \multicolumn{2}{|l|}{ Geochemistry } \\
\hline & Background information & 2.2 .10 \\
\hline & Surface and groundwater chemistry & 2.2 .10 \\
\hline & Subsurface geochemistry & 2.2 .10 \\
\hline & Experiments & 2.2 .10 \\
\hline & Data bases & 2.2 .10 \\
\hline & Computer codes & 3.5 .2 .2 \\
\hline & Data & 3.4 .3 .3 \\
\hline B.3.1.7 & \multicolumn{2}{|l|}{ Natural Resources } \\
\hline \multirow[t]{2}{*}{ B.3.1.7.1 } & \multicolumn{2}{|l|}{ Geologic Resources } \\
\hline & Geologic resource exploitation in area & 2.2 .11 \\
\hline \multirow[t]{3}{*}{ B.3.1.7.2 } & \multicolumn{2}{|l|}{ Water Resources } \\
\hline & Use of groundwater in area & $2: 2.11$ \\
\hline & Well construction practices & 2.2 .11 \\
\hline \multirow[t]{3}{*}{ B.3.1.8 } & \multicolumn{2}{|l|}{ Natural Background Radiation } \\
\hline & Environmental radiological information & 2.2 .12 \\
\hline & Radionuclide concentrations in groundwater & 2.2 .12 .2 \\
\hline \multirow[t]{2}{*}{ B.3.2 } & \multicolumn{2}{|l|}{ Principal Facility Design Features } \\
\hline & $\begin{array}{l}\text { Detailed descriptions of all design features significant } \\
\text { to analysis }\end{array}$ & 2.4 \\
\hline \multirow[t]{2}{*}{ B.3.2.1 } & \multicolumn{2}{|l|}{ Water Infiltration } \\
\hline & $\begin{array}{l}\text { Design features that minimize water infiltration on } \\
\text { divert water away from disposal facility }\end{array}$ & 2.4 .1 .4 \\
\hline
\end{tabular}


DOE/RL-97-69

Rev. 0

\begin{tabular}{|c|c|c|}
\hline Guidance $^{(1)}$ & Description & $\begin{array}{l}\text { Location in this } \\
\text { Document }^{(2)}\end{array}$ \\
\hline \multirow[t]{3}{*}{ B.3.2.2 } & \multicolumn{2}{|l|}{ Disposal Unit Cover Integrity } \\
\hline & design features to ensure integrity of cover & 2.4 .1 \\
\hline & degradation of cover & 3.4 .5 .7 \\
\hline \multirow[t]{4}{*}{ B.3.2.3 } & \multicolumn{2}{|l|}{ Structural Stability } \\
\hline & $\begin{array}{l}\text { structural stability of the fill, wastes, and waste } \\
\text { covering }\end{array}$ & 2.4 .1 \\
\hline & effects of voids & 4.5 .3 \\
\hline & $\begin{array}{l}\text { degradation of fill, waste forms, engineered features, } \\
\text { and waste cover materials }\end{array}$ & 3.4 .5 .7 \\
\hline \multirow[t]{2}{*}{ B.3.2.4 } & \multicolumn{2}{|l|}{ Inadvertent Intruder Barrier } \\
\hline & $\begin{array}{l}\text { Design features include degradation, engineered } \\
\text { barriers, and materials separating stable and unstable } \\
\text { wastes }\end{array}$ & 2.4 .1 .4 \\
\hline \multirow[t]{7}{*}{ B.3.3 } & \multicolumn{2}{|l|}{ Waste Characteristics } \\
\hline & Volume & 2.3 .5 \\
\hline & Radionuclide concentrations & 3.2 \\
\hline & Chemical and physical Form & 2.3 .7 \\
\hline & Packaging methods & 2.3 .7 \\
\hline & $\begin{array}{l}\text { Acceptance restrictions for chelating and complexing } \\
\text { agents }\end{array}$ & 2.3 .7 \\
\hline & Other acceptance restrictions & Appendix A \\
\hline
\end{tabular}


DOE/RL-97-69

Rev, 0

\begin{tabular}{|c|c|c|}
\hline Guidance ${ }^{(1)}$ & Description & $\begin{array}{l}\text { Location in this } \\
\text { Document }\end{array}$ \\
\hline B.4 & \multicolumn{2}{|l|}{ ANALYSIS OF PERFORMANCE } \\
\hline \multirow[t]{9}{*}{ B.4.1 } & \multicolumn{2}{|l|}{ Source Terms } \\
\hline & Release rate of radionuclides & $3.3 .3,3.4 .4 .4$ \\
\hline & Mechanicisms for release & 3.3 .3 \\
\hline & Concept models for release & 3.3 .3 \\
\hline & Screening of radionuclides & 3.2 .1 \\
\hline & Development of source term & 3.3 .3 \\
\hline & $\begin{array}{l}\text { Conceptual models, computer codes, and other tools } \\
\text { used in development of source term }\end{array}$ & $3.3,3.4,3.5$ \\
\hline & Summary table of source term for each radionuclide & 3.2 \\
\hline & Effects of degradation & 3.4.5.7 \\
\hline \multirow[t]{8}{*}{ B.4.2 } & \multicolumn{2}{|l|}{ Pathways and Scenarios } \\
\hline & $\begin{array}{l}\text { Description of transport/pathway/scenario } \\
\text { development }\end{array}$ & 3.3 \\
\hline & Transport mechanicisms & 3.3 .4 \\
\hline & Receptor locations & 3.3 .5 \\
\hline & Exposure Media & 3.3 .5 \\
\hline & Uptake pathways & 3.3 .5 \\
\hline & Describe pathways and scenarios & 3.3 \\
\hline & Justify pathway and scenario & 3.3 \\
\hline
\end{tabular}


DOE/RL-97-69

Rev. 0

\begin{tabular}{|c|c|c|}
\hline Guidance $^{(1)}$ & Description & $\begin{array}{l}\text { Location in this } \\
\text { Document }^{(2)}\end{array}$ \\
\hline \multirow[t]{6}{*}{ B.4.3 } & \multicolumn{2}{|l|}{ Analysis Methodology } \\
\hline & Conceptual models & 3.4 \\
\hline & Methods used to simulate transport & 3.5 \\
\hline & Justify methods used to simulate transport and uptake & 3.5 \\
\hline & Discuss theoretical basis & 3.5, Apps C D \\
\hline & Discuss limitations & 3.5 \\
\hline B.5 & \multicolumn{2}{|l|}{ RESULTS OF ANALYSIS } \\
\hline \multirow[t]{2}{*}{ B.5.1 } & \multicolumn{2}{|l|}{ Results of All-Pathways Analysis } \\
\hline & Results of all-pathways analysis & $4 ., 4.2$ \\
\hline \multirow[t]{3}{*}{ B.5.2 } & \multicolumn{2}{|l|}{ Results of Air-Pathway Analysis } \\
\hline & Results of air-pathway analysis & 4.12 \\
\hline & Results of radon analysis & 4.12 \\
\hline \multirow[t]{2}{*}{ B.5.3 } & \multicolumn{2}{|l|}{ Results of Water Resource Protection Analysis } \\
\hline & Results of water resource protection analysis & $4 ., 4.2$ \\
\hline \multirow[t]{3}{*}{ B.5.4 } & \multicolumn{2}{|l|}{ Results of Sensitivity and Uncertainty Analysis } \\
\hline & Description of sensitivity and uncertainty analysis & 3.5 .5 \\
\hline & Results of sensitivity and uncertainty analysis & $4.3-4.9$ \\
\hline \multirow[t]{2}{*}{ B.5.5 } & \multicolumn{2}{|l|}{ ALARA Analysis } \\
\hline & $\begin{array}{l}\text { Document the ALARA process used in design and } \\
\text { operations }\end{array}$ & 4.11 \\
\hline
\end{tabular}


DOE/RL-97-69

Rev. 0

\begin{tabular}{|c|c|c|}
\hline Guidance $^{(1)}$ & Description & $\begin{array}{l}\text { Location in this } \\
\text { Document }^{(2)}\end{array}$ \\
\hline \multirow[t]{5}{*}{ B.6 } & \multicolumn{2}{|l|}{ INADVERTENT INTRUDER ANALYSIS } \\
\hline & Results of intruder scenarios & 5.4 \\
\hline & Screening of radionuclides & 3.2 .1 \\
\hline & Performance of barriers to discourage intrusion & 5.4 .1 \\
\hline & Model and codes used & 5.4 .1 \\
\hline \multirow[t]{3}{*}{ B.6.1 } & \multicolumn{2}{|l|}{ Acute Scenarios } \\
\hline & Scenario description & 5.2 \\
\hline & Data used in acute scenarios & 5.3 \\
\hline \multirow[t]{3}{*}{ B.6.2 } & \multicolumn{2}{|l|}{ Chronic Scenarios } \\
\hline & Scenario description & 5.2 \\
\hline & Data used in chronic scenarios & 5.3 \\
\hline \multirow[t]{2}{*}{ B.6.3 } & \multicolumn{2}{|l|}{ Intruder Analysis Results } \\
\hline & Results of intruder scenarios & 5.4 \\
\hline \multirow[t]{2}{*}{ B.6.4 } & \multicolumn{2}{|l|}{ Intruder Sensitivity/Uncertainty Analysis } \\
\hline & Results of intruder sensitivity/uncertainly cases & 5.4 \\
\hline B.7 & PERFORMANCE EVALUATION & \\
\hline \multirow[t]{3}{*}{ B.7.1 } & \multicolumn{2}{|l|}{ Comparison of Results to Performance Objectives } \\
\hline & Comparison of results to performance objectives & 6.2 \\
\hline & $\begin{array}{l}\text { Additional material (assumptions, } \\
\text { sensitivity/uncertainty) to aid reader understand results }\end{array}$ & 6.3 \\
\hline \multirow[t]{5}{*}{ B.7.2 } & \multicolumn{2}{|l|}{ Use of Performance Assessment Results } \\
\hline & Waste acceptance criteria & 6.3 .3 \\
\hline & Operational limits on facility & 6.3 .4 \\
\hline & Include concentration and total limits & 6.3 .3 \\
\hline & Specify rules (i.e. sum of fraction rule) & 6.3 .3 \\
\hline
\end{tabular}


DOE/RI-97-69

Rev. 0

\begin{tabular}{|c|c|c|}
\hline Guidance $^{(1)}$ & Description & $\begin{array}{l}\text { Location in this } \\
\text { Document }\end{array}$ \\
\hline \multirow[t]{4}{*}{ B.7.3 } & \multicolumn{2}{|l|}{ Further Work } \\
\hline & $\begin{array}{l}\text { Additional work (monitoring, testing, and research) to } \\
\text { support performance assessment }\end{array}$ & 6.4 \\
\hline & $\begin{array}{l}\text { Specification of how each item aids performance } \\
\text { assessment }\end{array}$ & 6.4 \\
\hline & Specification of on-going or future activity & 6.4 \\
\hline \multirow[t]{2}{*}{ B.8 } & \multicolumn{2}{|l|}{ QUALITY ASSURANCE } \\
\hline & Quality Assurance Plan should be cited & 7. \\
\hline \multirow[t]{2}{*}{ B.9 } & \multicolumn{2}{|l|}{ PREPARERS } \\
\hline & List prepares with their qualifications & 8. \\
\hline B. 10 & REFERENCES & 9 \\
\hline B.11 & APPENDICES & A-H \\
\hline
\end{tabular}

(1) The table of contents for DOE Order 435.1 performance assessment is taken from "Format and Content Guide and Standard Review Plan for Performance Assessments', Item 1 of DOE G 435.1-5, draft dated February 28, 1997. The final version has not yet been released.

(2) Table of Contents of this document is mainly based on the guidance for draft DOE Order 435.1. However, guidance from the DOE Order 5820.2A review process as contained in Case 1989 and Dodge 1991 was also used. 
DOE/RL-97.69

Rev. 0

\section{Index}

Air Releases

ALARA

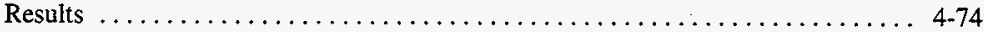

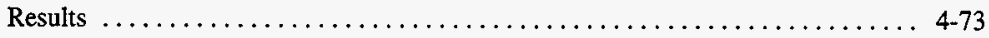

Base Analysis Case

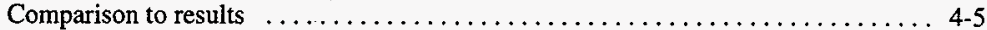

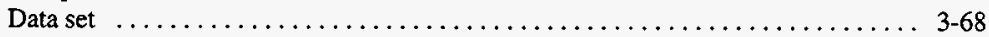

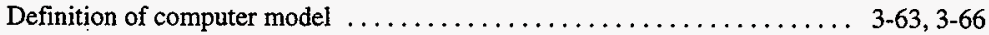

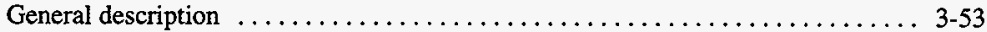

Results - Summary $\ldots \ldots \ldots \ldots \ldots \ldots \ldots \ldots \ldots \ldots \ldots \ldots \ldots \ldots \ldots, 4,66$

Calculational Assumptions

Definition of sensitivity cases $\ldots \ldots \ldots \ldots \ldots \ldots \ldots \ldots \ldots \ldots \ldots \ldots, \ldots, 8, \ldots \ldots$

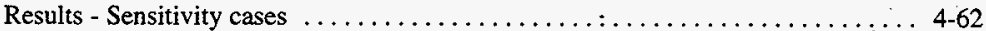

Catastrophic Events

Results $\ldots \ldots \ldots \ldots \ldots \ldots \ldots \ldots \ldots \ldots \ldots \ldots \ldots \ldots \ldots \ldots \ldots, 4: 72$

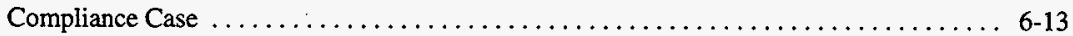

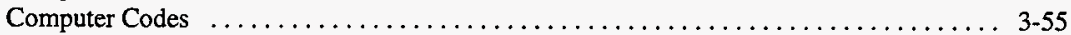

Concept 2

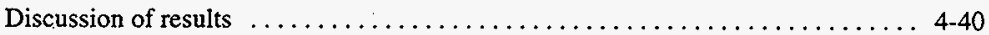

Simulation Results ................................ 4-24

Contaminant Transport

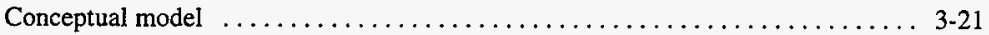

Deterministic Waste Form Release Rates

Conceptual model $\ldots \ldots \ldots \ldots \ldots \ldots \ldots \ldots \ldots \ldots \ldots \ldots \ldots \ldots \ldots \ldots, 3-20$

Results - Sensitivity cases $\ldots \ldots \ldots \ldots \ldots \ldots \ldots \ldots \ldots \ldots \ldots \ldots \ldots \ldots, 4.37$

Results - Waste form release $\ldots \ldots \ldots \ldots \ldots \ldots \ldots \ldots \ldots \ldots \ldots \ldots \ldots \ldots \ldots \ldots \ldots, 31$

Disposal Facility

Conceptual model $\ldots \ldots \ldots \ldots \ldots \ldots \ldots \ldots \ldots \ldots \ldots \ldots \ldots \ldots \ldots \ldots, 3-42$

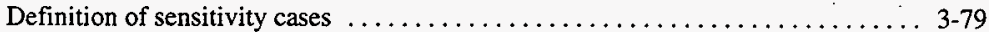

Future Work $\ldots \ldots \ldots \ldots \ldots \ldots \ldots \ldots \ldots \ldots \ldots \ldots \ldots \ldots \ldots \ldots, 6,21$

General description $\ldots \ldots \ldots \ldots \ldots \ldots \ldots \ldots \ldots \ldots \ldots \ldots \ldots \ldots \ldots \ldots \ldots \ldots \ldots \ldots \ldots, 2-50$

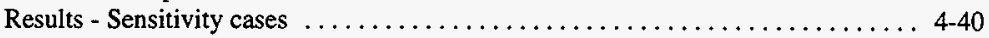

Disposal Facility Degradation

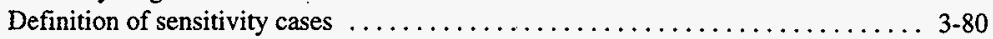

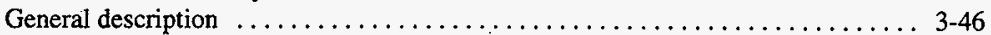

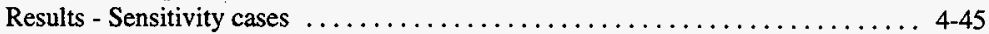

Disposal Facility Location

Definition $\ldots \ldots \ldots \ldots \ldots \ldots \ldots \ldots \ldots \ldots \ldots \ldots \ldots \ldots \ldots \ldots, 2-4$

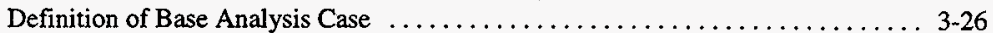

Definition of sensitivity cases $\ldots \ldots \ldots \ldots \ldots \ldots \ldots \ldots \ldots \ldots \ldots \ldots \ldots \ldots, 3-82$

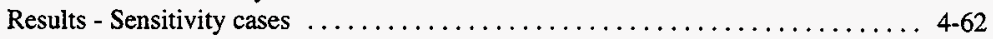


Exposure Parameters

Conceptual model

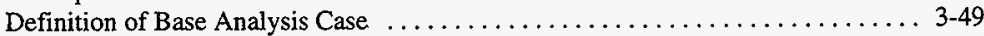

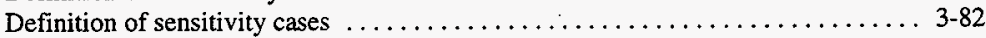

Results - Sensitivity cases $\ldots \ldots \ldots \ldots \ldots \ldots \ldots \ldots \ldots \ldots \ldots \ldots \ldots, 4.61$

Future Work

Disposal facility data $\ldots \ldots \ldots \ldots \ldots \ldots \ldots \ldots \ldots \ldots \ldots \ldots \ldots \ldots, 6,21$

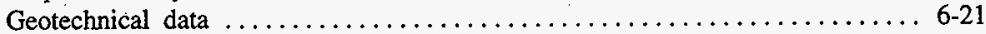

Inventory data $\ldots \ldots \ldots \ldots \ldots \ldots \ldots \ldots \ldots \ldots \ldots \ldots \ldots \ldots, 6,22$

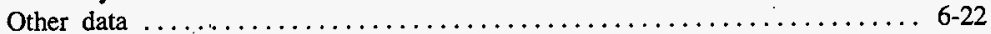

Performance assessments ................................ 6-17

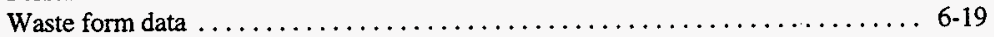

Geochemical Parameters

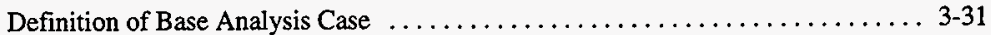

Definition of sensitivity cases $\ldots \ldots \ldots \ldots \ldots \ldots \ldots \ldots \ldots \ldots \ldots \ldots \ldots, 8, \ldots \ldots \ldots$

Future Work $\ldots \ldots \ldots \ldots \ldots \ldots \ldots \ldots \ldots \ldots \ldots \ldots \ldots \ldots \ldots, 6,21$

General description $\ldots \ldots \ldots \ldots \ldots \ldots \ldots \ldots \ldots \ldots \ldots \ldots \ldots \ldots \ldots \ldots \ldots \ldots \ldots, 2-38$

Results - Sensitivity cases $\ldots \ldots \ldots \ldots \ldots \ldots \ldots \ldots \ldots \ldots \ldots \ldots \ldots \ldots, 4-50$ Geology

Definition of Base Analysis Case $\ldots \ldots \ldots \ldots \ldots \ldots \ldots \ldots \ldots \ldots \ldots \ldots . \ldots \ldots$

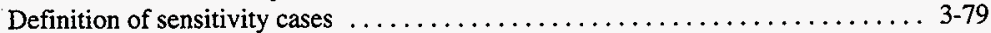

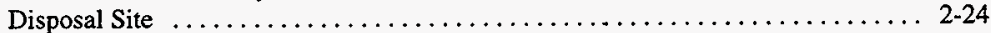

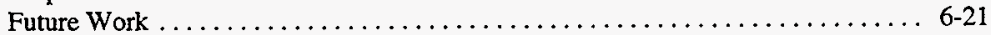

Regional .......................................... $2-14$

Hydraulic Parameters

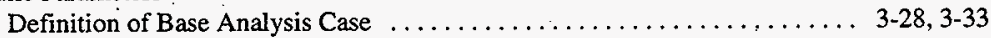

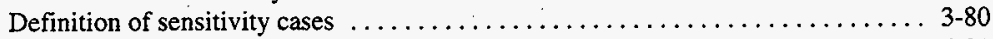

Future Work $\ldots \ldots \ldots \ldots \ldots \ldots \ldots \ldots \ldots \ldots \ldots \ldots \ldots \ldots \ldots \ldots \ldots \ldots \ldots \ldots, 21$

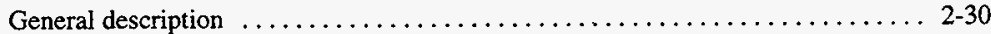

Results - Sensitivity cases $\ldots \ldots \ldots \ldots \ldots \ldots \ldots \ldots \ldots \ldots \ldots \ldots \ldots \ldots \ldots \ldots, 45$

Inadvertent Intruder

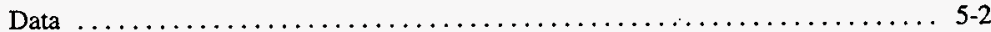

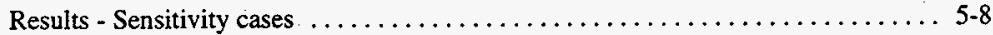

Results for Driller Scenario .............................. 5-4

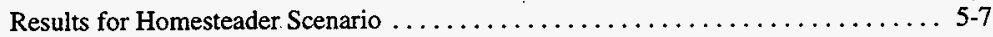

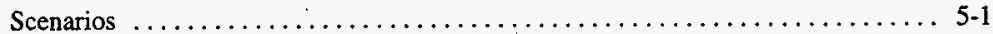

Summary $\ldots \ldots \ldots \ldots \ldots \ldots \ldots \ldots \ldots \ldots \ldots \ldots \ldots \ldots \ldots \ldots \ldots \ldots \ldots, 5,15$

Infiltration Rate

Conceptual model $\ldots \ldots \ldots \ldots \ldots \ldots \ldots \ldots \ldots \ldots \ldots \ldots \ldots \ldots, 3-48$

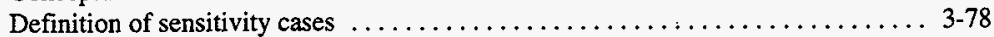

Future Work $\ldots \ldots \ldots \ldots \ldots \ldots \ldots \ldots \ldots \ldots \ldots \ldots \ldots \ldots \ldots, 6,21$

Results - Sensitivity cases $\ldots \ldots \ldots \ldots \ldots \ldots \ldots \ldots \ldots \ldots \ldots \ldots \ldots \ldots, 4-52$ 


\section{DOE/RL-97-69}

Rev. 0

Inventory

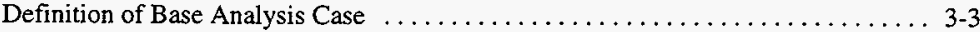

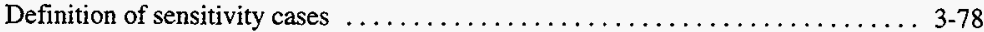

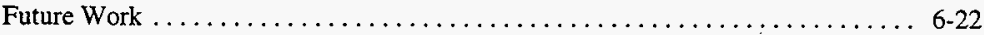

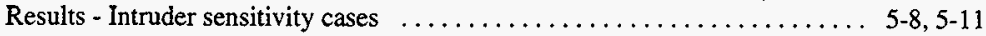

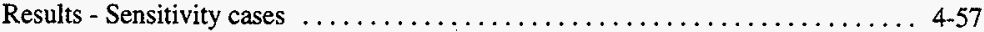

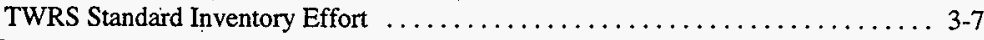

Land Use

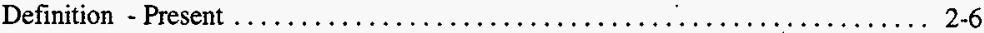

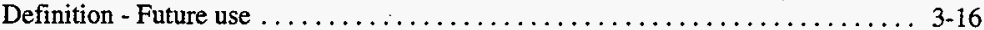

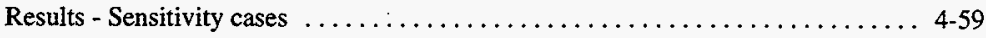

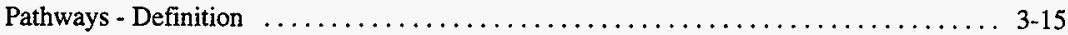

Performance Objectives

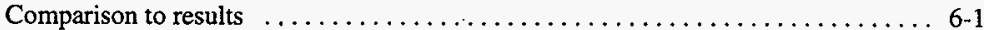

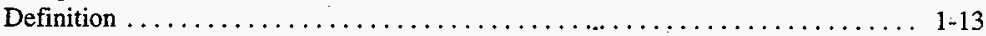

Plume Overlap

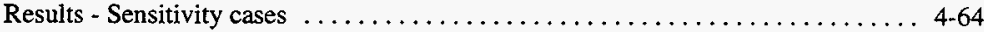

Program Office $\ldots \ldots \ldots \ldots \ldots \ldots \ldots \ldots \ldots \ldots \ldots \ldots \ldots \ldots \ldots \ldots \ldots \ldots \ldots \ldots$

Requirements Set by PA

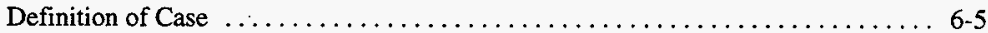

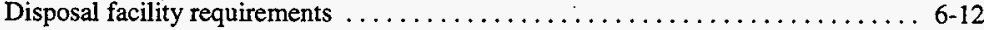

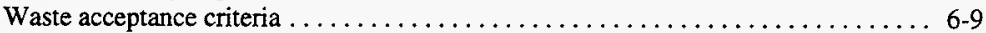

Sensitivity Cases

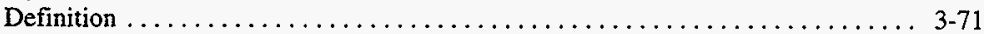

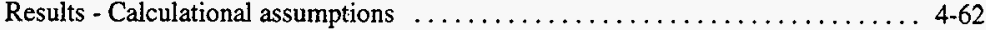

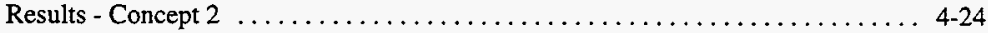

Results - Disposal Facility . . . . . . . . . . . . . . . . . . . . . 4-40

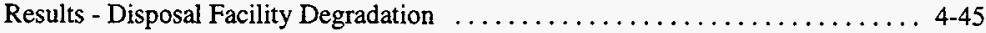

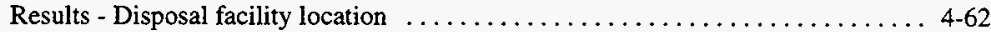

Results - Exposure parameters . . . . . . . . . . . . . . . . . . . . 4-61

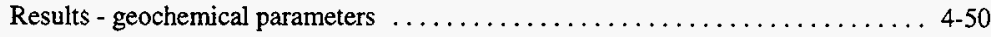

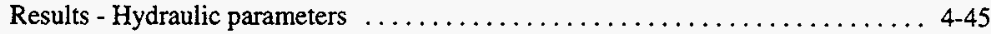

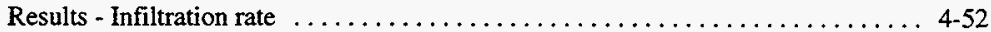

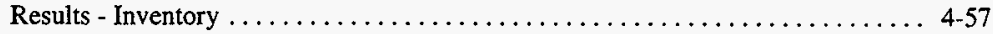

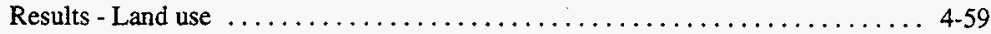

Results - Plume overlap ............................ 4-64

Results - Release rates . . . . . . . . . . . . . . . . . . . . . . 4-31

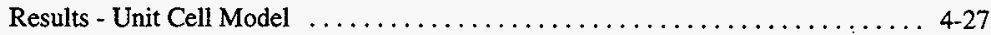

Unit Cell Model

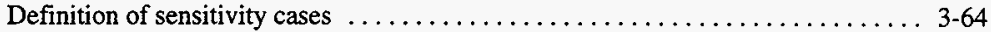

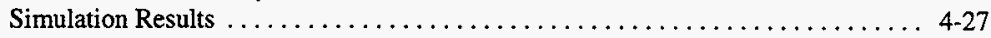

Waste Acceptance Criteria $\ldots \ldots \ldots \ldots \ldots \ldots \ldots \ldots \ldots \ldots \ldots \ldots \ldots \ldots \ldots$ 


\section{DOE/RL-97-69}

Rev. 0

Waste Form Release Rates

Definition of Base Analysis Case

Definition of sensitivity cases

Future Work ........................................ 6-19

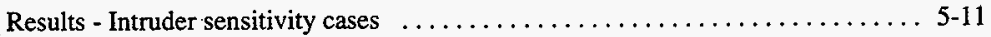

Results - Sensitivity cases 


\section{DISTRIBUTION}

\section{U.S. Department Of Energy}

EM-45

20400 Century Blvd.

Germantown, MD 20874

Julie Dambrosia

U.S. Department of Energy, Richland

Operations Office (18)

C.V. Banks

S7-53

N.R. Brown

K6-51

D.D. Button

K6-5I

A.K. Crowell

C. Haass

R.A. Gilbert

R.D. Hildebrand

L.A. Huffman

Philip E. LaMont (5)

G.H. Sanders

K.M.Thompson

W.J. Taylor

C.D. West

D.D. Woodrich

Defense Nuclear Facility Safety Board Suite 700, 625 Indiana Avenue, N.W. Washington, D.C. 2004

John T. Conway

Flour Daniel Hanford (2)

A.M. Umek

S7-40

D.J. Washenfelder

S7-40

Fluor Daniel Northwest (20)

Terry A. Carlson

H5-27

Raziuddin Khaleel H0-31

Frederick M. Mann (15) H0-31

Mel Piepho

R3-15

Raymond J. Puigh

HO-31

Paul D. Rittmann
Hanford Education Action League

1408 West Broadway Avenue

Spokane, Washington 99201-1902

Todd Martin

Lockheed Martin Hanford Company (8)

Harry L. Boston

G3-21

J.O. Honeyman

S7-81

Russell J. Murkowski

H5-03

Jeff A. Voogd (5)

H5-03

Lockheed Martin Services, Inc. (7)

Central Files

B1-07

Correspondence Control A3-01

Document Clearance

H6-08

Document Processing Center A3-93

DOE/RL Reading Room H2-53

Hanford Technical Library $\quad$ P8-55

Niall W. Kline

HO-31

Massachusetts Institute of Technology

Ralph M. Parsons Laboratory

Department of Civil Engineering

Cambridge, MA 02139

Lynn Gelhar

Nuclear Regulatory Commission

Mail Stop T-706

11545 Rockville Pike

Rockville, MD 20852-2738

Jennifer Davis 
Numatec Hanford Company (3)

Ed Fredenburg

H5-61

J.S. Garfield

H5-49

C.A. Petersen

H5-27

Oregon State Department of Energy

Nuclear Safety Division

625 Marion St. NE

Salem, Oregon 97310

Dirk Dunning

Pacific Northwest National Laboratory (11)

Yueting Chen

M.J. Fayer

K2-40

K9-33

Daniel I. Kaplan

$\mathrm{K} 6-81$

Charles T. Kincaid

K9-33

B. Peter McGrail

K6-81

E.M. Murphy

Stephen P. Reidel

K3-61

K6-81

K3-54

K. Rhoads

K9-33

M.L. Rockhold

Technical Library

P8-55

Joseph H. Westsik, Jr.

Puget Sound Naval Yard

NRRO

Bremerton, WA

M. French

SGN Euisys Services Corp.

Dewey A. Burbank, Jr.

H5-27
Washington State Department of Ecology

PO Box 1386

Richland WA 99352

J. Grantham

Washington State Department of Ecology

1315 West 4th Avenue.

Kennewick, WA 99336

Suzanne L. Dahl

Robert J. Jullian

Waste Management Services, Hanford

Marcus I. Wood

H6-06

Westinghouse Savannah River Company

P.O. Box 616

Aiken, South Carolina 29802

Elmer Wilhite

Louis Kovach

7000 Huntley Road

Columbus, $\mathrm{OH} 43229$

Bill Prindle

1556 Crestline Drive

Santa Barabara, CA 93105

George F. Williamson

254 Rockwood Drive

Richland, WA 99352
Southwest Research

San Antonio, TX 78284

B. Sagar 